\title{
Zorgplichtbepalingen in het strafrecht
}

Citation for published version (APA):

Visser, M. J. C. (2001). Zorgplichtbepalingen in het strafrecht. [Doctoral Thesis, Maastricht University]. Gouda Quint. https://doi.org/10.26481/dis.20010330mv

Document status and date:

Published: 01/01/2001

DOI:

10.26481/dis.20010330mv

Document Version:

Publisher's PDF, also known as Version of record

\section{Please check the document version of this publication:}

- A submitted manuscript is the version of the article upon submission and before peer-review. There can be important differences between the submitted version and the official published version of record.

People interested in the research are advised to contact the author for the final version of the publication, or visit the DOI to the publisher's website.

- The final author version and the galley proof are versions of the publication after peer review.

- The final published version features the final layout of the paper including the volume, issue and page numbers.

Link to publication

\footnotetext{
General rights rights.

- You may freely distribute the URL identifying the publication in the public portal. please follow below link for the End User Agreement:

www.umlib.nl/taverne-license

Take down policy

If you believe that this document breaches copyright please contact us at:

repository@maastrichtuniversity.nl

providing details and we will investigate your claim.
}

Copyright and moral rights for the publications made accessible in the public portal are retained by the authors and/or other copyright owners and it is a condition of accessing publications that users recognise and abide by the legal requirements associated with these

- Users may download and print one copy of any publication from the public portal for the purpose of private study or research.

- You may not further distribute the material or use it for any profit-making activity or commercial gain

If the publication is distributed under the terms of Article $25 \mathrm{fa}$ of the Dutch Copyright Act, indicated by the "Taverne" license above, 
Zorgplichtbepalingen in het strafrecht 



\section{Zorgplichtbepalingen in het strafrecht}

\section{PROEFSCHRIFT}

ter verkrijging van de graad van doctor aan

de Universiteit Maastricht,

op gezag van de Rector Magnificus,

Prof.dr. A.C. Nieuwenhuijzen Kruseman

volgens het besluit van het College van Decanen,

in het openbaar te verdedigen

op vrijdag 30 maart 2001

om 14.00 uur

door

Maria Johanna Christina Visser 


\section{Promotores:}

Prof.dr. M.G. Faure L.LM

Prof.mr. Th.A. de Roos (Universiteit Leiden)

Beoordelingscommissie:

Prof.mr. E. Prakken (Voorzitter)

Prof.mr. Y. Buruma (Katholieke Universiteit Nijmegen)

Mr.dr. J.C. Hage

Prof.mr.drs. F.C.M.A. Michiels (Universiteit Utrecht)

Prof.mr. L.F.M. Verhey 


\section{Woord vooraf}

Dit boek is een verslag van mijn onderzoek naar zorgplichtbepalingen in het Nederlandse strafrecht. Aan de totstandkoming van deze dissertatie hebben velen een positieve bijdrage geleverd, die ik gaarne wil danken. Een aantal van hen wil ik hier noemen.

Mijn promotores Michael Faure en Theo de Roos wil ik bedanken voor de enthousiaste en leerzame manier waarop zij mijn onderzoekswerkzaamheden hebben begeleid. Bovendien wil ik Michael bedanken voor de prettige samenwerking bij het schrijven van het boek De strafrechtelijke bescherming van het leefmilieu in België, Duitsland en Nederland. Degenen die belangstelling hebben voor rechtsvergelijkende componenten, samenhangende met het voorliggende boek, verwijs ik hier gaarne naar. Tevens worden in dit "andere boek" zorgplichtbepalingen besproken en vergeleken met drie andere modellen van strafbaarstelling in het milieustrafrecht. In dit boek staat het model "zorgplichtbepalingen" centraal binnen diverse strafrechtelijke gebieden.

De leden van de beoordelingscommissie, Prof.mr. Y. Buruma, mr.dr. J.C. Hage, Prof.mr.drs. F.C.M.A. Michiels, Prof.mr. E. Prakken en Prof.mr. L.F.M. Verhey ben ik zeer erkentelijk voor hun bereidheid zitting te nemen in deze commissie en het manuscript van commentaar te voorzien. Hun opmerkingen waren zeer waardevol.

Ook ben ik dank verschuldigd aan Inge van der Vlies en Rob Widdershoven die bereid waren kritisch met mij van gedachten te wisselen over wetgevingstechniek en de in dit boek geformuleerde "algemene vereisten van behoorlijke regelgeving".

De Universiteit Maastricht en de Universiteit van Amsterdam ben ik erkentelijk voor de tijd voor en de ondersteuning bij het verrichten van mijn onderzoek. De periodes doorgebracht bij METRO, het Seminarium van Hamel en het Centrum voor Milieurecht waren zeer leerzaam, stimulerend en vooral ook leuk. Bijzondere dank gaat uit naar het secretariaat van METRO, en in het bijzonder naar Marina Jodogne en Marjo Mullers voor de snelle en accurate hulp bij het camera-ready maken van dit boek.

Met collega's en vrienden is het goed gedachten wisselen over onderzoek en recht. Vooral aan de discussies met Marius Aalders, Steven Bartels, Marlon Boeve, Chris Ingelse, Ingrid Klinge-van Rooij, Jürgen Lefevere, Arthur van Rossem, Rosa Uylenburg, Rob Widdershoven en Louisa Wissink bewaar ik goede herinneringen. Ook mijn Limburgse "gastadressen" ben ik zeer dankbaar voor de altijd gezellige en gastvrije ontvangsten waarvan ik in de loop der jaren heb mogen genieten. Mede door Chris Ingelse, Petra Vranken en Louisa Wissink zijn tochten naar het Zuiden iets om 
naar uit te kijken. Ook een ieder die mij de afgelopen jaren de vraag heeft gest $d$ of "het" al af was, wil ik hierbij danken voor de ongetwijfeld gemeende belangstelpg... en JA, "het" is af!

Dankbaar ben ik ook mijn familie, voor de trouwe steun en de zekerheid dat zijltijd voor mij klaarstaan en mij zo nodig "redden". Tot slot, maar op de eerste plaats, lank ik Peter voor zijn liefde, zorg en onontbeerlijke steun die hij mij heeft gegeven tens het schrijven van dit boek.

Het manuscript is op 1 oktober 2000 afgesloten.

Marjolein Visser 


\section{Inhoudsopgave}

Lijst van afkortingen

\section{Hoofdstuk 1}

\section{Algemene inleiding}

1. Inleiding .........................................................................

2. Zorgplichtbepalingen - definiëring, afbakening en probleemstelling ........ 2

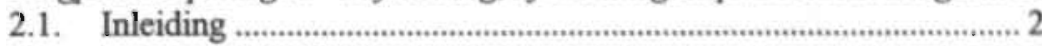

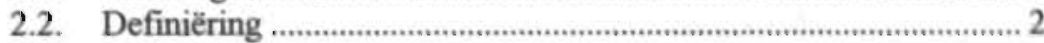

2.3. Afbakening; andere soorten zorgplichtbepalingen........................... 4

2.4. Probleemstelling .................................................................... 10

2.5. Afbakening van het onderwerp en methode van onderzoek.......... 10

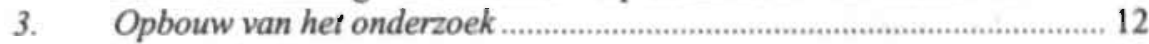

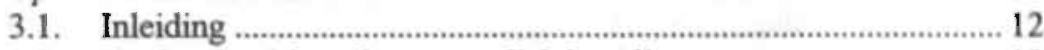

3.2. Het betekenisbereik van zorglichtbepalingen................................ 12

3.3. De wetgever en de algemene vereisten van behoorlijke

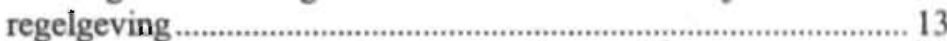

3.4. Het bestuur en voorwaarden voor strafbaarstelling......................... 14

3.5. De rechter en voorwaarden voor strafbaarstelling …..................... 14

3.6. Zorgplichtbepalingen in strafwetgeving ...................................... 15

3.6.1. Het niveau van regelgeving.......................................... 15

3.6.1.1. Wetgeving in formele zin .................................. 15

3.6.1.2. Wetgeving in materiële zin ................................. 16

3.6.1.3. Beschikkingen................................................... 17

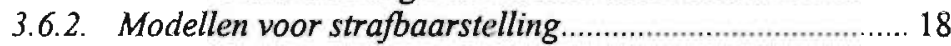

3.6.2.1. Verschillende modellen ...................................... 18

3.6.2.2. Abstracte gevaarzettingsdelicten ......................... 19

3.6.2.3. Concrete gevaarzettingsdelicten .......................... 19

3.6.2.4. Zelfstandige gevaarzettingsdelicten ..................... 20

3.6.2.5. Zorgplichtbepalingen .......................................... 20

3.6.3. Functies van zorgplichtbepalingen .................................... 21

3.7. Zorgplichtbepalingen en de algemene vereisten van

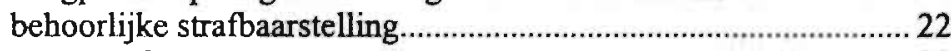

4. Plan van aanpak …………………................................................. 22 


\section{Hoofdstuk 2}

Voorwaarden voor de toepassing van strafbaarstellingen

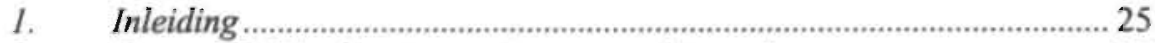

2. Toepasselijkheid en toepassing van rechtsregels .................................... 26

2.1. Toepasselijkheid en toepassing.....................................................26

2.2. Niet toepasselijk, wel toegepast?..................................................27

2.3. Wel toepasselijk, niet toegepast?..................................................2 29

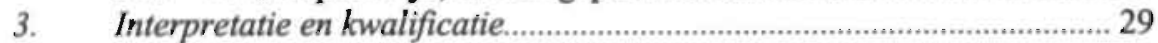

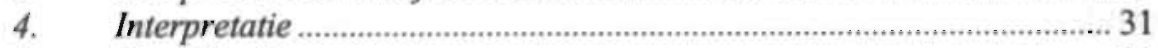

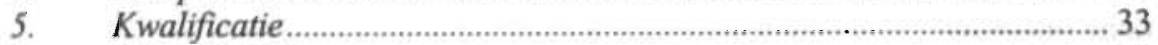

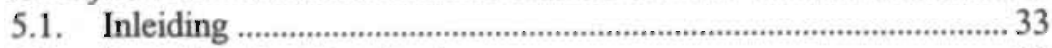

5.2. Recht, Taal en Betekenis.............................................................. 33

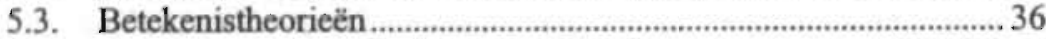

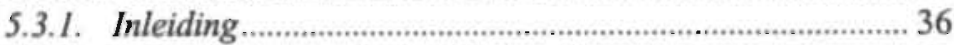

5.3.2. De Criteriatheorie ........................................................ 37

5.3.3. Afgezwakte Criteriatheorie .............................................. 39

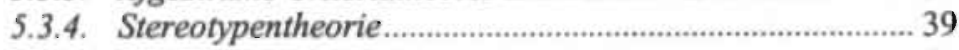

5.4. "Vaagheid" van een regel ............................................................... 41

5.4.1. Inleiding ........................................................................... 41 .

5.4.2. Vaagheid en open texture ................................................... 41

5.4.2.1. Inleiding ............................................................. 41

5.4.2.2. Vaagheid ............................................................ 41

5.4.2.3. Open texture......................................................... 45

5.4.3. Aóstracte, concrete en graảeie rermen .......................... 45

5.4.4. Normatieve en evaluatieve termen ............................... 47

5.5. Kwalificatie; een slotbeschouwing ............................................ 48

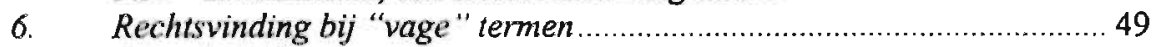

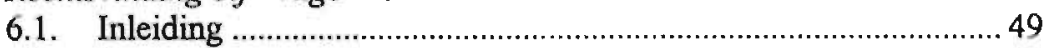

6.2. Ongeschreven recht bij de kwalificatie ................................... 50

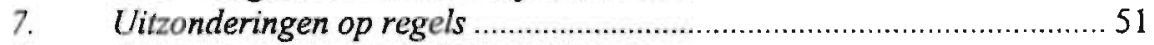

8. De toepassing van strafbaarstellingen............................................. 53

\section{Hoofdstuk 3}

De wetgever en de algemene vereisten van behoorlijke regelgeving

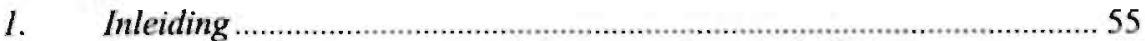

2. De totstandkoming van een algemeen wetgevingsbeleid.........................56

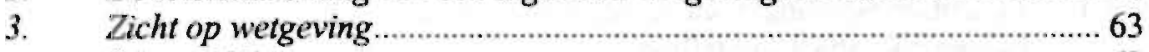

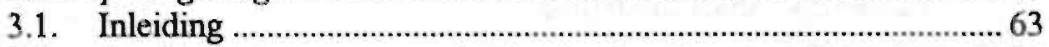

3.2. Kwaliteitseisen voor overheidsoptreden via wetgeving................ 64

3.2.1. Rechtmatigheid en verwerkelijking van

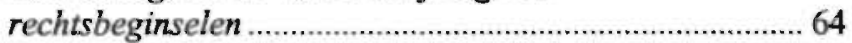

3.2.2. Effectiviteit en doelmatigheid ..........................................64

3.2.3. Subsidiariteit en proportionaliteit ...................................... 65 
3.2.4. Uitwoerbaarheid en handhaafbaarheid ............................. 65

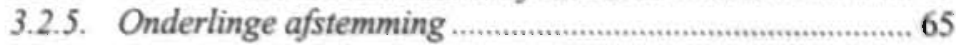

3.2.6. Eenvoud, duidelijkheid en toegankelijkheid ..................... 66

3.3. Verhouding tussen de kwaliteitseisen............................................... 66

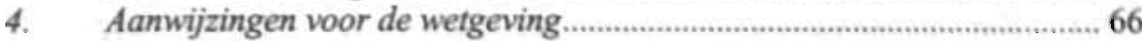

5. Beginselen van behoorlijke regelgeving .................................................. 67

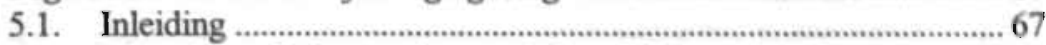

5.2. Inhoud van de beginselen van behoorlijke regelgeving ................ 72

5.3. Formele beginselen van behoorlijke regelgeving ........................... 74

5.3.1. Beginsel van duidelijke doelstelling................................. 74

5.3.2. Beginsel van het juiste orgaan .......................................... 75

5.3.3. Het noodzakelijkheidsbeginsel ........................................ 75

5.3.4. Het beginsel van uitvoerbaarheid ..................................... 76

5.3.5. Het beginsel van consensus.............................................. 76

5.4. Materiële beginselen van behoorlijke regelgeving......................... 77

5.4.1. Beginsel van duidelijke terminologie en duidelijke systematiek...................................................................... 77

5.4.2. Kenbaarheidsbeginsel ....................................................... 77

5.4.3. Het rechisgelijkheids beginsel............................................ 78

5.4.4. Het rechtszekerheidsbeginsel ............................................ 79

5.4.5. Het beginsel van individuele rechtsbedeling ..................... 79

5.5. Verhouding tussen de beginselen van behoorlijke

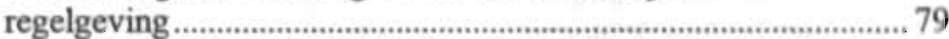

6. De beginselen en de Raad van State ...................................................... 80

7. Criteria voor strafbaarstelling ........................................................... 81

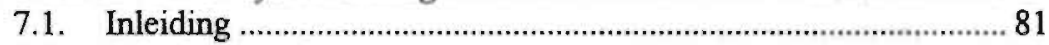

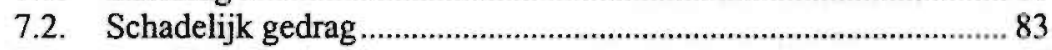

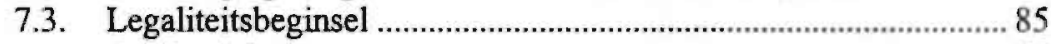

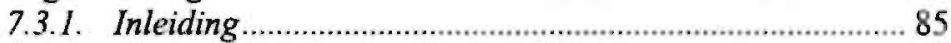

7.3.2. Het legaliteitsbeginsel in het EVRM ........................... 87

7.3.3. Het nationaal legaliteitsbeginsel ................................... 92

7.3.4. De wetgever en het legaliteitsbeginsel............................ 94

7.3.5. Het bestuur en het legaliteitsbeginsel.............................. 97

7.3.6. De rechter en het legaliteitsbeginsel............................... 98

7.4. Het schuldbeginsel ................................................................ 104

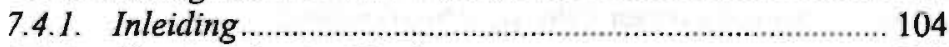

7.4.2. Opzet als bestanddeel ............................................... 106

7.4.3. Culpa als bestanddeel ................................................ 108

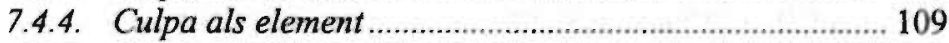

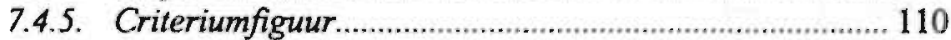

7.4.6. Schuldkwadratuur........................................................ 112

7.4.7. Consequenties van opzet of culpa ............................... 116

7.5. Het subsidiariteitsbeginsel .................................................. 117

7.6. Het proportionaliteitsbeginsel............................................. 122

7.7. Effectiviteit........................................................................... 125

7.8. Verhouding tussen de criteria voor strafbaarstelling................... 126 
8. Algemene vereisten van behoorlijke regelgeving ….............................. 127

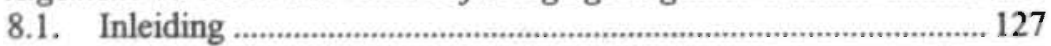

8.2. Algemene vereisten van behoorlijke regelgeving ....................... 128

8.3. Het vereiste van evenredigheid................................................. 129

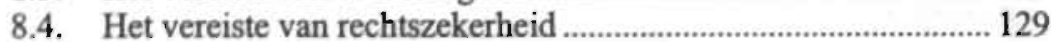

8.5. Het vereiste van rechtsgelijkheid................................................ 130

8.6. Het vereiste van samenhang .................................................... 130

8.7. Het vereiste van effectiviteit ...................................................... 130

8.8. Verhouding tussen de vereisten .................................................. 130

\section{Hoofdstuk 4}

Het bestuur en voorwaarden voor strafbaarstelling

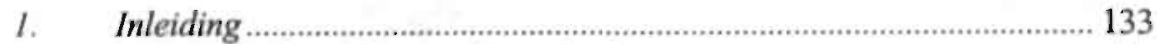

2. Wetgeving door decentrale overheden …………............................... 134

3. Strafrecht en de redenen voor gelede normstellingen …......................... 136

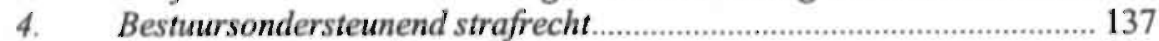

5. De definiëringsmacht van het bestuur............................................ 140

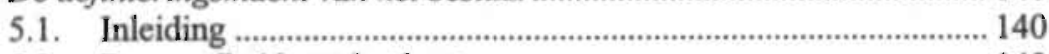

5.2. Bevoegdheid van het bestuur................................................... 140

5.3. Belangenafweging bij besluitvorming door het bestuur .............. 143

5.4. Het bestuur definieert................................................................ 145

6. Bestanddeel of strafuitsluitingsgrond.............................................. 146

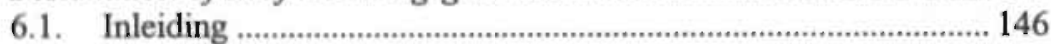

6.2. Bestanddeel of element......................................................... 148

6.3. Processuele consequenties ....................................................... 149

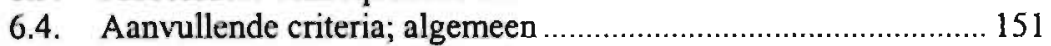

6.5. Aanvullende criteria; de hoofdregel ....................................... 152

6.6. Aanvullende criteria; andere mogelijkheden.............................. 154

6.7. Bestanddeel of strafuitsluitingsgrond ........................................ 159

7. Het bestuur en voorwaarden voor strafbaarstelling............................... 160

\section{Hoofdstuk 5}

De rechter en voorwaarden voor strafbaarstelling

1. Inleiding

2. Uitleg beschikking en algemeen verbindend voorschrift van feitelijke aard?

3. Toetsingsbevoegdheid en formele rechtskracht …………......................167

4. Exceptie van onverbindendheid .................................................... 173

5. Samenloop bestuursrechtelijke en strafrechtelijke procedure................ 175

6. Strafrechtelijke uitspraak voorafgaand aan bestuursrechtelijke uitspraak 
7. Consequenties van bestuursrechtelijke uitspraak voorafgaand aan de strafrechtelijke uitspraak.

7.1. Inleiding

7.2. Consequenties bij vernietiging begunstigende beschikking ......... 179

7.3. Consequenties bij vernietiging belastende beschikking................ 180

7.4. Consequenties bij strafrechtelijke voorlopige maatregel .............. 182

7.5. Consequenties van bestuursrechtelijke uitspraken voor de strafrechter

8. Cumulatie van bestuursrechtelijke en strafrechtelijke reactie ................... 184

9. De strafrechter en voorwaarden voor strafbaarstelling.......................... 186

\section{Hoofdstuk 6}

\section{De ontwikkeling van het commuun strafrecht}

1. Inleiding

2. Het bijzonder strafrecht en de totstandkoming van het commuin strafrecht.

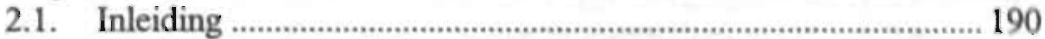

2.2. Het (straf)recht in de Republiek der Verenigde Nederlanden ..... 191

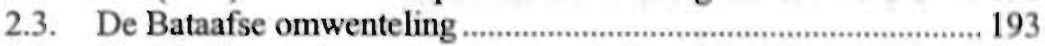

2.4. Codificatie van het strafrecht voor de Code Pénal....................... 194

2.5. De Code Pénal................................................................... 197

2.6. Codificatie van het strafrecht na de Code Pénal.......................... 199

3. Misdrijven en overtredingen; Boek II en Boek III en bijzondere wetgeving ......

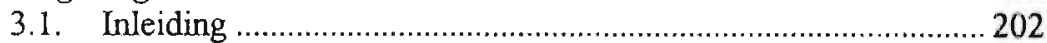

3.2. Onderscheidend criterium tussen misdrijven en overtredingen

3.3. Verschillen tussen misdrijven en overtredingen en de

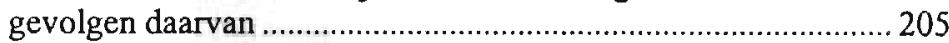

4. Van strafrechtelijke naar bestuursrechtelijke handhaving ....................2208

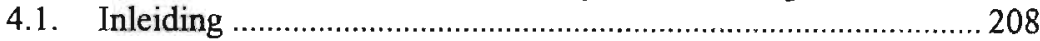

4.2. Het "handhavingstekort",........................................................ 208

4.3. Handhaven door het bestuur ...................................................... 213

4.4. Mogelijke consequenties van de uitbreiding en/ of

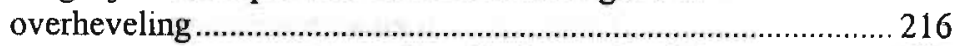

5. Daderschap; een algemeen leerstuk op basis van Boek I.......................220

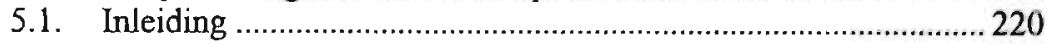

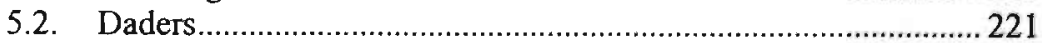

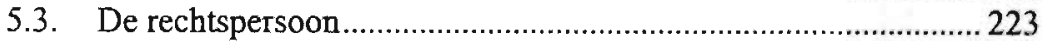

5.4. De opdrachtgever en de feitelijk leidinggever .............................. 225

5.5. De publiekrechtelijke rechtspersoon ........................................... 227

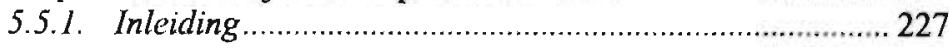

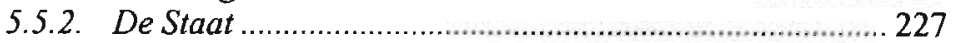


5.5.3. Openbare lichamen als bedoeld in hoofdstuk

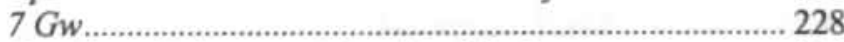

5.5.4. Openbare lichamen uit hoofdstuk $7 \mathrm{Gw}$......................... 231

5.5.5. Knelpunten bij publiekrechtelijke rechtspersonen........... 234

5.5.6. Standpunt van de minister inzake vervolgbaarheid van de Staat ..................................................................... 237

6. Zorgplichtbepalingen en het commuun strafrecht..................................2 238

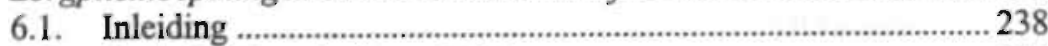

6.2. Artikel 425 aanhef en sub $2 \mathrm{Sr}$...................................................239

6.2.1. De zorgplichtbepaling ................................................. 239

6.2.2. De zorgplichtbepaling nader beschouwd ..................... 239

6.3. Artikel 426, eerste lid Sr ...........................................................24

6.3.1. De zorgplichtbepaling ................................................. 241

6.3.2. De zorgplichtbepaling nader beschouwd ....................... 241

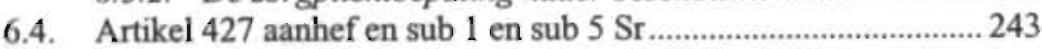

6.4.1. De zorgplichtbepalingen ............................................... 243

6.4.2. De zorgplichtbepalingen nader beschouwd................... 244

6.5. Artikel 429 aanhef en sub 3 Sr.................................................. 246

6.5.1. De zorgplichtbepaling ................................................ 246

6.5.2. De zorgplicht nader beschouwd.................................... 247

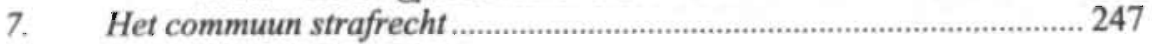

\section{Hoofdstuk 7}

\section{De ontwikkeling van het bijzonder strafrecht}

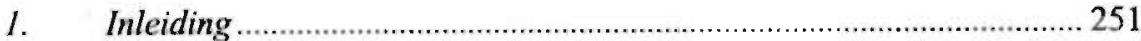

2. De ontwikkeling van het bijzonder strafrecht .................................... 252

3. Zorgplichtbepalingen in het bijzonder strafrecht ............................... 255

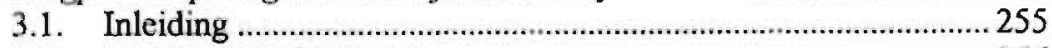

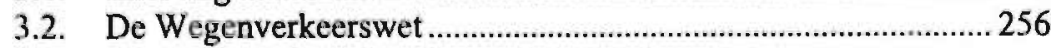

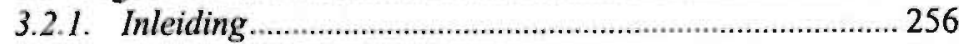

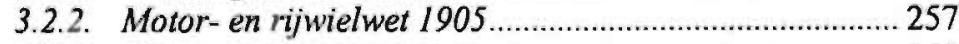

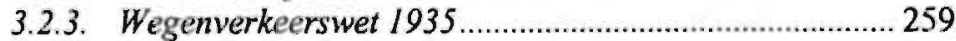

3.2.4. RVV 1966 en RVV 1990 …........................................... 263

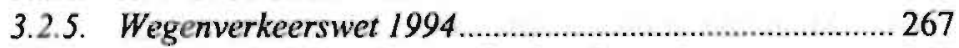

3.2.6. De zorgplichtbepaling nader beschouwd ...................... 268

3.3. De Luchtvaartwet en de Wet Luchtverkeer.................................. 274

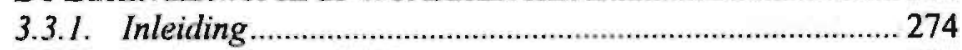

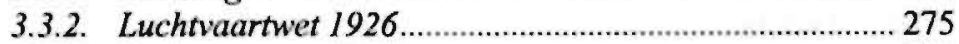

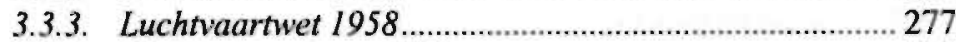

3.3.4. Wet Luchtverkeer 1993.................................................. 278

3.3.5. De zorgplicht nader beschouwd................................... 280

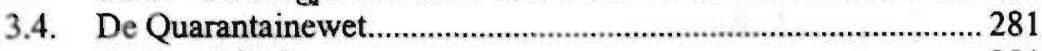

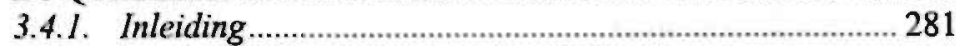


3.4.2. Wet tot wering van besmetting door uit zee aankomende schepen.

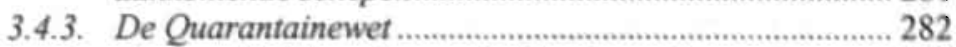

3.4.4. De zorgplichtbepaling nader beschouwd ........................ 283

\section{Hoofdstuk 8}

De ontwikkeling van het economisch strafrecht

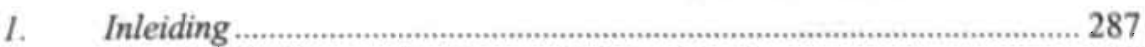

2. De ontwikkeling van het economisch strafrecht …_...........................287

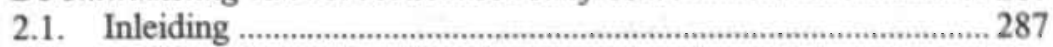

2.2. De opkomst van het economisch strafrecht in de

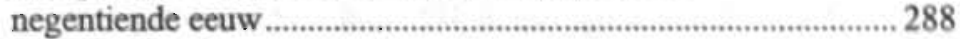

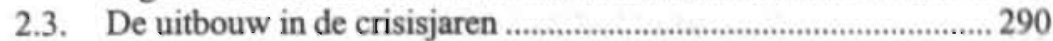

2.4. Ordening tijdens de Tweede wereldoorlog ..................................293

2.5. De Wet op de economische delicten …….................................... 298

3. Zorgplichtbepalingen in het economisch strafrecht ...............................303

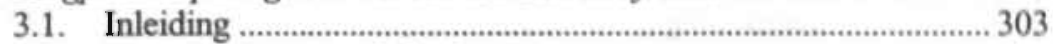

3.2. De Arbeidsomstandighedenwet..............................................304

3.2.1. Het Kinderwetje uit 1874 ........................................ 304

3.2.2. De Arbeidswet 1889 en de Arbeidswet 1919................... 305

3.2.3. De Veiligheidswet I895 ............................................. 306

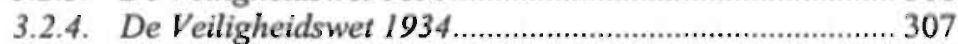

3.2.5. De Arbeidsomstandighedenwet 1980 .............................. 308

3.2.6. Artikel 12 Arbo-wet 1980 ..........................................310

3.2.7. De zorgplichtbepaling uit artikel 12 nader

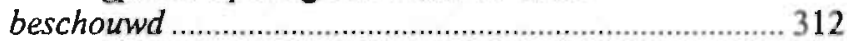

3.2.8. De Arbeidsomsiandighedenwet 1998..............................313

3.2.9. Opsporing en handhaving van de Arbo-wet 1998........... 316

3.2.10. Zorgplichtbepalingen in de Arbo-wet 1998 …............... 320

4. Het economisch strafrecht ......................................................... 322

\section{Hoofdstuk 9}

De ontwikkeling van het milieustrafrecht

1. Inleiding

2. De ontwikkeling van het milieustrafrecht ……..................................325

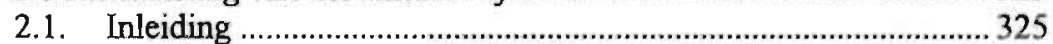

2.2. Milieustrafrecht door decentrale overheden ................................326

2.3. Milieuwetgeving in formele zin................................................327

2.4. Milieustrafrecht en de Wed........................................................332

3. Zorgplichtbepalingen in het milieustrafrecht .....................................334

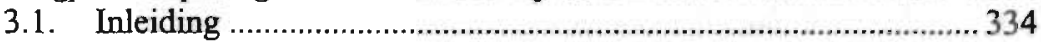




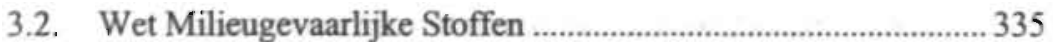

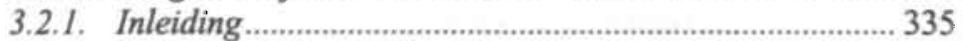

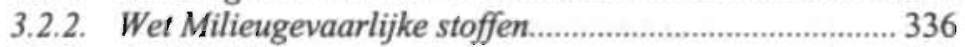

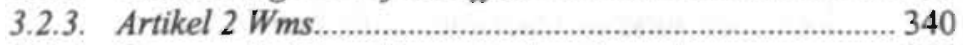

3.2.4. De zorgplichtbepaling nader beschouwd ........................ 345

3.2.5. Het subjectief element bij artikel $2 \mathrm{Wms}$ als

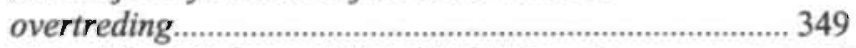

3.2.6. Het subjectief element bij artikel $2 \mathrm{Wms}$ als

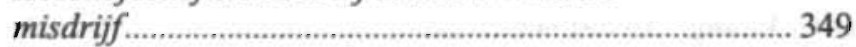

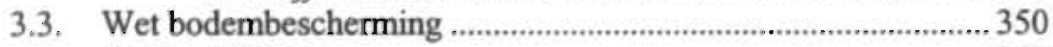

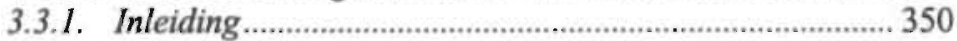

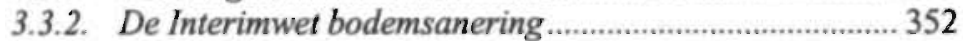

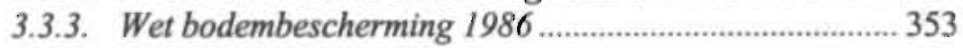

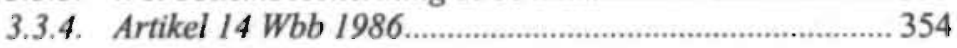

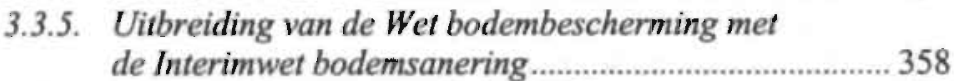

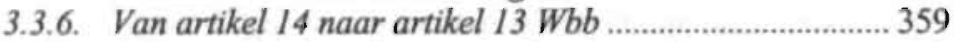

3.3.7. De zorgplichtbepaling nader beschouwd ....................... 364

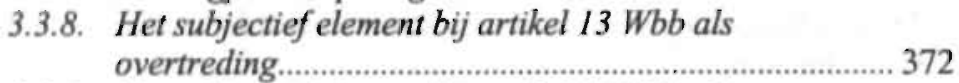

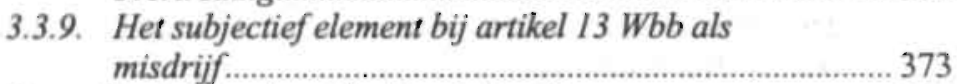

3.4. Wet milieubeheer, hoofdstuk A.fvalstoffen .................................375

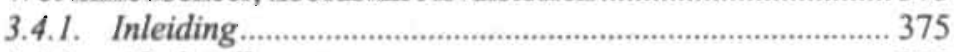

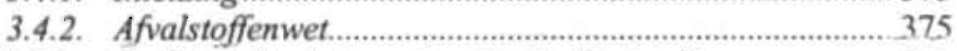

3.4.3. De Wet milieubeheer, hoofdstuk Afvalstoffen ……........... 377

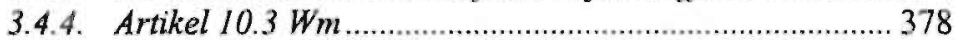

3.4.5. Artikel 1.1a Wm ................................................ 384

3.4.6. De zorgplichtbepaling uit artikel $10.3 \mathrm{Wm}$ nader

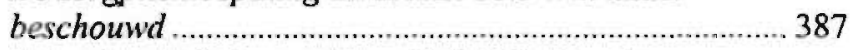

3.4.7. Het subjectief element bij artikel $10.3 \mathrm{Wm}$ als overtreding................................................................. 390

3.4.8. Het subjectief element bij artikel $10.3 \mathrm{Wm}$ als

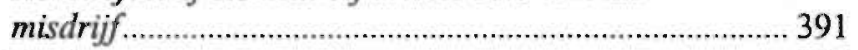

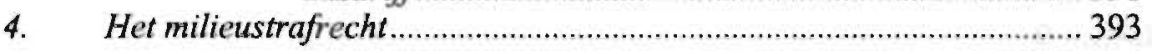

\section{Hoofdstuk 10}

Zorgplichtbepalingen en algemene vereisten van behoorlijke regelgeving

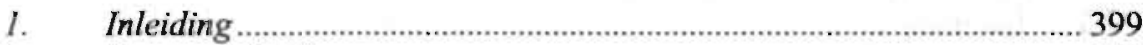

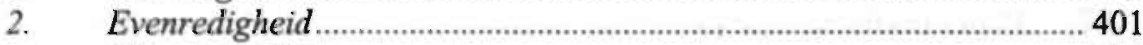

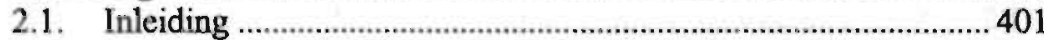

2.2. Het doel ....................................................................... 401

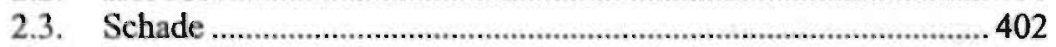

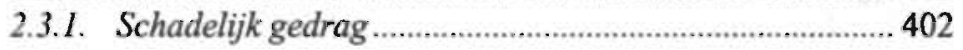


2.3.2. Geen schade vereist .......................................................... 406

2.4. Subsidiariteit.................................................................................4 407

2.5. Proportionaliteit................................................................. 413

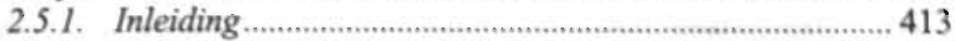

2.5.2. De indeling................................................................. 414

2.5.3. De strafbedreiging ......................................................... 419

2.6. Zorgplichtbepalingen en evenredigheid .................................. 422

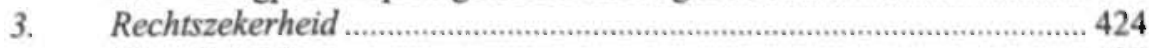

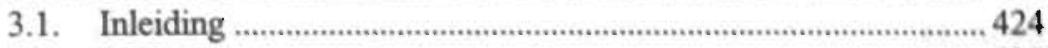

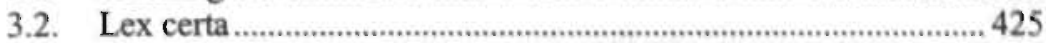

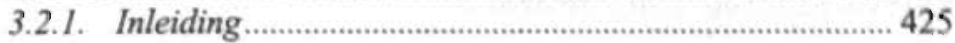

3.2.2. De gedraging ............................................................... 426

3.2.3. Het gevolg.................................................................. 428

3.2.4. De normadressaat .......................................................... 430

3.2.5. Aanvullende criteria en het bestuar ................................ 432

3.2.6. Aanvullende criteria en het Openbaar Ministerie........... 434

3.2.7. Aanvullende criteria en de rechter................................... 436

3.3. Zorgplichtbepalingen en rechtszekerheid .................................. 440

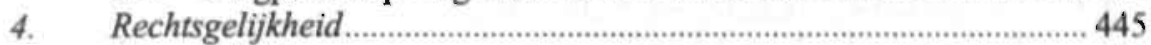

4.1. Inleiding .............................................................................4 445

4.2. Gelijke gevallen gelijk behandelen........................................... 445

4.3. Verwijtbaarheid.....................................................................446 446

4.3.1. Inleiding ......................................................................... 446

4.3.2. Zorgplichtbepalingen zonder een subjectief bestanddeel ............................................................. 447

4.3.3. Zorgplichtbepalingen met een subjectief bestanddeel als overtreding ...................................... 447

4.3.4. Zorgplichtbepalingen met een subjectief bestanddeel als misdriff ............................................. 448

4.3.5. Zorgplichtbepalingen en verwijtbaarheid ..................... 450

4.4. Zorgplichtbepalingen en rechtsgelijkheid ............................... 451

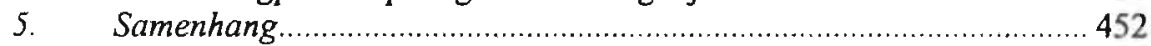

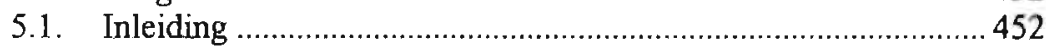

5.2. Samenhang binnen het systeem van wctgeving ......................452

5.3. Samenhang in interpretatie van zorgplichtbepalingen door

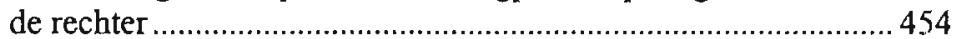

5.4. Zorgplichtbepalingen en samenhang ...................................... 460

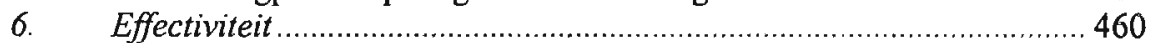

6.1. Inleiding ........................................................................ 460

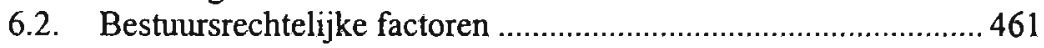

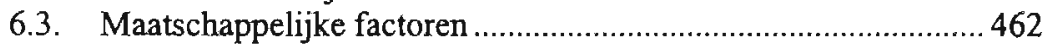

6.4. Bewijsrechtelijke factoren .................................................. 463

6.5. Zorgplichtbepalingen en effectiviteit.................................... 464

7. Zorgplichtbepalingen en algemene vereisten van behoorlijke regelgeving.... 465

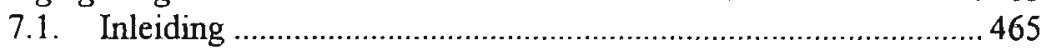




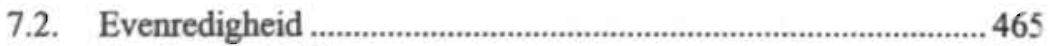

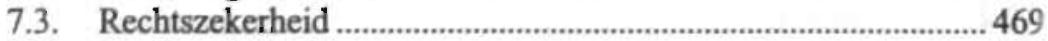

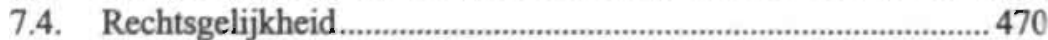

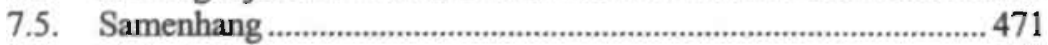

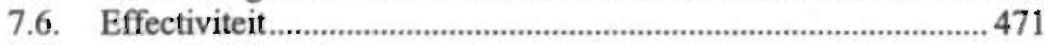

7.7. Zorgplichtbepalingen en algemene vereisten van behoorlijke regelgeving

\section{Hoofdstuk 11}

Zorgplichtbepalingen in het strafrecht

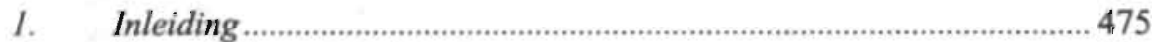

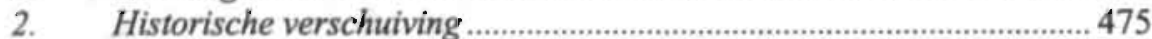

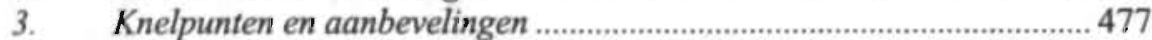

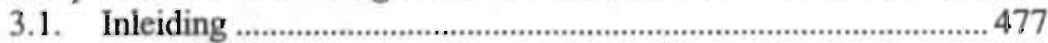

3.2. Evenredigheid: bescherming van het rechtsgoed ...........................478

3.3. Evenredigheid: systeem van strafbaarstellingen ...........................479

3.4. Evenredigheid: indeling en strafbedreiging.................................481

3.5. Rechtszekerheid: het lex certa-beginsel ....................................483

3.6. Rechtsgelijkheid: gelijke gevallen, gelijk behandelen .................. 485

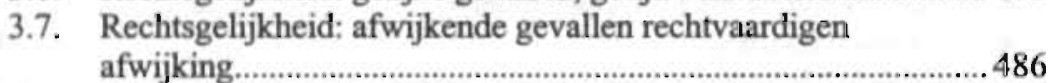

3.8. Samenhang: het systeem van strafbaarstellingen .........................487

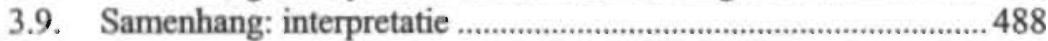

3.10 Fffectiviteit

3.11. Knelpunten en aanbevelingen; algemeen .................................... 489

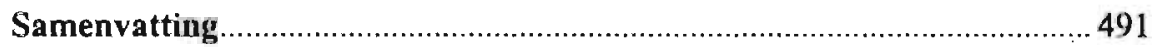

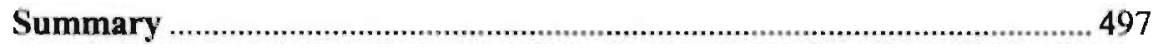

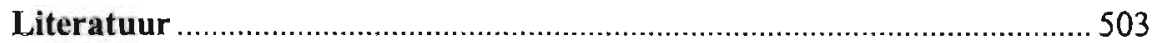

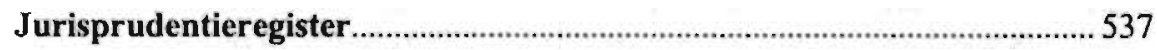

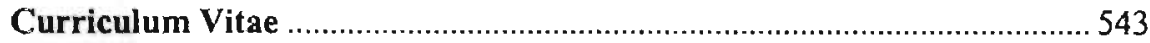




\section{Lijst van afkortingen}

$\begin{array}{ll}\text { AA } & \text { A.rs Aequi } \\ \text { AB } & \text { Administratiefrechtelijke beslissingen } \\ \text { AG } & \text { Advocaat-Generaal } \\ \text { AIDP } & \text { Association International de Drait Pénal } \\ \text { ABR } & \text { Afdeling Bestuursrechtspraak van de Raad van State } \\ \text { amvb } & \text { algemene maatregel van bestuur } \\ \text { APV } & \text { Algemene Politieverordening/ Algemene Plaatselijke Verorde- } \\ & \text { ning } \\ \text { AR } & \text { Afdeling Rechtspraak van de Raad van State } \\ \text { Arbo-wet } & \text { Arbeidsomstandighedenwet } \\ \text { Arbo-besluit } & \text { Arbeidsomstandighedenbeshit } \\ \text { art. } & \text { artikel } \\ \text { avas } & \text { afwezigheid van alle schuld } \\ \text { Aw } & \text { Afvalstoffenwet } \\ \text { Awb } & \text { Algemene wet bestuursrecht } \\ \text { BS } & \text { Belgisch Staatsblad } \\ \text { BW } & \text { Burgerlijk Wetboek } \\ \text { CTW } & \text { Commissie voor de Toetsing van Wetgevingsprojecten } \\ \text { DD } & \text { Delikt en Delinkwent } \\ \text { EG } & \text { Europese Gemeenschap } \\ \text { EHRM } & \text { Europees Hof voor de Rechten van de Mens } \\ \text { EK } & \text { Eerste Kamer } \\ \text { EVRM } & \text { Europees Verdrag tot bescherming van de Rechten van de Mens } \\ \text { Gw } & \text { en de fundamentele vrijheden } \\ \text { HR } & \text { Grondwet } \\ \text { IMP } & \text { Hoge Raad } \\ \text { IVBPR } & \text { Indicatief Meerjaren Programma } \\ \text { jo. } & \text { Internationaal Verdrag inzake Burgerrechten en Politieke rechten } \\ \text { JV } & \text { juncto } \\ \text { KB } & \text { Justitiële Verkenningen } \\ \text { MenR } & \text { Koninklijk Besluit } \\ \text { MvT } & \text { Tijdschrift voor Milieu en Recht } \\ \text { NJ } & \text { memorie van toelichting } \\ \text { NJB } & \text { Nederlandse Jurisprudentie } \\ \text { NJV } & \text { Nederlands Juristenblad } \\ \text { NJW } & \text { Nederlandse Juristenvereniging } \\ \text { nr. } & \text { Neue Juristische Wochenschrift } \\ \text { NStZ } & \text { nummer } \\ & \text { Neue Zeitschrift für Strafrecht } \\ & \end{array}$




$\begin{array}{ll}\text { NTB } & \text { Nederlands Tijdschrift voor Bestuursrecht } \\ \text { OM } & \text { Openbaar Ministerie } \\ \text { PbEG } & \text { Publicatieblad der Europese Gemeenschappen } \\ \text { Rb. } & \text { Rechtbank } \\ \text { RC } & \text { Rechter-Commissaris } \\ \text { R\&R } & \text { Nederlands Tijdschrift voor Rechtsfilosofie \& Rechtstheorie } \\ \text { RvS } & \text { Raad van State } \\ \text { RVV } & \text { Reglement verkeersregels en verkeerstekens } \\ \text { RW } & \text { Rechtskundig Weekblad (België) } \\ \text { SEW } & \text { Sociaal-economische wetgeving } \\ \text { SMA } & \text { Tijdschrift over arbeid en sociale zekerheid } \\ \text { Sr } & \text { Wetboek van Strafrecht } \\ \text { Stb. } & \text { Staatsblad } \\ \text { Stcrt. } & \text { Staatscourant } \\ \text { StGB } & \text { Strafgesetzbuch } \\ \text { Sv } & \text { Wetboek van Strafvordering } \\ \text { TK } & \text { Tweede Kamer } \\ \text { TMA } & \text { Tijdschrift voor Milieuaansprakelijkheid } \\ \text { TMR } & \text { Tijdschrift voor Milieurecht } \\ \text { Trb. } & \text { Tractatenblad } \\ \text { TvS } & \text { Tijdschrift voor Strafrecht } \\ \text { Vr } & \text { Verkeersrecht, Juridisch maandblad betreffende het wegverker } \\ \text { Vz ABR } & \text { Voorzitter Afdeling Bestuursrechtspraak Raad van State } \\ \text { VROM } & \text { Ministerie van Volkshuisvesting, Ruimtelijke Ordening en } \\ & \text { Milieubeheer } \\ \text { W. } & \text { Weekbiad van het Recht } \\ \text { WAHV } & \text { Wet administratiefrechtelijke handhaving verkeersvoorschriften } \\ \text { Wamb } & \text { Wet algemene bepalingen milieuhygiëne } \\ \text { Wbb } & \text { Wet bodembescherming } \\ \text { Wed } & \text { Wet op de economische delicten } \\ \text { Wm } & \text { Wet milieubeheer } \\ \text { Wms } & \text { Wet milieugevaarlijke stoffen } \\ \text { Wet RO } & \text { Wet op de Rechterlijke Organisatie } \\ \text { WuV } & \text { Wirtschaft und Verwaltung } \\ \text { Wvo } & \text { Wet verontreiniging oppervlaktewateren } \\ \text { WVW } & \text { Wegenverkeerswet } \\ \text { ZRP } & \text { Zeitschrift für Rechtspolitik } \\ \text { ZStW } & \text { Zeitschrift für die gesamte Strafrechtswissenschaft } \\ & \end{array}$




\section{Algemene inleiding}

\section{Inleiding}

Zorgen of verzorgen is zo normaal dat we er niet meer bij stilstaan. Zo zorgen we bijvoorbeeld voor ons gezin, ons werk, ons huis, en maken we ons zorgen als het niet zo gaat zoals we willen of gewend zijn. Het zorgen weerspiegelt vaak een machts- en/ of gezagsverhouding. Zo wordt men doorgaans verondersteld te zorgen voor datgene waarvoor men verantwoordelijk wordt gehouden of waarop men invloed kan uitoefenen.

Het vanzelfsprekende wordt echter anders wanneer de overheid gaat bepalen wanneer en waar we voor moeten zorgen. Dit geldt met name wanneer dit nog verder gaat, en de overheid niet alleen zegt waar we voor moeten zorgen, maar dit verplicht stelt en het niet voldoen aan deze zorgplicht met een sanctie bedreigt. Dergelijke zorgplichten komen in steeds grotere mate voor in, met name bestuurijike ordeningswetgeving. $\mathrm{Zij}$ bestrijken in het algemeen een groot gebied, het betekenisbereik is vaak onduidelijk en ze verplichten de normadressaat tot het "zorgen" voor dit gebied. Het verplichtende karakter van de bepalingen komt tot uiting in het feit dat het niet betrachten van de "juiste" mate van zorg wordt bedreigd met een strafrechtelijke sanctie. Via deze zorgplichten wordt derhalve een bepaalde verantwoordelijkheid voor de justitiabele aangegeven, die strafrechtelijk kan worden gehandhaafd. Het zijn deze strafrechtelijk afdwingbare zorgplichten die in dit boek centraal staan.

In dit hoofdstuk zal eerst de definiëring, afbakening en probleemstelling worden gegeven die als uitgangspunt hebben gediend bij het onderzoek waarvan in dit boek de resultaten worden gepresenteerd (hoofdstuk 1 paragraaf 2). Daarbij zal ter afbakening en inperking van het eigenlijke onderzoeksobject ook een beschrijving worden gegeven van andere soorten zorgplichtbepalingen waarop dit onderzoek geen betrekking heeft (hoofdstuk 1 paragraaf 2.3.). Ook worden enkele belangrijke keuzes toegelicht die zijn gemaakt bij de gevolgde methode van onderzoek (hoofdstuk 1 paragrauf 2.5.) Vervolgens worden kort de verschillende onderdelen waaruit het onderzoek is opgebouwd toegelicht (hoofdstuk 1 paragraaf 3). Deze onderdelen zijn duidelijk terug te vinden in de opbouw van dit boek, aangezien zij zoveel mogelijk in afzonderlijke hoofdstukken aan de orde komen. Dit hoofdstuk wordt afgesloten met een plan van aanpak (hoofdstuk 1 paragraaf 4 ). 
2. Zorgplichtbepalingen - definiëring, afbakening en probleemstelling

\subsection{Inleiding}

Dit onderzoek gaat over zorgplichtbepalingen in het Nederlandse strafrecht Het gebruik van strafrechtelijk handhaafbare zorgplichtbepalingen' lijkt steeds vakervoor te komen in ordeningswetgeving. Ze bestrijken in het algemeen een groot gebitd en bevatten vaak een aantal vaag geformuleerde bestanddelen. De ontwikkeling naa een toenemend gebruik van zorgplichtbepalingen wordt zowel toegejuicht als betreurd. ${ }^{2}$ Toegejuicht bijvoorbeeld vanwege de toename van algemene materiële normen in bestuurlijke wetgeving die zij bewerkstelligen. ${ }^{3}$ Betreurd bijvoorbeeld vanweg: het gebrek aan rechtszekerheid dat zij bieden. Anderen staan er meer neutraal tegerover en achten ze onvermijdelijk, waarbij het gebruik veeleer wordt beschouwd als een blijk van legislatieve onmacht. ${ }^{5}$

\subsection{Definiëring}

Bij de besluitvorming over wetgeving waarin zorgplichtbepalingen zijn opgenomen is gebleken dat er regelmatig verschil in opvatting bestaat over de juridische aanvaardbaarheid, de effectiviteit en de handhaving van dit soort bepalingen. Hierloor word de te maken afweging tussen het al dan niet gebruiken van deze bepalingen gecompliceerd. Aangezien deze bepalingen behalve strafrechtelijk ook bestuursrechtelijk en civielrechtelijk kunnen worden gehandhaafd, wordt de afwering bovendien bemoeilijkt door de betrokkenheid van de verschillende rechtsgebieder bij de handhaving.

Ten einde tot een meer algemene lijn in het Nederlandse wetgevingsbeleid te komen met betrekking tot zorgplichtbepalingen in de wetgeving heeft de Commissie Toetsing

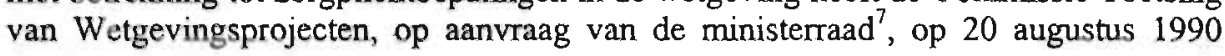

1 Een beschrijving van de afbakening van zorgplichtbepalingen kan ook worden gevonden in Visser, M., "Straficchtelijke zorgplichtbepalingen over de grens? De strafrechtelijke afdwingbaarheid van milieuzorgplichtbepalingen in België en Nederland", pp. 205-213; Faure, M. en Visser, M., De strafrechtelijke bescherming van het leefmilieu in België, Duitsland en Nederland, pp. 321-324.

2 Advies van de Commissie voor de Toetsing van Wetgevingsprojecten inzake zorgplichtbepalingen, CTW 90/6; korte weergave van dit advies is te vinden in het Jaarverslag van de Commissic voor de toetsing van wetgevingsprojecten over het jaar 1989-1990, TK 1990-1991, 21800 VI, nr. 24, pp. 33-36.

3 Zie bijvoorbeeld Lambers, C., De ontbrekende schakel in het milieurecht.

4 Zie bijvoorbeeld Teunissen, J.M.H.F. en Tak, A.Q.C., "Recht ist was der Umwelt nutzt?", pp. 605-616.

5 Zie bijvoorbeeld Remmelink, J., Hoofdwegen door het verkeersrecht, pp. 33-34; Beckers, W.J.G.M., "Art. 25 WVW, een blijk van legislatieve onmacht", p. 212.

6 Jaarverslag van de Commissie voor de Toetsing van Wetgevingsprojecten over het jaar 1989-1990, p. 33.

7 Deze commissie heeft tot taak het adviseren over wetgevingsthema's en wetgevingscomplexen. Tevens omvat haar taak de advisering over concrete 
advies uitgebracht over zorgplichtbepalingen. In dit advies geeft zij een definitie van een zorgplichtbepaling. Zij verstaat hieronder ${ }^{8}$ :

"een vrij algemeen geformuleerde, tot de burger gerichte (zorg)verplichting die een bepaalde verantwoordelijkheid van de burger markeert en waarvan het de bedoeling is deze juridisch te handhaven. Een zorgplicht bevat een algemene verplichting tot het in acht nemen van een bepaalde graad van zorgvuldigheid met het oog op het door de desbetreffende wet te beschermen belang, en kan zowel betrekking hebben op een handelen als een nalaten van de normadressaat. De wetstechnische vormgeving van een zorgplichtbepaling kan verschillen; het kan gaan om een gebod (een positief geformuleerde verplichting), of om een verbod. De handhaving van de norm kan langs bestuurlijke, strafrechtelijke of privaatrechtelijke weg geschieden, of zelfs via een combinatie van deze methoden."

In dit boek wordt grotendeels bij deze definitie aangesloten, op één essentieel punt na. Dit is de vraag wie de adressaat is van zorgplichtbepalingen. In de definitie van de Commissie wordt nadrukkelijk gesteld dat de adressaat van zorgplicht-bepalingen de burger is. Onduidelijk is waarom de Commissie aanneemt dat een zorgplichtbepaling alleen maar ten aanzien van de burger zou gelden en niet ten aanzien van de overheid. Aangezien zorgplichtbepalingen zich ook richten tot de overheid, vervalt deze beperking uit de definitie. ${ }^{10}$

De vraag of "de overheid" in het strafrecht een normadressaat kan zijn van zorgplichtbepalingen, hangt in het strafrecht samen met de algemene vraag of de overheid, openbare lichamen en/ of ambtenaren strafrechtelijk (moeten) kunnen worden vervolgd. De vervolgbaarheid van de publiekrechtelijke rechtspersonen en ambtenaren is een thema dat de laatste jaren in Nederland sterk in de belangstelling staat en zich verder ontwikkelt. Aangenomen wordt dat strafrechtelijke immuniteit (op dit moment) slechts wordt verleend aan de Staat ${ }^{11}$ en aan een openbaar lichaam als bedoeld in hoofdstuk $7 \mathrm{Gw}$ indien de "desbetreffende gedragingen naar aard en gelet op het wettelijk systeem rechtens niet anders dan door bestuursfunctionarissen kunnen worden verricht in het kader van de uitvoering van de aan het openbaar lichaam opgedragen bestuurstaak". ${ }^{12}$ In de overige gevallen kunnen overheden, openbare

wetsvoorstellen, voorontwerpen daarvan en nota's ter voorbereiding van wetgeving. De taak van de Toetsingscommissie is vervat in het op 11 januari 1989 vastgestelde herziene instellingsbesluit, Stcrt. 1989, p. 20.

8 Advies van de Commissie voor de Toetsing van Wetgevingsprojecten inzake zorgplichtbepalingen, p. 3. In haar jaarverslag Over het jaar 1989-1990 geeft de Commissie op p. 33 een verkorte definitic. De Commissie verstaat hier onder een zorgplichtbepaling: (...) "een vrij algemeen geformuleerde, tot de burger gerichte (zorg)verplichting die een bepaalde verantwoordelijkheid markeert en waarvan het de bedoeling is deze juridisch (bestuurlijk, privaatrechtelijk of strafrechtelijk) te handhaven".

9 Zie ook Lambers, C., De ontbrekende schakel in het milieurecht, p. 7.

10 Zie over normadressaten en daderschap in het strafrecht hoofdstuk 6 paragraaf 5.

11 Zie HR 25 januari 1994, NJ 1994, 598, met noot Corstens (Vliegbasis Volkel).

12 Zie HR 6 januari 1998, $N J$ 1998, 367, met noot De Hullu (Pikmeer II). 
lichamen en bestuursfunctionarissen strafrechtelijk worden vervolgd voor onder andere het overtreden van een zorgplichtbepaling. ${ }^{13}$

Het onderzoek beperkt zich tot zorgplichtbepalingen in het strafrecht. Derhalve richt het zich uitsluitend op die bepalingen die strafbaar zijn gesteld. Juist daar zal de spanning tussen de waarborgfunctie en de instrumentele functie van regelgeving duidelijk naar voren treden. De definitie van zorgplichtbepalingen wordt in het kader van dit onderzoek beperkt tot zorgplichtbepalingen die strafrechtelijk handhaafbaar zijn. In dit boek luidt dan ook de definitie van een zorgplichtbepaling:

Een viij algemeen geformuleerde (zorg)verplichting die een bepaalde verantwoordelijkheid van de normadressaat markeert en die strafrechtelijk kan worden gehandhaafd. Een zorgplichtbepaling bevat een algemene verplichting tot het in acht nemen van een bepaalde graad van zorgvuldigheid met het oog op het door de desbetreffende wet te beschermen belang, en kan zowel betrekking hebben op een handelen als een nalaten van de normadressaat. De wetstechnische vormgeving van een zorgplichtbepaling kan verschillen; het kan gaan om een gebod (een positief geformuleerde verplichting), of om een verbod.

\subsection{Afbakening; andere soorten zorgplichtbepalingen}

Naast de zorgplichtbepalingen die vallen onder de in dit boek gehanteerde definitie, zijn er ook andere categorieën bepalingen aan te wijzen die in de literatuur worden aangedtiid als zorgplichtbepalingen. Deze bepalingen hebben gemeen dat degene tot wie de norm zich richt een bepaalde mate van zorg moet betrachten voor een bepaald rechtsgoed. In deze paragraaf zal een kort overzicht worden gegeven van zorgplichtbepalingen die buiten het in dit boek beschreven onderzoek vallen.

Gezien de gegeven definitie gaat dit boek alleen over zorgplichtbepalingen die strafrechtelijk handhaafbaar zijn. Hierdoor vallen bepalingen die voor het overige aan de definitie voldoen, maar alleen civielrechtelijk en/ of bestuursrechtelijk handhaafbaar zijn buiten het bereik van dit boek. Een voorbeeld van een dergelijke zorgplichtbepaling is artikel $1.1 \mathrm{a}$.Wm. Deze bepaling zal (in hoofdstuk 9 paragraaf 3.4.) wel enkele keren aan de orde komen, omdat zij nauw samenhangt met de totstandkoming van het strafrechtelijk handhaafbare artikel $10.3 \mathrm{Wm}$.

Een andere belangrijke categorie zijn de grondwettelijke zorgplichtbepalingen. Het betreft de zogenaamde sociale grondrechten ${ }^{14}$, die opdrachten aan de overheid bevatten tot het uitoefenen van zorg. ${ }^{15}$ Zo zijn het bevorderen van voldoende

13 Zie over de strafrechtelijke aansprakelijkheid van (publiekrechtelijke) rechtspersonen hoofdstuk 6 paragraaf 5 .

14 Deze zijn met name bij de grondwetsherziening van 1983 in de Grondwet opgenomen, Wet van 19 januari 1983, Stb. 1983, 22.

15 Uit de MvT blijkt dat waar er sprake is van een opdracht aan de overheid daarmee de regelgevende of besturende organen van zowel de centrale overheid als de lagere overheid worden bedoeld. $T K, 1975-1976,13873, \mathrm{nr} .3$, pp. 6-7. 
werkgelegenheid (artikel 19, eerste lid Gw), de bewoonbaarheid van het land en de bescherming en verbetering van het leefmilieu (artikel $21 \mathrm{Gw}$ ), de bevordering van voldoende woongelegenheid (artikel 22, tweede lid Gw) en het onderwijs (artikel 23, eerste lid Gw) voorwerpen van zorg voor de overheid, respectievelijk de regering. De overheid heeft bij de uitvoering van deze zorgplichten een ruime beleidsmarge, waarbij de mate en de snelheid van verwezenlijking, gezien de niet onbeperkte sociaaleconomische mogelijkheden, aan het inzicht van het betrokken overheidsorgaan zijn overgelaten. ${ }^{16}$ Wel sporen ze de overheid aan tot actieve ondersteuning van de autonomie van burgers. ${ }^{17}$ Alhoewel, ongeacht de aard van de rechtsverhouding, grondrechten integraal van toepassing zijn op de verhouding tussen overheid en burger $^{18}$, heeft de burger slechts beperkte mogelijkheden deze zorgplichten in te roepen tegenover de overheid. De formulering en het rechtskarakter van deze bepalingen maakt dat de overheid niet snel in strijd hiermee zal handelen. ${ }^{19}$ Tevens wordt de mogelijkheid voor burgers grondwettelijke zorgplichten in te roepen tegen wetgeving van de centrale overheid beperkt door het verbod aan de rechter, neergelegd in artikel $120 \mathrm{Gw}^{20}$, om de wet in formele zin en verdragen te toetsen aan de Grondwet. ${ }^{21}$ Sociale grondrechten kunnen doorwerken in horizontale verhoudingen. ${ }^{22}$

16

TK, 1975-1976, 13873 , nr. 3, p. 7.

Vlemminx, F., Het profiel van sociale grondrechten, p. 44.

De Regering is van mening dat de overheid in elke relatie waarin zij tot de burger kan staan de grondrechten in acht dient te nemen; zie MvT, TK 1975-1986, 13 872, nr. 3, p. 15; Heringa, A.W. en Zwart, T., Grondwet 1983, p. 27.

Zo stelt bijvoorbeeld de Voorzitter van de RvS dat artikel 22 GW, dat een zorgplicht aan de overheid oplegt, zich niet leent voor rechtstreekse toepassing. VzAr 6 november 1987, $A B$ 1989, 96 (Woonwagens zonder vergunning). In een andere zaak werd een verzoek om beroepskostenvergoeding op grond van artikel 19, derde lid Gw door de Voorzitter van de Raad van State afgewezen, waarbij deze overwoog: "Uit de geschiedenis van de totstandkoming van deze bepaling valt immers, anders dan verzoeker meent, af te leiden dat deze bepaling geen zorgplicht voor de overheid in het leven roept in die zin dat van overheidswege iedere nederlander financieel in staat moet worden gesteld de arbeid van zijn keuze te verrichten, maar een vrijheidsrecht voor verzoeker, een plicht tot overheidsonthouding, inhoudt. Het gaat bij deze bepaling om het waarborgen van de vrije keuze van een beroep uit de mogelijkheden die beschikbaar zijn, zowel persoonlijk als maatschappelijk." VzAR 30 november 1989, AB 1990, 279 (Grenzen vrije beroepskeuze).

Zie hierover bijvoorbeeld de Preadviezen van Prakke, L., "Bedenkingen tegen het toetsingsrecht", Koopmans, T., "Constitutionele toetsing" en Barendrecht, J.M., "Het constitutionele toetsingsrecht van de rechter" in Handelingen Nederlandse JuristenVereniging; Bloembergen, A.R., "Rechtsvorming door de rechter", pp. 494-496; Brenninkmeijer, A.F.M., "Constitutionele toetsing als vraagstuk van constitutioneel recht", pp. 721-725; Dölle, A.H.M., "De prijs voor afschaffing van het toetsingsverbod is nog te hoog", pp. 13-15; Dornmering, E.J., "Wetgevingsonrecht en wetsprekende rechters", pp. 2-9; Dölle, A.H.M. en Engels, J.W.M., Constitutionele rechtspraak; Engels, J.W.M., "Toetsing van de wet: rechter naast wetgever", pp. 5-7; Hirsch Ballin, E.M.H. en Houten, M.L.P. van, "Toetsing van wetgeving: sluitstuk van de democratische rechtsstaat", pp. 19-26; Stroink, F.A.M., De plaats van de rechter in het staatsbestel.

21 Ondanks het toetsingsverbod zijn er procedures tegen de overheid bekend waar de 
De uitwerking van de horizontale werking is een kwestie van interpretatie ran de grondrechtbepalingen ${ }^{23}$, waarbij in elk afzonderlijk geval zal moeten vorden uitgemaakt of, en zo ja in welke mate, horizontale werking moet vorden aangenomen. ${ }^{24}$ De interpretatie van grondrechten in horizontale verhoudinger vindt vooral plaats in het kader van de strafrechtspraak ${ }^{25}$ en via privaatrechtelijke begippen als maatschappelijke zorgvuldigheid en redelijkheid en billijkheid. ${ }^{26}$ Ondanks de rol die ze binnen het strafrecht spelen, vallen ze buiten het bestek van dit boek daaruit dit soort bepalingen geen zelfstandige strafbaarstellingen voortvloeien.

Daarnaast is ook een categorie zorgplichtbepalingen te onderscheiden die eel taak toebedelen aan een overheidsorgaan, een burger of een organisatie. Een voorbeed van een dergelijke zorgplichtbepaling is artikel 10.11 , eerste lid $\mathrm{Wm}$, dat bepaalt dat elke gemeente er zorg voor draagt, al dan niet in samenwerking met andere gerneenten, dat ten minste eenmal per week de huishoudelijke afvalstoffen -grove huishouclijke afvalstoffen daaronder niet begrepen- worden ingezameld bij elk binnen haar grondgebied gelegen perceel waar zodanige afvalstoffen geregeld kunnen ontstan. ${ }^{27}$ Artikel 3 van de Wet op het hoger beroepsonderwijs is een ander voorbeeld van een taaktoebedelende zorgplichtbepaling. Het legt de taak tot de verzorging van oger beroepsonderwijs op aan de instellingen waarop de wet betrekking heeft, waariij zij dienen bij te dragen aan de ontwikkeling van beroepen waarop het onderwis is gericht, onderzoek kunnen verrichten en overdracht van kennis aan de maatsclappij kunnen bevorderen voor zover dit verband houdt met het onderwijs van de insteling. Dit type zorgplichtbepalingen is (doorgaans) niet strafrechtelijk te handhiven. Hierdoor vallen ook zij, voor zover ze niet voldoen aan de in de vorige paragraaf gegeven definitie, buiten het onderhavig onderzoek.

rechter toetst aan een sociaal grondrechtelijk belang. Dit gebeurde zowel orn de overheid op haar vingers te tikken, alsook om haar optreden te legitimeren. Heringa, A.W., Sociale grondrechten, pp. 274-278 en 143-144 en 288-305.

22 Er zijn verschillende situaties waarin van een horizontale werking van grondrechten kan worden gesproken. Uitgegaan kan worden van de aard van de rechtsverhouding. Van horizontale werking is dan sprake indien de verhouding een privaatrechtelijke is. Daarnaast kan worden uitgegaan van de betrokken rechtssubjecten. Dan wordt gesproken van horizontale werking als bij die verhoudingen geen overheidsorgaan betrokken is. Ongeacht de betekenis van horizontale werking zal de overheid in elke relatie waarin zij tot de burger staat, en derhalve ook in privaatrechtelijke rechtsbetrekkingen, de grondrechten in acht dienen te nemen.

23 Zie ook TK 1975-1976, 13 872, nr. 3, pp. 15-16.

24 Bijlagen bij de MvT, Bijlage II Nader rapport, $T K$ 1975-1976, 13 872, nr. 4, pp. 76-77.

25 Bijlagen bij de MvT, Bijlage I Advies van de Raad van State, TK 1975-1976, 13 872, nr. 4, pp. 57-58.

26 Zie voor horizontale werking van sociale grondrechten bijvoorbeeld Vlemminx, F., Het profiel van sociale grondrechten, pp. 57-64; Heringa, A.W., Sociale grondrechten, pp. 271-274.

27 De minister van VROM spreekt in dit verband over een bijzondere zorgverplichting van de overheid, zie TK 1988-1989, 21 246, A, p. 16. 
Bekend zijn ook de bijzondere zorgplichten, die functionarissen uit hoofde van hun functie in acht moeten nemen ten opzichte van personen tot wie zij in een bepaalde relatie staan ten gevolge van deze functie. Deze zorgplichten worden meestal gebaseerd op algemene privaatrechtelijke bepalingen. Zo heeft bijvoorbeeld een notaris een zorgplicht jegens de bank voor wie hij optreedt om voldoende te onderzoeken of degenen die in naam van de bank optreden daartoe gevolmachtigd zijn. ${ }^{28}$ Voorts rust op iedere bestuurder een zorgplicht om kennelijk onbehoorlijk bestuur te voorkomen en indien dit zich toch heeft voorgedaan, dienen zij benadeling van crediteuren zoveel mogelijk te voorkomen. ${ }^{29}$ Dergelijke zorgplichten zijn vaak niet terug te vinden in zelfstandige bepalingen, maar zijn gevormd in de jurisprudentie en worden meestal privaatrechtelijk gehandhaafd. Hierdoor zullen zij doorgaans niet voldoen aan de definitie van het type zorgplichtbepalingen waarop het onderzoek in dit boek betrekking heeft.

Voorts is een tendens te bespeuren om in het kader van de uitbouw van zelfregulering gebruik te maken van zorgplichtbepalingen. ${ }^{30}$ Dit speelt bijvoorbeeld bij de bedrijfsinterne milieuzorg, waar in bedrijven milieuzorgsystemen worden ingevoerd ${ }^{31}$ die tot doel hebben de opbouw van een adequaat instrumentarium op bedrijfsniveau om de totale milieubelasting van een bedrijf te beheersen en te beperken. ${ }^{32}$ Indien het systeem aan bepaalde vooraf gestelde voorwaarden voldoet, kan het worden gecertificeerd. Het voordeel van de invoering van een dergelijk systeem is onder andere gelegen in de reductie van de handhavingslasten van de overheid. ${ }^{33}$ Het overtreden van een zorgplichtbepaling uit een bedrijfsintern milieuzorgsysteem is tot op heden niet strafrechtelijk handhaafbaar. In toenemende mate is er sprake van normalisatie van

28 HR 24 december 1993, NJ 1994, 303 (Geen onderzoek volmacht).

29 HR 22 december 1993, NJ 1994, 313 (Naheffing voor bestuur BV).

30 Zie over de relatie tussen bedrijfsinterne milieuzorg en zorgplichten Houweling, P., "Zorgplichtbepalingen in de nieuwe art. 8.40 Wm-besluiten", pp. 147-148; Nijenhuis, C.T. en Aalders, M., Naar een flexibele vergunning: koppeling van het milieusorgsysteem aan de milieuvergunning.

31 "Een milieuzorgsysteem kan worden gedefinieerd als de systematische toepassing door het bedrijf van het geheel van voorzieningen, gericht op het inzicht krijgen in, het beheersen van en waar mogelijk beperken van de beïnvloeding van het milieu door de bedrijfsactiviteiten.", zie notitie Milieuzorg, TK 1988-1989, 20 633, nr. 3, p. 18. Zie over de bedrijfsinterne milieuzorgsystemen bijvoorbeeld Aalders, M., "Handhaving en zelfregulering", pp. 47-69; Gestel, R.A.J. van, "Zelfregulering door bedrijfsinterne milieuzorg gaat niet vanzelf", pp. 166-175 en de bijdragen in Wiggers-Rust, L.F. (red.), De flexibele milieuvergunning en bedrijfsinterne milieuzorg.

32 TK 1988-1989, 20633, nr. 2, p. 1.

33 Zie in dit verband ook het debat over de "flexibele vergunning": Backes, Ch., "Legaliteit van een flexibele vergunning", pp. 23-38 en Gestel, R.A.J. van, "Milieuzorg op maat", pp. 26-68. De handhaving van gecertificeerde bedrijven zou grotendeels kunnen worden overgedragen aan de instelling die ook verantwoordelijk is voor de certificering. De overheid kan zijn toezicht dan beperken tot indirecte controle. Zie over de certificatie van bedrijfsinteme milieuzorgsystemen: Gunster, J.W., "Certificatic van milieuzorg", pp. 204-209 en Blomberg, A.B. en Michiels, F.C.M.A., Handhaven met effect, pp. 299 301. 
milieuzorgsystemen. Hierdoor zijin de systemen van verschillende bedrijven beter met elkaar vergelijkbaar en wordt voor bedrijven duidelijker aan welke richtlijnen ze precies moeten voldoen. ${ }^{34}$ Normalisatie blijkt ook uit de Europese eco-auditverordening. ${ }^{35}$ Deze verordening heeft betrekking op de vrijwillige invoering van milieuzorgsystemen door industriële bedrijven in de Europese Unie. ${ }^{36}$ De verordening kent een vaster stramien dan de voornoemde Nederlandse notitie voor bedrijfsinterne milieuzorgsystemen. Het is mogelijk dat in de toekomst in regelgeving op national of communautair niveau zorgplichtbepalingen worden gebruikt bij regulering of nomalisering van milieuzorgsystemen. Het overtreden van een dergelijke zorgplichtbepalingen zou dan op nationaal niveau strafbaar kunnen worden gesteld. ${ }^{37}$ Aangezien dit heden nog niet het geval is, wordt in dit boek verder niet stilgestaan bij deze (speculatieve) mogelijkheid.

Ook kunnen geluiden worden gehoord die de "export" van zorgplichtbepalingen aanbevelen. Op dit moment zijn er geen Europeesrechtelijke zorgplichtbepalingen die strafrechtelijk kunnen worden gehandhaafd. Hiervoor wordt echter wel gepleit door Biezeveld, die zulks voorstelt ten behoeve van harmonisatie van Europese regelgeving op het gebied van het milieurecht. De Nederlandse situatie dient hiervoor als uitgangspunt. Hij stelt voor om de emstige schending van de zorgplicht voor de instandhouding van het milieu en de natuur op EU-niveau strafbaar te stellen. ${ }^{38}$ Deze benadering onderbouwt hij door erop te wijzen dat de lidstaten hebben uitgesproken dat de EU en dus ook de lidstaten een zorgplicht hebben ten opzichte van het milieu. Dit wordt afgeleid uit de oude bepalingen $130 \mathrm{R}$, eerste ${ }^{39}$ en tweede lid ${ }^{40}$ EG-verdrag. ${ }^{41}$

34 Kok, E.H.J., "Bedrijfsinterne milieuzorg", pp. 183-185.

35 Eco-management and audit, Verordening nr. $1836 / 93$ van de Raad van 29 juni 1993 inzake de vrijwillige deelneming van bedrijven uit de industriēle sector aan een communautair milieubeheer- en milieuaudit-systeem. Zie daarover Heuvel, J.H. van den, "Ontwikkelingen in het milieubeleid voor bedrijven", pp. 11-21.

36 Het door de verordening ingevoerde systeem dient voor de beoordeling en de verbetering van de milieu prestatie van industrièle activiteiten, alsmede voor de verstrekking van de nodige informatie daarover aan het publiek. Het doel van het systeem is het bevorderen van continue verbeteringen in de milieu prestatie van bedrijven. Zie hierover Jans, J.H., Sevenster, H.G. en Vedder H.H.B. (red.), Europees milieurecht in Nederland, pp. 476-478; Gille, B., "Milieu-audit in het Decreet Bedrijfsinterne Milieuzorg", pp. 167-191.

37 Zie over de strafrechtelijke handhaving van milieuzorgsystemen Waling, C., "Bedrijfsinterne milieuzorg; De keerzijde van transparantie", pp. 94-99; Biezeveld, G.A., "Handhaving op basis van de flexibele vergunning vanuit strafrechtelijk perspectief", pp. 57-65.

38 Biezeveld, G.A., "Naar een Europces milieustrafrecht", pp. 117-130. Kritischer daarover is Faure, M., "Bedenkingen over de rol van het recht bij grensoverschrijdende milieuverontreiniging", pp. 231-242.

39 Artikel 130R, eerste lid EG-Verdrag luidde: "Het beleid van de Gemeenschap op milieugebied draagt bij tot het nastreven van de volgende doelstellingen: - behoud, bescherming en verbetering van de kwaliteit van het milieu; - bescherming van de gezondheid van de mens;-behoedzaam en rationeel gebruik van natuurlijke hulpbronnen; - bevordering op internationaal vlak van maatregelen om het hoofd te 
De sterke nadruk die, ook blijkens het vijfde Milieuactieprogramma ${ }^{42}$, wordt gelegd op de eigen verantwoordelijkheid van bedrijven en burgers toont volgens Biezeveld aan dat ook zij een dergelijke zorgplicht hebben. Om behalve overheden ook bedrijven en burgers te kunnen aanspreken op hun zorgplicht, stelt hij voor dit zorgplichtbeginsel zodanig te verankeren dat in alle lidstaten tegen emstige schending daarvan bestuursrechtelijk en strafrechtelijk kan worden opgetreden. ${ }^{43}$ Op deze manier wil hij de nationale zorgplichtbepalingen als exportartikel gebruiken. Hoe hij dit zou willen doen, wordt door hem niet besproken. Het is overigens de vraag of, en zo ja in hoeverre, het streven naar uniformiteit en harmonisatie, dan wel intensievere samenwerking, van het strafrecht wenselijk is in Europa. De nationale soevereiniteit van lidstaten komt immers bij uitstek tot uitdrukking op het gebied van het strafrecht, waar de nationale culturele identiteit een prominente rol speelt. Strafrechtelijke problemen hangen ook nauw samen met de maatschappelijke structuur van een land. De mogelijkheden om hier snel en effectief op in te spelen kunnen door de Europese bureaucratie afnemen. ${ }^{44}$ Bovendien lijken de artikelen waarop hij zijn betoog baseert zich niet direct te richten tot de lidstaten ${ }^{45}$, laat staan tot de burgers uit deze lidstaten.

bieden aan regionale of mondiale milieuproblemen."

40 Artikel 130R, tweede lid EG-Verdrag luidde: "De Gemeenschap streeft in haar milieubeleid naar een hoog niveau van bescherming, rekening houdend met de uiteenlopende situaties in de verschillende regio's van de Gemeenschap. Haar beleid berust op het voorzorgbeginsel en het beginsel van preventief handelen, het beginsel dat milieuaantastingen bij voorrang aan de bron dienen te worden bestreden, en het beginsel dat de vervuiler betaalt. De eisen ter zake van milieubescherming moeten in het bepalen en uitvoeren van Gemeenschapsbeleid op andere gebieden worden geĭntegreerd."

41 Deze bepalingen zijn nu te vinden in de artikelen 174, eerste en tweede lid EG-verdrag. Het integratie beginsel uit het tweede lid van artikel $130 \mathrm{R}$ oud EG-verdrag is verplaatst naar artikel 6 EG-verdrag.

42 "Op weg naar duurzame ontwikkeling; een beleidsplan en actieprogramma van de Europese Gemeenschap op het gebied van het milieu en duurzame ontwikkeling", PbEG, nr. C138 van 17 mei 1993.

43 Biezeveld, G.A., "Naar een Europees milieustrafrecht", p. 122.

44 De problematiek van de nationale soevereinitcit van lidstaten binnen de Europese Gemeenschap komt uitgebreid aan de orde in Lefevere, J., "Soevereiniteit: gevaarlijke stof? De rol van soevereiniteitsargumenten bij het totstandkomen van milieuwetgeving in de Europese gemeenschap", pp. 53-74 en in Bekkers, V.J.J.M., Hurk, H.T.P.M. van den en Leenknegt, G. (red.), Subsidiariteit en Europese integratie; Een oude wijsheid in een nieuwe context. Zie voor een bespreking van mogelijkheden en gevaren van het streven naar uniformiteit en harmonisatie van het strafrecht in Europa: Klip, A.H., "Uniestrafrecht is op hol geslagen", pp. 663-670.

45 Dit kan worden afgeleid uit Hof van Justitie EG 14 juli 1994, zaak C-379/92 (Strafzaak tegen M. Peralta). De Advocaat-Generaal stelt: "Ingevolge deze bepalingen kan de Raad onder bepaalde voorwaarden bepalingen (..) op milieugebied (artikel $130 \mathrm{R}$ ) vaststellen. 33. Deze bepalingen kunnen dus in principe geen criterium vormen voor het optreden van de Lid-Staten op deze gebieden. Dit geldt in het bijzonder voor het beginsel van preventief handelen van artikel $130 \mathrm{R}$ van het verdrag". Het Hof stelt: "Anderzijds beperkt artikel $130 \mathrm{R}$ zich ertoe, de algemene doelstelling van de Gemeenschap op milieugebied te omschrijven. De bevoegdheid inzake de te nemen maatregelen komt ingevolge artikel $130 \mathrm{~S}$ toe aan de Raad." 
Het voorstel, om nationale zorgplichtbepalingen te exporteren naar communantair niveau, lijkt dan ook voorbarig, en zal in dit boek niet verder worden besproken. ${ }^{46}$

Voorts kan worden aangevoerd dat veel culpose abstracte gevaarzettingsdelicten zijn aan te merken als zorgplichtbepaling. Culpose abstracte gevaarzettingsdelicten stellen het verwijtbaar uitvoeren (of nalaten) van een bepaalde gedraging strafbaar. ${ }^{47}$ Bovenstaande definitie van zorgplichtbepaling dient echter strikter te worden geïnterpreteerd, zodat alleen die bepalingen eronder vallen die een specifieke zorgplicht opleggen aan de normadressaat.

\subsection{Probleemstelling}

Dit onderzoek heeft zoals werd aangegeven betrekking op de vrij algemeen geformuleerde zorgplichtbepalingen die een bepaalde verantwoordelijkheid var de normadressaat markeren en die strafrechtelijk kunnen worden gehandhaafd. Zij bevatten een algemene verplichting tot het in acht nemen van een bepaalde graad van zorgvuldigheid met het oog op het door de desbetreffende wet te beschermen belang.

Door de algemene formulering van zorgplichtbepalingen kan het betekenisbereik van de betreffende bepaling onduidelijk zijn. Aangezien zij steeds vaker voorkomen en zij in het relatief jonge milieustrafrecht een belangrijke plaats innemen is nader onderzoek naar deze bepalingen gewenst.

\subsection{Afbakening van het onderwerp en methode van onderzoek}

Het onderzoek heeft betrekking op de vraag wie het betekenisbereik van zorgplichtbepalingen en dus de grenzen van de strafrechtelijke aansprakelijkheid vaststelt, op welke manier dat gebeurt, welke knelpunten hierdoor (kunnen) ontstaan en hoe deze kunnen worden verminderd. Met het oog hierop wordt onderzocht wat de algemene vereisten van behoorlijke regelgeving zijn waarmee de instantie die een bepaling invoert rekening moet houden. Voorts worden de voorwaarden voor strafbaarstelling en de invloed daarop van en de consequenties daarvan voor het bestuur en de strafrechter onderzocht. Daarna worden de ontwikkeling van en enkele leerstukken uit respectievelijk het commune, bijzondere, economische en milieustrafrecht in het algemeen en een aantal daarin voorkomende zorgplichtbepalingen in het bijzonder bestudeerd.

De bestudeerde zorgplichtbepalingen zijn over de volle breedte van het strafrecht in formele zin gekozen. Bepalend voor de keuze is geweest dat alle "type" zorgplichtbepalingen met hun specifieke kenmerken en mogelijke problemen aan de

46 Zie Visser, M., "Strafrechtelijke zorgplichtbepalingen over de grens? De strafrechtlijke afdwingbaarheid van zorgplichtbepalingen in België en Nederland", pp. 212-213; Faure, M. en Visser, M., De strafrechtelijke bescherming van het leefmilieu in België, Duitsland en Nederland, pp. 334-335.

47 Zie over abstracte gevaarzettingsdelicten hoofdstuk 1 paragraaf 3.6.2.2. 
orde zouden komen. $\mathrm{Er}$ is gekozen om zowel veel toegepaste als weinig (tot niet) toegepaste bepalingen als voorbeeld de nemen. $\mathrm{Bij}$ de keuze is er rekening mee gehouden dat bepalingen die duidelijk van invloed zijn geweest op de totstandkoming en invulling van andere zorgplichtbepalingen in ieder geval als voorbeeid worden onderzocht, terwijl ook enkele van de onder hun invloed tot stand gekomen zorgplichtbepalingen zijn bestudeerd.

De op basis van dit onderzoek verkregen inzichten worden aangewend bij de toetsing van de bestudeerde zorgplichtbepalingen aan de geformuleerde algemene vereisten van behoorlijke regelgeving. Door deze toetsing zal duidelijk worden waar en waardoor de belangrijkste knelpunten (kunnen) ontstaan bij de toepassing en toepasselijkheid van deze bepalingen. Hierdoor is het mogelijk de inhoud en betekenis van zorgplichtbepalingen te beoordelen. Naar aanleiding hiervan worden aanbevelingen geformuleerd die kunnen bijdragen aan het (ten dele) oplossen van deze knelpunten. Ook kunnen zij behulpzaam zijn bij het voorkomen van het ontstaan van knelpinten bij nieuw in te voeren strafbaarstellingen.

Derhalve is het onderzoek zowel positief als normatief rechtelijk van aard. Het is positief in die zin dat de totstandkoming van zorgplichtbepalingen wordt geanalyseerd en verklaard, en de effecten van het gebruik van zorgplichtbepalingen in het geheel van het strafrechtelijk raamwerk worden angegeven. Het onderzoek is tevens normatief, omdat een theoretisch toetsingskader wordt ontwikkeld en gebruikı, teneinde de bestudeerde zorgplichtbepalingen uit wetgeving in formele zin te beoordelen.

Het onderzoek zal worden uitgevoerd als een desk-research van traditionele aard, waarbij de verschillende onderdelen vanuit juridisch dogmatisch perspectief worden benaderd. De diverse leerstukken en zorgplichtbepalingen worden tevens vanuit een historisch context bestudeerd. Hierdoor worden de door de wetgever gemaakte keuzen duidelijk(er), waardoor de inrichting en vormgeving van het hedendaags strafrecht beter kunnen worden begrepen. Bij dit onderzoek wordt gebruik gemaakt van parlementaire stukken, de jurisprudentie en de doctrine. Er zal een interne rechtsvergelijking worden uitgevoerd teneinde inzicht te krijgen in de belangrijkste knelpunten die (kunnen) ontstaan bij de toepassing en toepasselijkheid van zorgplichtbepalingen. De verworven inzichten worden aangewend bij het formuleren van de aanbevelingen.

Daar waar nodig is gebruik gemaakt van buitenlandse literatuur en internationaal rechtelijke uitspraken. Het onderzoek als zodanig is niet rechtsvergelijkend van aard. Degenen met belangstelling voor rechtsvergelijkende componenten samenhangende met het voorliggende boek verwijs ik gaarne naar het boek De strafrechtelijke bescherming van het leefmilieu in België, Duitsland en Nederland. ${ }^{48}$ Hierin worden zorgplichtbepalingen vanuit rechtsvergelijkend perspectief besproken en vergeleken

48 Faure, M. en Visser, M., De strafrechtelijke bescherming van het leefmilieu in België, Duitsland en Nederland. 
met drie andere modellen van strafbaarstelling uit het milieustrafrecht. De voor dit onderzoek relevante bevindingen uit "dit andere onderzoek" zijn in dit boek verwerkt.

\section{Opbouw van het onderzoek}

\subsection{Inleiding}

Het onderzoek naar zorgplichtbepalingen bestaat uit verschillende onderdelen. Deze onderdelen keren terug in de opbouw van dit boek, aangezien zij zoveel mogeljk in afzonderlijke hoofdstukken aan de orde komen. Hierdoor laten deze zich ook op zichzelf lezen. De in de verschillende hoofdstukken besproken onderwerpen staan onderling in nauw verband, en leiden naar de algemene toetsing in hoofdstuk $10 \mathrm{op}$ basis waarvan in hoofdstuk 11 aanbevelingen worden geformuleerd. In deze parazraaf worden de diverse delen waaruit het onderzoek bestaat kort besproken, waarbij de volgorde van de opbouw van dit boek is aangehouden.

\subsection{Het betekenisbereik van zorglichtbepalingen}

Een gemeenschappelijk kenmerk van de zorgplichtbepalingen is, gezien de defnitie, dat zij in vrij algemene bewoording de plicht in het leven roepen zorg te dragen voor een bepaald rechtsgoed. Zij markeren een bepaalde verantwoordelijkheid vocr de normadressaat, aangezien ze deze verplichten een bepaalde mate van zorg te betrachten voor een bepaald rechtens te beschermen belang.

Bij zorgplichtbepalingen kumnen zich probiemen voordoen bij het vaststellen van de voorwaarden waaronder zij van toepassing zijn. Ten gevolge van de vrij algemene bewoording die wordt gebruikt bij de redactie worden zij ook wel aangeduid als vaag, open of abstract. Wat met deze typeringen wordt bedoeld is vaak niet duidelijk, behalve dan dat zij aangeven dat er onduidelijkheid bestaat ten aanzien van de omstandigheden waarin de zorgplichtbepaling van toepassing is. Vaak worden deze begrippen door elkaar gebnikt, zonder dat de oorzaak van de onduidelijkheid wordt gespecificeerd.

De oorzaak van dergelijke typeringen is gelegen in het gebruik van bepaalde (algemene) termen die deel uitmaken van de delictsomschrijving. Indien de inhoud van deze termen onduidelijk is, ontstaan problemen bij het vaststellen van het betekenisbereik van deze termen. De onduidelijkheid over het betekenisbereik van de termen heeft tot gevolg dat de reikwijdte van de strafbaarstelling ook onduidelijk wordt.

Indien immers de voorwaarden waaraan voldaan moet zijn, wil een bepaalde term toepasselijk zijn, onvoldoende bekend zijn, ontstaat er onduidelijkheid ten aanzien van het toepassingsbereik van de betreffende rechtsregel. Bij het vaststellen of een zorgplichtbepaling in een concreet geval van toepassing is, dient de rechtsregel te 
worden geïnterpreteerd en dienen de feiten van de casus te worden gekwalificeerd. Hierbij spelen de termen van de delictsomschrijving een belangrijke rol.

Er zijn diverse factoren die maken dat het vaststellen van de voorwaarden waaronder zorgplichtbepalingen van toepassing zijn en het bepalen van het betekenisbereik van termen problemen opleveren. Deze factoren dienen eerst theoretisch te worden onderscheiden, zodat zij bij de bespreking van de voorwaarden voor de toepassing van zorgplichtbepalingen op een consequente wijze kunnen worden gehanteerd. Dit theoretisch onderscheid zal worden gemaakt en uitgewerkt in hoofdstuk 2.

\subsection{De wetgever en de algemene vereisten van behoorlijke regelgeving}

Indien de factoren die maken dat het vaststellen van de voorwaarden waaronder zorgplichtbepalingen van toepassing zijn zijn onderscheiden en de daarbij gehanteerde termen zijn uitgewerkt, doet zich de vraag voor welke instantie het toepassingsbereik van zorgplichtbepalingen vaststelt. Het onderzoek naar de vraag wie de inhoud van een strafbaarstelling en dus de grenzen van de strafrechtelijke aansprakelijkheid vaststelt, vergt onderzoek naar de vraag welke actor de reikwijdte van de aansprakelijkheid kan bepalen, uitbreiden of inperken. De verschillende instituties die hier een rol spelen zijn. de wetgever, het bestuur en de rechterlijke macht. $\mathrm{Zij}$ kurnen de (aanvullende) criteria bepalen waaraan moet worden voldaan voordat de voorwaarden van de strafbaarstelling zijn vervuld.

De instantie die de zorgplichtbepaling invoert, bepaalt in eerste instantie de inhoud van de strafbaarstelling. Door het vaststellen van de inhoud van de bepaling worden immers tevens de voorwaarden vastgesteld waaraan een casus moet voldoen wil de rechtsregel toepasselijk zijn. Dit is het geval indien de interpretatie van de rechtsregel overeenkomt met de kwalificatie van de feiten van de casus.

Zorgplichtbepalingen kunnen door verschillende instanties in regelgeving worden opgenomen. De wetgever in formele zin is verantwoordelijk voor zorgplichtbepalingen in wetgeving in formele zin, maar hij kan ook de bevoegdheid creëren voor regelgeving door bestuurlijke organen. Deze zijn dan verantwoordelijk voor de invulling van de aan hen gedelegeerde regelgevende bevoegdheden, en daarmee voor het vaststellen van de voorwaarden voor de toepassing ervan.

De voorwaarden voor de toepassing van een zorgplichtbepaling worden in de eerste plaats bepaald door de instantie die verantwoordelijk is voor de invoering van de strafbaarstelling. Deze kan tevens aanvullende criteria vaststellen, maar dit kan ook gebeuren door andere instanties. Zo kunnen het bestuur, de bestuurs- en de strafrechter aanvullende criteria vaststellen, hetgeen vooral zal gebeuren indien het betekenisbereik niet duidelijk is. Per zorgplichtbepaling kan er verschil zijn in de mate van beïnvloeding door één of meer van deze instanties. Een belangrijke factor in dezen is de plaats die de zorgplichtbepaling inneemt in het systeem van wetgeving. Zo zal de invloed van de wetgever in formele zin groter zijn op zorgplichtbepalingen uit wetten in formele zin, terwijl deze afneemt bij lagere regelgeving. De invloed van het bestuur 
zal daarentegen groter zijn bij het vaststellen van het toepassingsbereik van zorgplichtbepalingen uit lagere regelgeving. En de invloed van de rechter zal groter zijn bij bepalingen waarvan het betekenisbereik onduidelijk is.

Indien de zorgplichtbepaling door de wetgever of het bestuur wordt vastgesteld, en deze ook zelf aanvullende criteria vaststellen die het toepassingsbereik van termen van de bepaling markeren, kan de reikwijdte van de bepaling duidelijk zijn. Deze duidelijkheid kan ook voortkomen uit jurisprudentie. De inhoud van de regelgeving en van de aanvullende criteria dienen zoveel mogelijk tegemoet te komen aan de kwalteitseisen voor wetgeving en de beginselen van behoorlijke regelgeving. Aangezien het schenden van deze zorgplichtbepalingen is strafbaar gesteld, dient tevens zoveel mogelijk te worden tegemoet gekomen aan de criteria voor strafbaarstelling. De veelheid van voorwaarden uit deze drie stelsels (te weten de kwaliteitseisen voor regelgeving, de beginselen van behoorlijke regelgeving, de criteria voor strafbaarstelling) komt de inzichtelijkheid en duidelijkheid van een analyse van regelgeving niet ten goede. Vandaar dat deze stelsels worden gë̈ntegreerd, zodat ze niet elk apart maar in onderlinge samenhang worden beschouwd. Dit leidt in hoofdstuk 3 tot de formulering van vijf algemene vereisten waaraan regelgeving moet voldoen wil zij behoorlijk zijn. Deze vereisten worden gebruikt bij de analyse van zorgplichtbepalingen in hoofdstuk 10 .

\subsection{Het bestuur en voorwaarden voor strafbaarstelling}

De wetgever kan het vaststellen van regelgeving dan wel het bepalen van aanvullende criteria overlaten aan het bestuur. Aangezien het bestuur in het bijzondere strafrecht een grote rol speelt bij het vaststellen van de materiële norm van abstracte gevaarzettingsdelicten, is het wenselijk te onderzoeken in hoeverre het daarbij vrij is strafbaarstellingen en aanvullende criteria te creëren. Dit is temeer van belang angezien het bestuur bij het vaststellen van dergelijke materiële normen in sommige gevallen gebruik blijkt te maken van zorgplichtbepalingen. De vrijheid van het bestuur bij het bepalen van de voorwaarden voor strafbaarstelling wordt besproken in hoofdstuk 4.

\subsection{De rechter en voorwaarden voor strafbaarstelling}

De soort regelgeving waarin de zorgplichtbepaling voorkomt, bepaalt tevens mede welke rechterlijke instantie de bevoegdheid heeft aanvullende criteria vast te stellen. Het is dan de taak van de rechter in een voorliggend geval te bepalen of de voorwaarden van een strafbaarstelling al dan niet van toepassing zijn in het concrete geval. Hierdoor stelt hij in het concrete geval de criteria van de strafbaarstelling vast. Zijn uitspraak kan verder strekken dan het onderhavige geval, waardoor jurisprudentie een kenbron van recht wordt. Deze bron zal aanvullende criteria bevatten voor de regelgeving waarop zij is gebaseerd. Een belangrijke vraag is nu welke rechter bevoegd is deze aanvullende criteria door middel van jurisprudentie te ontwikkelen, en hoever deze bevoegdheid gaat. Dit zal behalve van de door de betrokken partijen gevolgde procedure afhankelijk zijn van de vraag of sprake is van een zorg- 
plichtbepaling uit wetgeving in formele zin, wetgeving in materiële zijn of een beschikking. Deze omstandigheid is bepalend voor de vraag of het toepassingsbereik voornamelijk wordt bepaald door de bestuursrechter dan wel door de strafrechter. Voorts is de plaats van de zorgplichtbepaling in het systeem van wetgeving relevant voor de beantwoording van de vraag aan welke gerechtelijke instantie de zaak ter beoordeling kan worden voorgelegd. De relatie tussen de mogelijkheden voor de rechterlijke macht en de soort regelgeving zal in hoofdstuk 5 worden uitgewerkt.

Zorgplichtbepalingen in strafwetgeving

\subsubsection{Het niveau van regelgeving}

Het onderzoek uit de hoofdstukken 3, 4 en 5 naar welke instantie het betekenisbereik van zorgplichtbepalingen vaststelt, is relevant voor de het onderzoek naar de inhoud van zorgplichtbepalingen in de hoofdstukken $6,7,8$ en 9 . In deze hoofdstukken worden de ontwikkeling van en enkele leerstukken uit respectievelijk het commune, bijzondere, economische en milieustrafrecht in het algemeen en een aantal daarin voorkomende zorgplichtbepalingen in het bijzonder bestudeerd. Hierbij wordt vooral gefocust op de wetgeving in formele zin. Achtereenvolgens worden het commune strafrecht in hoofdstuk 6, het bijzonder strafrecht in hoofdstuk 7, het economisch strafrecht in hoofdstuk 8 en het milieustrafrecht in hoofdstuk 9 bestudeerd. Uit de beschrijvingen van de ontwikkeling van deze gebieden, enkele leerstukken en de in deze gebieden voorkomende zorgplichtbepalingen zal blijken hoe en waarom zij tot stand komen, wat het betekenisbereik ervan is en dat zij geen nieuw of bijzonder verschijnsel zijn.

Zij kunnen op diverse niveaus van regelgeving worden aangetroffen. Zo komen zij voor in wetgeving in formele en in materiële zin en worden zij door het bestuuí gebruikt bij de formulering van beschikkingen, zoals vergunningen. De diverse niveaus van regelgeving waar zorgplichtbepalingen kunnen worden gevonden, worden hier kort aangegeven.

\subsubsection{Wetgeving in formele $z$ in}

Zorgplichtbepalingen kunnen behalve in het commuun strafrecht worden aangetroffen in het bijzondere strafrecht, het economisch strafrecht en het milieustrafrecht. ${ }^{49}$ Een aantal zorgplichtbepalingen uit deze wetgeving in formele zin worden in de hoofdstukken 6, 7, 8 en 9 behandeld. Zij komen relatief veel voor in het milieustrafrecht, en lijken een belangrijke plaats in te nemen bij de verdere ontwikkeling van dit jonge rechtgebied.

Het commuun strafrecht is behalve voor het onderzoek naar de hierin voorkomende: zorgplichtbepalingen, door zijn algemene karakter van belang, voor het gehele: 
strafrecht en de daarin voorkomende zorgplichtbepalingen. ${ }^{50}$ Zo nemen bijvoorbeeld de algemene bepalingen een belangrijke plaats in bij het vaststellen of (al dan niet) sprake is van strafrechtelijke aansprakelijkheid. Hierbij spelen de bepalingen over daderschap en medeplichtigheid een belangrijke rol. Het toepassingsbereil van zorgplichtbepalingen wordt daarnaast beïnvloed door de mogelijke toepasselijkheid van strafuitsluitingsgronden.

\subsubsection{Wetgeving in materiële zin}

Zorgplichtbepalingen kunnen behalve in wetgeving in formele zin ook worden anngetroffen in wetgeving in materiële zin. Indien zij voorkomen in (gemeentelijke, provinciale of waterschaps-) verordeningen zijn de bepalingen uit de Titels I-VIII A. van het eerste boek $\mathrm{Sr}$ involge artikel $91 \mathrm{Sr}$ toepasselijk, tenzij de wet anders bepaalt. ${ }^{51}$

Ook zorgplichtbepalingen uit voorschriften gesteld bij of krachtens bepalingen uit het economisch strafrecht kunnen strafrechtelijk worden gehandhaafd indien dit volgt uit artikel 1 of 1a Wed. Indien zij zijn gebaseerd op een voorschrift uit een bijzondere wet in formele zin (die niet is strafbaar gesteld via de Wed) kan de zorgplichtbepaling ook strafrechtelijk handhaafbaar zijn indien de betreffende wet dit aangeeft.

Dat de groei van het aantal zorgplichtbepalingen in het milieustrafrecht nog niet tot staan is gekomen, blijkt onder meer uit het in het kader van de dereguleringsoperatie omzetten van een aantal milieuvergunningplichten in amvb's ex artikel 8.40, eerste lid Wm. ${ }^{52}$ In deze amvb's wordt veelvuldig gebruik gemaakt van zorgplichtbepalingen. Aangezien 8.40 , eerste lid Wm is aangehaakt aan artikel la Wed is het schenden van deze bepalingen een strafbaar feit. ${ }^{99}$ Het is overigens niet mogelijk de milieuvergunning van installaties die vallen onder de Europese IPPC Richtlijn ${ }^{54}$ te vervangen

$50 \quad$ Zie hoofdstuk 6.

51 Zie ook hoofdstuk 6 paragrafen 2, 3, 4 en 5 en hoofdstuk 9 paragraaf 2.2 .

$52 T K$ 1994-1995, 24 036, nr. 6. De Werkgroep Inrichtingen- en vergunningenbesluit milieubeheer werkgroep heeft een groot aantal voorstellen gedaan die door het kabinet in dit kamerstuk worden onderschreven Het eindrapport van deze werkgroep is als bijlage bijgevoegd. Een samenvatting van de voorstellen van deze werkgroep biedt: Geest, H.J.A.M. van, "Marktwerking, deregulering en wetgevingskwaliteit: forenzen tussen macht en markt", pp. 118-122.

53 Zie over vergunningvervangende- en vangnet-algemene maatregelen van bestuur: Gestel, R.A.J. van en Verschuuren, J.M., "Marktwerking, deregulering en wetgevingskwaliteit ... en de kwaliteit van het milieu?", pp. 157-164; Blomberg, A.B. en Michiels, F.C.M.A., Handhaven met effect, p. 294; Houweling, P., "Zorgplichtbepalingen in de nieuwe art. 8.40 Wm-besluiten", pp. 142-148; Huiberts, W., Verschuuren, J. en Berg, K. van den, Onderzoek naar vangnetregels; X., "Milieuregels voor bedrijven worden vereenvoudigd", pp. 30-31.

54 De IPPC (Integrated Pollution and Prevention Control) Richtlijn werd op 24 september 1996 vastgesteld door de Raad van de Europese Unie, en is op 30 oktober 1996 in werking getreden. De richtlijn is d.d. 10 oktober 1996 gepubliceerd in het $P b E G G \mathrm{~L}$ $257 / 26$. 
door amvb's, bijvoorbeeld op basis van artikel 8.40 , eerste lid Wm, zonder in strijd te komen met deze Richtlijn. ${ }^{55}$

\subsubsection{Beschikkingen}

Niet alleen in wetgeving wordt gebruik gemaakt van zorgplichtbepalingen. Ook het bestuur onderkent het voordeel van deze bepalingen en laat een dergelijke norm soms deel uitmaken van een beschikking, zoals een vergunning of een ontheffing. Het niet naleven van vergunningvoorschriften is doorgaans strafbaar gesteld in de wet in formele zin waarop de beschikking is gebaseerd. Indien deze wet is gekoppeld aan de Wed zal de strafbaarstelling ook moeten blijken uit artikel 1 of 1a Wed. Ook hier is sprake van een toenemend gebruik van zorgplichtbepalingen in het milieurecht. $\mathrm{Zo}$ is er bijvoorbeeld sprake van een toename van de "milieuvergunning op hoofdzaken", waarin vaak zorgplichtbepalingen zijn opgenomen. ${ }^{56}$

Een andere aanwijzing voor deze toename kan worden gevonden in afspraken dan wel overeenkomsten tussen het bestuur (al dan niet in samenwerking met het $\mathrm{OM}$ ) en een bepaalde branche. Deze afspraken of overeenkomsten worden vervolgens gebruikt bij het vaststellen van de inhoud van een beschikking vooi de leden uit deze branche. Uit de gemaakte afspraken kan voortvloeien dat hierbij gebruik zal worden gemaakt van één of meer zorgplichtbepalingen in de vergunning. Een voorbeeld van een dergelijke overeenkomst is de Overeenkomst Uitvoering Milieubeleid tussen het bestuur en de bollenbranche. In deze overeenkomst staat de plicht van de ondernemers tot zorgvuldig handelen bij de uitvoering van gewasbespuiting centraal. Het bestuur en de bollenbranche hebben deze overeenkomst gesloten omdat de reductie van de emissie van bestrijdingsmiddelen onvoldoende is geweest. Met behulp van deze overeenkomst wordt emaar gestreefd in de toekomst beter tegemoet te komen aan de reductie van bestrijdingsmiddelen. De plicht van de ondernemer tot zorgvuldig handelen zou op basis van deze overeenkomst opgenomen moeten worden in de Wvo-vergunning van ondernemers uit de bollenbranche. Het schenden van de zorgplichtbepalingen in Wvovergunningen is involge artikel 26 Wvo jo. la sub 1 Wed strafbaar gesteld.

55 Broek, J.H.G. van den, "Europa op weg naar een integrale milieuvergunning. IPPC in werking getreden", p. 14. Zie in het algemeen over de IPPC-richtlijn Faure, M. en Lefevere, I.G.I., "The Draft Directive on Integrated Pollution Prevention and Control: an Economic Perspective", pp. 112-120.

56 Dit wordt ook bepleit, zie bijvoorbeeld de Circulaire Vergunning op Hoofdzaken/ Vergunning op Maat, Den Haag, 3 juni 1999 van het ministerie van VROM; en Gestel, R.A.J. van en Verschuuren, J.M., Juridische handleiding bedrijfs-interne milieuzorg en vergunning op hoofdzaken, vooral pp. 54-60. Het schenden van de zorgplichtbepalingen in de milieuvergunning op basis van de Wet milieubeheer is involge artikel $18.18 \mathrm{Wm}$ jo. 1a Wed strafbaar gesteld.

57 Zie hierover Groenhuis, P., "Bollenteelt", pp. 23-24. 


\subsubsection{Modellen voor strafbaarstelling}

\subsubsection{Verschillende modellen}

Er zijn in een eerder rechtsvergelijkend onderzoek naar de opbouw en structuur van een zo optimaal mogelijk vormgegeven milieustrafrecht, een viertal modellen voor strafbaarstelling onderscheiden. ${ }^{58}$ Het betreft de abstracte gevaarzettingsdelicten, de concrete gevaarzettingsdelicten, de zelfstandige strafbaarstellingen en de zorgpichtbepalingen. ${ }^{59}$ Hoewel de grenzen tussen de verschillende modellen niet altijd duicelijk zijn te trekken, wordt in deze paragraaf ieder model met zijn specifieke kenmerken kort beschreven. Het voorliggende onderzoek heeft niet zozeer betrekking op het totale systeem van strafbaarstellingen die kunnen worden ingezet bij de bescherming van bepaalde rechtsgoederen, maar focust op één van deze modellen, te weten de zorgplichtbepalingen. In dit onderzoek is de plaats die dit model van strafbaarstellingen inneemt in het systeem wel van belang. Aangezien het niet wenselijk is het onderzoek uit 1999 over te doen, maar het wel van belang is bij de plaatsbepaling en waardering van zorgplichtbepalingen in het systeem van wetgeving, wordt in deze inleiding een korte samenvatting gegeven van de specifieke kenmerken van elk van de vier modellen.

Zorgplichibepalingen kunnen gezien hun specifieke kermerken als één van de vier modelilen worden aangemerkt. Maar daarnaast blijken zij ook tot een van de andere modellen te kunnen worden gerekend. Welk ander model dit is, is echter afhankelijk van de specifieke wetstechnische vormgeving van de betreffende zorgplichtbepaing. Vaak blijken zij echter vanwege hun specifieke kenmerken a-typische representanten van strafbaarstellingen uit het betreffende model. Door gebruik te maken van de modellen is het relatief eenvoudig deze a-typische kenmerken, die in meer of mindere mate voorkomen bij de diverse zorgplichtbepalingen, te herkennen. Indien deze kenmerken worden herkend, is het mogelijk de voor- en nadelen van deze afwijking nauwkeuriger te onderscheiden en een standpunt in te nemen inzake de wenselijkheid van deze afwijking.

Bij de bestudering en de analyse van zorgplichtbepalingen wordt in dit boek verwezen naar de in het onderzoek uit 1999 ontwikkelde indeling, die in deze paragraaf kort wordt samengevat.

58 Overigens kurnen naast deze indeling ook andere modellen worden onderscheiden, bijvootbeeld de krenkingstelicten en de gevolgsdelicten. Zie bijwoorbeeld Heine, G., "Umweltstrafrecht in der Bundesrepublik Deutschland: Entwicklung und gegenwärtiger Stand, Grundprobleme und Altemativen", pp. 67-129.

59 Zie Faure, M. en Visser, M., De strafrechtelijke bescherming van het leefinilieu in België, Duitsland en Nederland. 


\subsubsection{Abstracte gevaarzettingsdelicten}

Het begrip abstracte gevaarzetting verwijst naar het feit dat de strafbaarstelling een gedraging strafbaar stelt zonder dat het eventuele gevolg als voorwaarde voor strafbaarheid is opgenomen. De betreffende gedraging kan weliswaar leiden tot het schenden van een bepaald rechtsgoed, maar het abstracte gevaarzettingsdelict geeft niet aan welke belangen of rechtsgoederen het beoogt te beschermen. ${ }^{60} \mathrm{De}$ strafbaarstelling is doorgaans dan ook niet gericht op een rechtstreekse bescherming van een bepaald rechtsgoed. ${ }^{61}$

In dit model wordt het (bijzonder, economisch en milieu)strafrecht soms beschouwd als supplement van een uitgebreid bestuursrechtelijk netwerk waarbinnen primair de beslissing over de toelaatbare hoeveelheid en kwaliteit van de inbreuk op het beschermde rechtsgoed wordt genomen. Dit doet zich voor indien daar de abstracte gevaarzettingsdelicten via gelede normstellingen worden ingevuld. De materiële inhoud van de strafbaarstelling wordt dan vastgesteld door het bestuur. Het bestuur kan in deze besluiten zorgplichtbepalingen opnemen die zo mede de materiële inhoud bepalen van de strafbaarstelling. ${ }^{62}$

\subsubsection{Concrete gevaarzettingsdelicten}

Bij concrete gevaarzettingsdelicten moet sprake zijn van het ontstaan van een concree! gevaar voor het beschermde rechtsgoed, waardoor ziji zijn gericht op een directe bescherming van dit rechtsgoed. Het concrete gevaar hoeft zich vaak njet te manifesteren, zodat het bewijs van actuele schade vaak niet wordt vereist. Een concrete dreiging van het rechtsgoed volstaat dan. Deze bedreiging of het bereiken van het strafbaar gestelde gevolg moet daarnaast wedlerrechtelijk hebben plaatsgevonden. Zolang de bestuursrechtelijke voorschriften worden nageleefd zal hierdoor normaliter geen strafrechtelijke aansprakelijkheid volgen, aangezien de gedraging niet als wederrechtelijk wordt bestempeld. ${ }^{63}$

De in de volgende paragrafen besproken zelfstandige gevaarzettingsdelicten en zorgplichtbepalingen zijn eventueel ook (afhankelijk van de gehanteerde definitie) aan te merken als concrete gevaarzettingsdelicten. Gezien hun bijzondere kenmerken worden zij hier echter als afzonderlijke modellen besproken.

60 Het OM zal dan ook kunnen volstaan met het stellen en bevijizen van die gedraging. Zie. Remmelink, J., Mr. D. Hazewinkel-Suringa's Inleiding tor de studie van het Nederlandse strafrecht, pp. 96-98.

61 Voorbeelden van dergelijke zorgplichtbepalingen zijn artikel 19, eerste enı derde lid Quarantainewet (zie hoofdstuk 7 paragraaf 3.4.) en artikel 11, aanhef en sub a tot en met f Arbo-wet 1998 (zie hoofdstuk 8 paragraaf 3.2.10.).

62 Zie over deze mogelijkheden van het bestuur hoofd'stuk 4.

63 Zie bijvoorbeeld artikel 10.3 , eerste en tweede lid $\mathrm{Wm}$, indien wordit aangenomen dat het laatste deel van deze bepaling wordt opgevat als bestanddeel, zie hoofdstuk 9 paragraaf 3.4. 


\subsubsection{Zelfstandige gevaarzettingsdelicten}

Indien de wederrechtelijkheidseis zoals vereist bij de concrete gevaarzettingsdelicten niet wordt gesteld, is er sprake van een zelfstandige strafbepaling. Het belangrijkste verschil tussen deze twee manieren van strafbaarstelling is dat bij de zelfstandige gevaarzettingsdelicten strafrechtelijke aansprakelijkheid kan ontstaan, ook indien de bestuursrechtelijke voorschriften werden nageleefd.

De wetgever die het mogelijk wil maken bepaalde ernstige vormen van bedreiging van een bepaald rechtsgoed strafrechtelijk te sanctioneren, zelfs indien sprake is van handelen conform een bestuursrechtelijke regeling of beschikking, staat onvermijdelijk voor de vraag welke gevallen van bedreiging van het betreffende rechtsgoed als zodanig ernstig moeten worden beschouwd dat de "administratieve afhankelijkheid" dient te worden doorbroken. ${ }^{64} \mathrm{Hij}$ zal in algemene termen de grenzen moeten aangeven van vaak toekomstige bestuursrechtelijke regelgeving en beschikkingen De vraag of de wetgever een keuze voor deze bepalingen maakt is in sterke mate van. rechtspolitieke aard. In het algemeen blijkt de wetgever, indien hij gebruik maakt van. dit model van strafbaarstelling, ervoor te kiezen een zelfstandige bescherming te bieden aan het rechtsgoed menselijke gezondheid dan wel menselijk leven. ${ }^{65}$

In dit model is een (potentieel) schadeverwekkende handeling een voorwaarde voor het ontstaan van strafrechtelijke aansprakelijkheid. Vereist wordt dat er een concreet gevaar voor het beschermde rechtsgoed optreedt, dat wordt teweeggebracht door een bepaalde gedraging. ${ }^{66}$ Teneinde de vraag te kunnen beantwoorden of de straftaarstellingen uit dit model inderdaad zijn gericht op de sanctionering van schadeverwekkend gedrag is het aangewezen stil te staan bij de specifieke voorwaarden voor strafbaarheid, de bestanddelen dus. Het is mogelijk een zorgplichtbepaling zodanig samen te stellen dat hij is aan te merken als zelfstandige strafbaarstelling. ${ }^{6}$

\subsubsection{Zorgplichtbepalingen}

In dit model gaat het om zorgplichtbepalingen die voldoen aan de in hoofdstuk 1 paragraaf 2.2. gegeven definitie van zorgplichtbepalingen. Het gaat dus om die bepalingen die een vrij algemeen geformuleerde (zorg)verplichting bevatten voor de normadressaat en die strafrechtelijk kan worden gehandhaafd. Zij bevat een algemene verplichting tot het in acht nemen van een bepaalde graad van zorgvuldigheid met het oog op het door de desbetreffende wet te beschermen belang, en kan zowel betrekking hebben op een handelen als een nalaten van de normadressaat.

64 Zie over aḍministratieve afhankelijkheid hoofdstuk 4 paragraaf 4.

65 Zie bijvoorbeeld het zelfstandige gevaarzettingsdelict \& $330 \mathrm{a}$ StGB, dat als een "Personenschutzdelikt" wordt beschouwd, zie Kloepfer, M. en Vierhaus, H.P., Umweltstrafrecht, p. 123.

66 Kloepfer, M. en Vierhaus, H.P., Umweltstrafrecht, pp. 123-124.

67 De meeste zorgplichtbepalingen zijn vormgegeven als concreet gevaarzettingsdelict zonder dat het bestanddeel wederrechtelijk er deel van uitmaakt. 
Zoals uit de bespreking van de andere modellen duidelijk is geworden kunnen zorgplichtbepalingen behalve als een zelfstandig model ook worden aangemerkt als abstract gevaarzettingsdelict, als concreet gevaarzettingsdelict, of als zelfstandig gevaarzettingsdelict. Tot welk model een bepaalde zorgplichtbepaling kan worden. gerekend is afhankelijk van de specifieke wetstechnische vormgeving van de betreffende zorgplichtbepaling. Dit zal in hoofdstuk 10 paragraaf 2.4. worden uitgewerkt voor de in de hoofdstukken $6,7,8$ en 9 besproken zorgplichtbepalingen.

\subsubsection{Functies van zorgplichtbepalingen}

Door de wetgever en in de doctrine worden diverse redenen naar voren geschoven voor het gebruik van zorgplichtbepalingen. Geargumenteerd wordt onder andere dat zij als een vangnet kunnen functioneren omdat een specifieke regulering niet op alle mogelijke feitelijke omstandigheden betrekking kan hebben en de regelgeving bij het ontbreken van een vangnet ten dele ineffectief zou zijn. ${ }^{68}$ Tevens wordt erop gewezen dat de noodzaak dergelijke bepalingen te gebruiken een signaal aan de wetgever kan geven dat bepaalde feitenconstellaties in de toekomst door meer specifieke wetgeving zullen moeten worden gereguleerd. ${ }^{69}$ Daarnaast wordt gesteld dat zorgplichtbepalingen in wetgeving noodzakelijk zijn omdat specifieke regels die op welbepaalde feitelijke omstandigheden van toepassing zijn, niet altijd kunnen worden geformuleerd. Dit kan te maken hebben met het feit dat het onderwerp van de regulering te complex is en/ of dat dit onderhevig is aan snelle wijziging zodat een gedetailleerde wettelijke regulering niet mogelijk is, terwijl een regulering van de problematiek toch noodzakelijk lijkt. ${ }^{\text {to }}$ Zij worden dan onvermijdelijk geacht, waarbij het gebruik door de wetgever van deze bepalingen wordt beschouwd als een blijk van legislatieve onmacht. ${ }^{71}$ Bovendien wordt aangevoerd dat het gebruik van zorgplichtbepalingen in de wetgeving een

68 Advies van de Commissie voor de Toetsing van Wetgevingsprojecten inzake zorgplichtbepalingen, pp. 5-6; een samenvatting van dit advies is terug te vinden in het Jaarverslag van de Commissie voor de Toetsing van Wetgevingsprojecten over het jaar 1989-1990, TK 1990-1991, 21800 VI, nr. 24, pp. 33-36; Bastmeijer, C.J., "De algemene zorgplicht in de Wet Milieubeheer", pp. 469-474 en Hendriks L.E.M., "De Hoge Raad en artikel 14 Wbb", pp. 143-144. Dresden benadrukt de aanvullende functie van de zorgplicht, zie Dresden, M.J., "De zorgplicht in de milieuwetgeving", pp. 50-67, en ook de minister stelt dit bij de behandeling van artikel 10.3 Wm, zie TK 1991-1992, 21 246, nr. 5 , p. 33 .

69 Zie de minister bij de behandeling van $10.3 \mathrm{Wm}, T K 1988-1989,21246, \mathrm{nr} .3$, p. 31. Zie ook algemener, het Advies van de Commissie voor de Toetsing van Wetgevingsprojecten inzake zorgplichtbepalingen, p. 6.

70 Zie Hart, H.L.A., The Concept of Law, p. 131, die stelt: "Sometimes the sphere to be legally controlled is recognized from the start as one in which the features of individual cases will vary so much in socially important but unpredictable respects, that uniform rules to be applied from case to case without further offical direction cannot usefully be framed by the legislature in advance".

71 Zie bijvoorbeeld Remmelink, J., Hoofdwegen door het verkeersrecht, pp. 33-34 en Beckers, W.J.G.M., "Artikel 25 WVW, een blijk van legislatieve onmacht", p. 212. Zie ook TK 1988-1989, 21 256, A, pp. 4-5, en dat dit geen vrijblijvende waarschuwing is wordt onderstreept in TK 1988-1989, 21 246, A, p. 4. 
bijzonder verantwoordelijkheidsgevoel zal meebrengen voor justitiabelen ten aanzien van het beschermde rechtsgoed. ${ }^{72}$ Gesteld wordt dat wanneer dit verantwoordelijkheidsgevoel ook door sancties kan worden afgedwongen ingeval van een schending van de betreffende zorgplicht, zulks ook een preventief effect zal sorteren. ${ }^{73}$ Ook wordt een derogerende functie gezien voor deze bepalingen, omdat het in een stelsel met verfijnde (verbods)wetgeving soms onder omstandigheden noodzakelijk kan zijn een bepaling te overtreden ten einde het door de wetgeving beschermde belang te dienen. Dan kunnen zorgplichtbepalingen waarin het te beschermen belang in algemene zin is neergelegd derogeren aan deze bepalingen en zodoende als bijzondere strafuitsluitingsgrond functioneren. ${ }^{74}$

Deze argumenten zijn overigens niet zozeer bedoeld om het gebruik van zorgplichtbepalingen te rechtvaardigen, maar eerder om het te verklaren. Zo beantwoorden zij bijvoorbeeld niet de vraag of deze bepalingen ook strafrechtelijk dienen te worden gehandhaafd. Zij komen daar waar zij een rol hebben gespeeld bij de totstandkoming en interpretatie aan de orde in de hoofdstukken 6, 7, 8 en 9.

\subsection{Zorgplichtbepalingen en de algemene vereisten van behoorlijke strafbaarstelling}

In hoofdstuk 10 worden de zorgplichtbepalingen die zijn bestudeerd in de hoofdstukken 6, 7, 8 en 9 getoetst aan de in hoofdstuk 3 ontwikkelde algemene vereisten van behoorlijke regelgeving. Hierbij wordt gebruik gemaakt van het in hoofdstuk 2 ontwikkelde terminologisch kader en van de in de hoofdstukken 4 en 5 onderzochte verhouding tussen het bestuur en de rechter tot deze bepalingen. Door deze toetsing zal duidelijk worden waar en waardoor knelpunten (kunnen) ontstaan bij de toepassing en toepasselijkheid van zorgplichtbepalingen. In hoofdstuk 11 worden op basis van de bevindingen uit dit onderzoek 34 concrete aanbevelingen geformuleerd die kunnen bijdragen aan het (ten dele) oplossen van deze knelpunten.

\section{Plan van aanpak}

Nadat in dit hoofdstuk duidelijk is geworden op welke typen zorgplichtbepalingen dit onderzoek betrekking heeft, wat de voor dit onderzoek gehanteerde probleemstelling is en hoe het onderzoek is opgezet, worden in hoofdstuk 2 eerst de diverse factoren theoretisch onderscheiden die bepalend zijn voor het vaststellen van het betekenisbereik van termen en aldus voor de voorwaarden waaronder (zorgplicht)bepalingen van toepassing zijn. In de hoofdstukken 3, 4 en 5 wordt onderzocht welke instantie dit

72 Zie bijvoorbeeld TK 1988-1989, 21 246, nr. 3, p. 29.

73 Zie het Advies van de Commissie voor de Toetsing van Wetgevingsprojecten inzake zorgplichtbepalingen, pp. 5-6. Bastmeijer, C.J., "De algemene zorgplicht in de Wet Milieubeheer", pp. 469 en 474-475. Zie ook TK 1988-1989, 21 246, nr. 3, p. 30.

74 Advies van de Commissie voor de Toetsing van Wetgevingsprojecten inzake zorgplichtbepalingen, p. 6. 
betekenisbereik van strafbaarstellingen vaststelt. In hoofdstuk 3 ligt de nadruk op de wetgever en worden de algemene vereisten van behoorlijke regelgeving geformuleerd. In hoofdstuk 4 wordt de verhouding tussen het bestuur en de voorwaarden voor strafbaarstelling besproken. In hoofdstuk 5 staat de rechter centraal, waarbij de nadruk ligt op de bespreking van zijn verhouding ten opzichte van de voorwaarden voor strafbaarstelling. In de hierop volgende hoofdstukken wordt de ontwikkeling van verschillende gebieden van het strafrecht en enkele algemene leerstukken besproken. Bij elk van deze gebieden worden enkele daarin voorkomende zorgplichtbepalingen die zijn opgenomen in wetgeving in formele zin onderzocht. Hierbij wordt ingegaan op de historische ontwikkeling, de plaats in het systeem van wetgeving en het betekenisbereik van deze zorgplichtbepalingen. Achtereenvolgens komen aan de orde het commuun (hoofdstuk 6), het bijzonder (hoofdstuk 7), het economisch (hoofdstuk 8) en het milieustrafrecht (hoofdstuk 9). In hoofdstuk 10 worden zorgplichtbepalingen in hun algemeenheid getoetst aan de in hoofdstuk 3 vastgestelde algemene vereisten van behoorlijke regelgeving. Op basis van de in dit onderzoek geconstateerde knelpunten worden in hoofdstuk 11 aanbevelingen geformuleerd die kunnen bijdragen aan het verminderen van deze knelpunten. 



\section{Voorwaarden voor de toepassing van strafbaarstellingen}

\section{Inleiding}

Zorgplichtbepalingen verplichten de normadressaat een zekere mate van zorgvuldigheid te betrachten ten aanzien van een bepaald rechtsgoed. Indien de normadressaat hieraan niet voldoet wordt de schending bedreigd met een bepaalde strafrechtelijke sanctie. Omdat het vaststellen van het betekenisbereik van zorgplichtbepalingen problematisch kan zijn, is het vaak niet duidelijk onder welke omstandigheden de zorgplichtbepaling wordt geschonden. Problemen betreffende het vaststellen van het betekenisbereik van rechtsregels kunnen verschillende oorzaken hebben. Om hier inzicht in te krijgen worden in dit hoofdstuk ${ }^{1}$ eerst de belangrijkste factoren die de voorwaarden van regeltoepassing bepalen besproken.

Juridische beslissingen in concrete gevallen worden in het strafrecht gebaseerd op rechtsregels. De problematiek van rechtsvinding en rechtsvorming heeft dan ook vaak betrekking op de vraag wanneer rechtsregels moeten worden toegepast. Deze problematiek hangt sterk samen met die van "vage normen".

Zorgplichtbepalingen worden regelmatig aangeduid als vaag, open of abstract. Wat hiermee wordt bedoeld is niet zonder meer duidelijk. Aangezien de betekenis van deze begrippen niet helder is, is het moeilijk vast te stellen of een dergelijke kwalificatie al dan niet terecht is gegeven. De reden om een delictsomschrijving op deze manier aan te duiden blijkt te zijn gelegen in één of meer termen die deel uitmaken van de bepaiing. Daar een term geen bestanddeel behoeft te zijn ${ }^{2}$, wordt in dit hoofdstuk het begrip term gehanteerd om een woord aan te duiden dat deel uitnaakt van een bepaling. Er kunnen verschillende oorzaken aanwezig zijn die maken dat het betekenisbereik van een term onduidelijk is. In dit hoofdstuk zal op basis van rechtstheoretisch onderzoek een onderscheid worden gepresenteerd van deze oorzaken waarbij tevens terminologische duidelijkheid wordt geschept.

Teneinde de problematiek van "vage normen" te analyseren zal worden ingegaan op de toepasselijkheid en de toepassing van rechtsregels (hoofdstuk 2 paragraaf 2). Bij het vaststellen of een rechtsregel in een concreet geval van toepassing is, dient de rechtsregel te worden geïnterpreteerd en de feiten vañ de casus gekwalificeerd (hoofdstuk 2

1 Dit hoofdstuk is gedeeltelijk gebaseerd op Visser, M. en Hage, J., "Voorwaarden var, regeltoepassing".

2 Zie over de vraag of een term bestanddeel of strafuitsluitingsgrond is hoofdstuk 4 paragraaf 6. 
paragraaf 3). Deze twee elementen worden achtereenvolgens besproken, waarbij eerst wordt ingegaan op interpretatie (hoofdstuk 2 paragraaf 4) en daarna op kwalificatie (hoofdstuk 2 paragraaf 5). Onduidelijkheid met betrekking tot het toepassingsbereik wordt vaak veroorzaakt doordat de betekenis van de termen die van toepassing moeten zijn onvoldoende bekend is. Dit is gedeeltelijk onvermijdelijk omdat delictsomschrijvingen, maar ook recht in het algemeen, gebruik maken van taal. Hierom zal worden ingegaan de samenhang van recht en taal en de consequenties daarvan (hoofdstuk 2 paragraaf 5.2.). Vervolgens wordt een korte uiteenzetting gegeven van de verschillende theorieën die kunnen worden gebruikt om de betekenis van termen te achterhalen (hoofdstuk 2 paragraaf 5.3.). Met behulp hiervan zal een systematische opsomming worden gepresenteerd van verschillende verschijnselen die vaak onder de noemer van "vaagheid" van een term of regel worden gebracht, en die maken dat het toepassingsbereik van rechtsregels voor betwisting vatbaar kan zijn. Hier worden onder ander de betekenissen van de kwalificaties vaag, open en abstract besproken (hoofdstuk 2 paragraaf 5.4.). Aan de hand van de gemaakte onderscheidingen wordt aangegeven. welke beslismomenten er zijn bij de vraag of een bepaalde regel moet worden toegepast. Deze factoren worden systematisch onderscheiden, teneinde de bespreking en analyse van zorgplichtbepalingen in volgende hoofdstukken een duidelijker grosdslag te bieden.

Het is niet de bedoeling in dit hoofdstuk een uitspraak te doen over de knelpunten van. zorgplichtbepalingen in het strafrecht, noch om bruikbare handvatten te geven voor juridische besluitvorming. Daarvoor zijn namelijk naast de onderhavige rechtsnorm. aanvullende beslissingen nodig. Wel wordt inzicht geboden in de soort van besluitvorming die nodig is in de verschillende gevallen. In zoverre is het hier aangeboden theoretisch kader van belang voor volgende hoofdstukken.

\section{2.}

\section{Toepasselijkheid en toepassing van rechtsregels}

\subsection{Toepasselijkheid en toepassing}

Het redeneren met behulp van rechtsregels wordt traditioneel voorgesteld als een syllogisme, waarbij de rechtsregel de major vormt van de redenering en de feiten van het concrete geval de minor. Als de feiten voldoen aan de voorwaarden van de regel treedt het rechtsgevolg in en anders niet. ${ }^{3}$ De problemen van de rechtstoepassing worden dan "opgehangen" aan de formulering van de regel, de interpretatie van de regel en aan de classificatie van de feiten.

Dit model voldoet voor het merendeel van de rechtsbeslissingen, zij het dat het weinig zicht biedt op de complicaties van juridische besluitvorming. Een veel voorkomende moeilijkheid is om in de minor de juridisch relevante factoren te vinden, opdat een

3 Vergelijk Nieuwenhuis, J.H., "Legitimatie en heuristiek van het rechterlijk oordeel", pp. 494-515 en MacCormick, D.N., Legal Reasoning and Legal Theory. 
verantwoorde rubricering onder de major mogelijk wordt. ${ }^{4}$ De complicaties van de besluitvorming worden vaak "weggestopt" in de premissen van de redenering. Toch zijn er ook gevallen waarin het syllogistische model in het geheel niet voldoet, bijvoorbeeld als zich een uitzondering op een regel voordoet. ${ }^{5}$ Om zicht te krijgen op deze gevallen wordt een technische onderscheiding geïntroduceerd, namelijk die tussen de toepasselijkheid van een rechtsregel en de toepassing ervan.

Een rechtsregel is in een bepaald geval toepasselijk, indien de feiten van dat geval voldoen aan de voorwaarden van die regel. Of een regel in een concreet geval toepasselijk is, kan voorwerp zijn van discussie. De factoren die daarbij een rol spelen worden besproken in de paragrafen 3,4 en 5 .

\subsection{Niet toepasselijk, wel toegepast?}

Als een regel in een concreet geval niet toepasselijk is, zal hij normaliter niet op dat geval worden toegepast. Toch is het in uitzonderlijke gevallen denkbaar dat een regel toch wordt toegepast, ook al is hij strikt genomen niet toepasselijk. In dergelijke gevallen wordt gesproken van analoge toepassing van de regel. De regel wordt dan toegepast op een geval dat (sterke) gelijkenis vertoont met gevallen waarop de regel wel toepasselijk is.

In het Nederlandse strafrecht wordt de mogelijkheid om strafbepalingen analogisch toe te passen afgewezen. ${ }^{6}$ Ondanks, deze afwijzing heeft de Hoge Raad in enkele arresten gebruik gemaakt van analoge regeltoepassing. De regel werd dan uitgelegd buiten het betekenisbereik dat wordt gevormd door de bestanddelen van de strafbaarstelling. Indien dat gebeurt wordt een nieuwe regel en zodoende nieuw recht ontwikkeld, geformuleerd en toegepast. De nieuwe regels zijn tot stand gekomen binnen de grondgedachte, respectievelijk de ratio, van de niet toepasselijke bepaling. ${ }^{7}$ Analoge regeltoepassing speelt daarom wel een (kleine) rol in het strafrecht. Indien het niet gaat om de strafbaarheid maar om de strafuitsluiting stuit het gebruik ervan op minder bezwaren. Door de uitbreiding van de strafuitsluitingsgronden wordt de rechtszekerheid

4 Zie ook Remmelink, J., Mr. D. Hazewinkel-Suringa's Inleiding tot de studie van het Nederlandse strafrechr, p. 68.

5 Uitzonderingen op regels komen uitvoeriger aan de orde in hoofdstuk 2 paragraaf 7.

6 Dit volgt ook uit artikel $1 \mathrm{Sr}$ en 6 EVRM. Overigens is analoge toepassing van regels niet alijijd afgewezen. Het verbod is niet via nationale wetgeving maar alieen via het EVRM van toepassing in Enigeland en gold bijvoorbeeld niet in Duitsland fussen 1935 en 1945, in Nederland tussen 1943 en 1945, in Rusland tussen 1926 en 1958. Hiervan werd niet alleen misbruik gemaakt zoals gedurende de nazi-tijd, maar werd ook verdedigd vanuit de idee om zo tot reëlere en cerlijker strafrechtstoepassing te komen. Zie bijvoorbeeld Pompe, W.P.J., "Verruiming van de toepasselijkheid van wettelijke strafbepalingen", pp. 105-116; Binsbergen, W.C. van, "Analogische uitbreiding van strafbepalingen in het licht der rechtsgeschiedenis", pp. 36-54.

7 Zie Remmelink, J., Mr. D. Hazewinkel-Suringa's Inleiding tot de studie van het Nedierlandse strafrecht, pp. 488-489. 
van met name de verdachte ${ }^{8}$, één van de redenen om vast te houden aan het anapgieverbod $^{3}$, niet aangetast. Door deze toepassing worden uitzonderingen op de hoofcregel gecreëerd, waardoor het mogelijk wordt te strikte toepassing van de strafbepalipg te voorkomen indien dit zou leiden tot onrecht. De aanname van de buitenwettlijke schulduitsluitingsgrond "geen straf zonder schuld"10 is een duidelijk voorbeelc van analoge regeltoepassing. Een beroep hierop ingeval de verdachte wordt veriolgd wegens schending van een zorgplichtbepaling heeft, gezien de vereisten van dit type strafbaarstelling meestal niet veel kans van slagen. ${ }^{1}$ In een aantal gevallen is jet al voldoende indien kan worden aangetoond dat de verdachte "redelijkerwijs had kvanen weten" dat mogelijk schade aan het door de bepaling beschermde rechtsgoed zou kunnen ontstaan.

Tevens wordt de analogiegedachte gevonden bij het rubriceren van de minor onder de major. De rechter zal voor een nieuw geval zoeken naar gelijkenissen bij eedere casus. Hierdoor kunnen bij de beoordeling van een casus andere verwante casus worden betrokken. Indien een regel die toepasselijk is voor een bepaald geval, ook van toepassing wordt verklaard op gevallen die ook onder de regel kunnen werden gebracht is er geen sprake van analoge regeltoepassing. Wel wordt bij het zoekennaar de rubricering gebruik gemaakt van de analogiegedachte. De argumenten die de leuze voor een bepaalde interpretatiemethode onderbouwen kunnen echter ook inhoude 1 dat een regel dient te worden toegepast op een geval waarvoor deze niet toepasselijk is. ${ }^{13}$ In dat geval zal deze benadering leiden tot analoge regeltoepassing.

8 Zie over rechtszekerheid vooral hoofdstuk 3 paragrafen 5.4.4. en 8.4. en hoofdstuk 10 paragraaf 3 . Ook wordt hierdoor tegemoet gekomen aan het beginsel van individuele rechtsbedeling, zie hierover onder andere hoofdstuk 3 paragraaf 5.4 .5 .

9 Andere redenen zijn: dat de eenheid van rechtspraak behouden blijft dat de wetgeving niet te sterk bij de rechter wordt gelegd; dat de rechter niet ontvankelijker wordt voor emotionele beslissingen; dat de wetsgeschiedenis zich ertegen verzet; dat het volk vertrouwen in de wet stelt; dat het in strijd is met het EVRM. Zie bijvoorbeeld Valk, M.H. van der, De regel nuillum crimen sine lege en het Chinese recht, p. 28; Remmelink, I., Mr. D. Hazewinkel-Suringa's Inleiding toi do studie van het Nederlandse strafrecht, pp. 490-491.

10 Voor het eerste in het fameuze Melk en water-arrest, HR 14 februari 1916, NJ 1916, pp. 681-684. Zie over subjectieve elementen hoofdstuk 3 paragraaf 7.4.4.

11 Zie bijvoorbeeld inzake artikel 13 Bestrijdingsmiddelenwet HR 13 april 1976, NJ 1976, 425 (Vluchtige bijen) en HR 19 januari 1999, NJ 1999, 291 (Vaten op bodem); inzake artikel 7 Veiligheidswet HR 26 april 1983, $N J$ 1983, 689 (Gevaar voor vallende voorwerpen).

12 Indien een beroep op "afwezigheid van alle schuld" niet slaagt, kan de schuld zo gering worden geacht dat geen straf wordt toegepast Zie bijvoorbeeld inzake artikel 7 Veiligheidswet Rb. Assen, 8 december 1972, NJ 1973, 446 (Knellende pers).

13 Zie Remmelink, J., Mr. D. Hazewinkel-Suringa's Inleiding tot de studie van het Nederlandse strafrecht, pp. 68-71. 


\subsection{Wel toepasselijk, niet toegepast?}

Als een regel in een concreet geval toepasselijk is, zal hij normaliter op dat geval worden toegepast en zal het rechtsgevolg van die regel intreden. Toch is het denkbaar dat een toepasselijke regel in een concreet geval niet wordt toegepast, bijvoorbeeld omdat dit in strijd zou zijn met de strekking van de regel, of omdat toetsing aan een grondrecht, een verdrag of een (ander) rechtsbeginsel daartoe aanleiding geeft. Deze gevallen, waarin een uitzondering op de regels wordt gemaakt, worden besproken in hoofdstuk 2 paragraaf 6.

3.

\section{Interpretatie en kwalificatie}

$\mathrm{Bij}$ het vaststellen of een rechtsregel in een concreet geval toepasselijk is, spelen twee kwesties een rol. Aan de ene kant moet de tekst van de regel worden geïnterpreteerd teneinde de betekenis van de regelvoorwaarden vast te stellen. Aan de andere kant moeten de feiten van de casus worden gekwalificeerd om vast te stellen of ze onder de regelvoorwaarden kunnen worden gebracht.

Interpretatie en kwalificatie vormen communicerende vaten. Door interpretatie kunnen de voorwaarden van een regel tot een grote mate van concreetheid worden uitgewerkt. Door kwalificatie kunnen de feiten uit een casus in abstractere termen worden omschreven. De uiteindelijke vraag is of het mogelijk is een gemeenschappelijk niveau van abstractie te vinden waartoe de regel geconcretiseerd en de casus geabstraheeru' kan woruln.

Juist omdat interpretatie en kwalificatie communicerende vaten zijn, is er geen principieel verschil tussen interpretatie zoals hierboven omschreven en kwalificatic. Het enige verschil is het vertrekpunt. Wordt uitgegaan van de regel, dan wordt gesproken van interpretatie; wordt uitgegaan van de casus, dan gaat het om kwalificatie. ${ }^{14} \mathrm{Bij}$ het onderzoek naar het betekenisbereik van zorgplichtbepalingen worden beide methoden gehanteerd.

De interpretatie betreft de betekenis van de te onderscheiden termen die in de voorwaarden van een regel voorkomen. De vraag waar het bij deze interpretatie om gaat is welke casus nog wel en welke casus niet meer onder het bereik van de termen vallen. Deze vorm kan dan ook semantische interpretatie worden genoemd, omdat het gat om het betekenisbereik van bepaalde uitdrukkingen. ${ }^{\text {is }}$

14 Het gaat bij kwalificatie niet altijj om abstrahering. Als een gedraging als onrechımatig wordt gekwalificeerd, gaat het niet om een abstractere omschrijving van die gedraging, maar om een waardering. Bovendien gaat het bij kwalificatie om een concreet geval, terwijl regels, hoe concreet ook geînterpreteerd, universeel blijven. Deze nuanceringen doen echter niet af aan de hoofdlijnen van het in dic tekst gestelde.

15 De semantiek is het resultaat van het onderzoek naar de relaties tussen de tekens van een tekensysteem en datgene wat zij betekenen. Zie Loth, M.A., Recht en taal, 1991, p. 2.1. 
Daarnaast kan een andere vorm van interpretatie worden onderscheiden, namelik die welke op basis van de wettekst tracht te komen tot de precieze voorwaarden van een regel. Artikel 51, eerste lid Sr kan bijvoorbeeld zo worden gelezen dat daarin de regel staat dat enkel natuurlijke en rechtspersonen strafbare feiten kunnen plegen. ${ }^{16}$ In deze lezing zouden bijvoorbeeld verenigingen zonder rechtspersoonlijkheid geen strafbare feiten kunnen plegen. Het artikel kan echter ook zo worden gelezen dat het bepalt dat niet alleen natuurlijke, maar ook rechtspersonen strafbare feiten kunnen plegen. in die laatste lezing zegt het niets over samenwerkingsverbanden zonder rechtspersoonlijkheid. Het kiezen voor één van deze beide lezingen is een kwestie van interpretatie van artikel 51 , eerste lid $\mathrm{Sr}^{17}$, maar het befreft niet de betekenis van één van de $\mathrm{n}$ dat artikel gebruikte bestanddelen, maar veeleer de structuur van de door interpretatie vastgestelde regel. We zouden daarom van syntactische interpretatie kunnen spreken. $^{18}$

Anders dan de uitdrukkingen "semantische interpretatie" en "syntactische interpretatie" misschien suggereren, gaat het bij deze soorten interpretatie niet on wat wel interpretatiemethoden worden genoemd. Deze zogenaamde interpretatiemethoden zijn. veelal soorten argumenten die kunnen worden gebruikt om een bepalde inhoudelijke interpretatie te rechtvaardigen. ${ }^{19}$ Bijvoorbeeld, het feit dat een bepualde interpretatie (of kwalificatie) in overeenstemming is met de bedoelingen van de historische wetgever is een reden om deze interpretatie of kwalificatie te prefereren boven een andere. Juist in het strafrecht neemt de (wets) historische interpreatiemethode een belangrijke plaats in. ${ }^{20}$ Dit is dan ook mede een reden waarom in de hoofdstukken $6,7,8$, en 9 een beschrijving word gegeven van de totstandkoming van diverse zorgplichtbepalingen Hierin kunnen belangrijke aunwijzingen worden gevonden die een rol spelen bij het vaststellen van het betekenisbereik van de betreffende zorgplichtbepaling. Semantische en syntactische interpretatie betreffen niet redenen voor of tegen een bepaalde interpretatie, maar vormen veeleer categorieën van gevallen waarin interpretatie nodig is.

Omdat er twee soorten interpretatie zijn, waarvan er één eigenlijk samenvalt met kwalificatie, wordt de volgende terminologische conventie aangehouden: Als wordt gesproken van interpretatie gaat het steeds om het vaststellen van de precieze voorwaarden en het rechtsgevolg van een regel. Volgens deze conventie is interpretatie

16 Artikel 51, eerste lid Sr luidt: "Strafbare feiten kunnen worden begaan door natuurlijke personen en rechtspersonen." Zie over de strafrechtelijke aansprakelijkheid van rechtspersonen hoofdstuk 6 paragraaf 5 .

17 In het licht van artikel 51 , derde lid $3 \mathrm{Sr}$ verdient de tweede interpretatie duidelijk de voorkeur. Dat illustreert evenwel dat verschillende interpretaties mogelijk zijn op grond van de tekst van het eerste lid.

18 De syntaxis heeft betrekking op de interne relaties tussen de tekens onderling. Zie Loth, M.A., Recht en taal, p. 21; Nuchelmans, G., Overzicht van de analytische wijsbegeerte, p. 405.

Evenzo Alexy, R., Theorie der juristischen Argumentation, p. 301.

20 Zie Remmelink, J., Mr. D. Hazewinkel-Suringa's Inleiding tot de studie van het' Nederlandse strafrecht, pp. 75-76. 
steeds syntactische interpretatie; semantische interpretatie wordt ondergebracht bij de kwalificatie. Interpretatie heeft dan niet zozeer betrekking op rechtsregels, maar op rechtsbronnen. Het is het vaststellen van welke rechtsregels voortvloeien uit de bronnen van het recht. Kwalificatie is het bepalen of een concreet geval, of een soort van gevallen, onder de voorwaarden van een regel valt.

Teneinde vast te kunnen stellen of een concreet geval onder het toepassingsbereik van de regel valt, zal nu worden ingegaan op de vraag naar de interpretatie (hoofdstuk 2 paragraaf 4) en de kwalificatie (hoofdstuk 2 paragraaf 5) in het algemeen. Hierbij in gedachten houdend dat kwalificatie zo ruim dient te worden opgevat dat daaronder ook semantische interpretatie valt.

\section{4.}

\section{Interpretatie}

Bij (syntactische) interpretatie gaat het er om dat de tekst van de regeling wordt geïnterpreteerd teneinde de regelvoorwaarden en het rechtsgevolg vast te stellen. ${ }^{21}$ Het betreft niet de betekenis van één van de in een bepaling gebruikte termen, maar veeleer de vorm en structuur van de door interpretatie vastgestelde regel. Het gaat om de onderlinge verhouding tussen de termen uit een bepaling, maar ook over de plaats die de betreffende bepaling inneemt in het systeem van wetgeving en de onderlinge samenhang van bepalingen.

Interpretatie heeft niet zozeer betrekking op rechtsregels, maar op rechtsbronnen. Het is het vaststellen van weike rechtsregeis voortvloeien uit de bronnen van het recht. Hierdoor vindt identificatie van geldende rechtregels plaats. Rechtsbronnen zijn de wet, het verdrag, de rechtsbeginselen, de rechispraak en de gewoonte. ${ }^{22}$. Voor beantwoording van de vraag of sprake is van een rechtsbron, is uiteindelijk de sociale praktijk beslissend. ${ }^{23}$ Welke rechtsbron in welke omstandigheid prevaleert hangt af van de samenleving waarin het betreffende rechtssysteem geldt. Rechtsbronnen bestaan in Nederland naast elkaar en zijn nauw met elkaar verbonden, waardoor identificatie van rechtsregels plaatsvindt door de verschillende rechtsbronnen in onderlinge samenhang te hanteren.

Interpretatie van een rechtsregel is onder andere geboden indien de wettelijke omschrijving van het strafbare feit voor de materiële norm verwijst naar bestuursrechtelijke regelgeving of omdat in definitiebepalingen de inhoud van

21 De bespreking van de syntactische interpretatie wordt beperkt tot die van rechtsregels. De vorm en structuur van taal bij bijvoorbeeld juridische argumentatie en de rechtsorde vallen buiten het bestek van dit boek.

22 Rechtsbeginselen behoren hier ook toe aangezien identificatie van rechtsrege!s, en dus het achterhalen welk gedragsvoorschrift in de rechtsregel wordt uitgedrukt, pas plaats vindt indien de criteria van een van de andere rechtsbronnen wordt geplaatsit tegen de achtergrond van de fundamentele waarde van ons rechtssysteem. Zie Franken, H., e.a., InLeiden tot de rechtswetenschap, p. 101.

23 Franken, H., e.a., InLeiden tot de rechtswetenschap, pp. 98 en I01-103. 
bestanddelen wordt uitgewerkt. ${ }^{24}$ De interpretatie of deze onderdelen al dan ret als bestanddeel deel uitmaken van de strafbepaling heeft direct gevolgen vor de bewijspositie in het strafproces. ${ }^{25}$ Interpretatie of de bestuurlijke regeling waarnar een strafbaarstelling verwijst is aan te merken als bestanddeel of als gescreven strafuitsluitingsgrond ${ }^{26}$ speelde bijvoorbeeld bij de voorloper van de huidigezorgplichtbepaling uit artikel $10.3 \mathrm{Wm} .{ }^{27}$ Gezien de hoofdregel dat de clausuleringlie in de zin staat die de strafbepaling bevat in het algemeen dient te worden opgeat als bestanddeel ${ }^{28}$, zou de vergunning waarnaar in de delictsomschrijving wordt vevezen zijn aan te merken als bestanddeel van deze zorgplichtbepaling. Of de Hoge Raa deze interpretatie zou hebben gevolgd is onduidelijk gebleven. ${ }^{29}$

Bij de beantwoording van de vraag of al dan niet sprake is van een bestanddeel vorden interpretatiemethoden gebruikt om een bepaalde inhoudelijke interpretatie te echtvaardigen. Bij de beantwoording van deze vraag wordt (meestal) als uitgangspnt de wil van de wetgever genomen. ${ }^{38}$ Deze vraag zal hierdoor per artikel dienen te wrden beantwoord. Doorgaans biedt de redactionele opzet van de bepaling voldende duidelijkheid. De hoofdregel luidt dat wat in de bepaling staat waarin het verbodn feit is omschreven doorgaans dient te worden aangemerkt als bestanddeel. Indien spike is van een strafbepaling waarin de uitzondering is opgenomen in een apart wetsartiel of in een afzonderlijk artikellid, is de uitzondering geen bestanddeel van de dictsomschrijving. Bevat een strafbepaling in één zin zowel het verbod als de uitzonering dan wordt conform de hoofdregel in het algemeen aangenomen dat de uitzonering een bestanddeel uitmaakt van de verbodsbepaling. De hoofdregel geldt niet onvekort. Als het verbod in dezelfde zin nader wordt geclausuleerd, maar toch de overtiging opkomt dat het verbod moet worden beperkt tot bet deel van,dezin,wanrin.bet terbod staat, is nader onderzoek geboden. Op basis van bijvoorbeeld de wetsgeschiedenis, de

24 Deze situatie doet zich soms voor bij delictsomschrijvingen in het bijzondere (milieu)strafrecht.

25 Zie hierover ook hoofdstuk 2 paragraaf 7 "Uitzonderingen op regels" en hoofdstuk 4 paragraaf 6.

26 Zie over deze vraag hoofdstuk 4 paragraaf 6 .

27 Zie hierover hoofdstuk 9 paragraaf 3.4. Artikel 10.3, eerste lid Wm luidde: "Het is een ieder bij wie in de uitoefening van zijn beroep of bedrijf afvalstoffen ontstaan, verboden handelingen met betrekking tot die afvalstoffen te verrichten of na te laten waarvan hij weet of redelijkerwijs had moeten weten dat daardoor nadelige gevolgen voor het milieu ontstaan of kunnen ontstaan. Het verbod geldt niet voor zover het betreft zodanige handelingen die hem bij of krachtens de wet uitdrukkelijk zijn toegestaan."

28 Zie hoofdstuk 4 paragraaf 6.5.

29 Zie HR 23 april 1996, NJ 1996, 512 (Waterschap Westfriesland). Inmiddels is de uitzondering in een aparte zin opgenomen, zie hoofdstuk 9 paragraaf 3.4.4.

30 Zie over de vraag of aanvullende criteria moeten worden aangemerkt als bestanddeel of niet, en de praktische gevolgen van dit verschil hoofdstuk 4 paragraaf 6 . Zie hierover onder andere ook Remmelink, J., Mr. D. Hazewinkel-Suringa's Inleiding tot de studie van het Nederlandse strafrecht, pp. 253-257; Buiting, Th.J.B., Strafrecht en milieu, pp. 45-71; Bemmelen, J.M. van en Veen, Th.W. van, bewerkt door Jong, D.H. de en Knigge, G., Het materiële strafrecht, pp. 52-56; Vellinga, W.H., "Strafwetgeving als techniek van regel en uitzondering", pp. 359-368. 
ratio of het systeem van wetgeving kan de rechter oordelen dat een uitzondering op de hoofdregel moet worden gemaakt. Ook als het hanteren van de hoofdregel in concreto tot onrecht zal leiden, kan er een reden zijn om ervan af te wijken.

Een ander voorbeeld van interpretatie is de vaststelling op welke bestanddelen opzet of schuld betrekking hebben in een delictsomschrijving. Ook het antwoord op deze vraag is relevant voor de bewijsposities in het strafrecht. Het OM zal de opzet of schuld ten aanzien van de bestanddelen waarop ze van toepassing zijn immers dienen te bewijzen. Ook hier zal gebruik worden gemaakt van interpretatiemethoden om een bepaalde inhoudelijke interpretatie te rechtvaardigen. ${ }^{31}$

\section{5.}

Kwaiificatie

\section{1.} Inleiding

Het is vaak voor discussie vatbaar of een casus kan worden gekwalificeerd met een bepaalde term die in de voorwaarden van een rechtsregel wordt genoemd. Deze onduidelijkheid wordt vaak veroorzaakt doordat de betekenis van de termen die de inhoud van de bepaling stipuleren onvoldoende duidelijk is. In dergelijke gevallen wordt die term en soms ook de regel waarin die term voorkomt vaag genoemd. ${ }^{32}$ Het gebruik van dergelijke termen is gedeeltelijk onvermijdelijk omdat bepalingeñ, maar ook recht in het algemeen, gebruik maakt van taal. De samenhang van rechi, taal en de betekenis van taal in het recht wordt eerst besproken (hoofdstuk 2 paragraaf 5.2.) Vervolgens wordt een korte uiteenzetting gegeven van de verschillende betekenistheorieën (hoofdstuk 2 paragraaf 5.3.). Met behulp hiervan zal een onderscheiding worden gepresenteerd van verschillende verschijnselen die vaak onder de noemer van "vaagheid" van een regel worden gebracht (hoofdstuk 2 paragraaf 5.4.). Duidelijk zal worden dat vaagheid in engere zin maar één van de oorzaken is van de vaagheid in ruime zin die de kwalificatie-problemen veroorzaakt. Vaagheid is namelijk geen eenduidig verschijnsel, maar er is een groot aantal verschillende oorzaken aan te wijzen voor de kwalificatie-problematiek.

\subsection{Recht, Taal en Betekenis}

Recht en taal zijn onlosmakelijk met elkaar verbonden, bijvoorbeeld schriftelijk in de vorm van wetten, verdragen, arresten, beschikkingen, maar ook verbaal bij het uitwisselen van argumenten. Hierbij blijkt regelmatig dat niet iedereen dezelfde betekenis toekent aan een bepaalde term. Een belangrijke oorzaak hiervoor is gelegen in het gebruik van taal.

31 Zie voor de interpretatie van opzet en schuld in het algemeen en bij zorgplichtbepalingen hoofdstuk 3 paragraaf 7.4 .

32 Vergelijk bijvoorbeeld Wiarda, G.J., Drie typen van rechtsvinding, p. 47; Barendrecht, J.M. Recht als model van rechtvaardigheid, p. 3 en Vranken, J.B.M., Algemeen deel, p. 36. 
Een belangrijk uitgangspunt in het strafrecht is dat de woorden van de strafbeyaling door de normadressaat (tot wie de bepaling zich richt) redelijkerwijs zjn te begrijpen. ${ }^{33}$ Wil de bepaling voor de betreffende justitiabele duidelijk zijn, dan zal de bepaling zodanig dienen te zijn geformuleerd dat hij hem ook kan begrijpen. Hiervoor is het nodig dat de bepaling zo veel mogelijk in natuurlijke taal is opgestell. De vaagheid van normen wordt echter ook veroorzaakt door het gebruik van de natuurlijke taal, aangezien de betekenis van taal niet is gefixeerd. ${ }^{34}$

Het recht kan echter niet zonder het gebruik van deze taal. ${ }^{35}$ De inhoud van termen uit de wet worden in de eerste plaats ontleend aan het dagelijks spraakgebruik. $\mathrm{h}$ het spraakgebruik is het betekenisbereik van veel termen echter niet eenduidig. Het recht moet bij de toepassing van deze termen een scherpe lijn trekken, en zo van het tegrip iets bijzonders, iets specifiek juridisch maken. Op deze manier vormt het rech zijn eigen begrippen. ${ }^{36}$ Hieruit zal in zekere mate de ontwikkeling van (voor "de burger" minder begrijpelijke) vaktaal voort vloeien, waardoor een spanning kan onstaan tussen wetenschappelijke eenduidigheid (door middel van het gebruik van voor bepaalde groepen mogelijk- onbegrijpelijke vaktaal) en duidelijkheid voor justitiabelen. $^{37}$

De omgangstaal en rechtstaal als vaktaal worden niet in twee verschillende werclden gesproken, maar staan in voortdurende wisselwerking met elkaar en zullen ekaar wederzijds beïnvloeden en gebruiken ${ }^{38}$ Zo zal van de woorden die juridisch gekwalificeerde dingen, verhoudingen, gebeurtenissen en dergelijke betekenen het juridische aspect in de woorden van de omgangstaal implicieter en in de rechstaal explicieter tot uiting worden gebracht. Hierbij kam worden gedacitt aan net gebruik van het woord zaak in de zin van handelsonderneming. In geval van gebruik van woorden die juridisch gekwalificeerde dingen en dergelijke betekenen, zoals bijvoorbeeld

33 Zie hierover in het kader van het legaliteitsbeginsel hoofdstuk 3 paragraaf 7.3.

34 "In all fields of experience, not only that of rules, there is a limit, inherent in the nature of language, to the guidance which general language can provide."; Hart, H.L.A., The concept of law, p. 126.

35 Zie voor voorbeelden en literatuurvenwijzingen van gebruik van taal in het recht: Valkhoff, J., "Nieuwe termen en begrippen in de rechtswetenschap", pp. 61-73.

36 Scholten, P., De structuur der rechtswetenschap, p. 13; later opgenomen in Scholten, P., Verzamelde Geschriften van Mr. Paul Scholten, p. 440. Hij merkte op pagina 19, respectievelijk pagina 445 , op dat recht aan taal is gebonden aangezien de uitlegging der formules, de uitdrukking in taal-tekens een voornaam stuk is der rechtswetenschap. Daarnaast zijn er nog andere oorzaken aan te voeren voor het ontstaan van juridische vaktaal. Zie hierover Leliard, J.D.M., Het kleed van themis, pp. 19-24; Dölle, H., Vom Stil der Rechtsspirache. Podlech merkt op dat de juridische vaktaal waarschijnlijk ook geen cenheid vormt, maar dat er sprake is van verschil in juridische vaktaal tussen de taal in de praktijk en die welke gebruikt wordt in de wetenschap. Podlech, A., "Die juristische Fachsprache und die Uingangssprache", pp. 31-52.

37 Jörg, N., Recht voor militairen, p. 65.

38 Van Eikema Hommes, H.J., De elementaire grondbegrippen der rechtswetenschap, pp. 380-382. Zie over recht als factor in de taal en taal als factor in het recht: Bergh, G.C.J.J. van den, Recht en Taal, pp. 12-15, en over vaktaal en volkstaal pp. 55-56. 
huwelijk of hypotheek, zal de omgangstaal primair of in sterke mate afhankelijk zijn van de betekenissen die deze termen in het dynamisch rechtsvormingsproces verkrijgen.

Rechtstaal kan nooit zo geschakeerd zijn als de taal van het dagelijks leven. ${ }^{39}$ De dynamiek van de natuurlijke taal zal in het algemeen spontaner, soepeler, minder grijpbaar zijn dan die van de rechtsontwikkeling, die meer bedacht, gerationaliseerd en gepreciseerd zal verlopen. ${ }^{40}$ Tevens zal de rechtstaal al bij de introductie verouderd klinken en onvermijdelijk verder verouderen. ${ }^{41}$ Hierdoor kunnen problemen omtrent het betekenisbereik van termen, die ontstaan door het gebruik van natuurlijke taal, nog worden versterkt voor de justitiabelen tot wie de rechtstaal zich richt. Niet alleen kan de betekenis van termen onduidelijk zijn door het gebruik van natuurlijke taal, maar ook omdat de natuurlijke taal slechts in beperkte en verouderde vorm is te vinden in de rechtstaal. Het beperkte gebruik van natuurlijke taal kan, evenals het gebruik van oude en eventueel verouderde taal, aan de andere kant duidelijkheid omtrent het betekenisbereik in de hand werken, omdat wordt begrepen wat wordt bedoeld. Het gebruik van nieuwe en vernieuwde taal kan zodoende ook problemen opleveren, omdat onduidelijk is wat schuil gaat achter de nieuwe termen.

39 Rechtstaal zal zich moet behoeden voor emotionele exclamaties, voor suggestiviteit, voor dichterlijk woordgebruik alsook voor verschillende vormen van een wetenschappelijk ingekleed betoog, aldus van Ven, J.J.M. van der, "Recht spreken, Aantekeningen over recht en taal", pp. 509-510.

40 Rechtstaal is in het algemeen het meest starre, conservatieve deel van de taal, waar als bijna in geen ander taalgebied zoveel staande uitdrukkingen, formules en archaïsmen voorkomen, aldus Bergh, G.C.J.J. van den, Themis en de muzen, p. 125. Zo ook: Ven, J.J.M. van der, "Recht spreken, aantekeningen over recht en taal", p. 513. Deze waarneming heeft betrekking op het huidige gebruik van rechtstaal, die ook afhankelijk is van tijd, plaats en cultuur. Zo werd waarschijnlijk aanvankelijk regelgeving in de vorm van poëzie en pas later in proza doorgegeven, zie Bergh, G.C.J.J. van den, Themis en de muzen, onder andere pp. 99-112; zo ook Scherer, W., Poetik, p. 23. Daarnaast blijkt deze verandering onder andere uit het dichterlijk taalgebruik in het recht ten tijde van de Barok en Rococo en het verschil per land. Zie hierover Triepel, H., Vom Stil des Rechts, pp. 132-133 en 137-141 en Dölle, H., Vom Stil der Rechtssprache, pp. 32-34. Een ander voorbeeld is dat aanvankelijk de rolbeschrijvingen in artikelen vooral in mannelijke vorm werden opgenomen, hetgeen sinds de tweede helft van de twintigste eeuw meestal geslachtsneutraal geschiedt. Zie hierover Schneider, R., "Recht und Sprache", pp. 482-484. De wetgever had de keuze voor gebruik van de mannelijke vorm meestal niet toegelicht. Toen bleek dat vrouwen aan het einde van de negentiende eeuw bepaalde rechten en functies voor zich gingen opeisen (zoals de mogelijkheid zich verkiesbaar te stellen, het uitoefenen van het beroep rechter of notaris), werden vrouwen door de wetgever uitgesloten van deze rechten en functies. Opvallend is dat de in mannelijke vorin opgestelde bepalingen in het Wetboek van Strafrecht door de Hoge Raad wel van toepassing werden verklaard voor vrouwen, zie HR 13 juni 1905, $W$. 1905, 8244 (Vrouwen ook "Hij". Zie ook Schimmel-Bonder, W.G., "Onderscheid naar geslacht in de wetgeving", pp. 179-195.

4 Zie over het veranderen en verouderen van de rechtstaal: Triepel, H., Vom Stil des Rechts, pp. 127-134; Leliard, J.D.M., Het kleed van themis, pp. 23-25. 
De betekenis van termen uit een bepaling is eveneens aan verandering onderhevis. Dit wordt veroorzaakt door de wisselwerking die plaatsvindt tussen de betekenis vin de bepaling en de verandering van omstandigheden en de veranderde tijdsgeest waain zij geldt. De betekenis van de wettelijke bepaling zal vaak anders zijn, en anders beloren te zijn, dan ten tijde waarin zij werd vastgesteld. ${ }^{42}$ Indien de discrepantie tissen hetgeen "er staat" en hetgeen "het betekent" te groot wordt, kan de betekenis vinn de bepaling onduidelijker worden voor de justitiabele. Het is dan ook belangrijk om de formulering tijdig aan te passen aan het veranderende gebruik van de bepling. Daarnaast kan de situatie zich voordoen dat de formulering van de bepaling nog steeds van toepassing is op de oorspronkelijke situaties, maar dat er ook een nieuwe betesenis aan wordt gegeven. Met oog op de duidelijkheid van de bepaling kan het dan wenselijk zijn een nieuwe bepaling te maken die ziet op de nieuwe situatie(s. De bestaande bepaling blijft van toepassing op de situaties waarvoor zij is bedoeld. Onduidelijkheid kan ontstaan als dit wordt nagelaten. Wie denkt bijvoorbeelè aan verduistering ex artikel $322 \mathrm{Sr}$ bij het opzettelijk kopiëren van computerbestandeil van de werkgever voor eigen gebruik ${ }^{43}$, aan valsheid in geschrifte ex artikel $225 \mathrm{Sr}$ bj het manipuleren van computergegevens ${ }^{44}$ of aan heling ex artikel $416 \mathrm{Sr}$ bij het witw:ssen van geld?

Niet ieder gebruik van natuurlijke taal behoeft dezelfde problemen op het gebied van het betekenisbereik te veroorzaken. De kunst is om zoveel mogelijk in natuurlijke taal de delictsomschrijving samen te stellen, waarbij het betekenisbereik van de gebriikte termen voor een ieder zo duidelijk mogelijk is. Belangrijk hierbij is dat tijdig (naar ook weer niet te snel) ertoe wordt overgegaan de gebruikte taal aan te passen a a de

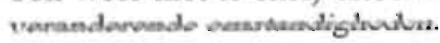

\subsection{Betekenistheorieën}

\subsubsection{Inleiding}

Bij zorgplichtbepalingen kunnen zich problemen voordoen bij het vaststellen van de voorwaarden waaronder zij van toepassing zijn. Ten gevolge van de vrij algemene bewoording die wordt gebruikt bij de redactie worden zij ook wel aangeduid als vaag,

42 Eggens duidt deze omzetting van de betekenis van de wetstekst aan met de term transpositie, zie Eggens, J., Transpositie en conversie, opgenomen in Eggens, J., Verzamelde privaatrechtelijke opstellen, Deel 2, p. 82-102. In navolging hierop: Schoordijk, H.C.F., Oordelen en vooroordelen, p. 66. Zie ook Loefi, J.J., "Enkele opmerkingen aangaande de verhouding van taal en recht", p. 305. Hij bespreekt Schoordijk ter verduidelijking van zijn stelling dat het probleem van de hermeneutiek inherent is aan het zich-rekenschap-geven van het taalfenomeen.

43 Hof Arnhem, 27 oktober 1983, NJ 1984, 80 (Computergegevens). Zie over dit arrest en de daarop volgende discussie Groenhuijsen, M.S. en Wiemans, F.P.E., Van electriciteit naar computercriminaliteit, pp. 81-100; Smits, J.M., "Stelen van computergegevens voortaan strafbaar; Het spook in de kraag gevat?", pp. 33-38.

44 HR 15 januari 1991, $N J$ 1991, 668, met noot Corstens (Rotterdamse conputerfraude). Zie over dit arrest Wiemans, F.P.E., "De Rotterdamse computerfraude", pp. 115-119. 
open of abstract. Wat met deze typeringen wordt bedoeld is vaak niet duidelijk. Ook blijken zij vaak door elkaar te worden gebruikt. Dit ligt vooral aan de (onbewust) gehanteerde betekenistheorie en aan onbekendheid met de betekenis van deze begrippen (binnen deze theorie).

\subsubsection{De Criteriatheorie}

Vaak wordt aangenomen dat het gaat om de betekenis van de kwalificerende term. ${ }^{45}$ Het is niet ongebruikelijk om bij beschrijvende termen zoals zelfstandige en bijvoeglijke naamwoorden en werkwoorden een driedeling te maken. ${ }^{46} \mathrm{Om}$ te beginnen is er de term zelf, een symbool waar nog geen betekenis aan wordt toegekend. De betekenis van de term wordt gevormd door de intensie en de extensie van deze term.

De extensie van een term bestaat uit de verschijnselen die met de term (terecht) kunnen worden aangeduid. De extensie van de term "goed" zoals gebruikt in artikel $310 \mathrm{Sr}$ omvat bijvoorbeeld alle goederen in de zin van artikel $310 \mathrm{Sr}$. Deze goederen worden de extensie van de term "goed" genoemd.

Het verband tussen een term en zijn extensie wordt, volgens een betekenistheorie die vroeger een grote populariteit genoot, gelegd door de intensie van de term. ${ }^{47}$ Deze intensie zou bestaan uit een verzameling eigenschappen, zodanig dat iets dat al die eigenschappen heeft onder de betreffende term valt, en iets dat niet (al) die eigenschappen heeft niet onder die term valt. De omschrijving van een term bestaat uit een opsomming van verschillende elementen. Deze elementen corresponderen met de kenmerken die tezamen de intensie van die term uitmaken. De intensie van een term bestaat derhalve uit een aantal kenmerken die zijn te beschouwen als begripselementen.

De wetgever geeft soms in (derinitie)bepalingen de betekenis van een term aan, door een aantal eigenschappen vast te stellen waaraan moet worden voldaan. Zo wordt de term "weg" uit artikel 5 WVW $^{48}$ in artikel 1, eerste lid sub b WVW omschreven als "alle voor het verkeer openstaande wegen of paden met inbegrip van de daarin liggende bruggen en duikers en de tot die wegen behorende paden en bermen of zijkanten". Een voorbeeld waar de Hoge Raad gebruik maakt van het bepalen van de betekenis van een term door het vaststellen van een aantal eigenschappen is het

Zie bijvoorbeeld Franken, H., e.a., InLeiden tot de rechiswetenschap, pp. 65-91, Loth, M., Recht en Taal, p. 93 e.v. en Zippelius, R, Einführung in die juristische Methodenlehre, p. 51 e.v.

46 Zie bijvoorbeeld Franken, H. (e.a.), InLeiden tot de rechtswetenschap, pp. 68-71 en Loth, Recht en taal, pp. 73-79. Het onderscheid heeft ingang gevonden door het werk van de logicus Frege. Vgl. diens "Über Sinn und Bedeutung", pp. 25-50.

47. Deze theorie vond zijn meest uitvoerige uiteenzetting in Carnap, R. Meaning and Necessity. Hij wordt voor een aantal termen en genuanceerd ook nog verdedigd in Franken, H., e.a., InLeiden tot de rechiswetenschap en Loth, M., Recht en Taal. Zie over deze zorgplichtbepaling hoofdstuk 7 paragrafen 3.2.5. en 3.2.6. 
elektriciteitsarrest. ${ }^{49}$ De intensie van de term "goed" in artikel $310 \mathrm{Sr}$ dient blijens de Hoge Raad (tenminste) de volgende eigenschappen te bevatten: (een goed) an een zeker zelfstandig bestaan niet worden ontzegd, het kan door menselijk toedoerop een zaak worden overgebracht, en zelfs geaccumuleerd worden, het kan door toeden van de mens worden opgewekt c.q. tot stand gebracht en ter beschikking blijen van degene die het opwekte, en het vertegenwoordigt een zekere vermogenswaarde ${ }^{0}$

De eigenschappen in de intensie van een term vormen in deze theorie, lie de Criteriatheorie wordt genoemd, afzonderlijk bezien noodzakelijke voorwaarda voor de toepasselijkheid van de term en tezamen een voldoende voorwaarde. De bekenis van een term bestaat uit de intensie, die criteria geeft voor wat er onder de ten valt. De intensie van de term bepaalt de extensie. ${ }^{51}$ Als de criteria die de Hoge Raain het elektriciteitsarrest noemde de intensie van de term "goed" in artikel $310 \mathrm{Sr}$ vrmen, dan is elk van die voorwaarden noodzakelijk voor het zijn van een goed, tervjl iets dat aan alle voorwaarden voldoet daarmee zeker een goed is, aldus de Criteriathorie.

De Criteriatheorie lijdt aan ernstige bezwaren van zowel theoretische als pratische aard. Een theoretisch bezwaar is dat de criteria die de betekenis van een term tpalen zelf ook weer in tal geformuleerd zijn en dus termen bevatten die een bekenis hebben. Die betekenis zou zelf ook weer in termen van criteria gegeven wordn, die op hun beurt weer opnieuw temen bevatten. Er ontstaat een oneindig regrs van termen die gedefinieerd worden in andere termen, maar nergens wordt er viband gelegd met de werkelijkheid. Dit regres kan worden voorkomen door aan te nern dat sommige termen rechtstreeks naar hun extensie verwijzen zonder tussenkomst vn een

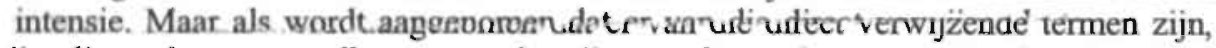
rijst direct de vraag welke termen dat zijn en of er ook termen zijn die niet direct verwijzen.

Die laatste vraag is nogal dringend, want - en nu komt een praktisch bezwaar tegen de Criteriatheorie - mensen zijn vaak prima in staat om dingen in de werkelijkheid aan te wijzen die onder een term vallen, maar slagen er niet vaak in om criteria to formuleren die noodzakelijke en voldoende voorwaarden geven voor de toepasselijkheid van een term. Mensen kunnen bijvoorbeeld prima een afvalstof herkennen, maar zijn niet in staat noodzakelijke en voldoende voorwaarden te geven voor wanneer iets een afvalstof is. ${ }^{52}$ Kortom, de extensie van een term identificeren is vaak mogelijk zonder

49 HR 23 mei 1921, NJ 1921, pp. 564-574 (Elektriciteitsarrest).

50 Omschrijvingen van een woord behoeven natuurlijk niet herleidbaar te zijin tot cen definitiebepaling of een definiëring door bijvoorbeeld de Hoge Raad, al was het maar omdat veel woorden niet op een dergelijke manier zijn gedefinieerd.

51 Vergelijk Loth, M.A., Recht en taal, pp. 76-79. Zie ook Schwartz, S.P. (red.), Naming, Necessity and Natural Kinds, de inleiding door de redacteur.

52 Aanvankelijk was in het wetsvoorstel tot uitbreiding van de Wet milieubeheer met het Hoofdstuk afvalstoffen afgezien van het opnemen van een definitiebepaling van het begrip afvalstof, omdat het niet goed mogelijk leek het begrip zodanig te definiëren dat alle relevante factoren werden meegenomen, zie hoofdstuk 9 paragraaf 3.4.6. en TK 1988-1989, 21 246, nr. 4, p. 105; zie ook TK 1991-1992, 21 246, nr. 5, p. 44. 
dat de intensie kan worden aangeven. Dat roept de vraag op of normaliter wel criteria worden gehanteerd om het verband te leggen tussen termen en hun extensie.

\subsubsection{Afgezwakte Criteriatheorie}

Om deze praktische bezwaren te ontlopen, wordt wel een afgezwakte versie van de Criteriatheorie verdedigd. ${ }^{53}$ Deze afgezwakte versie makt onderscheidt tussen de intensie en de kern-intensie van een term. De kern-intensie is dan de verzameling kenmerken die tezamen een noodzakelijke en voldoende voorwaarde opleveren. De kern-intensie is een deelverzameling van de totale intensie. Deze totale intensie is het geheel van kenmerken toekomen die aan elk van de objecten die onder de term vallen. ledere verzameling kenmerken die slechts een deel bevatten van de voorwaarden die tezamen voldoende en noodzakelijk zijn wordt dan een onvolledige intensie genoemd. De intensie is in deze theorie een verzameling eigenschappen die de extensie karakteriseren.

De genoemde praktische bezwaren van de Criteriatheorie zouden dan wel gelden voor de kern-intensie, maar niet voor de intensie. Het is echter niet duidelijk wat in deze Afgezwakte Criteriatheorie de functie van de intensie nog is. Waarschijnlijk gaat het om een stereotype in de zin van de hierna te behandelen Stereotypentheorie, waarbij de kenmerken van het stereotype als criteria worden geïnterpreteerd.

\subsubsection{Stereotypentheorie}

Een modern alternatief voor de Criteriatheorie gaat ervan uit dat de relatie tussen een term en zijn ex.tensie niet wordt gelegd door een intensie, maar rechtstreeks ${ }^{54}$ Mensen hebben vaak stereotype voorstellingen van wat tot een soort behoort. Zo hebben we stereotype voorstellingen wanneer iets kan worden aangeduid als bijvoorbeeld een gevaarlijk dier, persoonlijke beschermingsnniddelen, of het milieu. ${ }^{55}$ Als iets voldoende op dat stereotype lijkt, dan zijn we geneigd om het bij de categorie van dat stereotype onder te brengen. Maar het betreft hier een psychologische theorie over hoe we species van een scort herkennen, niet om een semantische theorie over de betekenis van de term die de soort aanduidt. Deze moderne theorie wordt de Stereotypentheorie genoemd. ${ }^{56}$

53 Bijvoorbeeld Franken, H., e.a., InLeiden tot de rechisweienschap, pp. 65-91.

54 Het psychologische onderzoek over kwalificatie vindt zijn basis in het werk van Rosch. Zie Rosch, E., "Principles of Categorization". Voorlopers in de sociale- en rechtswetenschap zijn Weber's theorie van de normaaltypen, respectievelijk Meijer's theorie van de normaal typen, zie Meijer, E.M., Algemene Leer van het Burgerlijk Recht: Deel l, vooral pp. 29-33.

55 Zie over "gevaarlijk dier" hoofdstuk 6 paragraaf 6.2 ; оvei "persoonlijke beschermingsmiddelen" hoofdstuk 8 paragraaf 3.2.7. en over "milieu" hoofdstuk 9 paragraalf 3.2.4.

56 Deze modeme theorie is filosofisch uitgewerkt in Wittgenstein's theorie over familiegelijkenissen en Putnam's theorie over stereotypen. Zie Wittgenstein, L., Philosophische Grammatik; Wittgenstein, L., Philosophical Investigations, en Putnam, 
De Stereotypentheorie gaat ervan uit dat de werkelijkheid gecompliceerder is dan eerder genoemde theorieën suggereren, omdat het bij talloze termen niet zo is dat alle objecten die onder een term vallen beantwoorden aan alle gedefinieerde kenmerken van die term. Het blijkt zelf regelmatig voor te komen dat er niet één kenmerk is dat terugkeert bij alle objecten die onder het betekenisbereik van de term vallen. Dit wil niet zeggen dat die objecten geheel los van elkaar staan. Het duidt er enkel op dat de definiërende kenmerken ongelijk over de verschillende objecten zijn verdeeld. De objecten die onder het betekenisbereik van de term vallen vertonen wel gelijkenissen ondanks dat ze geen gemeenschappelijke eigenschappen hebben. ${ }^{57}$ De vraag rijst nu aan hoeveel kenmerken, eventueel in combinatie met aan welke kenmerken in ieder geval, moet worden voldaan wil een object onder het betekenisbereik van een term vallen. Dergelijke beslissingen zullen moeten worden genomen om de vele tussenfiguren en overgangsvormen te classificeren. ${ }^{58}$

Een verdergaande invulling die aan de Stereotypentheorie wordt gegeven is dat er geen officiële semantische criteria zijn die de grenzen van categorieën afbakenen. Met andere woorden, er zijn geen taalregels die bepalen wat wel en wat niet onder een bepaalde categorie valt. ${ }^{59}$ Wel is het mogelijk om empirisch te onderzoeken of de elementen van een categorie bepaalde groepen van eigenschappen gemeenschappelijk hebben. Aldus is het mogelijk om empirische hypothesen te vormen over wat kenmerkend is voor bijvoorbeeld een kelder, die als voorlopige criteria gaan functioneren. Het resultaat van dergelijk onderzoek kan zijn dat de door "gewone" mensen gehanteerde stereotypen geen goede afbakening van de categorieën vormen, bijvoorbeeld omdat ze walvissen ten onrechte tot vissen maken en wit goud ten onrechte niet tot goud. Een juridisch voorbeeld van een dergelijk faien van de stereotypen zijn de termen diefstal en verduistering of stof en preparaat. ${ }^{60} \mathrm{De}$ juridische leek ziet hier gemakkelijk juridisch relevante verschillen over het hoofd.

In een aantal gevallen voldoen de psychologische tests voor het herkennen van objecten die vallen onder een bepaalde term niet, omdat er fijnzinniger onderscheidingen dienen te worden gemaakt. In dat geval kunnen bovenop de psychologische "criteria" aanvullende semantische criteria worden gegeven om verschillende termen te onderscheiden. Zo kan op grond van juridische criteria onderscheid worden gemaakt tussen verschillende varianten van schuld of opzet. ${ }^{61}$ Deze criteria bepalen evenwel

H., "The Meaning of Meaning".

57 Wittgenstein spreekt dan ook van familiegelijkenissen, aangezien de objecten op elkaar lijken als leden van een familie.

58 Zie Wittgenstein, L., Philosophische Grammatik, nr. 74 en verder; Wittgenstein, L., Philosophical Investigations; Franken, H., e.a., InLeiden tot de rechtswetenschap, pp. 81-83.

59 De versie van de Stereotypentheorie die hier wordt besproken is een variant op Putmam's theorie van de directe verwijzing. Een term verwijst rechtstreeks naar een soort, zonder dat er taalkundige criteria zijn die de soort afbakenen. Zie Putnam, H., "The Meaning of Meaning".

60 Zie over "stof" en "preparaat" hoofdstuk 9 paragraaf 3.2.4.

61 Zie over het schuldbeginsel hoofdstuk 3 paragraaf 7.4. 
niet uitputtend wat onder de verschillende varianten van schuld of opzet dient te worden verstaan, maar zijn primair een verfijning op de bestaande psychologische mechanismen.

\section{4. "Vaagheid" van een regel}

\subsubsection{Inleiding}

In deze paragraaf zal een onderscheid worden gepresenteerd van verschillende verschijnselen die vaak onder de noemer "vaagheid" van een regel worden gebracht. De oorzaak hiervan is gelegen in een of meer gebruikte termen die deel uitmaken van de bepaling. Er zal een onderscheid worden gemaakt tussen vaagheid en "open texture" van termen (hoofdstuk 2 paragraaf 5.4.2.), abstracte en concrete termen en graduele termen (hoofdstuk 2 paragraaf 5.4.3.), normatieve en evaluatieve termen (hoofdstuk 2 paragraaf 5.4.4.). Tevens wordt aan de hand van de gemaakte onderscheidingen aangegeven welke beslismomenten er zijn bij de vraag of een bepaalde regel moet worden toegepast. De betekenissen die aan deze termen worden gegeven, worden in het verdere verslag van het onderzoek naar zorgplichtbepalingen gehanteerd.

\subsubsection{Vaagheid en open texture}

\subsubsection{Inleiding}

Met behulp van de Stereotypentheorie is het mogelijk een analyse te geven van de semantische problematiek rond de toepassing van rechtsregels. Hier zullen de verschijnselen vaagheid (in enge zin) (hoofdstuk 2 paragraaf 5.4.2.2.) en open texture (hoofdstuk 2 paragraaf 5.4.2.3.) worden besproken. Maar alvorens daartoe over te gaan nog een algemene opmerking. Veel van wat juristen onder de noemer "vaagheid" plegen te brengen valt beter op een andere manier te kwalificeren. De in dit verband gehanteerde termen "vaag", "open", "abstract" en "normatief" lijken niet eenduidig te worden gebruikt. In de nu volgende paragrafen zal worden aangegeven op welke manier deze termen wel eenduidig zijn te gebruiken.

\subsubsection{Vaagheid}

Volgens de Stereotypentheorie correspondeert er met een term een soort van verschijnselen in de werkelijkheid. Deze soort is niet anders gedefinieerd dan doordat mensen de betreffende term er op van toepassing achten. Mensen gebruiken een stereotype om species van een soort te herkennen. Een stereotype is dan ook geen definitie die bepaalt wat er onder een soort valt. (Rechts)wetenschappers kunnen proberen op te sporen wat typerend is voor een bepaalde soort, bijvoorbeeld "haven" uit artikel 19 Quarantainewet. ${ }^{62}$ Een dergelijk onderzoek leidt enkel tot empirische hypothesen die als voorlopige criteria kunnen fungeren, maar niet tot definities die 
bepalend zijn voor wat een haven is. (Dit wordt nog genuanceerd.) Verschijnseh die stereotype voorbeelden van een haven zijn, zoals een jachthaven en de zeehasn in Rotterdam, zullen zeker met de term "haven" worden gekwalificeerd. Verschijselen die van het stereotype afwijken zullen soms minder stereotype havens zijn,zoals bijvoorbeeld de open zee haven in Hong Kong, soms duidelijk geen havens zijnzoals een rivier, en soms op de grens liggen van wat wel en wat geen haven is, zoa een aanlegsteiger in een meer. ${ }^{6}$

Voor alle termen geldt, op zijn minst in theorie, dat zij zo'n grensgebied hebbe van wat wel of niet onder de term valt. ${ }^{64}$ Men zou daarom kunnen zeggen dat alle temen vaag zijn. Dat zou evenwel het onderscheidend vermogen van de uitdrukking "aag" in verband met termen opheffen. Niet alle termen die een grensgebied ir hun betekenisbereik hebben worden daarom aangemerkt als vaag. Enkel als we vel te maken hebben met gevallen die in dat grensgebied liggen, spreken we van eenvage term. ${ }^{65}$ Als zulke gevallen zich in de praktijk niet voordoen, of als we er zelden ree te. maken hebben, heeft de term voldoende onderscheidend vermogen om zijn exnsie van die van andere termen af te bakenen en noemen we de term niet vaag.

De term "schip" uit artikel 19 Quarantainewet ${ }^{66}$ is bijvoorbeeld niet vaag, want hewel men met wat fantasie wel voorwerpen kan bedenken waarvan onduidelijk is of z nog wel een schip kunnen worden genoemd, komen we dergelijke voorwerpen 1 de praktijk niet of hoogst zelden tegen. De term "zaak" daarentegen is wel vaag, wat we komen in praktijk vaak dingen tegen waarvan het onduidelijk is of het een zaak is

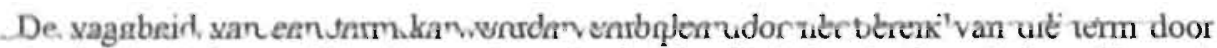
criteria af te bakenen. Hier ligt mede gezien het legaliteitsbeginsel een belangrijke taak voor de wetgever. ${ }^{67}$ Hij dient het gebruik van vage termen zo veel mogelijk te vermijden, aangezien de voorwaarden voor strafbaarheid ex ante zodanig nauwkeurig moeten worden omschreven dat de justitiabele voorafgaande aan zijn handelen kan

63 In dit verband schrijft Hart over cen "core of meaning" en een "penumbra of doubt". Zie Hart, H.L.A., The Concept of Law, p. 119.

64 Sommige termen zijn expliciet gedefinieerd, zoals de term "weg" als gebruikt in artikel 1, eerste lid sub b van de Wegenverkeerswet 1994. Voor die termen gaat de criteriatheorie van betekenis $\mathrm{op}$, omdat de officiële definitie die criteria geef. Echter die definitie zal zelf weer termen gebruiken die niet expliciet zijn gedefinieerd en waarvoor de Criteriatheorie niet opgaat. De vaagheid van deze laatste termen veroorzaakt dan de vaagheid van de expliciet gedefinieerde term. Bijvoorbeeld, voor wat als weg geldt in de zin van de. Wegenverkeerswet 1994 is ondermeer gedefinieerd in termen van het begrip "brug". De grensgevallen van wat als een brug geldt zijn daardoor ook grensgevallen van wat als een weg geldt.

65 Door het gebruik van algemene regels wordt het gebruik van vage termen in de hand gewerkt. "(...) in the case of legislation, as a general feature of human language; uncertainty at the borderline is the price to be paid for the use of general classifying terms in any form of communication concerning matters of fact."; Hart, H.L.A., The concept of law, p. 128. Het gebruik van nadere criteria kan de vaagheid tegengaan.

66 Zie over deze zorgplichtbepaling hoofdstuk 7 paragrafen 3.4.3, en 3.4.4.

67 Zie over het legaliteitsbeginsel hoofdstuk 3 paragraaf 7.3. 
weten of zijn gedraging al dan niet onder de delictsomschrijving valt. Aangezien bij vage termen veel gevallen in het grensgebied van het betekenisbereik van de strafbaarstelling vallen, is niet op voorhand duidelijk of de justitiabele al dan niet strafbaar handelt.

Indien het bereik van de term niet door criteria is af te bakenen, kan de wetgever bijvoorbeeld een opsomming van gedragingen in de strafbaarstelling opnemen en deze aanvullen met een vaag bestanddeel zoals "het op andere wijze onbehoorlijk gedragen". De grenzen van het vage bestanddeel worden dan gedeeltelijk ingekleurd door de niet-vage overige bestanddelen. ${ }^{68}$ Ook kan de wetgever in de memorie van toelichting aanvullende criteria geven.

Dat toch gebruik wordt gemaakt van vage termen zonder of met gebrekkige toelichting. kan worden veroorzaakt, doordat de kwaliteit van wetgeving niet altijd het hoogste doel is in een politiek besluitvormingsproces. Ten gevolge van bijvoorbeeld uiteenlopende partijbelangen en politieke compromissen wordt soms doelbewust gebruik gemaakt van vage termen in regelgeving zonder dat nadere criteria worden geformuleerd. Het voorkomen van vage termen is dan niet in het belang van degenen die beslissen over de inhoud en totstandkoming van de betreffende regelgeving. ${ }^{69}$

Het afbakenen van een vage term met behulp van criteria kan behalve in een toelichting van de wetgever ook plaatsvinden door het bestuur ${ }^{70}$ en de jurisprudentie. ${ }^{71}$ Aan de rechter is de taak de vage term in een voorliggende zaak te concretiseren en toe te passen. ${ }^{72}$ Door het toepassen van het recht, door het vaststellen of de concrete situatie onder de delictsomschrijving valt, vormt de rechter voor de betrokken partijen het recht. Zijn uitspraak en motivering met eventuele algemene toelichting bind in beginsel alleen de betrokken partijen en niet derden. Deze kan echter ook verder strekken dan alleen de onderhavige situatie. Door het vast stellen van de rechtsregel in. concrete situaties kan de rechtsregel worden geïdentificeerd aan de hand van de rechterlijke uitspraken. De jurisprudentie kan ook als kenbron van recht fungeren. ${ }^{73}$

68 Zie hoofdstuk 3 paragraaf 7.3. en bijvoorbeeld de zorgplichtbepaling uit artikel II Arbowet. 1998 hoofdstuk 8 paragraf 3.2.10.

69 Zie Werkgroep kwaliteit van EG-regelgeving, De kwaliteit van EG-regelgeving: Aandachtspunten en voorstellen, pp. 3 en 7; Sorgdrager, W., $O_{p}$ de grens tussen Europa en de nationale wetgeving, pp. 3-4. De Haan onderkende reeds dat de ingewikkeldheid van de sociale wetten veroorzaakt werd door de moeizame politieke compromissen die er aan ten grondslag lagen; Zie hierover van den Bergh's inleiding in J.I. de Haan, De taal zegt meer dan zij verantwoorden kan, p. Ii.

70 Zie over de mogelijkheid van het bestuur om de voorwaarden voor strafbaarheid te bepalen hoofdstuk 4 .

71 Zie over de mogelijkheid van de rechter om de voorwaarden voor strafbaarheid te bepalen hoofdstuk 5 .

72 Zo ook Remmelink, J., Mr. D. Hazewinkel-Suringa's Inleiding tot de studie van het Nederlandse strafrecht, pp. 131-132; Remmelink, J., Hoofdwegen door het verkeersrecht, p. 33.

73 Zie over jurisprudentie als kenbron van recht onder andere Neerhof, A.R., Het geschil 
Dit is het geval indien een nieuwe regel aan het bestaande regelstelsel vordt toegevoegd. ${ }^{1 / 4}$ Het beslissende criterium hierbij is of de regel ook gezag heeft vor de samenleving als geheel. In dat geval is door de uitspraak of motivering bij justitioelen de verwachting gewekt dat in de toekomst regels op soortgelijke wijze zullen wrden gehanteerd. De verwachting zal sterker zijn naarmate de regel een groter gezag leeft. De rechter zal daarom bij zijn beslissing niet alleen rekening houden met wettlijke voorschriften maar ook met eerdere uitspraken van andere rechters. ${ }^{75}$

Ook de doctrine heeft een belangrijke functie bij het ontwikkelen van criteria d: een vage term kunnen afbakenen. De invloed van de doctrine op de afbakening van temen $\mathrm{zal}$ indirect verlopen. $\mathrm{Zij}$ is zelf immers geen rechtsbron, daartoe mist zij de bevegdheid. Wel heeft zij invloed op de rechtsbronnen. Hoe groot deze invloed is zal nede afhankelijk zijn van de mate van gezag die ervan uitgaat.

Zowel voor criteria ontwikkeld door de wetgever, het bestuur, jurisprudentie is de doctrine geldt dat als dergelijke criteria (gezaghebbend) worden geformuleer, zij fungeren in de afbakening van de betreffende term als noodzakelijke of voldende voorwaarden. Deze functie vervullen zij evenwel tegen de achtergrond van a ter aanvulling op, de aan het gewone taalgebruik ontleende afbakening van de beripsomvang. Als bijvoorbeeld de Hoge Raad criteria formuleert ter onderscheidin van goederen komen die criteria in beginsel niet in plaats van het gewone taalgetuik, maar dienen zij ter aanvulling van dat taalgebruik. ${ }^{1 / 6}$

$\mathrm{Nu}$ is het de vraag waar die aanvullende criteria vandaan komen. Aan de enekant

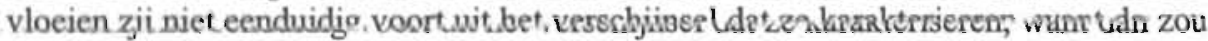
de tem niet vaag zijn en zou er geen behoefte zijn aan criteria. Aan de andere kant kunnen de criteria niet willekeurig zijn, want zij moeten de stereotype gevallen onder de soort laten vallen en zij moeten een praktisch werkbare afscheiding maken tussen de gekarakteriseerde soort en wat er buiten valt. Als de Hoge Raad criteria formuleert voor wat te gelden heeft als goed in de zin van artikel $310 \mathrm{Sr}$, moeten die criteria typische goederen tot goederen verklaren en bovendien moeten zij een werkbaar onderscheid maken tussen goederen en niet-goederen. Wat een onderscheid tot een werkbaar onderscheid maakt, is afhankelijk van de context waarin het wordt gemaakt.

voorbij.

74 Scholten stelt dat dit nieuw-gevormd recht tevens bestaand recht is, daar de rechter ervan uitgaat dat het recht dat hij naar wetenschappelijk oordeel schept al bestond voor hij het in zijn vonnis necrlegde. Scholten, P., De structuur der rechtswetenschap, pp. 1011 en 37; en later opgenomen in Scholten P., samengesteld door Scholten, G.J., Scholten, Y., Bregstein, M.H., Verzamelde Geschriften van Mr. Paul Scholten, Deel I, pp. 439 en 458.

Franken, H., e.a., InLeiden tot de rechtswetenschap, pp. 123-125.

76 Dit sluit niet uit dat in het recht geformuleerde preciseringen ten dele kunnen afwijken van het gewone taalgebruik. Het sluit wel uit dat het gewone taalgebruik geheel terzijde wordt gesteld. In dat laatste geval zou het namelijk niet meer gaan om semantische interpretatie, maar om het toekennen van een geheel nieuwe betekenis aan een term. 
In het recht zullen daarbij onder meer het systeem van het recht, rechtszekerheid en rechtvaardigheid van belang zijn.

\subsubsection{Open texture}

Een onderwerp dat nauw verwant is aan vaagheid, maar daarvan toch moet worden onderscheiden, is de "open texture" van termen. ${ }^{77}$ In de vorige paragraf bleek dat de vaagheid van een term niet zozeer een eigenschap is van de term op zich, maar veeleer van de term in combinatie met de verschijnselen die we tegenkomen. Het is denkbaar dat een term, eventueel in combinatie met aanvullende criteria voor toepasselijkheid, op een bepaald moment niet vaag is, omdat er zich geen grensgevallen voordoen, en op een later tijdstip wel vaag is, omdat de grensgevallen zich opeens wel gaan voordoen. In verband met die mogelijkheid spreken we van "open texture". Een voorbeeld van open texture biedt de term "geschrifte" uit artikel $225 \mathrm{Sr}$. Door de introductie van software en computers werd bijvoorbeeld onduidelijk of een weggeschreven computerbestand valt aan te merken als "geschrift". 78

Op zich is open texture geen reden waarom het toepassingsbereik van rechtsregels omstreden is. Alle beschrijvende termen hebben open texture, maar dat houdt slechts in dat ze de potentie hebben om vaag te worden. Zolang die potentie zich niet realiseert, is er niets aan de hand. Als die potentie zich wel realiseert, is de betreffende term vaag geworden en zijn de problemen met betrekking tot het toepassingsbereik van de regel die van vaagheid.

\subsubsection{Abstracte, concrete en graduele termen}

Regelgeving dient meestal op meer situaties van toepassing te zijn. Dit heeft tot gevolg dat concrete omstandigheden geabstraheerd worden weergegeven in algemene regelgeving. Algemene regelgeving vat zodoende veel concrete gevallen in abstracte termen samen. ${ }^{79}$ Ook in regelgeving die maar op één geval van toepassing is, zoals beschikkingen, kunnen regelvoorwaarden in algemene termen worden omschreven. Hierdoor bevat regelgeving vaak abstracte termen.

De term abstract en zijn tegenhanger concreet zijn graduele termen. Een term is niet abstract of concreet zonder meer, maar meer of minder abstract en minder of meer concreet. Er is sprake van een glijdende schaal. Daarbij geldt dat er geen absolute onder- of bovengrenzen aan abstractie zijn, zodat eigenlijk alleen maar gezegd kan worden dat een term abstracter of concreter is dan een andere term. Zo is bijvoorbeeld

77. De term "open texture" is afkomstig van Waismann in een artikel waarin hij zich afzet tegen de mogelijkheid om termen in wetenschappelijke theorieeln uitputtend te definiëren in termen van waarnemingsgegevens. Zie Waismann, F., "Verifiability". De term is in het recht geïntroduceerd door Hart, H.L.A., The Concept of Law, p. 120.

78 De Hoge Raad oordeelde van wel, zie HR 15 januari 1991, NJ 1991, 668 (Rotterdamse computerfraude).

79 Zie Haft, F., "Recht und Sprache", pp. 284-285. 
de term "motorrijtuig" uit de WVW 1994 abstracter dan de term "bromfiel" uit diezelfde wet. ${ }^{80}$

(Relatieve) abstractie van een term op zich leidt niet tot onduidelijkheid omtret het toepassingsbereik van die term. Bijvoorbeeld, de term "mishandeling" is rlatief abstract, maar dat leidt niet tot onduidelijkheid. Weliswaar zijn er grensgevallenn het toepassingsbereik van die uitdrukking, maar die grensgevallen vormen, s ze veelvuldig voorkomen, vaagheid. Het is dan die vaagheid die de problemen vroorzaakt en niet de mate van abstractie. Vandaar dat abstractie op zich nooit reen is waarom het toepassingsbereik van regels omstreden is.

Nu zou nog kunnen worden verdedigd dat relatief abstracte termen vaak vaązijn, maar dat lijkt geen juist standpunt. Om terug te komen op het voorbeeld it de Wegenverkeerswet, de relatief concrete term "bromfiets" zou wel eens vager knnen zijn dan de abstractere term "motorrijtuig", omdat hij alle vaagheid van "motorrtuig" erft en bovendien nog de extra vaagheid heeft van "een door constructie bepalde maximumsnelheid". Het omgekeerde standpunt dat concretere termen in het algeneen vager zijn dan abstractere gaat ook niet op. Zo is de term "zaak" vager dh de concretere uitdrukking "materieel voorwerp".

Gesteld werd dat een term niet zonder meer abstract of concreet is, maar mer of minder abstract. "Gevaar", dat in een aantal zorgplichtbepalingen als bestandiel is opgenomen $^{81}$, is een ander voorbeeld van een graduele term evenals "strijdig" (mt het algemeen belang). Het gaat hier om termen die steeds in meerdere of mindere me op

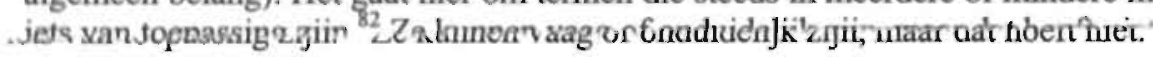

Graduele termen en uitdrukkingen ${ }^{83}$ kunnen tot problemen leiden, omdat ze in regelvoorwaarden vaak worden gebruikt alsof ze absoluut zijn. Zo stelt artikel 261 van de Provinciewet dat besluiten van het provinciaal bestuur worden vemietigd (onder meer) voor zover ze in strijd zijn met "het algemeen belang". Dit suggereert dat een besluit of wel of niet in strijd met het algemeen belang is. In werkelijkheid zal het in bepaalde mate voor bepaalde aspecten van het algemeen belang gunstig en voor andere ongunstig zijn. De "oplossing" dat een besluit wordt vernietigd als het ook maar enigszins in strijd met het algemeen belang is, gaat te ver. ${ }^{84}$ In de praktijk zal op

80 Vergelijk Wegenverkeerswet 1994 artikel 1, eerste lid sub e.

81 Zie bijvoorbeeld artikel 5 WVW, die wordt besproken in hoofdstuk 7 paragraaf 3.2 .

82 Ook "gewone" termen als "dief" kunnen in meerdere of mindere mate van toepassing zijn, maar dan gaat het om de mate van overeenstemming met de typische (stereotype) dief. Er bestaat dan een normal geval en slechts bij niet normale gevallen spelen gradaties een rol. Bij graduele termen is er vaak geen normale situatie en is er steeds sprake van gradaties.

83 Graduele termen en uitdrukkingen werden reeds als aparte categorie onderkend in Crombag, H.F.M., Wijkerslooth, J.L. de en Cohen, M.J., Een theorie over rechterlijke beslissingen.

84 Overigens zijn er in dit voorbeeld nog een aantal complicaties, omdat "algemeen" in algemeen belang vaag is en omdat de term "belang" evaluatief is. Deze complicaties 
een glijdende schaal van minder naar meer strijd met het algemeen belang een grens moeten worden getrokken die aangeeft wanneer een besluit geacht wordt in absolute zin in strijd te zijn met het algemeen belang. Alles afwegende volgt dan het eindoordeel dat het besluit wel of niet in strijd is met het algemeen belang. Waar die grens moet worden getrokken hangt af van ongeschreven aanvullende criteria.

\subsubsection{Normatieve en evaluatieve termen}

Als juristen het over vage termen hebben, bedoelen ze vaak normatieve en evaluatieve termen. ${ }^{85} \mathrm{Zij}$ geven een bepaalde waardebetekenis aan hetgeen dat is beschreven in de strafbepaling. Iedere strafbaarstelling bevat (als bestanddeell en/ of als element) termen die een waardeoordeel geven aan de beschreven omstandigheden uit de bepaling. ${ }^{86}$ Voorbeelden van evaluatieve termen zijn "redelijk", "billijk", "schuld (in de zin van verwijtbaarheid)", "deugdelijk" en "duidelijk". Ook de veel in zorgplichtbepalingen voorkomende bestanddelen "redelijkerwijs had kunnen vermoeden" en "redelijkerwijs van hem kunnen worden gevergd" zijn aan te merken als evaluatieve termen. Voorbeelden van normatieve termen zijn "onrechtmatig", "wederrechtelijk", "toegelaten", "verboden" en "opgedragen".

Kenmerkend, voor deze twee categorieën is dat het gewone taalgebruik geen antwoord geeft op de vraag of een concreet geval onder hun toepassingsbereik valt. Het is geen kwestie van de Nederlandse taal of iemands gedrag als redelijk, een kaart als duidelijk, een handeling als onrechtmatig, en een toe-eigening als wederrechtelijk dient te worden gekwalificeerd. Het verschil tussen evaluatieve en normatieve termen is dat evaluatieve termen worden gebruikt voor waardeoordelen die inherent gradueel zijn, terwijl normatieve termen worden gebruikt voor moeten (of mogen) oordelen, die inherent niet gradueel zijn.

Waardeoordelen leiden natuurlijk niet automatisch tot gedragsvoorschriften. Wel bestaat er een nauw verband tussen waardeoordelen en gedragsvoorschiriften. Voordat voorschriften behoren te worden gecreëerd dient te worden voldaan aan een aantal (andere) voorwaarden. Zo stelt Bos dat een handeling door de wetgever als delict behoort te worden beschouwd indien ${ }^{87}$

komen in andere paragrafen aan de orde.

Crombag, H.F.M., Wijkerslooth, J.L. de en Cohen, M.J., Een theorie over rechterlijke beslissingen, onderscheidde ook al tussen vaagheid in enge zin en wat zij "juricische maatstaven" noemden.

Deze termen vormen de maatlat waaraan het al dan niet voldoen aan de norm wordt gemeten. Orn deze reden zullen zij, al dan niet geschreven, altijd deel uitmaken van een strafbaarstelling.

Bos, A.M., Het begrip strafbaar feit in de rechtsvorming, p. 12. Het schadebegrip wordt door de Roos nader uitgewerkt. Hij stelt dat met het vaststellen van de schade de competentie van de staat om te straffen niet is gegeven, omdat ter bescherming van de individuele vrijheid tevens moet worden vastgesteld dat de schadelijke gedragingen intolerabel zijn. Roos, Th.A. de, Strafbaarstelling van economische delicten, pp. 33-49. Zie ook het door hem ontwikkelde crimineel-politiek toetsingsschema. Zie over 
"die schadelijk is voor een of meer leden van de gemeenschap, en waartegen optreden met een strafsanctie zowel effectief als voordelig als nodig is."

De problemen waar evaluatieve en normatieve termen toe leiden worden verooraakt door het feit dat de toepassing van deze termen niet-talige criteria veronderstelt. Voor zover het geschreven recht deze criteria zelf geeft, vallen die problemen wel nee. Maar als er een beroep wordt gedaan op ongeschreven recht of zelfs op criteria die niet eens juridisch van aard zijn, dan rijst de vraag naar de rechtvaardiging van de te hanteren criteria. Dit kan bijvoorbeeld leiden tot de vraag of er in de betreffende casus sprake is van een strafuitsluitingsgrond.

In het geval van evaluatieve termen koint daar nog het probleem bij dat deze temen gradueel zijn, zodat ook nog een lijn op een glijdende schaal moet worden getrolken. Hoe verwijtbaar moet immers een gedraging zijn, om te kunnen spreken van schuid in strafrechtelijke zin. Soms geeft het geschreven recht zelf aanwijzingen, bijvoorbeed in de vorm van geschreven schulduitsluitingsgronden. Daarmee wordt aangegeven dit de grens hoger op de schaal ligt dan de situaties waarin deze schulduitsluitingsgronden van toepassing zijn. Maar zelfs dan zegt het geschreven recht niet hoe hoog die grens precies ligt. Aanvullende criteria blijven nodig en het is niet op voorhand duidelijk waar die vandaan zouden moeten komen.

Als een term vaag is moet veelal een beroep worden gedaan op ongeschreven crieria om de door die term aangeduide categorie af te bakenen. Hetzelfde geldt roor graduele, evaluatieve en normatieve termen. Bij de keuze voor die aanvullende crieria

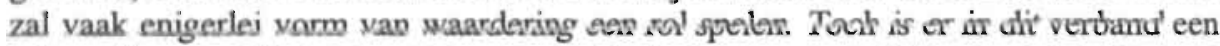
belangrijk verschil tussen vage en graduele termen enerzijds en evaluatieve en normatieve termen anderzijds. De aanvullende criteria die nodig zijn in geval van vage en graduele termen zullen zelf niet waarderend of normatief zijn, al zal hun keuze op waardering zijn gebaseerd. Bij evaluatieve en normatieve termen zullen de aanvullende criteria zelf waarderingsmaatstaven en gedragsnormen zijn. Hier speelt evaluatie zowel een rol bij de inhoud als bij de keuze van de criteria.

\subsection{Kwalificatie; een slotbeschouwing}

Het bovenstaande samenvattend kan worden gesteld dat om te bepalen of een regel op een casus moet worden toegepast in de eerste plaats de vraag moet worden beantwoord of de regel toepasselijk is, of - met andere woorden - aan de voorwaarden van de regel is voldaan. Deze vraag werd benaderd als een kwalificatie-vraag: Is het mogelijk de casus zo te kwalificeren dat hij voldoet aan de regelvoorwaarden?

Als de casus niet reeds in termen van de regelvoorwaarden is beschreven, zijn aanvullende criteria nodig, die verband leggen tussen een "brute" beschrijving van de casus en de gekwalificeerde casus die nodig is om de regel toepasselijk te doen zijn. Deze aanvullende criteria kunnen zelf weer bestaan uit geschreven rechtsregels

schadelijk gedrag hoofdstuk 3 paragraaf 7.2. 
(bijvoorbeeld wettelijke definities), maar ze kunnen ook ongeschreven zijn. Zo veronderstelt de toepassing van regels waarin evaluatieve of normatieve termen voorkomen het gebruik van aanvullende criteria die veelal zullen worden gebaseerd op ongeschreven normen dan wel beginselen. Men zou kunnen zeggen dat dergelijke regels impliciet verwijzen naar andere normen. Het komt ook voor dat geschreven rechtsregels expliciet verwijzen naar ongeschreven normen of beginselen. Zo gebiedt artikel 7:611 BW aan werkgevers en werknemers om zich als een goed werkgever c.q. werknemer te gedragen. Hier vormt het in belangrijke mate ongeschreven karakter van de normen waarnaar wordt verwezen een bron van onzekerheid. ${ }^{88}$ De vraag rijst primair hoe die aanvullende criteria gerechtvaardigd kunnen worden en secundair in welke mate zij nog recht zijn.

Tenslotte moet worden opgemerkt dat het ondanks de hier gepresenteerde indeling niet altijd duidelijk zal zijn tot welke categorie een term behoort. Dit wordt ten eerste veroorzaakt doordat sommige termen tot meer dan één categorie kunnen worden gerekend. In de tweede plaats zal de grens tussen termen die al dan niet tot een bepaalde categorie worden gerekend niet altijd scherp zijn.

Tevens komt het regelmatig voor dat de hele bepaling de aanduiding van de categorie van een bepaalde term krijgt. Deze bepalingen worden dan bijvoorbeeld als geheel vaag genoemd. Een dergelijke kwalificatie is in zoverre onnauwkeurig dat niet de bepaling als geheel maar één of meer termen uit de bepaling vaag zijn. Natuurlijk kan een dergelijke term de gehele bepaling zodanig beïnvloeden dat ook daarvan het toepassingsbereik onduidelijk kan zijn. De oorzaak blijft echter gelegen in de betreffende term(en).

\section{Rechtsvinding bij "vage" termen}

\subsection{Inleiding}

Het valt buiten het bestek. van dit boek om te proberen de problemen met betrekking tot rechtsvinding en rechtsvorming bij "vage" termen uitputtend te bespreken en op te lossen, zo dit al mogelijk ware. In dit hoofdstuk is echter meer dan eens aangegeven dat het betekenisbereik van "vage" termen onder andere kan worden vastgesteld met behulp van ongeschreven recht. Het is de problematiek van het vaststellen van ongeschreven (rechts)normen, die de kern vormt van de problematiek van rechtsvinding en rechtsvorming bij "vage" termen. Daarom zal in deze paragraaf worden ingegaan op de rol van ongeschreven recht bij "vage" termen. Bij de bespreking van de kwalificatie van zorgplichtbepalingen wordt hier nog op terug gekomen.

88 De wet geeft vele regels die gelden voor werkgevers en werknemers en dus a fortiori voor goede werkgevers en werknemers, maar de strekking van artikel 7:611 BW is juist om daarnaast ongeschreven regels van kracht te doen zijn. 
Als het toepassingsbereik van een regel omstreden is tengevolge van de vaagheid van één of meer termen, dan is het nodig om aanvullende criteria te formuleren die de omvang van de betreffende categorie bepalen. Daarbij moet enerzijds recht worden gedaan aan de betekeniskern van die term(en) en anderzijds aan bet functioneren van die regel in de rechtspraktijk.

Soms geeft het geschreven recht, in de vorm van interpretatienormen, geschreven aanwijzingen met betrekking tot die aanvullende maatstaven. ${ }^{89}$ Meestal is dat niet het geval en dan moet een beroep worden gedaan op ongeschreven maatstaven. In dat verband doet zich een tweetal problemen voor. Ten eerste zijn er weinig of geen dwingende aanknopingspunten bij de keuze van die maatstaven. Weliswaar kan men proberen aan te sluiten bij bijvoorbeeld het systeem van het recht, of bij de bedoelingen van de wetgever en men kan ook proberen wenselijk geachte maatschappelijke gevolgen te bewerkstelligen ${ }^{90}$, zowel in het concrete geval als voor toekomstige gevallen, maar het risico van goedbedoelde willekeur is groot.

Ten tweede is het onduidelijk in hoeverre men hierbij aan het recht gebonden is, nu geen steun kan worden gevonden in het geschreven recht. Met name rijst de vraag of binnen de ruime categorie van ongeschreven normen, maatstaven en criteria onderscheid kan en dient te worden gemaakt tussen juridische normen enz. en nietjuridische. Dat is vooral van belang als de afbakening van categorieën aan de hand van het (ongeschreven) recht dient te gebeuren.

Barendrecht wijdde uitgebreide beschouwingen aan de binding aan "de wet en het recht". ${ }^{91}$ Opvallend is hoe hij in dit verband wet en recht identificeert. Uitgaande van die identificatie komt hij tot de conclusie dat de gebondenheid aan het recht (lees: de wet) vaak niet veel voorstelt. Het is tegenwoordig gebruikelijk om aan te nemen dat er meer recht is dan wettenrecht. In deze opvatting houdt de gebondenheid aan het recht meer in dan gebondenheid aan de wet. Met name de gebondenheid aan het ongeschreven recht wordt dan een belangrijke kwestie, een kwestie overigens die de vraag oproept welke ongeschreven normen rechtsnormen zijn.

Langemeijer pleitte ervoor te onderscheiden tussen wenselijke gedragsnormen en gedragsnormen die we bereid zouden moeten zijn juridisch af te dwingen. ${ }^{92}$ In aansluiting op dit pleidooi zou men onderscheid kunnen maken tussen ongeschreven rechtsnormen en, bijvoorbeeld, ongeschreven normen van moraal en fatsoen die men niet als rechtsnormen wil aanvaarden. ${ }^{93}$ Normen die we bereid zijn af te dwingen

89 Zo bevatte het oude BW voorschriften over het uitleggen van overeenkomsten.

90 Vergelijk bijvoorbeeld de door Scholten gepropageerde "factoren bij vaststelling van de zin van de wet". Scholten, P., bewerkt door Scholten, G.J., Mr. C. Asser's Handleiding tot de beoefening van het Nederlands Burgerlijk Recht, Algemeen deel.

91 Barendrecht, J.M., Recht als model van rechtvaardigheid.

92 Langemeijer, G.E., Inleiding tot de studie van de wijsbegeerte des rechts, pp. 252-265.

93 Dit sluit vanzelfsprekend niet uit dat sommige normen van moraal en fatsoen als 
zouden volgens dit criterium rechtsnormen zijn; normen die we niet bereid zijn af te dwingen zijn dan geen rechtsnormen. De gebondenheid aan het recht zou volgens dit criterium inhouden dat ter rechtvaardiging van rechtsbeslissingen slechts een beroep kan worden gedaan op ongeschreven normen die we bereid zijn als rechtsnormen te aanvaarden, dat wil zeggen: bereid zijn af te dwingen.

7.

\section{Vitzonderingen op regels}

Uitzonderingen op regels kunnen in twee hoofdcategorieên worden ondergebracht. De eerste categorie, de oneigenlijke uitzonderingen, bestaat uit negatieve regelvoorwaarden. Het betreffen "gewone" regelvoorwaarden, met dien verstande dat ze negatief geformuleerd zijn. Dat brengt evenwel geen speciale complicaties met zich. Derhalve zal niet verder worden ingegaan op deze categorie van "uitzonderingen".

Naast de oneigenlijke uitzonderingen worden de uitzonderingen in strikte zin onderscheiden. Als het in het navolgende gaat over uitzonderingen, betreft het deze uitzonderingen in strikte zin. Eén soort uitzondering op een regel doet zich voor als een toepasselijke regel niet wordt toegepast en er geen geschreven regels zijn die aangeven dat er zo'n uitzondering is. In dit verband valt te denken aan toetsing van regels aan de (ongeschreven invulling van) grondrechten of (andere) rechtsbeginselen. Een dergelijke toetsing kan tot de conclusie leiden dat de regel onverbindend is. Dan is er eigenlijk geen sprake van een uitzondering op de regel, want onverbindende regels bestaan strikt genomen niet. Het gaat dan slechts om een mislukte poging tot regelgeving, waarbij wel wettelijke bepalingen zijn gemaakt, maar waarbij die bepalingen er niet in zijn geslaagd rechtsregels te genereren. ${ }^{94}$ In de praktijk treedt deze consequentie duidelijk naar voren in het bestuursrecht. Indien de bestuursrechter een besluit of daaraan verbonden voorwaarden vernietigt, treedt de fictie in werking dat het betreffende besluit of de voorwaarden nooit hebben bestaan. De vernietiging heeft terugwerkende kracht. Deze bestuursrechtelijke fictie kan ook strafrechtelijke gevolgen hebben, bijvoorbeeld indien een justitiabele wordt vervolgd voor het schenden van het besluit terwijl dit later door de bestusursrechter wordt vernietigd. ${ }^{95}$ Indien de strafrechter een besluit onverbindend verklaart, heeft dit geen algemene werking, maar blijven de gevolgen beperkt tot de bij het geschil betrokken partijen. ${ }^{96}$

Toetsing kan er ook toe leiden dat een regel in zijn algemeenheid wel verbindend is, maar in een concreet geval buiten toepassing dient te blijven, bijyoorbeeld wegens strijd met een fundamenteel rechtsbeginsel. De rechter heeft de bevoegdheid om wetgeving in materiële zin rechtstreeks te toetsen aan ongeschreven rechtsbeginselen,

94 Het is denkbaar dat "rechtsgevolgen" van de onverbindende regel ter wille van de rechtszekerheid in bepaalde gevallen toch intreden. Die rechtsgevolgen worden dan niet ontleend aan de onverbindende regel, maar bijvoorbeeld aan het rechtszekerheidsbeginsel dat aan het feit van de onverbindende regelgeving rechtsgevolgen verbindt.

95 Zie hierover hoofdstuk 5 paragraaf 6 en 7.

96 Zie hoofdstuk 5 paragraaf 4. 
maar een doelmatigheidscontrole ligt daarbij buiten zijn competentie. ${ }^{97}$ In beginsel is het toetsen van wetgeving in formele zin aan algemene rechtsbeginselen en de Grondwet niet mogelijk. Wel kunnen algemene rechtsbeginselen bij niet door de wetgever verdisconteerde omstandigheden contra-legem werken, zodat een wet in formele zin in een bepaald geval buiten toepassing wordt gelaten. ${ }^{98}$

Als het OM in een zaak een beroep op de regel doet, hoeft het in beginsel niet aannemelijk te maken dat zich geen uitzondering op de regel voordoet. Het OM dient well aannemelijk te maken dat aan de voorwaarden van de regel is voldaan. De termen die deel uitmaken van een bepaling moeten immers door het $\mathrm{OM}$ worden ten laste. gelegd en bewezen, voordat door de rechter kan worden getoetst of de bewezenverklaring voldoet aan de wettelijke delictsomschrijving. Indien de bewezen gedraging niet is te kwalificeren zal de verdachte moeten worden ontslagen van rechtsvervolging. Het OM behoeft het bestaan van een uitzondering in de vorm van een strafuitsluitingsgrond niet aan te tonen. In de praktijk zal dit doorgaans door de verdachte of diens raadsman ter terechtzitting aan de orde worden gesteld. Dit hoeft overigens niet. Ook het OM kan dit doen, maar is er niet toe gehouden. ${ }^{99}$ Tevens kan het ambtshalve door de rechter gebeuren. Een belangrijk verschil tussen bestanddelen en strafuitsluitingsgronden is dat bestanddelen door het $\mathrm{OM}$ moeten worden ten laste gelegd en bewezen, terwijl het voor strafuitsluitingsgronden voldoende is dat de rechter ze niet onaannemelijk heeft bevonden. ${ }^{18}$ Het onderscheid tussen de voorwaarden van de regel en de gronden om een uitzondering te maken uit zich aldus onder meer in de verdeling van de bewijslast. ${ }^{101}$

Dit geldt zowel voor expliciet als voor impliciet genoemde uitzonderingen. Het geldt daarom zowel voor de geschreven als de ongeschreven strafuitsluitingsgronden. Steeds geldt dat het $\mathrm{OM}$ aannemelijk moet maken dat er sprake was van handelen in strijd met de strafbepaling, terwijl het (in beginsel) niet hoeft te bewijzen dat er sprake is van een uitzondering. In dit opzicht verschilt een uitzondering in strikte zin van een oneigenlijke uitzondering, want het OM moet wel bewijzen dat zich geen oneigenlijke uitzondering voordoet.

Uitzonderingen op rechtsregels op zich leiden niet altijd tot onduidelijkheid over de vraag of een regel moet worden toegepast. Dat zij toch regelmatig tot een dergelijke

97 Zie HR 16 mei 1986, NJ 1987, 251, met noot Scheltema; $A B$ 1986, 574, met noot Van der Burg (Landbouwvliegers); zie ook HR 7 oktober 1992, NJ 1994, 44 (L.egesverordening Beerta). Zie hierover ook hoofdstuk 3 paragraaf 5.1 .

98 HR 14 april 1989, $N J 1989,469$, met noot Scheltema; $A B$ 1989, 207, met noot Van der Burg (Harmonisatiewetarrest). Zie hierover ook hoofdstuk 3 paragraaf 5.1.

99 Zie bijvoorbeeld HR 17 november 1992, $N J 1993,267$, met noot Van Veen (Aannemelijke overmacht).

100 Overigens kan er discussie ontstaan op welke manier de uitzondering moet worden opgevat; als bestanddeel of als strafuitsluitingsgrond. Zie hierover hoofdstuk 4 paragraaf 6.

101 Vergelijk Sartor, G., "The Structure of Norm Conditions and Nonmonotonic Reasoning in Law", pp. 155-164. 
onduidelijkheid aanleiding geven, is te wijten aan twee factoren. Ten eerste berusten uitzonderingen vaak op regels van ongeschreven recht, waarvan de inhoud voor discussie vatbaar is. De problemen rond de inhoud van het ongeschreven recht spelen dus, niet alleen als de oplossing van een casus aan het ongeschreven recht dient te worden ontleend, maar ook als regels van geschreven recht op grond van ongeschreven recht buiten toepassing worden gelaten.

De tweede factor die aanleiding geeft tot onduidelijkheid met betrekking tot de toepassing van een regel is dat uitzonderingen vaak berusten op normatieve of evaluatieve oordelen die op hun beurt vaak niet op het positieve recht kunnen worden gebaseerd. De uitzondering op de gewone criteria wordt dan afhankelijk gemaakt van het normatieve oordeel of de betreffende gedraging al dan niet rechtmatig was. In dergelijke gevallen speelt de problematiek rond normatieve en evaluatieve termen niet alleen bij gewone regelvoorwaarden, maar ook bij uitzonderingen.

\section{De toepassing van strafbaarstellingen}

Samenvattend kan worden geconstateerd dat er twee momenten zijn waarop discussie kan ontstaan over de toepassing van een rechtsregel op een concreet geval. Om te beginnen is er de vraag of de regel toepasselijk is, dat wil zeggen, of aan de voorwaarden van de regel is voldaan. Er van uitgaande dat de voorwaarden van de regel zelf bekend zijn, kunnen er bij de kwalificatie van de casus problemen ontstaan doordat termen in de regelvoorwaarden vaag, gradueel, normatief of evaluatief zijn. In alle vier deze gevallen zijn aanvullende criteria nodig, die soms wel, maar meestal niet aan het geschreven recht kunnen worden ontleend. Is het laatste het geval, dan zal een beroep moeten worden gedaan op ongeschreven recht, of op niet-juridische criteria.

Als een regel toepasselijk is, dan zal hij normaal gesproken ook worden toegepast, maar het is denkbaar dat een uitzondering wordt gernaakt. De gronden om een uitzondering te maken kunnen aan het geschreven recht worden ontleend. Daarbij doen zich mogelijk de bovengenoemde complicaties rond de toepasselijkheid van uitzonderingen gevoelen. Daarnaast kunnen de gronden om een uitzondering te maken aan geschreven en ongeschreven (rechts-)normen worden ontleend.

Uit het overzicht dat in dit hoofdstuk werd gegeven blijkt dat de problematiek rond de toepassing van rechtsregels direct, of via een - soms lange - omweg, vaak valt terug te voeren op de noodzaak een beroep te doen op niet geschreven (rechts-) normen. De aard van die normen is verschillend al naar gelang de aard van de complicatie. Hetgeen de situatie problematisch makkt is echter niet zozeer de aard van de ongeschreven normen die moeten worden ingeroepen, alswel het feit dat er geen harde maatstaven bestaan voor het kiezen van die normen.

De onderscheidingen die in dit hoofdstuk zijn gemaakt geven een handvat om vast te stellen wat voor soort aanvullende norm moet worden gezocht, maar bieden geen hulp bij de rechtvaardiging van die normen. Het biijkt dat alle rechtsvindingsproblematiek 
direct of indirect berust op de vraag wat als geldend recht dient te worden aanvaard. Op die vraag is geen eenvoudig antwoord te geven en er is alle reden om aan te nemen dat het antwoord mede afhankelijk is van de context waarbinnen de vraag speelt. Het betreft bijvoorbeeld de vraag of het gaat om de toepasselijkheidsgrenzen van beschrijvende of graduele termen; of het een kwestie is van invulling van normatieve of evaluatieve termen; of er een discrepantie is tussen wat rechtens het geval lijkt te zijn en wat (al dan niet rechtens) wenselijk wordt geacht. Dit zijn factoren die - naast vele andere - bepalend kunnen zijin voor wat we als recht willen aanvaarden. Het in dit hoofdstuk gegeven kader biedt wel aanknopingspunten voor de beantwoording van die vraag door duidelijk te maken welke vragen moeten worden beantwoord en welke antwoorden rechtvaardiging behoeven. Daarnaast biedt het systematische onderscheid van de diverse factoren een duidelijker grondslag bij de bespreking en analyse van zorgplichtbepalingen in volgende hoofdstukken. 


\section{De wetgever en de algemene vereisten van behoorlijke regelgeving}

\section{Inleiding}

De wetgever en het bestuur kunnen zorgplichtbepalingen vaststellen. Deze bepalingen en het systeem van wetgeving waarvan zij deel uitmaken dienen zoveel mogelijk in overeenstemming te zijn met het algemeen wetgevingsbeleid en daarom ook met de beginselen van behoorlijke regelgeving die daarvan deel uitmaken. Aangezien het schenden van deze bepalingen strafbaar is gesteld, dient tevens zoveel mogelijk te worden tegemoet gekomen aan de criteria voor strafbaarstelling. Deze criteria zijn in de strafrechtsdogmatiek onafhankelijk van de in het staatsrecht ontwikkelde vereisten en beginselen die aan regelgeving moeten worden gesteld tot ontwikkeling gekomen. Ze hebben echter betrekking op dezelfde materie; te weten de vraag waaraan wet- en regelgeving dient te voldoen voordat gesproken kan worden van behoorlijke regelgeving.

In dit hoofdstuk wordt de inhoud en betekenis beschreven van deze diverse los van elkaar ontwikkelde vereisten, beginselen en criteria, zodat duidelijk wordt waaraan wetgeving in het algemeen en strafbaarstellingen zoals zorgplichtbepalingen in het bijzonder dienen te voldoen wil sprake zijn van behoorlijke regelgeving. Achtereenvolgens worden behandeld: de totstandkoming van het algemeen wetgevingsbeleid (hoofdstuk 3 paragraaf 2), de Nota "Zicht op wetgeving" (hoofdstuk 3 paragraaf 3), de aanwijzingen voor de regelgeving (hoofdstuk 3 paragraaf 4 ), de beginselen van behoorlijke regelgeving (hoofdstuk 3 paragraaf 5), de beginselen en de Raad van State (hoofdstuk 3 paragraaf 6) en de criteria voor strafbaarstelling (hoofdstuk 3 paragraaf 7).

Het bestaan van vele voorwaarden uit de drie los van elkaar staande stelsels komt de inzichtelijkheid en duidelijkheid vanı de analyse van de behoorlijkheid van regelgeving niet ten goede. Daarom is het wenselijk deze stelsels te integreren, zodat zij niet enkel apart maar ook in onderlinge samenhang kunnen worden beschouwd. $O_{\mathrm{p}}$ basis van de inhoudelijke beschrijving van de vereisten, beginselen en criteria is het mogelijk vijf algemene vereisten te formuleren waaraan regelgeving (waaronder begrepen strafbaarstellingen) moet voldoen wil zij behoorlijk zijn (hoofdstuk 3 paragraaf 8 ). Deze vijf vereisten worden nader ingevuld door de in de paragrafen 3,5 en 7 besproken eisen, beginselen en criteria. De in dit hoofdstuk geformuleerde algemene vereisten van behoorlijke regelgeving worden in dit boek gebruikt bij de analyse van zorgplichtbepalingen (hoofdstukken 6 tot en met 10). 
Voordat een beschrijving en analyse van zorgplichtbepalingen wordt gegeven, zal eerst worden stilgestaan bij nadere voorwaarden waaraan het bestuur (hoofdstuk 4) en de rechter (hoofdstuk 5) dienen te voldoen, indien het vaststellen van regelgeving (waaronder zorgplichtbepalingen) of aanvullende criteria van regelgeving daaraan is overgelaten.

\section{De totstandkoming van een algemeen wetgevingsbeleid}

De wetgeving was lange tijd gericht op het vastleggen van regels die de wetgever elders "vorgefunden" had; bijvoorbeeld in gewoonterecht, zeden, fatsoensregels, algemeen aanvaarde ethische beginselen. Uitgangspunt was dat in het geschreven recht slechts bestaande rechtsregels werden vastgelegd, aangezien het niet de taak van de wetgever werd geacht de richting van de rechtsontwikkeling te bepalen. ${ }^{1}$ In deze tijd werd het vanzelfsprekend gevonden dat de wetten in overeenstemming waren met fundamentele rechtsbeginselen. ${ }^{2}$

Met de opkomst van de industriële samenleving werd men zich ervan bewust dat armoede, werkeloosheid en welvaartsverschillen te beïnvloeden en zelfs gedeeltelijk te verhelpen of te voorkomen zijn. Naarrnate het besef groeide dat deze euvelen door rationeler menselijk handelen zijn te veranderen, vond het bewust streven naar maatschappelijke veranderingen ingang. Hierdoor kwamen technieken tot ontwikkeling om processen van sociale verandering op gang te brengen en te houden. Een belangrijke methode om in te grijpen in de organisatie van de samenleving werd gevonden in wetgeving. De aanvankelijke terughoudendheid van de wetgever maakt langzaam maar zeker plaats voor een vastbesloten beïnvloeding en sturing van de samenleving, waarmee hij beoogt door legislatieve activiteiten veranderingen in de maatschappij te bewerkstelligen. ${ }^{3}$ Het karakter van de wetgeving is door deze ontwikkeling veranderd. Koopmans stelt ${ }^{4}$ :

1 Koopmans, T., "De rol van de wetgever", pp. 221-222.

2 Vlies, I.C. van der, Handboek wetgeving. p. 140.

3 In de Nota "Zicht op wetgeving" wordt dan ook gesteld: "Niet zelden is er evenwel grote maatschappelijke en politieke druk om matschappelijke problemen door middel van wetgeving op te lossen. In onze politieke en bestuurlijke cultuur wordt wetgeving gezien als het middel bij uitstek om veranderingen in de samenleving te realiseren. De politieke ambities zijn dan hoog." TK 1990-1991, 22 008, nrs. 1-2, p. 7.

4 Zie (ook voor een overzicht van deze ontwikkeling) Koopmans, T., "De rol van de wetgever", pp. 222-223. Zie ook Groenhuijsen, M.S. en Peters, J.A.F., "Over het stuk en de spelers", pp. 2-5. 
"De wetgever volgt niet, hij loopt voorop. De ontstane verzorgingsstaat is dan ook goeddeels zijn schepping. Daarbij is geen enkele zede of gewoonte gecodificeerd, is ook niet de wet aangepast aan de dynamiek van de samenleving, maar is voetje voor voetje een anderssoortige samenleving, met andere zeden en gewoonten, en misschien zelfs met een enigszins anders gerichte dynamiek, in het leven geroepen. Anders gezegd: de wetgever streeft niet meer primair naar codificatie maar naar modificatie."

Dit onderscheid is overigens minder strikt dan het op het eerste gezicht lijkt. Ook modificerende wetgeving kan worden gecodificeerd, in die zin dat het conform artikel 107 Grondwet kan worden opgenomen in algemene wetgeving in formele zin. ${ }^{5}$ Dergelijke regels kunnen ook codificerend zijn, in de zin dat zij een neerslag vormen van hetgeen in de maatschappij leeft. ${ }^{6}$ Ondanks dat de codificatie van modificerende wetgeving mogelijk is, kent het een antal specifieke problemen, zowel bij de voorbereiding, de totstandkoming als de toepassing. ${ }^{\text {? }}$

Naast de beleidsuitvoerende en beleidsbepalende wetgeving die tot stand is gekomen, blijft er natuurlijk ook wetgeving die niet of minder beleidsmatig van karakter is. Deze wetgeving dient onder invloed van de maatschappelijke ontwikkelingen wel regelmatig (maar ook weer niet te vaak ${ }^{8}$ ) te worden bijgesteld of zelfs (opnieuw) vorm te worden gegeven, teneinde deze ontwikkelingen te volgen. ${ }^{9}$

Door de groeiende behoefte aan wetgeving als sturingsmechanisme ontstaat in de jaren zeventig een steeds grotere achterstand op wetgevingsgebied. J.M. Polak stelt ${ }^{10}$ :

"Er dreigt een grote achterstand te ontstaan. Want tegenover een geringere produktic aan wetgeving staat een toenemende behoefte aan wettelijke regelingen die adequaat reageren op de vele gerechtvaardigde wensen die juist nu op ons afkomen. Het mag dan zo zijn dat niet alle problemen door wetgeving kunnen worden opgelost, er moge dan ruimschoots plaats zijn voor

5 Hier wordt een andere betekenis gegeven aan "gecodificeerde wetgeving" dan in hoofdstuk 6 waar alleen het Wetboek van Strafrecht werd aangemerkt als gecodificeerd strafrecht.

6 Zie Polak, J.M., "Codificerende wetgeving", p. 21; Geest, H.J.A.M. van, Leede, L.J.M. de en Ringeling, A.B., "De weerbarstige norm".

7 Zie Polak, J.M., "Codificerende wetgeving", p. 21. Zo kan de voorbereiding zich niet beperken tot juridische techniek, zal de inspraak gecompliceerder zijn en kunnen onder het mom van juridische techniek politieke wensen worden ingebracht. Daarnaast blijkt de tot stand gekomen regel nogal eens te falen in het bereiken van de vooraf bepaalde doelstelling. Zie Veld, R.J. in "t, "Planning: ge(s)laagde ontregeling?", pp. 220-224.

8 Veelvuldige veranderingen dienen te worden voorkomen, omdat continuïteit en bestendigheid van geldende regels van belang zijn voor de rechtszekerheid en voor de beoogde beïnvloeding van het gedrag van justitiabelen en daarmee voor de doeltreffendheid van veel overheidsbeleid. Zie de Nota "Zicht op wetgeving", TK 19901991, 22 008, nrs. 1-2, pp. 23-24.

9 Bijvoorbeeld door het bijstellen van het Wetboek van Strafrecht door de invoering van artikel 138a Sr (computervredebreuk); het opnieuw vormgeving van het Burgerlijk Wetboek; de invoering van de Algemene wet bestuursrecht.

Polak, J.M., "De wetgeving van het Departement van Justitie", p. 1. 
rechtsvorming door anderen, zoals de rechtspraak, dit neemt niet weg dat de wetgever voorop moet blijven lopen en leiding geven. Ook al geschiedt dat dan met meer aarzeling dan vroeger en al erkennen we dat veel wetgeving experimenteel is."

Door de sterke toename van modificerende regelgeving ${ }^{11}$ geeft de wet sterker dan voorheen juridisch vorm aan sociale ingrepen die de parlementaire meerderheid van het moment wil bewerkstelligen. ${ }^{12}$ Als de wet dienstbaar wordt gemaakt aan maatschappelijke veranderingen, gaat de wetgeving deel uitmaken van een bepaald beleid. De wet is dan één van de instrumenten waarover de overheid beschikt om dit beleid te realiseren, waardoor wetgeving tot beleidsinstrument is geworden. ${ }^{13}$ Juist bij dergelijke "instrumentele beleidswetgeving" kan niet altijd voldoende worden aangesloten bij het rechtsbewustzijn van justitiabelen. Hierdoor komt de materiële legitimatie $^{14}$ van de regelgeving onder druk te staan. Het gevolg hiervan is een geringere acceptatie van die normen. ${ }^{15}$ In 1988 wordt in de: voortgangsrapportage van het beleidsplan Samenleving en criminaliteit erkend ${ }^{16}$ :

"dat het invoeren van wetgeving op een tijdstip dat de maatschappelijke voorwaarden voor het functioneren daarvan onvoldoende zijn vervuld, zoveel mogeijk moet worden vermeden."

\section{Hierop wordt vervolgens wel meteen een uitzondering gemaakt ${ }^{17}$ :}

"Soms noopt echter de schending van belangen in het maatschappelijk verkeer tot een onmiddellijk wettelijk ingrijpen, dat zijn vervolg kan hebben in bestuurlijk optreden tegen het ongewenste gedrag, al was het maar in de meest schrijnende gevallen."

Indien wetgeving wordt gebruikt als sturingsinstrument ${ }^{18}$ rijzen vragen naar de legitimiteit van dergelijk optreden door de wetgever. ${ }^{19}$ Teneinde de legitimiteit niet

11 Die tevens een enorme groei van bijzondere wetgeving tot gevolg hebben gehad. Zie hierover ook hoofdstuk 6 paragraaf 2 .

12 Koopmans, T., "De rol van de wetgever", pp. 221-223.

13 Koopmans, T., "De rol van de wetgever", p. 227.

14 Dit is de legitimatie van de overheid om in te grijpen die moet uitgaan van de inhoud van de wettelijke norm. Zie Peters, H., "Gedachten over 'pretenties van wetgeving"', pp. $25-29$.

15 Nota "Zicht op wetgeving", TK 1990-1991, 22 008, nrs. 1-2, pp. 16-17; Daudt, H., "Legitimiteit en legitimatie", pp. 5-16; Brandhof, J.C.E. van den, "Reactie; Pretenties van wetgeving", pp. 6-7; Peters, H., "Gedachten over "pretenties van wetgeving", pp. 25-29. Onder "instrumentele beleidswetgeving" wordt in de Nota "Zicht op wetgeving" verstaan de wetgeving die betrekking heeft op inkomens- en vermogensoverdrachten (fiscale wetgeving, sociale zekerheidswetgeving en subsidieregels) en wetgeving die randvoonwaarden stelt aan het maatschappelijk verkeer (bijvoorbeeld de milieuwetgeving, de verkeersveiligheidswetgeving en de wetgeving op het terrein van de volksigezondheid). Deze: wetgeving wordt ook wel aangeduid als "regelgeving van de sociale rechtsstaat", zie Wetenschappelijke Raad voor het Regeringsbeleid, Rechtshandhaving, p. 24.

16 Voortgangsrapportage over de uitvoering van het beleidsplan Samenleving en criminaliteit, TK 18995 , nr. 35 , p. 30.

17 Zie hierover Polak, J.M., "De wetgeving van het departernent van Justitie", p. 1. 
nog sterker te ondergraven is de rechtmatigheid van dit soort wetgeving van groot belang.

De als gevolg van de gewijzigde taakopvatting van de wetgever verhoogde productie van regelgeving heeft er echter toe geleid dat er vraagtekens werden gezet bij het rechtsgehalte van de regelgeving. ${ }^{20}$ De kwaliteit van de regelgeving werd aanvankelijk schoorvoetend maar later steeds vaker ${ }^{21}$ inzet van rechterlijke procedures, waarbij direct belanghebbenden de rechter regelmatig aan hun zijde vonden. ${ }^{22}$ Met de toenemende invloed van Europees en internationaal recht zijn de toetsingsmogelijkheden van de wet in formele zin uitgebreid. ${ }^{23} \mathrm{Bij}$ de rechterlijke toetsing blijkt regelmatig dat de nationale wetgeving in strijd is met deze hogere normen. De kritiek op de kwaliteit van regelgeving kan overigens ook worden gehoord bij de wetgever zelf. Hij speelt dan ook een actieve rol bij het optimaliseren van de kwaliteit van regelgeving.

De kwaliteit van de regelgeving staat ook onder druk door de, ten gevolge van het geloof in de "maakbaarheid, van de maatschappij" ontstane ondoorzichtige weigeving, overregulering en centralisering van sturingsmechanismen. Als reactie daarop werden in de jaren tachtig door de wetgever pogingen ondernomen tot decentralisering en deregulering ${ }^{24}$ en het duidelijker en directer verantwoordelijk stellen van veroorzakers van bepaalde maatschappelijke of beleidsmatige ongewenste situaties. ${ }^{25}$ Het besef bij

Zie hierover bijvoorbeeld de bundels: Bovens, M.A.P. en Witteveen (red.), Het schip van staat; Beschouningen over recht, staat en sturing; Bovens, M.A.P., Derksen, W. en Witteveen, W.J. (red.), Sturing van de samenleving; Conferentie over 'Het schip van staat'; Bovens, M.A.P., Derksen, W. en Witteveen, W.J., (red.), Rechtsstaat en sturing. Dit optreden zous op gespannen voet staan met de rechtsstaatgedachte, zie bijvoorbeeld Foqué, R. en Hart, A.C. 't, Instramentaliteit en rechtsbescherming en Hart, A.C. 't, Het schild van Perseus.

20 "De Harmonisatiewet laat zien dat ook algemene beginselen van behoorlịke wet- en regelgeving door Regering en Parlement geschonden kunnen worden." Aldus Polak, J.M., "De wetgeving van het Departement van Justitie", p. 1.

21 Voor zover mogelijk gezien het toetsingsverbod uit artikel $120 \mathrm{Gw}$.

22 Zie over onrechtmatige wetgeving Wijk, H.D. van, bewerkt door Konijnenbelt, W. en Male, R.M. van, Hoofdstukken van bestuursrecht, pp. 752-759.

23 Zie bijvoorbeeld de diverse ingrijpende uitspraken van het EHRM en van het Hof van Justitie van de EG zoals EHRM 20 november 1989, $N J$ 1990, 245, met noot Alkema (Kostovski) en Hof van Justitie EG 30 april 1996, NJ 1997, 214 (Securitel) en Hof van Justitie EG 16 juni 1998, NJB i998, nr. 23 (Bewijs ondanks Securitel).

Zie bijvoorbeeld de dereguleringsrapporten Geelhoed en Van dei Grinten, TK 1992 1983, 17931 , nrs. 5, 9 en 10 en het advies terzake van de commissie voor de toetsing van wetgevingsprojecten die uitmonden in de Aanwijzingen inzake terughoudendheid met regelgeving bij besluit van 5 november 1984, TK 1984-1985, 17931 , nr. 46.

Voorbeelden zijn het bekende statement "de vervuiler betaale" uit de tachtiger jaren en de verdere ontwikkeling van risico-aansprakelijkheid in het privaatrecht; zie bijvoorbeeld artikel 6:175 $\mathrm{BW}$ dat stelt dat in beginsel degene die in de uitoefening van zijn beroep of bedrijf een stof gebruikt of onder zich heef, terwijl van deze stof bekend is dat zij zodanige eigenschappen heeft, dat zij een bijzonder gevaar van ernstige aard voor 
zowel de overheid als de samenleving groeide dat sturing door de overheid principiële en praktische grenzen kent ${ }^{26}$, dat de positie van de overheid in de samenleving wordt overschat ${ }^{27}$, dat nogal eens de tot stand gekomen (modificerende) regels faalden ${ }^{28}$ en dat sectoren in de samenleving maar beperkt en moeizaam doordringbaar zijn met sturingsmechanismen van buiten. ${ }^{29}$ Geconstateerd werd dat er (maatschappelijke) problemen zijn die zich er nauwelijks toe lenen om met behulp van wettelijke maatregelen tot een oplossing te worden gebracht. ${ }^{30}$

Het inzicht in de beperkingen van regelgeving als sturingsinstrument leidde ertoe dat in toenemende mate naar nieuwe vormen van overheidsregulering werd en wordt gezocht. Het betreft vormen waarbij niet de uitkomsten van sociale processen en het overnemen van de verantwoordelijkheid daarvoor door de overheid centraal staat, maar waarbij door de overheid wordt getracht zelfregulerende mechanismen in maatschappelijke sectoren te ondersteunen, te institutionaliseren en zo nodig te beïnvloeden. ${ }^{3 f}$ Deze ontwikkelingen leidden ertoe dat er in toenemende mate bij regulering gebruik werd gemaakt van zelfregulering en convenanten, dat bestuursrechtelijke wetgeving nauwelijks meer inhoudelijke normen bevatte ${ }^{32}$, dat de (uitleg van) wetgeving langzaam maar zeker meer kenmerken van risicoaansprakelijkheid gaat vertonen en dat de ontwikkeling in de richting van een risicomaatschappij in gang lijkt te zijn gezet. ${ }^{33}$ Overigens lijkt (ook internationaal) een

personen of zaken oplevert, aansprakelijk is wanneer dit gevaar zich verwezenlijkt. Een ander voorbeeld is artikel 185 Wegenverkeerswet, dat stipuleert dat indien een motorrijtuig betrokken is bij een verkeersongeval waardoor schade wordt toegebracht aan niet in dat voertuig vervoerde personen of zaken de eigenaar of houder van het voertuig in beginsel verplicht is die schade te vergoeden.

26 Zie Pennock, J.R. en Chapman, J.W., The limits of law.

27 Er zijn ook grenzen aan de mogelijkheden tot planning, zie bijvoorbeeld Gunsteren, H.R. van, The quest for control.

28 Regels falen indien ze de van te voren geëxpliciteerde doelen ex post niet blijken te bereiken. De typische ontwikkeling van de verzorgingsstaat blijkt de effectiviteit van de vooral daarbij gehanteerde modificerende regelgeving te verminderen. Veld, R.J. in ' $t$, "Planning: ge(s)laagde ontregeling?", pp. 220-224. Zie ook Mok, M.R., "Economisch recht", pp. 160-164.

29 Zie de Nota "Zicht op wetgeving", TK 1990-1991, 22 008, nrs. 1-2, p. 26; zie ook Snellen, I.Th.M., Boeiend en geboeid.

30 Zo noemde Prakke, L., Reede, J.L. de en Wissen, G.J.M. van, Handboek van het Nederlands staatsrecht, p. 484 als voorbeeld de milieuvervuiling, waarvoor slechts marginale oplossingen aanwezig zouden zijn, die volgens hen niet meer doen dan de achteruitgang van het milieu enigszins vertragen. De verbeteringen die de afgelopen jaren door (de handhaving van) regelgeving zijn geboekt ten aanzien van de lucht-, water- en (zij het langzaam ook de) grondkwaliteit lijken hiermee in tegenspraak.

31 Nota "Zicht op wetgeving", TK 1990-1991, 22 008, nrs. 1-2, p. 26; zic ook Teubner, G., "Substantive and reflexive elements in modem law".

32 Zie Geest, H.J.A.M. van, Leede, L.J.M. de en Ringeling, A.B., "De weerbarstige norm", p. 3 en 10. Indien de wetgeving geen materiele normen meer bevat zal de rechter in de problernen komen. Zie Ruiter, D.W.P., "Kloven in het bestuursrecht", pp. 352-370.

33 Zie hierover bijvoorbeeld Beck, U., Risicogesellschaft; de bijdragen in Lash, S., 
tegenbeweging op gang te zijn gekomen. Dit blijkt bijvoorbeeld uit de toename van normstellingen in en de wijziging van handhavingsmogelijkheden van enkele ordeningswetten. ${ }^{34}$

De techniek van wetgeving in West-Europa is pas in de loop van de negentiende eeuw, in de tijd van de grote codificaties, als zodanig specifiek tot ontwikkeling gekomen. ${ }^{33}$ In Nederland verschijnen de eerste belangrijke studies in de twintigste eeuw ${ }^{36}$ Van belang is vooral het rapport van een commissie uit de Vereniging van administratief recht $^{37}$, naar aanleiding waarvan de ministerraad een Contactcommissie voor de Wetgevingstechniek instelde. ${ }^{38} \mathrm{Zij}$ kwam met aanbevelingen die in 1951 als richtlijnen voor de wetgevingstechniek werden vastgesteld. ${ }^{39} \mathrm{De}$ richtlijnen zijn bedoeld voor ambtenaren die op de departementen de wetgeving in concepten ontwerpen. Daarnaast kwamen vele naast elkaar staande voorschriften tot stand op het gebied van wetgeving. ${ }^{40}$

In de jaren zeventig wordt de kritiek op de wetgever steeds scherper. Zo stelt Langemeijer dat het ernstig tekort schieten van het parlement in zijn verschillende

Szerszynski, B. en Wynne, B. (red.), Risk, Environment \& Modernity; Towards a New Ecology en Beck, U., De wereld als risicomaatschappij, met een inleiding van Hajer, M. en Schwarz, M., pp. 7-37; Buruma, Y., "Het schuldig subject", pp. 1-9.

34. Zo is hiervan binnen de financielle sector duidelijk sprake; zie bijvoorbeeld de Wet Toezicht Effectenverkeer 1995, de in 1994 inwerking getreden Wet Identificatie bij Financiële dienstverlening, de uit 1995 stammende Wet inzake: wisselkantoren en de in 1994 inwerking getreden Wet Melding Ongebruikelijke Transacties, maar ook bij recentere wijzigingen van de Wet milieubeheer lijkt hiervan sprake. Zie hierover Aalders, M. en Niemeijer, B., "Zelfregulering en reflexief handhaven in vier sectoren", pp. $75-113$.

35 Specifiek omdat F. Bacon al in 1605 zich niet alleen bewust was van de waarde en de inhoud, maar ook van de vorm van de wet, en dit ook heeft uitgedragen. Zie voor een overzicht van de geschiedenis van de wetgevingstechniek: Groenendaal, J., Inleiding tot de wetgevingstechniek, pp. 17-28. Zie ook Vlies, 1.C. van der, Handboek wetgeving, p. 141.

36 Zie bijvoorbeeld Fockema Andreae, J.P., "Welke methode behoort te worden gevolgd bij de herziening van ons Burgerlijk Recht (inrichting en indeling van het Wetboek; herziening in een of bij gedeelten; wijze van voorbereiding en behandeling)": Zie voor een overzicht nogmaals Groenendaal, J., Inleiding tot de wetgevingsiechniek, pp. 26-28.

37 Deze commissie die op initiatief van P.W. Oosterhoff in 1941 begon onder voorzitterschap van J.P. Fockema Andreae presenteerde in 1948 haar rapporn over wetgevingstechniek.

38 In 1950 deed zij voorstellen met betrekking tot formulieren voor brieven op het gebied van wetgeving. Deze werden op 8 januari 1951 in de ministerraad behandeld en bij brief van 4 augustus 1952, nr. 33.201 rondgezonden. Nadat met deze voorstellen enige ervaring was opgedaan werden ze in gedrukte tekst door W. Drees verspreid onder de titel Aanwijzingen en brieven op het gebied van de wetgeving.

39 Deze richtlijnen werden in 1954 en 1984 herzien.

40 Zie artikel 2 Besluit tot vaststelling van de Aanwijzingen voor de regelgeving. 
functies een voorname misschien wel de voornaamste oorzaak is van de onvrede tegenover de rechtsorde. ${ }^{41}$ In zijn rede als voorzitter van de NJV stelt C. Polak ${ }^{42}$ :

"Bij de huidige omvang van de overheidszorg hebben kamerfracties behoefte aan allerhande soort van deskundigen in hun midden. De zorg voor het recht en de rechtsvorming is niet meer de voomaamste overheidstaak, maar wordt meer en meer beschouwd als een der onderdelen daarvan en politiek bij lange na niet een van de belangrijkste. Er is in het parlement een afnemende belangstelling voor typisch juridische zaken. (...) Het parlement heeft de gewichtige taak te waken voor het rechtsgehalte van nieuwe normen, voor het behoud en de uitwerking van de beginselen van de rechtsstaat. (...) Misschien lijkt velen van U mijn beduchtheid voor het rechtsgehalte van onze rechtsstaat wat overdreven. Maar de wetten worden onoverzichtelijker en tegenstrijdiger, de vergunningstelsels stapelen zich op, de wetshandhaving wordt grilliger en zwakker, ten aanzien van vele takken van omvangrijke overheidszorg ontbreken vaste regels."

Het algemeen wetgevingsbeleid kwam vervolgens tot ontwikkeling eind jaren tachtig. ${ }^{3}$ Dit gebeurde mede onder invloed van de enorme toename van de hoeveelheid regelgeving en de vele problemen waarmee dit gepaard gaat. Zo werd bijvoorbeeld de Commissie voor de toetsing van wetgevingsprojecten ingesteld ${ }^{44}$, die in haar eerste jaarverslag onder meer spreekt over de verwezenlijking van een terughoudend, sober, doeltreffend, doelmatig en rechtmatig wetgevingsbeleid. ${ }^{45}$ Eind 1989 schrijft formateur Lubbers aan de Koningin het volgende ${ }^{46}$ :

"Bevestigd werd voorts dat het algemeen wetgevingsbeleid gericht op de verbetering van rechtsstatelijke en bestuurlijke kwaliteit van de wetgeving en de constitutionele en Europees- en internationaal rechtelijke toetsing van wetgeving tot de primaire verantwoordelijkheid van de minister van justitie behoort."

In de regeringsverklaring wordt vervolgens aangekondigd dat de minister van justitie medio 1990 een nota aan de Tweede Kamer zal voorleggen waarin wordt ingegaan op de vormgeving van zijn primaire verantwoordelijkheid voor het algemeen wetgevingsbeleid, gericht op de verbetering van de bestuurlijke en rechtsstatelijke kwaliteit van wetgeving. ${ }^{4 ?}$

41 Langemeijer, G.E., "De toekomst van onze rechtspleging", pp. 62-63.

42 Polak, C.H.F., "Hulp voor de wetgever", pp. 910-911.

43 Zie over de ontwikkeling van een algemeen wetgevingsbeleid bijvoorbeeld Eijlander, Ph., De wet stellen, pp. 160-171; Haan, P. de, Drupsteen, Th.G. en Fernhout, R., Bestuursrecht in de sociale rechtsstaat, Deel I, pp. 249-266. Belangrijk voor deze ontwikkeling is ook de studie van Noll geweest, Noll, P., Gesetzgebungslehre.

44 Commissie voor de toetsing van wetgevingsvraagstukken ingesteld bij besluit van 10 september 1987, Sicrt, 1987, 181. Deze Commissie heeft tot taak het adviseren over wetgevingsthema's en wetgevingscomplexen. Tevens omvat haar taak de advisering over concrete wetsvoorstellen, voorontwerpen daarvan en nota's ter voorbereiding van wetgeving. De taak van deze commissie is vervat in het op 11 januari 1989 vastgestelde herziene instellingsbesluit, Stcrt., 1989, 20.

45 Jaarverslag van de Commissie voor de toetsing van wetgevingsprojecten 1987-1988, TK 1988-1989, 20800 , hoofdstuk VI, nr. 13, p. 8.

46 Brief van 7 november 1989, TK 1989-1990, 21 132, nr. 12, p. 2.

47 Alvorens de nota aan de kamer wordt gestuurd, wordt in september 1989 de Stafafdeling 
3. Zicht op wetgeving

\subsection{Inleiding}

De aangekondigde nota verscheen in 1991 onder de naam "Zicht op wetgeving". ${ }^{48}$ Met de nota werd een grondslag gelegd voor een algemeen wetgevingsbeleid dat is gericht op de verbetering van de rechtsstatelijke en bestuurlijke kwaliteit van de wetgeving. ${ }^{49}$ Een bekende tweedeling van de functies van wetgeving die hierbij aansluit is die in waarborg en instrument, aangezien wetgeving enerzijds de rechtszekerheid, rechtsgelijkheid en rechtsbescherming tracht te bevorderen door in algemene termen de rechtspositie van justitiabelen te bepalen, maar anderzijds wordt gebruikt om die menselijke gedragingen tegen te gaan die om welke reden dan ook als schadelijk, bedreigend, nadelig worden beschouwd voor door de gemeenschap als beschermenswaardig bestempelde belangen en/ of het gedrag van justitiabelen tracht te sturen in de richting van wenselijk geachte (beleids)doelstellingen.

De beoordelingsmaatstaven ten aanzien van de kwaliteit van wetgeving die hieruit voortvloeien worden ten aanzien van de waarborgfunctie afgeleid uit rechtsstatelijke waarden en zijn bij de instrumentele functie gelegen in de effectiviteit (ook wel aangeduid met doeltreffendheid) en doelmatigheid (een andere term hiervoor is efficiëntie) van de regeling dan wel bepaling. ${ }^{50}$

De. Nota "Zicht op wetgeving" sluit aan bij deze tweedeling. Ten behoeve van een nadere specificatie worden de kwaliteitseisen voor overheidsoptreden via wetgeving onderverdeeld in een zestal categorieën. Aangezien het kwaliteitseisen voor overheidsoptreden betreft zijn zij zowel gericht tot de wetgever in formele zin als in materiële zin, zodat ook het bestuur dat bevoegd is tot het stellen van wetgeving is gehouden deze eisen in acht te nemen. De kwaliteitseisen zijn zowel van belang voor het beantwoorden van de vraag of wetgeving wel noodzakelijk is als bij het bepalen van de inhoud van te eventuele regeling en de evaluatie daarvan. ${ }^{51}$ Opvallend is dat in deze nota niet de link wordt gelegd met de inmiddels tot ontwikkeling gekomen beginselen van behoorlijke regelgeving. Zo wordt bijvoorbeeld niet angesloten bij of verwezen naar de door Van der Vlies in 1984 beschreven en geanalyseerde beginselen

Algemeen Wetgevingsbeleid ingestelả bij besluit van 10 oktober 1989 (nr. 226/089), die blijkens dit besluit onder meer tot taak heeft de kwaliteit van wetgeving te bevorderen, de harmonisatie van wetgeving te bevorderen en verwezenlijken en zorg te dragen voor algemene wetgevingsvraagstukken.

48 Het betreft een beleidsplan voor de verdere ontwikkeling en uitvoering van het algemeen wetgevingsbeleid, gericht op de verbetering van de rechtsstatelijke en bestuurlijke kwaliteit van het everheidisbeleid, die verscheen op 5 maart 1991 onder de naam "Zicht op wetgeving", TK 1990-1991, 22 008, nrs. 1-2.

49 Nota "Zicht op wetgeving", TK 1990-1991, 22 008, nrs. 1-2, p. 22.

50 Zie ook Eijlander, Ph., De wet stellen, p. 162.

51 Nota "Zicht op wetgeving", TK 1990-1991, 22 008, nrs. 1-2, pp. 23-24. 
van behoorlijke regelgeving, terwijl haar onderzoek op dit gebied een enorme impuls heeft gegeven aan de ontwikkeling van deze beginselen. ${ }^{52}$

De zes categorieën uit de Nota "Zicht op wetgeving" zijn: de rechtmatigheid en verwerkelijking van rechtsbeginselen, doeltreffendheid en doelmatigheid, subsidiariteit en evenredigheid, uitvoerbaarheid en handhaafbaarheid, onderlinge afstemming, eenvoud, duidelijkheid en toegankelijkheid. ${ }^{53}$ De betekenis die in de nota aan deze begrippen wordt gegeven, zal in de volgende paragraaf kort worden weergegeven.

\subsection{Kwaliteitseisen voor overheidsoptreden via wetgeving}

\subsubsection{Rechtmatigheid en verwerkelijking van rechtsbeginselen}

Het betreft het vereiste dat wetgeving voliedig recht doet aan het intemationale en communautaire recht, de Grondwet en algemene rechtsbeginselen, zoals het rechtszekerheidsbeginsel en juridische aspecten inzake het juiste niveau van regelgeving, attributie en delegatie van bevoegdheden, inwerkingtreding en overgangsrecht. De rechtmatigheid van wetgeving wordt de meest wezenlijke kwaliteitseis voor wetgeving genoemd, terwijl daarnaast veel wetgeving op de verwerkelijking van rechtsbeginselen is gericht. Onrechtmatige wetgeving is in een rechtsstaat principieel onjuist, en vermindert bovendien het vertrouwen van justitiabelen in de overheid. Tevens leidt dergelijke wetgeving nogal eens tot rechterlijk ingrijpen, hetgeen de effectiviteit van het beleid kan frustreren. Dat dergelijke wetgeving toch tot stand komt wordt geweten aan het krachtenspel bij de totstandkoming van wetgeving, waarbij politieke en beleidsmatige overwegingen soms prevaleren boven de juridische, terwijl ook de onduidelijkheid van hogere regels, de geringe voorspelbaarheid van rechterlijke uitleg en beperkte deskundigheid van wetgevingsjuristen een rol kunnen spelen.

\subsubsection{Effectiviteit en doelmatigheid}

Het vereiste van effectiviteit, ook wel doeltreffendheid genoemd, ziet op de mate waarin de door de wetgever beoogde doelstellingen bij het invoeren van een bepaalde wet worden verwezenlijkt door die wet. Belangrijk voor de toetsing aan dit vereiste is dat voorafgaande aan de invoering van de betreffende regeling de daaraan ten grondslag liggende doelstellingen helder en volledig worden geformuleerd. ${ }^{54}$ Daamaast dient wetgeving ook doelmatig te zijn, hetgeen wil zeggen dat er geen ongunstige verhouding mag ontstaan tussen de baten en lasten die uit de

52 Zie over de beginselen van behoorlijke regelgeving hoofdstuk 3 paragraaf 5.

53 De nu volgende bespreking van de zes categorieën is gebaseerd op de Nota "Zicht op wetgeving", TK 1990-1991, 22 008, nrs. 1-2, pp. 23-30. Zie voor een andere korte bespreking ook bijvoorbeeld Eijlander, Ph., De wet stellen, pp. 163-I67.

54 Effectiviteitsonderzoek blijkt bij wetgevingsevaluaties vrij zeldzaam te worden toegepast. Zie Winter, H.B., Scheltema, M. en Herweijer, M., Evaluatie van wetgeving, p. 234. 
inwerkingtreding van de wet voortvloeien. Daarom moet worden getracht de beoogde doelstelling te bereiken met de inzet van zo min mogelijk middelen. ${ }^{55}$

\subsubsection{Subsidiariteit en proportionaliteit}

Onder subsidiariteit wordt verstaan dat waar mogelijk verantwoordelijkheden bij decentrale overheden en maatschappelijke organisaties moeten worden gelaten of gelegd. Dit sluit aan bij het streven naar deregulering. ${ }^{56}$ Dat de wetgever waar mogelijk steeds ruimte moet laten voor het zelfregulerende vermogen van burgers en maatschappelijke organisaties vloeit eveneens voort uit het proportionaliteitsbeginsel, dat ook wel het evenredigheidsbeginsel wordt genoemd. Uit dit beginsel vloeit daarnaast onder andere ook nog voort dat de overheid zorg moet dragen voor een redelijke verhouding tussen de baten en de lasten die uit de regeling kunnen voortvloeien. Uit beide eisen vloeit dan ook voort dat de overheid niet nodeloos vergaand in de samenleving ingrijpt.

\subsubsection{Uitvoerbaarheid en handhaafbaarheid}

Regelgeving die beoogt gedragveranderingen te bewerkstelligen dient witvoerbaar en handhaafbaar te zijn, aangezien het anders slechts dode letters betreft hetgeen zowel beleidsmatig als rechtsstatelijk onaanvaardbaar wordt geacht. Ten eerste dienen de regels uitvoerbaar en handhaafbaar te zijn. Vervolgens dienen de kosten die dit meebrengt voor het bestuurlijk en justitieel apparaat zo beperkt mogelijk te blijven. De voor- en nadelen van verschillende mogelijke handhavingstelsels dienen te worden afgewogen. De nota stelt verder dat in het verleden te makkelijk gebruik is gemaakt van het strafrecht, terwijl het bestuursrecht een goed alternatief kan bieden. Voorts wordt opgemerkt ${ }^{37}$ :

"Indien toch wordt gekozen voor strafrechtelijk te sanctioneren bepalingen, vereist de formulering van de elementen van de delictsomschrijving bijzonder veel zorg. Vage en te complexe delictsomschrijvingen leiden immers niet alleen tot rechtsonzekerheid, maar bieden ook onvoldoende mogelijkheden voor een succesvolle strafvervolging."

\subsubsection{Onderlinge afstemming}

Aandacht voor de onderlinge afstemming is ten eerste noodzakelijk daar waar regelingen weliswaar een verschillend onderwerp betreffen maar door hun effecten sterk op elkaar inwerken. Door coördinatie of integratie van regelgeving of bestuurlijk optreden kan dit worden tegengegaan. Ten tweede is onderlinge afstemming gewenst indien sprake is van onnodige en ongewenste verscheidenheid ten aanzien van dezelfde of verwante kwesties, in regelingen of in praktijken. Door harmonisatie, bijvoorbeeld door algemene wetgeving waarop bijzondere wetgeving wordt afgesternd, kan dit worden tegengegaan. Indien de onderlinge afstemming van

55 Zie Eijlander, Ph., De wet stellen, p. 164.

56 Zie ook Eijlander, Ph., De wet stellen, pp. 164-165.

57 Nota "Zicht op wetgeving", TK 1990-1991, 22 008, nrs. 1-2, p. 28. 
regelgeving tekortschiet, ontstaan er inconsistenties en onnodige fricties bij lagere regelgevers, uitvoerders, handhavers, justitiabelen en rechters.

\subsubsection{Eenvoud, duidelijkheid en toegankelijkheidl}

Wetgeving dient voor een ieder die met de regel wordt geconfronteerd, eenvoudig, duidelijk en toegankelijk te zijn. Dit geldt zowel ten aanzien van de justitiabelen als voor degene die de regels toepassen, het bestuur en de rechterlijke macht. Dit stelt hoge eisen aan de formulering van wettelijke bepalingen en aan de structuur en vormgeving van regelgeving. Ingewikkelde, ondoorzichtige en sterk gedetailleerde wetgeving dient dan ook te worden vermeden.

\subsection{Verhouding tussen de kwaliteitseisen}

Er wordt in de nota geen precieze rangorde tussen de categorieën aangegeven. Terecht wordt opgemerkt dat deze kwaliteitseisen vaak samenhangen en elkaar kunnen overlappen, terwijl er ook wel eens spanning tussen twee of meer vereisten kan bestaan. De uitwerking in concreto zal niet statisch en onveranderlijk zijn aangezien de inhoud van de geconcretiseerde vereisten mede wordt beïnvloed door maatschappelijke, juridische, politieke en bestuurlijke veranderingen. Waar het om gaat is dat een "juist" evenwicht wordt gevonden. ${ }^{58}$ Maar wat "juist" wordt bevonden is ook weer afhankelijk van de visie op de rol en functie van het (straf)recht in de samenleving. Door wetgeving echter te toetsen aan bepaalde vaste criteria, in dit geval kwaliteitseisen, is het wel mogelijk wetgeving systematisch te analyseren waardoor (meer) zicht kan worden verkregen op haar functie(s) en knelpunten.

4.

\section{Aanwijzingen voor de wetgeving}

De in de Nota "Zicht op wetgeving" geformuleerde kwaliteitseisen zijn sinds 1993 terug te vinden in de aanwijzingen voor de wetgeving. ${ }^{59}$ Deze aanwijzingen zijn een voorzetting van de eerder genoemde richtlijnen voor de wetgevingstechniek. ${ }^{60}$ Met de invoering van deze aanwijzingen zijn diverse bestaande aanwijzingen, richtlijnen en circulaires, die betrekking hebben op verschillende aspecten van wetgeving komen te vervallen. Deze zijn met in acht neming van een aantal belangwekkende beleidsplannen $^{61}$, rapporten ${ }^{62}$, adviezen ${ }^{63}$ op dit terrein geactualiseerd en geüntegreerd opgenomen in deze (nieuwe) aanwijzingen voor regelgeving.

58 Zie de Nota "Zicht op wetgeving", TK 1990-1991, 22. 008, nrs. 1-2, p. 23.

59 Zie aanwijzing 254. Blijkens de toelichting betreft de wetgevingstoets met name deze zes categorieèn kwatiteitseisen. Deze worden in de aanwijzingen aangeduid als de eisen van goede wetgeving.

$60 \quad$ Zie hoofdstuk 3 paragraaf 2.

61 Naast de Nota "Zicht op wetgeving" dient hier het dereguleringsbeleid, waamee een aanvang is gemaakt begin jaren tachtig te worden vermeld. Zie de dereguleringsrapporten Geelhoed en Van der Grinten, TK 1992-1983, 17 931, nrs. 5, 9 en 10 en het advies terzake van de Commissie voor de toetsing van wetgevingsprojecten die 
De aanwijzingen voor de regelgeving uit $1993^{64}$, herzien in 1996 en in $1998^{65}$, zijn aanwijzingen voor de rijksdienst. Hierdoor binden zij alleen ministers en staatssecretarissen en de onder hun gezag werkzame personen. Vooral wetgevingsambtenaren $^{66}$, maar ook beleidsambtenaren maken gebruik van de aanwijzingen. De aanwijzingen richten zich niet tot bijvoorbeeld de Staten-Generaal, externe adviesorganen, zelfstandige bestuursorganen en decentrale overheden. $\mathrm{Zij}$ hebben geen zelfstandig bindende kracht, waardoor derden er geen rechten aan kunnen ontlenen. Wel is het mogelijk dat de aanwijzingen in een rechterlijke procedure als aanvullend argument een rol van betekenis kunnen spelen. ${ }^{67}$ In de aanwijzingen zijn tevens een aantal beginselen van behoorlijke regelgeving terug te vinden. Gezien de beperkte werkingssfeer, de constatering dat de belangrijke algemene inhoudelijke eisen aan wetgeving zijn te vinden in de (reeds besproken) kwaliteitseisen en in de (te bespreken) beginselen van behoorlijke regelgeving en het feit dat zij geen zelfstandig bindende kracht hebben, worden zij hier niet verder besproken.

\section{Beginselen van behoorlijke regelgeving}

\subsection{Inleiding}

De laatste decennia zijn de beginselen van behoorlijke regelgeving geleidelijk tot ontwikkeling gekomen. Langzamerhand wordt erkend dat zij deel uitmaken van het algemeen wetgevingsbeleid ${ }^{68}$, zodat de in deze paragraaf beschreven totstandkoming

uitmonden in de Aanwijzingen inzake terughoudendheid met regelgeving bij besluit van 5 november 1984, TK 1984-1985, 17 931, nr. 46. Zie over de ontwikkeling van deregulering naar algemeen wetgevingsbeleid Eijlander, $\mathrm{Ph}$., De wet stellen, pp. 155-172 ook verschenen als "Wetgeving in de jaren negentig; van deregulering naar algemeen wetgevingsbeleid", pp. 26-32.

62 Zie vooral het Eindrapport van de Commissie Wetgevingsvraagstukken, Orde in de regelgeving en het kabinetsstandpunt ter zake TK 1990-1991, 20 038, nrs. 1-2. Dit rapport betreft een samenstel van richtlijnen die voor de praktijk enig houvast kunnen bieden bij het gebruik van onderscheiden vormen van regelgeving en daarbij te maken keuzen.

63 Denk met name aan de adviezen van de Commissie voor de toetsing van wetgevingsvraagstukken. Belangrijk in dit kader is bijvoorbeeld het advies over implementatie van EG-regelgeving in de nationale rechtsorde (CTW 90/22) dat werd gevolgd door twee kabinetsstandpunten TK 1990-1991, 21 109, nrs. 34 en 43 die uitmondden in de Aanwijzingen over de voorbereiding en de implementatie van communautaire regelgeving.

64 Zie over deze aanwijzingen Eijlander, Ph. en Voermans, W., "Nieuwe aanwijzingen voor de regelgeving", pp. 169-174; Polak, J.M., "Aanwijzingen voor de regelgeving", pp. 1396-1399; Kortmann, C.A.J.M., "Ontregeling", p. 1376.

65 Zie Ministerie van Justitic, Aanwijzingen voor de regelgeving uit 1996 en Aanwijzingen voor de regelgeving: Aanwijzingen voor convenanten, uit 1998.

66 Zie Eijkern, W.J. van, "De macht van de zwoegers in het vooronder", p. 41.

67 Zie Toelichting, in Ministerie van Justitie, Aanwijzingen voor de regelgeving.

68 Zie bijvoorbeeld Haan, P. de, Drupsteen, Th.G. en Fernhout, R., Bestuursrecht in de 
in samenhang dient te worden gelezen met de in hoofdstuk 3 paragraaf 2 beschreven ontwikkelingen.

Een aantal beginselen van behoorlijke regelgeving is opgenomen in de (in de vorige paragraaf beschreven) "Aanwijzingen voor de wetgeving", terwijl ет ook direct zijn te vinden in wet- of regelgeving. De primaire betekenis van deze beginselen is dat de wetgever ze bij het maken van regelgeving in acht neemt. Daarvan afgeleid vormen ze, indien ze voldoende zijn ontwikkeld om als rechtsnorm te gelden ${ }^{69}$ en de wet beroep op een rechter of een hoger bestuursorgaan terzake van handelen van de betreffende wetgever toestaat, een beroepsgrond voor justitiabelen en een toetsingsgrond voor de controlerende instanties. ${ }^{70}$

Bij de behandeling in de Eerste Kamer van het wetsontwerp voor een algemene pensioenwet politieke ambtsdragers in 1950 , merkte Troostwijk op ${ }^{71}$ dat het wetsontwerp zou

"moeten worden verworpen, als zijnde op zeer bedenkelijke wijze in strijd met de goede politieke zeden en als zijnde voorts in strijd met de logica."

Over het hier gehanteerde criterium van de "politieke zeden" wordt opgemerkt dat ${ }^{72}$

"daarmede tevens een antwoord is gegeven op de vraag, of er, behalve beginselen van behoorlijk bestuur, ook beginselen van behoorijke wetgeving zijn."

Twee jaar later stelt $C$. Polak dat niet alleen naar algemene beginselen van behoorlijk bestuur zou moeten worden gezocht, maar ook naar algemene beginselen van behoorlijke wetgeving, mede omdat ${ }^{9 / 3}$

69 Sociale rechisstaat, Deel 1, p. 264

69 Rechtsnormen bepalen rechtsbetrekkingen terwijl rechtsbeginselen uitdrukking geven aan richtinggevende ideeën die aan rechtsnormen en de interpretatie daarvan ten grondslag liggen. Het onderscheid tussen vage rechtsnormen en rechtsbeginselen is soms moeilijk te maken. Zie Hirsch Ballin, E.M.H., "Rechtsbeginselen en algemene beginselen van behoorlijk bestuur", p. 107.

70 Zie voor de rechtskracht van deze beginselen Vlies, I.C. van der, Het wetsbegrip, en beginselen van behoorlijke regelgeving, pp. 209-211 en voor de toetsingsmogelijkheden doror de rechter ook hoofdstuk 5.

71 EK 25 april 1967, p. 157. Troostwijk constateerde onder andere dat in het ontwerp een anti-cumulatie bepaling ontbrak, en had uitgerekend dat daardoor de pensioenen van een aantal politiek ambtdragers (waaronder die van de toenmalige minister-president, de ministers van Binnenlandse Zaken en Justitie) zouden uitgaan boven het salaris van een Commissaris van de Koningin in functie, zie $E K 25$ april 1967, pp. 155-158.

72 Deze beginselen van behoorlijke wetgeving "moeten ons allen, ambtenaar of geen ambtenaar, ter harte gaan R. en H., "De Algemene pensioenwet politieke ambtsdragers in de Eerste Kamer gestrand; Prof. Troostwijk, de exorbitante pensioenen en de politieke zederi", pp. 242-243; zie hierover ook Oostenbrink, J.J., Algemene beginselen van behoorlijke wetgeving?, pp. 3-4.

73 Interventie Polak, C.H.F., Geschriften van de Vereniging voor administratief recht, p. 
"onbehoorlijk gebruik van de wetgevende bevoegdheid wel niet getoetst zal kunnen worden aan de algemene beginselen van behoorlijk bestuur."

De vraag is of algemene beginselen van behoorlijke regelgeving een zelfstandige plaats zouden moeten innemen naast de algemene beginselen van behoorlijk bestuur. Oostenbrink stelt ${ }^{74}$ :

"van uit een algemeen rechtstheoretisch gezichtspunt zou men, dunkt me, beter kunnen spreken van voor het overheidsoptreden geldende rechtsbeginselen, daarbij wel verdisconterend, dat niet elk beginsel voor elke vorm van overheidsoptreden een zelfde betekenis behoeft te hebben, dat niet elk beginsel steeds door dezelfde instantie als toetsingsgrond behoeft te worden gehanteerd en dat niet elk beginsel voor elk terrein, waarop de overheid haar taak vervult, een zelfde juridische kracht behoeft te bezitten. Ook óngelijke beginselen zal men niet als gelijke behandelen, evenmin als ongelijke gevallen."

Door de snelle ontwikkeling van de algemene beginselen van behoorlijk bestuur, mede door vele jurisprudentie hierover van de bestuursrechter in het kader van de toetsing van beschikkingen, en de achterblijvende ontwikkeling van de algemene beginselen van behoorlijke regelgeving, mede door het toetsingsverbod uit artikel $120 \mathrm{Gw}$, hebben deze twee categorieën rechtsbeginselen voor overheidsoptreden een uiteenlopende ontwikkeling doorgemaakt. De beginselen van behoorlijke regelgeving zijn in verhouding minder tot wasdom gekomen. Dit wordt tevens veroorzaakt doordat zij zich richten op een andere vorm van overheidshandelen, terwijl zij vaak ook een ander rechtskarakter hebben. ${ }^{75}$ Hoewel ze ten dele geînspireerd zijn op en verwant zijn aan de algemene beginselen van behoorlijk bestuur, vallen ze daar niet mee samen. Ze hebben immers betrekking op een andere vorm van overheidshandelen, te weten de totstandkoming van nieuwe regelgeving. ${ }^{76}$ De algemene beginselen van behoorlijk bestuur zijn op zichzelf niet, althans niet zonder meer, geschikt om wetgeving aan te toetsen. 77 De beginselen van behoorlijke regelgeving lijken zich overigens ook niet (zonder meer) te lenen voor rechterlijke toetsing, maar dienen in de praktijk verder tot ontwikkeling te komen. ${ }^{78}$

\section{0.}

74 Oostenbrink, J.J., Algemene beginselen van behoorlijke wetgeving?, p. 18.

75 Zie voor de verschillen tussen algemene beginselen van behoorlijk bestuur en algemene. beginselen van behoorlijke regelgeving bijvoorbeeld Vlies, I.C. van der, Het wetsbegrip. en beginselen van behoorlijke regelgeving, pp. 190-191; Angeren, J.A.M. van, "Beginselen van behoorlijke wetgeving", pp. 67-74.

76. Klink, B. van, De wet als symbool, p. 143.

77 HR 18 april 1967, NJ 1967, 442, AA 1968, pp. 229-235, met noot H.J.M. Jeukens (Zuivering waterkering polder). Dit werd aanvankelijk wel door sommige schrij.vers verdedigd. Zie de bespreking van literatuur pro en contra in de conclusie van HR 3 oktober 1986, NJ 1987, 911, met noot Scheltema; $A B$ 1987, 90, met noot Van der Burg (Heffing op auto's Antillen).

78 Mok in zijn conclusie bij HR 16 mei 1986, NJ 1987, 251, met noot Scheltema; AB 1986, 574, met noot Van der Burg (Landbouwvliegers). Hij geeft ook aan dat: "al zijn de algemene beginselen van behoorlijk bestuur hiervoor niet als zodanig geschikt, sommige 
De primaire bronnen voor de ontwikkeling van deze beginselen zijn, voor zover het geen wettelijke of verdragsrechtelijke beginselen betreffen, de adviezen van de Raad van State $^{79}$, de schriftelijke stukken over en de openbare behandeling van een voorstel van wet, de rechtspraak, de aanwijzingen voor de regelgeving, de doctrine en de literatuur. ${ }^{80}$ De algemene beginselen van behoorlijk bestuur en de algemene beginselen van behoorlijke regelgeving zijn hierdoor aan te merken als twee verschillende categorieën die deel uitmaken van de voor het overheidsoptreden geldende rechtsbeginselen, die weer deel uitmaken van de algemene rechtsbeginselen. ${ }^{81}$

Overheidshandelen dat externe werking heeft, dient dan ook niet alleen te berusten op algemene regels en daarmee in overeenstemming te zijn, het moet ook voldoen aan deze voor het overheidsoptreden geldende rechtsbeginselen. De rechter heeft de bevoegdheid overheidshandelen én regelgeving hieraan te toetsen. ${ }^{82}$ De mogelijkheid wetgeving in materiële zin te toetsen aan ongeschreven rechtsbeginselen werd door de Hoge $\mathrm{Raad}^{83}$ (met een duidelijke verwijzing naar de grenzen van deze bevoegdheid) voor het eerst uitdrukkelijk aanvaard in het arrest Landbouwvliegers. ${ }^{84}$ De Hoge Raad overwoog dat voor voorschriften als onderhavige (in casu een ministeriële regeling),

"geen rechtsregel eraan in de weg staat dat de rechter een zodanig, niet door de formele wetgever gegeven voorschrift onverbindend en in verband daarmee de vaststelling en uitvoering daarvan onrechtmatig kan oordelen op de grond dat sprake is van willekeur in dier voege dat het desbetreffende overheidsorgaan, in aanmerking genomen de belangen die aan dit orgaan ten tijde van de totstandbrenging van het voormelde uitvoeringsbesluit bekend waren of behoorden te zijn, in redelijkheid niet tot het desbetreffende voorschrift is kunnen komen.

Daarbij heeft de rechter niet tot taak om de waarde of het maatschappelijk gewicht dat aan de betrokken belangen moeten worden toegekend, naar eigen inzicht vast te stellen, terwijl zowel de aard van de wetgevende functie als de positie van de rechter in ons staatsbestel, zoals deze

van deze beginselen herleid kunnen worden tot algemene rechtsbeginselen die ook voor de wetgever gelden."

79 Zie bijvoorbeeld het advies van de Raad van State bij het wetsontwerp afbreking zwangerschap, waar het college de beginselen van behoorlijke regelgeving blijkbaar erkent aangezien het er enkele malen aan refereert. Zie TK 1978-1979, 15 475, nrs I-4, bijlage 5 en 6; zie daarover ook Net, B.J. van der, "Naar invulling van algemene beginselen van behoorlijke wetgeving?", pp. 196-197.

80 Zie hierover ook Vlies, I.C. van der, Handboek wetgeving, p. 148.

81 Waaldijk stelt dan ook dat "beginselen van behoorlijke wetgeving een nader gespecificeerde subcategorie vormen van beginselen van behoorlijke regelgeving, die op hun beurt weer een nader gespecificeerde subcategorie van algemene rechtsbeginselen vormen." Waaldijk, K., Motiveringsplichten van de wetgever, p. 297.

82 Zie Kortmann, C.A.J.M., Constitutioneel recht.

83 HR 16 mei 1986, $N J 1987,251$, met noot Scheltema; $A B$ 1986, 574, met noot Van der Burg (Landbouwvliegers).

84 Scheltema stelt dat "Omdat andere overheidsbesluiten aan ongeschreven rechtsregels getoetst worden (waarbij de algemene beginselen van behoorlijk bestuur een grote rol spelen), ligt het in het verlengde van deze ontwikkelingen om ook het vaststellen van lagere wetgeving aan het ongeschreven recht te toetsen." In noot onder HR 16 mei 1986, NJ 1987, 251 (Landbouwvliegers). 
mede in art. 11 Wet Algemene Bepalingen tot uiting komt, meebrengen dat hij ook overigens bij deze toetsing terughoudendheid moet betrachten."

De rechter heeft aldus wel de bevoegdheid om wetgeving in materiële zin rechtstreeks ${ }^{85}$ te toetsen aan ongeschreven rechtsbeginselen, maar mag involge artikel 11 Wet AB "in geen geval de innerlijke waarde of billijkheid der wet beoordelen", waardoor doelmatigheidscontrole buiten zijn competentie ligt. Maar ook binnen zijn bevoegdheidsgrenzen kan hij een grote rol spelen bij het verder invulling geven aan en vaststellen van de grens van de politieke machtsuitoefening. Bij regelgeving die minder voldoet aan de eisen die vanuit democratisch oogpunt daaraan kunnen worden gesteld, ligt de bescherming van de belangen van justitiabelen voor een belangrijk deel bij hem.

Aandacht verdient ook het Harmonisatiewet-arrest. ${ }^{87}$ Hier maakte de Hoge Raad onderscheid tussen toetsing aan beginselen als zodanig en de contra-legem werking ervan. De Hoge Raad maakt duidelijk het

"wezenlijke verschil tussen enerzijds: het in bepaalde (groepen van) gevallen buiten toepassing laten van een wetsbepaling op de grond dat toepassing van die bepaling in verband met daarin niet verdisconteerde omstandigheden (in de regel: de wijze waarop de overheid is opgetreden) in strijd zou komen met een fundamenteel rechtsbeginsel, en anderzijds: het wegens zulk een strijd buiten toepassing laten van een wetsbepaling op grond van omstandigheden welke bij haar tot stand komen in de afweging zijn betrokken, dus in gevallen waarvoor zij nu juist is geschreven. Het eerste raakt niet aan de verbindende kracht van de betrokken bepaling en staat de rechter ingevolge voormelde jurisprudentie vrij; het tweede ontneemt echter aan die bepaling haar verbindende kracht en is de rechter ingevolge art. 120 Gr.w verboden."

Toetsing van wetgeving in formele zin aan de Grondwet of algemene rechtsbeginselen is derhalve in beginsel niet mogelijk. Dit betreft immers het beoordelen van rechtmatigheid van de wet als zodanig, dus het resultaat van de afweging van de belangen, feiten en omstandigheden die de wetgever in zijn overwegingen heeft betrokken. De contra-legem werking van beginselen ziet op het niet toepassen van een wet in een bepaald geval omdat de toepassing de overheid in conflict zou brengen met het ongeschreven recht. Het buiten toepassing laten van de wet in fomele zin is wel toegestaan indien het gaat om niet door de wetgever verdisconteerde omstandigheden. ${ }^{88}$

85. Scheltema stelt in zijn noot onder HR 3 oktober1986, $N J 1987,911$ (Heffing op auto's Antillen): "Nieuw is nu, dat in de lijn van het landbouwvliegers-arrest de foetsing niet verloopt via de omweg van de veronderstelde wil van de wetgever, maar direct aan het vertrouwensbeginsel of rechtszekerheidsbeginsel."

86 Zie Brenninkmeijer, A.F.M., "Democratische rechtspraak en ondemocratische wetgeving", pp. 1387-1395. Zie over de rechter en de voorwaarden voor strafbaarstelling hoofdstuk 5.

87 HR 14 april 1989, $N J 1989,469$, met noot Scheltema; $A B$ 1989, 207, met noot Van der Burg (Harmonisatiewetarrest).

88 Zie Wijk, H.D. van, bewerkt door Konijnenbelt, W. en Male, R.M. van, Hoofdstukken van bestuursrechi', p. 756. Zie ook HR 9 juni 1989, NJ 1989, 718; AB 1989, 412, met 
Voorts is de rechter involge artikel 93 jo. $94 \mathrm{Gw}$ bevoegd wetgeving in materiële en formele zin te toetsen aan een ieder verbindende verdragsbepalingen. Nationale wetgeving kan zodoende worden getoetst aan de hierin opgenomen fundamentele rechtsbeginselen, ook als deze (nog) geen uitdrukking hebben gevonden in de nationale rechtsorde of hieraan involge artikel $120 \mathrm{Gw}$ niet zijn. te toetsen.

\subsection{Inhoud van de beginselen van behoorlijke regelgeving}

De beginselen van behoorlijke regelgeving betreffen criteria waaraan regelgeving zou moeten voldoen, wil zij "behoorlijk" zijn. ${ }^{89}$ Aangezien ze niet alleen zien op wetgeving in formele zin, maar ook betrekking hebben op besluiten van andere organen betreft het niet slechts beginselen van behoorlijke wetgeving maar beginselen van behoorlijke regelgeving. ${ }^{90} \mathrm{Zij}$ zijn gedeeltelijk gecodificeerd in internationale verdragen, de Grondwet en wetgeving in formele zin, daarnaast zijn zij gedeeltelijk ongeschreven.

\section{Het doel van deze beginselen is er vooral in gelegen ${ }^{91}$}

"de wetgevende taak van de overheid in goede banen te leiden en te houden: zij kunnen een leidraad vormen bij het ontwerpen van nieuwe regelingen en een maatstaf bieden voor de Raad van State bij de toetsing ervan".

Daarnaast zijn zij belangrijk om via rechterlijke toetsing duidelijkheid te krijgen over de (on)rechtmatigheid van regelgeving op basis waarvan (direct of indirect) de verdachte wordt aangesproken. Op deze manier geven ze invulling aan de rechtsbescherming van justitiabelen tegen bepaalde vormen van overheidshandelen.

Zij zijn zoals in het voorafgaande werd aangegeven, niet te rekenen tot de algemene beginselen van behoorlijk bestuur aangezien ze een ander rechtskarakter hebben en van toepassing zijn op een andere vorm van overheidshandelen. Ondanks het onderscheid tussen de algemene beginselen van behoorlijk bestuur en de beginselen van behoorlijke regelgeving vertonen ze ook overeenkomsten. ${ }^{92}$ Sinds de codificatie

noot Van der Burg (Kortverbanders).

89 Kortmann, C.A.J.M., "Behoorlijke wetgeving", p. 70.

90 Vlies, I.C. van der, Het wetsbegrip, en beginselen van behoorlijke regelgeving, p. 189. Haar onderzoek heeft een belangrijke impuls gegeven aan de ontwikkeling van deze beginselen.

91 Zie conclusie Biegman-Hartogh bij HR 3 oktober1986, $N J$ 1987, 911, met noot Scheltema; $A B$ 1987, 90, met noot Van der Burg (Heffing op auto's Antillen).

92 Scheltema stelt in zijn noot onder HR 3 oktober1986, $N J$ 1987, 911 (Heffing op auto's Antillen) dat het verschil tussen de toeting van regelgeving aan algemene rechtsbeginselen/ algemene beginselen van behoorlijke regelgeving en beschikkingen aan algemene beginselen van behoorlijk bestuur niet groot hoeft te zijn. "In de gevallen waarin volgens het arrest een beschikking onrechtmatig zou zijn als gevolg van een contra legem toepassing van het vertrouwensbeginsel, zou een specifieke bepaling in de regeling die dergelijke beschikkingen uitdrukkelijk zou voorschrijven, onrechtmatig zijn geweest. Het kan dus van de gedetailleerdheid van de regeling afhangen of het 
van een aantal algemene beginselen van behoorlijk bestuur in de Awb is evident geworden dat de in deze beginselen opgesloten normen allereerst rechtsnormen zijn voor het handelen van bestuursorganen, met name voor het nemen van besluiten ${ }^{93}$, en dus niet alleen voor beschikkingen. De beginselen van behoorlijke regelgeving zijn mede van toepassing op besluiten van andere organen dan de wetgever in formele zin. Het deel van deze beginselen dat betrekking heeft op de besluitvorming van regelgeving komt daardoor parallel te lopen, en overlapt gedeeltelijk de algemene beginselen van behoorlijk bestuur die betrekking hebben op hetgeen tijdens de procedure bij het nemen van besluiten in acht moeten worden genomen. ${ }^{94}$

De beginselen van behoorlijke regelgeving zijn in te delen in meer formele en meer materiēle beginselen. ${ }^{95}$ De formele beginselen hebben vooral betrekking op de totstandkoming, de systematiek en de inwerkingtreding van een regel terwijl de materiële beginselen meer op zien de inhoud van een regel. Hoewel in het kader van dit hoofdstuk de bespreking van de formele beginselen minder voor de hand lijkt te liggen is, vindt zij toch plaats daar tussen deze twee categorieën geen scherpe scheiding is aan te brengen aangezien vorm en inhoud een sterke samenhang vertonen. Vooral de materiële beginselen liggen (gezien inhoud en doelstelling) in dezelfde lijn als de in de Nota "Zicht op wetgeving" geformuleerde kwaliteitseisen voor overheidsoptreden via regelgeving. Desondanks zijn ze tot op heden niet geïntegreerd tot één systeem van uitgangspunten die door de wetgever en het bestuur in acht dienen te worden genomen bij het realiseren van regelgeving. Daarom zal de nu volgende bespreking van de meer formele beginselen (hoofdstuk 3 paragraaf 5.3.) en de meer materiële beginselen (hoofdstuk 3 paragraaf 5.4.) aansluiten bij de in het staatsrecht gangbare betekenis van deze begrippen, zonder dat aansluiting of samenhang wordt gezocht bij de vereisten uit de Nota "Zicht op wetgeving". ${ }^{6}$

vertrouwensbeginsel leidt tot onrechtmatigheid van een bepaling in een regeling, of slechts tot onrechtmatigheid van een daarop gebaseerde beschikking. Men zou veronderstellen dat het vertrouwensbeginsel in beide gevallen op dezelfde wijze als toetsingsmaatstaf wordt gehanteerd."

93 Wijk, H.D. van, bewerkt door Konijnenbelt, W. en Male, R.M. van, Hoofdstukken van bestuursrecht, pp. 410-417.

94 Zie ook Koopimans, T., "Beginselen van wetgeving", p. 124.

95 Bij de bespreking van de beginselen wordt de door Van der Vlies aangebrachte indeling gevolgd; niet alleen heeft zij een belangrijke bijdrage geleverd aan de ontwikkeling van deze beginselen, ook is haar bespreking het meest compleet en zijn de meeste andere beschrijvingen in het algemeen gebaseerd op haar indeling.

96 Voor de nu volgende bespreking is voorzover niet anders aangegeven gebruik gemaakt van: Vlies, I.C. van der, Handboek wetgeving, pp. 140-181; de bespreking hiervan door Schreuder-Vlasblom, M., "Boekbespreking", pp. 324-326; Vlies, I.C. van der, Het wetsbegrip, en beginselen van behoorlijke regelgeving, pp. 188-219; Kortmann, C.A.J.M., "Behoorlijke wetgeving", pp. 63-75. Kistenkas, F.H., Problemen van regelgeving, pp. 34-49; Bracke, N., Voorwaarden voor goede EG-wetgeving, pp 15-23; Klink, B. van, De Wet als symbool, pp. 143-151. 


\subsection{Formele beginselen van behoorlijke regelgeving}

\subsubsection{Beginsel van duidelijke doelstelling}

Het beginse! van duidelijke doelstelling wordt ook wel aangeduid als het motiveringsbeginsel voor regelgeving. Dit beginsel heeft betrekking op het kenbaar maken van motieven voor een bepaalde regel, en betreft de vraag of de regeling in het algemene beleidskader past, wat het specifieke doel is van de regel in het algemeen en van de verschillende onderdelen. Hoewel enkele regelingen een toelichtingplicht voor toekomstige algemeen verbindende voorschriften kennen, is er in Nederland geen algemene juridische verplichting aanwezig tot het motiveren van algemeen verbindende voorschriften. De meeste regelingen worden wel voorzien van een toelichting ${ }^{97}$, hetgeen ten dele historisch is bepaald en ten dele voortkomt uit de juridische plicht om besluiten te voorzien van een deugdelijke motivering. ${ }^{98}$ De motivering kan bijvooibeeld gebeuren in de considerans of de Memorie of Nota van Toelichting. Naleving van dit beginsel is onder meer van belang voor de verbetering van de kwaliteit van de regelgeving en om na te gaan of een bepaalde regel wel nodig is. Ook kan de rechter het gebruiken bij de interpretatie van de regel en kan hij uitvoeringsbesluiten, voor zover hij daartoe bevoegd is, hieraan toetsen. ${ }^{9}$ Daarnaast kan het bestuur op grond van bijzondere omstandigheden afwijken van de regeling, voor zover deze dat toelaat. Probleem bij de motivering kan zijn dat het moeilijk is vooraf aan te geven wat het effect ervan zal zijn. Natuurlijk kan wel het beoogde effect worden aangegeven. De ex ante evaluatie van het beoogd effect is echter een moeilijke zaak, en blijkt weinig te worden toegepast. ${ }^{100}$ Daarbij komt dat evaluaties meestal kostbaar zijn, veel tijd vergen, en ook de stabiliteit van wetgeving niet altijd gebaat is bij het $e x$ post periodiek uitvoeren van evaluaties. Voorts blijken zij doorgaans zelden tot het ingrijpend bijstellen van bestaande regelingen te leiden, maar geven de bevindingen vaak wel aanleiding voor het oplossen van problemen in de uitvoeringspraktijk. ${ }^{01}$ Een ander probleem is dat het overheidsorgaan dat de regel stelt bepaalde motieven voor het tot stand brengen van de regel niet openbaar maakt maar overlaat aan het bestuur dat de wet toepast. Ook komt het voor dat hij de (ware) motieven voor de regel niet openbaar wil maken, bijvoorbeeld op grond van partijpolitieke overwegingen. Ondanks deze

97 Het is vooral gewoonterecht dat wetgeving moet worden gemotiveerd door vermelding van het doel van de wet en door bespreking van de overwegingen die hebben geleid tot de voornaamste in de wet gemaakte keuzen. Zie Waaldijk, K., Motiveringsplichten van de wetgever, pp. 206-207 en 295-297. Zie ook Male, R.M. van, "Geen wetgeving zonder motivering", pp. 279-291.

98 Eijlander, P. en Voermans, W., Wetgevingsleer, p. 171. Zie over de grondslag en inhoud van deze plicht Waaldijk, K., Motiveringsplichren van de wetgever.

99 De rechter kan dit, maar moet dit niet, hetgeen zeer duidelijk blijkt uit de contra legem jurisprudentie. Zie hierover bijvoorbeeld Kistenkas, F.H., "Contra legem: een leerstuk op drift?", pp. 81-98; Kistenkas, F.H., Problemen van regelgeving, pp. 24-33.

100 Winter, H.B., Scheltema, M. en Herweijer, M., Evaluatie van wetgeving, p. 234. Zie over de effectiviteit van regelgeving ook Huppes-Cluysenaer, L., "Onderzoek naar de effectiviteit van strafrechtelijk optreden", pp. 133-158 en hoofdstuk 3 paragraaf 7.7 .

101 Eijlander, P. en Voermans, W., Wetgevingsleer, pp. 355-368. 
problemen is het ex ante en ex post evalueren van wetgeving van groot belang voor de bevordering van de kwaliteit van regelgeving. ${ }^{102}$

\subsubsection{Beginsel van het juiste orgaan}

Indien conform het beginsel van duidelijke doelstelling is vastgesteld wat de doelstelling van de regel is en welke plaats deze regel inneemt tussen de bestaande regels, kan worden beoordeeld welk orgaan bevoegd is om de regel uiteindelijk vast te stellen. Bovendien zal hij dit dienen te motiveren. Indien de wetgever een bepaalde bevoegdheid niet zelf uitoefent, maar aan een bepaald orgaan (horizontaal of verticaal), delegeert behoort hij dat toe te lichten. De belangrijkste normstellingen horen door de wetgever in formele zin te worden vastgesteld, bij minder belangrijke kan dit ook een lager orgaan zijn. Indien besluiten die diep ingrijpen in het leven van burgers door de wetgever in materiële zin onontkoombaar zijn, dient de wet in formele zin de belangrijkste oriëntatiepunten aan te geven. ${ }^{103}$ De Commissie Wetgevingsvraagstukken stelt in dit kader ${ }^{104}$ :

"Gegeven de noodzaak van delegatie en rekening houdend met het belang van overzichtelijke regelgeving, kan uit het axioma van het primaat van de wetgever de algemene norm worden afgeleid dat de wet ten minste zowel de reikwijdte en de hoofdlijnen van een regeling alsmede de belangrijkste naar buiten werkende voorschriften behoort te bevatten, terwijl aan de lagere wetgever de nadere uitwerking en de regeling van details kan worden overgelaten."

Daarnaast: geldt het uitgangspunt dat wat naar zijn aard bij lagere lichamen behoort, ook door het betreffende orgaan dient te worden geregeld. ${ }^{105}$ Regelgeving van de centrale overheid bevat veelal beleidsvrijheid met betrekking tot belangrijke zaken voor de centrale overheid en meer uitvoerende taken voor de lagere overheden. Van belang is dat de takkverdeling tussen de centrale overheid en lagere overheden zo duidelijk mogelijk is. Tevens dient te worden bezien of de toebedeelde taak voor dit orgaan reëel is, of een goede coördinatie mogelijk is, en of aansluiting kan worden gevonden bij de taken van het betrokken orgaan.

\subsubsection{Het noodzakelijkheidsbeginsel}

Indien het doel van de regel duidelijk is, en zodoende hetgeen beoogd wordt te bereiken met de regeling, moet worden bezien of het uitvaardigen van de regel werkelijk noodzakelijk is. Indien de regelgever niet overtuigd is van de noodzaak van verandering of als het doel ook zonder de regel kan worden bereikt, dient regelgeving achterwege te blijven. Als toch wordt besloten tot regelgeving dient de voor de burger en de overheid minst belastende vorm van regelgeving te worden gekozen waarvan het meeste effect wordt verwacht, met handhaving van alle juridische waarborgen. Een

102 Gesteld kan worden dat de evaluatie van regelgeving steeds belangrijker lijkt te worden, zie Eijlander, P. en Voermans, W., Wetgevingsleer, p. 365.

103 Klink, B. van, De wet als symbool, p. 139.

104 Commissie Wetgevingsvraagstukken, Orde in de regelgeving, p. 43.

105 Zie artikel $124 \mathrm{Gw}$ dat uitgaat van dit beginsel en hoofdstuk 4 paragraaf 2. 
regel die op een gegeven moment niet meer noodzakelijk is of die het beoogde effect niet teweegbrengt, zou moeten worden ingetrokken of bijgesteld. Dit laatste kan lastig zijn aangezien het beoordelen van de effectiviteit problemen kan opleveren.

\subsubsection{Het beginsel van uitvoerbaarheid}

Het beginsel van uitvoerbaarheid, ook wel aangeduid als het beginsel van handhaafbaarheid, heeft betrekking op de vraag of er garanties zijn dat aan hetgeen in de regel is gesteld gevolg zal worden gegeven. De organen en diensten die de regel gaan uitvoeren dienen daartoe uitgerust te zijn en dienen te beschikken over toereikende financiële middelen en sancties. Tevens is het van belang dat er voldoende maatschappelijk draagvlak aanwezig is. Dat de naleving van gestelde normen niet meer vanzelfsprekend is, wordt onder meer veroorzaakt door de snelle ontwikkeling op sociaal-economisch en cultureel gebied, en het instrumenteel inzetten van regelgeving. ${ }^{106}$ Maar ook onvoldoende technische kwaliteit van regelgeving (bijvoorbeeld door omslachtige procedures, inadequate sancties, niet op elkaar of op de regel afgestemde bevoegdheden), wetgeving in strijd met het recht, normschendingen door overheden zelf alsmede gebrekkige of lakse handhaving kunnen het vertrouwen in de regelgeving ondermijnen.

\subsubsection{Het beginsel van consensus}

Het beginsel van consensus, ook wel aangeduid als het beginsel van zorgvuldige voorbereiding, houdt in dat zoveel mogelijk moet worden gezocht naar consensus tussen de overheid en betrokkenen voor het stellen en de inhoud van een regel. Bij een zorgvuldige voorbereiding van regelgeving dient het betreffende overheidsorgaan niet alleen kennis te vergaren maar ook te overleggen. Dit beginsel wordt teruggevoerd op de parlementaire democratie en de idee van een democratische rechtsstaat. Consensus bevordert niet alleen de democratische legitimatie van de regel, maar ook de acceptatie en daarmee de naleving van de regeling. ${ }^{107}$ In veel gevallen bestaat er een wettelijke plicht voor ministers om over voorgenomen wetgeving advies te vragen. Voor de totstandkoming van lagere regelgeving is deze verplichting in wisselende mate aanwezig. Op basis van de algemene beginselen van behoorlijk bestuur dienen bijvoorbeeld belanghebbenden op de juiste wijze te worden gehoord en moeten adviezen worden ingewonnen. Consensus wordt niet alleen gezocht in het parlement, maar ook met bijvoorbeeld belangengroepen, deskundigen en adviesorganen. Het overleg dient door de toenemende invloed van het Europese en internationale recht niet alleen op nationaal niveau plaats te vinden.

106 Zie over de geringere acceptatie van normen uit instrumentele beleidswetgeving hoofdstuk 3 paragraaf 2.

107 Klink, B. van, De wet als symbool, pp. 149-151. 


\subsection{Materiële beginselen van behoorlijke regelgeving}

\subsubsection{Beginsel van duidelijke terminologie en duidelijke systematiek}

Involge het beginsel van duidelijke terminologie en systematiek dienen regels begrijpelijk en helder te zijn, zowel wat betreft de gebruikte termen als wat betreft de structuur. Niet alleen vage termen, maar ook bijvoorbeeld zeer gecompliceerde zinsconstructies, gebrek aan eenheid in terminologie, ondoorzichtige gelede normstellingen en onduidelijke rubriceringen dienen te worden vermeden. ${ }^{108}$ Hierdoor wordt de rechtszekerheid en de rechtsgelijkheid gediend. Ook voor de rechtspraktijk is het van groot belang aangezien de interpretatie van een regel begint met de tekst en de rubricering van die regel.

\subsubsection{Kenbaarheidsbeginsel}

Dit beginsel houdt in dat een regel door een ieder voor wie hij van belang kan zijn moet kunnen worden gekend. Voor wetten in formele zin, amvb's en ministeriële verordeningen geldt een grondwettelijke publicatieplicht. ${ }^{109}$ Daarnaast zijn er nog vele andere vormen van regelgeving zoals andere algemeen verbindende voorschriften, beleidsregels en richtlijnen. Ook deze moeten worden gepubliceerd. Maar de regelingen zijn door de officiële bekendmaking natuurliik niet echt hekend oewurden aangezien de meeste normadressaten van deze regels dergelijke bladen niet lezen. De officiële publicatie geldt als authentieke en onbetwistbare bron en is derhalve niet zinloos. Maar als het doel is dat de normadressaten de rechten en plichten die uit de regels voortvloeien kennen, is terzake een actief voorlichtingsbeleid noodzakelijk. ${ }^{110}$

Ook het EVRM stelt eisen aan de kenbaarheid van regelgeving. In het Sunday Timesarrest werd door het EHRM als volgt uitleg gegeven aan de woorden "prescribed by law"111:

"49. In the Court's opinion, the following are two of the requirements that flow from the expression "prescribed by law". Firstly, the law must be adequately accessible: the citizen must

108 Kortmann stelt "Als het regelcomplex te ingewikkeld en ondoorgrondelijk is geworden, houdt men zich eenvoudig niet meer aan de regels." Kortmann, C.A.J.M., "Ontregeling", pp. 1375-1380.

109 Involge artikel 88 , artikel $89 \mathrm{Gw}$ jo. de Bekendmakingswet. Als datum van uitgifte van een regel "moet worden verstaan de datum van verschijning in het Staatsblad, waarin het is geplaatst"; HR 4 november 1975, NJ 1976, 173, met noot Prins (Regel na verșchijning Stb.),

110 Zie Verheij, N., "Bekendmaking van gemeentelijke regelgeving", p. 11.

III EHRM 26 april 1979, NJ 1980, 146, met noot Alkema (Sunday Times). De engelse tekst gebruikt overigens een aantal verschillende termen op de plaats waar de franse tekst "prevues par la loi" aangeeft, te weten "prescibed by law", "in accordance with the law", "provided for by law" en "in accordance with law". Deze komen voor in de artikelen 8, 9, 10 en 11 EVRM en artikel 1 van het eerste Protocol en artikel 2 van het vierde Protocol. Zie over deze term uitgebreider hoofdstuk 3 paragraaf 7.3.2. 
be able to have an indication that is adequate in the circumstances of the legal rules applicable to a given case. Secondly, a norm cannot be regarded as a "law" unless it is formulated with sufficient precision to enable the citizen to regulate his conduct: he must be able - if need be with appropriate advice - to foresee, to a degree that is reasonable in the circumstances, the consequences which a given action may entail. Those consequences need not be foreseeable with absolute certainty: experience shows this to be unattainable. Again, whilst certainty is highly desirable, it may bring in its train excessive rigidity and the law must be able to keep pace with changing circumstances. Accordingly, many laws are inevitably couched in terms which, to a greater or lesser extent, are vague and whose interpretation and application are questions of practice."

De Hoge Raad legt de criteria uit het Sunday Times-arrest ook aan bij andere gevallen die buiten de specifieke bepalingen van het EVRM vallen. Desondanks schort het nogal eens aan de accessibility van regelgeving. Wijzigingen in wetgeving worden vaak separaat gepubliceerd, zodat het een ware speustocht kan zijn de gehele actueel geldende wet te achterhalen. ${ }^{112}$ Ook de kenbaarheid van lagere regelgeving laat vaak veel te wensen over. ${ }^{113}$

\subsubsection{Het rechtsgelijkheidsbeginsel}

Het rechtsgelijkheidsbeginsel dat, mede involge de artikelen. 1 en $3 \mathrm{Gw}, 26$ IVBPR en 14 EVRM aan alle regelgeving ten grondslag ligt, houdt in dat gelijke gevallen gelijk moeten worden behandeld. ${ }^{114}$ Regels dienen, in onderlinge samenhang, zo weinig mogelijk rechtsongelijkheid ten gevolge te hebben. Een regeling mag daarom geen willekeurig of ongemotiveerd onderscheid maken tussen personen of groepen uit de samenleving. Belangrijk hierbij is in het oog te houden ten aanzien waarvan de gelijkheid wordt nagestreefd. De rechter kan hieraan alle (nationale) regelgeving toetsen, maar doet dit doorgaans met enige terughoudendheid, vaak zelfs alleen via een redelijkheidstoets. Het gelijkheidsbeginsel speelt geen absolute rol, maar dient steeds tegen andere beginselen te worden afgewogen. ${ }^{115}$

112 Sternmen gaan op om in navolging van bijvoorbeeld Zwitserland te komen tot een door de regering verzorgde "Sammlung" met systematisch codificatie van geldende wetgeving die regelmatig wordt bijgehouden. Zie bijvoorbeeld Kortmann, C.A.J.M., "Behoorlijke wetgeving", pp. 73-74 en Vlies, I.C. van der, Het wetsbegrip, en beginselen van behoorlijke regelgeving, p. 203.

113 Zie Winter, R.E. de, "Toetsing van gemeentelijke verordeningen door de strafkamer van de Hoge Raad", pp. 181-266; vooral het voorbeeld op p. 220 spreekt aan. Toen hij een APV trachtte te bemachtigen bleek geen bijgewerkt exemplaar aanwezig op het gemeentehuis. Een met potlood bijgewerkte APV was aanwezig op het politiebureau alwaar een gemeenteambtenaar hem zelf moest gaan halen voordat hij hem kon opsturen.

114 Niet alleen moeten gelijke gevallen gelijk worden behandeld, ook ongelijke gevallen moeten ongelijk worden behandeld naar de mate waarin ze verschillen. Zie ook Scheuder-Vlasblom, "De noordwand van het gelijkheidsbeginsel; Opmerkingen over ongelijkheden en hardheidsclausules", pp. 5-20.

115 Denk bijvoorbeeld an regelgeving die positieve discriminatie nastreven. Van der Vlies stelt dan ook dat "De formele juridische gelijkheid past in het kader van de liberale 


\subsubsection{Het rechtszekerheidsbeginsel}

Het rechtszekerheidsbeginsel indiceert dat gerechtvaardigde verwachtingen dienen te worden gehonoreerd. Hiervan kan worden afgeweken indien de inbreuk kan worden voorzien en wordt gemotiveerd door middel van een deugdelijke belangenafweging. Hienuit volgt niet alleen dat moet worden voorzien in adequaat overgangsrecht maar ook dat regels in beginsel ${ }^{116}$ geen terugwerkende kracht hebben, en dat zij zo duidelijk en precies mogelijk moeten worden geformuleerd. Dit laatste sluit aan bij het beginsel van duidelijke terminologie en systematiek. Indien de systematiek van de regelgeving beter is en de norm nauwkeurig en dus met zo min mogelijk vage termen wordt geformuleerd, zal de voorspelbaarheid en daarmee de rechtszekerheid in het algemeen groter worden.

\subsubsection{Het beginsel van individuele rechtsbedeling}

Het beginsel van individuele rechtsbedeling houdt in dat zoveel mogelijk moet worden voorzien in de mogelijkheid om recht te doen aan de omstandigheden van het individuele geval. Aan dit beginsel wordt tegemoet gekomen door gebruik te maken van bijvoorbeeld gelede normstellingen in de vorm van veriofstelsels en hardheidsclausules in regelgeving. Hierbij treedt een spanning op tussen recht als regei en recht op maat. Indien immers teveel wordt tegemoet gekomen aan het beginsel van individuele rechtsbedeling zullen andere beginselen hierdoor in de verdrukking komen. Zo kunnen gelede normstellingen de inzichtelijkheid en kenbaarheid van de wet $^{117}$, en hardheidsclausules de algemene rechtszekerheid verminderen. ${ }^{118}$ In het strafrecht wordt aan het beginsel van individuele rechtsbedeling ook tegemoet gekomen door het schuldbeginsel. ${ }^{\| 19}$

\subsection{Verhouding tussen de beginselen van behoorlijke regelgeving}

De beginselen van behoorlijke regelgeving spelen zowel een rol bij de totstandkoming van de regel als bij de toetsing van die regel na inwerkingtreding. ${ }^{120}$ De te onderscheiden beginselen hebben betrekking op verschillende aspecten van regelgeving. De

rechtsstaat; in het kader van de sociale verzorgingsstaat wordt een ander gelijkheidsbeginsel ontwikkeld. Het hangt dus mede van de doelstelling van de regelgever af of hij vindt dat de door hem gestelde regel de gelijkheid bevordert, althans niet schaadt." Vlies, I.C. van der, p. 171.

116 Ook in het strafrecht geldt dit niet onherroepelijk. Als bijvoorbeeld wetgeving voor de verdachte gunstiger is geworden dient de rechter daar ambtshalve rekening mee te houden, zie ook artikel $1 \mathrm{Sr}, 16 \mathrm{Gw}$ en 7 EVRM.

117 Zie hoofdstuk 4.

118 Hardheidsclausules kunnen het primaat van de wet sauveren en tegenwettelijk bestuursoptreden legaliseren. Zie Scheuder-Vlasblom, M., "De harde wet en haar zachte kant; enige opmerkingen over hardheidsclausules", pp. 100-117.

119 In het algemeen vereist het strafrecht individuele schuld van de verdachte voordat voldaan is aan vereisten voor strafbaarheid. Zie hoofdstuk 3 paragraaf 7.4.

120 Vlies, I.C. van der, Het wetsbegrip, en beginselen van behoorlijke regelgeving, p. 209. 
formele beginselen hebben vooral betrekking op de totstandkoming, de systematiek en de inwerkingtreding van een regel, terwijl de materiële beginselen meer zien op de inhoud van de regel. Hoewel de beginselen elkaar vooral aanvullen, kan er ook wel eens spanning tussen twee of meer beginselen optreden. Het zijn dan voomamelijk rechtspolitieke keuzes die mede worden ingegeven door de mate van inbreuk op de persoonlijke levenssfeer van justitiabelen en het rechtsgebied waarvan de betreffende bepaling deel uitmaakt, die de voorkeur in concreto bepalen.

\section{De beginselen en de Raad van State}

Inmiddels blijken de beginselen van behoorlijke regelgeving een belangrijke rol te spelen bij de beleidstoetsing, de juridische toetsing en de wetstechnische toetsing van wetsvoorstellen en ontwerpen van amvb's door de Raad van State. ${ }^{121}$ Dit geldt overigens ook voor de in hoofdstuk 3 paragraaf 3 besproken kwaliteitsvereisten voor overheidsoptreden via wetgeving en de aanwijzingen voor de wetgeving uit hoofdstuk 3 paragraaf 4.

Bij de advisering over een regeling vormt de Raad zich eerste een oordeel over het aan de regeling ten grondslag liggende beleid. Hierbij wordt onderzocht wat de regering heeft willen regelen, of er een probleem is, welke oplossing adequaat is, of er voldoende maatschappelijk draagvlak is voor de regeling, of nieuwe regels nodig zijn en of de regels proportioneel zijn ten opzichte van het op te lossen probleem.

Bij de juridische toetsing toetst hij op rechtmatigheid en verwezenlijking van rechtsbeginselen alsmede op de inpasbaarheid van het voorstel in het bestaande recht. Hierbij is niet alleen een belangrijke rol weggelegd voor de toetsing aan hoger recht, te weten de mensenrechtenverdragen, het gemeenschapsrecht, de Grondwet en algemene wetten zoals de Awb, de Provinciewet en de Gemeentewet. Ook de toetsing aan ongeschreven recht is belangrijk. Het gaat dan zowel om toetsing aan de algemene eisen van rechtsstaat en democratie als aan beginselen van constitutioneel recht zoals het primaat van de wet. Dat stelt grenzen aan de mogelijkheden van (sub)delegatie van regelgevende bevoegdheden en aan rechtsbeginselen als rechtszekerheid, rechtsgelijkheid, adequate rechtsbescherming en evenredigheid.

In het kader van de wetstechnische toetsing beoordeelt de Raad van State of de te regelen materie op een logische wijze is benoemd en of de instrumenten die de wetgever ter beschikking staan om de wenselijke effecten te bereiken doelmatig zijn toegepast en vormgegeven.

Duidelijk is dat de Raad van State vele beoordelingscriteria hanteert die ook zijn te vinden in de (hierboven besproken) kwaliteitseisen en beginselen van behoorlijke regelgeving. Bij wet- en regelgeving die strafrechtelijk handhaafbaar is, zal hij

121 Zie Raad van State, Jaarverslag 1998, pp. 27-48 en Raad van State, Jaarverslag 1999, pp. 29-44. 
daarnaast ook maatstaven hanteren die deel uitmaken van de (in de volgende paragraaf besproken) criteria voor strafbaarstelling. Ten gevolge van de samenhang met de in dit hoofdstuk besproken vereisten van behoorlijke regelgeving, en omdat de beoordelingscriteria van de Raad van State in algemene zin weinig zijn uitgewerkt aangezien dit veeleer advies- of zaakgebonden plaatsvindt, wordt in dit onderzoek niet expliciet ingegaan op deze beoordelingsmaatstaven.

\section{Criteria voor strafbaarstelling \\ 7.1. Inleiding}

De vraag wanneer en onder welke omstandigheden iemand voor zijn (nalaten te) handelen strafrechtelijk aansprakelijk zou moeten kunnen worden gesteld, is zowel binnen als buiten het strafrecht vanouds punt van discussie. Onder invloed van onder andere tijd, cultuur en politiek zijn de grenzen van de strafrechtelijke aansprakelijkheid voortdurend in beweging. Bestudering van deze grenzen kan systematisch en rationeel verlopen aan de hand van een aantal criteria voor strafbaarstelling. Dergelijke criteria zijn door verschillende schrijvers onderkend en uitgewerkt. ${ }^{122}$ Opvallend is dat hierbij geen aansluiting is gezocht bij de ontwikkelingen op het gebied van het algemeen wetgevingsbeleid en de daar tot ontwikkeling gekomen kwaliteitseisen voor overheidsoptreden via wetgeving en de beginselen van behoorlijke regelgeving, terwijl ze veel verwantschap vertonen.

Een belangrijke impuls bij de ontwikkeling van deze criteria is gegeven door Hulsman ${ }^{123}$, die hierbij werd geînspireerd door Packer. ${ }^{124}$ De Roos heeft, mede voortbordurend op het werk van Hulsman, zijn crimineel politiek toetsingsschema ontwikkeld. ${ }^{125}$ Veel latere schrijvers hebben (onder andere) deze criteria (mede) gebruikt als uitgangspunt voor hun analyse van strafwetgeving. ${ }^{126}$ Aangezien de criteria invulling geven aan de vereisten van behoorlijke regelgeving (hoofdstuk 3 paragraaf 8 ) worden ze ook in dit boek (mede) gebruikt bij de analyse van zorgplichtbepalingen (hoofdstukken 6 tot en met 10).

122 Zie bijvoorbeeld Bemmelen, J.M. van, "Positieve criteria voor strafbaarstelling", pp. 1-14; Dupont, L., Beginselen van behoorlijke strafrechtspleging en Packer, H.L., The Limits of the Criminal Sanction en voor criteria voor strafbaarstelling van milieuverstoring: Faure, M., "Bedenkingen over de rol van het strafrecht bij de bestrijding van milieuverontreiniging", pp. 229-263.

123 Hulsman, L.H.C., Handhaving van recht; Hulsman, L.H.C., Afscheid van het strafrecht en Hulsman, L.H.C., "Kriteria yoor strafbaarstelling", pp. 80-92.

124 Zie Packer, H.L., The limits of the criminal sanction.

125 De Roos, Th., Strafbaarstelling van economische delicten, pp. 53-84.

126 Zie bijvoorbeeld Hout, P.J. van den, Knooppunt van valsheid en bedrog en Koopmans, I.M., De strafbaarstelling van milieuverontreiniging, Faure, M., "Waarom milieustrafrecht?"; Haveman, R., Voorwaarden voor strafbaarstelling van vrouwenhandel, pp. 3041. 
Het is wenselijk dat strafbaarstellingen zoveel mogelijk tegemoet komen aan de criteria voor strafbaarstelling. Zowel de instantie die de strafbaarstelling beoordeelt en/ of vaststelt, als de instantie die deze toepast, kan van deze criteria gebruik maken. Het betekenisbereik van de strafbaarstelling zal door de toepassing van deze criteria duidelijker worden. $\mathrm{Zij}$ maken het tevens mogelijk strafbaarstellingen op een systematische manier te analyseren. Door een dergelijke analyse wordt mede duidelijk waar en waardoor mogelijke knelpunten bestaan bij het gebruik van de betreffende bepalingen in het strafrecht.

De criteria zijn deels gecodificeerd in nationale en internationale regelgeving. Sommige criteria vallen (gedeeltelijk) samen met de kwaliteitseisen voor overheidsoptreden via wetgeving en/ of de beginselen van behoorlijke regelgeving. Een aantal criteria is rechtsnorm, aangezien ze, al dan niet in samenhang met andere rechtsnormen, de strekking van een rechtsbetrekking kunnen bepalen. Andere zijn veeleer rechtsbeginselen aangezien ze uitdrukking geven aan richtinggevende ideeën die aan rechtsnormen en de interpretatie ervan ten grondslag liggen. ${ }^{127}$

In deze paragraaf zal een beschrijving worden gegeven van de te onderscheiden criteria voor strafbaarstelling. Zij vormen, evenals de kwaliteitseisen voor overheidsoptreden via wetgeving, een uitwerking van de tweedeling in de functies van wetgeving; te weten de waarborgfunctie en de instrumentele functie. Deze twee aspecten dienen zoveel mogelijk in evenwicht te zijn wil sprake zijn van "gekanaliseerde machtsuitoefening". ${ }^{128} \mathrm{Bij}$ regelgeving die het mogelijk maakt dat inbreuk wordt gemaakt op de persoonlijke levenssfeer van justitiabelen (wat strafbaarstellingen per definitie doen) is van groot belang dat de twee functies zoveel mogelijk in evenwicht zijn. Dit wil niet zeggen dat het een of - of keuze betreft, het gaat er juist om dat zoveel mogelijk wordt tegemoet gekomen aan beide functies, maar dat daar waar inbreuken groter kunnen zijn, de waarborgen sterker moeten zijn. ${ }^{129}$

Dat de relatie tussen inbreuk en waarborg ten grondslag ligt aan het hele strafrecht blijkt bijvoorbeeld uit de samenhang tussen waarborgen en (mogelijke) inbreuken op basis van dwangmiddelen. De wetgever heeft hiervoor een stelsel ontwikkeld waarin "de burger" maar enkele bevoegdheden zijn toebedeeld, en de strafvorderlijke bevoegdheden naar mate zij ingrijpender zijn door steeds hogere justitiële autoriteiten moeten worden gehanteerd (en eventueel ook door steeds hogere justitielle autoriteiten kunnen worden gecontroleerd) en vaak aan steeds strengere voorwaarden zijn gekoppeld. ${ }^{130}$ De samenhang blijkt ook uit het feit dat indien sprake is van een "criminal charge" in de zin van artikel 6 EVRM alle waarborgen uit dit artikel van toepassing zijn. Of sprake is van een strafvervolging in de zin van artikel 6, eerste lid

127 Zie Hirsch Ballin, E.M.H., "Rechtsbeginselen en algemene beginselen van behoorlijk bestuur", p. 107.

128 Foqué, R. en Hart, A.C. 't, Insirumentaliteit en Rechtsbescherming, zie ook Hart, A.C. " $t$, "Strafrecht: de macht van een verhaalsstructuur".

129 Dit verklaart ten dele waarom bij de ontwikkeling van de criteria de nadruk sterk heeft gelegen op de rechtsbeschermende aspecten.

130 Zie Corstens, G.J.M., Het Nederlands strafprocesrecht, p. 345. 
EVRM beoordeelt het Europese hof aan de hand van drie niet-cumulatieve criteria, te weten: de plaats van de regeling in het nationale recht, de aard van de gedragsregel en de aard en zwaarte van de sanctie. ${ }^{131}$ Het verdragsrecht blijkt regelmatig de waarborgfunctie van het nationale strafrecht te versterken. ${ }^{132}$

Als criteria voor strafbaarstelling worden de volgende zes categorieën onderscheiden: de vraag of er sprake is van strafbaarstelling van schadelijk gedrag (hoofdstuk 3 paragraaf 7.2.), het legaliteitsbeginsel (hoofdstuk 3 paragraaf 7.3.), het schuldbeginsel (hoofdstuk 3 paragraaf 7.4.), het subsidiariteitsbeginsel (hoofdstuk 3 paragraaf 7.5.), het proportionaliteitsbeginsel (hoofdstuk 3 paragraaf 7.6.) en de effectiviteit en bruikbaarheid (hoofdstuk 3 paragraaf 7.7.). Gezien het belang van deze criteria in de strafrechtsdogmatiek zal deze beschrijving uitvoeriger zijn dan die van de kwaliteitseisen voor overheidsoptreden via wetgeving (hoofdstuk 3 paragraaf 3) en beginselen van behoorlijke regelgeving (hoofdstuk 3 paragraaf 5).

\subsection{Schadelijk gedrag}

In het algemeen kan worden gesteld dat wetgeving de rechtszekerheid, rechtsgelijkheid en rechtsbescherming tracht te bevorderen door in algemene termen de rechtspositie van justitiabelen te bepalen, en wordt gebruikt om die menselijke gedragingen tegen te gaan die om welke reden dan ook als schadelijk, bedreigend, nadelig worden beschouwd voor door de gemeenschap als beschermenswaardig bestempelde belangen en/ of het gedrag van justitiabelen tracht te sturen in de richting van wenselijk geachte (beleids)doelstellingen. ${ }^{133}$ Ook in het strafrecht spelen beide functies een grote rol. Het doel dat met strafwetgeving wordt beoogd zal in beginsel echter nooit alleen beleidsmatig van aard te zijn. ${ }^{134}$ Hiervoor is het bestuursrecht doorgaans immers een effectiever en bruikbaarder instrument.

Het strafrecht wordt aldus gebruikt om die menselijke gedragingen tegen te gaan die om welke reden dan ook als schadelijk, bedreigend, nadelig worden beschouwd voor doọr de gemeenschap als beschermenswaardig bestempelde belangen. Eén van de vragen die in de algemene strafbaarstellingtheorie dan ook wordt gesteld is of de specifieke strafbaarstelling gericht is op de bestraffing van schadeverwekkende gedragingen. Schade dient hier overigens ruimer te worden opgevat dan enkel materiële of financieel-economische schade aangezien het tevens een ethischnormatieve component omvat. ${ }^{135}$

131 Zie EHRM 8 juni 1976, NJ 1978, 223 (Engel); EHRM 21 februari 1984, NJ 1988, 937, AA 1985, pp. 145-154, met noot Swart (Oztürk); EHRM 24 februari 1994, NJ 1994, 496, met noot Alkema (Bendenoun).

132 Denk aan inverzekeringstelling die is aangepast naar aanleiding van de zaak Brogan EHRM 29 november 1988, NJ 1989, 815, met noot Alkema en de verdedigingsrechten van de raadsman bij verstek onder invloed EHRM 22 september 1993, NJ 1994, 733, met noot Knigge (Lala).

133 Zie hoofdstuk 3 paragraaf 3.1,

134 Zie hierover ook het subsidiariteitsbeginsel, hoofdstuk 3 paragraaf 7.5.

135 Roos, Th. de, Strafbaarstelling van economische delicten, pp. 70-72. De Roos stelt dat 
De door het strafrecht beschermde belangen worden ook wel rechtsgoederen genoemd. Hoewel het begrip rechtsgoed in navolging van Duitsland ook in Nederland steeds meer ingeburgerd raakt is een korte toelichting wat met dit begrip wordt bedoeld op zijn plaats. In de Duitse strafrechtsdogmatiek staat de rechtsgoed beschermende functie van het strafrecht centraal. Het begrip rechtsgoed, ook wel aangeduid als rechtsbelang, verwijst naar belangen en maatschappelijke waarden die de wetgever door een strafbaarstelling bij uitstek heeft willen veilig stellen, hetzij tegen schending, hetzij tegen gevaarzetting. ${ }^{36}$ Het ligt voor de hand dat met dit oogmerk van de wetgever bij de uitleg van een strafbepaling rekening wordt gehouden. ${ }^{137}$ Daarnaast heeft het rechtsgoed ook een rubricerende ${ }^{138}$ en een legitimerende functie. ${ }^{139}$ Overigens is het vaak moeilijk te achterhalen wat het betreffende rechtsgoed (ofwel beschermenswaardig belang) van een strafbepaling is. Desondanks kan het verhelderend zijn te bedenken dat achter iedere strafbepaling de wetgever een onwenselijkheid ziet die hij tracht te bestrijden, en die de kern van het onrecht uitmaakt. ${ }^{140}$

Ook in de Nederlandse strafrechtswetenschap wordt, in navolging van Duitsland ${ }^{141}$, enige aandacht besteed aan het begrip rechtsgoed. ${ }^{142}$ Het kan een rol spelen bij de

het handelen in strijd met de materiêle norm die het abstracte gevaarzettingsdelict invult, schade berokkent aan de maatschappij. Degene die de norm schendt laat zijn individuele, of een ander, belang prevaleren boven het belang dat wordt beschermd op basis van de bestuurlijke afweging. Dit handelen kan in die zin worden gekwalificeerd als onethisch en immoreel. Vanuit ethisch-normatief perspectief is daarom wel degelijk sprake van schade indien wordt gehandeld in strijd met een door het bestuur vastgestelde. norm.

136 Zie in het algemeen: Jescheck, $\mathrm{H}-\mathrm{H}$ en Weigend, T., Lehrbuch des Strafrechts, pp. 7-8 en 256-260; Tiedemann, K., Tatbestandsfunktionen im Nebenstrafrecht, pp. 113-132 en Jakobs, G., Strafrecht Allgemeiner Teil, pp. 37-48. Zie met betrekking tot het milieurecht: Dreher, E. en Tröndle, H. (Hrsg.), "Straftaten gegen die Umwelt (§ $324 \mathrm{ev),}$ Vorbemerkung, Geschutztes Rechtsgut".

137 Remmelink, J., Mr. D. Hazewinkel-Suringa's Inleiding tot de studie van het Nederlandse strafrechi, pp 16-17.

138 Zo achtte de wetgever bij de indeling en rangschikking van het Wetboek van Strafrecht: "Niet zelden is blijkbaar bijzonder gewicht gehecht aan de oorzaken en beweegredenen en aan de mogelijke gevolgen, die de misdrijven kunnen hebben, terwijl toch, om een goede volgorde te verkrijgen, niet daarop maar veeleer op de aard en het object van het misdrijf moeten worden gelet." Smidt, H.J., Geschiedenis van het Wetboek van Strafrecht, Deel II, p. 2.

139 Deze functie houdt in dat de overheid slechts in de vrijheid van justitiabelen mag ingrijpen ats daarmee rechtsgoederen worden beschermd. De nadruk van deze functie is sinds Feuerbach verschoven naar de interpretatieve functie. Zie Machielse, A.J., "Enige opmerkingen over het rechtsgoed", pp. 24-25.

140 Machielse, A.J., "Enige opmerkingert over het rechtsgoed", p. 43.

141 Machielse legt het verband tussen de Duitse en de Nederlandse situatie in Machielse, A., "Enige opmerkingen over het rechtsgoed", pp. 24-43.

142 Sommigen bepleiten een grotere rol voor de rechtsgoed beschermende functie van het strafrecht in Nederland. Zie Schaffmeister, D. en Heijder A., "Concretisering van de. wederrechtelijkheid in het strafrecht", 441-474; Strijards, G.A.M., Aansprakelijkheids. gronden, p. 49 en Nieboer, W., "Verzuim", pp. 455-464. 
interpretatie van strafbepalingen; zo kan bij het wederrechtelijkheidsoordeel de vraag aan bod komen of de gedraging inderdaad het rechtsgoed schendt dat wordt beschermd door de delictsomschrijving. Deze legitimerende functie is in Nederland echter beperkt, want ${ }^{143}$

"het Nederlandse strafrecht bestraft niet alleen sociaal-ethisch verwerpelijke, maar ook slechts ongemakkelijke, lastige, hinderlijke gedragingen, en vaak wordt daar niet duidelijk welke toestanden en gedragingen door de wetgever (...) als onwenselijk werden gezien."

Tevens blijkt de beperkte werking van het rechtsgoed uit het feit dat ze opzij geschoven kan worden om tegemoet te komen aan een ander, hoger belang. ${ }^{144}$ Remmelink stelt dan ook ${ }^{145}$ :

"Het zal dan echter meestal blijken, dat wij in de Nederlandse verhoudingen met dit ook niet altijd nauwkeurig te bepalen begrip alleen, niet tot een oplossing komen." (Maar hij besluit) "Toch dient erkend, dat het. rechtsgoed bij dat alles een intrinsiek belangrijke, altijd meespelende, factor is."

Gebruik van het begrip rechtsgoed is nuttig omdat het toelaat te verduidelijken welke maatschappelijke belangen door de concrete strafbepaling worden beschermd. Duidelijk wordt of, en zo ja in hoeverre een strafbaarstelling ervan uitgaat dat de kern van het onrecht van deze bepaling schending van een bepaald rechtsgoed is. Bovendien karı door een identificatie van het beschermde rechtsgoed ook de werkwijze van de door de strafbepaling verleende bescherming, evenals de effectiviteit ervan worden getoetst. Door de voorwaarden voor strafbaarheid, zoals deze uit een delictsomschrijving blijken, te ontrafelen, kan worden nagegaan of de strafbepaling wel in staat is de vooropgestelde bescherming aan specifieke rechtsgoederen te bieden.

\subsection{Legaliteitsbeginsel}

\subsubsection{Inleiding}

Een ander criterium voor strafbaarstelling is het legaliteitsbeginsel. De essentie van dit beginsel is aan te duiden met de regel: "geen straf zonder wet". De regel werd reeds gedurende de hele achttiende eeuw erkend, en hij kan in meer of minder uitgewerkte vorm worden gevonden in bijvoorbeeld de werken van Pufendorf en Beccaria. Ook in de geschriften van Locke en Montesquieu zijn er al sporen van terug te vinden. Na codificatie van het legaliteitsbeginsel in de Amerikaanse constitutie in $1789^{146}$, kon het

143 Machielse, A.J., "Enige opmerkingen over het rechtsgoed", p. 43.

144 Remmelink, J., Mr. D. Hozewinkel-Suringa's Inleiding iot de studie van het Nederlandse. strafrecht, pp. 16-17.

145 Remmelink, J., Mr. D. Hazewinkel-Suringa's Inleiding tot de studie van het Nederlandse strafrecht, p. 17.

146. De bepaling in de confederale Constitutie luidt: "No bill or Attainder or post facto law shall be passed". 
steeds vaker in nationale (straf)wetgevingen worden aangetroffen. ${ }^{147}$ In het begin van de negentiende eeuw werd hij door Von Feuerbach opgenomen als eerste van zijn drie $^{148}$ "höchste Prinzipien des peinlichen Rechts". ${ }^{149}$

De regel dat geen feit strafbaar is dan uit kracht van een daaraan voorafgegane wettelijke strafbepaling is een product van de Verlichting. Hij geeft uitdrukking aan het rechtszekerheidsbeginsel en behoort tot de grondbeginselen van het Nederlandse strafrecht. Justitiabelen worden erdoor beschermd tegen willekeurige optreden van de overheid, aangezien de uitoefening van de macht van de overheid wordt gebonden aan wettelijke regelgeving. Juist daar waar de overheid justitiabelen strafrechtelijk sanctioneert voor hun (nalaten te) handelen, een zeer ingrijpende vorm van uitoefening van macht, mag dit alleen op basis van de wet. ${ }^{150}$ Ook in diverse verdragen is het strafrechtelijk legaliteitsbeginsel opgenomen. Zo luidt artikel 7 EVRM $^{151}$ :

147 Zo werd bijvoorbeeld in 1789 in Frankrijk in de Déclaration des droits de I'homme et du citoyen opgenomen "Nul ne peut être puni qu'en ventue d'une loi établie et promulguée antérieurement au délit". Zie voor een historisch overzicht met voorbeelden Coopmans, J.P.A., "Nullum delictum, nulla poena sine praevia lege poenali", pp. 21-26.

148 Het eerste grondbeginsel, "Jede Zufügung einer Strafe setzt ein Strafgesetz voraus. (Nulla poena sine lege)", houdt in dat een feit niet strafbaar is dan uit kracht van een daaraan voorafgaande wettelijke strafbepaling. Het tweede grondbeginsel, "Die Zufiugung einer Strafe ist bedingt durch die Existenz der bedohten Handlung. (Nulla poena sine crimine)", behelst dat toepassing van straf slechts mogelijk is als de door de wet met straf bedreigde gedraging heeft plaatsgevonden, terwijl het derde grondbeginsel, "Das gestezliche bedrohte Factum (die gesetliche Voraussetzung) ist bedingt durch die gesetzliche Strafe. (Nullum crimen sine poena legali)", stipuleert dat wettelijke met straf bedreigde gedraging tot rechtsgevolg heeft dat de door de wet daarop gestelde straf wordt toegepast. De citaten zijn afkomstig van Feuerbach, P.J.A., Lehrbuch des gemeinen in Deutschland geltenden peinlichen Rechts, p. 20.

149 Deze drie beginselen worden afgeleid uit "des höchste Princip des peinlichenRechts: Jede rechtliche Strafe, in Staat ist die rechtliche Folge eines, durch die Nothwendigkeit der Erhaltung âusserer Rechte begrünndeten, und eine Rechtsverletzung mit einem sinnlichen Uebel bedrohenden, Gesetzes." Feuerbach, P.J.A., Lehrbuch des gemeinen in Deutschland geltenden peinlichen Rechts, p. 20. Zie over de invloed van Feuerbach op de Nederlandse wetgeving: Mulder, G.E., "P.J.A. Feuerbach en het crimineel wetboek voor het Koninkrijk Holland", pp. 175-185.

150 Zie over de ontwikkeling en de inhoud van het legaliteitsbeginsel onder andere: Schreiber, H.L., Gesetz und Richter; Groenhuijsen, M.S., "Legaliteit als probleem", pp. 277-287; Groenhuijsen, M.S., Straf en wer; Schünemann, B., Nulla poena sine lege?; Heijder, "Nullum crimen sine lege?", pp. 137-153; Donk, W.A. van der, "Rondom de regel 'Nulla poena sine lege, nulla poena sine crime, nullum crimen sire poena legali", pp. 337-399: Dorst, A.J.A. van, "Enkele aspecten van artikel I Wetboek van Strafrecht", pp. 169-187; Eck, D. van, "Enkele beschouwingen onntrent het nulla-poena-beginsel", pp. 107-127; Bemmelen, J.M. van en. Veen, Th.W. van, bewerkt door Jong, D.H. de en Knigge, G., Het materiële strafrecht, pp. 27-37; Remmelink, J., Mr. D. Hazewinkel-Suringa's Inleiding tot de studie van het Nederlandse strafrechs, pp. 483507.

151 Voorts kan het legaliteitsbeginsel worden gevonden in artikel 15 IVBPR. 
"1. No one shall be held guilty of any criminal offence on account of any act or omission which did not constitute a criminal offence under national or international law at the time when it was committed. Nor shall a heavier penalty be imposed than the one that was applicable at the time the criminal offence was commited.

2. This Article shall not prejudice the trial and punishment of any person for any act or omission which, at the time when it was committed, was criminal according to the general principles of law recognised by civilised nations."

\subsubsection{Het legaliteitsbeginsel in het EVRM}

De (ver)eisten die aan regelgeving worden gesteld wil deze in overeenstemming zijn met het legaliteitsbeginsel waren aanvankelijk gering. De Commissie achtte het voldoende indien een feit in de wet strafbaar is gesteld, ook indien de omschrijving vaag is en de uitleg in de rechtsprak bijgevolg sterk kan variëren. ${ }^{152}$ In de zaak Kokkinakis oordeelde het Hof dat artikel 7 EVRM analoge toepassing van strafbaarstellingen ten nadele van de verdachte verbiedt. ${ }^{153}$ Bovendien moet het strafbare feit "clearly defined in law" zijn. Hieraan is voldaan als de justitiabele uit de tekst van de bepaling, indien nodig met behulp van jurisprudentie, kan weten welke handelingen aansprakelijkheid kunnen veroorzaken. Het Hof overwoog ${ }^{154}$ :

"52. The Court points out that Article $7 \S 1$ of the Convention is not confined to prohibiting the retrospective application of the criminal law to an accused's disadvantage. It also embodies, more generally, the principle that only the law can define a crime and prescribe a penalty (nullum crimen, nulla poena sine lege) and the principle that the criminal law must not be extensively construed to an accused's detriment, for instance by analogy: it follows from this that an offence must be clearly defined in law. This condition is satisfied where the individual can know from the wording of the relevant provision and, if need be, with the assistance of the courts' interpretation of it, what acts and omissions will make him criminally liable."

Dat toepassing van nieuwe strafbepalingen ten voordele van de verdachte wel zijn toegestaan, bleek uitdrukkelijk in de zaak G. v. France. De gedraging van G. viel zowel onder de oude bepaling, zoals die naar vaste jurisprudentie werd uitgelegd, als onder de nieuwe strafbepaling. Met betrekking tot de strafoplegging en de kwalificatie van het strafbare feit werden de nieuwe bepalingen toegepast. Aangezien dit in het voordeel was van de verdachte, was er geen sprake van schending van artikel 7 , eerste lid EVRM. ${ }^{155}$

152 Zie Alkema, E.A., Studies over Europese grondrechten, p. 69.

153 Dit is voor Nederland gezien artikel I Sr niets nieuws.

154 EHRM 25 mei 1993, Series A, no. 260-A (Kokkinakis v. Greece).

155 EHRM 27 september 1995, NJ 1996, 49, met noot Knigge (G. v. France). "26. The Court notes that the acts of which the applicant was accused also fell within the scope of the new legislation. On the basis of the principle that the more lenient law should apply both as regards the definition of the offence and the sanctions imposed, the national courts applied the new Article (...) for the imposition of sanctions as that provision downgraded the offence of which Mr G. was accused from serious offence (crime) to less serious offence (délit) (...). Its application, admittedly retrospective, therefore operated in the applicant's favour." 
Verdragsrechtelijk worden meer (kwaliteits)eisen gesteld aan regelgeving. Deze zijn met name tot ontwikkeling gekomen in de uitspraken van het Europese Hof bij de uitleg van de Franse verdragsterm "prevues par la loi", en de Engelse verdragstermen "prescribed by law", "in accordance with the law", "provided for by law" en "in accordance with law". Deze termen komen voor in de artikelen 8, 9, 10 en 11 EVRM en artikel 1 van het eerste Protocol en artikel 2 van het vierde Protocol. Het Europese Hof heeft aan het begrip "law" uit deze bepalingen een geheel eigen interpretatie gegeven. Een "norm" wordt pas aangemerkt als "law" indien aan bepaalde (kwaliteits)eisen is voldaan.

In boven aangehaalde zaak G. v. France werd de lijn tussen artikel 7 EVRM en de eisen ten aanzien van "foreseeability and accessibility" die voortvloeien uit "law" getrokken. Het Hof betrok deze vereisten bij de toetsing of sprake was van schending van artikel $7^{156}$ :

"25. In the present case the Court, like the Commission, is of the opinion that the offences of which the applicant was accused fell within the scope of the former Articles 332 and 333 of the Criminal Code, which satisfied the requirements of foreseeability and accessibility (...) There was consistent case-law from the Court of Cassation, which was published and therefore accessible, on the notions of violence and abuse of authority. As regards the notion of violence, the new provisions in the new Articles 332 and 333 of the Criminal Code merely confirmed this case-law."

Dat de term "law" in artikel 7 EVRM dezelfde betekenis heeft als elders in het verdrag, zodat daarvoor dezelfde kwaliteitseisen gelden, werd uitdrukkelijk gesteld in de zaak C.R. v. United Kingdom. ${ }^{157}$ Deze vereisten (die meer inhouden dan "foreseeability and accessibility") zijn daarom ook van belang bij de beoordeling of regelgeving in overeenstemming is met het verdragsrechtelijke legaliteitsbeginsel.

Blijkens de uitleg die is gegeven aan "prescribed by law" omvat het begrip "law" zowel geschreven als ongeschreven recht, waaraan kwalitatieve eisen worden gesteld inzake toegankelijkheid (accessibility) en voorzienbaarheid (foreseeability). Bij de vraag of een veroordeling viel te voorzien wordt niet alleen gekeken naar de wetstekst, maar ook naar de uitleg die daaraan in de jurisprudentie is gegeven. Vage wettelijke termen kunnen indien zij nader zijn uitgewerkt in (vaste) jurisprudentie voldoende voorzienbaar worden. ${ }^{158}$

Dit laatste lijkt curieus omdat als jurisprudentie de vereiste duidelijkheid moet geven, het onduidelijk is hoe het staat met de wetmatigheid in de zin van het EVRM van vage termen in nieuwe, pas afgekondigde wetgeving. ${ }^{159}$ "Foreseeability" lijkt dan alleen

156 EHRM 27 september 1995, NJ 1996, 49, met noot Knigge (G. v. France).

157 EHRM 22 november 1995, NJ 1997, 1, met noot Knigge (C.R. v. United Kingdom).

158 Het betekenisbereik van vage wettelijke termen kan immers door aanvullende criteria uit de jurisprudentie voldoende duidelijk worden. Zie hoofdstuk 2 paragraaf 5.4.2.

159 Zie noot Alkema onder EHRM 20 november 1989, NJ 1991, 738 (Markt inem Verlag en Klaus Beermann). 
mogelijk indien de (nationale) rechter de vage termen dusdanig restrictief interpreteert dat de betekenis die eraan wordt gegeven niet in het grensgebied van het betekenisbereik van de term ligt. Ten behoeve van de rechtsontwikkeling en de beoordeling van toekomstige gevallen is het wenselijk dat de rechter aangeeft waarom het concrete geval onder de term valt en door middel van aanvullende criteria het bereik van de term nader concretiseert. ${ }^{160}$

In het eerder genoemde Sunday times-zaak heeft het Europese Hof aangegeven wat onder de vereiste "accessibility and foreseeability" moet worden verstaan. ${ }^{161}$ Deze vereisten zijn vaste rechtspraak die in de Andersson-zaak als volgt werd samengevat $^{162}$ :

"the expression (...) requires firstly that the impugned measures should have a basis in domestic law. It also refers to the quality of the law in question, requiring that it be accessible to the persons concerned and formulated with sufficient precision to enable them - if need be, with appropriate legal advice - to foresee, to a degree that is reasonable in the circumstances, the consequences which a given action may entail. A law which confers a discretion is not in itself inconsistent with this requirement, provided that the scope of the discretion and the manner of its exercise are indicated with sufficient clarity, having regard to the legitimate aim in question, to give the individual adequate protection against arbitrary interference."

Het Europese Hof stelt de eis dat regels voldoende toegankelijk moeten zijn, zodat de justitiabele een voldoende (hetgeen redelijkerwijs kan worden voorzien in die omstandigheden) aanwijzing kan hebben of regels van toepassing zijn in een bepaald geval. Voorts wordt een norm niet aangemerkt als rechtsregel tenzij hij met voldoende nauwkeurigheid is geformuleerd zodat de justitiabele in staat is zijn gedrag daarop af te stemmen. Hij dient, eventueel met behulp van passend advies, op een niveau dat gezien de omstandigheden redelijk is, voorafgaande aan zijn gedraging de gevolgen te kunnen voorzien die de gedraging met zich kan brengen. Het Hof zal bij de interpretatie van het nationale recht terughoudend zijn, aangezien het van oordeel is dat het primair aan de nationale autoriteiten is het nationale recht te interpreteren en toe te passen $^{163}$ :

160 Zie over vage termen hoofdstuk 2 paragraaf 5.4.2.

161 Zie yoor de overweging van het EHRM in de Sunday Times-zaak inzake de betekenis van de vereiste "accessibility and foreseeability", EHRM 26 april 1979, NJ 1980, 146, met noot Alkema, nr. 49 geciteerd in hoofdstuk 3 paragraaf 5.4.2. bij de bespreking van het kenbaarheidsbeginsel.

162 EHRM 25 februari 1992, Series A, no. 226-A, $\$ 75$ (Margareta and Roger Andersson); zie voor andere rechtspraak bijvoorbeeld: EHRM 2 augustus 1984, NJ 1988, 534, met noot van Dijk (Malone) en EHRM 13 juli 1995, NJ 1996, 544, met noot Dommering (Tolstoy Miloslavsky), waar in $\S 37$ wordt verwezen naar deze samenvatting. Het legaliteitsbeginsel raakt de kern van de rechtsstaat, of de "rule of law" waaraan in de preambule van het EVRM veel aandacht wordt besteed. Zie Traest, P, "Recht(on)zekerheid in materieel en formeel strafrecht en strafrechtelijk legaliteitsbeginsel", pp. 1190-1207.

163 EHRM 26 september 1995, NJ 1996, 545, met noot Dommering (Vogt). 
"48. The Court reiterates that the level of precision required of domestic legislation - which cannot in any case provide for every eventuality - depends to a. considerable degree on the content of the instrument in question, the field it is designed to cover and the number and status of those to whom it is addressed. It is moreover primarily for the national authorities to interpret and apply domestic law (see the Chorherr v. Austria judgment of 25 August 1993, Series A, no. 266-B, pp. 35-36, \& 25)."

Zoals gezegd wordt bij de vraag of een veroordeling viell te voorzien niet alleen gekeken naai de wettekst, maar ook naar de tuitleg die daaraan in de jurisprudentie is gegeven. Hierbij gaat het er niet zozeer om of de uitleg ten opzichte van de grammaticale betekenis van de wettelijke terminologie extensief is, maar meer of zij zich te ver heeft verwijderd van de betekenis die aan die terminologie in de rechtspraktijk is gegeven. ${ }^{164}$ Het EVRM lex certa-beginsel staat het gebruik van vage termen in regelgeving niet in de weg. De vereiste duidelijkheid kan ook worden verschaft door de invulling en concretisering die het heeft gekregen in de jurisprudentie. ${ }^{165}$ Zelfs indien de wet misleidend is omdat er meer onder valt dan uit de tekst blijkt, kan aan het vereiste van "forseeability" zijn voldaan als de uitleg vaste jurisprudentie is. ${ }^{166}$ Maar ook wijziging van de vaste jurispudentie behoeft de toepassing van een strafbaarstelling niet in de weg te staan. Het Hof geeft aan dat aan rechtsontwikkeling en dus aan een zekere mate van rechtsonzekerheid niet is te ontkomen, aangezien er steeds behoefte bestaat aan opheldering van twijfelpunten en aanpassing aan veranderende omstandigheden. ${ }^{167}$ Het stelt als voorwaarden dat de jurisprudentiële ontwikkeling in overeenstemming moet zijn met de essentie van het delict en dat zij redelijk voorzienbaar moet zijn geweest. Het Hof geeft bovenstaande "General principles" als volgt aan ${ }^{168}$ :

" 83 32. The guarantee enshrined in Article 7, which is an essential element of the rule of law, occupies a prominent place in the Convention system of protection, as is underlined by the fact that no derogation from it is permissible under Article 15 in time of war or other public emergency. It should be construed and applied, as follows from its object and purpose, in such a way as to provide effective safeguards against arbitrary prosecution, conviction and punishment. $\S 33$. Accordingly, as the Court held in its Kokkinakis v. Greece judgment of 25 May 1993 (Series A no. 260-A, p. 22, \& 52), Article 7 is not confined to prohibiting the retrospective application of the criminal law to an accused's disadvantage: it also embodies, more generally, the principle that only the law can define a crime and prescribe a penalty (nullum crimen, nulla poena sine lege) and the principle that the criminal law must not be extensively construed to an accused's detriment, for instance by analogy. From these principles it follows that an offence must be clearly defined in the law. In its aforementioned judgment the Court added that this requirement is satisfied where the individual can know from the wording of the relevant provision and, if need be, with the assistance of the courts' interpretation of it, what acts and omissions will make him criminally liable. The Court thus indicated that when speaking of

164 Zie Knigge noot bij EHRM 22 november 1995, $N J$ 1997, I (C.R. v. United Kingdom).

165 Zie Knigge noot bij EHRM 27 september 1995, NJ 1996, 49 (G. v. France).

166 Zie EHRM 27 september 1995, NJ 1996, 49, met noot Knigge (G. v. France).

167 Hierdoor lijkt het voor de hand te liggen dat open termen niet in strijd zijn met artikel 7 EVRM en vage termen wel. Zie over deze begrippen hoofdstuk 2 paragraaf 5.4.2.

EHRM 22 november 1995, $N J$ 1997, 1, met noot Knigge (C.R. v. United Kingdom). 
"law" Article 7 alludes to the very same concept as that to which the Convention refers elsewhere when using that term, a concept which comprises written as well as unwritten law and implies qualitative requirements, notably those of accessibility and foreseeability (see, as a recent authority, the Tolstoy Miloslavsky v. the United Kingdom judgment of 13 July 1995, Series $A$, no. 323, p. 23, §37).

\$34. However clearly drafted a legal provision may be, in any system of law, including criminal law, there is an inevitable element of judicial interpretation. There will always be a need for elucidation of doubtful points and for adaptation to changing circumstances. Indeed, in the United Kingdom, as in the other Convention States, the progressive development of the criminal law through judicial law-making is a well entrenched and necessary part of legal tradition. Article 7 of the Convention cannot be read as outlawing the gradual clarification of the rules of criminal liability through judicial interpretation from case to case, provided that the resultant development is consistent with the essence of the offence and could reasonable be foreseen."

De beslissing van het Hof sluit aan bij eerdere uitspraken, waarin het bepaalde dat "law" uit artikel 7 EVRM zowel geschreven als ongeschreven recht omvat. In deze uitspraak wordt daar het aspect van de rechtsontwikkeling aan toegevoegd. Uitdrukkelijk wordt gesteld dat daaraan niet valt te ontkomen, aangezien in ieder rechtsstelsell behoefte bestaat aan "elucidation" (opheldering van twijfelpunten) en "adaptation" (aanpassen aan veranderde omstandigheden). Inherent aan het zich ontwikkelende recht is een bepaalde mate van rechtsonzekerheid. Artikel 7 EVRM vormt, volgens het Hof blijkens deze uitspraak, geen beletsel voor strafrechtelijke aansprakelijkheid mits voldaan is aan twee voorwaarden. Ten eerste dient de jurisprudentiële ontwikkeling in overeenstemming te zijn met de essentie van het delict. Ten tweede dient de jurisprudentiële ontwikkeling in redelijkheid voorzienbaar te zijn geweest. ${ }^{169}$ Naar aanleiding van deze uitspraak stelt Knigge ${ }^{170}$ :

"Het arrest onderstreept dat het legaliteitsbeginsel op Europees niveau een andere invulling krijgt dan op nationaal niveau. Dat komt doordat art. 7 EVRM zowel continentale als Angelsaksische rechtsstelsels moet overkoepelen. (...) Het Europese Hof moet deze verschillen in rechtstradities in zijn rechtspraak verdisconteren. In de vraag of de Engelse rechters de opheffing van de immuniteit niet aan het parlement hadden moeten overlaten, kan het Hof dan ook bezwaarlijk treden. De verhouding wetgever-rechter is met andere woorden primair een taak van nationaal recht waar het Hof buiten dient te blijven. Het is dan ook op zich begrijpelijk dat het Hof in deze zaak vast houdt aan het uitgangspunt dat de uitleg van de wet is voorbehouden aan de "national authotities, notably the courts" en dat om die reden de aan de 1976 Act gegeven interpretatie wordt gerespecteerd $(\S 40)$."

Het Europese Hof geeft een andere invulling aan het legaliteitsbeginsel en het lex certa-beginsel dan de nationale wetgever en rechter. In het navolgende wordt aangegeven wat de invulling hiervan in Nederland is, of zou behoren te zijn.

169 Zie § 34 EHRM 22 november 1995, NJ 1997, 1, met noot Knigge (C.R. v. United Kingdom).

170 Knigge in zijn noot bij EHRM 22 november 1995, NJ 1997, 1 (C.R. v. United Kingdom). 


\subsubsection{Het nationaal legaliteitsbeginsel}

De lidstaten dienen zich gezien de bindende kracht van het EVRM te houden aan de waarborgen die voortvloeien uit dit verdrag en de jurisprudentie van het Europese Hof. Gezien de artikelen 93 en $94 \mathrm{Gw}$ heeft artikel 7 EVRM, en hebben dus ook de daar gestelde kwaliteitseisen voor regelgeving, in Nederland verbindende kracht en voorrang op nationale wettelijke voorschriften. Het nationale recht moet dan ook conform deze vereisten zijn en mag daarnaast alleen verdergaande eisen stellen.

Het legaliteitsbeginsel is in Nederland gecodificeerd in artikel 1, eerste lid Sr en artikel $16 \mathrm{Gw}$. Deze artikelen luiden:

\section{"Geen feit is strafbaar dan uit kracht van een daaraan voorafgegane wettelijke strafbepaling."}

Op dit beginsel wordt door het Besluit Buitengewoon Strafrecht ${ }^{171}$ uitzondering gemaakt voor ernstige misdrijven tegen de veiligheid van de Staat en de mensheid. ${ }^{1 / 2}$ Het gecodificeerde legaliteitsbeginsel omvat een viertal normen, te weten: dat strafbaarstellingen niet met terugwerkende kracht worden vastgesteld; dat de verboden gedraging in de delictsomschrijving duidelijk en precies wordt omschreven; dat de rechter een verdachte niet strafbaar mag verklaren op grond van gewoonterecht; dat wettelijke strafbepalingen niet analogisch mogen worden toegepast. ${ }^{73}$

Deze normen hebben een eigen, aanvullende betekenis die past binnen de Nederlandse rechtstraditie. De tekst van de strafbaarstelling is hier wel maatgevend voor de vraag of de strafbaarstelling voldoende duidelijk en precies is en of in een concreet geval sprake is van analogie. Dit is een belangrijk verschil met het EVRM aangezien daar de "law", dat zowel geschreven als ongeschreven recht omvat, als basis voor aansprakelijkheid kan dienen. ${ }^{174}$ Een ander verschil is dat het verdrag geen specifieke taaleisen stelt, terwijl de strekking van de waarborg van de Nederlandse bepalingen meebrengt dat de van een strafbedreiging voorziene normen in de Nederlandse taal moeten zijn gesteld en bekendgemaakt. ${ }^{17}$

171 Besluit Buitengewoon Strafrecht van 22 december 1943, Stb. D. 61.

172 Zie ook het additionele artikel IX Gw. Ook verdragsrechtelijk wordt blijkens artikel 7, tweede lid EVRM en artikel 15, tweede lid IVBPR uitzondering gemaakt op het legaliteitsbeginsel voor misdrijven overeenkomstig de algemene rechtsbeginselen die door de volkerengemeenschap worden erkend.

173 De eerste twee normen richten zich vooral tot de wetgever, de laatste twee tot de rechter, zie Groenhuijsen, M.S., Strafen wet, p. 15.

174 Zie ook Hullu, J. de, "Het legaliteitsbeginsel in de Straatsburgse spiegel", p. 187; Hullu, J. de, "Het legaliteitsbeginsel in de Straatsburgs perspectief", p. 512; Knigge, G., Verandering van wetgeving, pp. 200-203.

175 HR 24 juni 1997, NJ 1998, 70, met noot 't Hart (Rusttijd AETR is geen Wettelijke strafbepaling). 
Het uit het legaliteitsbeginsel afgeleide lex certa-beginsel ${ }^{176}$, dat de eis inhoudt dat de wetgever strafbaarstellingen zo duidelijk en, precies mogelijk omschrijft ${ }^{177}$, brengt mee dat de voorwaarden voor strafbaarheid ex ante zodanig nauwkeurig moeten worden omschreven dat de justitiabele voorafgaande aan zijn handelen kan weten of zijn gedrag al dan niet onder de delictsomschrijving valt. ${ }^{178}$ Vage en te complexe strafbaarstellingen bieden deze mogelijk te weinig, zodat zij in strijd kunnen komen met dit beginsel.

Het nationaal legaliteitsbeginsel is naast de genoemde artikelen 1, eerste lid en $\mathrm{Sr} 16$ $\mathrm{Gw}$, voor algemene maatregelen van bestuur en andere vanwege het Rijk vastgestelde algemeen verbindende voorschriften ook te vinden in artikel $89 \mathrm{Gw}^{179}$ Involge artikel $89 \mathrm{Gw}$, derde lid regelt de wet de bekendmaking en de inwerkingtreding van amvb's. Voorts stipuleert het derde lid dat amvb's, en jo. het vierde lid ook algemeen verbindende voorschriften, niet in werking treden voordat zij zijn bekendgemaakt. ${ }^{180}$ Uit het tweede lid van dit artikel blijkt dat de bevoegdheid tot het vaststellen van voorschriften door straffen te handhaven, alleen krachtens de wet kunnen worden gegeven. De wet zelf bepaalt in dat geval de op te leggen straffen waarmee schending van deze voorschriften kunnen worden bedreigd. Door dit tweede lid wordt de ruimte voor de vaststelling van een zelfstandig amvb, waarvoor de bevoegdheid is gegeven in het eerste lid, sterk ingeperkt. Er is immers een wettelijke grondslag nodig voor door straffen te handhaven voorschriften uit amvb's (evenals voor algemeen verbindende voorschriften), terwijl de wet de op te leggen straffen bepaalt. Het kabinet onderschrijft het standpunt (dat de Commissie wetgevingsvraagstukken in haar eindrapport "Orde in de regelgeving" heeft ingenomen) ${ }^{1811}$,

"dat het bij delegatie van de bevoegdheid tot het geven van door straffen te handhaven voorschriften gaat om een delegatie waarbij extra zorgvuldigheid moet worden betracht. Het is, dit erkend hebbende, evenwel van oordeel dat ook deze materie in beginsel wordt beheerst door de, grenzen die in het algemeen aan delegatie van bevoegdheden moeten worden gesteld. De bevoegdheid tot het scheppen van strafbare feiten kan onder omstandigheden aan een minister worden toegekend. Daarvoor kan aanleiding zijn, wanneer uit een oogpunt van doorzichtigheid

176 In Duitsland wordt dit beginsel aangeduid als het "Bestimmtheitsgebot". Zie daarover Tiedemann, K., Tatsbesiandfinktionen im Nebenstrafrecht, p. 445.

177 Tijdens de AIDP conferentie werd de lex certa-eis in de aanbevelingen met betrekking tot het milieustrafrecht verwoord als "consistent with the principle of legality, there should be certainty in the definition of crimes against the environment". Zie Resolutie 6 van het XVde International Congress of Penal Law. Deze aanbevelingen zijn gepubliceerd in de International Review of Penal Law, 1995, pp. 48-53.

178 Zie ook Groenhuijsen, M.S., Straf en wet, p. 15.

179 Zie over de begrippen algemene maatregelen van bestuur en algemeen verbindende voorschriften Kortmann, C.A.J.M., Constitutioneel recht en Commissie Wetgevingsvraagstukken, Orde in de regelgeving en het kabinetstandpunt "Regelgeving centrale overheid", TK 1986-1987, 20238 , nr. 2, pp. 2-4.

180 Involge de Bekendmakingswet, Stb. 1988, 18, gebeurt. dit bij amvb's ex artikel 3 in het Staatsblad, en bij algemeen verbindende voorschriften ex artikel 3 en 4 in het Staatsblad of de Staatscourant.

181 Zie $T K 1986-1987,20238$, nr. 2, p. 8. 
van de regeling het strafbare feit, gelet op de samenhang met andere voorschriften, beter in dezelfde regeling als waarin die voorschriften zijn vervat, kan worden opgenomen of wanneer spoed moet worden betracht bij het tot stand brengen van een wettelijke regel."

Het regeringsstandpunt is derhalve dat bij de delegatie tot het geven van door straffen te handhaven voorschriften extra zorgvuldigheid moet worden betracht. Helaas lijkt dit soms niet het geval te zijn. Het gevolg hiervan is dat in veel amvb's vage voorschriften, bijvoorbeeld in de vorm van zorgplichtbepalingen, kunnen worden aangetroffen. Aangezien het schenden van de voorschriften uit een amvb vaak is strafbaar gesteld, is het schenden van deze vage bepaling een strafbaar feit. Meestal zal dit op basis van de wet een overtreding zijn, die niet met zeer zware sancties wordt bedreigd. Maar dit kan ook anders zijn. Zo kunnen voorschriften bij of krachtens economische wetten worden aangehaakt aan de Wed. Indien dit delict in artikel 1 sub 1 of 2, of in artikel la sub 1 en 2 Wed is opgenomen, kan het ex artikel 2 Wed worden aangemerkt als een misdrijf indien het opzettelijk is begaan. Indien de strafbaarstelling is opgenomen in artikel 1 sub 3 Wed is het van belang of de wet het voorschrift als misdrijf dan wel overtreding aanmerkt. De schending van een dergelijke bepaling wordt bedreigd met niet onaanzienlijke sancties. Het is soms de vraag of de wetgever dergelijke vergaande delegatie wel heeft beoogd, en of de instantie aan wie de bevoegdheid is gedelegeerd bij het vaststellen van de voorschriften zich wel voldoende bewust is dat het daarmee de materiële inhoud van een strafbaarstelling vaststelt.

\subsubsection{De wetgever en het legaliteitsbeginsel}

Het is in eerste instantie de taak van de wetgever de voorwaarden voor strafbaarheid duidelijk, nauwkeurig en inzichtelijk te omschrijven. Mede onder invloed van de maatschappelijke veranderingen en de gewijzigde taakopvatting van de wetgever in het laatste decennium wordt regelgeving vaak gebruikt als sturingsinstrument. Het instrumentele aspect van het strafrecht is daardoor sterk tot ontwikkeling gekomen. ${ }^{182}$ Betoogd wordt dat door deze veranderingen (straf)wetgeving sterker is aangewezen op het gebruik van vage normen ${ }^{183}$, en dat de strikte consequenties van het legaliteitsbeginsel minder dan vroeger aanvaardbaar zouden zijn aangezien de bestanddelen van de delictsomschrijving geen begrensde betekenis hebben maar veeleer het beeld vertonen van een kem met een brede periferie. ${ }^{184}$ Op dit ogenblik kan geen uitspraak worden gedaan aangaande de al dan niet aanvaardbaarheid van de vaagheid van een norm. Die vaagheid is immers ten dele niet te vermijden. Hart heeft er terecht op

182. Zie hoofdstuk 3 paragraf 2.

183 Mulder, G.E., "Vage normen", pp. 409-427; Remmelink, J., Mr. D. Hazewinkel-Suringa's Inleiding tot de studie van het Nederlandse strafrecht, p. 132; Remmelink, J., Hoofdwegen door het verkeersrecht, p. 33. Ook 't Hart is van mening dat open delictsomschrijvingen en vage termen onvermijdelijk zijn. Zie Hart, A.C. 't, "Het nulla-poenabeginsel", pp. 332-345. Zie over "vaagheid van een regel" hoofdstuk 2 paragraaf 5.4 .

i 84 Heijder, A., "Nullum crimen sine lege?", p. 152. Pas als er veel gevallen zijn die liggen in het grensgebied van wat wel en wat niet onder de term valt is sprake van een vage term, zie hoofdstuk 2 paragraaf 5.4.2.2. 
gewezen dat de vaagheid van een norm wordt veroorzaakt door het feit dat het recht een taal- en begrippenapparaat hanteert dat veelal onvermijdelijk vaag zal zijn. ${ }^{185}$ Die vaagheid wordt ten dele ook veroorzaakt door de juridische context, die immers vereist dat wettelijke regelingen op een groot antal verschillende situaties van toepassing zijn. Dit brengt mee dat deze regelingen relatief algemeen zullen moeten zijn ${ }^{180}$, waardoor een grijs gebied kan ontstaan tussen wat zeker wel en wat zeker niet onder de reikwijdte van de bepaling valt. ${ }^{187}$ Hoe breder dit grijze gebied is, hoe vager de bepaling. ${ }^{188}$

Een reden voor de wetgever om over te gaan tot het opnemen van vage termen in wetgeving is gelegen in het feit dat hij bij het maken van de regelgeving niet in staat of bereid is specifieker het niet-toelaatbare te omschrijven. De reden hiervan kan zijn dat de werkelijkheid te complex, veelvormig of weerbarstig is voor meer specifieke regelgeving. Remmelink stelt dan ook dat ${ }^{189}$

"algemene typeringen onvermijdelijk kunnen zijn om de eenvoudige reden, dat er een oeverloze variêteit van gedragingen is welke de delictsinhoud kan vervullen, zodat het niet doenlijk is te proberen deze meer concreet op te sommen."

Algemene typeringen hoeven echter niet vaag te zijn. Ook kunnen problemen met betrekking tot het specifiek omschrijven ontstaan doordat de ontwikkelingen in het betreffende gebied te snel gaan, hetgeen ten dele kan samenhangen met voortgaande technische ontwikkelingen en "de vooruitgang". ${ }^{190}$ Specifieke regels die op welbepaalde feitelijke omstandigheden van toepassing zijn, kunnen daardoor niet altijd worden geformuleerd, terwijl regulering van de problematiek toch noodzakelijk wordt geacht. ${ }^{191}$ Daarom worden soms (te) specifieke regels deels ineffectief geacht. Dit kan

185 "In all fields of experience, not only that of rules, there is a limit, inherent in the nature of language, to the guidance which general language can provide." Hart, H.L.A., The Concept of Law, p. 126. Zie over recht, taal en betekenis hoofdstuk 2 paragraaf 5.2 .

186 Zie voor wat betreft het gebruik en de juridische achtergrond van vage normen Klap, A.P., Vage normen in het bestuursrecht, pp. 3-9.

187 " $(\ldots)$ in the case of legislation, as a general feature of human language, uncertainty at the borderline is the price to be paid for the use of general classifying terms in any form of communication concerning matters of fact." Hart, H.L.A., The Concept of Law, p. 128.

188 Zie hoofdstuk 2 paragraaf 5.4.2.2.; indien veel gevallen in deze periferie vallen is sprake van een vage term.

189 Remmelink, J., Mr, D. Hazewinkel-Suringa's Inleiding tot de studie van het Nederlandse strafrecht, p. 131 en bijna gelijkluidend Remmelink, J., Hoofdwegen door het verkeersrecht, p. 33.

190 Berg geeft met betrekking tot technische vooruitgang aan: "Aber die Rechtsordnung sollte mit der Konkretisierung nicht so lang warten, bis die Ziele unerreichbar geworden sind." Berg, W., "Vom Wettlauf zwischen Recht und Technik", p. 407.

191 "Sometimes the sphere to be legally controlled is recognized from the start as one in which the features of individual cases will vary so much in socially important but unpredictable respects, that uniform rules to be applied from case to case without further offical direction cannot usefully be framed by the legislature in advance." Hart, H.L.A., The Concept of Law, p. 131. 
zich voordoen als bepalingen met vage(re) termen, die als vangnet kunnen functioneren, ontbreken. ${ }^{192}$

Vage termen worden dan ook vaak onvermijdelijk geacht, waarbij het gebruik ervan door de wetgever wordt beschouwd als een blijk van legislatieve onmacht. ${ }^{193}$ Het argument van onvermijdelijkheid heeft overigens het risico van lijdzaamheid voor de wetgever in zich. Niet uitgesloten is dat minder vaagheid wel degelijk bereikbaar is. ${ }^{194}$ Indien de grenzen van het betekenisbereik duidelijker aanwezig zijn (geworden), kan de wetgever de strafbaarstelling aanpassen en deze grenzen opnemen in de bepaling. ${ }^{195}$ Ook kan blijken dat door specifieke strafbaarstellingen het betreffende rechtsgoed voldoende kan worden gereguleerd. ${ }^{196}$ Eventueel kan dit worden bewerkstelligd door het betekenisbereik of het aantal van deze strafbaarstellingen uit te breiden. De noodzaak van een algemene en vaag geformuleerde bepaling kan daardoor komen te vervallen, zodat het wenselijk is deze af te schaffen.

Het gevolg van het gebruik van strafbaarstellingen met vage termen is dat de wetgever dan iets in algemene termen strafbaar stelt, terwijl hij zelf van tevoren niet altijd weet welke gedraging hij al dan niet toelaatbaar acht en welke gedragingen onder de reikwijdte van de strafnorm dienen te vallen. Het gevolg hiervan kan zijn dat de justitiabele tot wie de norm zich richt niet duidelijk voor ogen staat of zijn handelen al dan niet strafrechtelijk verwijtbaar is en onder de werkingssfeer van de strafbaarstelling valt. Hierdoor kunnen dergelijke bepalingen in strijd komen met het lex certabeginsel. ${ }^{197}$

Indien de behoefte aan ordening leidt tot een bovenstelling van het instrumentele ten opzichte van het rechtsbeschermende aspect, is sprake van een onevenwichtigheid. Deze twee aspecten dienen namelijk in evenwicht te zijn wil sprake zijn van

192 Zie ook het advies van de Commissie voor de Toetsing van Wetgevingsprojecten inzake zorgplichtbepalingen, pp. S-6; een samenvatting van dit advies is terug te vinden in het Jaarverslag van de Commissie voor de Toetsing van Wetgevingsprojecten over het jaar 1989-1990, TK 1990-1991, 21800 VI, nr. 24, pp. 33-36; Bastmeijer, C.J., "De algemene zorgplicht in de Wet Milieubeheer", pp. 469-474 en Hendriks L.E.M., "De Hoge Raad en artikel 14 Wbb", pp. 143-144. Dresden benadrukt de aanvullende functie van de zorgplicht. Dresden, M.J., "De zorgplicht in de milieuwetgeving", pp. 50-67.

193 Zie bijvoorbeeld Remmelink, J., Hoofdwegen door het verkeersrecht, pp. 33-34 en Beckers, W.J.G.M., "Artikel 25 WVW, een blijk van legislatieve onmacht", p. 212.

194 Hullu, J. de, "Rechtszekerheid en vertrouwensbeginsel in het strafrecht", p. 98.

195 Er wordt op gewezen dat vage bepalingen een signaal aan de wetgever kunnen geven zodat bepaalde feitenconstellaties in de toekomst door meer specifieke wetgeving kunnen worden gereguleerd. Zie Advies van de Commissie voor de Toetsing van Wetgevingsprojecten inzake zorgplichtbepalingen, p. 6.

196 Zie in deze zin met betrekking tot artikel 25 WVW: Groenhuijsen, M.S., Straf en wet, pp. 17-18 en 41-42; Groenhuijsen, M.S., "Legaliteit als probleem", pp. 277-287; Otte, $\mathrm{M}$. Het stelsel van gedragsregels in het wegverkeer, $\mathrm{pp} .177-178$.

197 Zje ook Visser, M. "Strafrechtelijke zorgplichtbepalingen over de grens? De strafrechtelijke afdwingbaarheid van milieuzorgplichtbepalingen in België en Nederland", pp. 222-225. 
"gekanaliseerde machtsuitoefening". 198 Het blijft ook. in de veranderde samenleving met meer instrumentele regelgeving van groot belang dat het strafrecht in overeenstemming is met rechtsstatelijke uitgangspunten, zoals het legaliteitsbeginsel $^{199}$, temeer omdat beleidswetgeving toch al minder aansluit bij het rechtsbewustzijn van justitiabelen waardoor het minder draagvlak heeft en in mindere mate wordt geaccepteerd. ${ }^{200}$ Toepassing van het legaliteitsbeginsel formaliseert en. versterkt de band tussen bevoegdheden en wet ${ }^{201}$, wat ook de aanvaarding en het overeenkomstig handelen in de samenleving ten goede zal komen. Indien de wetgever, om wat voor reden dan ook bij het maken van regelgeving gebruik maakt van vage termen waardoor deze minder tegemoet komen aan het lex certa-beginsel kan het bestuur of de rechter dit hiaat opvullen. Zij kunnen aanvullende criteria formuleren. Indien het betekenisbereik onduidelijk is dient de rechter om tegemoet te komen aan het kenbaarheidsvereiste de grenzen van het bereik te trekken rond of nabij de kern die wel duidelijk is. Op deze manier specificeren de aanvullende criteria het betekenisbereik van de (aanvankelijk nog) vage term, waardoor deze niet langer vaag is. Indien de betekenis duidelijk is, kan hij eventueel onder invloed van gewijzigde opvattingen in een later stadium de grenzen van het betekenisbereik verruimen.

Het omgekeerde kan ook gebeuren. Een bepaling kan een (relatief) duidelijk betekenisbereik hebben. Indien blijkt dat de weglating van één of meer bestanddelen het betekenisbereik niet aantasten, kan dit door de wetgever bij een herziening gebeuren. Dit kan resulteren in een op het eerste gezicht vage(re) bepaling, die echter bij nadere bestudering niet vaag of vager blijkt te zijn, aangezien de oorspronkelijke aanvullende criteria nog steeds de grenzen van het betekenisbereik mede bepalen. Hoewel dit geen gunstige ontwikkeling is, aangezien het altijd te prefereren is dat de betekenis zo veel mogelijk uit de regel zelf is op te maken, behoeft het de duidelijkheid van de regel niet aan te tasten. ${ }^{202}$

\subsubsection{Het bestuur en het legaliteitsbeginsel}

Een mogelijkheid om vage termen verder te specificeren en zo de spanning met het lex certa-beginsel te verminderen, is door het vaststellen van aanvullende criteria die het betekenisbereik van de vage term en zo van de bepaling aangeven. Interessant is de bedenking van Hart die erop wijst ${ }^{203}$ :

198 Foqué, R. en Hart, A.C. 't, Instrumentaliteit en Rechtsbescherming, zie ook Hart, A.C. 't, "Strafrecht: de macht van een verhaalsstructuur", pp. 413-470.

199 En het legaliteitsbeginsel dient meer dus te hebben dan vooral symbolische waarde, zie. Stolwijk, S.A.M., "Artikel 1, eerste lid en het legaliteitsbeginsel”, pp. 159-170.

200. Zie hoofdstuk 3 paragraaf 2.

201 Groenhuijsen, M.S., "Legaliteit als probleem", p. 286.

202. Het huidige artikel 5 WVW lijkt ten dele een dergelijke ontwikkeling te hebben doormaakt. Zie over deze bepaling hoofdstuk 7 paragraaf 3.2. 
"It may be found best to defer the use of sanctions for violations until the administrative body has by regulations specified what, for a given industry, is to count as a "fair rate" or a "safe system","

Hij suggereert daarmee dat de vage norm weliswaar in wetgeving kan worden gebruikt, maar dat de inhoud van een dergelijke bepaling veeleer door regulering vanuit het bestuur dient te worden ingevuld en dat tot aan een dergelijke invulling met (strafrechtelijke) sanctionering dient te worden gewacht. Het bestuur stelt zo aanvullende criteria vast die de vage term(en) invullen en specificeren. Pas indien het betekenisbereik voldoende duidelijk is, zou de bepaling eventueel een rol kunnen spelen in het strafrecht.

Deze visie is ook van belang voor zorgplichtbepalingen. Een enkele zorgplichtbepaling verwijst zelfs expliciet naar uitvoeringsmatregelen die door het bestuur kunnen worden genomen. Deze kunnen een nadere specificering vormen van de zorgplichtbepaling. Een voorbeeld is artikel $13 \mathrm{Wbb}$, die verwijst naar de artikelen 6 tot en met 11 uit dezelfde wet, op basis waarvan bij amvb regels kunnen worden gesteld. De Hoge Raad biedt echter de mogelijkheid deze zorgplichtbepaling toe te passen zonder dat sprake is van uitvoeringsmaatregelen. ${ }^{204}$ Nus deze zelfs niet nodig zijn voor de toepassing van de zorgplichtbepaling die duidelijk verwijst naar deze aanvullende criteria, wordt deze voorwaarde natuurlijk in het geheel niet gesteld aan zorgplichtbepalingen die niet zo expliciet hiemaar verwijzen.

\subsubsection{De rechter en het legaliteitsbeginsel}

Indien de wetgever de voorwaarden voor strafbaarheid minder duidelijk en precies omschrijft zal de rechter in een voorliggend geval de strafbaarstelling dienen te interpreteren en concretiseren. De reikwijdte van de strafbaarstelling zal hij casusgewijs en dus ex post vaststellen. Onder invloed van het gevoerde beleid komt de strafrechter onder druk te staan om naast de rechtsbeschermende ook de instrumentele aspecten zwaar mee te laten wegen in zijn beoordeling. ${ }^{205} \mathrm{Bij}$ het gebruik van vage termen in de strafbaarstelling zal hij deze echter ondanks het gevoerde beleid restrictief dienen te interpreteren dan wel de strafbaarstelling onverbindend dienen te verklaren. $^{206}$ Door het ruim interpreteren van een toch al vage bepaling wordt de werkingssfeer van deze bepaling nog verder opgerekt. Hierdoor zal het voor de

204 HR 26 oktober 1993, NJ 1994, 99; MenR 1994, nr. 22, met noot Tideman (Kabelbranden). Zie over dit arrest ook: Hendriks, L.E.M., "De Hoge Raad en artikel 14 Wbb", pp. 139-140 en hoofdstuk 9 paragraaf 3.3.7. en hoofdstuk 10 paragrafen 3.2.5. en 3.2.7.

205 Zie K.ool, R.S.B., "Ontucht(ig): een rechtonzeker begrip?", p. 268; zie ook Maris, C.W, "Romantisch recht", pp. 896-897.

206 De nationale rechter is gezien artikel $120 \mathrm{Gw}$ niet bevoegd wetten in formele zin te toetsen aan de Grondwet. Wel mag hij algemeen verbindende voorschriften van bestuur en beschikkingen aan de Grondwet toetsen. Overigens is hij bevoegd in een voorliggend geval alle nationale regelgeving te toetsen aan de verdragssechtelijke vereisten. Zie over de toetsingsbevoegdheid van de rechter hoofdstuk 5 . 
justitiabele nog moeilijker zijn om vast te stellen of zijn gedraging al dan niet onder de delictsomschrijving valt. Deze interpretatie kan daardoor in strijd komen met het lex certa-beginsel. De mogelijkheid bestaat dan dat een justitiabele wordt veroordeeld voor een feit waarvan hij voorafgaande aan zijn handelen niet kon weten dat het onder de reikwijdte van de delictomschrijving zou vallen. Dit zal noch het rechtsbeschermende, noch het instrumentele aspect (dit laatste zeker op langere termijn) ten goede komen.

De grens tussen het wel en niet in overeenstemming zijn van een delictsomschrijving met het lex certa-beginsel is moeilijk te trekken. ${ }^{207}$ Terwijl sommigen stellen dat vage normen hieraan niet voldoen ${ }^{208}$, menen anderen dat een omschrijving van de belangrijkste normen in de wet in formele zin voldoende is, ${ }^{209}$ Het gangbare criterium is of de verdachte in staat is zijn gedraging af te stemmen op de strafbaarstelling. Zo overwoog de Hoge Raad ${ }^{210}$ :

"5.2.2. In art. 115 WvMS wordt strafbaar gesteld "de militair die door het stelselmatig niet nakomen van dienstverplichtingen het functioneren van de krijgsmacht belemmert". De aard en inhoud van de aan deze strafbaarstelling ten grondslag liggende norm maakt enerzijds een zekere vaagheid in de delictsomschrijving onvermijdelijk, terwijl anderzijds die tot de militair gerichte norm voldoende concreet is om deze in staat te stellen zijn gedrag daarop af te stemmen."

De betekenis van het lex certa-beginsel lijkt in de praktijk van de rechtspraak niet groot, aangezien de eisen die de Hoge Raad stelt aan de nauwkeurigheid van de wettelijke formulering van de verboden gedraging gering zijn. Dit bleek bijvoorbeeld uit de verwerping van een beroep op de onverbindendheid van artikel $140 \mathrm{Sr}$ (oud) ${ }^{211}$ wegens strijd met het legaliteitsbeginsel en meer in het bijzonder met het lex certa-

207 Zie de bespreking over "vaagheid van een regel" hoofdstuk 2 paragraaf 5.4.

208 Vage normen bevatten één of meer vage termen; hiermee hebben we te maken indien veel gevallen in het grensgebied van het betekenisbereik van de term vallen. Visser, $M$. en Hage, J., "Voorwaarden van regeltoepassing", p. 202. Wanneer sprake is van een vage term is hierdoor juist bij grensgevallen lastig vast te stellen, waardoor het ook moeilijk is aan de hand daarvan vast te stellen of de regel is strijd is met het lex certabeginsel.

209 Zie Ru, H.J. de, De algemene wet gaat voor de bijzondere, p. 44. Pompe stelde zelfs: "de wetgever blijft in de redactie van der strafwet vrij, hij kan deze dus in zoo algemeene termen vervatten, en in de keuze der termen zooveel aan het vrije oordeel des. rechters overlaten, dat uit den geschreven tekst zelf weinig zekerheid voor den burger of misdadiger overblijft." Pompe, W.P.J., Het nieuwe tijdperk en het recht, p. 50.

210 HR 8 maart 1994, $N J$ 1994, 412 (Krijgsmacht belemmert). Artikel 115 WvMS luidt: "Met gevangenisstraf van ten hoogste een jaar en negen maanden of geldboete van de: vierde categorie wordt gestraft de militair die door het stelselmatig niet nakomen van dienstverplichtingen het functioneren van de krijgsmacht belemmert. Indien het feit. wordt gepleegd in tijd van oorlog wordt gevangenisstraf van ten hoogste vier jaren of geldboete van de vierde categorie opgelegd."

211 HR 16 oktober 1990, NJ 1991, 442, met noot Corstens (Mariënburcht). 
beginsel. Ter illustratie van het feit dat de Hoge Raad maar geringe eisen stelt aan regelgeving wordt regelmatig het volgende voorbeeld gegeven ${ }^{22}$ :

"6.2. Art. 4 par. 3 aanhef en onder d Algemeen Reglement Vervoer luidt: "Het is verboden: d. op enig gedeelte van de stations of in de treinen te vechten, handtastelijkheden te plegen, vuurwerk af te steken, anderen uit te schelden of lastig te vallen dan well zich op andere wijze onbehoorlijk te gedragen."

6.3. Anders dan het middel stelt is deze bepaling, ook voor wat betreft het verbod zich op de stations en in de treinen - op andere wijze dan in het voorafgaande gesteld - onbehoorlijk te gedragen, niet onverenigbaar met de in het middel bedoelde bepalingen. Daarbij is van belang dat evenbedoelde norm in zoverre is geconcretiseerd dat het gaat om gedrag op de stations en in de treinen, en dat het voorts betreft een norm die, in de bewoordingen van het Europese Hof voor de rechten van de mens in zijn arrest van 26 april 1979, $N J 1980,146$, is "inevitably couched in terms which, (...) are vague and whose interpretation and application are questions of practice".

6.4. Het middel treft dus geen doel."

De Hoge Raad komt hier tot het oordeel dat de norm niet vaag is omdat deze is geconcretiseerd tot gedrag op een bepaalde locatie, te weten in stations en treinen. De plaats van handeien zegt echter niets over het soort gedagingen die op die plaats al dan niet verboden zijn. ${ }^{213}$ De strafbaarstelling geeft een opsomming van gedragingen en vult deze aan met het vage bestanddeel "dan wel zich op andere wijze onbehoorlijk te gedragen". Niet altijd kunnen alle gedragingen worden opgesomd die de delictsomschrijving kunnen vervullen. ${ }^{214}$ Door eerst een opsomming te geven en deze te besluiten met het vage bestanddeel, of het vage bestanddeel vooraf te laten gaan aan de opsomming ${ }^{215}$, wordt het vage bestanddeel tegen een bepaalde achtergrond geplaatst. De concreet omschreven gedragingen worden aangevuld door het vage bestanddeel, waarvan de grenzen ten dele worden bepaald door de concrete. Het "op andere wijze" 216 duidt erop dat de gedragingen die niet zijn omschreven in redelijke verhouding dienen te staan met de wel opgesomde, bijvoorbeeld qua ernst en soort. De context waarin het vage bestanddeel is opgenomen specificeert hierdoor het type gedragingen dat onder de reikwijdte van de strafbaarstelling valt. Het is dan ook wenselijk dat de wetgever indien hij zich genoodzaakt ziet vage bestanddelen te gebruiken de context van deze bestanddelen zoveel mogelijk concretiseert door voorbeelden van gedragingen op te nemen in de delictsomschrijving. Ook het systeem

212 HR 2 april 1985, NJ 1985, 796 (Onbehoorlijk gedrag). Het Algemeen Reglement Vervoer (op de spoonvegen) is opgenomen in Stb. 1971, 404.

213 Zie ook Groenhuijsen, M.S., Straf en wet, p. 17 en Otte, M., Het stelsel van gedragregels in het wegverkeer, pp. 172-173. Anders Simmelink, J.B.H.M., "Het RVV 1990 , niet iedere verandering is een verbetering", pp. 53-54. Zie over de WVW hoofdstuk 7 paragraaf 3.2 .

214 Zie de bespreking van het legaliteitsbeginsel en de wetgever in hoofdstuk 3 paragraaf 7.3 .4 .

215 Zie bijvoorbeeld artikel 11 Arbo-wet 1998, hoofulstuk 8 paragraaf 3.2.

216 En bij artikel 11 Arbo-wet 1998 door het zinnetje "Met name zijn zij verplicht om:" tussen de (vage) aanhef en (de specifiekere) sub a tot en met $\hat{f}$, zie hoofdstuk 8 paragraaf 3.2.10. 
en de inhoud van de rest van de regeling geeft inhoud aan de vage normstelling. ${ }^{217}$ Het systeem alleen zal echter vaak niet voldoende zijn om de inhoud te specificeren dan wel het bestaansrecht van de vage bepaling te rechtvaardigen. ${ }^{218}$ Er zijn meer manieren dan het opsommen van gedragingen om een norm (verder) te specificeren, bijvoorbeeld door het opnemen van een bestanddeel dat het resultaat aangeeft dat door de gedraging teweeg wordt gebracht. Ook de rechter kan het bereik van vage termen inperken door nadere criteria te stellen. ${ }^{219}$ Dergelijke vereisten kunnen het strafbare feit verder concretiseren, zodat eerder voldaan wordt aan de uit het EVRM voortvloeiende vereisten van "accessibility and forseeability". Of voldaan is aan deze vereisten wordt door de Hoge Raad in bovenstaande zaak niet onderzocht, ondanks dat ze blijkens de door hem aangehaalde uitspraak van het Europees Hof worden gesteld aan "law". Evenmin heeft de Hoge Raad onderzocht of aan de verder gaande vereisten van het nationale recht is voldaan, te weten of de tekst van de strafbaarstelling voldoende duidelijk en precies is, zodat de verdachte voorafgaande aan zijn handelen kon weten of zijn gedrag al dan niet onder de delictsomschrijving zou vallen. ${ }^{220}$

Dat bovenstaande zaak geen uitschieter is, wordt duidelijk uit de overweging van de Hoge Raad inzake schending van artikel 54 APV Amsterdam (oud). Dit artikel kent een zelfde structuur als bovengenoemd artikel 4 par. 3 aanhef en onder d Algemeen Reglement Vervoer. Artikel 54 luidde:

"Het is verboden, zich zonder redelijk doel of op voor anderen hinderlijke wijze op te houden in een portaal, telefooncel, parkeergarage of een andere soortgelijke, voor publiek, toegankelijke ruimte dan wel deze te verontreinigen en/of te bezigen voor een ander doel dan waarvoor deze ruimten zijn bestemd."

\section{Ten. laste van een verdachte werd bewezenverklaard}

"dat hij op voor anderen hinderlijke wijze zich heeft opgehouden in een liftportaal (...) en dit liftportaal heeft gebezigd voor een ander doel dan waarvoor deze ruimte was bestemd, immers ging hij, verdachte, toen aldaar op verdovende middelen gelijkende waar gebruiken."

Het beroep van de raadsman dat deze bepaling te ruim is geformuleerd waardoor zij in strijd is met het lex certa-beginsel wordt door de Hoge Raad met een overweging van tafel geveegd ${ }^{22 i}$ :

217 Hart, A.C. 't, "Art. 25 WVW en het legaliteitsbeginsel", p. 205; zie ook Simmelink, J.B.H.M., "Het RVV 1990, niet iedere verandering is ook een verbetering", p. 54.

218 Otte, M., Het stelsel van gedragsregels in het wegverkeer, pp. 172-174.

219 Zie over vage normen en aanvullende criteria door de rechter hoofdstuk 5. Zie ook Hullu, J. de, "Rechtszekerheid en vertrouwensbeginsel in het strafrecht", p. 99, die als voorbeeld artikel $140 \mathrm{Sr}$ bespreekt.

220 Deze eis sluit aan bij het later door het Hof gestipuleerde vereiste "that an offence must be clearly defined in law. This condition is satisfied where the individual can know from the wording of the relevant provision and, if need be, with the assistance of the courts' interpretation of it, what acts and omissions will make him criminally liable." EHRM 25 mei 1993, Series A, no. 260-A, nr. 52, p. 22 (Kokkinakis v. Greece).

221 HR I september 1998, NJ 1999, 61 (Liftportaal). 


\section{Hoofdstuk 3}

"5.1. De Rechtbank heeft geoordeeld dat hetgeen onder 4 (zie Rechtbank; red.) is vermeld overtreding oplevert van artikel 54 (oud) van de Algemene Plaatselijke Verordening van de gemeente Amsterdam. Het in het vonnis besloten liggende oordeel dat artikel 54 niet onverbindend is, geeft niet blijk van een verkeerde rechtsopvatting, in aanmerking genomen dat artikel 54 niet in strijd is met de in het middel genoemde bepalingen, nu de norm in zoverre is geconcretiseerd dat het gaat om in dit artikel omschreven gedrag in - onder andere - een portaal. 5.2. Het middel faalt dus."

Indien de norm is opgenomen in een beschikking zal de Hoge Raad slechts toetsen of de uitleg die de lagere instantie an het betreffende voorschrift heeft gegeven begrijpelijk is. ${ }^{222}$ Een veel voorkomend vergunningvoorschrift als "Het is in de inrichting verboden voor de omgeving hinderlijke werkzaamheden te verrichten", behoeft blijkens de Hoge Raad niet in strijd te zijn met het lex certa-beginsel. ${ }^{223}$

De feitenrechters hebben de bevoegdheid in een voorliggende zaak lagere regelgeving of beschikking(voorschrift)en onverbindend te verklaren wegens strijd met het in artikel 1, eerste lid $\mathrm{Sr}$ en artikel $16 \mathrm{Gw}$ verankerde legaliteitsbeginsel. Een zeldzaam maar aardig voorbeeld van een zaak waarin een klacht over een te vage norm door de strafrechter werd gehonoreerd is een zaak waarin een arts ten laste was gelegd dat hij een honorarium had gerekend dat niet overeenkomstig de Wet Tarieven Gezondheids-

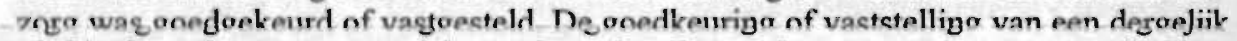
tarief is door de wetgever gedelegeerd aan het Centraal orgaan tarieven gezondheidszorg. De arts diende een bezwaarschrift in tegen de aan hem uitgereikte dagvaarding met als argument dat de norm die hij volgens de tenlastelegging zou hebben geschonden niet in overeenstemming was met het legaliteitsbeginsel. Uit de betreffende richtlijn bleek dat de berekening van dit tarief is gebaseerd op een redelijkheidscriterium, te weten "zoveel X als redelijk is". Het oordeel van de rechtbank luidde ${ }^{224}$ :

223 HR 27 juni 1995, NJ 1995, 722; MenR 1996, nr. 6, met noot Hendriks (Uitleg vergunning is feitelijk). De Hoge Raad overwoog: "5.4. Het Hof heeft omtrent een ter terechtzitting in hoger beroep gevoerd verweer als volgt overwogen en beslist: "Een redelijke uitleg van dit voorschrift brengt mee hieronder in ieder geval onnodige en/ of uitzonderlijk hinderlijke werkzaamheden te begrijpen, gelijk zich in het onderhavige geval hebben voorgedaan. (...) 5.5. Het Hof heeft aldus als zijn oordeel tot uitdrukking gebracht dat het voorschrift ertoe strekt om naast specifieke gedragsvoorschriften onnodige - dat wil zeggen gelet op het normale bedrijfsproces redelijkerwijs vermijdbare - hinder opleverende werkzaamheden alsmede werkzaamheden die uitzonderlijk hinderlijk zijn, tegen te gaan. Dat oordeel is niet onbegrijpelijk, terwijl daarin besloten ligt het niet van een verkeerde rechtsopvatting blijk gevende en evenmin onbegrijpelijke oordeel dat het aldus uitgelegde voorschrift voldoende concreet is."

$224 \mathrm{Rb}$. Breda I oktober 1985, NJ 1986, 114 (Onduidelijke norm). Dit is overigens een van de weinige voorbeelden waar de Nederlandse strafrechter een vage norm strijdig heeft verklaard met het lex certa-beginsel. Zie over dit vonnis ook Mulder, G.E., "Vage normen", pp. 420-422; Waling, C., Het materiële milieustrafrecht, p. 64, noot $156 \mathrm{en}$ Hullu, J. de, "Rechtszekerheid en vertrouwensbeginsel in het strafrecht", p. 97. 
"I.c. doet zich de vraag voor, of een dergelijke bepaling als strafrechtelijke norm voldoet aan de eisen die aan dergelijke normen behoren te worden gesteld. Artikel $16 \mathrm{Gr} . \mathrm{w}$ en artikel $1 \mathrm{Sr}$ bepalen dat geen feit strafbaar is dan uit kracht van een daaraan voorafgegane wettelijke bepaling. De strekking van deze bepaling is, dat iedere burger in de wet precies moet kunnen lezen welk gedrag van hem wordt verlangd en welke sancties hem te wachten staan, warneer hij zich anders gedraagt. Dit brengt mede, dat in de bepaling die de strafrechtelijke norm bevat dat gedrag zo nauwkeurig behoort te worden omschreven, dat voor de burger geen twijfel behoeft te bestaan, of een bepaald gedrag valt binnen de door de bepaling in kwestie bestreken categorie. In dit geval is de norm neergelegd in artikel 2 Wet Tarieven Gezondheidszorg en de bij het eerder genoemde besluit van het Centraal orgaan tarieven gezondheidszorg van $20 \mathrm{dec}$. 1982 behorende tarieflijsten, die voor de onderhavige verrichtingen in feite niet meer inhouden dan de bepaling, dat gedeclareerd mag worden wat redelijk is. Naar het oordeel der Rb. kunnen de betrokkenen uit deze bepaling niet met voldoende duidelijkheid hun verplichtingen te dezen leren kennen, zodat het besluit van het Centraal orgaan tarieven gezondheidszorg van 20 dec. 1982 in dit opzicht als strafrechtelijke norm onverbindend is, waarmee geen oordeel wordt uitgesproken over de vraag, of de door verdachte in rekening gebrachte tarieven naar civielrechtelijke maatstaven redelijk zijn. Aangezien derhalve de ten laste gelegde feiten niet strafbaar zijn, zal de $\mathrm{Rb}$. de verdachte buiten vervolging stellen."

Zoals uit bovenstaande blijkt brengt het lex certa-beginsel mee dat de voorwaarden voor strafbaarheid zodanig moeten zijn omschreven dat de justitiabele voorafgaande aan zijn handelen kan weten of zijn gedrag al dan niet onder de delictsomschrijving valt. Hierdoor kunnen ook complexe strafbaarstellingen in strijd komen met dit beginsel. De Hoge Raad past ook dit vereiste, dat meer overeen komt met "accessibility", niet restrictief toe. In het bijzonder strafrecht zijn vele voorbeelden te vinden van gelede normstelling die het bepalen van de reikwijdte van de strafbaarheid voor de justitiabele een ware zoektocht maken. Zo speelde de ongrijpbaarheid van regelgeving een rol in een strafzaak waar een boer werd vervolgd omdat hij in strijd met dit artikel een mestbassin voor dunne mest niet goed had afgedicht. ${ }^{225} \mathrm{De}$ Advocaat-Generaal had ruim twee bladzijden nodig om kort de inhoud van dit gelaagde voorschrift aan te geven. Van belang hierbij waren verschillende artikelen van de Wet milieubeheer, een Inrichtingen- en Vergunningenbesluit Milieubeheer met bijbehorende bijlage, een Besluit Mestbassins Milieubeheer met bijlage en de Bouwtechnische Richtlijnen Mestbassins 1987 (welke voorschriften regelmatig werden gewijzigd). Ondanks deze ondoorzichtigheid werd het beroep van verdachte op het ontbreken van "een duidelijke en deugdelijke voorafgegane strafbaarstelling" verworpen. $^{226}$

De relatief autonome waarde van het legaliteitsbeginsel wordt door het toekennen van een beperkte rol ten onrechte gering. Het vereiste van een duidelijke en inzichtelijke wettelijke formulering van de verboden gedraging is immers een hoog te noteren

225 HR 1 juli 1996, DD 96.364 (Mestbassin).

226 Zie hierover Hullu, J. de, "Rechtszekerheid en vertrouwensbeginsel in her strafrecht", p. 100. De Hullu achtte deze beslissing juist, "(...) waarbij misschien nog wel moet worden bedacht dat dergelijke regelgeving voor een jurist moeilijker te doorgronden kan zijn dan voor een agrarisch ondernemer." 
belang. ${ }^{227}$ Het zou steeds als toetssteen aan het positieve recht moeten worden voorgehouden, enerzijds om het optreden van controleurs te normeren ${ }^{228}$, maar ook om op een legitieme wijze schadelijke, bedreigende, nadelige gedragingen tegen te gaan. ${ }^{229}$ Voorts is het van belang voor de rechtshandhaving; politie en justitie hebben dan te weinig houvast bij het uitoefenen van hun strafvorderlijke bevoegdheden. ${ }^{230}$ In hoeverre kan immers naleving worden gevraagd en al dan niet met gebruikmaking van strafvorderiijke bevoegdheden worden afgedwongen, indien niet duidelijk is waaraan jemand zich heeft te houden. ${ }^{231}$ Dit is in het kader van de strafvordering onder andere van belang voor de rechtmatige toepassing van dwangmiddelen. ${ }^{232}$ Vage termen in delictsomschrijvingen kunnen immers tot gevolg hebben dat dwangmiddelen die inbreuken op grondrechten mogelijk maken, willekeurig of te ruim worden toegepast. $^{233}$

\subsection{Het schuldbeginsel}

\subsubsection{Inleiding}

De reikwijdte van een strafbepaling kan ook worden getoetst aan de hand van de vraag of bijzondere eisen worden gesteld aan de subjectieve zijde van de delictsomschrijving. ${ }^{234}$ Bewust is overigens hier voor de veeleer overkoepelende term "subjectief element" gekozen. ${ }^{235}$ Dit omvat de twee "schuldvormen" opzet en culpa die als bestanddelen van de delictsomschrijving bijzondere voorwaarden voor strafbaarheid uitmaken en schuld als algemene voorwaarde voor de strafbaarbeid. ${ }^{236}$

De werking van het subjectieve element beheerst het hele strafrecht. ${ }^{237}$ Begrijpelijk is dat wordt gesteld dat indien het schuldverwijt nauwelijks tot geen rol speelt het de vraag is of de strafbaarstelling wel in het strafrecht thuis hoort en niet veeleer op

227 Groenhuijsen, M.S., Straf en wet, pp. 49-51.

228 Peters, A.A.G., Het rechtskarakter van het strafrecht, p. 10.

229 Zie Groenhuijsen, M.S., Straf en wet.

230 In de Nota "Zicht op wetgeving" zie hoofdstuk 3 paragraaf 3. wordt gesteld dat "Vage en te complexe delictsomschrijvingen leiden immers niet alleen tot rechtsonzekerheid, maar bieden ook onvoldoende mogelijkheden voor een succesvolle strafvervolging". Zie Blomberg, A.B. en Michiels, F.C.M.A., Handhaven met effect, p. 293.

232 Hullu, J. de, "Rechtszekerheid en vertrouwensbeginsel in het strafrecht", pp. 99-100.

233 Denk aan de vrijheidsbeneming van Eurotop demonstranten op basis van artikel $140 \mathrm{Sr}$.

234 Beschouwingen uit deze paragraaf werden deels eerder gepubliceerd in Visser, M.J.C., "Uitholling van het schuldbeginsel bij zorgplichtbepalingen door schending van het lex certa-beginsel", pp. 65-80.

235 Indien culpa of opzet is opgenomen als bestanddeel van een delictsomschrijving wordt gesproken van een subjectief bestanddeel. Zie Bemmelen, J.M. van en Veen, Th.W. varn, bewerkt door Jong, D.H. de en Knigge, G., Het materiële strafrecht, p. 57.

236 Zie Peters, A.A.G., Opzet en schuld in het strafrecht.

237 Zie over de schuldvereisten bij milieudelicten in het algemeen Wemes, L.T., "Commune delicten betreffende de milieuvervuiling in de sleutel van de schuld", pp. 205-256, en Koopmans, I.M., "Strafrechtelijke aansprakelijkheid in het milieustrafrecht: afscheid van schuld?", pp. 545-562. 
andere wijze dient te worden gehandhaafd, bijvoorbeeld via het bestuursrecht. ${ }^{238}$ In beginsel is de strafwet alleen van toepassing op degene die verwijtbaar de wet overtreedt. De beoordeling of het feit aan schuld te wijten is, heeft hierdoor ondanks dat het een waardeoordeel betreft slechts een beperkte sociaal-ethische impact. Zij kan nooit geïsoleerd worden bekeken, maar is nauw verbonden met de strafbare gedraging en haar gevolgen. ${ }^{239}$ Aangezien de gedraging geen onderdeel vormt van het schuldverwijt maar daarvan het object is, zal altijd eerst moeten worden bezien of sprake is van een strafbaar gestelde gedraging die wederrechtelijk heeft plaats. gevonden. Immers, een niet wederrechtelijke gedraging kan per definitie de dader niet worden verweten. ${ }^{240}$

Het subjectief element hangt nauw samen met het in de vorige paragraaf besproken lex certa-beginsel, dat eist dat strafbare feiten zodanig zijn geformuleerd dat de justitiabele voorafgaande aan zijn handelen kan weten of zijn gedraging onder de reikwijdte van de strafbaarstelling zal vallen. Dit dient op een dusdanige wijze te gebeuren dat op grond van de formulering toerekening aan de individuele persoon mogelijk is. Naarmate de gedraging duidelijker in de delictsomschrijving wordt omschreven, zal degene die de handeling verricht hierop ook meer legitiem kunnen worden aangesproken. ${ }^{241}$ De concretisering van het verwijt lijkt bij strafbaarstellingen met vage bestanddelen problemen op te leveren. Het is de vraag of, en zo ja waardoor en in welke omstandigheden, een dergelijke strafbaarstelling voor de justitiabele zodanig onvoorspelbaar is in haar concrete uitwerking, dat inzicht in de verwijtbaarheid van de gedraging ontbreekt. ${ }^{242}$

Het subjectieve element kan op verschillende manieren zijn verwerkt in de delictsomschrijving. Zo worden verschillende vormen van opzet of culpa gebruikt in delictsomschrijvingen van misdrijven, warbij culpa wordt beschouwd als een uitzondering naast het gebruikelijke opzet. Volgens de memorie van toelichting op het Wetboek van Strafrecht is ${ }^{243}$ :

238 Jonkers, W.H.A., "Het strafrechtelijk schuldverwijt", p. 231.

239. Remmelink, J., Mr. D. Hazewinkel-Suringa's Inleiding to de studie van het Nederlandse strafrecht, pp. 195 .

240 Jonkers, W.H.A., "Het strafrechtelijk schuldverwijt", p. 233.

24I De Roos, Th., Strafbaarsielling van economische delicten, p. 75. Zie tevens over de relatie tussen het legaliteitsbeginsel en het schuldbeginsel: Bos, J.T., "Het schuldbeginsel als machtswoord", pp. 5-42, evenals Koopmans, 1.M., "Strafrechtelijke aansprakelijkheid in het milieustrafrecht: afscheid van schuld?", pp. 548-549. Remmelink stelt dat: " (...) schuld nu cenmaal moet functioneren in de orde van het recht, hetgeen meebrengt, dat zij nauw verbonden is aan de strafbare gedraging en haar gevolgen, dus nooit geïsoleerd kan worden bekeken." Remmelink, J., Mr. D. Hazewinkel-Suringa's Inleiding tot de studie van het Nederlandse strafrecht, p. 195.

242 De Commissie Toetsing Wetgevingsprojecten stelt dat: "Tegen vage strafrechtelijk gesanctioneerde normen bestaan dus bezwaren, omdat de (her)kenbaarheid of de inzichtelijkheid van de norm voor de burger al gauw tekort schiet". Advies van de Commissie voor de Toetsing van Wetgevingsprojecten inzake zorgplichtbepalingen, $\mathrm{p}$. 7.

243 Smidt, H.J., Geschiedenis van het Wetboek van Strafrecht, Deel I, pp. 84-85. 
"schuld (...) de zuivere tegenstelling van opzet aan de eene, van toevall (casus) aan de andere zijde. (...) Geen delictum culposum zonder bewezen schuld bij den dader. In de opsomming der verschillende soorten van schuld (verzuim, nalatigheid, onvoorzigtigheid, gebrek aan voorzorg enz.) moet de wetgever niet treden. Veel beter is het hier in alle gevallen dezelfde algemene uitdrukking te bezigen, ten einde de regter geheel vrij zij in de waardering van de bewezen omstandigheden ter beslissing van de bloot feitelijke vraag, of, bij gebreke van opzet, het feit aan des beklaagden schuld is te wijten."

Ondanks bovenstaand uitgangspunt heeft de wetgever in delictsomschrijvingen van zowel misdrijven als overtredingen soms andere soorten van schuld opgenomen. Deze vormen kunnen een andere graad van schuld vereisen ten aanzien van de bestanddelen waarop zij betrekking hebben dan het bestanddeel schuld. ${ }^{244}$ Overigens wordt bij overtredingen culpa (of een van haar vormen) vaak niet uitdrukkelijk opgenomen in de delictsomschrijving. Zij speelt dan een rol als element van de bepaling. De verschillende subjectieve elementen die een rol spelen in het strafrecht zullen in deze paragraaf eerst worden besproken (hoofdstuk 3 paragrafen 7.4.2., 7.4.3. en 7.4.4.), waama wordt ingegaan op de criteriumfiguur (hoofdstuk 3 paragraaf 7.4.5.), de "schuldkwadratuur" (hoofdstuk 3 paragraaf 7.4.6.) en de mogelijke consequenties van opzet of culpa (hoofdstuk 3 paragraaf 7.4.7.).

\subsubsection{Qnzet als hestanddeel}

Indien sprake is van een wederrechtelijke gedraging, kan worden onderzocht of deze de dader kan worden toegerekend. Hiervoor is het noodzakelijk dat de dader vanuit een innerlijke keuze tot zijn wederrechtelijke gedraging is gekomen (deze vrije zelfbepaling ligt primair in de wilssfeer) en dat er bij de dader opzet is met betrekking tot die wederrechtelijke gedraging (dit opzet-vereiste ligt primair in de kensfeer). ${ }^{245}$

Opzet als vereiste voor de strafbaarheid wordt als bestanddeel opgenomen, tenzij de opzet reeds uit de taalkundige betekenis van de omschrijving van de gebezigdc woorden voortvloeit. ${ }^{246}$ De opzet-eis zou blijkens de memorie van toelichting van het Wetboek van Strafrecht betrekking hebben op de gehele omschrijving van het strafbare feit zoals het daarna volgt ${ }^{247}$, waardoor het kan zien op de gedraging, het gevolg en/ of andere bestanddelen. De wetgever heeft zich helaas niet zorgvuldig aan deze regel gehouden, waardoor soms bestanddelen die volgen op opzet hierdoor niet worden beheerst en soms bestanddelen die eraan voorafgaan er wel door worden beheerst. ${ }^{248}$ Per delictsomschrijving zal dan ook moeten worden onderzocht of moet worden afgeweken van de oorspronkelijke regel.

244 Remmelink, J., Mr. D. Hazewinkel-Suringa's Inleiding tot de studie van het Nederlandse strafrecht, p. 228-229.

245 Jonkers, W.H.A., "Het strafrechtelijk schuldverwijt", pp. 233-234.

246 Smidt, H.J., Geschiedenis van het Wetboek van Strafrecht, Deel I, p. 78. Zie bijvoorbeeld "opruit" (artikel $131 \mathrm{Sr}$ ), "verzet" (artikel $180 \mathrm{Sr}$ ), "dwingt tot" (artikel 252 $\mathrm{Sr}$.

247 Smidt, H.J., Geschiedenis van het Wetboek van Strafrecht, Deel I, p. 78.

248 Zie Remmelink, J., Mr. D. Hazewinkel-Suringa's Inleiding tot de studie van het 
De betekenis van het bestanddeel opzet wordt in de wet niet gedefinieerd. Duidelijk is dat onder opzet ten eerste wordt verstaan het willens en wetens handelen. Ook voorwaardelijk opzet wordt door de Hoge Raad onder opzet begrepen; de dader moet dan willens en wetens de kwade kans hebben aanvaard ofwel bewust op de koop toe hebben moeten genomen. Naast opzet gebruikt de wetgever soms ook andere bestanddelen om deze vorm van verwijtbaarheid aan te geven, zoals bijvoorbeeld "kennis dragende van" (artikel $135 \mathrm{Sr}$ ), "wetende dat" (artikel $188 \mathrm{Sr}$ ). De betekenis van deze termen is dan bepalend als vereiste voor strafbaarheid.

Bij de totstandkoming van het Wetboek van Strafrecht heeft de wetgever bewust gekozen het begrip "opzet" niet te verstaan als "boos opzet", maar als "kleurloos opzet" ${ }^{249}$ Hiervoor is (in tegenstelling tot boos opzet) niet nodig dat het opzet gericht hoeft te zijn op het ongeoorloofde van de daad, zodat de dader het op straffe verboden zijn van zijn gedraging niet behoeft te hebben geweten. ${ }^{250}$

Bij crisis- en economische wetgeving ${ }^{251}$ is aanvankelijk van deze invulling van het begrip opzet afgeweken. ${ }^{252}$ De toepassing van opzet bij het overtreden van voorschriften waarvan de betrokkenen niet (redelijkerwijs) behoefde te weten dat deze verboden waren, werd als onrecht gevoeld. De Hoge Raad heeft bij deze bijzondere wetten, en later bij de Wet op de economische delicten waarin deze wetten zijn gebundeld, de opzet-eis zo uitgelegd dat hiervoor het besef van het verbodene van de gedraging noodzakelijk is. Bij het niet kennen van het verbod kon nog wel veroordeling volgen; de schending van het betreffende voorschrift werd dan niet als misdrijf maar als overtreding aangemerkt.

In 1952 is de Hoge Raad van standpunt veranderd; het "opzet" uit de bepalingen van de Wed. werd vanaf toen ook als "kleurloos opzet" opgevat. ${ }^{253}$ Hiervoor werd als motivering aangevoerd dat "onvoldoende blijkt van een bijzondere grond voor zo een afwijkende regeling". Het vasthouden aan de oude opvatting wordt afgewezen omdat het "ergerlijke gevallen van zelfzuchtige onwetendheid omtrent de strafbepalingen vijuit laat gaan". Voor "opzet" geldt zodoende, conform de gebruikelijke uitleg, dat

Nederlandse strafrecht, p. 211. Ook komt het voor dat de opzet-eis en de culpa-eis als alternatieven in een bepaling zijn opgenomen, zie bijvoorbeeld artikel $134 \mathrm{Sr}$ "weet of ernstige reden heeft om te vermoeden". Ook dan heeft de opzet-eis geen betrekking op de culpa-eis. Zie hierover hoofdstuk 3 paragraaf 7.4.6.

249 Smidt, H.J., Geschiedenis van het Wetboek van Strafrecht, Deel I, pp. 73-83. Die over deze begrippen Brouns, P.J.H.M., Opzet in het wetboek van strafrecht, pp. 113-125.

250 Remmelink, J., Mr. D. Hazewinkel-Suringa's Inleiding tot de studie van het Nederlandse strafrechi, pp. 226-228.

25! In artikel 1 en la Wed worden economische delicten buiten het Wetboek van Strafrecht opgesomd, waardoor deze onder het regime van de Wed worden gebracht. Zie over het bijzonder (niet zijnde economisch) strafrecht hoofdstuk 7 , over het economisch strafrecht hoofdstuk 8 en over het milieustrafrecht hoofdstuk 9 .

252. Economische delicten zijn blijkens artikel 2 Wed een misdrijf indien de normschending opzettelijk is begaan en in de overige gevallen een overtreding.

253 HR 18 maart: 1952, NJ 1952, 314 en 315, met noot Röling (Kleurloos opzet). 
niet vereist is dat de verdachte zich bewust was in strijd met het verboden voorschrift te handelen.

De inhoud van het begrip opzet is zodoende betrekkelijk duidelijk, maar er bestaat nog wel onduidelijkheid over de reikwijdte ervan. ${ }^{254}$ De opzet-eis uit de Wed geldt in het algemeen voor alle bestanddelen van de delictsomschrijving uit de economische wet. Ook hierop is een uitzondering aanwezig: deze interpretatie is namelijk niet houdbaar indien de betrokken bepaling reeds een of meer schuldbestanddelen bevatten, hetgeen met name bij zorgplichtbepalingen in het milieustrafrecht (meestal) het geval is. ${ }^{255}$

Het $\mathrm{OM}$ zal de ten laste gelegde schuldvorm trachten te bewijzen. Indien het bijvoorbeeld stelt dat de verdachte gevaarlijke stoffen, die bij algemene maatregel van bestuur zijn aangewezen als goederen waarvan vervoer niet is toegestaan, opzettelijk heeft vervoerd, dan baat een verweer dat de verdachte de inhoud van deze regel niet kende niet. Indien het OM echter stelt dat de verdachte opzettelijk in strijd met de algemene maatregel van bestuur gevaarlijke stoffen heeft vervoerd waarvan vervoer niet is toegestaan, dan beheerst het opzet de rest van de bestanddelen van de tenlastelegging, dus ook het in strijd met deze regel handelen. Indien naar de overtuiging van de rechter het door opzet beheerste deel van de tenlastelegging niet kan worden bewezen, zal hij de verdachte vrijspreken. Als door opzet beheerste delen van de delictsomschrijving niet zijn ten laste gelegd zal hij het bewezene niet kunnen kwalificeren waardoor de verdachte wordt ontslagen van rechtsvervolging. Wel is het mogelijk dat de verdachte op basis van de eventueel subsidiair ten laste gelegde overtreding-variant wordt veroordeeld. ${ }^{256}$

\subsubsection{Culpa als bestanddeel}

In een aantal strafbaarstellingen is een subjectief bestanddeel opgenomen, dat de verwijtbaarheid van het gedrag van de dader aangeeft. De redactie is overigens niet consequent. Zo wordt naast het gebruikelijke bestanddeel "schuld" bijvoorbeeld gebruik gemaakt van de formulering "aan wiens schuld te wijten is", "weet of redelijkerwijs had kunnen vermoeden" of "weet of redelijkerwijs had kunnen weten". Deze kunnen een andere betekenis hebben dan het bestanddeel "schuld". De culpose bestanddelen zijn vaak niet van toepassing op alle bestanddelen van de delictsomschrijving. Het deel dat is onttrokken aan de subjectieve bestanddelen, wordt beheerst door schuld als element.

Ook bij schuld als bestanddeel geldt dat het gaat om een wederrechtelijke gedraging waartoe de dader vanuit een innerlijke keuze moet zijn gekomen en moet er bij de

254. Zo ook Keulen, B.F., Economisch strafrecht, p. 41.

255 Zie hierover hoofdstuk 3 paragraaf 7.4.6. en de uitwerkingent van de "schuldkwadratuur" bij zorgplichtbepalingen in het milieustrafrecht in hoofdstuk 9 paragrafen 3.2.6., 3.3.9, $3.4 .8 \mathrm{en} 4$.

256 Zie Jörg, N., "Economische delicten", 64.2.1.b. 
dader culpa zijn met betrekking tot die gedraging. ${ }^{257}$ De beoordeling is een normatieve aangelegenheid. Culpa houdt een verwijtbaar niet-weten in. Degene die culpoos handelt is zich er niet van bewust dat hij handelt, of dat zijn handelwijze wederrechtelijk is dan wel strafrechtelijk relevante gevolgen kan hebben. De dader behoorde echter wel te weten, na te denken, oplettend te zijn, zich op de hoogte te stellen. Deze innerlijke onzorgvuldigheid kan resulteren in een uitwendige wederrechtelijke strafbare gedraging die hem dan op basis van de innerlijke onzorgvuldigheid kan worden verweten. ${ }^{258}$ De rechter zal bij de beoordeling of sprake is van culpoos handelen naar aanleiding van de bewezen uiterlijke gedraging de innerlijke culpa eventueel presumeren. ${ }^{259}$

Indien het $\mathrm{OM}$ overgaat tot vervolging op grond van een dergelijke strafbaarstelling zal het wel het bestanddeel dat ziet op de verwijtbaarheid van de dader in de tenlastelegging moeten opnemen. Anders zal de bewezen verklaarde gedraging niet kunnen worden gekwalificeerd, waardoor de verdachte zal moeten worden ontslagen van rechtsvervolging. Het OM zal het verwijt dat de verdachte wordt gemaakt dienen te staven.

\subsubsection{Culpa als element}

Bij overtredingen wordt vaak volstaan met de omschrijving van het materiële feit. Er is dan geen subjectief bestanddeel opgenomen, zodat opzet noch culpa door de delictsomschrijving worden vereist. Toch is voor strafbaarheid van een gedraging wel steeds een zekere mate van schuld vereist. ${ }^{260}$ Indien schuld in de vorm van culpa geen bestanddeel is van de delictsomschrijving vormt het een element daarvan. ${ }^{261}$ Indien er wel subjectieve bestanddelen zijn opgenomen beheerst het element schuld de bestanddelen waarop de schuld-eis niet reeds van toepassing is. Als in een bepaald geval geen sprake is van schuld in de zin van verwijtbaarheid, zal het gevolg zijn dat viijspraak volgt indien de schuld is ten laste gelegd, dan wel dat de verdachte gezien de toepasselijkheid van een schulduitsluitingsgrond zal worden ontslagen van alle rechtsvervolging.

Indien geen schuld-bestanddelen zijn opgenomen in de delictsomschrijving, zal dit niet in strijd zijn met het nationaal schuldbeginsel noch met het EVRM, ondanks dat artikel 6 , tweede lid stipuleert dat "Een ieder tegen wie een vervolging is ingesteld wordt voor onschuldig gehouden totdat zijn schuld in rechte is komen vast te staan." Schuld wordt hier niet opgevat in de zin van verwijtbaarheid, maar als daderschap. Als het

257 Jonkers, W.H.A., "Het strafrechtelijk schuldverwijt", pp. 233-234.

258 Jonkers, W.H.A., "Het strafrechtelijk schuldverwijt", pp. 238-239.

259 Jonkers, W.H.A., "Het strafrechtelijk schuldverwijt", p. 240.

260 In het fameuze Melk en water-arrest werd overwogen dat in het Nederlandse strafrecht het beginsel geen straf zonder schuld geldt. Voor strafbaarheid is in beginsel steeds schuld vereist. HR 14 februari 1916, NJ 1916,681.

261 Voor de betekenis van de begrippen bestanddeel en element wordt aangesloten bij Bemmelen, J.M. van en Veen, Th.W. van, bewerkt door Jong, D.H. de en Knigge, G., Het materiele strafrecht, pp. 51-52. 


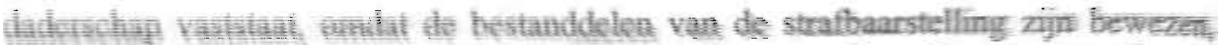

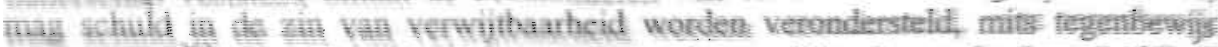

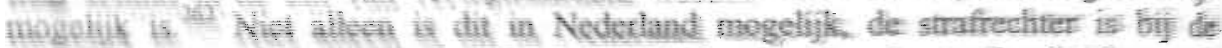

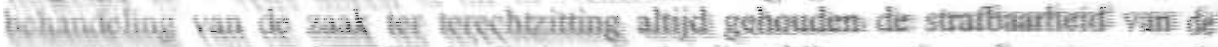

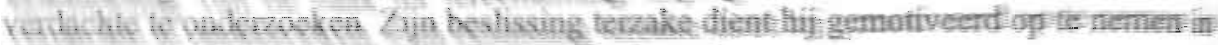

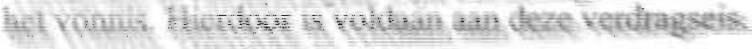

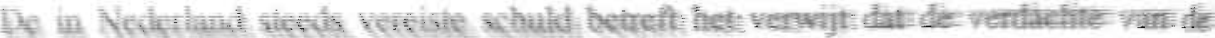

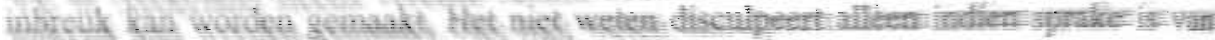

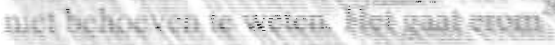

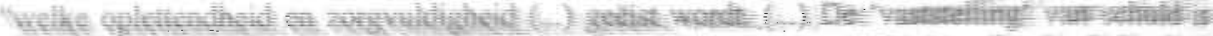

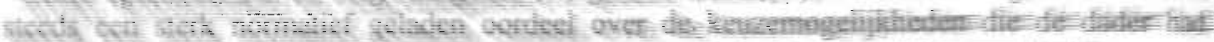

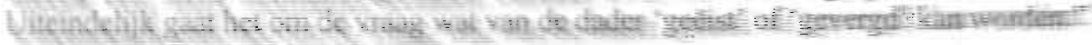

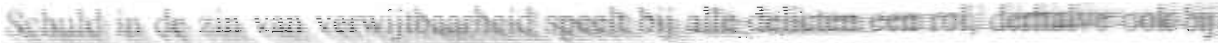

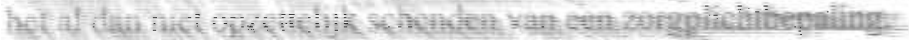

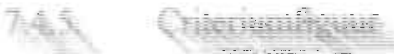

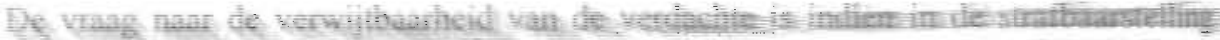

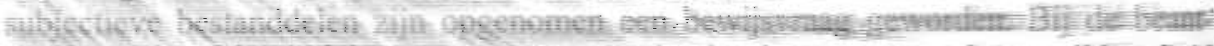

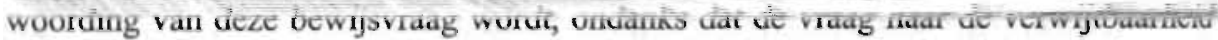
moet worden beoordeeld op basis van de individuele aard, situatie en (on)mogelijkheden van het betreffende rechtssubject, meestal uitgegaan van een sterk van de feitelijke situatie geabstraheerde criteriumfiguur. Deze figuur wordt in de plaats gesteld van de verdachte ten behoeve van de beoordeling of de verdachte al dan niet opzettelijk dan wel culpoos handelen of nalaten te handelen kan worden verweten. Groenhuijsen stelt dan ook $^{264}$ :

"Als een 'normale' burger in vergelijkbare omstandigheden met een bepaalde psychische gesteldheid handelt, dan wordt ook deze verdachte geacht dezelfde instelling te hebben gehad."

Hierdoor is niet bepalend wat de werkelijke psychische gesteldheid van de verdachte was ten tijde van zijn gedraging. De invulling van culpa en opzet wordt zo niet afhankelijk gemaakt van een niet-strafrechtelijke (psychologische) beschouwing. ${ }^{265} \mathrm{De}$

262 Zie EHRM 7 oktober 1988, NJ 1991, 351, met noot Alkema (Salabiaku); EHRM 25 september 1992, NJ 1995, 593, met noot Alkema (Pham Hoang).

263 Bemmelen, J.M. van en Veen, Th.W. van, bewerkt door Jong, D.H. de en Knigge, G., Het materiële strafrecht, p. 40.

264 Groenhuijsen, M.S., "Schuld en boete; Een beschouwing over strafrechtelijke verantwoordelijkheid", p. 46. Zie ook Hullu, J. de, Zijn er grenzen aan de strafrechtelijke aansprakelijkheid, pp. 47-48; Koopmans, I.M., "Strafrechtelijke aansprakelijkheid in het milieustrafrecht: afscheid van schuld?", pp. 547-548 en Bos, J.T., "Het schuldoordeel als machtswoord", pp. 5-42.

265 De wil van de verdachte is door de gebruikmaking van de criteriumfiguur niet 
criteriumfiguur objectiveert derhalve de opzet en de culpa. Hierdoor is het echter ook mogelijk dat bewezen wordt verklaard dat de verdachte opzettelijk dan wel culpoos de ten laste gelegde gedraging heeft verricht, terwijl de persoonlijke opzet of schuld wellicht ontbrak. ${ }^{266}$ Dit behoort tot de mogelijkheden omdat er geen enkele richtlijn is voor de beantwoording van de vraag hoever en hoe consequent die objectivering tot gelding mag komen. ${ }^{269}$ Dat is zeer onwenselijk, omdat we in Nederland immers een individu gericht schuldstrafrecht hebben. De vraag of er sprake is van opzet of culpa dient te worden beoordeeld voor de betreffende verdachte.

Indien de hierboven aangegeven onwenselijke situatie zich voordoet, moet het voor de verdachte mogelijk zijn dat de beoordeling (of er sprake is van een opzettelijke dan wel culpose gedraging) aan de hand van zijn gedraging plaatsvindt. De rechter beoordeelt of aan de voorwaarden van de bestanddelen opzet of culpa is voldaan bij de eerste vraag van artikel $350 \mathrm{~Sv}$; te weten de vraag of het feit is bewezen. Indien de rechter uitgaat van de criteriumfiguur, is het mogelijk dat hij tot het oordeel komt dat sprake is van opzet of culpa (van de criteriumfiguur). De verdachte kan nu als bewijsverweer aanvoeren dat van opzet of culpa in zijn individuele geval gezien bepaalde omstandigheden geen sprake is. Afhankelijk van de inhoud van de bewijsmiddelen kan dan sprake zijn van een Meer en Vaart-verweer. ${ }^{268}$ De rechter zal dan kunnen oordelen dat het ten laste gelegde feit niet kan worden bewezen verklaard. Indien de rechter tot een bewezenverklaring komt, zal hij de bewezenverklaring moeten motiveren op grond van artikel 359, tweede lid Sv. Indien sprake is van een Meer en Vaart-verweer zal hij de verwerping hiervan ook dienen te motiveren.

Het ligt niet voor de hand een verweer, inhoudende dat er geen sprake is van opzet of culpa bij de verdachte, indien wordt aangenomen dat dit er wel is voor de criteriumfiguur, te beschouwen als een beroep op een strafuitsluitingsgrond. Het bewezen verklaren van de aanwezigheid van opzet of culpa, waarna deze weer komt te ontvallen omdat de verdachte niet strafbaar is, is in strijd met de systematiek van het strafprocesrecht. ${ }^{269} \mathrm{De}$ individualisering zal in deze gevallen dan ook plaats moeten vinden bij de bewijsvraag.

De mogelijkheid van een succesvol avas-verweer zal bij de aanwezigheid van subjectieve bestanddelen in de delictsomschrijving klein zijn. Deze mogelijkheid moet echter niet geheel worden uitgesloten. Het zal afhangen van de vraag welk subjectief bestanddeel nu precies is opgenomen in de delicisomschrijving, op weike bestanddelen dit betrekking heeft, wat is ten laste gelegd en bewezen verklaard en of daarnaast nog

uitsluitend bepalend voor de aansprakelijkheid. Nieboer, W., "Causaliteit en aansprakelijkheid", p. 218.

266 Groenhuijsen, M.S., "Schuld en boete; Een beschouwing over strafrechtelijke. verantwoordelijkheid", p. 47.

267 Nieboer, W., "Causaliteit en aansprakelijkheid", p. 218.

268 Zie het bekende Meer en Vaart-arrest, HR 1 februari 1972, NJ 1974, 450, met noot van. Veen.

269 Zie ook Vellinga, W.H., Schuld in spiegelbeeld; Afwezigheid van alle schuld, pp. 147148; Heijder, A., "Rechtsdwaling-arrest; noot bij HR 18 november 1975", p. 72. 
ruimte overblijft voor het weerleggen van de verwijtbaarheid van de betreffende dader. Als de vraag naar de aanwezigheid van de verwijtbaarheid speelt op het niveau van de schulduitsluitingsgronden, is het voldoende dat de rechter de aanwezigheid ervan niet aannemelijk heeft bevonden. Indien een uitdrukkelijk voorgedragen verweer dat is gericht op de aanwezigheid van een schulduitsluitingsgrond door de rechter wordt verworpen, zal hij deze beslissing in zijn vonnis moeten opnemen en motiveren ${ }^{270}$ Overigens geldt dit niet bij de strafbaarstelling van de zorgplichtbepaling via de Wed als misdrijf. Opzet uit de Wed is dan namelijk een bestanddeel dat betrekking heeft op de andere van toepassing zijnde bestanddelen uit de delictsomschrijving.

Door het opnemen in de strafbaarstelling van subjectieve bestanddelen die de verwijtbaarheid van de dader stipuleren, wordt het schuldbeginsel verankerd. Dit geldt echter alleen voor het deel van de delictsomschrijving waar de subjectieve bestand. delen betrekking op hebben. Bij de culpose schending van de meeste zorgplichtbepalingen is een deel van de delictsomschrijving echter onttrokken aan subjectieve bestanddelen. Het OM zal de subjectieve bestanddelen voor dat deel van de delictsomschrijving waarop ze betrekking hebben moeten bewijzen, terwijl de rechter op basis van de inhoud van dit bewijs de overtuiging zal moeten krijgen dat dit verwijt moet worden gemaakt. Als de verwijtbaarheid niet zou zijn opgenomen als subjectief bestanddeel, zal de rechter de aanwezigheid van een schulduitsluitingsgrond niet onaannemelijk moeten hebben bevonden. Dit verweer zal meestal door de verdachte moeten worden voorgedragen en onderbouwd. Hierdoor kan een beperkte omkering van de bewijsfast plaatsvinden. Beperkt: het hoeft immers niet te worden bewezen, het niet-onaannemelijk achten is voldoende.

\subsubsection{Schuldkwadratuur}

De inhoud van het begrip opzet is zoals in hoofdstuk 3 paragraaf 7.4.2. bleek betrekkelijk duidelijk, maar er bestaat nog wel onduidelijkheid over de reikwijdte ervan. ${ }^{271}$ Schuld speelt, zoals gezegd, bij alle delicten een rol, dus ook bij het al dan niet opzettelijk schenden van een zorgplichtbepaling. Door de koppeling van strafbaarstellingen uit economische wetgeving aan de Wed is sprake van een misdrijf indien de normschending opzettelijk is begaan. Indien geen subjectieve bestanddelen zijn opgenomen in de delictsomschrijving, is er in het algemeen nauwelijks discussie over de vraag op welke bestanddelen het opzet ziet. Dit kan anders worden indien er wel subjectieve bestanddelen zijn opgenomen. Indien dit gebeurt bij een delictsomschrijving (zoals bij de zorgplichtbepalingen in het milieurecht ${ }^{272}$ ) in een bijzondere wet, terwijl de strafbaarstelling is te vinden in een andere wet (WED) kan indien deze wetten aan elkaar zijn gekoppeld volgens sommige schrijvers sprake zijn van een "schuldkwadratuur". Involge artikel 2, eerste lid Wed is er sprake van een misdrijf indien de normschending opzettelijk is begaan en is er in de overige gevallen sprake

270 Zie artikel 358, derde lid jo 259, tweede lid Sv. Zie over deze artikelen Kortenhorst, B.M., De motiveringsplicht in strafzaken.

271 Zo ook Keulen, B.F., Economisch strafrecht, p. 41

272 Zie hoofdstuk 9 paragrafen 3 en 4. 
van een overtreding. Het verschijnsel "schuldkwadratuur" houdt in dat de opzet-eis die voortkomt uit de Wed ook betrekking heeft op de subjectieve bestanddelen van de delictsomschrijving. ${ }^{273}$ De vraag is hoe het opzet-vereiste uit de Wed bij misdrijven. zich verhoudt ten opzichte van de subjectieve bestanddelen uit de strafbaarstellingen die zijn aangehaakt aan de Wed.

Het is de vraag of de opzet ook betrekking heeft op subjectieve bestanddelen uit de strafbaarstelling zoals "weet of redelijkerwijs had kunnen vermoeden" of "weet of redelijkerwijs had kunnen weten", en zo ja hoe deze zich tot elkaar verhouden. Door deze onduidelijkheden over de reikwijdte van. het opzet-vereiste kan de koppeling van strafbaarstellingen met subjectieve bestanddelen aan de Wed met de opzet-eis voor misdrijven worden aangemerkt als een legislatief wanprodukt.

Betoogd kan worden dat het opzet uit artikell 2, eerste lid Wed het overtreden voorschrift in zijn geheel beheerst. Aangesloten wordt dan bij de wijze waarop dit doorgaans in het commune strafrecht wordt gehanteerd. Bij de totstandkoming van het Wetboek van Strafrecht is met zorg bezien of het woord opzettelijk moest worden opgenomen in een delictsomschrijving,

"terwijl met gelijke zorg de plaats is gekozen, die het woord opzettelijk in elke zinsnede inneemt, in dier voege dat het, waar het gebezigd wordt, steeds de gehele omschrijving beheerst van het strafbare feit, zoals die daarna volgt". 278

Indien deze interpretatie wordt overgenomen bij delictsomschrijvingen die onder de Wed vallen, kan worden volgehouden dat opzet gericht moet zijn op alle bestanddelen van het delict. De tenlastelegging die dan wordt geformuleerd combineert de opzet-eis uit de Wed met de subjectieve bestanddelen van de strafbepaling. Bij strafbaarstellingen met culpose bestanddelen zoals zorgplichtbepalingen geeft een dergelijke interpretatie echter problemen, want "opzettelijk redelijkerwijs kunnen vermoeden vormt een tegenspraak in zichzelf". ${ }^{275}$

Het is de vraag of de rechter de wetgever hier moet "redden". De rechter kan namelijk constateren dat een dergelijke tenlastelegging innerlijk tegenstrijdig is. ${ }^{276}$ Het gevolg daarvan is dat dit strafbare feit niet met succes als misdrijf kan worden vervolgd. Hierdoor zou alleen het strafbare feit in de overtredingsvorm overblijven, ook indien de gedraging zelf opzettelijk geschiedt "omdat opzet op de schuldvorm er nooit kan zijn". 277

Zie Doorenbos, D.R., "Schuldkwadratuur. lets over de betekenis van art. 2, lid I WED", p. 812; Doorenbos, D.R., Financieel strafrecht, pp. 14-18.

274. Smidt, H.J., Geschiedenis van het Wetboek van Strafrecht, Deel I, p. 78.

275 Buiting, Th.J.B. en Huygen, A.E.H., "Milieustrafrecht: een ondoordachte chaos", p. 81.

276 Jörg, N., "Economische delicten", 64.2.1.a.

277 Buiting, Th.J.B. en Huygen, A.E.H., "Milieustrafrecht: een ondoordachte chaos", p. 82. 
Deze interpretatie lijkt dan ook te ver te gaan. Niet alleen omdat zij te drastisch is en tot onbevredigende resultaten leidt ${ }^{278}$, maar ook omdat deze uitleg strijdig lijkt te zijn met de opbouw en structuur van strafbaarstellingen met culpose bestanddelen zoals zorgplichtbepalingen en met het systeem van de Wed. Maar de vraag blijft onbeantwoord of het mogelijk is de wetgever te "redden", zonder de strafrechtsdogmatiek geweld aan te doen.

Ter oplossing van dit probleem zal eerst moeten worden nagegaan of voor de Wed dezelfde voorwaarden met betrekking tot de interpretatie van de reikwijdte van het subjectief vereiste gelden als voor commune delicten. Dit lijkt niet het geval te zijn. Voorts heeft het opnemen van de subjectieve bestanddelen in de delictsomschrijving zoals bij veel zorgplichtbepalingen het geval is, als voordeel dat de rol van het schuldbeginsel wordt versterkt. Juist bij deze bepalingen die worden gekenmerkt door het gebruik van vage bestanddelen ${ }^{279}$, is dit van belang. De slotsom dat hierdoor het feit dat onder het betekenisbereik van de bepaling valt niet meer strafbaar kan zijn als misdrijf, gaat dan ook te ver.

Ook de mogelijke consequentie dat de wetgever de subjectieve bestanddelen uit de delictsomschrijving haalt, waardoor dit probleem zich niet meer voordoet, is onwenselijk. Uit het voorafgaande bleek juist dat het opnemen van deze bestanddelen het schuldbeginsel verankert. Bezien moet worden welke interpretatie moet worden gegeven aan de reikwijdte van de opzet-eis uit de Wed (met zijn autonome systematiek en sterk instrumenteel karakter) bij strafbaarstellingen met subjectieve bestanddelen (met hun specifieke opbouw en samenstelling).

Gezien bovenstaande overwegingen moet worden onderzocht of de opzet-eis uit de Wed ook van toepassing is op de subjectieve bestanddelen. Twee mogelijke interpretaties $^{280}$ omtrent de reikwijdte van deze opzet-eis worden hier besproken. ${ }^{281}$ Gekozen is voor de uitwerking van deze interpretaties, en niet voor andere mogelijkheden, omdat deze twee het best lijken aan te sluiten bij het karakter van de Wed en bij de specifieke opbouw en de samenstelling van strafbaarstellingen met subjectieve

278 Zo ook Doorenbos, D.R., "Schuldkwadratuur. Iets over de betekenis van art. 2, lid 1 WED", p. 812; Doorenbos, D.R., Financieel strafrecht, pp. 14-18.

279 Zie over de betekenis van "vaag" hoof́dstuk 2 paragraaf 5.4.

280 Een andere oplossing van dit probleem wordt gesuggereerd door Doorenbos die het probleem rond de opzet-eis benadert als een kwalificatiekwestic: zie Doorenbos, D.R., "Schuldkwadratuur. lets over de betekenis van art. 2, lid l WED", pp. 815-819; Doorenbos, D.R., Financieel strafrecht, pp. 14-18; zie ook de reactie hierop van Pelser, C.M., Reactie op D.R. Doorenbos 'Schuldkwadratuur: iets over de betekenis van art. 2, lid I WED", pp. 387-389. Een andere oplossing is dat opzet alleen wordt vereist voor de centrale delictshandeling, zie Mulder, A. en Doorenbos D.R., Schets van het economisch strafrecht, p. 173. Anders is de interpretatie dat het bereik van opzet wordt beperkt tot die bestanddelen die er taalkundig door worden beheerst, zie Jörg, N., "Economische delicten", 64.2.1.a.

281 Ook Keulen geeft deze twee mogelijkheden. Keulen, B.F., Economisch strafrecht, pp. 45-46. 
bestanddelen. Bij de keuze van de meest bevredigende interpretatie, zal rekening moeten worden gehouden met de wetsgeschiedenis. Het gaat immers om de vraag op welke manier de wetgever gedragingen strafbaar heeft willen stellen. Dit is overigens een heikel punt nu de wetgever bij de invoering van de Wed een andere interpretatie van de opzet-eis voor ogen had dan de manier waarop "opzet" sinds 1952 wordt geïnterpreteerd. ${ }^{282}$

De eerste mogelijkheid is dat wordt aangesloten bij de opbouw en samenstelling van strafbaarstellingen. Vaak zijn in de bepaling subjectieve bestanddelen opgenomen die als alternatieven van elkaar dienen te worden gelezen, zoals "weet of redelijkerwijs had kunnen vermoeden". De strafbaarstelling waar deze bestanddelen deell van uitmaken, stelt hierdooi twee strafbare gedragingen onafhankelijk van elkaar strafbaar. Het betreft een strafbaarstelling van de culpose gedraging en een van de opzettelijke gedraging. Indien wordt vastgehouden aan de interpretatie uit het commune strafrecht, die inhoudt dat het de opzet-eis het overtreden voorschrift in zijn geheel beheerst, behoeft dit niet tot problemen te leiden. De betreffende strafbepaling stelt immers twee gedragingen onafhankelijk van elkaar strafbaar. Bij de opzettelijke variant van de strafbaarstelling zullen zich geen problemen voordoen. De opzet-eis uit de Wed is in het algemeen op meer bestanddelen van toepassing dan de opzet uit de strafbepaling. ${ }^{283}$ Ook de opzet-eis van de Wed ten aanzien van het weten levert geen problemen op, aangezien deze twee vereisten elkaar gedeeltelijk overlappen. Indien deze overlap niet totaal is omdat in de strafbaarstelling een andere opzet-variant is opgenomen, zijn de bewijsrechtelijk zwaarste eisen, van toepassing. Indien de opzetvariant uit de strafbaarstelling zwaardere eisen stelt dan de Wed opzet-eis, blijven deze gelden voor de bestanddelen die reeds door deze opzet-variant uit de delictsomschrijving zelf worden beheerst. Zo valt het veel gebruikte bestanddeel weten samen of stelt hogere eisen aan de bewijslast van het OM dan opzet. Het weten dient dan te prevaleren, waardoor aan het uitgangspunt in dubio pro reo (dat wil zeggen dat bij twijfel de voor de verdachte meest gunstige interpretatie dient te worden gevolgd) tegemoet wordit gekomen. Bij het culpose bestanddeel leidt deze interpretatie van de reikwijdte van de opzet-eis uit de Wed wel tot onoverkomelijke problemen. Een opzettelijke culpose gedraging is natuurlijk niet mogelijk.

In de tweede plaats is de interpretatie mogelijk dat de opzet-eis niet van toepassing wordt geacht op de subjectieve bestanddelen en de bestanddelen waar deze subjectieve bestanddelen betrekking op hebben. Dit heeft tot gevolg dat voor de opzettelijke variant opzet wordt vereist voor de gehele delictsomschrijving. De opzet-variant van de strafbaarstelling (bijvoorbeeld weten) zorgt ervoor dat die eis wordt gesteld aan het deel van de delictsomschrijving waarop dit bestanddeel ziet, terwijl de opzet-eis uit de Wed van toepassing is op de overige bestanddelen. Dat de Wed opzet-eis ten aanzien

282. Zie hoofdstuk 3 paragraaf 7.4.2.

283 Zo wordt bijvoorbeeld bij artikel 13 Wbb nu ook opzet vereist ten aanzien van de op of in de bodem verrichte handelingen als bedoeld in de artikelen 6 tot en met 11. Het opzetvereiste dat de zorgplichtbepaling stelt ten aanzien van het weten dat door die handelingen de bodem kan worden verontreinigd of aangetast blijft gehandhaafd. 
van het opzet bestanddeel uit de strafbaarstelling hier niet van toepassing is maakt inhoudelijk niets uit indien deze twee vereisten elkaar overlappen, danwel dat de opzet-variant uit de strafbaarstelling verdergaande bewijsrechtelijke eisen stelt aan het OM. $\mathrm{Bij}$ deze interpretatie wordt in die gevallen. ook tegemoet gekomen aan het uitgangspunt in dubio pro reo. De zwaarste opzet-eis (de opzet-variant uit de strafbaarstelling) blijft gelden voor de bestanddelen die reeds door de opzet-variant uit de delictsomschrijving zelf worden beheerst. Zo valt bijvoorbeeld het veel gebruikte bestanddeel weten samen of stelt hogere eisen aan de bewijslast van het OM dan de opzet-eis uit artikel 2 Wed. Tussen de eerste en de tweede interpretatie is zodoende bij de opzet-variant geen inhoudelijk verschil aanwezig. Bij de culpose-variant van de strafbaarstelling ligt dit anders. De opzet-eis uit de Wed is nu niet van toepassing op het subjectieve bestanddeel en de bestanddelen waarop dit bestanddeel betrekking heeft. Hierdoor doen zich op het gebied van de mogelijk toepasbare interpretatie geen onoverkomelijke problemen voor bij de culpose-variant. Het gevolg van deze interpretatie is wel dat de bewijsrechtelijke vereisten voor het $\mathrm{OM}$ veel geringer zullen zijn. Deze vereisten zullen ten aanzien van de bestanddelen die worden beheerst door het culpose subjectieve bestanddeel uit de delictsomschrijving minder zwaar zijn dan bij de opzet-eis uit de Wed het geval is. Gezien de onduidelijkheden over de reikwijdte van deze opzet-eis, wordt bij deze interpretatie niet voldaan aan het uitgangspunt in dubio pro reo.

\subsubsection{Consequenties van opzet of culpa}

In het algemeen geldt de opzet-eis als voorwaarde voor strafbaarheid voor misdrijven en zijn overtredingen culpose delicten. Dit geldt gezien artikel 2 Wed zeker voor economische delicten. Indien opzet of culpa bestanddeel zijn van de delictsomschrijving geldt dat het verwijt dat de verdachte wordt gemaakt in beide gevallen moet worden ten laste gelegd en bewezen. Door het opnemen van subjectieve bestanddelen wordt dan ook het schuldbeginsel verankerd.

Het onderscheid tussen het gebruikte subjectief element leidt doorgaans tot een andere tenlastelegging en kwalificatie van het delict (overtreding respectievelijk misdrijf) en tot gedifferentieerde mogelijkheden in de sanctionering. ${ }^{284}$ Doorgaans wordt er opzettelijk dan wel culpoos handelen (met een lagere strafbedreiging) vereist, gekoppeld aan enig voorzienbaarheidsvereiste ten aanzien van het gevaar dat uit het handelen kan voortvloeien. De strafmaat heeft tevens consequenties voor de mogelijkheid bepaalde dwangmiddelen toe te passen, aangezien hiervoor de hoogte van de maximum strafbedreiging vaak een maatstaf is.

284 Zie daarover Hullu, J. de, Koopmans, I.M. en Roos, Th.A. de, Het wettelijk strafmaximum, pp. 120-121. Zie over specifieke sancties op basis van de WED Jörg, N., "Economische delicten" "64.3.; Keulen, B.F., Economisch strafrecht, pp. 167-230; Roos, Th.A. de en Visser M.J.C., "Milieustrafrecht", 70.5.6.; Huisman, W. en Bunt, H.G. van de, "Sancties, organisatiecriminaliteit en milieudelicten", p. 686. 
De vraag of sprake is van een tenlastelegging van de opzettelijke of culpose variant kan behalve voor de bewijsvraag en de maximum strafbedreiging ook van belang zijn voor de ontvankelijkheid van partijen in hoger beroep en cassatie. ${ }^{285}$ Bij cornmune overtredingen zijn meestal de kantongerechten competent, waarna hoger beroep kan worden ingesteld bij de rechtbank, terwijl bij commune misdrijven (meestal is hier opzet een bestanddeel) in het algemeen de rechtbanken in eerste aanleg competent zijn, waarna vaak bij het hof hoger beroep kan worden ingesteld. ${ }^{286}$ In het geval van een einduitspraak ter zake van een overtreding is in een aantal gevallen het recht op hoger beroep bij de rechtbank niet aanwezig. ${ }^{289}$ Tegen een vonnis van de reclitbank ter zake van misdrijven uit de Wed (waarbij opzet blijkens artikel 2 Wed bestanddeel is) kan meestal hoger beroep worden ingesteld bij het hof. ${ }^{288}$ Voor de ontvankelijkheid in cassatie is het voor partijen naast de inhoud van de uitspraak van de laatste feitelijke rechter, ook van belang te weten of hoger beroep tegen de uitspraak van de rechtbank open staat of heeft gestaan. De eis tot cassatie kan, involge artikel 96 Wet RO, door een partij niet worden ingesteld indien haar een ander gewoon rechtsmiddel openstaat of heeft opengestaan. Voorts kan cassatie in belang der wet niet worden ingesteld indien voor partijen een gewoon rechtsmiddel openstaat. ${ }^{289}$

\section{5 .}

Het subsidiariteitsbeginsel

Ook kan een strafbaarstelling steeds op haar merites worden getoetst door te verifiëren of aan het subsidiariteitsbeginsel is voldaan. ${ }^{290}$ Het subsidiariteitsbeginsel verwijst naar de vraag of een strafbaarstelling noodzakelijk is om de vooropgezette doelstellingen te bereiken. Hier dient onderscheid te worden gemaakt tussen de noodzaak tot regelgeving, de inhoud van de regelgeving en de toepassing daarvan.

De beantwoording van de vraag naar de noodzaak van een strafbaarstelling zal ten eerste afhangen van het standpunt dat wordt ingenomen met betrekking tot de rol die het strafrecht in het algemeen dient te vervullen. Deze rol kan worden beschreven door de relatie te leggen met de ultimum remedium gedachte. ${ }^{291}$ Begrijpelijkerwijs kan de

285 Zie hierover AG Fokkens in zijn conclusie voor HR 23 april 1996, NJI 1996, 512 (Waterschap Westfriesland). De door hem besproken problematiek doet zich ook voor bij vervolging van delicten van de opiumwet, zie bijvoorbeeld HR 11 juni 1996, $N J$ 1996, 700 (Cassatie overtreding Opiumwet).

286 Zie vooral de artikelen 44, 56, 58 en 68 Wet RO.

287 Zie voor de verdachte artikel 51 , cerste lid sub $1^{\circ}, 2^{\circ}$ en $3^{\circ}$ Wed en voor het OM artikel 51 , tweede lid sub $1^{\circ}$ en $2^{\circ}$ Wed.

288 Zie over hoger beroep en cassatie bij economische delicten Jörg, N., "Economische delicten", 64.8. en 64.9; Keulen, B.F., Economisch strafrecht, pp. 421-439; Roos, Th.A. de en Visser M.J.C., "Milieustrafrecht", 70.5.7.

289 Zie over absolute competentie, hoger beroep en cassatie Corstens, G.J.M., Het Nederlands strafprocesrecht, pp. 701-761.

290 Zie voor wat het subsidiariteitsvereiste betreft onder meer Roef, D., "Zoektocht naar een meer-zinnige betekenis van het strafrecht voor het leefmilieu", pp. 482-485.

291 Deze ultimum remedium gedachte is in Nederland voor het milieurecht aangevallen door Van de Bunt: Bunt, H.G. van de, "Bestuurlijke. verwachtingen en ervaringen omtrent de 
vraag of een bepaalde strafbaarstelling noodzakelijk is om de vooropgezette doelstellingen te bereiken moeilijk in abstracto worden beantwoord. Veel hangt af van de gedragingen die onder toepassing van de betreffende delictsomschrijving vallen. Daarnaast geldt dat voor de beoordeling of een bepaalde strafbaarstelling noodzakelijk is het hele systeem dat het betreffende beschermde rechtsgoed beschermt moet worden bekeken. Slechts in het licht van het totale systeem valt te beoordelen of de gekozen wijze van strafbaarstelling noodzakelijk is. Daarbij dient, tevens de vraag te worden gesteld. of niet had kunnen worden volstaan met andere middelen, bijvoorbeeld uit het civiel- of het bestuursrecht.

Een argument voor gebruik van het strafrecht in plaats van civiel- of bestuursrecht kan worden gevonden in de economische theorie van het strafrecht die voorhoudt dat bij een lage pakkans een zeer hoge sanctie dient te dreigen om een behoorlijke afschrikking te bewerkstelligen. ${ }^{292}$ Een zeer hoge monetaire sanctie kan ineffectief zijn, gelet op het feit dat deze het individueel vermogen van de verdachte kan overstijgen. Dit is in deze theorie dan een argument voor toepassing van nonmonetaire sancties ${ }^{293}$ die, gelet. op hun ingrijpende karakter, in beginsel alleen langs strafrechtelijke weg dient te kunnen worden opgelegd. ${ }^{294}$ Deze benadering kan er toe leiden dat een strafbaarstelling ook bij veeleer administratief georiënteerde delicten

strafrechtelijke handhaving van milieurecht", pp. 1-76. Zie ook Huisman, W. en Bunt, H.G. van de, "Sancties, organisatiecriminaliteit en milieudelicten", pp. 688-689, terwijl Drupsteen en Kleijs-Wijnnobel stellen dat praktische overwegingen zoals de beschikbare capaciteit bij het OM wel tot een prioriteitsstelling kunnen leiden in concrete gevallen: Drupsteen, Th.G. en Kleijs-Wijnnobel, C.J., "Handhaving van milieurecht door middel van civiel-, administratief- en strafrecht", pp. 31-47. In België wordt de ultimum remedium gedachte onder meer door Deketelaere gehuldigd: Deketelaere, K., "Administratiefrechtelijke handhaving van de milieuhygiënewetgeving in het Vlaamse gewest", pp. 207-26, en bekritiseerd door Morrens, P., "Het leefmilieu als handhavingsmiddel", p. 343.

292 Becker, G., "Crime and Punishment: an Economic Approach", pp. 169-217 en Faure, M. en Heine, G., "The Insurance of Fines: the Case of Oil Pollution", pp. 39-58. Zie ook Huisman, W. en Bunt, H.G. van de, "Sancties, organisatiecriminaliteit en milieudelicten", pp. 695-697, dic erop wijzen dat sommige milieudelicten uit "berekening" worden gepleegd, andere daarentegen uit "onkunde of onwil".

293 Shavell, S., "Criminal Law and the Optimal Use of Non-Monetary Sanctions as a Deterrent", pp. 1232-1262.

294 Een uitzondering hierop is met de invoering van de bestuurlijke ophouding mogelijk gemaakt. Zie de Wet van 25 april 2000 tot wijziging van de Gemeentewet ter verbetering van de mogelijkheden tot bestrijding van grootschalige verstoringen van de openbare orde van de artikelen Gemeentewet, Stb. 2000, 174. Zie hierover Brouwer, J.G. en Schilder, A.E., "Het wetsvoorstel bestuurlijke ophouding; Een verkenning van de rechtsstatelijke grenzen", pp. 1640-1648. 
noodzakelijk is. ${ }^{295}$ Dit kan niet in het algemeen worden aangenomen, omdat het ontdekkingsrisico bij dit soort normschendingen vrij hoog kan zijn. ${ }^{266}$

Doorgaans wordt overigens ook in de strafbaarstellingstheorie juist de noodzaak om non-monetaire sancties te kunnen toepassen als argument voor een strafbaarstelling naar voren gebracht. ${ }^{297}$ In dit verband kan, ten aanzien van het milieustrafrecht, bijvoorbeeld ook worden gewezen op Resolutie 11 van de AIDP-aanbevelingen, waarin wordt gesteld dat ${ }^{298}$ :

"criminal sanctions should be utilized only when civil and administrative sanctions and remedies are inappropriate or ineffective to deal with particular offences against the environment."

Het is in dit verband ook interessant erop te wijzen dat in Resolutie 7 van het XVe International Congress of Penal Law wordt opgemerkt dat ${ }^{299}$ :

"for non-observance of administrative and regulatory standards sanctions should not include deprivations of liberty."

Hiermee lijkt de AIDP te suggereren dat de schending van bestuursrechtelijke regelgeving of beschikkingen in beginsel niet mogen worden bedreigd met vrijheidsbenemende sancties. Gesteld kan worden dat dit dan impliciet de noodzaak van strafrechtelijke sancties uitsluit. ${ }^{300}$

Indien sterker de nadruk wordt gelegd op de toepassing van regelgeving, kan worden voorgehouden dat een strafbaarstelling niet moet worden toegepast indien de regel

295 Dit is bijvoorbeeld het geval voor de strafbepalingen in het Vlaamse Bodemsaneringsdecreet van 22 februari 1995, aldus Faure, M., "De handhaving van het Bodemsaneringsdecreet via toezicht, dwangmaatregelen en strafsancties", pp. 218-222.

296 Zie hierover Faure, M. en Visser, M., De strufrechtelijke bescherming van het leefmilieu in België, Duitsland en Nederland, pp. 140-148; Faure, M., "Strafrechtelijke aansprakeliikheid, toezicht en sancties in het Decreet Bedrijfsinterne Milieuzorg", pp. 217-269.

297 Zie bijvoorbeeld Hulsman, L.H.C., "Kriteria voor strafbaarstelling", pp. 80-92; Roos, Th.A. de, Strafbaarstelling van economische delicten, pp. 53-114; en voor de strafbaarstelling ten aanzien van milieuverstoring Faure, M., "Bedenkingen over de rol van het strafrecht bij de bestrijding van milieuverontreiniging", pp. 229-263 en Faure, M., "Waarom milieustraffecht?", pp. 446-479.

298 Dit congres vond plaats in Rio de Janeiro van 4 tot 10 september 1994. Op basis van eerder geredigeerde landenrapporten (gepubliceerd in de International Review of Pena! Law, 1994, pp. 633-1221), werden na discussie verschillende (niet bindende) aaribevelingen voor het gebruik van het strafrecht ter bestrijding van milieuverstoring aangenomen. Deze aanbevelingen zijn gepubliceerd in de International Review of Penal Law. 1995, pp. 48-53.

299 De aanbevelingen zijn opgenomen in de International Review of Penal Law, 1995, pp. 48-53.

300 Zie Faure, M. en Visser, M., De strafrechtelijke bescherming van he! leefmilieu in België, Duitsland en Nederland, p. 143. 
waarvan de handhaving moet worden gegarandeerd met andere middelen kan worden gehandhaafd. Blomberg en Michiels onderscheiden drie verschillende opvattingen ten aanzien van het ultimum remedium beginsel. De eerste houdt in dat het strafrecht alleen in uitzonderingsgevallen, dus bij zeer ernstige delicten, mag worden toegepast, omdat het een uitzonderlijk zwaar instrument is. De tweede opvatting is dat het strafrecht het laatste redmiddel is dat alleen mag worden toegepast indien de overige juridische handhavingsmiddelen ontoereikend zijn. De derde houdt in dat de primaire verantwoordelijkheid voor de handhaving bij het bestuur ligt, waarbij het strafrecht alleen dient ter ondersteuning van het bestuur(sbeleid). ${ }^{30 \mathrm{i}}$ Handhaving van bijzondere regelgeving is veelal ook mogelijk door andere middelen. Dit kunnen zowel juridische middelen zijn, zoals mogelijkheden uit het civiel- of bestuursrecht, als buitenjuridische middelen, zoals voorlichting.

In het algemeen wordt aangenomen dat niet strafrechtelijke middelen de voorkeur verdienen. Dit is gebaseerd op de vooronderstelling dat inschakeling van het strafrecht als handhavingsmechanisme doorgaans de meest vergaande vorm van overheidsinterventie op het terrein van de normhandhaving is. De minder ingrijpende, voor justitiabelen minder bezwarende methoden van handhaving verdienen de voorkeur. ${ }^{302}$

Over de keuze tussen civiel-, bestuurs- en strafrechtelijke handhaving valt natuurlijk nog veel meer te zeggen. ${ }^{303}$ Er zijn op zichzelf wel argumenten aan te voeren voor een strafrechtelijke handhaving van bijzondere wetgeving, los van het zojuist

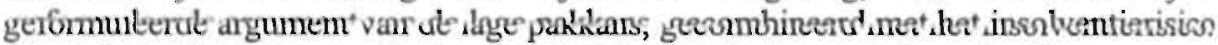
Als belangrijk nadeel van bestuursrechtelijke handhaving wordt veelvuldig gewezen op de vaak te sterke bindingen van de overheid met de gereguleerde industrie, waardoor een krachtig handhavings- en sanctiebeleid wordt bemoeilijkt. ${ }^{304}$ Bestuursrechtelijke handhaving is immers regelmatig op het coöperatiemodel gebaseerd. ${ }^{305}$ Gesteld wordt dat de overheid, indien de coöperatie faalt, dan over onvoldoende onafhankelijkheid beschikt om nog een zware sanctie te kunnen opleggen. ${ }^{306}$ Volgens bijvoorbeeld Nentjes en Hommes (in 1990) is de bijdrage van het bestuurlijk handhavingsinstrumentarium aan de preventie van milieuovertredingen voor een grote

301 Blomberg, A.B. en Michiels, F.C.M.A., Handhaven met effect, pp. 107-109. Zij bespreken op pagina pp. 109-111 tevens de visie van de regering en het OM met betrekking tot deze opvattingen. Zie ook Hendriks, L.E.M. en Wöretshofer, J., Milieustrafrecht, pp. 5-10.

302 Roos, Th.A. de, Strafbaarstelling van economische delicten, pp. 60-61.

303 Dat zou het kader van dit boek te buiten gaan. Zie daarover onder andere Blomberg, A.B. en Michiels, F.C.M.A., Handhaven met effect.

304 Zie bijvoorbeeld Meinberg, V., "Empirische Erkentnisse zum Vollzug des Umweltstrafrechts", pp. 112-157; Boes, M. en Deketelsere, K., "Administratieve sancties", p. 177 en Morrens, P., "Het leefmilieu als handhavingsmiddel", pp. 344-345.

305 Aalders spreekt in dit verband van het met zachte hand in de richting van het gewenste gedrag leiden van de wetsovertreder: Aalders, M., "De politiefunctie van de bijzondere opsporingsambtenaar", pp. 287-298.

306 Zie Diez, J. en Gneiting, J., "Koordinationsprobleme zwischen Verwaltungs- und Strafrechtsimplemention im Umweltbereich", pp. 190-211. 
categorie bedrijven nihil. Zij stellen zelfs dat de bestaande praktijk milieuovertredingen aanmoedigt omdat ondernemingen die na een bestuurlijk optreden alsnog tijdig gehoorzamen geen nadelige gevolgen ondervinden. Door de kosten van vereiste maatregelen uit te stellen, spaart de ondernemer rente uit, zonder additioneel risico. ${ }^{307}$ Daar lijkt de onafhankelijkheid van het $\mathrm{OM}$ en de strafrechter voordelen te bieden. ${ }^{308}$ Nochtans behoeft dit niet tot een eenzijdig pleidooi voor de strafrechtelijke aanpak te leiden. ${ }^{309}$ Immers, de splitsing van bestuurlijke taken kan de onafhankelijkheid van het bestuurlijk controleapparaat versterken. Het probleem van de afhankelijkheid van het bestuur kan worden overwonnen indien een controle op het bestuur kan worden ingebouwd. Indien dat laatste mogelijk is, biedt handhaving, en een eventuele sanctieoplegging, door het bestuur het voordeel dat deze doorgaans over veel betere informatie beschikt dan de strafrechtelijke handhavers; bijvoorbeeld over de optimaal op te leggen maatregel. Ook lijken besturursrechtelijke sancties, zeker de monetaire sanctie, het voordeel te bieden tegenover de strafrechtelijke geldboete, dat de oplegging sneller en procedureel gemakkelijker kan plaatsvinden. ${ }^{.10}$ Daar staat evenwel tegenover dat hetzelfde door een transactie of sepot onder voorwaarden door of vanwege het $\mathrm{OM}$ kan worden bereikt. ${ }^{311}$ Uiteindelijk rijst dan de vraag welk (beleidsmatig) doel men met de sanctie wenst te realiseren. De bestuursrechtelijke procedure en eventuele sanctie hebben ongetwijfeld een minder stigmatiserend effect dan een strafrechtelijke procedure die vaak langer zal duren. Hetzelfde geldt voor de publiciteit die naar aanleiding van een veroordeling kan volgen, ook indien slechts een geldboete wordt opgelegd.

Natuurlijk spreekt het voor zich dat indien de bestuursrechtelijke handhavingsoptie wordt gekozen en sprake is van een "criminal charge", aan alle in artikel 6 EVRM en artikel 14 IVBPR gestelde eisen dient te worden voldaan. ${ }^{312}$ Bestuursrechtelijke sancties kunnen vaak immers net zo punitief (of punitiever) zijn dan sommige strafsancties. Het EHRM heeft dan ook regelmatig geoordeeld dat niet via een "Etikettenschwindel" van sancties fundamentele rechtsbescherming aan justitiabelen

307 Aldus Nentjes, A. en Hommes, J., "Handhaving van het milieurecht", pp. 1-7. Zie ook Faure, M. en Roos, Th.A. de (red.), De berekening van het wederrechtelijk verkregen voordeel uit milieudelicten, vooral pp. 235-248 en 258-260.

308 Aldus ook Bunt, H.G. van de, "Bestuurlijke verwachtingen en ervaringen omtrent de strafrechtelijke handhaving van milieurecht", p. 27.

309 Het hangt er, in de: woorden van Huisman en Van de Bunt, vanaf of men een punitieve dan wel een coöperatieve handhavingsstrategie verkiest; zie Huisman, W. en Bunt, H.G. van de, "Sancties, organisatiecriminaliteit en milieudelicten", pp. 689-690.

310 Zie hierover Michiels, F.C.M.A., De boete in opmars en Jurgens, G.T.J.M. en Michiels, F.C.M.A., Bestuurlijke boeten in het milieurecht; Corstens, G.J.M., Een stille revolutie in het strafrecht, Commissie Toetsing van Wetgevingsprojecten, "Handhaving door bestuurlijke boeten".

3!. Zie over de transactie in het milieustrafrecht: Jurgens, G.J.T.M. en Michiels, F.C.M.A., Bestuurlijke boeten in het milieurecht; Hendriks, L.E.M., "De strafrechtelijke boete en de transactie in het milieurecht", pp. 133-134; Schaffmeister, D., "Handhaving van bestuursrecht door boete of straf?", pp. 59-80.

312 Zie ook hoofdstuk 5 paragraaf 8. 
mag worden ontnomen. ${ }^{313}$ Terecht waarschuwen velen ervoor dat een verschuiving van strafrecht naar bestuursrecht onder het mom van een decriminalisering er natuurlijk niet toe mag leiden dat het bestuurs(straf)recht alleen maar punitiever wordt, zodat de justitiabele slechter af is. ${ }^{314}$ In ieder geval dient ervoor te worden gewaakt dat in die gevallen waar voor een sterker gebruik van bestuursrechtelijke sancties wordt gekozen, de aan het strafrecht inherente rechtsbescherming niet verloren gaat.

Bij de beantwoording van de vraag of een strafbaarstelling noodzakelijk is om de vooropgezette doelstellingen te bereiken dient, hoewel zij sterk samenhangen, onderscheid te worden gemaakt tussen de noodzaak tot regelgeving, de inhoud van de regelgeving en de toepassing daarvan. Indien hetzelfde doel met minder vergaande regelgeving of andersoortige maatregelen kan worden bereikt, ontbreekt de noodzaak tot het creëren van een strafbaarstelling. Een strafbaarstelling creëert immers de meest vergaande mogelijkheid tot het maken van een inbreuk op de persoonlijke levenssfeer van justitiabelen, al was het maar vanwege de mogelijkheid bij schending een vrijheidsstraf op te leggen. Indien hetzelfde doel niet (altijd en effectief) met andere middelen kan worden bereikt en dit wel wenselijk is, kan worden gekozen voor strafbaarstelling. Hier heeft de wetgever de keuze tussen verder en minder ver gaande methoden van strafbaarstelling, bijvoorbeeld door de ongewenste gedraging strafbaar te stellen als overtreding of misdrijf, of de soort en hoogte van de maximum strafbedreiging te variëren. Opnieuw moet worden gekozen voor de (nu inhoudelijk) minder ver gaande vorm van regelgeving waarmee het gestelde doel (op effectieve wijze) kan worden bereikt. De strafbaarstelling dient derhalve siet ingrijpender te worden geformuleerd dan noodzakelijk. Indien de strafbaarstelling tot stand is gekomen, dient zij terughoudend te worden toegepast. De toepassing van de strafbaarstelling dient zich te beperken tot die gevallen waarin met minder ingrijpende (handhaving)methoden niet (op effectieve wijze) het gewenste doel kan worden bereikt. Alleen indien voldaan is aan deze voorwaarden kan ten aanzien van een strafbaarstelling worden gezegd dat zij in dat geval noodzakelijk is om het gestelde doel te bereiken, en is derhalve voldoende tegemoet gekomen aan het subsidiariteitsbeginsel.

\subsection{Het proportionaliteitsbeginsel}

In het kader van de proportionaliteit kan, als vaststaat dat strafbaarstelling noodzakelijk is, worden nagegaan of de strafbare gedraging in gebalanceerde verhouding staat met de sanctie die is gesteld op de overtreden delictsomschrijving. Het legaliteitsbeginsel vereist, naast het uitvoerig besproken lex certa-beginsel, dat het type sanctie evenals de hoogte ervan dat de justitiabele bij normschending bedreigt door de wetgever wordt vastgesteld, zodat zij worden beschermd tegen willekeurig overheidsoptreden. De wetgever heeft in het commuun en deels in het bijzonder

313 Zie daarover onder meer Michiels, F.C.M.A., De boete in opmars, pp. 20-29 en 37-38 en Bijloos, A.W.M., "Administratieve boeten en art. 6 EVRM in Nederland", pp. 12-18.

314 Zie Corstens, G.J.M., Een stille revolutie in het strafrecht; Nauw, A. de, Les métamorphoses administratives du droit pénal de l'entreprise, pp. 45-72. 
strafrecht per delictsomschrijving normschending van een specifiek maximum voorzien. Bij de economische delicten is dit gebeurd per categorie misdrijven of overtredingen, hetwelk aanleiding kan zijn voor discrepanties aangezien via de gelede normstelling op basis van abstracte gevaarzettingsdelicten een veelheid en verscheidenheid van gedragingen onder een bepaalde categorie kunnen komen te vallen. Voor alle strafbare feiten geldende natuurlijk. wel de algemene minima uit boek I van het Wetboek van Strafrecht.

Uitgangspunt bij het vaststellen van strafsancties is dat de maxima van de vrijheidsbenemende sancties in hun onderlinge verhouding en waardering de ernst van de betreffende delicten tot uitdrukking brengen. In de memorie van toelichting bij het Wetboek van Strafrecht wordt gesteld ${ }^{315}$ :

"De hoofdstraffen zijn geene andere dan tweeërlei vrijheidsstraf, gevangenisstraf en hechtenis en téne vermogensstraf, geldboete. Dit stelsel kenmerkt zich door groote eenvoudigheid, zeker op zich zelve een groot voordeel. Hoe minder straffen toch, hoe gemakkelijker hare onderlinge vergelijking; en zonder zoodanige vergelijking is geene toebedeling van de straf in juiste verhouding tot de betrekkelijke zwaarte der misdrijven mogelijk."

Bij de Wet vermogenssancties in 1983 wordt ook aangesloten bij de gedachte dat de zwaarte van het delict en de (monetaire) sanctie evenredig moeten zijn aan elkaar, ${ }^{316}$ Bij de totstandkoming van de Wet indeling geldboetecategorieën in 1984 is voor een belangrijk deel bij de vaststelling van de maximum hoogte van monetaire sancties angesloten bij de oorspronkelijke indeling van de maximum (vrijheidsbenemende) sancties in het Wetboek van Strafrecht. In de memorie van toelichting valt te lezen ${ }^{317}$ :

"Bij de totstandkoming van het Wetboek van Strafrecht is ernstig getracht de relatieve zwaarte van de als misdrijf strafbaar gestelde feiten in de hoogte van die maxima tot uiting te brengen. Hoewel thans niet meer alle gezichtpunten die daarbij een rol hebben gespeeld in dezelfde mate gelden, biedt het toen verantwoorde grondslag voor de waardering van de ernst der onderscheiden feiten."

315 Smidt, H.J., Geschiedenis van het Wetboek van Strafrecht, Deel I, p. 149. Zie voor het vergelijkend overzicht van strafmaxima in het oorspronkelijke wetboek Smidt, H.J., Geschiedenis van het Wetboek van Strafrecht, Deel III, pp. 363-376.

316 Zie MvT, TK 15 012, nrs. 1-3, p. 20: "Een ideale sanctic is de vermogenssanctie stellig niet. Zowel de Commissie vermogensstraffen als ettelijke commentatoren hebben daarop ook gewezen. In de eerste plaats treft een vermogenssanctic van een bepaalde omvang de een nu eenmaal zwaarder dan de ander. Dit effect kan door toepassing van een draagkrachtbeginsel we! worden verminderd, maar niet worden opgeheven. Volledige en consequente toepassing van het draagkrachtbeginsel is nl. niet mogelijk. In de woorden van de Commissie vermogensstraffen: 'De eis van evenredigheid tussen de zwaarte van het delict en de opgelegde straf mag minder overschaduwd worden door de eis van een zekere relatie tussen boete en draagkracht. Men kan zelfs een miljonair niet een boete van $\mathrm{f} 3000$ laten betalen voor een parkeerovertreding." Verwezen wordt naar het Intrimrapport Commissie vermogenssancties, p. 50.

TK. 1981-1982, 17 524, nr. 3, p. 29. 
Ook bij de wijziging van de Wet op de economische delicten in 1994 is bij het opnieuw vaststellen van de sanctiemogelijkheden een duidelijk verband gelegd tussen de ernst van het feit en de wenselijke strafmaat, waarbij werd gekeken naar het systeem van strafsancties in de oude Wed en de hoogte van de sancties in het Wetboek van Strafrecht. ${ }^{318}$

In de literatuur en de dogmatiek wordt naast het emst van het feit (dat kan worden onderverdeeld in de objectieve ernst, de subjectieve emst en of er sprake is van een reactie op een incident) nog op andere punten gewezen die een rol (kunnen) spelen bij het vaststellen van het strafmaximum van een bepaald delict. Het betreft voornamelijk: de gewenste consistentie (vergelijking met andere strafmaxima in het algemeen), systematische overwegingen (afstemming tussen delicten die samenhangen), differentiatie (algemene bepaling al dan niet in combinatie met strafverlichtende en strafverzwarende omstandigheden opnemen), wetgevings-technische overwegingen, internationale overwegingen (binding door verdragen, indicaties uit de rechtsvergelijking, wenselijkheid gezien internationale rechtshulp), strafprocessuele overwegingen en instrumentele overwegingen. ${ }^{319}$

Deze andere punten spelen in wisselende mate een rol bij de vaststelling van de soort sanctie met zijn maximum. Het zoeken naar de (achterliggende) argumenten van de wetgever om voor een bepaalde sanctie met zijn maximum te kiezen, kan door oog te hebben voor deze, maar incidenteel ook andere, punten worden vergemakkelijkt. Het

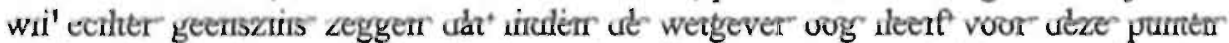
voldaan is aan het proportionaliteitsvereiste. Daarvoor moet ook hier een afweging worden gemaakt tussen instrumentaliteit en rechtsbescherming, waarbij de inbreuk door de sanctie niet groter maar ook niet kleiner mag zijn dan door de emst van het feit wordt gerechtvaardigd. Zowel uit te hoge als uit te lage strafbedreiging kunnen legitimiteitproblemen voor de overheid voortvloeien. ${ }^{320}$

Door het gehanteerde systeem, waarbij de wetgever de maximaal op te leggen sanctie per delict en in de minimaal op te leggen sanctie in het algemeen vaststelt, heeft de rechter een ruime discretionaire bevoegdheid de sanctie in een concreet geval vast te stellen. Hierdoor kan hij bijvoorbeeld rekening houden met de emst van de schending, de mate van verwijtbaarheid en de omstandigheden van het geval. Deze proportionaliteit tussen de gedraging en sanctie vloeit ook voort uit artikel 6 EVRM. Het EHRM oordeelde dat de rechter bij de beoordeling van de punitieve sanctie bevoegd moet zijn tot een "assesment of the proportionality of the sanction." 321

318 TK 1992-1993, 23 196, nrs. 1-2, pp. 5-7

319 Zie Hullu, J. de, Koopmans, I.M. en Roos, Th.A. de, Het wettelijk strafmaximum, pp. 47 en 108-109.

320 Hullu, J. de, Koopmans, I.M. en Roos, Th.A. de, Het wettelijk strafmaximum, pp. $106-$ 107.

321 EHRM 10 februari 1983, NJ 1987,315 (Albert en Le Compte); ook het Hof van Justitie van de Europese Gemeenschap heeft herhaaldelijk geoordeeld dat de toepassing van sancties in het kader van de uitvoering van gemeenschapsrecht in overeenstemming moet zijn met het proportionaliteitsbeginsel, zie bijvoorbeeld Hof van Justitie EG 21 juni 
Een criterium dat ten slotte wordt gebruikt om de noodzaak van regelgeving in het algemeen ${ }^{322}$ en strafbaarstellingen in het bijzonder te toetsen, is de effectiviteit. Een belangrijk onderscheid dat in de literatuur over beleidsevaluaties in het algemeen wordt gemaakt is dat tussen doelbereiking en effectiviteit van beleid. Onder de doelbereiking wordt verstaan de mate waarin bepaalde doelstellingen worden bereikt, terwijl de effectiviteit de mate is waarin de wetgeving bijdraagt aan het bereiken van een bepaald doel. ${ }^{323}$ De effectiviteit van regelgeving kan kleiner zijn dan de doelbereiking. Dit is het geval indien andere factoren aan de doelbereiking hebben bijgedragen. Juist bij strafbepalingen zal dit vaak het geval zijn, omdat de gedragsvormende invloed van bijvoorbeeld opvoeding, onderwijs, sociale instituties groter zal zijn. ${ }^{324}$ Daarnaast kan ook het omgekeerde het geval zijn, zelfs zonder enige doelbereiking kan de wetgeving zeer effectief zijn, doordat deze een verslechtering uit het oogpunt van het doel heeft weten te voorkomen. ${ }^{325}$ Ook de wetgever werd zich bij de toenemende druk om wetgeving te gebruiken als sturingsinstrument ${ }^{326}$ steeds meer van de effectiviteitvraag bewust, hetgeen onder andere blijkt uit de opmerking van (de toenmalige) minister van $\mathrm{Agt}^{327}$ :

"Hierbij komt nog, dat ook voorzover overeenstemming bestaat over de doeleinden ter wille waarvan rechtsregels worden gesteld, niet zelden twijfel heerst over de vraag of deze regels werkelijk bij machte zijn tot verwezenlijking van die doeleinden bij te dragen."

De vraag naar de effectiviteit betreft hier dus de vraag of en zo ja in welke mate de strafbaarstelling er aan bijdraagt het vooraf bepaalde doel te bereiken. ${ }^{328}$ Hierbij is het noodzakelijk dat het doel van de strafbaarstelling duidelijk wordt bepaald, zodat vervolgens kan worden gekeken of dit doel door de betreffende bepaling is bereikt of kan worden bereikt. Het meten van de effectiviteit van regelgeving blijkt zeer moeilijk te $\mathrm{zijn}^{329}$, ten gevolge van methodologische problemen die zich voordoen bij deze vorm van sociaal-wetenschappelijk onderzoek. ${ }^{330}$ Daarbij speelt mee dat de mix van factoren die bijdragen aan de doelbereiking als neveneffect heeft dat het resutaat van

1979, zaak 240/78, Jur. 2137 (Atalanta).

322 Dit criterium is ook één van kwaliteitseisen voor overheidsoptreden via regelgeving in de Nota "Zicht op wetgeving", besproken in hoofdstuk 3 paragraaf 3.

323 Zie Nelissen, N.J.M., "Effectiviteit van milieuwetgeving", p. 124.

324 Zie ook Bunt, H. van de en Roos, Th. de, "Zwarte toga's kontra witte boorden?", p. 28.

325 Zie Nelissen, N.J.M., "Effectiviteit van milieuwetgeving", p. 124.

326 Zie hierover hoofdstuk 3 paragraaf 2.

327 TK 1971-1972, 11500 , Hoofdstuk VI, nr. 2, p. 5.

328 Het gaat dus niet om de vraag naar de effectiviteit in ruime zin, te weten de vraag in hoeverre de wet voldoet aan de doelstellingen van de sociale rechtsstaat. Zie over dit onderscheid Peeters, M.G.W.M., "Effectiviteit van milieuwetgeving: toepassing van wettelijke instrumenten", p. 156.

329 Zo zal evaluatie-onderzoek van wetgeving bijna nooit kunnen voldoen aan het 'ideale' model voor evaluatie-onderzoek zoals geformuleerd door Albinski, M., "Inbreng van sociaal-wetenschappelijk onderzoek in de beleidsvoering", pp. 495-520.

330 Nelissen, N.J.M., "Effectiviteit van milieuwetgeving", pp. 123-143. 
de meting van het effect moeilijk tot niet kan worden herleid tot de afzonderlijke factoren. ${ }^{31}$ Voorts kunnen rechtsregels totaal verschillende effecten teweegbrengen die in meer of mindere mate de doelbereiking al dan niet bevorderen. Hierbij kan onderscheid worden gemaakt tussen (1) de directe effecten die het gedrag in de regel voorzien, (2) de indirecte effecten die het sociale gevolg zijn van het gedrag dat in de regel wordt voorgeschreven, (3) de onafhankelijke effecten die de (on)bedoelde sociale gevolgen zijn van de regel en die niet afhankelijk zijn van de directe gevolgen, en (4) de onbedoelde effecten die niet beoogd zijn maar wel optreden. ${ }^{332}$

In het algemeen zijn ondanks deze problemen wel een aantal factoren te onderscheiden die de effectiviteit van rechtsregels mede negatief beïnvloeden. Het betreft bijvoorbeeld de structuur van de regelgeving, onvoldoende handhaving, gebrekkige naleving, gebrek aan eenheid bij de toepassing, het niet aansluiten bij de belevingswereld van de normadressaten, gebrekkige informatie aan de normadressaten, en verkeerde verwachtingen over sancties bij de normadressaten. ${ }^{333}$

Ondanks de problemen bij het bepalen van het effect van regelgeving blijft het zinvol dat door de wetgever voorafgaande aan de invoering of herziening van regelgeving de vraag naar het door de regel te bereiken doel zo helder en volledig mogelijk wordt beantwoord. ${ }^{334}$ Behalve dat de informatie kan worden gebruikt bij evaluatie-onderzoek zal het de kwaliteit van regelgeving ten goede komen $^{335}$ en kan de rechter het gebruiken bij het interpreteren en toetsen van de regel. Voorts kan hierdoor ook vraag of dit doel niet beter op een andere manier kan worden bereikt (hetgeen samenhangt met de subsidiariteitvraag ${ }^{336}$ ) beter worden beantwoord.

\subsection{Verhouding tussen de criteria voor strafbaarstelling}

Tussen de criteria is geen hiërarchische rangorde aanwezig. Ze zijn deels gecodificeerd in nationale en internationale regelgeving, waardoor schending van dat criterium tot gevolg kan hebben dat sprake is van onrechtmatige regelgeving. De criteria hangen vaak samen en kunnen elkaar overlappen, terwijl er ook wel eens spanning tussen twee of meer criteria kan bestaan. Zo zal het (over)benadrukken van het belang van het

331 Peters, J.A.F., "Informatie en effectiviteit", pp. 161-169.

332 Griffith, J., "Recht en ontwikkeling", pp. 175-191; hij stelt dat de onbedoelde effecten zowel directe, indirecte en onafhankelijke effecten kunnen zijn, waardoor ze geen aparte categorie uitmaken, zie (met voorbeelden) ook Aalders, M.V.C., Industrie, milieu en wergeving, pp. 28-29.

333 Zie bijvoorbeeld Aalders, M.V.C., Industric, milieu en wetgeving, pp. 34-35 en de behandeling van kwaliteitseisen voor overheidshandelen en de beginselen van behoorlijke regelgeving in hoofdstuk 3 paragrafen 3 en 5 .

334 Dan wordt tegemoet gekomen aan het motiveringsbeginsel voor regelgeving, één van de formele beginselen van behoorlijke regelgeving, zie hoofdstuk 3 paragraaf 5.3.1.

335 Evaluatie van regelgeving kan op zichzelf ook een zinvolle bijdrage leveren aan de kwaliteit van wetgeving. Zie Winter, H.B., Evaluatie van het wetgevingsforum.

336 Deze laatste vraag wordt ook wel opgevat als een onderdeel van de effectiviteit. Zie Blomberg, A.B., Michiels, F.C.M.A., Handhaven met effect, pp. 35-36. 
beschermde rechtsgoed zodanig doorslaan dat het lex certa-vereiste te veel uit het oog wordt verloren, waardoor de waarborgen die dit beginsel biedt op het gebied van de rechtsbescherming tekort zal schieten. De uitwerking in concreto zal evenmin als de kwaliteitseisen statisch en onveranderlijk zijn aangezien ook hier de inhoud van de criteria mede wordt beïnvloed door maatschappelijke, juridische, politieke en bestuurlijke veranderingen.

De criteria vormen, evenals de kwaliteitseisen voor overheidsoptreden via wetgeving, een uitwerking van de tweedeling van de functies van wetgeving, te weten de waarborgfunctie en de instrumentele functie. Hierbij wordt door de criteria schadeverwekkend gedrag, het legaliteitsbeginsel, het schuldbeginsel, het subsidiariteitsbeginsel en het proportionaliteitsbeginsel vooral invulling gegeven aan de waarborgfunctie, en geven de criteria inzake effectiviteit en bruikbaarheid vooral invulling aan de instrumentele functie. Waar het om gaat is dat een "juist" evenwicht wordt gevonden tussen de criteria. Maar wat "juist" wordt bevonden, zal op zijn beurt ten dele ook weer afhankelijk zijn van de visie op de rol en functie van het (straf)recht in de samenleving.

\section{Algemene vereisten van behoorlijke regeigeving \\ 8.1. Inleiding}

De algemene kwaliteitseisen voor overheidsoptreden door middel van wetgeving (zie hoofdstuk 3 paragraaf 3 ) richten zich evenals de algemene beginselen van behoorlijke regelgeving (zie hoofdstuk 3 paragraaf 5) zowel tot de wetgever in formele als tot de wetgever in materiële zin, en zijn gezien hun algernene karakter ook toepasselijk op strafbaarstellingen. Daamaast dienen vooral strafbaarstellingen zoveel mogelijk de toetsing aan de criteria voor strafbaarstelling (zie hoofdstuk 3 paragraaf 7 ) te kunnen doorstaan.

De vocrwaarden uit deze drie stelsels vertonen grote samenhang met één of meer vocrwaarden binnen het eigen stelsel als ook met één of meer voorwaarden uit andere stelsels, en blijken elkaar soms (gedeeltelijk) te overlappen. De vele voorwaarden uit de drie los van elkaar staande stelsels komt de inzichtelijkheid en duidelijkheid van de analyse van de behoorlijkheid van regelgeving niet ten goede. Vandaar dat het wenselijk. is deze stelsels te integreren, zodat ze niet enkel apart maar ook in onderlinge samenhang kunnen worden beschouwd. Zo kunnen in deze paragraaf algemene vereisten waaraan regelgeving (waaronder begrepen strafbaarste!lingen) moet voldoen wil zij behoorlijk zijn, worden aangeduid (hoofdstuk 3 paragraaf 8.2.), en kunnen. deze vereisten met gebruikmaking van de in hoofdstuk 3 paragrafen 3, 5 en 7 besproken eisen, beginselen en criteria worden ingevuld (paragrafen 8.3. tot en met. 8.7.). Dit zijn. tevens de voorwaarden waaraan zorgplichtbepalingen in het strafrecht in dit boek zullen worden getoetst (hoofdstukken 6 tot en met 10). 
Indien de diverse los van elkaar ontwikkelde vereisten, beginselen en criteria inhoudelijk worden geanalyseerd blijken ze veel verwantschap te vertonen, maar liggen de accenten duidelijk anders. Dit kan worden verklaard door het feit dat de kwaliteitsvereisten en de beginselen betrekking hebben op regelgeving in het algemeen, waarbij vooral bij de beginselen het accent lijkt te liggen op bestuursrechtelijke regelgeving, terwijl de criteria vooral betrekking hebben op strafbaarstellingen.

Tussen de verschillende gebieden van regelgeving en binnen ieder gebied zal het belang en de invulling van de eisen die worden gesteld aan regelgeving anders zijn. Gezocht is naar hoofdgroepen van vereisten waaraan regelgeving inhoudelijk moet voldoen wil zij behoorlijk zijn. Uit dit onderzoek zijn vijf vereisten voortgekomen die gelden voor alle regelgeving. Het betreft: de evenredigheid, de rechtszekerheid, de rechtsgelijkheid, de samenhang en de effectiviteit.

De vereisten vormen opnieuw een uitwerking van de waarborgfunctie en de instrumentele functie van wetgeving, waarbij het van groot belang is dat deze twee functies zoveel mogelijk in evenwicht zijn. Het gaat niet om een of - of ketrze, maar juist om het zoveel mogelijk tegemoet komen aan beide functies; maar daar waar inbreuken groter kunnen zijn, moeten de waarborgen sterker zijn. ${ }^{337}$ Hierdoor worden in het strafrecht in het algemeen hogere eisen gesteld aan de waarborgfunctie van regellgeving. De criteria die daar verband mee houden zijn daar dan ook sterker en specifieker ontwikkeld dan in het algemene wetgevingsbeleid, waar (vooral ten aanzien van het bestuursrecht) juist de vereisten die betrekking hebben op de effectiviteit en bruikbaarheid van regelgeving domineren. Gezien de dubbele functie van regelgeving zijn alle criteria die tot ontwikkeling zijn gekomen in de bijzondere rechtsgebieden ook van belang voor de andere gebieden.

Het belang van iedere hoofdgroep en vooral zijn invulling per en binnen ieder rechtsgebied zal per gebied in meer of mindere mate verschillen vertonen. Zodoende zal wel aan alle vereisten moet worden voldaan wil sprake zijn van behoorlijke regelgeving, maar de mate waarin zal per rechtsgebied en per onderwerp (sterke) verschillen (kunnen) vertonen. Indien regelgeving wordt getoetst aan deze vereisten zal daarmee rekening moeten worden gehouden. Deze toetsing dient plaats te vinden voordat de regelgeving wordt ingevoerd, maar kan ook worden gebruikt bij de evaluatie en herziening van regelgeving. Door de toetsing aan deze vereisten en hun uitwerking wordt duidelijk waar en waardoor knelpunten (kunnen) ontstaan bij de toepassing en toepasselijkheid van regelgeving. Hierdoor is het mogelijk een bewustere rechtspolitieke keuze te maken ten aanzien van de inhoud en betekenis van de betreffende regeigeving.

337 Dit verklaart ten dele wasrom bij de ontwikkeling van de criteria de nadruk sterk heeft gelegen op de rechtsbeschermende aspecten. 
In de volgende paragrafen worden de vijf hoofdgroepen besproken. Per hoofdgroep wordt steeds aangegeven waar de in de vorige paragrafen besproken vereisten, bıginselen en criteria moeten worden ondergebracht. Voor de betekenis hiervan wordt sleeds verwezen naar de uitwerking in de vorige paragrafen. Aangezien dit boek betrekking heeft op strafbaarstellingen zullen bij de invulling van en toetsing van zorgplichtbepalingen aan deze vereisten, de in hoofdstuk 3 paragraaf 7 besproken criteria een belangrijke rol spelen. Voor andere rechtsgebieden zal vaak minder nadruk liggen op de toepasselijkheid van deze criteria.

\section{3.}

\section{Het vereiste van evenredigheid}

Irdien de wetgever nieuwe regelgeving wil introđuceren, dan wel oudere regelgeving wil bijstellen of veranderen, is het allereerst noodzakelijk dat wordt nagegaan wat het doel is dat met regelgeving wordt beoogd (hoofdstuk. 3 paragraaf 5.3.1.). Hierbij moet rekening worden gehouden met de schadelijkheid van de gedraging voor het beschermde rechtsgoed (hoofdstuk 7 paragraaf 7.2.). De doelstelling zal (ook ten bchoeve van andere vereisten) zoveel mogelijk moeten worden duidelijk gemaakt. Ten behoeve van het nastreven van deze doelstelling dient de regelgeving gerechtvaardigd, ncodzakelijk en als middel geschikt te zijn (hoofdstuk 3 paragraaf 3.2.3. over subsidiariteit hoofdstuk 3 paragrafen 5.3.3. en 7.5.). Uitgangspunt is dat de overheid nit nodeloos (vergaand) mag ingrijpen in de samenleving, voordat zorgvuldig is ngegaan wie, bij welke gedraging, onder welke omstandigheden onder de reikwijdte van een bepaling zal vallen, en welk rechtsbelang hierdoor wordt beschermd. Rechtsregels maken gezien hun aard inbreuk op fundamentele vrijheden van justitiabelen, maar kunnen tevens fundamentele vrijheden (van anderen) beschermen. Nagegaan moet worden op welke manier de inmenging kan plaatsvinden, waarbij zo min mogelijk wordt ingegrepen in deze vrijheden maar wel het gewenste effect wordt bereikt. Hierbij dient de regelgeving en de daaraan gekoppelde consequenties voor justitiabelen proportioneel (ook wel evenredigheid in enge zin genoemd) te zijn (hoofdstuk 3 paragraaf 3.2.3. over proportionaliteit en paragraaf 7.6.).

\section{4.}

\section{Het vereiste van rechtszekerheid}

Indien vaststaat dat regelgeving op een bepaald gebied is gewenst, dient deze zo te worden ingericht dat zoveel mogelijk wordt tegemoet gekomen aan de rechtszekerheid van justitiabelen (hoofdstuk 3 paragraaf 5.4.4.). Hiervoor is van belang dat de regels rechtmatig zijn, zodat ze voldoen aan de eisen uit intemationale verdragen, de (grond)wet en algemene rechtsbeginselen (hoofdstuk 3 paragraaf 3.2.1.). In het kader van de rechtszekerheid wordt hier vooral gedacht aan het legaliteitsbeginsel en het daanuit afgeleide lex certa-beginsel (hoofdstuk 3 paragraaf 7.3.), angezien regels voldoende kenbaar dienen te zijn (hoofdstuk. 3 paragrafen 3.2.6., 5.4.1. over duidelijke terminologie en 5.4.2.). Ook bij wijziging van regelgeving en ten aanzien van verkregen rechten en opgewekte verwachtingen dient aan het rechtszekerheidsvereiste tegemoet te worden gekomen, bijvoorbeeld door adequaat overgangsrecht. 


\section{5 .}

Gelijke gevallen dienen gelijk te worden behandeld, maar afwijkende gevallen rechtvaardigen ook afwijking (hoofdstuk 3 paragraaf 5.4.3.), zodat naast gelijkheid ruimte is voor individuele rechtsbedeling (hoofdstuk 3 paragraaf 5.4.5.). De beoordeling van een zaak moet plaats vinden op zijn merites, waarbij er ruimte is een hardheidsclausule toe te passen indien toepassing van een bepaling in een specifiek geval niet gewenst is. Hierbij is van belang na te gaan tot wie de norm zich richt en wie wegens de normschending in een specifiek geval kan worden aangesproken (hoofdstuk 6 paragraaf 5). In het strafrecht moet bijvoorbeeld rekening worden gehouden met de mate van verwijtbaarheid van de aangesprokene (hoofdstuk 3 paragraaf 7.4.).

\subsection{Het vereiste van samenhang}

Dit vereiste heeft betrekking op de samenhang tussen bepalingen binnen een rechtsgebied en met bepalingen buiten dat rechtsgebied (hoofdstuk 3 paragraaf 5.4.1. over systematiek). Het is van belang voor de rechtseenheid, en in die zin ook voor de rechtszekerheid en rechtsgelijkheid dat regels voldoende op elkaar worden afgestemd (hoofdstuk 3 paragraaf 3.2.5.), wat overigens niet wil zeggen dat regels in verschillende rechtsgebieden nooit een andere betekenis kunnen hebben. Hoewel het orgaan dat de regelgeving, al dan niet in overleg met betrokkenen (hoofdstuk 3 paragraaf 5.3.5.), vaststelt (hoofdstuk 3 paragraaf 5.3.2.), vooral van belang is in het kader van procedurele vereisten, kan het ook van invloed zijn op het vereiste van samenhang. Vandaar dat bij deze uitwerking van dit vereiste ook deze twee overwegend formele beginselen worden genoemd.

\section{7. $\quad$ Het vereiste van effectiviteit}

Indien regels evenredig zijn, voldoende tegemoet komen aan de rechtszekerheid en rechtsgelijkheid van justitiabelen, en voldoende samenhang vertonen, dienen zij ook uitvoerbaar en handhaafbaar te zijn, aangezien zij anders niet effectief zijn. Hierbij is van belang dat, hoewel dit moeilijk is te realiseren, ex ante wordt onderzocht in hoeverre door een bepaling het gestelde doel kan worden verwezenlijkt, en ex post wordt getoetst of dit werd bereikt (hoofdstuk 3 paragrafen 3.2.2., 3.2.4., 5.3.4. en 7.7.).

\subsection{Verhouding tussen de vereisten}

Wederom moet erop worden gewezen dat de te onderscheiden vereisten onderling samenhangen en elkaar soms overlappen. Indien in onvoldoende mate wordt tegemoetgekomen aan één of meer vereisten kan op de korte of langere termijn blijken dat het evenwicht verstoord is tussen de waarborgfunctie en de instrumentele functie van wetgeving, aangezien de vereisten een uitwerking zijn van deze functies. Het is dan ook van groot belang regelgeving voorafgaand aan de invoering te analyseren aan de hand van deze vereisten, en indien blijkt dat onvoldoende wordt tegemoetgekomen aan één of meer vereisten de bepalingen aan te passen. 
Odk na invoering blijft het belangrijk regelmatig de regelgeving te analyseren. Door onjer andere onverwachte gevolgen, onvolledige analyse (bijvoorbeeld in verband met onvoldoende kennis van en inzicht in mogelijke gevolgen van de invoering), matschappelijke veranderingen, en rechterlijke interpretatie kan regelgeving in de priktijk anders dan voorzien functioneren. De vraag is dan aan de orde of de regelgeving met haar nieuwe en/ of onvoorziene werking dient te worden gehandhaafd, moet worden aangepast of ingetrokken. 



\section{Het bestuur en voorwaarden voor srafbaarstelling}

\section{Inleiding}

Net de opkomst van de industriële samenleving en de uit de maatschappelijke ortwikkelingen voortvloeiende gewijzigde taakopvatting van de wetgever is het krakter van wet- en regelgeving veranderd. ${ }^{1}$ Het bestuur is in toenemende mate een ro van betekenis gaan spelen bij de totstandkoming en invulling van regelgeving. ${ }^{2}$ Dit wirdt met name veroorzaakt door het sterk toegenomen gebruik van delegatie van rejelgevende bevoegdheden, hetgeen welhaast onvermijdelijk is om de doelstellingen van de welvaartstaat te verwezenlijken. Daarnaast heeft het bestuur steeds meer vriheid gekregen bij het uitvoeren van zijn werkzaamheden, terwijl deze door de opkomst van de welvaartsstaat ook in omvang zijn toegenomen. Zowel de toegenomen beroegdheden inzake regelgeving, als de verstrekte vrijheid bij de uitoefening van de tobedeelde werkzaamheden, heeft geleid tot sterk geïndividualiseerde regelgeving, bivoorbeeld in de vorm van beschikkingen. ${ }^{3}$ Veel regelgeving is derhalve afkomstig van decentrale overheden. (hoofdstuk 4 paragraaf 2). Het bestuur kan bevoegd zijn in de door hem gemaakte regelingen zorgplichtbepalingen op te nemen.

De betekenis van het bestuur is ook bij de totstandkoming en invulling van het bijzondere strafrecht sterk toegenomen. Dit wordt vooral veroorzaakt doordat het bestuur op vele teireinen via gelede normstellingen een grote rol speelt bij het vaststeilen van rechten en plichten voor justitiabelen. Deze door het bestuur vastgestelde normen zijn soms aan te merken als de materiële norm van abstracte gevaarzettingsdelicten. ${ }^{4}$ Er zijn diverse redenen aan te geven waarom de wetgever gebruik maakt van gelede normstellingen (hoofdstuk 4 paragraaf 3).

Bij strafbaarstellingen waarvan de materiële norm door het bestuur wordt bepaald, wordt vaak gesteld dat het strafrecht bestuursondersteunend is (hoofdstuk 4 paragraaf' 4). Het is de vraag in hoeverre sprake is van strafrechtelijke sanctionering van "administratieve ongehoorzaamheid" dan wel van bescherming van het door de wet in formele zin beschermde belang (rechtsgoed), of een combinatie van deze twee.

Zie hoofdstuk 3 paragraaf 2 .

Mede hierdoor gaan de drie staatsfuncties (wetgeven, besturen en rechtspreken) die op basis van de in Nederland nooit strikt toegepaste. leer de machtenscheiding zijn te onderscheiden, in toenemende mate door elkaar heen lopen. Zie Klink, B. van, De wet als symbool, pp. 136-137. Zie Klink, B. van, De wet als symbool, pp. 132-134.

4 Zie over abstracte gevaarzettingsdelicten hoofdstuk 1 paragraaf 3.6.2.2. 
Door het gebruik van gelede normstellingen kan het bestuur aanvullende criteria vaststellen voor de toepassing van zorgplichtbepalingen. Het blijkt echter ook mogelijk dat het bestuur bij de invulling van de gelede normen gebruik maakt van zorgplichtbepalingen. Indien het bestuur bevoegd is tot het maken van regelgeving, is het de vraag in hoeverre het bestuur vrij is de bevoegdheid tot regelgeving naar eigen inzicht in te vullen (hoofdstuk 4 paragraaf 5). Hieruit volgt of het de bevoegdheid heeft (aanvullende criteria voor) zorgplichtbepalingen vast te stellen.

Kenmerkend voor gelede normstellingen is dat specifieke (gedrags)voorschriften niet in de wet in formele zin zijn te vinden, maar zijn opgenomen in uitvoeringsbesluiten of beschikkingen. ${ }^{5}$ Schending van deze voorschriften kan via abstracte gevaarzettingsdelicten, opgenomen in de bijzondere strafwetgeving, strafbaar zijn gesteld. Daarnaast is het mogelijk dat het naleven van de door het bestuur vastgestelde normen ervoor zorgt dat het feit niet strafbaar is. Gezien de processuele consequenties is het van belang na te gaan of de door het bestuur vastgestelde norm bestanddeel of strafuitsluitingsgrond is van de delictsomschrijving (hoofdstuk 4 paragraaf 6 ).

\section{Wetgeving door decentrale overheden}

Oorspronkelijk was de taak van de centrale overheid inzake regelgeving beperkt. Veel en belangrijke regelgeving was afkomstig van decentrale overheden, zoals gemeenten, provincies, wattrschappen en beuhijisurgamsanies. ${ }^{6}$ Met her sueven naar en codinceren van regelgeving ${ }^{7}$, en de toename van modificerende regelgeving ${ }^{8}$ werd steeds meer regelgeving gecentraliseerd. Niet alle lagere regelgeving was dit lot beschoren, en het gewijzigd gebruik van regelgeving veroorzaakte op haar beurt juist weer een toename van de hoeveelheid van (ook lagere) regelgeving. Er zijn dan ook zowel praktische als inhoudelijke argumenten aan te geven voor de delegatie van de bevoegdheid tot regelgeving. ${ }^{9}$ Nederland wordt mede vanwege het veelvuldig gebruik van deze mogelijkheden wel getypeerd als een gedecentraliseerde eenheidsstaat. ${ }^{10}$

Gemeenten, provincies en waterschappen beschikken nog steeds over een grote vrijheid inzake het vaststellen van verordeningen. Gemeenteraden ontlenen de bevoegdheid tot het vaststellen van verordeningen aan artikel $127 \mathrm{Gw}$ jo. artikel 149 Gemeentewet. Involge artikel 108 Gemeentewet is "de bevoegdheid tot regeling en bestuur inzake de huishouding van de gemeente" overgelaten aan het

5 Het verschijnsel van gelede normstelling, waarbij de normen waaraan een justitiabele zich heeft te houden nauwelijks door de parlementaire wetgever wordt bepaald, maar in hoofdzaak afhangt van besluiten van bestuursorganen, wordt ook wel aangeduid als de terugtred van de wetgever. Wijk, H.D. van, bewerkt door Konijnenbelt, W. en Male, R.M. van, Hoofdstukken van besturursrecht, p. 173.

6 Zie over bedrijfsorganisaties ook hoofdstuk 8 paragraaf 2.

7 Zie hoofdstuk 6 paragraaf 2.

$8 \quad$ Zie hoofdstuk 3 paragraaf 2.

$9 \quad$ Zie hoofdstuk 4 paragraaf 3.

10 Boon, P.J., Brouwer, J.G. en Schilder, A.E., Regelgeving in Nederland, p. 136. 
overtredingen betreft hechtenis van ten hoogste drie maanden of een geldboete van de tweede categorie $(f .5000,-)$, al dan niet met openbaarmaking van de rechterlijke uitspraak. ${ }^{13}$ Overigens zijn op strafbaarstellingen in verordeningen de bepalingen uit de Titels I-VIII A van het eerste boek Sr involge artikel $91 \mathrm{Sr}$ toepasselijk, tenzij de wet anders bepaalt.

Maar het zijn niet enkel de Gemeentwet, de Provinciewet en de Watenschapswet op basis waarvan decentrale overheden de bevoegdheid tot het maken van (bepaalde) regelgeving kunnen verkrijgen. De bevoegdheidsgrondslag kan ook in een andere wet zijn gelegen, en ook andere overheden kunnen op basis van een wet in formele zin een dergelijke bevoegdheid verkrijgen. Hier gaat het niet alleen om amvb's en ministeriële regelingen waaraan een zekere democratische legitimatie niet kan worden ontzegd, maar ook om regelingen vastgesteld door vele bijzondere organen die op basis van de wet de bevoegdheid daartoe hebben verkregen. Zo is bijvoorbeeld het goedkeuren of vaststellen van tarieven uit de Wet Tarieven Gezondheidszorg door de wetgever gedelegeerd aan het Centraal orgaan tarieven gezondheidszorg. ${ }^{18}$ Afhankelijk van de bevoegdheid die door de wet wordt gedelegeerd, de beslissingsruimte die wordt verleend en de algemene beginselen waaraan moet worden voldaan, bestaat de mogelijkheid dat ook in deze regelgeving zorgplichtbepalingen worden opgenomen. ${ }^{15}$

\section{Strafrecht en de redenen voor gelede normstellingen}

Er zijn verschillende redenen aan te geven waarom de wetgever gebruik maakt van gelede normstellingen, waarbij de materiële strafrechtelijke normstelling door het bestuur wordt bepaald. ${ }^{16}$ Ten eerste kan worden gewezen op het kwantitatieve probleem. Het totaal van bestuurlijke normstellingen kan onmogelijk bij wet in formele zin worden geregeld. ${ }^{17}$

Daarnaast spelen ook meer inhoudelijke argumenten een rol. Wetten in formele zin kunnen in tegenstelling tot door het bestuur vastgestelde normen niet snel worden aangepast aan veranderende omstandigheden en aan het voortschrijden van bijvoorbeeld technische ontwikkelingen. Daarmee hangt samen dat aanvullende normstellingen soms vergaande technische kennis en beoordeling vergen of dat zij administratieve en technische details betreffen, waarvan kan worden gesteld dat het onmogelijk en/ of zinloos is de wetgever in formele zin daarmee te belasten. Bovendien kan vaak pas in concreto worden aangegeven hoe in een specifiek geval

13 Zie artikel 154, eerste lid Gemeentewet, artikel 150, eerste lid Provinciewet en artikel 81 , eerste lid Waterschapswet.

14 Zie ook hoofdstuk 3 paragraaf 7.3.6 en hoofdstuk 10 paragraaf 3.2.7.

15 Zie ook hoofdstuk 3 paragraaf 7.3.3.

16 Zie over de gelede normstelling in het Nederlands milieustrafrecht: Hendriks, L.E.M. en Wöretshofer, J., Milieustrafrecht, pp. 32-34.

17 Door het streven van de wetgever de samenleving te beïnvloeden en te sturen is veel beleidswetgeving tot stand gekomen en is de rol van het bestuur bij de invulling sterk toegenomen. Zie hierover hoofdstuk 3 paragraaf 2 en hoofdstuk 6 paragraaf 2. 
moet worden gehandeld, omdat de gevallen een eindeloze variatie vertonen. Met name beschikkingen zijn dan een aangewezen instrument. ${ }^{18}$ Ook het feit dat het vaak gewenst is de normen pas vast te leggen na overleg met betrokkenen of inspraak van belanghebbenden maakt dat hiervoor bestuursorganen geschikter kunnen zijn dan de wetgever in formele zin. ${ }^{19}$ Voorts speelt hierbij het uitgangspunt dat wat aan lagere overheden kan worden overgelaten moet worden overgelaten, een rol. ${ }^{20}$

Een probleem bij gelede normstellingen kan worden veroorzaakt door het niet optimaal functioneren van de wetgevingstechniek. Hiervoor kan ais belangrijke oorzaak worden aangegeven dat de regelingen in de bijzondere wetten van bestuursrechtelijke oorsprong zijn. ${ }^{21}$ Vanuit dat perspectief dienen de regelingen zo zorgvuldig mogelijk te worden geformuleerd, zodat wat geregeld moet worden vooral goed en sluitend geregeld is. Dit gaat nogal eens ten koste van de inzichtelijkheid en kenbaarheid, bijvoorbeeld door het veelvuldig verwijzen en doorverwijzen, waarbij gebruik wordt gemaakt van definitiebepalingen die soms ook weer doorverwijzen. ${ }^{22}$ Ten behoeve van de sluitendheid van dit systeem komt het voor dat gebruik wordt gemaakt van zorgplichtbepalingen. ${ }^{23}$

\section{Bestuursondersteunend strafrecht}

Door het gebruik van gelede normstellingen kunnen het strafrecht en het bestuursrecht op elkaar worden afgestemd. Bij de handhaving kunnen zij elkaar aanvullen, waarbij recht wordt gedaan aan de taak en functie van het bestuur dat in een voortraject een zorgvuldige belangenafweging heeft gemaakt. Het strafrecht kan vervolgens

18 Belinfante hanteerde de term 'concrete norm' voor "administratiefrechtelijke rechtshandelingen waardoor aan een algemeen verbindend voorschrift concrete inhoud en praktische toepasbaarheid naar tijd en plaats kan worden gegeven". Deze norm houdt het midden tussen de algemene regeling of wet in materiêle zin en de administratieve beschikking. Belinfante, A.D., Kort begrip van het administratieve recht, hoofdstuk 3. Bestreden door Wijk, H.D. van, De norm is per definitie abstract. Zie ook Wijk, H.D. van, bewerkt toor Konijnenbelt, W. en Male, R.M. van, Hoofdstukken van bestuursrecht, pp. 285-286.

19 Wijk, H.D. van, bewerkt door Konijnenbelt, W, en Male, R.M. van, Hoofdstukken van bestuursrecht, pp. 173-174. Zie ook Hendriks, L.E.M. en Wöretshofer, J., Milieustrafrecht, pp. 46-47. Hierdoor kan bijvoorbeeld worden tegemoetgekomen aan het beginsel van consensus, zie hoofdstuk 3 paragraaf 5.3.5.

20 Artikel $124 \mathrm{Gw}$ gaat zelfs van dit beginsel uit.

21 Ook binnen het besturssrecht onderkent men de problemen die samenhangen met deze wetgevingstechniek. Zie bijvoorbeeld Ommeren, F.J. van, De verplichting verankeri, pp. 2-3.

22 De juist in bijzondere wetgeving met zijn gelede normstellingen vaak voorkomende gecompliceerde, vergaande detaillering en slechte praktische toepasbaarheid zijn tekenen van matige kwaliteit van wetgeving. Zie Scheltema, M., "De verwachtingen voor de toekomst", p. 346.

23 Zie Van Dorst in zijn conclusie, punt 5, HR. 27 juni 1995, NJ 1995, 722; MenR 1996, nr. 6 , met noot Hendriks (Uitleg vergunningvoorșchrift is feitelijk). 
aanvullend sanctionerend optreden als de justitiabele zich niet blijkt te houden aan de bestuurlijke regelgeving. ${ }^{24}$

De rol van het strafrecht bij abstracte gevaarzettingsdelicten met gelede normstellingen beperkt zich er vaak toe elke schending van de normen uit de betreffende regelgeving of beschikking strafrechtelijk te sanctioneren. Het strafrecht vervult hier een supplementaire rol ter sanctionering van vooraf genomen bestuurlijke beslissingen. "Bestuurlijk afhankelijk" wordt ook wel aangeduid als "bestuursaccessoir". ${ }^{25}$ In de Duitse dogmatiek, waaraan deze begrippen zijn ontleend, wordt gesproken over "Verwaltungsakzessorietät". ${ }^{26}$ Hiermee wordt bedoeld dat het strafrecht ten opzichte van het bestuursrecht een secundaire, accessoire functie heeft, omdat de inhoud van de normen niet wordt bepaald door de wetgever ten tijde van de strafbaarstelling, maar door het bestuur dat bijvoorbeeld de algemeen verbindende voorschriften en beschikkingen vaststelt, beschikkingen verleent of weigert, en aan de beschikkingen voorschriften verbindt.

Overigens moet nog worden opgemerkt dat in de Duitse dogmatiek wel een onderscheid wordt gemaakt tussen de Verwaltungsrechtsakzessorietät, waarbij een afhankelijkheid van het strafrecht van beginselen en regels van het bestuursrecht wordt bedoeld en Verwaltungsaktsakzessorietät, waarbij een afhankelijkheid van het strafrecht van individuele bestuursrechtelijke beslissingen wordt bedoeld. ${ }^{27} \mathrm{De}$ administratieve afhankelijkheid van het strafrecht heeft bij gelede normstellingen

24. Dit is de reden dat deze bepalingen van groot belang zijn in het milieustrafrecht. Zie Heine, G. en Meinberg, V., Empfehlen sich Anderungen im strafrechlichen Umweltschutz, insbesondere in Verbindung mit dem Venwaltungsrecht?, pp. 35-37; Laufhütte, H. en Möhrenschlager, M., "Ũmweltstrafrecht in neuer Gestalt", pp. 917-919 en Möhrenschlager, M., "Kausalitätsprobleme im Umweltstrafrecht des Strafgesetz" buches", pp. 56-57.

25 Haentjens, R.C.P., "De bedreiging der samenleving door aantasting van het natuurlijk. milieu en het strafrecht als middel tot afweer", pp. 473-480. Melai, A.L., Het gezag van norm en feit in sirafzaken, pp. 34-35, maakt onderscheid tussen wetgeving van originaire huize die de Grondwet, de wet in formele zin en verordeningen van lagere wetgevende. organen omvat, en wetgeving van accessoire huize die de nadere regelingen betreft waartoe bijzondere organen in opdracht van de originaire wetgever op legitieme wijze zijn geroepen.

26 Zie daarover Winkelbauer, W., Zur Verwaltungsakzessorie!ät des Umweltstrafrechts.

27 Zie Heine, G., "Verwaltungsakzessorietăt des Umweltstrafrechts", pp. 2425-2434; Heine, G., "Zur Rolle des strafrechtlichen Umweltschutzes", pp. 728-732; Heine, G., "Die Verwaltungsakzessorietät im deutschen Umweltstrafrecht unter Berücksichtigung des österreichischen Rechts. Aktuelle Probleme und Reformüberregungen", pp. 370-

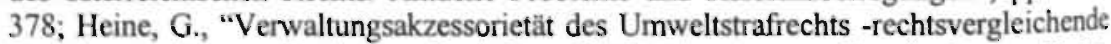
Funktionsanalysen-unbestimmte Rechtsbegriffe-Reichweite von Genehmigungen", pp. 55-80; Kloepfer, M., Zur Rechtsumbildung durch Umweltschutz, vooral pp. 21-24; Kühl, K., "Probleme der Verwaltungsakzessorietät des Strafrechts, insbesondere im Umweltstrafrecht", pp. 815-861; Schall, H., "Umweltschutz durch Strafrecht: Anspruch und Wirklichkeit", pp. 1265-1266 en Schmitz, R., Verwaltungshandeln und Strafrecht: zur Verwaltungsakzessorietät des Umweltstrafrecht. 
betrekking op beide begrippen. Het gaat immers zowel om de situaties waarin de strafbaarheid wordt beperkt tot inbreuken op algemeen verbindende voorschriften als om situaties waarin de stafbaarheid wordt beperkt tot inbreuken op (individuele) beschikkingen.

Deze administratief afhankelijke strafbepalingen zijn doorgaans eenvoudig geformuleerd waardoor ze een tamelijk ongenuanceerd karakter hebben wat betreft de formulering van de voorwaarden voor strafbaarheid. De bepaling staat doorgaans in een bijzondere strafwet, en houdt in dat eenieder die de bepalingen van die wet, of de uitvoeringsbesluiten die op basis daarvan werden genomen schendt, dan wel handelt zonder vergunning of in strijd met de vergunning(voorschriften), wordt bedreigd met een specifieke strafrechtelijke sanctie.

Overigens bepaalt het bestuur met de door hem vastgestelde regelgeving niet enkel de omvang van de strafrechtelijke aansprakelijkheid doordat het schenden van deze bepalingen strafbaar is gesteld via een abstract gevaarzettingsdelict. Het wel voldoen aan de door het bestuur vastgestelde regels werkt daarnaast vaak strafuitsluitend, omdat dan niet voldaan is aan de voorwaarden voor strafbaarheid aangezien bijvoorbeeld de bestanddelen niet zijn vervuld of de wederrechtelijkheid ontbreekt. Dit lijkt bijvoorbeeld niet zo bezwaarlijk in het geval dat ex artikell $8.1 \mathrm{Wm}$ is "verboden zonder een daartoe verleende vergunning een inrichting in werking te hebben". Dit wordt snel anders indien men zich realiseert dat bijvoorbeeld een justitiabele die opzettelijk maar met vergunning een stof in het water brengt waarvan hij weet dat daarvan gevaar voor de openbare gezondheid te duchten is, in het algemeen niet strafbaar zal zijn wegens schending van artikel $173 \mathrm{a} \mathrm{Sr}{ }^{28}$

Het bestuur krijgt hierdoor de reële macht om de omvang van de strafrechtelijke aansprakelijkheid te bepalen. Dit wordt doorgaans in de literatuur als belangrijkste bezwaar tegen de absolute administratieve afhankelijkheid aangevoerd. ${ }^{29}$ De strafrechtelijke aansprakelijkheid wordt door de administratieve afhankelijkheid immers in belangrijke mate door het bestuur en niet langer door de wetgever in formele zin bepaald. Er is volgens de Duitse dogmatiek bij dit type strafbaarstellingen dan ook sprake van een "Selbstentmachtung des Gesetzgebers".

28. Zie hierover Faure, M. en Visser, M., De strafrechtelijke bescherming van het leefmilieu in België, Duitsland en Nederland, pp. 233-242, 273.

29. Heine, G., "Verwaltungsakzessorietăt des Umweltstrafrechts", pp. 2426-2427.

30. Heine, G., "Die Verwaltungsakzessorietät im deutschen Umweltstrafrecht unter Berücksichtigung des österreichischen Rechts. Aktuelle Probleme und Reformüberregungen", p. 372; Kloepfer, M. en Vierhaus, H.P., Umweltstrafrecht, pp. 26-28 en Schall, H., "Umweltschutz durch Strafrecht: Anspruch und Wirklichkeit", p. 1266. Deze kritiek wordt overigens ook gedeeld door Roef, D., "Zoektocht naar een meer-zinnige betekenis van het strafrecht voor het leefmilieu", p. 488. 


\section{De definiëringsmacht van het bestuur}

\subsection{Inleiding}

Het bestuur kan bevoegd zijn tot het maken van regelgeving waarvan schending via een abstract gevaarzettingsdelict strafbaar is gesteld. De vraag is waaraan het bestuur gebonden is bij het gebruik van deze bevoegdheid, en wat voor soorten beslissingsruimte hem resteert (hoofdstuk 4 paragraaf 5.2.). Voorts speelt de vraag welke belangen hij moet afwegen bij zijn besluitvorming (hoofdstuk 4 paragraaf 5.3.). Indien deze vragen zijn onderzocht kan een uitspraak worden gedaan hoever de definiërings. macht van het bestuur gaat (hoofdstuk 4 paragraaf 5.4.).

\subsection{Bevoegdheid van het bestuur}

De wetgever kan door middel van delegatie zijn bevoegdheid tot het nemen van bepaalde besluiten overdragen an het bestuur. ${ }^{31}$ Aangezien delegatie het wettelijk bevoegdheidspatroon doorbreekt is hiervoor blijkens artikel 10:15 Awb altijd een wettelijke basis vereist. Indien het bestuur de bevoegdheid wordt verleend strafbepalingen in te vullen via gelede normstellingen, rijst de vraag hoe ruim deze bevoegdheid is. Wordt het strafrecht aangewend ter sanctionering van "administratieve ongehoorzaamheid", of is veeleer sprake van strafrechtelijke bescherming van het door de wet in formele zin beschermde rechtsgoed, of betreft het een combinatie van deze twee?

De wettelijke regeling op basis waarvan de bevoegdheid is gegeven, zal altijd tot stand zijn gebracht vanuit een bepaalde noodzaak en om bepaalde belangen te beschermen; de bescherming van die belangen is het doel van de "wettelijke regeling. ${ }^{32}$ De strafbaarstellingen in het bijzondere strafrecht hebben gelet op de wettelijke opdracht als algemeen doel het bieden van bescherming aan (aspecten van) het door de betreffende wet beschermde belang. De abstracte gevaarzettingsdelicten, die in de wet zijn opgenomen en waarvan de materiële norm door het bestuur wordt ingevuld, zullen daarom tevens dit belang dienen. ${ }^{33}$

Iedere bepaling uit de wet zal op haar beurt weer tot doel hebben een met het hoofddoel samenhangend specifieker belang te beschermen. In hoeverre de bepalingen het rechtsgoed beschermen, kan behalve uit de formulering van de bepaling zelf, ook worden afgeleid uit de overige bepalingen van de betreffende wet, de systematiek van de wet, de wetsgeschiedenis en de considerans van de wet. ${ }^{34}$ De mate van bescherming die via gelede normstellingen aan het door de wet beschermde rechtsgoed wordt

31 Zie algemeen over delegatie van bevoegdheden bijvoorbeeld Wijk, H.D. van, bewerkt door Konijnenbelt, W. en Male, R.M. van, Hoofdstukken van bestuursrecht, pp. 154159.

32 Konijnenbelt, W., "Het specialiteitsbeginsel in het Nederlandse en het Franse administratieve recht", p. 306.

33 Buiting, Th.J.B., Strafrecht en milieu, p. 26.

34 Hendriks, L.E.M., Wöretshofer, J., Milieustrafrecht, p. 28. 
gebden zal daarom wisselen. Hieruit volgt dat, gelet op de doelgebondenheid van de belngenafweging door het bestuur, de bestuurlijke beslissing (die strafrechtelijk wordt geicrimineerd) in beginsel het door de betreffende wet en het door de specifieke bepling beoogde belang moet dienen.

Bijnalyse van abstracte gevaarzettingsdelicten blijkt dat deze strafbaarstellingen divese deelbelangen beschermen. ${ }^{35}$ Afhankelijk van de formulering van strafbaarsteing en de aanvullende criteria in de wetgeving zijn er bepalingen die het door de webeschermde belang min of meer direct beschermen, terwijl ook bepalingen worden aanetroffen die weinig met dit rechtsgoed hebben te maken. Naarmate de band met hetdoor de wet beschermde rechtsgoed zwakker wordt, (b)lijken de bepalingen veeier "administratieve belangen" te beschermen ${ }^{36}$ Gezien de wisselende sterkte van de escherming van het rechtsgoed als doel van de bepalingen, is het bestuur in wiselende mate aan dit belang gebonden bij het vaststellen van regelgeving.

De itoefening van de bevoegdheid van het bestuur wordt behalve door de wet ook bepckt door algemene beginselen van behoorlijk bestuur en andere algemene begiselen. ${ }^{37}$ Een belangrijk beginsel dat in artikel 3:3 Awb is gecodificeerd, is dat het bestur dat op basis van de wet de bevoegdheid heeft gekregen om de materiële inhad van de norm vast te stellen, deze bevoegdheid in beginsel niet mag gebruiken vooieen ander doel dan waarvoor die is verleend. Ook hierdoor wordt de uitoefening vanle bevoegdheid beperkt door de bepaling uit de wet in formele zin op basis waarvan de bevoegdheid is verleend. Dit betekent dat het bestuur bij de invulling van de gelede normen het doel waarvoor de bevoegdheid is verleend dient te behartigen. terwijl het blijft binnen de gegeven bevoegdheidsgrenzen.

Ondanks de gebondenheid van het bestuur aan de wet en de beginselen, heeft het vaak een zekere mate van beslissingsruimte bij het gebruik van zijn gedelegeerde bevoegdheid. ${ }^{38}$ De ruimte die toekomt aan het bestuur kan worden onderverdeeld in twee soorten beslissingsruimte. ${ }^{39}$

Zie voor een overzicht van strafbaarstellingen met gradaties van bescherming van het door de wet beschermde rechtsgoed: Buiting, Th.J.B., Strafrecht en milieu, pp. 25-34. Zie ook Hendriks, L.E.M. en Wöretshofer, J., Milieustrafrecht, pp. 29-32; Tonnaer, F.P.C.L., Handboek van het Nederlandse milieurecht, pp. 1091-1093 en Waling, C., Het materiële milieustrafrech', pp. 16-21.

36 Hoewel ook dat doorgaans moet worden gerelativeerd: ook de "administratieve belangen" behartigen uiteindelijk het rechtens te beschermen belang. Maar iedereen wordt bij de beoordeling van situaties en het nemen van besluiten sterk beïnvloed door de positie die hij inneemt, ook bestuursorganen; zie Scheltema, M., De partijdige wetgever, pp. 7-18 en 39-42.

37 Bijvoorbeeld in hoofdstuk 3 besproken algemene beginselen van behoorlijke regelgeving en criteria voor strafbaarstelling.

38 Wijk, H.D. van, bewerkt door Konijnenbelt, W. en Male, R.M. van, Hoofdstukken van bestuursrecht, pp. 177-178.

39. Zie Duk, W., "Beoordelingsvrijheid en beleidsvrijheid", pp. 156-169; Wijk, H.D. van, bewerkt door Konijnenbelt, W. en Male, R.M. van, Hoofdstukken van bestuursrecht, pp. 
Ten eerste de beoordelingsruimte. Het betreft de ruimte van het bestuursorgaan om zelf te beslissen of het gebruik zal maken van de gedelegeerde bevoegdheid (de "kan" bevoegdheid). Deze beslissingsruimte is afhankelijk van de door de wetgever omschreven condities waaronder een bestuursorgaan een bepaalde bevoegdheid mag of moet gebruiken. Hoe nauwkeuriger deze condities zijn omschreven, hoe minder ruimte het bestuursorgaan bij de keuze heeft. De wettelijke regeling bepaalt hoeveel beoordelingsruimte er is; de uitkomst geeft aan of het galat om een gebonden dan wel om een vrije bevoegdheid.

Ten tweede gaat het om de beleidsruimte van het bestuur. Indien de toepasselijkheidcondities die liggen besloten in de beoordelingsruimte zijn vervuld, rijst de vraag hoeveel ruimte het bestuur heeft bij het bepalen op welke manier de gedelegeerde bevoegdheid wordt ingevuld. Ook hier is van belang of, en zo ja in welke mate, de wetgever blijkens de wettelijke basis van de delegatie het bestuursorgaan beleidsruimte en dus beleidsvrijheid heeft gegeven. Dat delegatie niet zonder gevaar is voor de democratische legitimatie van regelgeving blijkt uit de opmerking van Scheltema die stelt ${ }^{40}$ :

"Kortom door veelvuldige delegatie van wetgeving en door het toekennen van een grote beleidsvrijheid aan de 'uitvoerende macht' worden de garanties die in het optreden van de wetgever besloten liggen, uitgehold."

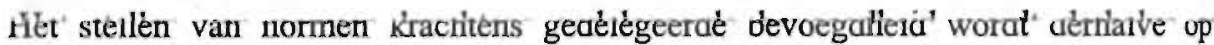
verschillende wijzen begrensd. Dit gebeurt zowel door de delegatiebepaling als zodanig, door de strekking van de wet, als door de geschreven en ongeschreven rechtsbeginselen. ${ }^{41}$ De mate van beslissingsruimte die het bestuur heeft bij het gebruik van zịn gedelegeerde bevoegdheid, is ondermeer afhankelijk van de beoordelingsruimte en de beleidsruimte die het op het betreffende gebied heeft.

De vraag of het bestuur de bevoegdheid heeft tot het opnemen van zorgplichtbepalingen in uitvoeringsbesluiten, moet onder andere worden bepaald aan de hand van de wet in formele zin, en de strekking daarvan. Deze heeft het bestuur de bevoegdheid gegeven een (uitgebreid) stelsel van nadere normstellingen te ontwikkelen. Zorgplichtbepalingen met vage bestanddelen hebben een eigen karakter in vergelijking tot andere (meer specifieke) bepalingen. De bevoegdheid om zorgplichtbepalingen op te nemen kan niet zonder meer worden aangenomen. ${ }^{42}$ Het lijkt veeleer aangewezen dergelijke (uit een oogpunt van rechtsbescherming vaak

175-186.

40 Scheltema, M., "Preadvies; Dient wijziging te worden gebracht in het proces van wetgeving?", p. 71.

41 Zie in het algemeen over de normering van bestuurshandelen bijvoorbeeld Nicolai, P., Olivier, B.K., Vlies, I.C. van der, Damen, L.J.A. en Schueler, B.J., Bestuursrecht, pp. 233-304.

42 Zie ook hoofdstuk 3 paragraaf 7.3.3. 
disatabele) strafbaarstellingen, met oog op het legaliteitsbeginsel ${ }^{43}$, indien daartoe de noolzaak bestaat, op te nemen in de wet in formele zin.

\subsection{Belangenafweging bij besluitvorming door het bestuur}

Blijt staan de vraag welke belangen het bestuur in de besluitvorming moet betrekken bij let vaststellen van de materiële norm die het doel van de wettelijke regeling behrtigt. Involge artikel 3:4, eerste lid Awb zal in Nederland het bestuursorgaan de rechstreeks bij dat besluit betrokken belangen moeten afwegen, voor zover niet uit een wettelijk voorschrift of uit de aard van de uit te oefenen bevoegdheid een bepeking voortvloeit. ${ }^{44}$ De wetgever heeft hier een algemene wettelijke grondslag gegeren voor het in aanmerking nemen van belangen waarop de wettelijke bepaling niet echtstreeks ziet. Deze belangen moeten nu door het bestuur worden meegewogen in d besluitvorming. Hierdoor is een speciale motivering vereist waarom sommige belagen niet een rol zouden mogen spelen bij het te nemen besluit. ${ }^{45}$

Een leugdelijke besluitvorming door het bestuursorgaan vereist dus in ieder geval dat de blangen die het wettelijk voorschrift beoogt te beschermen worden betrokken bij de aweging. ${ }^{46}$ Voorlopig is echter nog onduidelijk welke belangen ex artikel $3: 4$, eerst lid Awb door het bestuur moeten worden meegewogen. ${ }^{47}$ In ieder geval heeft het lestuursorgaan zich te houden aan eventuele in de wet opgenomen bepalingen die

43 Zie ook. Vlies, I.C. van der, Het wetsbegrip, en beginselen van behoorlijke regelgeving, pp. $81-82$.

44 Deze bepaling is rechtstreeks van toepassing op andere besluiten dan algemeen verbindende voorschriften; rechtstreeks op algemeen verbindende voorschriften voor zover de aard van de besluiten zich daartegen niet verzet. Op andere handelingen van bestuursorganen dan besluiten is het artikel overeenkomstig van toepassing voor zover de aard van de handeling zich daar niet tegen verzet. Zie artikel 3:1 Awb. Zie daarover Wijk, H.D. van, bewerkt door Konijnenbelt, W. en Male, R.M. var, Hoofdstukken van bestuursrecht, p. 342.

45 Konijnenbelt, W., "Het specialiteitsbeginsel in het Nederlandse en het Franse, administratieve recht", pp. 309-310. Zie over het specialiteitsbeginsel in het bestuursrecht Schlőssels, R.J.N., Het specialiteitsbeginsel.

46 De plicht tot het afwegen van belangen is ondergeschikt aan het bevoegdheidsbeginsel, hetgeen onder andere blijkt uit het feit dat artikel 3:4, eerste lid Awb ondergeschikt wordt geacht aan artikel 3:3 Awb (verbod détournement de pouvoir). Zie Schlössels, R., "Het specialiteitsbeginsel en derdebelangen: een frisse benadering of rechtsstatelijk drijfzand?", p. 86; Nicolaï, P., Olivier, B.K., Vlies, I.C. van der, Damen, L.J.A. en Schueler, B.J., Bestuursrecht, p. 441. Zie hierover ook: Stoter, W.S.R., De belangenafweging door de wetgever.

47 Wijk, H.D. van, bewerkt door Konijnenbelt, W. en Male, R.M. van, Hoofdstukken van. bestuursrecht, pp. 342-345; Schlössels, R., "Het specialiteitsbeginsel en derdebelangen: een frisse benadering of rechtsstatelijk drijfzand?", pp. 81-86; Konijnenbelt, W., "Het specialiteitsbeginsel in het. Nederlandse en het Franse administratieve recht", pp. 309-310 en Nicolaĭ, P., Olivier, B.K., Vlies, L.C. van der, Damen, L.J.A. en Schueler, B.J., Bestuursrecht, pp. 442-446. 
aanvullende criteria aangeven ${ }^{48}$, bijvoorbeeld in de vorm van uitdrukkelijke weigeringsgronden, het soort voorschriften dat (uitsluitend) aan een besluit mogen worden verbonden, en beperkingen betreffende de mee te wegen belangen. ${ }^{49}$ Ook uit criteria die niet in de wet in formele zin zijn opgenomen kunnen beperkingen voor het bestuur voortvloeien. Deze beperkende criteria zijn dan bijvoorbeeld te vinden in (op hoger niveau) vastgestelde uitvoeringsbesluiten, kwaliteitsdoelstellingen ${ }^{50}$ en beleidsdocumenten.

Met betrekking tot de vraag naar de toelaatbaarheid ten principale van handelingen waarvoor een vergunning wordt aangevraagd, mogen alleen de belangen worden meegewogen van de aanvrager van de vergunning en de belangen die de wettelijke regeling dienen, waarop het vergunningvereiste berust. Indien de afweging op basis van bovenstaande punten leidt tot de uitkomst dat de vergunning in beginsel kan worden verleend, dan moeten vervolgens de belangen van de toekomstige vergunninghouder worden afgewogen tegen die van andere belanghebbenden. Dit wil zeggen tegen alle belangen die rechtstreeks bij het besluit zijn betrokken. ${ }^{51}$ Bepaalde particuliere belangen dienen vanwege hun aard uitgesloten te worden van deze afweging. Dit geldt onder andere voor belangen die door een andere bestuursrechtelijke regeling worden beschermd. ${ }^{52}$

Het bestuursorgaan dient dus zorgvuldig zowel het doel van de wettelijke regeling als bepaalde particuliere belangen te betrekken in de belangenafweging die uiteindelijk

48 Zie bijvoorbeeld artikel 8.40, eerste lid Wm, dat blijkens artikel 8.1 , tweede lid Wm de bevoegdheid geeft tot het voor inrichtingen stellen van amvb's die de algemene vergunningplicht opheffen. De totstandkoming van deze amvb's vindt plaats met toepassing van artikel $21.6 \mathrm{Wm}$ waarvan het eerste lid luidt: "Bij de vaststelling, wijziging of intrekking van een algemene maatregel van bestuur krachtens deze wet wordt rekening gehouden met het geldende nationale milieubeleidsplan."

49 Een ander voorbeeld is dat voor vergunningen op basis van hoofdstuk 8 . Wm blijkens artikel 8.8 , tweede lid Wm de eis geldt dat het bevoegd gezag bij de beslissing op aanvraag in ieder geval rekening moet houden met het voor hem geldende milieubeleidsplan en de voor de onderdelen van het milieu, waarvoor de inrichting gevolgen kan hebben, geldende richtwaarden, voor zover de verplichtingen tot het rekening houden daarmee is vastgelegd krachtens of overeenkomstig artikel 5.2 .

50 De regeling inzake het stellen van kwaliteitseisen is in Nederland onder meer te vinden in hoofdstuk 5 van de Wet milieubeheer. Zie daarover Michiels, F.C.M.A., De Wet milieubeheer, pp. 130-146. Het betreft hier zogenaamde emissienormen die voor een bepaald gebied moeten worden gehaald. Zie over het belang van deze milieukwaliteitsdoelstellingen onder andere Backes, Ch., Juridische bescherming van ecologiseh waardevolle gebieden, pp. $233-240$ en Tonnaer, F.P.C.L., Handboek van he! Nederlandse milieurecht, pp. 521-538.

51 Onder het begrip belanghebbende wordt blijkens artikel 1:2 Awb verstaan: "degene wiens belang rechtstreeks bij een besluit is betrokken."

52 Zie over af te wegen belangen op basis van artikel 3:4, eerste lid Awb: Konijnenbelt, W, "Het specialiteitsbeginsel in het Nederlandse en het Franse administratieve recht", p. 310 en Schlossels, R. "Het specialiteitsbeginsel en derdebelangen: een frisse benadering of rechtsstatelijk drijfzand?", pp. 85-86; Schlössels, R., Het specialiteitsbeginsel. 
leid tot de vaststelling van de materiële inhoud van besluit. Het abstracte gevarzettingsdelict dat in de wet is opgenomen en waarvan de materiële norm door het bestuur wordt ingevuld, wordt derhalve ingevuld door de door het bestuur gemaakte belangenafweging. De op basis van de wet in formele zin te beschermen rechtsgoederen worden door deze abstracte gevaarzettingsdelicten door het strafrecht niet zwaarder beschermd dan het beschermingsniveau dat het bestuur, in de belangenafweging eraan heeft toegekend. De mate van bescherming die door deze strafoepalingen wordt geboden zal ook daarom wisselen.

De strafrechtelijke bescherming via deze gelede normstellingen gaat derhalve uit van een primaire belangenafweging door het bestuur. Loopt die afweging, om welke reden ook, spaak en reflecteert het resultaat van de afweging niet (of in onvoldoende mate) het rechtens te beschermen belang. Het strafrecht kan dan via deze bepalingen de nooczakelijke bescherming ook niet bieden.

\subsection{Het bestuur definieert}

Uit het voorafgaande volgt dat het correct is te stellen dat abstracte gevarzettingsdelicten, waarvan de materiële normen via gelede normstellingen door het bestuur worden vastgesteld, de door het bestuur gemaakte belangenafweging beschermen. Het resultaat daarvan zou echter meer moeten zijn dan de bescherming van "administratieve belangen".

Natuurlijk bestaan er vele soorten verschillend geformuleerde bepalingen op basis waarvan het bestuur de bevoegdheid heeft tot regelgeving. De vrijheid van het bestuur bij de vaststelling van lagere regelgeving en aanvullende criteria kan daardoor sterk uiteenlopen. In het algemeen blijken de strafbepalingen uit de wet in formele zin (op basis waarvan deze materiële normstellingen zijn strafbaar gesteld) echter tamelijk eenvoudig te zijn geformuleerd, waardoor ze weinig tot geen specifieke eisen stellen aan de voorwaarden voor strafbaarheid. Het gevolg is dat ook veeleer specifieke bestuursrechtelijke belangen onder het bereik van deze strafbaarstellingen kunnen vallen. De strafbepaling wordt vaak immers reeds geschonden zodra niet overeerkomstig de materiële nomstelling (afkomstig van het bestuur) wordt gehandeld, terwijl het handelen conform de door het bestuur vastgestelde normen bovendien vrijwel altijd strafuitsluitend werkt.

De vrijheid van het bestuur bij regelgeving loopt sterk uiteen, aangezien de bescherming van de door de bevoegdheidverlenende wetgeving beschermde rechtsgoederen naast de strafbaarstelling onder andere afhankelijk is van elders (bijvoorbeeld in de wet, hogere regelgeving en beleidsdocumenten) aangegeven beperkende criteria. Daamaast spelen als beperkende factoren bij deze vrijheid ook de algemene beginselen van behoorlijk bestuur en andere algemene beginselen een rol. Zo dient het bevoegde bestuursorgaan op grond van de in de Awb gecodificeerde algemene beginselen van behoorlijk bestuur in ieder geval het doel van de wettelijke regeling en bepaalde particuliere belangen te betrekken in de belangenafweging die uiteindelijk leidt tot de vaststelling van de beschikking, die invulling geeft aan de 
materiële inhoud van een dergelijke strafbaarstelling. Daarbij geldt voor het bestuur de eis dat een bevoegdheid niet voor een ander doel mag worden gebruikt dan die waarvoor hij is gegeven. Per normstelling zal niet alleen het doel van de wetgeving en de betreffende bepaling anders zijn, ook de inhoud van de rechtstreeks bij het besluit betrokken belangen die in de afweging door het bestuur moeten worden meegenomen zal wisselen. Dit alles maakt dat het geboden beschermingsniveau voor de door de wetgeving beschermde rechtsgoederen via abstracte gevaarzettingsdelicten met gelede normstellingen, sterk zal uiteenlopen.

Gebleken is dat de beperkende factoren voor de vrijheid van het bestuur bij het vaststellen van de inhoud van regelgeving sterk kunnen wisselen. De bevoegdheidsverlenende en -beperkende factoren blijken in de praktijk vaak ruimte te geven om. een zorgplichtbepaling op te nemen als bepaling die deel uitmaakt van de materiële inhoud van een abstract gevaarzettingsdelict.

\section{Bestanddeel of strafuitsluitingsgrond \\ 6.1. Inleiding}

De wetgever kan het schenden van criteria die worden vastgesteld door het bestuur strafbaar stellen. Indien de materiële inhoud van de strafbaarstelling alleen maar is te vinden in de door het bestuur vastgestelde regeling, is het deel van de door het bestuur vastgestelde regeling waamaar het abstracte gevaarzettingsdelict verwijst bestanddeel van de strafbaarstelling. Een duidelijk voorbeeld van een dergelijke strafbaarstelling is, naast de in hoofdstuk 4 paragraaf 5 genoemde artikelen uit de Gemeentewet, Provinciewet en Waterschapswet, artikel $18.18 \mathrm{Wm}$ dat luidt "Een gedraging in strijd met een voorschrift dat is verbonden aan een krachtens deze wet verleende vergunning of ontheffing, is verboden." ${ }^{n 3}$

Vaak is de strafbaarstelling uit de wet in formele zin specifieker vormgegeven. Aangezien onder het bereik van strafbaarstellingen niet meer maar ook niet minder gedragingen dienen te vallen dan beoogd, kan de wetgever het bereik van de strafbepaling preciseren door aanvullende criteria aan te geven. Dit kan hij doen door de gedraging strafbaar te stellen onder bepaalde voorwaarden, bijvoorbeeld door het aangeven van de omstandigheden waaronder de gedraging moet plaatsvinden en/ of door het aangeven van het gevolg dat door de gedraging moeten worden veroorzaakt. Deze omstandigheden of gevolgen maken in dat geval in het algemeen als bestanddeel deel uit van de delictsomschrijving. Zo stellen de artikelen 173a en 173b Sr

53 Een veel voorkomende praktijk is om as de vergunning de vergunningaanvraag te hechten en in de vergunning te verwijzen naar de bepalingen uit de aanvraag. Indien deze worden gesehonden levert dat echter geen schending van artikel $18.18 \mathrm{Wm}$ op omdat artikel I Sr niet toelaat dat het bestanddeel "voorschrift" wordt uitgebreid tot al hetgeen in de vergunningaarıvraag is opgenomen." Hof "s-Hertogenbosch 15 oktober 1998, MenR 1999, nr. 27, met noot de Lange (Rutte II). 
bijoorbeeld als voorwaarde dat het moet gaan om een stof die in de bodem, de lucht of a het oppervlaktewater wordt gebracht. Daarnaast vereisen deze artikelen dat ten geolge van de emissie bijvoorbeeld gevaar voor de openbare gezondheid of levensgevar voor een ander te duchten is.

Dewetgever kan de strafbaarstelling ook (nog verder) preciseren door in de deltsomschrijving naast enkele specifieke bestanddelen een bestanddeel op te nemen datverwijst naar de bestuurlijke norm. Deze aanvullende criteria vormen dan (mede) de ateriële norm van de strafbaarstelling voor de normadressaat van de bestuurlijke reglgeving. Zo zijn in de bovengenoemde artikelen 173a en 173b Sr ook het besinddeel "wederrechtelijk" te vinden. In de memorie van toelichting wordt over dit besinddeel onder andere gesteld ${ }^{54}$ :

"In e voorgestelde bepalingen wordt beoogd hiermee het volgende aan te geven. Verschillende bijzndere milieuwetten kennen het vereiste van een vergunning voor het verrichten van daarbij omshreven handelingen die verband houden met het milieu. Handelt iemand in overenstemming met zo een vergunning, dan is dit niet wederrechtelijk. Ook al zou hij voor het ovege voldoen aan alle bestanddelen van de voorgestelde bepaling, dan nog is zijn handelen niet trafbaar. Niet alle bestanddelen van het strafbaar feit zijn aanwezig en in geval van een vervlging zou een vrijspraak moeten volgen. Het is dus niet nodig dat hij zich op een strafitsluitingsgrond beroept."

Hieait blijkt dat de wetgever van mening is dat bij deze bepalingen degene die zich conform de door het bestuur vastgestelde regels gedraagt, niet wederrechtelijk handelt. De consequentie daarvan is dat degene die overeenkomstig de aan hem verleende vergunning en de daarin beschreven voorwaarden stoffen in het milieu brengt, involge artikel 173a en 173b Sr in beginsel niet strafbaar is wegens de niet bewijsbaarheid van het bestanddeel wederrechtelijk. Een beroep op een strafuitsluitingsgrond is daarvoor niet nodig. ${ }^{55}$

Een andere veel gehanteerde methode om het bereik van een strafbaarstelling te preciseren is het opstellen van een algemeen ge- of verbod waaraan één of meer uitzonderingen zijn gevoegd. Zie bijvoorbeeld artikel $8.1 \mathrm{Wm}$ op basis waarvan het is verboden een inrichting op te richten zonder een daartoe verleende vergunning. Lang niet altijd is echter duidelijk of deze uitzondering is aan te merken als een bestanddeel

54 TK 1984-1985, 19 020, nirs. 1-3, p. 13. Buiting en Huygen bekritiseren deze keuze en stellen dat het eenvoudiger en dogmatisch beter zou zijn geweest indien de wetgever zou hebben gekozen voor het minder ruime begrip "zonder of in strijd met een vergunning". Buiting, Th.J.B. en Huygen, A.E.H., "Milieustrafrecht: een ondoordachte chaos", p. 91. Zie hierover ook Koopmans, L.M., De strafbaarstelling van milietverontreiniging, p. 37; Faure, M. en Visser, M., De strafrechtelijke bescherming van het leefmilieu in België, Duitsland en Nederland, pp. 234-242.

55 Zie ook Koopmans, I.M., De strafbaarstelling van milieuverontreiniging, p. 35. Zij trekt uit dit deel van de MvT de conclusie dat: "Hieruit kan worden afgeleid dat diegene die zich niet conform de door het bestuur vastgestelde regels gedraagt, wederrechtelijk handelt." 
of als een bijzondere strafuitsluitingsgrond ${ }^{56}$, die ook wel fait d'excuse worden genoemd. ${ }^{57}$ Dit probleem wordt in hier verder onderzocht.

\subsection{Bestanddeel of element}

De voorwaarden dat het feit en de dader strafbaar moeten zijn worden niet altijd uitdrukkelijk door de wetgever opgenomen als bestanddelen van de delictsomschrijving. De wetgever gaat bij het formuleren van de delictsomschrijving uit van de "normale" mens in de "normale" situatie, zodat als de bestanddelen zijn vervuld meestal kan worden aangenomen dat de gedraging in strijd is met het recht en dat het de dader valt te verwijten. Afhankelijk van de strafbaar gestelde gedraging worden de voorwaarden dat de gedraging wederrechtelijk en aan schuld te wijten dient te zijn, soms opgenomen in de delictsomschrijving. Indien wederrechtelijk en schuld echter geen bestanddeel zijn, vormen zij als element voorwaarden voor strafbaarheid.

Strafuitsluitingsgronden kunnen de wederrechtelijkheid van het feit of de schuld van de verdachte aantasten. Zij refereren aan buitengewone of abnormale omstandigheden waaronder de strafbare gedraging heeft plaatsgevonden en leveren mitsdien een contra-indicatie op voor de algemene aanname dat de gedraging die de bestanddelen van de delictsbestanddelen vervult strafbaar is ${ }^{58}$ Naast de algemene strafuitsluitingsgronden in het eerste boek van het Wetboek van Strafrecht zijn er bijzondere strafuitsluitingsgronden die slechts betrekking hebben op één of enkele verwante delicten en ongeschreven strafuitsluitingsgronden.

Een gedraging conform een door het bestuur vastgestelde norm (bijvoorbeeld in een algemene maatregel van bestuur of beschikking) zal in het algemeen niet strafbaar zijn. ${ }^{59}$ De gedraging valt niet onder de reikwijdte van de strafbaarstelling indien deze uitzondering is opgenomen als specifiek bestanddeel of als "wederrechtelijk" is opgenomen als bestanddeel. Ook indien een dergelijk bestanddeel geen deel uitmaakt van de bepaling, wordt door de door het bestuur verleende toestemming de strafbaarheid van het feit weggenomen. In dat geval zal meestal de wederrechtelijkheid als element ontbreken. ${ }^{60}$ De door het bestuur vastgestelde norm is in die gevallen aan te merken als een geschreven bijzondere rechtvaardigingsgrond. ${ }^{61}$ Geschreven; niet

56

57

58

59

60

61

Het betreft overigens altijd een bijzondere rechtvaardigingsgrond.

Zie André de la Porte, E., "Commentaar bij artikel 26I".

Zie ook Wemes, L.T., "Uitsluiting en verhoging van strafbaarheid", p. 192.

Een uitzondering betreft het geval dat de betrokkene wist of had moeten weten dat de beschikking ten onrechte was afgegeven of als zij werd verleend op door de verkrijger verstrekte onjuiste of misleidende informatie. Zie hoofdstuk 5.

Ook kan de verwijtbaarheid ontbreken. Zo kan bijvoorbeeld degene die, zij het achteraf ten onrechte, doch wel vergeeflijk, op een ongeldige toestemming of beschikking heeft vertrouwd, zich doorgaans met vrucht beroepen op avas. Zie hoofdstuk 5 paragraaf 7 .

Remmelink beschouwd de "toestemming" als een van de vijf groepen van ongeschreven rechtvaardigingsgronden waarbij de materiële wederrechtelijkheid ontbreekt. Zie Remmelink, J., Mr. D. Hazewinkel-Suringa's Inleiding tot de studie van het Nederlandse strafrechi, pp. 354-356. 
alleen is de algemene maatregel van bestuur of de beschikking geschreven, maar het bestuur zal de bevoegdheid om deze norm vast te stellen ontlenen aan een wettelijk voerschrift. Bijzonder; de norm waarmee de verdachte in overeenstemming handelde heeft geen algemene werking, maar beperkt zich tot één of enkele verwante strafbaarstellingen. Rechtvaardigingsgrond; de strafbaarheid van het feit wordt weggenomen.

\section{3}

\section{Processuele consequenties}

De beantwoording van de vraag of een uitzondering als bestanddeel dan wel als bijzondere strafuitsluitingsgrond dient te worden aangemerkt heeft vergaande consequenties in het strafproces, aangezien het OM de bestanddelen ten laste moet leggen en bewijzen, voordat kan worden getoetst of de bewezen verklaarde gedraging volloet aan de wettelijke delictsomschrijving. Indien de bewezen gedraging niet is te kwalificeren zal de verdachte moeten worden ontslagen van rechtsvervolging. ${ }^{62}$ Strafuitsluitingsgronden hoeven daarentegen niet te worden bewezen en de aanvaarding is niet gebonden aan de wettelijke bewijsmiddelen; het is voldoende als deze door de strafrechter niet onaannemelijk worden bevonden. ${ }^{63}$

Inden het aanvullend criterium wordt aangemerkt als strafuitsluitingsgrond, zal het opremen van dit criterium processueel weinig of geen meerwaarde hebben. Indien het criterium niet is opgenomen zal immers de strafbaarheid ook ontbreken omdat de gedraging niet "wederrechtelijk" is. Hooguit wijst het betrokkenen hier extra (maar ten overvloede) op. Ook inhoudelijk kan de meerwaarde ontbreken. Slechts indien het aanvullend criterium niet geheel onder de reikwijdte van de ingevolge artikel $350 \mathrm{~Sv}$ vereiste wederrechtelijkheid valt is deze aanwezig. Bij de hier besproken situatie (handelen in strijd met een strafbaarstelling maar conform een door het bestuur vastgestelde norm) lijkt dit zich in beginsel niet voor te doen. ${ }^{64}$

62 Artikel 352, tweede lid Sv. Sinds 1860 is het vaste rechtspraak dat het ontbreken van een bestanddeel in de tenlastelegging leidt tot ontslag van rechtsvervolging en niet tot nietigheid van de dagvaarding; zie HR 19 december $1960, W .2244$ : "Het ontbreken van eer bestanddeel tast (...) de geldigheid van de dagvaarding als zodanig niet aan, maar kan, bij bewezenverklaring van het ten laste gelegde, slechts tot ontslag van rechtsvervolging ieiden: het bewezen verklaarde is dan niet "congruent" aan de vereisten van de strafbepaling."

63 Zie daarover Buiting, Th.J.B. en Huygen, A.E.H., "Milieustrafrecht: een ondoordachte chaos", pp. 73-74 en Hendriks, L.E.M. en Wöretshofer, J., Milieustrafrecht, pp. 34-35.

64 Betoogd wordt dat het bestaan van bijzondere strafuitsluitingsgronden vooral de opportuniteit van strafrechtelijke sanctionering wegneemt. Zie Keulen, B.F. Economisch strafrecht, pp. 65-66. Bij het vermoeden dat sprake is van een strafuitsluitingsgrond zal het $\mathrm{OM}$ vaak afzien van vervolging, indien een technischjuridische hinderpaal (zoals bijvoorbeeld het ontbreken van de wederrechtelijkheid) de veroordeling in de weg lijkt te staan. Ook zal het op gronden aan het algemeen belang ontleend onwenselijk zijn de zaak aan de rechter voor te leggen, omdat de berechting en mogelijke veroordeling niet gewenst is. Zie over het technisch- en beleidssepot: Franken, AA, "Alternatieve afdoeningsmogelijkheden", 23.7.; Reijntjes, J.M., "Artikel 167; beslissing omtrent vervolging", aantekening la; Corstens, G.J.M., Het Nederlands strafprocesrecht, p. 486. 
In het algemeen wordt het bestaan van een mogelijke strafuitsluitingsgrond door de verdachte of diens raadsman ter terechtzitting aan de orde gesteld. Dit hoeft overigens niet; ook het OM kan dit doen. ${ }^{65}$ Als de rechter (eventueel ambtshalve ${ }^{66}$ ) het bestaan van een strafuitsluitingsgrond aanneemt, volgt ontslag van rechtsvervolging. Indien de strafuitsluitingsgrond door het $\mathrm{OM}$ in de tenlastelegging is opgenomen dient hij wel op grond van een wettig bewijsmiddel bewezen te worden verklaard. Indien het niet in dit bewijs slaagt zal de verdachte moeten worden vrijgesproken. ${ }^{67}$

Uit het voorafgaande volgt dat het voor het OM voordelen heeft indien de strafbaarstelling wordt gepreciseerd door een bijzondere strafuitsluitingsgrond in plaats van door een bestanddeel. Het zal dan immers minder hoeven ten laste te leggen en te bewijzen. Voor de verdachte zal het daarom juist gunstiger zijn indien het criterium is opgenomen in een bestanddeel. ${ }^{68}$

Wanneer onduidelijkheid bestaat of een aanvullend criterium dient te worden aangemerkt als een bestanddeel of als een strafuitsluitingsgrond lijkt het op het eerste gezicht voor de hand te liggen dat het $\mathrm{OM}$ dit criterium ten laste legt. ${ }^{69}$ Indien het een bestanddeel blijkt te zijn wordt dan immers voorkomen dat het bewezen feit niet te kwalificeren zal zijn. Als het OM hier echter toe over gaat en het criterium blijkt een strafuitsluitingsgrond te zijn, zal het door het ten laste te leggen de zaak nodeloos ingewikkeld en tijdrovend maken met een verhoogde kans op straffeloosheid van de

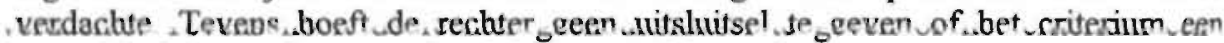
bestanddeel dan wel een strafuitsluitingsgrond is, zodat het $\mathrm{OM}$ een volgende keer waarschijnlijk opnieuw het criterium zal opnemen in de tenlastelegging.

Deze problemen kunnen worden voorkomen door het criterium niet ten laste te leggen. Indien ontslag van rechtsvervolging volgt kan het in hoger beroep op grond van artikel $313 \mathrm{~Sv}$ wijziging van de tenlastelegging vorderen. Het criterium kan dan alsnog worden opgenomen in de tenlastelegging. De verhoogde kans op straffeloosheid in eerste aanleg kan het OM ook voorkomen door gebruik te maken van een samengestelde of een alternatieve tenlastelegging. In het eerste geval legt het $\mathrm{OM}$ het criterium primair niet en subsidiair wel ten laste, terwijl het in het tweede geval deze twee varianten altematief ten laste legt. Deze methoden zijn wat tijdrovender en ingewikkelder, maar voorkomen dat over de vragen of het feit en of de dader strafbaar

65 Zie bijvoorbeeld HR 17 november 1992, NJ 1993, 267, met noot Van Veen (Aannemelijke overmacht).

66 De strafrechter zal de mogelijkheid van de aanwezigheid van een strafuitsluitingsgrond op eigen initiatief slechts onderzoeken als hij bij het onderzoek ter terechtzitting daar aanleiding toe ziet. Zie André de la Porte, E., "Commentaar bij artikel 261", nr. 36.

67 Tevens is de omschrijving van de strafbepaling belangrijk bij het vaststellen of er sprake is van voorbereidingshandelingen, poging, deelneming of andere vormen van daderschap. Hierbij spelen de bestanddelen van het gronddelict wederom een grote rol.

68 Zie André de la Porte, E., "Commentaar bij artikel 261", nr. 36, p. 79.

69 André de la Porte, E., "Commentaar bij artikel 26l", nr. 36; Taveme in noot onder HR 24 april 1939, $N J$ 1939, 1017 ("Tenzij" dan bestanddeel); Taverne in noot onder HR 20 oktober 1941, NJ 1942, 60 (Boven de gemeentegrond). 
is ıaar door één feitelijke instantie wordt beslist. ${ }^{70}$ Tevens dient de rechter bij de kwlificatie van het bewezen feit een keuze te maken, zodat op dit punt (ook voor toeomstige gevallen) duidelijkheid wordt verkregen op welke manier de strafbaarsteing moet worden geïnterpreteerd.

Bijanvullende criteria (voorwaarden) in de regelgeving die de wederrechtelijkheid varde gedraging beperken of uitbreiden, kan zoals gezegd onduidelijkheid bestaan of zij estanddeel zijn van de delictsomschrijving of een strafuitsluitingsgrond. Dit speelt vocal bij strafbaarstellingen in de sociaal-economische sfeer $^{71}$, waar (meestal via gelde normstellingen) aanvullende criteria worden aangegeven, bijvoorbeeld in de von van uitzonderingen op of voorwaarden voor de strafbare gedragingen. Dergelijke critria kunnen in dezelfde maar ook in een aparte zin, een ander artikellid of een andre bepaling zijn opgenomen. Het achterhalen wat bestanddeel is van een delitsomschrijving kan nog verder worden gecompliceerd door het gebnik van defiitiebepalingen, verwijzingen naar uitzonderingen ${ }^{72}$ en het beperken van uitznderingen. ${ }^{9 / 3}$ Over de vraag welke aanvullende criteria nu deel uitmaken van de

70 Slechts indien terugverwijzing of verwijzing na cassatie plaatsvindt wordt hierover door de feitenrechter opnieuw beslist.

71 Zie Remmelink, J., Mr. D. Hazewinkel-Suringa's Inleiding tot de studie van het Nederlandse strafrecht, p. 253.

72 Artikel 8.1, eerste lid Wm stipuleert een algemene vergunningplicht voor inrichtingen: "Het is verboden zonder daartoe verleende vergunning een inrichting: a. op te richten; b. te veranderen of de werking daarvan te veranderen; $c$. in werking te hebben." Maar deze plicht geldt blijkens het tweede lid niet onbeperkt: "Het verbod geldt niet met betrekking tot inrichtingen, behorende tot een categorie die bij een algemene maatregel van bestuur krachtens artikel 8.40, eerste lid, is aangewezen, behoudens in gevallen waarin, krachtens de tweede volzin van dat lid, de bij die algemene maatregel gestelde regels niet gelden voor cen zodanige inrichting." Terwijl involge artikel $1.1 \mathrm{Wm}$ in deze wet onder inrichting wordt verstaan: "elk door de mens bedrijfșmatig of in omvang alsof zij bedrijfsmatig was, ondernomen bedrijvigheid die binnen een zekere begrenzing pleegt te worden verricht."

73 Zie bijvoorbeeld artikel i Wvo. In de verbodsnorm uit artikel 1 , eerste lid Wvo is al een uitzondering opgenomen. Dit artikel luidt: "Het is verboden zonder vergunning met behulp van een werk afvalstoffen, verontreinigende of schadelijke stoffen, in welke vorm ook, te brengen in oppervlaktewateren." Op dit algemene verbod wordt in het tweede lid opnieuw een uitzondering gemaakt die op haar beurt ook weer niet onbeperkt geldt. Het tweede lid luidt: "Flet verbod, bedoeld in het eerste lid, geldt niet voor een lozing met behulp van een werk dat op een ander werk is aangesloten. Deze uitzondering geldt niet voor lozingen waarbij door Ons bij algemene maatregel van bestuur aan te wijzen stoffen in oppervlaktewateren worden gebracht en voor lozingen vanuit door Ons bij algemene maatregel van bestuur aan te wijzen soorten van inrichtingen, voor lozingen van ten minste een door Ons bij algemene maatregel van bestuur vast te stellen hoeveelheid verontreinigende stoffen of afvalwater, alsmede voor lozingen met behulp varn een werk, niet zijnde een voorziening als bedoeld in artikel 10.15, eerste lid, van de Wet milieubeheer, dat is aangesloten op een inrichting, in gebruik bij een provincie, een gemeente, een waterschap of een ander openbaar lichaam 
delictsomschrijving lopen de meningen uiteen. ${ }^{74}$ Wel lijkt de doctrine het er over eens dat het uiterst moeilijk is voor dit onderscheid een materieel criterium aan te leggen. ${ }^{75}$ Het zijn vooral crimineelpolitieke motieven die in concreto het antwoord op de vraag zullen bepalen. ${ }^{76}$

\subsection{Aanvullende criteria; de hoofdregel}

Het beantwoorden van de vraag welke aanvullende criteria als bestanddeel en welke als bijzondere strafuitsluitingsgrond zijn aan te merken is, afgezien van de procesrechtelijke implicaties, ook van belang voor het vaststellen van de reikwijdte van de strafbaarstelling. Als uitgangspunt bij de beantwoording wordt de wil van de wetgever genomen. ${ }^{77}$ Dit geldt voor zowel de wetgever in formele als in materiële zin. Hierdoor is het noodzakelijk per artikel interpretatiegewijs deze vraag te beantwoorden.

Aangezien de bedoeling van de wetgever niet behoeft te blijken uit de redactie van de bepaling en omdat overigens ook zijn bedoeling moeilijk te achterhalen kan zijn, wordt vaak gewerkt met een formeel criterium, te weten ${ }^{78}$ :

voor het zuiveren van afvalwater."
74 Zie over deze vraag bijvoorbeeld: Remmelink, J., Mr. D. Hazewinkel-Suringa's Inleiding tot de studie van het Nederlandse strafrecht, pp. 253-257; Buiting. Th.J.B., Strafrecht en milieu, pp. 45-71; Keulen, B.F., Economisch Strafrecht, pp. 23-30; Bemmelen, J.M. en Veen, Th.W. van, bewerkt door Jong, D.H. de en Knigge, G., Het materiële strafrecht, pp. 52-56; Vellinga, W.H., "Strafwetgeving als techniek van regel en uitzondering", pp. 359-368; Jong, D.H. de, De macht van de tenlastelegging, Pompe, W.P.J., Handboek van het Nederlandse strafrecht, pp. 69-80; Remmelink, J., "Visies op telastelegging", pp. 432-435; André de la Porte, E., "Commentaar bij artikel 261", nrs. $35-41$.

75 Ook spoedig na de totstandkoming van het Wetboek van Strafrecht en de opkomst van het bijzondere strafrecht werd de vraag naar de onderscheidend criterium al gesteld. Zie bijvoorbeeld Feltz, A.A. van der, "Element of Fait justificatif"; Besier, L.Ch., "Rechtvaardigingsgrond of bestanddeel van het strafbaar feit?"; Wijnbergen, A. van, "Element van strafbaar feit, of fait d'excuse, in eene verbodsbepaling met 'tenzij"' en Langemeijer, G.E., "Beweringslast en bewijsrisico in het strafproces".

76 Röling, B.V.A.R, Noot onder HR 24 november 1953, NJ 1954, 37 (Vastgelegde hond); "Theoretisch is het cen questie van criminele politiek. Wat wil men telastgelegd hebben en negatief-wettelijk door het O.M. bewezen? T.a.v. welke omstandigheden is telastelegging niet nodig, verawaring van de taak van de verdachte en vrij bewijs te prefereren?" Zie ook zijn noot onder HR 14 december 1954, NJ 1955, 118 (Herbebossing).

77 Buiting hanteert een ander uitgangspunt, want hij beantwoordt de vraag wat bestanddeel is en wat niet aan de hand van twee criteria: is de vergunning een essentieel onderdeel van de regeling en is dit in het zinsverband tot uitdrukking gebracht? Voor verwijzingen naar algemene maatregelen van bestuur en ministeriële beschikkingen hanteert hij dezelfde methode, namelijk dat in beginsel de gekozen formulering beslissend is, tenzij van een andere bedoeling blijkt. Deze benadering zal waarschijnlijk tot dezelfde uitkomsten leiden als de door de Hoge Raad en de meeste schrijvers gehanteerde methode. Buiting, Th.J.B., Strafrecht en milieu, pp. 49-50.

78 Leijten in zijn conclusie bij HR 13 september 1994, NJ 1994, 746 (Olielozing door 
"als de clausulering in de zin staat die het verbod of de strafbepaling zelf bevat, zal zij vaak als klevend aan het verbod of de strafbepaling daarvan deel uitmaken en dus bestanddeel zijn."

De redactionele opzet van de bepaling biedt derhalve vaak voldoende duidelijkheid. De hoofdregel luidt dat als in één zin zowel het verbod staat als de term(en) of zinsnede(s) die daarop een uitzondering vormt, deze uitzondering meestal dient te worden aangemerkt als een bestanddeel van de verbodsbepaling. Indien de criteria die de uitzondering markeren zijn te vinden in een afzonderlijk artikel(lid), betreft het in het algemeen een strafuitsluitingsgrond. Met behulp van dit formele onderscheid is bij strafbaarstellingen in het Wetboek van Strafrecht zonder veel problemen na te gaan of de uitzondering al dan niet een bestanddeel is. ${ }^{79}$

In het bijzondere strafrecht geldt deze hoofdregel niet onverkort. Als hij wel opgaat dan is bijvoorbeeld het niet hebben van een vergunning een onderdeel, vaak zelfs de kern van de verbodsbepaling. ${ }^{80}$ Het schenden van de "administratieve rechtsplicht" is dan een bestanddeel van de strafbepaling. In 1930 overwoog de Hoge Raad ${ }^{81}$ :

"dat artikel 2 Mollen-, Egels en Kikvorschenwet ten aanzien van het vervoer van mollen luidt: 'Het is verboden mollen (...) te vervoeren, tenzij met schriftelijke machtiging van Onzen Commissaris in de provincie, waar het feit gepleegd wordt'; dat uit de bij de behandeling van het Ontwerp dier wet in de Tweede Kamer gewisselde stukken blijkt, dat de Regeering beoogde met betrekking tot de mollen, wier nut voor de landbouw, - in tegenstelling met dat der kikvorschen, - niet onbetwist is, de vrijheid niet meer te beperken dan strikt noodzakelijk is (memorie van toelichting en Memorie van Antwoord), in welk stelsel een algemeen verbod niet past, zoodat dan ook het Voorlopig Verslag artikel 2 opvat, als strafbaar stellende het vervoer van mollen zonder machtiging van den Commissaris;

dat dit stelsel tot uiting komt in het verschil van redactie tusschen artikel 2 en artikel 4 van genoemde wet, bij welk laatstgenoemd artikel het eerste lid een algemeen verbod inhoudt onder andere van het vervoer van meer dan tien kikvorschen, terwijl daarop volgt een tweede lid dat luidende: 'Van het in het vorige lid bepaalde kan in bijzondere gevallen door Onzen Commissaris in de provincie, waar het feit gepleegd wordt, ontheffing worden verleend;'

dat uit dit alles voortvloeit, dat in artikel 2 de daarin genoemde machtiging niet bedoeld is als eene de strafbaarheid opheffende omstandigheid, maar het ontbreken daarvan als een element voor de strafbaarheid van het vervoer;"

De Hoge Raad oordeelde derhalve dat de machtiging van de commissaris een bestanddeel is van deze strafbaarstelling. Het $O M$ zal het ontbreken van die machtiging moeten ten laste leggen en bewijzen, wil het tot een veroordeling van de verdachte kunnen komen. Indien het ontbreken van de machtiging niet wordt ten laste gelegd, zal het feit niet zijn te kwalificeren, zodat ontslag van rechtsvervolging zal volgen.

Financial Enterprise).

79 Zie voor een uitwerking met voorbeelden. André de la Porte, E., "Commentaar bij artikel 261 ", nr. 37.

80 Bemmelen, J.M. en Veen, Th.W. van, bewerkt door Jong, D.H. de en Knigge, G., Het materiële strafrecht, pp. 53-54.

81 HR 29 september 1930, NJ 1931, pp. 28-29 (Vervoer mollen). 
De formulering "tenzij vergunning is verleend" ${ }^{82}$ uit een verbodsbepaling wordt sindsdien overwegend opgevat als een bestanddeel van de delictsomschrijving ${ }^{83}$ Dit geldt volgens de Hoge Raad in het algemeen ook voor andere formuleringen zoals bijvoorbeeld bijzinnen die aanvangen met "behoudens" "tenzij" gevallen verwijzen naar een andere regeling. Meestal betreft het regelgeving van dezelffe of lagere orde als de regeling waarin het betreffende voorschrift is opgenomen. Dit hoeft echter niet zo te zijn, aangezien er ook verwezen kan worden naar regelgeving van hogere orde. Ook bij strafbaarstellingen die zijn aangehaakt aan de Wed is dit op zichzelf geen probleem, aangezien het niet in strijd is met artikel 1 of la Wed, omdat deze artikelen slechts eisen dat het een overtreding betreft van een regel gesteld bij of krachtens een hierin opgenomen wetsartikel. ${ }^{87}$

\subsection{Aanvullende criteria; andere mogelijkheden}

Als het verbod in dezelfde zin nader wordt geclausuleerd, maar toch de gedachte opkomt dat het verbod moet worden beperkt tot het deel van de zin waarin het verbod staat, is nader onderzoek geboden. Het formele criterium is niet beslissend indien de strekking van de wet anders leert. Deze strekking kan bijvoorbeeld worden afgeleid uit de wetsgeschiedenis. Ook kan deze overtuiging opkomen indien de verboden gedraging als zodanig als sociaal niet aanvaardbaar, onmaatschappelijk of ongewenst moet worden aangemerkt, of als het hanteren van de hoofdregel in concreto tot onrecht zal leiden. ${ }^{88}$ Op basis van bijvoorbeeld de wetsgeschiedenis, de ratio, het systeem van wetgeving of het door de wettelijke regeling beschermde rechtsbelang ${ }^{89}$ kan de rechter

82 Zie ook bijvoorbeeld: HR 11 januari 1932, NJ 1932, 464-465 (Motorrijtuig in Overschie); HR 24 april 1939, NJ 1939, 1017, met noot Taverne ("Tenzij" dan bestanddeel).

83 Zie Röling in zijn noot onder HR 24 november 1953, NJ 1954, 73 (Vastgelegde hond).

84 Zie bijvoorbeeld HR 7 juni 1937, NJ 1937, 1145, met noot Taverne (Vogelnetten in Angerlo); HR 20 oktober 1941, $N J 1942,60$, met noot Taveme (Boven de gemeentegrond).

85 Zie bijvoorbeeld HR 25 november 1940, NJ 1941, 209 (Neergeworpen vuilnis).

86 Zie bijvoorbeeld HR 26 juni 1962, NJ 1963, 32, met noot Röling (Bijzondere voorwaarde $70 \mathrm{~km} / \mathrm{u}$ ); het betrof hier de bijzondere voorwaarde "tenzij de weg of het weggedeelte is aangewezen als een weg of weggedeelte, waarop de snelheid van ten hoogste $70 \mathrm{~km}$ per uur is toegestaan".

87 Zie hierover Keulen, B.F., Economische strafrecht, p. 29, hij noemt als voorbeeld 17 Rijtuigenbesluit dat gelet op artikel 31 a Rijtijdenbesluit het niet handelen overeenkomstig de artikelen 6-9 van verordening 3820/85 strafbaar stelt. Ook wetgeving in formele zin betreft dergelijke verwijzingen, zie bijvoorbeeld artikel $10.44 \mathrm{e}$, eerste lid Wm dat luidt: "Het is verboden handelingen te verrichten als bedoeld in artikel 26, eerste lid, van de EEG-verordening overbrenging van afvalstoffen."

88 Bemmelen, J.M. en Veen, Th.W. van, bewerkt door Jong, D.H. de en Knigge, G., Het materiêle strafrecht, p. 54; Remmelink, J., Mr. D. Hazewinkel-Suringa's Inleiding tot de studie van het Nederlandse strafrecht, p. 256.

89 Zie bijwoorbeeld HR 24 november 1953, NJ 1954, 73, met noot Röling (Vastgelegde hond). 
oordelen dat een uitzondering op de hoofdregel moet worden gemaakt. ${ }^{90}$ Ook indien het een uitzondering op de regel betreft, bijvoorbeeld een vrijstelling, kan dit erop wijzen dat sprake is van een strafuitsluitingsgrond. ${ }^{91} Z_{0}$ oordeelde de Hoge Raad dat de clausulering een strafuitsluitingsgrond is bij de strafbaarstelling ${ }^{92}$ :

“'Fen jeugdig persoon mag geen arbeid verrichten, bestaande uit het zagen met cirkelzagen, tenzij het districtshoofd als zijn oordeel heeft te kennen gegeven, dat die arbeid in een bepaald geval geen gevaar oplevert;"

dat aangenomen moet worden, dat bij het stellen van dit voorschrift de gedachte heeft voorgezeten, dat wanneer jeugdige personen zagen met cirkelzagen, dit steeds voor hun gezondheid of leven gevaren meebrengt, en zulk gevaar slechts dan niet aanwezig is geacht, indien het districtshoofd heeft verklaard, dat naar zijn oordeel in een bepaald geval die arbeid geen gevaar oplevert;

dat in de t.l.1. de afwezigheid van laatstbedoelde verklaring niet als bestanddeel van het strafbare feit behoeft te worden opgenomen;"

De Hoge Raad hanteerde in deze zaak het criterium dat sprake is van een strafuitsluitingsgrond indien de gedraging uit de strafbaarstelling zonder het aanvullend criterium steeds gevaar oplevert voor het beschermde rechtsgoed ter bescherming waarvan het verbod is gesteld. ${ }^{93}$

De geclausuleerde voorwaarde, zoals bijvoorbeeld een met "behoudens" aanvangende bijzin kan daarom in afwijking van de hoofdregel soms als een uitzondering, en daarom als een strafuitsluitingsgrond van de betreffende strafbepaling worden aangemerkt. ${ }^{94}$ Zo oordeelde de Hoge Raad op basis van de wetsgeschiedenis en het systeem van wetgeving ${ }^{95}$ :

90 Rernmelink, J., Mr. D. Hazewinkel-Suringa's Inleiding tot de studie van het Nederlandse strafrecht, pp. 253-257.

91 Rernmelink in zijn conclusie bij HR 14 mei 1974, NJ 1974, 325 (Zeiftank Kreekhuizen).

92 HR 3 november 1959, NJ 1960, 209, met noot Pompe (Gevaarlijke cirkelzagen). Het. betreft artikel 3 aanhef en onder J Arbeidsbesluit 1920.

93 Zie ook Pompe in zijn noot onder HR 3 novernber 1959, $N J$ 1960, 209 (Gevaarlijke cirkelzagen).

94 Zie bijvoorbeeld ook HR 10 november 1987, NJ 1988, 426 (Flacons met antibioticum) waar de afwezigheid van een aankoopvergunning geen bestanddeel is van artikel 5 , tweede lid Antibioticawet dat luidt: "Eveneens is het verboden antibiotica, hormoonpreparaten, thyreostatica en chemotherapeutica, die bestemd of mede bestemd zijn voor aanwending bij dieren aanwezig te hebben op terreinen, in ruimten of vervoemiddelen in gebruik bij personen, welke ingevolge de art. 4 en 5 Wet op de uitoefening van de diergeneeskunde zijn toegelaten tot de uitoefening van de diergeneeskunst in beperkte omvang, dan wel bij andere personen, welke als pluimveeselecteur of voederadviseur ten behoeve van pluimvee- of veehouderijbedrijven werkzaam zijn, behoudens voor wat betreft het aanwezig hebben van middelen door personen, die deze krachtens een aankoopvergunning als bedoeld in art. 2 vijfde lid hebben aangekocht."

95 HR 13 septernber 1994, NJ 1994, 746 (Olielozing door Financial Enterprise). Leijten concludeerde in deze zaak: "Naar gangbare begrippen van vandaag is het lozen in zee van gevaarlijke stoffen als olie ongetwijfeld ongeoorloofd. De uitzonderingen daarop hebben wel veel woorden nodig maar betreffen slechts heel weinig, kleine gevallen van 
"5,1.1. Art. 5, eerste lid, Wet voorkoming verontreiniging door schepen (WVVS) luidt: "Het is verboden vanaf een schip een schadelijke stof in zee te lozen behoudens in de gevallen en op de wijze vast te stellen bij of krachtens algemene maatregel van bestuur."

5.1.2. De memorie van toelichting bij het wetsvoorstel dat heeft geleid tot de Wet voorkoming verontreiniging door schepen houdt onder meer in (Kamerstukken II 1981-1982, 17320, nr. 3, blz. 3): "Aangezien het wetsontwerp ten doel heeft aantasting van het mariene milieu door lozing in zee van schadelijke stoffen door schepen te voorkomen is in beginsel elke dergelijke lozing verboden."

5.2.1. Art. 9, eerste lid, aanhef Besluit olieverontreiniging door schepen luidt: "Behoudens het bepaalde in de artikelen 10 en 11 , en het bepaalde in het tweede lid, is elke lozing in zee van olierestanten of olichoudende mengsels vanaf schepen verboden, tenzij wordt voldaan aan alle onderstaande voorwaarden: (...)."

5.2.2. De Nota van Toelichting bij het Besluit olieverontreiniging door schepen houdt onder meer in: "In beginsel geldı voor alle oliën een totaal lozingsverbod, waarvan alleen mag worden afgeweken indien aan alle voor de lozing gegeven voorwaarden wordt voldaan."

5.3. Gelet op het hiervoor onder 5.1 en 5.2 overwogene moet art. 5, eerste lid, WVVS aldus worden verstaan dat daarbij strafbaar is gesteld vanaf een schip een schadelijke stof in zee te lozen, waarbij een beroep op de in die bepaling bedoelde algemene maatregel van bestur moet worden aangemerkt als een beroep op een strafuitsluitingsgrond. Het middel, dat van een andere opvatting uitgaat, faalt mitsdien."

Ook de aanduiding van de afdeling waarin de strafbepaling is opgenomen kan, behalve invloed hebben op de uitleg van de strafbepalingen die daaronder vallen, soms zelfs als bestanddeel deel uitmaken van het strafbare feit. De Hoge Raad oordeelde ${ }^{96}$ :

“'Art. 49: 1. Het is de houder van een avondzaak verboden gedurende het tijdvak, liggende tussen 2 uur en 16 uur in die zaak bezoekers te ontvangen, toe te laten of te hebben";

dat deze bepalingen in de Verordening deel uitmaken van afd. 8, welke blijkens haar opschrift handelt over het toezicht op voor het publiek toegankelijke gebouwen en samenkomsten;

dat, gelet op de definities welke in art. 47 van onderscheidenlijk "Inrichting" en "Avondzaak" worden gegeven, het eerste lid van art. 49 - naar de letter genomen - het de houder van een avondzaak verbiedt gedurende het in die bepaling genoemde tijdvak in die zaak bezoekers te ontvangen, toe te laten of te hebben, ook indien de avondzaak het karakter zou missen van een voor het publiek toegankelijke inrichting;

dat evenwel uit de plaatsing van art. 49 in afd. 8 van de Verordening moet worden afgeleid dat de gemeentelijke wetgever in het eerste lid van dat artikel slechts het ontvangen, toelaten en hebben van bezockers in een voor het publiek toegankelijke avondzaak heeft willen regelen, en een redelijke uitleg dier bepaling dan ook medebrengt, dat het in het eerste lid vervatte verbod

olie-lozing of het geval dat zo'n lozing nodig is omdat de veiligheid van schip en bemanning daarbij op het spel staat (art. 11 Besluit). Naar het mij voorkomt zou dat als overmacht ook dan niet strafbaar zijn als art. 11 niet bestond. Kortom: op grond van het materieel criterium (en de cnbillijke uitkomst van hantering van het formele criterium) meen ik dat de gewraakte passage uit de verbodsbepaling (die niet met "tenzij" maar met "behoudens" aanvangt) niet is een bestanddeel van het verbod en daardoor van de strafbepaling maar een rechtvaardigingsgrond, een fait d'excuse dat, indien terecht voorgedragen, tot niet-strafbaarheid van het feit moet leiden en daarmee tot ontslag van rechtsvervolging."

96 HR 3 mei 1977, $N J$ 1977, 536, met noot Van Veen (Avondzaak Rosmalen). 
slechts is gegeven voor het geval dat een avondzaak het karakter heeft, van een voor het publiek toegankelijke inrichting;

dat het bewezen verklaarde niet inhoudt, dat de daarin bedoelde avondzaak zodanig karakter had, zodat dit geen overtreding oplevert van het eerste lid van meergenoemd art. 49; dat het bewezen verklaarde evenmin ingevolge enig ander wettelijk voorschrift een strafbaar feit oplevert;

dat mitsdien het bewezen verklaarde niet strafbaar had behoren te worden verklaard en req. van alle rechtsvervolging had moeten worden ontslagen;"

Indien sprake is van een strafbaarstelling waarin de uitzondering is opgenomen in een afzonderlijk artikellid ${ }^{97}$ of in een apart wetsartikel ${ }^{98}$ is de uitzondering in het algemeen geen bestanddeel van de delictsomschrijving. Ook hierop zijn om dezelfde redenen uitzonderingen mogelijk en dient wederom per artikel interpretatiegewijs te worden nagegaan of (een deel van) een andere bepaling bestanddeel is en in de tenlastelegging moet worden verwerkt. ${ }^{99}$ De mogelijkheid dat de wetgever zijn delictsomschrijving over twee leden of bepalingen verdeelt, zal zich vooral voordoen indien hetgeen in het tweede lid of bepaling staat als aanvullende uitwerking van het eerste lid of bepaling moet worden beschouwd. ${ }^{100}$ Zo oordeelde bijvoorbeeld de Hoge Raad ${ }^{101}$ :

97 Zie bijvoorbeeld HR 14 februari 1989, NJ 1989, 671 (Kind in draagzak in auto), waarin werd geoordeeld dat de uitzonderingen, genoemd in artikel 95, derde lid RVV geen bestanddeel zijn van het de verbodsbepaling uit artikel 95, tweede lid RVV; HR 24 november 1981, NJ 1982, 209 (Gekwalificeerde luchtvervoerders), waar de Hoge Raad oordeelde dat de viijstelling door de minister uit artikel 16, zevende lid Luchtvaariwet niet als bestanddeel van het strafbare feit van overtreding van artikel 16 , eerste lid Luchtvaartwet is aan te merken

Zie bijvoorbeeld HR 8 juli 1994, NJ 1994, 758 (Verkoop Kooivogels) waar de Hoge Raad oordeelde dat, artikel $\ 2$ Vogelwet 1936 geen bestanddeel is van artikel 7 Vogelwet 1936; HR 23 december 1986, $N J$ 1987, 640 (Gevelde houtopstand) waarin werd geoordeeld dat de uitzonderingsbepaling van artikel 1, vierde lid onder $\mathrm{c}$ Boswet geen bestanddeel is van artikel 2, derde lid Boswet; HR 14 mei 1974, NJ 1974, 325 (Zelftank Kreekhuizen) waar bleek dat artikel 15, eerste lid. Winkelsluitingstijdenwet 1951 geen bestanddeel is van de verbodsbepaling van artikel 2, aanhef en onder a Winkelsluitingstijdenwet 1951; HR 24 november 1953, NJ 1954, 73, met noot Röling (Vastgelegde hond) waarin de Hoge Raad oordeelde dat artikel 3 geen bestanddeel is van artikel 1 Gemeentelijke Verordening Putten.

99 Dit zal het geval zijn bij de zorgplichtbepaling uit artikel 3, eerste lid Wet bescherming Antarctica, waar het bepaalde in het tweede lid deel uitmaakt van de strafbaarstelling in het eerste lid. De tekst luidt: "1. Een ieder neemt in het Antarctisch gebied zo veel mogelijk zorg voor het Antarctisch milieu in acht." " 2 . De zorg, bedoeld in het eerste lid, houdt in dat een ieder die weet of redelijkerwijs kan vermoeden dat door zijn handelen of nalaten nadelige gevolgen voor het Antarctisch milieu kunnen worden veroorzaakt, verplicht is dergelijk handelen achterwege te laten voor zover zulks in redelijkheid kan worden gevergd, dan wel alle maatregelen te nemen die redelijkerwijs van hem kunnen worden gevergd teneinde die gevolgen te voorkomen of, voor zover die gevolgen niet kunnen worden voorkomen, deze zoveel mogelijk te beperken of ongedaan te maken." Alleen artikel 3, eerste lid is aangehaakt, aan de Wed; opvallend genoeg trouwens aan artikel la, onder 2 .

100 Remmelink in zijn conclusie bij HR 24 november 1981, NJ 1982, 209 (Gekwalificeerde 


\section{Hoofdstuk 4}

"O. dat, daargelaten dat de omschrijving van art. 5 lid 1 den gebruiksgerechtigde nog geheel in het onzekere laat, te welken tijde hij aan zijn verplichting moet hebben voldaan, het voldaan-zijn aan die verplichting reeds blijkens lid 2 van datzelfde artikel onder omstandigheden aan den directeur van het Staatsbosbeheer gebonden is;

dat dan ook veeleer de algehele bepaling dier verplichting aan de hand van het samenstel der in de artt. 5 en 6 vervatte voorsehriften beoordeeld moet worden; (...)

dat bovendien lid 3 van art. 6 wijst op het inzake Bosbouw en Houtteelt regelmatig gepaard gaan van "gestelde termijnen" met de meerbedoelde "verplichting tot herbebossing of herbeplanting"; dat dienvolgens aangenomen moet worden, dat deze verplichting omvat dat zij binnen den door den directeur van het Staatsbosbeheer krachtens art. 6 lid 2 sub c te stellen termijn moet zijn opgevolgd, en dat eerst bij verstrijken van dien termijn de niet-nakoming van het in art. 5 gegeven gebod kan worden vastgesteld;

dat derhalve, nu niet is telastegelegd en bewezenverklaard dat gereq. niet binnen zodanigen hem gestelden termijn zijn verplichting is nagekomen, een bestanddeel van het strafbare feit ontbreekt en gereq. bij het bestreden arrest terecht is ontslagen van rechtsvervolging, zodat het middel niet tot cassatie kan leiden".

Tevens komt het voor dat wijziging van de regelgeving tot gevolg heeft dat een uitzondering die oorspronkelijk het karakter van een bestanddeel had in de nieuwe regel is opgenomen als strafuitsluitingsgrond. ${ }^{102}$ Ook het omgekeerde komt voor, te weten dat de uitzondering die aanvankelijk was aan te merken als strafuitsluitingsgrond in de nieuwe regel bestanddeel is geworden. ${ }^{103}$ Indien sprake is van een dergelijke wetswijziging kan het blijk geven van een gewijzigd inzicht van de wetgever omtrent de strafwaardigheid van de strafbaar gestelde gedraging. In dat geval zal sprake zijn van een verandering in wetgeving als bedoeld in artikel 1 , tweede lid Sr. Indien de verandering in de wetgeving plaatsvindt na het tijdstip waarop het feit is begaan, dient met betrekking tot de aangaande de onderwerpelijke gedraging te nemen beslissing de nieuwe bepaling te worden toegepast voor zover deze voor de verdachte gunstiger is. Het gevolg zal zijn dat de uitzondering in dat geval (nog) wordt beschouwd als een bestanddeel (hetgeen uiteraard gunstiger is voor de verdachte) en

luchtvervoerders).

101 HR 14 december 1954, NJ 1955, 118, met noot Röling (Herbebossing). De relevante onderdelen van de artikelen uit de Bodemproductiebeschikking 1949 Bosbouw en Houtteelt Sc. No. 184, zoals gewijzigd bij de Overgangswet Bodemproductie 1950 S. K 413 luidden: Artikel 5: 1. "De gebruiksgerechtigde van grond, waarop na 9 Dec. 1939 een bos of houtopslag is geveld of gerooid, is verplicht te herbebossen of te herbeplanten." 2. "De verplichting tot herbebossen of herbeplanten omvat: a. het bebossen of het beplanten van de grond, die werd ontbloot, of, met toestemming van de directeur van het Staatsbosbeheer, van een gelijkwaardige oppervlakte;" Artikel 6: 1. "De directeur van het Staatsbosbeheer kan van de verbodsbepalingen in deze beschikking, al dan niet onder voorwaarden, ontheffing verlenen. 2 . De directeur van het Staatsbosbeheer is bevoegd: (...) c. termijnen te stellen, waarbinnen de verplichtingen, aanwijzingen of maatregelen ingevolge deze beschikking moeten zijn opgevolgd of uitgevoerd."

102 Zie bijvoorbeeld HR 15 oktober 1968, NJ 1969, 141 (Algemeen verbod $50 \mathrm{~km} / \mathrm{u}$ in bebouwde kom).

103 HR 13 oktober 1992, NJ 1993, 141 (Straf afleveren pistool); HR 10 december 1991, NJ 1992, 322, met noot Knigge (Wapen tijdelijk bij dochter). 
niet 1 ls een bijzondere strafuitsluitingsgrond. Het OM dient immers bestanddelen op te nemen in de tenlastelegging en met behulp van wettige bewijsmiddelen te bewijzen, wil tet bewezenverklaarde feit kunnen worden gekwalificeerd. Dit in tegenstelling tot schuiduitsluitingsgronden, die niet hoeven te worden ten laste gelegd en bewezenverkaard voordat het bewezenverklaarde feit kan worden gekwalificeerd.

\subsection{Bestanddeel of strafuitsluitingsgrond}

Wameer de wetgever in een strafbepaling die de vorm heeft van een algemeen verbod eén of meer uitzonderingen opneernt, is het lang niet altijd duidelijk of deze uitzondering is aan te merken als een bestanddeel of als een bijzondere strafuitshitingsgrond. In hoofdstuk 4 paragraaf 6 werd aangegeven wat het belang is van het mderscheid en op welke manier de rechter dit probleem kan oplossen.

Uitgngspunt is dat de wil van de wetgever bepalend is voor de keuze. Hierdoor is het nooczakelijk per artikel interpretatiegewijs deze keuze te maken. Het criterium dat de uitzondering die in dezelfde zin staat als het verbod of de strafbepaling is aan te merken als bestanddeel (het zogenaamde formele criterium), is vaak doorslaggevend. Maat van dit formele criterium wordt door de rechter om uiteenlopende redenen regelmatig afgeweken.

De keuze om het aanvullende criterium an te merken als een bestanddeel of een strafuitsluitingsgrond heeft vergaande consequenties voor het strafproces. Wanneer wordt gekozen voor "bestanddeel" zal het OM dit deel moeten ten laste leggen en bewijzen. Dit geldt ook indien de wederrechtelijkheid is opgenomen als bestanddeel. Bij een "strafuitsluitingsgrond" is het daarentegen voldoende dat deze door de strafrechter niet onaannemelijk wordt bevonden.

De gedraging conform een door het bestuur vastgestelde norm zal ook bij het ontbreken van een aanvullend criterium meestal niet strafbaar zijn, aangezien de wederrechtelijkheid als element ontbreekt. Er is dan sprake van een geschreven bijzondere rechtvaardigingsgrond. Indien de gedraging conform een bestuurlijke normstelling als strafuitsluitingsgrond (en dus niet als bestanddeel) is opgenomen in de bepaling heeft dit in het algemeen geen processuele en inhoudelijke meerwaarde ten opzichte van bepalingen waarin dit niet is opgenomen.

Gezien de processuele implicaties, de kenbaarheid van de wetgeving en de gevolgen voor de reikwijdte van de strafbaarstelling verdient het de voorkeur dat de wetgever strafbaarstellingen zoveel mogelijk conform het formele criterium vorm geeft. Hij kan daamaast voor de duidelijkheid in de toelichting op de bepaling zijn oordeel, of het aanvullende criterium dient te worden aangemerkt als bestanddeel of als strafuitsluitingsgrond, toelichten. Wanneer de wetgever niet volgens bovenstaande methode te werk gaat blijven onduidelijkheden bestaan. In het strafproces geldt het uitgangspunt in dubio pro reo, dat wil zeggen dat bij twijfel de voor de verdachte meest gunstige interpretatie dient te worden gevolgd. Dit heeft tot gevolg dat de rechter bij twijfel het aanvullend criterium dient aan te merken als bestanddeel. Hij zal 
dan ook slechts in zeer uitzonderlijke omstandigheden mogen afwijken van de hoofdregel dat het aanvullende criterium dat (in overeenstemming met het formele criterium) in dezelfde zin is opgenomen als de rest van de strafbepaling, een bestanddeel is.

\section{Het bestuur en voorwaarden voor strafbaarstelling}

Het bestuur speelt in het bijzondere strafrecht door het gebruik van gelede normstellingen een grote rol bij het vaststellen van de materiële norm van strafbaarstellingen. Op basis van veel wetgeving in formele zin verkrijgt het bestuur de bevoegdheid tot het maken van regelgeving, waarvoor zowel kwantitatieve als inhoudelijke argumenten kunnen worden gegeven. Het schenden van deze door het bestuur vastgestelde regelgeving kan, via de gelede normstelling van abstracte gevaarzettingsdelicten, zijn strafbaar gesteld. Hierdoor beperkt het strafrecht zich vaak ertoe enkel deze schending te sanctioneren, waardoor het strafrecht een supplementaire rol vervult. Door deze administratieve afhankelijkheid verkrijgt het bestuur, zeker bij dit type strafbaarstellingen, de reële macht de omvang van de strafrechtelijke aansprakelijkheid te bepalen.

Het bestuur is op zijn beurt nooit geheel vrij de inhoud van de materiële norm te bepalen. Het stellen van normen krachtens gedelegeerde bevoegdheid wordt derhalve op verschillende wijzen begrensd. Dit gebeurt zowel door de delegatiebepaling als zodanig, door de strekking van de wet, als door de geschreven en ongeschreven rechtsbeginselen. De mate van beslissingsruimte die het bestuur heeft bij het gebruik van zijn gedelegeerde bevoegdheid, is onder meer afhankelijk van de beoordelingsnuimte en de beleidsruimte die het op het betreffende gebied heeft. Het bestuur dient hierdoor bijvoorbeeld in ieder geval het doel van de bepaling en wettelijke regeling en de rechtstreeks bij het besluit betrokken belangen af te wegen, voor zover uit een wettelijk voorschrift of uit de aard van de uit te oefenen bevoegdheid geen beperking voortvloeit. Indien echter de vaststelling van de normstelling door het bestuur om een of andere reden niet goed verloopt, dan kan het strafrecht via deze bepalingen de noodzakelijke bescherming ook niet bieden.

Aangezien er veel verschillende soorten bevoegdheidverlenende bepalingen zijn, is het niet mogelijk een eenduidige uitspraak te geven over de mogelijkheden van het bestuur lagere regelgeving en aanvullende criteria vast te stellen. Per normstelling zal immers niet alleen het doel van de wetgeving en de betreffende bepaling anders zijn, maar zal ook de inhoud van de rechtstreeks bij het besluit betrokken belangen wisselen. In de praktijk blijkt dat bijvoorbeeld bij vergunningverlening de bevoegdheidsverlenende en beperkende factoren vaak wel ruimte geven om zorgplichtbepalingen op te nemen, waardoor deze deel kunnen uitmaken van de materiële inhoud van een abstract gevaarzettingsdelict.

Door het gebruik van de delegatietechniek behoeft de wetgever op het ogenblik dat hij een strafbepaling vastlegt nog geen welomlijnd idee te hebben van het gedrag dat 
nadien door het bestuur al dan niet onder de reikwijdte van de strafbepaling wordt gebracht. Hierdoor kan onder omstandigheden het democratisch gehalte van deze bepalingen ter discussie worden gesteld. Dit doet zich vooral voor indien sprake is van het structureel en op grote schaal onttrekken van de invulling van de regelgeving aan de darvoor democratisch gelegitimeerde organen. ${ }^{104}$

De wetgever kan, zoals werd aangegeven, het schenden van de bestuurlijke norm (via de gelede normstelling van een abstract gevaarzettingsdelict) strafbaar stellen. De besturlijke norm zal dan bestanddeel zijn van de strafbaarstelling. Aangezien de straftepaling vaak ingrijpt op het moment dat de door het bestuur bepaalde materiële norm wordt geschonden, wordt het door de wet te beschermen rechtgoed bij deze straftaarstellingen niet zwaarder beschermd dan het beschermingsniveau dat het bestum in de belangenafweging eraan heeft toegekend. Deze bepalingen beschermen daardoor de door het bestuur gemaakte belangenafweging, waarvan het resultaat meer zou moeten zijn, maar helaas niet altijd is, dan de bescherming van "administratieve belangen".

Aangezien onder een strafbaarstelling niet minder maar ook niet meer gedragingen moeten vallen dan wordt beoogd, bevatten veel strafbaarstellingen specifiekere bestanddelen. Dit kunnen bestanddelen zijn die verwijzen naar de bestuurlijke norm, zoals "wederrechtelijk". Een beroep op een strafuitsluitingsgrond bij het wel voldoen an de bestuurlijke norm waarnaar wordt verwezen is dan niet nodig, aangezien dan het bestanddeel niet kan worden bewezen verklaard zodat vrijspraak zal volgen. Het gevolg is dat de bescherming van het betreffende rechtsgoed stagneert op het moment dat voldaan is aan een door het bestuur vastgestelde (relevante) norm.

Een andere veel gehanteerde methode is om aan een algemeen verbod één of meer uitzonderingen te voegen, die verwijzen naar bestuurlijke normstellingen. Dan ontsiaat het probleem dat niet altijd duidelijk is of het aanvullende criterium is aan te merken als bestanddeel of als bijzondere strafuitsluitingsgrond. Gezien de gevolgen voor de reikwijdte van de strafbaarstelling en de processuele implicaties verdient het de voorkeur dat de wetgever strafbaarstellingen zoveel mogelijk conform het formele criterium vorm geeft, en dus de uitzondering opneemt in de zin waarin het verbod is vervat. De rechter zal door het uitgangspunt in dubio pro reo (dat wil zeggen dat bij twijfel de voor de verdachte meest gunstige interpretatie dient te worden gevolgd) alleen in zeer uitzonderlijke omstandigheden mogen afwijken van de hoofdregel dat het aanvullende criterium dat in dezelfde zin is opgenomen als de strafbaarstelling, een bestanddeel is.

104 Dit lijkt niet de bedoeling van de wetgever, zie oọk hoofdstuk 3 paragraaf 7.3.3. 



\section{De rechter en voorwaarden voor strafbaarstelling}

\section{Inleiding}

Een belangrijke vraag bij het vaststellen van het betekenisbereik van zorgplichtbepalingen is, welke rechter bevoegd is bij de interpretatie van vage termen aanvullende criteria door middel van jurisprudentie te ontwikkelen. Door beantwoording van deze vraag wordt duidelijk of de rechter kan verifiëren of de toepasselijke strafbepalingen in overeenstemming zijn met wet- en regelgeving en algemene beginselen.' In hoofdstuk 5 paragraf 2 zal daarom eerst worden onderzocht wat de rol van de feitenrechter en de Hoge Raad is bij de uitleg van strafbaarstellingen.

In het bijzonder strafrecht bedient de wetgever zich veelvuldig van de techniek van gelede normsteliing, waardoor de materiële norm vaak te vinden is in bestuursrechtelijke regelgeving. ${ }^{2}$ De vraag is of de strafrechter toetsingsbevoegdheid heeft ten aanzien van beschikkingen en bestuursrechtelijke regelingen (die daaraan ten grondslag liggen). Indien een beschikking tot stand komt staat hiertegen in de regel een bestuursrechtelijke rechtsgang open. De vraag die rijst is of de strafrechter zelfstandig de rechtmatigheid van dergelijke beschikkingen mag en moet beoordelen (hoofdstuk 5 paragraaf 3 ) en of een beroep op de exceptie van onverbindendheid mogelijk is (hoofdstuk 5 paragraaf 4).

Indien een vervolging is aangevangen terwijl naar aanleiding van dezelfde zaak een bestuursrechtelijke bezwaar- of beroepsprocedure in gang is gezet, kan de raadsman zo nodig aandringen op schorsing van de strafrechtelijke procedure totdat bestuursrechtelijk onherroepelijk is beslist (hoofdstuk 5 paragraaf 5). Indien niet wordt overgegaan tot schorsing, of de bestuursrechtelijke procedure pas later aanvangt, kan het voorkomen dat een strafrechtelijke uitspraak vooraf gaat aan een bestuursrechtelijke uitspraak (hoofdstuk 5 paragraaf 6). Voorts rijst de vraag wat de consequenties voor de strafrechter zijn indien een bestuursrechtelijke uitspraak vooraf gaat aan een strafrechtelijke uitspraak, waarbij de bestuursrechter zich heeft uitgesproken over de omstreden administratieve rechtshandeling (hoofdstuk 5 paragraaf 7). Indien zowel een bestuursrechtelijke als een strafrechtelijke procedure wordt gevolgd ten aanzien van een zelfde feitencomplex kan het voorkomen dat sprake is van een cumulatie van een bestuursrechtelijke en een strafrechtelijke reactie (hoofdstuk 5 paragraaf 8 ).

Zie ook over de toetsingsmogelijkheden van de rechter aan algemene beginselen hoofdstuk 3 paragraaf 5.1.

2 Zie hoofdstuk 4. 
Afgesloten wordt met een terugblik op de mogelijkheden van de strafrechter om bij de interpretatie van vage termen, die veelvuldig deel uitmaken van zorgplichtbepalingen, aanvullende criteria door middel van jurisprudentie te ontwikkelen (hoofdstuk 5 paragraaf 9 ).

\section{Uitleg beschikking en algemeen verbindend voorschrift van feitelijke aard?}

Zoals gezegd bedient de wetgever zich in het bijzondere strafrecht veelvuldig van de techniek van gelede normstelling. In de bepaling die de schending van bestuursrechtelijke normen strafbaar stelt zijn de specifieke gedragsnormen veelal niet te vinden. Deze staan dan bijvoorbeeld in amvb's of beschikkingen. Hierdoor kan men de materiële norm van de bepaling slechts vaststellen door kennis te nemen van de inhoud van de voorschriften waarvan overtreding is verboden. De vraag is of de strafrechter bevoegd is deze regels uit te leggen. Deze vraag zal eerst worden beantwoord voor de Hoge Raad.

Blijkens de Wet RO zijn er twee cassatiegronden, te weten schending van vormen en schending van recht. ${ }^{3}$ In de cassatieprocedure wordt hierdoor de zaak niet meer in volle omvang onderzocht. Het onderzoek richt zich op de vraag of het recht juist is toegepast. Dit onderzoek wordt verricht op basis van de door de lagere rechter (de zogenaamde feitenrechters) vastgestelde materiële en processuele feiten. De Hoge Raad gaat bij zijn onderzoek af op het toegezonden dossier, de feitelijke vaststellingen van de lagere rechters in het vonnis, het proces-verbaal van de terechtzitting en alle in het dossier gevoegde stukken mits de daarin opgenomen informatie onomstotelijk vaststaat. ${ }^{4}$

Aangezien de feitenrechter het laatste woord heeft over de feitelijke vaststellingen en hij vaak een grote en vrije beoordelingsruimte heeft, kan een groot deel van zijn beslissingen in de (strafrechtelijke) procedure niet worden getoetst in cassatie. De taken van de Hoge Raad met betrekking tot de bevordering van eenheid in strafrechtspraak, de strafrechtsvorming en de controle op een behoorlijk verloop van de procedure kunnen hierdoor maar in beperkte mate worden uitgeoefend. ${ }^{5}$ Deze taken

3 Zie over de cassatiegronden Hullu, J. de, Over rechtsmiddelen in strafzaken, pp. 241245; Groenhuijsen, M.S. en De Hullu, J., Het stelsel van rechtsmiddelen in strafzaken, pp. 35-37; Corstens, G.J.M., Het Nederlands strafprocesrecht, pp. 726-729; Brucken Fock, E.P. von, bewerkt door Dorst, A.J.A. van, Cassatie in strafzaken, pp. 58-66.

4 De Hoge Raad verricht op een klein terrein wel feitenonderzoek, bijvoorbeeld met betrekking tot de vraag of het cassatie beroep tijdig en rechtmatig is ingesteld. Zie Brucken Fock, E.P. von en Dorst, A.J.A. van, Cassatie in strafzaken, p. 71 . In de praktijk is de scheiding tussen feitelijke en rechtsvragen ook iets minder strikt, omdat de Hoge raad de motivering van veel feitelijke beslissingen kan toetsen op haar begrijpelijkheid en houdbaarheid, waardoor de Hoge Raad toch een beperkte greep heeft op de feiten.

5 Zie Hullu, J. de, Over rechtsmiddelen in strafzaken, p. 244. 
vormen echter ook een reden voor de beperkte toetsingsruimte. De betekenis van de (nadere) vastlegging van het objectieve recht (in een algemene regel) ligt juist buiten een concrete zaak, waardoor de bijzondere omstandigheden van het geval waarin de uitsprak is gegeven niet tot het aandachtsterrein van de Hoge Raad behoort. ${ }^{6}$ De beantwoording van feitelijke vragen behoort niet tot zijn taak en hij is hiertoe dan ook niet bevoegd. Feitelijk vragen zijn eenmalige, unieke en onherhaalbare vragen waarbij het gaat om geïsoleerde (waarderings-)oordelen over het bijzondere of het onherhaalbare. Deze vragen worden overgelaten aan de lagere rechters. De Hoge Raad zal daarentegen wel rechtsvragen beantwoorden. Dit zijn vragen die herhaalbaar zijn en oordelen of redeneringen betreffen waarvan de (in cassatie te behouden of te vormen) algemeenheid in geding is.?

Bij de beantwoording van de vraag of sprake is van een feitelijk oordeel dan wel een rechtsvraag wordt onderscheid gemaakt tussen algemeen verbindende voorschriften en beschikkingen. Indien de materiële norm te vinden is in een algemeen verbindend voorschrift zal de Hoge Raad meestal ${ }^{8}$ bevoegd zijn uitleg te geven aan (bepalingen uit) deze regeling. Zo bepaalde de Hoge Raad reeds in 1919 in een strafzaak dat ${ }^{9}$

"onder "wet." in den zin van art. 99 R.O. mede zijn te begrijpen naar buiten werkende, dus tot een ieder gerichte algemeene regelingen, welke zijn uitgegaan van een openbaar gezag, dat de bevoegdheid daartoe aan de wet, in den zin van eene regeling door de wetgevende macht, ontleert".

In 1963 is de toetsing aan de "wet" vervangen door toetsing aan het "recht"10, waardoor de Hoge Raad ook de mogelijkheid heeft gekregen rechtstreeks te

6 Zie ook Bins, J., "Cassatie in strafzaken", p. 264.

7 Groenhuijsen, M.S. en Hullu, J. de, Het stelsel van rechtsmiddelen in strafzaken, pp. 3234 en Melai ${ }_{n}$ A.L., noot onder HR 8 juni 1971, $N J$ 1972, 218 (Houden varkens). Zie ook Bins, J., "Cassatie in strafzaken", pp. 264-267.

8 Een uitzondering is (een voorschrift dat is opgenomen in) een algemeen verbindende regeling, dat slechts individuele werking heeft. Zie bijvoorbeeld HR I maart 1918, $\mathrm{NJ}$ 1918, pp. 440-443 (Overgedragen straten) alwaar de Hoge Raad overwoog dat "aangehaalde besluiten van 1894, al zijn zij in den zin van art. 150 der Gemeentewet plaatselijke verordeningen, niet met vrucht in cassatie kan worden beweerd, daar zij slechts inhouden beschikkingen op een verzoek van bepaalde personen betreffende goedkeuring van een stratenplan en afstand van grond".

$9 \quad$ HR 10 juni 1919, NJ 1919, pp. 647-650 (Teelt in Beemster). De verdachte werd in deze zaak veroordeeld wegens "het overtreden van eene regeling van den Minister van Landbouw, Nijverheid en Handel, waarbij het verbouwen van bij algemeenen maatregel van bestuur aangewezen gewassen niet dan voorwaardelijk wordt toegestaan". Zie ook HR 10 juni 1919, NJ 1919, pp. 650-651 (Verbod aflevering rogge), waar de verdachte werd veroordeeld wegens "het opzettelijk niet nakomen van eenige verplichting voorgeschreven bij een distributieregeling als in artikel 8, eerste lid der Distributiewet bedoeld".

10 Wet van 20 juni 1963, Stb. 1963, 272. Zie hierover Veegers, D.J., bewerkt door Korthals Altes, E. en Groen, H.A., Cassatie in burgerlijke zaken, pp. 61-62. 
controleren of er sprake is van schending van verdragsrecht, beginselen van goede proceserde en gepubliceerde richtlijnen.

Ten aanzien van beschikkingen heeft de Hoge Raad uitgemaakt dat de uitleg van een vergunningvoorschrift ${ }^{11}$ en de onderlinge verhouding tussen vergunningvoorschriften ${ }^{12}$ kwesties van feitelijke aard zijn en dienen te geschieden naar aanleiding van het onderzoek op de terechtzitting. Het gevolg is dat de Hoge Raad vergunningvoorschriften niet zal uitleggen, aangezien dienaangaande een cassatiegrond ontbreekz. Hij beperkt zich ertoe te controleren of de feitenrechter geen onbegrijpelijke uitleg aan het voorschritt heeft gegeven. ${ }^{13}$ Zo overwoog de Hoge Raad ${ }^{14}$ :

"5.2. Het middel klaagt dat het hof ten onrechte het voorschrift A-1-f van de vergunning niet buiten toepassing heeft gelaten, nu dit zo vaag is dat het als strafrechtelijke norm onverbindend is, althans dat het hof het dienaangaand gevoerd verweer op ontoereikende gronden heeft verworpen.

5.3. De uitleg van vergunningvoorschriften - tegen de inhoud waarvan in de administratiefrechtelijke rechtsgang door de belanghebbende kan worden opgekomen, hetgeen te dezen klaarblijkelijk niet is geschied - is van feitelijke aard. In dit verband is dus van belang of 's hofs uitieg van het desbetreffende voorschrift begrijpelijk is.

5.4. Het hof heeft omtrent een ter terechtzitting in hoger beroep gevoerd verweer als volgt overwogen en beslist:

De raadsman heeft betoogd dat het aan de Hinderwetvergunning verbonden voorschrift A-1-f: 'Het is in de inrichting verboden voor de omgeving hinderlijke werkzaamheden te verrichten' een onvoldoende concrete norm bevat. Overtreding daarvan zou dan niet tot strafbaarheid (het hof begrijpt: van het feit) leiden. Het hof overweegt daaromtrent het volgende.

Een redelijke uitleg van dit voorschrift brengt mee hieronder in ieder geval onnodige en/ of uitzonderlijk hinderlijke werkzaamheden te begrijpen, gelijk zich in het onderhavige geval hebben voorgedaan.

5.5. Het hof heeft aldus als zijn oordeel tot uitdrukking gebracht dat het voorschrift ertoe strekt om naast specifieke gedragsvoorschriften onnodige - dat wil zeggen gelet op het normale bedrijfsproces redelijkerwijs vermijdbare - hinder opleverende werkzaamheden die vitzonderlijk hinderlijk zijn, tegen te gaan. Dat oordeel is niet onbegrijpelijk, terwijl daarin besloten ligt het niet van een verkeerde rechtsopvatting blijk gevende en evenmin onbegrijpelijke oordeel dat het aldus uitgelegde voorschrift voldoende concreet is.

5.6. Het middel faalt dus."

11 Dit vloeit voort uit de begripsbepaling van "wet" uit artikel 99 Wet RO. Zie bijvoorbeeld ook HR 19 februari 1985, DD 85.286 (Stof en kaf).

12 Zie HR 26 juni 1964, NJ 1965, 83 (Overspanning Lek), met noot Beekhuis onder HR 14 juni 1963, NJ 1965, 82 (Hinder bokken door overspanning Lek). De beslissing omtrent de onderlinge verhouding van de onder de ministerielle vergunningvoorschriften voorkomende bepalingen komt evenals dat omtrent de uitlegging van de vergunning voor het overige voor rekening van de rechter die over de feiten beslist.

13 HR 23 mei 1995, NJ 1995, 695, met noot Scheltema; MenR 1996, nr. 5, met noot Hendriks (Uitleg vergunning van feitelijke aard) en HR 27 juni 1995, NJ 1995, 722; MenR 1996, nr. 6, met noot Hendriks (Uitleg vergunningvoorschrift is feitelijk).

14 HR 27 juni 1995, $N J$ 1995, 722, MenR 1996, nr. 6, met noot Hendriks (Uitleg vergunningvoorschrift is feitelijk). 
De Hoge Raad gaat niet over tot het uitleggen van de materiële norm van abstracte gevaarzettingsdelicten indien deze is te vinden in een beschikking, terwijl deze norm een bestanddeel of een strafuitsluitingsgrond is van de delictsomschrijving. ${ }^{15}$ In beschikkingen zijn vaak gedeeltelijk dezelfde standaardvoorschriften (en zodoende dezelfde bestanddelen of strafuitsluitingsgronden) te vinden. ${ }^{16}$ Aangezien de Hoge Raad zichzelf onbevoegd acht uitleg te geven aan dergelijke criteria kan het voorkomen dat feitenrechters een verschillende uitleg geven aan gelijkluidende voorschriften.

De oorzaak van het verschil dat hierdoor ontstaat tussen de uitleg van aigemeen verbindende voorschriften van bestuur en beschikking(voorschrift)en wordt soms toegeschreven aan het feit dat er een bestuursrechtelijk rechtsgang open staat om bezwaar te maken of beroep aan te tekenen tegen voorschriften verbonden aan een vergunning ${ }^{17}$, terwijl deze mogelijkheid ontbreekt voor (door het bestuur vastgestelde) algemeen verbindende voorschriften. Deze opvatting is niet houdbaar aangezien (zoals werd aangetoond) het verschil is gelegen in het al dan niet kwalificeerbaar zijn van de regel als "recht" in de zin van artikel 99 Wet RO. Het gaat erom of de uitleg van de regel (naar het oordeel van de Hoge Raad) een kwestie van feitelijke aard is. ${ }^{18}$

\section{3.}

\section{Toetsingsbevoegdheid en formele rechtskracht}

Zoals gezegd bedient de wetgever zich in het bijzondere strafrecht veelvuldig van de techniek van de gelede normstelling, waardoor de materiële norm vaak te vinden is in bestuursrechtelijke regelgeving. De vraag is of de strafrechter toetsingsbevoegdheid heeft ten aanzien van beschikkingen en bestuursrechtelijke regelingen (die daaraan ten grondslag liggen). Indien een beschikking tot stand komt staat hiertegen in de regel een bestuursrechtelijke rechtsgang open. De vraag rijst dan, of de strafrechter zelfstandig de rechtmatigheid van dergelijke beschikkingen mag beoordelen. Deze problematiek is in die zin van belang dat zij iets zegt over de taakverdeling tussen het bestuur, de bestuursrechter en de strafrechter, wat betreft het vaststellen en de toetsing van beschikkingen en de daarin opgenomen voorschriften.

Bij de in het privaatrecht ontwikkelde leer van de formele rechtskracht van besluiten blijkt het verschil tussen beschikkingen en algemeen verbindende voorschriften van

15 Zie over de vraag of een dergelijk voorwaarde een bestanddeel of een strafuitsluitingsgrond is, hoofdstuk 4 paragraaf 6.

16 Dit is een van de redenen waarom de wetgever bijvoorbeeld voorstelt bepaalde vergunningplichten in het milieurecht op te heffen en te regelen in amvb's op basis van artikel $8.40 \mathrm{Wm}$.

17 Zie overweging 5.3. HR 27 juni 1995, NJ 1995, 722; MenR 1996, nr. 6, met noot Hendriks (Uitleg vergunningvoorschrift is feitelijk).

18 Het ligt dan ook niet in de lijn der verwachting dat als tegen algemeen verbindende voorschriften administratief beroep open komt te staan de Hoge Raad geen uitleg meer zal geven aan deze regelgeving. 
bestuur opnieuw een rol te spelen. ${ }^{19}$ Deze leer houdt in dat de burger bij het openstaan van een met voldoende waarborgen omklede bestuursrechtelijke rechtsgang zijn bezwaren tegen een besluit van het bestuur met gebruikmaking van die rechtsgang naar voren moet brengen. Doet hij dat niet, dan kan hij in een andere rechtsgang niet meer met vrucht het standpunt innemen dat het besluit van het bestuur onjuist was. Besluiten waartegen in het bestuursrecht kan worden opgekomen, worden hierdoor na het ongebruikt aflopen van de beroepstermijn van de bestuursrechtelijke beslissing rechtmatig geacht. Zowel voor de wijze van totstandkoming als wat betreft de inhoud dient te worden uitgegaan dat het besluit in overeenstemming is met de desbetreffende wettelijke voorschriften en algemene rechtsbeginselen. ${ }^{20}$ Ook indien de bestuursrechter maar in beperkte mate heeft getoetst aan de beginselen van behoorlijk bestuur bijvoorbeeld vanwege "vaste rechtspraak" van het Hof van Justitie van de EG, geldt dat in beginsel moet worden uitgegaan van de onaantastbaarheid van het betreffende besluit. ${ }^{21}$ Deze leer werd door de burgerlijke rechter ontwikkeld. ${ }^{22}$ De strafkamer van de: Hoge Raad lijkt deze leer, in navolging van de burgerlijke rechter, (gedeeltelijk) te aanvaarden. ${ }^{23}$ Dit blijkt bijwoorbeeld uit de volgende overweging ${ }^{24}$ :

"Hofs verwerping van het gevoerde verweer moet aldus worden begrepen dat het Hof heeft vooropgesteld dat in beginsel van de rechtmatigheid van de vergunning dient te worden uitgegaan, nu deze kennelijk niet is bestreden in de daartoe openstaande rechtsgang (...) Dit oordeel geeft niet blijk van een onjuiste rechtsopvatting."

19 Zie voor het systeem van toetsing van bestuurlijke rechtshandelingen in het strafrecht onder andere Roos, Th.A. de en Visser, M.J.C., "Milieustrafrecht", 70.2.; Hendriks, L.E.M. en Wöretshofer, J., Milieustrafrechl, pp. 66-73; Koopmans, I.M., De strafbaarstelling van milieuverontreiniging, pp. 107-223; Faure, M., "De gevolgen van de "administratieve afhankelijkheid" van het milieustrafrecht: een inventarisatie van knelpunten", pp. 91-150; Faure, M. en Visser, M., De strafrechtelijke bescherming van het leefmilieu in België, Duitsland en Nederland, pp. 82-112.

20 Zie bijwoorbeeld HR 7 april 1995, NJ 1997, 166, met noot Scheltema (Terugbetaling bezoldiging) en HR 21 april 1995, NJ 1995, 437 (Professioneel automobielbedrijf).

2I Zie HR 28 mei 1999, N.J 1999, 508, met noot Bloembergen (Tariefcommissie en invoerrechten Transol). De Tariefcommissie had in deze zaak (volgens verweerder) maar ten dele getoetst aan het vertrouwensbeginsel en geheel niet aan het gelijkheidsbeginsel, hetgeen werd gegrond op "vaste rechtspraak" van het Hof van Justitic van de EG.

22 Zie bijvoorbeeld Mok M.R. en Tjittes, R.P.J.L., "Formele rechtskracht en overheidsaansprakelijkheid", pp. 383-404; Linden, E.C.H.J. van der, Formele en materiële rechtskracht. De kleren van de keizer.

23 Zie over deze leer bijvoorbeeld Cluysenaer, J.L.H., "De toetsing van administratieve beschikkingen door de strafrechter", pp. 1000-1007; Buruma, Y. en Daalder, E.J, "Formele rechtskracht en strafrecht", pp. 320-334; Hendriks, L.E.M., en Wöretshofer, I., Milieustrafrecht, pp. 66-73; Koopmans, I.M., De strafbaarstellingen van milieu. verontreiniging, pp. 114-132, met name 126-132; Roos, Th.A. de en Visser, M.J.C., "Milieustrafrecht", 70.2.1.2.; Faure, M. en Visser, M., De strafrechtclijke bescherming van het leefmilieu in Belgiè, Duitsland en Nederland, pp. 91-96.

24 HR 11 januari 1994, MenR 1994, 85, met noot Hendriks (Mobil Oil), zie ook in deze zaak Hof Amsterdam 30 december 1992, MenR 1993, 85 (Mobil Oil bij Hof). 
De le $e_{\mathrm{r}}$ van de formele rechtskracht heeft in een aantal gevallen een wettelijke basis.

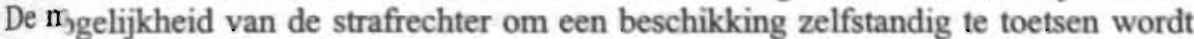

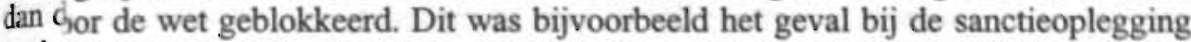
op bsis van artikel 26 (oud) WAHV. De eerste zin van artikel 26, derde lid (oud) WAFV stipuleerde:

"Tege de tenuitvoerlegging van het dwangbevel kan verzet worden gedaan, hetwelk niet

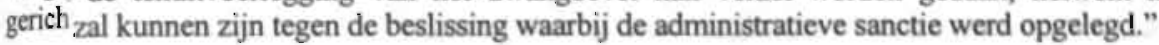

De $\mathrm{H}_{\text {gge }}$ Raad legt een verband tussen deze wettelijk verankerde blokkade en de leer van d formeel rechtskracht; hij overwoog ${ }^{25}$ :

"Ingeblge het bepaalde in art. 26, derde lid, WAHV zal het verzet tegen de tenuitvoerlegging van $\mathrm{eq}_{1}$ dwangbevel niet gericht kunnen zijn tegen de beschikking waarbij een administratieve sancticis opgelegd. Aan die bepaling ligt het beginsel ten grondslag dat tegen de oplegging van de adtinistratieve sanctie een met waarborgen omklede rechtsgang heeft opengestaan en dat, ingeve deze rechtsgang niet is gebruikt, de rechter die in de verzetprocedure heeft te oordelen over d gegrondheid van de tenuitvoerlegging van een dwangbevel, ervan kan, en moet, uitgaan dat de inleidende beschikking zowel wat haar wijze van tot stand komen als wat haar inhoud betreft in overeenstemming is met de desbetreffende wettelijke voorschriften en algemene rechts eginselen."

De.leer van de formele rechtskracht geldt niet onvoorwaardelijk. Een beperking die door de Hoge Raad wordt aangebracht blijkt uit de volgende overweging uit hetzelfde arrest:

"De aan dit beginsel verbonden bezwaren kunnen evenwel door bijkomende omstandigheden zo klemmend worden dat hierop, gezien de bijzonderheden van het geval, een uitzondering moet worden aanvaard (...). Van zodanige uitzondering kan met name sprake zijn wanneer een betrokkene uit verklaringen en gedragingen van de overheid in redelijkheid heeft mogen afleiden dat de bij de inleidende beschikking opgelegde sanctie niet zou worden geêffectueerd".

In de casus van dit arrest deed deze situatie zich voor nu de politie toestemming had verleend voor het fout parkeren van een auto en de vervolgens reeds voldane wegsleepkosten had terugbetaald. De betrokkene kon het er in redelijkheid voor houden dat de sanctionerende beschikking op een vergissing berustte en zou worden ingetrokken.

Opvallend is dat deze beperking werd aangebracht in het kader van een artikel 26 (oud) WAHV procedure. Hier werd niet enkel de leer van de formele rechtskracht gerelativeerd, maar dit gebeurde in een procedure waar deze leer een wettelijke basis had.

In een andere zaak ging de betrokkene in verzet tegen de tenuitvoerlegging van een dwangbevel (ex artikel 26 WAHV). Hij stelde dat de sanctie ten onrechte aan hem als

HR 6 juni 1995, $N J$ 1995, 696, met noot Scheltema (Vergissing met dwangbevel). 
kentekenhouder was opgelegd, aangezien het betreffende kenteken nimmer op zijn naam had gestaan. De Hoge Raad oordeelde dat de officier van justitie die belast is met het innen van administratieve boeten zich bij de inning dient te laten leiden door algemene beginselen van behoorlijk bestuur. Indien dus vaststaat dat de sanctie ten onrechte is opgelegd ten gevolge van een fout van een overheidslichaam, is het in strijd met deze beginselen als de officier van justitie zijn vervolging doorzet op de enkele grond dat het verzet tegen het dwangbevel niet gericht zal kunnen zijn tegen de beschikking waarbij de bestuurlijke sanctie is opgelegd. ${ }^{26}$

De mogelijkheid bestaat dat de strafrechter (ook buiten het verkeersrecht) zal overgaan tot het (al dan niet beperkt) toepassen van de leer van de formele rechtskracht. Het kan dan voorkomen dat het verweer van een verclachte, die wordt vervolgd voor het handelen in strijd met een vergunning, dat het voorschrift nietig is omdat het in strijd met de wet is genomen, kan stuiten op de formele rechtskracht van de vergunning. ${ }^{27}$ Aangezien het nog niet duidelijk is of de strafrechter de leer van de formele rechtskracht zal toepassen (alleen verkeersrecht of ook daasbuiten? alleen indien geen gebruik is gemaakt van de bestuursrechtelijke rechtsgang of ook als dat wel is gebeurd?), is het voor de verdediging altijd aan te raden ook in het geval van beschikkingen zo nodig een beroep te doen op de exceptie van onverbindendheid. Deze leer zal namelijk niet toepasselijk zijn op algemeen verbindende voorschriften (van bestuur), al ware het maar omdat daartegen (in het algemeen ${ }^{28}$ nog) geen

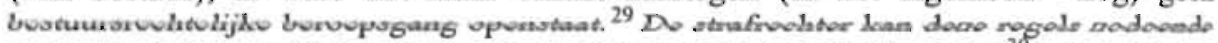
ongeacht de aanvaarding van deze leer, op hun rechtmatigheid toetsen. ${ }^{30}$ Dit geldt dus ook voor de toetsing van het algerneen verbindende voorschrift op basis waarvan een

HR 17 juli 1995, $N J$ 1995, 697, met noot Scheltema (Motorhuis M.).

27 Noot Hendriks onder Hoge Raad 11 januari 1994, MenR 1994, 85 (Mobil Oil). Noot Scheltema onder HR 6 juni 1995, $N J$ 1995, 696 (Vergissing met dwangbevel).

Dit is bijvoorbeeld wel het geval bij bepaalde besluiten op basis van de Wet op de ruimtelijke ordening.

Hierin kan verandering komen als op grond van de Awb ook tegen algemeen verbindende voorschriften een bestuursrechtelijke rechtsgang wordt open gesteld. Het was aanvankelijk de bedoeling dat de mogelijkheid om tegen algemeen verbindende voorschriften en beleidsregels in beroep te gaan zou ontstaan vijf jaar na de inwerkingtreding van de Awb (te weten 1 januari 1999). Dit is uitgesteld tot een nader te bepalen tijdstip (zie $T K$ 1997-1998, 26 077, nrs. 1-3), omdat de rechter en het bestuur nog in een gewenningsfase zitten met betrekking tot de Awb en omdat deze mogelijkheid procesrechtelijke voorzieningen vergt waarover nog moet worden overlegd in verband met de discussie over de juridisering van het openbaar bestuur (zie TK 1996-1997, 25 383, nr. 1). Zie over enkele mogelijke consequenties op strafrechtelijk vlak bij invoering van deze mogelijkheid: Hendriks, L.E.M., "Het systeem van vergunningen en algemene regels (hoofdstuk $8 \mathrm{Wm}$ ) in strafrechtelijk perspectief", p. 89. Overigens behoeft de leer van de formele rechtskracht ook na invoering van deze mogelijkheid, in navolging van de Wet op de ruimtelijke ordening, niet van toepassing te zijn op deze besluiten.

30 Zie daarover Hendriks, L.E.M., "Het systeem van vergunningen en algemene regels (hoofdstuk $8 \mathrm{Wm}$ ) in strafrechtelijk perspectief", pp. 86-87. Zie ook hoofdstuk 3 paragraaf 5.1. 


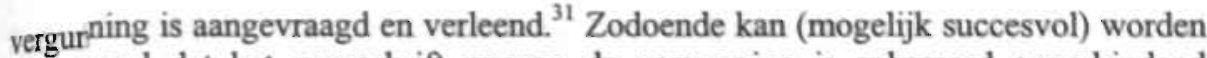
aanget 0 erd dat het voorschrift waarop de vergunning is gebaseerd onverbindend

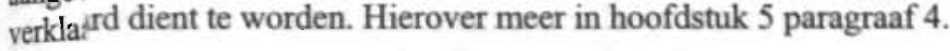

De $A \hat{\mu}$ Van Dorst heeft voorgesteld ${ }^{32}$ ten aanzien van de formele rechtskracht

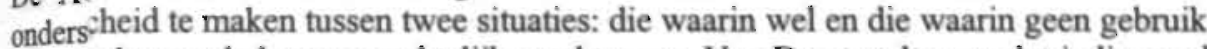

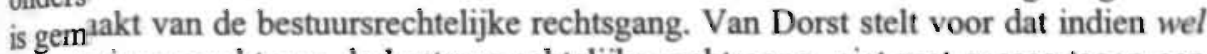
gebruif is gemaakt van de bestuursrechtelijke rechtsgang, niet met succes tegen een eerdert beslissing op een rechtspunt kan worden opgekomen, tenzij daarop een ander (strafrechtelijk relevant) licht zou vallen. In het geval dat er geen gebruik is gemaakt van de bestuursrechtelijke rechtsgang denkt hij an het hanteren van een stelplicht door $d^{e}$ verdachte. Deze moet dan de gronden aangeven waarom hij geen gebruik heeft jemaakt van de bestuursrechtelijke voorziening. Tevens moet de verdachte aangeven wat de vermoedelijke uitkomst van deze procedure was geweest als hij hem wel ha ${ }^{1}$ benut. Indien hij niet voldoet aan deze stelplicht zal volgens Van Dorst een terughiudende opstelling van de strafrechter voor de hand liggen.

De jurisprudentie lijkt echter uit te gaan van het primaat van het bestuur, niet alleen bij de inh?udelijke vaststelling van vergunningvoorschriften, maar ook bij de toetsing. Had de justitiabele de mogelijkheid om het vergunningvoorschrift langs bestuursrechtelj jke weg aan te vechten en heeft hij dat niet gedaan, dan bestaat de mogelijkheid dat do bestuurlijke beslissing daarmee formele rechtskracht verkrijgt waardoor de beschikking met zijn voorschriften meestal niet meer voor toetsing door de strafrechter in aanmerking komt.

De bevoegdheid van de strafrechter om de grenzen van de strafrechtelijke aansprakelijkheid te bepalen kan bij aanvaarding van deze leer in het geval van beschikkingen relatief beperkt zijn. ${ }^{33}$ Dat deze bevoegdheid bij gelede normstellingen primair bij het bestuur ligt moet echter enigszins worden genuanceerd. Zoals in hoofdstuk 4 werd aangeven, is de bevoegdheid van het bestuur om materiële normen te bepalen ook begrensd. Dit gebeurt door zowel de delegatiebepaling als zodanig, als door geschreven en ongeschreven rechtsbeginselen. ${ }^{34}$

Bij het vasthouden aan het leerstuk van de formele rechtskracht wordt aangenomen dat het bestaan van een bestuursrechtelijke rechtsgang meebrengt dat de strafrechter de

31 De Hoge Raad (civiele kamer) sprak zich in deze zin uit in de zaak "Ventvergunning \& APV" (HR 11 oktober 1996, NJ 1997, 165, met noot Scheltema), zie hoofdstuk 5 paragraaf 4.

32 Conclusie AG van Dorst, HR 27 juni 1995, NJ 1995, 722; MenR 1996, nr. 6, met noot Hendriks (Uitleg vergunningvoorschrift is feitelijk).

33 In dezelfde zin Roef, D., "Strafrecht versus leefmilieu: van geschiktheid naar ondergeschiktheid?", p. 473.

34 Zie hoofdstuk 4 paragraaf 5.2. Zie onder andere over de betekenis van de algemene beginselen van behoorlijk bestuur voor de normstelling Nicolaï, P., Beginselen van behoorlijk bestuur en Wijk, H.D. van, bewerkt door Konijnenbelt, W. en Male, R.M. van, Hoofdstukken van bestuursrecht, pp. 317-322. 
beschikking niet kan toetsen aan dit kader. De redenering luidt dan: de justitiabele had de mogelijkheid om via een bestuursrechtelijke rechtsgang tegen de bestreden beschikking op te komen. Nu hij dat niet heeft gedaan, en als het ware in de beschikking berust, behoort de strafrechter niet de bevoegdheid te hebben om de geldigheid van die beschikking te beoordelen. Toch is deze op het eerste gezicht wellicht aantrekkelijke redenering bij nadere beschouwing onbevredigend. De toetsingsbevoegdheid dient immers niet om de justitiabele een extra beroepsmogelijkheid tegen beschikkingen te geven, maar is van belang omdat er door de rechter in beginsel geen gevolgen mogen worden verbonden aan onrechtmatige voorschriften. De toetsingsbevoegdheid dient ertoe de rechter in elk individueel geval te laten toetsen of het voorschrift dat hij toepast, rechtmatig is. Daarom is de rechtmatigheidcontrole ook een plicht voor de rechter. Het is een logisch uitvloeisel van de trias-leer dat de rechter toetst of de voorschriften van de uitvoerende macht die hij eventueel toepast in overeenstemming zijn met (hogere) wet- en regelgeving en (on)geschreven rechtsbeginselen. Zeker in het strafrecht is het belangrijk dat de rechter de rechtmatigheid van bestuurshandelingen toetst, omdat anders een justitiabele kan worden veroordeeld voor een inbreuk op een beschikking(voorschrift) die objectief gezien ongeldig is, bijvoorbeeld omdat zij niet aan de wettelijke voorwaarden beantwoordt. De eenheid van de rechtsorde vereist juist dat de (straf)rechter toetst of de beschikking die hij toepast in overeenstemming is met (hogere) wet- en regelgeving en (on)geschreven rechtsbeginselen. Dit wordt niet anders indien er een bestuursrechtelijke rechtsgang oprenstaat en de betrokkene daarvan geen gebroik maakt of heeft gemaakt Het ongebruikt laten van deze rechtsgang zou geen alibi mogen vormen om de rechtmatigheidcontrole achterwege te laten, hetgeen immers kan meebrengen dat een onrechtmatige beschikking strafrechtelijk wordt gehandhaafd. Daarom zou de toetsingsbevoegdheid moeten blijven gelden, ook als er een bestuursrechtelijke rechtsgang openstaat of heeft gestaan en daarvan geen gebriik is gemaakt. Het is mogelijk dat de jurisprudentie, via de aanvaarding van het leerstuk van de formele rechtskracht in de toekomst een andere richting uitgaat, maar duidelijk is dit nog niet.

Wenselijk is dat toetsing door de strafrechter van bestuurlijke beslissingen mogelijk blijft, ook als daartegen een bestuursrechtelijke rechtsgang heeft opengestaan. De enige beperking die kan worden aangebracht is dat de toetsing door de strafrechter van een rechtspunt niet mogelijk is indien gebruik is gemaakt van de bestuursrechtelijke rechtsgang en daar tegen dit rechtspunt is opgekomen, tenzij daarop een ander (strafrechtelijk relevant) licht zou vallen. Overigens behoeft de strafrechter hiervoor geen gebruik te maken van de leer van de formele rechtskracht. Indien een bestuursrechtelijke uitspraak vooraf gaat aan een strafrechtelijke, zal de strafrechter in het algemeen aansluiting zoeken bij de interpretatie van de bestuursrechter. Zelfs indien geen sprake is van een eerdere bestuursrechtelijke uitspraak in de betreffende zaak, zal hij zich meestal richten op naar de in het bestuursrecht gangbare interpretatie.

Indien geen gebruik is gemaakt van de bestuursrechtelijke rechtsgang om tegen het betreffende rechtspunt op te komen, zou de toetsingsbevoegdheid van de strafrechter niet moeten worden aangetast. Het hanteren van een stelplicht van de verdachte waarom hij geen gebruik heeft gemaakt van de bestuursrechtelijke rechtsgang (zoals 
voorgesteld door Van Dorst) lijkt erg ver te gaan. Deze toetsing zal door de strafrechter meestal plaatsvinden in het kader van het onderzoek of sprake is van een strafutsluitingsgrond. Hierbij kan een actieve houding van de verdachte worden verwacht, maar dit is niet noodzakelijk, aangezien de strafrechter hier zijn eigen veranwoordelijkheid heeft.

\section{Exceptie van onverbindendheid}

Doorgaans zal een vraag naar de verenigbaarheid van bijvoorbeeld een vergunningvoorschrift met hogere normen niet in de formele termen van een toetsing worden gestell, maar zal de strafrechter de bepaling die werd geschonden of het hogere vocrschrift dienen te interpreteren teneinde de verenigbaarheid van beide bepalingen vast te stellen. De strafrechter zal indien nodig deze voorschriften, inclusief die uit wetten in formele zin, zelf uitleggen. De Hoge Raad vormt hierop een uitzondering aangecien hij, zoals hierboven in. hoofdstuk 5 paragraaf 2 is betoogd, wel over gaat tot het uileggen van algemeen verbindende voorschriften, maar niet tot het uitleggen van beschkkingen omdat dit een oordeel van feitelijke aard is.

De stafrechter kan de betreffende regel toetsen aan bepalingen van Europees en interntionaal recht, de Grondwet, wetten in formele zin, wetten in materiële zin, alsmede aan algemene rechtsbeginselen, al moet hierbij worden aangetekend dat sommige auteurs nog onderscheid in rechtsgevolg maken naar gelang de geschonden rechtsbeginselen. ${ }^{35}$ Hierbij geldt wel de uitzondering dat (bepalingen uit) wetten in formele zin niet mogen worden getoetst aan de Grondwet ${ }^{36}$ en meestal ook niet aan algemene rechtsbeginselen ${ }^{37}$, maar weer wel aan normen van het Europese en internationale recht.

Deze toetsingsbevoegdheid is niet beperkt tot een wetmatigheidcontrole, maar omvat tevens een rechtmatigheidcontrole. Er vindt echter geen volle toetsing van de bestuurs-

35 Volgens $\mathrm{C}$. Waling moet onderscheid worden gemaakt tussen schendingen wegens strijd met een materieel, en wegens strijd met een formeel beginsel van behoorlijk bestuur, Waling, C., "Het milieustrafrecht, een uitdaging, voor de advocatuur", pp. 465. Faure meent daarentegen, terecht, dat evenals dat in de civielrechtelijke jurisprudentie het geval is, de rechter in strafzaken mag toetsen aan alle beginselen van behoorlijk bestuur, Faure, M.G., "De gevolgen van de 'administratieve afhankelijkheid' van het milieurecht: een inventarisatie van knelpunten", p. 109.

36 Artikel 120 Grondwet luidt: "De rechter treedt niet in de beoordeling van de grondwettigheid van wetten en verdragen." Zie over het constitutionele toetsingsverbod de Preadviezen van Prakke, L., Koopmans, T. en Barendrecht, J.M., opgenomen in Toetsing: Handelingen 1992 der Nederlandse Juristenvereniging, Stroink, F.A.M., De plaats van de rechter in het staatsbestel; Dölle, A.H.M. en Engels, J.W.M., Constitutionele rechtspraak.

37 Zie hoofdstuk 3 paragraaf 5.1. 
handeling plaats. Deze is voorbehouden aan de bestuursrechter. Het is de strafrechter dus niet toegestaan de opportuniteit van de beslissing van het bestuur te beoordelen. ${ }^{38}$

De strafrechter kan een algemeen verbindend voorschrift toetsen op (on)verbindendheid. De mogelijkheid tot toetsing is afhankelijk van de toepassing ven het leerstuk van de formele rechtskracht. Duidelijk is dat bij algemeen verbindende voorschriften voor de verdachte (in het algemeen nog) geen bestuursrechtelijke beroepsgang open staat om tegen een dergelijke regel op te komen. De leer van de formele rechtskracht is hier dan ook niet van toepassing. Tegen beschikkingen staat een dergelijke beroepsgang wel open. Een toetsing van een beschikking(voorschrift) in het kader van de exceptie van onverbindendheid door de strafrechter kan hierdoor (gedeeltelijk) worden geblokkeerd. ${ }^{39}$

Ongeacht de al dan niet (gedeeltelijke) aanvaarding van de leer van de formele rechtskracht is het mogelijk het algemeen verbindende voorschrift op basis waarvan een beschikking is verstrekt te toetsen op (on)verbindendheid. De Hoge Raad (civiele kamer) sprak zich in deze zin uit in een zaak waar de betrokkene een APV had overtreden door te venten in strijd met zijn ventvergunning. De Hoge Raad overwoog ${ }^{40}$ :

"Indien de overheid het standpunt inneemt dat een burger voor het verrichten van bepaalde handelingen, zoals het uitoefenen van een bepaalde vorrn van bedrijf of beroep, involge een algemeen verbindend voorschrift een vergunning nodig heeft, maar die burger dit voorschrit onverbindend en daarom het inroepen en handhaven ervan jegens hem onrechtmatig acht, de eisen van een doeltreffende rechtsbescherming tegen de overheid meebrengen dat de burger het geschil omtrent de verbindendheid van het voorschrift aan de rechter moet kunnen voorleggen. Zolang de beslechting van een dergelijk geschil niet aan de bestuursrechter is opgedragen (...) moet die burger de vraag of het voorsehrift verbindend is, in beginsel door middel van een vordering gegrond op onrechtmatig overheidsoptreden kunnen voorleggen aan de burgerlijke rechter. Dit laatste wordt niet anders doordat, indien de burger zonder de vereiste vergunning handelt en tegen hem (...) een strafvervolging wordt ingesteld of bestuursdwang wordt toegepast, de verbindendheid van de desbetreffende regeling kan worden getoetst in een procedure voor de strafrechter resp. de bestuursrechter."

De strafrechter zal deze toetsing slechts kunnen verrichten in een concreet geschil, waarin de verbindendheid van de regeling voor de beslechting van het geschil van belang is. Indien een verdachte zich met vrucht beroept op het feit dat een strafbepaling op grond waarvan hij wordt vervolgd onverbindend is wegens strijd met een andere regeling, zal de strafrechter, afhankelijk van de tenlastelegging, moeten overgaan tot ontslag van rechtsvervolging of vrijspraak.

Aan de onverbindendverklaring van de strafrechter wordt geen algemeen bindend karakter toegekend. De door de strafrechter uitgesproken onverbindendverklaring van

40 HR 11 oktober 1996, $N J$ 1997, 165, met noot Scheltema (Ventvergunning en APV). 
een aigemeen verbindend voorschrift blijft beperkt tot de bij het geschil betrokken partijen.

\section{Samenloop bestuursrechtelijke en strafrechtelijke procedure}

Een bestuursrechtelijke en een strafrechtelijke procedure, waarbij dezelfde ongewenst geachte gedraging van een justitiabele centraal staat, kunnen samenlopen. Deze procedures kunnen betrekking hebben op dezelfde bepaling of voorschrift uit een wet in formele zin, algemeen verbindend voorschrift van bestuur of een beschikking.

Indien een vervolging is aangevangen terwijl naar aanleiding van dezelfde zaak een bestuursrechtelijke bezwaar- of beroepsprocedure in gang is gezet, kan de raadsman zo nodig aandringen op schorsing van de strafrechtelijke procedure (ex artikel $281 \mathrm{~Sv}$ ) totdat bestuursrechtelijk onherroepelijk is beslist. De strafrechter behoeft daartoe echter niet over te gaan. De hoofdregel is dat bezwaar of beroep in het strafrecht geen schorsende werking tot gevolg hebben. Dit is slechts anders indien de wet het tegendeel bepaalt. De Hoge Raad overwoog ${ }^{41}$ :

"Aangezien geen wetsbepaling, voor het geval na zodanige ongeldigverklaring enig administratief bezwaar of beroep wordt ingesteld, daaraan schorsende werking verleent, is gedurende de behandeling van het bezwaar of beroep de ongeldigverklaring onverminderd van kracht en doet het aanhangig zijn van zodanige procedure niet af aan het in art. 32, tweede lid, WVW vervatte verbod.

5.3.2. 's Hofs verwerping van het verweer dat er hangende de gestelde administratiefrechtelijke procedure geen sprake was van een ongeldig verklaard rijbewijs, geeft derhalve geen blijk van een verkeerde rechtsopvatting. Tot nadere motivering was het Hof niet gehouden. (...).

5.4.1. Indien echter een ongeldigverklaring als bedoeld in art. $18 \mathrm{~b}$, vijfde lid, WVW naar aanleiding van een administratiefrechtelijke procedure alsnog is ingetrokken of herzien bijvoorbeeld nadat alsnog een verzoek om een ander onderzoek als bedoeld in het iweede lid van art. 18b WVW is ingewilligd en het resultaat daarvan gunstig is voor de betrokkene - brengt zulks in beginsel mee dat achteraf moet worden geoordeeld dat die ongeldigverklaring nimmer heeft gegolden, zodat op gedragingen begaan gedurende de hiervoren onder 5.3 .1 . bedoelde periode het in art. 32 , tweede lid, WVW vervatte verbod toepassing mist."

Indien men ervan uitgaat dat het resultaat van een bestuursrechtelijke procedure in beginsel wordt gevolgd door de strafrechter, valt er, mede om een mogelijk conflict met het beginsel van de eenheid van de rechtsorde te vermijden, wel iets voor te zeggen om toch (ex artikel $281 \mathrm{~Sv}$ ) het onderzoek ter terechtzitting te schorsen zolang

4) HR 14 februari 1995, N.J 1995, 407 ((On)bevoegd rijden). In deze zaak werd de verdachte strafrechtelijk vervolgd voor het rijden terwijl zijn rijbewijs ongeldig was verklaard. Tegen deze ongeldigverklaring had de verdachte administratief bezwaar en beroep was ingesteld, omdat het in deze zaak wettelijke beroep op contra-expertise op ondeugdelijke gronden was vernietigd. Het verzoek was wegens termijn overschrijding niet in behandeling genomen, terwijl de mededeling van de uitslag van het onderzoek waartegen dit openstond ten onrechte naar het oude adres van de verdachte was gestuurd. 
nog geen definitieve bestuursrechtelijke uitspraak is gedaan over de beschikking. Als hiertoe niet wordt overgegaan kan de strafrechter de verdachte veroordelen, terwijl later de overtreden norm door de bestuursrechter wordt vernietigd. Als de bestuursrechtelijke uitspraak eerder wordt gegeven, zou de strafrechter hieraan in beginsel zijn gebonden en zou, afhankelijk van de tenlastelegging, vrijspraak of ontslag van alle rechtsvervolging de uitspraak zijn geweest. Om dergelijke tegenstrijdigheden te vermijden, lijkt het beter dat de vervolging wordt geschorst, zolang er nog niet definitief in de bestuursrechtelijke procedure is beslist. ${ }^{42}$ Dit lijkt een logische processuele consequentie van de administratieve afhankelijkheid.

Dit standpunt heeft wel een belangrijk praktisch nadeel: indien de strafrechter moet schorsen zodra er een bestuursrechtelijke procedure is ingeleid tegen een beschikking die hij dient toe te passen, wordt het strafproces vertraagd. ${ }^{43}$ Ondanks het feit dat de procedure voor de bestuursrechter ook aan termijnen is gebonden, kan het jaren duren voordat sprake is van een onherroepelijke uitspraak (denk bijvoorbeeld aan het geval dat een prejudiciële beslissing wordt gevraagd aan het EG-Hof te Luxemburg). In die gevallen kan het onder omstandigheden onwenselijk zijn dat de strafrechtelijke procedure daarop zou moeten wachten. Het gevolg kan zelfs zijn dat een bestuursrechtelijke procedures wordt ingesteld, louter om de strafvervolging voor het schenden van de beschikking(voorschriften) op de lange baan te schuiven. Aan de schorsing is involge artikel $73 \mathrm{Sr}$ overigens wel de consequentie verbonden dat de verjaring wordt geschorst gedurende de periode dat de bestuursrechtelijke procedure nog niet is beëindigd. Verjaringsproblemen worden derhalve vermeden terwijl anderzijds wordt voorkomen dat op strafrechtelijk vlak een uitspraak wordt gedaan die mogelijk in conflict kan komen met een bestuursrechtelijke uitspraak.

De vraag rijst echter of dit systeem van schorsing van de strafrechtelijke procedure bij een belastende beschikking(voorschrift) ook zou moet worden toegepast bij een begunstigende beschikking(voorschrift). ${ }^{44}$ Nog al eens wordt immers een activiteit reeds ontplooid zonder dat de betreffende justitiabele over de nodige beschikkingen beschikt. Strafrechtelijke vervolging wordt dan vaak ingesteld teneinde de justitiabele ertoe aan te zetten de vereiste beschikking(en) aan te vragen. Het lijkt onwenselijk indien in dat geval de strafrechter de bestuursrechtelijke uitspraak dient af te wachten, zijnde in casu de eventuele beschikkingverlening. Dit geval ligt wellicht moeilijker dan de belastende beschikking(voorschrift) omdat de beschikking in principe steeds dient te worden verkregen voordat men een activiteit start. In beginsel is derhalve de niet-vergunde periode illegaal en werkt de beschikking alleen voor de toekomst. ${ }^{45}$

42. In dezelfde zin in Duitsland: Wüterich, Ch., "Die Bedeutung von Verwaltungsakten für die Strafbarkeit wegen Umweltvergehen (\$\$ 324 ff. StGB)", pp. 108-109.

43 Zie daarover ook Hendriks, L.E.M. en Wöretshofer, J., Milieustrafrecht, pp. 72-73.

44 Zie over het verschil tussen begunstigende en belastende beschikkingen onder andere Koopmans, I.M., De strafbaarstelling van miliewerontreiniging, pp. 146-149; Hendriks, L.E.M. en Wöretshofer, J., Milieustrafrecht, pp. 71-73 en Blomberg, A.B. en Michiels, F.C.M.A., Handhaven met effect, pp. 119-120.

45 De mogelijkheid bestaat dat dit in bijzondere omstandigheden anders ligt indien het bestuur de illegale situatie toestaat involge een gedoogbeschikking. Zie de 
Maar het is niet uitgesloten dat het bestuur een besluit met terugwerkende kracht neemt, hetgeen bijgevolg de strafbaarheid voor het verleden zou wegnemen. Ook bij het vervolgen wegens niet-vergund handelen, zou een ultieme consequentie van de administratieve afhankelijkheid zijn dat de strafrechter dient te wachten tot over de beschikkingaanvraag uitspraak is gedaan.

\section{Strafrechtelijke uitspraak voorafgaand aan bestuursrechtelijke uitspraak}

Aangezien vooralsnog bezwaar of beroep in het strafrecht geen schorsende werking tot gevolg hebben, kan het voorkomen dat de strafrechter al een onherroepelijk oordeel heeft geveld op het moment dat de bestuursrechter met de voor de gewezen verdachte gunstige eindbeslissing afkomt. In het algemeen zal het $\mathrm{OM}$ niet snel tot vervolging overgaan, indien gerede twijfel bestaat met betrekking tot de rechtmatigheid van de bestuursrechtelijke beschikking. Uitgesloten is dit echter niet, en het komt voor dat nadat in een strafrechtelijke procedure is geoordeeld over de schending van een besluit, de bestuursrechter het besluit onrechtmatig acht of een voor de verdachte of veroordeelde gunstiger uitleg geeft aan het besluit.

Indien de strafrechtelijke uitspraak voorafgaat aan de bestuursrechtelijke, heeft de strafrechter, als eerste, de casus in het licht van zijn interpretatie van de beschikking beoordeeld. Dit deed zich voor in een zaak waarin een autosloperij strafrechtelijk werd vervolgd wegens het handelen in strijd met de aan zijn vergunning gebonden voorschriften, hetgeen tot een veroordeling door het Hof had geleid. Ter zake van dezelfde overtreding werd ook bestuursdwang tegen hem toegepast. Bij de procedure tegen de beschikking tot toepassing van bestuursdwang oordeelde de bestuursrechter, in een latere uitspraak dan die van het Hof, dat de voorschriften van de vergunning niet waren overtreden. De Hoge Raad overwoog in deze zaak ${ }^{46}$ :

"4.1. Het middel berust op de stelling dat de bewezenverklaring niet naar de eis der wet is omkleed omdat het hof de in de bewezenverklaring bedoelde vergunningvoorschriften niet op een andere wijze had mogen uitleggen, zoals het heeft gedaan, dan de Afdeling bestuursrechtspraak van de Raad van State heeft gedaan in haar op 11 november 1994, en derhalve na de bestreden uitspraak, gedateerde uitspraak.

4.2. Deze stelling kan in haar algemeenheid niet als juist worden aanvaard. De uitleg van de in het middel bedoelde vergunningvoorschriften is van feitelijke aard en dient te geschieden naar aanleiding van het onderzoek op de terechtzitting. Het stond het hof vrij om tot zijn uitleg van de meerbedoelde vergunningvoorschriften te komen, ook al zou deze afwijken van een later door de Afdeling bestuursrechtspraak gegeven uitleg."

merkwaardige uitspraak van het Hof Amsterdam 17 mei 2000, MenR 2000, nr. 66, met. noot Hendriks (Gedoogbeschikking als vergunning). Overigens is tegen deze uitspraak door het $\mathrm{OM}$ cassatie ingesteld.

46 HR 23 mei 1995, NJ 1995, 695, met noot Scheltema; MenR 1996, nr. 5, met noot Hendriks (Uitleg vergunning van feitelijke aard). 
De rechters kwamen derhalve tot tegenstrijdige uitspraken. Het betrof hier niet de vraag naar de rechtsgeldigheid van de vergunning, maar de vraag of een bepaald handelen in strijd was met de voorschriften daarvan. Op het moment van de uitspraak van het Hof was er nog geen uitspraak van de bestuursrechter. De strafrechter kon dus "zijn eigen weg gaan".

De Hoge Raad zorgt in dergelijke gevallen niet voor gelijkluidende interpretatie. Hij acht hiertoe zichzelf, zoals in hoofdstuk 5 paragraaf 2 werd aangegeven, niet bevoegd omdat hij de uitleg van vergunningvoorschriften van feitelijke aard acht en van oordeel is dat deze uitleg dient te geschieden naar aanleiding van het onderzoek ter terechtzitting. De Hoge Raad toetst slechts of de uitleg van het Hof al dan niet begrijpelijk is.

Indien iemand onherroepelijk is veroordeeld op basis van het overtreden van een besluit, terwijl later blijkt dat de bestuursrechter het betreffende besluit onrechtmatig oordeelt dan wel anders (voor de veroordeelde gunstiger) interpreteert, kan de onherroepelijk veroordeelde in het algemeen geen succesvolle herziening vragen. ${ }^{47} \mathrm{Er}$ is namelijk geen sprake van conflict van Nederlandse strafrechtspraak, zodat de herzieningsgrond ex artikel 457, eerste lid sub 1 Sv niet van toepassing is. Voor de tweede herzieningsgrond op basis van artikel 457, eerste lid sub $2 \mathrm{~Sv}$, is het noodzakelijk dat sprake is van een nieuw feitelijk gegeven. Nieuwe juridische

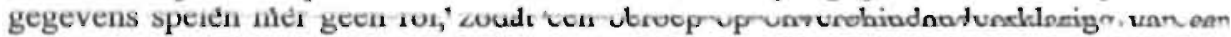
wettelijke regeling op grond waarvan de rechter het gepleegde feit strafbaar heeft geacht geen herzieningsgrond oplevert. ${ }^{48}$ Ook nieuwe rechterlijke uitspraken of jurisprudentie ${ }^{49}$ of rechtsdwaling door de rechter ${ }^{50}$ leveren op zichzelf geen novum op. Soms hebben feiten met een juridische component wel aanleiding tot herziening gegeven. ${ }^{51}$ Degene die onherroepelijk is veroordeeld, terwijl later blijkt dat de bestuursiechter het besluit dat hij heeft overtreden onrechtmatig oordeelt of gunstiger interpreteert kan mogelijk wel met vrucht een gratieverzoek ex artikel $122 \mathrm{Gw}$ indienen. $^{52}$

47 Zie hierover Hullu, J. de, in Cleiren, C.P.M. en Nijboer, J.F. (red.), Strafvordering. Tekst en Commentaar, pp. 1036-1037.

48 HR 13 januari 1976, $N J$ 1976, 339 (Hyacinthenteelverordening).

49 Ook niet van het EHRM, zie HR 6 juli 1999, $N J$ 1999, 800, met noot De Hullu (EHRM is geen herzieningsgrond).

50 HR 30 januari 1990, $N J 1990,610$ (Rechtsdwaling rechter geen herzieningsgrond).

51 HR 10 februari 1987, $N J 1987,848$, met noot Corstens (Herziening, ex tunc-redenering).

52 Zie HR 10 februari 1987, $N J$ 1987, 848, met noot Corstens (Ingetrokken beschikking). 


\section{Consequenties van bestuursrechtelijke uitspraak voorafgaand aan de strafrechtelijke uitspraak}

\subsection{Inleiding}

De olgende vraag die rijst is wat de houding van de strafrechter dient te zijn wanneer vóó de strafrechtelijke uitspraak de bestuursrechter zich heeft uitgesproken over de rectmatigheid van de omstreden bestuursrechtelijke rechtshandeling.

Indin een procedure voor de bestuursrechter leidt tot de bevinding dat het besluit (de vopichriften van het besluit) rechtsgeldig was, is de situatie relatief eenvoudig. Gelet op et karakter van de toetsing door de bestuursrechter, die wordt geacht de beste expitise te hebben aangaande de verenigbaarheid van besluiten (en zijn voorschriften) methogere normen, zal deze toetsing de strafrechter voor wat betreft de thema's

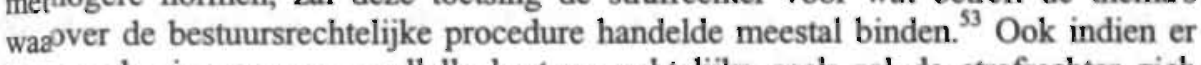
geer sprake is van een parallelle bestuursrechtelijke zaak za! de strafrechter zich meetal richten naar de in het bestuursrecht gangbare interpretatie. ${ }^{54}$

De estuursrechter kan een besluit of daaraan verbonden voorschriften, vernietigen. De estuursrechtelijke consequentie van deze vernietiging is dat involge artikel 8:72, twede lid Awb ook de rechtsgevolgen van het vernietigde besluit (of de vernietigde voorschriften van het besluit) worden vernietigd. In het bestuursrecht treedt de fictie in werking dat het betreffende besluit of de betreffende voorschriften, nooit hebben bestaan. De vernietiging heeft bestuursrechtelijk. derhalve terugwerkende kracht. De vraag rijst of degene die het voorschrift uit de beschikking heeft overtreden voordat de vernietiging werd uitgesproken hiervoor strafrechtelijk kan worden veroordeeld. In ieder geval geldt dat wanneer de bestuursrechter zich over de rechtmatigheid van een besluit heeft uitgesproken, de strafrechter in het algemeen dat standpunt zal volgen. ${ }^{55}$ De vraag is evenwel welke consequenties hieraan op strafrechtelijk vlak worden verbonden: indien een begunstigende beschikking wordt vernietigd (hoofdstuk 5 paragraaf 7.2.), indien een belastende beschikking wordt vernietigd (hoofdstuk 5 paragraaf

7.3.) en indien een voorlopige maatregel wordt geschonden (hoofdstuk 5 paragraaf 7.4.).

\section{Consequenties bij vernietiging begunstigende beschikking}

Indien sprake is van de vernietiging van een begunstigende beschikking ${ }^{56}$ (of daaraan verbonden voorschriften) wordt het uitgangspunt gehanteerd dat wie op regelmatige

53 Faure, M., "De gevolgen van de 'administratieve afhankelijkheid' van het milieustrafrecht: een inventarisatie van knelpunten", pp. 122-123.

54 Faure, M., "De gevolgen van de "administratieve afhankelijkheid" van het milieustrafrecht: een inventarisatie van knelpunten", pp. 122-123.

55 Hendriks, L.E.M. en Wöretshofer, J., Milieustrafrecht, p. 70.

56 Zie over het verschil tussen begunstigende en belastende beschikkingen onder andere. Koopmans, I.M., De strafbaarstelling van milieuverontreiniging, pp. 146-149; Hendriks, L.E.M. en Wöretshofer, J., Milieustrafrecht, pp. 71-73 en Blomberg, A.B. en Michiels, 
wijze een vergunning (dan wel ontheffing) heeft verkregen erop mag vertrouwen dat hij rechtmatig handelt wanneer hij daarvan gebruik maakt. Indien blijkt dat de beschikking in strijd met het recht werd verleend, vloeit uit het vertrouwensbeginsel voort dat de houder daarvan niet de dupe mag worden; een (avas)verweer dat betrekking heeft op de verkregen beschikking zal dan in het algemeen moeten worden gehonoreerd, ook al is deze vernietigd. ${ }^{57}$ De Hoge Raad stelt ${ }^{58}$ :

"De houder van een vergunning mag in het algemeen erop vertrouwen dat deze vergunning overeenkomstig de wettelijke voorschriften is verstrekt en dat hij gerechtigd is van deze vergunning gebruik te maken, ook wanneer later zou blijken dat zij in strijd met een wettelijk voorschrift en derhalve ten onrechte is gegeven."

Maar niet altijd leidt de gegeven beschikking tot straffeloosheid. In ieder geval dan niet, wanneer blijkt dat de betrokkene wist of had moeten weten dat de beschikking ten onrechte was afgegeven of als zij werd verleend op door de verkrijger verstrekte onjuiste of misleidende informatie. ${ }^{59}$

\subsection{Consequenties bij vernietiging belastende beschikking}

Indien de bestuursrechter een belastende beschikking onherroepelijk heeft vernietigd, is de bestuursrechtelijke consequentie dat de fictie in werking treedt dat de beschikking (met zijn voorschriften) nooit heeft bestaan. ${ }^{60}$ Indien voorafgaande aan

F.C.M.A., Handhaven met effect, pp. 119-120.

57 Zie ook Hendriks, L.E.M. en Wöretshofer, J., Milieustrafrecht, p. 71 en Blomberg, A.B. en Michiels, F.C.M.A., Handhaven met effect, p. 119.

58 HR 13 november 1984, NJ 1985, 294; $A B$ 1985, 361, met noot Van der Burg (Kampeerverordening Domburg). Overigens leidde dit uitgangspunt in deze zaak uitzondering nu "de verlening van de vergunning een ook voor de verdachte zo onmiskenbare wetschending opleverde dat hij had moeten begrijpen dat $\mathrm{B}$ en $\mathrm{W}$ hem deze niet hadden mogen verlenen."

59 HR 10 februari 1987, NJ 1987, 662, met noot 't Hart (Onterechte vergunning). Zie voor de criteria voor rechtsdwaling Vellinga, W.H., Schuld in spiegelbeeld; Afwezigheid van alle schuld, pp. 160-168 en voor voorbeelden uit de jurisprudentie Faure, M., "De gevolgen van de 'administratieve afhankelijkheid' van het milieustrafrecht: een inventarisatie van knelpunten", pp. 138-139.

60 Overigens werd vóór februari 1995 aangenomen dat de belastende beschikking tot het moment dat de vernietiging werd uitgesproken of de schorsende werking van kracht werd, kon worden overtreden. Dit standpunt lijkt thans verlaten. Dit gebeurde bijvoorbeeld in de zaak Omega. De vergunning op grond van de afvalstoffenwet werd door de Afdeling geschillen van bestuur van de Raad van State vernietigd. De raadsman deed in de strafzaak waar overtreding van de vergunning(voorschriften) ten laste was gelegd een beroep op deze vernietiging. Hij stelde dat deze vemietiging terugwerkende kracht heeft. De Rechtbank oordeelde dat dit beroep faalt. Zij overwoog dat weliswaar bij een vernietiging achteraf wordt uitgegaan (als principe) dat de fictie dat deze vergunning geacht wordt niet te hebben bestaan, maar zolang echter zo'n vernietiging niet is uitgesproken en in geval het beroep geen schorsende werking heef, de vergunning geldig is. De aan de vergunning verbonden voorschriften kunnen in die periode worden overtreden met strafrechtelijke gevolgen. Rb Amsterdam 26 april 1991 . 
een dergelijke uitspraak is gehandeld in strijd met (de voorschriften in) deze beschikking, en de verdachte hiervoor wordt vervolgd lijkt de strafrechter conform de bestuursrechtelijke uitspraak ook terugwerkende kracht toe te kennen aan de vernietiging van de beschikking(voorschriften). Zo oordeelde het Hof 'sHertogenbosch ${ }^{61}$ :

"Het hof acht - evenals de eerste rechter - niet wettig en overtuigend bewezen hetgeen aan verdachte bij - gewijzigde - inleidende dagvaarding is ten laste gelegd, zijnde het hof van Dordeel dat aan de vernietiging van de betreffende vergunning terugwerkende kracht moet worden toegekend, zodat niet bewezen kan worden verklaard, dat verdachte handelde in strijd met voorschriften, verbonden aan een krachtens de Wet Milieubeheer verleende vergunning."

In deze zaak was geconstateerd dat een bedrijf de vergunningvoorschriften niet naleefde, hetgeen resulteerde in een strafrechtelijke vervolging wegens schending van de vergunningvoorschriften. De beschikking was echter bestuursrechtelijk bestreden, hetgeen leidde tot de vernietiging van de vergunning door de bestuursrechter op formele gronden. ${ }^{62}$ De consequentie van deze vernietiging is in het bestuursrecht dat involge artikel 8:72, tweede lid Awb ook de rechtsgevolgen van het vernietigde besluit worden vernietigd. De bestuursrechtelijke fictie treedt in werking dat het betreffende besluit nooit heeft bestaan. De strafrechter volgt hier deze fictie. Het gevolg is dat niet bewezen kan worden verklaard dat verdachte handelde in strijd met (voorschriften verbonden aan) de beschikking.

Mogelijk kan in dat geval de verdachte wel met succes worden vervolgd voor het handelen zonder vergunning. ${ }^{63}$ De vergunning die hij had is namelijk met terugwerkende kracht vernietigd, waardoor de fictie in werking treedt dat deze nooit heeft bestaan, zodat hij (eveneens als fictie) op het moment van handelen niet beschikte over een vergunning. ${ }^{64}$

De verdachte kan een (avas)beroep doen op het feit dat hij op het moment van handelen wel beschikte over een (ten aanzien van deze vervolging) bevrijdende vergunning. Het is nu aan de rechter om te oordelen of de handeling al dan niet wordt gerechtvaardigd door deze vergunning. Indien de handeling was toegestaan op basis

MenR' 1991, nr. 121. Zie ook Waling, C., "Het milieustrafrecht, een uitdaging voor de. advocatuur", pp. 460-466, vooral 464-465.

6I Hof 's-Hertogenbosch, 20 april 1999, MenR 1999, nr. 98, met noot De Lange (Terugwerkende: vergunning).

62 Overigens worden meestal, indien de vergunninghouder de vergunning met succes heeft bestreden, alleen bepaalde vergunningvoorschriften vernietigd. Ook indien derden met succes de vergunning hebben bestreden, zal vaak een gedeeltelijke vernietiging volgen. In beide situaties kan de vergunninghouder wellicht weten dat er aan de beschikking een gebrek kleefde.

Hierbij wordt ervan uitgegaan dat het handelen zonder vergunning is strafbaar gesteld. Zoals gesteld door De Lange in zijn noot onder Hof 's-Hertogenbosch, 20 april 1999, MenR 1999, nr. 98 (Terugwerkende vergunning). Dit heeft tot gevolg dat primair ten laste wordt gelegd het handelen in strijd met de beschikking en subsidiair het handelen zonder beschikking, hetgeen de annotator terecht "niet fraai" noemt. 
van de vergunning zal de verdachte (afhankelijk van de tenlastelegging) worden vrijgesproken of ontslagen van rechtsvervolging. Indien de handeling niet was toegestaan involge de vergunning valt de handeling niet onder het bereik van de (vernietigde) vergunning, zodat het (avas)verweer niet zal slagen en sprake zal zijn van handelen zonder vergunning.

\subsection{Consequenties bij strafrechtelijke voorlopige maatregel}

Ook de invloed van een bestuursrechtelijke uitspraak bij een strafrechtelijke voorlopige maatregel kan interessant zijn. Een dergelijke voorlopige maatregel kan op grond van artikel 28, eerste lid Wed worden gebaseerd op een bestuursrechtelijke beschikking, bijvoorbeeld een sluitingsbevel. Indien deze beschikking door de Raad van State wordt vernietigd, kan de situatie zich voordoen dat de justitiabele wegens overtreding van de voorlopige maatregel wordt vervolgd. Het overtreden van de voorlopige maatregel, die (indirect) is gekoppeld aan een eerder genomen bestuursrechtelijk sluitingsbevel, levert een apart strafbaar feit op. De Hoge Raad overweegt ${ }^{65}$ :

"Een zodanige maatregel verliest zijn kracht door tijdsverloop of door intrekking als in het derde lid van dat artikel omschreven. De (...) stelling dat vervolging wegens overtreding van een voorlopige maatregel als de onderhavige achterwege moet blijven op de enkele grond dat cen door het college van burgemeester en wethouders eerder gegeven bevel tot sluiting van de inrichting nadien doar de Raad van State is vernietigd, vindr geen steun in het recht"

\section{Annotator Corstens merkt op dat voorlopige maatregelen rechtsmaatregelen zijn}

"en dus op enigerlei wijze een dwingend karakter hebben. Die dwang bestaat hier in strafrechtelijke sanctionering bij ongehoorzaamheid. Indien men straffeloos zo'n maatregel kan negeren, erop vertrouwende dat die straks in het administratiefrechtelijke geschil van zijn basis zal worden beroofd, wordt het gezag van voorlopige maatregelen sterk aangetast. In die benadering is het delict van art. 33 jo. 28 WED een delict tegen het openbaar gezag. Dan wordt geabstraheerd van de eventuele vernietiging straks in de onderliggende beschikking van burgemeester en wethouders."

De strafrechter ziet de schending van de strafrechtelijk opgelegde voorlopige maatregel als een zelfstandig strafbaar feit. ${ }^{60}$ Voor de justitiabele kan dit resultaat moeilijk zijn te begrijpen. Tegen een door de officier opgelegde voorlopige maatregel staat overigens op grond van artikel 28 , derde lid Wed appel open.

65 HR 8 december 1992, NJ 1993, 618, met noot Corstens (Sluitingsbevel).

66 De annotator hoopt dat deze mager gemotiveerde uitspraak een uitzondering is op een "nieuwe praktijk" van bredere motivering. Hij wijst op de herzieningsbeslissing HR 10 februari 1987, $N J$ 1987, 848, met noot Corstens (Ingetrokken beschikking), waarin wel een ex tunc-redenering is toegepast. 


\subsection{Consequenties van bestuursrechtelijke uitspraken voor de strafrechter}

Indien een bestuursrechtelijke uitspraak voorafgaat aan de strafrechtelijke, zal de strafrechter in het algemeen aansluiting zoeken bij de interpretatie van de besturrsrechter. Ook indien er geen sprake is van een parallelle bestuursrechtelijke zaak zal de strafrechter zich meestal richten naar de in het bestuursrecht gangbare interpretatie. De bestuursrechter is doorgaans de meest gerede instantie om te oordelen over de uitleg van een (in oorsprong) bestuursrechtelijk voorschrift. ${ }^{67}$

Indien bestuursrechtelijk bezwaar of beroep wordt ingesteld tegen de beschikking behofft dit geen consequenties te hebben voor de strafrechtelijke procedure. ${ }^{68}$ Indien geen wetsbepaling, voor het geval na zodanige ongeldigverklaring enig bestuursrechtelijk bezwaar of beroep wordt ingesteld daaraan schorsende werking verleent, is gedurende de behandeling van het bezwaar of beroep de beschikking onverminderd van lracht.

Indien een begunstigende beschikking (of een begunstigend voorschrift uit een beschikking) wordt vernietigd, wordt het uitgangspunt gehanteerd dat wie op regelnatige wijze een vergunning (dan wel ontheffing) heeft verkregen erop mag vertrouwen dat hij rechtmatig handelt wanneer hij daarvan gebruik maakt. Dit geldt niet onverkort. Zo zal dit niet opgaan indien de betrokkene wist of had moeten weten dat de beschikking ten onrechte was afgegeven of als zij werd verleend op door de verkrijger verstrekte onjuiste of misleidende informatie.

Indien een belastende beschikking (of een belastend voorschift uit een beschikking) wordt vernietigd, is de bestuursrechtelijke consequentie dat de fictie in werking treedt dat de beschikking (of het vernietigde voorschrift) nooit heeft bestaan. Indien voorafgaande aan een dergelijke uitspraak is gehandeld in strijd met deze beschikking (dit voorschrift), en de verdachte hiervoor wordt vervolgd, lijkt de strafrechter conform de bestuursrechtelijke uitspraak ook terugwerkende kracht toe te kennen aan de vernietiging van de beschikking (of het voorschrift). Het gevolg is dat niet bewezen kan worden verklaard dat verdachte handelde in strijd met (voorschriften verbonden aan) de beschikking. Mogelijk kan in dat geval de verdachte wel met succes worden vervolgd voor het handelen zonder beschikking.

Indien een strafrechtelijke voorlopige maatregel op grond van artikel 28 , eerste lid Wed wordt gebaseerd op een bestuursrechtelijke beschikking, en deze beschikking door de Raad van State wordt vernietigd, kan de justitiabele wegens overtreding van de voorlopige maatregel met succes worden vervolgd. Het overtreden van de voorlopige maatregel, die (indirect) is gekoppeld aan een eerder genomen bestuursrechtelijke beschikking, levert een zelfstandig strafbaar feit op.

\footnotetext{
67 Faure, M., "De gevolgen van de "administratieve afhankelijkheid" van het milieustrafrecht: een inventarisatie van knelpunten", pp. 122-123.

Zie hoofdstuk 5 paragraaf 5.
} 
Dit wil echter niet zeggen dat de strafrechter altijd de bestuursrechter zal volgen. Er zijn uitzonderingen mogelijk. Het betreft immers een ander rechtsgebied dat ook een ander doel heeft en waaraan andere eisen worden gesteld. ${ }^{69}$

\section{Cumulatie van bestuursrechtelijke en strafrechtelijke reactie}

Bij het gebruik van gelede normstellingen wordt de inhoud van de norm (gedeeltelijk) bepaald door het bestuur. Er bestaan veelal ook bestuursrechtelijke mogelijkheden om op te treden tegen handelen in strijd met een door het bestuur vastgestelde norm. Hierdoor kan het voorkomen dat ter zake van een zelfde feitencomplex een strafrechtelijke veroordeling vooraf wordt gegaan door een bestuursrechtelijke sanctieoplegging. ${ }^{70}$ Het is vaste rechtspraak dat noch een beslissing van de bestuurs- of burgerlijke rechter, noch een tuchtrechtelijke beslissing de vervolging ter zake van hetzelfde feit bij de strafrechter in de weg staat", tenzij het een "criminal charge betreft".

Deze rechtspraak werd onder andere bevestigd in een zaak tegen een verdachte die in 1991 een puinbreekinstallatie had overgenomen. Het bedrijf beschikte tot 1989 over een vergunning krachtens de toen nog geldende Afvalstoffenwet. Daarna werd de bedrijfsuitoefening gedoogd, zo lang men zich hield aan de voorschriften die aan deze vergunning waren verbonden. Deze voorschriften werden echter niet nageleefd, waarna verdachte werd vervolgd wegens het in werking hebben van een inrichting in de zin van de Afvalstoffenwet zonder vergunning. Door de verdediging werd aangevoerd dat het $O M$ niet ontvankelijk moest worden verklaard in zijn vervolging omdat er sprake zou zijn van vervolging in strijd met het ne bis in idem-beginsel, respectievelijk het una via-beginsel en het fair trial-beginsel, vanwege de cumulatie van "charges", namelijk een strafvervolging naast een dwangsombeschikking van Gedeputeerde Staten. Het Hof verwierp dit verweer, met instemming van de Hoge Raad, met de overweging ${ }^{72}$ :

"Geen rechtsregel brengt met zich dat het enkele feit van een naar aanleiding van overtreding van de Afvalstoffenwet opgelegde dwangsombeschikking van de provincie het openbaar

69 Hendriks, L.E.M. en Worretshofer, J., Milieustrafrecht, p. 53. Zie bijvoorbeeld HR 29 november 1994, MenR 1995, nr. 73, met noot De Lange (Afgeleverde afvalstoffen). De Lange stelt dat van slaafse administratieve afhankelijkheid geen sprake kan zijn, maar dat het aan de rechter (dus zowel de strafrechter als de bestuursrechter) is om beide gebieden op elkaar af te stemmen, waarbij zoveel mogelijk rekening wordt gehouden met elkaars belangen.

70 Het gaat te ver om in het kader van dit boek deze problemen uitvoerig te bespreken, zie hierover bijvoorbeeld Rogier, L.J.J., Strafsancties, administratieve sancties en het una via beginsel.

71 Corstens, G.J.M., Het Nederlands strafprocesrecht, p. 191 en Tonnaer, F.P.C.L., Handboek van het Nederlandse milieurecht, pp. 496-498.

72 HR 30 januari 1996, MenR 1996, nr. 47, met noot De Lange (Dwangsom en strafvervolging). 
ministerie het vervolgingsrecht ten aanzien van diezelfde overtreding ontneemt. Er is hier sprake van zelfstandige, rechtens naast elkaar bestaande bevoegdheden, die gelijktijdig als handhavingsinstrument kunnen worden gebezigd. Art. 6 EVRM noch art. 14 IVBPR staan hieraan in de weg, evenmin als de door de raadsman genoemde beginselen."

Indien het bestuur een boete kan opleggen, ligt dit anders. Zo overwoog de Hoge Raad $^{3}$ :

"Voorts verzet het wettelijk stelsel zich ertegen dat, indien een strafrechtelijke vervolging is. ingesteld ter zake van overtreding van art. 5 WVW 1994 nadien een administratieve sanctie wordt opgelegd ter zake van een of meer gedragingen die deel uitmaken van het strafrechtelijk verweten verkeersgedrag en anderzijds dat, indien ter zake van een gedraging een administratieve sanctie is opgelegd, die gedraging in aanmerking genomen bij de beoordeling van de vraag of het verkeersgedrag als een overtreding van art. 5 WVW $1994 \mathrm{zal}$ worden vervolgd."

Het EVRM en het IVBPR bevatten een aantal belangrijke rechten en waarborgen voor degere tegen wie een "criminal charge" wordt ingesteld. Voor de betekenis van het begrip "criminal charge" is het volgens het EHRM niet van belang of een bepaaide sanctie naar nationaal recht als strafrechtelijk of bestuursrechtelijk wordt gekwalificeerd Beslissend is slechts of de sanctie materieel het karakter van een straf heeft, hetgeen vooral afhangt van de al dan niet algemene aard van de overtreden norm en het karakter van de sanctie, in het bijzonder of deze bestraffend en "afschrikwekkend" is. ${ }^{74}$ Bestuurlijke boeten zijn op zichzelf niet in strijd is met het EVRM. ${ }^{75} \mathrm{Zij}$ dienen echter wel te voldoen aan de waarborgen en vereisten van het EVRM en het IVBPR. Dit hoeft overigens niet in iedere fase het geval te zijn, voldoende is dat de procedure als geheel eraan voldoet. ${ }^{76}$ Het betreft onder ander het ne bis in idem-beginsel ${ }^{77}$, dat inhoudt dat niemand ten tweede male kan worden vervolgd voor een feit waarover te zijnen aanzien een rechter onherroepelijk uitspraak heeft gedaan. In de bijzondere (economische) wetten die deze bevoegdheid toekennen aan het bestuur zijn daarom (in het algemeen) samenloopbepalingen opgenomen, zodat in die gevallen samenloop tussen de bestuursrechtelijke en de strafrechtelijke vervolging wordt voorkomen.

73 Zie bijvoorbeeld HR 12 januari 1999, NJ 1999, 289 (Samenloop sancties 5 WVW). Zie ook hoofdstuk 3 paragraaí 7.5 .

74 Zie EHRM 8 juni 1976, $N J$ 1978, 223 (Engel) en EHRM 21 februari 1984, $N J$ 1988, 937; AA 1985, pp. 145-154, met noot Swart (Öztürk).

75 EHRM 24 februari 1994, $N J$ 1994, 496, met noot Alkema (Bendenoun).

76 EHRM 23 juni 1981, $N J$ 1982, 602 (Le Compte, Van Leuven en De Meyere) en EHRM 10 februari 1983, $N J$ 1987, 315 (Albert en Le Compte).

77 Daarnaast zijn belangrijke waarborgen en rechten die door de artikelen 6 en 7 EVRM en 14 en 15 IVBPR worden gegarandeerd: het recht op een eerlijke en openbare behandeling binnen een redelijke termijn door een onafhankelijke en onpartijdige instantie, het legaliteitsbeginsel, de onschuldpresumptie, het zwijgrecht van de beschuldigde en een aantal verdedigingsrechten.

78 Zie bijvoorbeeld de bestuurlijke boete in de Arbo-wet 1998, hoofdstuk 8 paragraaf 3.2.9. 
Ook in het Voorontwerp voor de vierde tranche van de Awb waarin wordt voorgesteld de bestuurlijke boete op te nemen, zijn dergelijke samenloopbepalingen opgenomen. ${ }^{79}$

\section{9.}

\section{De strafrechter en voorwaarden voor strafbaarstelling}

Bij het vaststellen van het betekenisbereik van zorgplichtbepalingen is het belangrijk welke rechter bevoegd is bij vage termen aanvullende criteria door middel van jurisprudentie te ontwikkelen.

Hierbij blijkt een onderscheid te moeten worden gemaakt tussen de feitenrechter en de Hoge Raad. De Hoge Raad acht zichzelf niet bevoegd tot het uitleggen van beschikkingen, omdat dit kwesties van feitelijke aard zijn die dienen te geschieden naar aanleiding van het onderzoek op de terechtzitting. De Hoge Raad acht zichzelf meestal wel bevoegd tot het uitleggen van algemeen verbindende voorschriften. De feitenrechters zijn in het algemeen wel bevoegd tot het uitleggen van beschikking(voorschrift)en en van algemeen verbindende voorschriften, zodat zij voor al deze regels aanvullende criteria kunnen vaststellen.

Ook blijkt dat de strafrechter bij de interpretatie van vage termen kan worden beïnvloed door het al dan niet (volledig) aanvaarden van de leer van de formele rechtskracht. Opnieuw speelt het verschil tussen beschikkingen en algemeen verbindende voorschriften een rol. Op dit moment is nog onduidelijk in hoeverre de leer van de formele rechtskracht door de strafrechter zal worden toegepast. Indien dit gebeurt zal de consequentie daarvan zijn dat besluiten waartegen in het bestuursrecht kan worden opgekomen, te weten beschikkingen, na het sluiten van de beroepstermijn rechtmatig worden geacht. De strafrechter mag deze dan niet meer zelfstandig op hun rechtmatigheid toetsen. Het gevolg daarvan kan zijn dat een justitiabele strafrechtelijk wordt veroordeeld wegens het schenden van een onrechtmatige beschikking waarvan de schending is strafbaar gesteld. Dit is onwenselijk. Het lijkt dan ook noodzakelijk dat de toetsing door de strafrechter van bestuurlijke beslissingen mogelijk blijft. De enige beperking die kan worden aangebracht is dat de toetsing door de strafrechter van een rechtspunt niet mogelijk is indien gebruik is gemaakt van de bestuursrechtelijke rechtsgang en daar tegen dit rechtspunt is opgekomen, tenzij daarop een ander (strafrechtelijk relevant) licht zou vallen. Dit kan echter ook gebeuren door het aansluiting zoeken bij de (gangbare) interpretatie van de bestuursrechter.

Ondanks de eventuele aanvaarding van de leer van de formele rechtskracht kan de exceptie van onverbindendheid (al dan niet met succes) voor de strafrechter worden ingeroepen. De regeling op basis waarvan de beschikking is genomen kan wel worden getoetst op (on)verbindendheid. Dit geldt immers voor alle andere wet- en regelgeving, met uitzondering van (bepalingen uit) wetten in formele zin die niet

79 Commissie wetgeving algemene regels van bestuursrecht, Voorontwerp Algemene wet bestuursrecht; Vierde Tranche, zie de voorgestelde artikelen 5.4.1.4. en 5.4.1.5 en pp. 89-101 en 122-125. 
mogen worden getoetst aan de Grondwet, en meestal ook niet aan algemene rechtsbeginselen. Indien de strafrechter een, regel onverbindend verklaart, heeft dit geen algemeen bindend karakter.

Daarraast wordt de strafrechter bij de interpretatie van een bepaling mede beïnvloed door een eventueel gevolgde bestuursrechtelijke procedure ten aanzien van de betreffende bepaling. Zo zal de strafrechter, ook als de bestuursrechter zich (nog) niet heeft uitgesproken over een specifiek besluit, meestal aansluiting zoeken bij de (gebruikelijke) interpretatie van de bestuursrechter. Als nog geen bestuursrechtelijke procedure is gevolgd, zal de strafrechter binnen zijn bevoegdheden zijn eigen weg kunnen gaan.

Indien de bestuursrechtelijke en de strafrechtelijke procedure samenlopen, behoeft de strafrechter geen rekening te houden met de mogelijke bestuursrechtelijk uitkomst. Een bestuursrechtelijke bezwaar- of beroepsprocedure heeft in het strafrecht in begissel geen schorsende werking tot gevolg. Dit verhoogt de kans op afwijkende beoordelingen over dezelfde feiten en rechtsvragen in verschillende procedures.

Indien een begunstigende beschikking(voorschrift) wordt vernietigd, geldt in het strafrecht het uitgangspunt dat wie op regelmatige wijze een beschikking heeft gekregen erop mag vertrouwen dat hij rechtmatig handelt indien hij daarvan gebruik maakt. Bij vernietiging van een belastende beschikking(voorschrift) kunnen de zaken anders liggen. De fictie treedt in werking dat het besluit nooit heeft bestaan, zodat niet bewezen kan worden verklaard dat in strijd met de beschikking is gehandeld. Mogelijk kan de verdachte dan wel worden vervolgd voor het handelen zonder deze beschikking.

Indien een strafrechtelijke voorlopige maatregel op grond van artikel 28 , eerste lid Wed wordt gebaseerd op een bestuursrechtelijke beschikking, en deze beschikking door de Raad van State wordt vernietigd, kan de justitiabele wegens overtreding van de voorlopige maatregel met succes worden vervolgd. Het overtreden van de voorlopige maatregel, die (indirect) is gekoppeld aan een eerder genomen bestuursrechtelijke beschikking, levert een zelfstandig strafbaar feit op.

Ten aanzien van een zelfde feitencomplex kan een strafrechtelijke veroordeling samenlopen met een besturursrechtelijke (maar ook een civiele- of tuchtrechtelijke) sanctieoplegging, tenzij het een "criminal charge" betreft. Bij een "criminal charge" geldt het $n$ e bis in idem-beginsel dat inhoudt dat niemand ten tweede male kan worden vervolgd voor hetzelfde feit waarover te zijnen aanzien een rechter onherroepelijk uitspraak heeft gedaan.

Indien de strafbaarstelling, zoals bij veel zorgplichtbepalingen het geval is, vage termen bevat waarvoor geen aanvullende criteria zijn vastgesteld door de wetgever of het bestuur zal de strafrechter in een voorliggend geval zelfstandig moeten bepalen of de strafbepaling van toepassing is en al dan niet wordt toegepast. Hoe vager de gebruikte termen des te belangrijker de taak van de strafrechter is om aanvullende 
criteria te bepalen. Bij de strafrechter berust dan ook de opdracht de grens tussen strafbare en niet strafbare gedragingen vast te stellen. Dit biedt een grote discretionaire bevoegdheid aan de rechter. Nochtans zal de rechter bij de interpretatie niet "ins Blaue hinein" interpreteren. Hij kan ter beantwoording van de vraag of een bepaalde gedraging een schending van de (zorgplicht)bepaling oplevert gebruik maken van de wetsgeschiedenis, jurisprudentie, ongeschreven recht en doctrine. Tevens zal hij rekening houden met het systeem van de betreffende regelgeving, en de plaats die de bepaling daar inneemt. De regeling in haar geheel kleurt als het ware de vage termen (uit de zorgplichtbepaling) in. Zo wordt de inhoud van de term nader bepaald door de overige bepalingen en kan het betreffende artikel leemten, die bestaan in de regeling, opvullen. ${ }^{80}$ Ook kan de rechter bij de afweging of er al dan niet sprake is van schending van de (zorgplicht)bepaling gebruik maken van informatie van deskundigen. Rechters die in de toekomst worden geconfronteerd met het bepalen van de inhoud van de norm kunnen vervolgens ook de eerdere uitspraken gebruiken als richtsnoer voor de invulling van de norm in hun specifieke zaak. Hierdoor bepaalt de rechterlijke macht mede de inhoud van, met name de vage bestanddelen van, de zorgplichtbepalingen ${ }^{81}$ Het risico is evenwel dat de betreffende bepaling zeer ruim kan worden uitgelegd, hetgeen schending van het lex certa-beginsel tot gevolg kan hebben.

De inhoud van de strafbaarstelling en de aanvullende criteria kunnen aldus bij vage termen ook door de strafrechter worden bepaald. Het bestuur kan op de uitleg van de (zorgplicht)bepaling natuurlijk wel degelijk invloed uitoefenen, bijvoorbeeld door het vaststellen van aanvullende regelgeving of richtlijnen. Indien deze geen duidelijk houvast bieden voor de casus die de rechter dient te beantwoorden, zal hij zelf interpreterend dienen na te gaan of de verdachte in het specifieke geval de zorgplichtbepaling heeft geschonden. In het algemeen zal de strafrechter in beginsel gebonden zijn aan de (mits aanwezige) voorbeslissingen van de wetgever, het bestuur en de bestuursrechter.

80 Hart, A.C. "t, "Art. 25 WVW en het legaliteitsbeginsel", pp. 189-23, bespreekt dit en werkt het uit aan de hand van artikel 25 WVW.

81 Zie MacCormick die opmerkt dat "The judge must go beyond the law and (without sacrifice of impartiality) consult his own sense of moral and political rightness or equity and of social expediency in order to come to what seerns the best decision on the problem in hand. At least for the parties to the case he partly makes the "law", which he "applies". And if the rule of recognition sets precedent as a binding source of law, he also makes law for the future by his own decision (...)". MacCormick, N., H.L.A. Hart, p. 126. Zie over jurisprudentie als kenbron van recht ook hoofdstuk 2 paragraaf 5.4 . 


\section{De ontwikkeling van het commuun strafrecht}

\section{Inleiding}

In de strafrechtsliteratuur wordt onderscheid gemaakt tussen het algemeen of commuun strafrecht en het bijzonder strafrecht. ${ }^{\prime}$ Het commuun strafrecht omvat het Wetboek van Strafrecht, terwijl het bijzonder strafrecht is te vinden in de overige wetgeving in formele zin en lagere regelgeving zoals verordeningen. Bij de diverse pogingen tot codificatie en het uiteindelijk tot stand gekomen Wetboek van Strafrecht, werd gezien hun bijzonder karakter steeds uitzondering gemaakt voor twee categorieën in het bijzonder strafrecht. Het betreft het fiscaal en het militair strafrecht. ${ }^{2}$ Daarnaast bleef een aantal strafbaarstellingen uit bijzondere wetgeving naast het Wetboek van Strafrecht en het fiscaal en militair strafrecht in stand.

Het strafrecht valt hierdoor uiteen in twee delen ${ }^{3}$, en ontwikkelt zich langs deze lijnen nog steeds verder. Sinds de invoering in 1950 van de Wet op de economische delicten valt het bijzonder strafrecht op zijn beurt ook weer uiteen in twee delen, te weten het bijzonder niet economisch strafrecht en het bijzonder economisch strafrecht. Sinds ongeveer 1970 is sprake van het aanhaken van steeds meer milieuwetten aan de Wed, hetgeen in 1994 leidde tot een herverdeling van de opsomming van aangehaakte strafbepalingen in de Wed. Hierdoor is een tweedeling zichtbaar geworden in het economisch strafrecht; de in artikel 1 aangewezen wetten die voornamelijk een sociaal-economische doelstelling hebben en de in het nieuw ingevoerde artikel la aangewezen wetten waaraan milieu-aspecten zijn verbonden. In al deze verschillende delen van het strafrecht zijn zorgplichtbepalingen opgenomen.

In dit hoofdstuk zal de ontwikkeling en splitsing van het strafrecht in commuun en bijzonder strafrecht worden beschreven (hoofdstuk 6 paragraaf 2). Voorts worden de tweedeling in misdrijven en overtredingen (hoofdstuk 6 paragraaf 3), de overheveling van de handhaving van bepaalde vormen van onwenselijke gedragingen van het strafrecht naar het bestuursrecht (hoofdstuk 6 paragraaf 4) en diverse vormen van.

1 Zie Nolte, H.J.A., Het strafrecht in de afzonderlijke wetten, p. 3. Hij maakt onderscheid tussen gecodificeerd strafrecht (dat in het Wetboek van Strafrecht is omschreven) en het niet-gecodificeerd strafrecht (zoals het bij afzonderlijke wetten en verordeningen is vastgesteld). Deze terminologie wordt hier niet gevolgd, aangezien in dit boek conform artikel $107 \mathrm{Gw}$, met de term gecodificeerd (straf)recht al het (straf)recht dat te vinden is in wetgeving in formele zin wordt aangeduid; zie hoofdstuk 3 paragraaf 2.

2 Aan het militair en het fiscaal strafrecht wordt in dit boek geen specifieke aandacht besteed aangezien hierin geen zorgplichtbepalingen zijn opgenomen.

3 Men kan ook betogen dat er sprake is van vier delen: het algemeen strafrecht, het fiscaal strafrecht, het militair strafrecht en het (overig) bijzonder strafrecht. 
daderschap (hoofdstuk 6 paragraaf 5) besproken. Vervolgens worden een aantal zorgplichtbepalingen in het commuun strafrecht onderzocht (hoofdstuk 6 paragraaf 6). Hierdoor wordt duidelijk dat zorgplichtbepalingen geen nieuw of bijzonder verschijnsel zijn. Tevens is het een aanzet bij het inzichtelijk maken in welke systemen dit type strafbaarstellingen al dan niet incidenteel zijn opgenomen.

De bespreking van de ontwikkeling en betekenis van het commuun strafrecht en enkele daarin opgenomen zorgplichtbepalingen, zal in de volgende hoofdstukken worden gevolgd door die van het bijzonder strafrecht (hoofdstuk 7), het economisch strafrecht (hoofdstuk 8) en het milieustrafrecht (hoofdstuk 9). De algemene vereisten van behoorlijke regelgeving (uit hoofdstuk 3) worden bij het onderzoek naar de diverse zorgplichtbepaling betrokken. Aan de hand van deze vereisten is het mogelijk de in de wetgeving voorkomende zorgplichtbepalingen te analyseren (hoofdstuk 10).

\section{Het bijzonder strafrecht en de totstandkoming van het commuun strafrecht}

\subsection{Inleiding}

Voor de totstandkoming van het Wetboek van Strafrecht, maakte al het strafrecht deel uit van hetgeen nu bijzonder strafrecht wordt genoemd. Ten gevolge van de codificatie van een deel van het strafrecht is er een onderscheid ontstaan tussen strafrecht dat is opgenomen in het Wetboek van Strafrecht en hetgeen niet is opgenomen in dit wetboek, te weten het bijzonder strafrecht. ${ }^{4}$ In deze paragraaf vangt de historische beschrijving van de totstandkoming van het commuun strafrecht aan ten tijde van de Republiek (ongeveer 1580-1798) (hoofdstuk 6 paragraaf 2.2.). Ook daarvoor was er natuurlijk strafrecht, maar voor de bespreking van enkele leerstukken en de plaatsbepaling van zorgplichtbepalingen in het huidige strafrecht kan worden volstaan met de bespreking van meer recente ontwikkelingen. ${ }^{6}$ In de laatste periode van de

4 Zie over de ontwikkeling van het bijzonder strafrecht Nolte, H.J.A., Het strafirecht in de afzonderlijke wetten, pp. 18-54.

$5 \quad$ Zie over de ontwikkeling van het (straf)recht van het voormiddeleeuws tijdperk (de Germaanse en de Frankische periode) tot de Bataafse omwenteling in 1795: Monté ver loren, J.Ph. de, bewerkt door Spruit, J.E., Hoofdlijnen wit de ontwikkeling der rechterlijke organisatie in de Noordelijke. Nederlanden tot de Bataafse omwenteling. Hiertegen kan natuurlijk worden in gebracht dat ondanks grote omwentelingen of kleinere wijzigingen door de tijd heen het recht zich vooral kenmerkt door continuïteit. Zie Monté ver loren, J.Ph. de, bewerkt door Spruit, J.E., Hoofdlijnen uit de ontwikkeling der rechterlijke organisatie in de Noordelijke Nederlanden tot de Bataufse ormwenteling, p. 261; die venwijst naar Immink, P.W.A., At the roots of medieval society $I$, The Western empire, pp. 10-11. Het startpunt bij en de onderwerpen van een historische bespreking zijn tot op zekere hoogte willekeurig. Zie voor een uitgebreide historische bespreking van het (bijzonder) strafrecht, vooral gericht op wetgeving, de organen belast met wetgeving, het onderzoek en de afdoening in de periode tussen 1200-1400 en heden Buruma, X., De strafrechtelijke handhaving van bestuurswetten, pp. 35-130. 
Republiek die werd gevolgd door de Bataafse omwenteling (in 1795) (hoofdstuk 6 paragraf 2.3.) deed een aantal van de huidige criteria voor strafbaarstelling ${ }^{7}$ (zoals het legaliteitsbeginsel en het gelijkheidsbeginsel) hun intrede in het strafrecht. Na de omwenteling kwamen de eerste Nederlandse Grondwet en het Wetboek van Strafrecht tot stand (hoofdstuk 6 paragraaf 2.4.), maar door de inlijving bij het Franse Keizerrijk werden zij al snel buiten werking gesteld (hoofdstuk 6 paragraaf 2.5.). $\mathrm{Na}$ de onafhankelijkheid werden opnieuw pogingen ondernomen te komen tot een nationaal Wetboek van Strafrecht, hetgeen in 1886 resulteerde in het huidige Wetboek (hoofdistuk 6 paragraaf 2.6.).

\subsection{Het (straf)recht in de Republiek der Verenigde Nederlanden}

Sinds de zestiende eeuw bestond in de Gewesten een strafrecht met publiekrechtelijk karakter dat op vele rechtsbronnen was gebaseerd. ${ }^{8}$ In de rechtskringen, de grondbezitverhoudingen en daarmee samenhangende rechten, de standenstructuur en de structuur van het privaatrecht en het publiekrecht deden zich ten tijde van de Republiek geen grote wijzigingen voor. Evenals in de voorafgaande periode was er geen eenheid van de rechtsvormende organen. ${ }^{9}$ De wetgeving ging op grond van de Unie van Utrecht uit 1579 voor de Generaliteit uit van de Staten-Generaal; de centrale regering. Tot de Bataafse omwenteling in 1795 waren de Gewestelijke Staten als rechtsvormend orgaan belangrijker. De op grote schaal uitgevaardigde regelgeving maakte deel uit van het landsgemene, recht als zij gold voor het gehele gewest, en was deel van het plaatselijke recht indien zij gold voor bepaalde steden of kleinere rechtskringen. Daarnaast waren besturen van steden en van kleinere rechtskringen voor hun gebied belangrijk als rechtsvormend orgaan. Door de toenemende bedrijvigheid, de groei van de steden en de professionalisering van het bestuurlijk apparaat kwamen steeds meer regels tot stand. Naast de regelgeving van deze organen waren ook vroegere wetgevingen van kracht voor zover ze niet uitdrukkelijk waren ingetrokken of afgeschaft. Hierdoor waren het Romeinse recht, het natuurrecht, de billijkheid en het gewoonterecht, gezaghebbende auteurs, evenals delen van het canoniek en mozaiisch recht belangrijke rechtsbronnen. Hoewel kan worden aangenomen dat zij niet formeel van kracht is geweest, deed ook de invloed van de Constitutio Criminalis Carolina van 1532 zich gelden, hetgeen vooral werd veroorzaakt door haar toepassing door sommige rechtscolleges en haar bewerking door gezaghebbende auteurs. Ook de Criminele Ordonnantiën van Philips II uit 1570 hebben, tot de invoering van het Crimineel

Zie hierover hoofdstuk 3 paragraaf 7.

8 Hamel, G.A. van, bijgewerkt door Dijck, J.V. van, Inleiding tot de studie van het Nederlandse strafrecht, p. 59; zie over de omstandigheden die ertoe leidde dat aan het eind van de middeleeuwen de publieke straf de private wraakoefening heeft vervangen: Simons, D. bijgewerkt door Pompe, W.P.J., Leerboek van het Nederlandsche strafrechi; Eerste deel Algemene leerstukken, p. 43.

9 Monté ver loren, J.Ph. de, bewerkt door Spruit, J.E., Hoofdlijnen uit de ontwikkeling der rechterlijke organisatie in de Noordelijke Nederlanden tot de Bataafse omwenteling, $\mathrm{p}$. 220. 
Wetboek van 1809, ondanks veel oppositie en twijfel aan hun rechtskracht, vooral op het procesrecht grote invloed gehad.

Vaak was uit deze veelheid van regelgeving niet duidelijk op te maken of iemands gedraging was aan te merken als een strafbaar feit. ${ }^{11}$ Vanaf de tweede helft van de zeventiende eeuw werden in grote delen van Europa pogingen ondernomen de bestaande regelgeving samen te brengen in verzamelingen. Deze ontberen een duidelijke indeling en systematiek. ${ }^{12}$ Strafbepalingen bestonden niet in de huidige vorm, evenmin als algemene bepalingen zoals thans vervat in Boek I van het Wetboek van Strafrecht. Ook de belangrijke regel uit het hedendaags (internationaal) strafrecht dat geen feit strafbaar is dan uit kracht van een daaraan voorafgegane wettelijke strafbepaling bestond niet. Voor de strafbaarheid werd onderscheid gemaakt tussen de situatie waarbij de wet een zekere bepaling de sanctie gaf, en die waarbij dit afhankelijk was van de omstandigheden van het geval en het oordeel van de rechter. Veel werd overgelaten aan het oordeel (het arbitrium) van de rechter. Als subsidiaire rechtsbronnen hanteerde hij het Romeinse recht, het Canonieke recht en voor zover hierin niet vervat de "beste reden". ${ }^{13}$ Door de onvastheid, onvolledigheid en onduidelijkheid van de bronnen nam het arbitrair karakter van de strafrechtspleging toe en werd de beslissingsbevoegdheid van de rechter over steeds meer punten groter. ${ }^{14}$

Het strafrecht was gericht op vergelding, afschrikking en onschadelijkmaking en werd

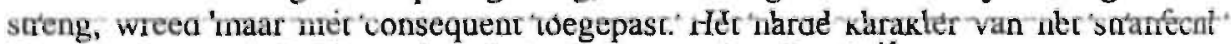
bleef tot de tweede helft van de achttiende eeuw gehandhaafd. ${ }^{15}$

10 Zie over de Criminele Ordonnantięn Vrugt, M. van de, Aengaende Criminele Saken, pp. 12-26. Voor het materiële strafrecht waren de Criminele Ordonnantiën van minder betekenis. Simons, D. bijgewerkt door Pompe, W.P.J., Leerboek van het Nederlandsche strafrecht; Eerste deel Algemene leerstukken, p. 45; Pompe, W.P.J., Handboek wan het Nederlandse strafrecht, p. 21

11 Nog voordat de grote codificatiebeweging op gang kwam was er in diverse land- en stadsrechten sprake van een vrij volledig strafrechtelijk systeem, met als functie naast afschrikking, verzaneling en canonisering van verșreid strafrecht, alsmede bevordering van eenheid van recht en rechtstoepassing. Zie Enschedé, CH.J., "Het wetboek als boek", pp. 9-10; Hamel, G.A. van, bijgewerkt door Dijck, J.V. van, Inleiding tot de shidie van het Nederlandse strafrecht, p. 56.

12 Zie Buruma, Y., De strafrechtelijke handhaving van bestuurswetten, p. 46.

13 Zie voor de ontwikkeling van het strafrecht tijdens de Republiek Nolte, H.J.A., Her strafrecht in de afzonderlijke wetten, pp. 18-32.

14 Zo oordeelde hij steeds meer over de strafbaarheid van handelingen waartegen in het geschreven recht geen straf was gesteld, het soort straffen en hun titvoering en de afkoopbaarheid daarvan. Zie Hamel, G.A. van, bijgewerkt door Dijck, J.V. van, Inleiding tot de studie van het Nederlandse strafrecht, pp. 64-65.

15 Remmelink, J., Mr. D. Hazewinkel-Suringa's Inleiding tot de studie van het Nederlandse strafrechi, p. 47. De toepassing van de pijnbank als middel van onderzoek in extraordinaire processen versterkte dit harde karakter. Deze toepassing was ruimer dan waarschijnlijk in de Ordonnantiën op de Stijl bedoeld was, hij werd niet alleen aangewend in het geval er meer was dan vol half bewijs en minder dan volledig bewijs, maar ook bij vol bewijs zonder bekentenis. In 1798 werd het gebruik: officieel 


\subsection{De Bataafse omwenteling}

In deachttiende eeuw groeide de onvrede met en het verzet tegen veel maatschapelijke en juridische omstandigheden. ${ }^{16}$ Afgezien van de "verlatinge" van de landsker en daarmee samenhangende ontwikkelingen was de rechterlijke organisatie tot 175 grotendeels gelijk gebleven aan die van de late middeleeuwen. ${ }^{17}$ Veel werd onbillk ervaren zoals de invloed van het standenbeginsel, de rechtelijke organisatie waar fficieren van justitie geldelijk belang hadden bij de rechtspraak, het strenge en hardestrafrecht, de keuze van straf en strafmaat die sterk afhankelijk waren van de willekur van de rechters en de daaruit voorkomende rechtsverscheidenheid. Maar ook de vemipperde regelgeving met haar talrijke leemten, de honderden commentaren die nodigwaren bij de uitleg van de regelgeving, het gebruik van Romeins recht en het Latiji dat vaak nog werd gebruikt als rechtstaal riepen verzet op. Het ging aanvakelijk niet eens zozeer orm codificatie, het verzamelen en inzichtelijk maken van het gedende recht stond voorop. Zo werd in 1777 opgemerkt $^{18}$ :

"Onzestrafwetten zijn overal verspreid. Men weet zelfs niet waar ze te vinden zijn. Maar hoe kan $\mathrm{m}$ ze kennen en toepassen wanneer men zelfs niet weet waar ze te vinden zijn."

Moeijk bleek het het verlangen naar rechtsontwarring, rechtsverbetering en rechtseiligheid te realiseren. Deze verlangens werden gevoed door de hervormingsbéweging die een verschijnsel was van "het tijdperk van de Verlichting". ${ }^{19}$ De ontwikkeling van het strafrecht in de tweede helft van de negentiende eeuw werd zeer sterk beheerst door de theorieën van de Verlichting.

De tijd van de grote hervorming brak aan in de decennia voorafgaande aan de Franse revolutie. Deze werd voorbereid en begeleid door de op het hele rechtsgebied werkzame richting van de natuur- en rederecht. ${ }^{20}$ Nieuwe denkbeelden kwamen tot

afgeschaft. Zie Vrugt, M. van de, Aengaende Criminele Saken, pp. 21-23. Zie ook Ingelse H.C., De rol van het Comité in de ontwikkeling van het VN-Verdrag tegen Foliering, pp. 24-26.

16 Zie hierover Monté ver loren, J.Ph. de, bewerkt door Spruit, J.E., Hoofdlijnen uit de ontwikkeling der rechterlijke organisatie in de Noordelijke Nederlanden tot de Bataafse omwenteling, pp. 248-251; Nolte, H.J.A., Het strafrecht in de afzondertijke wetten, pp. 33-36.

17 Van Hamel laat zien dat vanaf de zestiende eeuw tot het tijdperk van de eerste algemene codificatie in de gewesten een strafrecht met publiekrechtelijk karakter gold dat aan vele bronnen werd ontleend. Hamel, G.A. van bijgewerkt door Dijck, J.V. van, Inleiding tot de studie van het Nederlandse strafrecht, pp. 51-59.

18 Citaat van magistraat G.F. Letrosne, opgenomen in Dupont, L., Beginselen van behoorlijke strafrechtsbedeling, p. 54 en Buruma, Y., De strafirechtelijke handhaving van bestuurswetten, p. 59.

19 De Verlichting/ A.ufklärung, het tijdperk van het rationalisme en gezonde verstand waarde van het eind van de zeventiende eeuw tot het eind van de achttiende eeuw door Europa, en liet haar invloed ook gelden op juridisch gebied.

20 Hamel, G.A. van bijgewerkt door Dijck, J.V, van, Inleiding tot de studie van het Nederlandse strafrecht, p. 67. 
bloei en gaven richting aan de ontwikkelingen in Europese landen. Belangrijk waren onder meer de beschrijving van Voltaire van het rechtsgeding tegen Jean Calas en het bekende geschrift van Beccaria. ${ }^{21}$ Ook de opkomst van de Duitse strafrechtswetenschappen en overige geschriften deden hun invloed in de Verenigde Nederlanden gelden. ${ }^{22}$ Zowel in Frankrijk als in andere Europese landen streefden hervormers naar gelijkheid van alle burgers en helderheid, nauwkeurigheid en eenvormigheid van regelgeving, te bereiken door rationalistisch opgezette codificatie. ${ }^{23}$ Ten aanzien van de verschillende codificaties van het strafrecht valt op te merken dat de wetboeken van de landen die staatkundig de sterkste positie innamen, afgezien van hun wetenschappelijke verdiensten, de grootste invloed hebben gehad op de codificaties in andere landen. Dit verklaart onder andere de grote invloed van de Code Pénal op diverse Westeuropese codificaties en van het Pruisische Wetboek van Strafrecht uit 1851 op het Duitse strafrecht. ${ }^{24}$

In de Nederlanden maakte de Bataafse omwenteling in 1795 met de daaruit voortvloeiende staatskundige wijzigingen en verschuiving van machtsverhoudingen het mogelijk wijzigingen door te voeren en te werken aan de codificatie van (onder andere) het strafrecht. Het doel van deze codificaties ging verder dan alleen verzamelen en inzichtelijk maken van het geldende recht. Men wilde ook systematiseren, uniformeren, vereenvoudigen en zekerheid bieden. ${ }^{25}$

\subsection{Codificatie van het strafrecht voor de Code Pénal}

Ir 1798 kreeg Nederland met de Staatsregeling zijn eerste Grondwet. Van Statenbond werden de Verenigde republieken een eenheidsstaat. In deze Grondwet werd naast tal van fundamentele staatkundige wijzigingen een aantal grondrechten opgenomen. Zo werd voor de eerste keer in Nederland het legaliteitsbeginsel verankerd in regelgeving. ${ }^{26}$ Ook was nieuw dat een codificatieartikel werd opgenomen dat luidde ${ }^{27}$ :

21 Italiaan Cesare de Beccaria Bonesana geschreven Dei delitti e delle pene, dit werk uit 1764 werd voor het eerst in 1768 in het Nederlands vertaalt. De lastste versie bevat een uitgebreide toelichting; Beccaria, $C_{\text {, }}$ Over misdaden en straffen, 1971. Zijn idecên gaven richting aan de ontwikkeling van het strafrecht in geheel Europa en speciaal in Frankrijk, zie Bosch, A.G., Het ontstaan van het Wetboek van Strafrecht, p. 15.

Zie bijvoorbeeld de geschriften van Feuerbach P.J.A., met name zijn Lehrbuch des gemeinen in Deutschland geltenden Peinlichen Rechts, en zijn Revision der Grundszäte und Grundbegriffe des positiven peinlichen Rechts. Dit wil overigens niet zeggen dat er een rechtstreekse invloed is van deze werken op het Nederlandse Wetboek van Strafrecht, zie Mulder, G.E., "P.J.A. Feuerbach en het crimineel wetboek voor het koninkrijk holland", pp. 175-185.

23 Zie over de codificatie van vooral het civiel recht in Italië, Frankrijk, de Duitse landen, Nederland en Zwitserland Lokin, J.H.A. en Zwalve, W.J., Hoofdstukken uit de Europese Codificatiegeschiedenis, pp. 80-340.

24 Zie Bosch, A.G., Het ontstaan van het Wetboek van Strafrecht, p. 16.

25 Buruma, Y., De strafrechtelijke handhaving van bestuurswetten, p. 60.

26 Zie voor een overzicht van de belangrijkste punten uit deze Grondwet Monté ver loren, J.Ph. de, bewerkt door Spruit, J.E., Hoofdlijnen uit de ontwikkeling der rechterlijke organisatie in de Noordelijke Nederlanden tot de Bataafse omwenteling, pp. 258-260; 
"Er zal een Wetboek gemaakt worden (...) van Lijfstraffelijke Wetten, te gelijk met de wijze van Regtsvordering $(\ldots)^{\prime \prime}$.

Over de interpretatie van dit artikel liepen de meningen uiteen. Gesteld werd dat gezien de terminologie (Lijfstraffelijke Wetten) niet is vereist dat het strafrecht werd samengebracht in één wetboek. Daarentegen werd ook beweerd dat juist wel werd gedacht aan één wetboek dat diverse wetten omvatte, waarbij het woord wetten doelde op geldende regels van recht. ${ }^{28}$ Het gebruik van meer wetten die niet deel uitmaken van één wetboek werd door de Grondwet van 1887 explicieter toegestaan.

Tot een volledige codificatie van het strafrecht is het in Nederland nooit gekomen. Het duurde tot 1809 voordat sprake was van een zekere mate van codificatie. Voordien werden diverse pogingen ondernomen, maar aangezien deze niet succesvol waren bleef het bestaande strafrecht tot dat tijdstip in stand. De mislukte poging uit 1804 verdient hier wel enige aandacht, omdat daarin onderscheidende criteria tussen bijzonder en algemeen strafrecht naar voren komen en omdat deze poging de voorloper is van het uiteindelijk wel ingevoerde Wetboek van Strafrecht.

Met de staatseenheid na de Bataafse omwenteling werd ook het streven naar rechtseenheid ter hand genomen. De eerste poging uit 1796 ging niet verder dan het benoemen van twee commissies; één voor een Crimineel een één voor een Burgerlijk recht. Deze poging liep op niets uit.

$\mathrm{Na}$ de invoering van de constitutie werd wederom een poging ondernomen. Er werd in 1798 een algemene commissie van wetgeving ingesteld om overeenkomstig de codificatiegedachte te komen tot één wetboek. Het Lijfstraffelijk deel was in 1801 gereed. Aangezien het burgerlijk deel op zich liet wachten, werd dit ontwerp afzonderlijk ingediend bij het Staatsbewind, die het in november 1804 ter beoordeling heeft voorgelegd aan het Hoog Nationaal Geregtshof. In dit ontwerp waren door de Commissie niet alle strafbaarstellingen opgenomen. Het deel van het strafrecht dat niet was opgenomen zou naast het Wetboek moeten blijven bestaan. Het oordeel van het Hof in oktober 1806 was negatief $^{29}$, waarna ook de Staatsraad het ontwerp verwierp.

Het legaliteitsbeginsel werd opgenomen in artikel 29 van de Staatsregeling van 1789 , in navolging van artikel 8 van de Franse Déelaration de l'homme et du citoyen. Zie over de geschiedenis van het legaliteitsbeginsel Schreiber, H.L., Gesetz und Richter. Zie over het legaliteitsbeginsel ook hoofdstuk 3 paragraaf 7.3.

27 Artikel 28 van de Burgerlijke en Staatkundige Grondregels bij de Staatsregeling luidde: "Er zal een Wetboek gernaakt worden, zoo wel van Burgerlijke, als van Lijfstraffelijke Wetten, te gelijk met de wijze van Regtsvordering, op gronden, door de Staatsregeling verzekerd, en algemeen voor de gantsche Republiek." in de Staatsregeling van 1801 luidde artikel 84: "Het Staats-Bewind zorgt, dat een algemeen Civiel en Crimineel Wetboek (...) aan het Wetgevend Lichaam ter bekrachtiging worde aangeboden." Enschedé heêt onder andere deze codificatie-artikelen opgenomen in Enschedé, CH.J., "Het wetboek als boek", pp. 7-8.

28 Enschedé, CH.J., "Het wetboek als boek", p. 8.

29 De bezwaren waren talrijk, zie Bosch, A.G., Het ontstaan van het Wetboek van 
Een van de bezwaren van het Hof was dat een criterium ontbrak aan de hand waarvan de Commissie had besloten sommige misdaden wel en andere niet op te nemen in het ontwerp, waardoor onduidelijk was welke motieven bij de Commissie hadden gegolden inzake het onderscheid tussen gecodificeerd en niet-gecodificeerd strafrecht. Het maken van een dergelijk onderscheid werd door het Hof niet afgewezen, slechts het ontbreken van een motivering van een onderscheidend criterium kreeg kritiek. In deze ontwikkelingen ligt de oorsprong van de tweedeling in commuun en bijzonder strafrecht. ${ }^{30}$ Het Hof stelde aan de in juni 1806 aangetreden Koning ${ }^{31}$ in zijn rapport ${ }^{32}$ :

"dat, hoe zeer de Ontwerpers van dit algerneen Lijfstraffelijk Wetboek, buiten twijfel, moeten voor den geest gehad hebben zekere regelmaat, waar naar de inhoud van het zelve is ingerigt, en waar naar zij beoordeeld hebben, welke soorten van misdaden en overtredingen daarin al of niet behoorden behandeld te worden, wij nogtans deze regelmaat nergens hebben vastgesteld of uitgedrukt gevonden.

Het zal niet ondienstig zijn, onze denkbeelden op dit stuk eenigzins nader te ontwikkelen.

Het is, zoo wij meenen, reeds in den eersten opslag zigtbaar, dat niet a 11 e misdaden, welke in de Burgerlijke Maatschappij kunnen gepleegd worden, niet a 11 e overtredingen van Wetten, welke het doen of laten van eenige daad, onder bedreiging van straf, gebieden of verbieden, in dit Wetboek zijn behandeld geworden.

(...)

Wij willen door deze opgave dezer voorbeelden geenszins beweren, dat alle deze misdaden en overtredingen in dit Wetboek hadden behooren behandeld te worden; maar wij brengen dezelven slechts bij, tot staving van onze aanmerking dat niet a / I e misdrijven, welke in de Burgerijike Maatschappij kunnen begaan worden, daarin behandeld zijn; en dat derhalve de Ontwerpers moeten voor den geest gehad hebben zekeren regel, volgens welke zij geoordeeld hebben, of deze of gene soorten van misdaden en overtredingen moesten geacht worden tot den inhoud van dusdanig algemeen Lijfstraffelijk Wetboek te behooren, dan wel, of dezelve moesten gerekend worden daar toe geene betrekking te hebben.

En het is deze regelmaat, welke wij wenschten, dat de Ontwerpers hadden goedgevonden ergens uit te drukken; niet slechts, om dat uit de juistheid daar van, zoo wel in stelling als in toepassing, de volledigheid en volkomenheid van dit Wetboek eerst regt zoude hebben kunnen worden beoordeeld; maar voornamelijk ook, om dat, na het invoeren van het zelve, daar aan dikwijls zal moeten getoetst worden, of en in hoeverre deze of gene Plakkaten, Publicatiën, Reglementen,

Strafrecht, p. 32.

30 Nolte, H.J.A., Het strafrecht in de afzonderlijke wetten, pp. 37-38; Simons, D. bijgewerkt door Pompe, W.P.J., Leerboek van het Nederlandsche strafrecht; Eerste deel Algemene leerstukken, p. 47; Hamel, G.A. van, Inleiding tot de studie van het Nederlandse Strafrecht, p. 71.

31 Koning Lodewijk Napoleon was bij de beraadslagingen van de Staatsraad overigens alleen bij de aanvang (namelijk bij de bespreking van de doodstraf) aanwezig. Zie Hamel, G.A. van, Inleiding tot de studie van het Nederlandse Strafrecht, p. 72.

32 Het rapport van het Hof is bij de Staatsdrukkerij gedrukt en samen met overige stukken uitgegeven onder de titel "Stukken door de Commissie tot het ontwerpen van een burgerlijk en lijfstraffelijk wetboek overgegeven aan het Staatsbewind der Bataafse Republiek", zie Hamel, G.A. van, Inleiding tot de studie van het Nederlandse Strafrecht, p. 72, ondanks dat Kemper vermeldt dat de wet hem verbiedt het over te nemen. Kemper, J.M., Crimineel Wetboek voor het Koninkrijk Holland met eene Inleiding en aanmerkingen en wordt uitvoerig geciteerd door Nolte, H.J.A., Het strafrecht in de afzonderlijke wetten, pp. 38-40. 
Ordonnantiën, costumen en gebruiken, bevorens in dit land, of eenig gedeelte van het zelve, nopens eenige ontwerpen vastgesteld zijnde, of plaats gehad hebbende, moeten geacht worden als dan nog kracht van Wet te hebben behouden, dan wel stilzwijgende afgeschaft en vervallen te zijn."

$\mathrm{Na}$ de afwijzing van het ontwerp werd bij decreet van november 1807 een nieuwe Commissie tot herziening van en bewerking van het Crimineel Wetboek aangesteld. Zij herzag het voorgestelde wetboek uit 1804, waarbij zij gebruik maakte van de opmerkingen van het Hoog Nationaal Geregtshof en de Staatsraad. ${ }^{33}$ In maart 1808 werd het ontwerp aan de Koning aangeboden. Ook in dit ontwerp werden niet alle strafbaarstellingen opgenomen. De Commissie schreef in het begeleidend rapport aan de Koning:

"dat misdaden en overtredingen, bepaaldelijk aan zekere standen eigen, uit afzonderlijke wetten voortspruitende, of te veel van tijdelijke of plaatselijke omstandigheden afhangende, niet gevoeglijk in een Wetboek konden gebragt worden, hetwelk voor alle standen, voor alle tijden en voor alle plaatsen behoorde geschikt te zijn, en als een zamenhangend geheel, zooveel mogelijk, tegen gedurige veranderingen moest bewaard blijven."

\section{Artikel4 van het ontwerp bepaalde dat:}

"met de datum van invoering zullen zijn afgeschaft alle plakkaten, publicatien, ordonnantien, reglementen, statuten, keuren, octrooijen, handvesten en andere wetten. Het zij dezelve het geheel koninkrijk, eenig gedeelte van hetzelve " of eenige bijzondere plaats hebben betroffen, waarbij eenige straffen of boeten op misdaden of overtredingen zijn vastgesteld."

In artikel 7 werd een dertigtal categorieën van wetten, reglementen en voorzieningen opgesomd waarvoor uizondering werd gemaakt, zodat deze bij de invoering niet zouden worden afgeschaft. Dit ontwerp haalde het en werd op 1 februari 1809 ingevoerd, waardoor Nederlands voor het eerst beschikte over een gecodificeerde Wetboek van Strafrecht. ${ }^{34}$ Hierdoor ontstond voor het eerst in Nederland het onderscheid tussen commuun en bijzonder strafrecht. Deze regelgeving kwam echter niet totaal naast elkaar te staan, daar de algemene bepalingen uit het commuun strafrecht ook toepasselijk werden verklaard op het bijzonder strafrecht.

\subsection{De Code Pénal}

Het Wetboek uit 1809 was slechts korte tijd van kracht aangezien na de inlijving in juli 1810 van het Koninkrijk bij het Franse Keizerrijk, in maart 1811 de Franse Code Pénal werd ingevoerd. ${ }^{35}$ Dit was overigens de tweede Code. De eerste codificatie van het

Bosch, A.G., Het ontstaan van het Wetboek van Strafrecht, p. 33.

34 Zie over dit wetboek Binsbergen, W.C. van, Algemeen karakter van het Crimineel Wetboek voor het Koninkrijk Holland.

35 Na de Franse revolutie van 1789 kwam in 1791 eerste Code Pénal tot stand, die duidelijk was beïnvloed door de ideeën van Beccaria. Deze bleek te idealistisch en werd in 1810 vervangen door een nieuwe Code Pénal die sterk was beïnvloed door de ideeên van de Brit Bentham, waardoor het wetboek sterk is gericht op afschrikking door vooral hoge 
strafrecht vond in Frankrijk plaats in 1791 en was sterk geïnspireerd door de ideeën van Beccaria. Het gevolg was dat de eerste Code een strak systeem van straffen bevatte zonder het recht op gratie. Als reactie op de grote vrijheid van de rechter tijdens het ancien régime waren er vaste sancties op elk delict. De uit Engeland overgenomen jury werkte echter met verkeerde zachtzinnigheid. Mede ten gevolge van de toenemende wanorde in Frankrijk en de steeds minder wordende rechterlijke repressie nam de criminaliteit steeds grotere vormen aan. De Code werd herzien, en in 1810 kwam de Code Penál tot stand die in 1811 in Nederland werd ingevoerd. Deze legde sterker de nadruk op de generale preventie. De hoeveelheid strafbaarstellingen nam toe en delicten die de Staat en zijn instellingen bedreigden namen een belangrijker plaats in. De fixatie van straffen werd afgeschaft en maakte plaats voor een systeem met een maximum en minimum straf bij elke delictsomschrijving, binnen welke grenzen de rechter de straf kon bepalen. De Code Pénal was nog steeds sterk beïnvloed door de ideeën van de Verlichting, maar was anderzijds hardvochtig, omdat men de in 1791 gemaakte "fouten" wilde vermijden. ${ }^{36}$

In de Code werd een driedeling gemaakt van strafbare feiten in misdaden, wanbedrijven en politie-overtredingen. Naast deze gecodificeerde wetgeving waren ook velerlei Franse wetten en imperiale decreten toepasselijk, zodat ook in deze tijd naast de algemene strafwetgeving bijzonder strafrecht van kracht was.

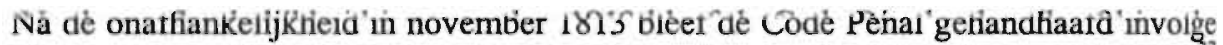
een uit december 1813 stammende Besluit "totdat daarin nader zou zijn voorzien"."? Dit zou tot 1886 duren. Naast de Code bleven vele bijzondere strafwetten gehandhaafd. Het betrof niet alleen de wetten van Franse oorsprong die waren ingevoerd tijdens het keizerrijk, maar ook wetten, decreten en ordonnantiën van de Franse koningen en strafbepalingen uit de Bataafse Republiek, bijvoorbeeld uit de oude ordonnantiën, placaten, gewestelijke en plaatselijke keuren, octrooijen en statuten. Daarbij kwamen nog de wijzigingswetten van de Code Pénal en de nieuwe afzonderlijke strafwetten die tot stand kwamen na de Franse tijd. ${ }^{38}$ Het bijzonder strafrechi werd dan ook (opnieuw) zeer omvangrijk en onoverzichtelijk. ${ }^{39}$

strafbedreigingen. Deze Code werd in 1811 Nederland ingevoerd. Pompe, W.P.J. Handboek van het Nederlandse strafrecht, p. 22.

36 Bosch, A.G., Het ontstaan van het Wetboek van Strafrecht, pp. 33-35.

37 Zie artikel 1 van het Besluit houdende bepalingen ten aanzien van de lijfstraffelijke regtsoefening in de Verenigde Nederlanden van 11 decenber 1813, Sib. 1813, 10. Bij dit besluit werd de jury afgeschaft, het strafstelsel herzien en de mogelijkheid van verzachtende omstandigheden uitgebreid, zie Bosch, A.G., Het ontstaan van het Wetboek van Strafrechi, p. 35.

38 Zie voor een overzicht van de geldende wetgeving in die tijd: Deinse, A.J. van, Het Wetboek van Strafregt (Code Pénal) en Diense, A.J. van, Strafwetten.

39 Zie over de Code Pénal: Hamel, G.A. van bijgewerkt door Dijek, J.V. van, Inleiding tot de studie van het Nederlandse strafrecht, pp. 73-78. Hierin wordt verwezen nar wijzigings- en aanvullingswetgeving. 


\subsection{Codificatie van het strafrecht na de Code Pénal}

In apri 1814 ging een nieuwe Commissie aan de slag die in januari 1815 een vooronwerp voor een nieuw Wetboek van Strafrecht presenteerde. Na diverse wijzigigen werd dit in oktober 1827 voorgelegd aan de Tiweede Kamer. Het werd mede vnwege de onbepaaldheid van de wet slecht ontvangen, waarop de regering het ontwer introk ${ }^{40}$ Ook dit ontwerp ging overigens uit van een onderscheid tussen commun en bijzonder strafrecht.

In oktoer 1839 werd door de Regering een nieuw ontwerp Wetboek van Strafrecht an de Tweede Kamer aangeboden. Dit ontwerp behelsde alleen een algemeen deel. Dit dee werd aangenomen, maar bij de behandeling van Boek II werden wijzigingen verlangl. Uiteindelijk leidde dit tot intrekking van de overige ontwerpen. ${ }^{41}$

Het durde tot januari 1847 voordat een ontwerp voor een geheel nieuw wetboek werd ingedield. Ook dit ontwerp maakte onderscheid tussen commun en bijzonder strafrect. De Regering motiveerde het in stand houden van het bijzonder strafrecht nast hit nieuwe wetboek door er op te wijzen dat de systernatiek zich verzet tegen het opnemn van alle strafbepalingen uit de bijzondere wetten, omdat het niet wenselijk is indien én onderwerp in twee verschillende wetten zou worden behandeld. Daarnaast voerde zij aan dat de aard van het bijzonder strafrecht met zijn vele veranderingen en wijzigingen zich niet leent voor opneming in een wetboek dat nu juist zo veel mogelijk van blijvende en vaste aard dient te zijn. Ook dit ontwerp haalde het niet. Interessant is dat de Tweede Kamer bij de behandeling opmerkte dat een eerste vereiste van een Wetboek van Strafrecht volledigheid is. ${ }^{42}$

In 1859 diende minister Boot een nieuw ontwerp in van Boek I. Dit ontwerp werd echter zonder behandeling het jaar daarop door de nieuwe minister Godefroi ingetrokken zonder dat het door de Tweede Kamer in behandeling is genomen. ${ }^{43}$

Alle pogingen hadden aldus schipbreuk geleden, terwijl de bezwaren tegen de Code Pénal met de dag groter werden. De problemen namen toe, onder andere ten gevolge van het geheel ontwrichte strafstelsel, de indeling van de Code die veel te wensen overliet, de gebrekkige redactie van de artikelen, de te kort schietende Nederlandse vertaling, het hanteren van de. Franse tekst uit $1810 \mathrm{bij}$ de interpretatie, alsmede

40 Andere redenen waren het stelsel van afschrikking, het gebruik van lijfstraffen en de strenge strafbedreiging. Zie Hamel, G.A. van bijgewerkt door Dijck, J.V. van, Inleiding tot de studie van het Nederlandse strafrecht, p. 78.

4I Hamel, G.A. van bijgewerkt door Dijck, J.V. van, Inleiding tot de studie van het Nederlandse strafrecht, pp. 79-80. Aangezien Boek I was afgekondigd diende dit in 1886 bij de invoeringswet van het nieuwe Wetboek van Strafrecht uitdrukkelijk te worden ingetrokken.

42 Nolte, H.J.A., Het strafrecht in de afzonderlijke wetten, pp. 47-48.

43 Hamel, G.A. van bijgewerkt door Dijck, J.V. van, Inleiding tot de studie van het Nederlandse strafrecht, p. 81 . 
doordat vele strafbaarstellingen uit bijzondere wetgeving de systematiek van de Code niet volgden. ${ }^{44}$

Wederom ging in september 1870 een Commissie aan de slag om een ontwerp te maken voor een nieuw Wetboek van Strafrecht. ${ }^{45}$ De "Staatscommissie voor de Zamenstelling van een Wetboek van Strafrecht" ging in tegenstelling tot de eerder codificaties en pogingen daartoe uit van de idee dat de Grondwet een volledige codificatie van het gehele nationale strafrecht gebood. ${ }^{46}$ Het geldende strafrecht voldeed daar niet aan, het was immers nog steeds gedeeltelijk Frans, en het bestond naast de (gewijzigde) Code Pénal uit een enorme verzameling bijzondere wetten. Wel makkte de Commissie bij het streven naar volledige codificatie uitzondering voor het de militaire en fiscale strafrecht. In de memorie van toelichting van het Wetboek van Strafrecht valt te lezen ${ }^{47}$ :

"Van niet minder gewigt voor het bijzondere deel, in zoover dit in het tweede boek is vervat, is de oplossing van alle bepalingen over eigenlijke misdrijven, thans voorkomende in andere wetten, behalve de militaire en fiscale, in het wetboek.

Welke feiten, thans in de militaire wetten met straf bedreigd, zouden kunnen vallen in de bepalingen van het gemeene regt en inhoever het algemeene deel van de militaire strafwetboeken voor vereenvoudiging vatbaar zoude zijn, nu art. 98 van het tegenwoordig ontwerp de subsidiare kracht van het algemeene deel van het gemeene strafregt ook voor het militaire strafregt uitdrukkelijik erkent, - ziedaar vragen die alléén met de vereischte zorg ovenwogen en besiist kunnen worden bij eene eventuele herziening van de militaire súafwetter. Tot zoolang moet elke poging om die wetten op te lossen in het gemeene strafregt, achterwege blijven.

De bijzondere aard der fiscale wetten maakt het wenschelijk ook in deze geen verandering te brengen bij de invoering van het nieuwe wetboek. Wel brengt art. 98 mede dat het eerste boek van het wetboek ook toepasselijk is op feiten in rijksbelastingwetten met straf bedreigd, tenzij die wetten anders bepalen, maar verder moet men niet gaan. Belastingen en de maatregelen vereischt tot verzekering harer invordering zijn uit haar aard afwisselend, en de daartoe betrekkelijke strafbepalingen dus minder geschikt om deel uit te maken van eene blijvende algemeene codificatic. Dit is op zich zelf reeds voldoende om deze strafbepalingen te houden buiten het gemeene strafwetboek, afgescheiden van andere overwegingen die zich tegen de inlassching verzetten, zoo als de moeijelijkheid om in deze materie de strafbepalingen van de gebods - of verbodsbepalingen te scheiden."

44 Bosch, A.G., Het ontstaan van het Wetboek van Strafrecht, p. 43.

45 Zie over deze commissie en haar werk Bosch, A.G., Het ontstaan van het Wetboek van Strafrecht.

46 In de Notulen en Bijlagen van de Staatscommissie voor de Zannenstelling van een Wetboek van Strafregt, 1870/1876 valt te lezen: "Zal Nederland eindelijk in het bezit worden gesteld van een eigen strafwetboek, dan moet dit ook bevatten eene nieuwe zelfstandige en volledige codificatie van het nederlandsche strafrecht. Van niet minder gewigt voor het bijzondere deel is de strenge toepassing van het grondwettig beginsel van codificatie, de oplossing van alle strafwetten, behalve de militaire, en van alle strafregtelijke bepalingen voorkomende in andere wetten, behalve de fiscale, in het wetboek."

47 Zie Smidt, H.J., Geschiedenis van het Wetboek van Strafrecht, Deel l, p. 43. 
Met name het bijzondere karakter van het militaire en het fiscale strafrecht waren reden $\mathrm{cm}$ deze niet op te nemen in het nieuwe Wetboek van Strafrecht. Ook de raktaten bleven vanwege hun bijzondere aard buiten de codificatie. Het Wetboek deelde de strafbare feiten in in misdrijven en overtredingen. Voor overtredingen werd ook eer uitzondering gemaakt bij het streven naar totale codificatie ${ }^{48}$ :

"Voor cvertredingen (Boek III) kon in het algemeen en behoudens enkele uitzonderingen dezelfde weg niet gevolgd worden als voor misdrijven. Zeer groot is het aantal bijzondere wetten, vaarin, zonder dat zij tot het gebied van het strafregt behooren, feiten worden strafbaar gesteld, die het karakter van overtreding dragen. Het is niet wel mogelijk alle daartoe betrekkelijke bepalingen te codificeren en, al ware volledigheid bij zoodanige codificatie bereikbar, het wetboek zoude toch onmiddellijk na zijne invoering door nieuwe strafbepalingen in nieuwe wetten onvolledig worden. Daarenboven is de scheiding tusschen gebod of verbod en straf in cen zoo groot aantal wetten aan veel bezwaar onderhevig, omdat er gevaar bestaat, dat daardoo: het noodzakelijk verband tusschen beiden zoude worden verbroken."

Er werd zodoende afgezien van codificatie van alle overtrecingen. ${ }^{49}$ Alleen die overtredingen die onderwerpen behandelden die voor alle provincies, gemeenten en waterschappen gelijkelijk behoorden te worden geregeld en die niet reeds elders in een bijzondere wet voorkwamen werden in het Wetboek opgenomen. ${ }^{50}$

Het in mei 1875 ingediende ontwerp werd in juni 1878 in opdracht van de Koning door de minister van justitie voor advies werd voorgelegd aan de Raad van State. Deze maakte bezwaar tegen de "volledige" codificatie en oordeelde dat":

"sornmige onderdeelen daarvan, bepaaldelijk in het IIde en IIIde boek als niet noodzakelijk tot het bestek van een wetboek van strafregt behoorenden, daaruit zouden dienen te worden geligt."

De opmerkingen van de Raad leidde tot enkele wijzigingen en het inkrimpen van vooral Boek III door weglating van bepalingen uit bijzondere wetten. ${ }^{52}$ Het nieuwe ontwerp bevatte daardoor 76 artikelen minder. In februari 1879 werd het ontwerpSmidt aán de Tweede Kamer gezonden. De Tweede Kamer Comnissie deed verslag, waarop minister Modderman enkele wijzigingen aanbracht. Het gewijzigd ontwerpModderman werd in oktober 1880 door de Tweede Kamer en in maart 1881, onder toezegging van enkele wijzigingen, door de Eerste Kamer aangenomen. Blijkens het rapport aan de koning zou het nog verder worden ingeperkt om het gebied waarover het wetboek handelt niet verder dan nodig uit te breiden. Op 3 maart 1881 werd de wet

48 Zie MvT in Smidt, H.J., Geschiedenis van het Wetboek van Strafrecht, Deel I, pp. 43-44.

49 Zie over het onderscheid en de verschillen tussen misdrijven en overtredingen hoofdstuk 6 paragraaf 3 .

50 Enschedé, Ch.J. en Corstens, G.J.M., "Strafrecht en strafvordering", p. 230; zie ook de MvT in Smidt, H.J., Geschiedenis van het Wetboek van Strafrecht, Deel III, pp. 174176.

5I Zie Smidt, H.J., Geschiedenis van het Wetboek van Strafrecht, Deel I, p. 11.

52 Het bijzonder strafrecht bleef daardoor reeds vanaf de invoering van het Wetboek een belangrijke plaats innemen in het gehele strafrechtelijke systeem. Zie voor het bijzonder strafrecht hoofdstuk 7 . 
tot vaststelling van het Wetboek van Strafrecht goedgekeurd ${ }^{53}$, waana het op 1 september 1886 in werking is getreden. In de memorie van toelichting bij de Invoeringswet wordt over het gehanteerde onderscheid tussen het commuun en het overige strafrecht opgemerkt ${ }^{54}$ :

'De 'strafwet' heeft het positieve strafrecht tot object; de 'andere' wet gebruikt het positieve strafrecht als middel."

Vanwege de wijzigingen die de Eerste Kamer verlangde werd op 15 januari 1886 een wijzigingswet voor het in maart 1881 vastgestelde wetboek goedgekeurd, die gelijktijdig met de nieuwe wet in werking zouden treden. Ze behelsde enkele wijzigingen, aanvullingen en verbeteringen. ${ }^{55}$ Reeds kort na de invoering werd op 31 december 1887 opnieuw een wijzigingswet goedgekeurd. ${ }^{56}$ Dit zou niet de laatste zijn; het Wetboek is in de loop der tijd regelmatig aangepast aan nieuwe inzichten en omstandigheden.

\section{Misdrijven en overtredingen; Boek II en Boek III en bijzondere wetgeving}

\subsection{Inleiding}

Bij de invoering van het Wetboek van Strafrecht verdween de driedeling van strafbare feiten in misdrijven, wanbedrijven en overtredingen die stamde uit de Franse wetgeving van $1791 \mathrm{en}$ ook is te vinden in de in 1810 ingevoerde Code Pénal. Zij werd vervangen door een tweedeling in misdrijven en overtiedingen. Deze tweedeling is niet alleen in het Wetboek van Strafrecht (misdrijven in Boek II, overtredingen in Boek III), maar ook in het bijzonder strafrecht terug te vinden. Het is interessant om te zien wat het inhoudelijke verschil is tussen misdrijven en overtredingen (hoofdstuk 6 paragraaf 3.2.). Dit kan relevant zijn voor de keuze of de schending van zorgplichtbepalingen moet worden angemerkt als misdrijf of niet. De indeling heeft immers enkele belangrijke verschillen in rechtsgevolg (hoofdstuk 6 paragraaf 3.3.).

\subsection{Onderscheidend criterium tussen misdrijven en overtredingen}

Toen bij de invoering van het huidige Wetboek van Strafrecht de driedeling uit de Code Pénal werd vervangen door een tweedeling, werd in de memorie van toelichting

53 Wet van 3 maart 1881, Stb. 1881, 35 .

54 Smidt, H.J., Geschiedenis van het Wetboek van Strafrecht, Deel III.

55 Wet houdende wijzigingen van het Wetboek van Strafrecht, Stb. 1886, 6. Zie hierover Hamel, G.A. van bijgewerkt door Dijck, I.V. van, Inleiding tot de studie van het Nederlandse strafrecht, pp. 84-85.

56 Zie chronologisch de verschillende stadia van de totstandkoming van het Wetboek van Strafrecht: Smidt, H.J., Geschiedenis van het Wetboek van Strafrecht, Deel I, pp. 1-4. 
stil gestaan bij het onderscheid tussen deze twee categorieën strafbare feiten. De wetgever zag een principieel verschil en merkte op ${ }^{57}$ :

"Nu eens wordt straf bedreigd tegen een feit (handeling of verzuim) dat, ook al kon het toen nog niet door den regter gestraft worden, reeds onregt was vóórdat de wetgever sprak, en waarvan. wij het onregtvaardige zouden beseffen ook al had de wetgever niet gesproken. In dit geval is er >misdrijf". Dan weder geldt het een feit dat ook in den hoogeren, regtswijsgeerigen zin eerst onregt wordt DOOR de wet; - waarvan ons het ontegtvardige alleen UIT de wet bekend $\mathrm{k}$ a $\mathrm{n}$ zijn. In dit geval bestaat eene >>overtreding"."

Zo wordt een onderscheid gemaakt tussen "rechts"delicten; de misdrijven die uit eigen aard reeds in strijd zijn met de rechtsorde en de "wets"delicten; overtredingen die strafwaardig zijn door of uit kracht van de wet. ${ }^{58}$ De wetgever merkte voorts op dat ${ }^{59}$ :

"Waar rechtsdelicten nieuwe regeling behoeven behoort dit via het Wetboek van Strafrecht te geschieden."

De eerste categorie heeft betrekking op gedragingen waarvan een ieder de onrechtmatigheid beseft ook al zou de wet hebben gezwegen, terwijl de tweede categorie gedragingen betreft die pas onrechtmatig zijn geworden door de strafbaarstelling. ${ }^{60}$ Deze laatste worden ook angeduid als zuiver formeel onrecht, omdat hier geen schending van rechtsgoederen wordt vereist. Maar aangezien ook overtredingen onduldbaar worden geacht, vooronderstellen ook deze strafbaarstellingen een gevaarzetting of schending van een rechtsbelang. ${ }^{61}$ Binding stel ${ }^{62}$ :

"Unbestreitbar verlangt kein vernünftig Gesetz den Gehorsam um seiner selbst willen. Die Norm als Freiheitsbeschränkung kann ihre Rechtfertigung nur darin finden, dass die Untersagung einer bestimmten Handlungsgruppe in den Augen des Gesetzgebers ein geringeres Öbel ist als ihre Freigabe, und kein verbot kann anders ergehen als in Hinblick auf die Folgen der untersagten Handlung für das Rechtsleben."

Het intrinsieke verschil dat zou bestaan tussen misdrijven en overtredingen werd dan ook al snel bekritiseerd ${ }^{63}$ en niet houdbaar geacht, evenmin als enig ander materieel

57 Zie Mv'T in Smidt, H.J., Geschiedenis van het Wetboek van Strafrechr, Deel I, p. 64.

58 Zie over het onderscheid tussen het onrecht vóór de wet en het onrecht dóór de wet in de MvT: Smidt, H.J., Geschiedenis van het Wetboek van Strafrech, Deel I, pp. 63-72.

59 Zie hierover Buruma, Y., De strafiechtelijke handhaving van bestuurswetten, p. 73.

60 Zie Boek, J. in Cleiren, C.P.M. en Nijboer, J.F. (red.), Strafrecht. Tekst en Commentaar, p. 1133.

61 Remmelink, J., Mr. D. Hazewinkel-Suringa's Inleiding tot de studie van het Nederlandse strafrecht, p. 103.

62 Binding, G., Die Normen und ihre Ubertretung, pp. 397-398.

63 Zie Hoeven, H. van der, De vraag: mag het Wetboek van Strafrecht ongewijzigd. ingevoerd worden?; Hoeven, H. van der, "De invoering van het Strafwetboek"; Pons, M.S., "De invoering van het Wetboek van strafrecht"; Pols, M.S., "De verdeeling der strafbare handelingen in misdrijven en overtredingen", pp. 223-248; Hoeven, H. van der, "Misdrijven en overtredingen", pp. 453-485; Andel, L. van, De Indeeling der strafbare. 
onderscheidend criterium. ${ }^{64}$ Wel kan worden gesteld dat misdrijven in het algemeen als emstiger en meer afkeurenswaardig worden beschouwd dan overtredingen. ${ }^{65}$ Aangenomen wordt dat een aantal factoren tezamen bepalen of een strafbaar feit dient te worden aangemerkt als misdrijf of als overtreding. Het betreft voomamelijk de betekenis van het geschonden rechtsgoed, de omvang van de krenking, de wijze van aantasting ${ }^{66}$ en of er al dan niet sprake was van opzet. ${ }^{67}$ Daarnaast kan ook de plaats van het strafbare feit in het systeem van wetgeving bepalend zijn. Zo kan het schenden van een bepaling uit een gemeentelijke, provinciale of waterschapsverordening alleen als overtreding worden strafbaar gesteld.

Het rangschikken van "lichtere" delicten onder het strafrecht is van relatief jonge datum. Niet voor niets werd het strafrecht aangeduid als "lijfstraffelijk recht". Het oude strafrecht hield zich in tegenstelling met het huidige strafrecht bijna uitsluitend bezig met ernstige feiten. ${ }^{69}$ Het overgrote deel van de overtredingen staat dan ook niet in het Wetboek van Strafrecht, maar is te vinden in lagere regelgeving zoals verordeningen van gemeenten, provincies en waterschappen en in de vele bijzondere wetgeving uit de twintigste eeuw. ${ }^{70}$ Op dit moment lijkt langzaam maar zeker een tegenbeweging in gang te zijn gezet. De enorme uitbouw van het strafrecht door de

feiten in Misdrijven en Overiredingen. Zie met overzicht van de gevoerde discussie Pompe, W.P.J., Geschiedenis der Nederlandsche rechtswetenschap, pp. 355-358; zie verder Schaffmeister, D., "Delictsclassificaties - misdrijven en overtredingen", pp. 189214; Schaffmeister, D., "Politiële en justitiële delikten", pp. 142-156; Buruma, Y., De strafrechtelijke handhaving van bestuurswetten, pp. 73 .

64 Remmelink, J., Mr. D. Hazewinkel-Suringa's Inleiding tot de studie van het Nederlandse strafrecht, p. 103.

65 Zie bijvoorbeeld Enschedé, Ch.J. en Corstens, G.J.M., "Strafrecht en strafvordering", pp. 229-230. Zij stellen: "In de loop der jaren heeft dit onderscheid tussen rechts- en wetsdelicten aan scherpte ingeboet. Thans kan men niet veel meer zeggen dan dat de wetgever emstiger delicten eerder tot misdrijven stempelt, de minder emstige tot overtredingen." Voorts wordt opgemerkt dat misdrijven meestal emstiger zaken betreffen en de verwevenheid met de ethiek sterker is dan bij overtredingen, zie Noyon, T.J., Langemeijer, G.E. en Remmelink, J., bewerkt door Dorst, A.J.A. van, Fokkens, J.W. en Machielse, A.J.M., Het Wetboek van Strafrecht, "Overtredingen", p. 1 (juni 1985). De "ernst van het feit" is overigens een complex begrip, aangezien bij het bepalen van de ernst uiteenlopende factoren een rol spelen. Zie hierover Hullu, J. de, Koopmans, I.M. en Roos, Th.A. de, Het wettelijk strafmaximum, pp. 114-123.

66 Zie Remmelink, J., Mr. D. Hazewinkel-Suringa's Inleiding tot de studie van het Nederlandse strafrecht, p. 103.

67 Opzet is voor de meeste economische delicten het onderscheidend criterium aangezien artikel 2, eerste lid Wed luidt: "De economische delicten, bedoeld in artikel 1, onder $1^{\circ}$ en $2^{\circ}$, en artikel $1 a$, onder $1^{\circ}$ en $2^{\circ}$, zijn misdrijven, voor zover zij opzettelijk zijn begaan: voor zover deze economische delicten geen misdrijven zijn, zijn zij overtredingen." Zie hierover hoofdstuk 8 paragraaf 2.5 . Zie hierover hoofdstuk 9 paragraaf 2.2 .

69 Zie Enschedé, Ch.J. en Corstens, G.J.M., "Strafrecht en strafvordering", p. 230.

70 Noyon, T.J., Langemeijer, G.E. en Remmelink, J., bewerkt door Dorst, A.J.A. van, Fokkens, J.W. en Machielse, A.J.M., Het Wetboek van Strafrecht, "Overtredingen", p. 2 (juni 1985). 
toename van modificerende wetgeving ${ }^{71}$ wordt vaak onwenselijk en inefficiënt geoordeeld, en heeft geleid tot (een zekere mate van) overbelasting van de (straf) rechtspleging ${ }^{72}$, de uitbreiding van bestuursrechtelijke instrumenten en bevoegdheden en de overheveling van de handhaving naar het bestuursrecht. ${ }^{73}$

\section{3.}

\section{Verschillen tussen misdrijven en overtredingen en de gevolgen daarvan}

Of een strafbaar feit is aan te merken als misdrijf of als overtreding heeft een groot aantal materiēle en procesrechtelijke consequenties. Ook de manier waarop de strafbaarstelling is vormgegeven is vaak anders. Enkele kenmerkende verschillen en de gevolgen daarvan worden in deze paragraaf besproken. ${ }^{74}$

Overtredingen zijn vaak formele delicten (waarbij wordt volstaan met het aangeven van een bepaald soort handeling of nalaten), die meestal eenvoudiger zijn vorm gegeven en waarbij vaak een subjectief bestanddeel ontbreekt. ${ }^{75}$ Deze verschijnselen worden deels veroorzaakt doordat de wetgever bij de totstandkoming van het Wetboek van Strafrecht zich voor een belangrijk deel heeft laten leiden door de leer van het naakte feit; de pure gedraging. ${ }^{76}$ Misdrijven zijn daarentegen meestal materie̋le delicten (die het veroorzaken van een bepaald gevolg omvatten waarbij meestal de daartoe voerende gedraging als bestanddeel is opgenomen), waarin wel een subjectief bestanddeel is opgenomen.

Afhankelijk of sprake is van opzet dan wel schuld wordt het misdrijf meestal in een apart artikel strafbaar gesteld, waarbij de opzettelijk begane variant met een hogere maximum straf wordt bedreigd dan de culpoos begane variant. ${ }^{77}$ Dit is overigens niet altijd het geval. Enkele strafbaarstellingen in het Wetboek van Strafrecht bevatten de, ook in zorgplichtbepalingen uit met milieurecht veelvuldig voorkomende, subjectieve bestanddelen "weet of emstige reden heeft om te vermoeden" of "weet of

$71 \quad$ Zie hierover hoofdstuk 3 paragraaf 2.

72 Het verschijnsel van overbelasting is irouwens niet nieuw, zie bijvoorbeeld de preadviezen uit 1884 van Hamel, G.A. van, "Is vereenvoudiging van het strafgeding voor den Kantonregter wenselijk? Zoo ja, in welken zin?", pp. 262-334 en Swinderen, P.J. van, "Is vereerivouđiging van het strafgeding voor den Kantonregter wenselijk? Zoo ja, in welken zin?", pp. 336-369.

73 Zie over deze overheveling hoofdstuk 6 paragraaf 4 .

74 Zie voor een beknopt overzicht Remmelink, J., Mr. D. Hazewinkel-Suringa's Inleiding tot de studie van het Nederlandse strafrecht, pp. 104-107; Noyon, T.J, Langemeijer, G.E. en Remmelink, J., bewerkt door Dorst, A.J.A. van, Fokkens, J.W. en Machielse, A.J.M., Het Wetboek van Strafrecht, "Overtredingen", p. 1 (juni 1985).

75 Schuld is dan element van de strafbaarstelling. Zie hierover hoofdstuk 3 paragraaf 7.4.4.

76 Zie Smidt, H.J., Geschiedenis van het Wetboek van Strafrechi, Deel III, p. 175; Remmelink, J., Mr. D. Hazewinkel-Suringa's Inleiding tot de studie van het Neder!andse strafrecht, p. 105.

77 Zie bijvoorbeeld de artikelen 157 en 158; 161 bis en 16!ter; 161quater en 161quinquies; 161 sexies en 161 septies; 162 en $163 ; 164$ en $165 ; 166$ en $167 ; 168$ en 169; 170 en 171 ; 172 en 173; 173a en 173b; 174 en 175; 175a en 175b; 287 en 307; 350a en 350b; 351 en 351 bis; 355 , sub 4 en $356 ; 416$ en 417 bis Sr. 
redelijkerwijs moet vermoeden". ${ }^{78}$ Dergelijke samengestelde subjectieve bestanddelen dienen bij deze commune strafbaarstellingen te worden gelezen als alternatieven van elkaar. Niet voor niets staat het woord of tussen de twee bestanddelen opgenomen. Gebruikelijk is dan dat het bestanddeel "weet" wordt gerubriceerd als een vorm van opzet. De bestanddelen "ernstige reden heeft om te vermoeden" en "redelijkerwijs moet vermoeden" worden gezien als de culpose variant. De delictsomschrijving waarvan de samengestelde bestanddelen deel uitmaken stelt daardoor in feite twee strafbare feiten onafhankelijk van elkaar strafbaar, te weten de culpose en de opzettelijke gedraging. ${ }^{79}$ Deze strafbaarstellingen in het Wetboek van Strafrecht worden aangemerkt als misdrijf of overtreding, afhankelijk of van de opneming in Boek II of Boek III, waarbij in de wet geen onderscheid wordt gemaakt in de maximum strafbedreiging. ${ }^{80}$ Indien de delictsomschrijvingen wel zijn gesplitst in aparte culpose en opzettelijke strafbaarstellingen, is er wel een differentiatie ten aanzien van de maximum strafbedreiging. Als de strafbaarstelling is gekoppeld aan de Wed is het onderscheid tussen misdrijf en overtreding vaak afhankelijk van de vraag of het delict al dan niet opzettelijk is begaan, hetgeen meestal ook gevolgen heeft voor de maximum strafbedreiging. ${ }^{81}$

Een ander kenmerkend verschil tussen misdrijven en overtredingen is dat poging (ex. artikel $45 \mathrm{Sr}$ ) en medeplichtigheid (ex artikel 48 jo. $52 \mathrm{Sr}$ ) aan overtredingen nief strafbaar is, tenzij anders blijkt uit de (bijzondere) wet. Zo gelden bijvoorbeeld de

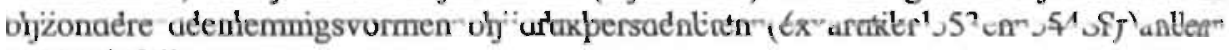
voor misdrijven.

Het onderscheid is tevens van belang voor de rechterlijke competentie. Indien in de wetgeving niet is aangegeven of een strafbaar gesteld feit een overtreding dan wel een misdrijf betreft, is berechting van de normschending niet mogelijk. De Hoge Raad overweegt $^{82}$ :

78 Zie de artikelen 97b, 98a eerste lid, 113, 119, 132, 134, 240, 240a en 437bis Sr.

79 Zie over opzet, culpa en deze samengestelde subjectieve bestanddelen ook hoofdstuk 3 paragraaf 7.4.

80 Zie de commentaren bij de artikelen uit noot 787 in Noyon, T.J., Langetneijer, G.E. en. Remmelink, J., bewerkt door Dorst, A.J.A. van, Fokkens, J.W. en Machielse, A.J.M, Het Wetboek yan Strafrecht, en in Cleiren, C.P.M. en Nijboer, J.F. (red.), Strafrecht. Tekst en Commentaar.

81 Zie hierover hoofdstuk 8 paragraaf 2.5., hoofdstuk 9 paragraaf 2.4. en hoofdstuk 10 paragraaf 2.5.3. en over de problemen die dit kan opleveren met oog op het eventueel eptreden van de "schuldkwadratuur" hoofdstuk 3 paragraaf 7.4.6., daar blijkt ook dat altijd moet worden onderzocht op welke bestanddelen uit de delictsomschrijving de subjectieve bestanddelen betrekking hebben, aangezien ze meestal niet van toepassing zijn op alle bestanddelen. Het deel dat is ontrokken aan de subjectieve bestanddelen word: beheerst door schuld als element.

82 HR 6 juni 1922, NJ 1922, pp. $922-925$ (Geen bevoegde rechter). Het betrof de Woningwet van 1918, waaraan bij wet van 29 februari 1921, Stb. 1921, 72 aan artikel 10 , tweede lid werd toegevoegd wardoor met straf werd bedreigd de overtreding van het verbod gesteld in artikel $8 \mathrm{c}$, eerste lid van die wet. Ten tijde van het plegen van het ten laste gelegde ontbrak een bepaling die stelde of het feit een overtreding dan wel een 
" 0 ., d. tijdens het plegen van de telastegelegde handeling evenwel in die wet ontbrak eene bepalis (...) waarbij werd aangewezen of het strafbaar gestelde feite eene overtreding dan wel een mdrijf opleverde, terwijl zoodanige aanwijzing evenmin in eenige andere wettelijke bepalig is gegeven;

0 , da als gevolg hiervan bij de wet geen rechter is aangewezen, die bevoegd is om het telasteelegde feit te berechten, kunnende geen Kantonrechter aan artikel 44 R.O. en geen Arr.Rechtbnk aan artikel 56 dier wet de macht daartoe ontleenen, terwijl in verband hiermede ook geen Anbtenaar van het Openbaar Ministerie bij de artikelen 22 of 23 Sv. Of bij eenige andere wettelike bepaling belast is met de vervolging van bedoeld feit; $(\ldots)$

0 ., (.. Verklaart dien rechter onbevoegd om van de zaak kennis te nemen."

De vrag of sprake is van een tenlastelegging van een misdrijf of van een overtreding is ool van belang voor de competentie van de rechter en de ontvankelijkheid van partija in hoger beroep en cassatie. ${ }^{83}$ Een verdachte en de officier van justitie kunnen bijvorbeeld involge de artikelen $404 \mathrm{~Sv}$ of 51 Wed (bij economische delicten) met uitzorlering van de daar genoemde gevallen, tegen een vonnis van de rechtbank hoger beroe instellen. Het is ook voor de ontvankelijkheid in cassatie van belang te weten of in sen strafzaak hoger beroep tegen een uitspraak open staat of heeft gestaan. Beroe in cassatie kan door de veroordeelde immers niet worden ingesteld indien een andergewoon rechtsmiddel openstaat of heeft opengestaan. ${ }^{84}$ Niet altijd is op basis van d regelgeving en de tenlastelegging duidelijk of een misdrijf of een overtreding is ten late gelegd. Dit kan dan bij de ontvankelijkheidvraag in hoger beroep of cassatie een heel gepuzzel opleveren. ${ }^{85}$

De maximum en soort strafbedreiging kennen ook verschillen tussen misdrijven en overtredingen. Meestal is de maximum strafbedreiging voor het schenden van een misdrijf hoger. Ook de sanctiemogelijkheden zijn vaak verschillend. Zo komt gevangenisstraf als sanctievorm bij overtredingen niet voor evenals de terbeschikkingstelling tenzij sprake is van souteneurschap. Naast de algemene bepalingen uit Boek I van het Wetboek van Strafrecht, geven de strafbaarstellingen zelf en de wet waarin ze zijn strafbaar gesteld de mogelijkheden aan. ${ }^{86}$

misdrijf betrof. Bij Wet van 13 januari 1922, Stb. 1922, 19 werd deze omissie gecorrigeerd.

83 Zie de artikelen 44,58 en 68 Wet op de rechterlijke organisatie.

84 Zie Corstens, G.J.M., Het Nederlands strafproces, p. 726.

85 Zie voor een oplossing van de puzzel Fokkens in zijn conclusie voor HR 23 april 1996, NJ 1996, 512 (Waterschap Westfriesland). De Hoge Raad kwam hier overigens niet toe aan het beantwoorden van de vraag of de puzzel goed was opgelost, omdat het OM op andere gronden niet-ontvankelijk werd verklaard. De problematiek van onduidelijkheid door regelgeving en tenlastelegging of primair een misdrijf of een overtreding is ten laste gelegd, en de gevolgen daarvan voor de ontvankelijkheid in cassatie, kan zich ook voordoen bij vervolging van delicten uit de Opiumwet, zie bijvoorbeeld HR 11 juni 1996, $N J$ 1996, 700 (Cassatie overtreding Opiumwet).

86 Zie bijvoorbeeld artikel 5 Wed, zie hierover hoofdstuk 8 paragraaf 2.5 . 


\section{Van strafrechtelijke naar bestuursrechtelijke handhaving}

\subsection{Inleiding}

De overbelasting van de strafrechtspleging is één van de redenen dat de laatste decennia een tendens is waar te nemen om bepaalde soorten onwenselijke gedragingen niet langer aan te duiden als misdrijf of overtreding, maar over te hevelen naar het bestuursrecht (hoofdstuk 6 paragraaf 4.3.). ${ }^{87}$ Eén van de redenen is dat sprake zou zijn van een "handhavingstekort" (hoofdstuk 6 paragraaf 4.2.). Ook in omringende landen is deze tendens zichtbaar. ${ }^{88}$ Het bestuur wordt daarom nieuwe instrumenten gegeven om normschending te kunnen aanpakken (hoofdstuk 6 paragraaf 4.3.). Er zijn naast enkele ogenschijnlijke voordelen enkele belangrijke nadelen verbonden aan deze ontwikkeling (hoofdstuk 6 paragraaf 4.4.). Ondanks dat deze tendens vooral lijkt plaats te vinden in het niet-commuun strafrecht wordt dit thema op deze plaats besproken. De reden hiervoor is dat het een algemeen leerstuk betreft en dat dit leerstuk samenhangt met de discussie op welke manier een onwenselijke gedraging moet worden aangemerkt.

\subsection{Het "handhavingstekort"}

Doordat het strafrecht een belangrijke rol kreeg toebedeeld bij de handhaving van (steeds meer) bestuursrechtelijke wet- en regelgeving, werd in toenemende mate beroep gedaan op het strafrechtelijk apparaat. Geconstateerd werd dat mede door het gelijktijdig toenemen van de handhaving van het commuun strafrecht, het strafrechtelijk handhavingsapparaat onder druk kwam te staan en de handhaving van bestuursrechtelijke wetgeving te wensen overliet. ${ }^{89}$ Hierdoor was sprake van een "handhavingstekort".

Dit handhavingstekort werd geweten aan de steeds ingewikkelder samenleving die voor steeds meer aspecten van het maatschappelijk leven steeds meer regels vraagt, en het verschijnsel dat diezelfde samenleving steeds minder geneigd is zich spontaan aan regels te houden. ${ }^{90}$ Voorts bleek de regelgeving zelf soms ook tekort te schieten ten aanzien van de handhaafbaarheid en kwaliteit.

87 Corstens, G.J.M., "Civielrechteliike, administratiefrechtelijke of strafrechtelijke handhaving?", pp. 1-126; Carstens, G.J.M., Een stille revolutie in het strafrech;; Hartmann, A.R. en Russen Groen, P.M. van, Contouren van het bestuursstrafrecht, pp. 50.68 .

88 Zie Schaffmeister, D., "Politiële en justitiële delikten", pp. 127-291.

89 Zie de Nota "Recht in beweging; een beleidsplan voor Justitie in de komende jaren", TK. 1990-1991, 21 829, nrs. 1-2.

90 Zie de Nota "Met vaste hand; verbetering van de kwaliteit van de rechtshandhaving", $T K$. 1990-1991, 22 045, nrs. 1-2, zie over de toename van modificerende wetgeving en de geringere acceptatie van de hierin opgenomen normen hoofdstuk 3 paragraaf 2 .

91 Zie de Nota "Zicht op wetgeving", TK 1990-1991, 22 008, nrs. 1-2, zie over deze nota hoofdstuk 3 paragraaf 3 . 
Het "handhavingstekort" omvat twee verschillende situaties. Aan de ene kant gaat het om bet niet handhaven door een tot handhaving bevoegde instantie die rechtens moet handhaven maar het "wel wil maar niet kan", aan de andere kant betreft het de situatie dat deze instantie "wel kan maar niet wil". 92 Bij de beschouwingen over het "handhavingstekort" wordt er vaak stilzwijgend vanuit gegaan dat tegen elike schending van de regelgeving publiekrechtelijk zou moeten worden opgetreden. ${ }^{93}$ Zeker in het strafrecht is meestal eerder sprake van het omgekeerde. Daar wordt veelvuldig gebruik gemaakt van de mogelijkheid een zaak niet of buitengerechtelijk af te doen. ${ }^{98}$ Belangrijke instrumenten hierbij zijn het politiesepot, het technisch sepot, het beleidssepot, het (beleids)sepot onder voorwaarden en de transactie. Deze worden in deze paragraaf kort besproken. Hiermee is niet bedoeld te ontkennen dat sprake is van een "handhavingstekort" in het strafrecht ${ }^{95}$, maar is veeleer bedoeld om te laten zien dat er nogal wat valt af te dingen op het uitgangspunt bij de benadering van dit "tekort".

Zo is de politie bevoegd zelfstandig zaken te seponeren; het politiesepot. In dat geval wordt afgezien van het opmaken van een proces-verbaal, dan wel wordt het opgemaakte proces-verbaal niet ingezonden aan de (hulp) officier van justitie. Het OM kan de politie instructies geven omtrent de prioriteitsstelling bij de opsporing. In gevallen waarin de politie anticipeert op het beleid van het OM, heeft de Hoge Raad het politiesepot aanvaard. ${ }^{96}$

Het OM heeft onder andere tot taak te beslissen welke van de strafzaken die op het parket binnenkomen ter terechtzitting aan de strafrechter worden voorgelegd. De officier van justitie kan afzien van vervolging op basis van artikel 167, tweede lid Sv of, indien er een gerechtelijk vooronderzoek heeft plaatsgevonden of voorlopige hechtenis is toegepast, op basis van artikel 242 , tweede lid Sv.

Bij het nemen van deze vervolgingsbeslissing zal de officier van justitie ten eerste nagaan of de zaak strafrechtelijk haalbaar is. Hij behoort van vervolging af te zien indien een technisch-juridische hinderpaal aan de veroordeling in de weg lijkt te staan; er is dan sprake van een technisch sepot. Bij het beoordelen of de zaak haalbaar is anticipeert de officier van justitie op het te verwachten oordeel van de strafrechter over de vragen uit de artikelen 348 en. 350 Sv. Indien naar zijn oordeel één of meer van

92 Zie Commissie bestuursrechtelijke en privaatrechtelijke handhaving, Handhaven op niveau, pp. 36-58.

93 Daarop wijst ook de Commissie bestuursrechtelijke en privaatrechtelijke handhaving, Handhaven op niveau, p. 35.

94 Zie over de buitengerechtelijke afdoening van strafbare feiten in het milieustrafrecht Hendriks, L.E.M., "De strafrechtelijke boete en de transactie in het milieurecht", pp. 133-134; Schaffmeister, D., "Handhaving van bestuursrecht door boete of straf?", pp. 59-80; Hendriks, L.E.M. en Wöretshofer, J., Milieustrafrecht, pp. 219-221.

95 Hoewel ook dit in de praktijk gezien het beschikbare empirisch bewijs ook wel mee lijkt te vallen, zie Blomberg, A.B. en Michiels, F.C.M.A., Handhaven met effect; Commissie bestuursrechtelijke en privaatrechtelijke handhaving, Handhaven op niveau. HR 31 januari 1950, $N J$ 1950, 668, met noot Pompe (Broodjeswinkel). 
deze vragen door de strafrechter negatief zal worden beantwoord, zal hij doorgaans de zaak dienen te seponeren. Aan dit sepot mogen geen voorwaarden worden verbonden. De officier van justitie kan ondanks het te verwachten oordeel van de rechter de zaak toch aan hem voorleggen indien hij van mening is dat een rechterlijke uitspraak over de zaak behoort te worden verkregen en indien het gaat om de beoordeling van een gebeurtenis die grote beroering heeft veroorzaakt.

Indien dit niet het geval is zal hij involge de artikelen 167 en 242 Sv zijn oordeel moeten vormen over de vraag of de vervolging van de verdachte gewenst, opportuun is. Hij kan op gronden aan het algemeen belang ontleend van oordeel zijn dat het onwenselijk is de zaak aan de rechter voor te leggen, omdat hij de berechting dan wel de veroordeling niet gewenst acht. In dat geval is sprake van een zogenaamd beleidssepot. Er wordt onderscheid gemaakt tussen positieve en negatieve toepassing van het opportuniteitsbeginsel. De positieve toepassing houdt in dat het algemeen belang de vervolging noodzakelijk moet maken, terwijl de negatieve opvatting inhoudt dat het $O M$ ieder strafbaar en bewijsbaar feit dient te vervolgen tenzij het algemeen belang daarmee niet wordt gediend. ${ }^{97}$ Het uitgangspunt lijkt veeleer de vraag "waarom vervolgen" dan "waarom niet vervolgen" te zijn. Corstens stelt dienaangaande ${ }^{98}$ :

"Daarin kan een aansporing worden gezien om bij het bepalen van het vervolgingsbeleid afweging van alle in het geding zijnde belangen te doen plaats vinden en ongemotiveerde automatismen uit te sluiten."

De keuze omtrent de wijze van afdoening blijkt bij zaken die geen exceptioneel karakter hebben, in sterke mate te worden bepaald door routine en beleid. Ten aanzien van beleid dient te worden opgemerkt dat de keuze wordt bepaald door het geldende sepotbeleid én door het van toepassing zijnde vervolgingsbeleid. Indien de algemene beleidsvraag "dient in bepaalde gevallen te worden vervolgd" positief is beantwoord, zal bij een dergelijk geval vervolging de regel en sepot de uitzondering zijn. ${ }^{99}$ Het algemeen belang uit de artikelen 167 en $242 \mathrm{~Sv}$ is echter een te vaag criterium om voor het $\mathrm{OM}$ als richtsnoer te dienen bij zijn vervolgingsbeslissing. ${ }^{100} \mathrm{De}$ vaagheid van het criterium kan leiden tot onwenselijke situaties zoals willekeur bij het nemen van de vervolgingsbeslissing, bevocrdelen of benadelen van bepaalde personen of groepen in de samenleving, uitbreiden van de macht van het $O M$ ten koste van de wetgever. Het $O M$ is dan ook gehouden bij gebruikmaking van zijn discretionaire bevoegdheid een bepaald beleid te ontwikkelen en te voeren, waaraan hij zich moet houden en waarvan hij alleen gemotiveerd kan afwijken. ${ }^{101}$ Daarnaast geven transactie-, sepot- en

97 Zie hierover Hart, A.C. 't, Om het OM.

98 Corstens, G.J.M., Het Nederlands strafprocesrecht, pp. 484-485.

99 Reijntjes, J.M., "Artikel 167; beslissing omtrent vervolging", aantekening 6.

100 Zie hierover ook hoofdstuk 2. paragraaf 5.4.3. Aangezien het "dienen van" het algemeen belang steeds in meerdere of mindere mate van toepassing zal zijn, is sprake van een graduele term, die in dit geval ook vaag kan zijn.

101 De opportuniteitsgronden voor sepotbeslissingen zijn in een vijftal groepen verdeeld, te weten: gronden die samenhangen met maatregelen genomen of nog te nemen door anderen dan de officier van justitie; gronden ontleent aan de algemene rechtsorde; 
vervolgingsrichtlijnen invulling aan het sepotbeleid, zodat ook hienuit (al dan niet nadrukkelijk) kan volgen dat een verdachte (in beginsel) al dan niet zal worden vervolgd. Behalve door dit beleid wordt de bevoegdheid van het $\mathrm{OM}$ bij de toepassing van het opportuniteitsbeginsel begrensd door de beginselen van behoorlijk procesrecht $^{102}$

Het technisch sepot en het beleidssepot kunnen in de praktijk sterke samenhang vertonen, zodat ze wel zijn te onderscheiden maar niet volledig zijn te scheiden. ${ }^{103} \mathrm{De}$ officier van justitie is op basis van de wet niet verplicht zijn beslissing tot seponeren te motiveren. Of sprake is van een sepot dient hij te beantwoorden aan de hand van een aantal vastgestelde vragen. Indien hij besluit te seponeren, is hij sinds 1980 gehouden de sepotgrond(en) door middel van een cijfercode onder te brengen in een van de vaste categorieën uit de "Handleiding rubricering sepotgronden". ${ }^{104}$ Het doel hiervan is dat enig inzicht kan worden verkregen in het gevoerde beleid. ${ }^{105}$

De officier van justitie kan een onvoorwaardelijk beleidssepot al dan niet vergezeld doen gaan van een waarschuwing aan de verdachte. Het aantal kale beleidssepots (sepot zonder waarschuwing) dient te worden teruggedrongen. De waarschuwing kan mondeling plaatsvinden op het parket, of schriftelijk bij de mededeling tot niet verdere vervolging. Ook worden schadebriefjes gestuurd. Indien de verdachte kan aantonen dat de schade is vergoed of dat een schaderegeling is getroffen wordt de zaak onvoorwaardelijk geseponeerd. Deze laatste praktijk is echter door de uitbreiding van de transactieregeling in 1983 minder wenselijk geworden, het formele kader van de transactie verdient de voorkeur boven de informele praktijk van het schadebriefje. ${ }^{106}$

In de artikelen 244, derde lid en 245, derde lid Sv heeft de wetgever de wettelijke basis gecreëerd voor het voorwaardelijk (beleids)sepot. De wettelijke voorwaarden die voortvloeien uit deze bepalingen blijken bij de toepassing van het voorwaardelijk sepot echter niet strikt te worden nageleefd. ${ }^{107}$ De wet geeft geen opsomming van

gronden die samenhangen met het gepleegde feit; gronden die samenhangen met de persoon van de verdachte en gronden die samenhangen met de verhouding tussen de verdachte en de benadeelde.

102 Zie over deze beginselen, Cleiren, C.P.M., Beginselen van een goede procesorde.

103. Reijntjes, J.M., “Artikel 167; beslissing omtrent vervolging", aantekening la.

104 De Handleiding rubricering sepotgronden wordt door het ministerie van justitie uitgegeven. Deze handleiding werd ingesteld bij beschikking van de minister van justitie van 25 oktober 1976. De huidige versie dateert van 1993.

105 De haalbaarheids- en opportuniteitsgronden van sepotbeslissingen zijn gerubriceerd in een landelijke lijst. Zie over deze lijst en de daardoor beoogde harmonisatie van het beleid: Franken, A.A., "Hoofdstuk 23 Alternatieve afdoeningsmogelijkheden", 23.7.; Reijntjes, J.M., "Artikel 167; beslissing omtrent vervolging", aantekening Ia; Corstens, G.J.M., Het Nederlands strafprocesrecht, p. 486.

106 Zie over het kaal beleidssepot, het parketstandje, de schriftelijke waarschuwing en het schadebriefje: Franken, A.A., "Alternatieve afdoeningsmogelijkheden", 23.7.2.

107 Zie bijvoorbeeld Biggelaar, G.J.M. van den, De buitengerechtelijke afdoening van strafbare feiten door het openbaar ministerie, pp. 50-53; Franken, A.A., "Alternatieve afdoeningsmogelijkheden", 23.6.2.; Tonino, L.J.M., "Titel IV. Beslissingen omtrent 
voorwaarden die in het kader van een voorwaardelijk sepot kunnen worden gesteld (aan volwassenen). Dit in tegenstelling tot de transactie op basis van artikel $74 \mathrm{Sr}$. Gesteld kan worden dat de voorwaarden van het voorwaardelijk sepot in het algemeen het gedrag en de levenswijze van de verdachte beogen te beïnvloeden. Het onvoorwaardelijk sepot blijkt in wisselende frequentie te worden toegepast. ${ }^{108}$

Een wijze van afdoening die veel gelijkenis vertoont met het voorwaardelijk sepot is de transactie. ${ }^{109}$ Ook dan wordt het strafbare feit afgedaan zonder tussenkomst van de rechter. In de artikelen 74, 74a, 74b Sr en 36 Wed is de transactie door de officier van justitie geregeld. ${ }^{110}$ Op grond van het Wetboek van Strafrecht kan een transactie worden aangeboden voor strafbare feiten, met uitzondering van misdrijven waarop naar de wettelijke omschrijving gevangenisstraf is gesteld van meer dan zes jaar. Indien sprake is van een economisch delict kan dit involge artikel 36 Wed worden afgedaan met een transactie. ${ }^{111}$ Indien de verdachte voldoet aan de transactievoorwaarden vervalt het recht tot strafvordering. Dit recht kan involge artikel 74c Sr voor misdrijven herleven na een bevel als bedoeld in artikel 12K Sv.

Het belangrijkste verschil tussen de transactie en het sepot onder voorwaarden is dat transactie voorwaarden limitatief zijn opgesomd in artikel 74, tweede lid $\mathrm{Sr}$ die voor economische delicten is uitgebreid met de extra voorwaarde uit artikel 36 Wed. De voorwaarden die kunnen worden gesteld aan het sepot zijn (voor volwassenen) niet in de wet geregeld. ${ }^{112}$ De transactiebevoegdheid van de officier van justitie is nader uitgewerkt in transactierichtlijnen. Deze vormen recht in de zin van artikel 99 Wet RO,

verdere vervolging; Artikelen 242-257".

108 Zie Berg, E.A.I.M. van de, Openbaar Ministerie en milieu; terugblik op 1992, p.55; Hendriks, L.E.M. en Wöretshofer, J., Milieustrafrecht, pp. 219-221.

109 Groenhuijsen, M.S. en Kalmthout, A.M. van, "Transactie en voorwaardelijk sepot: lood OM oud ijzer", pp. 474-487 Zij stellen dat er geen principieel verschil meer bestaat; Reijntjes, J.M., "Voorwaardelijk sepot", pp. 295-316 ziet de transactie als een bijzondere verschijningsvorm van het voorwaardelijk sepot en Biggelaar, G.J.M. van den, De buitengerechielijke afdoening van strafbare feitent door het openbaar ministerie, $\mathrm{pp}$. 58 . 59 en 392-393 is van mening dat gezien het ontbreken van een wezenlijk verschil een gemeenschappelijke regeling wenselijk is.

110 Op basis van artikel $74 c \mathrm{Sr}$ heeft ook de politie de mogelijkheid ter zake van bepaalde overtiedingen en bepaalde in artikel 74 , eerste lid $\mathrm{S}_{\mathbf{r}}$ bedoelde misdrijven transactiebevoegdheid tot een bedrag van f. 750,- Zie Noyon, T.J. en Langerneijer, G.E., bewerkt door Remmelink, J., Het Wetboek van Strafrecht, "Artikel 74c", juni 1998; Franken, A.A., "Alternatieve afdoeningsmogelijkheden", 23.4.1.

III Zie over de transactie: Osinga, P., Transactie in strafzaken; Franken, A.A., "Alternatieve afdoeningsmogelijkhederi", 23.3; Corstens, G.J.M., Het Nederlands strafprocesrecht, pp. 202 en 775-778; Noyon, T.J. en Langemeijer, G.E., bewerkt door Remmelink, J., Het Wetboek van Strafrecht, "Artikel 74, 74a en 74b", juni 1998; Keulen, B.F., Economisch strafrecht, pp. 245-253.

112 Het onderscheid tussen deze twee rechtsfiguren kan leiden tot vreemde resultaten, zic Rb Middelburg, 9 maart 1995, MenR. 1995, 48-K (Compliance officier); Oudijk, J.C., "Een strafrechtelijke schikking? Enige opmerkingen naar aanleiding van een opmerkelijk transactie", pp. 171-174. 
zodat de officier van justitie hiervan alleen mag afwijken indien hij erin slaagt gemotiveerd aan te geven waarom dit in de betreffende zaak is gerechtvaardigd.

\subsection{Handhaven door het bestuur}

Er is een ontwikkeling op gang gekomen het "handhavingstekort" terug te dringen. door het inzetten van het bestuursrecht. ${ }^{113}$ Hierdoor wordt beoogd de eigen verantwoordelijkheid voor de uitvoering en handhaving van bestuursrechtelijke regelgeving door het bestuur te versterken. ${ }^{114}$

De overheveling van strafrecht naar bestuursrecht en vice versa wordt mede mogelijk gemaakt doordat het bestuursrecht en het strafrecht beide behoren tot het publiekrecht. ${ }^{115}$ Alhoewel er duidelijke verschillen aanwezig zijn tussen deze rechtsgebieden lijkt het moeilijk inhoudelijke criteria ter onderscheiding van strafrechtelijk en bestuursrechtelijk onrecht aan te duiden.

In de praktijk lijkt de keuze of de schending van de normschending via het strafrecht of via het bestuursrecht met een sanctie wordt bedreigd, naast het soort sanctie, vooral op pragmatische gronden plaats te vinden ${ }^{116}$, zoals de frequentie van de normschending ${ }^{117}$ en de aard van het bewijs en de bewijsmiddelen. ${ }^{118}$

De Commissie voor de Toetsing van Wetgevingsprojecten heeft in een advies over de bestuurlijke boete vijf criteria geformuleerd om te bepalen of wetten voor bestuursrechtelijke handhaving in aanmerking komen. Het betreft ${ }^{119}$ :

113 Zie hierover ook hoofdstuk 8 paragraaf 3.2.9.

114 Zie Commissie bestuursrechtelijke en privaatrechtelijke handhaving, Handhaven op niveau; en voor het milieurecht Blomberg, A.B., Integrale handhaving van het milieurecht.

115 Over de keuze tussen bestuursrechtelijke en strafrechtelijke handhaving natuurlijk nog. veel meer te zeggen. Dit zou echter het kader van dit boek te buiten gaan. Zie daarover onder meer de studie van Blomberg, A.B. en Michiels, F.C.M.A., Handhaven met effect.

116 Hartmann, A.R. en Russen Groen, P.M. van, Contouren van het bestuursstrafrecht, pp. 11-48; zie ook de criteria voor toedeling van onrecht aan de verschillende stelsels van Corstens, G.J.M., "Civielrechtelijke, administratiefrechtelijke of strafrechtelijke handhaving?", pp. 51-53.

117 Schaffmeister, D., "Politiële en justitiële delikten", pp. 216-291. Zo wordt de zorgplichtbepaling van artikel 11 Arbo-wet 1998 in eerste instantie aangemerkt als beboetbaar feit, terwijl bij recidive sprake kan zijn van een overtreding. Niet langer bepaalt dan het feit de indeling, maar de frequentie, zie hoofdstuk 8 paragrafen 3.2.9. en 3.2.10.

118 Zie over de afgrenzing van strafrecht en ordnungswidrigkeiten onder ander Jakobs, G., Strafrecht Allgemeiner Teil, pp. 49-55; Jesheck, H-H en Weigend, T., Lehrbuch der Strafrechts, pp. 56-60. Ook hier wordt het onderscheid gezocht in het justitiee! onrecht, die betrekking heeft op moreel verwerpbare normschendingen en administratief onrecht: dat meer waardeneutraal is en betrekking heeft op de ordening van de maatschappij. In de praktijk lijken vaak ook pragmatische overwegingen ten grondslag te liggen aan de gemaakte keuzes. Zie hoofdstuk 8 paragrafen 3.2.9. en 3.2.10.

119 Zie het advies van de Commissie voor de Toetsing van Wetgevingsprojecten, 
“1. De wettelijke norm heeft een geringe normatieve lading;

2. De overtreding pleegt geen letsel aan personen of schade aan goederen toe te brengen;

3. De norm is zo duidelijk in de wet omschreven dat het mogelijk is om op grond van de wettelijke normen en de praktijk een vaste gedragslijn te ontwikkelen;

4. De ambtenaar of dienst die belast wordt met de handhaving beschikt over voldoende expertise om aan de handhaving voldoende adequaat gestalte te geven;

5. Voor de handhaving van de norm zijn geen vrijheidsbenemende of andere ingrijpende dwangbevoegdheden nodig."

In april 2000 is in het kabinetsstandpunt "Handhaven op niveau" een paragraaf opgenomen over de toepassing van bestuurlijke boete. Gesteld wordt ${ }^{120}$ :

"De bestuurlijke boete vormt geen haarlemmerolie voor alle handhavingskwalen, maar kan op sommige beleidsterreinen een nuttige, vaak aanvullende, rol vervullen. Aan de randen van de harde kern van het strafrecht kan invoering van de bestuurlijke boete onder omstandigheden een gewenste aanvulling zijn op de bestaande handhavingsmogelijkheden, mits de bestuursrechtelijke en strafrechtelijke afdoening van overtreden normen niet van elkaar vervreemden."

Het lijkt wenselijk om (ook vanuit strafrechtelijk perspectief, opnieuw) een fundamentele discussie te voeren over de vraag wat de inhoudelijke criteria zijn waarop het onderscheid tussen straf- en bestuursrechtelijke afdoening van normschendingen wordt gebaseerd.

Dogmatisch lijken dezelfde factoren van belang die een keuze bepalen tussen misdrijven en overtredingen, terwijl hier ook het (hoewel opnieuw moeilijk aan te duiden) "onrechtsgehalte" een rol speelt. Zo zullen overtredingen (in strafrechtelijke zin) in het algemeen als ernstiger en meer afkeurenswaardig worden beschouwd dan "beboetbare feiten" (overtredingen in bestuursrechtelijke zin), en spelen opnieuw een groot aantal factoren te samen een rol. ${ }^{121}$

Bij de fundamentele discussie over de vraag naar de criteria waarop waarop het onderscheid tussen straf- en bestuursrechtelijke afdoening van normschendingen wordt gebaseerd, dienen ook de mogelijke afdoeningsmogelijkheden (sancties) te worden betrokken. Zo kunnen het OM en de strafrechter bij de strafrechtelijke handhaving van Wed-delicten ook (voorlopige) situationele maatregelen en straffen opleggen die op hun beurt effectief sterk overeenkomen met bestuursrechtelijke sanctiemogelijkheden. ${ }^{122}$

Handhaving door bestuurlijke boeten.

$120 T K$ 1999-2000, $26800 \mathrm{VI}$, nr. 67, p. 8.

121 Deze factoren zijn voornamelijk de betekenis van het geschonden rechtsgoed, de omvang van de krenking, de wijze van aantasting, of al dan niet sprake is van opzet en de plaats in het systeem van regelgeving. Zie over het onderscheidend criterium tussen misdrijven en overtredingen hoofdstuk 6 paragraaf 3.2 .

122 Zie bijvoorbeeld Hof Amsterdam 14 maart 1995, MenR 1995, nr. 95, met noot De Lange (Verwijderen autowrakken) en Rb. Assen 10 februari 1999, MenR 1999, nr. 99, met noot De Lange (Meer doelen $\mathrm{Sr}$ ). 
De bestuursrechtelijke handhavingsbevoegdheden vallen uiteen in toezichtsbevoegdheden en sanctiebevoegdheden. Deze sancties betreffen vooral preventieve en reparatoire sancties, alhoewel er ook enkele leedtoevoegende sancties kunnen worden opgelegd. Dit in tegenstelling tot het strafrecht, waar de nadiuk veeleer ligt op (de bevoegdheid tot gebruik van) leedtoevoegende sancties. In mindere mate beschikt het strafrecht over reparatoire sancties en (nog minder) preventieve sancties.

De toezichtsbevoegdheden zijn bij de derde tranche van de Awb in deze wet opgenomen. Ook enkele sancties hebben reeds hun weg gevonden naar de Awb. Het betreft de in titel 5 opgenomen bestuursdwang en de last onder dwangsom. Daarnaast zijn er sancties opgenomen in bijzondere wetgeving, die soms vooruit lijken te lopen op nieuwe ontwikkelingen. Gewezen kan worden op de in het kader van de uitbouw van de Awb voorgestelde algemene regeling inzake de bestuurlijke boete. ${ }^{123}$ De bevoegdheid tot het opleggen van een bestuurlijke boete is de laatste jaren in steeds meer bijzondere wetgeving opgenomen. ${ }^{124}$ Ook kan worden gewezen op diverse andere sancties zoals de intrekking van een begunstigende beschikking, de bestuurlijke waarborgsom, de uitsluiting, de maatregel in het sociale zekerheidsrecht en de disciplinaire straf in het ambtenarenrecht. ${ }^{125}$ Hierbij wordt er wel op gewezen dat in de praktijk van de handhaving juist een combinatie van strafrechtelijke en bestuursrechtelijke middelen de beste kans op resultaat biedt. ${ }^{126}$

Voorts uit deze ontwikkeling zich onder andere in de proef om bij bepaalde overtredingen op het terrein van het milieu een strafrechtelijke transactiebevoegdheid toe te kennen aan het bestuur. ${ }^{127}$ Deze bevoegdheid is gebaseerd op artikel 37 Wed, en wordt geregeld in het "Transactiebesluit milieudelicten". ${ }^{128}$ Het betreft feiten die eenvoudig van aard zijn, veel voorkomen, gemakkelijk zijn op te sporen en te bewijzen en die niet tot veel discussie met de verdachte leiden. Als voomaamste reden wordt gegeven de verbetering van de efficiëntie en effectiviteit van de handhaving, doordat het bestuur snel en slagvaardig tegen overtreders kan optreden en de

123 Zie: Commissic wetgeving algemene regels van bestuursrecht, Voorontwerp Algemene wet bestuursrecht; Vierde tranche, onder andere pp. 94-105 en 120-136.

124 Zo kent de. Arbo-wet i998 een dergelijke regeling, zie hoofdstuk 8 paragraaf 3.2.9.

125 Commissie wetgeving algemene, regels van bestuursrecht, Voorontwerp Algemene wet bestuursrecht; Vierde tranche, p. 91. Zie bijvoorbeeld de mogelijkheid tot (gedeeltelijke) intrekking van een Wm-vergunning door het bestuur invoige artikel 18.12 Wm indien niet overeenkomstig die vergunning is of wordt gehandeld.

126 Commissie bestuursrechtelijke en privaatrechtelijke handhaving, Handhaven op niveau, onder andere pp. 63-82, 89-90; Commissie wetgeving algemene regels van bestuursrecht, Voorontwerp Algemene wet bestuursrecht; Vierde tranche, p. 91.

127 Transactiebesluit milieudelicten, Stb. 2000, 320. Deze proef is op 1 november 2000 van start gegaan.

128 Deze mogelijkheid wordt eerder al besproken door Jurgens, G.T.J.M. en Michiels, F.C.M.A., Bestuurlijke boeten in het milieurecht, pp. 68-69, en meer algemeen door Schaffmeister, D., "Politiêle en justitiele delikten", pp. 152-156, clie wijst op de op basis van artikel 37 Wed toegekende transactiebevoegdheid aan de Nederlandse Bank en de directeurs van 's-Rijksbelastingen. 
overtreder snel wordt geconfronteerd met een reactie op zijn strafbaar gedrag. Het bestuur krijgt door het besluit een extra instrument voor de handhaving van de milieuwetgeving, zodat het kan optreden in situaties waarin dit met bestuursrechtelijke middelen voorheen niet (goed) mogelijk was.

\subsection{Mogelijke consequenties van de uitbreiding en/ of overheveling}

Door deze ontwikkelingen worden steeds meer instrumenten geïntroduceerd, die door steeds meer instanties kunnen worden gehanteerd bij de handhaving van steeds meer regelgeving. ${ }^{129}$ Hierdoor bestaat het risico dat de handhaving zeer complex gaat worden, want welke handhaver en welke justitiabele kan straks zijn weg nog vinden in het "instrumenten-bos"? Daarbij bestaat het gevaar dat de officier van justitie zijn centrale rol in het punitieve handhavingsveld verliest of niet meer overziet. Ook kan de toename van instrumenten en bevoegdheden ertoe leiden dat niemand zich meer verantwoordelijk voelt voor de handhaving, of in complexere (en tijdrovende) gevallen de verantwoordelijkheid almaar zal worden doorgeschoven. Het gevaar bestaat dat de jacht op eenvoudige normschendingen zal worden geopend. Dit zal vaak normschendingen betreffen die voorheen bevredigend werden afgedaan met bijvoorbeeld voorlichting of een waarschuwing. Zo kan "decriminalisering" leiden tot "verhoogde sanctionering", een ontwikkeling die op sommige gebieden al heeft plaatsgevonden. ${ }^{130}$

Dit gevaar van doorschuiven zal worden versterkt indien de financiering van de handhavende instanties en/ of de personele bezetting daarvan mede afhankelijk wordt gemaakt van de toepassing van de instrumenten. Dit is geen idee-fixe gezien het pleidooi van sommige besturen bij de introductie van de bestuurlijke boete en transactie om de opbrengsten van die instrumenten te gebruiken voor de financiering van de handhaving. Hierdoor kan de introductie en later de toepassing van het handhavingsinstrument iets oneigenlijks krijgen, aangezien vreemde prikkels kunnen meespelen die niet primair te maken hebben met het rechtsgoed dat zou moeten worden beschermd. Ook als dit niet het geval is maar in de maatschappij het idee bestaat dat dit wel zo is, zal de legitimiteit van het instrument worden aangetast. ${ }^{131}$

Tegen deze ontwikkeling bestaan ook bezwaren vanwege de geboden graad van rechtsbescherming. ${ }^{132}$ Terecht wordt ervoor gewaarschuwd dat een verschuiving van strafrecht naar bestuursrecht onder het mom van een "decriminalisering" er niet toe mag leiden dat het recht alleen maar punitiever wordt, en justitiabelen slechter af zijn

129. Zie hierover bijvoorbeeld Faure, M., "Opinie; Afscheid van het milieustrafrecht?", MenR, 2000, p. 143.

130 Denk bijvoorbeeld aan de gevolgen van de introductie van de HAL.T-projecten op basis van artikel $77 \mathrm{e} \mathrm{Sr}$.

131 Zo veroorzaakte bijvoorbeeld ook in de achttiende eeuw het belang van officieren van justitie bij de uitkomst van de rechtspraak veel onvrede en verzet in de maatschappij, zie hoofdstuk 6 paragraaf 2.3 .

132. Zie Faure, M. en Visser, M., De strafrechtelijke bescherming van het leefmilieu in België, Duitsland en Nederland, pp. 142-147. 
omdat de aan het strafrecht inherente rechtsbescherming (deels) verloren gaat. ${ }^{133}$ Indien de bestuursrechtelijke handhavingoptie wordt gekozen (en op die grond van strafbaarstelling wordt afgezien) zal althans tot op zekere hoogte ook deze handhavingmogelijkheid aan alle in artikel 6 EVRM en artikel 14 IVBPR gestelde eisen dienen te voldoen. Bestuursrechtelijke sancties kunnen vaak immers net zo punitief (of punitiever) zijn dan (sommige) strafsancties, zodat het EHRM terecht regelmatig heeft geoordeeld dat men niet via een "Etikettenschwindel" van sancties een fundamentele rechtsbescherming aan justitiabelen zou kunnen ontnemen. ${ }^{134}$ Indien sprake is van een "criminal charge" dient onafhankelijk van het rechtsgebied te worden voldaan aan de vereisten van artikel 6 EVRM. Bij het vaststellen of sprake is van een "criminal charge" is niet doorslaggevend op welke manier de nationale wetgever het voorschrift heeft geclassificeerd in het systeem van wetgeving. Wel bepalend is de aard van de overtreding, waarbij het EHRM uitgaat van de reikwijdte die het voorschrift in het nationale recht heeft. Ook de aard en de zwaarte van de op te leggen sanctie is doorslaggevend, wanneer de sanctie beoogt bestraffend en preventief te werken is sprake van een "criminal charge". ${ }^{135}$ Ondanks (of misschien zelfs door) de garanties van het EVRM bestaat het risico dat bij overheveling van strafrechtelijke naar bestursrechtelijke handhaving de rechtsbescherming van justitiabelen wordt uitgehold. Het is immers niet denkbeeldig dat het bij die minimale verdragsrechtelijke garanties blijft en de verdergaande (strafrechtelijke) bescherming achterwege blijft. ${ }^{136}$

Een ander belangrijk nadeel van bestuursrechtelijke handhaving is dat de overheid vaak een (te) sterke bindingen heeft met de normadressaat, waardoor een krachtig handhaving- en sanctiebeleid wordt bemoeilijkt. ${ }^{137}$ Het bestuursrecht is voor een groot

133 Zie: Corstens, G.J.M., Een stille revolutie in het strafrecht en Nauw, A. de, Les métamorphoses administratives du droit pénal de l'entreprise, pp. 45-72. Interessant is in dat verband dat het Belgische Arbitragehof recent heeft beslist dat de Belgische wet van 30 juni 1971 betreffende de administratieve geldboeten het grondwettelijke gelijkheidsbeginsel en discriminatieverbod schendt, omdat die wet niet de mogelijkheid biedt een verlaging van de boete tot onder de wettelijke minima te genieten, terwiji dit voor de strafrechter overeenkorristig artikel 85 Sw wel kan op basis van verzachtende omstandigheden. Arbitragehof 14 juli 1997, RW, 1997-98, pp. 1047-1049.

134 Zie daarover onder meer Michiels, F.C.M.A., De boete in opmars, pp. $20-29$ en pp. 37-38 en Bijloos, A.W.M., Administratieve boeten en ari. 6 EVRM in Nederland, pp. 12 18.

135 In de volgende arresten werd deze lijn uitgezet: EHRM 8 juni 1976, N.J 1978, 223 (Engel); EHRM 21 februari 1984, NJ 1988, 937; AA 1985, pp. 145-154, met noot Swart (Öztürk); EHRM 26 augustus 1987, $N J$ 1988, 938, met noot Alkema (Lutz). Zie Hartmann, A.R. en Russen Groen, P.M. van, Contouren van het bestuursstrafrecht, pp. 71-73.

I36 Zo lijken, bij de voorgestelde regeling inzake de bestuurlijke boete in de Awb (voorontwerp vierde tranche), de waarborgen vooral gebaseerd op deze verdragvereisten. Zie Commissie wetgeving algemene regels bestuursrecht, Voorontwerp Algemene wet bestuursrecht vierde tranche, pp. 120-136.

137 Zie onder meer Meinberg, V., "Empirische Erkentnisse zum Vollzug des Umweltstrafrechts", 112-157; Boes, M. en Deketelaere, K., "Administratieve sancties", p. 177 en Morrens, P., "Het leefinilieu als handhavingsmiddel", pp. 344-345. 
deel op het coöperatiemodel gebaseerd ${ }^{\mathrm{i} 38}$, waardoor de overheid, indien de coöperatie faalt, over onvoldoende onafhankelijkheid beschikt om nog een zware sanctie te kunnen opleggen ${ }^{139}$, zonder additioneel risico. Hierdoor kunnen overtredingen zelfs worden aangemoedigd, aangezien ondernemingen die na een bestuurlijk optreden alsnog (tijdelijk) gehoorzamen hiervan doorgaans geen nadelige gevolgen ondervinden. ${ }^{140}$ Door de kosten van de vereiste maatregelen uit te stellen, spaart de ondernemer zelfs rente uit. ${ }^{141}$

Daar lijkt de onafhankelijkheid van het $\mathrm{OM}$ en de strafrechter voordelen te bieden. ${ }^{142}$ Nochtans hoeft dit niet tot een eenzijdig pleidooi voor de strafrechtelijke aanpak te leiden. ${ }^{143}$ Immers, het probleem van de afhankelijkheid van de bestuurlijke overheid kan worden opgelost indien een controle kan worden ingebouwd. Indien dat laatste mogelijk is, biedt een handhaving en sanctie-oplegging door het bestuur het voordeel dat deze doorgaans over veel betere informatie beschikt dan de strafrechtelijke handhavers over bijvoorbeeld de optimaal op te leggen maatregel.

Ook lijkt de bestuurlijke sanctie, zeker de monetaire, diverse belangrijke voordelen te bieden tegenover de (strafrechtelijke) geldboete. ${ }^{144}$ Er wordt onder andere op gewezen dat de oplegging sneller en procedureel gemakkelijker kan plaatsvinden ${ }^{145}$, waarbij

138 Aalders spreekt in dit verband van het met zachte hand in de richting van het gewenste gedrag leiden van de wetsovertreder. Aalders, M.V.C., "De politiefunctie van de bijzondere opsporingsambtenaar", Tijdschrift voor Criminologie, pp. 287-298.

139 Zie Diez, J. en Gineiting, J., "Koordinationsprobleme zwischen Verwaltungs- und Strafrechtsimplemention im Umweltbereich", pp. 190-211.

140 Aldus Nentjes, A. en Hommes, J., "Handhaving van het milieurecht", pp. 1-7. Zij stellen dat de bijdrage van het bestuurlijk handhavingsinstrumentarium aan de preventie van milieuovertredingen voor een grote categorie bedrijven zeer beperkt is.

14I Zie hierover onder andere Niessen, R., "Fiscaaljuridische en Bedrijfseconomische analyse", pp. 235-248 en Bakker, S., Faure, M., Landen, D. van der, Niessen, R. en Roos, Th. de, "Algemene conclusies en vuistregels", pp. 258-260.

142 Aldus ook Bunt, H.G. van de, "Besfuurlijke verwachtingen en ervaringen omtrent de strafrechtelijke handhaving van milieurecht", p. 27.

143 Het hangt er, in de woorderı van Huisman en Van de Bunt, vanaf of men een punitieve dan wel een coöperatieve handhavingsstrategie verkiest. Zie Huisman, W. en Bunt, H.G. van de, "Sancties, organisatiecriminaliteit en milieudelicten", pp. 689-690.

144 Zie bijvoorteeld de in het kabinetsstandpunt "Handhaven op niveau" aangegeven voordelen TK 1999-2000, 26800 VI, nr. 67, pp. 9-10.

145 Die is dan ook thans in Nederland in opmars, aldus Michiels, F.C.M.A., De boete in opmars; Jurgens, G.T.J.M. en Michiels, F.C.M.A., Bestuarlijke boeten in het milieurecht en Hartmann, A.R. en Russen Groen, P.M. van, Contouren van het besitutrsstrafrecht, pp. 96-97; Jansen, O.J.D.M.L., Het handhavingsonderzeek" Buuren, P.J.J. van, "De bestuurlijke boete in het bestuursrecht", pp. 60-62; Knigge, G., "De bestuurlijke boete als teken aan de wand", pp. 63-68; Michiels, F.C.M.A., "De bestuurlijke boete in het milieu-recht", pp. 69-73; Lange, A. de, "De besturrlijke boete in het juiste spoor", pp. 74-78; Corstens, G.J.M., Een stille revolutie in het strafrecht, die ook het advies van de Toetsingscommissie voor Wetgevingsprojecten over de wenselijkheid van de bestuurlijke boete bespreekt. 
tevens de mogelijk stigmatiserende werking van een strafrechtelijke veroordeling wordt ontlopen. ${ }^{146}$ Daar staat evenwel tegenover dat hetzelfde door een sepot onder voorwaarden of een transactie vanwege het $\mathrm{OM}$ kan worden bereikt. ${ }^{147}$ Het nadeel van de hier genoemde instrumenten is natuurlijk wel dat de publieke controle en de transparantie die gepaard gaan met een openbare terechtzitting verloren gaan.

Tevens is het niet ondenkbaar dat de capaciteitsproblemen van het strafrechtelijk apparaat zich zullen voordoen in het bestuurlijk apparaat, aangezien ook een vereenvoudigde afdoening door bevoegde personen zal moeten worden uitgevoerd. Dit geldt ook voor het rechterlijk apparaat, aangezien in plaats van de strafrechter, nu (naast bezwaarschriftencommissies) de bestuursrechter en/ of de strafrechter zullen worden geconfronteerd met beroep van justitiabelen tegen de gehanteerde wijze van afdoening. Natuurlijk kan dit worden ondervangen door een uitbreiding van de vele bestuursorganen die bij deze handhaving zijn betrokken. De vraag is dan echter of het, ten behoeve van het tegengaan van de strafrechtelijke capaciteitsproblemen, niet meer voor de hand ligt de instanties die betrokken zijn bij de strafrechtelijke handhaving uit te breiden.

Uiteindelijk draait het vooral om de vraag welk beleidsmatig doel men met de sanctie wenst te realiseren. De bestuursrechtelijke procedure en sanctie hebben ongetwijfeld een minder stigmatiserend effect dan een strafrechtelijke procedure die vaak ook langer zal duren. Hetzelfde geldt voor de publiciteit die naar aanleiding van een veroordeling kan volgen. De uitbreiding van handhavingsbevoegdheden in het bestuursrecht kan derhalve zeker een waardevolle rol spelen.

Opgemerkt moet worden dat de meeste nieuwe bestuursrechtelijke instrumenten en handhavingsmogelijkheden naast de reeds bestaande strafrechtelijke komen. Daarenboven zijn er die ervoor in de plaats komen. Dit betreft meestal de bestuurlijke boetebevoegdheid, die in plaats komt van de strafrechtelijke handhavingsmogelijkheid. Het is van groot belang bij de invoering van nieuwe instrumenten en bevoegdheden steeds opnieuw de vraag te beantwoorden of de theoretische en praktische nadelen opwegen tegen de (vermeende) voordelen van (vooral) efficiëntie en effectiviteit. Zo niet, dan moet worden onderzocht op welke manier hier aan wel kan worden voldaan. Pas als hieraan is voldaan kan een goed functionerend, evenwichtig, rechtsgebiedoverschrijdend handhavingsysteem vorm krijgen ${ }^{148}$, dat voldoende tegemoet komt aan de specifieke kenmerken van de verschillende rechtsgebieden en handhavingsdiensten, en waarbij tevens de waarborgfunctie en de instrumentele functie in evenwicht zijn.

146 Zie Corstens, G.J.M., Een stille revolutie in het strafrechi, p. 20.

I47 De wettelijke basis voor het sepot is gelegen in artikel 244, derde lid en 245, derde lid Sv en van transactie in artikel 74, 74a, 74b, 74c Sr en 36 Wed. Zie hierover hoofdstuk: 6 paragraaf 4.2 .

148 Zie over dit thema Blomberg, A.B., Integrale handhaving van het milieurecht. 


\subsection{Inleiding}

Vanzelfsprekend is het commuun strafrecht van belang bij de analyse van zorgplichtbepalingen. Dit geldt zowel voor bepalingen die zijn opgenomen in het Wetboek van Strafrecht als voor die daarbuiten. Zoals uit de voorafgaande paragrafen is gebleken, neemt het commuun strafrecht een centrale plaats in in het geheel van de Nederlandse strafwetgeving. Involge artikel $91 \mathrm{Sr}$ zijn de algemene bepalingen uit Boek I ook van toepassing op feiten waarop bij andere wetten of verordeningen straf is gesteld, tenzij de wet in formele zin anders bepaalt. Hierdoor is het commuun strafrecht ook van groot belang voor het vaststellen van daderschap. Gezien het belang van daderschap voor de analyse van zorgplichtbepalingen wordt in deze paragraaf een korte beschrijving gegeven onder welke voorwaarden op grond van de wet (Boek I Sr en de specifieke strafbaarstelling) en de rechtspraak (rechts)personen als dader kunnen worden vervolgd en gestraft voor het schenden van (onder andere) zorgplichtbepalingen. ${ }^{149}$ Artikel 1 Sr geeft aan dat de strafbaarstelling en de strafwetgeving bepalen wie de normadressaat van een strafbepaling is.

Voor een aantal zorgplichtbepalingen is een ieder de normadressaat, zodat de strafbaarstelling zelf geen onderscheid maakt tussen groepen personen die aangesproken kunnen worden inzake schending van deze bepaling. ${ }^{50}$ Daarnaast zijn er zorgplichtbepaling waarbij de normadressaat wordt gekoppeld aan een bepaalde zaak, zo betreft het bijvoorbeeld ieder met een "onder zijn hoede staand gevaarlijk dier", of "ieder die op de openbare weg een rij-, trek- of lastdier laat staan". ${ }^{151}$ Ook kan de normadressaat degene betreffen die in een bepaalde toestand verkeert, zoals "in staat van dronkenschap" 152 , of die een bepaalde hoedanigheid heeft zoals "de eigenaar of gebruiker die ten opzichte van toegangen tot of openingen van kluizen, kelders, onderaardsche lokalen en ruimten, waar die op de openbare weg uitkomen". ${ }^{153}$ Voorts wordt de kring van normadressaten soms ook beperkt tot deze die handelt of een beroep, zoals "luchtverkeersleiding", de "gezagvoerder van een schip", "hij, die de leiding heeft bij trein- of wegverkeer", "de werknemer", "ieder die beroepshalve" of "een ieder bij wie in de uitoefening van zijn beroep of bedrijf". ${ }^{154}$

149 Zie uitgebreidei Roos, Th.A. de en Visser, M.J.C., "Strafrechtelijke milieurisico"s van ondernemer en onderneming; Nederlands recht gekenmerkt door pragmatische aanpak", pp. 279-284.

150 Zie bijvoorbeeld artikel 5 WVW (hoofdstuk 7 paragraaf 3.2.) en artikel 13 Wbb (hoofdstuk 9 paragraaf 3.3.).

151. Zie bijvoorbeeld artikel 425 aanhef en sub $2 \mathrm{Sr}$ ( hoofdstuk 6 paragraaf 6.2.) en artikel 427, aanhef en sub $5 \mathrm{~S} \overline{\text { İ }}$ (hoofdstuk. 6 paragraaf 6.4.).

152 Zie bijvoorbeeld artikel 426, eerste lid Sr ( hoofdstuk 6 paragraaf 6.3.).

153 Zie bijvoorbeeld artike! 427 aanhef en sub $1 \mathrm{Sr}$ (hoofdstuk 6 paragraaf 6.4.).

154 Zie bijvoorbeeld artikel 5 WVW (hoofdstuk 7 paragraaf 3.2.), artikel 5 Wet Luchtverkeer 1993 (hoofdstuk 7 paragraaf 3.3.), artikel 19, eerste en derde lid Quarantainewet (hoofdstuk 7 paragraaf 3.4.), artike! 11 Arbo-wet 1998 (hoofdstuk 8 paragraaf 3.2.), artikel 2 Wms (hoofdstuk 9 paragraaf 3.2.) en artikel 10.3, eerste en 
Er zijn diverse vormen van daderschap te onderscheiden. Voor de hand liggend uitgangspunt is, dat als dader wordt aangemerkt diegene die het strafbare feit zelf heeft gepleegd. Naast degene die het feit pleegt worden involge artikel $47 \mathrm{Sr}$ als daders angemerkt degene die het feit doen plegen, medeplegen of uitlokken. Daarnaast kunnen ex artike! $51 \mathrm{Sr}$ ook rechtspersonen dader zijn van een strafbaar feit. Indien een strafbaar feit wordt begaan door een rechtspersoon kan, indien zij daarvoor in aannerking komen, ook degene die tot het feit opdracht heeft gegeven, alsmede degene die aan de verboden gedraging feitelijk leiding heeft gegeven, als dader worcen aangemerkt. Tot voor enkele jaren leek het zeer problematisch de overheid, operbare lichamen, ambtenaren en/ of arbeidscontractanten in dienst van het openbaar licham strafrechtelijk te vervolgen. Inmiddels is de strafrechtelijke immuniteit die deze groepen werd geboden een heel stuk teruggedrongen. Alleen voor de centrale overheid lijkt thans nog een uitzondering te worden gemaakt. Al deze categorieën die in deze paragraaf achtereenvolgens worden besproken, kunnen te maken krijgen met een strafrechtelijke vervolging wegens het schenden van (bepaalde) zorgplichtbepalingen.

\subsection{Daders}

Als dader kunnen involge artikel $47 \mathrm{Sr}$ worden aangemerkt degene die het strafbare feit zelf heeft gepleegd, die het heeft doen plegen, heeft mede gepleegd en heeft uitgelokt. Daarnaast bestaat mogelijkheid de functioneel dader aan te merken als dader. ${ }^{155}$ Dit kan bijvoorbeeld de ondernemer zijn die zelf de zorgplichtbepaling schendt, of die anderen de opdracht geeft handelingen te verrichten in strijd met een dergelijke bepaling. Ook de werknemer die dit in opdracht van zijn leidinggevende doet, kan (onder omstandigheden) als dader worden gestraft. Aangezien al deze personen als dader worden aangemerkt is het mogelijk dat voor de schending van één strafbaarstelling meer dan één dader wordt vervolgd en eventueel veroordeeld.

Als voorwaarden voor strafbaarheid is niet alleen maatgevend dat de gedraging valt binnen de grenzen van de strafbaarstelling, maar ook dat het feit wederrechtelijk is en an de daders schuld is te wijten. Zo kan bijvoorbeeld van een werknemer niet worden verlangd dat hij bij alle opdrachten die hij krijgt nagaat of deze al dan niet een schending opleveren van een in een beschikking opgenomen (zorgplicht)bepaling. Indien de strafbare gedraging hem niet kan worden verweten, ontbreekt de schuld en zal hij niet worden veroordeeld. ${ }^{156}$

Op bedrijfsmatig handelen zijn doorgaans een veelheid van (strafrechtelijk gesanctioneerde) regelingen van toepassing. Dat brengt met zich mee dat de ondernemer niet kan volstaan met een enkele vergunning, maar een hele set

tweede lid Wm (hoofdstuk 9 paragraaf 3.4.).

155 Zie over functioneel daderschap, doen plegen en uitlokking Woensel, A.M. van, In de daderstand verheven en over medeplegen Toorenburg, M.M. van, Medeplegen.

156 Zie over (het ontbreken van) schuld hoofdstuk 3 paragraaf 7.4. 
vergunningen dan wel ontheffingen behoeft om zijn bedrijf legaal te kunnen uitoefenen. De rechtbank Amsterdam overweegt dienaangaande ${ }^{15 \%}$ :

"Een verleende vergunning op een bepaald gebied geeft de houder geen carte blanche op het terrein van andere - aanverwante - wetgeving noch ontslaat deze hem van de plicht zich van de toelaatbaarheid van zijn handelingen te vergewissen".

In alle toepasselijke regelgeving en beschikkingen kunnen zorgplichtbepalingen zijn opgenomen. Een verweer dat de formulering van bijvoorbeeld de in de beschikking opgenomen zorgplichtbepaling erg vaag is of dat (andere) beschikkingvoorschriften erg ondoorzichtig zijn ten gevolge van de vele toepasselijke regels of gelaagdheid, zal de ondernemer meestal ook niet verder helpen. Doorgaans wordt een beroep op het ontbreken van "een duidelijke en deugdelijke voorafgegane strafbaarstelling" verworpen en bestaat het gevaar dat de toetsing van vage voorschriften uit de beschikking afstuit op de formele rechtskracht. ${ }^{158}$

Een beroep op het ontbreken van schuld zou wel honorabel kunnen zijn wanneer bestuursorganen in hun voorlichtende taak wezenlijk tekortschieten. Dit bestuursorgaan moet dan wel de bevoegde instantie zijn, en het moet aannemelijk zijn dat degene die er een beroep op doet door dat advies daadwerkelijk op het verkeerde been is gezet. ${ }^{159}$ Wanneer een advies van een onbevoegd bestuursorgaan is opgevolgd zal dat niet snel een kansrijk avas-verweer opleveren. en dat geldt a fortiori indien het om een advies van een advocat of van een ander professioneel dienstverlener afkomstig is. Ook bij een eenmalige toestemming van het bevoegd gezag tot afwijking van de vergunningvoorschriften mag niet voetstoots worden aangenomen dat ook in toekomstige situaties die toestemming wel zal worden verleend. ${ }^{160}$ Wanneer het bevoegd gezag tegenover de betrokkene een formulering bezigt in de trant van: 'Wij stellen $\mathrm{U}$ voor de laatste maal in de gelegenheid om tot naleving van voormelde voorschriften over te gaan en wel tot uiterlijk die en die datum, bij gebreke waarvan wij tot maatregelen zullen moeten overgaan', behoeft dat nog niet straffeloosheid te impliceren van reeds geconstateerde inbreuken op beschikkingvoorschriften. ${ }^{161}$

157 Rb. Amsterdam 26 april 1991, MenR 1991, nr. 121 (Geen carte blanche).

158 Zie voor over de afwijzing van een verweer betreffende de ondoorzichtigheid van regelgeving hoofdstuk 3 paragraaf 7.3.6. en over de formele rechtskracht hocfdstuk 5 paragraaf 3 .

159 Een provinciaal ambtenaar, die bevoegdheden in het kader van de (voormalige) Wet chemische afvalstoffen ontbeerde, had een bedrijf toestemming verleend tot storting van kalkslib. Zijn advies was onvoldoende grond om het ontbreken van schuld aan te nemen, temeer omdat het bedrijf niet had gesteld dat het zelf had gedwaald over de vraag of die storting was toegestaan: Rb. 's-Hertogenbosch 2 januari 1990, MenR 1990, nr. 66 (Fout advies provinciaal ambtenaar).

160 Rb. 18 december 1990, MenR. 1992, nr. 14 (Opslag oil slobs); De enige directeur had er niet op toegezien dat toestemming werd gevraagd voor de opslag van zgn. oil slobs, noch daartoe instructies gegeven.

161 Vergelijk HR 6 december 1988, MenR 1989, nr. 38 (Aangifte ondanks brief B\&W) in een Hinderwetzaak: de verdachte heeft aan de brief van $\mathbf{B}$ en $\mathbf{W}$ niet een gerechtvaardigd vertrouwen kunnen ontlenen "dat terzake van de niet-naleving van de vier in het verweer 


\subsection{De rechtspersoon}

Ook rechtspersonen kunnen strafbare feiten begaan, zodat ook jegens de rechtspersoon een trafvervolging kan worden ingesteld en straffen en maatregelen kunnen worden uitgsproken. ${ }^{162}$ Het begrip rechtspersoon moet overigens ruim worden opgevat: daarnder vallen niet alleen verenigingen, coöperaties, onderlinge waarborgmaaschappijen, NV's, BV's en stichtingen. Ook publiekrechtelijke rechtspersonen en kerkjenootschappen, worden door deze term bestreken, evenals maatschappen, redeijen en doelvermogens.

Aanrankelijk konden alleen natuurlijke personen zoals bestuurders, opdrachtgevers en leidiggevers voor strafbare feiten aansprakelijk worden gesteld. Voor het economisch strafecht ${ }^{163}$ bestond sinds 1950 de mogelijkheid ook rechtspersonen strafrechtelijk aansrakelijk te stellen. ${ }^{164}$ Sinds 1976 is dit met de invoering van artikel $51 \mathrm{Sr}$ wettlijk geregeld voor het gehele strafrecht. De rechtspersoon kan dus voor delicten uit let commuun en het bijzonder strafrecht als dader of medeplichtige worden aangmerkt. Het betreft zowel misdrijven als overtredingen. Nederland is met de invoring van deze mogelijkheid bepaald modern geweest. Nog steeds hebben diverse buitølanden, waaronder Duitsland, onoverkomelijke bezwaren tegen de erkenning van ret daderschap van de rechtspersoon, zodat zij zich, om toch aan de nu eenmaal bestande rechtspolitieke behoefte te voldoen, met allerlei ingewikkelde constructies moeten behelpen. In Frankrijk en België zijn - niet zonder ampel beraad - het daderschap en de aansprakelijkheid van ondernemingen dan wel rechtspersonen recent ingevoerd. ${ }^{165}$

bedoelde voorschriften, verbonden aan de verleende vergunning, geen aangifte zou worden gedaan."

162 Zie over de strafrechtelijke aansprakelijkheid van rechtspersonen: Torringa, R.A., Strafbaarheid van rechtspersonen; Torringa, R.A., De rechtspersoon als dader, Strien, A.L.J. van, De rechtspersoon in het strafproces; Roef D. en Roos, Th.A. de, "De strafrechtelijke aansprakelijkheid van de rechtspersoon in Nederland: rechtstheoretische beschouwingen bij enkele praktische knelpunten", pp. 49-121.

163 Onder economisch strafrecht wordt dat strafrecht verstaan dat valt onder de werkingssfeer van de Wed, zie hoofdstuk 8.

164 Daryoor bestond deze mogelijkheid soms al op basis van de betrefiende wet, zie hoofdstuk \& paragraaf 2.

165 In België is dit gebeurd bij Wet van 4 mei 1999 tot invoering van de strafrechtelijke verantwoordelijkheid van rechtspersonen, BS 22 juni 99 . Zie voor een landenoverzicht van onder andere België, Duitsland en Engeland: Eser, A., Heine, G. en Huber, B. (red.), Criminal Responsibility of Legal and Collective Entities en voor Belgiē, Frankrijk en Nederland: Driessche, H. van, "Evolutie naar de strafrechtelijke (milieu) aansprakelijkheid van alle publiekrechtelijke rechtspersonen?", pp. 833-843; Roef, D., "De strafrechtelijke aansprakelijkheid van overheden voor milieuverontreiniging in rechtsvergelijkend perspectief", pp. 243-259; en voor België: Deruyck, F., De rechtspersoon in het strafrecht; Deruyck, F., "Naar een strafrechtelijke aansprakelijkheid van de rechtspersoon in België?", pp. 35-47. 
Indien sprake is van een strafbaar feit gepleegd in het kader van een rechtspersoon za] het OM nagaan of de rechtspersoon daar ook zelfstandig voor kan en moet worden vervolgd, al dan niet naast natuurlijke personen. De gedraging van de rechtspersoon vindt immers steeds plaats door een gedraging van een natuurlijk persoon. Het is voor de strafbaarheid van de rechtspersoon vereist dat de strafbare gedraging van de natuurlijke persoon de rechtspersoon kan worden toegerekend. De strafbaarheid van de rechtspersoon wordt vastgesteld aan de hand van drie criteria.

Allereerst moet worden bezien of de rechtspersoon geadresseerde is van de norm. Delicten in het bijzonder strafrecht worden veelal begaan door ondernemingen en andere corporaties (zoals publiekrechtelijke lichamen), maar het zijn doorgaans geen typisch functionele delicten. De delictsomschrijvingen richten zich doorgaans niet tot specifieke personen die een bepaalde functie in het sociaal en economisch verkeer vervullen. Rechtspersonen zijn meestal ook adressaat van deze delictsomschrijvingen; aangenomen wordt dat er maar zeer weinig strafbare feiten zijn die niet kunnen worden begaan door een rechtspersoon. Voor zorgplichtbepalingen wordt in het algemeen geen uitzondering gemaakt; ook deze bepalingen kunnen meestal door rechtspersonen worden geschonden.

Indien de rechtspersoon als normadressaat is aan te merken, moet worden onderzocht of de verboden gedraging van de natuurlijke persoon in het voorliggende geval aan de recittspersoon kan worden toegerekend. De strafoare handelingen worden in de fysieke zin van het woord gewoonlijk uitgevoerd door de lager geplaatste functionarissen binnen de rechtspersoon. Indien de hogere echelons die een "zorgplicht" hebben met betrekking tot instructies en toezicht, deze plicht verzaken, kan het strafbare feit meestal aan de rechtspersoon worden toegerekend, omdat dan aan de in de jurisprudentie ontwikkelde criteria zal zijn voldaan: beslissend is dat de rechtspersoon over de verboden gedraging kon beschikken en dat hij de gedraging aanvaardde of soortgelijke gedragingen placht te aanvaarden. ${ }^{166}$ De plichtsverzaking dient op aanvaardbare wijze in de tenlastelegging te worden omschreven, evenals dat de eventuele bewezenverklaring op alle onderdelen moet zijn gebaseerd op bewijsmiddelen. Dat op dat punt wel eens iets mis gaat blijkt bijvoorbeeld in een zaak waar het ontbreken van een afsluiter op een slang meetelde voor het bewijs van daderschap. Daarvoor was echter geen bewijsmiddel aangevoerd. ${ }^{167}$ Er is sprake van "beschikken" indien de gedraging valt binnen de invloedssfeer van de rechtspersoon, dat wil zeggen dat de (leiding van) de rechtspersoon over de gedraging zeggenschap kon uitoefenen. De strafbare handeling behoeft daarom niet te zijn begaan door een orgaan van de rechtspersoon, terwijl evenmin nodig is dat degene die het feit pleegt bij de rechtspersoon formeel in dienst is. Onder omstandigheden kunnen gedragingen van

166 HR 23 februari 1954, NJ 1954, 378, met noot Röling (IJzerdraad). De ijzerdraadcriteria bezitten echter geen monopolie. De Hoge Raad heeft ook wel aanvaard dat daderschap van de rechtspersoon werd aangenomen op grond van "de normale bedrijfsvoering"; zie HR 23 februari 1993, NJ 1993, 605, met noot 't Hart (Monsters bij Orpahell).

167 HR 2 oktober 1984, MenR 1986, nr. 6 (Afsluiter op slang). De HR besloot echter op andere gronden tot cassatie en kwam aan dit punt niet toe. Zie Strien, A.L.J. van, Het daderschap van de rechtspersoon bij milieudelicten, pp. 257-301, met name pp. 296-297 
iemand die belangrijk werk doet voor de rechtspersoon ook worden angemerkt als een handeling van de rechtspersoon. ${ }^{168}$ De voorwaarde dat de rechtspersoon de verboden gedraging "(pleegt te) aanvaarden" heeft betrekking op de gedraging inclusief de omstandigheden die de gedraging strafbaar maken. Voor het overtreden van een vergunning(voorschriften) is het bijvoorbeeld nodig dat de rechtspersoon niet alleen het uitvoeren van de gedraging aanvaardt, maar ook dat dit in strijd met de vergunning(voorschriften) gebeurt. De rechtspersoon behoeft de strafbare gedraging waarroor hij wordt vervolgd niet altijd te hebben aanvaard; het is reeds voldoende dat zij eerder soortgelijke gedragingen heeft aanvaard.

Tensiotte moet worden onderzocht of de subjectieve bestanddelen kunnen worden bewezen. Indien in de delictsomschrijving geen subjectieve bestanddelen zijn opgenomen, moet sprake zijn van schuld als element. De vraag naar de verwijtbaarheid dienthier te worden beantwoord voor de rechtspersoon. ${ }^{169}$

Indien de rechtspersoon failliet gaat behoeft dit een vervolging niet in de weg te staan. Als zij wordt voorgezet door of omgezet in een andere rechtspersoon kan deze laatste worden vervolgd voor strafbare feiten die de oorspronkelijke rechtspersoon heeft began. Voor de vraag welke rechtspersoon wordt vervolgd is de maatschappelijke realiteit doorslaggevend, en niet de civielrechtelijke constructie. Ook de rechtspersoon die ophoudt te bestaan kan worden vervolgd, zolang de vervolging maar is gestart voordat de ontbinding voor derden kenbaar is, bijvoorbeeld door inschrijving in het handelsregister. De eventuele sanctie in de vorm van een geldboete kan ook na de ontbinding worden geëxecuteerd. ${ }^{170}$

\subsection{De opdrachtgever en de feitelijk leidinggever}

Artikel $51 \mathrm{Sr}$ stelt verder dat indien een strafbaar feit wordt begaan door een rechtspersoon strafvervolging niet alleen tegen de rechtspersoon kan worden ingesteld, maar ook - indien zij daarvoor in aanmerking komen - tegen degenen die tot het feit opdracht hebben gegeven, alsmede tegen hen die aan de verboden gedraging feitelijk leiding hebben gegeven. ${ }^{17 !}$

Als opdrachtgever(s) of feitelijk leidinggever(s) worden vaak aangemerkt de bestuurder, de filiaalchef, de manager of het afdelinghoofd. Het gaat erom dat men hiërarchisch boven het niveau van de uitvoerende "werknemer" staat. Deze kan als hij de stafbare gedraging begaat gewoon op grond van daderschap worden vervolgd. Ook de opdrachtgever of feitelijk leidinggever kan, als hij zelf de verboden gedraging verricht, (ook) als dader worden vervolgd.

168 Bemmelen, J.M. van en Veen, Th.W. van, bewerkt door Jong, D.H. de en Knigge, G., Het materiële strafrecht, pp. 220-221.

169 Zie over het schuldbeginsel in het algemeen hoofdstuk 3 paragraaf 7.4.

170 Woensel, A.M. van, in Cleiren, C.P.M. en Nijboer, J.F. (red.), Strafrecht. Tekst en Commentaar, pp. 283-295, met name 285.

171 Zie over functioneel daderschap en feitelijk leidinggeven Woensel, A.M. van, In de daderstand verheven, pp. 45-106. 
Het antwoord op de vraag wat onder opdracht geven moet worden verstaan, sluit nauw aan bij het normale spraakgebruik en is daardoor redelijk eenvoudig te geven. Het gaatt dan om een actieve betrokkenheid bij het strafbare feit. Uit de term feitelijk leidinggever lijkt eveneens voort te vloeien dat sprake moet zijn geweest van tamelijk actieve betrokkenheid bij de verboden gedraging. Dit hoeft echter niet het geval te zijn. Ook meer passieve vormen van betrokkenheid van leidinggevenden, zoals nalatigheid op het punt van toezicht op en instructies aan het uitvoerende personeel, kunnen daaronder vallen. De Hoge Raad heeft, dit begrip interpreterend, sterk op de IJzerdraadcriteria gelijkende criteria vastgesteld, en wel in de bekende Slavenburgzaken. Daar valt te lezen dat van feitelijk leiding geven in de zin van artikel $51 \mathrm{Sr}$ sprake is wanneer de desbetreffende functionaris, hoewel daartoe bevoegd en redelijkerwijs gehouden, maatregelen ter voorkoming van de gewraakte gedragingen achterwege laat en bewust de aanmerkelijke kans aanvaardt dat de verboden gedragingen zich zullen voordoen. De functionaris wordt dan geacht opzettelijk de verboden gedragingen te bevorderen. ${ }^{172} \mathrm{De}$ leidinggevende kan zich dus niet simpelweg op het ontbreken van wetenschap van het verboden handelen beroepen, hoe aannemelijk dat verweer op zichzelf ook moge zijn. Anderzijds kan bijvoorbeeld het feit dat een bepaalde portefeuilleverdeling binnen de raad van bestuur van een onderneming met zich meebrengt dat een leidinggevende niet alleen niet op de hoogte was, maar dat redelijkerwijs ook niet behoefde te zijn, wel degelijk disculperend werken. In die zin is het strafrechtelijk schuldbeginsel intact gelaten.

Gezien deze criteria kan deze leidinggever meestal ook zelf als pleger (een vorm van daderschap) worden aangemerkt. Het OM heeft dan de keuze of het de leidinggever op grond van artikel $51 \mathrm{Sr} z a l$ vervolgen of als dader (en dus buiten artikel $51 \mathrm{Sr}$ om). Voor de eerste variant is het nodig dat de rechtspersoon dader is. Mocht dit om welke reden dan ook niet het geval zijn, dan kan de betrokkene als dader worden vervolgd.

Indien de rechtspersoon is ontbonden en niet meer kan worden vervolgd, is dit geen beletsel om de opdrachtgever(s) en/ of feitelijk leidinggever(s) op basis van artikel 51 Sr te vervolgen. Vereist is slechts dat de rechtspersoon dader is, niet dat deze vervolgbaai is. De ontbinding van de rechtspersoon staat ook de vervolging van natuurlijke personen als dader niet in de weg.

Het is mogelijk dat het $\mathrm{OM}$ besluit de rechtspersoon niet als dader te vervolgen, maar wel zijn opdrachtgever(s), feitelijk leidinggever(s) en/ of andere daders. Het OM heeft op basis van het opportuniteitsbeginsel een zelfstandige beslissingsbevoegdheid met betrekking tot de vraag of naar aanleiding van een opsporingsonderzoek vervolging moet plaatsvinden. Het beslist dus of, en zo ja waarvoor het de werknemer(s), de opdrachtgever(s), de feitelijk leidinggever(s) en/ of de rechtspersoon zal vervolgen. Het staat het OM vrij één of enkele personen te vervolgen en de strafzaak tegen anderen te seponeren of te transigeren. Ook het gelijkheidsbeginsel staat hieraan in het algemeen niet in de weg; zo stelt de Hoge Raad dat het enkele feit, dat het OM ten opzichte van de ene verdachte handelt in afwijking van of strijd met een 
vervdgingsrichtlijn niet meebrengt dat het in strijd met het gelijkheidsbeginsel handelt ten orzichte van de verdachte die wel wordt vervolgd. ${ }^{173}$

\subsection{De publiekrechtelijke rechtspersoon}

\subsubsection{Inleiding}

De vrvolgbaarheid van de publiekrechtelijke rechtspersonen en ambtenaren is een them dat de laatste jaren sterk in de belangstelling staat en zich verder ontwikkelt. ${ }^{17}$ De stafwetgeving maakt bijna nergens expliciet een uitzondering voor het ontstaan van trafrechtelijke aansprakelijkheid voor de overheid, openbare lichamen en/ of ambtnaren. Uit artikel $51 \mathrm{Sr}$ volgt dat zowel natuurlijke als rechtspersonen opdrachtgeves en feitelijk leidinggevende kunnen worden vervolgd. Ook dit artikel maakt geenonderscheid tussen publiekrechtelijke en privaatrechtelijke rechtspersonen. ${ }^{175} \mathrm{Op}$ basis van jurisprudentie is onderscheid aanwezig bij de vervolging van privaatrechtlijke en publiekrechtelijke rechtspersonen, opdrachtgevers, feitelijk leidinggeveiden en/ of ambtenaren. Aangezien de verschillen in de praktijk (ook bij de scherding van zorgplichtbepalingen) aanleiding vormen tot onduidelijkheid inzake de vervdgingsmogelijkheden van vooral publiekrechtelijke organisaties, wordt in het navogende de verschillende mogelijkheden besproken.

\subsubsection{De Staat}

Zorgplichtbepalingen maken, gezien de gebruikte redactie, eveneens geen uitzondering voor publiekrechtelijke rechtspersonen en ambtenaren. Op basis van deze door de wet geboden mogelijkheden deed de situatie zich voor dat het ministerie van defensie werd vervolgd wegens het overtreden van artikel 14 (oud) Wbb, een zorgplichtbepaling die een algemene zorgplicht voor de bodem oplegt aan de

173 Zie HR 18 mei 1999, NJ 1999, 578 (Opgeduwde spoorwegwagons).

174 Zie over deze problematiek bijvoorbeeld: Brants C.H. en Lange R. de, Strafvervolging van overheden; Brants, C., "The king can do no wrong. Daderschap, feitelijk leidinggeven en de Staat", pp. 509-532; Brants, C., "The king can do no wrong; naschrift", pp. 655-659; Roef, D., "Kan de Staat in haar eigen staart bijten?", pp. 332-348; Drupsteen, T., "De overheid straffeloos?" "p. 155 en Fransen, T., "Arrest Hoge. Raad stelt overheid boven wet", p. 3.

175 De memorie van toelichting stelt wel dat de vervolging van publiekrechtelijke lichamen voor door hen gepleegde strafbare feiten in het algemeen weinig opportumn is, maar dat het anderzijds ook weer niet vanzelfsprekend is dat de mogelijkheid publiekrechtelijk rechtspersonen te vervolgen en te bestraffen zonder meer in de wet dient te worden uitgesloten. De meest voor de hand liggende differentiatic is volgens de wetgever die waarbij onderscheid wordt gemaakt all naar gelang het strafbare feit is te plaatsen in het verband van een algemene of specifieke bestuurstaak waarmee het publiekrechtelijk lichaam is belast dan wel is gepleegd binnen het kader van een ondernemingsactiviteit die ook door particulieren wordt of kan worden verricht. In dit laatste geval zou dan strafrechtelijke vervolging mogelijk zijn. Zie $T K 1975-1976$, nr. 13 655, nr. 3, p. 20-21. 
gebruiker daarvan. ${ }^{176}$ In deze zaak overwoog de Hoge Raad in 1994 dat er een uitzondering moet worden gemaakt voor de Staat ${ }^{177}$ :

"6.1. Als uitgangspunt heeft te gelden dat de handelingen van de Staat geacht moeten worden te strekken tot de behartiging van het algemeen belang. Daartoe kan de Staat door wet- en regelgeving, bestuur, feitelijke gedragingen of anderszins zich alle aangelegenheden aantrekken.

6.2. Voor de handelingen van de Staat zijn ministers en staatssecretarissen in het algemeen verantwoording schuldig aan de Staten-Generaal. Daarnaast kunnen zijn ter zake van ambtsmisdrijven strafrechtelijk worden vervolgd en berecht op de voet van de artikelen 483 en volgende Sv.

6.3. Met dit stelsel strookt niet dat de Staat zelf voor zijn handelingen strafrechtelijk aansprakelijk kan worden gesteld.

6.4. Het vorenoverwogene brengt mee dat de Rechtbank de Officier van Justitie nietontvankelijk had behoren te verklaren in zijn vervolging."

Aldus is de totale immuniteit van de Staat door de rechter vastgelegd. Het is overigens de vraag of deze totale immuniteit van de Staat in stand zal blijven. Zeker nu de immuniteit voor lagere overheden een flink stuk is teruggedrongen (zie hoofdstuk 6 paragraaf 5.5.3.) is deze discussie actueel. Op regeringsniveau is de discussie gevoerd of, en zo ja onder welke omstandigheden, de immuniteit van de centrale overheid moet worden gehandhaafd, dan wel moet worden gekomen tot de invoering van (een bepaalde modaliteit) strafrechtelijke aansprakelijkheid van de centrale overheid. ${ }^{178}$ In september 2000 heeft de minister van Justitie het Kabinetsstandpunt dienaangaande bekend gemaakt. ${ }^{179} \mathrm{Op}$ basis van de huidige jurisprudentie inzake aansprakelijkheid van publiekrechtelijke rechtspersonen, is verschil gecreëerd tussen de Staat (de centrale overheid) en andere overheden. ${ }^{180}$ Hierdoor ontstaan tussen diverse te onderscheiden categorieën overheden ook weer verschillen. Dit zal worden toegelicht in het navolgende.

\subsubsection{Openbare lichamen als bedoeld in hoofdstuk $7 \mathrm{Gw}$}

Door het Volkel-arrest en de jurisprudentie waarin de Hoge Raad een oordeel heeft gegeven over de immuniteit van "andere" overheden, is een verschil gecreëerd in de immuniteit van diverse overheden. Aanvankelijk was dit verschil niet (zo duidelijk) aanwezig, en werd aangenomen dat ook lagere overheden totale strafrechtelijke immuniteit konden bezitten. Dit bleek onder andere in 1996 in een zaak waarin een waterschap werd vervolgd wegens het overtreden van een zorgplichtbepaling uit artikel $10.3 \mathrm{Wm}^{181}$ De officier van justitie heeft tegen de uitspraak van de rechtbank

176 Zie over artikel 14 (oud) Wbb en het huidige 13 Wbb hoofdstuk 9 paragraaf 3.3.

177 HR 25 januari 1994, NJ 1994, 598, met noot Corstens (Vliegbasis Volkel) Zie over dit arrest Hullu, J. de, "De Staat zelf in de verdachtenbank?", pp. 50-56.

178 Zie TK 1999-2000, 25 294, bijvoorbeeld nrs. 10 en 11.

179 TK 2000-2001, 25 294, nr. 12.

180 Zie ook de brief van de minister van Justitie, $T K$ 1999-2000, 25294 , nr. 10, p. 1.

181 Zie over artikel 10.3 Wm hoofdstuk 9 paragraaf 3.4. 
dat hij niet ontvankelijk is in zijn vervolging cassatie aangetekend. De Hoge Raad overwoog ${ }^{182}$ :

"5.2. In aanmerking genomen dat waterschappen openbare lichamen zijn in de zin van Hooféstuk 7 van de Grondwet, en dat ingevolge art. 1, tweede lid, Waterschapswet de zorg voor de waterkering aan hen als zodanig wordt opgedragen, heeft de Rechtbank door aldus te overwegen en te beslissen geen blijk gegeven van een verkeerde rechtsopvatting.

53. De in de toelichting op het middel aangevoerde omstandigheid dat de verdachte heeft "nagelaten te opteren voor een uitvoering waarbij het plegen van strafbare feiten achterwege had kunnen blijven" doet aan het evenoverwogene niet af. Evenmin doet daaraan af de in die toelichting eveneens aangevoerde omstandigheid dat ingevolge de daar bedoelde bepalingen van de keur van het Hoogheemraadschap van de Uiterwaterende Sluizen in Hollands Noorcerkwartier enige verplichting voortvloeit die mede op de verdachte als eigenaar van een perceel grond rust.

5.4. Het middel is derhalve tevergeefs voorgesteld."

De Hoge Raad creëerde zo een strafrechtelijke immuniteit voor publiekrechtelijke rechtspersonen die een openbaar lichaam zijn in de zin van artikel 7 Grondwet, dat optreedt ter vervulling van een in de wet opgedragen bestuurstaak. Dit laatste bracht blijkens het op dezelfde dag gewezen arrest mee dat ook ambtenaren en arbeidscontractanten in dienst van het openbaar lichaam, indien zij in die hoedanigheid ter uitvoering van die bestuurstaak opdracht hebben gegeven tot of feitelijk leiding hebben gegeven aan de verboden gedraging als bedoeld in artikel $51 \mathrm{Sr}$ niet met succes strafrechtelijk konden worden vervolgd. De betreffende feitelijk leiding gevende ambtenaar werd in deze zaak strafrechtelijk vervolgd wegens het overtreden van een zorgplichtbepaling in $10.3 \mathrm{Wm}$. De Hoge Raad overwoog ${ }^{183}$ :

" 5.2 . Het Hof heeft veronderstellenderwijs aangenomen dat de Gemeente strafrechtelijk niet kan worden vervolgd. Kennelijk is het Hof tot die veronderstelling gekoment omdat het ervan is uitgegaan dat de Gemeente de verontreinigde baggerspecie in het Pikmeer heeft gebracht in haar hoedanigheid van openbaar lichaam als bedoeld in Hoofdstuk 7 van de Grondwet en ter behartiging van een aan haar als zodanig opgedragen bestuurstaak. Een en ander dient dan ook in cassatie eveneens als uitgangspunt te worden genomen.

6.3. Het middel stelt de vraag aan de orde of het onder 6.2. vermelde uitgangspunt meebrengt dat ook de verdachte als degene die aan de gedraging van de Gemeente feitelijke leiding heeft

182 HR 23 april 1996, NJ 1996, 512 (Waterschap Westfriesland). De Hoge Raad gaat nog. verder en stelt tevens dat: "De in de toelichting op het middel aangevoerde: omstandigheid dat de verdachte heeft nagelaten te opteren voor een titvoering waarbij het plegen van strafbare feiten achterwege had kunnen blijven doet aan het. evenoverwogene niet af."

183 HR 23 april 1996, NI 1996, 513, met noot 't Hart (Pikmeer I); Roos, Th. de, "Het, Pikmeerarrest en zijn gevolgen", pp. 226-233. Opvallend is dat de Hoge Raad na de. overweging dat de uitspraak van het Hof niet in stand kan blijven overweging 7,2. toevoegt, luidende: "Opmerking verdient nog dat het Hof na terugwijzing dient vast te stellen of de hiervoor onder 6.2 . bedoelde veronderstelling juist is en dat, indien zulks het geval is, dit de mogelijkheid onverlet laat dat de verdachte uit hoofde van eigen daderschap wordt veroordeeld." 
worden onder andere genoemd het hebben van verordenende bevoegdheid en/ of het hebben van leden of ingezetenen, maar deze criteria bleken niet doorslaggevend. ${ }^{188}$ Inmiddels lijkt er enige overeenstemming te zijn ontstaan wanneer sprake is van een "openbaar lichaam". Kortmann stelt dat ${ }^{189}$

"het bezit van rechtspersoonlijkheid en van verordenende bevoegdheid geen wezenskenmerk van een openbaar lichaam is. Naar het voorkomt, is een bevredigende omschrijving van een openbaar lichaam een op het publiekrecht gestoeld verband van ambten en personen, welke ambten publiekrechtelijke bevoegdheden jegens die personen uitocfenen en over de samenstelling waarvan de personen (mede) zeggenschap hebben."

De openbare lichamen die vallen onder artikel $134 \mathrm{Gw}$ én die rechtspersoonlijkheid bezitten, wordt (involge het Pikmeer II-arrest) dezelfde beperkte immuniteit verleend als provincies, gemeenten en waterschappen. Aangezien ex artikel 134, eerste lid Gw openbare lichamen bij of krachtens de wet kunnen worden ingesteld of opgeheven is delegatie terzake geoorloofd. Voorbeelden van openbare lichamen met rechtspersoonlijkheid zijn de lichamen van publiekrechtelijke bedrijfsorganisaties, de Nederlandse Orde Van Advocaten en de Koninklijke Notariële Beroepsorganisatie. ${ }^{190}$

Artikel $135 \mathrm{Gw}$ ziet op vormen van samenwerking tussen openbare lichamen, waarbij de instelling van een nieuw openbaar lichaam (in de zin van hoofdstuk $7 \mathrm{Gw}$ ) mogelijk is. Dergelijke openbare lichamen kunnen ook weer beschikken over rechtspersoonlijkheid. Als dit het geval is komt aan hun tevens de beperkte strafrechtelijke immuniteit toe. ${ }^{191}$

Opgemerkt moet worden dat het hier gat over openbare lichamen als bedoeld in hoofdstuk $7 \mathrm{Gw}$ die tevens rechtspersoon zijn. Dit is van belang ondat er vele openbare lichamen zijn, en vele publiekrechtelijke rechtspersonen zijn, maar deze twee categorieën elkaar lang niet altijd helemaal dekken. ${ }^{92}$ Dit onderscheid is relevant ondat de grondslag voor de vervolging is gelegen in artikel $51 \mathrm{Sr}_{\text {, dat betrekking heef }}$ op de strafvervolging van rechtspersonen, maar de Hoge Raad voor de toekenning van immuniteit aan publiekrechtelijke rechtspersonen aansluiting zoekt bij het begrip "openbare lichamen als bedoeld in hoofdstuk $7 \mathrm{Gw}$ ".

Naast de openbare lichamen in de zin van hoofdstuk $7 \mathrm{Gw}$ die rechtspersoonlijkheid hebben, zijn er ook overheidsorganisaties die niet zelf beschikken over rechtspersoonlijkheid. De rechtspersoonlijkheid in de zin van artikel $51 \mathrm{Sr}$ wordt geregeld in de betreffende wet zelf, in boek $2 \mathrm{BW}$ en in artikel 51, derde lid Sr. Involge artikel 2:1,

188 Brants, C.H. en Lange, R. de, Strafivervolging van overheden, p. 28.

189 Kortmann, C.A.J.M., in Grondwet voor het Koninkrijk der Nederlanden; Tekst en Commentaar, p. 136.

190 Zie Berge, J.B.J.M. ter en Zijlstra, S.E., "De publiekrechtelijke rechtspersoon in ontwikkeling", pp. 24-26.

191 Berge, J.B.J.M. ter en Zijlstra, S.E., "De publiekrechtelijke rechtspersoon in ontwikkeling", p. 26.

192 Zie Brants, C.H. en Lange, R. de, Strafivervolging van overheden, p. 23. 
eerste lid BW zijn de Staat, provincies, gemeenten, waterschappen en openbare lichamen met verordenende bevoegdheden krachtens de Grondwet rechtspersonen. Involge artikel 2:1, tweede lid BW kan bij wet rechtspersoonlijkheid aan een lichaam worden toegekend, indien daaraan een overheidstaak is opgedragen. ${ }^{193}$ Indien een overheidsorganisatie niet zelf beschikt over rechtspersoonlijkheid (op basis van artikel $2: 1$, rerste of tweede lid BW of artikel 51, derde lid Sr), heeft zij uiteindelijk toch altijd rechtpersoonlijkheid. Deze overheidsorganisatie behoort, simpelweg deel uitmakend van het staatsverband, tot de Staat der Nederlanden. Hierdoor deelt zij in diens rechtpersoonlijkheid. ${ }^{194}$ Dit heeft tot gevolg dat bij een strafrechtelijke vervolging van deze overheidsorganisatie, hieraan dezelfde vergaande strafrechtelijke immuniteit wordt toegekend als aan de Staat (centrale overheid) in het Volkel-arrest. Een voorbeeld van een dergelijke organisatie is de Registratiekamer. ${ }^{195}$

Er żjn zeer veel overheidsorganisaties die niet zelf beschikken over rechtspersconlijkheid, en derhalve dezelfde rechtspersoonlijkheid toekomt als de Staat der Nederlanden. Tot deze groep behoren ook een aantal zelfstandige bestuursorganen. Ook deze beschikken. immers lang niet. altijd zelf over rechtspersoonlijkheid. Een voorbeeld hiervan is Staatsbosbeheer. Aangezien zij behoren tot de Staat, beschikken zij ook over de vergaande strafrechtelijke immuniteit die hieraan is toegekend in het Volkel-arrest. Dit is opmerkelijk aangezien de ministeriële verantwoordelijkheid zich in beginsel niet volledig uitstrekt over deze zelfstandige bestuursorganen. ${ }^{196}$

Voorts blijken er ook publiekrechtelijke rechtspersonen te bestaan die niet zijn aan te merken als openbaar lichaam in de zin van hoofdstuk $7 \mathrm{Gw}$. Deze overheidsorganisaties is op basis van artikel 2:1, tweede lid BW rechtspersoonlijkheid toegekend, maar zij voldoen niet aan de vereisten die worden gesteld aan openbaar lichaam. Ten gevolge van deze toegekende rechtspersoonlijkheid vallen zij wel onder de werkingssfeer van artikel 51 Si. Juist door deze rechtspersoonlijkheid behoren zij niet tot de Staat, zodat zij de zeer vergaande immuniteit ontberen. Ook vallen zij niet onder hoofdstuk $7 \mathrm{Gw}$, zodat zij evenmin de beperkte immuniteit involge het Pikmeer IIarrest hebben. Dit doet zich bijvoorbeeld voor bij Rijksuniversiteiten, die wel rechtspersoonlijkheid hebben maar geen openbaar lichaam zijn in de zin van hoofdstuk 7 Gw. Dit bleek reeds in 1987 in een zaak waar niet alleen een wetenschappelijk hoofdmedewerker van de Rijksuniversiteit Groningen werd vervolgd, maar ook zijn werkgever de Rijksuniversiteit voor het door een van zijn ambtenaren gepleegde feit. Deze had namelijk als archeoloog zonder vergunning van de minister en daardoor in strijd met de Monumentenwet, gegraven in een als monument beschermde grafheuvel.

193 Zie over rechtspersoonlijkheid van publiekrechtelijke instellingen en artikel 2:1 BW; Berge, J.B.J.M. ter en Zijlstra, S.E., "De publiekrechtelijke rechtspersoon in ontwikkeling", pp. 21-31.

194 Peters, J.A.F., "Wordt vervolgd?; Over de criteria bij het beleid inzake vervolging van overheden", pp. 379-380.

195 Peters, J.A.F., "Wordt vervolgd?; Over de criteria bij het beleid inzake vervolging van overheden", p. 385.

196 Peters, J.A.F., "Wordt vervolgd?; Over de criteria bij het beleid inzake vervolging van overheden", p. 385. 


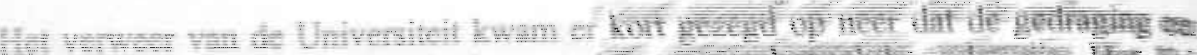

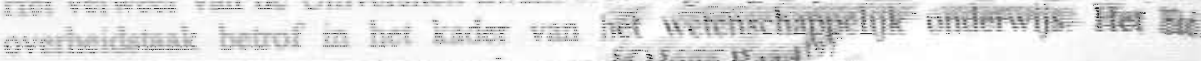

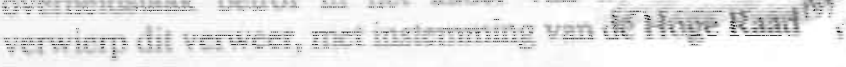

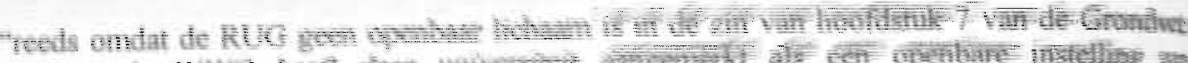

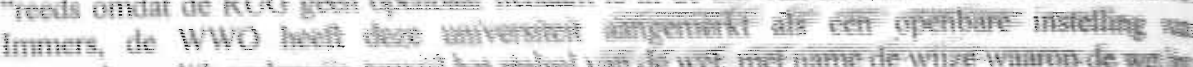

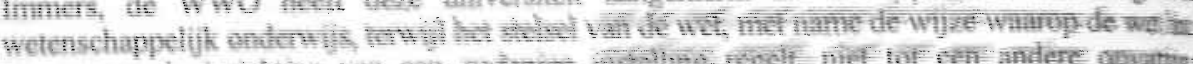

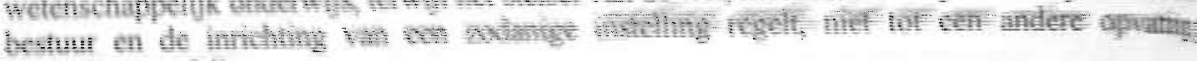
atmleithe gect.

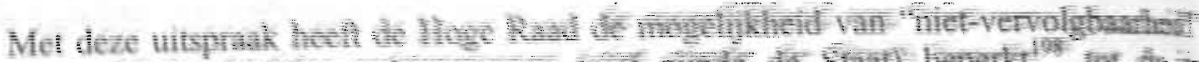

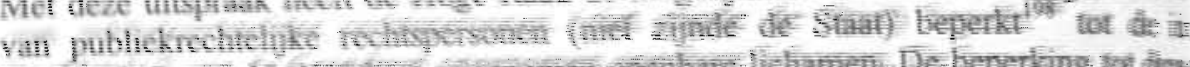

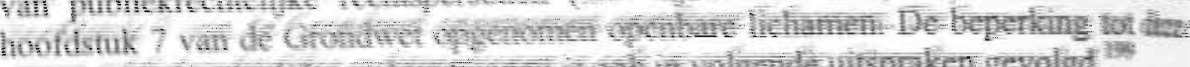

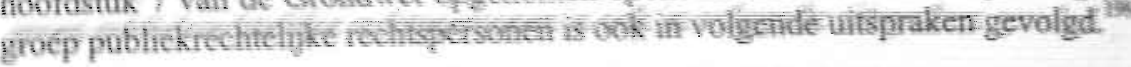

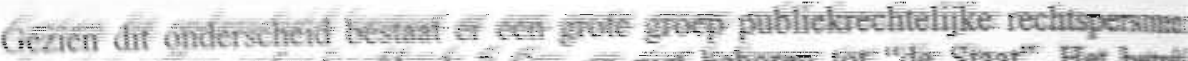

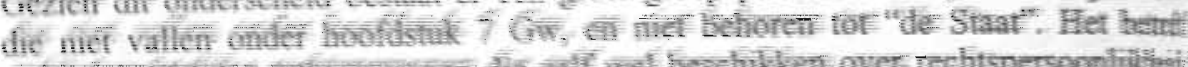

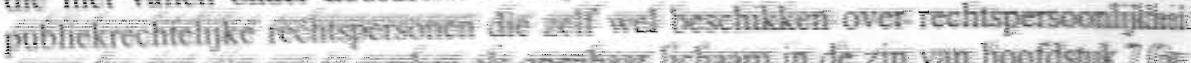

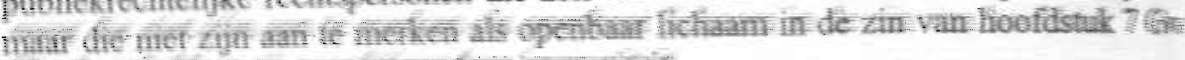

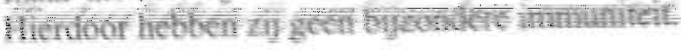

Juist bij zelfstandige bestuursorganen ontstaat er door het door de Hoge Raad aangelegde criterium "openbare lichamen als bedoeld in hoofdstuk $7 \mathrm{Gw}$ " een opvallend onderscheid bij een strafrechtelijke vervolging van deze organen op grond van artikel $51 \mathrm{Sr}$. Indien zij zelf geen rechtspersoonlijkheid hebben, komt hun de zeer vergaande immuniteit van de Staat op basis van het Volkel-arrest toe; indien zij wel rechtspersoonlijkheid hebben én zijn aan te merken als "openbare lichamen als bedoeld in hoofdstuk $7 \mathrm{Gw}$ " beschikken zij over de beperkte immuniteit uit het Pikmeer II-arrest; indien zij wel rechtspersoonlijkheid hebben maar niet zijn aan te merken als een dergelijk openbaar lichaam, hebben zij geen bijzondere immuniteit.

Dit verschil is nog opmerkelijker te noemen aangezien de keuze of aan een dergelijk orgaan rechtspersoonlijkheid wordt toegekend, vaak afhangt van de mate waarin dit orgaan bij de vervulling van zijn taken behoefte heeft aan eigen privaatrechtelijke bevoegdheden naast de reeds aanwezige publiekrechtelijke bevoegdheden. Bij dit oordeel gaat het vooral om de keuze inzake de toegang tot het civielrechtelijk

197 HR 10 novenber 1987, $N J 1988,303$, met noot Van Veen (RU Groningen vervolgd).

198 Hieraan vooraf ging de uitspraak inzake de niet ontvankelijkheid van het OM bij de vervolging van gemeenten. Hierin overwoog de Hoge Raad dat een gemeente nief strafrechtelijk aansprakelijk kan worden gesteld voor de vervulling van een overheidstaak, te weten de zog voor de veiligheid van publieke wegen, zie HR 27 oktober 1981, $N J$ 1982, 474 (Tilburgse verkeersdrempels).

199 Zie bijvoorbeeld de eerder besproken Pikmeer-arresten en HR 9 juni 1992, $N J$ 1992, 794; MenR 1993, nr. 37 (Streekgewest Oostelijk Zuid-Limburg). 
metalverkeer. De toekenning van rechtspersoonlijkheid aan een dergelijk orgaan heeft ditulitve niet (primair) te maken met de strafrechtelijke consequenties die uit deze liters: voortkomen. ${ }^{200}$

Af itseapt zijn aan te merken als openbaar lichaam, te bestaan. Zij kunnen involge artikel stise "gewoon" worden vervolgd. Tot deze groep publiekrechtelijke rechtspersonen ithetinen naast de Openbare Universiteiten bijvoorbeeld ook de politieregio's die nintikkelijk geen openbaar lichaam zijn, maar wel zijn aan te merken als rechtsmense ${ }^{201}$ Ook de vervolging van een politieregio zal derhalve niet afstuiten op de niteit van deze rechtspersoon. ${ }^{202}$

stafuechtelijke immuniteit voor openbare lichamen als bedoeld in hoofdstuk $7 \mathrm{Gw}$ en him:-opdrachtgevers en/ of feitelijk leidinggevenden bestaat slechts indien de tosteffende gedraging naar haar aard en gelet op het wettelijk systeem rechtens niet niste dan door bestuursfunctionarissen kunnen worden verricht in het kader van de uitutring van de aan het openbaar lichaam opgedragen bestuurstaak (beperkte inimiteit). ${ }^{203}$

nevan de overweging van de Hoge Raad dat het vervolgen van decentrale overheden (aievede centrale overheid wordt in Pikmeer II met geen woord gerept) niet strijdig is awi'uet wettelijk stelsel van politieke verantwoordelijkheid, lijkt ook hier het opportiniteitsbeginsel zich te doen gelden. Een reden om van vervolging af te zien kan zijn gelegen in de omstandigheid "dat ingrijpen van de strafrechter ontijdig is of de goede gang van een bestuurlijk proces verstoort". Het komt er derhalve op neer dat ten aanzien van vervolging op basis van artikel $51 \mathrm{Sr}$ van openbare lichamen in de zin van hoofdstuk $7 \mathrm{Gw}$ die zijn aan te merken als rechtspersoon, de opdrachtgevers en/ of feitelijk leidinggevenden, het OM en de rechter een grotere speelruimte wordt gelaten dan vöór het Pikmeer II-arrest. De blokkade van de strafrechtelijke immuniteit is voor deze normadressaten een flink stuk teruggedrongen. ${ }^{204}$

200 Zie Peters, J.A.F., Publiekrechtelijke rechtspersonen, p. 97 en Peters, J.A.F., "Wordt vervolgd?; Over de criteria bij het beleid inzake vervolging van overheden", p. 385; zie over motieven en gevolgen ook Berge, J.B.J.M. ter en Zijlstra, S.E., "De publiekrechtelijke rechtspersoon in ontwikkeling", pp. 31-54.

201 Zie Brants, C.H. en Lange, R. de, Strafivervolging van overheden, pp. 27, 31.

202. Zie over de vervolging van de politie Noord-Brabant naar aanleiding van een beklag ex artikel 12 Sv de beschikking van Hof 's-Hertogenbosch (Beschikking) 2 april 1999, niet gepubliceerd (Politie vervolgd), beproken door Knoops, G.G.J., "Politie vervolgd; Doorbreking van strafrechtelijke immuniteit", pp. 541-543, die de vergaande conclusie trekt dat door de toekenning van dit beklag de immuniteit van de Staat (in de zin van centrale overheid) zou zijn doorbroken.

203 Zie voor een overzicht van de belangrijkste jurisprudentie hieromtrent TMA 1997, pp. 11-18, met noot Fransen.

204 Zie ook Roos, Th.A. de en Visser, M.J.C., "Milieustrafrecht", 70.5.8.1. 
Het meest omstreden knelpunt betreft de totale immuniteit van de Staat, die door de Hoge Raad in het Volkel-arrest werd aanvaard. Op deze rechtspraak is in de rechtsgeleerde literatuur vele kritiek gekomen, die heeft geleid tot herbezinning op politiek niveau. Uiteindelijk blijkt de regering niet van plan te zijn door middel van wetgeving op dit punt verandering te brengen. minister van justitie Korthals vroeg in deze advies aan de Raad van State. Dit college wilde in het geheel niet weten van vervolgbaarheid van de Staat, en ging zelfs nog verder: ook de vervolgbaarheid van andere overheden werd in het advies ter discussie gesteld. In zijn reactie op dit advies stelt de minister in navolging van de Raad van State - dat de specifieke positie van de Staat de wenselijkheid van algehele immuniteit van strafvervolging met zich meebrengt. ${ }^{205} \mathrm{Op}$ de (magere) onderbouwing die hij hiervoor geeft, valt echter heel wat af te dingen. ${ }^{206}$ Dit is zeker het geval indien de verschillen in ogenschouw worden genomen die hierdoor ontstaan tussen zelfstandige bestuursorganen met en zonder rechtspersoonlijkheid, die al dan niet zijn aan te merken als openbaar lichaam in de zin van hoofdstuk $7 \mathrm{Gw}$. Het wettelijk stelsel van politieke verantwoordelijkheid strekt zich in beginsel over deze organen niet volledig, zodat ook daaraan niet zonder meer corrigerende werking kan worden voorondersteld.

De verschillen die zich voordoen bij zelfstandige bestuursorganen zijn evenwel niet de enige die (ten opzichte van de maatschappij en de justitiabelen) moeilijk zijn te rechtvaardigen. Zo kan bijvoorbeeld bij schending van de Arbeidstijdenwet door de

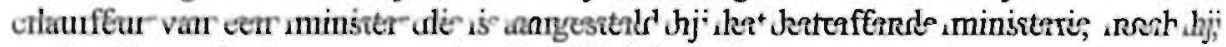
noch zijn opdrachtgever, noch zijn feitelijk leidinggever, noch de rechtspersoon waarbij hij is angesteld, strafrechtelijk worden vervolgd voor deze schending. Zijn collega bij een ander ministerie wordt door dit ministerie "ingehuurd", en is werkzaam bij een privaatrechtelijk vervoersbedrijf. Indien die collega tijdens zijn werkzaamheden voor de minister de Arbeidstijdenwet schendt, kan zijn werkgever (evenals onder omstandigheden zijn opdrachtgevers en feitelijk leidinggevers) die werkzaam is bij het vervoersbedrijf (en het bedrijf) wel worden vervolgd, maar dat geldt niet voor het ministerie en de bij het ministerie werkzame opdrachtgevers en feitelijk leidinggevenden. Indien de chauffeur gaat werken voor de directeur van een grote privaatrechtelijke onderneming kunnen zowel zijn werkgever, de rechtspersoon en zijn opdrachtgever en feitelijk leidinggevende, voor de schending van de Arbeidstijdenwet worden vervolgd. Deze verschillen laten zich gezien de overeenkomstige aard van de werkzaamheden en de feitelijke gezagsverhoudingen moeilijk verklaren. Ook het systeem van politieke verantwoordelijkheid zal hier voor de chauffeurs die werken voor de minister, niet snel corrigerend werken.

205 Zie voor het advies van de Raad van State en het nader rapport van de minister TK. 1999 2000, 25 294, A, en de bijbehorende brief van de minister TK 1999-2000, 25 294, nr. 10.

206 Zie ook Roos, Th.A. de, "Geen strafrechtelijke aansprakelijkheid voor de Staat? Minister Korthals als Oblomov", p. 96. 


\subsection{Standpunt van de minister inzake vervolgbaarheid van de Staat}

In en brief aan de Tweede Kamer van 22 september 2000 heeft de minister van justrie een streep onder de discussie willen zetten door als kabinetsstandpunt te formuleren dat het geen aanbeveling verdient de Nederlandse Staat strafrechtelijk vervilgbaar te maken. ${ }^{207}$ De inmiddels bekende tegenargumenten passeren weer de revu:

"De Staat is zowel vervolger als vervolgde, zij betaalt boetes aan zichzelf (...). Een kempobleem bij vervolging van de Staat is, dat straffen en maatregelen op zichzelf bezien nauwelijks effect kunnen sorteren. (...) waar andere straffen en maatregelen niet met vrucht kunnn worden opgelegd, kan proceseconomisch geen reden zijn om toepassing van deze mategelen in het strafrecht mogelijk te maken. Zinvolle strafrechtelijke sanctionering van de Staatbehoort derhalve nauwelijks tot de mogelijkheden. Dat zet de vraag op scherp, welke strafichtelijke doelstellingen vervolging van de Staat desalniettemin zouden kunnen rechtaardigen. Genoemd wordt wel de doelstelling normbevestiging. (...) De normbevestiging die vn een veroordeling zonder strafoplegging, uitgaat, is evenwel beperki. In strafzaken waarbij op di grens van de strafwaardigheid het recht gevonden moet worden kan normbevestiging zondr strafoplegging passend zijn. Indien evident strafwaardig gedrag leidt tot een veroordeling zondr effectieve: sanctie kan het resultaat echter averechts zijn. Een dergelijke veroordeling suggreert dat de bevestigde norm voor de veroordeelde een loze norm is".

Nietemin heeft de minister zich nog gebogen over de vraag, hoe een strafrechtelijke vervolging van de staat vorm zou moeten krijgen. De beslissing daartoe zou volgens hem (en volgens het kabinet) evenals in het geval van vervolging van ministers, aan de Tweede Kamer en de regering moeten worden toevertrouwd. De Procureur-Generaal bij de Hoge Raad zou de vervolgingsbeslissing moeten uitvoeren. Een autonome bevoegdheid voor deze (niet gekozen) magistraat zou diens functievervulling politiseren. Wanneer de normale weg zou worden bewandeld (vervolging door de officier van justitie) zou de politiek verantwoordelijke minister, en uiteindelijk de gehele regering, in een onmogelijke positie terechtkomen, zelfs wanneer men in aanmerking neemt dat het in de regel niet zo'n vaart zou lopen omdat het meestal om milieudelicten gaat.

Het zou onbevredigend zijn als dit inderdaad het laatste, woord zou zijn. Het argument van de onmogelijke positie waarin de regering zou kunnen belanden (toch wel het centrale motief in het kabinetsstandpunt) overtuigt niet. Het miskent de psychologische betekenis van de rechtsgelijkheid en onderschat het belang van de normbevestiging. Beide aspecten zijn in hoge mate medebepalend voor de legitimiteit van de rechtshandhaving, de strafrechtpleging in het bijzonder. Het onderscheid tussen de centrale overheid en de talrijke decentrale overheden en andere (semi) overheidsorganen is in onze moderne, complexe en dynamische samenleving willekeurig en voortdurend aan verandering onderhevig. En het is tenslotte zeer de vraag of andere correctiemechanismen in voldoende mate aanwezig zijn dan wel zullen worden benut.

TK 2000-2001, 25 294, nr. 12. 
6.

Zorgplichtbepalingen en het commuun strafrecht

6.I.

Inleiding

Vanzelfsprekend is het Wetboek van Strafrecht van belang bij de analyse van alle zorgplichtbepalingen. Dit wetboek neemt een centrale plaats in in het geheel van de Nederlandse strafwetgeving. Het bijzonder strafrecht volgt het algemeen strafrecht en laat zich er vaak door inspireren. ${ }^{208}$ Het omgekeerde is zeker ook het geval. Het bijzonder strafrecht loopt vaak voorop, en vormt op zijn beurt een inspiratiebron voor het algemeen strafrecht. ${ }^{209}$ Juist in het bijzonder strafrecht komt de spanning tussen het strafrecht als instrument en de rechtsbeschermende functie duidelijk naar voren. In dit spanningsgebied dienen nieuwe rechtsvragen, ontwikkelingen en problemen zich aan en zien nieuwe interpretaties en oplossingen (tijdelijk) het licht.

Het huidige Wetboek van Strafrecht is samengesteld uit drie boeken. Boek I behelst het algemeen deel. Dit bevat algemene bepalingen die behoudens enkele uitzonderingen gelden voor het gehele strafrecht. Artikel $91 \mathrm{Sr}$ stipuleert:

"De bepalingen van de Titels I-VIII A van dit boek zijn ook toepasselijk op feiten waarop bij andere wetten of verordeningen straf is gesteld, tenzij de wet anders bepaalt."

Aangezien met de term "wet" de wet in formele zin wordt bedoeld, mogen lagere wetgevers geen regels geven die in strijd zijn met de regels uit Boek I. Op grond van artikel $91 \mathrm{Sr}$ zijn bijwoorbeeld de artikelen betreffende de omvang en werking van de strafwet $^{210}$, straffen en maatregelen, uitsluiting en verhoging van de strafbaarheid, de poging en voorbereiding, deelneming en samenloop in beginsel ook toepasselijk op zorgplichtbepalingen in het bijzonder strafrecht.

Daarnaast worden onder het algemeen deel van het strafrecht vaak ook algemene leerstukken inzake culpa, opzet ${ }^{211}$ en wederrechtelijkheid begrepen. Aanduidingen van het betekenisbereik van deze begrippen/ leerstukken zijn niet in het algemeen deel van het Wetboek terug te vinden, maar spelen uiteraard wel een grote rol in het gehele strafrecht.

208 Bemmelen, J.M. van en Veen, Th.W. van, bewerkt door Jong, D.H. de en Knigge, G., Het materiële strafrecht, pp. 5-7.

209 Denk aan de strafbaarheid van de rechtspersoon dat aanvankelijk alleen in bijzondere wetten was geregeld, in 1942 in het Economisch Sanctiebesluit en in 1976 in het Wetboek van Strafrecht werd geregeld (zie hoofdstuk 8 paragraaf 2 en hoofdstuk 6 paragraaf 5), de mogelijkheid van transacties bij misdrijven was aanvankelijk alleen in de Wed geregeld evenals andere vermogenssancties dan de geldboete zoals de onttrekking wederrechtelijk verkregen voordeel en de verbeurdverklaring. Zie ook Bos, P.A.H., "Osmose tussen het economische en commune strafrecht", pp. 381-387.

210 Zoals artikel I Sr; zie daarover hoofdstuk 3 paragraaf 7.3.3.

211 Zie hierover hoofdstuk 3 paragraaf 7.4. 
Boek II bevat een aantal belangrijke misdrijven. Zoals uit het voorafgaande is gebleken, heeft het Wetboek van Strafrecht nooit alle misdrijven omvat. In dit Boek zijn geen zorgplichtbepalingen opgenomen die voldoen aan de in hoofdstuk 1 paragraaf 2.2. gegeven definitie. Boek III bevat een aantal overtredingen. Hier zijn wel enkele zorgplichtbepalingen opgenomen. Het betreft de artikelen 425 aanhef en sub 2 (hoofdstuk 6 paragraaf 6.2.), 426, eerste lid (hoofdstuk 6 paragraaf 6.3.), 427 aanhef en sub 1 en 5 (hoofdstuk 6 paragraaf 6.4.), 429 aanhef en sub 3 Sr (hoofdstuk 6 paragraaf 6.5.). Deze zijn met uitzondering van 429 aanhef en sub $3 \mathrm{Sr}$ al te vinden in het Wetboek van 1886. De wijzigingen die zij inhoudelijk in de loop der tijd hebben ondergaan, zijn vooral van taalkundige aard. Wel is van al deze zorgplichtbepalingen de maximum strafbedreiging aangepast. Een korte bespreking van deze bepalingen is hier op haar plaats ${ }^{212}$, aangezien daaruit blijkt dat zorgplichtbepalingen reeds lang deel uitmaken van het commuun strafrecht, en geen recente eigenaardigheid zijn van het bijzonder strafrecht.

\subsection{Artikel 425 aanhef en sub $2 \mathrm{Sr}$}

\subsubsection{De zorgplichtbepaling}

Deze bepaling is niet geheel nieuw in Nederland, aangezien een soortgelijke bepaling is te vinden in artikel 475, no. 7 Code Pénal. In het Wetboek 1886 luidt de bepaling:

"Met hechtenis van ten hoogste zes dagen of geidboete van ten hoogste vijf en twintig gulden wordt gestraft:

$2^{\circ}$ hij die geene voldoende zorg draagt voor het onschadelijk houden van een onder zijne hoede staand gevaarlijk dier."

Het huidige artikel 425 aanhef en sub $2 \mathrm{Sr}$ luidt nog nagenoeg hetzelfde:

"Met hechtenis van teri hoogste zes maanden of geldboete van de derde categorie wordt gestraft: $2^{\circ}$ hij die geen voldoende zorg draagt voor het onschadelijk houden van een onder zijn hoede staand gevaarlijk dier."

De maxinnum strafbedreiging van deze zorgplichtbepaling werd in 1993 aangepast. ${ }^{213}$ Het betreft een overtreding.

\subsubsection{De zorgplichtbepaling nader beschouwd}

De normadressaat is een ieder die een gevaarlijk dier onder zijn hoede heeft, waarbij onder zijn hoede wil zeggen, onder zijn feitelijk toezicht. Een zoon die door zijn vader was belast met het toezicht op en het hoede van zijn vaders koeien was tijdens het laten lopen op de dijk afwezig. Tijdens zijn afwezigheid heeft een koe een

212 Overigens worden deze bepalingen niet als voorbeeld van zorgplichtbepalingen genoemd door in het Advies van de Commissie voor de toetsing van wetgevingsprojecten inzake zorgplichtbepalingen.

213 Bij Wet van 24 september 1992, Stb. 1992, 585, inwerkingtreding 1 juni 1993. 
voorbijganger aangevallen. De vader werd als eigenaar van het dier vervolgd, waarbij werd uitgegaan van de stelling dat de eigenaar van een dier dat dier onder zijn hoede heeft, indien niet blijkt dat het dier onder eens anders hoede staat. Dit hield bij de Hoge Raad geen stand aangezien uit de bewijsmiddelen niet bleek dat de vader de koe "onder zijn 'hoede', dat is zijn feitelijk toezicht, heeft gehad."214 Overigens behoeft een dier niet (door de eigenaar) aan iemands hoede te zijn toevertrouwd voordat kan worden gesproken van "onder zijn hoede"; voldoende is dat hij het onder zijn hoede heeft genomen. ${ }^{215}$

In de memorie van toelichting wordt opgemerkt dat met een gevaarlijk dier alle dieren zijn bedoeld die gevaarlijk zijn. Een dier is gevaarlijk indien schade voor lijf of goed te duchten is, waarbij het geen verschil maakt of deze eigenschap aan alle exemplaren van die soort of alleen aan het "corpus delicti" eigen is, en evenmin of men met een voortdurende eigenschap of met een ziekte te doen heeft. Als voorbeeld wordt gegeven dat de bepaling ook van toepassing is op kwaadwillende of dolle honden. ${ }^{216}$ Een gevaarlijk dier is dan ook niet alleen een dier van een gevaarlijk soort, maar ook een gevaarlijk exemplaar van een ongevaarlijk soort. ${ }^{217}$ Ook een dier van een ongevaarlijk soort dat met zijn gedrag niet heeft laten blijken gevaarlijk te zijn, maar waarvan op grond van andere feiten en omstandigheden kan worden aangenomen dat het gevaar oplevert, kan als gevaarlijk worden aangemerkt. ${ }^{218}$

Het is niet nodig dat daadwerkelijk schade worut toegebracht. ${ }^{219}$ Niet voldoende is dat het dier op het moment dat het schade kon aanrichten niet onschadelijk werd gehouden. Voorafgaande aan de gedraging waaruit blijkt dat een dier gevaarlijk is, moet zijn gebleken dat het moest worden beschouwd als een gevaarlijk dier dat onschadelijk moest worden gehouden. Zo overwoog de Rechtbank ${ }^{200}$ :

214 HR 16 januari 1928, NJ 1928, pp. 250-251 (Hoede over koe).

215 Noyon, T.J., Langemeijer, G.E. en Remmelink, J., bewerkt door Dorst, A.J.A. van, Fokkens, J.W. en Machielse, A.J.M., Het Wetboek van Sirufrecht, "Overtredingen; Artikel 425" (februari 1994), p. 13.

216 Smidt, H.J., Geschiedenis van het Wetboek van Strafrecht, Deel III, pp. 183-184. Het gevaarlijk zijn betreft gezien deze toelichting geen abstracte maar een concrete eigenschap, zie p. 185 .

217 HR i6 januari 1922, NJ 1922, pp. 343-345 (Afgerichte hond). Het betrof in casu een ongevaarlijk dier dat nict van nature behoort tot een gevaarlijk soort maar dit door zijn eigen bijzondere aard of dressuur is, te weten een op de man afgerichte hond die na op beve! van zijn meester een persoon te hebben gesteld, toebijt als deze persoon tracht weg te lopen of zich verweeri. Het gaat er niet om of het als gevaarlijk bekend staat, maar of het gevaarlijk is: HR 14, maart 1904,W. 8049 (Hond bijt rijksveldwachter).

218 HR 10 maart 1992, NJ 1992, 571 (Pitbullterriër).

219 HR 14 januari 1907, W. 1907, 8488 (Gevaarlijk dier en schade) "Geen vereischte voor de overtreding van art. $425,2^{\circ}$. Strafr. is, dat schade toegebracht is, maar dat is niet verhinderd of voorkomen worde, dat deze door een gevaarlijk dier toegebracht worde": Overigens was in deze zaak het slachtoffer gebeten door een hond.

220 Zie bijvoorbeeld Rb. Middelburg 24 september 1901, W. 1902, 7696 (Hond in wei). 
"dat het door eene hond achtervolgen van eenige koeien in eene weide, waardoor eene der koeien de beide voorpooten breekt, wel aantoont dat die hond op dat oogenblik een gevaarlijk dier is, doch dat om een hond als zoodanig in den zin der wet te kunnen aanmerken moet vaststaan, dat het dier aan zijnen meester of aan hen die het onder zijne hoede heeft, als gevaarlijk dier bekend was, vóór de handelingen welk tot eene vervolging aanleiding hebben gegeven; dat toch als gevaarlijk is aan te merken zoodanig dier, waarvan schade voor lijf of goed te duchten is."

\subsection{Artikel 426, eerste lid Sr}

\subsection{De zorgplichtbepaling}

Ook deze bepaling is in het Nederlandse recht niet geheel nieuw. Een gelijksoortige bepaling was al te vinden in het in Nederland geldende artikel 29 , tweede lid van een decreet uit: $1813 .^{221}$ In het Wetboek 1886 luidt de bepaling:

"Hij die, terwijl hij in staat van dronkenschap verkeert, hetzij in het openbaar het verkeer belemmert of de orde verstoort, hetzij eens anders veiligheid bedreigt, hetzij eenige handeling verticht waarbij, tot voorkoming van gevaar voor leven of gezondheid van derden, bijzondere omzichtigheid of voorzorgen worden vereischt, wordt gestraft met hechtenis van ten hoogste zes dagen of geldboete van ten hoogste vijf en twintig gulden."

Het huidige artikel 426 eerste lid Sr luidt nog bijna hetzelfde:

"Hij die, terwijl hij in staat van dronkenschap verkeert, hetzij in het openbaar het verkeer belemmert of de orde verstoort, hetzij eens anders veiligheid bedreigt, hetzij enige handeling verricht waarbij, tot voorkoming van gevaar voor leven of gezondheid van derden, bijzondere omzichtigheid of voorzorgen worden vereist, wordt gestraft met hechtenis van ten hoogste zes dagen of geldboete van de eerste categorie."

Alleen de maximum strafbedreiging met betrekking tot de geldboete is sinds de invoering van het Wetboek aangepast. De indeling in boetecategorieën vond plaats in 1984. ${ }^{222}$ Het betreft een overtreding.

Artikel 426, eerste lid Sr omvat ten gevolge van de opsomming van verschillende gedragingen van degene die "in staat van dronkenschap verkeert" zeven verschillende situaties.

\subsubsection{De zorgplichtbepaling nader beschouwd}

De normadressaat is een ieder die in staat van dronkenschap verkeert. Deze dronkenschap behoeft niet zoals bij artikel 453 Sr vereist is "kenlijk" te zijn, hetgeen

221 Het betreft het Décret contenant des dispositions de police relatives à l'exploitation des mines, Janvier 1813, Bulletin des Lois no. 467, zie de memorie van toelichting van het Wetboek van Strafrecht, opgenomen in Smidt, H.J., Geschiedenis van het Wetboek van Strafrecht, Deel III, p. 185.

Bij Wet van 10 maart 1984, Stb. 1984, 91, inwerking getreden 1 mei 1984. 
betekent dat het voor elke toeschouwer aan uiterlijke kenmerken herkenbaar is. Voldoende is dat de dronkenschap is kunnen worden geconstateerd door hen die met de overtreder in aanraking komen. De dionkenschap moet wel bewijsbaar zijn. ${ }^{223}$

De dronkenschap is op zichzelf niet strafbaar, het gaat erom dat deze persoon in het openbaar het verkeer belemmert of de orde verstoort, hetzij een handeling verricht waarbij tot voorkoming van gevaar voor leven of gezondheid van derden bijzondere omzichtigheid of voorzorgen worden vereist. De verbinding van de dronkenschap met de handeling vormt de overtreding.

Het betreft handelingen waardoor hetzij in het openbaar het verkeer wordt belemmerd of waardoor de orde wordt verstoord. Deze belemmering óf verstoring moet worden veroorzaakt door de handeling van de beschonkene, en niet door handelingen van anderen als reactie op zijn beschonkenheid. Indien door de aanwezigheid van een dronken persoon een oploop ontstaat waardoor de openbare orde wordt verstoord, kan niet worden gezegd dat de openbare orde wordt verstoord door de beschonkene. Dit is mogelijk wel indirect de oorzaak, maar de directe oorzaak ligt bij de personen die deel uitmaken van de oploop. ${ }^{224}$

Dit deel van de bepaling ziet niet op handelingen die deel uitmaken van het verkeer of de orde binnenshuis, of op een afgesloten erf plaatsvinden. Een dronken man die op zijn aan de openbare weg gelegen erf luidkeels staat te schreeuwen, waardoor de buren. uit hun huizen op het rumoer afkwamen, levert geen schending op van artikel 426 , tweede lid Sr, omdat de "handeling niet is geschied op den openbaren weg of op eene voor het publiek toegankelijke plaats". ${ }^{225}$ Het betreft alle voor publiek toegankelijke plaatsen ${ }^{226}$, waarbij overigens de daadwerkelijke aanwezigheid van publiek niet is vereist. $^{227}$

Voorts betreft het handelingen waardoor eens anders veiligheid wordt bedreigi, hieronder is niet de veiligheid van de beschonkene zelf begrepen. De bedreiging geldt niet de persoon van een ander maar diens veiligheid. ${ }^{228}$ Voldoende is dat men objectief eens anders veiligheid onmiddellijk in gevaar brengt. ${ }^{22}$

223 Noyon, T.J., Langemeijer, G.E. en Remmelink, J., bewerkt door Dorst, A.J.A. van, Fokkens, J.W. en Machielse, A.J.M., Het Wetboek van Strafrecht, "Overtredingen; Artikel 426" (juni 1996), p. 15; zie over het verschil tussen "kenlijke staat" (artikel 453 $\mathrm{Sr}$ ) en "staat" (artikel $426 \mathrm{Sr}$ ) reeds Cnopius, A.A., "Het derde boek van het Wetboek van strafrecht in de praktijk", pp. 61-63.

224 Cnopius, A.A., "Het derde boek van het Wetboek van strafrecht in de praktijk", pp. 65 . 66. Hij stelt "Waar de ordeverstoring het gevolg is van een vrijwillige daad, voortkomende uit nieuwsgierigheid, bemoeizucht of baldadigheid van het publiek, mag men degene, die daartoe onwillekeurig aanleiding geeft, er niet voor straffen."

225 HR 18 mei 1903, W. 1803, 7927 (Dronken op eigen erf).

226 HR 28 april 1902, W. 1902, 7765 (Ordeverstoring in bierhuis).

227 HR 16 februari 1988, NJ 1988, 821 (Openlijk geweld op parkeerplaats). In casu werd de verdachte vervolgd wegens schending van artikel $141 \mathrm{Sr}$.

228 Noyon, T.J., Langemeijer, G.E. en Remmelink, J., bewerkt doar Dorst, A.J.A. van, 
Bij welke handelingen de bedoelde bijzondere omzichtigheid of voorzorgen worden vereist, is door de wetgever bewust aan de rechter overgelaten. Het behoeven geen beroepsbezigheden te zijn, hoewel alle voorbeelden uit de memorie van toelichting dit wel zijn; te weten degene die in beschonken staat dienst doet als verloskundige, als machinist een locomotief of als koetsier een rijtuig wil besturen, of als loodgieter met vuur op een dak klimt. ${ }^{230}$ Het gevaar behoeft zich niet te openbaren. De wetgever heeft deze bepaling juist ingevoerd om "preventief op te treden"231 en "om de culpose misdrijven van de Titels VII en XXI Boek II te voorkomen"232, want indien er wil is om het gevaar teweeg te brengen of gevaarlijke gevolgen ontstaan valt het feit onder de misdrijven. ${ }^{223}$ De bepaling beperkt zich niet tot handelingen waarbij een uiterste omzichtigheid nodig is of buitengewone voorzorg moet worden betracht. Opgemerkt wordt dat er geen handeling denkbaar is waarbij niet enige omzichtigheid of enige voorzorg wordt vereist. De bijzondere omzichtigheid of voorzorg is elke die meer dan de gewone, dagelijkse is. De beschonkene is licht roekeloos of mist de macht om zijn eigen verrichtingen te beheersen; de verrichtingen zijn van dien aard dat zij voorzichtigheid of meesterschap nodig hebben om niet voor eens anders leven of gezondheid gevaarlijk te worden. ${ }^{234}$

\subsection{Artikel 427 aanhef en sub l en sub 5 Sr}

\subsubsection{De zorgplichtbepalingen}

Het eerste deel van deze bepaling is niet opgenomen in de Code Pénal. De staatscommissie verwijst in de toelichting op dit deel van de bepaling naar soortgelijke bepalingen uit Duitsland. ${ }^{235}$ De voorloper van de strafbaarstelling onder sub 5 is te vinden in artikel 475, no. 3 Code Pénal. Daar was in tegenstelling tot het artikel uit 1886, de strafbedreiging afhankelijk van het bestaan van een bijzondere verordening. Deze bepaling in het Wetboek 1886 luidt:

Fokkens, J.W. en Machielse, A.J.M., Het Wetboek van Strafrecht, "Overtredingen; Artikel 426" (juni 1996), p. 16.

229 Beraadslagingen Tweede Kamer, Opmerking van minister Modderman, Smidt, H.J., Geschiedenis van het Wetboek van Strafrecht, Deel III, p. 189.

230 MvT, Smidt, H.J., Geschiedenis van het Wetboek van Strafrecht, Deel III, pp. 185-I86.

231 Beraadslagingen Tweede Kamer, Opmerking van minister Modderman, Smidt, H.J., Geschiedenis van het Wetboek van Strafrecht, Deel III, p. 188.

232 Mv'T in Smidt, H.J., Geschiedenis van het Wetboek van Strafrecht, Deel III, p. 186.

233 Rapport aan den Koning; Smidt, H.J., Geschiedenis van het Wetboek van Strafrecht, Deel III, p. 186.

234 Noyon, T.J., Langemeijer, G.E. en Remmelink, J., bewerkt door Dorst, A.J.A. van, Fokkens, J.W. en Machielse, A.J.M., Het Wetboek van Strafrecht, "Overtredingen; Artikel 426" (februari 1994), p. 17.

235 Zij stelt dat de bepaling "is ontleend aan art. $367 \mathrm{n}^{\circ} .12$ D.W. Zij komt ook voor in de wetboeken van Beijeren (art. 147) en van Baden (art. 108)." Toelichting der Staatscommissie, Smidt, H.J., Geschiedenis van het Wetboek van Strafrecht, Deel III, p. 193. 
"Met geldboete van ten hoogste vijf en twintig gulden wordt gestraft:

$1^{\circ}$ de eigenaar of gebruiker die ten opzichte van toegangen tot of openingen van kluizen, kelders, onderaardsche lokalen en ruimten, waar die op den openbaren weg uitkomen, niet de noodige voorzorgsmaatregelen neemt ten behoeve van de veiligheid van voorbijgangers."

" $5 \circ$ hij die op den openbaren weg een rij-, trek- of lastdier laat staan, zonder de noodige voorzorgsmaatregelen tegen het aanrichten van schade te hebben genomen."

Het huidige artikel 427, aanhef en sub 1 en sub 5 Sr luidt nog steeds bijna hetzelfde:

"Met geldboete van de eerste categorie wordt gestraft:

$1^{\circ}$ de eigenaar of gebruiker die ten opzichte van toegangen tot of openingen van kluizen, kelders, onderaardsche lokalen en ruimten, waar die op de openbare weg uitkomen, niet de nodige voorzorgsmaatregelen neemt ten behoeve van de veiligheid van voorbijgangers."

" $5^{\circ}$ hij die op de openbare weg een rij-, trek- of lastdier laat staan, zonder de noodige voorzorgsmaatregelen tegen het aanrichten van schade te hebben genomen."

Op het schenden van artikel $427 \mathrm{Sr}$ is geen hechtenis gesteld. De maximum strafbedreiging met betrekking tot de geldboete is wel aangepast. De indeling in boetecategorieën vond plaats in $1984 .{ }^{236}$ Het betreft een overtreding.

Artikel 427 sub 1 Sr bevat door het gebruik van "of" tusssen de twee verschillende normadressaten, het "of" tussen toegangen of openingen en de opsomming van vier verschillende lokaties, zestien verschillende situaties. Artikel 427 sub $5 \mathrm{Sr}$ omvat door de opsomming van de drie soorten dieren, drie verschillende situaties.

\subsubsection{De zorgplichtbepalingen nader beschouwd}

In het rapport aan den Koning wordt opgemerkt dat deze strafbaarstellingen gezien hun onbepaaldheid niet thuis horen in het Wetboek van Strafrecht. Het wordt wenselijk gevonden deze strafbaarstellingen over te laten aan provinciale en gemeentelijke verordeningen aangezien hetgeen nodig is veelal van lokale omstandigheden afhankelijk is. ${ }^{237}$ Hiertoe is echter niet overgegaan, waardoor het artikel nog steeds kan worden aangetroffen in het Wetboek van Strafrecht. De minister geeft als toelichting voor het laten bestaan van sub 1, dat door het opnemen van deze bepaling in een wet in formele zin de veiligheid van de voorbijganger, de gebruiker van de weg, zoveel mogelijk onafhankelijk heeft willen maken van de grotere of geringere zorgvuldigheid van lagere overheden. De bepaling eist een minimum, waarvan kan worden aangenomen dat het voor het hele land nodig is. Daamaast behouden lagere overheden onverminderd de bevoegdheid om deze bepaling aan te vullen indien dat op grond van plaatselijke omstandigheden nodig is. ${ }^{238}$

236 Bij Wet van 10 maart 1984, Stb. 1984, 91, inwerkingtreding 1 mei 1984.

237 Rapport aan den Koning, Smidt, H.J., Geschiedenis van het Wetboek van Strafrecht, Deel III, p. 194.

238 Beraadslagingen Tweede Kamer, Opmerking van minister Modderman, Smidt, H.J., Geschiedenis van het Wetboek van Strafrecht, Deel III, p. 195. Zie ook HR 5 oktober 1908, W. 1908, 8753 (IJzer op weg): De APV-bepaling Dordrecht waarin werd verboden iets op de weg te laten liggen werd niet onverbindend geacht. 
Het artikel ziet op het voorkomen van gevaar of belemmeringen van de openbare weg. Fen weg is openbaar indien de overheid een daartoe strekkend besluit heeft genomen of indien een particulier de weg gedurende dertig aaneengesloten jaren openbaar laat gebruiken. De formele bestemming van de weg tot openbare weg is in het laatste geval niet vereist. ${ }^{239}$ Dat de bepaling ziet op het voorkomen van gevaar of belemmering van de openbare weg en niet daarbuiten bleek al snel na de invoering. De Hoge Raad stelde: ${ }^{240}$

"dat wanneer de opening, zooals hier het geval is, uitkomt op het eigen terrein van den requirant, nog wel 2 meter verwijderd van den openbaren weg, deze alleen gevaar kan opleveren voor hen die den openbaren weg voorbij gaan, dat is misloopen, en de wetgever voor de veiligheid van deze soort van voorbijgangers niet heeft willen waken; dat al is de plaats, waar de opening ligt, ook toegankelijk voor het publiek, die plaats toch nimmer is openbare weg;"

Wat de nodige voorzorgsmaatregelen zijn, is afhankelijk van de omstandigheden van het geval. De bewering dat niet meer maatregelen dan de getroffene heeft genomen konden worden genomen, zal niet snel aanleiding zijñ om de verdachte vrij te spreken. Het betreft telkens situaties waarvoor in beginsel voldoende maatregelen zijn te treffen, en indien dit niet mogelijk is dient de betreffende situatie zich niet voor te doen. Alle situaties zijn in beginsel slechts geoorloofd onder de voorwaarde dat de voorzorgsmaatregelen voldoende zijn. ${ }^{241}$ Dit geldt niet absoluut, aangezien met een geoorloofd risico rekening moet worden gehouden. ${ }^{242}$ Een voorbeeld is de zaak waar de verdachte een voor een melkwagen gespannen paard op de weg had laten staan, nadat hij het voorwiel zo had gemaakt dat het niet kon draaien. Het paard stond anderhalve meter van een tramrails. Gesteld werd dat als het paard de wagen in beweging had gebracht op het moment dat de tram passeerde het niet uitgesioten was geweest dat het achterstuk van de wagen een draaiende beweging naar links had gemaakt en met de tram in aanraking was gekomen. Na veroordeling door de Kantonrechter voerde hij in zijn cassatieschriftuur aan dat artikel $427 \mathrm{sub} 5 \mathrm{Sr}$ voorschrijft "om de 'noodige' voorzorgsmaatregelen tegen bet aanrichten van schade te nemen; dat toch door dien maatregel met den 'normalen' gang van zaken werd rekening gehouden, terwijl het nemen van absoluut 'voldoende' maatregelen niet is vereischt". De Hoge Raad overwoog dienaangaande: ${ }^{243}$

239 Boek, J. in Cleiren, C.P.M. en Nijboer, J.F. (red.), Strafrecht. Tekst en Commentaar, p. 1142 .

240 HR 30 juni 1890, W. 1890, 5905 (Opening naast openbare weg).

241 Noyon, T.J., Langemeijer, G.E. en Remmelink, J., bewerkt door Dorst, A.J.A. van, Fokkens, J.W. en Machielse, A.J.M., Het Wetboek van Strafrecht, "Overtredingen; Artikel 427" (juni 1985), p. 24.

242. Noyon, T.J., Langemeijer, G.E. en Remmelink, J., bewerkt door Dorst, A.J.A. van, Fokkens, J.W. en Machielse, A.J.M., Het Wetboek van Strafrecht', "Overtredingen; Artikel $427^{\prime \prime}$ (juni 1985), p. 24 , noot 2.

243. HR 28 april 1930, $N J 1930$, pp. 842-843 (Paard en voorzorgsmaatregelen). 
"dat de Kantonrechter geenszins heeft beslist dat dit laatste wel nodig zou zijn; dat wijders de vraag of met een bepaalden maatregel genoeg was gedaan tegen het aanrichten van schade in elk bijzonder geval naar de omstandigheden is te beantwoorden;"

\subsection{Artikel 429 aanhef en sub $3 \mathrm{Sr}$}

\subsubsection{De zorgplichtbepaling}

Dit artikel dat (thans nog maar ten dele ${ }^{244}$ ) ziet op het voorkomen en beteugelen van brand(gevaarlijke situaties) is niet terug te vinden in het Wetboek van Strafrecht 1886 , maar werd in 1918 ingevoerd. ${ }^{245}$ Door de Staatscommissie was een uitgebreider artikel 429 Sr voorgesteld dan in 1886 werd ingevoerd, maar het bevatte niet het later ingevoerde sub 3 . In het verslag aan den Koning wordt gesteld dat delen van het voorgestelde artikel onder andere zijn weggelaten omdat: ze afhankelijk zijn van nadere voorschriften, ze te onbepaald zijn, alles wat betreft voorkoming en beteugeling van brand bij uitstek een onderwerp is van de gemeentelijke politiezorg waarin de wet zich zo weinig mogelijk moet mengen, als de wet deze voorschriften geeft de plaatselijke verordeningen niet nader kunnen aanwijzen wanneer die nalatigheid geacht wordt aanwezig te zijn. ${ }^{246}$ Aangezien de Tweede Kamer wel van mening was dat het waken tegen brandgevaar een onderwerp van algemeen belang en derhalve van Rijkswetgeving is, is een deel van het artikel toch opgenomen in het Wetboek van Strafrecht

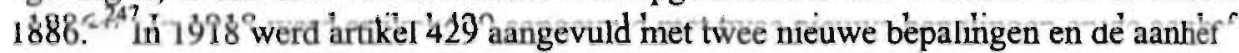
werd gewijzigd. De nieuwe aanhef en sub 3 luiden:

"Met hechtenis van ten hoogste veertien dagen of geldboete van ten hoogste honderd gulden wordt gestraft:"

" $3^{\circ}$. hij die door gebrek aan de noodige omzichtigheid of voorzorg gevaar voor bosch-, heide-, helm-, gras- of veenbrand doet ontstaan."

Het artikel werd nog enkele malen gewijzigd en aangevuld. ${ }^{248}$ De in 1918 ingevoerde bepaling is nog steeds nagenoeg geluikluidend terug te vinden in artikel 429 , aanhef en sub $3 \mathrm{Sr}$ :

244. Gezien de verschillende onderwerpen waarop het artikel betrekking wordt ook wel gesproken dat artikel 429 de restcategorie van gevaarzettingsdelicten bevat. Zie Boek, J. in Cleiren, C.P.M. en Nijboer, J.F. (red.), Strafrecht. Tekst en Commentaar, p. 1143.

245 Wet van 17 juni 1918, Stb. 1918, 395.

246 Rapport aan den Koning, Smidt, H.J., Geschiedenis van het Wetboek van Strafrecht, Deel III, pp. 199-200.

247 Verslag van de Tweede Kamer met Regeringsantwoord, Smidt, H.J., Geschiedenis van het Wetboek van Strafrecht, Deel III, p. 200. Onduidelijk blijft waarom maar een deel van de voorgestelde artikel is opgenomen en niet het voorstel in zijn geheel is ingevoerd.

248 Zie voor overige wijzigingen en aanvullingen de wetten van 9 septernber 1949, Sib. 1949,$422 ; 23$ juni 1952, Stb. 1952, 362; 13 november 1969 , Stb. 1969, $536 ; 5$ juni 1975 , Stb. 1975, 353; 24 maart 1983, Stb. 1983, 135. 
"Me hechtenis van ten hoogste veertien dagen of geldboete van de tweede categorie wordt gest $\mathrm{tt}: "$

${ }^{\circ} 3^{\circ} \mathrm{b}$ die door gebrek aan de nodige omzichtigheid of voorzorg gevaar voor bos-, heide-, helm,gre of veenbrand doet ontstaan."

$\mathrm{Sub}^{3}$ omvat door het gebruik van "of" tussen omzichtigheid of voorzorg en de opsmming van vijf verschillende locaties waar de normadressaat de brand doet ontsaan, tien verschillende situaties. De maximum strafbedreiging voor het schenden vanén van de tien situaties uit sub 3 is wat betreft de hechtenis termijn sinds 1918 ongwijzigd gebleven, terwijl de geldboete in de tussentijd wel is aangepast. De. indeng in boetecategorieën vond plaats in $1984 .{ }^{249}$ Het betreft een overtreding.

\subsection{De zorgplicht nader beschouwd}

De mzichtigheid is waarschijnlijk niet op te vatten als culpa, maar betreft een objetief begrip, waarbij kan worden gedacht aan het wegwerpen van brandende lucitrs of sigaretten. ${ }^{250}$ Of door gebrek aan de nodige omzichtigheid of voorzorg het gevar ontstaat, is afhankelijk van de omstandigheden van het geval.

Het evaai moet ontstaan voor bos-, heide-, helm-, gras- of veenbrand. Hieronder valt daarm bijvoorbeeld niet het gevaar voor brand van gemaaid of vervoerd gras.

\section{Het commuun strafrecht}

Het commuun strafrecht omvat het strafrecht dat is opgenomen in het Wetboek van Strafrecht. Het overige strafrecht dat wordt aangeduid als het bijzonder strafrecht, wordt in de volgende hoofdstukken besproken. Het Wetboek is van belang voor zorgplichtbepalingen omdat het een centrale plaats inneemt in het geheel van de Nederlandse strafwetgeving. Het in Boek I opgenomen algemeen deel is behoudens enkele uitzonderingen van toepassing op het gehele strafrecht.

In en buiten het Wetboek wordt een tweedeling aangehouden van strafbare feiten in misdrijven en overtredingen. Een aantal factoren bepalen tezamen tot welke categorie een strafbaar feit moet worden gerekend. Het betreft voomamelijk: de betekenis van het geschonden rechtsgoed, de omvang van de krenking, de wijze van aantasting, of er sprake was van een opzettelijk dan wel culpose gedraging en de plaats van het strafbare feit in het systeem van wetgeving. Of een strafbaar feit is aan te merken als misdrijf of als overtreding heeft een groot aantal materiële en procesrechtelijke consequenties. $\mathrm{ZO}_{0}$ is het bijvoorbeeld van invloed op de maximum en soort strafbedreiging, de toepasselijkheid van deelnemingsvormen, de rechterlijke competentie en de ontvankelijkheid van partijen in hoger beroep en cassatie.

249 Bij Wet van 10 maart 1984, Stb. 1984, 91, inwerkingtreding 1 mei 1984.

250 Boek, J. in Cleiren, C.P.M. en Nijboer, J.F. (red.), Strafrecht. Tekst en Commentaar, p. 1144 
Er is op dit moment een ontwikkeling gaande naar het introduceren van steeds meer instrumenten en handhavingsbevoegdheden binnen het publiekrecht. Zo worden ongewenste gedragingen niet langer strafbaar gesteld als misdrijf of overtreding, maar kunnen zij (ook) steeds vaker worden aangemerkt als bestuursrechtelijk "beboetbaar feit". De meeste van deze bestuursrechtelijke instrumenten en bevoegdheden komen naast de reeds bestaande strafrechtelijke mogelijkheden. Daarenboven zijn er die ervoor in de plaats komen. Deze uitbreiding en overheveling worden vooral gemotiveerd vanuit het idee dat sprake is van een "handhavingstekort". Het is van groot belang dat bij de invoering van nieuwe instrumenten en bevoegdheden steeds wordt nagegaan of de theoretische en praktische nadelen hiervan opwegen tegen de (vermeende) voordelen van (vooral) efficiëntie en effectiviteit. Pas als hieraan is voldaan kan een goed functionerend, evenwichtig, rechtsgebiedoverschrijdend handhavingsysteem vorm krijgen, dat voldoende tegemoet komt aan de specifieke kenmerken van de verschillende rechtsgebieden en handhavingsdiensten, en waarbij tevens de waarborgfunctie en de instrumentele functie in evenwicht zijn.

Vanzelfsprekend is het commuun strafrecht ook van groot belang bij het vaststellen van daderschap. Er zijn diverse vormen van daderschap te onderscheiden. Voor de hand liggend uitgangspunt is, dat als daders wordt aangemerkt diegenen die het strafbare feit zelf hebben gepleegd. Naast degene die het feit pleegt worden involge artikel $47 \mathrm{Sr}$ als daders aangemerkt degenen die het feit doen plegen, medeplegen of uitlokken. Ook functioneel leidinggevenden kunnen ais dader worden gestraft. Daarnaast kunnen ex artikel $51 \mathrm{Sr}$ ook rechtspersonen strafrechtelijk aansprakelijk worden gesteld voor de strafbare feiten. Indien een strafbaar feit wordt begaan door een rechtspersoon kunnen, indien zij daarvoor in aanmerking komen, ook degenen die tot het feit opdracht heeft gegeven, alsmede degenen die aan de verboden gedraging feitelijk leiding heeft gegeven, als dader worden gestraft. Met uitzondering van vooralsnog de Staat kunnen ook openbare lichamen, ambtenaren en/ of arbeidscontractanten in dienst van het openbaar lichaam strafrechtelijk worden vervolgd, "als de desbetreffende gedraging naar haar aard en gelet op het wettelijk systeem rechtens niet anders dan door bestuursfunctionarissen kunnen worden verricht in het kader van de uitvoering van de an het openbaar lichaam opgedragen bestuurstaak". Al deze categorieën kunnen te maken krijgen met een strafrechtelijke vervolging wegens het schenden van (bepaalde) zorgplichtbepalingen.

In het Wetboek van Strafrecht zijn enkele zorgplichtbepalingen opgenomen. Ze maken al lang deel uit van het Nederlandse strafrecht, aangezien ze al vanaf het begin zijn opgenomen in het Wetboek. Dit geldt alleen niet voor artikel 429 aanhef en sub $3 \mathrm{Sr}$ dat in 1918 werd ingevoerd.

De vijf besproken voorbeelden van zorgplichtbepalingen uit het Wetboek van Strafrecht zijn alle opgenomen in Boek III (overtredingen). In de volgende hoofdstukken zal blijken dat deze lijn (zorgplichtbepalingen zijn overtredingen) doorgaans wel bij de besproken zorgplichtbepalingen in het bijzonder en economisch strafrecht (hoofdstukken 7 en 8), maar vaak niet bij de zorgplichtbepalingen in het milieustrafrecht (hoofdstuk 9) wordt gevolgd. 
De naximum strafbedreiging loopt uiteen van enkel een geldboete van de eerste categorie (artikel 427, aanhef en sub 1 en $5 \mathrm{Sr}$ ) en/ of hechtenis van zes dagen (artikel 426 aanhef, eerste lici $\mathrm{Sr}$ ), hechtenis van veertien dagen en/ of een geldboete van de tweede categorie (artikel 429 aanhef en sub $3 \mathrm{Sr}$ ), tot hechtenis van zes maanden en een geldboete van. de derde categorie (artikel 425 aanhef en sub $2 \mathrm{Sr}$ ). 



\section{Deontwikkeling van het bijzonder strafrecht}

\section{Inleiding}

Zoalsin het vorige hoofdstuk is beschreven valt het strafrecht uiteen in twee delen, te wetei het commuun strafrecht en het bijzonder strafrecht. In het Wetboek van Strafecht is het algemeen deel (in Boek I) en zijn de meeste gewone strafbare feiten (mistijven in Boek II en overtredingen in Boek III) opgenomen. Daarnaast is er het bijzodder strafrecht, dat bestaat uit zo veel speciale wetten als de behoefte vordert. $\mathrm{Na}$ de Gondwetswijziging van 1887 is het duidelijker dat het in overeenstemming is met de costitutie dat veel strafrecht buiten het Wetboek van Strafrecht in andere wetten wordneergelegd. In de Grondwet werd opgenomen': "De wet regelt het burgerlijk en handèsregt, het burgerlijk en militair strafregt, de regtspleging en de inrigting der regteiijke magt worden bij de wet geregeld in algemene wetboeken." Deze regel is in aangoaste vorm nog steeds te vinden in artikel 107 van de huidige Grondwet: "De wet rgelt het (...) strafrecht (...) in algemene wetboeken, behoudens de bevoegdheid tot regeling van bepaalde onderwerpen in afzonderlijke wetten." Gezien het huidige artikel $16 \mathrm{Gw}$ en artikel $1 \mathrm{Sr}$ die luiden "Geen feit is strafbaar dan uit kracht van een daaraan voorafgegañe wettelijke strafbepaling", kan het materiële strafrecht zowel in wetgeving in formele zin als in lagere regelgeving worden aangetroffen. Van deze ruime mogelijkheid heeft de wetgever veelvuldig gebruik gemaakt. ${ }^{2}$

Nadat in het vorige hoofdstuk de totstandkoming en ontwikkeling van het commuun strafrecht is beschreven, wordt in dit hoofdstuk de ontwikkeling van het bijzonder strafrecht in wetgeving in formele zin besproken, zoals dit heeft plaatsgevonden na de totstandkoming van het Wetboek van Strafrecht. Voorts wordt er een overzicht gegeven van de totstandkomingsgeschiedenis en de inhoud van enkele zorgplichtbepalingen, te weten artikel 5 Wegenverkeerswet (hoofdstuk 7 paragraaf 3.2.), artikel 13. Luchtvaartwet (hoofdstuk 7 paragraaf 3.3.) en artikel 19 Quarantainewet (hoofdstuk 7 paragraaf 3.4.). ${ }^{3}$ In dit hoofdstuk wordt niet ingegaan op het economisch strafrecht, dat vanzelfsprekend wel deel uitmaakt van het bijzonder strafrecht. Gezien

De grondwetgever draaide de volgorde van één wetboek en verschillende wetten om ten opzichte van eerdere codificatie-artikelen. Zie hierover Enschedé, CH.J., "Het wetboek als boek", pp. 8-9. "De wet regelt" wil zeggen dat strafrechtspleging slechts mogelijk is op basis van bij of krachtens die wet vastgestelde regeling.

2 Dit geldt alleen voor het materiele strafrecht, strafvordering mag immers gezien artikel 1 Sv alleen worden gebaseerd op wetgeving in formele zin.

$3 \mathrm{Bij}$ de keuze van te bespreken bepalingen wordt aangesloten bij het Advies van de Commissie voor de toetsing van wetgevingsprojecten inzake zorgplichtbepalingen. Zie ook $\mathrm{Ru}, \mathrm{H} . J$. de, De algemene wet gaat voor de bijzondere, notities over wetgevingsbeleid, p. 14. 
het bijzondere karakter van dit deel van het strafrecht, wordt hieraan in de hoofdstukken 6 en 7 afzonderlijk aandacht besteed, waarbij opnieuw voorbeelden worden gegeven van zorgplichtbepalingen.

\section{De ontwikkeling van het bijzonder strafrecht}

In hoofdstuk 6 is beschreven dat het eerste Nederlandse Crimineel Wetboek uit 1809 ertoe heeft geleid dat onderscheid werd gemaakt tussen commuun en bijzonder strafrecht. ${ }^{4}$ Ook de Code Pénal die in 1811 werd ingevoerd kende dit onderscheid. Na de onafhankelijkheid duurde het tot 1847 voordat een ontwerp (dat het overigens niet haalde) voor een geheel nieuw nationaal wetboek werd ingediend. Hierin werd wederom onderscheid gemaakt tussen commuun en bijzonder strafrecht. De Regering motiveerde het in stand houden van het bijzonder strafrecht naast het commune door er op te wijzen dat de systematiek zich verzet tegen het opnemen van alleen de strafbepalingen uit de bijzondere wetten, omdat daardoor één onderwerp in twee verschillende wetten zou worden behandeld. Daarnaast voerde zij aan dat de aard van het bijzonder strafrecht met zijn vele veranderingen en wijzigingen zich niet leent voor opname in een wetboek dat nu juist zo veel mogelijk van blijvende en vaste aard dient te zijn. De in 1870 ingestelde commissie wier voorstel uiteindelijk leidde tot invoering van het huidige Wetboek van Strafrecht, maakte bij haar streven tot volledige codificatie van misdrijven vanwege het bijzondere karakter uitzondering voor het militaire en fiscale strafrecht. De Raad van State maakte bezwaar tegen deze "volledige" codificatie, omdat delen van dit algemeen strafrecht niet tot het bestek van een algemeen Wetboek van Strafrecht behoorden. Uiteindelijk werd in 1886 een beperkter Wetboek van Strafrecht ingevoerd, waarnaast veel bijzonder strafrecht werd gehandhaafd. ${ }^{5}$ Bij de invoering van het Wetboek werden 23 wetten afgeschaft omdat ze overbodig waren geworden, maar er bleven 53 bijzondere wetten met strafbepalingen gehandhaafd, eventueel na de nodige wijzigingen. ${ }^{6}$

Ook na 1886 is de ontwikkeling van bijzonder strafrecht doorgegaan. Van de in de Grondwet gegeven bevoegdheid tot het creëren van strafrecht buiten het Wetboek van Strafrecht is dan ook veelvuldig gebrnik gemaakt. Dit gebeurde omdat het onpraktisch werd gevonden deze strafbaarstellingen los te koppelen van de wetgeving die een bepaald specifiek onderwerp regelt, en over te brengen naar het Wetboek van Strafrecht. Daar zouden ze ook lang niet altijd hebben gepast, mede gezien hun tijdelijke of aan wijziging onderhevig zijnde aard. Juist bij veel bijzondere wetgeving, die vaak modificerend van aard is, maakt de wetgeving (en maken daardoor ook de

5 Zie over de totstandkoming van het huidige Wetboek van Strafrecht en het daarin gemaakte onderscheid tussen algemeen en bijzonder strafrecht, hoofdstuk 6 paragraaf 2.

6 Zie artikel 10 en 12 Invoeringswet; Nolte, H.J.A., Het strafrecht in de afzonderlijke wetten, p. 50; Buruma, Y., De strafrechtelijke handhaving van bestuurswetten, pp. 72 73. Van Hamel geeft een overzicht naar soort regelgeving die na de invoering van het Wetboek van Strafrecht al dan niet van kracht is gebleven; Hamel, G.A. van bijgewerkt door Dijck, J.V. van, Inleiding tot de studie van het Nederlandse strafrecht, pp. 96-106. 
strafbaarstellingen) deel uit van een bepaald beleid. Hierdoor wordt niet altijd (voldoende) aangesloten bij het rechtsbewustzijn van justitiabelen. ${ }^{7}$ Aangezien door de wetgever het schenden van een aantal voorschriften uit bijzondere wetgeving ernstig werd gevonden, werden ook zij aangemerkt als misdrijf. Tengevolge daarvan konden ook nisdrijven steeds vaker worden aangetroffen buiten het Wetboek van Strafrecht.

In het Wetboek van Strafrecht is aldus het commuun strafrecht opgenomen. Het betreft voor het merendeel strafbaarstellingen van feiten die, hoewel dit niet als onderscheidend criterium werd gehanteerd, hecht in de positieve moraal zijn verankerd. ${ }^{8}$ Deze bepalingen zijn tamelijk onafhankelijk van tijd en plaats, en beschermen rechtsgoederen die in het algemeen los van de politieke context beschermenswaardig worden geacht. De wetgever gaf bij de invoering van het Wetboek van Strafrecht als onderscheidend criterium tussen het commune en het overige strafrecht aan dat het Wetboek het positieve strafrecht als object heeft en de overige wetgeving het positieve strafrecht gebruikt als middel. ${ }^{9}$ Dit onderscheid wordt niet houdbaar geacht. In de praktjk blijkt dat de keuze om strafbaarstellingen al dan niet op te nemen in het Wetboek van Strafrecht vaak gebeurt op grond van min of meer toevallige, historisch bepaalde omstandigheden en om redenen van wetstechniek. ${ }^{10}$ Een pragmatische oplossing ten aanzien van de strafbaar gestelde feiten die zich op meer dan één gebied van het bijzondere strafrecht (kunnen) voordoen, is dat zij met oog op de rechtseenheid en systematiek niet telkens in bijzondere wetten, maar eenmalig in algemene regelgeving worden opgenomen. Het ligt dan voor de hand deze strafbaarstellingen op te nemen in het Wetboek van Strafrecht.

De ethische indifferentie of de mate van morele afkeuring als onderscheidend criterium wordt niet houdbaar geacht." Strafbaarstellingen buiten het Wetboek zijn immers vaak zeker zo "ethisch en moreel afkeurenswaardig". Wel wordt er vooral in de Duitse dogmatiek op gewezen dat vooral de levensbeschernnende functie van bepaalde rechtsgoederen een indicatie is om de bescherming daarvan via het Strafgesetzbuch te reguleren. Ook wordt erop gewezen dat de opname van strafbaarstellingen in het Strafgesetzbuch soms gewenst is, omdat daardoor de generaal-preventieve werking van het strafrecht zou worden bevorderd, evenals het bewustzijn van de bescherming van de betreffende rechtgoederen. ${ }^{12}$

7 Zie hierover hoofdstuk. 3 paragraaf 2.

8 Zie Bemmelen, J.M. van en Veen, Th.W. van, bewerkt door Jong, D.H. de en K.nigge, G., Het materiële strafrecht, p. 6. De wetgever nam dit aan voor misdrijven "zie de overweging uit de MV'T opgenomen in hoofdstuk 6 paragraaf 3.

$9 \quad$ Zie hoofdstuk 6 paragraaf 2.6.

10 Bunt, H.G. van der, "Bestuurlijke verwachtingen en ervaringen omtrent de strafrechtelijke handhaving van milieurecht", pp. 19-20.

11 Zie Enschedé, Ch.J., "Strafrecht", pp. 31-65 en gewijzigd Enschedé, Ch.J., "Strafrecht", pp. 15-36; Roos, Th.A. de, Strafbaarstelling van economische delicten, pp. 88-92; Buruma, Y., De strafrechtelijke handhaving van bestuurswetten, p. 81 .

12 Zie bijvoorbeeld Tiedemann, K., Die Neuordmung des Umweltstrafrechts, p. 18; Tiedemann, K. en Kindhăuser, H., "Umweltstrafrechtiche Bewăhrung oder Reform?, p. 339. Zie over de rechtsgoed beschermende functie van het strafrecht hoofdstuk 3 
Het bijzonder strafrecht in formele zin betreft de overige (dus niet commune) strafbaarstellingen (overtredingen en misdrijven) die in wetgeving in formele zin zijn opgenomen of op basis daarvan kunnen worden gecreëerd. Ze staan verspreid over een veelheid van wetten die soms meer, maar vaak minder zijn gericht op de strafrechtelijke bescherming van universele belangen. Deze wetgeving en de daaraan gekoppelde uitvoeringsbesluiten hebben doorgaans betrekking op een bepaald te reguleren onderwerp. De strafbaarstellingen uit deze regelgeving vullen elkaar vaak aan, maar ook komt het voor dat ze elkaar overlappen of een bepaald rechtens te beschermen belang niet beschermen. Voorts worden in de uitgebreide regelgeving (soms inclusief het Wetboek van Strafrecht) soortgelijke belangen niet eenduidig maar op verschillende wijze beschermd, hetgeen de inzichtelijkheid van het bijzonder strafrecht niet ten goede komt. ${ }^{13}$ Het betreft vaak overwegend bestuursrechtelijke wetgeving waarin slechts een enkele of één strafbaarstelling is opgenomen. Lang niet altijd is op basis van de wet de materiële inhoud van deze bepalingen te achterhalen. Die is dan te vinden in lagere regelgeving of beschikkingen. De onduidelijkheden worden hierdoor bevorderd. Hoewel de verschillen, veroorzaakt doordat de bijzondere wetgeving van verschillende departementen afkomstig is ${ }^{14}$, sterk zijn teruggedrongen ${ }^{15}$, kunnen nog steeds verschillen in de redactie van strafbaarstellingen worden aangetroffen. Hierbij komt dat ze materieel worden ingevuld door vele verschillende organen die er ook niet altijd op dezelfde manier mee om gaan. Dit verhoogt de kans op "disharmonieën"16 tussen termen uit het (bijzonder) strafrecht en tussen termen uit het strafrecht en het bestuurs- ${ }^{17}$ en privaatrecht. ${ }^{18}$

13. Doorenbos, D.R., Financieel strafrecht, p. 1.

14 Gesproken wordt dan ook over "14 wetsfamilies", deze term werd geïntroduceerd door Poelje, S.O. van, "Coördinatie van het milieubeleid", p. 65; zie ook Dijke, P. van, Goede, B. de, Kocken, E.H.A., Polak, J.M. en Reijen, L.G. van (red.), De 14 wetsfamilies; Mulder, A., "Departementale voorbereiding van wetgeving. Een exemplarische benadering", pp. 71-88; Mok, M.R., "Economisch recht", pp. 147-148.

15 Onder andere door gebruikt te maken van de: "Alanwijzingen voor de wetgever" (zie hoofdstuk 3 paragraaf 4) wordt getracht dit zoveel mogelijk tegen te gaan. Ook de harmonisatie van wetgeving door de inwerkingtreding van algemene wetten zoals de Awb en sectorale wetten zoals de Wet milieubeheer hebben hieraan bijgedragen. Voorts is dit sterk verbeterd door de toegenomen contacten tussen wetgevingsambtenaren, hun doorstroming en opleiding. Zie hierover Eijlander, P. en Voermans, W., Wetgevingsleer, pp. 6-7.

16 Ovver disharmonieën in het algemeen: Renmelink, J., Mr. D. Hazewinkel-Suringa's Inleiding tot de studie van het Nederlandse strafrecht, pp. 15-16; Bemmelen, J.M. van en Veen, Th.W. van, bewerkt door Jong, D.H. de en Knigge, G., Het materiële strafrecht, pp. 9-12.

17 Zie over de invloed van bestuursrechterlijke uitspraken op de interpretatie door de strafrechter hoofdistuk 7.

18 Zie hierover met vele voorbeelden Demeersseman, H.A., De autonomie van het materiële strafrecht en verder onder andere Beekhuis, J.H., Rechterlijke matiging bij de actie tot schadevergoeding uit onrechtmatige daad; Jonkers, J.E., "Raakpunter tussen straf- en burgerlijk recht", pp. 143-155; Remmelink, J., "Disharmonieèn tussen civielen strafrecht", pp. 243-288. 
Zoals werd aangegeven is na de totstandkoming van het Wetboek van Strafrecht de ontwikkeling van bijzonder strafrecht op zeer uiteenlopende gebieden in een hoog tempo doorgegaan. Simons heeft in zijn handboek een opsomming opgenomen van wetten met nieuwe of gewijzigde bepalingen van strafrechtelijke aard, met uitzondering van de wetten betrekking hebbend op het fiscale strafrecht. In zijn laatste werk, bijgewerkt door Pompe, werd aangegeven dat het antal (gewijzigde) bijzondere strafsepalingen bijna niet meer is te overzien, waardoor mogelijk sprake is van onvolledigheid of onnauwkeurigheid. De lijst die is bijgewerkt tot 1 januari 1936 bevat meer dan honderdvijftig nieuwe en nog veel meer wijzigingen van bestaande bijzondere wetgeving. ${ }^{19}$ Daarnaast is onder invloed van de Eerste Wereldoorlog nog een zeventiental wetten van tijdelijke aard in verband met buitengewone omstandigheden vastgesteld, die overigens in 1936 deels nog van kracht waren. ${ }^{20}$ De in 1930 begonnen economische crisis heeft opnieuw geleid tot de (tijdelijke) invoering van vele strafbaarstellingen in het bijzonder strafrecht. ${ }^{21} \mathrm{Na}$ de Tweede Wereldooriog is sprake van een enorme toename van modificerende wet- en regelgeving, waardoor steeds meer strafbepalingen worden gevonden buiten het Wetboek van Strafrecht. ${ }^{22}$

\section{Zorgplichtbepalingen in het bijzonder strafrecht}

\subsection{Inleiding}

Het bijzonder strafrecht neemt zowel kwantitatief als kwalitatief een belangrijke plaats in in het strafrecht. Indien het economisch recht buiten beschouwing wordt gelaten zijn vooral de strafbaarstellingen uit de Wegenverkeerswet 1994, de Wet wapens en munitie en de Opiumwet bekende voorbeelden van de honderden in het bijzonder strafrecht. In het bijzonder strafrecht wordt soms gebruik gemaakt van zorgplichtbepalingen. Een bekende is te vinden in artikel 5 WVW (hoofdstuk 7 paragraaf 3.2.), maar ook artikel 13 Luchtvaartwet (hoofdstuk 7 paragraaf 3.3.) en artikel 19

19 Simons, D. bijgewerkt door Pompe, W.P.J., Leerboek van het Nederíandsche strafrecht; Eerste deel Algemene leerstukken, pp. 65-76.

20 Simons, D. bijgewerkt door Pompe; W.P.J., Leerboek van het Nederlandsche strafrecht; Eerste deel Algemene leerstukken, pp. 77-78; Simons, D. bijgewerkt door Pompe, W.P.J., Leerboek van het Nederlandsche strafrecht; Tweede deel Bijzondere strafbare feiten, pp. 516-521.

21 Zie voor een overzicht voorzover het misdrijven betreft: Simons, D. bijgewerkt door Pompe, W.P.J., Leerboek van het Nederlandsche strafrecht; Tweede deel Bijzondere strafbare feiten, pp. 522-527.

22 In de bijzondere wet waarin de strafbaarstelling voorkomt zal de wetgever in die wet of in een andere wettelijke bepaling moeten aangeven of het een misdrijf of een overtreding betreft, aangezien anders geen rechter bevoegd is de zaak te behandelen. Zie hoofdstuk 6 paragraaf 3.3. Dit deed bijvoorbeeld voor bij de Wet van 11 januari 1904, Stb. 1904, 7, betreffende aanleg, exploitatie en gebruik van telegrafen en telefonen. Deze wet werd aangevuld bij Wet van 2 januari 1905, Stb. 1905, 2, met een nieuw lid bij artikel 20 luidende "De feiten in dit artikel strafbaar gesteld, worden beschouwd als overtredingen." 
Quarantainewet (hoofdstuk 7 paragraaf 3.4.) zijn voorbeelden van zorgplichtbepalingen. ${ }^{23}$ Deze zorgplichtbepalingen in het bijzonder strafrecht, worden hier achtereenvolgens besproken.

\subsection{De Wegenverkeerswet}

\subsubsection{Inleiding}

Op zeer veel en zeer verschillende gebieden heeft het bijzonder strafrecht zijn intrede gedaan. Zo speelt het (ook kwantitatief ${ }^{24}$ ) een belangrijke rol in het verkeersrecht. Dit is tevens een van de oudere gebieden van het hedendaags bijzonder strafrecht. In de negentiende eeuw bestonden op het terrein van het verkeersrecht reeds allerlei lokale regelingen. De noodzaak tot regelgeving werd na de introductie van de drie en vierwielige voertuigen met gasmotoraandrijving in 1885 en 1886 duidelijk. Het verkeersrecht viel aan het eind van de negentiende eeuw uiteen in drie belangrijke hoofdgroepen, te weten politieverordeningen die bepalingen bevatten binnen de bebouwde kom, de provinciale reglementen die bepalingen bevatten aangaande verkeerssituaties op de provinciale wegen en rijkswegen die vanaf 1891 vielen onder het Rijkswegenreglement. ${ }^{25}$ In de Code Pénal was voor het eerst in het algemeen strafrecht een strafbaarstelling aangaande het overtreden van een aantal plaatselijke en provinciale verkeersregelingen opgenomen. $\mathrm{Bij}$ de nationale codificatie werd aanvan-

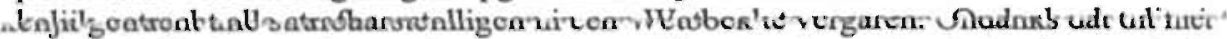
succesvol bleek, werden enkele strafbaarstellingen die verband houden met de instandhouding, bescherming, het gebruik van of het verkeer op de wegen opgenomen in het nieuwe wetboek. ${ }^{26}$ In 1905 werd, na enkele mislukte pogingen, een eerste bijzondere wet met een repressief stelsel van controle ingevoerd die betrekking had op de openbare wegen. Het betreft de Motor- en rijwielwet. ${ }^{27}$ Deze werd in 1935 vervangen door een nieuwe bijzondere wet (de Wegenverkeerswet 1935), waarvoor met ingang van 1 januari 1995 de huidige Wegenverkeerswet 1994 in de plaats is gekomen. ${ }^{28}$ In deze laatste wet is in artikel 5 een zorgplichtbepaling opgenomen. Deze bepaling en haar voorlopers zijn in het kader van de bespreking van zorgplichtbepalingen zeer interessant aangezien bij de (discussies voorafgaande aan de)

23 Zie ook het Advies van de Commissie voor de toetsing van wetgevingsprojecten inzake zorgplichtbepalingen.

24 Zie Buruma, Y., De strafrechtelijke handhaving van bestuurswetten, p. 85.

25 Otte, M., Het stelsel van gedragsregels in het wegverkeer, pp. 7-10.

26 Het betreft de artikelen 162, 163, 426 en $427 \mathrm{Sr}$. Zie hierover Smidt, H.J., Geschiedenis van het Wetboek van Strafrecht, Deel II, p. 142-143 en Deel III, pp. 185-196. Deze bepalingen zijn niet rechtstreeks te rubriceren als verkeersrecht; zie Remmelink, J., Hoofdwegen door het verkeersrecht, p. 19. Zie over de codificatie van het verkeersrecht Otte, M., Het stelsel van gedragsregels in het wegverkeer, pp. 10-14.

27 Wet van 10 februari 1905, Stb. 1905, 69.

28 Zie over deze ontwikkeling Otte, M., Het stelsel van gedragsregels in het wegverkeer, pp. 14-21; Kroeze, F.J.J., Wegenverkeerswetgeving, pp. 3-165; Weersma, W.J.M. en Polak, N.J., De Wegenverkeerswet, pp. 99-105; Remmelink, J., Hoofdwegen door het verkeersrecht, pp. 19-24. 
invering van nieuwe zorgplichtbepalingen op andere terreinen van het bijzonder straecht regelmatig wordt verwezen naar de zorgplichtbepaling uit de Wegenverkerswet.

\subsection{Motor- en rijwielwet 1905}

In d Motor- en rijwielwet uit 1905 werd in artikel 15 voor het eerst een algemeen veilgheidsvoorschrift opgenomen dat zich richtte tegen verkeersgedrag dat de vrijheid en $d$ veiligheid van het verkeer in gevaar brengt. Voordat sprake was van deze eerste bijzndere wet diende degene die met een motorvoertuig op rijkswegen ging rijden te besaikken over een door de minister te verlenen vergunning. Aan deze vergunning warn voorschriften verbonden, zoals dat de snelheid in sommige gevallen niet meer moat zijn dan acht kilometer per uur en dat afhankelijk van de omstandigheden de sneleid moest worden verminderd telkens als het verkeer dat vereiste. Uniforme sneleidsregelingen waren op dat moment nog niet ontwikkeld, en veel sterk uiteenlopade lokale regelingen bevatten soms regels omtrent de maximumsnelheid. ${ }^{29}$ De autowerd als potentieel gevaarlijk gezien. ${ }^{30}$ Gevaarlijk rijden diende in de nieuwe wet stra)aar te worden gesteld in een algemene strafbepaling, die gerelateerd moest zijn aan en maximumsnelheid. ${ }^{31}$

In 0 bijlage van het wetsvoorstel werden enkele verkeerswetten opgenomen die in andere landen reeds tot stand waren gekomen. ${ }^{32}$ De zorgplichtbepaling is geînspireerd op het Belgische en het Engelse recht. ${ }^{33}$ In het Belgische Algemeen Reglement op de politie van het vervoer en van het verkeer uit 1899 was een in artikel 15 een algemene veiligheidsvoorschrift opgenomen dat luidde:

"Het is verboden voertuigen en dieren met eene snelheid te doen rijden welke het verkeer in gevaar zou brengen."

De minister wees ook op de Engelse Motorcar Act 1903, waarvan artikel 1 luidde:

"If any person drives a motor car on a public highway recklessly or negligently, or at a speed or in a manner which is dangerous to the public, having regard to all circumstances of the case,

29 Otte, M., Het stelsel van gedragsregels in het wegverkeer, p. 23.

30 Op 24 september 1901 vond in Valkenburg aan de voet van de Cauberg het eerste. Nederlandse auto-ongeval met dodelijke afloop plaats; zie hierover Remmelink, J., Hoofdwegen door het verkeersrecht, p. 30.

31 Otte, M., Het stelsel van gedragsregels in het wegverkeer, p. 23. Zie TK 1902-1903, nr. 128.4 , p. 11 , waar het voorstel van sommige leden wordt besproken om een strafbepaling in te voeren "volgens hetwelk verboden is, motorrijtuigen met cene snelheid te doen rijden, welke het verkeer in gevaar zoude brengen." De minister kan zich hier tot. op zekere hoogte mee verenigen, zie TK 1903-1904, nr. 14.1, p. 2 en bespreekt kort enkele buitenlandse oplossingen.

32 TK 1903-1904, nr. 14.2, waarin de wetgeving uit Groot-Britaniê en Ierland, Frankrijk en. Duitsland is opgenomen.

33 Rernmelink, J., Hoofdwegen door het verkeersrecht, p. 9; Otte, M., Het stelsel van gedragsregels in het wegverkeer, p. 24. 
including the nature, condition, and use of the highway, and the amount of traffic which actually is at the time, or which might reasonably be expected to be, on the highway, that person shall be guilty of an offence under this act."

Deze laatste bepaling vond hij echter minder geschikt omdat zij nodeloos uitvoerig zou zijn geformuleerd en een eenvoudiger uitdrukking de voorkeur verdiende. ${ }^{34}$ In de oorspronkelijke eenvoudige versie was in artikel 15 wel de link met de maximumsnelheid opgenomen. Bij de behandeling in de kamer werd echter een amendement ingediend waardoor deze directe band gedeeltelijk werd losgelaten. ${ }^{35}$ Het uiteindelijk tot stand gekomen artikel 15 Motor- en rijwielwet 1905 luidde $^{36}$ :

"Het is den bestuurder van een motorrijtuig of een rijwiel verboden daarmede over een weg te rijden op zoodanige wijze of met zoodanige snelheid, dat de vrijheid of de veiligheid van het verkeer op dien weg wordt belemmerd of in gevaar gebracht."

De schending van artikel 15 werd involge artikel 18 van deze wet bedreigd met hechtenis van ten hoogste dertig dagen of geldboete van maximaal honderdvijftig gulden. Bij een veroordeling was het ex artikel 20 Motor- en rijwielwet 1905 mogelijk de veroordeelde de bevoegdheid motorrijtuigen te besturen voor ten hoogste een jaar te ontzeggen. Involge artikel 19 Motor- en rijwielwet 1905 betrof het een overtreding.

De Motor- en rijwielwet werd herhaaldelijk gewijzigd, waarbij steeds meer specifieke regels werden ingevoerd ter regulering van het verkeer. Artikel 15 bleef gehandhaafd, maar werd bij een wetswijziging in 1924 omgenummerd tot artikel $22 \mathrm{sub} \mathrm{a}^{37}$, waarbij tevens het bestanddeel "op dien weg" werd geschrapt. Een voorstel om de reikwijdte van de bepaling uit te breiden tot gedragingen van bestuurders van andere rij- of voertuigen of (geleiders van) rijdieren, zoals ruiters, koetsiers, en karrenvoerders haalde het niet. ${ }^{38}$ De normadressaten van de bepaling bleven dan ook beperkt tot de bestuurders van motorrijtuigen en rijwielen.

34 TK 1903-1904, nr. 14.1, p. 6, "Boven de noodeloos uitvoerige formulering van section I, subsection (1) der Engelsche wet van 1903, is de voorkeur gegeven aan een eenvoudiger uitdrikking in den geest van art. 15, eerste lid, van het Belgische politieregelement." De Hoge Raad gebruikte de Engelse bepaling overigens wel voor de interpretatie van artikel 22 Motor- en rijwielwet, zie HR 23 juni 1930, N.J 1930, pp. 1662-1664, met noot Taverne (Verblindende lantaarn).

35 Zie voor een uitvoeriger bespreking: Otte, M., Het stelsel van gedragsregels in het wegverkeer, pp. 23-26; Weersma, W.J.M. en Polak, N.J., De Wegenverkeerswet, pp. 100-104; Rosendahl Hubber, A.E., "Het kapstokartikel 22 sub a der Motor en Rijwielwet l", pp. 225-226.

36 Wet van 10 februari $1905,5: b .1905,69$.

37 Wet van 1 november 1924, Stb. 1924, 492, in werking getreden op 1 januari 1927. Zie over artikel 22 sub a Rosendahl Hubber, A.E., " Het kapstokartikel 22 sub a der Motoren Rijwielwet I" en II, pp. 221-227 en 237-243; en de reacties hierop: Besier, B.J., "Het kapstokartikel 22 sub a der Motor- en Rijwieiwet", pp. 282-284; Hollander, F., "Het kapstokartikel 22 sub a der Motor- en Rijwiclwet", pp. 285-286 en Rikmenspoel, E., "Het kapstokartikel 22 sub a der Motor- en Rijwielwet", pp. 286-287. $T K$ 1922-1923, nr. 97.4, p. 29, zij voerde aan dat ook door deze normadressaten 


\subsubsection{Wegenverkeerswet 1935}

In 1935 is artikel 22 sub a Motor- en rijwielwet na omnummering en aanpassing terug te vinden in artikel 25 Wegenverkeerswet $19355^{39}$ Deze wet trad echter pas na de bezetting en na enkele wijzigingen, op 1 januari 1951 in werking. ${ }^{40}$ Tot die tijd bleven de Notor- en rijwielwet en het Motor- en rijwielreglement en de daarop gebaseerde beschikkingen gedeeltelijk van kracht. Tijdens de Duitse bezetting werd een groot deel van de Motor-en rijwielwet buiten werking gesteld en gold van 16 december 1941 tot 1 januari 1951 de (uit het Duits vertaalde) Wegenverkeersregeling. ${ }^{41}$ Hierin was een bepaling opgenomen die gelijkenis vertoonde met het nog niet ingevoerde artikel 25 WVTV 1935; artikel 2 Wegenverkeersregeling luidde ${ }^{42}$ :

"Elke weggebruiker dient zich op een zoodanige wijze te gedragen, dat het verkeer niet in gevaar kan worden gebracht. Hij dient zich tevens zoo te gedragen, dat aan een ander geen schade wordt berokkend of die ander niet in sterker mate wordt belemmerd of overlast ondervindt dan in de gegeven omstandigheden onvermijdelijk is."

Bij de wetswijziging in 1935 werd de reikwijdte van deze bepaling niet langer beperkt tot bestuurders van motorrijtuigen en rijwielen. In het voorstel werden als normadressaat aangemerkt "den bestuurder van een motorijtuig, een rijwiel of een ander rij- of voertuig". ${ }^{43}$ Bij de behandeling in de kamer bleek de wens te bestaan de normadressaten van de bepaling nog verder uit te breiden, en wel tot de voetgangers. ${ }^{44}$ Deze uitbreiding haalde het aanvankelijk niet. $\mathrm{Na}$ de oorlog werd in 1948 de behandeling van het wetsvoorstel weer ter hand genomen. De Commissie voor Openbare Werken, Verkeer en Waterstaat rapporteerde dat zij van mening is dat alle weggebruikers dus ook de voetgangers aan de verkeersregeling onderworpen dienden te zijn. Dit beginsel behoort volgens de Commissie te worden overgebracht naar artikel $25 .{ }^{45}$ Dit standpunt werd onderschreven door de minister van Verkeer en

"somtijds de veiligheid van het verkeer in gevaar wordt gebracht en dat dit evenzeer moet worden voorkomen." Het voorstel werd afgewezen: "Eene regeling op dit punt houdt echter niet zoodanig verband met het motor-en rijwielverkeer, dat met het oog daarop opneming in deze wet gerechtvaardigd zoude zijn; zij behoort ook meer thuis in provinciale of plaatselijke verordeningen.", zie $T K$ 1923-1924, nr. 52.1, p. 7. Zie ook Otte, M., Het stelsel van gedragsregels in het wegverkeer, pp. 26-27.

Wet van 13 september 1935, Stb. 1935, 554.

Wet van 22 deçember 1948, Stb. 1948, 562.

Wegenverkeersregeling, Verordeningenblad 1941, no. 193. Vellinga, W.H., Gevaar en schuld op de weg, p. 25; Remmelink, J., Hoofdwegen door het verkeersrechi, pp. 20-21.

Zie over deze bepaling Vellinga, W.H., Gevaar en schuld op de weg, pp. 25-26.

4 Deze uitbreiding werd verklaard door te wijzen op de toenemende intensiteit van het verkeer waardoor de kans zou toenemen dat ook andere bestuurders gevaar veroorzaken, zie ook Otte, M., Het stelsel van gedragsregels in het wegverkeer, p. 27.

4 Het werd wenselijk geacht een soortgelijke bepaling op te nemen als Amsterdam sinds 1 januari 1935 kent voor voetgangers, $E K$ 1934-1935, p. 784, zie ook Otte, M., Het stelsel van gedragsregels in het wegverkeer, pp. 27-28.

45 TK 1948-1949, 800, nr. 4, p. 1, zie ook Vellinga, W.H., Gevaar en schuld op de weg, p. 26; Otte, M., Het stelsel van gedragsregels in het wegverkeer, pp. 28 en 176. 
Waterstaat ${ }^{46}$, en na wijziging zonder discussie goedgekeurd door de Eerste en Tweede Kamer. In het uiteindelijke artikel is hierdoor geen specifieke(re) aanduiding van de normadressaat te vinden, waardoor kan worden voorgehouden dat de bepaling zich richt tot een ieder. Dit wordt echter beperkt doordat de plaats van de gedraging van de normadressaat wel is aangegeven, deze moet plaatsvinden op een weg. De Hoge Raad oordeelde dat deze gedragingen bestaan uit enig daadwerkelijk gebruik van de weg." Maar ook door dit criterium was niet altijd duidelijk wie wel en wie niet tot de normadressaten kan worden gerekend. Zo werd een bediener van overwegbomen die een afsluitboom liet zakken op het moment dat een motorrijtuig zich op de overweg bevond waardoor de veiligheid op de weg in gevaar werd gebracht of kon worden gebracht ontslagen van rechtsvervolging omdat hij geen weggebruiker was. ${ }^{48} \mathrm{De}$ gedraging van een rangeerder die een trein begeleidde over een rangeerspoor en zonder de vereiste maatregelen te treffen de trein een overweg liet oprijden waardoor tussen de trein en een auto een botsing plaatsvond werd wel aangemerkt als "een gedraging als weggebruiker en derhalve als het "zich op een weg gedragen" als bedoeld in art. 25 W.V.W.,"49

Daamaast werd het artikel, dat geen nauwkeurige omschrijving bevat van gedraging(en) die ge- of verboden zijn ${ }^{50}$, ook opgerekt met betrekking tot de strafbaar gestelde gedragingen die onder de reikwijdte vallen. Niet langer was sprake van het vereiste dat sprake was van belemmering of het in gevaar brengen van het verkeer, maar de norm kan nu ook worden geschonden indien "redelijkerwijze is aan te nemen, dat de veiligheid op de weg in gevaar kan worden gebracht". Deze toevoeging werd aangebracht om duidelijk te doen uitkomen dat ook strafbaar is het ${ }^{\text {s1 }}$

"zoodanig rijden, hetwelk, alle omstandigheden in aanmerking genomen, door de wijze, waarop of de snelheid, waarmede het geschiedt, het verkeer op den weg onveilig kan maken. Gedacht

46 TK 1948-1949, 800, nr. 5, p. 1, zie ook Otte, M., Het stelsel van gedragsregels in het wegverkeer, pp. 28.

47 Simmelink, J.B.H.M., Algemeenheden in het wegenverkeersrecht, pp. 130-135. De Hoge Raad is echter niet altijd consequent, zie ook Jebbink die in tegenstelling tot Vellinga pleitte voor een ruimer toepassingsbereik van artikel 25 WVW, Jebbink, P.J., "Tot wie richt zich de norm van art. 25 W.V.W?", pp. 169-171; Vellinga, W.H., Gevaar en schuld op de weg, pp. 28-30. Zie ook Remmelink, J., "Tijd en plaats in het verkeersrecht", pp. 205-209 die aangeeft dat gevaarzettend verkeersgedrag kan ook worden veroorzaakt en zelfs uitgelokt door gedragingen die niet op de weg plaatsvinden.

48 HR 10 maart 1953, NJ 1965, 304; VR 1955, 56 (Afsluit-boom).

49 HR 23 februari 1965, NJ 1965, 303, met noot Pompe; VR 1965, 65 (Rangeerder is weggebruiker).

50 Peters stelt dat dergelijke delictsomschrijvingen dienen te worden vermeden omdat zij geen preventieve functie hebben aangezien zij niet een bepaalde gedraging verbieden. Peters, A.A.G., Opzet en schuld in het strafrecht, pp. 35-36. Zie ook Barendrecht, J.M., Recht als model van rechtvaardigheid, p. 190. Daarentegen meent van Schilfgaarde juist dat een norm 'behoorlijk gedrag' meer preventieve waarde heeft dan een scherp geformuleerd juridische abstractie. Schilfgaarde, P. van, "Vage normen", pp. 61-62.

51 Zie TK 1923-1924, 484, nr. 3, p. 12, zie ook Otte, M., Het stelsel van gedragsregels in het wegverkeer, p. 27. 
wordt bijv. aan de gevallen, dat men redelijkerwijs er op bedacht moet zijn ergens verkeer aan te treffen (zooals op hoeken van wegen) al bevinden zich precies op het oogenblik dat, en juist ter plaatse, waar het rijden plaat vindt, zonder dat men zich daaromtrent vooraf zekerheid kan verschaffen, geen andere voertuigen of personen."

Het is de bedoeling van de wetgever geweest de strafbaarheid uit te breiden tot gedragingen die niet onder het RVV vallen en ook niet (in concreto) enig gevaar hebben veroorzaakt. $^{52}$

Voorts werd ook de aanduiding ten aanzien van wie de vrijheid of veiligheid wordt belemmerd of in gevaar wordt gebracht versoepeld. Is in artikel 15 Motor- en rijwielwet 1905 en 22 sub a Motor- en rijwielwet 1924 nog sprake van de belemmering of gevaarzetting van de "vrijheid of de veiligheid van het verkeer", in de Wegenverkeerswet 1935 is nog wel sprake van de belemmering van de "vrijheid van het verkeer", maar betreft het een gevaarzetting van de "veiligheid op de weg". Hierdoor kunnen ook gedragingen die anderen dan weggebruikers in hun veiligheid (kunnen) bedreigen onder de reikwijdte van de strafbepaling vallen, waarbij bijvoorbeeld kan worden gedacht aan degene die zelf de gevaarzetting veroorzaakt, medepassagiers en goederen. ${ }^{53}$

Bij de behandeling in de kamer bleek dat deze uitbreidingen nog niet ver genoeg gingen, aangezien de bepaling slechts betrekking had op gevaarlijk rijden en niet op gevaarlijk stilstaan. $^{54}$ Ook deze uitbreiding haalde het aanvankelijk niet, maar in de uiteindelijke versie ziet de bepaling niet langer alleen op de wijze van rijden of de snelheid, maar op alle verkeersgedragingen op de weg.

Wel is de restrictie opgenomen dat de belemmering van het verkeer "zonder noodzaak" plaatsvindt. ${ }^{55}$ Deze restrictie geldt gezien de tekst van de strafbaarstelling niet voor de tweede en derde zorgplicht van artikel $25 \mathrm{WVW}$, te weten de gevaarzetting. ${ }^{56}$ Door opneming van "zonder noodzaak." in de delictsomschrijving is deze voorwaarde voor de eerste zorgplicht een bestanddeel geworden, die door het OM moet worden ten laste gelegd en bewezen, wil het tot een veroordeling kunnen komen. Het voordeel hiervan is dat het $\mathrm{OM}$ alvorens te vervolgen zich rekenschap moet geven of de verkeerssituatie niet zodanig was dat de betreffende gedraging werd gerechtvaardigd. ${ }^{57}$ Het in 1951 in werking getreden artikel 25 Wegenverkeerswet 1935 luidde ${ }^{38}$ :

52. Van Veen merkt op dat het gevallen van deze aard zijn, waarin een proces-verbaal soms zeer begrijpelijk irritatie bij de bekeurde persoon oproept. Veen, Th.W. van, "Strafrecht en verkeersveiligheid (I)", p. 123.

53. Remmelink, J., Hoofdwegen door het verkeersrecht, p. 39.

$54 \quad$ Zie Otte, M., Het stelsel van gedragsregels in het wegverkeer, p. 27.

55 Dit gebeurde zonder enig commentaar bij de naoorlogse wijziging van het artikel op 22 december 1948, $S b$ b. 1948, 562.

$56 \quad$ Zie HR 25 april 1961, VR 1961, 58 (Schuin overstekende truck).

57 Remmelink, J., "Omvang en functie van art. 25 W.V.W.", pp. 86-87; Remmelink, J., Hoofdwegen door het verkeersrecht, pp. 37-38; Vellinga, W.H., Gevaar en schuld op de 
"Het is verboden zich op een weg zodanig te gedragen, dat de vrijheid van het verkeer zonder noodzank wordt belemmerd of de veiligheid op de weg in gevaar wordt gebracht of redelijkerwijze is aan te nemen, dat de veiligheid op de weg in gevaar kan worden gebracht."

De in artikel 25 strafbaar gestelde feiten waren ex artikel $38 \mathrm{WVW}$ overtredingen. Het schenden van artikel 25 WVW werd ex artikel 35, derde lid WVW bedreigd met hechtenis van ten hoogste drie maanden of geldboete van ten hoogste duizend gunden. Voorts kon de bestuurder van het motorrijtuig bij veroordeling wegens schending van artikel 25 involge artikel 39 WVW de bevoegdheid tot het besturen van motorrijtuigen voor ten hoogste vijf jaren worden ontzegd. ${ }^{5}$

Artikel 25 WVW bestaat door het gebruik van het verbindingswoordje "of" uit drie verschillende situaties. Het betref: (1) Het verbod zich op de weg zodanig te gedragen dat de viijheid van het verkeer zonder noodzaak wordt belemmerd; (2) Het verbod zich op de weg zodanig te gedragen dat de veiligheid op de weg in gevaar wordt gebracht; (3) Het verbod zich op de weg zodanig te gedragen dat redelijkerwijze is aan te nemen dat de veiligheid op de weg in gevaar kan worden gebracht. Omdat het bestanddeel "gevaar" erg ruim werd uitgelegd, wordt ook wel gesteld dat artikel 25 WVW inhoudelijk twee in plaats van drie afzonderlijke situaties betreft. ${ }^{60} \mathrm{Het}$ in gevaar brengen en het in gevaar kunnen brengen kornt daardoor zo dicht bij elkaar te liggen dat het betekenisbereik van de tweede en de derde situatie samen vallen. ${ }^{61}$

Aan artikel 25 WVW liggen ten minste twee beginselen ten grondslag ${ }^{62}$; te weten van de veiligheid en de vlotheid. Veiligheid omdat de veiligheid van het verkeer niet in

weg, pp. 32-35 die aangeeft dat met "zonder noodzaak" wordt bedoeld "zonder verkeersnoodzaak", waardoor een beroep op een overmacht-noodtoestand gebaseerd op een verkeerssituatie kan leiden tot vrijspraak en een beroep op een overmachtnoodtoestand buiten het verkeer aanleiding kan zijn voor een ontslag van rechtsvervolging.

58 Zie voor artikel 25 WVW de wet van 22 december 1948, Stb. 1948, 562 .

59 Zie voor artikel 35,38 en 39 WVW de wet van 13 septernber 1935, Stb. 1935, 554.

60 Vellinga meent in tegenstelling tot bijvoorbeeld Remmelink, J., "Onvvang en functie van art. 25 W.V.W.", pp. 85-86 en latere schrijvers (zie volgende noot), dat artikel 25 WVW 1935 niet uit drie maar uit twee delicten bestaat. Hij stelt dat het derde deel van de bepaling werd opgenomen, om in navolging en ter bevestiging van jurisprudentie op artikel 22 sub a MRW te benadrukken dat de veiligheid op de weg ook wel in gevaar kan zijn gebracht als er toevallig niemand op de weg is. Vellinga, W.H., Gevaar en schuld op de weg, pp. 27-28.

61 Zie met voorbeelden Krabbe, H.G.M., "De artikelen 5 en 6 Gevaar veroorzaken, hinderen en schuld aan een verkeersongeval", pp. 90-91; Simmelink, J.B.H.M., Algemeenheden in het wegenverkeersrecht, p. 157.

62 Zie hierover Remmelink, J., “'Prinzipiënreiterei' door het verkeersrecht", pp. 193-197; Remmelink, J., Hoofdwegen door het verkeersrecht, pp. 24-29. Verder noemt hij het vertrouwensbeginsel; het beginsel dat degene die het "normale" verkeersbeeld wijzigt zich bij het uitvoeren van dergelijke manoeuvre aan het andere wegverkeer dient aan te passen/ niet mag hinderen; en het beginsel dat degene die de rechterweghelft berijdt zoveel mogelijk moet worden ontzien (hetwelk overigens deels wordt doorkruist door 
gevaar mag worden gebracht, en vlotheid gezien de eis dat men de vrijheid van het verkeer niet zonder noodzaak mag belemmeren. Deze twee beginselen zijn vaak elkaars tegengestelden, waardoor de rechter door een evenwichtige interpretatie de tegenstelling zal dienen te verzoenen, waarbij hij bij conflicten het veiligheidbeginsel meestal zal laten prevaleren. ${ }^{63}$

\subsubsection{RVV 1966 en RVV 1990}

Op 1 januari 1967 trad het Reglement Verkeersregels en Verkeerstekens (RVV 1966) in werking die conform de naam alleen betrekking had op de verkeersregels en tekens. Dit werd gebaseerd op artikel 2 WVW. Het Reglement bevatte een uitgewerkt en gedetailleerd systeem van normstellingen waardoor de reikwijdte van het strafrecht redelikk nauwkeurig werd vastgesteld. Aan deze RVV lag de gedachte ten grondslag dat voor elke denkbare verkeerssituatie een concrete instructie te formuleren, waardoor artikel 25 WVW overbodig zou worden, en daarom kan worden geschrapt. In de Nota van toelichting valt te lezen ${ }^{64}$ :

"Hij kan niet volstaan met een aantal regels te geven, die niet alle situaties dekken en dan met een algemene abstracte norm zijn eigen legislatief onvermogen laten aanvullen door de weggebruiker. Het huidige artikel 25 van de Wegenverkeerswet is een dergelijke abstacte norm. Het stat aan de verkeersdeelnemer om zonder dat daaromtrent nadere precisering gegeven wordt te zorgen, dat de vrijheid van het verkeer niet zonder noodzaak wordt belemmerd, dat de veiligheid op de weg niet wordt in gevaar gebracht en zelfs dat die veiligheid niet in gevaar kàn worden gebracht.

$\mathrm{Nu}$ is het natuurlijk niet mogelijk iedere verkeerssituatie in een concrete norm te vangen. $\mathrm{Er}$ blijven, ook bij een zo volledig mogelijke analyse, lacunes. Voor die gevallen moet cen meer algemene norm gegeven worden en moet een grotere wissel getrokken worden op het verantwoordelijkheidsgevoel van de weggebruiker. Ook die algemene normen behoren evenwel toch een zekere aanwijzing voor de justitiabelen te bevatten.

Het ontwerp is erop gericht volledig te zijn zonder dat het nodig is artikel 25 van de Wegenverkeerswet te hulp te roepen. Het bevat enerzijds concrete gedragsregels, die niet alle verkeerssituaties omvatten, en moet dus anderzijds de lacunes, die het bevat, dekken.

( ...)

Naar de mening van de ondergetekende is dit samenstel van bepalingen voldoende om de thans door artikel 25 van de Wegenverkeerswet opgevulde lacune te dichten. In plaats van een norm, die slechts aangeeft, dat een abstract omschreven gevolg moet worden vermeden, vindt men thans positieve aanwijzingen, hoe men zich moet gedragen. (...) De morele verwijtbaarheid is de grondslag voor een verantwoorde strafvervolging. $\mathrm{Zij}$ is in het voorgestelde systeem beter verankerd dan in het geldende.

het in opkomst zijnde keep-in-your-lane beginsel).

Zo stelde de Hoge Raad "het grondbeginsel van het verkeer op den weg hetwelk te allen tijde moet gelden en (...) iedere weggebruiker voorschrijft zich op zodanige wijze te gedragen dat het verkeer niet in gevaar kan worden gebracht" HR 9 mei 1950, $N J 1951$, 357 (Parkeren van auto op trottoir); zie ook Remmelink, J., Hoofdwegen door het verkeersrecht, p. 25.

Nota van Toelichting bij het RVV 1966, Stb. 1966, 181, p. 467. 
Intussen blijft artikel 25 van de Wegenverkeerswet ook bij inwerkingtreding van het onderhavige ontwerp gelden, totdat misschien bij vervanging van de Wegenverkeerswet tot afschaffing zal worden besloten."

Tot de afschaffing van artikel 25 WVW is het niet gekomen. De visie over normstellingen in het strafrecht veranderde, mede onder invloed van het streven naar deregulering. ${ }^{65}$ De Commissie Geelhoed gaf aan dat het hele RVV kritisch doorgenomen zou moeten worden ${ }^{66}$, en in het rapport van de Commissie Roethof valt te lezen ${ }^{67}$ :

"Het ministerie van Verkeer en Waterstaat dient op korte termijn een begin te maken met een nadere analyse van het huidige bestand van verkeersregels en verkeerstekens ten einde te schrappen wat bij nadere beschouwing kan worden gemist en aanpassingen door te voeren waar een teveel aan verfijning de effectiviteit van de regelgeving in de weg staat."

In het beleidsplan Samenleving en Criminaliteit werd aangekondigd dat de minister van verkeer en waterstaat prioriteit zou geven aan de deregulering van het RVV $1966{ }^{68}$ In het RVV 1990 die (wederom op basis van artikel $2 \mathrm{WVW}^{69}$ ) op 1 november 1991 werd ingevoerd en het RVV 1966 verving, werd het systeem van regulering met uitgewerkte en gedetailleerde normstellingen losgelaten. In de Nota van toelichting van het RVV 1990 wordt opgemerkt ${ }^{70}$ :

"De aangevoerde bezwaren betreffen veeleer de omvang van het regel- en tekenbestand. Het is de totaliteit die niet helder is.

Om die reden is gezocht naar uitgangspunten vooi een reglement dat duidelijk en geloofwaardig is. Daarbij zijn deze uitgangspunten gekozen:

65 In de Nota van toelichting van het RVV 1990 wordt verwezen naar de conclusies van de commissie vermindering en vereenvoudiging van overheidsregelingen, ook wel genoemd naar haar voorzitter, de commissie Geelhoed (Eindrapport TK 1983-1984, nr. 17931 , nr. 9) en bevat een aparte paragraaf XI Deregulering, Stb. 1990, 459, pp. 63-64 en 80-81; zie hierover bijvoorbeeld Salomon, F. (red.), "RVV 1990 Alg.", pp. 4-11; Simmelink, J.B.H.M. en Otte, M. "De herziening van het RVV: Een 'Salomonsoordeel'?", pp. 294-301.

66 Commissie Geelhoed, Eindrapport TK 1983-1984, nr. 17 931, nr. 9, zie vooral p. 259.

67 Interimrapport van de Commissie Kleine Criminaliteit, pp. 55-56 zie ook het Eindrapport van de Commissie Kleine Criminaliteit.

68 Samenleving en criminaliteit; Een beleidsplan voor de komende jaren, $T K$ 1984-1985, 18 995, nr. 2, pp. 74-78. Zie ook Samenleving en criminaliteit; Voortgangsrapportage 1986, TK 1985-1986, 18 995, nr. 14, pp. 13-14.

69 Ook de administratieve bepalingen inzake het wegverkeer die voorheen waren opgenomen in het RVV 1966 keerden niet terug in het RVV 1990, maar werden opgenomen in een nieuw eveneens op artikel 2 WVW genomen besluit dat ook op 1 november 1991 in werking trad, te weten het Besluit administratieve bepalingen inzake het wegverkeer (BABW), Besluit van 26 juli 1990, Stb. 1990, 460.

70 Nota van Toelichting bij het RVV 1990, Stb. 1990, 459, pp. 65-66 en 68, zie ook Otte, M., Het stelsel van gedragsregels in het wegverkeer, p. 169; Salomon, F. (red.), "RVV 1990 Alg.", 1-30. 
Verkeersregels moeten tot de basisregels worden beperkt. Ook verkeerstekens dienen slechts in essentiēle gevallen te worden toegepast.

Juridische regels zijn slechts aanvaardbaar als alternatieven ontbreken." (...)

"Het is wel duidelijk dat: de wetgever van een kwart eeuw geleden wilde de verkeersdeelnemer niet met een abstracte opdracht de woestijn insturen. Er moest voor elke denkbare situatie een concrete instructie komen. Daarna zou men artikel 25 gevoeglijk kunnen schrappen." (...)

"De vraag is nu of dit uitgangspunt van de jaren zestig nog geldt. Na wat vooraf ging, is die vraag in feite beantwoord. Alleen al om praktische redenen moet het antwoord <<nee >> luiden. Het aantal voorschriften is zo groot geworden dat de verkeersdeelnemers ze onmogelijk allemaal kunnen leren en onthouden, of ze in het drukke verkeer altijd naar de letter kunnen toepassen. Daamaast is een ervaringsregel dat weggebruikers veel regels en tekens bewust negeren, kennelijk omdat ze het nut van de bepalingen niet langer inzien." (...)

"Het hanteren van de beide uitgangspunten uit het vorige hoofdstuk, heeft tot een vermindering en vooral een vereenvoudiging van de voorschriften geleid. De veiligheid en de doorstroming zijn uiteraard bepalend gebleven. Dit is in artikel 25 van de Wegenverkeerswet (WVW) verwoord."

In de memorie van toelichting bij de vervanging van de Wegenverkeerswet wordt gewezen op dit nieuwe RVV. Opgemerkt wordt dat ${ }^{71}$ :

"in het kader van de deregulering bewust is gekozen voor het beperken van de verkeersvoorschriften tot de basisregels die voor een veilig en ordelijk verloop van het verkeer noodzakelijk zijn. Te ver afdalen in verfijningen door voor iedere situatie een regel te willen voorschrijven is een onderschatting van de complexiteit van het hedendaagse verkeer en een miskenning van de creativiteit en verantwoordelijkheid die de hedendaagse weggebruiker moet bezitten en als regel ook bezit. Die creativiteit en verantwoordelijkheid vormen tegelijk de andere kant van de medaille. Het handelen vaar eigen inzicht en verantwoordelijkheid draagt ertoe bij, zo is de laatste jaren wel gebleken, dat daar waar de regelgeving te ver is doorgeschoten, zij massaal wordt genegeerd. De geloofwaardigheid van de voorschriften, ook die welk de voor de verkeersveiligheid vanhet grootste belang zijn, neemt daardoor sterk af."

Uitgangspunt is dat het Reglement zich beperkt tot basisregels, omdat het onmogelijk is alle voorkomende verkeerssituaties te regelen. Het afschaffen van artikel 25 WVW past niet in deze visie. Eerder werd gedacht aan uitbreiding en/ of overbrenging ervan naar het Reglement, doch ook daarvan werd afgezien. ${ }^{72}$ Toch heeft de wijziging van de RVV direct gevolg voor de reikwijdte van artikel $25 \mathrm{WVW}$. Aangezien uit het Reglement veel regels zijn geschrapt en het zich beperkt tot basisregels, verschuift de rol van artikel 25 WVW van vangnet-regel die uit legislatieve onmacht van de wetgever bleef bestaan, naar grondnorm die ziet op vele gedragingen die in de RVV 1966 als geboden of verboden waren opgenomen. ${ }^{73}$ Otte stelt dan $0{ }^{74}$ :

72 Nota van toelichting bij het RVV 1990, Stb. 1990, 459, pp. 68-69, zie ook TK 19901991, 22 030, nr. 3, p. 66. Dit: gebeurde onder invloed van het Commissie Wetgevingsvraagstukken, Orde in de regelgeving. Zie ook Remmelink, J., Hoofdwegen door het verkeersrecht, p. 22; Otte, M., Het stelsel van gedragsregels in het wegverkeer, pp. 33-41; Salomon, F. (red.), "RVV 1990 Alg.", p. 12.

73 Otte, M., Het stelsel van gedragsregels in het wegverkeer, p. 30 en p. 169. Zie over de veranderde verhouding ook Doelder, $\mathrm{H}$. de, "De verhouding van artikel 25 WVW en het 
"Het referentiekader voor het weggedrag wordt aldus in verminderde mate vormgegeven door het regel- en tekenbestand uit het RVV maar in versterkte mate door ongeschreven zorgplichten waarvan de inhoud mede wordt bepaald door flankerend beleid."

Het uitgangspunt dat de wetgever door gebruik te maken van een uitgewerkt en gedetailleerd Reglement de reikwijdte van het strafrecht redelijk nauwkeurig vaststelt heeft plaatsgemaakt voor het uitgangspunt dat de wetgever zich in het Reglement beperkt tot basisregels. Hierdoor heeft tevens een verschuiving plaatsgevonden van wetgever naar rechter om het betekenisbereik van de bepalingen vast te stellen. De rol van de strafrechter bij het vaststellen van aanvullende criteria neemt immers toe ${ }^{75}$ omdat hij in een voorliggend geval de grenzen van het betekenisbereik van de basisregels moet vaststellen. ${ }^{76}$ Het RVV kan hem daarbij wel behulpzaam zijn, aangezien de meer specifieke bepalingen uit het RVV invulling geven aan de manier waarop mensen zich in het verkeer dienen te gedragen.

Doordat een gedraging zowel een schending kan opleveren van de specifieke bepalingen uit het RVV als van de zorgplichtbepaling uit de Wegenverkeerswet, kunnen samenloop problemen ontstaan. Van een aantal strafbaarstellingen uit het oude RVV werd aangenomen dat deze zich tot artikel 25 WVW verhielden als bijzondere strafbaarstelling in de zin van artikel 55, tweede lid Sr. Dit was het geval indien een bepaling van het RVV voor de strafbaarheid van het feit het bestanddeel gevaar of mogeljik gevaar vereiste. ${ }^{77}$ Indien een bjizonder voorschrift, (ujt het RVV, niet bet (mogelijk) gevaar als voorwaarde voor strafbaarheid vereist, maar het OM dit gevaar wel ten laste legde en het ter zitting werd bewezen, werd aangenomen dat sprake was van eendaadse samenloop ex artikel 55, eerste lid Sr, zodat artikell 25 WVW

nieuwe RVV", pp. 291-294.

74 Otte, M., Het stelsel van gedragsregels in het wegverkeer, p. 31. Het flankerend beleid ten behoeve van weggebruikers "beperkt zich niet tot de belangrijke basisregels, maar beoogt ook en vooral het verkeersinzicht en de juiste attitude aan te geven voor al die situaties waarvoor geen concrete tegel is en kan worden gegeven." Nota van toelichting bij het RVV 1990, Stb. 1990, 459, p. 74 zie ook pp. 74-76; zie hierover ook Otte, M. Verkeersregels in revisie; Pleidooi voor een uitputtende RVV, pp. 41-45; Salomon, F. (red.), "RVV 1990 Alg.", pp. 18-21; Salomon, F., "Flankerend beleid", p. 104; Bart, M.P., "Enkele kanttekeningen bij het RVV 1990", pp. 255-257.

75 De Roos stelt over "vage wettelijke normen" zoals "de beruchte vage verkeersrechtelijke norm van art. 25 Wegenverkeerswet": "Niettemin kan worden volgehouden dat de wetgever met de introductie van dergelijke normen een zo zware last op de schouders van de rechter legt, dat deze werkwijze in het algemeen dient te worden vermeden en hoogstens bij de aanwezigheid van betrekkelijk uitgekristalliseerde verwachtingspatronen acceptabel kan zijn." Roos, Th.A. de, Strafbaarstelling van economische delicten, p. 84.

76 Otte pleit ervoor dat hij de gestelde normen opvult met scherpere subnormen. Zie Otte, M., "In memoriam art. 25 WVW 1935. Een kleine geschiedenis", pp. 356-357.

77 Voorbeelden in het oude RVV waren bijvoorbeeld artikelen die betrekking hadden op het gevaarlijk verrichten van: keren (artikel 16), portier openen (artikel 17, eerste lid), inhalen (artikel 37, eerste lid), veranderen van richting (artikel 44, eerste lid), te hoge snelheid (artikel 49, eerste lid) en remmen (artikel 50, eerste lid). 
toepsselijk was. Dit artikel werd immers met een zwaardere straf bedreigd dan de scheiding van strafbaarstellingen uit het RVV. Ten aanzien van strafbaarstellingen in het neuwe RVV doet deze vraag zich niet meer voor aangezien bij de herziening van het IVV geen strafbaarstellingen in het RVV meer zijn opgenomen die (mogelijk) gevar als voorwaarden voor strafbaarheid vereisen. Aangezien er nog wel verschil bestat in de maximum strafbedreiging tussen het schenden van de strafbaarstellingen in he RVV en de opvolger van artikel 25 WVW, zal indien het (mogelijk) gevaar is ten iste gelegd involge artikel 55, eerste lid $\mathrm{Sr}$ de zorgplichtbepaling uit de Wegriverkeerswet van toepassing zijn. ${ }^{7}$

\subsubsection{Wegenverkeerswet 1994}

Opniuw werd de tekst van de Wegenverkeerswet ter hand genomen, en opnieuw werdde reikwijdte van de zorgplichtbepaling verder opgerekt. De bepaling kreeg nu duideijk de al eerder in de Nota van toelichting bij het RVV 1990 toegekende status van gondnorm. In de memorie van toelichting van de Wegenverkeerswet valt te lezen. dat arikel 5 WVW $^{79}$ :

"niet borkomt uit legislatieve onmacht, doch een noodzakelijk middel vormt als aanvulling op de bassregels. Daar waar de eigen verantwoordelijkheid van de weggebruiker te kort schiet, zal de algmene bepaling als vangnet voor ongewenst gedrag uitkomst bieden. Dit in aanvulling op de correte normen, de basisregels voor het gedrag van de verkeersdeelnemer, zoals die in met name het RVV 1990 zijn vervat. (...) het is een grondnorm waaraan ieder handelen dat van invloed is op de veiligheid en de vrijheid op weg moet kunnen worden getoetst."

Artikel 25 WVW 1935 kan in gewijzigde vorm worden teruggevonden in het huidige artikel 5 Wegenverkeerswet $1994^{80}$ Artikel 5 WVW luidt ${ }^{81}$ :

"Het is ieder verboden zich zodanig te gedragen dat gevaar op de weg wordt veroorzaakt of kan worden veroorzaakt of dat het verkeer op de weg wordt gehinderd of kan worden gehinderd."

Het niet naleven van artikel 5 WVW is involge artikel 178, tweede lid WVW een overtreding, en wordt ex artikel 177, eerste lid sub a en $\mathrm{A}$ WVW bedreigd met ten hoogste twee maanden hechtenis of een geldboete van de tweede categorie (f. 5000,-). Daarnaast bepaalt artikel 179 , tweede lid. WVW dat bij veroordeling terzake van dit feit de bestuurder van een motorrijtuig een ontzegging van de rijbevoegdheid kan worden opgelegd met een maximum termijn van twee jaren. Deze termijn kan involge

78 Zie hierover Remmelink, Hoofdwegen door het verkeersrecht, pp. 41-42; Otte, M., Het stelsel van gedragsregels in het wegverkeer, pp. 137-165.

79 TK 1990-1991, 22 030, nr. 3, p. 66; zie ook Krabbe, H.G.M., "De artikelen 5 en 6 Gevaar veroorzaken, hinderen en schuld aan een verkeersongeval", pp. 88-89; Simmelink, J.B.H.M., Algemeenheden in het wegenverkeersrecht, p. 131; Otte, M., "In memoriam art. 25 WVW 1935. Een kleine geschiedenis", pp. 352-353.

80 Zie over deze herziening onder andere Harteveld, A.E. en Krabbe, H.G.M. (red.), De Wegenverkeerswet 1994; een strafrechtelijk commentaar, Otte, M., "In memoriam art. 25 WVW 1935. Een kleine geschiedenis", pp. 349-358.

81 Wet van 21 april 1994, Stb. 1994, 475. 
artikel 179, vijfde lid WVW worden verruimd naar vier jaren indien er sprake is van recidive; hiervan is sprake indien het feit binnen twee jaren na een eerdere ontzegging van de rijbevoegdheid is gepleegd. ${ }^{82}$ Overigens moet wel worden opgemerkt dat de maximum strafbedreiging bij de herziening deels is verlaagd ten opzichte van het oude artikel $25 \mathrm{WVW} 1935 .{ }^{83}$ Dit werd veroorzaakt door de sterke vereenvoudiging van het sanctiestelsel uit de nieuwe WVW ten opzichte van de oude WVW. ${ }^{84}$

Het relatief korte artikel 5 WVW omvat, door het gebruik van het verbindingswoordje "of", vier afzonderlijke situaties. ${ }^{85}$ Het gaat namelijk een verbod zich zo te gedragen dat (1) gevaar op de weg wordt veroorzaakt, (2) gevaar op de weg kan worden veroorzaakt, (3) het verkeer op de weg wordt gehinderd, (4) het verkeer op de weg kan worden gehinderd.

\subsubsection{De zorgplichtbepaling nader beschouwd}

Het nieuwe artikel 5 WVW richt zich tot ieder. In artikel 25 WVW werd ondanks het ontbreken van een aanduiding van de normadressaat deze nog beperkt tot degene die enig daadwerkelijk gebruik maakt van de weg. Nu het criterium dat de normadressaat "een gedraging op de weg" moet hebben verricht is komen te vervallen, is tevens de groep normadressaten groter geworden. Dit geldt niet alleen voor natuurlijke personen, ook verzet de aard van de bepaling zich niet langer tegen de rechtspersoon, de opdrachtgever en de feitelijk leidinggever in de zin van artikel $51 \mathrm{Sr}^{86}$ als dader. ${ }^{87}$

Zoals hierboven is aangegeven zijn de bestanddelen "een gedraging op de weg" komen te vervallen. In artikel $5 \mathrm{WVW}$ betreft het een gedraging die gevaar op de weg veroorzaakt of kan veroorzaken, dan wel een gedraging die het verkeer op de weg hindert of kan hinderen. Ook gedragingen buiten de weg en zelfs gedragingen die in het geheel geen verkeersgedrag betreffen ${ }^{88}$, die dit gevaar of deze hinder (kunnen)

82 Zie hierover ook Simmelink, J.B.H.M., "Nieuwe orde in de wegenverkeerswetgeving (deel 2)", pp. 40-41.

83 Zie hoofdstuk 7 paragraaf 3.2.3. en hoofdstuk 10 paragraaf 2.5.3. Bij oude gevallen die werden vervolgd terwijl de nieuwe bepaling in werking was getreden diende de rechter de strafbaarstelling uit het oude artikell 25 WVW te hanteren omdat deze gezien de minder vergaande reikwijdte gunstiger was voor de verdachte, maar diende hij de nieuwe inzichten over de strafwaardigheid van de gedraging uit het nieuwe artikel 5 WVW ten gunste voor de verdachte te hanteren. Zie Krabbe, H.G.M., "De artikelen 5 en 6 Gevaar veroorzaken, hinderen en schuld aan een verkeersongeval", p. 88 .

84 De verlaging van de maximum strafbedreiging bij schending van artikel 5 WVW werd in de MvT niet specifiek toegelicht. Zie TK 1990-1991, 22 030, nr. 3, pp. 148-149.

85 Krabbe, H.G.M., "De artikelen 5 en 6 Gevaar veroorzaken, hinderen en schuld aan een verkeersongeval", pp. 90-92. Aangezien de rechter bij de kwalificatie geen keuze hoeft te maken tussen deze vier zorgplichten zal uit de gehanteerde bewijsmiddelen duidelijk moeten worden op basis van welke zorgplicht de verdachte is veroordeeld. Zie over deze normadressaten hoofdstuk 6 paragraaf 5.

87 Simmelink, J.B.H.M., Algemeenheden in her wegenverkeersrecht, p. 133 en algemeen over de normadressaat van artikel 5 WVW pp. 130-135 en 188-190.

88 Deze gedragingen die wel onder artikel 5 WVW vallen zouden het "kader van de 
veroorzaken vallen daarom onder de reikwijdte van de bepaling. ${ }^{89}$ De bestuurder van een laadbrug die langs een luchtspoor werd voortbewogen en tijdens het oversteken van de weg met het dak van een op de weg rijdende autobus in aanraking was gekomen viel in 1951 niet onder de reikwijdte van artikel 25 WVW, omdat de gedraging niet op maar boven de weg plaatsvond. ${ }^{90}$ Ook het verbranden van stoffen in de buurt van de weg, waardoor dichte rook boven de weg kwam en het verkeer op de weg plotseling (nagenoeg) elk uitzicht werd ontnomen was geen gedraging als bedoeld in artkel 25 WVW.91 Een veroordeling voor dergelijke gedragingen op basis van artikel $5 \mathrm{WVW}$ behoort wel tot de mogelijkheden, nu gedragingen die plaatsvinden buiten de weg waarvan men kan weten dat dit tot gevaarlijke situaties op de weg kan leiden onder de werkingssfeer van de bepaling zijn gebracht. ${ }^{92}$ Niet langer is immers de plats van de strafbare gedraging aangegeven, alleen de plaats van het strafbare gevolg wordt aangeduid. Indien het gevolg plaatsvindt buiten de weg is dit op zichelf onvoldoende om schending van artikel 5 WVW aan te nemen. Wel kan bijvoorbeeld een kapot gereden voortuin een aanwijzing zijn dat er ook sprake was van een gedraging die gevaar op de weg heeft of kan hebben veroorzaakt, dan wel een gedraging waardoor het verkeer op de weg is of kan zijn gehinderd, maar alleen een kapot gereden voortuin is onvoldoende om schending van artikel 5 WVW aan te nemen. ${ }^{93}$

Voorts betreft de eerste zorgplicht uit de WVW 1935 niet langer gedragingen op de weg waardoor de "vrijheid van het verkeer zonder noodzaak wordt belemmerd", maar betreft het gedragingen waardoor het verkeer op de weg wordt gehinderd of kan worden gehinderd. De minister geeft aan dat hinderen een minder ernstige vorm is dan belemmeren, waardoor naar verwachting bewijsrechtelijke problemen kunnen worden voorkomen. ${ }^{94}$ Ook betreft het niet langer gedragingen die deze belemmering veroorzaken, maar gaat het over gedragingen die de hinder veroorzaken of kunnen veroorzaken. De hinder, als minder emstige vorm van belemmeren ${ }^{95}$, behoeft zich in

Wegenverkeerswet te buiten gaan", omdat het niet meer gaat om verkeersgedrag; aldus Vellinga naar aanleiding van het voorstel van Jebbink die een algemene strekking van het oude artikel 25 WVW verdedigde. Hij stelde dat het van geen gewicht is of de handelende persoon is aan te merken als weggebruiker en of hij zich al dan niet op de weg bevindt. Zie Veliinga, W.H., Gevaar en schuld op de weg, p. 30 en Jebbink, P.J., "Tot wie richt zich de norm van art. 25 W.V.W.", p. 170.

89 Door deze wijziging is elke gedraging met bepaalde onwenselijke gevolgen voor het verkeer op de weg onder het bereik van artikel 5 WVW gekomen, zelfs gedragingen die in het geheel niets met het verkeer of verkeersafwikkeling te maken hebben. Zie Simmelink, J.B.H.M., "Nieuwe orde in de wegenverkeerswetgeving (deel 1)", p. 2. Ktg. Gorinchem 6 november 1951, N. 1952, 655 (Laadbrug raakt bus).

91 HR 28 april 1981, NJ 1981, 461 (Rook boven weg).

92 Zie ook TK 1990-1991, 22 030, nr. 3, p. 66.

93 Krabbe, H.G.M., "De artikelen 5 en 6 Gevaar veroorzaken, hinderen en schuld aan een verkeersongeval", pp. 113-114.

Krabbe, H.G.M., "De artikelen 5 en 6 Gevaar veroorzaken, hinderen en schuld aan een verkeersongeval", p. 105; Simmelink, J.B.H.M., Algemeenheden in het wegenverkeersrecht, pp. 171-172; Otte, M., Het stelsel van gedragsregels in het wegverkeer, pp. 31-32. Het belemmeren heeft betrekking op de "meest vergaande vorm van aantasting van de doorstroming: het daadwerkelijk belemmeren van de vrijheid van het verkeer", terwijl 
het geheel niet te manifesteren, wil er sprake zijn van schending van de nieuwe bepaling. Het gaat erom dat de reële mogelijkheid aanwezig was dat er sprake zou zijn geweest van hinder. Aangezien hinderen niet samenvalt met kunnen hinderen, is hier sprake van twee zorgplichten die inhoudelijk niet samenvallen. Met betrekking tot het kumnen hinderen moet volgens Krabbe wel sprake zijn van een "abstract-concrete" vorm van hinder. ${ }^{96}$ Desondanks is door het toevoegen van deze zorgplicht het betekenisbereik van deze bepaling erg groot geworden. ${ }^{97}$ (Mogelijk) hinderen doet zich al voor indien sprake is van het (mogelijk) feitelijk beperken van de bewegingsvrijheid van anderen, en indien de gedraging ongeoorloofd is uit verkeersoogpunt. Het gaat daarbij niet om last maar om overlast en derhalve om gedragingen die eerı inbreuk maken op een behoorlijke, normale gang van zaken. ${ }^{99}$ Zonder deze toevoeging zouden ook zeer veel gedragingen waarvan incriminatie niet gewenst is onder het betekenisbereik van dit bestanddeel vallen. De wetgever stelt ${ }^{100}$ :

"Overigens is het niet de bedoeling dat bij iedere vorm van hinder de algemene bepaling zal worden toegepast. Immers, lichte vormen van hinder zijn in het hedendaagse verkeer niet te vermijden. De bepaling strekt er slechts toe evidente vormen van gevaar of hinder aan te pakken,"

(kan) hinderon aok miet op "minder vergaande inbrouklen op do doorstronning of d6 kans daarop"; TK 1990-1991, 22 030, nr. 3, p. 66. In de Nota van toelichting bij het RVV 1990 , Sib. 1990, 459, p. 68 werd opgemerkt dat bij belemmeren primair wordt gedacht aan het (vrijwel) blokkeren van het verkeer, in tegenstelling tot hinderen, maar dat onder hinderen niet de lichtere vorm van hinderen wordt begrepen omdat die in het hedendaags verkeer niet zijn te voorkomen. Waar echter de grens van het betekenisbereik ligt wordt overgelaten aan de rechter.

96 Krabbe, H.G.M., "De artikelen 5 en 6 Gevaar veroorzaken, hinderen en schuld aan een verkeersongeval", p. 106. Hij ontleent deze term aan Noyon, T.J., Langemeijer, G.E. en Remmelink, J., bewerkt door Dorst, A.J.A. van, Fokkens, J.W. en Machielse, A.J.M., Het Wetboek van Strafrecht, "Titell VII Misdrijven waardoor de algemene veiligheid van personen of goederen wordt in gevaar gebracht" (juni 1998), aantekening 2 . Hier wordt de gevaarzetting van artikel 5 WVW op twee manieren omschreven: "Allereerst is. als een directe concrete gevaarzetting, doch voorts ook in meer potentiele vorm, $\mathrm{nl}$. in deze zin, dat (door de gedraging) de veiligheid in gevaar kán worden gebracht. Het is duidelijk, dat deze tweede "vorm" dicht in de buurt van de abstracte gevaarzettingsdelicten komt; men zou kunnen spreken van een abstract-concreet gevaarsdelict."

97 Deze uitbreiding had de wetgever dan ook beter achterwege kunnen laten aldus Krabbe, H.G.M., "De artikelen 5 en 6 Gevaar veroorzaken, hinderen en schuld aan een verkeersongeval", p. 107 en Simmelink, J.B.H.M., Algemeenheden in het wegenverkeersrecht, p. 183.

98 Vellinga, W.H., Gevaar en schuld op de weg, pp. 30-31; Krabbe, H.G.M., "De artikelen 5 en 6 Gevaar veroorzaken, hinderen en schuld aan een verkeersongeval", pp. 95-96 en 104-110.

99 Simmelink, J.B.H.M., Algemeenheden in het wegenverkeersrecht, pp. 174-175, zie voor de analyse 171-179.

100 TK 1990-1991, 22 030, nr. 3, p. 66. Zie ook Nota van Toelichting bij het RVV 1990, Stb. 1990,459 , p. 68. 
Voor de beoordeling wanneer de gedragingen echter vallen aan te merken als "evidinte vormen van gevaar of hinder", ongeoorloofd of overlast veroorzakend zijn geen vaste criteria te geven en zal deze afhangen van geschreven en ongeschreven norm $\mathrm{n}$, de feitelijke omstandigheden en de situatie zoals men die normaal gesproken gelet op alle omstandigheden ter plaatse mag verwachten. ${ }^{101}$ De waardering van de situate zal dan ook tijd- en plaatsgebonden zijn.

Ook de beperking tot gedragingen die zonder noodzaak de belemmering/ hinder (kunnen) veroorzaken, is komen te vervallen. De wetgever die dit bestanddeel uitlegt als "zonder verkeersnoodzaak" heeft afgezien van het behoud ervan, en gaat er kennelijk van uit dat het ontbreken van noodzaak ligt besloten in het begrip hinderen. ${ }^{102}$ Hij stelt ${ }^{103}$ :

"Niet soed valt in te zien hoe een strafbaar hinderen kan voortvloeien uit gedrag waartoe iemand door de verkeersomstandigheden wordt genoodzaakt. Zodra andere verkeersverplichtingen dwingen tot <<hinderen >> - bijvoorbeeld de links afslaande automobilist die op het tegemetkomende verkeer wacht, <<hinderb> daarbij de achter hem rijdende automobilist die rechtdoor wil - is er geen sprake van strafbaar hinderen (...) Er bestaat derhalve geen behoefte aan het expliciet opnemen van het bestanddeel <<zonder noodzaak〉>."

Tevers worden ook de tweede en de derde situatie uit artikel 25 WVW opgerekt in het nieuwe artikel 5 WVW. Niet langer is sprake van een gedraging waardoor "de veiligheid op de weg in gevaar wordt gebracht of redelijkerwijze is aan te nemen, dat de veiligheid op de weg in gevaar kan worden gebracht". Thans betreft het een gedraging waardoor gevaar op de weg wordt veroorzaakt of kan worden veroorzaakt, waarbij dit "gevaar" niet meer is beperkt tot het in gevaar brengen van "de veiligheid op de weg". Het beschermde rechtsgoed is daardoor niet langer opgenomen in de bepaling. ${ }^{104}$ Gevaar verwijst naar schade. ${ }^{105}$ Van het veroorzaken van gevaar is sprake indien een ongeval met schade voor een persoon of een zaak zich voordoet of hierop een aanzienlijk verhoogde kans bestaat. ${ }^{106}$ Het gaat erom dat naar de normale loop der

101 Krabbe, H.G.M., "De artikelen 5 en 6 Gevaar veroorzaken, hinderen en schulld aan een verkeersongeval", pp. 95-96 en 104-107.

102 Krabbe, H.G.M., "De artikelen 5 en 6 Gevaar veroorzaken, hinderen en schuld aan een verkeersongeval", pp. 96-97 en over het bestanddeel "gevaar" pp. 101-104.

103 TK 1990-1991, 22030 , nr. 3, p. 67.

104 Simmelink, J.B.H.M., Algemeenheden in het wegenverkeersrecht, pp. 138.

105 Zie Mooij, A.W.M., "Gevaar, gevaarlijk, gevaarlijkheid", pp. 21-24.

106 Discussie bestond over de vraag of (verhoogde kans op) schade aan de persoon zelf die het gevaar veroorzaakt al dan niet onder de reikwijdte van de bepaling valt. Voor: Krabbe, H.G.M., "De artikelen 5 en 6 Gevaar veroorzaken, hinderen en schuld aan een verkeersongeval", pp. 102-103; en met betrekking tot 25 WVW Remmelink, J., Hoofd-. wegen door het verkeersrecht, p. 39; Remmelink, J., "Omvang en functie van art. 25 W.V.W.", pp. 87-88; Beckers, W.J.G.M., "Artikel 25 Wegenverkeerswet, een blijk van legislatieve onmacht, p. 123. Tegen: Simmelink, J.B.H.M., Algemeenheden in het wegenverkeersrecht, pp. 139-142; en met betrekking tot artikel 25 WVW Vellinga , W.H., Gevaar en schuld op de weg, pp. 50-51; Fokkens in zijn conclusie bij HR 6 november 1990, NJ 1991, 257, met noot Van. Veen (Daalse Tunnel). 
dingen zonder buitengewone omstandigheden de emstige mogelijkheid aanwezig is van een noodlottige afloop. ${ }^{107}$ Ook al was er geen sprake van direct gevaar, dan lag dit eerder aan geluk dan aan wijsheid; wederom een "abstract-concrete" vorm van gevaar. ${ }^{108}$ Overeenkomstig hetgeen werd gesteld ten aanzien van hinder geldt ook hier dat geen vaste criteria kunnen worden gegeven wanneer gedragingen zijn aan te merken als "evidente vormen van gevaar" of ongeoorloofd. ${ }^{109}$ Dit zal ook hier afhangen van geschreven en ongeschreven normen, de feitelijke omstandigheden en de situatie zoals men die normaal gesproken gelet op alle omstandigheden ter plaatse mag verwachten. Deze waardering zal daarom tijd- en plaatsgebonden zijn. ${ }^{110}$

Het gevaar in artikel 5 WVW zal gezien de plaats van de bepaling, het systeem van wetgeving en de wetsgeschiedenis wel betrekking moeten hebben op verkeersrechtelijk relevante omstandigheden, ook al blijkt dit niet uit de bepaling zelf. ${ }^{\prime \prime \prime}$ Remmelink stelt ${ }^{12}$ :

"In welke mate een gedraging vanwege de mogelijkheid, dat zij nadeel voor de maatschappij oplevert, gevaarlijk 'is', hangt mede af van de vraag in hoeverre deze laatste dat risico aanvaardbaar 'acht'. (...) Gevaar is derhalve een ten dele normatief begrip, mede afhankelijk van onze sociaal-ethische opvattingen. Ook zal men (...) de opvatting van de wetgever, zoals deze uit afzonderlijke bepalingen is af te leiden, moeten meewegen."

Simmelink onderscheidt drie soorten gedragingen die door de eerste en tweede situatie uit artikel 5 WVW worden bestreken. Het betreft: een gedraging die ontoelaatbare risico's schept en blijkens een daarop volgend ongeval realiseert zich de kans op een

107 Noyon, T.J., Langemeijer, G.E. en Remmelink, J., bewerkt door Dorst, A.J.A. van, Fokkens, J.W. en Machielse, A.J.M., Het Wetboek van Strafrecht, "Artikel 157" (juni 1998), aantekening 2.

108 Zie ook bovenstaande bespreking van "kunnen hinderen". De term wordt gebruikt door Krabbe, H.G.M., "De artikelen 5 en 6 Gevaar veroorzaken, hinderen en schuld aan een verkeersongeval", p. 104, die deze term ontleent aan Noyon, T.J., Langemeijer, G.E. en. Remmelink, J., bewerkt door Dorst, A.J.A. van, Fokkens, J.W. en Machielse, A.J.M., Het Wetboek van Strafrecht, "Titel VII, Misdrijven waardoor de algemene veiligheid van personen of goederen wordt in gevaar gebracht" (juni 1998), aantekening 2.

109 Simmelink stelt "dat voor de beoordeling van de toelaatbaarheid of ontoelaatbaarheid van de door een verkeersmanoevre in het leven geroepen risico's geen vaste criteria kunnen worden gegeven." Simmelink, J.B.H.M., Algemeenheden in het wegenverkeersrecht, p. 154 zie zijn analyse op pp. 145-156. Zie over ongeoorloofd ook Vellinga, W.H., Gevaar en schuld op de weg, pp. 30-31 en over het gevaar-criterium ook Polak, R.J., Wegenverkeersrecht, pp. 227-233.

110 Zie ook Mooij, A.W.M., "Gevaar, gevaarlijk, gevaarlijkheid", pp. 29-30 die op p. 30 stelt: En iedere tijd heeft natuurlijk recht op zijn inhoudelijke invulling van het gevaarscriterium en schadebeginsel. Aan het recht is dan een taak het beginsel zelf te bewaken en ervoor te zorgen dat het gevaarscriterium in een ruime toepassing niet buiten zijn oevers treedt. In dat geval zou de grondslag van het moderne recht zelf ondergraven worden."

111 Krabbe, H.G.M., "De artikelen 5 en 6 Gevaar veroorzaken, hinderen en schuld aan een verkeersongeval", pp. 95-96, 101-104 en 108-110.

112 Remmelink, J., Hoofdwegen door het verkeersrecht, pp. 43-44. 
inbreuk op de verkeersveiligheid; een gedraging die ontoelaatbare risico's in het leven roept, doch door een noodgreep van een van de betrokkenen of door toeval blijft een ongeval uit; een gedraging met ontoelaatbare risico's die geen daadwerkelijke antasting van de veiligheid van weggebruikers vormt, omdat zij, hoewel normalerwijze op die plaats en tijd te verwachten, toevalligerwijs op het moment van uitvoeren van de gedraging niet aanwezig blijkt. ${ }^{113}$

Ook het vereiste dat "redelijkerwijze is aan te nemen" dat de veiligheid op de weg in gevaar kan worden gebracht is bij de zorgplicht waarbij dit gevaar zich niet hoeft te manifesteren komen te vervallen. Hierdoor gaat het niet langer om gedragingen waardoor "de veiligheid op de weg in gevaar wordt gebracht of redelijkerwijze is aan te nemen, dat de veiligheid op de weg in gevaar kan worden gebracht", maar om gedragingen waardoor gevaar op de weg wordt veroorzaakt of kan worden veroorzaakt.

Aan dit artikel liggen eveneens de beginselen van veiligheid en vlotheid ten grondslag. ${ }^{114}$ De veiligheid is het centrale belang dat de regelingen op het gebied van het verkeersrecht beogen te beschermen. Hierdoor dienen weggebruikers niet enkel overeenkomstig de verkeersregels en verkeerstekens te handelen, maar ook voortdurend de veiligheid als maatstaf voor het verkeersgedrag te hanteren. De verkeersregels zijn het primaire oriëntatiepunt bij het ontwikkelen van een veilig weggedrag, maar als de omctandigheden daartne aanleiding goven, kan hot rijn dat hot veiligheide. beginsel vereist dat de weggebruiker juist afwijkt van deze verkeersregels. Indien hij dit nalaat kan hij als gevaarzetter worden aangemerkt, hoewel hij conform de verkeersregels handelt. ${ }^{1 / 5} \mathrm{Hij}$ kan dan op grond van artikel $5 \mathrm{WVW}$ worden vervolgd. Indien de weggebruiker om veiligheidsredenen afwijkt van de verkeersregels of verkeerstekens kan artikel 5 WVW ook rechtvaardigend werken bij een eventuele vervolging wegens het schenden van de verkeersregels of verkeerstekens. ${ }^{116}$ Hierdoor werken de zorgplichtbepalingen uit artikel 5 WVW twee kanten op: aan de ene kant kunnen

113 Simmelink, J.B.H.M., Algemeenheden in het wegenverkeersrecht, pp. 162, zie voor de analyse pp. 156-163.

114 Zie over deze (belangen en) beginselen en het vertrouwensregel Otte, M., "Beginselen in het verkeers(straf)recht, pp. 289-296; Otte, M., Het stelsel van gedragregels in het wegverkeer, pp. 43-136; Simmelink, J.B.H.M., "Algemene opmerkingen over de WVW '94", pp. 20-42; Simmelink, J.B.H.M., Algemeenheden in het wegenverkeersrecht, pp. 201-255.

115 Ook het opvolgen van bevoegd gegeven bevelen of aanwijzingen behoeft geen straffeloosheid mee te brengen, aangezien deze verplichting niet geldi indien daardoor artikel 25 WVW zou worden overtreden. HR 5 maart 1957, NJ 1957, 396, met noot Pompe (Groen voor tram).

116 Dit was ook het geval bij artikel 25 WVW; zie bijvoorbeeld HR 26 juni 1973, NJ 1973, 376 (Rood voor auto in militaire colonne) waarin werd gesteld dat het niet naleven van een stopgebod onder bepaalde omstandigheden kan worden gerechtvaardigd door de plicht tot naleving van artikel 25 WVW; Simmelink, J.B.H.M., "Algemene opmerkingen over de WVW '94", pp. 26-28; Krabbe, H.G.M., "De artikelen 5 en 6 Gevaar veroorzaken, hinderen en schuld aan een verkeersongeval", p. 89; Beckers, W.J.G.M., "art. 25 Wegenverkeerswet, een blijk van legislatieve onmacht", pp. 123. 
gedragingen op basis van dit artikel strafbaar zijn zelfs als ze conform de overige regels plaatsvinden, aan de andere kant kunnen gedragingen die in strijd zijn met een andere regel door dit artikel worden gerechtvaardigd.

Uit bovenstaande bespreking van de zorgplichtbepaling blijkt duidelijk dat door de wijziging in de redactie de reikwijdte van de bepaling steeds groter wordt ${ }^{117}$, waarbij de regulering verschuift van specifieke bepalingen uit de RVV, naar de zorgplichtbepaling uit de WVW. ${ }^{118}$ Het gebruik van een dergelijke zorgplichtbepaling kent vooral met betrekking tot de verhouding tussen deze bepaling en het uit het legaliteitsbeginsel afgeleidde lex certa-beginsel en de bruikbaarheid en effectiviteit diverse voor- en tegenstanders. ${ }^{119}$ Op grond van het lex certa-beginsel dient de wetgever strafbaarstellingen zo duidelijk en precies mogelijk te omschrijven, zodat de voorwaarden voor strafbaarheid ex ante zodanig nauwkeurig zijn omschreven dat de justitiabele voorafgaande aan zijn handelen kan weten of zijn gedrag al dan niet onder de delictsomschrijving valt. ${ }^{120}$ Aan de andere kant dienen strafbaarstellingen slagvaardig strafrechtelijk optreden niet in de weg te staan. Deze spanning die is te herleiden tot de fundamentele spanning, die ontstaat bij het zoeken naar evenwicht tussen de waarborgfunctie en de instrumentele functie, lijkt ten grondslag te liggen aan de vele gewisselde argumenten. ${ }^{121}$

\subsection{De Luchtvaartwet en de Wet Luchtverkeer}

\subsubsection{Inleiding}

De wet tot regeling van de luchtvaart, de Luchtvaartwet, is in 1926 tot stand gekomen. ${ }^{122}$ Deze wet is vervangen door de nieuwe Luchtvaartwet 1959. ${ }^{123}$ Deze wet regelde voomamelijk het gebruik van luchtvaartuigen en luchtvaartterreinen. Daarnaast waren in deze wet enkele regels gegeven inzake het luchtverkeer, waaronder in artikel 13 een zorgplichtbepaling. Op 1 januari 1993 is een nieuwe Wet

117 Zo ook Remmelink, J., Hoofdwegen door het verkeersrecht, p. 34; Krabbe, H.G.M., "De artikelen 5 en 6 Gevaar veroorzaken, hinderen en schuid aan een verkeersongeval", p. 92; Otte, M., Verkeerșregels in revisie; Pleidooi voor een uitputtende $R V V_{\mathrm{n}} \mathrm{pp} .8-19$; Vellinga, W.H., "De strafbepalingen in de nieuwe Wegenverkeerswet", pp. 195-196.

118 Otte, M., Het stelsel van gedragsregel's in het wegverkeer, p. 21.

119 Zie bijvoorbeeld Beckers, W.J.G.M., "art. 25 Wegenverkeerswet, een blijk van legislatieve onmacht", pp. 121-124; Hart, A.C. "t, "A.rtikel 25 W.V.W. en het legaliteitsbeginsel", pp. 213-224; Groenhuijsen, M.S., "Legaliteit als probleem", p. 285; Groenhuijsen, M.S., Straf en wet, pp. 17-18 en 42; Ru, H.J. de, De algemene wet gaat voor de bijzondere; Doelder, H. de, "De verhouding van artikell 25 WVW en het nieuwe RVV", pp. 291-294; Otte, M., Het stelsel van gedragsnegels in het wegverkeer, Simmelink, J.B.H.M., Algemeenheden in het wegenverkeersrecht, pp. 257-299.

120 Zie over het legaliteitsbeginsel en het lex certa-beginsel in het algemeen hoofdstuk 3 paragraaf 7.3 .

121 Zie over deze spanning hoofdstuk 3 paragrafen 3, 5 en 7 en hoofdstuk 10 paragrafen 1 en 7.

122 Wet van 30 juli 1926, Stb. 1926, 249.

123 Wet van 15 januari 1958, Stb. 1958, 47. 
Lucbverkeer tot stand gekomen, die naast en los staat van de Luchtvaartwet. In deze nieuve wet is onder andere een meer uitgewerkte wettelijke regeling van het gebruik van let luchtruim opgenomen. In deze Wet Luchtverkeer werd in artikel 5 een zorgplichbepaling opgenomen, die in de plaats is gekomen van artikel 13 Luchtvaartwet.

\subsubsection{Luchtvaartwet 1926}

De Luchtvaartwet is niet uit de lucht komen vallen. ${ }^{124}$ Reeds in 1911 werd door de regemg de "Vlieg en Luchtvaartwet", de latere Luchtvaartwet $1926^{125}$, aan de Tweede Kamir aangeboden. Het wetsvoorstel is tot stand gekomen doordat het vliegen met vlieguigen steeds meer tot ontwikkeling kwam. De regering wilde ${ }^{126}$

"zondr deze ontwikkeling te belemmeren, bij wijze van voorloopige regeling eenige bepalingen in heteven roepen in het belang van de veiligheid van het publiek."

In he eerste voorstel uit 1911 is in artikell 8 al de voouloper van de huidige zorgplichtbepaing te vinden. Het voorgestelde artikel luidde:

"Het i den bestuurder van een vliegtuig of luchtschip verboden het vliegtuig of luchtschip in de open ucht te doen voortbewegen op zoodanige wijze, dat de openbare orde of veiligheid wordt verstord of in gevaar gebracht."

Blijkens het voorgestelde artikel 10 kunnen in het belang van de openbare orde of veiligheid verdere voorschriften in amvb's ter regeling van het verkeer met vliegtuigen en luchtschepen worden gegeven. Het schenden van zowel artikel 8 als van de uitvoeringsbesluiten op basis van artikel 10 was strafbaar gesteld. ${ }^{127}$ In de memorie van toelichting werd over artikel 8 alleen gesteld ${ }^{128}$ :

"Deze algemeene, op alle omstandigheden toepasselijke bepaling mag, in het licht der bekende jurisprudentie omtrent het overeenkomstige art. 15 der Motor- en Rijwielwet, van genoegzame draagwijdte worden geacht om het publiek te beschermen."

124. Zie over de totstandkoming van deze wet Slotemaker, L.H., Luchtvaartwet, pp. 13-24.

125 TK 1911-1912, nr. 168.1-2. De naamswijziging vond plaats naar aanleiding van de opmerking door enkele parlementariêrs "dat het vliegen ook tot de luchtvaart is te rekenen.", zie TK 1911-1912, nr. 168.5, p. 7 en voor de wijziging TK 1911-1912, 168.6, p. 11 en TK 1911-1912, 168.7, p. 12.

126 TK 1911-1912, nr. 168.3, p. 3.

$127 T K$ 1911-1912, nr. 168.1-2, pp. 1-2. Overtreding van artikel 8 werd ex artikel 11 bedreigd met hechtenis van ten hoogste een jaar of een geldboete van ten hoogste drieduizend gulden en artikel 10 ex artike! 12 met hechtenis van ten hoogste vier maanden of geldboete van ten hoogste duizend gulden. Gezien artikel 13 betreft het overtredingen. TK 1911-1912, nr. 168.3, p. 3. 
In het voorlopig verslag wordt de opmerking gemaakt dat de verbodsbepaling wel zeer vaag is en de rechter voor uiterst moeilijke beslissingen kan plaatsen. ${ }^{129}$ Hierop antwoordt de minister ${ }^{130}$ :

"Het schijnt wel van zelf te spreken, dat een antwoord op de vraag, wanneer de openbare orde of veiligheid in gevaar wordt gebracht of verstoord, niet van te voren in het algemeen is te geven, doch telkens afhankelijk is van de omstandigheden, die zich in ieder bijzonder geval voordoen. Het artikel schijnt niet vager dan art. 15 der Motor- en Rijwielwet waaraan het is ontleend, en zal den rechter dus wel niet voor moeilijker beslissingen stellen. Uit de omtrent bedoeld artikel 15 bestaande jurisprudentie mag veilig worden afgeleid, dat de rechter ook ten aanzien van de thans voorgestelde bepaling tegen zijn taak opgewasserı zal zijn."

De openbare orde en veiligheid bestaan volgens de Rechtbank Haarlem uit de "natuurlijke orde in de maatschappij", die op niet openbaar terrein evenzeer kan worden verstoord en in gevaar gebracht. ${ }^{131}$ De Hoge Raad gaf aan dat ${ }^{132}$

"de beslissing of eene zekere handelswijze verstoring of ingevaarbrenging der openbare orde en veiligheid oplevert, is afhankelijk hiervan, of die handelswijze om de werking, welke zij doet of kan doen gevoelen, treedt buiten de particuliere sfeer."

In 1926 komt de. Wet tot regeling van de luchtvaart tot stand. ${ }^{133}$ In deze wet is in artikel 10 een zorgplichtbepaling opgenomen, luidende:

"Het is verboden de luchtvaart uit te oefenen op zoodanige wijze, dat de openbare orde of veiligheid wordt verstoord of in gevaar gebracht."

Involge artikel 44 Luchtvaartwet 1926 wordt het schenden van deze bepaling bedreigd met hechtenis van ten hoogste één jaar of een geldboete van ten hoogste drieduizend. gulden. Bij een veroordeling van een lid van de bemanning van het luchtvaartuig kan involge artikel 47 Luchtvaartwet 1926 hem de bevoegdheid de luchtvaart uit te oefenen worden ontzegd voor ten hoogste zes maanden. Het betreft ex artikel 51 een overtreding.

Niet alleen degene die zelf de luchtvaart uitoefent, maar ook de eigenaar of houder van het luchtvaariuig die in strijd met artikel 10 de luchtvaart met dat luchtvaartuig doet of laat uitoefenen is strafbaar. Involge artikel 44, tweede lid wordt hij met dezelfde straf bedreigd als degene die artikel 10 schendt.

Artikel 10 Luchtvaartwet 1926 onvat door het gebruik van het verbindingswoordje "of" vier afzonderlijke situaties. Het is namelijk verboden de luchtvaart uit te oefenen op zoodanige wijze dat (1.) de openbare orde wordt verstoord, (2.) de openbare orde in

129. TK 1911-1912, nr: 168.5, p. 6.

130 TK 1910-1912, nr. 168.6, p. 10.

131 Rb. Haarlem, 19 maart 1936, Slotemaker, L.H., Luchtvaartwet, p. 34 (Natuurlijke orde in de maatschappij).

132 HR 29 juni 1936, Slotemaker, L.H., Luchtvaartwet, pp. 34-35 (Buiten particuliere sfeer).

133 Wet van 30 juli 1926, Stb. 1926, 249. 
gevaar wordt gebracht, (3.) de veiligheid wordt verstoord, (4.) de veiligheid in gevaar wordt gebracht. Dit verbod is gericht tot degene die zelf de gedraging verricht en tot de eigenaar of houder van het luchtvaartuig die in strijd met artikel 10 de luchtvaart met dat luchtvaartuig doet of laat uitoefenen.

\subsubsection{Luchtvaartwet 1958}

In 1958 kwam een nieuwe Luchtvaartwet tot stand. In deze wet werd in artikel 13, aanhef en sub a de zorgplichtbepaling uit artikel 10 van de vorige Luchtvaartwet overgenomen. Artikel 13, aanhef en sub a luidde ${ }^{134}$ :

"Het is verboden de luchtvaart uit te oefenen:

a. op zodanige wijze, dat de openbare orde of veiligheid wordt verstoord of in gevaar gebracht;"

De normadressaat van deze bepaling is blijkens artike! 62 , tweede lid Luchtvaartwet 1959 "de gezagvoerder". Blijkens artikel 2 van deze wet is de gezagvoerder degene

"die een luchtvaartuig alleen bedient", terwijl onder bedienen wordt verstaan "het verrichten van handelingen aan boord van een luchtvaartuig ten behoeve van het gebruik van dat luchtvaartuig".

Indien de gezagvoerder artikel 13 overtreedt, riskeert hij involge artikel 62, eerste lid Luchtvaartwet hechtenis van ten hoogste één jaar of een geldboete van ten hoogste drieduizend gulden. Bij een veroordeling wegens overtreding van artikel 13 kan de schuldige involge artikel 64 , eerste lid de bevoegdheid een luchtvaartuig te bedienen voor ten hoogste drie jaar worden ontzegd. Bij toepassing van deze maatregel verliest involge artikel 64 , tweede lid Luchtvaartwet "een aan de veroordeelde afgegeven bewijs van bevoegdheid om van gelijkstelling zijn geldigheid voor de duur van de ontzegging, zodra de rechterlijke uitspraak, voor wat betreft deze bijkomende straf, voor tenuitvoerlegging vatbaar is geworden". Schending van artikel 13 is involge artikel 70 Luchtvaartwet een overtreding.

Artikel 13 Luchtvaartwet heeft een stil bestaan gehad en is in 1988 bij de wijziging van de Luchtvaartwet gedeeltelijk vervallen. ${ }^{135}$ De zorgplichtbepaling uit sub a bleef toen echter bestaan.

Bij de inwerkingtreding op 1 januari 1993 van de Luchtvaartwet is artikel 13 vervallen. Dit artikel keerde in gewijzigde vorm gelijktijdig terug in artikel 5 van de nieuwe Wet Luchtverkeer 1993.

134 De subs b en c van deze bepaling luidde: "b. in strijd met door of vanwege Onze Minister gegeven voorschriften, als bedoeld in artikel 11; c. in strijd met door Ons gegeven voorschriften, als bedoeld in artikel 12." Deze twee verbodsbepalingen waren in de oude wet te vinden in artikel 11 en 12.

135 Bij Wet van 10 november 1988, Stb. 1988, 595, kwam sub c van artikel 13 te vervallen. 


\subsubsection{Wet Luchtverkeer 1993}

De Wet Luchtverkeer staat naast en los van de Luchtvaartwet. ${ }^{136}$ De nieuwe Wet Luchtverkeer regelt enerzijds de verzelfstandiging van de directie Luchtverkeersbeveiliging ${ }^{137}$ tot zelfstandig bestuursorgaan en geeft anderzijds vorm aan een meer uitgewerkte wettelijke regeling van het gebruik van het luchtruim. ${ }^{138}$ Voor dit laatste doel wordt voorzien in een nieuwe opzet voor luchtverkeersregels die waren verspreid over de Luchtvaartwet 1958 en het Luchtverkeersreglement 1980. ${ }^{139}$ De Luchtvaartwet regelt voornamelijk het gebruik van luchtvaartuigen en luchtvaartterreinen. Daarnaast waren er enkele regels in gegeven inzake het luchtverkeer, waaronder artikel 13. Gezien het verschil in materie heeft de regering er voor gekozen een nieuwe wet Luchtverkeer te ontwerpen en de artikelen die betrekking hebben op het luchtverkeer over te brengen van de Luchtvaartwet naar de wet Luchtverkeer. ${ }^{140}$

Omdat niet alle situaties door regels kunnen worden gedekt, is in de wet een aanvullend artikel 5 opgenomen teneinde het verwijtbaar in gevaar brengen van andere deel-nemers aan het luchtverkeer en personen aan boord of op de grond strafbaar te kunnen stellen. ${ }^{141}$ Volgens de wetgever moet hierbij worden bedacht dat dit artikel in bepaalde situaties kan worden geschonden, terwijl men zich aan de overige regels houdt. Door het opnemen van artikel 5 in de Wet Luchtverkeer is het niet langer noodzakelijk artikel 13 sub a Luchtvaartwet in stand te houden. ${ }^{142}$ Deze is bij de inwerkingteding var de nieuwe wer dar ont vervallar. ${ }^{143}$ In de memorie var toelichting van de Wet Luchtverkeer wordt in de "Artikelgewijze toelichting" bij artikel 5 alleen gesteld ${ }^{144}$ :

"Dit algemene artikel beoogt de bescherming van de openbare veiligheid bij het gebruik van het luchtruim (Equivalent van artikel 25 WVW)."

In het wetsvoorstel werd het schenden van artikel 5 bedreigd met een gevangenisstraf van ten hoogste zes maanden of een geldboete van maximaal de vierde categorie, en het feit zou een misdrijf zijn. ${ }^{145}$ Hierover werd in de memorie van toelichting alleen

136 Zie over de totstandkoming van deze wet Houten, M.C. van, Wet Luchtverkeer, 1995, pp. 3-19.

137 Deze ressorteerde onder het directoraat-generaal Rijksluchtvaartdienst van het ministerie van verkeer en waterstaat.

$138 T K 1990-1991,21993$, nr. 3, p. 14.

139 Houten, M.C. van, Wet Luchtverkeer, p. V.

140 TK. 1990-1991, 21 993, nr. 3, p. 11; Houten, M.C. van, Wet Luchtverkeer, pp. 13-14.

141 Het voorgestelde artikel luidde: "Het is verboden op zodanige wijze aan het luchtverkeer deel te nemen dat daardoor personen of zaken in gevaar worden of kunnen worden gebracht." TK 1990-1991, 21 993, nr. 1-2, p. 4. De normadressaat van dit artikel is de gezagvoerder die zijn luchtvaartuig aan het luchtverkeer laat deelnemen. TK 1990-1991, 21993, nr. 6, p. 11

142 TK. 1990-1991, 21993, nr. 3, p. 15.

143 Zie Wet Luchtverkeer, Stb. 1992, 368, artikel 56.

144 TK 1990-1991, 21 993, nr. 3, p. 18.

$145 T K$ 1990-1991, 21 993, nr. 1-2, p. 14. 
opgenerkt dat bij het onderscheid tussen misdrijven en overtredingen en bij de differentiatie in strafsancties zoveel mogelijk aansluiting is gezocht bij het overige verkersrecht. ${ }^{146}$ Dit is voor artikel 5 opmerkelijk te noemen gelet op de strafbedriging van het oudere artikel 13 sub a Luchtvaartwet. Ook artikel 25 WVW, waanaar wordt verwezen, kende een lagere strafbedreiging. ${ }^{147}$ Naar aanleiding van vragen in het voorlopig verslag ${ }^{148}$, volhardde de regering en gaf aan dat ${ }^{149}$ :

"de irhoud van artikel 5 zo'n centrale en elementaire rol speelt dat, ter bescherming van de opentare veiligheid en de veiligheid van het luchtverkeer, bestempeling tot misdrijf noodakelijk voorkomt."

Naar aanleiding van nieuwe vragen van de fracties ${ }^{150}$, werd artike! 5 (overeenkomstig artiktl $25 \mathrm{WVW}$ ) als overtreding aangemerkt en de maximum strafbedreiging werd overenkomstig aangepast. ${ }^{151}$ Dit gebeurde mede omdat niet alleen de gezagvoerder tot vie het voorgestelde artikel 5 zich richt, maar ook de luchtverkeersleiding en verkeersvliegers die op dat moment niet onder artikel 5 vallen (gemeenschappelijk) verartwoordelijk zijn voor de wijze van deelneming aan het luchtverkeer. De regering wilde, in tegenstelling tot enkele fracties, op dat moment uitdrukkelijk geen regeling maken voor deze laatste twee groepen. ${ }^{152}$ Vervolgens werd een amendement ingediend waarnee de luchtverkeersleiding wel onder de reikwijdte van artikel 5 wordt gebracht. De toelichting luidt: ${ }^{153}$

"Ten aanzien van de veiligheid van het luchtverkeer is sprake van een gezamenlijke verantwoordelijkheid van de gezagvoerder en de luchtverkeersleiding. Het amendement beoogt deze verantwoordelijkheid ook in de wet tot uitdrukking te brengen."

Het amendement wordt met algemene stemmen aangenomen, ${ }^{154}$ waarna het artikel zijn definitieve vorm krijgt. ${ }^{155}$ Artikel 5 Wet Luchtverkeer 1993 luidt:

146 TK 1990-1991, 21993 , nr. 3, p. 24.

147 Opmerkelijk is ook dat de Raad van State noch over artikel 5, noch over zijn strafbedreiging iets opmerkte en dat terwijl de Raad tot dan toe "geleidelijk aan in de. richting van een toenemende kritische benadering" lijkt te gaan, zie het Advies van de Commissie voor de toetsing van wetgevingsprojecten inzake zorgplichtbepalingen, p. 9. Evenmin blijkt dat door de Raad voor zijn advies dit inmiddels gepubliceerde rapport ter hand is genomen.

148 TK 1990-1991, 21993 , nr. 5, p. 9.

149 TK 1990-1991, 21993, nr. 6, p. 12.

150 TK 1991-1992, 21993 , nr. 8, pp. 9-11.

151 Zie de Nota van wijziging, TK 1991-1992, 21 993, nr. 10, p. 47.

152 TK 1991-1992, 21 993, nr. 9, p. 13.

153 Amendement 10 maart 1992, TK 1991-1992, 21 993, nr. 16.

154 TK 24 maart 1992, p. 65-3977.

155 Het wetsvoorstel wordt met algemene stemmen en in de Eerst Kamer zonder beraadslaging, aangenomen. TK 24 maart 1992, p. 65-3977; EK 16 juni 1992, p. 311379. 
"Het is verboden op zodanige wijze aan het luchtverkeer deel te nemen dan wel luchtverkeersleiding te geven dat daardoor personen of zaken in gevaar worden of kunnen. worden gebracht."

Aangezien deze bepaling zich tot twee zeer verschillende normadressaten richt, die ondanks de gelijke bewoording van de rest van de bepaling de normschending feitelijk op totaal verschillende wijze zullen veroorzaken, omvat deze bepaling twee verschillende zorgplichten; één voor degene die aan het luchtverkeer deelneemt en één voor de luchtverkeersleiding. ${ }^{156}$ Beide zorgplichten omvatten gezien het onderscheid dat wordt gemaakt tussen "personen of zaken" en "in gevaar worden of kunnen worden gebracht" 4 verschillende situaties, waardoor artikel 5 Wet Luchtverkeer 1993, op 8 verschillende manieren kan worden geschonden.

Schending van artikel 5 is strafbaar gesteld bij artikel 47 Luchtvaartwet. De maximum strafbedreiging voor het schenden van (één van de varianten van de zorgplichtbepalingen uit) artikel 5 is zes maanden hechtenis of een geldboete van ten hoogste de derde categorie. Bij een veroordeling kan de bevoegdheid een luchtvaartuig te bedienen of luchtverkeersleiding te geven voor ten hoogste drie jaar worden ontzegd. Het strafbaar gestelde feit betreft een overtreding.

\subsubsection{De zorgplicht nader beschouwd}

De normadressaat van het artikel is zowel de gezagvoerder (de eerste en tweede zorgplichtbepaling) als de luchisverkeersleider (de derde en vierde zorgplicht. bepaling). De gezagvoerder is blijkens artikel 1 sub i Wet Luchtverkeer "degene aan boord van het luchtvaartuig, die de leiding heeft bij en verantwoordelijk is voor de veilige uitvoering van de vlucht." Luchtverkeersleiding is involge artikel 1 sub $\mathrm{g}$ Wet Luchtverkeer "het regelen van het luchtverkeer door het geven van klaringen en aanwijzingen aan bestuurders van luchtvaartuigen."

Voor de betekenis van de bestanddelen in gevaar worden gebracht en in gevaar kunnen worden gebracht wordt door de wetgever verwezen naar de parlementaire behandeling van de Wegenverkeerswet 1994. Tijdens de parlementaire behandeling van de Wet Luchtverkeer is hierop niet ingegaan, afgezien van de opmerking dat door het opnemen van het bestanddeel kunnen worden de reikwijdte van de bepaling wordt verruimd, omdat ook gevaarzettend gedrag strafbaar wordt gesteld. Hierbij doet het er niet toe of door de gedraging daadwerkelijk personen of zaken in gevaar zijn gebracht. De regering merkte op dat dit tenslotte van toevallige omstandigheden afhankelijk is, terwijl het er juist om gaat gedragingen te voorkomen die zodanig zijn dat daardoor personen of zaken in gevaar kunnen worden gebracht. ${ }^{157}$

156 De relatie degene die aan het luchtverkeer deelneemt en de luchtverkeersleiding kan zeer complex zijn, zie hierover Eck, D, van, Luchtverkeersleiding en aansprakelijkheid, pp. 94-109.

157 TK 1991-1992, 21 993, nr. 9, pp. 13-14. Voorts wordit opnieuw de vergelijking gemaakt met artikel 25 WVW die zich ook uitstrekt over gedragingen die gevaar kunnen veroorzaken. 


\subsection{De Quarantainewet}

\subsubsection{Inleiding}

De Quarantainewet heeft een lange geschiedenis. Ten tijde van het Staatsbewind van de Bataafse Republiek is al een voorloper van de huidige wettelijke regeling te vinden. Deze regeling werd voortgezet door de Wet tot wering van besmetting door uit zee aankomende schepen uit 1877, die op zijn beurt in 1963 bij de invoering van de huidige Quarantainewet werd ingetrokken. In deze wet is in artikel 19 een zorgplichtbepaling opgenomen, die gedeeltelijk al in de oude regeling en wet is te vinden.

\subsubsection{Wet tot wering van besmetting door uit zee aankomende schepen}

De Wet tot wering van besmetting door uit zee aankomende schepen uit 1877 is een voortzetting van de publicatie van 10 januari 1805 van het Staatsbewind der Bataafse Republiek. Deze regeling werd bij de inwerkingtreding van de wet ingetrokken. ${ }^{158} \mathrm{De}$ wet bevat een uitgebreide regeling over de wijze van handelen door de schipper en loods van een aankomend mogelijk besmet schip, het gezondheidsonderzoek en de wijze van ontsmetting. Uit de artikelen 1 en 2 blijkt dat ieder schip dat aankomend of aangekomen is uit zee en in een Nederlandse haven of rede ligt, wordt onderworpen aan een gezondheidsonderzoek indien het schip uit een land of plaats komt dat door de minister van binnenlandse zaken besmet is verklaard wegens de pest, gele koorts of Aziatische cholera (in 1922 aangevuld met pokken en vlektyphus ${ }^{159}$ ), of als zodanige ziekte tijdens de laatste reis en/ of aan boord is waargenomen ${ }^{160}$ In artikel 3 van deze wet staat een zorgplicht opgenomen luidende:

"De schipper van een vaartuig, dat aan een gezondheidsonderzoek moet worden onderworpen, uit zee eene Nederlandsche haven of reede willende aandoen, laat, zoodra hij in het gezigt van den wal is, een gele vlag van den top, of bij gebreke van die, zijne natievlag op eene zigtbare plaats uit het voorwant waaijen, en zorgt, dat die blijve waaijen en dat geene gemeenschap van het schip met den wal of met andere vaartuigen plaats hebbe, alvorens het gezondheidsonderzoek is afgeloopen.

De schipper van het loodsvaartuig is verpligt, wanneer hij verneemt, dat eene der in art. 2 bedoelde ziekten aan boord voorkomt, zorg te dragen, dat de bemanning van het loodsvaartuig geene gemeenschap met het schip hebbe. Hij mag evenwel zijne hulp en die van den loods aan het schip niet onthouden. De aan boord genomen loods is verpligt voor de naleving van het in de eerste alinea van dit artikel vermelde voorschrift te waken, voor zoover dit nog niet vóór zijne komst aan boord is nageleefd, en den schipper bekend te maken met de namen der landen en plaatsen krachtens art. 1 besmet verklaard, en zijne verpligtingen volgens deze wet.

158 Zie considerans en artikel 21 van de Wet van 28 maart 1877 tot wering van besmetting door uit zee aankomende schepen.

159 Wet van 24 maart 1922, tot aanvulling van artikel 2 van de: wet van 28 maart 1877, Stb. 1922, 135.

160 Artikel 1 Wet van 28 maart 1877 tot wering van besmetting door uit zee aankomende schepen. Deze wet kan door algemene maatregel van (inwendig) bestuur ook op andere ziekten van toepassing worden verklaard. 
De loods, of bij ontstentenis van een loods, de schipper, geeft onverwijld aan den burgemeester van der havenplaats, of der gemeente, waartoe de reede behoort, die het schip zal aandoen, hetzij schriftelijk, berigt van den gezondheidstoestand der opvarenden en van de reden, waarom het schip de vlag, in de eerste zinsnede van dit artikel aangeduid, voert.

$(\ldots)^{n}$

Involge artikel 19 wordt het overtreden van artikel 3 "gestraft met gevangenisstraf van 14 dagen tot een jaar en een geldboete van $f 25$ tot $f 500$, te zamen of afzonderlijk." Ook staat er een bijzondere strafuitsluitingsgrond opgenomen in artikel 19: "De straf tegen het niet hijschen der vlag, zooals dat bij het eerste lid van art. 3 is voorgeschreven, is niet toepasselijk op hem, die tijdens het verzuim met de besmetverklaring niet bekend was."

\subsubsection{De Quarantainewet}

In 1963 werd de wet tot wering van besmetting door uit zee aankomende schepen $^{16 !}$, en de wet tot regeling van het sanitaire toezicht op de luchtvaart ${ }^{162}$, ingetrokken. ${ }^{163}$ Dit gebeurde bij de invoering van de Quarantainewet, een wet houdende voorziening nopens het weren van bepaalde besmettelijke ziekten, welke door internationaal verkeer worden verspreid. ${ }^{164}$ Deze wet is tot stand gekomen om op nationaal niveau uitvoering te geven aan de Internationale Sanitaire Regeling met Bijlagen van de World Health Organisation. Deze regeling met biilagen bebben involge de artikelen 21 en 22 van het Statuut van de World Health Organisation en de Nederlandse Grondwet. verbindende kracht. ${ }^{165}$ Aangezien deze internationale Gezondheidsregeling zowel de zee-, de lucht en de landquarantaine regelt, zijn deze onderwerpen ook in de Quarantainewet opgenomen. Voorts zijn er meer internationale regelingen die betrekking hebben op maatregelen die in international verband kunnen worden genomen ter voorkoming van besmettingsgevaar. De nieuwe wet is hierop afgestemd. In deze wet werd de zorgplichtbepaling uit artikel 3 van de wet tot wering van besmetting door uit zee aankomende schepen uit 1877 voortgezet in artikel 19. De zorgplichtbepaling uit artikel $19^{166}$ is sinds de invoering in 1963 niet gewijzigd en luidt:

161 Wet van 28 maart 1877, Stb. 1877, 35, laatstelijk gewijzigd bij de wet van 24 maart 1922, Stb. 1922, 135.

162 Wet van 26 oktober 1935, Stb. 1935, 626.

163 Zie artikel 37 Quarantainewet.

164 Wet van 14 juli 1960, Stb. 1960, 335, in werking getreden op 1 januari 1963 bij KB van 24 september 1963, nr. 408. Deze wet werd zonder beraadslaging en zonder hoofdelijke stemming op door de Tweede en Eerste Kamer aangenomen, TK 23 juni 1960, p. 4043 en $E K 12$ juli 1960 , p. 3523. Zie over de totstandkoming van deze wet Schaafsma, R.W., Quarantainewet, pp. 129-130.

165 Zie ook considerans bij de Qurantainewet, Stb. 1960, 335.

166 Advies van de Commissie voor de toetsing van wetgevingsprojecten inzake zorgplichtbepalingen. In dit advies wordt overigens alleen gewezen op het eerste lid van artikel 19 , terwijl ook het derde lid van dit artikel een zorgplichtbepaling bevat. Ook dit laatste voorbeeld zal in hoofdstuk 7 paragraaf 3.4.4 worden besproken. 
"1. D gezagvoerder van een schip, die een Nederlandse haven wil aandoen en weet of vermedt, dat zijn schip als besmet of verdacht moet worden beschouwd of een haven in een besmce kring heeft aangedaan, draagt zorg:

a. dahij van zijn wetenschap of vermoeden, zo mogelijk per radio, kennis geeft aan de burgeneester van de gemeente, waarbinnen de haven ligt, welke zijn schip zal aandoen, zodra het binen de Nederlandse wateren is aangekomen;

b. datzodra het schip in het gezicht van de wal komt, een door Onze Minister vast te stellen sein wordyevoerd, totdat het schip tot het vrije verkeer is toegelaten, of totdat dit het Nederlandse gebieheeft verlaten;

c. dateen gemeenschap van het schip met de wal of met andere schepen plaatsheeft, alvorens het mdische onderzoek is beëindigd en het schip tot het vrije verkeer zal zijn toegelaten.

2. (...

3. Hijdie de leiding heeft bij trein- of wegvervoer en weet of vermoedt, dat in zijn middel van vervo bij aankomst in Nederland personen aanwezig zijn, die afkomstig zijn uit een besmette kring $\mathrm{f}$ lijden aan, dan wel verdacht worden gevaar op te leveren voor verspreiding van, een quaratainabele ziekte, draagt zorg, dat hiervan onverwijld mededeling wordt gedaan aan de burgeneester van de gemeente, waar het vervoermiddel zich bevindt. Totdat hij terzake nadere aanwiingen heeft ontvangen van de burgermeester of de geneeskundige, die deze bijstaat, draaghij zorg, dat geen gevaar voor besmetting van anderen ontstaat.
4. $(\ldots$
5. $(\ldots$
6. $(\ldots)$

Hẻt hảndelen in strijd met alle bepalingen van de Quarantainewet, en derhalve ook met artikel 19 , is in artikel 35 , eerste lid van deze wet stafbaar gesteld. De maximum strafbedreiging voor het schenden van (één van de varianten uit) artikel 19 is één jaar hechtenis of een geldboete van ten hoogste de derde categorie. Het strafbaar gestelde feit betreft involge artikel 35 , tweede lid, een overtreding.

\subsubsection{De zorgplichtbepaling nader beschouwd}

Artikell 19 Quarantainewet richt zich in het eerste en in het derde lid tot twee zeer verschillende normadressaten; te weten de gezagvoerder van een schip en degene die de leiding heeft bij trein- of wegvervoer. Deze twwee normadressaten dienen daarnaast op verschilleude wijze zorg te dragen dat een mededeling wordt gedaan (eerste en tweede lid), een sein wordt gevoerd (eerste lid), geen contact plaatsvindt (eerste lid), geen besmettingsgevaar ontstaat (tweede lid). Hierdoor bevat artikel 19 Quarantainewet niet één maar twee zorgplichtbepalingen.

Gezien de vele alternatieven uit de bepalingen omvatten deze twee zorgplichtbepalingen op hun beurt weer een veelheid aan situaties. Naast de dertig verschillende situaties uit de zorgplichtbepaling in het eerste lid, bevat de zorgplichtbepaling in het derde lid nog eens vierentwintig situaties. Het vestigt dan ook een waar record met maar liefst 54 variaties van de manier waarop dit éne artikel kan worden geschonden.

Opvallend is dat de gezagvoerder van een schip, degene die de leiding heeft bij treinvervoer en degene die de leiding heeft bij wegvervoer wel moeten voldoen aan. zorgplichtbepalingen, maar dat een zorgplichtbepaling die zich richt tot de 
gezagvoerder van een luchtvaartuig niet nodig bleek. Tot hem richt zich artikel 19 , zesde lid Quarantainewet dat luidt:

"De gezagvoerder van een luchtvaartuig is gehouden, gelijktijdig met het overleggen van het gezondheidsgedeelte van de algemene verklaring voor luchtvaartuigen aan de burgermeester of aan de geneeskundige, bedoeld in artikel 14, mede te delen, of het luchtvaartuig gedurende zijin laatste intemationale reis een besmette kring heeft aangedaan."

In de Wet van 26 oktober 1935 tot regeling van het sanitair toezicht op de luchtvaart, die bij de inwerkingtreding van de Quarantainewet is komen te vervallen waren overigens wel enkele zorgplichtbepalingen opgenomen. ${ }^{167}$

\section{4.}

\section{Het bijzonder strafrecht}

Het bijzonder strafrecht omvat het strafrecht buiten het Wetboek van Strafrecht. In dit hoofdstuk is niet ingegaan op het economisch strafrecht dat daarvan natuurlijk wel deel uitmaakt. De ontwikkeling van het bijzonder strafrecht is na de totstandkoming van het Wetboek van Strafrecht in hoog tempo doorgegaan, zodat het thans kan worden aangetroffen in vele wetten die in het algemeen betrekking hebben op een bepaald te reguleren onderwerp.

in đii deei van net suairechi kunnen ook zorgpischibepaingen worden aangetroffen. Besproken zijn artikel 5 Wegenverkeerswet, artikel 5 Wet Luchtverkeer 1993 en artikel 19 Quarantainewet. Het veel gebruikte artikel 5 WVW heeft model gestaan voor een aantal zorgplichtbepalingen in het bijzonder strafrecht. De reikwijdte van dit artikel is in de loop der tijd steeds groter geworden, waardoor mede de regulering is verschoven van de specifieke bepalingen uit de RVV naar deze bepaling. Opvallend is dat deze bepaling twee kanten op werkt: aan de ene kant kunnen gedragingen op basis van dit artikel strafbaar zijn zelfs als ze conform de overige regels plaatsvinden, aan de andere kant kunnen gedragingen die in strijd zijn met een andere regel door dit artikel worden gerechtvaardigd. $\mathrm{Zij}$ werkt dus zowel strafbaarstellend als disculperend. Criterium voor de beoordeling van de gedraging wordt hierbij gevornd door het door artikel $5 \mathrm{WVW}$ beschermde belang: de verkeersveiligheid.

Het algemeen geformuleerde artikel 5 Wet Luchtverkeer richt zich specifiek tot gezagvoerders en luchtverkeersleiders. Dit artike! wordt zeer weinig toegepast. Dit geldt ook voor artikel 19 Quarantainewet. Bij dit artikel worden, in tegenstelling tot de andere twee zorgplichtbepalingen, de gedragingen die het betekenisbereik van de bepaling markeren wel duidelijk aangegeven.

167 Zie artikel 6, eerste lid; 6, tweede lid; 4 en 9 eerste lid van de Wet van 26 oktober 1935 tot regeling van het sanitair toezicht op de luchtvaart. Overtreden van deze bepalingen werd involge artikel 18 bedreigd met hechtenis van ten hoogste een jaar of een geldboete van vijf duizend gulden. De strafbare feiten werden ex. artikel 19 beschouwd als overtredingen. 


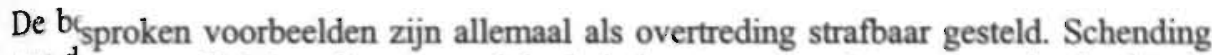

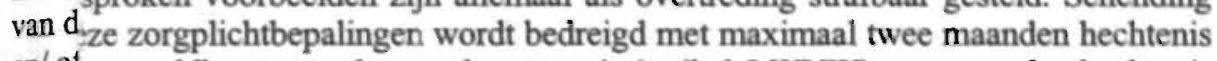
en/ of een geldboete van de tweede categorie (artikel 5 WVW), zes maanden hechtenis en/ o een geldboete van de derde categorie (artikel 5 Wet Luchtverkeer), één jaar

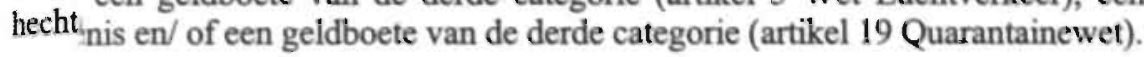





\section{Deontwikkeling van het economisch strafrecht}

\section{Inleiding}

Nada in hoofdstuk 6 de ontwikkeling van het commuun strafrecht, en in hoofdstuk 7 die vn het bijzonder (niet zijnde economisch) strafrecht zijn besproken, is het nu de beurt aan het economisch strafrecht. Wat economisch recht is hangt af van het theortisch vertrekpunt dat wordt ingenomen. ${ }^{1}$ In dit boek worden die strafbare feiten tot ht economisch recht gerekend die zijn opgenomen in de opsomming van de artikden 1 en 1a Wed. ${ }^{2}$ Deze wet is in werking getreden op 1 mei 1951. Daarmee is meten het tijdstip gemarkeerd waarop het economische strafrecht is ontstaan. De econumische delicten die aan deze wet werden gekoppeld, bestonden op dat moment vaakal in het bijzonder strafrecht. Daarom zal bij de beschrijving van de ontwikkeling, le plaats en de rol van het economisch strafrecht in dit hoofidstuk ook aandacht wordn besteed aan de periode voor 1951 (hoofdstuk 8 paragraaf 2). In enkele economiscle wetten zijn zorgplichtbepalingen opgenomen. Het betreft bijvoorbeeld artikel 11 Abo-wet 1998 (hoofdstuk 8 paragraaf 3) en artikel 15 Warenwet. Deze zorgplichtbepalingen zijn vooral interessant omdat ze recent niet langer primair strafrechtelijk handhaafbaar zijn, maar bij schending bestuursrechtelijk "beboetbare feiten" kunnen betreffen. Pas als sprake is van recidive kunnen het bij de Wed aangehaakte strafbare, feiten opleveren. Het lijken daarom voorbeelden van de ontwikkeling om de eigen verantwoordelijkheid voor de uitvoering en handhaving van bestuursrechtelijke regelgeving door het bestuur te versterken. ${ }^{3}$ De ontwikkeling en inhoud van de zorgplichtbepaling uit de Arbeidsomstandighedenwet zal dan ook in dit hoofdstuk worden onderzocht.

2. De ontwikkeling van het economisch strafrecht

2.1. Inleiding

Het economisch strafrecht maakt reeds lang deel uit van het (bijzonder) strafrecht. Bij de Romeinen kunnen al economische strafbepalingen worden gevonden. Zo vaardigde Keizer Diocletianus in 301 n.c. zijn Edictum de pretīs rerum venalium uit, waarin de doodstraf was gesteld op het verkopen van een groot aantal producten tegen een

Zie bijvoorbeeld Jörg, N, "Economische delicten", 64.1.; Mok, M.R., "Economisch recht", p. 145; Wladimiroff, M., Niets Bijzonders, pp. 7-9; Huidekoper, P.A., Hantering van het economisch strafrecht in Nederland, p. 4-5; Mulder, A. en Doorenbos, D.R., Schets van het economisch strafrecht, pp. 7-9.

2 Wet van 22 juni 1950, Stb. 1951, K 258.

3 Zie hierover hoofdstuk 6 paragraaf 4. 
hogere dan de door hem vastgestelde prijs. ${ }^{4}$ Een ander voorbeeld is de ingreep in de prijsvorming door Keizer Justinianus na de pestepidemie van 541 n.c. waarin op prijzen hoger dan voor de epidemie een boete was gesteld van drie maal het ten onrechte genoten voordeel. ${ }^{5}$ En ook in de middeleeuwen kende vele steden al economische strafbepalingen. Zo stelde Gorichem in 1436 een Keur vast waar involge artikel X één pond boete was gesteld op het "opblazen van vlees". ${ }^{6}$ De gemeenteraad van Amsterdam stelde in 1477 de prijs van een roggebrood vast toen de bakkers deze wilde verhogen, en verplichtte de bakkers in 1479 tot het aanleveren van broden op straffe van een boete en levenslange uitsluiting van het bedrijf. ${ }^{7}$ Het huidige economisch strafrecht is vooral tot stand gekomen in de tweede helft van de negentiende eeuw, met de opkomst van de industrialisatie (hoofdstuk 8 paragraaf 2.2.). Tijdens de crisisjaren (hoofdstuk 8 paragraaf 2.3.) en de Tweede wereldoorlog (hoofdstuk 8 paragraaf 2.4.) is het eerst op ad hoc basis, maar met een toenemende samenhang en onder invloed van het Duitse recht, steeds verder ontwikkeld en geordend. Na de oorlog heeft deze ontwikkeling zich voortgezet en is de Wet op de economische delicten tot stand gekomen (hoofdstuk 8 paragraaf 2.5.), waaraan ook enige zorgplichtbepalingen zijn aangehaakt (zie hierover hoofdstuk 8 paragraaf 3 ).

\subsection{De opkomst van het economisch strafrecht in de negentiende eeuw}

Aan het begin van de vorige eeuw was het economische recht vooral een

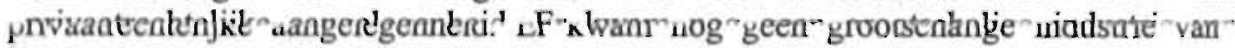
betekenis voor en economisch leven was vooral gericht op agrarische activiteiten en eenvoudige handnijverheid. De juridische structuur van het maatschappelijk leven was individualistisch, waarbij het privaatrecht een belangrijke rol speelde. De overheid onthield zich zo veel mogelijk van inmenging met het bedrijfsleven, en richtte zijn activiteiten vooral op het algemeen landsbestuur, de openbare orde en veiligheid en buitenlandse betrekkingen. ${ }^{8}$

In de tweede helft van de negentiende eeuw veranderde het economisch leven ingrijpend door de snelle ontwikkeling van de handel en industrie. Er is sprake van een toenemende onderlinge afhankelijkheid van individuen. Door de maatschappelijke veranderingen ontstond behoefte aan verdergaande ordening. De horizontale ordening, waarmee de ordening tussen organen met soortgelijke functies wordt bedoeld, kwam tot ontwikkeling, waardoor sprake was van vrijwillige ordening. Er ontstonden ondernemersverenigingen, vakverenigingen, trust en kartels, die zoveel mogelijk tegemoet komen aan de behartiging van het groepsbelang. Deze privaatrechtelijke constructies worden daardoor nog nauwelijks door elkaar bedreigd, maar er blijft het gevaar van

Mok, M.R., Op prijs gesteld, p. 5; Huidekoper, P.A., Hantering van het economisch strafrecht in Nederland, p. I.

5 Huidekoper, P.A., Hantering van het economisch strafrecht in Nederland, p. 1.

6 Huidekoper, P.A., Hantering van het economisch strafrecht in Nederland, p. 1.

7 Mok, M.R., Op prijs gesteld, pp. 4-5.

8 Foyer, H.A., "Economisch Recht; Een nieuw onderdeel der rechtswetenschap", pp. 415416; zie over de samenhang van economie en recht en de ontwikkeling van overheidsinterventie Valkhoff, J., Recht en economie. 
ondenijning door buitenstaanders; denk. hierbij bijvoorbeeld aan het dumpen van prodtten in een door productie- en prijsafspraken beheerste markt. ${ }^{9}$ Het privaatrecht krijgonder invloed van deze ontwikkelingen gedeeltelijk een ander karakter, bijvoorbeeldoordat er een aantal regelingen komt met dwingend karakter voor de publieke orde $\mathrm{n}$ het karakter van individuele overeenkomsten verandert door de opkomst van het goruik van het privaatrecht door maatschappelijke groepen. ${ }^{10}$

De vticale ordening, waarmee de ordening binnen een sector van "boven naar onder; van roducent tot eindverbruiker" wordt bedoeld, kwam daarentegen maar zeer bepert tot ontwikkeling. Met name binnen de verticale relaties ontstonden nieuwe problmen met grote maatschappelijke gevolgen, zoals lage lonen, lange werktijderl, kindarbeid. ${ }^{11}$, die niet "spontaan" werden opgelost binnen de sectoren. ${ }^{2}$ Well vindt er vana1 890 een snelle groei plaats van de arbeidsvakbewegingen.. ${ }^{13}$

Met $e$ opkomst van de industrialisatie ontstonden steeds meer horizontale en verticale relatis met alle (deels onopgeloste) problemen van dien. In deze tijd ontstaat het inzict dat de overheid een taak te vervullen heeft op het gebied van het bedrijfslever ${ }^{4}$ Het bestuursrecht en het strafrecht doen hierin aanvankelijk vooral op sociaal terrei, hun intreden. ${ }^{15}$ Een belangrijk beginpunt van deze ontwikkeling is gelegen in het i1 1874 op initiatief van Var Houten tot stand gekomen "Kinderwetje" de areid van kinderen onder de twaalf jaar wordt verboden. ${ }^{17}$ Daama veranderde het politieke klimaat en volgde rond de eeuwwisseling meer wetgeving inzake arbeids- en

9 Mulder, A., De handhaving der sociaal economische wetgeving; Naast strafrechtspraak bedrijfsrechtspraak?, p. 17.

10 Onder invloed van de opkomst van het overheidsrecht veranderen ook het karakter vanı het private eigendom en het contractsrecht. Zie Foyer, H.A., "Economisch Recht; Een nieuw onderdeel der rechtswetenschap", pp. 420-421 en 423.

11 Wladimiroff, M., Niets Bijzonders, p. 9.

12 Zie over de horizontale en verticale ordening Mulder, A., De handhaving der sociaal economische wetgeving; Naast strafrechispraak bedrijfsrechtspraak?, pp. 16-18.

13 Foyer, H.A., "Economisch Recht; Een nieuw onderdeel der rechtswetenschap", p. 418. In $1861 \mathrm{kwam}$ de eerste arbeidersorganisatie tot stand, zie over deze ontwikkeling Geers, A, Recht en humanisering van de arbeid, pp. 29-33. Tot 1872 gold overigens een verbod voor arbeiders zich te verenigen teneinde te staken, zie Geers, A., Veilig en wel, p. 16.

14 Foyer, H.A., "Economisch Recht; Een nieuw onderdeel der rechtswetenschap", pp. 415421. Zie hierover hoofdstuk 7 paragraaf 2.

15 Foyer, H.A., "Economisch Recht; Een nieuw onderdeel der rechtswetenschap", pp. 422.

16 Wet van 19 september 1874 houdende maatregelen tot het tegengaan van overmatigen arbeid en verwaarloozing van kinderen, Stb. 1874, 130. Zie hierover Geers, A, Recht en humanisering van de arbeid, pp. 33-35.

17 Geers merkt op: "Ten onrechte wordt dit wetje wel gezien als onze eerste sociale wet. Ten onrecht omdat het geen sociale misstanden bestreed (armoede), maar de arbeider juist trof in zijn enige kapitaal (kinderen die konden werken). Het belang van het wetje was vooral dat nu voor het eerst de overheid zich, hoe gebrekkig ook, bemoeide met wat tot dan toe gezien werd als een zaak die uitsluitend werkgevers en werknemers betrof." Geers, A., Veilig en wel, p. 16. 
concurrentie verhoudingen ${ }^{18}$, zoals veiligheids-, arbeids- en op de voedselvoorziening gerichte wetten. Zo resulteerde in 1889 de wantoestanden bij de productie en handel in levensmiddelen bijvoorbeeld in de wet tot voorkoming van bedrog in de boterhandel. ${ }^{19}$

Tijdens de eerste wereldoorlog voerde de overheid enkele tijdelijke maatregelen in om de nationale economie en de welvaart van de bevolking zo veel mogelijk op peil te houden. ${ }^{20} \mathrm{Er}$ was sprake van een snel opkomende en verbreidende vormen van economische criminaliteit. Zo leidde de oorlog in ons omringende landen tot het smokkelen van allerlei goederen. ${ }^{21}$ Deze wetten waren van tijdelijke aard in verband met buitengewone omstandigheden, maar zij zijn na afloop van de oorlog ten dele in stand gebleven. $^{22}$

\subsection{De uitbouw in de crisisjaren}

Nadat in 1929 ook Nederland in de wereldwijde economische crisis werd betrokken, volgen jaren van slepende economische depressie. De arbeidsmarkt en de markt voor landbouwproducten werden hierdoor geheel ontwricht, waardoor de overheid zich verplicht zag direct in te grijpen. De ernst van de crisis in de "landbouweconomie" wordt duidelijk indien men zich realiseert dat in de dertiger jaren hierbij één derde van de bevolking betrokken was. ${ }^{23}$ Maar ook elders waren de gevolgen van de crisis aanwezig; zo verstoorde de excessieve concurrentie het evenwicht bij de middenstand,

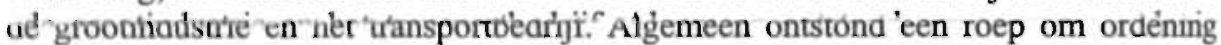
door de overheid. Daarbij werd echter voorop gesteld dat deze ordening van tijdelijke aard zou zijn. Op het moment dat het evenwicht van de markt zou zijn hersteld diende de overheid weer terug te treden. Het gevolg was dat een veelheid van sectorale en onderwerp gerichte ad hoc regelgeving tot stand is gekomen, waarbij vaak minder werd tegemoet gekomen aan de systematiek en onderlinge afstemming. ${ }^{24}$

\section{Wladimiroff, M., Niets Bijzonders, pp. 9-10}

19 Wet van 23 juni 1889 , houdende bepalingen tot voorkoming van bedrog in den botchandel, Stb. 1889, 82. Zie Boman, T.C., Wet op de economische delicten, p. XV.

20 Wladimiroff, M., Niets Bijzonders, p. 10; zie over deze regelingen Dullemen, A.A.L.F. van, "Met welke straffen en maatregelen, door welke rechterlijke en bestuursorganen en naar welke regels van proces behooren overtredingen van overheidsregelingen van het economisch leven te worden beteugeld?", pp. 132-145.

21 De noodsituatie blijki wel uit het feit dat het eerste verbod van uitvoer van goederen werd genomen zonder wettelijke grondslag bij K.B van 31 juli 1914, Stb. 1914, 333. Enkele dagen na afkondiging kreeg het zijn wettelijke basis bij artikel 3 van de Wet van 3 augustus 1914, Stb. 1914, 344, houdende verbod tot uit- en vervoer van sommige artikelen. Artikel 3 luidde: "Door de het in werking treden dezer wet verkrijgt het Koninklijk Besluit van 31 Juli 1914 (Staatsblad $n^{\circ}$. 333) houdende verbod van uitvoer van gouden munt of goudmuntmateriaal kracht van wet van het oogenblik zijner afkondiging af."

22 Zie hoofdstuk 6 paragraaf 2.

23 Mulder, A. en Doorenbos, D.R., Schets van het economisch strafrecht, p. 20.

24 Zie Mulder, A., De handhaving der sociaal economische wetgeving; Naast strafrechtspraak bedrijfsrechtspraak?, p. 104, en zijn bespreking van vijf te onderscheiden groepen regelingen pp. 104-121; Valkhoff, J., Inleiding tot het sociaal-economisch recht 
Het gbrek aan eenheid in de opzet van het economisch (straf)recht had tot gevolg dat bestursorganen zich allerlei buitengewone bevoegdheden zagen toegemeten. Deze bevogdheidsverdeling werd mede veroorzaakt doordat ${ }^{25}$

"in dceconomisch wetgeving veelal van het principe der functionele decentralisatie uitgaat (Rijksureaux en bedrijfsorganisaties), terwijl het strafrecht in hoofdzaak op het principe van territoale decentralisatie is gebaseerd, hetgeen slechte aansluiting tusschen beide functies verooraakt."

Het safrecht bleef het sluitstuk van de regelingen, maar de strafrechtspraak werd onvoloende repressief gevonden. Dit werd veroorzaakt doordat men de strafrechter onvoloende bekend en deskundig achtte met de geregelde onderwerpen ${ }^{26}$ en door de ontoeeikendheid van de gewone sanctiemiddelen. ${ }^{27}$ Door de aarzeling ten aanzien van het stfrecht als handhavingsinstrument, kreeg het tuchtrecht in de dertiger jaren een belanrijke plaats. ${ }^{28}$ Er komt een wettelijke grondslag voor het tuchtrecht en de tuchtrechteijke berechting wordt geregeld. Op strafrechtelijk gebied is nog geen sprake van ordemg van de regels uit de verschillende wetten.

Een blangrijke wet die tot stand is gekomen is de Landbouw-Crisiswet van $1933^{29}$, op grondwaarvan de regering steun kon verlenen aan producenten, verwerkers en handeunvarvan crisisproducten. ${ }^{30}$ Krachtens deze wet kan de minister het produceren en distribueren van de in de wet aangewezen (crisis)producten verbieden, daarbij bepalende, dat het handelen onder bepaalde voorwaarden wel is toegestaan aan aangeslotenen "bij een door of vanwege Ons aan te wijzen rechtspersoonlijkheid bezittend

in Nederland, p. 19, zie ook zijn overzicht van de ontwikkeling van het economisch recht in Nederland op pp. 15-34. Zie over de crisisjaren met voorbeelden Dullemen, A.A.L.F. van, "Met welke straffen en maatregelen, door welke rechterlijke en bestuursorganen en naar welke regels, van proces behooren overtredingen van overheidsregelingen van het economisch leven te worden beteugeld?", pp. 145-162.

25 Bloembergen, E., "Met welke straffen en maatregelen, door welke rechterlijke en bestuursorganen, naaj welke regelen van proces behocren overtredingen van overheidsregelingen van het economisch leven te worden beteugeld?", pp. 102.

26 Zie over het wantrouwen jegens de rechterlijke macht de openingsrede voor de Vereniging voor strafrechtspraak 1935 van Wijnveldt, J., opgenomen in de rubriek "Berichten en mededeelingen", $W$.

27 Borman, T.C., Wet op de economische delicten, p. XV.

28 Veegers merkt op dat "Op 1 mei 1934 heeft een nieuwe rechterlijke macht haar werkzaamheden aangevangen." Veegers, D.J., "Samenloop van strafbaar feit en tuchtrechtelijke overtreding bij de toepassing der Landbouw-Crisiswet"; Wladimiroff, M., Niets Bijzonders, pp. 10-11.

29 Wet van 5 mei 1933 tot verleening van bevoegdheden in het belang van den Landbouw (Landbouw-Crisiswet 1933), Stb. 1933, 261.

30 Andere voorbeelden zijn de Crisis-pachtwet, de Wet tot regeling van de overeenkomst van koop en verkoop op afbetaling en de We tot het algemeen onverbindend verklaren van ondernemersovereenkomsten, de Landbouwuitvoerwet 1929. 
lichaam". ${ }^{31}$ Welke op privaatrechtelijke basis werkende rechtspersonen dit waren werd geregeld in het Crisis-Organisatiebesluit. ${ }^{32}$ Van deze mogelijkheid is veelvuldig gebruik gemaakt, waardoor iedereen die deze producten wilde bewerken, verhandelen, in- en/ of uitvoeren zich gedwongen $\mathrm{zag}^{33}$ zich aan te sluiten bij één of meer landbouwcrisisorganisaties. De statuten van deze privaatrechtelijke organisaties ${ }^{34}$ verplichtten tot het in acht nemen van de voorschriften van de organisatie en van alle marktordenende voorschriften die van overheidswege werden uitgevaardigd. Bij niet nakoming van de verplichtingen was het mogelijk hiervoor de aangeslotene (dit konden ook rechispersonen zijn) tuchtrechtelijk te sanctioneren. ${ }^{35}$ Het CrisisOrganisatiebesluit regelde voorts op welke manier de tuchtrechtspraak werd uitgeoefend. Ondanks dat de crisistuchtregeling formeel op privaatrechtelijke leest was geschoeid $^{36}$, trad de landbouwcrisistuchtrechter "naar buiten op als een gewone strairechter" en had het tuchtproces "in hoge mate het aanzien van een (vereenvoudigd) strafproces". ${ }^{37}$ Ook wordt betoogd dat de tuchtrechtspraak in feite voor een belangrijk deel bestaat uit "gespecialiseerde strafrechtspraak" met een "quasi-tuchtrechtelijke overheidsrechter" ${ }^{30}$. Er is in plaats van tuchtrecht dan ook veeleer sprake van een vorm van "bestuursstrafrecht, uitgeoefend door organen van de uitvoerende macht volgens richtlijnen door die uitvoerende macht gegeven., ${ }^{, 0}$ Het overtreden van voorschriften gegeven bij of krachtens de Landbouw-Crisiswet was tevens strafbaar gesteld,

31 Zie artikel 13 Landbouw-Crisiswet van 1933. Zie over deze wet Mulder, A., De handhaving der sociaal economische wetgeving; Naast strafrechtspraak bedrijfsrechtspraak?, pp. 105-110.

32 Besluit van 28 juli !933, ter uitvoering van artikel 1 i der Landbouw-Crisiswet 1933 (Crisis-Organisatiebesluit), Stb. 1933, 410 en later gewijzigd bij het Besluit van 28 augustus 1935 tot wijziging van het Crisis-Organisatiebesluit 1933, Stb. 1935, 522.

33 De HR geeft aan dat wel degelijk sprake is van gedwongen toetreding, HR 26 februari 1934, NJ 1934, pp. 1136-1139 (Gedwongen toetreding).

34 Zie hierover Zwart, H.M., Privaatrechtelijke instellingen in de landbouw-crisis-wetgeving.

35 Zie hierover Gijsen, H.A.J., "Is het wenselijk, dat verband wordt gelegd tusschen de verschillende maatregelen naar aanleiding van een zelfde feit, te nemen door den strafrechter en andere bij of krachtens de wet ingestelde organen? Zoo ja, op welke wijze ware dit verband te regeien?", pp. i-36; Mulder, A. en Doorenbos, D.R., Schets van het economisch strafrecht, pp. 32-34.

36 Mulder, A. en Doorenbos, D.R., Schets van het economisch strafrecht, pp. 20 en 33.

37 Mulder, A., "De ontwikkeling van de Sociaal-economische Wetgeving", p. 104.

38 Gijsen, H.A.J., "Is het wenselijk, dat verband wordt gelegd tusschen de verschillende maatregelen naar aanleiding van een zelfde feit, te nemen door den strafrechter en andere bij of krachtens de wet ingestelde organen? Zoo ja, op welke wijze ware dit verband te regelen?", p. 34 .

39 Veegers, D.J., "Samenloop van strafbaar feit en tuchtrechtelijke overtreding bij de toepassing der Landbouw-Crisiswet".

40 Mulder, A., De handhaving der sociaal economische wetgeving; Naast strafrechtspraak bedrijfsrechtspraak?, p. 172, die de term "Ordnungsstrafrecht" ontleent aan de tijdens de bezetting ingevoerde Duitse tekst; zie ook Taat, J.F., Beschouwingen over tuchtrecht, p. 237. 
waardoor dubbele vervolging in de praktijk niet uitgesloten was. ${ }^{41}$ In de praktijk probeerde het OM dit wel zo veel mogelijk te voorkomen. ${ }^{42}$

Ondarks de economische problemen, de toename van economische regelgeving en haar overtredingen, kwamen maar weinig zaken voor de strafrechter, die in het algemeen bij veroordeling sanctioneerde met een boete. Het merendee! van de zaken kwam bij de tuchtrechter terecht, die bij veroordeling eveneens meestal sanctioneerde met een boete. Opvallend is dat met uitzondering van een enkele schorsing of schrapping van een georganiseerde als lid van een landbouwcrisisorganisatie en een enkele intrekking van een vergunning, de overige bijkomende straffen nooit door de tuchtrechter werden uitgesproken. Daarnaast werden vele zaken afgedaan door middel van een transactie of een sepot (waarschuwing). ${ }^{43}$

\subsection{Ordening tijdens de Tweede wereldoorlog}

Tijdens de bezetting werd naast de Landbouw-Crisiswet 1933 het Voedselvoorzieningstesluit ${ }^{44}$ ingevoerd. Hierin werden vele verplichtingen opgelegd aan elke producent, rerwerker, handelaar en in- en exporteur van crisisproducten. Dit besluit hield geen tuchtrecht in, maar kende wel een strafiechtelijke aansprakelijkheid voor rechtspersoren. ${ }^{45}$ Ook werd in 1941 het Organisatiebesluit Voedselvoorziening ingevoerd, waarbj een publiekrechtelijke organisatie voor het hele terrein van de voedselvoorziening (inclusief visseriij) werd mogelijk gemaakt met de instelling van bedrijfsschappen met verordenende bevoegdheden. Ter zake van het niet nakomen van door de organisatie uitgevaardigde regels kon door of namens de organisatie tuchtrechtelijk worden opgetreden. ${ }^{46}$ Voorts werd in 1942 de crisistuchtrechtspraak voor de landbouw

41 De samenloop was volledig, zie Mulder, A., De handhaving der sociaal economische wetgeving; Naast strafrechtspraak bedriffsrechtspraak?, p. 109; Zie over de samenloop in het algemeen Röling, B.V.A., "Is het wenselijk, dat verband wordt gelegd tusschen de verschillende maatregelen naar anleiding van een zelfde feit, te nemen door den strafrechter en andere bij of krachtens de wet ingestelde organen? Zoo ja, op weike wijze ware dit verband te regelen?", pp. 57-109; Veegers, D.J., "Samenloop varn ștrafbaar feit en tuchtrechtelijke overtreding bij de toepassing der Landbouw-Crisiswet".

42 Mulder, A., "De ontwikkeling van de Sociaal-economische Wetgeving", p. 104.

43 Zie over de afdoening van de schending van economische regelgeving tussen 1930 en 1940: Dullemen, A.A.L.F. van, "Met welke straffen en maatregelen, door welke rechterlijke en bestuursorganen en naar welke regels van proces behooren overtredingen van overheidsregelingen van het economisch leven te worden beteugeld?", pp. 160-íi.

44 Besluit van den Secretaris-Generaal van het Departement van Landbouw en Visscherij met betrekking tot de voedselvoorziening (Voedselvoorzieningsbesluit), van 13 januari 1941, Verordeningsblad voor het bezette Nederlandsche gebied, 1941, nr. i2.

Artikel 16 Besluit 12/1941 luidde: "Indien een der in artikel 15 strafbaai gestelde feiten door of vanwege een rechtspersoon wordt begaan, wordt de strafvervolging ingesteld en de straf uitgesproken tegen hem die de opdracht tot de strafbare handeling gegeven heeft of die de feitelijke leiding had bij het verboden handelen of nalater.."

46 Besluit van den Secretaris-Generaal van het Departement van Landbouw en Visscherij betreffende den opbouw van een organisatie voor de voedselvoorziening (Organisatiebesluit Voedselvoorziening 1941), van 1 april 1941, Verordeningsblad voor het bezette 
omgevormd tot het Besluit tuchtrechtspraak voor de voedselvoorziening. ${ }^{47}$ In dit besluit was in artikel 3 een bepaling opgenomen waardoor ook rechtspersonen, opdrachtgevers en feitelijk leidinggevenden rechtstreeks (tuchtrechtelijk) aansprakelijk konden worden gesteld voor het schenden van de in het Economisch sanctiebesluit uit 1941. De in Besluit tuchtrechtspraak voor de voedselvoorziening opgenomen straffen, bijkomende straffen en maatregelen kunnen worden gezien als voorlopers van die uit de latere Wed. ${ }^{48}$ De tuchtrechter beschikte in tegenstelling tot de strafrechter niet over de mogelijkheid vrijheidstraffen op te leggen. Na de bevrijding trad het Besluit tuchtrechtspraak voor de voedselvoorziening bijna ongewijzigd opnieuw in werking involge artikel 23 van het in Londen gemaakte Besluit berechting economische delicten. ${ }^{49}$

Het strafrecht kreeg tijdens de bezetting een belangrijker rol bij het vervolgen van economische delicten. In $1941 \mathrm{kwam}$ het besluit "met betrekking tot de berechting van strafzaken, rakende het economisch leven" tot stand.$^{50}$ Op basis van dit besluit werd bij iedere rechtbank een economische rechter ingesteld die in eerste aanleg oordeelde over de in het besluit opgesomde wetten en verordeningen. Voorts waren hierin rechtsmiddelen tegen uitspraken van economische rechters opgenomen en werden in geval van hoger beroep speciale kamers van de hoven belast met deze zaken. De economische rechters zijn involge dit besluit bij uitsluiting bevoegd te oordelen over alle misdrijven en overtredingen waartegen straf is bedreigd in de genoemde wetten en verordeningen. ${ }^{s /}$

Nederlandsche gebied, 1941, nr. 69. Artikel 19 kwam overeen met artikel 16 van het besluit 12/1941, zie vorige noot.

Besluit van de Secretarissen-Generaal van de Departementen van Landbouw en Visscherij en Justitie betreffende de tuchtrechtspraak op het gebied van de voedselvoorziening (Besluit Tuchtrechtspraak voedselvoorziening), Stcrt. 21 september 1942, 183, pp. 2-4. Zie hierover Dullemen, A.A.L.F. van, "Met welke straffen en maatregelen, door welke rechterlijke en bestuursorganen en naar welke regels van proces behooren overtredingen van overheidsregelingen van het economisch leven te worden beteugeld?", pp. 169-179.

48 Mulder, A. en Doorenbos, D.R., Schets van het economisch strafrecht, p. 33.

49 Besluit van 31 October 1944, houdende vaststelling van het Besluit berechting economische delicten, Staatsblad van het Koninkrijk der Nederlanden, verschenen te Londen, no. E. 135. De verschillen zijn dat de minimumstraf kwam te vervallen en de politicrechter wordt ingevoend. Zie over de tuchtrechtspraak voor de voedselvoorziening na de bevrijding Mulder, A., De handhaving der sociaal economische wetgeving; Naast strafrechtspraak bedrijfsrechtspraak?, pp. 180-182.

50 Besluit van den Secretaris-Generaal van het Departement van Justitie met betrekking tot de berechting van strafzaken, rakende het economisch leven, Verordeningsblad voor het bezette Nederlandsche gebied, 9 april 1941, nr. 71, inwerking getreden op 15 mei 1941; zie hierover Mulder, A. en Doorenbos, D.R., Schets van het economisch strafrecht, p. 31; Mulder, A., De handhaving der sociaal economische wetgeving; Naast strafrechtspraak bedriffsrechtspraak?, pp. 158-160.

51 Involge artikel 3 betreft het misdrijven en overtredingen waartegen straf is bedreigd in de Landbouw-Crisiswet 1933, de Bodemproductiewet 1939, de Distributiewet 1939, de Prijsopdrijvings- en Hamsterwet 1939, Voorschriften uitgevaardigd op grond van 
Ook kwam in 1941 het Besluit tot strafrechtelijk onderzoek in bepaalde strafzaken, rakende het economische leven tot stand. ${ }^{52}$ Involge dit besluit werden opsporingsbevoegdheden en de mogelijkheid tot het toepassen van dwangmiddelen bij overtreding van bepaalde wetten en besluiten verruimd. Door deze verruiming werden extra mogelijkheden gecreëerd naast de reeds bestaande van het Wetboek van Strafvordering.

Ook kwam het Economisch sanctiebesluit $1941^{53}$ tot stand, waardoor voor de in de in het besluit opgesomde (economische) wetten ${ }^{54}$ uniforme strafmaxima $^{55}$ en voor een aantal misdrijven (hoge) strafminima, bijkomende straffen en maatregelen werden vastgesteld. Indien opzettelijk in strijd met een van de genoemde voorschriften was gehandeld was doorgaans sprake van een misdrijf, terwijl bij het overig handelen in strijd met het voorschrift meestal sprake was van een overtreding. ${ }^{56}$ De strafbedreiging volgde dit onderscheid. ${ }^{57}$ Dit besluit werd in 1943 aangevuld met een nieuwe bepaling waardoor ook rechtspersonen, opdrachtgevers en feitelijk leidinggevenden rechtstreeks strafrechtelijk aansprakelijk konden worden gesteld voor het schenden van de in het besluit uit 1941 opgesomde economische wetgeving. ${ }^{58}$ De tekst van deze bepaling

Verordening 8/1940, 15/1940, 111/1940, 217/1940, het Prijsbeheerschingsbesluit 11/1941, het Voedselvoorzieningsbesluit 12/1941, Verordening 42/1941, het Deviezenbesluit 1941, het Organisatiebesluit Voedselvoorziening 1941 en "andere rechtsvoorschriften, voor zoover deze zulks uitdrukkelijk bepalen, een en ander voor zoover deze strafbare feiten tot de kennisneming van de rechterlijke macht behooren."

52 Besluit van den Secretaris-Generaal van het Departementen van Justitie met betrekking tot het strafrechtelijk onderzoek in bepaalde strafzaken, rakende het economisch leven, Verordeningsblad voor het bezette Nederlandsche gebied, 14 mei 1941, nr. 88.

53 Besluit van den Secretarissen-Generaal van het Departementen van Landbouw en Visscherij, van Handel, Nijverheid en Scheepvaart en van Justitie betreffende sancties op overtreding van verschillende wettelijke maatregelen, rakende het economisch leven (Economisch Sanctiebesluit 1941), Verordeningsblad voor het bezette Nederlandsche gebied, 6 september 1941, nr. 174; zie hierover Mulder, A., De handhaving der sociaal economische wetgeving; Naast strafrechtspraak bedrijfsrechtspraak?, pp. 160-162.

Involge artikel 1 betreft het voorschriften uit de Landbouw-Crisiswet 1933, de Distributiewet 1939, het Voedselvoorzieningsbesluit 12/1941, het Organisatiebesluit Voedselvoorziening 1941, waaraan later nog de Bodemproductiewet werd toegevoegd. Involge artikel 1, eerste lid betreft de maximum sanctie voor het handelen in strijd met de genoemde voorschriften: hechtenis van ten hoogste een jaar en een geldboete van ten hoogste vijfentwintigduizend gulden of én van deze straffen. Involge artikel 1, tweede lid is de maximum strafsanctie voor het opzettelijk handelen in strijd met de genoemde voorschriften gevangenisstraf van ten hoogste acht jaar en/ of een geldboete van ten hoogste honderdduizend gulden. Zie artikel 1, vierde lid, jo. tweede en eerste lid Economisch sanctiebesluit 1941.

Bijkomende straffen zoals voor bepaalde tijd het verbod tot uitoefening van bepaalde bedrijfshandelingen, sluiting of stillegging van de bedrijfsgebouwen, verbeurdverklaring, openbaarmaking rechterlijke uitspraak en betaling wederrechtelijk verkregen voordeel, konden involge artikel 3 voor alle strafbare feiten (met uitzondering van artikel 3, vierde lid) worden opgelegd.

Artikel 6 van het Besluit van den Secretarissen-Generaal van het Departementen van 
komt overeen met die van het latere artikel 15 Wed. Het Economisch sanctiebesluit 1941 werd na de bevrijding vervangen door het in Londen gemaakt Besluit berechting economische delicten. ${ }^{39}$ Dit besluit werd gezien als een tijdelijke noodoplossing. ${ }^{60}$ Het had betrekking op de in het eerste artikel opgesomde wetten en verordeningen. ${ }^{61} \mathrm{Bij}$ dit besluit werden onder andere de strafmaxima voor misdrijven en overtredingen geüniformeerd, de strafminima afgeschaft, de rechterlijke competentie opnieuw geregeld en de strafrechtelijke aansprakelijkheid voor rechtspersonen (beperkter ${ }^{62}$ ) gehandhaafd. De delictsomschrijvingen uit een aantal van de aan dit besluit gekoppelde wetten en verordeningen werd gewijzigd, zodat voortaan straf werd gesteld op: het opzettelijk handelen in strijd met de betreffende voorschriften als misdrijf en het handelen in strijd met zo'n voorschrift als overtreding. ${ }^{63}$

Vermeldenswaard is ook het in 1941 ingevoerde Prijsbeheersingsbesluit. ${ }^{64}$ Dit besluit geeft regels omtrent opsporing, vervolging en bestraffing bij het overtreden van

Landbouw en Visscherij, van Handel, Nijverheid en Scheepvaart en van Justitie, houdende wijziging en aanvulling van het Economisch sanctiebesluit 194!, Verordeningsblad voor het bezette Nederlandsche gebied, 20 februari 1943, nr. 17. Zie over de aansprakelijkheid van rechtspersonen, opdrachtgevers en feitelijk leidinggevenden hoofdstuk 6 paragraaf 5 .

59 Besluit van 31 October 1944, houdẻndé vaststelining van hè besiủnt bérechtring economische delicten, Staatsbiad van het Koninkrijk der Nederlanden, verschenen te Londen, no. E. 135.

60 Mulder, A. en Doorenbos, D.R., Schets van het economisch strafrecht, p. 35; Borman, T.C., Wet op de economische delicten, pp. XVI-XVII.

61 Het betreft involge artikel 1: de Landbouw-Crisiswet 1933, de Bodemproductiewet 1939, de Distributiewet 1939, de Prijsopdrijvings- en Hamsterwet 1939, prijsvoorschriften krachtens verordening 218/1940 voorzover niet buiten werking gesteld of geschorst, het Voedselvoorzieningsbesluit 12/1941 voorzover niet buiten werking gesteld of geschorst en het Organisatiebesluit Voedselvoorziening 69/1941 en de op grond van dit beshuit tot stand gekomen voorschriften voorzover niet buiten werking gesteld of geschorst.

62 Artikel 4 luidde: "Wordt een strafbaar feit als bedoeld in een der wrikelen I en 3, begaan door een rechtspersoon, dan wordt de straf, voor zoover deze een vriiheidsstraf is, tuitgesproken tegen den bestuurder of de bestuurders. Geen straf wordt uitgesproken tegen bestuurder, van wien blijkt, dat de overtreding buiten zijn toedoen is gepleegd." Zie hierover Mulder, A., De handhaving der sociaal economische wetgeving; Naast strafrechtspraak bedriffsrechtspraak?, p. 164.

63 Verordening van den Chef Militair Gezag, Delictsomschrijving Economische Delicten van 9 februari 1945, no. 61, Publicatieblad van het Militair Gezag, 17 januari 1945, nr. 16.

64 Besluit van den Secretarissen-Generaal van het Departementen van Handel, Nijverheid en Scheepvaart en van Justitie, houdende bepalingen omtrent straffen en strafvordering bij overtreding van prijsvoorschriften (Prijsbeheerschingsbesluit), Verordeningsblad voor het bezette Nederlandsche gebied, 13 januari 1941, nr. 11; zie hierover Dullemen, A.A.L.F. van, "Met welke straffen en maatregelen, door welke rechterlijke en bestuursorganen en naar welke regels van proces behooren overtredingen van overheidsregelingen van het economisch leven te worden beteugeld?", pp. 164-168. 
prijsvorschriften die krachtens artikel 2 van een besluit uit $1940^{65}$ en eerdere wetteike voorschriften met betrekking tot prijzen zoals de Prijsopdrijvings- en Hamserwet $1939^{66}$ zijn vastgesteld. Het besluit maakt onderscheid tussen het "gerehtelijk strafrecht" en het "tuchtrecht". Het strafrecht is in tegenstelling tot het tuchtrcht, in de praktijk waarschijnlijk nauwelijks toegepast. ${ }^{67}$ Involge dit besluit is hij diceen prijsvoorschrift overtreedt tuchtrechtelijk strafbaar, waarbij rechtspersonen en venootschappen op gelijke voet strafbaar zijn als natuurlijke personen. ${ }^{68}$ Ook het Prijsbheersingsbesluit werd na de bevrijding buiten werking gesteld. In plaats daarvn zijn strafbepalingen opgenomen in het nieuwe voorschrift van artikel 1 van het inLonden gemaakt Besluit berechting economische delicten. ${ }^{69}$ In dit besluit was teven de mogelijkheid opgenomen dat de tuchtrechter voor de prijzen in eerste aanleg kenni kan nemen van overtredingen van prijsvoorschriften. ${ }^{70}$

Evenens werden in 1941 bij besluit ${ }^{71}$ de opsporingsbevoegdheden en de toepassing van ekele dwangmiddelen ingeval van de in dit besluit opgesomde (economische) wette ${ }^{72}$ verruimd. Zo kregen opsporingsambtenaren bij de opsporing en vervolging van nisdrijven en overtredingen waartegen straf is bedreigd in de genoemde wetten, enkelt bijzondere opsporingsbevoegdheden toegekend. Zij waren ter zake ook bevoe, een verdachte buiten heterdaad aan te houden ${ }^{73}$ en ten behoeve van de

65 Besluit van den Secretarissen-Generaal van het Departementen van Handel, Nijverheid en Scheepvaart, van Landbouw en Visscherij, van Waterstaat, van Binnenlandsche Zaken, van Financiën, van Sociale Zaken en van Justitie, inzake de benoeming van een Gemachtigde voor de prijzen, Verordeningsblad voor het bezette Nederlandsche gebied, 30 november $1940,218$.

66 Stb. 1939, 634. Zie over deze wet, zijn voorlopers en opvolgers Mok, M.R., Op prijs gesteld; Mulder, A., De handhaving der sociaal' economische wetgeving; Naast strafrechtspraak bedrijfsrechtspraak?, pp. 126-130.

67 Mulder, A., De handhaving der sociaal economische wetgeving; Naast sirafrechtspraak bedrijfsrechtspraak?, p. 171.

68 Zie artikel 6, tweede lid Besluit 11/1941, dat geheel overeenkomt met artikel 6 Economisch sanctiebesluit 1941, Besluit 171/1941.

69 Besluit van 3! October 1944, houdende vaststelling van het Besluit berechting economische delicten, Staatsblad van het Koninkrijk der Nederlanden, verschenen te Londen, no. E. 135.

70 Zie artikel 5, tweede lid aanhef́ en A Besluit berechting economische delicten.

71 Besluit van den Secretaris-Generaal van het Departement van Justitie met betrekking tot het strafrechtelijk. onderzoek in bepaalde strafzaken, rakende het economisch leven, Verordeningsblad. voor het bezette Nederlandsche gebied, 14 mei 1941, nr. 88, inwerking getreden op 15 mei 1941; zie hierover Mulder, A., De handhaving der sociaal economische wetgeving; Naast strafrechtspraak bedrijfsrechtspraak?, pp. 162.

72 Het betreft involge artikel 1, de Landbouw-Crisiswet 1933, de Distributiewet 1939, de Prijsopdrijving- en Hamsterwet 1939, het Prijsbeheersingsbesluit 11/1941, het Voedselvoorzieningsbesluit 12/1941, het Organisatiebesluit Voedselvoorziening 1941.

73 De opsporingsambtenaar diende involge artikel 3 Besluit 88/1941 dan wel zorg te dragen dat de aangehoudene zo spoedig mogelijk voor de officier van justitie of de hulp officier van justitie wordt geleid. 
opsporing elke plaats inclusief lokalen, erven en woningen te betreden. ${ }^{74}$ Voorts worden in dit besluit de mogelijkheden voor de toepassing van enkele dwangmiddelen uitgebreid. ${ }^{75}$

\subsection{De Wet op de economische delicten}

Was er reeds voor de oorlog sprake van een snelle ontwikkeling van omvangrijke en onoverzichtelijke wetgeving op het terrein van het economisch recht, tijdens de oorlog werd dit niet beter. Er werd gedeeltelijk voortgebouwd op de crisismaatregelen, maar ook nieuwe vormen en regels waren door de bezetter ingevoerd ${ }^{76}$ Denk bijvoorbeeld aan de uitbreiding van het tuchtrecht en de introductie van de bijzondere tuchtrechter voor de prijzen, de invoering op grotere en algemenere schaal van bijkomende straffen voor economische delicten en aansprakelijkheid van rechtspersonen, opdrachtgevers en feitelijk leidinggevenden. Niet alleen de materiële regelgeving, maar ook de regels omtrent opsporing, vervolging en berechting vertoonden grote gebreken. Direct na de bevrijding was duidelijk dat aan deze "chaotische, verwarrende, onoverzichtelijke en zéér kostbare regeling" een eind moest komen. ${ }^{77}$ Ook heerste het algemeen gevoelen dat de overheid (voorlopig) sterker dan voorheen ordenende activiteiten diende te ontplooien op het economisch en sociaal terrein. Daarmee is het nog geen uitgemaakte zaak dat de strafrechtelijke handhaving niet geheel volgens de regels van het algemeen straf(proces)recht diende te verlopen. De ervaringen opgedaan vanaf de dertiger jaren waren echter zo negatief, dat voor het economisch strafrecht een speciale regeling nodig werd bevonden voor de opsporing, daderschap, dwangmiddelen, vervolging, delen van het procesrecht, rechterlijke organisatie en straffen en maatregen. ${ }^{78}$

In 1945 werd de Commissie Langemeijer ingesteld ${ }^{79}$, die tot tak had een nieuwe uniforme regeling voor de opsporing, vervolging en berechting van economische delicten te ontwerpen. ${ }^{80}$ De Commissie bood op 31 juli 1946 een ontwerp van de Wet op de economische delicten met memorie van toelichting aan de Regering aan, dat

74 Bij het binnentreden van woningen golden wel aanvullende vereisten, zie artikel 5 Besluit 88/1941.

75 De mogelijkheden voor inverzekeringstelling en voorlopige hechtenis werden verruimd. Zie artikel 3 en 4 Besluit 88/1941.

76 Mulder, A., "De ontwikkeling van de Sociaal-economische Wetgeving", p. 106.

77 Dullemen, A.A.L.F. van, "Met welke straffen en maatregelen, door welke rechterlijke en bestuursorganen en naar welke regels van proces behooren overtredingen van overheidsregelingen van het economisch leven te worden beteugeld?", p. 196; Mulder, A. en Doorenbos, D.R., Schets van het economisch strafrecht, p. 8; deze ontwikkeling lijkt een voorbeeld van een korte termijn cyclus van opkomst en verval van sectorale ordening. en de structurele ordening die pas geleidelijk aan onderkend wordt, zie hierover VerLoren van Themaat, P., "Het ontwerp vestigingswet detailhandel, de cyclische ontwikkeling van de sociaal-economische wetgeving en de EEG", p. 75

78 Mulder, A. en Doorenbos, D.R., Schets van het economisch strafrecht, pp. 8-9.

79 Besluit van 24 augustus 1945, 6de afdeling, no. 1115, zie over deze Commissie en de ontstaansgeschiedenis van de Wed: Hollander, F., Wet op de economische delicten.

80 Ook hieruit blijkt wel dat het Besluit berechting economische delicten werd gezien als een noodoplossing. 
vrijwel ongewijzigd in september 1947 aan de Tweede Kamer is aangeboden als ontwerp-Wet op de economische delicten. Tijdens de parlementaire behandeling werden enkele wijzigingen aangebracht, waarna het door zowel de Tweede Kamer in april $^{81}$ en de Eerste Kamer in mei $^{82} 1950$ zonder hoofdelijke stemming werd aanvaard. De Wet is op 1 mei 1951 in werking getreden. ${ }^{83}$ Tot die tijd zijn de in de vorige paragraaf besproken drie besluiten (Besluit tuchtrechtspraak voor de voedselvoorziening, Besluit berechting economische delicten, Besluit Tuchtrechtspraak voor de prijzen) geldig gebleven. Een aantal belangrijke kenmerken van deze besluiten zijn terug te vinden in de Wed. Zo bleef het systeem van verwijzing naar strafbaarstellingen uit bijzondere wetgeving gehandhaafd, en ook het onderscheid tussen misdrijven en overtredingen, het daderschap voor de rechtspersoon, opdrachtgever en feitelijk leidinggever alsmede enkele bijkomende straffen zijn bewaard gebleven.

Dat niet alleen een zuivering van de geschiedenis herziening van het (economisch) recht noodzakelijk maakte, maar ook de pluriformiteit van handhaving, de afwijkende procedures, de onoverzichtelijkheid van het recht en de mogelijkheid van meervoudige berechting, moge duidelijk zijn. In de eerste regels van de memorie van toelichting van de Wed, wordt al gesteld ${ }^{34}$ :

"De in omvang en maatschappelijke betekenis steeds toenemende wetgeving op het terrein van het economisch leven is van de aanvang af in haar werking belemmerd, doordat handelingen verricht in strijd met haar voorschriften, niet met voldoende snelheid en gestrengheid werden gestraft. Dit euvel heeft men getracht tegen te gaan door een groot aantal afzonderlijke regelingen voor bepaalde materies, welke regelingen verschillende na een kort bestaan weder ingrijpend zijn gewijzigd of door andere vervangen. Enkele van die regelingen hebben ook stellig belangrijke verbeteringen gebracht. Anderzijds echter hebben zij door haar onderlinge verschillen, waardoor niet altijd voldoende reden bestond, haar afwijking van de normale strafrechtspleging en het feit, dat sommige naast elkander voor dezelfde onderwerpen goiden, nieuwe bezwaren doen rijzen."

De Wed is vele malen gewijzigd. In 1969 zijn de artikelen 1, 2 en 6 gewijzigd $^{85}$, naar aanleiding van kritiek op het oude systeem. ${ }^{86}$ Ten gevolge van deze wijziging is de opsomming in artikel 1 uitputtend geworden en de opsomming werd chronologisch gerangschikt, waarbij de datum van afkondiging beslissend zou zijin.

Zoals uit de bespreking van de historische ontwikkeling van het economisch strafrecht naar voren is gekomen, konden aanvankelijk volgens bepaalde economische wetten ook hun bestuurders strafrechtelijk aansprakelijk worden gesteld voor overtredingen

Handelingen TK 1949-1950, pp. 1591-1606.

Handelingen EK 1949-1950, pp. 805-806.

Wet houdende vaststelling van regelen voor de opsporing, de vervolging en de berechting van economische delicten (Wet op de economische delicten), Stb. 1950, K. 258, in werking getreden op 1 mei 1951 bij KB 3 april 1951, Stb. 1951, 91.

Zie TK 1947-1948, 603, nr. 3, pp. 10-12; Mulder, A., "De ontwikkeling van de Sociaaleconomische Wetgeving", pp. 106-107; Wladimiroff, M., Niets Bijzonders, pp. 12-13.

Wet van 21 mei 1969 houdende nadere wijziging van de Wed, Stb. 1969, 232.

Zie hierover Keulen, B.F., Economische delicten, pp.. 18-19. 
van de rechtspersoon. Involge het Landbouw-Crisis-tuchtrecht konden ook rechtspersonen tuchtrechtelijke feiten begaan en daarvoor tuchtrechtelijk worden verooideeld. Tijdens de tweede wereldoorlog werd in 1941 de strafrechtelijke aansprakelijkheid van rechtspersonen geïntroduceerd en die van opdrachtgevers en feitelijk leidinggevenden uitgebreid. Deze mogelijkheid bleef in 1950 bestaan involge artikel 15 Wed. In 1976 werd de strafrechtelijke aansprakelijkheid ingevoerd in het commune strafrech ${ }^{87}$, waardoor artikel 15 Wed overbodig is geworden en vervallen. ${ }^{88}$

Een andere belangrijke wijziging vond plaats in $1994 .^{89}$ De chronologische rangschikking bleek niet tot de gewenste overzichtelijkheid te leiden. De milieudelicten die sinds de zeventiger jaren steeds vaker aan de Wed zijn aangehaakt werden ondergebracht in een nieuw artikel $1 \mathrm{a}$ Wed. ${ }^{90}$ Voorts werden de aangehaakte wetten die nu zijn opgesomd in de artikel 1 en la niet langer chronologisch, maar alfabetisch gerangschikt. Indien aan de Wed nieuwe strafbaarstellingen worden aangehaakt, iets wat in de loop van de tijd veelvuldig is gebeurd, dient de chronologische volgorde te worden aangehouden. ${ }^{91}$ Door de splitsing van de opsomming van de aangehaakte wetgeving in artikel 1 en la is tevens het economisch recht in twee delen verdeeld. Het betreft de economische delicten uit artikel 1 en de economische delicten uit de milieuwetgeving in artikel la. Deze laatste komen aan de orde in het volgende hoofdstuk.

Met de invoering van de Wed zijn de economische delicten een apart deel van het bijzonder strafrecht geworden. De criteria waarom een voorschrift al dan niet onder de reikwijdte van de Wed wordt gebracht, zijn niet altijd duidelijk. ${ }^{92}$ Het karakter van economische delicten is in de loop van de tijd ook niet constant gebleven. Door veranderingen in de economische structuren van de maatschappij en de verschuiving van problemen die ten dele worden veroorzaakt door deze structuren, is ook het karakter

87 Zie artikel 51 Sr, ingevoerd bij Wet van 23 juni 1976 houdende vaststelling van algemene bepalingen omtrent de strafbaarheid van rechtspersonen, Stb. 1976, 377.

88 Zie over de ontwikkeling, Mulder, A. en Doorenbos, D.R., Schets van het economisch strafrecht, pp. 17-22; Bemmelen, J.M. van, "Aansprakelijkheid voor Economische Delicten" "pp. 689-695, ook verschenen in Bernmelen, J.M. van, Op de grenzen van het strafrecht, pp. 261-270; Kist, F.C., "Dient het Wetboek van Strafrecht bepalingen te bevatten betreffende het daderschap en de strafrechtelijke aansprakelijkheid van andere dan natuurlijke personen?", pp. 1-70; Hulsman, L.H.C., "Dient het Wetboek van Strafrecht bepalingen te bevatten betreffende het daderschap en de strafrechtelijke aansprakelijkheid van andere dan natuurlijke personen?", pp. 73-157. Zie over daderschap door rechtspersonen, opdrachtgevers en feitelijk leidinggevenden hoofdstuk 6 paragraaf 5 .

89 Wet 4 februari 1994 tot wijziging van de Wed en andere wetten met oog op de verhoging van straffen gesteld op ernstige milieudelicten, de strafbaarstelling van een: aantal feiten als economisch delicten en de aanpassing van de indeling van de economische delicten, Stb. 1994, 135.

90 Zie over deze splitsing in de Wed hoofdstuk 8 paragraaf 2.5. en hoofdstuk 9 paragraf 2.4 .

91 Dit is te vinden in aanwijzing 147 van de Aanwijzingen voor de regelgeving van het: Ministerie van justitie. Zie over deze aanwijzingen hoofdstuk 3 paragraaf 4 .

92 Zie hierover Mulder, A. en Doorenbos, D.R., Schets van het economisch strafrecht, 1995, pp. 7-17 en 49-52. 
van economische delicten anders geworden..$^{93}$ Desalniettemin laten de artikelen 1 en 1a Wed geen misverstanden bestaan over de vraag wat economische delicten zijn, aangezien deze worden opgesomd in deze artikelen, die overigens allang niet meer alleen strafbaarstellingen betreffen uit sociaal-economische wetgeving. Voor deze delicten geeft de Wed bovendien regels voor de opsporing, vervolging en berechting, die op sommige punten afwijken van het commune straf(proces)recht.

Een belangrijk kenmerk van de Wed is dat hij niet (een enkele uitzondering daargelaten) zelf de materiële normstellingen bevat. Deze zijin namelijk te vinden in de vele bijzondere economische (milieu) wetten en in voorschriften die bij of krachtens deze wetten zijn gesteld. Vooral door het gebruik van gelede normstellingen en de invulling hiervan door de lagere wetgever is een enorme hoeveelheid strafrechtelijk te handhaven regelgeving tot stand gekomen. ${ }^{94}$ De delegatie en subdelegatie van regelgevende bevoegdheden beperkt zich niet tot overheidsinstellingen; ook privaatrechtelijke instellingen zijn op sommige gebieden bevoegd tot het vaststellen van materiêle normen. Hierdoor kan de democratische legitimatie van deze normstellingen ter discussie worden gesteld. ${ }^{95}$ Ook kan door het gebruik van gelede normen het achterhalen van de materiële normstelling een ware speurtocht worden. ${ }^{96}$ Overigens geldt dit niet voor alle strafbaarstellingen in de Wed, aangezien ook de in de artikelen 26,33 en 34 Wed omschreven gedragingen involge artikel 1 aanhef sub 5 strafbaar zijn gesteld.

Een ander belangrijk kenmerk is dat de Wed voor de meeste materiële normstellingen uit de bijzondere economische wetten bepaalt of deze zijn aan te merken als misdrijf of als overtreding. Het criterium dat voor het merendeel van de delicten wordt gebezigd, is blijkens artikel 2 Wed of het delict al dan niet opzettelijk is begaan.

Voor de opsporing en vervolging van economische delicten geldt het Wetboek van strafvordering, tenzij daarvan wordt afgeweken in de Wed of in de bijzondere wetten waarin de strafbaarstelling is opgenomen. De bevoegdheden van opsporingsambtenaren en de toepassingsmogelijkheden van dwangmiddelen worden hierdoor voor economische delicten verruimd ten opzichte van het commune strafrecht. ${ }^{97}$

Voorts is de Wed bij uitsluiting bepalend voor de mogelijke straffen, bijkomende straffen en maatregelen die kunnen worden getroffen bij economische delicten, tenzij de bijzondere wet waarin de strafbaarstelling is opgenomen anders bepaalt. De artikelen 1

93 Zie over de verandering van het karakter van economische delicten onder andere Mulder, A., "Economisch strafrecht en bestuur", pp. 378-380; Tiedemann, K., Wirtschaftsstrafrecht und Wirtschaftskriminalität.

94 Zie over delegatie en gelede normstelling hoofdstuk 4.

95 Faure, M. en Visser, M., De strafrechtelijke bescherming van het leefmilieu in België, Duitsland en Nederland, pp. 123-127, zie ook hoofdstuk 3 paragraaf 7.3.3.

96 Zie hoofdstuk 3 paragraaf 7.3.6.

97 Zie hierover Doorenbos, D.R., "De WED als bron van strafprocesrecht", pp. 69-83; Mulder, A. en Doorenbos, D.R., Schets van het economisch strafrecht, pp. 107-119; Keulen, B.F., Economische delicten, pp. 265-329. 
en 1a zijn onderverdeeld in verschillende categorieën. Deze indeling is niet alleen van belang voor de vraag of sprake is van een misdrijf of overtreding, maar ook voor de maximum strafbedreiging. ${ }^{98}$ De wetgever wilde aanvankelijk een uniforme regeling voor strafmaxima van economische delicten: ${ }^{99}$

"De gelijkheid van de maximum straffen voor alle economische misdrijven en voor alle economische overtredingen spruit voort uit het eigen karalkter van het economisch delict. Het zijn vooral de begeleidende omstandigheden van het economisch delict en de omvang van het delict, die de ernst van het delict bepalen. Daartegenover is de soort van het economische delict voor de ernst er van van minder gewicht. Het stelsel van ons. Wetboek van Strafrecht, dat de maximum straf afstemt op de ernst, welke ligt in de soort van de strafbare feiten, is daarom voor economische delicten niet bruikbaar."

Tegen deze uniformiteit rezen tijdens de parlementaire behandeling bezwaren waardoor een zekere differentiatie is ingevoerd. Er kwam zowel een tweedeling in de misdrijven als in de overtredingen, elk met een eigen strafmaximum. Naast het criterium of het delict opzettelijk is begaan, wordt dit bepaald door de categorie waarin de betreffende wet met het strafbaar gestelde artikel in artikel 1 of la is opgenomen. Aanvankelijk werd een wet met zijn strafbaarstellingen maar in één categorie opgesomd. Ook dit systeem van uniforme strafmaxima voor strafbaarstellingen uit één wet is losgelaten. Hierdoor kan een wet met verwijzing naar andere artikelen op meer plaatsen in artikel 1 of la worden teruggevonden. De plaats van de aangehaakte wet en daarbij behorend artikel in de categorieên van de artikèien l en là, en dẻ uutkómst van het onderzoek op basis van artikel 2 of sprake is van een misdrijf of een overtreding, is voor de meeste economische delicten involge de artikelen 5 en 6 bepalend voor de hoogte van de maximum strafbedreiging. Hiermee is enige differentiatie aangebracht in de strafwaardigheid van economische delicten. In deze differentiatie valt echter geen duidelijke lijn te ontdekken. De onevenwichtigheid in de indeling heeft tot gevolg dat relatief lichte delicten met een zware straf worden bedreigd en omgekeerd. ${ }^{900}$ Daarbij komt dat de wetgever in formele zin maar beperkt zicht heeft op de daadwerkelijke strafwaardigheid van gedragingen die zijn strafbaar gesteld via de Wed, omdat als gebruik wordt gemaakt van gelede normstellingen het de wetgever in materiële zin is die de uiteindelijke inhoud van de straftbarstelling vaststelt. Wat de bijkomende straffen en matregelen kunnen zijn wordt geregeld in artikel 7 en 8 . Overigens is hierbij geen differentiatie aanwezig, zodat deze ongeacht welk voorschrift is geschonden kunnen worden opgelegd met gelijke maxima. Deze nnogelijke toepassing kan vaak zeker zo punitief zijn als de "echte" straffen.

98 Zie over deze indeling Keulen, B.F., Economische delicten, pp. 20-22; Mulder, A. en Doorenbos, D.R., Schets van het economisch strafrecht, pp. 38-40; Jörg, N., "Economische delicten", 64.3.

$99 \quad T K 1948-1949,603$, p. 48.

100 Mulder, A. en Doorenbos, D.R., Schets van het economisch strafrecht, pp. 52-53; Jörg, N., "Economische delicten", 64.2. 
Een gvolg van de exclusiviteit van de Wed ten aanzien van de mogelijk toepasbare sanctis is dat de straffen, bijkomende straffen en maatregen uit Boek I Sr niet zonder meer an toepassing zijn op economische delicten. Artikel 5 Wed luidt:

"Tenz bij de wet anders is bepaald, kunnen ter zake van economische delicten geen andere voorziningen met de strekking van straf of tuchtmaatregel worden getroffen dan de straffen en maatrelelen, overeenkomstig deze wet op te leggen."

Dit arikel is vooral bedoeld om bestuursrechtelijke en tuchtrechtelijke sancties uit te sluite, maar het impliceert ook dat de strafrechtelijke sancties bij economische delictn niet in het Wetboek van Strafrecht maar in de Wed moeten zijn opgenomen. Het rikel heeft overigens slechts betrekking op "straffen en maatregelen", zodat het rechtelijk pardon (artikel 9a Sr), de voorwaardelijke veroordeling (artikel 14a Sr) en de be:kenis van het draagkrachtbeginsel (artikel $24 \mathrm{Sr}$ ) ook bij economische delicten van tepassing zijn. Betwijfeld moet echter worden of de rechter die bij een economische elict overweegt een onvoorwaardelijke vrijheidsstraf van niet meer dan zes maanen op te leggen, bevoegd is dit om te zetten in de straf tot het verrichten van onbetalde arbeid ten algemenen nutte. In de straffen en maatregelen van de Wed komt le onbetaalde arbeid ten algemenen nutte, zoals te vinden in artikel $22 \mathrm{~b} \mathrm{Sr}$, niet voor."

Wel estaat als de bijzondere economische wetgeving dit regelt, nog steeds de mogelijkheid van toepassing van het tuchtrecht. Hiervoor is onder andere in de Wet op de bedrijfsorganisatie, de Wet autovervoer goederen en de Landbouwkwaliteitwet een wettelijke basis geschapen. De keuze tussen de strafrechtelijke en tuchtrechtelijke afdoening wordt bepaald door de officier van justitie, zodat op deze manier problemen uit het verleden inzake dubbele vervolging kunnen worden voorkomen. ${ }^{102}$

\section{Zorgplichtbepalingen in het economisch strafrecht}

\subsection{Inleiding}

Het economisch strafrecht is dat deel van het bijzonder strafrecht dat is aangehaakt aan de Wed. Inmiddels zijn er meer dan honderd strafbaarstellingen opgenomen in de artikelen 1 en la Wed. Temidden van deze strafbaarstellingen bevinden zich ook enkele zorgplichtbepalingen. Twee bekende voorbeelden van dergelijke bepalingen in het economisch recht zijn artikel 11 Arbo-wet (hoofdstuk 8 paragraaf 3.2.) en artikel 15 Warenwet. Deze zorgplichtbepalingen zijn yooral interessant omdat ze recent niet langer primair strafrechtelijk handhaafbaar zijn, maar bij schending bestuursrechtelijk "beboetbare feiten" kunnen betreffen. Pas als sprake is van recidive kunnen het bij de Wed aangehaakte strafbare feiten opleveren. De zorgplichtbepaling uit artikel 11

\footnotetext{
101 Zie Mevis, P.A.M., Hoofdlijnen van het strafrechtelijk sanctiestelsel, pp. 112-113. Dat dit in de praktijk wel gebeurt blijkt bijvoorbeeld uit Wesselius, E.T., "De alternatieve Wet op de economische delicten", p. 22. Borman, T.C., Wet op de economische delicten, p. XXII.
} 
Arbo-wet zal dan ook in deze paragraaf als voorbeeld van een dergelijke bepaling in het economisch strafrecht worden onderzocht op ontwikkeling en inhoud.

\subsection{De Arbeidsomstandighedenwet}

De ontwikkeling van het arbeidsomstandighedenrecht begint aan het eind van de negentiende eeuw, toen door de opkomst van de industrialisatie de eerste wettelijke maatregel werd genomen die ingreep in de vrije verhouding tussen werkgevers en arbeiders (hoofdstuk 8 paragraaf 3.2.1.). De wettelijke bescherming van werknemers werd verder uitgebreid bij de Arbeidswet 1889 en zijn opvolger uit 1919 (hoofdstuk 8 paragraaf 3.2.2.) en ook de Veiligheidswet 1895 (hoofdstuk 8 paragraaf 3.2.3.) en zijn opvolger uit 1934 (hoofdstuk 8 paragraaf 3.2.4.) gaven een steeds verdergaande bescherming aan werknemers. De Veiligheidswet 1934 werd uiteindelijk na vele wijzigingen en aanpassingen vervangen door de Arbo-wet 1980, waarin de veiligheid, gezondheid en welzijn in verband met de arbeid centraal staan (hoofdstuk 8 paragraaf 3.2.5.). In deze wet was een zorgplichtbepaling opgenomen die werd aangehaakt bij de Wed (hoofdstuk 8 paragrafen 3.2.6. en 3.2.7.). Deze bepaling is bijna gelijkluidend terug te vinden in de Arbo-wet 1998 (hoofdstuk 8 paragrafen 3.2.8., 3.2.9. en 3.2.10.). Sinds de inwerkingtreding van deze wet op 1 november 1999 is deze zorgplichtbepaling niet langer primair strafrechtelijk handhaafbaar, maar kan de schending een bestuursrechtelijk "beboetbaar feit" opleveren. Pas als sprake is van recidive betreft het een bij de Wed aangehaakt strafbaar fert. Het iijkt dan ook een voorbeeid van de ontwikkeling om de eigen verantwoordelijkheid voor de uitvoering en handhaving van bestuursrechtelijke regelgeving door het bestuur te versterken. ${ }^{103}$

\subsubsection{Het Kinderwetje uit $\mathbf{1} 874$}

In de negentiende eeuw was regelgeving op het gebied van arbeid en welzijn voor werknemers en de kwaliteit en veiligheid van arbeid nauwelijks aanwezig. In het begin. van de negentiende eeuw speelde de idee van persoonlijke vrijheid en eigen verantwoordelijkheid een belangrijke rol. Ook arbeid werd door velen gezien als een. persoonlijke en vrije keuze, waarin de overheid niet diende te interveniëren. In het privaatrecht namen de vrijheid van eigendom en de contractsvrijheid belangrijke plaatsen in. Aanvankelijk was vooral sprake van afspraken tussen werkgevers en werknemers, waarbij deze laatste groep ondergeschikt was aan en afhankelijk was van de eerste. De staatsonthouding in combinatie met de ontwikkelende industrie gaf aanleiding tot vele problemen voor de arbeidende klasse. ${ }^{104}$ De behoefte aan arbeidsrechtelijke regelgeving werd met de opkomst van de industrialisatie steeds groter. ${ }^{105}$ Het inzicht groeide dat de overheid ook hier een taak heeft, en zich niet langer diende

103 Zie hierover hoofdstuk 6 paragraaf 4 .

104 Zie Fortanier, G.F. en Veraart, J.J.M., herzien door Rang, J.F., Arbeidsrecht, pp. 10-12; Bakels, H.L., Schets van het Nederlands arbeidsrecht, pp. 4-6; zie over de periode 18001870 Geers, A.J.C.M., Recht en humanisering van arbeid, pp. 19-29.

105 Zie over het ontstaan van arbeidsbeschermingsrecht in de negentiende eeuw Levenbach, M.G., Arbeid: Sociale verzekering, pp. 436-441, zie voor zijn historisch overzicht pp. 436-489; Molenaar, A.N., Arbeidsrecht, pp. 249-256. 
te onthouden. Nadat in diverse West-Europese landen regelgeving tot stand. was gekomen $^{106}$, kwam in Nederland in 1874 een eerste wettelijke maatregel tot stand die ingreep in de vrije verhouding tussen werkgevers en arbeiders. Dit gebeurde op imitiatef van Van Houten, met het naar hem genoemde "Kinderwetje van Van Houten". ${ }^{107}$ Dit uit vijf artikelen bestaande wetje heeft zijn hooggespannen verwachtingen niet waar kunnen maken. Al snel bleek dat door gebrekkige controle op de naleving en door de rechterlijke interpretatie van de wet, de werking teleurstellend was. ${ }^{16}$

\subsubsection{De Arbeidswet 1889 en de Arbeidswet 1919}

Er wedden in 1882 en 1885 voorstellen gedaan om de wettelijke regeling uit te breiden, maar deze mislukten vooral omdat feitelijke gegevens over misstanden ontbraken. Om dit te ondervangen werd in $\mathbf{1 8 8 6}$ in de Tweede Kamer een voorstel ingediend tot het houden van een parlementaire enquête. Dit voorstel werd aangenomen. De enquête behelsde de volgende twee vragen:

"a. Weke is de werking der wet van 19 Sept. 1874 (Stbld. no. 130) ook in verband met art. 82 van de wet van 17 Aug. 1878 (Stbld. no. 127)? In hoever geven de bestaande toestanden aanleid̄ng eene aanvulling en uitbreiding der eerstgenoemde wet in overweging te nemen?

b. Welk is de toestand van fabrieken en werkplaatsen hier te lande, met het oog op de veiligheid, de gezondheid en het welzijn der werklieden? In hoeverre worden tot verbetering van dien toestand maatregelen van overheidswege vereischt?"

$\mathrm{Na}$ bezoeken te hebben afgelegd, werd de Commissie in verband met de Grondwetsherziening genoodzaakt haar werkzaamheden te staken. Alvorens af te treden diende zij in 1887 een rapport in met de resultaten en met aanwijzing van wettelijke maatregelen die zij nodig en uitvoerbaar achtte. Deze aanbevelingen beperkten zich niet tot kinderen, maar betroffen ook jeugdigen personen (tot 16 jaar) en vrouwen. ${ }^{109}$ Uit dit rapport werd duidelijk dat het effect van de Kinderwet gering was en dat er sprake was van vele misstanden. ${ }^{110}$

Het gevolg van deze uitkomsten en de maatschappelijke onrust ten gevolge van de grote werkeloosheid leidde tot de Arbeidswet $1889^{111}$, die het verbod op kinderarbeid

106 Zie Geers, A.J.C.M., "Arbeidsbeschermingsrecht”, pp. 203-204.

107 Wet op de Kinderarbeid van 19 september 1874, Stb. 1874, 130. Zie over dit kinderwetje hoofdstuk 8 paragraaf 3.2.1.; Molenaar, A.N., Arbeidsrecht, pp. 257-271; Geers, A.J.C.M., Recht en humanisering van arbeid, pp. 33-35.

108 Diepenhorst, P.A., De Nederlandsche arbeidswetgeving, pp. 149-152; Drongelen, J. van, De ontwikkeling van de arbeidsinspectie in een veranderende wetgeving, pp. 20-22.

109 Molenaar, A.N., Arbeidsrecht, pp. 272-279.

110 Zie over de enquête en zijn resultaten onder andere: Diepenhorst, P.A., De Nederlandsche arbeidswetgeving, pp. 152-155; Goeman Borgesius, H., De Nederlandsche Arbeids- en Fabriekswetten benevens de besluiten ter uitvoering, met inleiding en aanteekeningen, pp. 5-8; Giele, J., Een kwaad leven: de arbeidsenquête van 1887; Sassen, P.E.M.S., "De arbeidsenquête van 1887", pp. 239-249.

III Wet van 5 mei 1889 houdende bepalingen tot het tegengaan van overmatigen en 
verscherpte en regels gaf inzake de werktijden voor jongeren tot 16 jaar en vrouwen. Aan de arbeid van volwassen mannen meende de wetgever in deze wet ${ }^{112}$ nog geen beperkingen te mogen opleggen. ${ }^{113}$ Op basis van deze wet werd, op aandrang van de Tweede Kamer, de Arbeidsinspectie ingesteld die bestond uit drie inspecteurs. Niet alleen waren zij belast met de controle op het naleven van deze wet, tevens moesten zij onderzoek verrichten naar de veiligheid en gezondheid van de werknemers, de werkgevers wijzen op maatregelen die verbetering kunnen brengen in de veiligheid en gezondheid van werknemers, jaarlijks aan de regering verslag uit brengen over de toestand waarin de door hun bezochte fabrieken en werkplaatsen zich bevonden en de regering adviseren over de toepassing van bestaande voorschriften en wijzigingen in de wetgeving. ${ }^{114}$

De Arbeidswet 1889 werd vervangen door de Arbeidswet 1919 die involge artikel 1 betrekking heeft op alle werkzaamheden in een onderneming. Het doel was vooral de beperking van de arbeidsduur met oog op de bescherming van werknemers, waarvoor regels waren opgenomen inzake arbeids- en rusttijden, die naast kinderen en vrouwen ook betrekking hadden op mannen. Voorts bevat de wet enkele specifieke bepalingen inzake de leeftijd waarop mag worden gewerkt, en enkele bijzondere voorschriften voor de bescherming van bepaalde categorieën. Deze wet is na vele wijzigingen en aanpassingen nog steeds van kracht. ${ }^{115}$

\subsubsection{De Veiligheidswet 1895}

Op basis van de rapportages van de arbeidsinspecteurs in het kader van de Arbeidswet 1889 werd besloten de wetgeving uit te breiden, opdat de veiligheid en gezondheid van werknemers door wetgeving beschermd zou worden. Dit gebeurde in de Veiligheidswet van 1895, die regels bevatte ter bescherrning van de gezondheid en de veiligheid van ieder die in een fabriek of werkplaats verbleef tegen de gevaren van industriële arbeid. De wet beperkte zich dus niet tot enkele kinderen, jeugdigen en vrouwen, maar had ook betrekking op volwassen mannen. De Arbeidsinspectie werd uitgebreid en bleef onder andere de belangrijke taak houden in het toezicht op de naleving van de wet.

Naast de Arbeidswet en de Veiligheidswet kwamen er diverse arbeidsbeschermende wetten tot stand die gericht waren op specifieke bedrijfstakken en werkzaamheden. Het betreft onder andere de Phosphorluciferwet uit 1901, de Mijnwet 1904 en de

gevaarlijken arbeid van jeugdige personen en varı vrouwen, Stb. 1889, 48.

112 Zie over regelgeving voar volwassen mannen Diepenhorst, P.A., De Nederlandsche arbeidswetgeving, pp. 165-186.

113 Molenaar, A.N., Arbeidsrecht, p. 285.

114 Zie Geers, A., Veilig en wel, pp. 16-17; Harryvan, R., Overtredingen van de Arbeidsomstandighedenwet, pp. 17-18; Geers, A.J.C.M., Recht en humanisering van arbeid, pp. $39-42$.

115 Zie Jacobs, A.T.J.M., Frenkel, B.S., Heerma van Voss, G.J.J. en Pieters, D.C.H.M. Elementair sociaal recht, pp. 82-90; en over de totstandkoming Diepenhorst, P.A., De Nederlandsche arbeidswetgeving, pp. 187-206. 
Stuwadoorswet uit 1914. Ook later is deze ontwikkeling doorgegaan, en zijn onder andere de Huisarbeidwet 1933, de Rijtijdenwet 1936, de Silicosewet 1951, de Wet op Gevarlijke Werktuigen 1952, de Kernenergiewet 1963 en de Wet op het werken onder overdruk 1968 . $^{16}$

\subsubsection{De Veiligheidswet 1934}

De Veiligheidswet 1895 werd in 1934 vervangen door een nieuwe Veiligheidswet. ${ }^{117}$ De werkingssfeer van de wet uit 1895 bleek te beperkt. Het doel van de wet werd gewijzigd in de beveiliging van arbeid in het algemeen en bij verblijven in fabrieken of werkplaatsen in het bijzonder. Onder arbeid wordt verstaan alle werkzaamheden in een onderneming, tenzij deze wordt verricht door het hoofd of de bestuurder of diens echtgenoot. Met een onderneming worden gelijk gesteld bouwwerken in eigen beheer, overheidsdiensten en -instellingen, onderwijsinrichtingen en inrichtingen waar voor de gezondheid schadelijke stralen kunnen voorkomen. De werkingssfeer werd zodoende ten opzichte van de Veiligheidswet 1895 uitgebreid. De wet onderscheidde vier sectoren, te weten de industrie, de landbouw, de binnenvaart en een restgroep. Bij amvb werden vaak zeer gedetailleerd nadere veiligheidsvoorschriften voor deze sectoren vastgesteld. Deze werden in de wet opgesomd, zodat de inzichtelijkheid in regelgeving op dit punt wordt gehandhaafd. Involge artikel 8, eerste lid Veiligheidswet 1934 werden strafrechtelijk handhaafbare plichten opgelegd aan het hoofd of de bestuurder var een onderneming. ${ }^{118}$ Voorts werd in deze wet een strafbaarstelling opgenomen op basis waarvan werknemers strafrechtelijk aansprakelijk konden worden gesteld indien zij voorschriften gericht op eigen veiligheid en gezondheid niet naleefden. ${ }^{119}$ In deze wet wordt de werknemer gezien als een te beschermen object. De zorg voor de veiligheid en de gezondheid binnen het bedrijf ligt geheel bij de werkgever en wordt niet gezien als een gezamenlijke taak van werkgever en werknemer. De gedachte aan overleg en samenwerking tussen werkgever en werknemer was ook verder nauwelijks

116 Zie over deze wetten Geers, A., Veilig en wel, pp. 20-23; Geers, A.J.C.M., Recht en humanisering van arbeid, pp. 53-59.

117 Wet houdende bepalingen tot beveiliging bij den arbeid in het algemeen en bij het verblijven in fabrieken of werkplaatsen in het bijzonder, van 2 juli 1934, Stb. 1934, 352, zie hierover Geers, A.J.C.M., Recht en humanisering van arbeid, pp. 66-71 en 74-77.

118 Artikel 8, eerste lid luidde: "Het hoofd of de bestuurder van eene onderneming, waarin arbeid wordt verricht in eene fabriek of werkplaats, is verplicht op last van het districtshoofd, op door dezen aan te wijzen plaatsen en zóo, dat het voor een ieder duidelijk leesbaar zij, een door dien ambtenaar opgemaakt en door hem en het hoofd of den bestuurder der ondememing ondertekend reglement op te hangen en opgehangen te. houden, bevattende hetgeen door de in de fabriek of werkplaats verblijvende personen aldaar behoort te worden nagekomen of nagelaten in het belang van der veiligheid van hen zelven of van anderen." Involge artikel 31, eerste lid sub a is het overtreden strafbaar gesteld en wordt bedreigd met hechtenis van ten hoogste drie maanden of geldboete van maximaal driehonderd gulden. Involge artikel 35 is het een overtreding. Zie hierover Zwam, H.J. van, Veranderingen in het arbeidsomstandighedenrecht, pp. Vraag. VII/4-10.

119 Harryvan, R., Overtredingen van de Arbeidsomstandighedenwet, p. 19; Geers, A., Veilig en wel, pp. 18-20. 
uitgewerkt en aan de enige daarop betrekking hebbende bepaling (inzake de veiligheidscommissie) werd nooit uitvoering gegeven. ${ }^{120}$

\subsubsection{De Arbeidsomstandighedenwet 1980}

De Veiligheidswet 1934 is uiteindelijk na vele wijzigingen en aanpassingen vervangen door de Arbo-wet $1980^{i 2 \mathrm{i}}$, waarin de veiligheid, gezondheid en welzijn in verband met de arbeid centraal staan. ${ }^{122}$ De wet gaat niet langer uit van een indeling van het bedrijfsleven in vier sectoren, en kiest voor een andere benadering. Deze houdt in dat de wetgever voor de bedrijfsgezondheidszorg op bedrijfsniveau een verhoogde deskundigheid tracht te verzekeren; dat de veiligheid en gezondheid van de werknemers wordt gezien als belangrijke facetten van de "humanisering van arbeid", waarbij ook andere aspecten daarvan zoals de organisatie en kwaliteit van arbeid worden betrokken; daarnaast worden werknemers in de besluitvorming betrokken en worden werkgevers gestimuleerd zelf beleid te formuleren. ${ }^{123}$

Met de invoering kwamen de Veiligheidswet 1934, de Silicosewet, de Wet op werken onder overdruk en het deel van de Stucadoorswet dat ziet op het veiligheidsaspect te vervallen. De werkingssfeer is opnieuw vernimd ten opzicht van zijn voorganger. De wet ziet niet alleen op werk in ondernemingen, ook andersoortige werkzaamheden vallen onder zijjn werkingssfeer. Zo blijkt uit de artikelen 1 en 2 Arbo-wet 1980 dat de

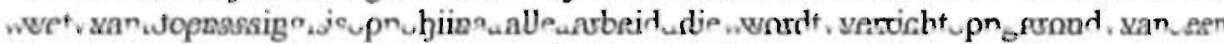
arbeidsovereenkomst, krachtens een publiekrechtelijke aanstelling en onder gezag van een ander, terwijl involge artikel 27 ook zelfstandige ondernemers gedeeltelijk onder de werkingssfeer kunnen vallen. De inhoud van de wet is ook verruimd: de Veiligheidswet richtte zich vooral op de gezondheid en veiligheid van werknemers, terwijl de nieuwe wet daarnaast voorschriften bevat die verband houden met het welzijn van de werknemer.

De werkgever heeft naast de specifieke plichten uit de artikelen 4 tot en met 11 en de vele verplichtingen die voortvloeien uit lagere regelgeving op grond van artikel 3 een algemene verplichting ten opzichte van zijn werknemers tot zorg voor een zo groot mogelijke veiligheid, zo goed mogelijke bescherming van de gezondheid en de bevordering van welzijn bij of in verband met de arbeid. ${ }^{12}$ Deze nieuwe plicht beperkt zich

120 Zie $T K 1976-1977,14497$, nrs. 1-2, p. 2. De Veiligheidswet 1934 is vervallen involge artikel 46 van de Arbo-wet 1980 van 8 november 1980, Stb. 1980, 664.

121 Wet van 8 november 1980, Stb. 1980, 664. Zie over deze wet Riet Paap, K.W. van, Arbeidsomstandighedenwet; Geers, A.J.C.M., Recht en humanisering van arbeid, pp. 89-97, 105-111, 115-142 en 269-298.

122 De Arbo-wet 1980 werd een aantal malen gewijzigd. Belangrijke is de wijziging als gevolg van de dereguleringsvoorstellen bij wet van 26 november 1987, Stb. 1987, 535 en wijziging ten gevolge van de samenloop van medezeggenschapbepalingen met die uit de WOR bij wet van I februari 1990, Stb. 1990, 91. Zie hierover Geers, A., "Inleiding", pp. 17-19.

123 TK 1976-1977, 14497, nr. 3, p. 3.

124 Ministerie van Sociale Zaken en Werkgelegenheid, De Arbeidsomstandighedenwet 
niet $\mathfrak{t}$ het naleven van wat bij of krachtens de wet is bepaald, maar kan zich onder omstadigheden uitstrekken tot het nemen van maatregelen waarin de wet (nog) niet voarzt. Zij vindt volgens de memorie van toelichting zijn rechtvaardiging in het feit dat dwerkgever primair bepaalt welke maatregelen in zijn bedrijf plaatsvinden, hoe het wrkproces verloopt en onder welke omstandigheden de werkzaamheden. worden verrict, zodat van hem mag worden verwacht dat hij bij het bepalen van deze onderwerpa de grootst mogelijke aandacht besteedt aan de eventuele gevarenrisico's waaran werknemers worden blootgesteld, mede daar de regelgeving in deze fase van de inustriële ontwikkeling nooit rekening kan. houden met alle omstandigheden die zich linnen voordoen. ${ }^{125}$ Daarnaast is hij involge artikel 11 verplicht maatregelen te neme tot voorkoming van gevaar voor de veiligheid of gezondheid van andere persoen dan de werknemers, dat kan ontstaan bij of in rechtstreeks verband met de arbeidie de werkgever door zijn werknemers doet verrichten in een bedrijf of een inrichng of in de onmiddellijke omgeving daarvan. Hierbij kan worden gedacht aan gevaz voor bezoekers, voorbijgangers of onmiddellijk omwonenden.

De Abo-wet 1980 wordt aangeduid als een raamwet, aangezien de meeste normstelliren zijn te vinden in (de vele) uitvoeringsbesluiten die op basis van de wet zijn. genoren. Bij de invoering van de Arbo-wet 1980 waren er ongeveer veertig. uitvoingsbesluiten die honderden normstellingen bevatten. Vele waren verouderd, er warerveel doublures, en de bepalingen waren vaak erg gedetailleerd. Ook door de invloed van de Europese regelgeving is sprake van een toename van de hoeveelheid, de gedetailleerdheid en de complexiteit van de regelgeving. ${ }^{126}$ Op 1 juli 1997 zijn alle besluiten op grond van de Arbo-wet 1980 vervangen door één (op artikel 24 Arbo-wet gebaseerd) Arbeidsomstandighedenbesluit dat ongeveer vierhonderd artikelen bevat. ${ }^{127}$ De bepalingen zijn hierin niet meer per sector gerangschikt maar naar onderwerp. Hierdoor zijn alle voorschriften die betrekking hebben op een bepaald onderwerp in één. hoofdstuk te vinden. Elk hoofdstuk geldt in beginsel voor alle sectoren en alle werknemers. In dit besluit zijn enkele zorgplichtbepalingen opgenomen, bijvoorbeeld in artikel 3.2 en 4.1 . Over dit type bepalingen, die worden aangeduid als "vangnet-bepalingen", wordt in de toelichting opgemerkt dat $\mathrm{zij}^{128}$

"door de toezichthoudende instanties gebruikt kunnen worden indien meer concrete. voorschriften niet toepasbaar of (nog) niet voorhanden zijn, bijvoorbeeld omdat de (on)schadelijkheid van een stof' of de gevaren van het gebruik van. een recent ontwikkelde machine, nog niet vaststaan."

Involge artikel 26, eerste lid Arbo-wet 1980 zijn werkgevers en werknemers verplicht tot de naleving vain de voorschriften of verboden uit dit Arbeidsomstanđigheden--

$$
\text { 1990, pp. 31-34. }
$$

125. TK 1976-1977, 14 497, nr: 3, pp. 4, 11.

126 Zwam, H.J. van, De handhaving van de Arbowet, pp. 91-92.

127 Besluit van 15 januari 1997, houdende regels in het belang van de veiligheid, de gezondheid en het welzijn in verband met de arbeid (Arbeidsomstandighedenbesluit), Stb. 1997, 660 .

128 Nota van toelichting Arbeidsomstandighedenbesluit, Stb. 1997, 60, p. 141. 
besluit, voor zover en op de wijze als bij deze maatregelen is bepaald. Dit artikel is aangehaakt bij artikel 1 sub 4 Wed, zodat deze feiten gezien artikel 2, vierde lid Wed overtredingen zijn, die op basis van artikel 6, eerste lid sub 4 Wed worden bedreigd met hechtenis van ten hoogste zes maanden of een geldboete van de vierde categorie. Bij de inwerkingtreding van de Arbo-wet 1998 is het inmiddels enkele malen gewijzigde: Arbeidsomstandighedenbesluit van kracht gebleven. Het besluit en deze artikelen vindt nu zijn grondslag in artikel 16 Arbo-wet $1998 .{ }^{129}$ Involge artikel 16, negende lid Arbo-wet 1998 zijn de werkgever, de werknemers en degene die worden aangewezen in het zesde, zevende en achtste lid van dit artikel, "verplicht tot naleving van voorschriften en verboden als bedoeld in de op grond van dit artikel vastgestelde algemene maatregel van bestuur voorzover en op de wijze als bij deze maatregel is bepaald." Als het blijkens deze algemene maatregel van bestuur een "beboetbaar feit" betreft kan involge artikel 33, eerste lid jo. 34, vierde lid een boete worden opgelegd van 10.000 of 25.000 gulden. Indien een zelfde feit waarvoor de boete is opgelegd birnen 24 maanden opnieuw plaatsvindt betreft het involge artikel 33, derde lid een strafbaar feit, dat zowel blijkens artikel 16 , tiende lid als artikel 33 , vijfde lid wordt aangemerkt als overtreding. Het strafbare feit is ex artikel 46 , eerste lid aangehaakt bij artikel 1 sub 3 Wed, dat involge artikel 6 , eerste lid sub 4 Wed wordt bedreigd met hechtenis van ten hoogste zes maanden of een geldboete van de vierde categorie (f. $25.000,-)$.

\subsubsection{Artikel 12 Arbo-wet 1980}

In de Arbo-wet 1980 zelf is één artikel opgenomen dat zich direct richt tot de werknemers. Dit artikel is een voorbeeld van de veranderde visie uit de Arbo-wet ten opzichte van de eigen en mede verantwoordelijkheid van de werknemers. ${ }^{130}$ Het betreft artikel 12. ${ }^{131}$ De memorie van toelichting wees op het volgende ${ }^{132}$ :

"Het wetsontwerp gaat echter - het is in deze memorie reeds vaker vermeld - van een ander standpunt uit. Het ziet de zorg voor een veilig en gezond arbeidsmilieu niet als een plicht die vrijwel geheel eenzijdig op de werkgever rust. Het voorziet in voorlichting en veiligheidsonderricht van de werknemers, en geeft hun mede een stem in het bepalen van het beleid op het terrein van veiligheid en gezondheid en geeft hun vertegenwoordigers bepaalde bevoegdheden en rechten. Onder deze omstandigheden mag van hen worden verwacht dat zij zich ook van hun verantwoordelijkheid bewust zijn en dat zij in dit verband bereid zijn ook een aantal verplichtingen en de daaruit voortvloeiende aansprakelijkheid te aanvaarden, al is deze uiteraard van veel beperkter omvang dan die van de werkgever."

De wetgever wilde de strafbaarstelling niet beperken tot die gevallen waarin sprake zou zijn van opzet of grove onachtzaamheid van de werknemer, omdat de bepaling

129 TK 1997-1998, 25879 , nr. 3, pp. 42-44.

130 Rood, M.G., Introductie in het sociaal recht, pp. 190.

131 Artikel 12 is gezien de gefaseerde inwerkingtreding van de Arbo-wet 1980 krachtens het Besluit van 18 maart 1985, Stb. 1985, 212, op 1 juni. 1985 in werking getreden. Zie over deze invoering Frenkel, B.S. en Jacobs, A.T.J.M., Sociaal bestuursrecht, pp. 56-61.

132 TK 1976-1977, 24497 , nr. 3, p. 12. 
ziet op situaties waarbij de niet-naleving van de voorgeschreven gedragingen ernstige repercussies kan hebben voor de veiligheid en gezondheid van de werknemer zelf, andere werknemers en derden. Hierin vindt hij het niet passen de strafbaarstelling te beperken nu ook een geringe mate van onachtzaamheid de onwenselijke situatie tot gevolg kan hebben. Uitbreiding met strafbaarstellingen die deze gevolgen door opzet of grove onoplettendheid veroorzaken wordt ook onnodig gevonden, omdat daarin de strafbarstellingen in het Wetboek van Strafrecht reeds voorzien. ${ }^{133}$

\section{Artikel 12 Arbo-wet 1980 luidt:}

"Onverminderd het elders bij of krachtens deze wet bepaalde zijn de werknemers verplicht in verband met de arbeid de nodige voorzichtigheid en zorgvuldigheid in acht te nemen ter vermijding van gevaren voor de veiligheid of de gezondheid van hern zelf of van anderen dan wel met het oog op het welzijn. Met name zijn zij verplicht om:

a machines, toestellen, werktuigen, gevaarlijke stoffen, transportmiddelen en andere hulpmiddelen op de juiste wijze te gebruiken;

b. de hun ingevolge deze wet ter beschikking gestelde persoonlijke beschermingsmiddelen op de juiste wijze te gebruiken en na gebruik op de daartoe bestemde plaats op te bergen, een en ander voor zover niet krachtens deze wet is bepaald dat werknemers niet verplicht zijn beschermingsmiddelen als vorenbedoeld te gebruiken;

c. de op werktuigen, toestellen of anderszins aangebrachte beveiligingen niet te veranderen of buiten noodzaak weg te halen en deze op de juiste wijze te gebruiken;

d. mede te werken aan het voor hen georganiseerde onderricht bedoeld in de artikelen 6, 7 en 8 ;

e. de door hen opgemerkte gevaren voor de veiligheid of de gezondheid terstond ter kennis te brengen aan de werkgever of degene, die namens deze ter plaatse met de leiding is belast;

f. de werkgever en de werknemers, andere personen en diensten, bedoeld in artikel 17, indien nodig, bij te staan bij de uitvoering van hun verplichtingen en taken op grond van deze wet."

Opgemerkt moet worden dat het overtreden van de algemeen geformuleerde zorgplicht uit de aanhef van artikel 12 niet strafbaar is gesteld, maar dat dit alleen is gebeurd bij de concrete uitwerkingen in sub a tot en met $f$. De strafbaarheid van gedragingen die onder deze uitwerkingen vallen, worden (waarschijnlijk) wel ingekleurd door de aanhef. Door deze splitsing in een algemeen deel dat niet en een uitgewerkt deel dat wel strafrechtelijk handhaafbaar is, is het een interessant voorbeeld voor zorgplichtbepalingen. Het algemene deel is immers tamelijk vaag ${ }^{134}$ en zou indien het schenden daarvan strafbaar was gesteld op gespannen voet staan met het lex certa-beginsel. ${ }^{135}$

Het schenden van artikel 12, onder a tot en met $f$ is involge artikel 57 Arbo-wet 1980 jo. 1 sub 4 Wed strafbaar gesteld. Gezien artikel 2, vierde lid Wed zijn economische

133 "Ten slotte zullen in gevaarlijke situaties opzettelijke of door grove onachtzaamheid begane gedragingen, indien zij leiden tot de dood of zwaar lichamelijk letsel van een collega van de werknemer, veelal vallen onder bijvoorbeeld de misdrijven dood door schuld of zwaar lichamelijk letsel door schuld." TK 1976-1977, 24 497, nr. 5, p. 27.

134 Zie hoofdstuk 2 paragraaf 5.4.

135 Zie hoofdstuk 3 paragraaf 7.3. 
delicten uit deze categorie overtredingen. De maximum strafbedreiging is blijkens artikel 6, vierde lid Wed hechtenis van ten hoogste zes maanden of een geldboete van de vierde categorie. Deze geldboete kan worden verhoogd tot de naast hogere categorie indien de waarde van de goederen waarmee of met betrekking tot het economisch delict is begaan, of die geheel of gedeeltelijk door middel van het economisch delict zijn verkregen, hoger is dan het vierde gedeelte van het maximum van de geldboete die voor dit delict kan worden opgelegd. Daarnaast kunnen de bijkomende straffen uit artikel 7 Wed en maatregelen uit artikel 8 Wed worden opgelegd. ${ }^{136}$ Voorts kan het districtshoofd involge artikel 35 Arbo-wet 1980 eventueel de werkgever of andere personen of diensten bedoeld in artikel 17 Arbo-wet 1980 een aanwijzing geven. Indien deze aanwijzing niet wordt opgevolgd kan dit involge artikel 57 Arbowet jo. 1 sub 4 Wed eveneens een strafbaar feit opleveren. Het OM is bij zijn vervolgingsbeslissing niet afhankelijk van een al dan niet gegeven aanwijzing door het districtshoofd. ${ }^{\text {T37 }}$

\subsubsection{De zorgplichtbepaling uit artikel 12 nader beschouwd}

De zorgplichtbepaling richt zich tot de werknemer die in de Arbo-wet 1980 een vergaande medeverantwoordelijkheid heeft gekregen. ${ }^{138}$ Blijkens artikel 1 is dit degene die krachtens arbeidsovereenkomst of publiekrechtelijke aanstelling gehouden is tot het verrichten van arbeid, degene die onder het gezag van een ander arbeid verricht en degene die niet onder gezag arbeid verricht in een woning in een bij amvb aangewezen geval.

Involge de uitwerkingen $\mathrm{a}, \mathrm{b}$ en $\mathrm{c}$ dient de werknemer de daarin opgesomde goederen op de juiste wijze te gebruiken. De werkgever moet voorlichting geven over het "juiste gebnik". Hiervoor staan hem onder andere de publicatiebladen van de Arbeidsinspectie, door de fabrikant verstrekte bedieningsvoorschriften, in (valk)opleidingen verworven kennis ter beschikking. Indien overleg tussen werkgever en werknemer (en eventueel de Arbeidsinspectie) bij een meningsverschil over het "juiste gebruik" niet tot een docr de werknemer gewenste uitkomst leidt, moet hij de instructie van de werkgever opvolgen, tenzij hierdoor naar zijn redelijk oordeel emstig gevaar voor hemzelf of anderen ontstaat. Dan zal hij involge artikel 38 Arbo-wet 1980 zijn werk mogen onderbreken. ${ }^{139}$

De persoonlijke beschermingsmiddelen uit sub $\mathrm{b}$ betreffen alleen beschermingsmiddelen die volgens de Arbo-wet 1980 of een daarop gebaseerd uitvoeringsbesluit zijn. voorgeschreven. Deze moeten door de werkgever ter beschikking zijn gesteld. Indien de werkgever verdergaand gebruik van beschermings-

136. Zie over de strafrechtelijke handhaving van de Arbo-wet 1980 ook Geers, A.J.C.M. en Gevers, J.K.M., Arbeidsomstandighedenrecht, pp. 73-90.

137 TK 1976-1977, 14497 nr. 5, p. 28. Het districtshoofd kan ook zelf kiezen of hij volstaat met een aanwijzing of proces verbaal opmaakt, waarbij de emst van de geconstateerde overtreding doorgaans een belangrijke rol zal spelen.

138. Zwam, H.J. van, De handhaving van de Arbowet, p. 98.

139. Poest Clemert, P.E. van der en Boere, A.H.M., Handboek ARBO wet, pp. 127-128. 
middelen vereist, valt het gebruik daarvan niet onder de reikwijdte van deze bepaling. ${ }^{140}$ Dit geldt niet voor de in sub c genoemde beveiligingen. Deze staan vaak niet expliciet opgenomen in wetgeving of uitvoeringsbesluiten. De plicht houdt in dat de werknemer de aangebrachte beveiligingen moet gebruiken, ook al zijn deze niet wettelijk voorgeschreven. ${ }^{141}$

Voorts zijn werknemers involge sub d verplicht mee te werken aan het voor hen georganiseerd onderricht. De werkgever is involge artikel 6, 7 en 8 Arbo-wet 1980 verplicht dit onderricht te organiseren. Hierbij is van belang dat de werknemer ook daadwerkelijk in staat is deze plicht na te leven. Ook behoeft hij niet ieder onderricht te volgen dat wordt aangeboden; deze plicht bestaat alleen voor het onderricht dat direct van belang is voor zijn werk. ${ }^{142}$

Sub $\mathrm{f}$ is in 1993 aan artikel 12 toegevoegd ${ }^{143}$ ter uitvoering van een EG-richtlijn. ${ }^{144}$ Deze regel geldt gezien de term indien nodig minder absoluut dan die onder a tot en met e. Hieruit kan worden afgeleid dat het niet de bedoeling is dat een ieder altijd uitvoering geeft aan deze plicht; zo is het niet de bedoeling dat de bestaande hiërarchische lijn wordt doorkruist. ${ }^{145}$

Of de werknemer aan bovenstaande verplichtingen kan voldoen, is mede afhankelijk van de vraag of de werkgever de wet naleeft. Doet de werkgever dat niet, dan kan de werknemer vaak moeilijk worden aangesproken op het niet voldoen aan zijn verplichtingen. ${ }^{146}$

\subsubsection{De Arbeidsomstandighedenwet 1998}

Nadat de Arbo-wet 1980 volledig in werking was getreden, werd vastgesteld dat het niet mogelijk is gebleken een overzichtelijk, actueel en doeltreffend regelcomplex te construeren waarin langs bestuursrechtelijke weg de verplichtingen rond de arbeidsomstandigheden uitputtend en hanteerbaar zijn genormeerd. In 1994 waren er meer dan 1200 normen in ongeveer 30 nog geldende amvb's op grond van de Arbo-wet 1980 en tal van lagere regels, waardoor geen sprake was van een duidelijk en toegankelijk systeem. ${ }^{147}$ De Commissie voor de toetsing van wetgevingsprojecten werd gevraagd on advies inzake het wetgevingsbeleid voor de arbeidsomstandig-

140 Poest Clemert, P.E. van der en Boere, A.H.M., Handboek ARBO wel, pp. 128- 129.

141 Poest Clemert, P.E. van der en Boere, A.H.M., Handboek ARBO wet, pp. 129.

142 Poest Clemert, P.E. van der en Boere, A.H.M., Handboek ARBO wet, p. 130.

143 Wet van 22 december 1993, Stb. 1993, 757.

144 Richtlijn van de Raad van Europese Gemeenschappen van 12 juni 1989 betreffende de tenuitvoerlegging van maatregelen ter bevordering van de verbetering van de veiligheid en de gezondheid van werknemers op het werk (PbEG 1989, L 183).

145 Poest Clemert, P.E. van der en Boere, A.H.M., Handboek ARBO wet, pp. 130-131.

146 Ministerie van Sociale Zaken en Werkgelegenheid, De Arbeidsomstandighedenwet 1990 , p. 47.

147 Commissie voor de toetsing van wetgevingsprojecten, Van Keurslijf naar Keurmerk; Wetgevingsbeleid voor veilig en gezond werk, p. 10. 
heden. Zij stelt in haar advies dat nonchalance en gebrek aan kemnis, tijd en geld vaak belangrijke weerstanden zijn bij de naleving van de zorg voor goede arbeidsomstandigheden. Zij betwijfelt of het er bij ongewijzigd wetgevingsbeleid beter zal worden, omdat zij meent dat de manier waarop de wetgever vorm en inhoud geeft aan de normering van arbeidsomstandigheden onvoldoende aanzet tot de noodzakelijke zorg. ${ }^{148}$ Het advies is geënt op het gedachtegoed van $\mathrm{De} \mathrm{Ru}$, die een voorstander is van het gebruik van in algemene wetten neergelegde open normen en voor het privaatrecht als reguleringsinstrument, waarbij hij ervan uitgaat dat de jurisprudentie als motor voor de rechtsontwikkeling fungeert. ${ }^{145}$ De Commissie adviseert ${ }^{150}$

"voor zover het strafrecht nog wordt ingezet op het terrein van de arbeidsomstandigheden" een
versterking "van de waarborgen voor de zekerheid en snelheid van strafrechtelijke interventie.
Daarbij verdient uitbreiding en aanscherping van het sanctie-arsenaal nadrukkelijk overweging."

Zij is voorstander van een verscherping van de strafrechtelijke sanctie mogelijkheden in geval van overtreding van een veel beperkter aantal bestuursrechtelijk genormeerde verplichtingen. Het strafrecht zou veel meer dan op dat moment het geval is teruggebracht moeten worden tot laatste middel, maar als het gebruik opportuun is, zijn waarborgen nodig voor de zekerheid en snelheid van de interventie, waarbij de wetgever voorziet in een doeltreffend arsenaal aan evenredige sancties. ${ }^{15}$

In december 1994 werd doon de ministers van Economische Zaken en Justitie in een brief aan de Tweede Kamer het plan van aanpak "Marktwerking, deregulering en wetgevingskwaliteit" gepresenteerd. Eén van de onderwerpen betreft de Arbo-wetgeving waarover onder andere wordt opgemerkt: dat de Arbo-wet ten gevolge van de vele wijzigingen onoverzichtelijk is geworden, dat een aantal bestuurlijke instrumenten niet of beperkt worden gehanteerd en dat de strafsancties niet steeds zodanig zijn dat de gestelde doelen worden gerealiseerd. ${ }^{152}$ In het hierop volgend rapport wordt voor de arbeidsomstandighedenwetgeving aanbevolen om de bevoegdheden omtrent de invulling van globale basisnormen en de handhaving daarvan meer te leggen bij de actoren

148 Commissie voor de toetsing van wetgevingsprojecten, Van Keurslijf naar Keurmerk; Wetgevingsbeleid voor veilig en gezond werk, p. 5.

149 Zie Hazewindus, W.G.A., Wilthagen, A.J.J.M. en Grimminck, E., "Handhaving van de Arbeidsomstandighedenwet", p. 405. Ru, H.J. de, De algemene wer gaat boven de bijzondere wet. De Ru was de voorzitter van de voorbereidende werkgroep voor het dit WTC-advies. Zie over het advies ook de Nota van toelichting Arbeidsomstandighedenbesluit, Stb. 1997, 60, pp. 151.

150 Commissie voor de toetsing van wetgevingsprojecten, Van Keurslijf naar Keurmerk; Wetgevingsbeleid voor veilig en gezond werk, p. 3, zie ook p. 23.

151 Commissie voor de toetsing van wetgevingsprojecten, Van Keurslijf naar Keurmerk; Wetgevingsbeleid voor veilig en gezond werk, p. 23.

152 Brief van 19 december 1994, TK 1994-1995, 24 036, nr. 1, pp. 9-10. Blijkens deze brief heeft de ministeriēle Commissie Marktwerking, Deregulering en Wetgevingskwaliteit een MDW-werkgroep ingesteld die de opdracht heeft gekregen bouwstenen aan te dragen voor een adviesaanvraag aan de SER over de heroriëntatie op de Arbo-wet 1980. Zie hierover Hazewindus, W.G.A., Wilthagen, A.J.J.M. en Grimminck, E., "Handhaving van de Arbeidsomstandighedenwet", pp. 405-406. 
die verantwoordelijk zijn voor goede arbeidsomstandigheden. De overheid dient involge dit advies een beperktere verantwoordelijkheid te behouden die gericht is op het stellen van een algemene zorgplicht voor werkgevers en basisnormen voor gevaarlijke situaties; de verplichte advisering van de werkgever door de arbodlienst; het houden van toezicht met strafrechtelijke sancties bij acuut of ernstig gevaar voor de veiligheid of gezondheid dan wel dit te doen via bestuurlijke boete en het toezicht op certificerende instanties. ${ }^{153}$ Er wordt advies gevraagd aan de SER. ${ }^{154}$ Dit advies richt zich op: meer ruimte voor maatwerk, normalisatie en certificatie, sanctionering en medezeggenschap. De SER stelt voor dat strafrechtelijk handhaafbaar zijn de bepalingen die in Publicatieblad 185 als emstige overtredingen worden aangeduid en in geval van recidive van bestuursrechtelijk te handhaven bepalingen. De overige bepalingen zouden via het bestuursrecht handhaafbaar moeten zijn. Verder merkt de SER op dat het systeem van bestuurlijke sanctionering ${ }^{155}$ :

"zich niet goed verdraagt met het streven van het kabinet een groter gebruik te maken van globale doelbepalingen. Uitgangspunt dient immers te zijn dat, op grond van de artikel 7 Europees verdrag tot bescherming van de rechten van de mens en de fundamentele vrijheden (EVRM) en artikel 16 Grondwet alleen een sanctie kan worden opgelegd naar aanleiding van de overtreding van een norm die duidelijk voor de burger kenbaar is. Bij doelbepalingen zall er evenwel niet altijd van een expliciet gedragsvoorschrift voor de burger sprake zijn Wel goed toepasbaar acht de raad een systeem van bestuursrechtelijke sanctionering in situaties waarin een concrete norm is overtreden."

Bij de invoering van de Arbo-wet 1998 op 1 november $1999^{156}$, werd de Arbo-wet 1980 ingetrokken. Er is gekozen voor een nieuwe wet in plaats van herziening van de oude gezien de ingrijpende wijzigingen die worden doorgevoerd. Niet alleen is de structuur van de wet gewijzigd, ook zijn de bepalingen opnieuw gestructureerd, de bestuurlijke boete is als sanctie ingevoerd, er zijn belangrijke veranderingen aangebracht in de toezichtbepalingen, er is een bepaling opgenomen die het bij overeenstemming tussen werkgever en werknemer mogelijk maakt af te wijken van middelvoorschriften, een aantal artikelen is algemener geformuleerd en een aantal

153 MDW-werkgroep Arbeidsomstandighedenwet, Maatwerk en bescherming: eindrapport van de $M D W$-werkgroep Arbeidsomsiandighedenwer; Den Haag, 22 juni 1995; zie hierover Hazewindus, W.G.A., Wilthagen, A.J.J.M. en Grimminck, E., "Handhaving van de Arbeidsomstandighedenwet", pp. 406-407; Nota van toelichting Arbeidsomstandighedenbesluit, $S t h$. 1997, 60, pp. 151-152.

154 Advies aanvraag Ministerie van Sociale Zaken en Werkgelegenheid, Heroriëntatie Arbobeleid' en Arbowet; Adviesaanvraag aan SER, maart 1996, met "Bijlage ! Voorstellen wijziging Arbowet".

155 Sociaal Economische Raad, Advies: Heroriëntatie arbobeleid en Arbowet; zie hierover Hazewindus, W.G.A., Wilthagen, A.J.J.M. en Grimminck, E., "Handhaving van de. Arbeidsomstandighedenwet", pp. 407-409.

156 Wet van 18 maart 1999 , houdende bepalingen ter verbetering van de arbeidsomstandigheden (Arbeidsomstandighedenwet 1998), Stb. 1999, 184. Zie over deze wet Geers, A.J.C.M. en Popma, J.R., "Voorstel arbeidsomstandighedenwett 1998", pp. 247256 en Geers, A.J.C.M. en Popma, J.R., "Arbowet 1998 niet millenniumproof”, pp. 234 245. 
verplichtingen zijn vervalien. Hierdoor zijn een groot aantal artikelen gewijzigd, aangepast of vervallen. ${ }^{157}$ Met deze wet wil de regering de effectiviteit en de efficiëntie van het arbeidsomstandighedenbeleid vergroten. $Z$ ij wil daartoe de verantwoordelijkheid van werkgevers en werknemers voor het arbo- en verzuimbeleid in ondernemingen versterken en waar mogelijk meer vrijheid creëren voor werkgevers en werknemers om zelf concreet inhoud te geven aan het arbeidsomstandighedenbeleid. ${ }^{158}$ De wet is evenals zijn voorganger een kaderwet en biedt een basis voor nadere regels in de vorm van besluiten en regelingen. ${ }^{159}$ De wet is van toepassing op alle arbeidsorganisaties in Nederland, waarbij afwijkende en anvullende regels voor bijzondere sectoren en categorieën werknemers indien noodzakelijk zijn terug te vinden in het Arbeidsomstandighedenbesluit. ${ }^{160}$

Uitgangspunt van de Arbo-wet 1998 is dat het voeren van beleid inzake arbeidsomstandigheden de verantwoordelijkheid is van de werkgever in samenwerking met de werknemers, en indien nodig met deskundige ondersteuning. Het arbeidsomstandighedenbeleid wordt niet gezien als iets zelfstandigs, maar als een aspect van het algemene bedrijfsbeleid.

\subsubsection{Opsporing en handhaving van de Arbo-wet 1998}

De opsporing en handhaving van de bepalingen uit deze wet en besluiten en regelingen op basis van deze wet, is ingrijpend gewijzigd ten opzichte van die uit de Arbo-wet 1980. De wet geeft vele nume toezichthoudende bevoegdheden aan daartoe aangewezen ambtenaren. Zo zijn niet alleen de bevoegdheden uit hoofdstuk 5 Awb van toepassing ${ }^{161}$, maar gaat de Arbo-wet 1998 verder. Zo is een toezichthouder op basis van artikel 5:15, eerste lid Awb bevoegd,

"met medeneming van de benodigde apparatuur, elke plaats te betreden met uitzondering van een woning zonder toestemming van de bewoner."

Ten gevolge van de invoering van de derde tranche van de Awb in 1997 zijn vele bijzondere wetten gewijzigd. ${ }^{162}$ Zo ook artikel 32 Arbo-wet 1980 , waarvan het derde lid kwam te luiden ${ }^{63}$;

157 Triemstra, R.O. (red.), Arbeidsomstandighedenwet 1998, p. 21; TK 1998-1999, 25879 , nr. 3, pp. 8-9. De opmerking dat er in vergelijking met de oude wet weinig is veranderd, zie bijvoorbeeld Robroek, F. in Boetelijst; Arbo \& Milieu, p. 3; Geers, A.J.C.M. en Popma, J.R., "Arbowet 1998 niet millenniumproof", pp. 234-245, gaat op het gebied van de handhaving niet op.

$158 T$ TK $1997-1998,25879$, nr. 3, p. 2.

159 Deze regels zijn te vinden het Arbobesluit en de Arboregeling. Zij leggen het basisniveau van bescherming vast. TK 1998-1999, 25 879, nr. 3, p. 9. Deze zijn ten gevolge van de invoering van de Arbo-wet 1998 ook aangepast, zie Triemstra, R.O. (red.), Arbeidsomstandighedenwet 1998, pp. 45-53.

160 TK 1998-1999, 25879 , nr. 3, p. 9.

161 Ingevoerd bij de derde tranche van de Awb, Stb. 1997, 510.

162 Wet van 6 november 1997 tot aanpassing van bijzondere wetten aan de derde tranche 
"De toezichthouder is bevoegd, met medeneming van de benodigde apparatuur, een woning binnen te treden zonder toestemming van de bewoner."

In de Arbo-wet 1998 is deze bepaling gehandhaafd in artikel 24, derde lid. De waarborgen uit het Wetboek van strafvordering die gelden bij de toepassing van een dergelijk dwangmiddel, zijn in de Awb of de Arbo-wet 1998 nauwelijks terug te vinden. Vooralsnog is zelfs onduidelijk of de Algemene wet op het binnentreden van toepassing is. ${ }^{164}$ Natuurlijk geldt wel dat moet worden voldaan aan de waarborgen die voortvloeien uit artikel 8 EVRM, maar deze zijn veel beperkter dan de bescherming die wordt geboden door de nationale regelgeving in het strafrecht. Een toelichting waarom deze verdergaande bevoegdheden noodzakelijk zijn en met welke waarborgen ze zijn omkleed, ontbreekt in de memorie van toelichting en de nota naar aanleiding van het verslag. Wel wordt in de memorie van toelichting opgemerkt ${ }^{165}$ :

"De artikelen 23 tot en met 30 zijn aangepasit conform de derde tranche van de Algemene wet bestuursrecht. (...) Voor een nadere toelichting wordt verwezen naar de memorie van toelichting bij de desbetreffende wet. Met uitzondering van de bepalingen (...) hebben de meeste handhavingsinstrumenten ten opzichte van de formuleringen in de bestaande wet verder geen wijziging ondergaan."

Door bovenstaande stelling van de regering ontbreekt ook een toelichting inzake de verdergaande bevoegdheid van artikel 24 , zevende lid, dat luidt:

"Ten dienste van het onderzoek naar een beboetbaar feit is de toezichthouder, voor zover dat voor de vervulling van zijn taak redelijkerwijs nodig is, bevoegd ieder staande te houden en te vorderen dat hij zijn naam, voomamen, geboortedatum en geboortejaar en adres opgeeft."

Deze bevoegdheid is aanzienlijk ruimer dan de bevoegdheid van opsporingsambtenaren bij het staande houden van een verdachte op basis van artikel $52 \mathrm{~Sv}$. Ook de Awb geeft geen bevoegdheid tot staande houden. Wel is hij op basis van artikel 5:16 Awb bevoegd "inlichtingen te vorderen." Degene van wie dit wordt gevorderd moet hieraan gezien artikel 5:20 Awb binnen redelijke temnijn voldoen, tenzij hij "uit hoofde van zijn ambt, beroep of wettelijk voorschrift, verplicht is tot geheimhouding, (...) voorzover dit uit hun geheimhoudingsplicht voortvloeit." Indien niet wordt voldaan aan de vordering en er geen sprake is van een verschoningsrecht, is het

van de Algemene wet bestuurswet (Aanpassingswet derde tranche Awb), Sib. 1997, 510.

163 De redactie van deze bepaling is conform de model bepaling die wordt voorgesteld in de Aanpassingswet derde tranche, TK 1996-1997, 25 280, nr. 3, p. 38. In de MvT wordt bij de artikel gewijze bespreking alleen gesteld dat artikel 32 , derde lid wordt vervangen door dit model. TK 1996-1997, 25 280, nr. 3, p. 114.

164 Over de soortgelijke bevoegdheid op grond van artikel 8 Wetsvoorstel bestuurlijke boeten visserij wordt opgemerkt dat de toezichthouder het woongedeelte van een vissersvaartuig mag onderzoeken zonder te beschikken over een machtiging op grond van artikel 2, eerste lid Algemene wet op het binnentreden, zie Mulder, A. en Doorenbos, D.R., Schets van het economisch strafrecht, pp. 153-154; Jansen, O.J.D.M.L., Het handhavingsonderzoek, p. 103.

165 TK 1998-1999, 25879 , nr. 3, p. 47. 
opzettelijk niet voldoen aan een toezichtsvordering en de medewerkingsplicht uit artikel 5:20 Awb involge artikel $184 \mathrm{Sr}$ (als misdrijf) strafbaar gesteld.

In artikel 33 van de Arbo-wet 1998 wordt een groot aantal feiten aangemerkt als "beboetbare feiten". ${ }^{166}$ Alhoewel naar verwachting een algemene regeling inzake de bestuurlijke boete in de Awb zal worden ingevoerd, is het einde van de discussie hieromtrent en de uiteindelijke vormgeving van deze regeling niet afgewacht. ${ }^{167}$

De invoering van de bestuurlijke boete in de Arbo-wet 1998 wordt bepleit, omdat de handhaving, van de bestuursrechtelijke wetgeving tekort schiet door onder andere het toegenomen beroep op het strafrechtelijk sanctiesysteem bij de handhaving van deze wetgeving. Voorts wordt erop gewezen dat het een kempunt van beleid is om de handhaving door het bestuur zelf te versterken. De regering verwacht dat het instrument van de bestuurlijke boete tot een verhoging van de effectiviteit van de handhaving van de Arbo-wet 1998 door de overheid zal leiden. ${ }^{168}$ Bij het vaststellen welke normschendingen uit de Arbo-wet 1998 kunnen worden aangemerkt als "beboetbaai feit", heeft de wetgever aansluiting gezocht bij de vijf criteria die zijn geformuleerd door de Commissie voor de Toetsing van Wetgevingsprojecten. ${ }^{169}$ Waarom de in artikel 33 Arbo-wet 1998 opgesomde feiten voldoen aan deze vijf criteria wordt niet specifiek uit gewerkt.

Het blijft derhalve duister waarom juist deze wettelijke normen de in het eerste criterium genoemde "geringe normatieve lading" hebben.

Aan de relatie van de in artikel 33 Arbo-wet 1998 genoemde bepalingen tot het tweede criterium "De overtreding pleegt geen letsel aan personen of schade aan goederen toe te brengen" is eveneens nauwelijks aandacht geschonken. Dit is opvallend omdat in de Arbo-wet de veiligheid, gezondheid en welzijn in verband met de arbeid centraal staat. De bepalingen uit deze wet zijn een uitwerking van deze doelstelling. Het schenden van deze bepalingen zal derhalve al snel potentieel gevaar voor de veiligheid en de gezondheid teweeg brengen. De relatie tussen de bepalingen die nu als "beboetbaar feit" worden aangemerkt en het potentieel gevaar dat door de schending van deze

166 Zie over de tendens om gedragingen in strijd met bestuursrechitelijke wetgeving niet langer strafrechtelijk maar (ook) bestuursrecht te handhaven hoofdstuk 6 paragraaf 4 .

167 Zie onder andere over de bestuurlijke sanctie: Commissie wetgeving algemene regels van bestuursrecht, Voorontwerp Algemene wet bestuarsrecht Vierde tranche. Zie ook het advies van 12 januari 1994 van de Commissie voor de Toetsing van Wetgevingsprojecten, Handhaving door bestuurlijke boeten, en Kabinetsstandpunt TK 1993-1994, 23400 VI, nr. 48. In zijn brief van 1 juli 1994 heeft het Kabinet aan de Tweede Kamer laten weten het CTW-advies op hoofdlijnen over te nemen; zie ook de Nota van toelichting Arbeidsomstandighedenbesluit, 15 januari 1997, Stb. 1997, 60, p. 150

168 TK 1998-1999, 25879 , nr. 3, pp. 24-25.

169 TK 1998-1999, 25879 , nr. 3, p. 24; zie het advies van 12. januari 1994 van de Commissie voor de Toetsing van Wetgevingsprojecten, Handhaving door bestuurlijke boeten; Triemstra, R.O. (red.), Arbeidsomstandighedenwet I998, pp. 39-40. Zie voor de vijf criteria hoofdstuk 6 paragraaf 4 . 
bepalingen wordt veroorzaakt, wordt door de wetgever niet specifiek toegelicht. Ook. de relatie tussen dit tweede criterium en de zorgplichtbepaling in artikel 11 Arbo-wet 1998 wordt niet toegelicht. Dit is opmerkelijk omdat deze bepaling zelfs expliciet verwijst naar de veiligheid en gezondheid van de werknemer die normadressaat is van deze bepaling en van andere personen.

Over het derde criterium "De norm is zo duidelijk in de wet omschreven dat het mogelijk is om op grond van de wettelijke normen en de praktijk een vaste gedragslijn te ontwikkelen" wordt door de regering slechts opgemerkt dat het globale karakter van sommige regels in de Arbo-wet de introductie van de bestuurlijke boete niet in de weg staat. Gesteld wordt dat de Arbeidsinspectie in dat geval bij een eerste bezoek een eis tot naleving op basis van artikel 26 Arbo-wet 1998 dient op te leggen, waardoor de bepaling wordt geconcretiseerd voor de betreffende werkgever. Dit uitgangspunt is behalve in de memorie van toelichting niet in de tot stand gekomen wet terug te vinden. Overigens acht de regering dit niet altijd nodig omdat het "overduidelijk" kan zijn dat het doel in zijn geheel niet is gerealiseerd en/ of dat mede gezien de praktijk in de bedrijfstak volstrekt onvoldoende maatregelen zijn getroffen. ${ }^{170}$

Boetes kunnen involge artikel 34, eerste lid Arbo-wet 1998 worden opgelegd aan natuurlijke personen of rechtspersonen die voor de naleving van de Arbo-wet 1998 en de daarop berustende bepalingen verantwoordelijk zijn. Er wordt ter zake geen differentiatie gemaakt. De wet kent involge artikel 34, vierde lid twee boete categorieën, te weten de eerste van ten hoogste 10.000 gulden en de tweede van ten hoogste 25.000 gulden, die involge het derde lid kunnen worden opgelegd voor een "beboetbaar feit". Het bedrag van 25.000 gulden is gebaseerd op de maximum boete die involge de Wed door de rechter kan worden opgelegd. ${ }^{171} \mathrm{Om}$ een indicatie te geven voor het onderscheid tussen emstige en minder ernstige overtredingen is voor deze laatste categorie het maximum bepaald op 10.000 gulden. ${ }^{172}$ De ambtenaar die deze oplegt mag deze involge artikel 34 , vijfde lid met ten hoogste $50 \%$ verhogen indien ter zake van het plegen van een "beboetbaar feit" nog geen 24 maanden zijn verlopen sedert een vroegere boete wegens het plegen van een zelfde "beboetbaar feit" onherroepelijk is geworden. Opgernerkt moet worden dat hier niet de datum van waarop het feit is begaan bepalend is, maar de dag dat de vorige boete onherroepelijk is geworden. Hierdoor kan het volgen van de bestuursrechtelijke bezwaar- en beroepsprocedure een verhoogde boete bij een zelfde feit eerder mogelijk maken, hetgeen nooit de bedoeling kan zijn geweest van het recht op beoordeling van een "criminal charge" door een onafhankelijke en onpartijdige rechter.

\footnotetext{
170 TK' 1998-1999, 25879 , nr. 3, p. 24.

171 Involge de Wed jo. artikel $23 \mathrm{Sr}$. is dit een boete van de vierde categorie. De mogelijkheid bij veroordeling van een rechtspersoon tot verhoging van de boete tot ten hoogste het bedrag van de naast hoge categorie niet is opgenomen.

172 TK 1998-1999, 25879 , nr. 3, p. 48-49; TK 1998-1999, 25879 , nr. 6, p. 27.
} 
Bij de handhaving van de Arbo-wet 1998 blijft volgens de memorie van toelichting het strafrecht op een. aantal punten noodzakelijk. Gesteld wordt ${ }^{173}$ :

"Overtreding van wettelijke regels, mogelijk leidend tot ongevallen met dodelijke afloop of ernstig letsel, dan wel leidend tot blijvende gezondheidsschade, is een dermate ernstige inbreuk op het rechtsgevoel, dat afdoening met een bestuurlijke boete niet past. Strafrechtelijke afdoening is daarom voorzien bij:

1. zeer ernstige risico's (delicten waarbij sprake is van ernstig gevaar voor de veiligheid en gezondheid);

2. delicten die letsel aan personen tot gevolg hebben gehad;

3. bepaalde gevallen van recidive van regels waaraan in eerste aanleg een bestuurlijke sanctie is verbonden."

Voor alle overige risico's die niet voor strafrechtelijke afdoening in aanmerking komen, wordt de mogelijkheid gecreëerd de betreffende bepalingen bestuursrechtelijk te handhaven. Dit kan eventueel gebeuren door het opleggen van een bestuursrechtelijke sanctie. De handhaving van overleg- en informatieplichten uit artikel 12 Arbo-wet 1998 wordt aan het civiele domein overgelaten. Vanuit deze criteria is de regeling van de Arbo-wet 1998 opgebouwd. ${ }^{174}$

\subsubsection{Zorgplichtbepalingen in de Arbo-wet 1998}

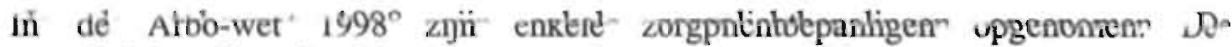
zorgplichtbepaling die zich richt tot werkgevers is te vinden in artikel 32 , eerste lid Arbo-wet 1998, dat luidt:

"Het is de werkgever verboden handelingen te verrichten of na te laten in strijd met deze wet of de daarop berustende bepalingen indien daardoor, naar hij weet of redelijkerwijs moet weten, levensgevaar of ernstige schade aan de gezondheid van een of meer medewerkers ontstaat of te verwachten is."

De wetgever heeft het niet naleven van deze verplichting in artikel 32, tweede lid Arbo-wet 1998 aangemerkt als een misdrijf "in verband met de emstige normschendingen die hierbij aan de orde zijn". ${ }^{175}$ Dat de schending van dit artikel wordt aangemerkt van als misdrijf is nieuw ten opzichte van de oude wet, aangezien de strafbare feiten uit de Arbo-wet 1980 allemaal werden aangemerkt als overtredingen. Involge artikel 46, eerste lid Arbo-wet 1998 is deze bepaling aangehaakt bij artikel 1 stib 3 Wed. De maximum strafbedreiging hiervoor is hechtenis van ten hoogste zes maanden of een geldboete van de vierde categorie (f. 25.000,-). Daarnaast kunnen ook de bijkomende straffen uit artikel 7 Wed en de maatregelen uit artikel 8 Wed worden opgelegd. 
In deznieuwe wet is het in hoofdstuk 8 paragrafen 3.2.6. en 3.2.7. besproken artikel 12 Arb-wet 1980 in gewijzigde vorm (verruimd) terug te vinden in artikel 11 Arbowet 198, dat luidt:

"De wcknemer is verplicht om in verband met de arbeid de nodige voorzichtigheid en zorgvuligheid in acht te nemen en naar vermogen zorg te dragen voor de eigen veiligheid en gezondeid en die van andere personen. Met name zijn zij verplicht om:

a. aveidsmiddelen en gevaarlijke stoffen op de juiste wijze te gebruiken;

b. d hem ter beschikking gestelde persoonlijke beschermingsmiddelen op de juiste wijze te goruiken en na gebruik op de daartoe bestemde plaats op te bergen, een en ander voor zver niet krachtens deze wet is bepaald dat werknemers niet verplicht zijn bschermingsmiddelen als vorenbedoeld te gebruiken;

c. $d$ op arbeidsmiddelen of anderszins aangebrachte beveiligingen niet te veranderen of biten noodzaak weg te halen en deze op de juiste wijze te gebruiken;

d. mde te werken aan het voor hen georganiseerde onderricht bedoeld in artikel 8;

e. d door hem opgemerkte gevaren voor de veiligheid of de gezondheid terstond ter kennis tebrengen aan de werkgever of degene die namens deze ter platse met de leiding is biast;

f. d werkgever en de werknemers, andere personen en diensten, bedoeld in artikel 14, irlien nodig bij te staan bij de uitvoering van hun verplichtingen en taken op grond van dre wet."

Een hadelen of nalaten in strijd met dit artikel wordt involge artikel 33, eerste lid Arbo-wet 1998 aangennerkt als een "beboetbaar feit". Niet langer is sanctionering voorbehouden aan de concreter uitgewerkte normen uit de onderdelen a tot en met $f$, zoals bij de Arbo-wet 1980; ook de algemeen geformuleerde zorgplicht uit de aanhef wordt aangernerkt als beboet feit. Dit deel vari de bepaling is vaag ${ }^{176}$ geformuleerd, waardoor het op gespannen voet kan staan met het lex certa-beginsel. ${ }^{177}$ Wel wordt de strafbaar gestelde zorgplicht uit de aanhef ten dele ingevuld door de in de onderdelen a tot en met $\mathrm{f}$ beschreven gedragingen. Deze plaatsen de algemene strafbaarstelling uit de aanhef tegen een bepaalde achtergrond, waardoor de grenzen van het betekenisbereik van de aanhef ten dele worden begiensd door de nauwkeurig beschreven gedra* gingen uit sub a tot en met $f^{178}$ De wetgever heeft deze uitbreiding van de te sanctioneren bepalingen niet toegelicht. Voor deze "beboetbare feiten" kan involge artikel 33, eerste lid Arbo-wet 1998 een bestuurlijke boete worden opgelegd van de eerste categorie (f. 10.000,-).

Het handelen of nalaten in strijd met artikel 33, eerste lid Arbo-wet 1998 kan involge artikel 33, derde lid Arbo-wet 1998 worden aangemerkt als strafbaar feit

"indien twee maal binnen 48 maanden voorafgaand aan de handeling of het nalaten ter zake van cenzelfde handeling of nalaten een bestuurlijke boete is opgelegd."

176 Zie hoofdstuk 2 paragraaf 5.4.

177 Zie hoofdstuk 3 paragraaf 7.3 .

178 Zie hierover hoofdstuk 3 paragraaf 7.3.6. 
In dat geval is involge artikel 33, vijfde lid sprake van een overtrecling, die involge artikel 46, eerste lid wordt aangehaakt bij artikel 1 sub 3 Wed. Involge artikel 6, eerste lid sub 4 Wed is strafbedreiging hechtenis van ten hoogste zes maanden of een geldboete van ten hoogste de vierde categorie $(f .25 .000,-)$. Daarnaast kunnen ook de bijkomende straffen uit artikel 7 Wed en de matregelen uit artikel 8 Wed worden opgelegd.

De omstandigheid dat de normadressaat twee maal binnen 48 maanden voorafgaand aan de handeling of het nalaten ter zake van eenzelfde handeling of nalaten een bestuurlijke boete is opgelegd is doorslaggevend voor de vraag of sprake is van een strafbaar feit. Dit is opmerkelijk te noemen aangezien hierdoor niet langer het feit maar de frequentie en het al dan niet beboeten van het feit bepalend zijn ${ }^{79}$, hetgeen leidt tot een "systeembreuk". Het lijkt wenselijk een fundamentele discussie te voeren over de vraag wat de inhoudelijke criteria zijn waarop het onderscheid tussen straf- en bestuursrechtelijke afdoening van normschendingen wordt gebaseerd. Hoewel deze grenzen moeilijk zijn te trekken ${ }^{180}$ is een afbakening zoals in de Arbo-wet (los van de vraag of via het bestuursrecht überhaupt boetes zouden moeten kunnen worden opgelegd) onwenselijk aangezien onvoldoende wordt tegemoetgekomen aan de fundamentele verschillen tussen de twee rechtsgebieden.

\section{4.}

\section{Het economisch strafrecht}

Het economisch strafrecht maakt reeds lang deel uit van het strafrecht. Door de ingrijpende wijziging van het economisch leven in de tweede helft van de negentiende eeuw ontstaat het inzicht dat de overheid een taak te vervullen heeft op het gebied van het bedrijfsleven. Het Kinderwetje van Van Houten wordt ingevoerd en rond de eeuwwisseling volgde meer wetgeving inzake arbeids- en concurrentie verhoudingen. Tijdens de Eerste wereldoorlog kwamen enkele wetten van tijdelijk aard in verband met buitengewone omstandigheden tot stand, die na de oorlog ten dele in stand bleven. Tijdens de crisisjaren en de Tweede wereldoorlog werd het economisch strafrecht verder uitgebouwd. Na de oorlog bleek sprake van een omvangrijke en onoverzichtelijke hoeveelheid wetgeving, waarvoor een speciale regeling nodig werd bevonden. Met de invoering in 1951 van de Wet op de economische delicten is het economisch strafrecht een apart deel geworden van het bijzonder strafrecht. Strafbaarstellingen uit andere wetten die zijn aangehaakt bij de Wed worden aangemerkt als economisch delict. De Wed kent onder andere een verruiming van de toepas-

179 Zie over de afgrenzing van strafrecht en ordnungswidrigkeiten onder ander Jakobs, G., Strafrecht Allgemeiner Teil, pp. 49-55; Jesheck, H-H en Weigend, T., Lehrbuch der Strafrechts, pp. 56-60.

180 Jakobs, G., Strafrecht Allgemeiner Teil, p. 55; Jesheck, H-H en Weigend, T., Lehrbuch der Strafrechts, pp. 58-59. Ook hier wordt het onderscheid gezocht in het justitieel onrecht, die betrekking heeft op moreel verwerpbare normschendingen en administratief onrecht dat meer waardeneutraal is en betrekking heeft op de ordening van de maatschappij. In de praktijk lijken vaak ook pragmatische overwegingen ten grondslag te liggen aan de gemaakte keuzes. 
singsmogelijkheden van dwangmiddelen en is bij uitsluiting bepalend voor de mogelijke straffen en maatregelen die kunnen worden getroffen, tenzij de aangehaakte wet anders bepaalt.

In de Arbo-wet 1998 is in artikel 12 een zorgplichtbepaling opgenomen die is aangehaakt bij de Wed. Opvallend is dat deze bepaling in eerste instantie wordt aangemerkt als (een via het bestuursrecht) "beboetbaar feit" die wordt bedreigd met een bote van maximaal $f .10 .000,-$. Het kan worden aangemerkt als strafbaar feit "indien twee maal binnen 48 maanden voorafgaand aan de handeling of het nalaten ter zake van eenzelfde handeling of nalaten een bestuurlijke boete is opgelegd." In dat geval is sprake van een overtreding, die wordt bedreigd met een hechtenis van ten hoogste zes maanden of een geldboete van ten hoogste de vierde categorie $(f .25 .000,-)$. Opmerkelijk is dat door deze constructie niet langer het feit maar de frequentie en het al dan net beboeten. van het feit bepalend zijn of sprake is van een strafbaar feit. 



\section{De ontwikkeling van het milieustrafrecht}

\section{Inleiding}

Nadat in de vorige hoofdstukken de ontwikkeling van het commuun strafrecht, het bijzonder strafrecht en het economisch strafrecht is besproken, is het nu de beurt aan het milieustrafrecht. Oorspronkelijk was dit vooral het terrein van decentrale overheden, zodat in beperkte mate in lokale verordeningen al lang regelgeving op het gebied van het leefmilieu kan worden aangetroffen. Hoewel er in de negentiende eeuw in beperkte omvang al centrale regelgeving bestond die te maken had met wat we thans aanduiden als milieurecht, is dit vooral in de zeventiger en tachtiger jaren tot ontwikkeling gekomen. Mede naar aanleiding van enkele incidenten, begon men het belang van regelgeving op dit gebied in te zien. In het Wetboek van Strafrecht werden enkele strafbaarstellingen opgenomen die (indirect) het leefmilieu beschermen. Daarnaast kwamen op milieurechtelijk gebied tal van bijzondere wetten tot stand. Deze hebben niet zozeer ten doel het leefmilieu in absolute zin te beschermen, maar reguleren veeleer de inbreuk die op het leefmilieu is toegestaan. In deze overwegend bestuursrechtelijke regelgeving zijn ook strafbaarstellingen opgenomen, die nagenoeg altijd zijn aangehaakt aan de in het vorige hoofdstuk besproken Wed (hoofdstuk 9 paragraaf 2). In het algemeen betreft het abstracte gevaarzettingsdelicten waarvan de materiële normstelling is te vinden in de op basis van die wet uitgevaardigde lagere regelgeving of beschikkingen. De hierin opgenomen zorgplichtbepalingen kunnen dan via de gelede normstelling ook strafrechtelijk handhaafbaar zijn. ${ }^{1}$ Ook kunnen in enkele milieuwetten zorgplichtbepalingen worden aangetroffen (hoofdstuk 9 paragraaf 3), bijvoorbeeld artikel 2 Wet Milieugevaarlijke Stoffen, artikel 13 Wet bodembescherming en artikel 10.3 Wet milieubeheer.

\section{2.}

\section{De ontwikkeling van het milieustrafrecht}

\subsection{Inleiding}

Aanvankelijk was regelgeving inzake het leefmilieu, zoals aangegeven, vooral een tak van decentrale overheden. Tot op de dag van vandaag zijn in de lokale verordeningen bepalingen te vinden die al dan niet direct betrekking hebben op het leefmilieu (hoofdstuk 9 paragraaf 2.2.). In de zeventiger en tachtiger jaren werd regelgeving inzake het leefmilieu ook een duidelijke taak van de centrale overheid. Vele sectorale en soortgerichte wetgeving kwam in korte tijd tot stand. Doordat elke wet zijn eigen onderwerp, doelstelling, systematiek en juridisch instrumentarium kende ontstond een

Zie over abstracte gevaarzettingsdelicten hoofdstuk 1 paragraaf 3.6.2.2., en over gelede normstellingen hoofdstuk 4 . 
doolhof van bevoegdheden, ambtelijke uitvoeringsdiensten, handhavingsapparaten en adviesinstellingen. Dit leidde ertoe dat werd gezocht naar mogelijkheden om te komen tot harmonisatie, systematisering en integratie van deze regels. ${ }^{2}$ Ter verwezenlijking hiervan kwam de Wet algemene bepalingen milieuhygiëne tot stand, die later werd opgevolgd door de Wet milieubeheer (hoofdstuk 9 paragraaf 2.3.). De strafbaarstellingen in deze en andere milieuwetten zijn in beginsel allemaal aangehaakt aan artikel 1a Wed (hoofdstuk 9 paragraaf 2.4.). Hieronder bevinden zich ook enkele zorgplichtbepalingen (hoofdstuk 9 paragraaf 3 ).

\subsection{Milieustrafrecht door decentrale overheden}

Tot de jaren zestig was er slechts in beperkte mate sprake van wetgeving in formele zin op het gebied van het milieu(straf)recht. ${ }^{3}$ Oorspronkelijk was het milieubeleid vooral het beleid van decentrale overheden. Bij gemeenten werd dit meestal ingegeven door de zorg voor veiligheid en volksgezondheid. Zo kende de stad Amsterdam in de veertiende en vijftiende eeuw vele bepalingen inzake afval. Deze werden reeds in 1413 gebundeld in één keur. In 1475 kwamen de eerste openbare vuilnisvaten, waarvan de inhoud ais mest aan de boeren uit de omgeving werd verkocht. Het bouwafval dat in de tweede helft van de zeventiende eeuw ontstond bij de vele bouwactiviteiten in de stad werd opgekocht, en vervolgens (samen met vuilnis) aangewend voor de verhoging van de stadswallen. De gemeente voerde deze activiteiten zelf uit, verpachte het of droeg het al dan niet met een subsidie over aan derden zoals het aalmoezeniersweeshuis. ${ }^{4}$

Gemeenteraden ontlenen tegenwoordig de bevoegdheid tot het vaststellen van veror. deningen aan artikel $127 \mathrm{Gw}$ jo. artikel 149 Gemeentewet, op basis waarvan de bevoegdheid tot regeling van de huishouding van de gemeente aan het bestuur van de gemeente is overgelaten. Door de opkomst van wetgeving in formele zin op het gebied van het milieurecht, is de autonome taakuitoefening van gemeenten steeds verder teruggedrongen. Het overgrote deel van de huidige gemeentelijke regels betreft verordeningen in medebewind. Maar ook nu kunnen bijvoorbeeld in de gemeentelijke APV's en Bouwverordeningen vaak milieubeschermende bepalingen worden aangetroffen. Zo kennen de meeste gemeenten bepalingen met betrekking tot het verontreinigen (al dan niet door honden) van straten en pleinen en met betrekking tot het

2 Ook de harmonisatie van het bestuursrecht door invoering van de Awb heeft hieraan bijgedragen.

3 Zie over de ontwikkeling van het milieustrafrecht Faure, M. en Visser, M., De strafrechtelijke bescherming van het leefmilieu in België. Duitsland en Nederland, pp. 40-50; Roos, Th.A. de en Visser, M.J.C., "Milieustrafrecht", 70.1.; Seerden, R. en Heldeweg, M., "Public Environmental Law in the Netherlands", pp. 274-275; Tonnaer, F.P.C.L., Handboek wan het Nederlandse milieurecht, pp. 347-393 en Faure, M. en Visser, M., "Het tekort van het Nederlandse milieustrafrecht", pp. 123-124.

4 Zie hierover Bronswijk, F. van, "Afval als aalmoes", pp. 64-68; Siemerink, J.B.M., De vuilnisverwerking in Amsterdam 1673-1804 - de rol van het Aalmoezeniersweeshuis bij de organisatie van de afvalverwerking en de betekenis van de afvalstoffen voor de agrarische sector. 
vervoer van gevaarlijke stoffen. Daarnaast kennen enkele gemeenten bijvoorbeeld een autonome verordening tot bescherming van wilde planten."

Tevens zijn vooral in de tweede helft van de twintigste eeuw provincies op het gebied van milieubescherming in toenemende mate autonoom gaan optreden. De grondslag voor het zelfstandig vaststellen van verordeningen door Provinciale Staten is gelegen in artikel $127 \mathrm{Gw}$ jo. artikel 145 Provinciewet. Op basis hiervan hebben de meeste provincies bijvoorbeeld een verordening ter bescherming van het landschapsschoon ingevoerd. Ook op provinciaal niveau is de autonome taakuitoefening steeds verder teruggedrongen ten gevolge van de uitbreiding van de milieuwetgeving in formele zin. $^{6}$

Ook de waterschappen namen al vroeg milieubeschermende maatregelen. Artikel 133, tweede lid Gw bepaalt onder andere dat de wet verordenende en andere bevoegdheden van de besturen van waterschappen regelt. Involge artikel 59, eerste lid Waterschapswet is het waterschapsbestuur bevoegd tot het maken van verordeningen waarin door een wet, een algemene maatregel van bestuur of een provinciale verordening is voorzien. Ook hier zijn door de uitbreiding van de milieuwetgeving in formele zin, vooral de Wvo, veel autonome bepalingen komen te vervallen. ${ }^{7}$

De bevoegdheid tot het vaststellen van verordeningen door deze lagere overheden is involge artikel 154, vierde lid Gemeentewet, artikel 150, tweede lid Provinciewet en artikel 81 , tweede lid Waterschapswet beperkt tot overtredingen, zodat het schenden van deze bepalingen niet als misdrijf strafbaar kunnen worden gesteld. ${ }^{8}$ Hierdoor zijn de in deze verordeningen opgenomen zorgplichtbepalingen (indien de overtreding daarvan strafbaar is gesteld) altijd overtredingen. De strafbedreiging voor deze overtredingen betreft hechtenis van ten hoogste drie maanden of een geldboete van de tweede categorie (f. 5000,-), al dan niet met openbaarmaking van de rechterlijke uitspraak. ${ }^{9}$

\subsection{Milieuwetgeving in formele zin}

De Nederlandse milieuwetgeving in formele zin is vooral vanaf de jaren zeventig en tachtig tot stand gekomen. ${ }^{10}$ Vanzelfsprekend waren er ook daarvoor wel enkele milieuweitten aanwezig. Reeds vanaf 27 oktober 1800 gold đe Arrêté van 5 Brumaire, an IX waarin de plaatselijke politie taken werden opgedragen met betrekking tot onder ander het weren van hinderlijke activiteiten. Na het vertrek van de Fransen werd het besluit in 1824 omgezet in het "Koninklijk. Besluit rakende de vergunningen der

Tonnaer, F.P.C.L., Handboek van het Nederlandse milieurechi', pp. 352-355.

Tonnaer, F.P.C.L., Handboek van het Nederlandse milieurechi, pp. 355-356.

Tonnaer, F.P.C.L., Handboek van het Nederlandse milieurecht, pp. 356-357.

8 Zie ook Remmelink, J., Mr. D. Hazewinkel-Suringa's Inleiding tot de studie van het Nederlandse strafrecht, p. 7.

9 Zie artikel 154, eerste lid Gemeentewet, artikel 150, eerste lid Provinciewet en artikel 81 , eerste lid Waterschapswet.

10 Voor een - praktisch geïnspireerd - overzicht. zie Wiggers-Rust, L.F. en Wasch, E.P.J. (red.), Handboek milieu en onderneming. 
oprigting van sommige fabrieken en trafyken", dat zich richtte tegen publieke overlast. Dit Besluit was een voorloper van de in 1875 tot stand gekomen Fabriekswet. ${ }^{11}$ en Hinderwet. ${ }^{12}$ In 1896 werd de Hinderwet afgestemd op en gekoppeld aan de Veiligheidswet 1895. Alhoewel reeds voor de Tweede Wereldoorlog de Hinderwet volgens velen aanpassing behoefde, heeft het tot na deze oorlog geduurd alvorens de regering aan een herziening van deze wet begon. Het ontwerp werd vanaf 1947 voorbereid, en in 1952 werd de nieuwe Hinderwet ingevoerd. ${ }^{13}$ Hij was niet ingrijpend gewijzigd; beoogd werd slechts modernisering van de oude wet en aanpassing aan de praktijk tot stand te brengen. De Hinderwet had ten doel de bescherming van de omgeving van inrichtingen, zoals fabrieken en werkplaatsen, tegen het gevaar, de schade en de hinder welke zulke inrichtingen naar buiten kunnen veroorzaken. Gevaar, schade en hinder binnen de inrichtingen viel derhalve niet onder deze wet; hierin werd in hoofdzaak voorzien door de Veiligheidswet (en zijn opvolgers). Al spoedig na de inwerkingtreding van de Hinderwet werd (opnieuw) onvrede over het functioneren van de wet geuit. De wet werd, mede naar aanleiding van de gemaakte opmerkingen, een aantal keren gewijzigd, en werd steeds meer een "milieuwet". Lange tijd was de Hinderwet de belangrijkste milieuwet in Nederland.

Maar in het algemeen was er zeker op landelijk niveau, lange tijd nauwelijks aandacht voor het milieu(straf)recht. Vanaf eind jaren zestig kwam langzaam maar zeker de ontwikkeling van specifieke milieuwetgeving naast de Hinderwet op gang. Mede naar aanleiding van de toenemende vervuiling door de industrialisatie, de vergroting van kennis omtrent de mogelijke gevolgen van deze vervuiling en enkele grote incidenten waardoor ernstige milieuschade en soms ook direct antoonbare gezondheidsschade ontstond, begon men zowel nationaal als internationaal het belang van regelgeving op dit gebied te onderkennen. Aanvankelijk was de regelgeving vooral gericht op bepaalde sectoren van het milieu of op bepaalde vormen van activiteiten of stoffen.

De nationale wetgever maakte, vooral nadat in 1971 het ministerie van volksgezondheid en milieuhygiëne werd ingesteld dat de zorg voor de hygiëne van het milieu tot taak had, haast met het tot stand brengen van sectorale regelingen om de te onderscheiden milieuvraagstukken te kunnen aanpakken. ${ }^{14}$ Zo kwam eindelijk de Wet verontreiniging oppervlaktewateren tot stand. ${ }^{15}$ Reeds in 1897 was een Staatscommissie ingesteld tot voorbereiding van maatregelen tegen verontreiniging van openbare wateren, en werd over dit onderwerp in 1909 een wetsvoorstel ingediend dat het niet haalde. Het duurde tot 1964 voordat een nieuw wetsvoorstel werd ingediend.

11 Deze wet is uiteindelijk opgevolgd door de Arbeidsomstandighedenwet 1980 en 1998. Wet van 8 november 1980, Stb. 1980, 664. Zie hierover hoofdstuk 8 paragrafen 3.2.8. en 3.2.9.

12 Wet van 2 juni 1875, Stb. 1875, 95, "tot regeling van het toezigt bij het oprigten van inrigtingen, welke gevaar, schade of hinder kunnen veroorzaken."

13 Wet van 15 mei 1952, Stb. 1952, 274. Zie over de (geschiedenis van) de Hinderwet: Aalders, M.V.C., Industrie, milieu en wetgeving.

14 Zie Koeman, N.S.J., "25 Jaar milieurecht: van geitenharen sokken naar een groen poldermodel", p. 206.

15 Wet van 13 december 1969, Stb. 1969, 536. 
Uiteindelijk werd de Wvo pas in 1970 ingevoerd. Ook andere sectorale wetten zoals de Wet inzake de luchtverontreiniging ${ }^{16}$ en de Wet bodembescherming ${ }^{17}$ kwamen tot stand. Naast de sectorale milieuwetgeving kwamen er voor de verschillende vormen van verontreiniging aparte milieuwetten. Gewezen kan worden op de Bestrijdingsmiddelenwet $1962^{18}$, de Wet Gevaarlijke Stoffen ${ }^{19}$, de Wet chemische afvalstoffen ${ }^{20}$, de Afvalstoffenwet ${ }^{21}$, de Wet geluidhinder ${ }^{22}$, de Wet milieugevaarlijke stoffen ${ }^{23}$ en de Meststoffenwet. ${ }^{24}$ De kwaliteitsverbetering van de sectorale en soortgerichte regelgeving in het milieurecht is nog steeds gaande.

Voorts zijn enkele (vroege) milieuwetten het gevolg van internationale verplichtingen. ${ }^{25} \mathrm{Zo}$ was de Wet verontreiniging zeewate ${ }^{26}$ het gevolg van het Verdrag van Oslo uit 1972 ter voorkoming van verontreiniging van de zee door het storten vanuit schepen en vliegtuigen ${ }^{27}$, en het ook uit 1972 stammende Verdrag van Londen ter voorkoming van verontreiniging van de zee door het storten van afval en andere stoffen. ${ }^{28}$ Tevens kan als voorbeeld worden gewezen op de Kernenergiewer ${ }^{29}$ die is te beschouwen als uitvoering van het Euratom-verdrag ${ }^{30}$ van de (huidige) Europese Unie en de daarop gebaseerde Europese Richtlijnen zoals met betrekking tot de vaststelling van basisnormen voor de bescherming van de bevolking en van arbeiders tegen ioniserende straling. ${ }^{31}$

Eind jaren zeventig groeide het besef dat dit grote aantal versnipperde sectorale en soortgerichte wetten aanleiding gaf tot nogal wat problemen. Deelproblemen werden behandeldi als zelfstandige problemen, hetgeen leidde tot oplossingen die slechts deeloplossingen konden zijn. Bij de toepassing van het tot stand gekomen wettelijk

16 Wet van 26 november 1970, Stb. 1970, 580, zie over de niet-invoering van een zorgplichtbepaling in deze wet hoofdstuk 9 paragraaf 3.1 .

17 Wet van 3 juli 1986, Stb. 1986, 374; zie hierover hoofdstuk 9 paragraaf 3.3.

18 Wet van 12 juli 1962, Stb. 1962, 288.

19 Wet van 20 juni 1963, Stb. 1963, 313.

20 Wet van 11 februari 1976, Stb. 1976, 214.

21 Wet van 23 juni 1977, Stb. 1977, 455; zie hierover hoofdstuk 9 paragraaf 3.4 .

22 Wet van 16 mei 1979, Stb. 1979, 99.

23 Wet van 5 december 1985, Stb. 1985, 639; zie hierover hoofdstuk 9 paragraaf 3.2.

24 Wet van 27 november 1986, Stb. 1086, 598.

25 Tonnaer, F.P.C.L., Handboek van het Nederlandse milieurecht, p. 357 en pp. 368-369.

26 Wet van 5 juni 1975 , Stb., 1975, 352, inwerking getreden per 1 januari 1977.

27 Oslo Dumping Convention, Trb., 1972, nr. 62, goedgekeurd bij wet van 5 juni 1975, Stb., 1975, 307. Het verdrag van Oslo is samen met het Verdrag van Parijs ter voorkoming van verontreiniging van de zee vanaf het land uit 1974, Stb., 1975, nr. 29 vervangen door het Verdrag van Parijs ter voorkoming en beperking van zeeverontreiniging in de Noordelijke Atlantische Oceaan van 22 september 1992, Trb., 1993, nr. 16.

28 London Dumping Convention, Trb., nr. 173, goedgekeurd bij wet van 23 juni 1977, Stb., $1977,404$.

29 Wet van 21 februari 1963, Stb. 1963, 82.

30 Verdrag tot oprichting van de Europese Gemeenschap voor Atoomenergie van 25 maart 1957.

31 Richtlijn 76/579, PbEG 1976 L 187 en Richtlijn 80/836, PbEG 1980 L 246. 
stelsel deden zich daarnaast vooral problemen voor bij de afstemming van de verschillende instrumenten. Doordat elke wet zijn eigen onderwerp, doelstelling, systematiek en juridisch instrumentarium kende, ontstond een doolhof van bevoegdheden, ambtelijke uitvoeringsdiensten, handhavingsapparaten en adviesinstellingen. Ook op het punt van de rechtsbescherming, de handhaving en de financiering bestonden grote verschillen tussen de diverse wetten. ${ }^{32} \mathrm{Om}$ deze problemen deels op te lossen werd besloten de Wet algemene bepalingen milieuhygiëne ${ }^{33}$ in te voeren, die een algemene regeling voor vergunningprocedures bevatte met uniforme regels van procedures en van inspraak en beroep. Later werd deze wet uitgebreid met bepalingen over de Centrale Raad voor de Milieuhygiëne, de milieueffectrapportage en de financiering van het milieubeleid. Hierdoor zou het milieurecht gedeeltelijk worden geüniformeerd, geharmoniseerd en geïntegreerd. Deze wet werd herhaaldelijk bijgesteld en bij de uitbreiding met hoofdstukken over vergunningen en algemene regels voor inrichtingen, milieubeleidsplanning, milieukwaliteitseisen en (vernieuwd) handhaving, werd de naam van de wet met ingang van 1 maart 1993 veranderd in de Wet milieubeheer. ${ }^{34}$ De veelvuldig gewijzigde Hinderwet, is daarbij komen te vervallen. De (alweer herhaaldelijk gewijzigde) overkoepelende Wet milieubeheer ${ }^{35}$ is het centrale instrument in het milieurecht geworden ${ }^{36} \mathrm{Hij}$ kan worden gekenschetst als een kaderwet met normatieve elementen. Het is een wet in ontwikkeling, die volgens de huidige planning nog zal worden uitgebreid met een aantal hoofdstukken. ${ }^{37}$ Tevens zal hij nog wijzigingen ondergaan in verband met het in werking treden van nieuwe delen van de Algemene wet besturursrecht on de daarbij horende aanpassingswetgeving. ${ }^{38}$ Ook kunnen de op dit moment bestaande hoofdstukken worden aangevuld of gewijzigd onder meer in verband met de verdergaande integratie en de uitbreiding van het sanctie-instrumentarium.

32 Tonnaer, F.P.C.L., Handboek van het Nederlandse milieurecht, p. 381 en Michiels, F.C.M.A., De Wet milieubeheer, p. 1.

33 Wet van 13 juni 1979, Stb. 1979, 442.

34 De term "algemene bepalingen" uit de oorspronkelijke naam zou te veel de indruk wekken dat het nog steeds om een procedurele wet zou gaan. TK 1989-1990, 21 137, nr. 22, p. 30 .

35 Zie over de harmonisatie en integratie van het milieurecht Tonnaer, F.P.C.L., Handboek van het Nederlandse milieurecht, pp. 382-393; Michiels, F.C.M.A., De Wet milieubeheer, pp. 1-9 en Gilhuis, P., "Experiences and Perspectives with Regard to the Codification of Environmental Law in the Netherlands", pp. 101-114.

36 De verhouding tussen het nog bestaande sectorale milieurecht en de Wet milieubeheer wordt besproken in Seerden, R. en Heldeweg, M., "Public Environmental Law in the Netherlands", pp. 276-278.

37 Zie over de toekomst van de Wet milieubeheer Michiels, F.C.M.A., De Wet milieubeheer, pp. 8-9 en pp. 242-243. Voorbereiding op ambtelijk niveau is gaande tent aanzien van hoofdstuk 3, Internationale zaken; hoofdstuk 6, Milieuzonering; hoofdstuk 9, Stoffen en producten; hoofdstuk 11, Andere handelingen en hoofdstuk. 16, Financiele zekerheid.

38 De Awb werd in 1994 ingevoerd ten behoeve van een codificatie van het bestuursrecht. Deze wet is van groot belang voor bijvoorbeeld de bestuurlijke handhaving van het milieurecht. 
De tot stand gekomen milieuwetten hebben voornamelijk een bestuursrechtelijk karakter. In deze wetten zijn ook strafrechtelijke bepalingen opgenomen, die meestal bepaalde vormen van handelen in strijd met bestuursrechtelijke bepalingen bij of krachters de betreffende milieuwet strafbaar stellen, bijvoorbeeld handelen zonder of in strijd met een (door het bestuur gegeven) beschikking. In de door het bestuur vastgestelde besluiten, waarvan schending strafbaar is gesteld, kunnen zorgplichtbepalingen zijn opgenomen. Ook zijn in enkele milieuwetten in formele zin zorgplichtbepalingen opgenomen. ${ }^{39}$

In het commuun strafrecht kon aanvankelijk slechts één bepaling worden aangetroffen die een bepaalde vorm van milieuverstoring strafbaar stelde; het betreft artikel $173 \mathrm{Sr}$ dat (ook nu nog) het vergiftigen van drinkwater strafbaar stelt. ${ }^{40}$ In samenhang met de invoering van de Wet verontreiniging oppervlaktewateren werden in 1969 in het Wetboes van Strafrecht enkele milieubepalingen opgenomen, te weten de artikelen 173a, 173b en 429 , vierde lid. In 1989 werden de artikelen 172 tot en met $173 \mathrm{~b} \mathrm{Sr}$ gewijzigd. ${ }^{41}$ De huidige bepalingen in het Wetboek van Strafrecht die zien op het strafbaat stellen van milieuverstoring zijn voornamelijk opgenomen in het tweede boek, Ttel VII "Misdrijven waardoor de algemene veiligheid van personen of goederen wordt in gevaar gebracht". Hiermee is meteen het karakter van het milieustrafrecht in het Wetboek van Strafrecht aangeduid; niet het milieu, maar de mens wordt beschermd. Voor zover het strafbaarstellingen van milieuverstoring betreft, is hiervoor steeds een concrete gevaarzetting van of schade aan mensen of goederen noodzakelijk. ${ }^{42}$ Strafbaar gesteld is: het opzettelijk (artikel $157 \mathrm{Sr}$ ) of culpoos (artikel 158 Sr) brand, ontploffing of overstroming veroorzaken; het opzettelijk (artikel 161 quater $\mathrm{Sr}$ ) of culpoos (artikel 161quinquies Sr) blootstellen van mensen, dieren, planten of goederen aan ioniserende straling, dan wel mensen, dieren, planten, goederen, bodem, water of lucht met radioactieve stoffen besmetten; het opzettelijk (artikel $172 \mathrm{Sr}$ ) of. culpoos (artikel $173 \mathrm{Sr}$ ) wederrechtelijk een stof in een drinkwatervoorziening dan wel waterleiding brengen; het opzettelijk (artikel 173a Sr) of culpoos (artikel 173b Sr) wederrechtelijk een stof op of in de bodem, in de lucht of in het oppervlaktewater brengen als daarvan gevaar voor de openbare gezondheid of levensgevaar voor een ander te duchten is, dan wel het feit iemands dood ten gevolge heeft.

Daarnaast kan nog worden gewezen op artikel $142 \mathrm{Sr}$, lit Titel V "Misdrijven tegen de openbare orde" dat bepaalt dat opzettelijke rustverstoring door alarmkreten of signalen, een misdrijf is; op artikel 429, vierde lid Sr, uit Titel I "Overtredingen betreffende de algemene veiligheid van personen en goederen", dat bepaalt dat het wederrechtelijk aanbrengen van een stof in een oppervlaktewater waardoor nadeel

39 Zie hoofdstuk 9 paragraaf 3.

40 Zie over de bepalingen in het Wetboek van Strafrecht die milieuverstoring strafbaar stellen onder andere Buiting, Th.J.B., Strafrecht en milieu, pp. 123-130 en Tonnaer, F.P.C.L., Handboek van het Nederlandse milieurecht, pp. 1094-1102.

41. Bij wet van 19 januari 1989, Stb. 1989, 7.

42 Zie hierover onder andere Haentjens, R.C.P, "De bedreiging der samenleving door aantasting van het natuurlijk milieu. en het strafrecht als middel tot afweer", pp. 472-473 en Tonnaer, F.P.C.L., Handboek van het Nederlandse milieurecht, p. 1099. 
ontstaat in verband met het gebruik dat gewoonlijk van die wateren wordt gemaakt, een overtreding is; en op artikel $431 \mathrm{Sr}$, uit Titel II "Overtredingen betreffende de. openbare orde", dat stipuleert dat het verwekken van rumoer of burengerucht waardoor de nachtrust wordt verstoord, een overtreding is. Het merendeel van deze bepalingen beoogt niet het milieu tegen verstoring te beschermen, maar bescherint veeleer het welzijn van de mens. Aangezien geen van deze commune bepalingen is aan te merken als zorgplichtbepaling worden zij in dit boek verder niet besproken.

\subsection{Milieustrafrecht en de Wed}

Voor de strafbaarstelling van bepalingen uit bijzondere milieuwetten, is het vooral van belang te wijzen op de in 1951 in werking getreden Wet op de economische delicten. ${ }^{43}$ Aan deze wet zijn vooral sinds begin jaren zeventig steeds meer strafbepalingen uit milieuwetten aangehaakt.

Bij een wijziging van de Wed in 1969 vanwege problemen van wetstechnische en praktische aard, kreeg de Wed een andere indeling. ${ }^{4}$ Hierbij werd tevens om redenen van consequentie en rechtszekerheid bepaald dat de opsomming van de artikelen uit de diverse wetten in artikel 1 Wed voortaan uitputtend was. De artikelen werden in dir almaar uitdjende artikel chronologisch gerangschikt, dat wil zeggen op datum varı totstandkoming van de betreffende wet.

In 1994 werd het systeem van de Wed opnieuw ingrijpend gewijzigd en kreeg het zijn huidige vorm. ${ }^{45}$ Het doel van deze wijziging was in de eerste plaats het aanmerkelijk verzwaren van de straffen gesteld op emstige milieudelicten. ${ }^{46}$ De maximum strafmaat voor milieudelicten werd verhoogd, doordat ze gedeeltelijk tot de zwaarste categonie economische delicten zijn gaan behoren. Bij het vaststellen welke feiten zodanig ernstig zijn dat zij moeten worden opgenomen in de eerste categorie die de hoogste strafbedreiging kent, is uitgegaan van het criterium $^{47}$ "dat het moet gaan om feiten die een directe aantasting opleveren van het milieu, dan wel daarvoor een ernstige en rechtstreekse bedreiging vormen." Hierdoor is "in beginsel de schadelijkheid, respectievelijk het risico van het feit voor het milieu als criterium genomen. ${ }^{48}$ Hieruit "vloeit voort, dat het aantal gevallen waarin aan andere feiten dan de emstige milieudelicten zelf, hogere strafposities worden verbonden, niet groter moet zijn dan

43 Wet van 22 juni $i 950$ houdende vaststelling van regelen voor de opsporing, de vervolging en de berechting van economische delicten, Stb. 1950, K258. Zie over de ontwikkeling van het economisch strafrecht hoofdstuk 8 paragraaf 2.

44 Dit gebeurde bij wet yan 21 mei 1969, Stb. 1969, 232.

45 Bij ivet van 4 februari 1994, Stb., 135. Zie over het belang van die wetswijziging Mulder, A. en Doorenbos, D.R., Schets van het economisch strafrecht, pp. 49-53.

46 Zie over de strafverzwaring van ernstige milieudelicten $T K .1992-1993,23$ 196, nr. 3, p. I en pp. 5-7; zie ook Mulder, A. en Doorenbos, D.R., Schets van het economisch strafrecht, pp. 13, 15-16.

47 TK 1992-1993, 23 196, nr. 3, p. 5, zie ook pp. 12-13.

48 TK 1992-1993, 23 196, nr. 3, p. 13. 
praktiscll onvermijdelijk is." ${ }^{29}$ Door invoering van de hogere strafbedreiging is tevens de verjaringstermijn verlengd en is het mogelijk geworden in de opsporingsfase bepaald dwangmiddelen toe te passen, angezien het toepassingsbereik van dwangmiddelel voor een belangrijk deel wordt bepaald door de hoogte van de maximaal op te leggel straf voor het feit waarvan men wordt verdacht. ${ }^{\text {so }}$

Artikel 1 werd gesplitst in een artikel 1 voor economische niet zijnde milieudelicten en artikel 1a waarin de milieudelicten werden samengebracht. ${ }^{51}$ In het nieuwe artikel la werden niet enkel de reeds aangehaakte milieustrafbepalingen opgenomen, tevens werden een aantal milieudelicten die tot dan toe in afzonderlijke wetten strafbaar waren gesteld opgenomen. Hierbij werd het begrip "milieudelict" ruim opgevat, zodat ook bijvoorbeeld bepalingen uit de Natuurbescher-mingswetgeving zijn aangehaakt. Tevens strekken niet alle bepalingen uit artikel la zonder meer of uitsluitend tot bescherning van het milieubelang. De keuze voor la in plaats van 1 is dat het "het milieu-aspekt. daarbij van zodanige betekenis is, dat onderbrenging onder dat artikel meer voor de hand ligt dan onderbrenging onder artikel 1 van de Wed." ${ }^{\circ 2}$

Het in 1069 ingevoerde systeem van chronologische opsomming was door de toename van aanjehaakte wetgeving dusdanig onoverzichtelijk en weinig gebruiksvriendelijk geworden, dat ook dit werd gewijzigd. Gekozen werd voor een alfabetische indeling van de bijzondere wetten binnen de categorieën van artikel 1 en 1a Wed, waarbij het eerste zelfstandige naamwoord dat in de citeertitel van de wet voorkomt als ijkpunt werd genomen. ${ }^{53}$ De in artikel la Wed geconcentreerde milieudelicten werden ingedeeld in drie categorieën. ${ }^{54}$ In de eerste categorie staan de ernstigste, in de tweede categorie de minder ernstige en in de derde categorie de lichtste milieudelicten. Deze indeling heeft onder andere gevolgen voor de vraag of sprake is van een misdrijf of een overtreding, en yoor de maximaal op te leggen strafmaat. Er is hier niet gekozen voor een indeling in vijf categorieën zoals bij artikel 1 Wed. De eerste categorie komt overeen met de eerste, en de tweede en de derde met de tweede en de vierde categorie uit artikel 1 Wed. De vijfde categorie uit artikel 1 Wed, waarin delicten uit de Wed zijn opgenomen, is hier niet nodig. Tevens achtte de wetgever de derde categorie van artikel 1 Wed, voor delicten waarvoor de bijzondere wet bepalend is of het delict

$49 T K$ 1992-1993, 23196, nr. 3, p. 13.

50 Zie verder over het belang van de Wed in het Nederlands milieustrafrecht bij Waling, C., Koopmans, I., Rutgers, M., Sjöcrona, J., Van Strien, N. en Tak, P, "Pays-Bas: Crimes Against the Environment", p. 1069.

51 Zie over de concentratie van milieudelicten in de Wed TK 1992-1993, 23 196, nr. 3, pp. 7-9; Mulder, A. en Doorenbos, D.R., Schets van het economisch strafrecht, pp. 13-14, die aangeven dat met "concentratie" iets te veel is gezegd nu de verordeningen van lagere overheden erbuiten vallen, evenals de strafbaarstellingen in het Wetboek van. Strafrecht die (indirect) betrekking hebben op de bescherming van het leefmilieu.

52 TK 1992-1993, 23 196, nr. 3, p. 8.

53 Zie over de verbeterde toegankelijkheid van de Wed: TK 1992-1993, 23 196, nr. 3, p. 1 en pp. 7-9.

54 Zie over de systematiek van de Wed: Mulder, A. en Doorenbos, D.R., Schets van het economisch strafrecht; Hendriks, L.E.M. en Wöretshofer, Milieustrafrecht, pp. 23-29. 
wordt aangemerkt als een miscrijf of als een overtreding, overbodig. ${ }^{55}$ Dit onderscheid wordt voor milieudelicten uitsluitend bepaald door de plaats in de indeling van artikel 1a Wed en de daaraan verbonden consequenties uit artikel 2 Wed.

\section{Zorgplichtbepalingen in het milieustrafrecht}

\subsection{Inleiding}

Tussen de delictsomschrijvingen uit bijzondere milieuwetten die zijn aangehaakt aan de Wed bevinden zich ook, enkele zorgplichtbepalingen. Er lijkt echter nauwelijks sprake van systematiek zowel in het opnemen als in het afwijzen van dergelijke bepalingen, terwijl ook de vormgeving verschillen vertoont. In de overkoepelende milieuwet, de Wet milieubeheer ${ }^{56}$, staat geen algemene milieubeschermende norm die strafrechtelijk is te handhaven. In deze wet is in artikel 1.1a wel een bestuurs- en civielrechtelijk handhaafbare zorgplicht opgenomen. ${ }^{57}$

Binnen de soortgerichte milieuwetgeving zijn bijvoorbeeld artikel 2 Wet Milieugevaarlijke Stoffen (hoofdstuk 9 paragraaf 3.2.) en artikel 10.3 Wet milieubeheer, hoofdstuk Afvalstoffen (hoofdstuk 9 paragraaf 3.4.) aan te merken als zorgplichtbepalingen.

In de sectorale milieuwetgeving bevat artikel 13 Wet bodembescherming een zorgplichtbepaling (hoofdstuk 9 paragraaf 3.3.), maar deze ontbreekt in de Wet verontreiniging oppervlaktewateren en de Wet inzake de luchtverontreiniging.

Bij de totstandkoming van de Wet inzake de luchtverontreiniging is, in tegenstelling tot de Wvo, wel gedebatteerd over het opnemen van een zorgplichtbepaling. Deze wet kwam in 1970 tot stand, teneinde de lucht als levensvoorwaarde beter te kumnen beschermen. Gesteld werd dat het gebnuik van fossiele brandstoffen het evenwicht van de samenstelling van de lucht enigszins dreigt te verstoren, aangezien hierdoor sprake is van een toename van het kooldioxidegehalte. Als ernstiger werd ervaren dat door de toename van de bevolking en industrialisatie, ook andere stoffen in grote hoeveelheden in de lucht worden gebracht die daarin van nature niet of in zeer geringe concentraties voorkwamen. ${ }^{38}$ Hierdoor komen verontreinigende stoffen in de

55 TK 192-1993, 23 196, nr. 3, p. 8.

56 Wet van 13 juni 1979, Stb. 1979, 442, en inmiddels herhaaldelijk gewijzigd. Zie over de zorgplichtbepalingen in deze wet: Michiels, F.C.M.A., De Wet milieubeheer, pp. 5-7, $110-111$ en 216.

57 Daarover vanuit bestuursrechtelijk perspectief Jong. P., Handhaafbaar milieurecht. Bestuurlijke handhaafbaarheid van milieurecht als normstellingsprobleem, pp. 244-255. Zie over artikel 1.1 a Wm hoofdstuk 9 paragraaf 3.4.5.

58 De wet wordt niet alleen noodzakelijk bevonden om in te kunnen ingrijpen op het gebied van de luchtverontreiniging afkomstig van het gemotoriseerd verkeer, de ruimteverwarming en enkele andere sectoren, maar ook door de noodzaak te beschikken over een specifieke wettelijke grondslag voor het optreden tegen de industricile 
atmosfeer die zich grotendeels onttrekken aan menselijke beïnvloeding. Daarbij komt dat verschillende stoffen chemische omzettingen kunnen ondergaan die voor levende organismen veel schadelijker zijn dan de oorspronkelijke stoffen. Aangezien het zogenaamde zelfreinigende vermogen van de lucht zeer beperkt is ten opzichte van de in de lucht gebrachte verontreiniging, werd het noodzakelijk gevonden alle mogelijke maatregelen te nemen teneinde de totaal in de lucht gebrachte hoeveelheden verontreinigende stoffen tot een minimum te beperken. ${ }^{59}$ De Vereniging van Nederlandse Gemeenten adviseerde nadrukkelijk in deze wet een bepaling op te nemen, op basis waarvan een ieder verplicht is al het mogelijke te doen om luchtverontreiniging te voorkomen. Hiervan werd afgezien: ${ }^{60}$

"De algemeenheid en vaagheid welke de formulering van een dergelijke verplichting onvermijdelijk zou inhouden, zouden de reële betekenis voor de praktijk wel bijzonder gering, in feite waarschijnlijk nihil doen zijn. Waar het nodig is ervan verzekerd te zijn dat de juiste, aan de actuele stand der techniek aangepaste maatregelen ook inderdaad worden genomen (door alle betrokkeren, resp. een bepaalde vervuiler), kunnen wettelijke verplichtingen in het leven kunnen worden geroepen".

Bij de parlementaire behandeling is niet aangedrongen op het opnemen van een zorgplichtbepaling, die dan ook niet in de tot stand gekomen wet is te vinden. ${ }^{61}$

In deze paragraaf worden enkele wel tot stand gekomen zorgplichtbepalingen besproken, in volgorde van inwerkingtreding van de wet in formele zin waarin ze zijn opgenomen.

\subsection{Wet Milieugevaarlijke Stoffen}

\subsubsection{Inleiding}

In de jaren zeventig werd duidelijk dat er behoefte was aan een wettelijke regeling orn de risico's van chemische stoffen te beperken. Dit werd mede veroorzaakt door enkele grote incidenten waaruit de relatie tussen dergelijke stoffen en de menselijke gezondheid indringend bleek. In $1985 \mathrm{kwam}$ de Wet milieugevaarlijke stoffen tot stand (hoofdstuk 9 paragraaf 3.2.2.). Hierin is een zorgplichtbepaling opgenomen (hoofdstuk 9 paragraaf 3.2.3.), waarvan de betekenis nader zal worden beschouwd (hoofdstuk 9 paragrafen 3.2.4., 3.2.5. en 3.2.6.).

luchtverontreiniging, zeker voor zover deze afkomstig is van de "belangrijke luchtverontreinigers" of wordt veroorzaakt in gebieden met aanzienlijke luchtverontreiniging, TK 1968-1969, 9816, nr. 2, p. 18.

$59 \quad T K 1968-1969,9816$, nr. 2, pp. 12-13.

60 TK 1968-1969, 9816, nr. 2, p. 19, zie ook Keizer, V.G., Milieuwetgeving; Wet inzake de luchtverontreiniging, p. 23.

61 Zie Wet inzake de luchtverontreiniging van 26 november 1970, Stb. 1970, 580, zie over deze wet Keizer, V.G., Milieuwetgeving; Wet inzake de luchtverontreiniging. 


\subsubsection{Wet Milieugevaarlijke stoffen}

De wenselijkheid om te komen tot een wettelijke regeling om de risico's met chemische stoffen te beperken kwam vanaf het begin van de zeventiger jaren in de (publieke) belangstelling te staan. Dit was mede het gevolg van een aantal incidenten met chemische stoffen, die duidelijk consequenties aan het licht brachten die samenhangen met de verspreiding van deze stoffen. Zo was er bijvoorbeeld de kwikverontreiniging van de Minamata-baai in Japan (Minamata-ziekte) die tientallen. slachtoffers eiste, de consumptie van met cadmium belaste rijst in Japan (itai-itaiziekte) waardoor botten en gewrichten werden aangetast, de vergiftiging van de veestapel en van mensen door PBB's in veevoeder in Michigan VS, de gaswolk met methylisocyanaat uit de tank van de Union Carbide fabriek in Bhopal waardoor ongeveer 20.000 doden en 100.000 gewonden vielen, en de aan het licht gekomen relaties tussen asbest en mogelijk formaldehyde en kanker. ${ }^{62}$ Dit werd als extra verontrustend ervaren, omdat vaak onbekend is in hoeverre deze blootstelling aanleiding kan geven tot schadelijke effecten ${ }^{63}$ door de ontoereikendheid van de beschikbare wetenschappelijke informatie. ${ }^{64}$ Hierbij kwam dat er, met name na de Tweede Wereldoorlog, sprake is van een grote toename van de chemische industrie, waardoor er in de westerse samenleving steeds intensiever gebruik wordt gemaakt van door de mens gemaakte stoffen. ${ }^{65}$

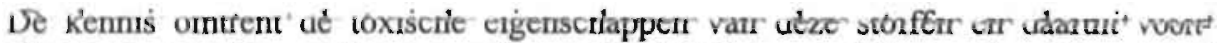
vloeiende risico's voor de mens en het milieu, hield geen gelijke trend met kennis met betrekking tot het ontwikkelen van stoffen en omtrent productie- en analysetechnieken. Uit het oogpunt van bescherming van de mens en het milieu werd het noodzakelijk geacht dat er onderzoek werd verricht naar de mogelijk schadelijke effecten van deze stoffen. Indien de diverse wetten met betrekking tot chennische stoffen in ogenschouw werden genomen, viel op dat geen van deze wetten voldoende grondslag bood voor een samenhangend beleid gericht op het tegengaan van de ongecontroleerde blootstelling van de mens en het milieu aan chemische stoffen in het algemeen. Ook deze regelingen tezamen leken hiervoor onvoldoende grondslag te bieden. ${ }^{66}$ De bestaande wetgeving bevatte derhalve lacunes inzake de integrale beoordeling van deze stoffen en de bescherming van de mens en het milieu tegen de gevaren die deze stoffen kunnen verooizaken. ${ }^{67}$ Een nieuwe wettelijke (soortgerichte) regeling werd noodzakelijk geacht. Deze moest waarborgen scheppen dat onderzoek naar chemische stoffen wordt verricht en dat de overheid wordt geïnformeerd over de resultaten. Tevens moest zij als basis dienen voor de beoordeling van mogelijke gevaren en voor het eventuele voorkomen daarvan. ${ }^{68}$ Het doel was dat een meer

TK 1980-1981, 16800 , A, pp. 15-16, TK 12-02-1985, p. 3190.

63 TK 1980-1981, 16800 , A, p. 14.

64 TK 1980-1981, 16800 , A, p. 14, nr. 3, p. 3.

65 Zo gaf de vaste kamercommissie voor milieuhygiẹne aan dat er in 1984 ongeveer 60.000 stoffen in regelmatige productie zijn en dat er voortdurend bijkomen.

66 TK 1980-1981, 16800 , A, p. 18 ; TK 1980-1981, 16800 , nr. 3, p. 11.

67 TK 1980-1981, 16800 , A, pp. 19, 31; TK 1980-1981, 16800 , nr. 3, pp. 11, 34.

68 TK 1980-1981, 16800 , A, pp. 15-16; TK 1980-1981, 16 800, nr. 3, pp. 5-6; TK 1983- 
omvattend en samenhangend beleid ter zake van de bescherming van de mens en het milieu tegen gevaarlijke stoffen en preparaten zou ontstaan. ${ }^{69}$

In 1978 vond er voor het eerste een gedachtewisseling plaats tussen de minister en de Tweede Kamer over aspecten van een wettelijke regeling voor de beheersing van stoffen die gevaar voor de mens en het milieu veroorzaken. ${ }^{70} \mathrm{Er}$ werd afgesproken dat een wetsontwerp met betrekking tot milieugevaarlijke stoffen met prioriteit ${ }^{71}$ zou worden voorbereid. ${ }^{72}$ De minister stelde voor in het voorjaar van 1979 te komen met een nottie ten behoeve van de vaste kamercommissie voor milieuhygiëne en op basis daarvan mondeling overleg te voeren. ${ }^{73}$

Op 28 februari 1979 diende de minister de toegezegde notitie milieugevaarlijke stoffen in. ${ }^{74} \mathrm{Als}$ redenen om over te gaan tot maatregelen met betrekking tot milieugevaarlijke stoffen werden daarin gegeven: de groei van de chemische industrie na de Tweede Wereldoorlog die tot gevolg had dat er steeds meer chemische stoffen in soms niet te verwaarlozen concentraties worden aangetroffen in lucht, water, planten, dieren, menselịk voedsel en de mens, het nauwelijks beoordelen van risico's en het dientengevolge daarvan niet betrekken in de besluitvorming terwijl juist de laatste jaren in toenemende mate onverwachte risico's voor mens en dier aan het licht zijn gekomen, de aandhcht van deze ervaringen door wetenschap en bevolking ${ }^{75}$ en het ontbreken van mogelijkheden in wetgeving ter integrale beoordeling en regulering door de overheid

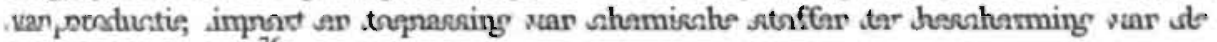
mens en het milieu. ${ }^{76}$

Voorts werd erop gewezen dat de aanpak van de problematiek in internationaal kader dient plaats te vinden, gezien de internationale wijze waarop in de behoefte aan chemische stoffen wordt voorzien, de niet grensgebonden belasting van het milieu en het zo efficiënt mogelijk gebruik maken van de technische en wetenschappelijke mogelijkheden tot het doen van onderzoek en het opstellen van criteria. ${ }^{77}$ De chemische industrie werd zelf in de eerste plaats verantwoordelijk gehouden voor de gevolgen van het produceren en op de markt brengen van chemische stoffen en producten. Deze verantwoordelijkheid en de consequenties daarvan zouden door de chemische industrie algerneen worden erkend. ${ }^{78}$ Voor zowel bestaande als voor nieuwe stoffen die op de markt (zullen) worden gebracht, diende de overheid de

1984,16800 , nr. 11, p. 1.

69 TK 1983-1984, 16800 , nr. 9, p. 6.

70 Dit gebeurde op 1 november 1978, bij de behandeling van de rijksbegroting voor 1979, TK 15 300-XVII; Volksgezondheid en Milieuhygiëne afdeling Milieuhygiēne.

71 TK 197931 oktober 1978, p. 993.

72 TK 19791 november 1978, p. 976.

73 TK 1979 1 november 1978, p. 980.

74 TK 1978-1979, 15566 , nrs. 1-2.

75 TK 1978-1979, 15 566, nrs. 1-2, pp. 4-5.

76 TK 1978-1979, 15566 , nrs. 1-2, pp. 27-28.

$77 \quad$ TK 1978-1979, 15566 , nrs. 1-2, p. 5.

78 TK 1978-1979, 15566 , nrs. 1-2, p. 29. 
bevoegdheid te krijgen deze te verbieden of aan beperkende voorschriften te onderwerpen. Uitgangspunt was dat deze beperkingen niet verder mogen gaan dan met het oog op de bescherming van het milieu en de volksgezondheid noodzakelijk is. ${ }^{79}$

In de notitie werden vijf buitenlandse wettelijke regelingen op het terrein van milieugevaarlijke stoffen kort besproken. Hierbij valt op dat de Noorse Wet op het toezicht op producten uit 1976 als enige voor een ieder die met mogelijk schadelijke producten omgaat de verplichting voorop stelt, de nodige voorzichtigheid en passende maatregelen te nemen om schadelijke effecten te voorkomen en te beperken. Deze wet kende algemene zorgvuldigheids- en onderzoeksverplichtingen voor degene die met deze producten omgaan. Over deze wet werd opgemerkt dat een systeem dat zich beperkt tot een algemene zorgvuldigheidsplicht en tot het scheppen van een regulerend instrumentarium voor het geval de stof risico's veroorzaakt, vooral is gericht op ingrijpen achteraf. Als groot probleem werd gezien dat gegevens over eigenschappen en risico's van nieuwe stoffen niet systematisch bij de overheid binnenkomen, hetgeen slechts mogelijk werd geacht met een wettelijke onderzoeks- en meldingsplicht. ${ }^{80}$

Ter aanvulling van het mondeling overleg met de vaste kamercommissie van 7 maart 1979 en de notitie, stuurde de minister op 21 juni 1979 een brief aan de Tweede Kamer $^{81}$, waarin hij aangaf dat de Wms ten aanzien van aanmelding en maatregelen uitvoering zal geven aan de EG-richtlijn. ${ }^{82}$ Voorts zou de wet de mogelijkheid bieden bestaande en reeds in productie en gehnuik zijinde stoffen die schadelijk zijin voor de volksgezondheid en het milieu te verbieden of te beperken. ${ }^{83}$

Op 27 juni 1979 vond er een openbare vergadering plaats van de vaste karnercommissie en de minister over de notitie. ${ }^{84}$ Door diverse sprekers werd aangegeven dat de EG-richtlijn te beperkt van strekking was en onvoldoende tegemoet kwam aan het verlangen naar een doeltreffende wettelijke regeling. Gesteld werd dat een preventief beleid diende te worden gevoerd ten aanzien van nieuwe stoffen, waarbij de eigen verantwoordelijkheid van de industrie voorop werd gesteld. Mevrouw LambersHacquebard pleitte voor omkering van de bewijslast in die zin "dat geen (nieuwe) stof kan worden toegepast of gebruikt, waarvan niet vooraf is aangetoond dat redelijkerwijs geen gevaar voor mens en milieu te duchten is", en diende een motie met deze strekking in ${ }^{85}$ De inhoud van de motie is, tot teleurstelling van sommige leden ${ }^{86}$, niet overgenomen in de Wms. ${ }^{87}$

79 TK $1978-1979,15566$, nrs. 1-2, p. 32.

80 TK 1978-1979, 15566 , nrs. 1-2, p. 31.

81 TK 1978-1979, 15.566, nr. 6.

$82 \mathrm{Bij}$ de totstandkoming werd rekening gehouden met richtlijn 79/831/EEG, PbEG 1979, L 259, houdende de zesde wijziging van de richtlijn 67/548/EEG van 18-09-1979 en 76/769/EEG van 02-07-1976, zie TK 1980-1981, 16 800, A, p. 19; TK 1980-1981, 16 800 , B, p. 1; TK 1980-1981, 16800 , nr. 3, p. 12.

$83 T K 15566$, nr. 6, p. 3, nadere detaillering zal bij de uitwerking van de wettekst volgen, zie p. 4.

84 Openbare Commissie Vergadering 27 juni 1978, pp. 1317-1331 (OCV 33).

85 TK 1978-1979, 15 566, nr. 8; zie ook $T K 1983-1984,16800$, nr. 9, p. 16 en de 
De Wms werd gedeeltelijk opgezet als een raamwet met de mogelijkheid tot uitwerking in een uitgebreid stelsel van gelede normstellingen. Zo werden op 34 plaatsen amvb's genoemd voor verdere uitwerking van regelgeving, terwijl er op 8 platsen werd gesproken over nadere regelen die de minister kan stellen. ${ }^{88}$ De wet voorziet in drie instrumenten waarmee de milieugevaarlijke stoffenproblematiek wordt aangepıkt, te weten het kennisgevingsysteem, de onderzoeksbevoegdheden en de bevoegdheden tot regulerende maatregelen. Hierdoor bevat de wet een systeem van onderzoek en informatieverschaffing voor de stoffen die, involge de richtlijn, na 18 september 1981 moeten worden aangerneld. Dit systeem (kennisgeving met basisdossiers, aanvullende meldingen, stapsgewijs toenemend nader onderzoek op elk momert bij gebleken noodzaak daartoe) werd gecompleteerd door het moment van kennisgeving te koppelen aan het tijdstip van productie en door de introductie van een algemene zorgplicht met betrekking tot informatieverschaffing en risicobeperkende maatregelen voor beroepsmatige handelingen met chemische stoffen. Beoogd werd een basis te leggen voor een preventief beleid ten aanzien van nieuwe stoffen ${ }^{89}$, zodat ten aanzien van nieuwe stoffen in zekere zin het stand-still beginsel werd ingevoerd. Voor bestaande stoffen werd een saneringsbeleid ingesteld. ${ }^{90}$

De Wms zou uitgaan van een integrale aanpak, waarmee werd bedoeld dat de wet betrekking heeft op alle chemische stoffen en preparaten, ongeacht de doeleinden waarvoor zij worden vervaardigd en gebruikt, en op alle fasen van hun levensloop, dat wil aeggen vanaf de vervaardiging tot en met de verwijdering of vernietiging in de afvalfase. Voorts beoogde de Wms grondslag te zijn voor een bescherming tegen alle schadelijke effecten die voor de mens of het milieu van die stoffen en preparaten

\section{behandeling rijksbegroting 1979 .}

86 Het betreft leden van de fracties van het CDA, de PvdA, D'66 en de PPR, TK 19811982,16800 , nr. 6, pp. 4, 6-7, 11-12. Zij wezen erop dat de zorgplichtbepaling uit artikel 2 aanmerkelijk minder ver gaat dan de omkering van de bewijslast. Zie over artikel 2 Wms hoofdstuk 9 paragrafen 3.2.3, 3.2.4., 3.2.5. en 3.2.6.

87 De minister geeft aan dat het principe van omkering van de bewijslast, te weten dat de initiatiefnemer onderzoek moet doen en alle informatie moet verschaffen die de overheid nodig oordeelt voor een evaluatie van de risico's in de verschillende fasen van de levensloop van een stof, is ingebouwd in het systeem van de Wms, zodat de motie niet formeel maar wel materieel wordt uitgevoerd. TK 1983-1984, 16 800, nr. 9, pp. 2425; TK 14 februari 1985 , p. 3296.

$88 T K 12$ februari 1985, p. 3210, hierover eerder: TK 1981-1982, 16800 , nr. 6, pp. 10-11, EK 3 december 1985, pp. 229-230.

89 TK 1980-1981, 16800 , A, p. 36; TK 1980-1981, 16 800, nr. 3, p. 44. Zie over de hoofdlijnen van de Wms: TK 12 januari 1985, p. 3209, TK 12 januari 1985, p. 3239. De kern van de Wms is de verplichting tot kennisgeving TK 1980-1981, 16800 , A, p. 19; TK. 1980-1981, 16800 , nr. 3, p. 13., die ten doel heeft beoordeling door de overheid van de eventuele gevaren van een stof voor de mens en het rnilieu mogelijk te maken, $T K$ 1980-1981, 16800 , A, p. 20; TK 1980-1981, 16 800, nr. 3, p. 14. Elke beoordeling van stoffen berust op het afwegen van de te verwachte blootstelling aan de stof en de effecten die voortvloeien uit een zekere mate van blootstelling, TK 1983-1984, 16 800, nr. 9, p. 41 ; zie ook $T K .1983-1984,16800$, nr. 12, p. 35.

90 TK 1980-1981, 16800 , A, p. 36; TK 1980-1981, 16800 , nr. 3, p. 44. 
kunnen uitgaan; er zijn geen beperkingen aangebracht naar milieucompartiment waarin die gevaren kunnen optreden noch naar de hoedanigheid van de te beschermen mens. ${ }^{91}$ Bij de besluitvorming in het kader van de Wms zou in zoverre rekening moet worden gehouden met sociaal-economische en andere belangen dat, bij de keuze van de middelen die tot de bescherming van de mens of het milieu kunnen leiden, steeds dat middel moet worden gekozen met de minste neveneffecten of met de meeste positieve effecten op sociaal-economische of andere belangen. ${ }^{92}$

De minister van VROM typeerde de Wms als een tweede generatie milieuwet. De eerste generatie bestond uit verbods- en gebodswetgeving. Deze was op dat moment (februari 1985) voor een groot deel ingevoerd. De tweede generatie milieuwetgeving behoorde volgens de minister meer bij de volwassenheidsfase van het milieubeleid. Preventie is bij deze wetgeving van groot belang, waarbij de eigen verantwoordelijkheid van justitiabelen een grote rol speelt. ${ }^{93}$

\subsubsection{Artikel $2 \mathrm{Wms}$}

Bij de betrokken tak van industrie en andere betrokken maatschappelijke instanties was blijkens de parlementaire behandeling van de Wms, het besef doorgebroken dat allen die beroepshalve bij productie, invoer en toepassing van chemische stoffen en preparaten zijn betrokken een eigen verantwoordelijkheid hebben voor de mens en het

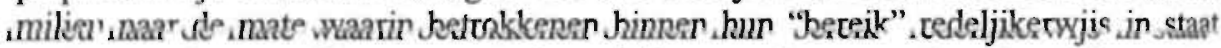
moeten worden geacht om eventuele nadelige gevolgen van hun handelingen te voorzien en te beperken. Het werd als een eis van maatschappelijke zorgvuldigheid gezien, dat een ieder die beroepshalve een chemische stof vervaardigt, verhandelt, invoert of toepast, zich naar vermogen op de hoogte stelt van mogelijke gevaarlijke effecten van die stof op de mens en het milieu én ervoor zorg draagt alle risicobeperkende maatregelen te nemen die redelijkerwijs kunnen worden gevergd indien hij die gevaren van de door hem verrichte handelingen kent of redelijkerwijs kan vermoeden. Als uitvloeisel daarvan ${ }^{94}$ was in het wetsvoorstel artikel $2 \mathrm{Wms}$, een zorgplichtbepaling, opgenomen luidende ${ }^{95}$ :

"Ieder die beroepshalve een stof vervaardigt, aan een ander ter beschikking stelt, in Nederland invoert of toepast, en die weet of redelijkerwijs had kunnen vermoeden dat door zijn handelingen met die stof gevaren kunnen optreden voor mens of milieu, is verplicht alle maatregelen te nemen die redelijkerwijs van hem kunnen worden gevergd, teneinde die gevaren zoveel mogelijk te beperken."

91 TK 1983-1984, 16800 , nr. 9, p. 6; Voor de bescherming van de mens en het milieu tegen de gevaren van chemische stoffen is inzicht in de eigenschappen van die stoffen noodzakelijk, TK 1980-1981, 16800 , A, p. 21; TK 1980-1981, 16800 , nr. 3, p. 21. Zie hierover TK 1983-1984, 16800 , nr. 9, p. 16; TK 14 februari 1985, p. 3264.

93 TK 14 februari 1985, pp. 3236-3237; EK 3 december 1985, pp. 229-230.

94 TK 1980-1981, 16800 , A, p. 23; TK 1980-1981, 16800 , nr. 3, pp. 21-22.

95 TK 1990-1991, 16800 , nrs. 1-2 p. 2. Dit voorgestelde artikel werd nagenoeg ongewijzigd in de wet opgenomen. 
De verntwoordelijkheid voor het onderzoeken en beoordelen van de risico's van producte en gebruik van een chemische stof werd gelegd bij de producent en de importer van die stof. Deze eigen verantwoordelijkheid, die tot uitdrukking komt in artikel , houdt in dat bedrijven primair zelf moeten beoordelen of hun activiteiten tot toelaatbre gevaren en schade voor de mens en het milieu kunnen leiden, en dat zij die activiteien, bij gebleken ontoelaatbaarheid, niet aanvangen of voortzetten. De overheil heeft ook een eigen verantwoordelijkheid, die voortvloeit uit zijn taak ten. aanzienvan de bescherming van de mens en het milieu. ${ }^{96}$ Hierom moet de overheid de risico's van een stof zelf kunnen beoordelen. Indien de risicobeoordeling dit dicteert, moeten naatregelen kunnen worden genomen ten aanzien van het gebruik van milieugevaarlike stoffen, waarbij de overheid inbreuk kan maken op de vrijheid van het produceen, het in de handel brengen en het toepassen van deze stoffen. ${ }^{97}$ Het "globale" artikel 2 gaf een mogelijkheid ontoelaatbare handelingen met (nieuwe en bestaanie) chemische stoffen aan te pakken, die niet reeds door specifieke wettelijke voorschiften worden gedekt. Opgemerkt werd dat wat dat betreft de bepaling vergelij]baar is met artikel 25 (oud) WVW. ${ }^{98}$

De Raai van State merkte over de voorgestelde zorgplichtbepaling op dat dit een zeer vergaanie norm is. Uit bestuurlijk oogpunt had de raad begrip voor deze aanpak van de veela nog onbekende gevaren van stoffen voor de mens en het milieu. Vanuit het oogpuntvan rechtszekerheid drong hij erop aan dat het gestelde in artikel 2 buiten toepassing blijft in de gevallen zoals bedoeld in artikel $27 . .^{99}$ De door de Raad voorgestelde beperking werd niet opgenomen in de wet. Artikel 2 zou dan onder andere niet gelden voor personen die beroepshalve omgaan met "oude" stoffen en voor personen die in het transitoverkeer of in laboratoria omgaan met chemische stoffen, terwijl de gevaren van die stoffen en de aard van de handelingen daarvoor geen rechtvaardiging bieden. Daamaast werd erop gewezen dat de verplichting van artikel 2 gelijke tred zou houden met de redelijkerwijze te verwachten kennis over de stof, waardoor de verplichting met betrekking tot nieuwe stoffen veelal een meer specifieke betekenis zou hebben. ${ }^{100}$

96 Overigens wordt de aansprakelijkheid van de overheid voor schade ten gevolge van stoffen waarvan zij de toelating niet heeft verhinderd, niet geregeld in de Wms. Een duidelijke onzorgvuldige beoordeling kan tot (mede-),aansprakelijkheid van de overheid leiden voor schade ten gevolge van aldus beoorcleelde stoffen. Bij de rechterlijke toetsing zal rekening moeten worden gehouden dat nieuwe gegevens naderhand tot andere inzichten in de toelaatbaarheid van een stof kunnen leiden. TK: 1983-1984, 16 800, nr. 9, p. 28; TK 1983-1984, 16800 , nr. 12, p. 15; TK 14 februari 1985, p. 3300.

97 Zie TK. 1980-1981, 16 800, A, pp. 16-17, 30, 38; TK 1980-1981, 16800 , nr. 3, pp. 7, 34, 47-48; TK 1983-1984, 16 800, nr. 9, pp. 25-26; TK 12 febraar 1985, p. 3195; TK 14 februari 1985, p. 3296.

98 TK 1983-1984, 16800 , nr. 9, p. 86. Zie over artikel 25 (oud) en 5 WVW hoofdstuk 7 paragraaf 3.2 .

99 TK 1980-1981, 16800 , B, p. 4. Het voorgestelde artikel 27 (gewijzigd opgenomen als artikel $19 \mathrm{Wms}$ ) verklaart de artikelen 3 tot en met 18 niet van toepassing op een aantal stoffen.

100 TK $1980-1981,16800$, C, p. 7. 
Gok was de Raad van State van oordeel dat het uit oogpunt van de rechtszekerheid aanbeveling verdient in het ontwerp zelf of in de memorie van toelichting nadrukkelijk tot uitdrukking te brengen dat de desbetreffende bedrijfstakken door middel van circulaires vanwege de minister van Volksgezondheid en Milieuhygiëne worden geïnformeerd over die stoffen - of categorieën daarvan - waarvoor het wetsontwerp Wms geen gelding heeft. ${ }^{101}$ De noodzaak het bedrijfsleven hierover voor te lichten werd onderschreven, en er werd aan de memorie van toelichting een passage toegevoegd over informatie aan het bedrijfsleven. ${ }^{102}$

De invoering van de algemeen geformuleerde zorgplicht werd onder meer gemotiveerd door te verwijzen naar de toegenomen mogelijkheden om informatie over stofeigenschappen te verkrijgen. De Raad gaf aan dat de wet een aanzienlijke bijdrage gaat leveren aan deze informatiemogelijkheden, maar vroeg, zich af of de individuele werknemer bij een productiebedrijf van stoffen, de kleine zelfstandige ondernemer, handelaar of ambachtelijke vakman wel voldoende zal zijn gebaat met deze informatie. Juist om aan de zorgplichtbepaling te kunnen voldoen moeten zij op zo's eenvoudig mogelijk wijze kennis kunnen nemen van de aard van de stoffen en de gevarencategorie waarin deze geplaatst (dienen te) zijn. Om hieraan tegemoet te komen adviseerde de Raad een eenvoudige, in gevarencategorieën ingedeelde, databank in overweging te nemen. ${ }^{103}$ Dit advies werd niet gevolgd. De databank werd overbodig geacht gezien de bestaande mogelijkheden en de in de Wms getroffen voorzieningen. ${ }^{104}$ Volgens de memorie van toelichting vormen de involge de EGrichtlijn voorgeschreven waarschuwingstekens, beschrijvingen van de gevaren en de veiligheidsaanbevelingen op de verpakking van gevaarlijke stoffen, de basisinformatie op grond waarvan de vereiste zorgvuldigheid kan worden betracht. ${ }^{105}$

In aanvulling op de opmerkingen die hij plaatst met betrekking tot artikel $2 \mathrm{Wms}$, merkte de Raad van State op bezwaar te hebben tegen de formulering van de zorgplicht zelf. ${ }^{106}$ Het komt hem juister voor indien in plaats daarvan een meldingsplicht wordt uitgewerkt in dezelfde zin als waarin dit is gebeurd in artikel 19 Ontwerpwet bodembescherming. ${ }^{107}$ Ook dit advies werd niet opgevolgd, omdat een wijziging van de bepaling in de door de Raad voorgestane richting een onaanvaardbare verschraling van de betekenis ervan zou zijn. Er werd op gewezen dat artikel 19 Ontwerpwet bodembescherming niet kan worden vergeleken met artikel $2 \mathrm{Wms}$,

101 TK 1980-1981, 16.800, B, p. 4.

102 TK 1980-1981, 16 800, C, p. 7; TK 1980-1981, 16800 , nr. 3, p. 32.

103 TK 1980-1981, 16800 , B, p. 4.

104 Volgens de minister is voldoende informatie afkomstig van: voorschriften voor indeling, aanduiding (etikettering) en veiligheidsmaatregelen indien cen nieuw aangemelde stof gevaren voor de mens, en het milieu oplevert, de mogelijke indeling van bestaande stoffen in gevarencategorieên, handboeken over gevaarlijke stoffen en de taak van werkgevers hun werknemers te informeren, zie TK. 1980-1981, 16800 , C. p. 8.

105 TK 1980-1981, 16800 , nr. 3, p. 22.

$106 \mathrm{Nr}$. 801001/35, advies naar aanleiding van artikel 19 van de. Ontwerpwet bodembescherming.

107 Zie $T K$ 1980-1981, 16 529, nr. 2; TK 1980-1981, 16800 , B, p. 4. 
omdat: artikel 19 zich richt tot alle betrokkenen en artikel 2 slechts tot degene die beroepshalve met stoffen omgaan, artikel 19 betrekking heeft op bijzondere situaties terwijl artikel 2 een algemene gedragsregel inhoudt voor degene die beroepshalve ongaan met gevaarlijke stoffen en artikel 19 zich richt op die gevallen waarin de verontreiniging heeft plaats gevonden terwijl artikel 2 mede verplicht tot het voorkomen van ongevallen. ${ }^{108}$

Tijdens de parlementaire behandeling werd gesuggereerd artikel 2 te verwijderen, of anders direct te koppelen aan de naleving van de in de Wms gestelde regels. Een dergelijke algemene wettelijke regel zou rechtsonzekerheid creëren en aanleiding zijn voor willekeur bij het toezicht op de naleving. De strafrechtelijke sanctionering werd als te vergaand beoordeeld. ${ }^{109}$ Deze suggestie werd niet opgevolgd, omdat de algemene zorgplicht in de Wms zo essentieel werd gevonden dat gesteld werd dat weglating ertoe zou leiden dat van een samenhangende wetgeving voor milieugevaarlijke stoffen en preparaten en van de grondslag voor preventief beleid geen sprake meer zou zijn. ${ }^{110}$ Erkend werd evenwel dat de zorgplichtbepaling zich naar haar aard minder gemakkelijk leent voor systematisch toezicht dan de concretere verplichtingen uit de Wms. Het gevolg daarvan zou zijn dat het constateren van overtreding van deze bepaling veelal beperkt zou blijven tot gevallen waarin schade of letsel aan derden is ontstaan. Dit zou echter niets afdoen aan de noodzaak om de naleving van deze zorgplicht strafrechtelijk te handhaven, waarbij werd gewezen op de Wegenverkeerswet. De maatschappelijke zorgvuldigheidsnorm uit artikel 1401 (oud) BW werd als waarborg onvoldoende geacht. ${ }^{119}$

Opgemerkt werd dat de Wms indirect wel effect kan hebben op civielrechtelijke aanspraken inzake schade ten gevolge van milieugevaarlijke stoffen en preparaten, omdat het kennisniveau toeneemt omtrent de eigenschappen van (nieuw ontwikkelde) stoffen en omdat uit de wet voortvloeiende verplichtingen (zoals de zorgplicht uit artikel 2) voor de rechter bakens kunnen vormen bij de beoordeling van civielrechtelijke geschillen over schade ten gevolge van milieugevaarlijke stoffen en preparaten. ${ }^{1 / 2}$

De zorgplicht uit artikel $2 \mathrm{Wms}$ werd gezien als een aanvulling op andere meer concrete wettelijke verplichtingen. $\mathrm{Zij}$ vervangt niet de wettelijke plicht tot het doen van onderzoek, kennisgeving en aanvullende meldingen, en de dwingende voorschriften. ${ }^{113} \mathrm{Bij}$ de parlementaire behandeling werd opgemerkt dat bij verdenking van het schenden van een specifieke, wettelijk. voorgeschreven maatregel, de vervolging

\footnotetext{
108 TK 1980-1981, 16800, C, p. 8.

109 TK 1981-1982, 16800 , nr. 6, p. 19.

110 TK 1983-1984, 16800 , nr. 9, p. 3.

111 Gesteld werd dat bewijsrechtelijke problemen benadeelden dikwijls zouden weerhouden van civielrechtelijke acties, zie $T K$ 1983-1984, 16800 , nr. 9, pp. 54-55.

112 TK 1983-1984, i6 800, пr. 9, pp. 27-28.

113 TK 1981-1982, 16800 , nr. 6, p. 18; TK 1983-1984, 16 800, nr. 9, pp. 53-55; Opgemerkt werd dat bijvoorbeeld de aanvullende meldingsplicht uit de Wms los staat van artikel 2, en kan worden gezien als een nadere uitwerking van de algemene zorgplicht.
} 
dient plaats te vinden op grond van de daarop betrekking hebbende strafbepaling, en niet op grond van artikel 2 Wms. ${ }^{114}$

Gesteld werd dat het leveren van het bewijs dat artikel 2 Wms werd geschonden niet eenvoudig zal zijn indien de verdachte, bijvoorbeeld uit onwetendheid of door gebrekkige middelen, tekort is geschoten in het nemen van de nodige matregelen. $D_{e}$ bewijslevering zal zich moeten richten op datgene wat de verdachte redelijkerwijs had moeten weten of kunnen vermoeden en op datgene wat van iemand in een vergelijkbare situatie als de verdachte mag worden gevergd. ${ }^{15}$ Opgemerkt werd dat zich hier geen andere bewijsproblemen zullen voordoen dan bij overtreding van vergelijkbare zorgplichtbepalingen, bijvoorbeeld ten aanzien van de veiligheid van het wegverkeer. ${ }^{116}$ Het bewijs van overtreding van artikel $2 \mathrm{Wms}$ zal evenwel niet moeilijk te leveren zijn indien de betrokkenen naar de geldende inzichten in eigen kring duidelijk tekort zijn geschoten, bijvoorbeeld ten gevolge van het niet lezen van instructies of gebruiksaanwijzingen en het niet opvolgen van veiligheidsaanbevelingen als bedoeld in de Wms. ${ }^{11 /}$ Artikel 2 Wms zou niet zozeer bestemd zijn om een strafrechtelijk optreden mogelijk te maken in twijfelgevallen, maar was juist bedoeld voor de gevallen waarin duidelijk is te kort geschoten naar de geldende inzichten in eigen kring, terwijl niettemin geen meer specifiek wettelijk voorschrift werd overtreden. ${ }^{18}$

De minister merkte aan het einde van de behandeling van de Wms in de Eerste Kamer op dat het hern verbaasde dat artikell 2 Wms weinig is besproken in de Tweede Kamer en in de publiciteit, terwijl het een belangrijk artikel betreft. Cok stelde hij dat de filosofie van artikel 2 Wms weinig aandacht heeft gekregen, terwijl deze heel belangrijk is en ten grondslag ligt aan de doelstelling met het milieubeleid, en het een van de eerste keren is dat het zo in een wetgeving voorkomt. ${ }^{119}$

De algemene zorgplicht uit artikel $2 \mathrm{Wms}$ luidt:

"Ieder die beroepshalve een stof of een preparaat vervaardigt, aan een ander ter beschikking stelt, in Nederland invoert of toepast, en die weet of redelijkerwijs had kunnen vermoeden dat door zijn handelingen met die stof of dat preparaat gevaren kunnen optreden voor mens en milieu, is verplicht alle maatregelen te nemen die redelijkerwijs van hem kunnen worden gevergd, teneinde die gevaren zoveel mogelijk te beperken."

De Wms wordt op 28 maart 1985 door de Tweede Kamer, en op 3 december 1985 door de Eerste Kamer aangenomen. ${ }^{120}$

114 TK 1983-1984, 16800 , nr. 9, p. 54.

115 Hier lijkt te worden gewezen op de beoordeling van de vraag of sprake is van schending aan de hand van een criteriumfiguur, zie hierover hoofdstuk 3 paragraaf 7.4.5.

116 Zie over de zorgplichtbepaling uit de Wegenverkeerswet hoofdstuk 7 paragraaf 3.2.

117 TK 1983-1984, 16800 , nr. 9, p. 54.

118 TK 1983-1984, 16800 , nr. 11, p. 24; TK 1983-1984, 16800 , nr. 12, p. 29.

119 EK 3 december 1985, pp. 238 en 240-141.

$120 T K 28$ maart 1985, p. 4419; EK 3 december 1985, p. 242. Het gewijzigde artikel 2 Wms werd op 19 maart 1985 zonder stemming door de Tweede Kamer aangenomen, zie TK. 
De zorgplicht van artikel 2 Wms ziet, gezien de gebruikte alternatieven, op 16 verschillende situaties. Het betreft immers vier verschillende gedragingen die opzettelijk of culpoos kunnen worden verricht met twee producten (stof of preparaat).

Op overtreding van het bij of krachtens de Wms gestelde is het stelsel van sancties van de Wed van toepassing verklaard. Dit gebeurde omdat de Wms vooral is gericht op handelingen die in het kader van economische activiteiten worden verricht. Dit economische criterium was al voor de invoering van de Wms achterhaald, omdat tijdens de parlementaire behandeling van de Wms ervoor werd gekozen alle strafbaarstellingen uit milieuwetgeving in beginsel aan te haken aan de Wed. ${ }^{121}$

Het schenden van artikel 2 Wms werd bij de invoering strafbaar gesteld involge artikel 65, eerste lid en artikel 66 Wms. Artikel 65, eerste lid luidde: "Een gedraging in strijd met het bij of krachtens artikel $2(.$.$) bepaalde is een misdrijf wanneer zij opzettelijk$ geschiedt, en overigens een overtreding." Artikel 66 luidde: "Aan artikel 1, onder 3, van de Wet op de economische delicten (Stb. 1950, K 258), wordt toegevoegd: <<de Wet milieugevaarlijke stoffen, de artikelen $2(\ldots) \gg>$."

Bij de invoering van artikel la Wed zijn de artikelen 65 en $66 \mathrm{Wms}$ vervallen. Artikel 2 Wms is aangehaakt bij artikel la sub 1 Wed. ${ }^{122}$ Involge artikel 2, eerste lid Wed betreft het een misdrijf indien het opzettelijk is begaan, en is het in de overige gevallen een overtreding.

\subsubsection{De zorgplichtbepaling nader beschouwd}

De gedragingen die tot overtreding van artikel $2 \mathrm{Wms}$ kunnen leiden, zijn beperkt tot het beroepshalve vervaardigen, aan een ander ter beschikking stellen, invoeren en toepassen. ${ }^{123}$ De term beroepshalve heeft geen andere betekenis dan in het normale spraakgebruik. Beoogd werd handelingen die incidenteel of in de sfeer van de particuliere consumptie worden verricht uit te sluiten. ${ }^{124}$ Naast werkgevers vallen ook werknemers onder deze term. Zij zullen door middel van voorlichting op de hoogte worden gebracht van de zorgplicht die zij hebben en de wijze waarop hieraan gevolg kan worden gegeven. ${ }^{125}$ Voorts werd opgemerkt dat ook de verplichtingen die de EGrichtlijn aan de producenten en importeurs van (nieuwe) chemische stoffen oplegt, als uitvloeisel van deze eis van maatschappelijke zorgvuldigheid zijn te beschouwen. ${ }^{26}$

19 maart 1985, p. 4118.

121 TK 1980-1981, 16800 , A, p. 55; TK 1980-1981, 16800 , nr. 3, p. 79; TK 1983-1984, 16 800 , nr. 9 , p. 83.

122 Zie over de Wed in het algemeen hoofdstuk 8 paragraaf 2.5. en over artikell la Wed hoofdstuk 9 paragraaf 2.4 .

123 TK 1983-1984, 16800, nr. 9, p. 54.

$124 T K .1983-1984,16800$, nr. 9, p. 86.

125 TK. 20 februari 1985 , p. 3368

126 TK. 1980-1981, 16800 , A, p. 23; TK. 1980-1981, 16800 , nr. 3, p. 22. 
De term aan een ander ter beschikking stellen omvat al het soort activiteiten die vallen. onder aanbieden of vervreemden van de stof, ook die waarbij van commerciële activiteiten geen sprake is. Op welke situaties deze term betrekking heeft, kon de minister niet op voorhand aangeven, maar veel zal volgens hem afhangen van de feitelijke en economische omstandigheden. De minister geeft aan dat bij de uitvoering van de wet hiervoor, zo nodig door de rechter, oplossingen moeten worden gevonden. ${ }^{127}$ In het voorlopig verslag werd de vraag gesteld of de wetgever zichzelf hiermee geen brevet van onvermogen geeft. Tevens werd erop gewezen dat door de wet rechtsonzekerheid wordt gecreëerd. ${ }^{128}$ De minister reageerde hierop door erop te wijzen dat interpretatie van dit begrip in eerste instantie rust bij het bestuur dat de wet uitvoert. ${ }^{129}$

De term stoffen wordt in artikel 1, eerste lid Wms gedefinieerd als: "chemische elementen en hun verbindingen, zoals deze voorkomen in de natuur of door toedoen van de mens worden voortgebracht". In het tweede lid wordt hieraan toegevoegd: "Onder stoffen werden voedings- en genotmiddelen, alsmede diervoeders niet begrepen". In navolging van het gewone spraakgebruik werd met "stoffen" chemische stoffen bedoeld, die in het algemeen op industriële wijze worden gefabriceerd of die beroepsmatig door de handel in chemische producten uit het buitenland worden ingevoerd. ${ }^{130}$ Het begrip "stoffen" wijkt af van de in de EG-richtlijn gebruikte terminologie. De woorden "bij de productie ontstaan" werden vervangen door "toedoen van de mens worden voortgebracht". Hiermee werd geen inhoudelijke wijziging beoogd, maar zou duidelijker tot uitdrukking worden gebracht dat niet alleen wordt gedoeld op industriële productie. Verder bevat de omschrijving van het begrip "stoffen" niet de zinsnede "en die eventueel alle additieven bevatten die nodig zijn voor het in de handel brengen van deze stoffen". Dit gebeurde door een onderscheid te doen ontstaan tussen "stoffen" en "preparaten".

Aanvankelijk bevatte de tekst van artikel 2 niet de tekst "of een preparaat" en "of dat preparaat". ${ }^{132}$ Naar aanleiding van de vraag in het voorlopig verslag van de Vaste Commissie voor Milieuhygiëne waarom de term preparaten niet in het algemene artikel 2 voorkomt ${ }^{133}$, overwoog de minister zulks opnieuw en kwam hij tot de conclusie dat dit ten onrechte was, aangezien stoffen vrijwel altijd in preparaatvorm zullen worden gehanteerd en omdat handelingen met preparaten tot even grote gevaren kunnen leiden. Vervolgens werd de term preparaat in artikel 2 opgenomen. ${ }^{134}$ De term preparaat wordt in artikel 1, eerste lid Wms gedefinieerd als "mengsels of oplossingen van stoffen". ${ }^{135}$

130 TK 1980-1981, 16800 , A, p 23; TK 1980-1981, 16800 , nr. 3, p. 20.

131. TK 1980-1981, 16800 , nr. 3, p. 66.

132 TK 1980-1981, 16800 , A, p.1; TK 1980-1981, 16800 , nrs. 1-2, p. 2.

133 TK 1981-1982, 16800 , nr. 6, p. 18.

134 TK 1983-1984, 16800 , nr. 9, p. 52, 55; TK. 1983-1984, 16800 , nr. 10, p. 1.

135 Zie ook: TK 1980-1981, 16800 , A, p. 23; TK 1980-1981, 16800 , nr. 3, p. 20. 
De term invoeren wordt in artikel 1, eerste lid Wms gedefinieerd als: "binnen het grondgebied van Nederland, onderscheidenlijk binnen de Europese Gemeenschappen brengen". Deze omschrijving wijkt af van de tenminologie in de richtlijn, waar immers gesproken wordt van "invoer op het douanegebied van de gemeenschap". Dit werd gedaan omdat het risico van een stof reeds bij het feitelijk binnen het territoir brengen ontstaat. ${ }^{136}$

De term toepassen heeft geen andere dan de normale betekenis; synoniemen zijn aanwenden en gebruiken. ${ }^{13}$ ?

Om de gevaarlijke eigenschappen van stoffen aan te duiden is een aantal termen in het spraakgebruik ingeburgerd. Veel gebruikte termen, zowel in wetgeving als in het gewone spraakgebruik, zijn "gevaarlijk" en "schadelijk". In de Wms is gekozen voor de termen gevaarlijk en gevaarlijk voor mens en milieu, om zoveel mogelijk aansluiting te zoeken bij de wettelijk gangbare terminologie. Het begrip "gevaarlijk voor mens en milieu" werd tijdens de parlementaire behandeling een synoniem genoemd van "milieugevaarlijk". Aangegeven werd dat het een relatief begrip is, aangezien de effecten van een stof of een preparaat niet alleen afhangen van de samenstelling en de eigenschappen van de stof, maar ook van de dosering, wijze en omstandigheden van blootstelling, van de gevoeligheid van het blootgestelde organisme en van andere factoren. De term milieugevaarlijk werd gebruikt om aan te geven op weike aspecten van stoffen de wet is gericht. ${ }^{138}$ Tijdens de parlementaire behandeling werd gevraagd of het mogelijk is een nadere omschrijving te geven van de term "gevaar", aangezien dit begrip een ruime betekenis heeft en er geen toetsingscriteria in de wet zijn opgenomen. ${ }^{139}$ De minister gaf aan dat het niet goed mogelijk is om van dit begrip een bevredigende omschrijving te geven. ${ }^{140}$ In de wet is een dergelijke omschrijving niet opgenomen.

De termen mens en milieu zijn, evennin als in andere milieuwetten, in de tekst van de wet gedefinieerd. Aangegeven werd dat de uiteindelijke operationalisering van de term "milieu" afhankelijk zou zijn van de concrete gevallen en de actuele inzichten in de gevaren voor de mens en het milieu van stoffen en preparaten. ${ }^{141}$ Voorts werd erop gewezen dat ook in andere milieuwetten de term milieu ongedefinieerd voorkomt, en dat in de praktijk de noodzaak niet zou zijn gebleken dit begrip door middel van definiëring te omliinen of te beperken. ${ }^{142}$

Tijdens de parlementaire behandeling werd opgemerkt dat artikel 2 Wms erg veel interpretatieruimte geeft ten gevolge van de tweemaal genoemde term redelijkerwijs

136 TK 1980-1981, 16800 , nr. 3, p. 66.

137 TK 1983-1984, 16 800, nr. 9, p. 86.

138 TK 1980-1981, 16800 , A, p. 23; TK 1980-1981, 16800 , nr. 3, pp. 20-21.

139 TK 1981-1982, 16800 , nr. 6, pp. 3-4.

140 TK 1983-1984, 16800 , nr. 9, p. 52. Hij verwijst hierbij naar de OESO Expert Group on the International Glossery of Key Terms.

141 TK 1980-1981, 16800 , A, p. 23; TK 1980-1981, 16800 , nr. 3, p. 21.

142 TK 1983-1984, 16800 , nr. 9, p. 53. 
en de term zo veel mogelijk. Over de tern "redelijkerwijs" werd gesteld dat dit juist de mogelijkheid biedt rekening te houden met de individuele omstandigheden en kwaliteiten van degene die van overtreding van de zorgplicht wordt verdacht, en niet zoals ook werd verondersteld dat de te algemene strekking van de zorgplicht tot een ruime interpretatie zal leiden. ${ }^{143}$ Wel werd aangegeven dat artikel $2 \mathrm{Wms}$ voor bepaalde categorieën van personen een betrekkelijk brede strafrechtelijke aansprakelijkheid schept voor "laakbare nalatigheid". ${ }^{144}$

De: wettelijke voorschriften uit de Wms kunnen niet leiden tot een volledige bescherming van de mens en het milieu, aangezien niet voorziene gevaren zich altijd kunnen voordoen ten gevolgen van nieuwe ontwikkelingen, zoals niet voorziene toepassingen van stoffen of preparaten, of de ontdekking van bijzondere gevaren. Daarom moeten degene die beroepshalve met deze stoffen omgaan, steeds grote zorgvuldigheid betrachten bij de omgang daarmee. Kennis vormt de basis van waaruit de maatschappelijke zorgvuldigheid in de omgang met chemische stoffen en preparaten kan worden betracht. ${ }^{145}$ Door artikel 2 Wms wordt eigenlijk gesteld dat alles verboden of geboden kan worden, maar dat als iemand nog iets anders had kunnen bedenken, hij dat uit zichzelf ook had moeten doen. ${ }^{146}$ Van alles wat niet expliciet is voorgeschreven per amvb, wordt verwacht dat als men het had kunnen weten, men de eigen verantwoordelijkheid had moeten nemen. Als iemand echter op een redelijke wijze inhoud heeft gegeven aan de zorgplicht en zijn best heeft gedaan, zal geen sprake zijn van schending van artikel $2 \mathrm{Wms} .{ }^{\text {(4T }}$ De verplichtingen van artikel 2 Wms zijn dan ook niet onbegrensd; de eigen verantwoordelijkheid en daarmee de in deze bepaling voorgeschreven zorgplicht is beperkt tot wat in het vermogen van de betrokkenen ligt. Dat wil zeggen dat aan producenten en importeurs met betrekking tot informatiemogelijkheden en redelijkerwijs te nemen maatregelen strengere en verder gaande eisen mogen worden gesteld dan aan degene die dezelfde stoffen bijvoorbeeld ambachtelijk toepassen of als werknemer volgens instructie verwerken. ${ }^{148}$ Onder zich naar vermogen op de hoogte stellen van mogelijke gevaarlijke effecten van de stof behoeft niet allereerst aan experimenteel onderzoek te worden gedacht, maar aan het inwinnen van reeds beschikbare informatie bij producent of importeur, uit hand- en chemieboeken en dergelijke. ${ }^{149}$

Over het gebruik van de term redelijkerwijs werd voorts opgemerkt dat het moeilijk kan zijn te bepalen of sprake is van een misdrijf of een overtreding aangezien hiervoor het onderscheidend criterium is of het feit opzettelijk werd begaan. ${ }^{150}$ Dit probleem wordt tijdens de parlementaire behandeling verder niet besproken.

143

144

145

146

147

148

149

150
TK 1981-1982, 16800 , nr. 6, p. 18; TK. 1983-1984, 16800 , nr. 9, p. 54.

TK 1983-1984, 16800 , nr. 9, p. 83.

TK 1983-1984, 16800 , nr. 9, p. 53.

EK 3 december 1985 , p. 238.

EK 3 december 1985 , p. 238.

TK 1980-1981, 16800 , A, p. 23-24; TK 1980-1981, 16800 , nr. 3, p. 22.

TK 1983-1984, 16800 , nr. 9, p. 54.

TK 1981-1982, 16800 , nr. 6, p. 43. Zie in algemene zin over de "schuldkwadratuur" hoofdstuk 3 paragraaf 7.4.6. 


\subsubsection{Het subjectief element bij artikel $2 \mathrm{Wms}$ als overtreding}

Artikel 2 Wms bevat subjectieve bestanddelen, die overigens afwijken van de in het strafrecht gebruikelijke redactie; te weten het vereisen van "opzet" of "schuld". ${ }^{151}$ In artikel 2 Wms is de schuldvorm geformuleerd als "weet of redelijkerwijs had kunnen vermotden" en "redelijkerwijs van hem kunnen worden gevergd". Deze subjectieve bestanddelen zijn bij de overtreding-variant niet van toepassing op alle bestanddelen van dedelictsomschrijving, maar zien slechts op enkele bestanddelen. Voor de overige bestanidelen geldt dat culpa daar een element is.

Boventaande heeft tot gevolg dat voor artikel $2 \mathrm{Wms}$ geldt dat bij "leder die beroephalve een stof of een preparaat vervaardigt, aan een ander ter beschikking stelt, in Nederland invoert of toepast" culpa een element is. Het deel dat daarop volgt: "en die wett of redelijkerwijs had kunnen vermoeden dat door zijn handelingen met die stof of dat preparaat gevaren kunnen optreden voor mens en milieu" wordt beheerst door di subjectieve bestanddelen die door het verbindingswoord "of" als altematieven zijn geormuleerd. Het deel dat daarop volgt, "is verplicht alle maatregelen te nemen die recelijkerwijs van hem kunnen worden gevergd, teneinde die gevaren zoveel mogelịk te beperken" wordt eveneens beheerst door (in dit geval) één subjectief bestancdeel.

De subjectieve bestanddelen in het eerste deel van de delictsomschrijving dienen door het verbindingswoord "of" te worden geïnterpreteerd als alternatieven. Hierdoor bevat de overtreding-variant zowel een culpose als een opzettelijke vorm. Overigens geldt dat culpa als element nog steeds een rol kan spelen voor de delen van de delictsomschrijving die worden beheerst door het culpose subjectieve bestanddeel. Schuld als element heeft namelijk een groter betekenisbereik dan de in artikel $2 \mathrm{Wms}$ opgenomen subjectieve bestanddelen. Indien ten aanzien van een verdachte het betreffende culpose bestanddeel kan worden bewezen verklaard, zijn er situaties mogelijk waarin toch geen sprake is van schuld (als element) voor het deel van de delictsomschrijving dat door het specifieke culpose bestanddeel wordt beheerst. De verdachte zal dan (ex artikel 352 , tweede lid Sv) moeten worden ontslagen van alle rechtsvervolging.

\subsubsection{Het subjectief element bij artikel $2 \mathrm{Wms}$ als misdrijf}

Artikel $2 \mathrm{Wms}$ is via artikel 1a sub 1 Wed aangehaakt aan de Wed. Involge artikel 2, eerste lid Wed is er bij deze bepaling sprake van een misdrijf indien de normschending opzettelijk is begaan en is er in de overige gevallen sprake van een overtreding. Daar artikel 2 Wms zelf ook subjectieve bestanddelen bevat, is er bij de misdrijf-variant sprake van een "schuldkwadratuur". ${ }^{152}$ Gezien de in hoofdstuk 3 paragraaf 6.4.6. beschreven oplossingen geldt voor de misdrijf-variant van deze zorgplichtbepalingen dat zij op een aantal manieren kunnen worden geïnterpreteerd. ${ }^{153}$ In hoofdstuk 3 zijn 
twee interpretatiemogelijkheden uitgewerkt; te weten de interpretatiemethode die aansluit bij de opbouw en samenstelling van strafbaarstellingen en de methode waarbij de opzet-eis uit de Wed niet van toepassing wordt geacht op de subjectieve bestanddelen en de bestanddelen waar deze betrekking op hebben. De praktische consequenties die het volgen van één van deze twee interpretatiemogelijkheden tot gevolg hebben zal hier worden uitgewerkt. De opzet-eis die voor misdrijven involge artikel 2 Wed geldt wordt bij deze uitwerking steeds tussen aanhalingstekens ingeschreven in de delictsomschrijving van artikel 2 Wms. Voorts wordt zij, evenals de subjectieve bestanddelen uit artikel $2 \mathrm{Wms}$ die blijven gelden, cursief weergegeven teneinde de verschillen duidelijker te laten zien. In hoofdstuk 9 paragraaf 4 en in hoofdstuk 10 paragrafen 4.3.3. en 4.3.4. zal worden ingegaan op de resultaten van deze uitwerking en op de uitwerkingen van artikel $13 \mathrm{Wbb}$ en 10.3 , eerste en tweede lid $\mathrm{Wm}$.

Artikel 2 Wms luidt bij het alternatief waarin "weet" bestanddeel is van de delictsomschrijving zowel bij de eerste als bij de tweede interpretatie: "Ieder die 'opzettelijk' beroepshalve een stof of een preparaat vervaardigt, aan een ander ter beschikking stelt, in Nederland invoert of toepast, en die weet dat door zijn handelingen met die stof of dat preparaat gevaren kunnen optreden voor mens en milieu, is verplicht alle maatregelen te nemen die redelijkerwijs van hem kunnen worden gevergd, teneinde die gevaren zoveel mogelijk te beperken."

Het alternatief waarbij de culpose bestanddelen deel uitmaken van artikel $2 \mathrm{Wms}$ is in de eerste interpretatie niet mogelijk. Indien de tweede interpretatie wordt gevolgd luidt dit artikel: 'Ieder die 'opzettelijk' beroepshalve een stof of een preparaat vervaardigt, aan een ander ter beschikking stelt, in Nederland invoert of toepast, en die redelijkerwijs had kunnen vermoeden dat door zijn handelingen met die stof of dat preparaat gevaren kunnen optreden voor mens en milieu, is verplicht alle maatregelen te nemen die redelijkerwijs van hem kunnen worden gevergd, teneinde die gevaren zoveel mogelijk te beperken."

\subsection{Wet bodembescherming}

\subsubsection{Inleiding}

De eind jaren zestig tot stand gekomen sectorale en soortgerichte wetgeving voor delen van het leefmilieu, leidde tot de gedachte dat er ook een wet zou moeten komen voor de voorkoming en beperking van bodemverontreinigingen en de beperking van het ontstaan en de verwijdering van afvalstoffen. Dit resulteerde in 1971 in een voorontwerp van de wet inzake de bodemverontreiniging, dat een afzonderlijk wettelijk kader voor afvalstoffen bevatte. ${ }^{154}$ De koppeling tussen bodernbescherming (sectoraal) en afvalstoffen (soortgericht) werd mede op basis van uitgebrachte 
adviezen verlaten, waarna de soortgerichte Wet chemische afvalstoffen ${ }^{155}$ en de Afvalsoffenwet ${ }^{156}$ tot stand kwamen. ${ }^{\text {B? }}$

Een wet op het gebied van bodembescherming liet op zich wachten. In 1976 werd in de Tweede Kamer een motie aanvaard waarin werd gepleit voor een algemene wet ter toetsing van alle bodemverontreinigende handelingen. ${ }^{158}$ Men wilde een wettelijke regeling specifiek. gericht op de bescherming van de bodem en het grondwater als bestanddeel van de bodem, waardoor mogelijk nadelige beünvloeding kan worden voorkomen of beperkt. ${ }^{159}$ Er was, zeker na de affaire Lekkerkerk waar, voor het eerst in Nederland, verontreinigde grond onder woningen werd aangetroffen, sprake van een toenemend inzicht in bepaalde risico's voor de bodemkwaliteit. Het besef groeide dat handelngen op en in de bodem, mede door het gebruik van sommige stoffen en de toename van dergelijke handelingen, steeds meer het karakter kregen van vrij ver gaande ingrepen. Het aspect van de onomkeerbaarheid van de meeste vormen van nadelige beïnvloeding van de bodem was aanleiding om te komen tot een sterk preventief beleid. ${ }^{160}$ Dit werd ingegeven doordat verontreinigingen en aantastingen vanwege de kosten of de beperkte technische mogelijkheden vaak niet ongedaan konden worden gemaakt, terwijl uit veiligheidsoverwegingen of vanwege esthetische redener steeds meer zaken in de bodem werden gebracht. ${ }^{16}$ Dit werd versterkt doordat de weg voor emissies in de lucht en het oppervlaktewater in toenemende mate werd verspert door stringentere milieuvoorschriften. ${ }^{162}$ Een regeling van de bodembescherming liep op dat moment ongeveer 15 jaar achter op de inwerkingtreding van

155 Wet Chemische afvalstoffen uit 1976.

156 Afvalstoffenwet uit 1977, zie hierover hoofḍstuk 9 paragraaf 3.4.2.

157 Zie Hartog, R.J. den, Hofland, J. en Meynen, P.F., Handleiding Milieuwetgeving, "8 Bodem", 8.2., pp. 1-2; Meijenfeldt, H.G. von en Wildeboer, L.J. (red.), Wet bodembescherming, "Toelichting (B-1)", pp. 1-2.

158 Motie van het lid De Boois c.s., 17 november 1976, TK 1976-1977, 14 100, XVII, nr. 13.

159 In 1976 wordt in de Nota milieuhygiènische normen $T K$ 1976-1977, 14 3i8, nrs. i-2 geconstateerd dat de wetgeving op milieuhygiëne lacunes vertoont op het punt van normstelling. De procedurele en organisatorische aspecten, met betrekking tot de Wbb zullen worden geregeld in de Wabm, de inhoudelijke aspecten zulien hun regeing moeten vinden in de verschillende bijzondere wetten, waarbij de: Wbb de wettelijke grondslag biedt voor het stellen van normen gericht op het milieucomponent bodem. Zie ook TK 1980-1981, 16529 , nrs. A-C, p. 29.

160 TK 1980-1981, 16 529, nrs. 3-4, p. 2.

161 In de Rijksbegroting van het departement van Volksgezondheid en Milieuhygiëne, $T K$ 1976-1977, 14 100, XVII, nr. 2, pp. 93-94, wordt opgemerkt: "De noodzaak regels te stellen ter bescherming van de bodem neemt toe naarmate er een meer intensief gebruik wordt gemaakt van de bodem", "Men beschouwt de bodem dan te zeer als gebruiksgoed en te weinig als milieucomponent. Met dat laatste wordt bedoeld de bodem als kwetsbaar en complex systeem dat veel capaciteiten in zich bergt en dat vooral door allerlei uitwisselingsprocessen ten nauwste is verbonden met de andere milieucomponenten water en lucht en met de meeste organismen." Zie ook TK 1980-1981, 16 529, nrs. A-C, p. 22.

162 TK 1980-1981, 16529 , nrs. A-C, p. 13. 
de wetten die het water en de lucht beogen te beschermen. ${ }^{163}$ Voorts werd de noodzaak om te komen tot een wet ingegeven door Europese ${ }^{164}$ en internationale ${ }^{165}$ ontwikkelingen, aangezien ook daar in toenemende mate aandacht werd gegeven aan de bescherming van de bodem. ${ }^{166}$ Diverse reeds bestaande wetten hadden wel raakvlakken met de bescherming van de bodem, maar er was geen wet die zich daar specifiek op richtte ${ }^{167}$, zodat het wenselijk werd geacht naast de wetgeving inzake water en lucht ook te kornen tot een wet ter bescherming van de bodem. ${ }^{16}$

Gezien de dringende behoefte aan een regeling om gevallen van (dreigende) bodemverontreiniging te kunneln aanpakken kwam de Interimwet bodemsanering tot stand (hoofdstuk 9 paragraaf 3.3.2.), die vooruitliep op de Wet bodembescherming 1986 (hoofdstuk 9 paragraaf 3.3.3.), waarin een zorgplichtbepaling was opgenomen (hoofdstuk 9 paragraaf 3.3.4.). De Wet bodembescherming werd uitgebreid met (delen van) de Interimwet bodemsanering (hoofdstuk 9 paragraaf 3.3.5.), waarbij de zorgplichtbepaling, werd aangepast (hoofdstuk 9 paragraaf 3.3.6.). Deze zorgplichtbepaling wordt nader beschouwd (hoofdstuk 9 paragrafen 3.3.7., 3.3.8. en 3.3.9.).

\subsubsection{De Interimwet bodemsanering}

Ten gevolge van de ontdekking van de bodemverontreiniging in Lekkerkerk in 1980, werd door de provincies op verzoek van het ministerie van Volksgezondheid en Milieuhygiếne een inventarisatie uitgevoerd van plaatsen waarvan het bekend was of het vermoeden bestond dat er afvalstoffen waren gestort. Vanwege de omvang van de problematiek werd besloten een wettelijke regeling te maken om aan het onderzoek en do sanering vorm te geven. Op dat moment was de Wbb, die een saneringsregeling bevatte, in behandeling bij de Tweede Kamer. Deze regeling werd te beperkt en te

163 De vertraging is mogelijk het gevolg van de totstandkoming van de Interimwet bodemsanering, zie $T K 1983-1984$, nr. 7., p. 3 en $T K 1984-1985$, 16529 , nr. 10, p. 2; van de beperkte wetgevingscapaciteit in kwantitatieve zin, de onderschatting van het risico van aantasting van de bodem, de weerstand vanuit de agrarische hoek en een competentiestrijd tussen de verschillende ministeries, zie TK 19 maart 1985 , p. 4128. Intussen is er, mede ten gevolge van Lekkerkerk en andere plaatsen met ernstige verontreinigingen en de daarbij horende imposante opruimingskosten, een hoge maatschappelijke druk gekomen om te komen tot een goede bescherming van bodem en grondwater, zie $T K 19$ maart 1985, p. 4128 en $T K$ 1981, 16529 , nr. 6, p. 1.

164 Richtlijnen van de Raad der Europese Gemeenschappen ter bescherming van de bodem en grondwater $P b E G$ nr. L 129/23 van 18-05-1976 en PbEG nr. L. 20/43 van 26-01-1980 in het kader van het actieprogramma van de Europese gemeenschappen inzake het milieu PbEG nr. C 1127 van 20-12-1973. Zie TK 1980-1981, 16 529, nrs. A-C, p. 13.

165 Bijvoorbeeld artikel 7, lid 2 van de Rijnchemie-overeenkomst $\operatorname{Tr} b$. 1977, 32; de aanbevelingen van de Raad van Europa zoals deze in 1973 zijn vastgelegd in het Europese Handvest voor de Bodem.

166 In een aantal landen zijn reeds wetten tot stand gebracht welke min of meer specifiek op bescherming van het voorkomen en tegengaan van bodemverontreiniging dan wel op bescherming zijn gericht. TK 1980-1981, 16529 , nrs. A-C, pp. 13-14.

167 TK $1980-1981,16529$, nrs. 3-4, p. 3.

$168 T$ TK 1980-1981, 16529 , nrs. A-C, pp. 14-15. 
weinig dwingend bevonden om de meest ernstige gevallen van (dreigende) bodemrerontreiniging te kunnen aanpakken. Daamaast was de verwachting dat deze regeling niet op korte termijn operationeel zou kunnen zijn. Op 22 mei 1981 werd bij de Tweede Kamer het ontwerp van de Interimwet bodemsanering ingediend. ${ }^{169}$ In 1983 tnd hij in werking, waarbij het onderzoek en de sanering uit de voorafgaande twee jarr onder de werkingssfeer van de wet werden gebracht. Vooruitlopend op de inwerkingtreding van de Wbb werd nu een interim-beleid gevoerd ${ }^{170}$ dat beoogde concreet inhoud te geven aan een preventief bodembeschermingsbeleid. ${ }^{171}$ Het was de bedoeling dat de Interimwet bodemsanering op 1 januari 1989 zou vervallen ${ }^{172}$, maar het bletk noodzakelijk hem twee maal met een jaar te verlengen ${ }^{173}$, waarna werd besloten dat hij zou vervallen op het moment dat hij zou zijn geïncorporeerd in de Wet bodemtescherming. ${ }^{174}$

\subsubsection{Wet bodembescherming 1986}

Tevens werd verder gewerkt aan een Wet bodembescherming, die een effectieve bescherning van de bodem en het zich daarin bevindende grondwater diende te verwezenlijken. Daartoe richtte hij zich vooral op de bedreigingen die uitgaan van allerlei handelingen waarbij stoffen betrokken zijn die de bodem kunnen verontreiniger of aantasten, alsmede op handelingen die de fysische eigenschappen van de bodem nadelig beïnvloeden. Om deze gevaren te verminderen en de reeds aantoonbare verontreiniging of aantasting van de bodem een halt toe te roepen, werd in het wetsvoorstel een "gedifferentieerd stelsel van regels" opgenomen. ${ }^{175}$

Het ontwerp werd opgezet als een raamwet, waardoor de wet een aantal kembegrippen bevat die ingevuld en uitgewerkt dienden te worden in nadere regelgeving. Hierbij speelde een belangrijke rol dat de opbouw van de kennis omtrent de gevolgen van allerlei activiteiten op de kwaliteit van de bodem geen gelijke tred hield met de expansie van deze activiteiten. Voorts zouden nieuwe ontwikkelingen moeilijk voorzienbaar zijn, zodat werd gekozen voor een flexibel instrumentarium. ${ }^{176}$

169 Zie over dit voorstel de (Voorlopige) Centrale raad voor de milieuhygiěne, "Commertaar van 08-04-198!", Reeks Verslagen, Adviezen en Rapporten van het Ministerie van Volksgezondheid en Milieuhygiëne 1981, 's-Gravenhage, Staatsuitgeverij, nr. 28 en de Raad van advies voor de ruimtelijke ordening, "Advies van 25-06-1981".

Zie over het interimbeleid bodembescherming: het Voorlopig Indicatief Meerjarenprogramma Bodem 1984-1988, TK 1982-1983, 17 600, hoofdstuk XI, nr. 130; Luigies, H.H., "Bodemsanering in Nederland", pp. 49-58. TK 1983-1984, 16529 , nr. 7, p. 3.

Dat blijkt uit de citeertitel en artikel 41, zie TK 1989-1990, 21 556, B, p. 7.

TK 1989-1990, 21 556, nr. 4, p. 1.

174 Zie ook Meijenfeldt, H.G. von en Wildeboer, L.J. (red.), Wet bodembescherming, "Toelichting (B-1)", p. 5.

$175 T K 1980-1981,16529$, nrs. A-C, p. 23.

176 TK 1983-1984, 16529 , nr. 7, pp. 12-13; TK 1980-1981, 16 529, nrs. A-C, pp. 24, $27,56$. 
Het wetsontwerp onderscheidde een zestal categorieën van activiteiten ten opzichte van de bodem, waarbij sprake kan zijn van aantasting of verontreiniging. Zij zijn terug te vinden in de artikelen 8 tot en met 13, en bepaalden primair de omvang van de bij de Wbb voorgestelde raamwetgeving. ${ }^{177}$ Deze zes categorieën zijn: handelingen waarbij stoffen op of in de bodem worden gebracht om ze daar te laten; handelingen waarbij stoffen aan de bodem worden toegevoegd met het doel de structuur of de kwaliteit van de bodem te beïnvloeden; het uitvoeren van werken op of in de bodem waarbij mechanische ingrepen worden verricht of stoffen worden toegepast die de bodem kunnen verontreinigen of aantasten; handelingen waarbij stoffen op of in de bodem worden getransporteerd; handelingen waarbij als nevengevolg stoffen de bodem kunnen verontreinigen of aantasten, op of in de bodem geraken; handelingen die erosie, verdichting of verzilting van de bodem tot gevolg kunnen hebben. ${ }^{178} \mathrm{De}$ artikelen gaven de overheid de mogelijkheid zo nodig regels te stellen met betrekking tot die in het maatschappelijk verkeer voorkomende handelingen die op enigerlei wijze de bodem zodanig kunnen verontreinigen of aantasten, dat gevaar bestaat voor de vele functies en gebruiksmogelijkheden van de bodem. ${ }^{179}$

\subsubsection{Artikel $14 \mathrm{Wbb} 1986$}

In het wetsvoorstel was alanvankelijk geen zorgplichtbepaling opgenomen. In de Tweede Kamer werd opgemerkt dat de wet zelf een indicatie zou moeten geven over de inhoud van de beoogde op grond van de artikelen 8 tot en met. 13 te stellen regels, door een algemene normstelling op te nemen die zou worden uitgewerkt bij algemene maatregel van bestuur. Gesteld werd dat daartoe in elk geval een algemeen verbod te handelen "in strijd met het bodembeschermingsbelang" in de wet zou kunnen worden opgenomen, dat een grondslag zou bieden tot optreden, ook als er (nog) geen van toepassing zijnd uitvoeringsbesluit is op basis van de artikelen 8 tot en met $13 .{ }^{180} \mathrm{De}$ minister onderschreef de aan dit voorstel ten grondslag liggende gedachte om eventueel te kunnen optreden voordat de uitvoeringsbesluiten van kracht zijn. Het kamervoorstel kwam volgens hem enigszins overeen met hetgeen in artikel $2 \mathrm{Wms}^{181}$ is opgenomen. Hij gaf aan dat het voorstel zal worden meegenomen in het onderzoek naar de mogelijkheden van het privaatrecht ten behoeve van een preventief bodembeschermingsbeleid. ${ }^{182}$ Op basis van dit onderzoek werd gesignaleerd dat enkele bedreigende activiteiten niet afdoende met het bestaande of in voorbereiding zijnde instrumentarium kunnen worden gereguleerd. ${ }^{183}$ Het bevatte een vijftal

177

178

179

180

181

182

treden om ernstige schade te voorkomen.

183 Zie over de uitkomsten van dit onderzoek $T K$ 1984-1985, 16 529, nr. 10, pp. 26-27, TK 21 maart 1985, p. 4225. 
aanbelingen; de derde hield in dat in de Wbb een privaatrechtelijk handhaafbare zorgpht moest worden opgenomen, waarbij het handelen in strijd met deze plicht een hdelen in strijd met een wettelijk voorschrift oplevert, zodat onrechtmatigheid uit di hoofde kan worden aangenomen. De minister gaf aan dat het opnemen van een dselijke zorgplicht niet alleen betrekking moest hebben op de bodem, maar ook zou neten gelden voor de overige milieucompartimenten. Hij zei dat het daarom in de redigt dat het eventueel opnemen van zo'n bepaling in de milieuwetgeving aan de orkomt bij de verdere uitbouw van de Wabm. Vooruitlopend daarop zag hij af van hopnemen van een dergelijke bepaling in de Wbb. ${ }^{184}$

Tijderde behandeling van het wetsvoorstel drong Lansink aan op een zo spoedig mogeke invoering van de $\mathrm{Wbb}$, met mogelijkheden tot preventief beleid naast de saneri uit de Interimwet bodemsanering. In dit kader stelde hij: ${ }^{185}$ "Tot het onmogelijke inatuurlijk niemand gehouden maar het rentmeesterschap verplicht wel tot een zorgvilig beheer van de Schepping, die ons slechts in bruikleen is gegeven." Hij merktop dat uitstel van de discussie over dit punt tot de behandeling van de herzieng van de Wabm onnodig is, gelet op het karakter van de Wbb. Het leek hem ${ }^{18}$ verstandig, nu al een zorgplicht vast te leggen, in aansluiting uiteraard op de artikei 8 tot en met 13." Daartoe diende hij een amendement in met de strekking dat na artil 13 een nieuw artikel 13a zou moeten worden ingevoerd, luidende ${ }^{187}$ :

"leder die op of in de bodem handelingen verricht als bedoeld in de artikelen 8-13 en die weet of redelijkerwijs had kunnen vermoeden dat door die handelingen de bodem kan worden verontreinigd of aangetast, is verplicht alle maatregelen te nemen die redelijkerwijs van hem kunnen worden gevergd, teneinde die verontreiniging of aantasting te voorkomen, dan wel indien die verontreiniging of aantasting zich voordoet, deze zoveel mogelijk te beperken en de gevolgen daarvan zoveel mogelijk ongedaan te maken.

II In artikel 75 wordt na $<<$ de artikelen 8-13, $>$ ingevoegd: 13a.

\section{Toelichting}

Deze amendementen beogen een algemene zorgplicht in de wet vast te leggen."

Bij de behandeling van het wetsvoorstel werden in de Kamer vraagiekens geplaatst bij de argumentatie van de minister om af te zien van een algemene zorgplicht voor de bodem. Onduidelijk was of een zorgplichtbepaling in de Wabm zou worden opgenomen, terwijl zijn redenering ook weinig consequent werd geacht, juist omdat artikel

TK 1984-1985, 16529 , nr. 10, pp. 3-4.

TK 13 maart 1985, p. 4026; ook bij het begrip rentmeesterschap van het CDA staat niet de aarde, maar in de eerste plaats het belang van de rentmeester voorop, zie over dit begrip, Tuin, L.J.M. van der, Catechese en diaconie; Een empirisch theologisch onderzoek naar de effecten van milieucatechese op milieubewust handelen. TK 13 maart 1985, p. 4027.

187 Het amendement werd ontvangen op 13 maart 1985, TK 1984-1985, 16 529, nr. 20. De tekst van 13a is hetzelfde als die van artikel 14 Wbb van 3 juli 1986, Stb. 1986, 374. 
2 Wms wel een dergelijke bepaling bevat. ${ }^{188}$ Ook werd vermeld dat uiteindelijk iedereen een zogenaamde zorgplicht voor het milieu en dus ook voor de bodem heeft, aangezien het gaat "om het verantwoordt en verantwoordelijk omgaan met Gods schepping", hetgeen moest doordringen tot een ieder. ${ }^{189}$ Wel werd de kanttekening geplaatst dat het probleem met het verantwoordelijk stellen van vervuilers voor hun daden hiermee niet geheel is opgelost aangezien verdwenen bedrijven verdwenen blijven en de bewijsbaarheid van de relatie tussen oorzaak en gevolg een probleem blijft. ${ }^{190}$

De minister's reactie was dat het meer in de rede ligt bij de uitbrouw van de Wabm met de zorgplicht te komen, aangezien het opnemen van de zorgplicht in de Wbb kan suggereren dat zo'n zorgplicht specifiek voor de bodem geldt omdat hij op vele andere plaatsen niet bestaat, terwijl Lansink naar hij aannam bedoelde dat zo'n zorgplicht ook voor andere milieucompartimenten waarde zou hebben. Hij vond dat het bij de Wms anders ligt aangezien het daar gaat on een integrale aanpak van het milieueffect van stoffen op bijvoorbeeld water, bodem, luchten organismen, en derhalve niet op een milieucompartiment, waardoor de zorgplicht daarin een andere plaats heeft. Hij gaf aan te willen voorkomen "dat het idee ontstaat, dat er voor de bodem een zorgplicht bestaat en dat we het voor de rest laten waaien." Hij liet het oordeel over aan de Kamer. ${ }^{191}$

Lansink reageerde door te stellen dat het duidelijk zal zijn dat hij niet zegt dat die zorgplicht niet op die andere plaatsen van toepassing zou moeten zijn, maar dat momenteel deze wet wordt behandeld en dat die een meer integraal karakter moet krijgen waardoor hij de zorgplicht hierin wil vastleggen. ${ }^{192}$ Aangezien de minister geen bezwaar zei te hebben tegen een algemene zorgplicht leek het hem verstandig de bepaling op te nemen en op deze manier een goede invulling te geven van het begrip rentmeesterschap. ${ }^{193}$ In de Kamer bleken de meeste fracties het opnemen varı de zorgplichtbepaling te steunen. ${ }^{194}$

188 TK 13 maart 1985, p. 4041.

189 TK 19 maart 1985, p. 4136.

190 TK 19 maart 1985, p. 4138.

191 TK 21 maart 1985, p. 4222; zie ook de brief vars Winsemius aan de voorzitter van de vaste Commissie voor Milieuhygiëne, waarin een overzicht staat van de amendementen, met bij elk. amendement een door hem gegeven kwalificatie. Amendernent nummer 20, betreffende artikel 13a laat hij aan het oordeel van de kamer over: TK. 1984-1985, 16 529 , nr. 62 , pp. 1-2.

192 TK 21 maart 1985, p. 4222.

193 TK 21 maart 1985, p. 4238.

194 Zie de opmerkingen van: Lansink TK 21 maart 1985, p. 4245; De Boois TK 21 maart 1985, p. 4248; Lankhorst TK. 21 maart 1985, p. 4248; Van der. Vlies TK 21 maart 1985, p. 4258; Tommel TK 21 maart 1985, p. 4255; Willems. TK 21 maart 1985, p. 4262 ent Emsting TK 21 maart 1985, p. 4263. 
Wel werd de vraag gesteld wat, indien het amendement-Lansink zou worden aangenomen, precies de gevolgen voor de sanctiemaatregelen zouden zijn. ${ }^{195}$ De minister antwoordde: ${ }^{196}$

"In het algemeen heeft een zorgplicht meer het karakter van een intentieverklaring; die kan wel verder gaan en in ernstige gevallen kan het iets toevoegen aan de strafrechtelijke mogelijkheden. (...) Toch moet men hiermee voorzichtig zijn in die zin dat wij niet te hoge verwachtingen moeten hebben van zo'n zorgplicht. De omschrijving van het delict maakt namelijk de bepaling van de wijze van overtreding niet eenvoudig. Het zal praktisch alleen kunnen worden gebruikt voor heel duidelijke gevallen, maar daarop slaat vaak al een andere strafbepaling. Mogelijkerwijs zal het dus een vangnetfunctie vervullen bij zeer ernstige gevallen, maar dit zal een klein aantal zeer moeilijke gevallen betreffen."

Ook werd de vraag gesteld hoe het zit met de opneming van de zorgplicht in de Wabm. ${ }^{197}$ De minister antwoordde dat in het volgende IMP-milieubeheer zal worden getracht een beeld te geven van de uitbouw van de Wabm, maar dat hij het op dat moment nog niet geheel kon overzien. ${ }^{198}$ De reactie van Lansink daarop was dat het verstandig is dat hij nu een amendement heeft ingediend. Het was zijn bedoeling ${ }^{199}$ "meer dan zomaar een filosofisch begrip in de wet vast te leggen. Daardoor krijgen sancties ook een wat dwingender karakter. (...) Tegenover het recht op het gebruik van de bodem staat immers de plicht, er zorgvuldig mee om te gaan." Tijdens de stemmingen in verband met de $\mathrm{Wbb}$ werd het amendement met algemene stemmen aangenomen ${ }^{200}$, waardoor het in het nieuwe voorstel van wet was te vinden in artikel $14 \mathrm{Wbb}^{201}$

Aanvankelijk was afgezien van het aanhaken van de strafbaarstellingen uit de Wbb aan de Wed ${ }^{202}$, omdat de uitslag van de discussie met betrekking tot de strafsancties in de milieuwetgeving werd afgewacht. ${ }^{203}$ Tijdens de behandeling in de Kamer werd aangedrongen op deze aanhaking ${ }^{204}$, en ook de minister nam het standpunt in dat de milieuwetgeving onder de werkingssfeer van de Wed diende te worden gebracht. ${ }^{205}$ Dit leidde tot een nadere standpuntbepaling over de plaats en de inhoud van de strafbepalingen in het wetsvoorstel, waarna werd besloten de Wbb onder de werkingssfeer

195
TK 21 maart 1985, p. 4262.

TK 26 maart 1985, p. 4285.

TK 26 maart 1985, p. 4262.

TK 26 maart 1985, p. 4285.

TK 26 maart 1985, p. 4285.

TK 11 juni 1985, p. 5553.

TK 1984-1985, 16529 , nr. 68, p. 4.

Zie de artikelen 75 tot en met 77 'Wbb, TK. 1980-1981, 16 529, nrs. A-C, p. 10; TK 19801981,16529 , nrs. 1-2, p. 20.

TK 1980-1981, 16529 , nrs. A-C, p. 44.

Zo merken de leden van de CDA, PvdA en D'66-fractie op het vreemd te vinden dat er niet is gekozen voor aansluiting bij de Wed, zie. TK. 1981, 16529 , nr. 6, p. 38.

Zie bijvoorbeeld de brief van de minister aan de Tweede Kamer d.d. 16 juli 1982 over de Uniser-affaire waarin hij bevestigt dat de Wbb onder de werking van de Wed zal worden gebracht. 
van de Wed te brengen. ${ }^{206}$ Artikel 14 Wbb werd evenals de artikelen 8 tot en met 13 Wbb, involge artikel 77 Wbb opgenomen in artikel 1 sub 3 Wed. Artikel 78 Wbb kwam te luiden ${ }^{207}$ :

"Een gedraging in strijd met enige bij of krachtens deze wet vastgestelde bepaling, waarop involge artikel 1 , onder $3^{\circ}$, van de Wet op de economische delicten straf is bedreigd, is een overtreding; indien de dader echter weet of emstige reden heeft om te vermoeden dat door zijn handelen aanmerkelijk gevaar ontstaat voor verontreiniging of aantasting van de bodem, is een zodanige gedraging een misdrijf."

De gewijzigde Wbb werd aangenomen ${ }^{208}$, waama het met artikel 14 en zijn strafbaarstelling ex artikel 77 en 78 in 1986 werd ingevoerd. ${ }^{2051}$

\subsubsection{Uitbreiding van de Wet bodembescherming met de Interimwet} bodemsanering

Begin jaren tachtig was de bodemsaneringsoperatie op gang gekomen, die de eerste jaren werd gekenmerkt door het voeren van een interimbeleid. De tweede helft van de jaren tachtig stond in het teken van een algemeen streven naar meer decentralisatie van taken en bevoegdheden van rijksniveau naar dat van lagere overheden en een vermindering van de omvang van het rijksambtenarenapparaat met name op het onderhavige beleidsterrein. Daarbij trad er een bestuurlijke accentverschuiving op, waardoor meer aandacht werd besteed aan preventie en aan de intensivering van het beginsel "de vervuiler betaalt" ${ }^{210}$

De Interimwet bodemsanering was een tijdelijke wet. Een uiteindelijke regeling diende gestalte te krijgen in de Wbb, waardooi een evaluatie gewenst was zodat bij het incorporeren de opgedane ervaringen zouden kunnen worden meegenomen. ${ }^{211}$ Aangezien de noodzakelijke algehele heroverweging van de saneringsregeling vermoedelijk aanleiding zou geven tot een vertraging van de totstandkoming van de $\mathrm{Wbb}$, werd besloten dat het incorporeren van de Interimwet zou plaatsvinden door middel van een apart wetsontwerp. ${ }^{212} \mathrm{Bij}$ het naderend einde van de Interimwet bodemsanering werden een aantal wijzigingen aangebracht in het systeem. ${ }^{213}$ De vertraging van de totstandkoming van de geïntegreerde Wbb had diverse corzaken, zoals de tijdsduur voor ontvangst van de diverse externe adviesorganen, de kabinetswisseling, de afstem-

206 TK 1983-1984, 16529, nr. 7, p. 48.

207 TK 1984-1985, 16529 , nr. 68, p. 22.

$208 T K 25$ juni 1985, p. 6023; EK 1 juli 1986, p. 1389. In de Eerste Kamer komt de zorgplichtbepaling niet voor in de schriftelijke stukken (EK 1985-1986, 16 529, nr. 61$61 \mathrm{~g}$ ) terwijl er ook bij de behandeling niet verder op wordt ingegaan (EK I juli 1986, pp 1369-1389).

209 Wet van 3 juli 1986, Stb. 1986, 374.

210 TK 1989-1990, 21556, nr. 3, p. 1.

211 TK 1983-1984, 16529 , nr. 7, p. 6 zie ook p. 31.

212 TK 1984-1985, 16529 , nr. 10, p. 24.

213 TK 1989-1990, 21 556, A, p. 1. 
ming met het kabinetsstandpunt inzake het Tien jaren-scenario bodemsanering en de interimrapportage van de Commissie bodemsanering in gebruik. zijnde bedrijfsterreinen. ${ }^{214}$ De nieuwe wet werd in fasen ingevoerd ${ }^{215}$, waarbij opvalt dat de derde fase nog steeds niet is voltooid. ${ }^{216}$

De Wbb bevat een aantal financiële en juridische instrumenten die ervoor moeten zorgen dat zoveel mogelijk het ontstaan van nieuwe gevallen van bodemverontreiniging wordt voorkomen. Het was de bedoeling dat. deze met name zouden worden opgenomen in de uitvoeringsbesluiten op grond van de artikelen 8 tot en met $13 \mathrm{Wbb}$. Andere instrumenten in de Wbb waren het eisen van financiële zekerheidsstelling en de regeling bij ongewone gevallen. Van de zorgplichtbepaling uit artikel $14 \mathrm{Wbb}$ werd een preventieve werking verwacht. Daarnaast werd beoogd bodemverontreiniging te voorkomen door gebruik te maken van andere (milieu)wetten alsmede van provinciale verordeningen. Tevens werd gesteld dat van de toegenomen aandacht voor handhaving van milieuvoorschriften in het algemeen een preventieve werking zou uitgaan. ${ }^{217} \mathrm{De}$ verwachting bestond dat door de preventieve maatregelen het aantal nieuwe gevallen kleiner zou zijn dan het aantal effenisgevallen. De preventieve instrumenten zouden echter niet in alle gevallen kunnen voorkomen dat er bodemverontreiniging ontstaat. Voor het aanpakken van de verontreiniging bleef de veroorzaker verantwoordelijk. ${ }^{218}$

De Wbb bevatte drie categorieën juridische instrumenten die van belang zijn bij het door de provincie juridisch afdwingen van onderzoek en sanering door en/ of op kosten van anderen; te weten de verplichting, het bevel en de verhaalsactie. De verplichting is de rechtstreeks uit de wet dan wel uit een algernene maatregel van bestuur voortvloeiende verplichting voor daarin aangewezen betrokkenen, bijvoorbeeld de verplichting tot bodemsanering ex artikel $14 \mathrm{Wbb}$ voor degene ten gevolge van wiens handelen (als bedoeld in de artikelen 8 tot en met $13 \mathrm{Wbb}$ ) de bodem werd verontreinigd of aangetast. ${ }^{219}$

\subsubsection{Van artikel 14 naar artikel $13 \mathrm{Wbb}$}

Op basis, van artike! $14 \mathrm{Wbb}$ rustte op een jeder die handelingen verricht als bedoeld in de artikelen 8 tot en met $13 \mathrm{Wbb}$, de verplichting te voorkomen dat door zijn handelingen de bodem kan worden verontreinigd of aangetast, dan wel indien die verontreiniging of aantasting zich voordoet, deze zoveel mogelijk te beperken en de

\footnotetext{
214 TK 1991-1992, 21556 , nr. 5, p. 1.

215 De eerste is inwerking getreden op 15 juli 1994 bij Besluit van 10 mei 1994, Stb. 1994, 333, de tweede op 1 januari 1995 bij Besluit van 19 december 1994, Stb. 1994, 908.

216 Zie hierover Wilt, C.J. van der, "Functiegericht saneren is nog steeds in strijd met de wet", pp. 220-221; Wilt, C.J. van der, Sanering en hergebruik van reinigbare grond; Spanning tussen wet en beleid; Vries, F.J. de, "Actualiteiten milieuaansprakelijkheid; Een ernstig geval van stroperigheid; Hoe zevenenzeventig weken al meer dan vijf jaren duren", pp. 173-174; Drupsteen, Th.G., "Kroniek van het milieurecht", pp. 1531-1532.

217 Zie de minister TK 1989-1990, 21 556, B, p. 12

218 TK 1989-1990, 21 556, B, p. 19.

219 TK 1991-1992, 21 556, nr. 5, p. 29.
} 
directe gevolgen daarvan zoveel mogelijk ongedaan te maken. In het voorstel van de geïntegreerde Wbb werden zonder toelichting enige wijzigingen aangebracht in artikel $14 \mathrm{Wbb}$. Voorgesteld werd de zinsnede na de laatste komma te laten luiden: ${ }^{220}$ "deze en de directe gevolgen daarvan te beperken en zoveel mogelijk ongedaan te maken." Het voorstel van wet bevatte een andere wijziging. ${ }^{221}$ Voorgesteld werd in artikel 14 de zinsnede "deze zoveel mogelijk te beperken en de gevolgen daarvan zoveel mogelijk ongedaan te maken" te vervangen door: "de bodem te saneren of de aantasting en de directe gevolgen daarvan zoveel mogelijk te beperken en ongedaan te maken."

In de Wbb was artikel 22, vierde lid opgenomen, die een bijzondere regeling gaf op grond waarvan onverwijld moest worden gehandeld bij iedere vorm van verontreiniging of aantasting van de bodem ten gevolge van een ongewoon voorval. Voorgesteld werd dit artikel te laten vervallen en artikel 14 aan te vullen met de volzin, luidende: ${ }^{222}$ "Indien de verontreiniging of aantasting het gevolg is van een ongewoon voorval, worden de maatregelen onverwijld genomen". Door deze toevoeging werd expliciet tot uitdrukking gebracht dat in geval van verontreiniging of aantasting van de bodem ten gevolge van een ongewoon voorval tevens de verplichting bestaat onverwijld maatregelen te nemen. ${ }^{223}$

In het gewijzigd voorstel van wet ${ }^{224}$ werd in artikel $14 \mathrm{Wbb}$ de zinsnede "deze zoveel mogelijk te beperken en de gevolgen daarvan te beperken en zoveel mogelijk ongedaan te maken" vervangen door: "de bodem te saneren of de aantasting en de directe gevolgen daarvan zoveel mogelijk te beperken en ongedaan te maken. Indien de verontreiniging of aantasting het gevolg is van een ongewoon voorval, worden de maatregelen onverwijld genomen." Deze wijziging werd aangepast ${ }^{225}$ waardoor de zinsnede "deze zoveel mogelijk te beperken en de gevolgen daarvan zoveel mogelijk te beperken en ongedaan te maken" werd vervangen door: "de bodem te saneren of de aantasting en de directe gevolgen daarvan te beperken en zoveel mogelijk ongedaan te maken." $\mathrm{Na}$ opnieuw een wijziging luidde het laatste deel van artikel 14: "de bodem te saneren of de aantasting en de directe gevolgen daarvan te beperken en zoveel mogelijk ongedaan te maken. Indien de verontreiniging of aantasting het gevolg is van een ongewoon voorval, worden de maatregelen onverwijld genomen." 226 Deze laatste wijziging was ingegeven door het op elkaar afstemmen van artikelen die betrekking hebben op saneren.

$220 T K 1989-1990,21556$, B, p. I.

221 TK 1989-1990, 21 556, nrs. 1-2, p. 2.

$222 T$ TK 1991-1992, 21556 , nr. 6, p. I.

223 TK 1991-1992, 21 556, nr. 5, p. 18, zie ook TK 1991-1992, 21 556, nr. 6, p. 10.

$224 T$ TK 1991-1992, 21556, nr. 8, p. 2.

$225 T K$ 1991-1992, 21556 , nr. 9. Deze wijziging is opgenomen in het nader voorstel van wet d.d. 10 september 1992, TK 1991-1992, 21 556, nr. 16, p. 2 en in het tweede gewijzigd voorstel van wet d.d. 9 februari 1993, TK 1991-1992, 21 556, nr. 24, p. 2.

$226 T K 1992-1993,21$ 556, nr. 101, p. 2, zie ook TK 1992-1993, 21 556, nr. 266, p. 2.

227 Het betreft de artikelen 14, 22, vierde lid (later vervallen) en 23, eerste en derde lid, die alle spreken over het beperken en zoveel mogelijk ongedaan maken van de 
Bij de behandeling van het wetsvoorstel werd opgernerkt dat over zorgplichtbepalingen in het algemeen op dat moment discussie plaatsvond in de Commissie voor de toetsing van wetgevingsprojecten. De minister zei te verwachten dat het Kabinet daarover binnenkort een standpunt zal innemen, dat consequenties kan hebben voor artikel $14 \mathrm{Wbb} .{ }^{228}$ Dit Kabinetsstandpunt is tot op heden niet verschenen.

Tijdens het stemmen over de nieuwe Wbb werd artikel 14 aangenomen $^{229}$, luidende:

"leder die op of in de bodem handelingen verricht als bedoeld in de artikelen 8-13 en die weet of redelijkerwijs had kunnen vermoeden dat door die handelingen de bodem kan worden verontrcinigd of aangetast, is verplicht alle maatregelen te nemen die redelijkerwijs van hem kunnen worden gevergd, teneinde die verontreiniging of aantasting te voorkomen, dan wel indien cie verontreiniging of aantasting zich voordoet, de bodem te saneren of de aantasting en de directe gevolgen daarvan te beperken en zoveel mogelijk ongedaan te maken. Indien de verontreiniging of aantasting het gevolg is van een ongewoon voorval, worden de maatregelen onverwilld genomen."

Voorts werd een amendement ingediend om de Wed te wijzigen, waardoor de strafmaat verhoogd zou worden van alle krachtens de Wbb strafbaar gestelde delicten van de vierde naar de tweede categorie, met uitzondering van overtredingen van de meldingsplichten. ${ }^{230}$ Betoogd werd dat de verhoogde strafbedreiging beter aansluit bij het maatschappelijk belang dat aan bodemvervuiling moet worden gehecht en bij wat overigens in de milieuwetgeving gebruikelijk is. ${ }^{231}$ De minister merkte over de verhoging van de strafmaat op dat hij de voorkeur gaf dit op een andere manier, en wel in een gezamenlijk wetsvoorstel met de minister van justitie, te regelen, aangezien dat beter aansluit bij de totale wetgevingssystematiek ${ }^{232}$, maar hij liet de beoordeling over aan de Kamer. ${ }^{233}$ Het voorstel werd aangenomen. ${ }^{234}$ Artikel $14 \mathrm{Wbb}$ werd hierdoor aangehaakt bij artikel 1 sub 2 in plaats van sub 3 Wed, zodat niet langer de Wbb bepaalde of sprake is van een overtreding of misdrijf, maar dit afhangt van het

verontreiniging en de directe gevolgen daarvan of van dreigende verontreiniging van de bodem, zie $T K 1989-1990,21556$, nr. 3, p. 38. Over deze wijziging wordt gezegd dat zij geen inhoudelijke gevolgen zal hebben, zie TK 1989-1990, 21 556, nr. 3, p. 39.

228 TK 1989-1990, 21556, nr. 3, p. 40.

229 Zonder stemming worden onder andere onderdeel $B$ (waaronder artikel 14 valt) en het gewijzigde amendement $\mathrm{nr} .93$ evenals het ten gevolge van dit amendement gewijzigde artikel II aangenomen, zie TK 30 maart 1993, pp. 59-4209, 59-4210 en 59-4214. Na de eindstemming concludeert de Voorzitter dat het wetsontwerp in de Tweede Kamer is aangenomen, zie $T K 20$ april 1993, pp. 61-4350 en 61-4351. Zie voō de Eerste Kamer, EK 10 mei 1994, pp. 32-1733 en 32-1734.

230 Amendement Esselink en van der Vaart, TK 1992-1993, 21 556, nr. 65; en met kleine wijziging, TK 1992-1993, 21 556, nr. 93.

231 TK 1992-1993, 21556, nr. 65.

232 TK 10 maart. 1993, p. 54-3903.

233 TK 1992-1993, 21 556, n.r. 100, p. 5.

$234 T K 30$ maart 1993, p. 59-4214, en opgenomen in het voorstel van wet TK 1992-1993, 21 556, nr. 101, p. 22 en TK 1992-1993, 21 556, nr. 266, p. 2. 
criterium uit artikel 2, eerste lid Wed; heeft de schending al dan niet opzettelijk. plaatsgevonden.

Artikel $14 \mathrm{Wbb}$ werd, evenals de artikelen 8 tot en met 13 omgenummerd; artikel 14 werd artikel 13 en de artikelen 8 tot en met 13 werden 6 tot en met $11 \mathrm{Wbb}$. Tevens werd de verwijzing in artikel 13 gewijzigd. Inhoudelijk zijn er geen wijzigingen meer geweest. Wel is in 1994 bij de herziening van de Wed ${ }^{235}$ waarbij artikel la werd ingevoerd ook de $\mathrm{Wbb}$ aangehaakt bij dit nieuwe artikel. Artikel $13 \mathrm{Wbb}$ werd ingedeeld in de eerste categorie van artikel la Wed, waardoor het tot de zwaarste categorie delicten is gaan behoren. Involge artikel 2, eerste lid Wed is het een misdrijf indien het opzettelijk is begaan en in de overige gevallen een overtreding. De strafbedreiging voor de misdrijf-variant is involge artikel 6 , eerste lid sub 1 Wed een gevangenisstraf van ten hoogste zes jaren of een geldboete van de vijfde categorie ( $)$. $100.000,-)$. Indien het een overtreding betreft is dit hechtenis van ten hoogste een jaar of een geldboete van de vierde categorie (f.25.000,-).

In wezen bevat artikel $13 \mathrm{Wbb}$ meer dan één zorgplicht. Fokkens stelde dat uit de zorgplichtbepaling volgt dat wanneer iemand nagelaten zou hebben om de noodzakelijke voorzorgsmaatregelen te nemen die deze bepaling van hem vereist, maar nadat de vervuiling is opgetreden de rommel opruimt, hij niet in strijd handelt met dit artikel. ${ }^{236}$ Het initiële gebrek aan voorzorg is in dat geval immers door de justitiabele zeif achteraf rechitgezet, zodat het gevaar is geweken en het door artikei 13 Wobo beschermde rechtsgoed niet werd geschaad. In die specifieke zaak heeft de Hoge Raad zich niet over deze materie uitgesproken. Wel kwam dit probleem in een later arrest aan de orde, waar bleek dat de Hoge Raad de redenering van Fokkens niet volgt. De verdachte in deze zaak was aan het sleutelen aan zijn auto, waarbij hij een niet afgetapt motorblok verving. Tijdens deze werkzaamheden liep olie op de straat. De verdachte stelde dat hij het motorblok zou hebben afgetapt indien hij van te voren had geweten dat dit nog niet was gebeurd. De olie die wegliep heeft hij meteen opgenuimd, waardoor de verontreiniging ongedaan werd gemaakt. De Hoge Raad overwoog dat indien zich feitelijk een verontreiniging of aantasting van de bodem voordoet of heeft gedaan, de betrokkene volgens artikel $13 \mathrm{Wbb}$ verplicht is deze zoveel mogelijk te beperken of ongedaan te maken. De omstandigheid dat men aan deze laatste verplichting heeft voldaan staat een veroordeling ter zake van het niet nakomen van de eerste plicht van deze bepaling niet in de weg. Deze eerste plicht strekt ertoe dat verontreiniging of aantasting van de bodem wordt voorkomen. ${ }^{23}$

Artikel 13 Wbb bevat, blijkens deze interpretatie van de Hoge Raad, drie afzonderlijke zorgplichten. De eerste zorgplicht uit artikel 13 Wbb is: "Ieder die op of in de bodem.

Zie hoofdstuk 9 paragraaf 2.4 .

236 Zie Fokkens, Conclusie bij HR 25 januari 1994. NJ 1994, 598, met noot Corstens (Vliegbasis Volkel). In deze zaak heeft de Hoge Raad zich niet over de door Fokkens opgeworpen vraag uitgesproken.

237 De verdachte werd in deze zaak veroordeeld tot een geldboete van vijfhonderd gulden, subsidiair tien dagen hechtenis, zie HR 22 november 1994, MenR, 1995, nr. 50, met noot Hendriks (Motorblok). 
handelingen verricht als bedoeld in de artikelen 6 tot en met 11 en die weet of redelijterwijs had kunnen vermoeden dat door die handelingen de bodem kan worden veronteinigd of aangetast, is verplicht alle maatregelen te nemen die redelijkerwijs van hem kunnen worden gevergd, teneinde die verontreiniging of aantasting te voorkomen".

De tweede zorgplicht overlapt gedeeltelijk met de eerste. De woorden dan wel markeren het onderscheid tussen de twee verplichtingen die voortvloeien uit de eerste zin van artikel 13 Wbb. Deze zorgplicht luidt: "Ieder die op of in de bodem handelingen verricht als bedoeld in de artikelen 6 tot en met 11 en die weet of redelijkerwijs had kunnen vermoeden dat door die handelingen de bodem kan worden verontreinigd of aangetast, is verplicht indien die verontreiniging of aantasting zich voordoet, de bodem te saneren of de aantasting en de directe gevolgen daarvan te beperken en zoveel mogelijk ongedaan te maken."

De derde zorgplicht luidt: "Indien de verontreiniging of aantasting het gevolg is van een ongewoon voorval, worden de maatregelen onverwijld genomen." Bij deze derde zorgplicht heeft "de verontreiniging of aantasting" zich reeds voorgedaan of doet zich nog steeds voor. Het betreft de verontreiniging of aantasting uit de tweede zorgplicht. Deze tweede zorgplicht maakt als geheel deel uit van de derde zorgplicht. De matregelen die onverwijld moeten worden genomen zijn de maatregelen uit de tweede zorgplicht. Tevens betreft het dezelfde normadressaat. Deze zorgplicht luidt dan ook volledig: "Ieder die op of in de bodem handelingen verricht als bedoeld in de artikelen 6 tot en met 11 en die weet of redelijkerwijs had kunnen vermoeden dat door die handelingen de bodem kan worden verontreinigd of aangetast, is verplicht indien die verontreiniging of aantasting zich voordoet, en deze het gevolg is van een ongewoon voorval de maatregelen (de bodem te saneren of de aantasting en de directe gevolgen daarvan te beperken en zoveel mogelijk ongedaan te maken) onverwijld te nemen."

Ook deze zorgplichten kunnen nog verder worden gesplitst. Door de redactie van de strafbaarstelling ${ }^{238}$ én de aanhaking aan de Wed kunnen deze drie zorgplichten op zes manieren worden geschonden, aangezien zowel de opzettelijke als de culpose-variant afzonderlijk strafbaar zijn gesteld. ${ }^{239}$ Gezien de verschillende handelingen uit artikel 6 tot en met 11 en omdat gesproken wordt van "verontreinigd of aangetast" omvat de eerste zorgplicht 24 varianten. Bij de tweede zorgplicht is sprake van 48 varianten; ook hier wordt verwezen naar de artikelen 6 tot en met 11, er wordt opnieuw gesproken van "verontreinigd of aangetast" én er is de plicht "te saneren of de aantasting en de

238 Door de subjectieve bestanddelen "weet of redelijkerwijs had kunnen vermoeden" worden in feite twee strafbare feiten onafhankelijk van elkaar strafbaar gesteld. Het woord of geeft aan dat sprake is van alternatieven, waarbij meestal "weet" wordt gerubriceerd als de opzet-variant en "redelijkerwijs had kunnen vermoeden" als de culpose-variant. Zie hierover hoofdstuk 3 paragraaf 7.4.6. en hoofdstuk 10 paragrafen 4.3.3. en 4.3.4.

239 Hierdoor is sprake van een "schuldkwadratuur", zie hierover hoofdstuk 3 paragraaf 6.4.6. en hoofdstuk 10 paragrafen 4.3.3. en 4.3.4. 
directe gevolgen daarvan te beperken en zoveel mogelijk ongedaan te maken". Bij de derde zorgplicht kunnen evenals bij de tweede zorgplicht 48 verschillende verschijningsvormen worden onderscheiden.

Overigens speelt hier voor het bestuursrecht de vraag welk bestuursorgaan op grond van artikel $13 \mathrm{Wbb}$ het bevoegd gezag is om bestuursrechtelijk tegen de schending van deze zorgplichtbepaling op te treden. De wet heeft dit namelijk niet geregeld, zodat kan worden voorgehouden dat ten gevolge van het ontbreken van een bevoegdheidsgrondslag, mede in het licht van het bestuursrechtelijk legaliteitsbeginsel, er geen bestuursorgaan bevoegd is. Ook deze tekortkoming wordt door rechterlijke instanties gladgestreken. De Raad van State heeft bepaald dat indien het een vergunningplichtige handeling betreft dit het vergunning verlenend orgaan is ${ }^{240}$, en dat dit bij de bestursrechtelijke handhaving buiten inrichtingen niet zijnde een ongewoon voorval ex 30 Wbb op grond van artikel $18.7 \mathrm{Wm}$ de minister van VROM is. ${ }^{241}$ Door de wetgever is eind 1999 een wetsvoorstel ingediend om de bevoegdheid tot bestuurlijk optreden bij schending van deze zorgplichtbepaling te regelen. Dit voorstel is overigens niet alleen gericht op artikel $13 \mathrm{Wbb}$, maar onder andere ook op het verhelpen van soortgelijke problemen ten aanzien van artikel $1.1 \mathrm{a}$ Wm en $10.3 \mathrm{Wm}{ }^{242}$

\subsubsection{De zorgplichtbepaling nader beschouwd}

De normadiessaat van abze bepaling is een ieukr die hamulat ir strijul met étre var de drie zorgplichten waaruit artikel 13 Wbb bestaat. ${ }^{243}$

Het beschermde rechtsgoed van artikel $13 \mathrm{Wbb}$ is de bodern, waarmee gezien de begripsomschrijving uit artikel $1 \mathrm{Wbb}$ wordt bedoeld: "het vaste deel van de aarde met de zich daarin bevindende vloeibare en gasvormige bestanddelen en organismen". Het gaat hierbij om de bodem in geologische en bodemkundige zin, zodat het zowel de buitenste deklagen als de ondergrond daaronder betreft. ${ }^{2 \sqrt{4}}$ De bescherming van de bodem vindt plaats door maatregelen gericht op het voorkomen, bestrijden of ongedaan maken van een nadelige beïnvloeding van de kwaliteit van de bodem als gevolg van menselijke activiteiten, en het behoud van een gewenste kwaliteit van de

240 Zie ABR 21 juli 1998, AB 1998, 142, met noot Backes (Bevoegd gezag 13 Wbb is B.WW).

241 Zie Vz ABR 18 juni 1997, 03.97.0316 (niet gepubliceerd) (Bevoegd gezag 13 Wbb is minister).

242 Zie wetsvoorstel TK 1999-2000, 26 929, nrs. 1-2, de MvT nr. 3; het advies van de RvS onder $\mathrm{A}$ en het interessante advies van prof. Michiels in nr. 4.

243 De eerst verantwoordelijke voor het aanpakken van bodernverontreiniging is degene die haar heeft vereorzaakt, zie $T K 1989-1990,21556$, nr. 3, p. 48, artikel 27 e impliceert dat een dergelijk handelen onrechtmatig is jegens de overheid; het artikel wordt daarom toegevoegd aan de opsomming in artikel 27e, zie TK 1991-1992, 21556, nr. 6, p. 13.

$244 T K$ 1980-1981, 16529 , nrs. A-C, p. 18. 
bodem. De doelstelling van de $\mathrm{Wbb}$ is het behoud van het multifunctionele karakter van de todem. ${ }^{245}$

Artikel 13 verwijst naar handelingen als bedoeld in de artikelen 6 tot en met 11 , waardorr de verplichting van artikel 13 alleen betrekking heeft op de handelingen ${ }^{246}$ uit dezt artikelen. ${ }^{247}$ De vraag rees of het nodig is voor het constateren van een schending van artikel $13 \mathrm{Wbb}$ dat op grond van die artikelen uitvoeringsmaatregelen bestaan in de vorm van amvb's die betrekking hebben op grond van artikel $13 \mathrm{Wbb}$ ten last gelegde verontreinigende handelingen. De Hoge Raad oordeelde in de Kabelbnndenzaak dat op basis van artikel 13 de wetgever de mogelijkheid heeft geschapen om reeds in afwachting van amvb's strafrechtelijk te kunnen optreden tegen (kort gezegd) bodembedreigende handelingen ${ }^{248}$, zodat strafrechtelijke sanctionering mogelijl is als er nog geen (bestuurlijke) invulling van de zorgplicht heeft plaatsgevonden. Deze interpretatie wordt sindsdien aangehouden.

Wel mot de op basis van artikel $13 \mathrm{Wbb}$ ten laste gelegde handeling natuurlijk vallen onder éen van de in de artikelen 6 tot en met $11 \mathrm{Wbb}$ genoemde handelingen. Een verdache die onder andere ten laste was gelegd dat hij afvalstoffen (huishoudelijk afval, nugenoeg lege jerrycans van bestrijdingsmiddelen en nagenoeg lege verfblikken) op de bodem heeft aanwezig gehad, terwijl hij wist of moest vermoeden dat door die handeling de bodem kon worden aangetast werd door het Hof ontslagen van rechtsvervolging. Het Hisf achitte het ten laste gelegdie hewezan, anar overwoge met

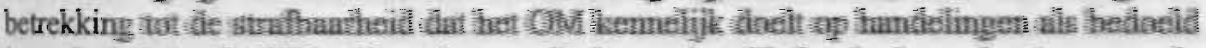

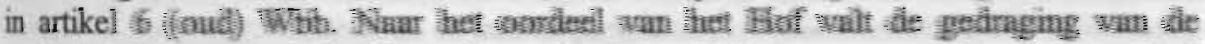

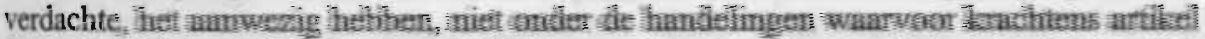

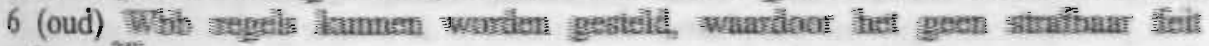
oplevert. $^{205}$

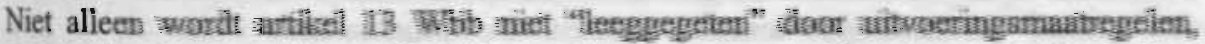

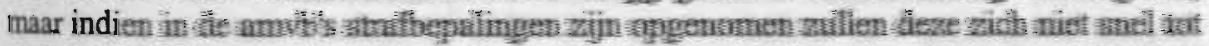

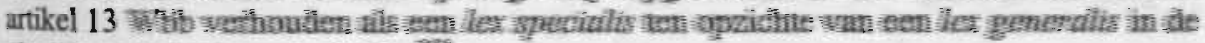
zin van artikel 55 , serrate lid st ${ }^{230}$

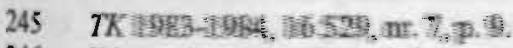

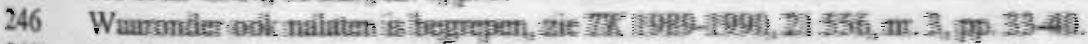

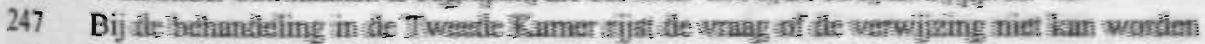

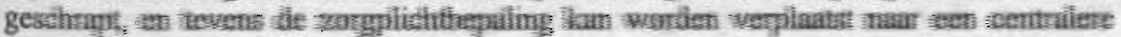

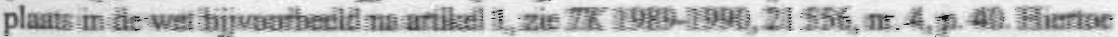

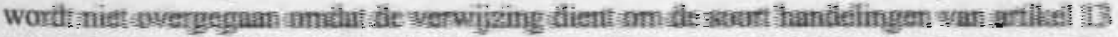

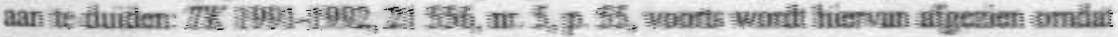

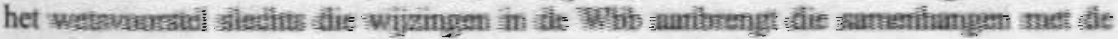
saneringaregeiling; zadiu hersehilasing niet gqpeat it:

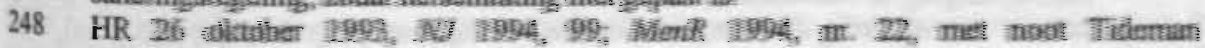
(Kahailinanderm).

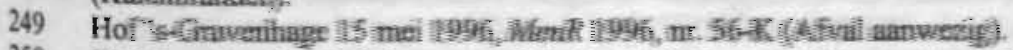

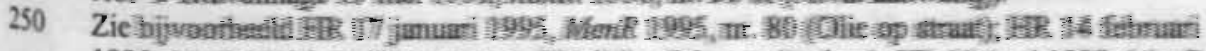

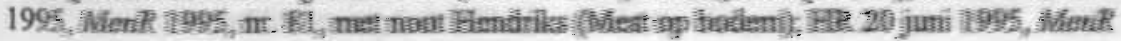


Indien voor handelingen waarop artikel 13 doelt regels zijn gesteld met het oog op de bescherming van de bodem, mag degene die zich aan die regels houdt er in beginsel van uit gaan dat hij daardoor voldoet aan de verplichting van artikel $13 .{ }^{251} \mathrm{Hij} \mathrm{zal} \mathrm{wel}$ de nodige zorgvuldigheid in acht moeten blijven nemen. Dit geldt ook voor degene die zich gedraagt overeenkomstig eisen gesteld bij of krachtens andere wetten voor zover bij het stellen van die eisen uitdrukkelijk (mede) het belang van de bescherming van de bodem in acht is genomen ${ }^{252}$ Dat dit niet onverkort geldt ${ }^{253}$ blijkt uit de volgende opmerking van de minister ${ }^{254}$ :

"Gesteld is dat degene die zich bij een handeling houdt aan de daarvoor gestelde algemene regels, er in beginsel van uit kan gaan dat hij ten aanzien van de daarbij geldende aspecten voldoet aan wat de zorgplicht van hem verlangt, maar hij zal toch de nodige zorgvuldigheid bij alle aspecten van zijn handeling in acht moeten nemen. Dus ook als er algemene regels zijn, is iemand die zich daaraan houdt, niet ontslagen van de verantwoordelijkheid voor de gevolgen van zijn handelen. Zijn er geen algemene regels gesteld, dan dient hij zelf te beoordelen welke maatregelen redelijkerwijs van hem kunnen worden gevergd. De leden van de CDA-fractie wezen er dan ook terecht op dat zich situaties kunnen voordoen waarin ondanks overheids. nomstelling de zorgplicht moet leiden tot afzien van een verontreinigende handeling."

Hierdoor lijkt het mogelijk dat ook als conform (nadere) regelgeving wordt gehandeld, toch sprake kan zijn van een schending van artikel $13 \mathrm{Wbb}$.

De subjectieve bestanddelen weet of redelijkerwijs had kunnen vermoeden zien op de verwijtbaarheid van de dader. ${ }^{255}$ Indien het $\mathrm{OM}$ overgaat tot vervolging, zal het ten minste één van deze bestanddelen moeten opnemen in de tenlastelegging en bewijzen. Dit gaf problemen in een zaak waarin een machinist met een bouwwerkkraan bezig was grondputten te graven. Ter plaatse bleken zich in de zwarte grond puin en asbestplaten te bevinden. De machinist zette desondanks zijn werkzaamheden voort en verplaatste de afgegraven zwarte grond, met daarin de asbestcementplaten, waardoor een nieuwe verontreinigde locatie ontstond. De politierechter veroordeelde hem wegens overtreding van artikel 14 (nu 13) Wbb. In cassatie werd deze uitspraak

1995, nr. 61-K (Niet vrijgestelde mest).

251 In het algemeen za! hij ook geen melding hoeven te doen op grond van artike! 21 , zie $T K$ $1989-1990,21556$, nr. 3, p. 40.

252 TK 1989-1990, 21556, nr. 3, p. 40.

253 In de Kamer werd twijfel geuit of het algemeen gestelde dat indien iemand zich houdt aan de regels van de overheid daardoor ook voldoet aan de zorgplicht. Gesteld wordt dat heel wat situaties denkbaar zijn waarbij ondanks generieke overheidsnormstelling de zorgplicht moet leiden tot afzien van een vervuilende activiteit in een concrete situatie. Uitvoeren van die activiteit betekent dan niet dat redelijkerwijs alles gedaan is om verontreiniging te voorkomen, $T K 1989-1990,21556$, nr. 4, p. 40. Ook wordt gesteld dat met de redenering dat "het zich houden aan algennene regels in beginsel gelijk staat aan het voldoen aan de zorgplicht" de eigen verantwoordelijkheid van een ieder te veel ontkracht, zie TK 1989-1990, 21 556, nr. 4, p. 40.

254 TK 1991-1992, 21 556, nr. 5, p. 55.

255 Zie over de subjectieve bestanddelen hoofdstuk 3 paragraaf 7.4. 
vernietigd. De Hoge Raad overwoog dat de politierechter in deze zaak terecht van algemene bekendheid heeft geoordeeld ${ }^{256}$ :

"dat asbest - in het algemeen gesproken - een gevaarlijke stof is. Dat ten tijde van het telastegelegde feit de verdachte redelijkerwijze kon vermoeden dat door vermenging van de grond met asbestcementplaten en/of delen daarvan welke in de grond werden aangetroffen de bodem kon worden verontreinigd of aangetast, kan daaruit echter niet zonder meer volgen en behoeft mitsdien nadere motivering. Aangezien de gebezigde bewijsmiddelen dienaangaande niets inhouden is de bewezenverklaring in zoverre niet naar de eis der wet met redenen omkleed"

waarna verwijzing naar de economische kamer van het Hof volgde. Problemen ontstonden ook in de strafzaak waar een verdachte werd verweten dat hij op een motorrijtuig met open laadbak een niet afgesloten vat met daarin afgewerkte olie, een of meer accu's, gasflessen en dergelijke had opgeslagen. Hij werd vrijgesproken van de ten laste gelegde overtreding van artikel $13 \mathrm{Wbb}$. Het Hof achtte niet bewezen dat de verdachte wist, althans redelijkerwijs had kunnen vermoeden dat door het ter bewaring opslaan van dit soort voorwerpen op een motorrijtuig met open laadbak de bodem kon worden verontreinigd. ${ }^{257}$

In de wet is geen definitie opgenomen van verontreiniging, omdat een groot aantal uiteenlopende factoren een rol speelt bij de bepaling of er sprake is van verontreiniging. ${ }^{258} \mathrm{Bij}$ de beoordeling of sprake is van een verontreiniging hechtte de minister vooral belang aan twee factoren; te weten de natuurlijke achtergrondwaarden en het zelfreinigend vermogen van de bodem, die zeer grote verschillen kumnen vertonen. ${ }^{259}$ In de Leidraad bodembescherming werd bodemverontreiniging als volgt omschreven ${ }^{260}$ :

"van verontreiniging van de bodem is sprake, indien stoffen zich op een dusdanige wijze op of in de bodem bevinden, dat deze stoffen - zich met de bodern vermengen, met de bodem kunnen reageren, zich in de bodem kunnen verspreiden en' of ongecontroleerd kunnen verplaatsen en een of meer van de functioncle eigenschappen die de bodem voor mens, plant en dier heeft, verminderen of bedreigen. Bij de functionele eigenschappen van de bodem moet worden gedacht aan de ecologische functie, de teelfunctic, de dragerfunctie en de functie van de bodem als vind- en winplaats van grondwater en delfstoffen."

Onder aantasting van de bodem wordt verstaan: ingrepen in de bodem door of als gevolg van menselijke activiteiten die de structuur van de bodem verstoren, zodanig

256 HR 20 februari 1996, MenR 1997, nr. 62 (Asbestplaten in bodem).

257 Hof Amsterdam 31 januari 1996, MenR 1996, nr. 38-K (Open laadbak).

258 De term verontreiniging wordt in de Leidraad toegelicht. Deze omschrijving heeft in de praktijk weinig aanleiding heeft gegeven voor misverstanden. De minister ziet dan ook af van definiëring in de wet, $T K$ 1991-1992, 21 556, nr. 5, p. 54.

$259 T$ TK 1989-1990, 21556, B, p. 29.

260 Leidraad bodembescherming p. 1-SAN-1. 
dat afbreuk wordt gedaan aan een of meer van de functionele eigenschappen van de bodem. ${ }^{261}$

Onder nadelige beïnvloeding (die het gevolg is van de verontreiniging of aantasting) wordt begrepen iedere verandering van materie of van eigenschappen die een vermindering of bedreiging betekent van de functionele eigenschappen van de bodem voor mens, plant en dier. ${ }^{262}$ In het bijzonder betreft het iedere afneming van de kwaliteit van de bodern in zodanige mate dat functionele eigenschappen emstig worden verstoord of teniet worden gedaan. Er bestaan vele vormen en gradaties van nadelige beïnvloeding. Wat in een concreet geval een nadelige beünvloeding is, is uiteindelijk een kwestie van beoordeling van de situatie en van de in geding zijnde bodemfuncties. Slechts ingrijpende activiteiten hebben deze nadelige beïnvloeding tot gevolg. ${ }^{263}$ Activiteiten die een bedreiging vormen voor de bodem kunnen in twee hoofdgroepen worden onderscheiden. Ten eerste betreft het activiteiten die een risico inhouden voor verontreiniging van bodem en grondwater door het direct of indirect inbrengen van chemisch, bacteriologisch onbetrouwbare, dan wel in ander opzicht ongewenste stoffen of een bepaalde kans daarop inhouden. Door het in de bodem geraken van stoffen in een zodanige hoeveelheid worden de eigenschappen van bodem en grondwater dermate nadelig beïnvloed dat deze minder geschikt wordt voor één of meer gebruiksdoeleinden en vormt het een bedreiging voor de ecologische functie van de bodem. Ten tweede betreft het activiteiten welke een risico inhouden voor beïnvloeding van de fysische eigenschappen c.q. de bodemstructuur aantasten, dan wel het evenwicht in de bodem zodanig verstoren dat verontreinigingen kunnen ontstaan of zich kunnen verspreiden. Het gaat dan niet om het toevoegen van stoffen aan het bodemsysteem maar om het aanbrengen van veranderingen in de geologische opbouw (structuur) van de bodem of in de fysisch-mechanische eigenschappen van bodem en grondwater. ${ }^{264}$

Overigens betreft het handelingen waardoor de bodem kan worden aangetast of verontreinigd, zodat voldoende is dat wordt aangetoond dat er sprake was van een potentieel gevaarlijke gedraging. ${ }^{265}$ Deze concrete gevaarzetting zal door het $\mathrm{OM}$ vrij eenvoudig zijn te bewijzen, waarbij het gebruik kan maken van alle wettige bewijsmiddelen. Het $\mathrm{OM}$ is hierbij niet gebonden aan gedetailleerde procedures die beschrijven op welke wijze een schending van een dergelijke bepaling dient te worden

TK 1991-1992, 21 556, nr. 5, p. 55.

262 Functionele eigenschappen van de bodem zijn de dragerfunctie, de gezonde en vruchtbare bodem voor de voedsel- en gewasproductic in de land- en tuinbouw en de betekenis van zuiver en betrouwbaar grondwater, de vind- en winplaats van een groot aantal delfstoffen en de meer algemene ecologische en esthetische functies, zie $T K$ 1980-1981, 16529 , nrs. A-C, p. 19.

263 TK 1980-1981, 16 529, nrs. A-C, p. 16; TK 1980-1981, 16 529, nrs. A-C, p. 18. Hierbij is een scherpe scheiding tussen chemische, fysische, biologische of mechanische beînvloeding van de bodemkwaliteit als gevolg van menselijke activiteiten met betrekking tot de bodem in feite niet goed mogelijk, zie $T K 1980-1981,16529$, nrs. AC. p. 20.

264 TK 1980-1981, 16 529, nrs. A.C, p. 21.

265 HR 22 november 1994, MenR 1995, nr. 50, met noot Hendriks (Motorblok). 
bewezen, of aan het vergaren en analyseren van technische bewijsmiddelen zoals bodenmonsters. Zo werd in de Kabelbrandenzaak bewezen verklaard dat de verdachte op een aangegeven stuk bodem elektriciteitskabels had verbrand waardoor verbrandingsresten op de bodem geraakten, zijnde afvalstoffen, die de bodem kunnen verontreinigen - zulks terwijl hij redelijkerwijs had kunnen vermoeden, dat door die handelingen de bodem kon worden verontreinigd - en toen niet alle maatregelen heeft genomen die redelijkerwijs van hem konden worden gevergd, teneinde die verontreiniging te voorkomen. Ter terechtzitting gaf een deskundige zijn. mening over de potentie tot verontreiniging van de bodem van de betreffende stoffen. Hij verklaarde dat het verbranden van elektriciteitskabels steeds bijzonder schadelijk is voor de bodem vanwege de plastic vezels, maar ook de zware metalen die door dit verbrandingsproces viijkomen en in het milieu worden verspreid. In deze zaak leidde die verklaring er mede toe dat schending van de zorgplichtbepaling uit artikel 14 (nu 13) Wbb werd bewezen verklaard. ${ }^{266}$ Door deze veroordeling gaf de rechtbank impliciet aan dat deze bepaling de toets der kritiek van het lex certa-beginsel in dit geval kon doorstaan. ${ }^{267}$ Vermoedelijk kan de Hoge Raad die deze uitspraak in 1993 bevestigde ${ }^{268}$, ook moeilijk anders. Immers: in het algemeen huldigt dit rechtscollege wel het beginsel dat de strafbepalingen restrictief dienen te worden geïnterpreteerd ${ }^{269}$, maar de zorgplichtbepalingen zijn zodanig breed geformuleerd dat zelfs in een restrictieve interpretatie het betekenisbereik zeer ruim blijft.

Schade behoeft overigens in het geheel niet te worden onderzocht of bewezen. Door het splitsen van de zorgplichtbepaling in afzonderlijke zorgplichten is ook: sprake van een schending door degene die het niet gewenste gevolg van onvoorzien onzorgvuldig handelen direct ongedaan maakt. ${ }^{270}$ Wel moet het gaan om een verontreinigende stof, maar of deze stof in concreto heeft geleid tot een aantasting of verontreiniging, behoeft in het geheel niet te worden onderzocht. ${ }^{271}$ Dit bleek bijvoorbeeld in een zaak, waar

266 Rb. Amsterdam 29 maart 1990, NJ 1990, 521, MenR 1990, nr. 58, met noot Fransen (Kabelbranden).

267 Hendriks, L.E.M., Techniek en normstelling in het milieustrafrecht, pp. 109-110. Hendriks stelt naar aanleiding van de kabelbranden-zaak: "Waar volgens de strafrechter zelfs deze, zo ruim geformuleerde strafbepaling door de beugel kan, is het aannemelijk te veronderstellen dat de boven weergegeven algemene verbodsbepaling niet op gespannen voet met het lex certa-beginsel staat."

268 HR' 26 oktober 1993, NJ 1994, 99; MenR 1994, nr. 22, met noot Tideman (Kabelbranden).

269 Zie bijvoorbeeld ook in verband met computercriminaliteit HR 2 december 1997, NJB 1998, 137 (Vernietigde computerbestanden).

270 AG Fokkens stelde in een eerdere zaak dat indien het initiële gebrek aan voorzorg door de justitiabele zelf achteraf is rechtgezet, zodat het gevaar is geweken en het door artikel $13 \mathrm{Wbb}$ beschermde rechtsgoed niet werd geschaad, niet in strijd zou zijn gehandeld met dit artikel. Zie de conclusie van Fokkens voor HR 25 januari 1994, NJ 1994, 598, met noot Corstens (Vliegbasis Volkel). In deze zaak heeft de Hoge Raad zich hierover niet uitgesproken.

271 Dit is in het Nederlandse milieustrafrecht overigens geen onbekend verschijnsel. In het algemeen wordt voor het schenden van de meeste strafbaarstellingen in het milieustrafrecht niet de eis gesteld dat sprake is van een concrete gevaarzetting of daadwerkelijke 
een kunstenaar werd vervolgd wegens schending van de zorgplichtbepaling uit artikel 14 (nu 13) Wbb die een bepaalde stof had gebruikt om een beeldhouwwerk te bewerken die vervolgens op straat terecht kwam. De politierechter overwoog dat niet is vastgesteld welke stof de verdachte had gebruikt. Wel achtte hij het duidelijk geworden dat het een bijtende stof moet zijn geweest, aangezien het was gebruikt om een metalen voorwerp een oud uiterlijk te geven, en tevens was vastgesteld dat de stof stonk en de keel van de verbaliserende agent irriteerde. Bovendien had de verdachte zelf omstanders gewaarschuwd niet in een plas met die stof te trappen, omdat die "bijtend" zou zijn. Uit deze omstandigheden leidt de politierechter af dat de gebruikte stof verontreinigend was, en tevens dat verdachte zich daarvan bewust is geweest. Hij veroordeelde de verdachte wegens schending van de zorgplichtbepaling. In cassatie verwierp de Hoge Raad zijn beroep en oordeelde dat uit de bewijsmiddelen kan worden afgeleid dat hij een stof op de bodem heeft gebracht die deze kan verontreinigen. ${ }^{272}$

Er moet overigens wel enig bewijs voorhanden zijn dat de betreffende stof(fen) de bodem kan (kunnen) verontreinigen. Zo werd een verdachte vrijgesproken van de ten laste gelegde overtreding van artikel $13 \mathrm{Wbb}$ wegens het op de bodem brengen van motorblokken en accu's. Het Hof Amsterdam overwoog ${ }^{273}$ :

"Nu niet aannemelijk is geworden dat de motorblokken en accu's die zich op de grond

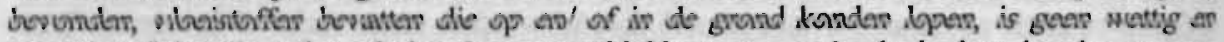
overtuigend bewijs geleverd dat deze motorblokken en accu's de bodem konden verontreinigen."

Op grond van artikel $13 \mathrm{Wbb}$ moeten alle maatregelen worden genomen die redelijkerwijs kunnen worden gevergd. Dat brengt met zich dat degene die bij het verrichten van handelingen als bedoeld in artikel 13 , kennis neemt van een verontreiniging of aantasting van de bodem ten gevolge van die handelingen, onverwijld passende curatieve maatregelen dient te nemen. ${ }^{274}$

aantasting of yerontreiniging van (componenten van) het leefmilieu. Zelfs het concreet in gevaar brengen dan wel aantasten van de openbare (-menselijke) gezondheid of het menselijk leven wordt in het milieustrafrecht slechts sporadisch als voonwaarde voor strafbaarheid gesteld.

272 HR 15 november 1994, MenR 1995, nr. 10-K (Bodemkunstenaar).

273 Hof Amsterdam 23 mei 1995, MenR 1995, nr. 56-K (Accu's op bodem). De verdachte in deze zaak werd overigens wel veroordeeld tot een voorwaardelijke boete van $f 1000$,wegens het overtreden van artikel $8.1 \mathrm{Wm}$; het betrof onder meer het zonder vergunning opslaan van vijf of meer autowrakken.

274 Hiervan dient hij op basis van artikel 21 zo spoedig mogelijk melding te doen aan gedeputeerde staten, zie TK 1989-1990, 21 556, nr. 3, p. 38, en TK 1989-1990, 21 556, ir. 3, p. 41. Deze meldings- en saneringsplicht geldt voor ieder nieuw optredende verontreiniging ongeacht de ernst van de verontreiniging en ongeacht de vraag of de verontreiniging veroorzaakt is door een ongewoon voorval of niet, zie TK 1991-1992, 21 556, nr. 5, p. 18. 
Uit atikel 13 Wbb lan de plicht voortvlseien, de bodema te: sanerent. De veranwoordelijkheid voor de aanpak werd gelegd bij de veroocraker. ${ }^{27 s}$ Er werd biy de totstandlioming vant artikel 13 Wbb geen verschil gemankt tussen de emst wan de veronreiniging. "Yoor het begrig saneren is het resultuat dat met de handeling wordt bereilt essentieel. De wetgever verwees voor de invulling van "saneren" naar de Leidrad, fie blijkens vaste jurisprodentie nomerende werking beeft. ${ }^{21}$ Onder saneren wordt diar serstaan" $27 \%$ "het beperken en zoveel mogelijk ongedan maken van veronteiniging en de directe gevolgen diarvan of van dreigende veruntreiniging van de bolem." Het doel van een sanering was het berstel van de multifinctionaliteit van de bofem, tenzij dit als gevolg van locatiespecifieke omstandigheden niet goed mogeljk is ${ }^{20}$ Thans wordt door de wetgever overwogen het uitgangspunt, Jaultifunctineel saneren, tenzij" (afhankelijk van de omstandigheden van het geval) lis te: laten, es uit te gan van "functiegericht saneren". Dit houdt in dat de mate waarin moet worden gesaneerd" wordt bepaald door het beoogde gebruik van de bodem. ${ }^{201}$ Onder bijpondere omstandigheden lijkt deze mogelijkheid soms af te bestaan.

De begrippen beperten en ongediaun shititen ann bij de definitie van bet belang van de bescherming van de bodem ${ }^{\text {an }}$ Het beperken ziet op het voerkamen van verdere versprialing , terwijl het zoveel mogelijk ongedaan maken ziet op het aanpokiken van de verontreiniging zelf. Gestreefd wordt naar herstel van de multifumetionaliteit van $d t$ bedem en reiniging zans de serontreinigde grood tot een nuttig toepasbaar product. $^{284}$

Indien sprake is van een ongewoon voorval moeten de maatregelen onverwijld worden genomen. Van een ongewoon voorval is sprake indien het niet gaat om de normale bij het verrichten van een handeling optredende beïnvloeding van de kwaliteit van de

\footnotetext{
$275 T K 1991-1992,21556$, nr. 14, p. 13 en $E K 1992-1993,21$ 556, nr. 226b, p. 29.

276 Zie ook Wilt, C.J. van der, Het saneringsbevel in de Wet bodembescherming, p. 92.

277 TK 1989-1990, 21556, nr. 3, p. 39.
}

278 In de begripsomschrijving van het kabinetsstandpunt inzake het Tien jarern-scenario bodemsanering, $T K 1991-1992,21556, \mathrm{nr} .14$, p. 32 is saneren omschreven als "het treffen van maatregelen gericht op het definitief opheffen (zoveel mogelijk ongedaan maken, verwijderen) of tegengaan (beperken, isoleren) van bodemverontreiniging en de schadelijke gevolgen daarvan".

279 TK 1991-1992, 21556 , nr. 5, p. 12, zie ook de CDA fractie in de Eerste Kamer, $E K$ 1992-1993, 21 556, nr. 226b, p. 19 het doel beoogt derelfde reikwijdte te hebben als die in het kabinetsstandpunt Tien jaren-scenario bodemsanering, TK 1991-1992, 21 556, nr. 14, p. 18.

280 Zie TK 1996-1997, 25411 , nr. 1, p. 11.

281 Zie hierover Wilt, C.J. van der, Het saneringsbevel in de Wet bodembescherming, pp. 91-95 en 283-284.

282 TK 1989-1990, 21556, nr. 3, p. 38.

283 TK 1989-1990, 21556, B, p. 28; TK 1989-1990, 21 556, nr. 3, p. 39.

284 Het is een streven aangezien specifieke omstandigheden er toe kunnen leiden dat niet onverkort uitwerking kan worden gegeven aan het beginsel van herstel van een multifunctionele bodem, TK 1989-1990, 21 556, B, p. 28; TK 1989-1990, 21 556, nr. 3, p. 39. 
bodem, maar om een bijzondere gebeurtenis of omstandigheid ten gevolge waarvan de verontreiniging of aantasting van de bodem is opgetreden. ${ }^{285}$ Er lijkt een dusdanig ruime betekenis aan te worden toegekend, dat het iedere gebeurtenis omvat die bij een normale gang van zaken niet zou hebben plaatsgehad. ${ }^{286}$ Dan moeten die maatregelen. worden genomen die redelijkerwijs van hem kunnen worden gevergd teneinde de verontreiniging of aantasting te voorkomen, dan wel de bodem te saneren of de aantasting en de directe gevolgen daarvan te beperken en zoveel mogelijk ongedaan te maken. ${ }^{289}$

\subsubsection{Het subjectief element bij artikel $13 \mathrm{Wbb}$ als overtreding}

Artikel 13 Wbb bevat subjectieve bestanddelen, die afwijken van de in het strafrecht gebruikelijke redactie; te weten het vereisen van "opzet" of "schuld" ${ }^{288}$ In artikel 13 Wbb is de schuldvorm geformuleerd als "weet of redelijkerwijs had kunnen vermoeden" en "redelijkerwijs van hem kunnen worden gevergd". Deze subjectieve bestand. delen zijn bij de overtreding-variant niet van toepassing op alle bestanddelen van de delictsomschrijving, maar zien slechts op enkele bestanddelen. Voor de overige bestanddelen geldt dat culpa daar een element is.

Voor de eerste zorgplichtbepaling uit artikel $13 \mathrm{Wbb}$ geldt dat voor "Ieder die op of in de bodem handelingen verricht als bedoeld in de artikelen 6 tot en met 11" culpa een element is. Het deel "en die weet of redelijkerwijs had kunnen vermoeden dat door die handelingen de bodem kan worden verontreinigd of aangetast" wordt beheerst door de twee subjectieve bestanddelen die als alternatieven zijn geformuleerd. En het deel "is verplicht alle maatregelen te nemen die redelijkerwijs van hern kunnen worden gevergd, teneinde die verontreiniging of aantasting te voorkomen" wordt beheerst door één subjectief bestanddeel.

Bij de tweede zorgplichtbepaling uit artikel $13 \mathrm{Wbb}$ geldt dat voor "Ieder die op of in de bodem handelingen verricht als bedoeld in de artikelen 6 tot en met 11 " wederom culpa een element is. Bij het deel "en die weet of redelijkerwijs had kunnen vermoeden dat door die handelingen de bodem kan worden verontreinigd of aangetast" wordt wederom beheerst door de twee als alternatieven geformuleerde subjectieve bestanddelen. Het daarop volgend deel "is verplicht indien die verontreiniging of aantasting zich voordoet, de bodem te saneren of de aantasting en de directe gevolgen daarvan te beperken en zoveel mogelijk ongedaan te maken" wordt beheerst door culpa als element.

De derde zorgplichtbepaling uit artikel 13 Wbb geldt dat voor het deel "Ieder die op of in de bodem handelingen verricht als bedoeld in de artikelen 6 tot en met $11^{\text {" }}$ opnieuw culpa een element is. Het deel "en die weet of redelijkerwijs had kunnen vermoeden

TK 1980-1981, 16529 , nrs. 3-4, pp. $31-33$ en 54.

286 TK 1989-1990, 21 556, B, p. 30-31.

$287 T K 1991-1992,21556$, nr. 5, p. 18.

288 Zie hoofdstuk 3 paragraaf 7.4. 
dat door die handelingen de bodem kan worden verontreinigd of aangetast" wordt wederom beheerst door de als alternatieven geformuleerde subjectieve bestanddelen. Bij het daarop volgend deel "is verplicht indien die verontreiniging of aantasting zich voorciot, en deze het gevolg is van een ongewoon voorval de maatregelen (de bodem te sateren of de aantasting en de directe gevolgen daarvan te beperken en zoveel mogelijk ongedaan te maken) onverwijld te nemen" wordt beheerst door culpa als element.

Deze subjectieve bestanddelen dienen door het verbindingswoord "of" te worden geïnterpreteerd als alternatieven. De overtreding-variant van artikel $13 \mathrm{Wbb}$ bevat zodoende een culpose en een opzettelijke vorm. Hierbij moet worden gerealiseerd dat culpa als element nog steeds een rol kan spelen voor de delen van de delictsomschrijving die worden beheerst door het culpose subjectieve bestanddeel. Schuld als element heeft namelijk een groter betekenisbereik dan de in artikel $13 \mathrm{Wbb}$ opgenomen subjectieve bestanddelen. Indien ten aanzien van een verdachte het betreffende culpose bestanddeel kan worden bewezen verklaard, zijn er situaties mogelijk waarin toch geen sprake is van schuld (als element) voor het deel van de delictsomschrijving dat door het specifieke culpose bestanddeel wordt beheerst. De verdachte zal dan (ex artikel 352, tweede lid Sv) moeten worden ontslagen van alle rechtsvervolging.

\subsubsection{Het subjectief element bij artikel $13 \mathrm{Wbb}$ als misdrijf}

Artikel $13 \mathrm{Wbb}$ is via artikel la sub 1 Wed aangehaakt aan de Wed. Involge artikel 2, eerste lid Wed is er bij deze bepaling sprake van een misdrijf indien de normschending opzettelijk is begaan, en is er in de overige gevallen sprake van een overtreding. Omdat artikel $13 \mathrm{Wbb}$ zelf ook subjectieve bestanddelen bevat, is er bij de misdrijfvariant sprake van een "schuldkwadratuur". ${ }^{289}$ Gezien de in hoofdstuk 3 paragraaf 7.4.6. beschreven oplossingen geldt voor de misdrijf-variant van deze zorgplichtbepaling dat zij op een aantal manieren kan worden geïnterpreteerd. ${ }^{290}$ In hoofdstuk 3 zijn twee interpretatiemogelijkheden uitgewerkt; te weten de interpretatiemethode die aansluit bij de opbouw en samenstelling van strafbaarstellingen en de methode waarbij de opzet-eis uit de Wed niet van toepassing wordt geacht op de subjectieve bestanddelen en de bestanddelen waar deze betrekking op hebben. De praktische consequenties die het volgen van één van deze twee interpretatiemogelijkheden tot gevolg hebben, zal hier worden uitgewerkt. De opzet-eis die voor misdrijven involge artikel 13 Wbb geldt, wordt bij deze uitwerking steeds tussen aanhalingstekens ingeschreven in de delietsomschrijvingen van artikel $13 \mathrm{Wbb}$. Voorts wordt zij, evenals de subjectieve bestanddelen uit artikel $13 \mathrm{Wbb}$ die blijven gelden, cursief weergegeven teneinde de verschillen duidelijker te laten zien. In hoofdstuk 9 paragraaf 4 en in hoofdstuk 10 paragrafen 4.3.3. en 4.3.4. zal worden ingegaan op de resultaten van deze uitwerking en op de uitwerkingen van artikel $2 \mathrm{Wms}$ en artikel 10.3, eerste en tweede lid Wm.

289 Zie hoofdstuk 3 paragraaf 7.4.6.

290 Zie hierover ook hoofdstuk 10 paragrafen 4.3.3. en 4.3.4. 
De eerste zorgplichtbepaling uit artikel $13 \mathrm{Wbb}$ luidt bij het alternatief waar "weet" bestanddeel is, zowel bij de eerste als de tweede interpretatie: "Ieder die 'opzettelijk' op of in de bodem handelingen verricht als bedoeld in de artikelen 6 tot en met 11 en die weet dat door die handelingen de bodem kan worden verontreinigd of aangetast, is verplicht alle maatregelen te nemen die redelijkerwijs van hem kunnen worden gevergd, teneinde die verontreiniging of aantasting te voorkomen".

Voor de eerste zorgplichtbepaling uit artikel $13 \mathrm{Wbb}$ geldt dat het alternatief waarbij de culpose bestanddelen deel uitmaken van de eerste interpretatie niet mogelijk is. Indien de tweede interpretatie wordt gevolgd luidt dit artikel: "Ieder die 'opzettelijk' op of in de bodem handelingen verricht als bedoeld in de artikelen 6 tot en met 11 en die redelijkerwijs had kunnen vermoeden dat door die handelingen de bodem kan worden verontreinigd of aangetast, is verplicht alle maatregelen te nemen die redelijkerwijs van hem kunnen worden gevergd, teneinde die verontreiniging of aantasting te voorkomen".

De tweede zorgplichtbepaling uit artikel 13 Wbb luidt bij het alternatief waar "weet" bestanddeel is, zowel bij de eerste als de tweede interpretatie: "Ieder die 'opzettelijk' op of in de bodem handelingen verricht als bedoeld in de artikelen 6 tot en met 11 en die weet dat door die handelingen de bodem kan worden verontreinigd of aangetast, is verplicht indien die verontreiniging of aantasting zich voordoet, de bodem te saneren of de aantasting en de directe gevolgen daarvan te beperken en zoveel mogelijk ongedaan te maken."

Voor de tweede zorgplichtbepaling uit artikel $13 \mathrm{Wbb}$ geldt dat bij het alternatief waarbij de culpose bestanddelen deel uitmaken de eerste interpretatie niet mogelijk is. Indien de tweede interpretatie wordt gevolgd luidt dit artikel: 'Teder die 'opzettelijk' op of in de bodem handelingen verricht als bedoeld in de artikelen 6 tot en met 11 en die redelijkerwijs had kunnen vermoeden dat door die handelingen de bodem kan worden verontreinigd of aangetast, is verplicht indien die verontreiniging of antasting zich voordoet, de bodem te saneren of de aantasting en de directe gevolgen daarvan te beperken en zoveel mogelijk ongedaan te maken."

De derde zorgplichtbepaling uit artikel $13 \mathrm{Wbb}$ luidt bij het alternatief waar "weet" bestanddeel is, zowel bij de eerste als de tweede interpretatie: 'Teder die 'opzettelijk' op of in de bodem handelingen verricht als bedoeld in de artikelen 6 tot en met 11 en die weet dat door die handelingen de bodem kan worden verontreinigd of aangetast, is verplicht indien die verontreiniging of aantasting zich voordoet, en deze het gevolg is van een angewoon voorval de maatregelen (de bodem te saneren of de aantasting en de directe gevolgen daarvan te beperken en zoveel mogelijk ongedaan te maken) onverwijld te nemen."

Voor de derde zorgplichtbepaling uit artikel $13 \mathrm{Wbb}$ geldit dat bij het alternatief waarbij de culpose bestanddelen deel uitmaken de eerste interpretatie niet mogelijk is. Indien de tweede interpretatie wordt gevolgd luidt dit artikel: 'Teder die 'opzettelijk' op of in de bodem handelingen verricht als bedoeld in de artikelen 6 tot en met 11 en die redelijkenwijs had kunnen vermoeden dat door die handelingen de bodem kan worden 
verontreinigd of aangetast, is verplicht indien die verontreiniging of aantasting zich voordoet, en deze het gevolg is van een ongewoon voorval de maatregelen (de bodem te saneren of de aantasting en de directe gevolgen daarvan te beperken en zoveel mogelijk ongedaan te maken) onverwijld te nemen."

\subsection{Wet milieubeheer, hoofdstuk Afvalstoffen}

\subsubsection{Inleiding}

Nadat in 1969 de Wvo en in 1970 de Wet inzake de luchtverontreiniging tot stand waren gekomen, groeide het besef dat er ook een wet zou moeten komen die zich zou richten op de bescherming van de bodem. Aangezien veel bodemverontreiniging werd veroorzaakt door afvalstoffen, werd een poging ondernomen beide problemen in een wet aan te pakken. Dit plan werd verlaten en er kwam een afzonderlijke regeling voor de afvalstoffen tot stand (hoofdstuk 9 paragraaf 3.4.2.). Deze wet werd later, geïntegreerd met de Wet chemische afvalstoffen, opgenomen in de overkoepelende Wet milieubeheer (hoofdstuk 9 paragraaf 3.4.3.). In het nieuwe hoofidstuk afvalstoffen van de Wet milieubeheer werd in artikel $10.3 \mathrm{Wm}$ een zorgplichtbepaling opgenomen (hoofdstuk 9 paragraaf 3.4.4). Bij de wetswijziging waarbij de Wet milieubeheer werd uitgebreid met dit hoofdstuk werd tevens een algemene niet strafrechtelijk. handhaafbare zorgplicht in deze wet opgenomen (hoofdstuk 9 paragraaf 3.4.5.). De zorgplichtbepaling uit artikel $10.3 \mathrm{Wm}$ zal nader worden beschouwd (hoofdstuk. 9 paragrafen 3.4.6., 3.4.7. en 3.4.8.).

\subsubsection{Afvalstoffenwet}

De eind jaren zestig tot stand gekomen sectorale wetgeving voor delen van het leefmilieu, leidde tot de gedachte dat er ook een wet zou moeten komen voor de voorkoming en beperking van bodemverontreinigingen en de beperking van het ontstaan en de verwijdering van afvalstoffen. Dit resulteerde in 1971 in een voorontwerp van de wet inzake de bodemveronireiniging, dat een afzonderlijk wettelijk kader voor afvalstoffen bevatte. ${ }^{291}$ De koppeling tussen bodembescherrning (sectoraal) en afvalstoffen (soortgericht) werd mede op basis van uitgebrachte adviezen verlaten. Het voorontwerp werd medio 1972 gesplitst $^{292}$ in een dee! dat uiteindelijk resulteerde in de sectorale Wet bodembescherming ${ }^{293}$, en een deel waaruit een aparte wettelijke regeling voor de afvalverwijdering zou moeten voortkomen.

Grote problemen met chemische afvalstoffen, waaronder begrepen afgewerkte olie, begonnen in deze tijd steeds sterker op de voorgrond te treden. In oktober 1972 werd

\footnotetext{
29! Voorontwerp wet inzake bodemverontreiniging, 14 april 197'1 door de Staatssecretaris van Sociale Zaken en Volksgezondheid gestuurd aan de Tweede Kamer: TK 1970-1971, 11268 , nrs. 1-3.

292 Zie Hartog, R.J. den, Hofland, J. en Meynen, P.F., Handleiding Milieuwetgeving, "8 Bodem", 8.2., pp. 1-2; Meijenfeldt, H.G. von en Wildeboer, L.J. (red.), Wet bodembescherming, "Toelichting (B-1)", pp. 1-2.

293 Zie over de Wbb hoofdstuk 9 paragraaf 3.3.
} 
een nadere beslissing genomen, inhoudende dat wegens de hoge urgentie met spoed een aparte wet inzake chemische afvalstoffen tot stand zou moeten komen. Deze zou vooruitlopen op een algemene wet inzake afvalstoffen. Het was de bedoeling dat de snel in te voeren wet chemische afvalstoffen naderhand in deze algemene wet afvalstoffen zou worden ingepast. ${ }^{294}$ Dit resulteerde in 1976 in de Wet chemische afvalstoffen. $^{295}$ Deze wet diende vooral om een organisatorisch kader te verschaffen voor het op doelmatige wijze verwijderen van chemische afvalstoffen en afgewerkte olie. Hierdoor droeg de wet bij tot, maar was niet in hoofdzaak gericht op, het rechtstreeks beschermen van het milieu. ${ }^{296}$

Daamaast werd doorgewerkt aan de totstandkoming van de Afvalstoffenwet. Deze wet. diende het milieu te beschermen tegen de belasting van afvalstoffen. Daartoe werden regels opgenomen die betrekking hebben op huishoudelijke afvalstoffen, autowrakken en andere, al dan niet van bedrijven afkomstige, afvalstoffen waarvoor nog geen in het bijzonder daarop gerichte wettelijke regeling bestond. ${ }^{297}$ De wet werd uitdrukkelijk niet van toepassing verklaard op gedragingen waaromtrent voorschriften waren gesteld bij of krachtens de Destructiewet, de Wet olieverontreiniging zeewater, de Bestrijdingsmiddelenwet, de Kemenergiewet, de Wet verontreiniging oppervlaktewateren, het Rijnvaartpolitiereglement, de Wet verontreiniging zeewater en de Wet chemische afvalstoffen. ${ }^{298}$ Aan deze wet lag, evenals aan de Wet chemische afvalstoffen, ${ }^{299}$

"de gedachte ten grondslag dat in beginsel een ieder die afvalstoffen produceert of doet ontstaan verantwoordelijk is voor dit afval; hij dient zèlf zorg te dragen voor een verantwoorde verwijdering en verwerking ervan en moet de daarmee gepaard gaande kosten òòk zelf dragen."

Ondanks deze gedachte werd noch in de in 1977 ingevoerde Afvalstoffenwet ${ }^{300}$, noch in de Wet chemische afvalstoffen een zorgplichtbepaling opgenomen. De strafbaarstellingen uit de Afvalstoffenwet werden involge artikel $83 \mathrm{Aw}$ gedeeltelijk aangehaakt aan de Wed, omdat het bepalingen betrof waarvan de gelding op grond van hun formulering doorgaans beperkt zai zijn tot ondernemingen. Ten aanzien van overtreding van enkele andere artikelen bevatte de wet ex artikel 84 en 85 Aw zelf sancties en maatregelen. Gedragingen in strijd met enkele artikelen werden involge artikel $82 \mathrm{Aw}$ aangemerkt als een misdrijf indien zij opzettelijk plaatsvonden, en in de overige gevallen waren het overtredingen. ${ }^{301}$

294 Zie over deze voorgeschiedenis TK 1973-1974, 12 662, nr. 3, pp. 8-9 (MvT Wet chemische afvalstoffen) en TK. 1974-1975, 13 364, nrs. 1-3, pp. 30-31 (MvT Afvalstoffenwet).

295 Wet van 11 februari i976, Stb. 1976, 214.

296 TK 1973-1974, 12662 , nr. 3. p. 14.

297 Zie TK 1974-1975, 13 364, nrs. 1-3 en de considerans bij de Afvalstoffenwet, Stb. 1977, 455.

298 Zie artikel 98 Aw 1977 en TK 1974-1975, 13 364, nrs. 1-3, pp. 30 en 62.

299 TK 1974-1975, 13364, nrs. 1-3, p. 30.

300 Wet van 23 juni 1977, Sib. 1977, 455 .

301 Zie hierover $T K$ 1974-1975, 13 364, nrs. 1-3, pp. 91-92; TK. 1975-1976, 13 364, nr. 4, 
In de zeventiger jaren lag de nadruk van het milieubeleid op het met spoed tot stand brengen van sectorale en soortgerichte regelingen om de vele milieuvraagstukken te kunnen aanpakken. Met het voltooien van deze regelingen kwam in de tachtiger jaren de nadruk meer te liggen op integratie van de afzonderlijke regelingen. ${ }^{302}$ In het Actieprogramma deregulering ruimtelijke ordening en milieubeheer ${ }^{303}$ in het rapport van de Unisercommissie ${ }^{304}$ en in het IMP Milieubeheer 1986-1990 $0^{305}$ werd reeds gewezen op de wenselijkheid van het samenvoegen van de wetgeving gericht op afvalstoffen.

$\mathrm{Na}$ de nodige wijzigingen en aanpassingen van de Afvalstoffenwet werd besloten de koers te volgen die in het IMP Milieubeheer 1986-1990 werd uitgezet, en deze wet in te bouwen in de inmiddels tot stand gekomen Wabm. ${ }^{306}$ Het wetsvoorstell tot uitbreiding en wijziging van de Wabm (Aw) werd in augustus 1989 ingediend bij de Tweede Kamer. De naam van deze wet werd in december 1991 bij Nota van wijziging veranderd in de naam "Wet milieubeheer". ${ }^{307}$

Het wetsvoorstel beoogde de regelingen inzake het voorkomen en beperken van het ontstaan van afvalstoffen en het verwijderen van afvalstoffen, zoals opgenomen in de Afvalstoffenwet en de Wet chemische afvalstoffen, te verbeteren en aan te vullen en daarbij in het bijzonder aandacht te schenken aan de mogelijkheden tot preventie en hergebruik. Deze wetgeving zou, gezien de onderlinge samenhang, geïntegreerd worden opgenomen in de $\mathrm{Wm}$, waarbij de nieuwe regeling tevens uitvoering zou moeten geven aan de richtlijnen van de Europese Gemeenschappen inzake afvalstoffen. ${ }^{303}$

Het stelsel was gericht op het zo goed mogelijk beheersen en sturen van de afvalstroom naar aanvaardbare verwijderingsfaciliteiten. Getracht werd de knelpunten en de problemen die zich bij de handhaving van de Afvalstoffenwet hadden gemanifesteerd in het nieuwe stelsel op te lossen. ${ }^{309}$ De bevoegdheden van de controlerende ambtenaren (toezicht en opsporing) werden geregeld in het Hoofdstuk Handhaving

302

303

304

305

306

307

308

pp. 34-35; TK 1976-1977, 13 364, nrs. 5-6, pp. 77-78.

TK 1988-1989, 21 246, nr. 3, p. 3.

TK. 1982-1983, 17931 , nr. 4.

TK 1983-1984, 18100 , hoofdstuk XI, nr. 2.

Indicatief Mcerjarenprogramma Milieubeheer 1986-1990, TK 1985-1986, 19 204, nrs. $1-2$.

TK 1988-1989, 21 246, nr. 3, p. 3.

TK 1991-1992, 21 246, nr. 6, p. 1; zie ook hoofdstuk 9 paragraaf 2.3.

Zie considerans van de Wet van 13 mei 1993 tot uitbreiding en wijziging van de Wm,

309 Zie over de versterking van de handhavingsmogelijkheden $T K$ 1988-1989, 21246 , nrs. 3, pp. 89-90; TK 1988-1989, 21 246, nrs. 3, p. 90; Ter versterking van de handhavingsmogelijkheden werd onder andere de zorgplichtbepaling opgenomen, zie $T K$ 1991-1992, 21246 , nr. 5, p. 71. 
van de Wm en in de Wed. ${ }^{310}$ De bestuursrechtelijke handhavingsmiddelen werden zo aangevuld door de strafrechtelijke handhavingsmiddelen, met name, doch niet uitsluitend, via de Wed. Indien daartoe de noodzaak zou bestaan kon daarnaast ook het civiele recht uitkomst bieden. ${ }^{311}$

Het centaal uitgangspunt van het afvalstoffenbeleid werd dat in beginsel een ieder die afvalstoffen produceert of doet ontstaan ook zelf verantwoordelijk is voor een milieu. hygiënisch verantwoorde en doelmatige verwijdering ervan. De overheid behield een taak bij de organisatorische kant van het ontstaan en verwijderen van afvalstoffen, omdat zonder zijn sturing de doelstelling van het milieubeleid, namelijk het zoveel mogelijk voorkomen en beperken van de milieubelasting, niet zou worden gerealiseerd. De mate en vorm van overheidsbemoeienis zouden afhangen van de mate waarin economische en maatschappelijke processen in staat zijn deze doelstellingen te verwezenlijken. ${ }^{312}$

Het wetsvoorstel werd opgezet als een kaderwet, die zijn vorm zou krijgen naarmate er meer amvb's en provinciale verordeningen zouden worden afgekondigd ${ }^{313}$ Daamaast verdeelde de wet diverse bevoegdheden ${ }^{314}$ De provincie werd in het kader van de afvalstoffenwetgeving het bevoegde overheidsniveau, maar ook gemeenten kregen een rol, aangezien bevoegdheden niet aan een hoger bestuursniveau werden toegekend dan woor de bescherming van het milien noodzakelijk is. ${ }^{315}$ Voorts kreeg de minister, in geval van ongewone omstandigheden in individuele gevallen, de bevoegdheid passende maatregelen te treffen. ${ }^{316}$

\subsubsection{Artikel $10.3 \mathrm{Wm}$}

In het voorstel van wet tot uitbreiding en wijziging van de Wabm (Aw) was in artikel 7.1 een zorgplichtbepaling opgenomen luidende ${ }^{317}$ :

310 TK 1991-1992, 21 246, nr. 5, p. 70.

311 TK 1991-1992, 21246, nr. 5, pp. 70 en 76.

312 TK 1988-1989, 21246, nr. 3, p. 31.

313 TK 1988-1989, 21246, nr. 4, p. 5.

314 TK 1991-1992, 21246, nr. 5, p. 18.

315 TK 1988-1989, 21 246, nrs. 3, p. 33. De provinciale overheid krijgt bij de handhaving, ondersteund door de regionale inspectie van de milieuhygiêne, zowell richting gemeente als richting rijksoverheid een coördinerende rol, zie TK 1988-1989, 21 246, nr. 3, p. 93; zie over het uitgangspunt dat wat aan een lagere overheid kan worden overgelaten ook moet worden overgelaten hoofdstuk 3 paragraaf 5.3.2. en. hoofdstuk 4 paragraaf 3.

316 TK 1988-1989, 21 246, nr. 3, p. 45.

317 TK 1988-1989, 21 246, nrs. 1-2, pp. 4-5. 
"Degene die zich van afvalstoffen ontdoet, deze inzamelt of anderszins in ontvangst neemt, bewart, bewerkt, verwerkt, vernietigt of op of in de bodem brengt dan wel op andere wijze verwijdert, en die weet of redelijkerwijs had kunnen vermoeden dat door die handelingen het milies in gevaar wordt gebracht, is verplicht alle matregelen te nemen die redelijkerwijs van hem kunnen worden gevergd, teneinde dat gevaar te voorkomen of zoveel mogelijk te beperken."

Involge de wijziging in het voorstel onder $W$ van artikel 13.19 , eerste lid, zou een gedraging in strijd met het bepaalde bij of krachtens artikel 7.1 een misdrijf zijn wanneer zij opzettelijk geschiedt, en in de overige gevallen een overtreding. ${ }^{318}$ Involge artikel IV zou artikel 7.1 worden aangehaakt aan de Wed, en worden opgenomen in artikel 1 , onder 3 Wed. ${ }^{319}$

In de memorie van Toelichting werd het opnemen van de zorgvuldigheidsnorm uit artikel 7.1 nader toegelicht ${ }^{320}$ :

"Aan de milieuwetgeving ligt van oudsher mede de gedachte ten grondslag dat degene die een bepaalde milieuverontreinigende aktiviteit verricht, verantwoordelijk is om de voor het milieu negatieve gevolgen van die aktiviteit zo veel mogelijk te voorkomen of te beperken. Zo zal degene die afvalstoffen produceert of doet ontstaan in beginsel zelf verantwoordelijk dienen te zijn voor een milieuhygiënisch verantwoorde verwijdering ervan. Met in het hoofdstuk afvalstoffen expliciet opnemen van dit beginsel wordt aangesloten bij een - mede door de afvalstoffenwetgeving - allerwegen gegroeid besef dat onzorgvuldig gedrag met afvalstoffen met als gevolg schadelijke effecten voor mens en milieu in het maatschappelijk verkeer als onbetamelijk dient te worden beschouwd. Het artikel geeft op deze wijze uitdrukking aan de gedachte dat de zorg voor het milieu een gedeelde zorg is: van overheid en burger tezamen."

Aangegeven werd dat een bepaling als deze niet nieuw is in de milieuwetgeving, waarbij werd gewezen op artikel $2 \mathrm{Wms}$ en artikel $14 \mathrm{Wbb}$. Het betreft soortgelijke zorgplichtbepalingen die de verantwoordelijkheid voor het milieu van degene die de activiteiten ontplooit, vastleggen. ${ }^{321}$

Het artikel gaf niet alleen het beginsel weer dat een ieder verantwoordelijk dient om te gaan met het milieu. Het kon ook als vangnet een functie vervullen indien het milieu in het geding is. De behoefte aan deze functie zou zich voor kunnen doen indien voor de betreffende handeling geen regels zijn gesteld, bijvoorbeeld bij handelingen met afvalstoffen die nieuw zijn; dat wil zeggen dat zij bij het opstellen van het wetsvoorstel niet voorzienbaar waren, of als geen gebruik werd gemaakt van een in het wetsvoorstel neergelegde facultatieve bevoegdheid tot regeling omdat zich tot dan toe geen problemen voordeden die het treffen van een algemene regeling nodig maakten. ${ }^{322}$ Ook zou artikel 7.1 aanvullend kunnen werken op die handelingen met afvalstoffen die

\footnotetext{
$318 T K 1988-1989,21246$, nrs. 1-2, p. 21.

319 TK 1988-1989, 21 246, nrs. 1-2, p. 25.

320 TK 1988-1989, 21246 , nr. 3, pp. 29-31.

321 TK 1988-1989, 21 246, nr. 3, p. 29.

322 TK 1988-1989, 21246, nr. 3, pp. 29-30.
} 
door andere wetten worden bestreken, maar op basis waarvan niet kan worden opgetreden als het milieu in het geding is. ${ }^{32.3}$

Voorts werd aangegeven dat van het enkele bestaan van de zorgplichtbepaling in de Wbb een preventieve werking zou uitgaan. ${ }^{324}$ Ook zou het artikel een signaleringsfunctie hebben, aangezien naar aanleiding van de noodzaak om ervan gebruik te maken het ter zake bevoegd gezag gedwongen zou zijn zich af te vragen of dergelijke gevallen voor de toekomst niet moeten worden voorkomen door het stellen van algemene verbindende voorschriften. ${ }^{325}$

Aan de praktijk werd overgelaten op welke wijze tegen overtreding van de zorgplichtbepaling zou worden opgetreden: bestuursrechtelijk, civielrechtelijk en/ of strafrechtelijk. Daarover viel nog niets te zeggen omdat nog geen ervaring was opgedaan met artikel $2 \mathrm{Wms}$ of artikel $14 \mathrm{Wbb}$. Gewezen werd op artikel 25 (oud) WVW, die niet alleen strafrechtelijk maar ook civielrechtelijk regelmatig werd toegepast. Deze bepaling had blijkens de jurisprudentie een ruim toepassingsgebied, en bestreek met name die gedragingen die niet elders in de Wegenverkeerswetgeving zijn geregeld. ${ }^{326}$ De zorgplichtbepaling zou ook een civielrechtelijk aspect hebben, omdat het een nadere invulling zou geven aan de zorgvuldigheidsnorm van artikel 1401 (oud) BW. Wederom werd gewezen op artikel 25 (oud) WVW dat ook in civielrechtelijike handhavingsacties een belangrijike rol speelde. ${ }^{327}$

De Raad van State had geen bezwaar tegen de zorgplichtbepaling, mede gelet op het feit dat het geenszins zou misstaan als het hoofdstuk waarin de moeilijk te reguleren afvalstromen werden geregeld, zou aanvangen met een legislatieve waarschuwing dat iedere Nederlander mede verantwoordelijk is voor een zorgvuldige behandeling van de afvalstoffen. ${ }^{328}$ De reactie van de regering was dat tegen de achtergrond van de met artikel 25 (oud) WVW opgedane ervaring, artikel 7.1 geen vrijblijvende waarschuwing zou zijn. ${ }^{329}$

De Raad van State had geen grote verwachtingen van een strafrechtelijke functie van het artikel, waarbij hij wees op de in het BW te introduceren risico-aansprakelijkheid voor gevaarlijke afvalstoffen dat op civielrechtelijk gebied deels kan bewerkstelligen wat artikel 7.1 beoogt. Bij de strafrechtelijke toepassing van het artikel voorzag hij bewijsproblemen, maar wees er meteen op dat ook elders in de wetgeving zorgplichtbepalingen, artikel 25 (oud) WVW, 13 Luchtvaartwet, 2 Wms en $14 \mathrm{Wbb}$, zijn

323 TK 1991-1992, 21246 , nr. 5, p. 33.

324 TK 1988-1989, 21246 , nr. 3, p. 30.

325 TK 1988-1989, 21246, nr. 3, p. 31 ,

326 TK $1988-1989,21246$, nr. 3, p. 30.

$327 T K 1988-1989,21246$, nr. 3, p. 30 . Deze opvatting werd tijdens de parlementaire behandeling betwist. Zie over de discussie die vooral betrekking heeft op de rol van de voorzienbaarheid van de schade in het civiel recht onder andere TK 199!-1992, 21 246, nr. 5, p. 45.

328 TK 1988-1989, 21246, A, pp. 4-5.

329 TK 1988-1989, 21246 , A, p. 4. 
opgenomen. Opgemerkt werd dat met beide laatste voorbeelden op dat moment nog geenervaring is opgedaan, maar dat artikel 25 WVW geen dode letter is gebleven. ${ }^{330}$ Naaraanleiding van zijn advies werden in de memorie van toelichting enkele ervaringen spgenomen met artikel 25 (oud) WVW.

Tijdens de behandeling van het wetsvoorstel komt de Commissie voor de toetsing van wetgevingsprojecten met haar advies over zorgplichtbepalingen. Zij stelde ten aanzien van let voorgestelde artikel 7.1 dat door de gebruikte formulering deze bepaling niet kan vorden gehandhaafd, omdat de formulering rechtsonzekerheid creëert en bewijslastpoblemen zou opleveren. De functie van het artikel werd aangeduid als ${ }^{331}$

"het lastleggen van een voor de individuele burger geldende zorgplicht en het mogelijk maken van o)treden in die gevallen waarin het milieu schade wordt toegebracht en de overige artikelen van hit wetsvoorstel onvoldoende soelaas bieden."

Ondanks dat hierdoor (aldus de memorie van toelichting) de zorgplichtbepaling niet andes dan (tamelijk) ruim van opzet kan zijn, werd gezocht naar mogelijkheden tot exactere formulering. Dit leidde ertoe dat de handelingen waarop de zorgplicht betrelking heeft specifieker in het artikel werden opgenomen. ${ }^{332}$ De aanscherping van de fomulering van het artikel zou overigens geen afbreuk doen aan de fundamentele beteknis van de zorgplicht. ${ }^{333}$ Tevens werden in navolging van het advies van de Commissie enige beperkingen aangebracht. Op degene die zich ontdoet van afvalstoffen rust slechts de verplichting om na te gaan of de afvalstoffen die hij afgeeft, wat betreft aard en samenstelling zijn genoemd in de vergunning van de ontvanger. Aan deze verplichting zou op redelijk eenvoudige wijze uitvoering kunnen worden gegeven, en een dergelijke verplichting zou in het maatschappelijk verkeer kunnen worden verlangd van degene die zich van deze stoffen ontdoet. Gesteld werd dat uit het voorgestelde artikel 7.1 voortvloeit dat in het concrete geval degene die afvalstoffen afgeeft een zo groot mogelijke zorgvuldigheid aan de dag dient te leggen. Ingeval hij bijvoorbeeld zijn afvalstoffen afgeeft om te bewaren, kan de zorgvuldigheid vereisen dat hij zich vergewist van de uiteindelijke bestemming van de afvalstoffen. Ook kan de zorgvuldigheid vereisen dat men zich afvraagt of een redelijke prijs (niet veel lager dan de gebruikelijke) voor het zich ontdoen wordt betaald. ${ }^{33}$.

In de Nota van wijziging werd hoofdstuk 7 vernummerd tot hoofdstuk 10, waarbij de aanduidingen van onderdelen en artikelen van dit hoofdstuk en de in die artikelen voorkomende verwijzingen naar die onderdelen of artikelen dienovereenkomstig

TK 1988-1989, 21 246, A, pp. 4-5.

TK 1988-1989, 21 246, nr. 3, p. 31.

TK 1988-1989, 21 246, nr. 3, p. 31.

TK 1988-1989, 21 246, nr. 3, p. 104.

TK 1988-1989, 21 246, nr. 3, p. 112. 
werden gewijzigd. Hierdoor werd artikel 7.1 , artikel $10.1 \mathrm{a}^{335}$, waarna het opnieuw werd vernummerd tot $10.1 \mathrm{~b} \mathrm{Wm}{ }^{336}$, luidende:

"1. Het is een ieder bij wie in de uitoefening van zijn beroep of bedrijf afvalstoffen ontstaan, verboden handelingen met betrekking tot die afvalstoffen te verrichten of na te laten waarvan hij weet of redelijkerwijs had moeten weten dat daardoor nadelige gevolgen voor het milieu ontstaan of kunnen ontstaan, behoudens voor zover dat krachtens een voor hem geldende vergunning uitdrukkelijk is toegestaan.

2. Het is een ieder verboden in de uitoefening van zijn beroep of bedrijf afvalstoffen in te zamelen of anderszins in ontvangst te nemen, te bewaren, te bewerken, te verwerken, te vernietigen of op of in de bodem te brengen dan wel op andere wijze te verwijderen, indien daardoor, naar hij weet of redelijkerwijs had moeten weten, nadelige gevolgen voor het milieu ontstaan of kunnen ontstaan, behoudens voor zover dat krachtens een voor hem geldende vergunning uitdrukkelijk is toegestaan."

Artikel $10.1 \mathrm{~b}$ werd in 1993 in de Wm opgenomen ${ }^{337}$ en was, na opnieuw een omnummering, in dezelfde bewoording terug te vinden in artikel $10.3 \mathrm{Wm}$. In 1997 zijn de bepalingen inzake afvalstoffen uit de Wet milieubeheer gedeeltelijk gewijzigd. Deze wijziging werd al zeer snel na de inwerkingtreding van de wet (die plaatsvond op 1 januari 1994) nodig geacht. De wijzigingen hadden gedeeltelijk een juridischtechnisch karakter en betroffen deels wijzigingen die voortkwamen uit de twee jaar praktijkervaring met het hoofdstuk Afvalstoffen. ${ }^{338}$ Voorgesteld werd ook de zorgphichtbepaling ut artikel $10.3 \mathrm{Wm}$ te wijzigen. De toevoeging "behoudens voor zover dat krachtens een voor hem geldende vergunning uitdrukkelijk is toegestaan" zou dienen te worden vervangen door een aparte zin "Het verbod geldt niet voor zover het betreft zodanige handelingen die hem bij of krachtens de wet uitdrukkelijk zijn toegestaan." Als reden hiervoor werd alleen gegeven ${ }^{339}$ :

"Ten onrechte was echter niet expliciet voorzien in de situatie waarin er geen vergunningplicht geldt in het kader van de Wet milieubeheer, maar er wel een bevoegdheid is om handelingen te verrichten waardoor nadelige gevolgen voor het milieu kunnen ontstaan. Het gaat hier bijvoorbeeld om krachtens artikel 8.40 bij algemene maatregel van bestuur vastgestelde regels ten behoeve van specifiek aangewezen categorieên van inrichtingen. Ingevolge artikel 8.I, tweede lid, geldt voor dergelijke inrichtingen niet de in artikel \&.1, eerste lid, vastgelegde vergunningplicht. Met de voorgestelde wijziging van artikel 10.3 wordt voorzien in deze lacune."

De voorgestelde wijziging van artikel $10.3 \mathrm{Wm}$ werd niet besproken in het advies van de Raad van State. Ook tijdens de parlementaire behandeling van het wetsvoorste] werd niet ingegaan op deze voorgestelde wijziging. Het voorstel werd zonder

TK. 1991-1992, 21 246, nr. 6, p. 4.

336 TK. 1991-1992, 21 246, nr. \&, p. 6; TK 19911-1992, 21 246, nr. 10, p. 3.

337 Wet van 13 mei 1993 tot uitbreiding en wijziging van de Wet milieubeheer (afvalstoffen), Stb. 1993, 283.

338 TK 1995-1996, 24 875, nr. 3, p. 1 en TK 1 mei 1997, p. 76-5356.

339 TK. 1995-1996, 24875 , nr. 3, p. 4. 
berodslaging aangenomen ${ }^{340}$, zodat het artikel $10.3 \mathrm{Wm}$ sinds deze wijziging in 1997 luid":

"1. Het is een ieder bij wie in de uitoefening van zijn beroep of bedrijf afvalstoffen ontstaan, verboden handelingen met betrekking tot die afvalstoffen te verrichten of na te laten waarvan hij weet of redelijkerwijs had moeten weten dat daardoor nadelige gevolgen voor het milieu ontstaan of kunnen ontstaan. Het verbod geldt niet voor zover het betreft zodanige handelingen die hem bij of krachtens de wet uitdrukkelijk zijn toegestaan.

2. Het is een ieder verboden in de uitoefening van zijn beroep of bedrijf afvalstoffen in te zamelen of anderszins in ontvangst te nemen, te bewaren, te bewerken, te verwerken, te vernietigen of op of in de bodem te brengen dan wel op andere wijze te verwijderen, indien daardoor, naar hij weet of redelijkerwijs had moeten weten, nadelige gevolgen voor het milieu ontstaan of kunnen ontstaan. Het verbod geldt niet voor zover het betreft zodanige handelingen die hem bij of krachtens de wet uitdrukkelijk zijn toegestaan."

De argplicht van artikel 10.3, eerste lid Wm omvat gezien de gebruikte alternatieven 16 vischillende situaties. De zorgplicht van artikel 10.3 , tweede lid Wm omvat gezien de goruikte alternatieven 64 verschillende situaties.

Op de gedragingen die in strijd zijn met hoofdstuk $10 \mathrm{Wm}$ werd, zoals dat vrijwel overl in de milieuwetgeving op dat moment al het geval was, het stelsel van de Wed van sepassing verklaard. ${ }^{342}$ Dit gold ook voor de zorgplichtbepaling uit artikel 10.3 Wm.

Bij de invoering werd artikel 18.19 eerste lid Wm gewijzigd en kwam te luiden ${ }^{343}$ : "Een gedraging in strijd met het bij of krachtens artikel (...) $10.1 \mathrm{~b}(\ldots)$ bepaalde is een misdrijf, wanneer zij opzettelijk geschiedt, en overigens een overtreding." Inmiddels is deze bepaling vervallen en is artikel $10.3 \mathrm{Wm}$ aangehaakt bij artikel la sub $1 \mathrm{Wed}^{344}$ Involge artikel 2, eerste lid Wed betreft het een misdrijf indien het opzettelijk is begaan, en is het in de overige gevallen een overtreding.

Overigens is in het voorstel van wet "Wijziging van de Wet milieubeheer (structuur wijziging afvalstoffen)" voorzien in (opnieuw) een wijziging van artikel $10.3 \mathrm{Wm}$. Het betekenisbereik van deze zorgplichtbepaling zal bij deze wijziging verder worden uitgebreid. Naar verwachting zal het artikel worden vernummerd tot artikel $10.1 \mathrm{Wm}$.

340 EK 4 november 1997, p. 4-90.

341 Dit gebeurde bij Wet van 6 november 1997 tot wijziging van de Wet milieubeheer (bepalingen inzake afvalstoffen), Stb. 1997, 533. Zie over deze wijziging hoofdstuk 9 paragraaf 3.4.6.

342 TK 1988-1989, 21246, A, p. 30.

343 Zie hierover TK 1991-1992, 21 246, nr. 5, p. 95.

344 Zie over de Wed in het algemeen hoofdstuk 8 paragraaf 2.5. en over artikel la Wed hoofdstuk 9 paragraaf 2.4 .

345 Zie TK 1998-1999, 26 638, nrs. 1-2, pp. 6-7 en nr. 3, p. 38. 


\subsubsection{Artikel 1.1a Wm}

Tijdens de parlementaire behandeling van de integratie van de Afvalstoffenwet in de Wet milieubeheer werd voorgesteld om in het kader van het onderzoek naar de toekomstige structuur van de Wabm ook de vraag op te nemen of de verschillende zorgplichten kunnen worden samengevoegd tot één geheel, en deze samenvoeging op te nemen als eerste artikel na de begripsomschrijvingen in de Wabm. Hierbij werd gewezen op de opmerking van de minister bij de parlementaire behandeling van de Wbb, die zich toen had uitgesproken voor het opnemen van een brede algemene zorgplicht in het kader van de uitbouw van de Wabm. ${ }^{346}$ Voorts werd de vraag gesteld of het niet mogelijk is om de zorgplicht thans in de Wabm te regelen, en de in de andere milieuwetten geregelde zorgplichten daarin op te laten gaan. ${ }^{3}$

Na de aanscherping van de formulering van de zorgplichtbepaling naar aanleiding van het advies van de Commissie werd nogmaals de wens geuit, ook in de Wm een algemene zorgplichtbepaling op te nemen. ${ }^{348}$ Juist omdat de specificering van de zorgvuldigheidsnorm ook de civielrechtelijke en bestuursrechtelijke betekenis van de bepaling ingeperkt, kan er reden zijn om een algemene zorgvuldigheidsnorm in de Wm op te nemen. Mede naar aanleiding van de positieve reacties van de Raad van State en van de verschillende fracties op de zorgvuldigheidsnorm werd onderzocht of tot een aanvaardbare formulering van een dergelijke algemene bepaling kan worden gekomen. ${ }^{349}$

In het eindverslag werd aangegeven dat het werd betreurd dat het normstellend karakter van het wetsvoorstel nog niet verder is opgetuigd, onder andere omdat de eerder gedane suggestie tot het opnemen van een algemene zorgplicht (nog) niet is gehonoreerd. Wel werd met enig genoegen kennis genomen van het voorzichtig positieve standpunt van de regering ten aanzien van het opnemen in de Wm van een algemene zorgplichtbepaling. In de Nadere memorie van toelichting werd zelfs aangegeven dat een dergelijke algemene bepaling eigenlijk niet kan worden gemist. Opnieuw werd aangedrongen op het opnemen van deze bepaling, waarbij werd opgemerkt dat de formulering van zo'n algemene bepaling niet op zulke grote problemen zou kunnen stuiten dat dit niet voor de plenaire behandeling van het wetsvoorstel mogelijk zou zijn. ${ }^{350} \mathrm{Er}$ werden (opnieuw) vragen gesteld over de noodzaak van een algemene zorgplichtbepaling in de $\mathrm{Wm}^{351}$ en hoe de regering, de toekomstige zorgplichtbepaling wettelijk wil vastleggen, in een wetswijziging of per amvb. ${ }^{352}$ De

346

347

350

351

352
TK 1988-1989, 21246 , nr. 4, p. 24.

TK 1989-1990, 21246 , nr. 4, p. 46.

TK 1991-1992, 21 246, nr. 8, pp. 4 en 6.

TK 1991-1992, 21 246, nr. 5, pp. 7 en 43; TK 1991-1992, 21 246, nr. 6, p. 25. Wanneer hierover een standpunt te verwachten is werd niet aangegeven, zie ook TK 1991-1992, 21 246, nr. 9, pp. 18-19; TK 1991-1992, 21 246, nr. 10, pp. 29-30.

TK 1991-1992, 21 246, nr. 13, pp. 2 en 11.

TK 1991-1992, 21 246, nr. 13, p. 11.

TK 1991-1992, 21 246, nr. 13, p. 11. 
miniser ging hier niet op in. ${ }^{353}$ Wel merkte hij op dat hij zeer hecht aan een algemene zorgplichtbepaling in de Wm, maar daarover nog in gesprek is met zijn ambtgenoot van Justitie. Ook gaf hij aan niet vooruit te willen lopen op de discussie in het kader van ket (te bepalen) regeringsstandpunt inzake een algemene zorgvuldigheidsnorm, die op dat moment in voorbereiding zou zijn. ${ }^{354}$ Dit regeringsstandpunt is, zoals werd aangegeven, tot op heden niet verschenen.

De parlementsleden Willems en Schimmel dienden hierop op 22 september 1992 een amendement in, waarin zij voorstelden in artikel 1 na onderdeel A een onderdeel in te voegen luidende ${ }^{355}$ :

"Artikel 1.1a

1. Een ieder dient voldoende zorg voor het milieu in acht te nemen.

2. De zorg, bedoeld in het eerste lid, houdt in ieder geval in dat een ieder die weet of redelijkerwijs kan vermoeden dat door zijn handelen of nalaten nadelige gevolgen voor het nilieu kunnen worden veroorzaakt, verplicht is dergelijke handelen achterwege te laten en alle maatregelen te nemen die redelijkerwijs van hem kunnen worden gevergd, teneinde die nadelige gevolgen te voorkomen of, voor zover de nadelige gevolgen niet kunnen worden voorkomen, zoveel mogelijk te beperken en ongedaan te maken.

3. Het eerste en tweede lid laten onverlet de uit het burgelijk recht voortvloeiende ansprakelijkheid en de mogelijkheid van de overheid om uit dien hoofde in rechte op te treden.

Toelichting

De laatste jaren is er sprake van een toenemend bewustzijn dat een ieder gehouden is voldoende zorg voor het milieu te betrachten. Dit besef is onder meer in het NMP en het NMP-plus tot uitdrukking gebracht. De Wet milieubeheer biedt een kader voor voorschriften met het oog op het voorkomen van nadelige gevolgen voor het milieu. In deze wet past dan ook een codificatie van de eigen verantwoordelijkheid van een ieder voor een schoon milieu. Een algemene zorgplichtbepaling zal voorts een functie vervullen in het kader van het aanspreken van personen op die eigen verantwoordelijkheid. Het komt inmers regelmatig voor dat met het verrichten van een milieugevaarlijke activiteit specifiek omschreven milieuvoorschriften niet worden overschreden, terwijl degene die de activiteit verricht wel een verwijt kan worden gemaakt. Om in een dergelijke situatie de betreffende persoon toch aan te kunnen spreken op zijn gedrag is het opnemen van een zorgplicht in de Wm noodzakelijk."

In de zesde nota van wijziging van 24 september 1992 werd het voorgestelde artikel 1.la grotendeels overgenomen. In het tweede nader gewijzigde voorstel van wet werd, na artikel 1.1, een artikel ingevoegd luidende ${ }^{356}$ :

\footnotetext{
353 Zie nota naar aanleiding van het eindverslag, $T K$ 1991-1992, 21 246, nr. 14.
354 TK 1991-1992, 21 246, nr. 14, p. 23.

355 TK 1992-1993, 21246 , nr. 27, pp. 1-2.

356 TK 1992-1993, $21246, \mathrm{nr} .37$, pp. 1 en 3.
} 
"Artikel 1.1a

I Een ieder neemt voldoende zorg voor het milieu in acht.

2. De zorg, bedoeld in het eerste lid, houdt in ieder geval in dat een ieder die weet of redelijkerwijs kan vermoeden dat door zijn handelen of nalaten nadelige gevolgen voor het milieu kunnen worden veroorzaakt, verplicht is dergelijk handelen achterwege te laten voor zover zulks in redelijkheid kan worden gevergd, dan wel alle maatregelen te nemen die redelijkerwijs van hem kunnen worden gevergd teneinde die gevolgen te voorkomen of, voor zover die gevolgen niet kunnen worden voorkomen, deze zoveel mogelijk te beperken of ongedaan te maken.

3. Het bepaalde in het eerste en tweede lid laat onverlet de uit het burgelijk recht voortvloeiende aansprakelijkheid en de mogelijkheid van rechtspersonen als bedoeld in artikel 1, Boek 2, van het Burgelijk Wetboek, om uit dien hoofde in rechte op te treden."

(...)

Toelichting (...)

"Dit nieuwe artikel kan worden beschouwd als een codificatie van de eigen verantwoordelijkheid van een ieder om zorg te dragen voor een schoon milieu. Deze bepaling past goed bij het karakter van de Wet milieubeheer, waarin die eigen verantwoordelijkheid mede tot uiting komt. Voorts bestaat aan een algemene zorgplichtbepaling behoefte om op te kunnen treden tegen milieubedreigend gedrag. Het komt immers voor dat met het verrichten of nalaten van een activiteit specifiek omschreven milieuvoorschriften niet worden overtreden, terwijl degene die de activiteit verricht, dan wel nalaat wel het verwijt kan worden gemaakt dat hij zich maatschappelijk onbetamelijk heeft gedragen. In dergelijke gevallen kan op grond van de onderhavige bepaling worden opgetreden. Daarbij moet worden aangetekend dat de bepaling niet strafrechtelijk, maar vooral civielrechtelijk gehandhaafd zal worden."

In het eindverslag werd de vraag gesteld of deze algemene zorgplicht nog gevolgen moet hebben voor de zorgplichtbepaling in de $\mathrm{Wbb}^{337}$ De minister gaf aan dat artikel 1.1 a Wm een algemeen geformuleerde bepaling is die ertoe strekt het milieu in zijn totaliteit te beschermen. Deze bepaling zal niet strafrechtelijk maar vooral civielrechtelijk worden gehandhaafd. Artikel $14 \mathrm{Wbb}$ daarentegen richt zich op handelingen als bedoeld in de artikelen 8 tot en met 13 Wbb en strekt tot bescherming van de bodem, en kan strafrechtelijk worden gehandhaafd. Artikel 1.1a Wm omvat een generale en artikel 14 Wbb een speciale regeling, hetgeen betekent dat bij verontreiniging van de bodem, onderdeel van het te beschermen milieu als bedoeld in het genoemde artikel $1.1 \mathrm{a} \mathrm{Wm}$, door de overheid zelf actie zal worden ondernomen dit in vrijwel alle gevallen op grond van de Wbb zal geschieden. Zou de Wbb in een concrete situatie niet kunnen worden toegepast, dan kan van artikel 1.1a Wm gebruik. worden gemaakt. Artikel 1.1a Wm fungeert dus in zoverre als vangnet. Daamaast zal het, evenals artikel $14 \mathrm{Wbb}$, door justitiabelen kunnen worden aangegrepen om in een civiele procedure op te komen tegen andere justitiabelen, die zich schuldig maken aan bodemverontreiniging. 358

TK 1991-1992, 21556, nr. 18, pp. 2-3.

$358 T K 1991-1992,21556, \mathrm{nr} .21$, p. 22. De civielrechtelijke betekenis van deze bepaling is echter maar gering ten gevolge van artikel 6:6i2 BW, zie bijvoorbeeld Bauw, E., "De privaatrechtelijke betekenis van zorgplichten in de milieuwetgeving", pp. 96-102; Acht, 
De alemene zorgplicht uit artikel 1.1a Wm is in de wet van 13 mei 1993 tot uitbreling en wijziging van de Wet milieubeheer (afvalstoffen) opgenomen. ${ }^{359}$ Het cerste id bevat de zorgplicht, terwijl het tweede lid (niet limitatief) aangeeft wat deze zorgpicht in ieder geval inhoudt. Het derde lid geeft aan dat deze zorgplicht de privaarechtelijke handhavingsmogelijkheden niet aantast. Schending van deze bepalig werd (zonder enige discussie) niet strafbaar gesteld. ${ }^{360}$ Evenmin werd ingegan op de al dan niet bestuursrechtelijke of civielrechtelijke meerwaarde van deze kpaling, noch werd het in werking blijven van de reeds bestaande zorgplichtbepaligen ter discussie gesteld. Zij zijn dan ook niet ingetrokken, noch opgegaan in deze agernene zorgplicht.

\subsubsection{De zorgplichtbepaling uit artikel $10.3 \mathrm{Wm}$ nader beschouwd}

Het vorgestelde artikel $7.1 \mathrm{Wm}$ richtte zich tot een ieder die bepaalde handelingen verrict. De Commissie toetsing voor wetgevingsprojecten geconcludeerde dat zorgpchtbepalingen met een specificatie naar beroeps- of bedrijfsmatig handelen in het alemeen meer inzichtelijk zijn dan bepalingen die tot een ieder gericht zijn. Tegen deze zhtergrond werd de zorgvuldigheidsnorm uit artikel 7.1 toegespitst op beroepsof becijfsmatig handelen. ${ }^{361}$ In het bijzonder met het oog op het legaliteitsbeginsel werd et oorspronkelijk voorgestelde artikel te ruim geacht. ${ }^{362}$ Opgemerkt werd dat door le toespitsing de strafrechtelijke handhaafbaarheid van deze bepaling werd verbeterd. De zorgplichtbepaling richt zich hierdoor tot degene die in de uitoefening van zijn beroep of bedriif bepaalde gedragingen verricht. Het artikel heeft daardoor betrekking op alle beroeps- en bedrijfsmatige handelingen met afvalstoffen. Hieronder is bijvoorbeeld ook het beroepsgoederenvervoer begrepen. Aangezien bij deze groep geen sprake is van "inzamelen" van afvalstoffen, werd het artikel uitgebreid met de zinsnede "of anderszins in ontvangst te nemen". ${ }^{363}$

R.J.J. van en Bauw, E., Milieuprivaatrecht, pp. 35-68; Bauw, E., Buiten-contractuele aansprakelijkheid voor bodemverontreiniging, 1994, pp. 103-180; Drupsteen, Th.G., "Aansprakelijkheid voor milieuschade", p. 278; Betlem, G. en Messer, E.A., "Aansprakelijkheid voor milieuschade: een reactie", pp. 522-523.

359 Sib. 1993, 283.

360 Zie over de (bestuursrechtelijke) handhaving van artikel 1.1a Wm: Jong, P., Handhaafbaar milieurecht, pp. 244-264; Bastmeijer, C.J., "De algemene zorgplicht in de Wet milieubeheer", pp. 446-475; Teunissen J.M.H.F. en Tak, A.Q.C., "Recht ist was der Umwelt nützt?", pp. 605-616; Tak, A.Q.C. en Teunissen J.M.H.F., "Wie zorgt er voor de rechtsstaat? Een voortgezet debat", pp. 340-354; Lambers, C., "Een algemene zorgplicht voor het milieu", pp. 1006-1007; Verschuuren, J.M., "Het belang van algemene normen in het milieurecht", pp. 1007-1008; Veen, G. van der, "Recht ist was der Uinwelt nützt?", pp. 1008-1010.

361 Zie hierover ook TK 1991-1992, 21 246, nr. 9, p. 19. Opgernerkt werd dat cen te ruime toepassing van de zorgplicht deze als het ware zou uithollen en niet meer handhaafbaar zou zijn, aangezien een te ruim geformuleerde norm zich in feite tot niemand richt. De burger, die zich natuurlijk ook zorgvuldig op het onderhavige terrein dient te gedragen, kan voldoende worden aangesproken via het $\mathrm{BW}$.

$362 T K 1991-1992,21246$, nr. 10, pp. 29-30.

363 TK 1991-1992, 21246 , nr. 10, p. 30. De Raad van State had aangegeven dat het wense- 
De opsomming van gedragingen wordt afgesloten met dan wel op andere wijze te verwijderen. Deze toevoeging werd opgenomen "omdat enerzijds het wetsvoorstel sommige handelingen die in het kader van de verwijdering van afvalstoffen een rol spelen niet expliciet regelt (men denke aan het vervoeren, de makelaars-functie uitoefenen) en anderzijds van te voren ook niet alle soorten handelingen zijn te voorzien". 364

Aanvankelijk was in het wetsvoorstel uitbreiding van de Wm geen definitie van het begrip afvalstof opgenomen, omdat het niet mogelijk leek het begrip op een zodanige wijze te definiëren dat alle relevante factoren werden meegenomen. ${ }^{365} \mathrm{Na}$ aandringen uit de $\mathrm{Kamer}^{366}$, werd in artikel $1.1 \mathrm{Wm}$ toch een definitie opgenomen. Deze definitie luidt: "afvalstoffen: alle stoffen, preparaten of andere produkten, waarvan de houder zich - met het oog op de verwijdering daarvan - ontdoet, voomemens is zich te ontdoen of zich moet ontdoen". ${ }^{367}$ De definitie sluit grotendeels ${ }^{368}$ aan bij die uit de EG-richtlijn afvalstoffen. ${ }^{369}$ Gezien de grote invloed van het Europees recht op de nationale wet- en regelgeving inzake afvalstoffen, lijkt er nauwelijks ruimte om af te wijken van de Europese invulling van deze term uit de richtlijn en de interpretatie daarvan door het Europese Hof.

Ten aanzien van de formules weet of redelijkerwijs had kunnen vermoeden en maatregelen die redelijkerwijs van hem kunnen wonden gevergd werd opgemerkt dat deze ook staan in artikel $2 \mathrm{Wms}$ en $14 \mathrm{Wbb}$, almede in andere wetten. De invulling is blijkens de MvT onder meer afhankelijk van de individuele omstandigheden, de kwaliteiten en de hoedanigheid van de handelende persoon. Zo zal het niveau van kennis van de verdachte een rol spelen bij de beoordeling welke maatregelen redelijkerwijs van hem kunnen worden gevergd. Maar ook geldt dat aan grotere producenten van chemisch afval en aan afvalverwijderingsbedrijven strengere en vergaande eisen mogen worden gesteld dan aan het afvalproducerende huishouden. ${ }^{370}$ De zorgplichtbepaling is door haar strekking tamelijk ruim van opzet. Door het gebruik van de term

364

365

366

367 Zie over het begrip afvalstoffen HR 29 november 1994, MenR 1995, nr. 73, met noot De Lange (Afgeleverde afvalstoffen).

368 Zie hierover ook het wetsvoorstel wijziging van de Wet milieubeheer (structuur verwijdering afvalstoffen), TK 1998-1999, nr. 3 en Tieman, J.R.C., "Het ruime begrip afvalstof", pp. 229-236.

369 Kaderrichtlijn afvalstoffen 75/442/EEG (PbEG i975 L 1194/47), herzien bij 91/156/EEG (PbEG 1991 L 78/32), zie TK 1991-1992, 21 246, nr. 5, p. 5. De richtlijn gaat uit van een ruime interpretatie, zie TK 1991-1992, 21 246, nr. 10, p. 20, zie hierover. Nijenhuis, C.T., in Wet milieubeheer; Tekst en Commentaar, pp. 7-9.

370 TK 1988-1989. 21246 , nr. 3, p. 105. 
redelijkerwijs werd aangegeven dat de werking van het artikel te modificeren is naar een voor de betreffende justitiabele aanvaardbaar niveau. ${ }^{371}$ Tijdens de parlementaire behandeling werd opgemerkt dat het leveren van bewijs niet eenvoudig zou zijn indien de verdachte hetzij uit onwetendheid, hetzij door bijvoorbeeld gebrekkige middelen tekort is geschoten in het nemen van de nodige maatregelen. In dergelijke gevallen zal de bewijsvoering zich moeten richten op datgene wat de verdachte redelijkerwijs had kumnen vermoeden en op datgene wat van iemand in een vergelijkbare situatie als die van de verdachte mag worden gevergd. ${ }^{372}$

Naar sanleiding van het advies van de Raad van State werd het artikel uitgebreid tot het voorkomen van gevaar, waarbij werd gedoeld op de situatie dat het gevaar zich nog niet daadwerkelijk heeft gemanifesteerd. Hierbij werd gewezen op artikel 14 Wbb. ${ }^{373} \mathrm{Er}$ is sprake van gevaar voor het milieu indien er duidelijk nadelige gevolgen voor het milieu zijn aan te wijzen, waardoor het milieu schade kan worden berokkend. $^{374}$ Het bestanddeel gevaar werd vervangen door nadelige gevolgen voor het milieu ontstaan of kunnen ontstaan.

De zorgplichten in het eerste en het tweede lid van artikel $10.3 \mathrm{Wm}$ gelden niet absoluut. Aan de bepalingen was bij de invoering de passage toegevoegd dat deze gelden behoudens voor zover dat krachtens een voor hem geldende vergunning uitdrukkelijk is toegestaan. Aangezien deze strafuitsluitingsgrond zowel in het eerste als in het tweede lid was opgenomen in dezelfde zin waarin het verbod was vervat, diende deze conform het "formele criterium" en het in het strafproces gehanteerde uitgangspunt in dubio pro reo te worden aangemerkt als bestanddeel. ${ }^{3 / 5}$ Fokkens concludeerde echter ${ }^{376}$

"na enige aarzeling, de passage (...) te beschouwen als een strafuitsluitingsgrond. De vergunning heeft zozeer een uitzonderingskarakter, dat deze uitleg mijns inziens het meest recht doet aan het verbod dat in art. 10.3 is geformuleerd."

De Hoge Raad heeft zich over dit punt niet uitgesproken. Indien de opvatting van Fokkens zou zijn gevolgd waardoor de passage niet wordt aangemerkt als bestanddeel zal bij het handelen conform een vergunning de wederrechtelijkheid ontbreken en sprake zijn van een bijzondere strafuitsluitingsgrond. Op iemand die niet beschikte over een vergunning, maar de handeling rechtstreeks krachtens wettelijk voorschrift verrichtte of naliet was de bijzondere strafuitsluitingsgrond uit artikel $10.3 \mathrm{Wm}$ niet

\footnotetext{
371 TK 1988-1989, 21 246, nr. 3, p. 105.

372 TK 1991-1992, 21 246, nr. 5, pp. 43-44.

373 TK 1988-1989, 21246, A, p. 5.

374 Gewezen werd op de mogelijkheid on bij zeer emstige verontreinigingen van het milieu, ook op grond van de (toekomstige) artikelen 173a en 173b Sr op te kunnen getreden, TK 1988-1989, 21 246, nr. 3, p. 105.

375 Zie hoofdstuk 4 paragraaf 6.

376 Zie HR 23 april 1996, NJ 1996, 512 (Waterschap Westfriesland) De Hoge Raad heeft over dit punt geen oordeel gegeven, aangezien het $\mathrm{OM}$ niet ontvankelijk werd verklaard in zijn vervolging. Zie over deze zaak hoofdstuk 6 paragraaf 5.5 .
} 
van toepassing. Ook dan zou sprake zijn van een bijzondere (geschreven) strafuitsluitingsgrond, aangezien de wederrechtelijkheid als element van de strafbaarstelling zou ontbreken ten gevolge van het handelen conform het wettelijk voorschrift. ${ }^{377}$

In 1997 werd dit deel van de zorgplichtbepaling gewijzigd. De toevoeging werd vervangen door een aparte zin luidende: "Het verbod geldt niet voor zover het betreft zodanige handelingen die hem bij of krachtens de wet uitdrukkelijk zijn toegestaan." Als enige reden voor de wijziging werd gegeven dat ten onrechte niet expliciet was voorzien in de situatie waarin er geen vergunningplicht geldt in het kader van de Wet milieubeheer, maar er wel een bevoegdheid is om handelingen te verrichten waardoor nadelige gevolgen voor het milieu kunnen ontstaan, bijvoorbeeld op basis van artikel $8.40 \mathrm{Wm}^{378}$ Door deze wijziging blijft de onduidelijkheid over de status van deze uitzondering bestaan. De toevoeging staat niet meer in dezelfde zin opgenomen, zodat kan worden gesteld dat het "formele criterium" niet meer opgaat. Aangezien de wijzing van de bepaling niet beoogt de status van de uitzondering te wijzigen, is het de vraag of de wijziging tevens tot gevolg zou moeten hebben dat de uitzondering die voorheen zou dienen te worden aangemerkt als bestanddeel nu strafuitsluitingsgrond is geworden. Dit brengt namelijk procesrechtelijk een verslechtering van de positie van de verdachte met zich mee. Gezien het in het strafproces gehanteerde uitgangspunt in dubio pro reo lijkt het aangewezen de uitzondering nog steeds aan te merken als bestanddeel. ${ }^{379}$

\subsubsection{Het subjectief element bij artikel $10.3 \mathrm{Wm}$ als overtreding}

Artikel $10.3 \mathrm{Wm}$ bevat subjectieve bestanddelen, die afwijken van de in het strafrecht gebruikelijke redactie; te weten het vereisen van "opzet" of "schuld". ${ }^{380}$ In artikel 10.3, eerste en tweede lid Wm is de schuldvorm geformuleerd als "weet of redelijkerwijs had moeten weten". Deze subjectieve bestanddelen zijn bij de overtreding-variant niet van toepassing op alle bestanddelen van de delictsomschrijving, maar zien slechts op enkele bestanddelen. Voor de overige bestanddelen geldt dat culpa daar een element is.

Voor artikel 10.3, eerste lid Wm geldt dat voor het eerste deel "Het is een ieder bij wie in de uitoefening van zijn beroep of bedrijf afvalstoffen ontstaan" culpa een element is. Het daarop volgend deel "verboden handelingen met betrekking tot die afvalstoffen te verrichten of na te laten waarvan hij weet of redelijkerwijs had moeten weten dat daardoor nadelige gevolgen voor het milieu ontstaan of kunnen ontstaan" wordt beheerst door de twee als alternatieven geformuleerde subjectieve bestanddelen. De zin die daarop volgt dient te worden gezien als bestanddeel (en niet als bijzondere rechtvaardigingsgrond) van deze zorgplichtbepaling. ${ }^{381}$ Voor deze zin "Het verbod

Zie over geschreven bijzondere strafuitsluitingsgronden hoofdstuk 4 paragraaf 6 .

378 Zie TK 1995-1996, 24 875, nr. 3, p. 4.

379 Zie hoofdstuk 4 paragraaf 6.

380 Zie hoofdstuk 3 paragraaf 7.4.

381 Zie hoofdstuk 9 paragraaf 3.4.8. en meer algemeen hoofdstuk 4 paragraaf 6. 
geldt riet voor zover het betreft zodanige handelingen die hem bij of krachtens de wet uitdrukkelijk zijn toegestaan" geldt dat ook dit wordt beheerst door culpa als element.

Voor artikel 10.3, tweede lid Wm geldt dat voor het deel "Het is een ieder verboden in de uitoefening van zijn beroep of bedrijf afvalstoffen in te zamelen of anderszins in ontvangst te nemen, te bewaren, te bewerken, te verwerken, te vernietigen of op of in de bodem te brengen dan wel op andere wijze te verwijderen" culpa een element is. Het volgende deel "indien daardoor, naar hij weet of redelijkerwijs had moeten weten, nadelige gevolgen voor het milieu ontstaan of kunnen ontstaan" wordt beheerst door de twee als alternatieven geformuleerde subjectieve bestanddelen. Voor de zin "Het verbod geldt niet voor zover het betreft zodanige handelingen die hem bij of krachtens de wet uitdrukkelijk zijn toegestaan" die ook hier moet worden opgevat als bestanddeel, geldt wederom dat culpa een element is.

Deze subjectieve bestanddelen dienen door het verbindingswoord "of" te worden geinterpreteerd als alternatieven. Het betreft een culpose en een opzettelijke variant. Gerealiseerd moet worden dat culpa als element nog steeds een rol kan spelen voor de delen van de delictsomschrijving die worden beheerst door het culpose subjectieve bestanddeel. Schuld als element heeft namelijk een groter betekenisbereik dan de in $10.3 \mathrm{Wm}$ opgenomen bestanddelen. Indien ten aanzien van een verdachte het betreffende culpose bestanddeel kan worden bewezen verklaard, zijn er situaties mogelijk waarin toch geen sprake is van schuld (als element) voor het deel van de delictsomschrijving dat door het specifieke culpose bestanddeel wordt beheerst. De verdachte zal dan (ex artikel 352, tweede lid Sv) moeten worden ontslagen van alle rechtsvervolging.

\subsubsection{Het subjectief element bij artikel $10.3 \mathrm{Wm}$ als misdrijf}

Artikel $10.3 \mathrm{Wm}$ is via artikel la sub 1 Wed aangehaakt aan de Wed. Involge artike! 2, eerste lid Wed is er bij deze bepaling sprake van een misdrijf indien de normschending opzettelijk is begaan en is er in de overige gevallen sprake van een overtreding. Aangezien artikel $10.3 \mathrm{Wm}$ zelf ook subjectieve bestanddelen bevat, is er bij de misdrijf-variant sprake van een "schuldkwadratuur" ${ }^{382}$ Gezien de in hoofdstuk 3 paragraaf 7.4.6. beschreven oplossingen geldt voor de misdrijf-variant dat zij op een aantal manieren kan worden geïnterpreteerd. ${ }^{383}$ In hoofústuk 3 zijn twee interpretatiemogelijkheden uitgewerkt; te weten de interpretatiernethode die aansluit bij de opbouw en samenstelling van strafbaarstellingen en de methode waarbij de opzet-eis uit de Wed niet van toepassing wordt geacht op de subjectieve bestanddelen en de bestanddelen waar deze betrekking op hebben. De praktische consequenties die het volgen van één van deze twee interpretatiemogelijkheden tot gevolg hebben zal hier worden uitgewerkt. De opzet-eis van de misdrijf-variant wordt bij deze uitwerking steeds tussen aanhalingstekens ingeschreven in artikel $10.3 \mathrm{Wm}$. Voorts wordt zij, evenals de subjectieve bestanddelen uit artikel $10.3 \mathrm{Wm}$ die blijven gelden, cursief weergegeven

Zie hoofdstuk 3 paragraaf 7.4.6.

383 Zie hierover ook hoofdstuk 10 paragraaf 4.3.4. 
teneinde de verschillen duidelijker te laten zien. In hoofdstuk 9 paragraaf 4 en in hoofdstuk 10 paragrafen 4.3.3. en 4.3.4. zal worden ingegaan op de resultaten van deze uitwerking en op de uitwerkingen van artikel $2 \mathrm{Wms}$ en $13 \mathrm{Wbb}$.

De zorgplichtbepaling in het eerste lid van artikel $10.3 \mathrm{Wm}$ luidt bij het alternatief waar "weet" bestanddeel is, zowel bij de eerste als de tweede interpretatie: "Het is een ieder bij wie in de uitoefening van zijn beroep of bedrijf 'opzettelijk' afvalstoffen ontstaan, verboden 'opzettelijk' handelingen met betrekking tot die afvalstoffen te verrichten of na te laten waarvan hij weet dat daardoor nadelige gevolgen voor het milieu ontstaan of kunnen ontstaan. Het verbod geldt niet voor zover het betreft zodanige handelingen die hem bij of krachtens de wet uitdrukkelijk zijn toegestaan."

Voor de zorgplichtbepaling in het eerste lid van artikel $10.3 \mathrm{Wm}$ geldt dat bij het alternatief waarbij de culpose bestanddelen deel uitmaken de eerste interpretatie niet mogelijk is. Indien de tweede interpretatie wordt gevolgd luidt dit artikel: "Het is een ieder bij wie in de uitoefening van zijn beroep of bedrijf 'opzettelijk' afvalstoffen ontstaan, verboden 'opzettelijk' handelingen met betrekking tot die afvalstoffen te verrichten of na te laten waarvan hij redelijkerwijs had moeten weten dat daardoor nadelige gevolgen voor het milieu ontstaan of kunnen ontstaan. Het verbod geldt niet voor zover het betreft zodanige handelingen die hem bij of krachtens de wet uitdrukkelijk zijn toegestaan."

De zorgplichtbepaling in het tweede fid van artikel $10.3 \mathrm{Wm}$ luidt bij het alternatief waar "weet" bestanddeel is, zowel bij de eerste als de tweede interpretatie: "Het is een ieder verboden in de uitoefening van zijn beroep of bedrijf 'opzetselijk' afvalstoffen in te zamelen of anderszins in ontvangst te nemen, te bewaren, te bewerken, te verwerken, te vernietigen of op of in de bodem te brengen dan wel op andere wijze te verwijderen, indien daardoor, naar hij weet, nadelige gevolgen voor het milieu ontstaan of kunnen ontstaan. Het verbod geldt niet voor zover het betreft zodanige handelingen die hem bij of krachtens de wet uitdrukkelijk zijn toegestaan."

Voor de zorgplichtbepaling in het tweede lid van artikel $10.3 \mathrm{Wm}$ geldt dat bij het alternatief waarbij de culpose bestanddelen deel uitmaken de eerste interpretatie niet mogelijk is. Indien de tweede interpretatie wordt gevolgd luidt dit artikel: "Het is een ieder verboden in de uitoefening van zijn beroep of bedrijf 'opzettelijk' afvalstoffen in te zamelen of anderszins in ontvangst te nemen, te bewaren, te bewerken, te verwerken, te vernietigen of op of in de bodem te brengen dan wel op andere wijze te verwijderen, indien daardoor, naar hij redelijkerwijs had moeten weten, nadelige gevolgen voor het milieu ontstaan of kunnen ontstaan. Het verbod geldt niet voor zover het betreft zodanige handelingen, die hem bij of krachtens de wet uitdrukkelijk zijn toegestaan." 
Het milieustrafrecht is te vinden in lokale verordeningen, het commuun strafrecht en het bijzonder strafrecht, dat is aangehaakt aan artikel la Wed. In de bijzondere milieuwetten zijn enkele zorgplichtbepalingen opgenomen. Er lijkt echter nauwelijks sprake van systematiek zowel in het opnemen als in het afwijzen van dergelijke bepalingen, terwijl ook de vormgeving verschillen vertoont. Zo is in de sectorale milieuwetgeving wel een zorgplichtbepaling opgenomen in de Wet bodembescherming, maar ontbreekt een dergelijke bepaling in de Wet verontreiniging oppervlaktewateren en in de Wet inzake de luchtverontreiniging. Het opnemen van een zorgplichtbepaling in deze laatste wet werd zelfs uitdrukkelijk afgewezen. Ook binnen de vele soortgerichte milieuwetgeving is geen duidelijk lijn te ontdekken. Zo zijn er wel zorgplichtbepalingen opgenomen in de Wet milieugevaarlijke stoffen, het hoofdstuk afvalstoffen van de Wet milieubeheer en de Bestrijdingsnniddelenwet, maar ontbreekt een dergelijke bepaling in de meeste andere soortgerichte milieuwetten. In de overkoepelende Wet milieubeheer is naar aanleiding van een ingediend amendement in artikel 1.1a Wm wel een algemene zorgplicht opgenomen die betrekking heeft op het gehele leefmilieu. Schending van deze zorgplicht is, zonder uitdrukkelijke overweging dienaangaande, niet strafbaar gesteld.

In het wetsvoorstel tot invoering van de Wet milieugevaarlijke stoffen was direct een zorgplichtbepaling opgenomen. Zowel in het advies van de Raad van State als tijdens de parlementaire behandeling werden kanttekeningen geplaatst bij deze bepaling. Desondanks werd zij nagenoeg ongewijzigd ingevoerd. Zij is aangehaakt bij artikel 1a sub 1 Wed en betreft involge artikel 2 Wed een misdrijf indien opzettelijk begaan, en in de overige gevallen een overtreding.

In het wetsvoorstel tot invoering van de Wet bodembescherming was aanvankelijk geen zorgplichtbepaling opgenomen. Pas in een laat stadium werd een amendement ingediend om wel een zorgplichtbepaling in te voeren. Dit amendement werd zonder veel discussie aangenomen, waama de voorgestelde zorgplichtbepaling zonder wijziging in de Wbb werd opgenomen. Bij de uitbreiding van de Wbb met de Interimwet bodemsanering werd de zorgplichtbepaling verder uitgebreid en kreeg zij haar huidige vorm. Deze bepaling werd vanaf het begin aangehaakt bij de Wed, aanvankelijk in artikel 1 sub 3 en thans in artikel 1a sub 1 Wed. Inhoudelijk heeft dit geen grote gevolgen gehad. Het is een misdrijf indien opzettelijk begaan en in de overige gevallen een overtreding.

Ook in de Afvalstoffenwet was aanvankelijk geen zorgplichtbepaling opgenomen. Bij de uitbreiding van de Wet milieubeheer met het hoofdstuk afvalstoffen werd in het wetsvoorstel een zorgplichtbepaling opgenomen, die na enkele wijzingen werd opgenomen in de Wet milieubeheer. In 1997 werd de zorgplichtbepaling gewijzigd en kreeg zij haar huidige vorm. Ook deze zorgplichtbepaling is involge artikel la sub 1 Wed aangehaakt aan de Wed. Ook hier is sprake van een misdrijf indien opzettelijk begaan en in de overige gevallen een overtreding. De parlementaire discussie over deze zorgplichtbepaling had tevens tot gevolg dat ex een amendement werd ingediend. 
om ook een (niet strafrechtelijk handhaafbare) algemene zorgplicht op te nemen vooraan in de Wet milieubeheer. Dit amendement werd aangenomen waardoor er thans in artikel $1.1 \mathrm{a} \mathrm{Wm}$ een algemene zorgplicht is te vinden.

Opmerkelijk is dat de drie zorgplichtbepalingen zonder discussie zijn aangehaakt bij de zwaarste categorie strafbaarstellingen van de Wed. Bij de invoering van artikel Ia Wed en de indeling van strafbaarstellingen uit "milieuwetten" in de drie categorieên van de Wed werd gesteld dat de eerste categorie de zwaarste is. Hierin staan de ernstigste milieudelicten, terwijl in de tweede categorie de minder ernstige en in die derde categorie de lichtste zijn te vinden. De plaats in de indeling heeft consequenties voor de vraag of sprake is van een misdrijf of een overtreding, en voor de maximaal op te leggen strafmaat. Bij de indeling van strafbare feiten in de drie categorieën van artikel la Wed werd voor de eerste categorie (die de hoogste strafbedreiging heeft) uitgegaan van het criterium "dat het moet gaan orn feiten die een directe aantasting opleveren van het milieu, dan wel daarvoor een ernstige, en rechtstreekse bedreiging vormen." Het is echter de vraag of hiervan wel sprake is bij de zorgplichtbepalingen, $\mathrm{nu}$ de schadelijkheid van de gedraging niet behoeft te worden onderzocht, noch bewezen. Voldoende is immers dat sprake is geweest van een potentieel gevaarlijke gedraging.

Ook vormt de mogelijkcheid dat een sohending van een zorgplichthepaling in het milieurecht wordt aangeduid als een misdrijf een breuk met de indeling van de zorg. plichtbepalingen uit de overige wetgeving die aldaar worden aangeduid als hetzij een overtreding, hetzij in eerste instantie een "beboetbaar feit" en bij recidive (eventueel) een overtreding. Dit is des te opvallender nu de zorgplichtbepalingen in het milieustrafrecht duidelijk zijn geïnspireerd op de reeds bestaande zorgplichtbepalingen uit de bijzondere wetgeving. Vooral artikel 25 (oud thans artikel 5) WVW blijkt het grote voorbeeld te zijn geweest. Deze zorgplichtbepaling is (net als de andere genoemde bepalingen uit bijzondere wetten) alleen als overtreding strafbaar gesteld.

Opvallend is ook de zwaarte van de maximurn strafbedreiging van de zorgplichtbepalingen in het milieustrafrecht. Involge artikel 2, eerste lid Wed betreffen het misdrijven indien ze opzettelijk zijn begaan en is in de overige gevallen sprake van een overtreding. De strafbedreiging voor de misdrijf-variant is involge artikell 6, eerste lid sub 1 Wed een gevangenisstraf van ten hoogste zes jaren of een geldboete van de vijfde categorie (f. 100.000,-). Indien het een overtreding betreft is dit hechtenis var ten hoogste een jaar of een geldbcete van de vierde categorie (f. 25.000,-). Ook dif wijkt af van de zorgplichibepalingen uit wetgeving die niet behoort tot het milieustrafrecht.

Ook is het opmerkelijk dat de zorgplichtbepalingen in het milieustrafrecht, in tegenstelling tot alle in de hoofdstukken 6,7 en 8 besproken zorgplichtbepalingen uit andere delen van het strafrecht, subjectieve bestandielen bevatten. De subjectieve bestanddelen van deze zorgplichtbepalingen wijken overigens af van de gebnuikelijke 
redactie; te weten het vereisen van "opzet" of "schuld". ${ }^{384}$ Voorts wordt de nieuw gekozen redactie niet consequent gebruikt in de verschillende zorgplichtbepalingen. In de artikelen 13 Wbb en 2 Wms is de schuldvorm geformuleerd als "weet of redelijkerwijs had kunnen vermoeden" en "redelijkerwijs van hem kunnen worden gevergd", terwijl die in artikel 10.3, eerste en tweede lid Wm luidt "weet of redelijkerwijs had moeten weten".

Deze subjectieve bestanddelen zijn bij de overtreding-variant niet van toepassing op alle bestanddelen van de delictsomschrijving, maar zien slechts op enkele bestanddelen. Voor de overige bestanddelen geldt dat culpa daar een element is. Deze subjectieve pestanddelen dienen door het verbindingswoord "of" te worden geïnterpreteerd als aliernatieven. Hierdoor kennen de overtreding-varianten van deze zorgplichtbepalingen zowel een culpose als een opzettelijke variant. Bij deze zorgplichtbepalingen kan culpa als element nog steeds een rol spelen voor de delen van de delictsomschrijving die worden beheerst door het culpose subjectieve bestanddeel. Schuld als elemeit heeft namelijk een groter betekenisbereik dan de hier opgenomen bestanddelen. Indien ten aanzien van een verdachte het betreffende culpose bestanddeel kan worden bewezen verklaard, zijn er situaties mogelijk waarin toch geen sprake is van schuld (als element) voor het deel van de delictsomschrijving dat door het specifieke culpose bestanddeel wordt beheerst. De verdachte zal dan (ex artikel 352, tweede lid Sv) mpeten worden ontslagen van alle rechtsvervolging.

De zorgplichtbepalingen in het milieustrafrecht zijn via artikel la sub 1 Wed aangehaakt aan de Wed. Involge artikel 2, eerste lid Wed is er bij deze bepalingen sprake van een misdrijf indien de normschending opzettelijk is begaan en is er in de overige gevallen sprake van een overtreding. Aangezien deze strafbaarstellingen zelf ook al subjectieve bestanddelen bevatten, is er bij de misdrijf-variant sprake van een "schuldkwadratuur". ${ }^{385}$ Gezien de in hoofdstuk 3 paragraaf 7.4.6. beschreven oplossingen geldt voor de misdrijf-variant van deze zorgplichtbepalingen dat zij op een aantal manieren kunnen worden geïnterpreteerd.

In hoofdstuk 3 bleek dat de eerste interpretatiemogelijkheid is dat wordt aangesloten bij de opbouw en samenstelling van strafbaarstellingen. De subjectieve bestanddelen uit deze zorgplichtbepalingen zijn als alternatieven geformuleerd, zodat twee strafbare gedragingen onafhankelijk van elkaar zijn strafbaar gesteld. Indien wordt vastgehouden aan de interpretatie in het commune strafrecht, die inhoudt dat de opzet-eis het overtreden voorschrift in zijn geheel beheerst, behoeft dit niet tot problemen te leiden. Bij de opzettelijke variant van de strafbaarstelling zullen zich geen problemen voordoen. De opzet-eis uit de Wed is ten eerste op meer bestanddelen van toepassing dan het deel dat beheerst wordt door het "weten", zodat voor deze bestanddelen geen probleem ontstaat. De opzet-eis uit de Wed zal voor het "weten" met zijn bestanddelen geen problemen opleveren, aangezien "opzet" geheel valt onder "weten", waarbij aan het "weten" zelfs verdergaande eisen worden gesteld. Bij het culpose bestanddeel leidt

Zie hoofdstuk 3 paragraaf 7.4 .

Zie hoofdstuk 3 paragraaf 7.4.6.
} 
deze interpretatie van de reikwijdte van de opzet-eis uit de Wed wel tot onoverkomelijke problemen. Een opzettelijke culpose gedraging is natuurlijk niet mogelijk.

In de tweede plaats is de interpretatie mogelijk dat de opzet-eis uit de Wed niet van toepassing wordt geacht op de subjectieve bestanddelen en de bestanddelen waar deze betrekking op hebben. Dit heeft tot gevolg dat voor de opzettelijke variant opzet wordt vereist voor alle bestanddelen die niet worden beheerst door het "weten" uit de zorgplichtbepaling. Dat de Wed opzet-eis ten aanzien van het "weten" met zijn bestanddelen niet van toepassing is maakt, gezien de verdergaande eisen die aan "weten" worden gesteld, inhoudelijk niets uit. Tussen de eerste en de tweede interpretatie is zodoende bij de opzet-variant geen inhoudelijk verschil aanwezig. Bij de culpose-variant van de strafbaarstelling ligt dit anders. De opzet-eis uit de Wed is bij deze tweede interpretatiemogelijkheid niet van toepassing op het subjectieve bestanddeel en de bestanddelen waarop dit betrekking heeft. Hier doen zich daarom geen onoverkomelijke problemen voor bij het strafbaar stellen van de misdrijf-variant met culpose bestanddelen.

De praktische consequenties die het volgen van een van deze twee interpretatiemogelijkheden tot gevolg hebben zijn uitgewerkt in hoofdstuk 9 paragraaf 3.2.6. (artikel $2 \mathrm{Wms}$ ), hoofdstuk 9 paragraaf 3.3.9. (artikel $13 \mathrm{Wbb}$ ) en hoofdstuk 9 paragraaf 3.4.8. (artikel $10.3 \mathrm{Wm}$ ). Indien deze uitwerkingen worden bestudeerd valt op dat het verschil tussen de overtreding en misdrijf-varianten van deze zorgplichtbepalingen niet erg groot lijkt te zijn. Bij deze strafbaarstellingen worden vooral de bestanddelen die de strafbare gedraging aangeven niet beheerst door subjectieve bestanddelen uit de strafbaarstelling van de milieuwet. Hiervoor geldt dat zij involge artikel 2 Wed bij de misdrijf-variant wel worden beheerst door het bestanddeel "opzet".

Zo geldt bij de misdrijf-variant de opzet-eis uit artikel 2 Wed bij artikel $2 \mathrm{Wms}$ voor de bestanddelen "Ieder die beroepshalve een stof of een preparaat vervaardigt, aan een ander ter beschikking stelt, in Nederland invoert of toepast". Zij die deze gedragingen beroepshalve verrichten zullen nagenoeg altijd deze gedragingen opzettelijk verrichten, temeer daar opzet ook voorwaardelijk opzet omvat, zodat de dader die zijn gedraging wil ondanks dat een niet gewenst gevolg kan intreden ook onder het betekenisbereik kan vallen. Indien de gedraging niet opzettelijk wordt verricht, zal meestal ook de schuld ontbreken, zodat een beroep op avas mogelijk succesvol kan zijn. Voorts ligt dan niet voor de hand dat de verdachte "weet of redelijkerwijs had kunnen vermoeden" dat door zijn gedraging de concrete gevaarzetting werd veroorzaakt, zodat de gedraging niet strafbaar zal zijn. Dat deze gedragingen beroepshalve meestal opzettelijk worden verricht is ook niet verwonderlijk, nu deze op zichzelf niet strafbaar zijn, tenzij zij wederrechtelijk plaatsvinden. Sterker nog, vaak zullen zij juist tot de kern van de bedrijfsmatige activiteiten behoren. Wat deze gedragingen strafbaar maakt, is de concrete gevaarzetting die uitgaat van deze gedragingen. Deze zijn door de wetgever dan ook opgenomen in de strafbaarstelling. Deze bestanddelen worden beheerst door de subjectieve bestanddelen. Hierdoor maakt niet enkel het mogelijk 
intreden van het gevolg de gedraging strafbaar, maar is dit pas het geval indien de verdachte ten aanzien van dit mogelijke gevolg over een bepaalde subjectieve gesteldheid beschikte. Deze gelden (als altematieven) ook voor de overtreding-variant. Indien hier bij de misdrijf-variant voor de tweede interpretatie wordt gekozen, wordt voor deze bestanddelen geen onderscheid gemaakt in de interpretatiemogelijkheden tussen de misdrijf- en de overtreding-variant. Indien wordt gekozen voor de eerste variant geldt dat deze interpretatie ook mogelijk is bij overtredingen, maar geldt dit alleen voor het alternatief waarbij de bestanddelen worden beheerst door "weten" en niet het alternatief waarbij zij worden beheerst door "redelijkerwijs had kunnen vermoeden". Aangezien misdrijven in het algemeen als ernstiger en meer afkeurenswaardig worden beschouwd dan overtredingen ${ }^{386}$ ligt deze interpretatie voor de hand. Voorts wordt met deze keuze ook tegemoet gekomen aan het uitgangspunt in dubio pro reo. Deze interpretatie ligt ook voor de hand omdat het $\mathrm{OM}$, gezien de samenstelling van de zorgplichtbepaling bij het ten laste leggen van de overtredingvariant, kan kiezen tussen "weet of redelijkerwijs had kunnen vermoeden". Hierbij zal het waarschijnlijk de voorkeur geven aan het eenvoudiger te bewijzen "redelijkerwijs had kunnen vermoeden". Door het maken van deze interpretatiekeuze wordt tevens bereilt dat er, in de praktijk althans, tenminste enig verschil ontstaat tussen de overtreding-en misdrijf-variant op het gebied van de ernst en de afkeurenswaardigheid van deze strafbare feiten.

Het bovenstaande gaat ook op voor de misdrijf-variant van artikel 10.3, eerste en tweede lid Wm. Bij de zorgplichtbepaling in het eerste lid geldt de opzet uit de Wed voor "Het is een ieder bij wie in de uitoefening van zijn beroep of bedrijf afvalstoffen ontstaan, verboden handelingen met betrekking tot die afvalstoffen te verrichten of na te laten". Bij de zorgplichtbepaling in het tweede lid geldt de Wed opzet voor "Het is een ieder verboden in de uitoefening van zijn beroep of bedrijf afvalstoffen in te zamelen of anderszins in ontvangst te nemen, te bewaren, te bewerken, te verwerken, te vernietigen of op of in de bodem te brengen dan wel op andere wijze te verwijderen". Ook deze gedragingen worden beroepsmatig verricht, en zullen nagenoeg altijd (voorwaardelijk) opzettelijk plaatsvinden. Indien dit niet het geval is, behoort waarschijnlijk een succesvol beroep op avas tot de mogelijkheden. Voorts zal dan het aantonen dat de verdachte "weet of redelijkerwijs had moeten weten" dat door de gedraging de concrete gevaarzetting wordt veroorzaakt problematisch zijn. Wederom ligt het voor de hand dat deze gedragingen beroepshalve meestal opzettelijk worden verricht, en soms zelfs tot de kem van de bedrijfsmatige activiteiten behoren. Op zichzelf zijn zij dan ook niet strafbaar, tenzij zij wederrechtelijk plaatsvinden. Wat deze gedragingen ook strafbaar maakt, zijn de in de strafbaarstellingen opgenomen concrete gevaarzettingen. De verdachte moet ook ten opzichte van deze concrete gevaarzettingen ten gevolge van de aanwezige subjectieve bestanddelen een bepaalde subjectieve gesteldheid hebben. Deze subjectieve bestanddelen gelden (als alternatieven) ook voor de overtreding-variant. Indien hier bij de misdrijf-variant voor de tweede interpretatie wordt gekozen, wordt voor deze bestanddelen geen onderscheid gemaakt in de interpretatiemogelijkheden tussen de misdrijf en de overtreding- 
variant. Indien wordt gekozen voor de eerste variant geldt dat deze interpretatie ook mogelijk is bij overtredingen, maar geldt dit alleen voor het alternatief waarbij de bestanddelen worden beheerst door "weten" en niet voor het alternatief "redelijkerwijs had moeten weten". Aangezien misdrijven in het algemeen ernstiger en meer afkeurenswaardig worden beschouwd dan overtredingen ligt deze interpretatie ook hier voor de hand. Dit volgt ook uit het beginsel in dubio pro reo. De keuze voor deze interpretatie ligt ook voor de hand, omdat het ook hier bij het ten laste leggen van de overtreding-variant kan kiezen tussen de subjectieve bestanddelen. Het zal daarom opnieuw de voorkeur geven aan de eenvoudigste te bewijzen variant, hetgeen hier "redelijkerwijs had moeten weten" zal zijn. In de praktijk ontstaat zo wederom tenminste enig verschil tussen de overtreding en misdrijf-variant inzake de emst en de afkeurenswaardigheid van deze strafbare feiten.

Bij de zorgplichtbepaling uit artikel $13 \mathrm{Wbb}$ heeft het opzet uit de Wed betrekking op "Ieder die op of in de bodem handelingen verricht als bedoeld in de artikelen 6 tot en met 11". Ook hier ligt het volgen van bovenstaande redenering in de rede, al moet worden opgemerkt dat de normadressaat hier, in tegenstelling tot bovengenoemde bepalingen, niet is beperkt tot degene die beroepsmatige gedragingen verricht maar tot een ieder. Voorts moet worden opgemerkt dat in geval van artikel $13 \mathrm{Wbb}$, "waarmee de wetgever de bedoeling heeft gehad een situatie te herstellen waarin een opzettelijk gepleegde gedraging waarvan de dader redelijkerwijs had kunnen vermoeden dat de bodem erdoor zou kunnen worden verontreinigd, een misdrijf oplevert" ${ }^{387}$, de wetgever lijkt te kiezen voor de tweede interpretatie. Edoch, gezien de consistentie in interpretatie van (nagenoeg) gelijkluidende bestanddelen wordt, in navolging van de artikelen $2 \mathrm{Wms}$ en 10.3 eerste en tweede lid Wm, ook hier gekozen voor de eerste interpretatiemethode. Het gevolg van deze keuze is dat de misdrijf-varianten alleen de versies zijn waarin de gevolgen van de (opzettelijke) gedraging worden beheerst door het bestanddeel "weet". De versies waarin de verdachte de concrete gevaarzetting "redelijkerwijs had kunnen vermoeden" zijn niet als misdrijf strafbaar, maar kunnen natuurlijk wel deel uitmaken van de overtreding-variant.

De extra opzet-eis uit artike! 2 Wed blijkt niet veel toegevoegde waarde te hebben. Aangezien misdrijuen in het algemeen als ernstiger en meer afkeurenswaardig worden beschouwd dan overtredingen ${ }^{388}$ is het opvallend dat dit onderscheid slechts in geringe mate tot uiting komt bij de zorgplichtbepalingen in het milieustrafrecht. Dit geldt nog sterker nu dit onderscheid vergaande processuele en materiële consequenties tot gevolg kan hebben. ${ }^{389}$

387 Keulen, B.F., Economisch strafrecht, pp. $45-46$

388 Zie hoofdstuk 6 paragraaf 3.

389 Denk hierbij bijvoorbeeld aan de mogelijkheid tot gebruik van dwangmiddelen, de verjaringstermijn, de registratie en de maximum strafbedreiging. Zie over het verschil tussen misdrijven en overtredingen hoofdstuk 6 paragraaf 3 . 


\section{Zorgplichtbepalingen en algemene vereisten van behoorlijke regelgeving}

1. Inleiding

Het onderzoek naar de vraag wie de inhoud van een strafbaarstelling en dus de grenzen van de strafrechtelijke aansprakelijkheid vaststelt, is een onderzoek naar de vraag welke actor de reële macht heeft om de reikwijdte van de aansprakelijkheid te bepalen, uit te breiden of in te perken. De verschillende instituties die hierbij een rol spelen zijn de wetgever, het bestuur en de rechterlijke macht. Zij kunnen de (anvullende) criteria bepalen waaraan moet worden voldaan opdat de voorwaarden van de strafbaarstelling zijn vervuld.

De instantie die de zorgplichtbepaling invoert, bepaalt in eerste instantie de inhoud van de strafbaarstelling. Door het vaststellen van de inhoud van de bepaling worden immers tevens de voorwaarden vastgesteld waaraan een casus moet voldoen wil de rechtsregel toepasselijk zijn. Dit is het geval indien de interpretatie van de rechtsregel overeenkomt met de kwalificatie van de feiten van de casus.

Zorgplichtbepalingen kunnen door verschillende instanties in regelgeving worden opgenomen. De wetgever in formele zin is verantwoordelijk voor zorgplichtbepalingen in wetgeving in formele zin, maar hij kan bovendien de bevoegdheid creëren voor regelgeving door bestuursorganen. Zij zijn het die in eerste instantie verantwoordelijk zijn voor de invulling van de door de wetgever (in formele zin) aan hen gedelegeerde regelgevende bevoegdheden, en daarmee voor het vaststellen van de voorwaarden voor de toepassing ervan. ${ }^{2}$

Indien bij de samenstelling van een rechtsregel gebruik is gemaakt van termen waarvan het betekenisbereik niet duidelijk is, zijn aanvullende criteria nodig teneinde dit betekenisbereik vast te stellen. De voorwaarden voor de toepassing van een zorgplichtbepaling worden aanvankelijk bepaald door de instantie die verantwoordelijk is voor haar invoering. Deze instantie kan tevens aanvullende criteria vaststellen, maar dit kan ook gebeuren door andere instanties. Zo kan bijvoorbeeld de wetgever in materièle zin door middel van amvb's op basis van de artikelen 6 tot en met $11 \mathrm{Wbb}$ aanvullende criteria geven voor de handelingen uit de zorgplichtbepaling van artikel $13 \mathrm{Wbb}$. Indien de zorgplichtbepaling door de wetgever of het bestuur wordt vastgesteld, en deze ook zelf aanvullende criteria vaststelt die het toepassingsbereik van

Zie hoofdstuk 2 paragraaf 2.1 .

Zie ter zake hoofdstuk 4. 
termen van de bepaling markeren, kan het betekenisbereik van de bepaling duidelijk zijn. Er zal dan nauwelijks behoefte bestaan aan nieuwe of extra aanvullende criteria.

De soort regelgeving waarin de zorgplichtbepaling voorkomt, bepaalt tevens mede welke rechterlijke instantie de bevoegdheid heeft om, indien nodig, aanvullende criteria vast te stellen. Het is dan de taak van de rechter in een voorliggend geval te bepalen of de voorwaarden van een strafbaarstelling al dan niet van toepassing zijn in het concrete geval. Hierdoor stelt hij in het concrete geval het betekenisbereik van de strafbaarstelling vast. Zijn uitspraak kan verder strekken dan het onderhavige geval, waardoor jurisprudentie een kenbron van recht wordt. Deze bron kan aanvullende criteria bevatten voor de regelgeving waarop zij is gebaseerd. ${ }^{3}$

De tot stand gekomen strafbaarstelling (met haar aanvullende criteria) dient echter wel te voldoen aan een aantal vereisten. Teneinde de inhoud, betekenis en grenzen van de strafbaarstelling vast te stellen en/ of te onderzoeken zijn vele voorwaarden geformuleerd. Deze zijn te vinden in de algemene kwaliteitseisen voor overheidsoptreden door middel van wetgeving, de algemene beginselen van behoorlijke regelgeving en de criteria voor strafbaarstelling. Om dit onderzoek overzichtelijk en gestructureerd te doen verlopen zijn deze vele voorwaarden in hoofdstuk 3 geïntegreerd in een vijftal algemene vereisten waaraan regelgeving, waaronder begrepen strafbaarstellingen, moet voldoen wil' zij bentoorlijk zijir: ${ }^{4}$. Het betreft: de evenredigheid (hoofdstuk. 10 paragraaf 2), de rechtszekerheid (hoofdstuk 10 paragraaf 3 ), de rechtsgelijkheid (hoofdstuk 10 paragraaf 4), de samenhang (hoofdstuk 10 paragraaf 5) en de effectiviteit (hoofdstuk 10 paragraaf 6). Deze vijf algemene vereisten worden verder ingevuld door specifieke eisen die gelden voor een specifiek rechtsgebied of een deel van dit specifieke rechtsgebied. Aangezien in dit boek de grenzen van de strafrechtelijke aansprakelijkheid in het kader van zorgplichtbepalingen worden onderzocht, zijn in hoofdstuk 3 deze vijf vereisten verder ingevuld en uitgewerkt met de eisen die worden gesteld aan materieel strafrechtelijke bepalingen.

Deze vijf vereisten en de invulling die daaraan is gegeven in de vorm van de in hoofdstuk 3 gegeven eisen vormen opnieuw een uitwerking van de waarborgfunctie en de instrumentele functie van wetgeving, waarbij het van groot belang is deze twee functies zoveel mogelijk in evenwicht zijn. Het gaat niet om een of - of keuze, maar juist om het zoveel mogelijk tegemoet komen aan beide functies; maar daar waar inbreuken op rechten en vrijheden van justitiabelen groter kunnen zijn, moeten de waarborgen sterker zijn. Hierdoor worden in het strafrecht doorgaans hogere eisen gesteld aan de waarborgfunctie van regelgeving dan in andere rechtsgebieden. Indien in onvoldoende mate wordt tegemoetgekomen aan één of meer vereisten kan op de korte of langere termijn blijken dat het evenwicht is verstoord tussen de waarborg. functie en de instrumentele functie van wetgeving, hetgeen negatieve consequenties

Zie over deze bevoegdheid van de rechter hoofdstuk 5 en over jurisprudentie als kenbron van recht hoofdstuk 2 paragraaf 5.4 .

4 Zie hoofdstuk 3. 
kan lebben voor de legitimiteit van de regelgeving, de wetgever, het bestuur en/ of de recherlijke macht.

Aan deze in hoofdstuk 3 geformuleerde vereisten worden in dit hoofdstuk de zorgplickbepalingen getoetst. Gezien het onderwerp van het in dit boek gepresenteerde onderzoek betreft het de analyse van de strafrechtelijke aansprakelijkheid van deze bepaingen. Door deze toetsing zal duidelijk worden waar en waardoor knelpunten (kumen) ontstaan bij de toepassing en toepasselijkheid van deze bepalingen in het strafecht, zodat het mogelijk is de inhoud en betekenis van zorgplichtbepalingen binnen het strafrecht te beoordelen. De toetsing van zorgplichtbepalingen aan deze vijf veresten, wordit in de paragrafen van dit hoofdstuk steeds voorafgegaan door korte introducties van deze vereisten, zoals geformuleerd in hoofdstuk 3 paragraaf 7. Deze introducties zijn gezien het voorliggende onderzoek gericht op en worden uitgewerkt voor zorgplichtbepalingen in het strafrecht. Hierbij wordt ter illustratie steeds gebruik. gemakt van de in de voorafgaande hoofdstukken besproken zorgplichtbepalingen.

\section{Evenredigheid}

\subsection{Inleiding}

Ihdien de wetgever strafbaarstellingen wil introduceren, dan wel oudere strafbaarstellingen wil bijstellen of veranderen is het allereerst noodzakelijk dat wordt nagegaan wat het doel is dat met deze regelgeving wordt beoogd. Hierbij moet rekening worden gehouden in hoeverre de strafbaarstelling dit doel ook daadwerkelijk behartigt en in hoeverre de gedraging (potentieel) schadelijk is voor het beschermde rechtsgoed. De doelstelling zal (ook ten behoeve van andere vereisten) zoveel mogelijk moeten worden duidelijk gemaakt.

Voor het nastreven van deze doelstelling dient de strafbaarstelling gerechtvaardigd, noodzakelijk en als middel geschikt te zijn. Uitgangspunt is gat de overheid niet nodeloos (vergaand) mag ingrijpen in de samenleving, voordat zorgvuldig is nagegaan. wie, bij welke gedraging, onder welke omstandigheden onder her betekenisbereik van. een strafbepaling zal vallen, en welk rechtsbelang hierdoor wordt beschermd. Strafbaarstellingen maken gezien hun aard inbreuk op fundamentele vrijheden van justitiabelen, maar kunnen tevens fundamentele vrijheden (van anderen) beschermen. Nagegaan moet worden op welke manier de inmenging kan plaatsvinden, waarbij zo min mogelijk wordt ingegrepen in deze vrijheden maar wel het gewenste effect wordt bereikt. Hierbij dienen de regelgeving en de daaraan gekoppelde consequenties voor justitiabelen proportioneel (ook wel evenredigheid in enge zin genoemd) te zijn.

\subsection{Het doel}

Indien zorgplichtbepalingen worden getoetst aan het beginsel van evenredigheid is de eerste vraag die moet worden beantwoord wat het (beoogde) doel van deze strafbaarstellingen is. Zoals al uit de definitie blijkt, markeert de zorgplichtbepaling een 
bepaalde verantwoordelijkheid van de normadressaat. Deze houdt in dat hij een algemene plicht heeft tot het in acht nemen van een bepaalde graad van zorgvuldigheid met het oog op het door de betreffende wet en de zorgplichtbepaling te beschermen belang. Het te beschermen belang waarop de zorgplichtbepaling zich richt, reflecteert daarom meestal het algemene principe van de betreffende wetgeving; zo verbiedt (grof gezegd) bijvoorbeeld de zorgplichtbepaling uit artikel 5 WVW het veroorzaken van gevaar of hinder op de weg en artikel $13 \mathrm{Wbb}$ het veroorzaken van verontreiniging of aantasting van de bodem. Derhalve kan worden beargumenteerd dat het rechtsgoed dat de wetgever beoogt te beschermen, door de zorgplichtbepaling ook wordt beoogd te worden beschermd.

In het kader van de beoordeling van de regeling als geheel, zou moeten worden nagegaan in hoeverre het doel van de wet kan worden bereikt door alle instrumenten (waaronder de zorgplichtbepaling) uit de betreffende wet (en eventueel de overige wet- en regelgeving op dit gebied en andere (sturings)mogelijkheden) tezamen. Deze beoordeling is voor veel wettelijke bepalingen vaak zeer complex en vergt uitgebreid onderzoek naar het doel van de wet, en de andere (sturings- en/ of sanctionerings) mogelijkheden. Daarom zal de toetsing hier worden beperkt tot het doel van de in dit boek centraal staande zorgplichtbepalingen.

\subsection{Schade}

\subsubsection{Schadelijk gedrag}

De volgende vraag die bij de analyse van zorgplichtbepalingen in het strafrecht aan de orde komt is of het optreden van schade wel noodzakelijk is om een schending van deze bepalingen aan te nemen. Zorgplichtbepalingen verplichten immers tot het in acht nemen van een bepaalde graad van zorgvuldigheid met oog op het door de desbetreffende wet te beschermen belang. Wanneer deze graad van zorgvuldigheid niet in acht wordt genomen, kan de overtreder hiervoor strafrechtelijke aansprakelijk worden gesteld. Het is niet zo dat deze in acht te nemen graad van zorgvuldigheid pas wordt overschreden indien het handelen (of nalaten) schadelijk is voor het beschermde belang. Over de vraag waar de grens tussen het wel of niet in acht nemen van de vereiste graad van zorgvuldigheid moet worden getrokken, kan verschillend worden gedacht. De vaststelling van deze grens bepaalt voor een groot deel het betekenisbereik van de betreffende zorgplichtbepaling.

Tussen de verschillende zorgplichten is duidelijk verschil aanwezig in hoeverre door de gedraging schade kan of moet worden veroorzaakt. Dit kan worden geillustreerd aan de hand van de in de voorafgaande hoofdstukken besproken zorgplichtbepalingen.

Enigszins afhankelijk van de specifieke formulering van de zorgplichtbepaling, dient bij de meeste wel te worden bewezen dat sprake is van door de verdachte gevaarzettend gedrag ten aanzien van het beschermde rechtsgoed. Deze zorgplichtbepalingen zijn vorm gegeven als concreet gevaarzettingsdelict, aangezien de strafbaar gestelde gedraging een bepaald gevolg teweeg moet (kunnen) brengen. Meestal wordt echter in 
het geheel niet vereist dat er ook daadwerkelijk (zo men wil tastbare) schade ontstaat door de gedraging.

Het verband tussen de schending van de zorgplichtbepaling en schade is duidelijk aanwezig bij artikel 425 aanhef en sub $2 \mathrm{Sr}$. Voor overtreding van "geen voldoende zorg draagt voor het onschadelijk houden van een onder zijn hoede staand gevaarlijk dier" is weliswaar niet vereist dat schade is toegebracht, maar wel dat niet is verhinderd of voorkomen dat schade door een gevaarlijk dier werd toegebracht. ${ }^{5}$

Involge artikel 426 eerste lid $\mathrm{Sr}$ worden enkele gedragingen strafbaar gesteld die het ontstaan van schade ornvatten. Het betreft hier iemand die "terwijl hij in staat van dronkenschap verkeert" "in het openbaar het verkeer belemmert of de orde verstoort". Daarnaast is ook het verrichten van handelingen strafbaar gesteld waardoor geen schade behoeft te ontstaan. Zo is strafbaar gesteld indien hij "eens anders veiligheid bedreigt". Hiervoor is het voldoende indien de normadressaat objectief eens anders veiligheid in onmiddellijk gevaar brengt. ${ }^{6}$ Realisering van dit gevaar in de vorm van schade is niet vereist. Verder gaat de afsluitende variant waarin is strafbaar gesteld de nomadressaat die "enige handeling verricht waarbij, tot voorkoming van gevaar voor leven of gezondheid van derden, bijzondere omzichtigheid of voorzorgen worden vereist". Welke handelingen de bedoelde bijzondere omzichtigheid of voorzorgen vereisen, heeft de wetgever bewust aan de rechter overgelaten. Wel geeft hij in de memorie van toelichting enkele voorbeelden die als richtsnoer kunnen dienen bij de interpretatie door de rechter. ${ }^{7}$ Duidelijk is evenwel dat het gevaar zich niet hoeft te openbaren. De wetgever heeft deze bepaling juist ingevoerd om "preventief op te treden" en "om de culpose misdrijven van de Titels VII en XXI Boek II te voorkomen", want indien de wil er is om het gevaar teweeg te brengen of gevaarlijke gevolgen ontstaan, valt het feit onder de misdrijven. ${ }^{10}$ De bepaling beperkt zich niet tot handelingen waarbij een uiterste omzichtigheid nodig is of buitengewone voorzorg moet worden genomen. Opgemerkt wordt dat er geen handeling denkbaar is waarbij niet enige omzichtigheid of enige voorzorg wordt vereist. De bijzondere omzichtigheid

5 HR 14 januari 1907, W. 1907, 8488 (Gevaarlijk dier en schade) "Geen vereischte voor de overtreding van art. $425,2^{\circ}$. Strafr. is, dat schade toegebracht is, maar dat is niet verhinderd of voorkomen worde, dat deze door een gevaarlijk dier toegebracht worde": Overigens was in deze zaak het slachtoffer gebeten door een hond.

6 Beraadslagingen. Tweede Kamer, Opmerking van Minister Modderman, Smidt, H.J., Geschiedenis van het Wetboek van Strafrecht, Deel III, p. 189.

7 Het behoeven overigens geen beroepsbezigheden te zijn, hoewel alle voorbeelden uit de MvT dit wel zijn, te weten: degene die in beschonken staat dienst doet als verloskundige, als machinist een locomotief of als koetsier een rijtuig wil besturen, of als loodgieter met vuur op een dak klimt. Zie Smidt, H.J., Geschiedenis van het Wetboek van Strafrecht, Deel III, pp. 185-186.

8 Beraadslagingen Tweede Kamer, Opmerking van Minister Modderman, Smidt, H.J., Geschiedenis van het Wetboek van Strafrecht, Deel III, p. 188.

9 MvT in Smidt, H.J., Geschiedenis van het Wetboek van Strafrecht, Deel III, p. 186.

10 Rapport aan den Koning; Smidt, H.J., Geschiedenis van het Wetboek van Strafrecht, Deel III, p. 186. 
of voorzorg is elke die meer dan de gewone, dagelijkse is. De beschonkene is licht roekeloos of mist de macht om zijn eigen verrichtingen te beheersen; de verrichtingen zijn van dien aard dat zij voorzichtigheid of meesterschap nodig hebben om niet voor eens anders leven of gezondheid gevaarlijk te worden. ${ }^{11}$

Artikel 5 WVW ziet naast gedragingen die gevaar op de weg of hinder voor het verkeer op de weg veroorzaken, ook op gedragingen die gevaar op de weg of hinder voor het verkeer op de weg kunnen veroorzaken. Dit laatste gaat erg ver aangezien lichte vormen van hinder in het verkeer niet zijn te vermijden. De wetgever merkt hierover op dat de bepaling er slechts toe strekt "evidente vormen van gevaar en hinder aan te pakken."12 Dit blijkt echter niet uit de bepaling aangezien deze term, die als bestanddeel het betekenisbereik nog enigszins zou kunnen beperken, daarin niet is opgenomen. Wat onder "evident" moet worden begrepen wordt overigens ook niet uitgewerkt. De delictsomschrijving vereist niet eens het ontstaan van gevaar of hinder. Ook is geen aanduiding gegeven wat voor soort mogelijk gevaar of hinder het moet betreffen. De enige beperking die het artikel vereist is dat het gevaar "op de weg" kan worden veroorzaakt en dat "het verkeer op de weg" kan worden gehinderd. Deze beperkingen zeggen evenmin iets over de gedraging waardoor het gevaar of de hinder ontstaat of kan ontstaan.

Artike1 5 Luchtvaartwet vereist evenmin dat personen of zaken in gevaā̃ worden gebracht, aangezien de normadressaten deze bepaling ook kunnen overtieden indien deze in gevaar kunnen worden gebracht. In deze bepaling is in tegenstelling tot artikel 5 WVW geen plaatsaanduiding opgenomen waar personen of zaken in gevaai kunnen worden gebracht, zodat ook hierdoor geen beperking van het betekenisbereik is aangebracht. Dit ligt ook wel voor de hand aangezien luchtverkeer in tegenstelling tot wegverkeer in het algemeen minder plaatsgebonden plaatsvindt.

De meeste zorgplichtbepalingen zijn vormgegeven als concreet gevaarzettingsdelict. Deze vereisen in meer of mindere mate dat de strafbaar gestelde gedraging een bepaald gevolg teweeg (kunnen) brengen. Uit bovenstaande vororbeelden blijkt dat zij gezien de gebruikte bestanddelen vaak nauwelijks en soms zelfs in het geheel niet een daadwerkelijke gevaarzetting vereisen aangezien een potentiële gevaarzetting reeds voldoende is. Daarnaast zijn er zorgplichtbepalingen waarbij de relatie tussen de gedraging en het gevolg minder duidelijk aanwezig is. Als voorbeeld van een dergelijke zorgplichtbepalingen kan worden gewezen op artikel. 11 sub a tot en met $f$ Arbowet 1998. Niet geheel duidelijk is de relatie die wordt vereist tussen de in sub a tot en met $\mathrm{f}$ genoemde gedragingen en het in de aanhef vereiste gevolg. Het ligt in de rede dat deze relatie strikt wordt geïnterpreteerd, zodat zij zijn aan te merken als concrete gevaarzettingsdelicten. Vereist wordt dan namelijk dat de in sub a tot en met $f$

11 Noyon, T.J., Langemeijer, G.E. en Remmelink, J., bewerkt door Dorst, A.J.A. van, Fokkens, J.W. en Machielse, A.J.M., Het Wetboek van Strafrecht, "Overtredingen, Artikel 426", p. 17 (februari 1994).

12 TK 1990-1991, 22 030, nr. 3, p. 66. Zie ook Nota van Toelichting bij het RVV 1990, Stb. 1990,459 , p. 68. 
genoemde gedragingen het in de aanhef gestelde tot gevolg hebben, te weten: dat de werknemer deze verplichtingen heeft "om in verband met de arbeid de nodige voorzichtigheid en zorgvuldigheid in acht te nemen en naar vermogen zorg te dragen voor de eigen veiligheid en gezondheid en die van andere personen".

Indien de minder voor de hand liggende interpretatie wordt gevolgd waarbij de relatie tussen de aanhef en de gedragingen uit sub a tot en met $f$ wordt losgelaten, heeft dit tot gevolg hebben dat deze gedragingen op zichzelf reeds strafbaar zouden zijn. De interpretatie luidt dan dat de werknemer verplicht is om in verband met de arbeid: (1) de nodige voorzichtigheid in acht te nemen; (2) de nodige zorgvuldigheid in acht te nemen; (3) naar vermogen zorg te dragen voor de eigen veiligheid en gezondheid; (4) naar vermogen zorg te dragen voor de veiligheid en gezondheid van andere personen. Bij deze lezing behoeft bij 1 en 2 geen potentieel gevolg te worden veroorzaakt door de gedraging, zodat deze dienen te worden aangemerkt als abstracte gevaarzettingsdelicten. Bij 3 en 4 ligt dit complexer. Gesteld kan worden dat het zorgdragen "voor de eigen veiligheid en gezondheid en die van andere personen" een potentiële gevaarzetting van deze rechtsgoederen vereist. In dat geval is sprake van concrete gevaarzettingsdelicten. Indien niet wordt vereist dat het niet voldoende zorgdragen de veiligheid of gezondheid tot een potentieel gevolg voor de veiligheid of gezondheid moet hebben geleid, is echter sprake van een abstract gevaarzettingsdelict. Deze interpretatie ligt gezien de redactie en de wetsgeschiedenis van de bepaling minder voor de hand. Aangezien deze interpretatie duidelijk minder gunstig is voor de verdachte, zal ook het strafrechtelijk beginsel in dubio pro reo zich hiertegen verzetten.

Voorts is ook de te volgen interpretatie bij de zorgplichtbepaling uit de aanhef van artikel 11 Arbo-wet 1998 niet op voorhand duidelijk. Deze bepaling luidt: "De werknemer is verplicht om in verband met de arbeid de nodige voorzichtigheid en zorgvuldigheid in acht te nemen en naar vermogen zorg te dragen voor de eigen veiligheid en gezondheid en die van andere personen. Met name zijn zij verplicht om: (...)" Door het opnemen van "met name" lijkt het betekenisbereik van deze aanhef verder te gaan dan slechts de gedragingen uit sub a tot en met $\mathrm{f}$. Ook andere gedragingen kunnen onder het betekenisbereik van deze strafbaarstelling vallen. Wel wordt de zorgplichtbepaling uit de aanhef door deze duidelijk uitgewerkte gedragingen tegen een bepaalde achtergrond geplaatst. De gedragingen die mogelijk onder de reikwijdte van deze aanhef vallen, vullen de concreet omschreven gedragingen uit de subs aan. Zij dienen in redelijke verhouding met de wel opgesomde gedragingen te staan, bijvoorbeeld qua emst en soort. ${ }^{13}$ Het ligt voor de hand dat ook voor deze gedragingen het zorg dragen "voor de eigen veiligheid en gezondheid en die van andere personen" een potentiële gevaarzetting van deze rechtsgoederen vereist. Deze zorgplichtbepaling dient dan te worden aangemerkt als een concreet gevaarzettingsdelict. De interpretatie dat dit niet wordt vereist is ook mogelijk. In dat geval is sprake van een abstract gevaarzettingsdelict. Deze interpretatie verdient gezien de redactie en de wetsgeschiedenis van de bepaling en het strafrechtelijk beginsel in dubio pro reo niet de voorkeur. 
Daarnaast zijn er zorgplichtbepalingen die in het geheel geen gevolg vereisen dat door de strafbaar gestelde gedraging ontstaat of kan ontstaan. Aangezien in dat geval een bepaalde gedraging reeds strafwaardig is, zijn deze zorgplichtbepalingen aan te merken als abstract gevaarzettingsdelict. Voorbeelden van deze zorgplichtbepalingen zijn artikel 19, eerste lid sub a, b en c. Quarantainewet en artikel 19, derde lid eerste zin Quarantainewet. Deze strafbaarstellingen vereisen niet dat sprake is van een bepaalde gevaarzetting van het beschermde: rechtsgoed, zodat het (mogelijk ontstaan van) tastbare schade in het geheel niet noodzakelijk is voor de schending van deze bepalingen.

\subsubsection{Geen schade vereist}

Voor schending van een zorgplichtbepaling is het derhalve meestal niet noodzakelijk dat (permanente) tastbare schade is toegebracht; voor de meeste zorgplichtbepalingen is het voldoende als kan worden aangetoond dat er potentieel gevaarlijk gedrag was. Indien wel schade optreedt behoeft dit geen blijvende schade te zijn, en ook het aantonen van deze schade is meestal niet noodzakelijk. Dit is ook niet altijd mogelijk, aangezien van de betrokkene soms tevens wordt geëist dat hij deze schade zoveel mogelijk beperkt of ongedaan maakt. Als hij dit niet doet, levert dat bij enkele zorgplichtbepalingen opnieuw een (ander) strafbaar feit op. Dit is bijvoorbeeld het geval bij artikel $13 \mathrm{Wbb}$. Ook indien de verdachte de schade geheel heeft ongedaan gemaakt, kan hij naderhand worden geconfronteerd met een veroordeling wegens schending van de zorgplichtbepaling. De potentiële gevaarzetting zal dan door het ontstaan van de (ongedaan gemaakte) schade zelfs eenvoudig zijn aan te tonen.

Indien een concrete gevaarzetting is vereist, kan deze zich bij veel zorgplichtbepalingen, gezien het ontbreken van aanvullende criteria, op vele manieren hebben voorgedaan. Meestal ontbreken gedetailleerde procedures die beschrijven op welke wijze een (mogelijke) schending van een het betreffende rechtsgoed dient te worden bewezen. ${ }^{14}$ Opmerkelijk is dat dit vaak niet het geval is bij andere strafbaarstellingen uit de betreffende wettelijke regeling. Hierdoor heeft de zorgplichtbepaling niet alleen ten aanzien van de gedraging, maar ook bewijstechnisch ten aanzien van het gevolg van die gedraging een "vangnetfunctie":

De strafrechtelijke aansprakelijkheid gaat derhalve potentieel zeer ver. De zorgplichtbepaling is ofwel een abstract gevaarzettingsdelict waardoor in het geheel geen gevolg wordt vereist voordat sprake is schending, ofwel een concreet gevarzettingsdelict waarbij het mogelijk gevolg meestal zeer vaag is geformuleerd, hoewel de Hoge Raad dan (meestal) wel een initiële gevaarzetting vereist. Het ethischnormatieve element neemt derhalve een belangrijke plaats in het schadeoordeel in. Dat beoordelingscriterium is echter veel vager dan de beoordeling of sprake is van aantoonbaar opgetreden schade. Indien de zorgplichtbepalingen vanuit de rechtsgoed-

14 Dit speelt met name bij het gebruik van technisch bewijs. Zie daarover Faure, M. en Visser, M., De strafrechtelijke bescherming van het leefmilieu in Belgiē, Duitsland en Nederland, pp. 358-363. 
beschermende functie van het strafrecht worden bekeken, zijin voor strafbaarstelling dan ook niet zoveel argumenten aan te voeren.

\subsection{Subsidiariteit'}

In het kader van de vereiste evenredigheid, rijst voorts de vraag in hoeverre strafbaarstellingen tegemoet komen aan de vereiste subsidiariteit. Hiervoor dient te worden nagegaan of zij gerechtvaardligd, noodzakelijk en als middel geschikt zijn. Uitgangspunt is dat de overheid niet nodeloos (vergaand) mag ingrijpen in de samenleving, voordat zorgvuldig is nagegaan wie, bij welke gedraging, onder welke omstandigheden onder het betekenisbereik van een bepaling zal vallen, en welk rechtsbelang hierdooir wordt beschernd. Nagegaan moet worden op welke manier de inmenging kan plaatsvinden, waarbij zo min mogelijk wordt geïntervenizerd in de rechten en vrijheden van justitiabelen, maar waarbij wel het gewenste effect wordt bereikt. Bij de toetsing van zorgplichtbepalingen aan het subsidiariteitsbeginsel wordt onderzocht of strafbaarstelling op het betreffende terrein noodzakelijk is. Bij de beantwoording van deze vraag dient, hoewel zij sterk samenhangen, onderscheid te worden gemaakt tussen de noodzaak tot strafbaarstelling, de inhoud van de strafbaarstelling en de toepassing daarvan. ${ }^{15}$ Het is de vraag of het gebruik van zongplichtbepalingen wordt gelimiteerd tot die gevallen waar de strafrechtelijke bescherming van de door de bepalingen beschermde rechtsgoederen niet op een andere wijze kan worden gegarandeerd.

Indien de rechtspolitieke keuze is gemaakt dat bepaalde rechtsgoederen dusdanig beschermenswaardig zijn dat zij (mede) door het strafrecht dienen te worden beschermd, kan de wetgever hiervoor gebruik maken van verschillende soorten strafbaarstellingen. Eerder rechtsvergelijkend onderzoek ter zake van het milieustrafrecht maakte daarbij, naast algerneen commune strafbaarstellingen, onderscheid tussen een viertal modellen van strafbaarstelling. Als vier modellen werden onderscheiden: de concrete gevaarzettingsdelicten, de abstracte gevaarzettingsdelicten, de zelfstandige gevaarzettingsdelicten en de zorgplichtbepalingen. ${ }^{16} \mathrm{Op}$ basis yan dit onderzoek werd aangegeven op welke manier de bescherming van een rechtsgoed, in casus het leefmilieu, idealiter zou kunnen worden vormgegeven. ${ }^{17}$ Hier bleek dat bij een goede vormgeving en afstemming van de eerste drie modellen, zorgplichtbepalingen niet nodig zouden zijn.

Zorgplichtbepalingen kunnen gezien hun specifieke kenmerken worden beschouwd als apart model, maar zij blijken tevens afhankelijk van de redactie ook tot één van de andere drie modellen te kunnen worden gerekend. Interessant is het na te gaan of, en

\footnotetext{
15 Zie over de toepassing van zorgplichtbepalingen hoofdstuk 10 paragraaf 6.

16 Zie over deze modellen ook hoofdstuk 1 paragraaf 3.6.2.

17 Zie hierover uitgebreid Faure, M. en Visser, M., De strafrechtelijke bescherming van het leefmilieu in België, Duitsland en Nederland, pp. 397-415; Faure, M., "Het Nederlandse milieustrafrecht: dringend aan herziening toe!", pp. 3-12 en Faure, M. en Visser, M., "Het tekort van het Nederlandse milieustrafrecht", pp. 123-144.
} 
zo ja op welke manier, zij kunnen worden ingedeeld binnen deze modellen, waaruit een optimaal vormgegeven stelsel bestaat. Dit wil niet zeggen dat hierdoor de bezwaren, die op basis van dit eerdere onderzoek naar voren zijn gekomen, die tegen het specifieke model "zorgplichtbepalingen" bestaan, worden weggenomen. Hiervoor is immers tevens de vormgeving en redactie van deze bepalingen, de afstemming met andere strafbaarstellingen en de opbouw van het totale stelsel maatgevend.

Wel laat het zien wat de plaats van de besproken zorgplichtbepalingen is binnen het eerder geformuleerde systeem. Ook kan door de plaatsing van zorgplichtbepalingen met hun specifieke kenmerken in één van de andere drie modellen duidelijker worden op welke punten zij afwijken van de overige bepalingen uit dit model. Voorts kan hierdoor inzicht ontstaan hoe zij zich verhouden tot (het optimaal geachte) totale stelsel van strafbaarstellingen dat gewenst is om het betreffende rechtsgoed te beschermen. De resultaten kunnen behulpzaam zijn bij het onderzoek naar en oplossen van knelpunten die ontstaan door de specifieke kenmerken van zorgplichtbepalingen.

In het navolgende zal dan ook bij de indeling uit het eerdere onderzoek worden aangeknoopt en worden bestudeerd op welke manier de besproken zorgplichtbepalingen een rol spelen binnen deze modellen van strafbaarstelling. Onderzocht wordt of, en zo ja op welke manier, sprake is van typische en a-typische kenmerken van zorgplichtbepalingen ten opzichte van de kenmerken van de strafbaarstellingen nit de andere drie modellen. Hiervoor zal het model in zijn algemeenheid kort worden beschreven, waarna de plaats van zorgplichtbepalingen met zijn specifieke kenmerken binnen het model zal worden aangegeven. Hierbij wordt ingegaan op het totale systeem van strafbaarstellingen.

Het betreft ten eerste het model van de abstracte gevaarzettingsdelicten. Deze stellen een bepaalde gedraging strafbaar, ongeacht een eventueel gevolg. Deze strafbaar gestelde gedraging kan met behulp van gelede normstellingen nader worden gespecificeerd in lagere regelgeving. Ten tweede kan de wetgever strafbaarstellingen vorngeven als concrete gevaarzettingsdelicten. Deze stellen een bepaalde gedraging strafbaar indien dit een bepaald gevolg teweegbrengt of kan brengen. Ten derde kan gebruik worden gemaakt van zelfstandige gevaarzettingsdelicten. Dit is een specifiek soort concrete gevaarzettingsdelicten die als aparte categorie zijn te onderscheiden, aangezien de toepassing van deze bepalingen mogelijk is ook al handelt de justitiabele overeenkomstig een door het bestuur vastgesteld besluit.

Indien de wetgever een bepaald rechtsgoed met behulp van het strafrecht wil beschermen kan hij yoor het probleem komen te staan dat aan rechtsstatelijke eisen moet worden voldaan, waarbij de strafbaarstelling zo moet worden geconstrueerd dat de onwenselijk geachte gedragingen binnen het strafrechtelijk bereik vallen. Terwij! de strafbaarstelling ook uitvoerbaar en handhaafbaar dient te zijn, omdat hij anders niet effectief is. Bij zijn keuze dient hij voorts rekening te houden met de consequenties die de keuze heeft voor de mate van autonomie van de strafrechter. Voor de bescherming voor een bepaald rechtsgoed blijkt vaak een combinatie van de eerste twee of drie soorten strafbaarstellingen noodzakelijk. 
In de eerste plaats worden de abstracte gevaarzettingsdelicten onderscheiden. Dit type strafbaarstelling wordt in wetgeving in formele zin als in materiële zin aangetroffen. Artikel 19, eerste en derde lid Quarantainewet zijn voorbeelden van zorgplichtbepalingen die zijn vormgegeven als abstract gevaarzettingsdelict. De strafbaar gestelde gedraging is in deze bepalingen zelf te vinden, terwijl het intreden van een (potentieel) gevolg als voorwaarde voor strafbaarheid niet wordt vereist.

Dagmaast speelt in het bijzonder, economisch en milieustrafrecht het bestuur een grote rol bij het vaststellen van de materiële normstellingen. Hier worden rechtsgoederen (mot uitzondering van de menselijke gezondheid of het menselijk leven) vaak niet absoluut beschermd, maar pas nadat de grenzen van de door het bestuur toegestane vorm of mate van inbreuk worden overschreden. Het bestuur beschikt vaak over de relevante informatie (en is derhalve in het algemeen beter geschikt) om de belangenafweging te maken op basis waarvan het beschermingsniveau wordt vastgesteld. Deze ziji dan te vinden in bijvoorbeeld beschikkingen of algemeen verbindende voorschriften, zoals het RVV, het Arbeidsomstandighedenbesluit of de vele amvb's op basis van de milieuwetgeving. Het bestuur blijkt in deze regelgeving soms ook zorgplichtbepalingen op te nemen. Een belangrijke taak van het strafrecht bestaat uit het incrimineren van schending van deze primair genomen bestuurlijke beslissingen. Dit betekent dat ook deze abstracte gevaarzettingsdelicten, die als gedraging het schenden van de door het bestuur vastgestelde regelgeving strafbaar stellen, noodzakelijk kunnen zijn. ${ }^{18}$ Kritiek op deze bepalingen heeft doorgaans ook geen betrekking op het feit dat deze strafbaarstellingen ongewenst zijn, maar is gericht op de veel voorkomende ondoorzichtigheid van deze bepalingen. Het gebruik van gelede normstelling kan een ware speurtocht noodzakelijk maken om de materiële inhoud van de strafbaarstelling te achterhalen, waarna de speurder uiteindelijk dan ook nog eens kan stuiten op een (weinig specifieke) zorgplichtbepaling. Ook kan de vraag rijzen in hoeverre het de bedoeling van de wetgever in formele zin is geweest dat het bestuur bij de invulling van zijn bevoegdheid tot het ontwikkelen van een (uitgebreid) stelsel van nadere normstellingen, gebruik maakt van zorgplichtbepalingen. Dit klemt te meer indien deze bepalingen vage bestanddelen bevatten. Een ander probleem is dat deze strafbaarstellingen vaak pas bescherming verlenen indien de door het bestuur vastgestelde voorschriften worden overschreden. Mede hierdoor ontstaat er kritiek indien de bescherming zich in belangrijke mate tot dit "administratief afhankelijke" strafrecht beperkt. ${ }^{19}$ Overigens rijst ook de vraag of de schending van dergelijke door het bestuur vastgestelde bepalingen met een strafrechtelijke sanctie moeten worden bedreigd, omdat voor de handhaving van deze bepalingen de mogelijkheden uit het bestuursrecht voldoende kunnen zijn. ${ }^{20}$ Het is derhalve belangrijk dat er (ook)

18 Hiermee is overigens niet gezegd dat iedere bestuurlijke normstelling bij schending strafrechtelijk moet worden geincrimineerd. Ook hier blijft een zorgvuldige afweging welke normstellingen onder het strafrecht worden gebracht noodzakelijk.

19 Zie over (de problemen bij) gelede normstellingen hoofdstuk 4.

20 Zie met betrekking tot abstracte gevaarzettingsdelicten in het milieurecht bijvoorbeeld Koopmans, I.M., "Zeven jaar milieustrafrecht in Nederland: een evaluatie", p. 362. 
strafbaarstellingen zijn die een verdergaande bescherming verlenen dan deze abstracte gevaarzettingsdelicten.

In de tweede plaats zijn daarom concrete gevaarzettingsdelicten vereist die niet alleen een bepaalde gedraging strafbaar stellen, maar dit doen indien deze gedraging een bepaald gevolg teweegbrengt of kan brengen. Door het aangeven van dit gevolg wordt directer het concreet in gevaar brengen van het beschermde rechtsgoed strafbaar gesteld. Aangezien de strafbaarstellingen in het bijzonder, economisch en milieustrafrecht doorgaans het beschermde rechtsgoed niet absoluut beschermen, maar dit pas doen indien deze schending verder gaat dan de door het bestuur toegestane inbreuk, wordt ten behoeve van het beperken van het betekenisbereik van deze strafbaarstellingen het bestanddeel "wederrechtelijk" opgenomen. Natuurlijk speelt hier de gekozen interpretatie van het bestanddeel "wederrechtelijk" een rol. ${ }^{21}$ De meest gebruikelijke interpretatie is dat inbreuken op het rechtsgoed die zijn toegestaan door het bestuur niet onder het betekenisbereik van de strafbepaling vallen. Maar ook als wordt gekozen voor de invulling van dit bestanddeel als in strijd met het objectieve recht, blijft de band met het bestuursrecht ten dele bewaard. Gedragingen conform de bestuurlijke regelgeving brengen ook dan in beginsel geen strafbaarheid mee, tenzij deze gedraging anderszins toch wederrechtelijk is. ${ }^{22}$ Indien het bestanddeel "wederrechtelijk" ontbreekt en dientengevolge wordt gekozen om degene die handelt conform de bestuurlijkè regeigeving onaèr ner bètekensobnen' laten vallen terwijl dit soort gedragingen veel voorkomen en niet zijn bedoeld om (strafrechtelijk) te worden gesanctioneerd, treedt een te grote breuk op met de bestuursrechtelijke voorbeslissingen. Dit is zowel uit oogpunt van regulering als vanuit de strafrechtspolitiek ongewenst. Bij de samenstelling van zorgplichtbepalingen wordt (nagenoeg) geen gebruik gemaakt van het bestanddeel wederrechtelijk of een equivalent daarvan. Wel bevat artikel 10.3, eerste en tweede lid Wm de toevoeging "Het verbod geldt niet voor zover het betreft zodanige handelingen die hem bij of krachtens de wet uitdrukkelijk zijn toegestaan.". Vooralsnog is onduidelijk of deze toevoeging dient te worden aangemerkt als een bestanddeel of als een (bijzondere) strafuitsluitingsgrond. Een belangrijk verschil met de abstracte gevaarzettingsdelicten is dat daar alleen een bepaalde gedraging is strafbaar gesteld ongeacht het gevolg, waarbij deze gedragingen zich vaak beperken tot een inbreuk op voorschriften van het bestuur, terwijl hier het concreet in gevaar brengen van het rechtsgoed door een bepaalde gedraging noodzakelijk is. Indien deze gedraging plaatsvindt conform de bestuurlijke regelgeving wordt dit type strafbaarstelling niet geschonden vanwege het bestanddeel

21 Zie over de interpretatie van "wederrechtelijk" ook hoofdstuk 4 paragraaf 6.1. en Faure, M. en Visser, M., De strafrechtelijke bescherming van het leefmilieu in Belgie, Duitsland en Nederland, pp. 236-242.

22 Dit doet zich bijvoorbeeld voor indien wordt geloosd overeenkomstig een Wvovergunning, maar in strijd met een grenswaarde die in een amvb is vastgelegd op basis van artikel la Wvo; zie hierover Lange, A. de, "Herijking van het milieustrafrecht", p. 81; Faure, M., “De gevolgen van de 'administratieve afhankelijkheid' van het milieustrafrecht: een inventarisatie van knelpunten", p. 133 en Roos, Th.A. de en Visser, M., "Milieustrafrecht", 70.8. 
"vderrechtelijk" of een equivalent daarvan. ${ }^{23}$ Maar ook dit type strafbaarstellingen is (entueel in combinatie met abstracte gevaarzettingsdelicten) vaak niet voldoende.

Inien sprake is van een zeer ernstige inbreuk op het beschermde rechtsgoed die phtsvindt conform een bestuurlijke voorbeslissing kunnen ten behoeve van de becherming van dit rechtsgoed in de derde plaats zelfstandige delicten noodzakelijk zi. Dit type strafbaarstelling incrimineert zeer ernstige inbreuken op het beschermie rehtsgoed, zelfs als deze plaatsvinden conform de bestuurlijke regelgeving. Het bangrijkste verschil met het tweede soort strafbaarstelling is dat het bestanddeel "ederrechtelijk" ontbreekt. ${ }^{24}$ In sommige gevallen dient ten behoeve van de beschermg van het rechtsgoed de "administratieve afhankelijkheid" 25 te worden verlaten en met een meer autonome strafrechtelijke bescherming worden verleend. Het probleem dd dan echter rijst, is hoe men op een met het lex certa-vereiste verenigbare wijze een stfbaarsteling construeert die deze "ernstige" schending omvat. Het is natuurijik een rchtspolitieke keuze of van dit type strafbaarstelling gebruik wordt gemaakt en wat hu beschermde rechtsgoed is dat deze vergaande bescherming toekomt. Vaak wordt er hr voor gekozen om als beschermd rechtsgoed de menselijke gezondheid of het nnselijk leven aan te merken. De gegeven ratio van deze strafbaarstellingen is dat het bsluit van het bestuur nooit een toelating zou kunnen inhouden tot het veroorzaken vn deze inbreuk. In die zin vormt deze bepaling dan ook geen breuk met het bestuursweht. Indien sprake is van een gedraging conform bestuursrechtelijke voorschriften zal dit bij de strafrechter natuurlijk wel een rol spelen. Hierdoor kán namelijk sprake zijn van een bijzondere rechtvaardigingsgrond, waardoor het feit niet strafbaar is en de rechter de verdachte zal ontslaan van alle rechtsvervolging. ${ }^{26}$ De meeste zorgplichtbepalingen zijn opvallend genoeg op deze manier vormgegeven. Dit is ten eerste opmerkelijk aangezien er geen ernstige inbreuken op de verschillende rechtsgoederen noodzakelijk zijjn, wil er sprake zijn van schending van de zorgplichtbepaling. Voorts betreft het in het algemeen gedragingen die veelvuldig voorkomen, en wel op gebieden waarop door het bestuur wordt bepaald wat voor soort inbreuken op de beschermde rechtsgoederen zijn toegestaan en in welke mate. In het strafrecht is het dan, met oog

23 Bij het concreet gevaarzettingsdelict vormt die schending van voorschriften van het bestuur een concretisering van de wederrechtelijkheid, in de woorden van Schaffmeister, D. en Heijder, A., "Concretisering van de wederrechtelijkheid in het strafrecht", pp. 441474.

24 Voorbeelden zijn het Duitse $\$ 330 \mathrm{a}$ StGB dat het verspreiden of vrijlaten van een stof die gif bevat of gif doet ontstaan strafbaar stelt indien dit "Gefahr des Todes oder einer schweren Gesundheitsschädigung eines anderen oder die Gefahr einer Gesundheitsschädigung einer großen Zahl von Menschen" veroorzaakt. In het Vlaamse gewest is in een artikel 7.3.4 van een Voorontwerp Decreet Milieubeleid een strafbaarstelling opgenomen die zich richt op een emissie waarbij de betrokkene "weet of dient te weten dat dit concreet gevaar oplevert voor de menselijke gezondheid". Zie voor een bespreking Koopmans, I.M., "Ontwikkelingen in het milieustrafrecht", pp. 140-141 en Faure, M. en Visser, M., De strafrechtelijke bescherming van het leefmilieu in België, Duitsland en Nederland, pp. 281-319.

25 Zie hierover hoofdstuk 4 paragraaf 4.

26. Zie hierover hoofdstuk 4 paragraaf 6. 
op het specificeren en beperken van het betekenisbereik van de strafbaarstelling, gebruikelijk de strafrechtelijke aansprakelijkheid te beperken tot die gevallen waarin sprake is van een wederrechtelijke schending van het beschermde rechtsgoed. Hierop wordt doorgaans slechts uitzondering gemaakt indien het rechtsgoed het menselijk leven en/ of de menselijke gezondheid betreft. Dit rechtsgoed wordt dan zo beschermenswaardig geacht dat de wetgever ervoor kiest dat daarop in beginsel geen inbreuken mogen worden gemaakt. ${ }^{27}$ Ook andere rechtsgoederen kan dit vergaande beschermingsniveau worden geboden, maar of dat gebeurt is veeleer een rechtspolitieke keuze. Bij zorgplichtbepalingen lijkt echter geenszins sprake van een dergelijke principiële keuze.

In het bovenvermelde eerder uitgevoerde onderzoek naar modellen van strafbaarstelling ${ }^{28} \mathrm{kwam}$ naar vormen dat bij het formuleren van strafbaarstellingen niet alleen rekening moet worden gehouden met de verschillende gradaties van schending van het beschermde rechtsgoed, maar ook met de mate waarin het bestuur(srecht) de omvang van de strafbaarheid kan bepalen. Geconcludeerd werd dat één allesomvattende strafbepaling in het algemeen niet zal voldoen. Afhankelijk van de rechtspolitieke keuzes, inzake de afhankelijkheid van het bestuur en de gradatie van bescherming van het rechtsgoed, dient een stelsel te worden vormgegeven dat bestaat uit een combinatie van bovenstaande soorten strafbaarstellingen. Ten eerste dient te worden gewerkt met concrete gevaarzettingsdelicten die een gedraging incrimineren indien deze wederrechtelijk plaatsvindt én een bepaald gevolg teweegbrengt of kan brengen. Daarnaast zijn zeker in een door het bestuursrecht inhoudelijk vormgegeven rechtsgebied abstracte gevaarzettingsdelicten noodzakelijk, die alleen een bepaalde gedraging (ongeacht het gevolg) strafbaar stellen. In het bijzonder, economisch en milieustrafrecht zal dit vaak het geval zijn. Daar wordt immers de regulering van de toegestane inbreuk op het beschermie rechtsgoed voor een groot deel bepaald door het bestuur, meestal met gebruikmaking van gelede normstellingen. De schending van deze materiële normen kan met behulp van dit type strafbaarstelling worden geïncrimineerd. Voorts kan ter complementering van het systeem gebruik worden gemaakt van zelfstandige delicten die een gedraging die een zeer ernstige inbreuk maakt op het rechtsgoed strafbaar stellen, zelfs als deze conform de bestuurlijke regelgeving plaatsvindt. ${ }^{29}$ Vooral de vraag of gebrrik wordt gemaakt van deze bepalingen is afhankelijk van de rechtspolitieke keuze om het betreffende rechtsgoed tegen vergaande inbreuken te beschermen.

27 Er zijn overigens ook strafbaarstellingen die de menselijke gezondheid beschermen waarin het bestanddeel wederrechtelijk is opgenomen, zie bijvoorbeeld artikel 173a en. $173 \mathrm{~b} \mathrm{Sr}$.

28 Zie Faure, M. en Visser, M., De strafrechtelijke bescherming van het leefmilieu in Belgiè, Duitsland en Nederland; Faure, M., "Het Nederlandse milieustrafrecht: dringend" aan herziening toe!"; Faure, M. en Visser, M., "Het tekort van het Nederlandse milieustrafrecht".

29 Het spreckt overigens voor zich dat, omdat de strafwaardigheid van het eerste naar het derde type strafbaarstelling toeneernt, de verhoogde strafwaardigheid ook in een aangepaste strafmaat dient te worden gereflecteerd. Zie ook de bespreking van de proportionaliteit in hoofdstuk 10 paragraaf 2.5 . 
Intien een optimale combinatie van abstracte gevaarzettingsdelicten en concrete gevaarzettingsdelicten, eventueel aangevuld met zelfstandige delicten wordt bereikt, lijt het mogelijk een systeem van strafbaarstellingen vorm te geven dat voldoende mogelijkheden biedt het te beschermen rechtsgoed daadwerkelijk te beschermen. Op basis van het eerder verrichte onderzoek blijkt dat het gebruik van zorgplichtbepalingen met hun specifieke kenmerken in een dergelijk systeem niet (meer) nodig is. Zorgplichtbepalingen kunnen, uit het oogpunt van het subsidiariteitsbeginsel, als apart model achterwege blijven. Dat dit wenselijk is blijkt niet zozeer uit de a-typische kenmerken van zorgplichtbepalingen ten opzichte van de kenmerken van de strafbaarstellingen uit de andere drie modellen. De wenselijkheid wordt veeleer veroorzaakt deor de bezwaren die zijn verbonden aan de typische kenmerken van deze bepalingen, et doordat de opbouw en werking van een strafrechtelijk systeem mogelijk blijkt zender deze bepalingen. De aan dit soort strafbaarstellingen verbonden bezwaren worden uitvoerig besproken bij de toetsing van zorgplichibepalingen in de overige delen van dit hoofdstuk.

\section{Proportionaliteit}

\subsection{Inleiding}

Irdien toch wordt gekozen voor het gebruik van zorgplichtbepalingen rijst, in het kader van de toetsing van zorgplichtbepalingen aan de vereiste evenredigheid, de vraag of de gehanteerde indeling van de zorgplichtbepaling in redelijke verhouding staan tot de betreffende gedraging. Bovendien speelt de vraag of de maximum strafbedreiging in redelijke verhouding staan tot de betreffende gedraging. Bij de beantwoording dient men zich te realiseren dat bij zorgplichtbepalingen het strafrecht reeds in een zeer vroege fase bescherming aan het rechtsgoed kan verlenen. Een krenking of het daadwerkelijk in gevaar brengen van het beschermde rechtsgoed door de strafbaar gestelde gedraging wordt door zorgplichtbepalingen vaak niet geëist. Op basis van deze omstandigheden zou kunnen worden verwacht dat de indeling en de strafdreiging van deze strafbepalingen licht zal zijn. De indeling die door de wetgever wordt gehanteerd wordt in dit hoofdstuk besproken in paragraaf 2.5.2., terwijl op de strafbedreiging wordt ingegaan in paragraaf 2.5.3.

Het beoordelen van de indeling en van de strafbedreiging kan bij zorgplichtbepalingen moeilijk zijn, aangezien het een probleem kan zijn de omvang van de schade te bepalen. Dit wordt veroorzaakt doordat vaak geen intreden van een tastbaar schadelijk gevolg wordt vereist, en omdat sommige vormen van schade zeer moeilijk meetbaar kunnen zijn. In hoofdstuk 10 paragraaf 2.3.1. werd reeds aangegeven dat zelfs indien ontstane schade nadien ongedaan wordt gemaakt, er nog steeds sprake kan zijn van een inbreuk op de zorgplichtbepaling. Het optreden van tastbare schade in de zin van bijvoorbeeld gezondheid, ecologische of financieel-economische schade, is immers meestal geen voorwaande voor de strafbaarheid bij zorgplichtbepalingen. Het kan voldoende zijn indien de in acht te nemen graad van zorgvuldigheid wordt veronachtzaamd. Ook ander gedrag kan als schending van de zorgvuldigheid en dus als onwenselijk worden aangeduid. Het is de vraag of in die gevallen sprake is van een 
evenredige verhouding tussen schade die wordt veroorzakt door het gedrag en de sanctie die op het overtreden van de bepaling is gesteld. Dit wordt nog versterkt indien het gedrag dat als onwenselijk wordt beschouwd niet specifiek wordt aangegeven. Het vaststellen van een evenwichtige relatie tussen enerzijds de omvang van de (potentiële) schade en anderzijds het soort strafbaarstelling en de maximum (en soort) strafbedreiging kan daarom problematisch zijn.

\subsubsection{De indeling}

In het kader van de proportionaliteit dient eerst te worden onderzocht op welke manier de zorgplichtbepalingen zijn ingedeeld; zijn het "beboetbare feiten", overtredingen of misdrijven. ${ }^{30}$ Deze keuze heeft enkele belangrijke verschillen in rechtsgevolg en heeft in het algemeen ook invloed op de maximum strafbedreiging.

Door de wetgever werd bij de totstandkoming van het Wetboek van Strafrecht een intrinsiek verschil aangegeven tussen overtredingen en misdrijven; bij overtredingen zou het gaan om "wets"delicten die strafwaardig zijn door of uit kracht van de wet, terwijl misdrijven als "rechts"delicten uit eigen aard reeds in strijd met de rechtsorde zouden zijn. Dit verschil werd niet houdbaar geacht. Wel is duidelijk dat misdrijven in het algemeen als ernstiger en meer afkeurenswaardig worden beschouwd dan overtredingen, waarbij een groot aantai' râctoren to sammor Jopraland ajin hji de henordeling of het strafbare feit dient te worden aangemerkt als overtreding of als misdrijf. Het betreft voornamelijk de betekenis van het geschonden rechtsgoed, de omvang van de krenking, de wijze van aantasting, of al dan niet sprake is van opzet en de plaats in het systeem van regelgeving. Ook de vormgeving is vaak anders, aangezien overtredingen vaak formele delicten zijn (waarbij wordt volstaan met het aangeven van een bepaald soort gedraging) die meestal eenvoudig zijn samengesteld en waar doorgaans een subjectief bestanddeel ontbreekt. Misdrijven zijn daarentegen meestal materiële delicten (die het veroorzaken van een bepaald gevolg omvatten en waarbij meestal de daartoe voerende gedraging als bestanddeel is opgenomen) waarin meestal wel een subjectief bestanddeel is opgenomen.

Een aantal strafbaarstellingen in het bijzonder, economisch en milieustrafrecht kan ook via het bestuursrecht worden gehandhaafd. ${ }^{31}$ Met name door de invoering van de bestuurlijke boete in het bijzonder en economisch strafrecht, de invoering van de bestuurlijke transactie in het milieustrafrecht en de eventuele uitbreiding van deze mogelijkheden in de toekomst, gaat het bestuursrecht bij de handhaving naast of in plaats van het strafrecht een (steeds) grote(re) rol spelen. Bij de keuze tussen indeling in het strafrecht of in het bestuursrecht, en meer specifiek. tussen overtreding of

30 Zie over misdrijven, overtredingen en "beboetbare feiten" hoofdstuk, 6 paragrafen $3 \mathrm{en}$ 4.

31 Denk hierbij niet alleen aan controle, voorlichting en waarschuwing (al dan niet in de vorm van een brief) maar bijvoorbeeld ook aan (preventieve) bestuursdwang of (preventieve) dwangsom, zie over deze laatste twee mogelijkheden bijvoorbeeld Buuren, P.J.J. van, Jurgens, G.T.J.M. en Michiels, F.C.M.A., Bestuursdwang en dwangsom. 
"bejoetbaar feit", lijken in de praktijk vooral pragmatische redenen een rol te spelen. Dogmatisch zijn echter dezelfde factoren van belang die een keuze bepalen tussen mistrijven en overtredingen, terwijl hier ook het (moeilijk aan te duiden) "orrechtsgehalte" van belang is, en de algemene vraag of en waarom het (in een aantal gevallen) wenselijk is dat het bestuursrecht over punitieve instrumenten ter sanctioneriṇ van onwenselijke gedragingen beschikt.

He schenden van een zorgplichtbepaling blijkt zowel te worden ingedeeld als "bboetbaar feit", als overtreding en als misdrijf. Een motivering van de wetgever voor eer bepaalde keuze wordt overigens soms niet en vaak nauwelijks gegeven. Dit kan woden geillustreerd aan de hand van de in de voorgaande hoofdstukken besproken zogplichtbepalingen.

Dezorgplichtbepalingen in het commune strafrecht, te weten artikel 425 aanhef en sub 2, utikel 426, eerste lid, artikel 427 aanhef en sub 1 en 5 en artikel 429 aanhef en sub $33 r$, zijn opgenomen in Boek III Sr. Het schenden van deze bepalingen betreft dehalve overtredingen. De motivering hiervoor is te vinden in de algemene overwegingen in de memorie van toelichting bij het Wetboek van Strafrecht. De wetgever gaff hirin aan dat het bij overtredingen zou het gaan om "wets"delicten die strafwaardig zij door of uit kracht van de wet terwijl misdrijven als "rechts"delicten uit eigen aard reds in strijd met de rechtsorde zouden zijn. Een toelichting waaruit blijkt waarom juist deze strafbare feiten zijn aangernerkt als overtreding ontbreekt. ${ }^{32}$

Dok de schending van de besproken zorgplichtbepalingen in het bijzonder strafrecht worden aangemerkt als overtreding. Artikel $5 \mathrm{WVW}$ wordt evenals zijn voorlopers aangeduid als overtreding. Tijdens de totstandkoming van de WVW 1994 is deze indeling niet heroverwogen. Reeds in 1905 werden de in artikel 15 Motor- en rijwielwet 1905 strafbaar gestelde feiten involge artikel 19 Motor- en rijwielwet 1905 aangemerkt als overtredingen. Dit gold ex artikel 38 WVW ook voor de in artikel 25 WVW 1935 strafbaar gestelde feiten. Voor het huidige artikel 5 WVW volgt dit uit artikel 178, tweede lid WVW.

In het wetsvoorstel Wet Luchtverkeer 1993 werd voorgesteld het schenden van artikel 5 aan te merken als misdrijf. ${ }^{33}$ Hierover werd in de memorie van toelichting alleen opgemerkt dat bij het onderscheid tussen misdrijven en overtredingen en bij de differentiatie in strafsancties zoveel mogelijk aansluiting is gezocht bij het overige verkeersrecht. ${ }^{34}$ Deze motivering is opmerkelijk te noemen aangezien zowel het schenden van de voorloper van deze zorgplichtbepaling uit artikei 13 sub a Luchtvaartwet 1958 als van artikel 25 (oud) WVW (waarnaar bij de totstandkoming werd

32 Smidt, H.J., Geschiedenis van het Wetboek van Strafrech, Deel I, pp. 60-72 en Smidt, H.J., Geschiedenis van het Wetboek van Strafrecht, Deel III, pp. 174-178 en artikelsgewijs pp. 178-196.

33 TK 1990-1991, 21993 , nr. 1-2, p. 14

34 TK 1990-1991, 21993 , nr. 3, p. 24. 
verwezen) overtredingen waren. Naar aanleiding van vragen in het voorlopig verslag ${ }^{35}$, volhardde de regering en gaf aan dat $^{36}$ :

"de inhoud van artikel 5 zo'n centrale en elementaire rol speelt dat, ter bescherming van de openbare veiligheid en de veiligheid van het luchtverkeer, bestempeling tot misdrijf noodzakelijk voorkomt."

Naar aanleiding van nieuwe vragen van de fracties ${ }^{37}$, werd schending van artikel 5 (overeenkomstig artikel 25 WVW) als overtreding aangemerkt. ${ }^{38}$ Dit gebeurde mede omdat niet alleen de gezagvoerder tot wie het voorgestelde artikel 5 zich richt, maar ook de luchtverkeersleiding en verkeersvliegers die op dat moment niet onder artikel 5 vallen (gemeenschappelijk) verantwoordelijk zijn voor de wijze van deelneming aan het luchtverkeer. De regering wilde, in tegenstelling tot enkele fracties, op dat moment uitdrukkelijk geen regeling maken voor deze laatste twee groepen. ${ }^{39}$ Vervolgens werd een amendement ingediend waarmee de luchtverkeersleiding wel onder de reikwijdte van artikel 5 wordt gebracht. Het amendement werd met algemene stemmen aangenomen ${ }^{40}$ waarna het artikel zijn definitieve vorm kreeg. ${ }^{41}$ Er vond geen nieuwe discussie plaats over de indeling van deze zorgplichtbepaling, waardoor het schenden van artikel 5 Wet Luchtverkeer 1993 involge artikel 47 van deze wet wordt aangemerkt als een overtreding. ${ }^{42}$

Over de gebezigde indeling van artikel 19 Quarantainewet als overtreding heeft geen specifieke discussie plaatsgevonden. In artikel 35 van deze wet is bepaald dat het handelen in strijd met alle bepalingen uit de Quarantainewet wordt aangemerkt als overtreding, hetgeen derhalve ook geldt voor artikel 19 Quarantainewet. ${ }^{43}$

Het handelen of nalaten in strijd met artikel 11 Arbo-wet 1998 levert involge artikel 33, eerste lid Arbo-wet 1998 sinds november 1999 een (bestuursrechtelijk) "beboetbaar feit" op. Het handelen of nalaten in strijd met artikel 33, eerste lid Arbowet 1998 kan involge artikel 33, derde lid Arbo-wet 1998 worden angemerkt als strafbaar feit

"indien twee maal binnerı 48 maanden yoorafgaand aan de handeling of het nalaten fer zake van een zelifde handeling of nalaten een bestuurlijke boete is opgelegd."

TK 1990-1991, 21 993, nr. 5, p. 9.

36 TK 1990-1991, 21993 , nr. 6, p. 12.

37 TK 1991-1992, 21993 , nr. 8, pp. 9-11.

38 Zie de Nota van wijziging, TK 1991-1992, 21 993, nr. 10, p. 47.

39 TK 1991-1992, 21993 , nr. 9, p. 13.

40 TK 24 maart 1992, p. 65-3977.

41 Het wetsvoorstel wordt met algemene stemmen en in de Eerst Kamer zonder beraadslaging, aangenomen. TK 24 maart 1992, p. 65-3977; EK. 16 juni 1992, p. 3!1379.

42 Zie hierover hoofdstuk 7 paragraaf 3.3.4.

43 Zie hoofdstuk 7 paragraaf 3.4.3.
} 
In dat geval is involge artikel 33, vijfde lid Arbo-wet 1998 sprake van een overtreding. Voorheen was deze normschending uit het economisch strafrecht ingedeeld als overtreding. Deze principiële overheveling wordt door de wetgever in de memorie van toelichting in algemene zin beschreven. ${ }^{44}$ Belangrijke motieven voor de wijziging zijn dat de strafrechtelijke handhaving tekort zou schieten, en het een kernpunt van beleid is om de handhaving door het bestuur zelf te versterken. De regering verwacht dat het instrument van de bestuurlijke boete tot een verhoging van de effectiviteit van de handhaving door de overheid zal leiden. ${ }^{45}$ De Commissie voor de Toetsing van Wetgevingsprojecten heeft in een advies over de bestuurlijke boete een vijf criteria geformuleerd om te bepalen of wetten voor bestuursrechtelijke handhaving in aanmerking komen. Bij deze criteria wordt door de wetgever in de memorie van toelichting van de Arbo-wet 1998 aangeknoopt. Het betreft ${ }^{46}$ :

"I. De wettelijke norm heeft een geringe normatieve lading;

2. De overtreding pleegt geen letsel aan personen of schade aan goederen toe te brengen;

3. De norm is zo duidelijk in de wet omschreven dat het mogelijk is om op grond van de wettelijke normen en de praktijk een vaste gedragslijn te ontwikkelen;

4. De ambtenaar of dienst die belast wordt met de handhaving beschikt over voldoende expertise om aan de handhaving voldoende adequaat gestalte te geven;

5. Voor de handhaving van de norm zijn geen vrijheidsbenemende of andere ingrijpende dwangbevoegdheden nodig."

Bij de handhaving van de Arbo-wet 1998 blijft volgens de memorie van toelichting het strafrecht op een aantal punten noodzakelijk. Gesteld wordt ${ }^{47}$ :

"Overtreding van wettelijke regels, mogelijk leidend tot ongevallen met dodelijke afloop of enstig letsel, dan wel leidend tot blijvende gezondheidsschade, is een dermate emstige inbreuk op het rechtsgevoel, dat afdoening met een bestuurlijke boete niet past. Strafrechtelijke afdoening is daarom voorzien bij:

1. zeer ernstige risico's (delicten waarbij sprake is van ernstig gevaar voor de veiligheid en gezondheid);

2. delicten die letsel aan personen tot gevolg hebben gehad;

3. bepaalde gevallen van recidive van regels waaraan in eerste aanleg een bestuurlijke sanctie is verbonden."

Op alle overige risico's die niet voor strafrechtelijke afdoening in aanmerking komen, werd in de Arbo-wet 1998 de mogelijkheid gecreëerd de betreffende bepalingen bestuursrechtelijk te handhaven. Dit kan eventueel gebeuren door het opleggen van een bestuursrechtelijke punitieve sanctie. Vanuit deze criteria is de regeling van de

Zie hierover hoofdstuk 8 paragrafen 3.2.9. en 3.2.10.

TK 1998-1999, 25 879, nr. 3, pp. 24-25.

46 TK 1998-1999, 25879 , nr. 3, p. 24; zie het advies van 12 januari 1994 van de Commissie voor de Toetsing van Wetgevingsprojecten, Handhaving door bestuurlijke boeten; Triemstra, R.O. (red.), Arbeidsomstandighedenwet 1998, pp. 39-40. Zie ook hoofdstuk 6 paragraaf 4 .

TK 1998-1999, $25879, \mathrm{nr} .3$, p. 25. Zie ook hoofdstuk 8 paragraaf 3.2.9.
} 
Arbo-wet 1998 opgebouwd. ${ }^{48}$ De overheveling het aanmerken van de schending van de zorgplichtbepalingen uit artikel 11 Arbo-wet 1998 van overtreding naar "beboetbaar feit", werd verder niet toegelicht.

Alleen de besproken zorgplichtbepalingen in het milieustrafrecht, te weten artike! 2 Wms, 13. Wbb en $10.3 \mathrm{Wm}$, vormen op de indeling van de overige besproken zorgplichtbepalingen een uitzondering. Deze bepalingen zijn namelijk via artikei $1 a$ sub 1 Wed aangehaakt aan de Wed. Deze delicten zijn involge artikel 2, eerste lid. Wed misdrijven voor zover zij opzettelijk zijn begaan en in de overige gevallen betreft het overtredingen. Deze strafbare feiten kunnen daarom niet alleen als overtreding, maar ook als misdrijf worden aangemerkt.

Dat het schenden van artikel $2 \mathrm{Wms}$ indien de gedraging opzettelijk geschiedt een misdrijf was en voor het overige een overtreding was, aanvankelijk in de artikel 65 en 66. Wms geregeld. Sinds de invoering van artikel 1a Wed zijn deze twee artikelen vervallen en is artikel $2 \mathrm{Wms}$ zonder verdere discussie aangehaakt bij artikel la sub 1 Wed.

De voorloper van artikel $13 \mathrm{Wbb}$ werd pas in een laat stadium van de parlementaire behandeling van de Wbb, naar aanleiding van een amendement ingevoerd. Ook dit

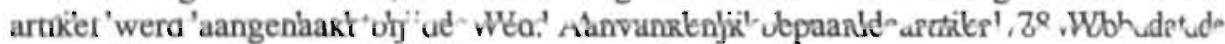
opzettelijke variant een misdrijf was en dat anders sprake zou zijn van een overtreding. Hierover heeft nagenoeg geen discussie plaatsgevonden. Bij wijziging van de Wed in 1994 is artikel 13 Wbb zonder verdere discussie aangehaakt aan artikel la sub 1 Wed.

De voorloper van artikel $10.3 \mathrm{Wm}$ werd in artikel $18.19 \mathrm{Wm}$ aangemerkt als misdrijf indien opzettelijk geschied en betrof in de overige gevallen een overtreding. Wederom werd ook deze zorgplicht bij de wijziging in 1994 van de Wed zonder specifieke motivering aangehaakt aan artikel 1a sub 1 Wed.

De keuze om in 1994 strafbaarstellingen aan te haken aan artikel la sub 1 Wed werd wel in algemene bewoordingen toegelicht in de memorie van toelichting van deze wijzigingswet. ${ }^{49}$ Een belangrijk doel van deze wijziging was het aanmerkelijk verzwaren van de straffen gesteld op emstige milieudelicten. ${ }^{50}$ Deze strafmaat is gerelateerd aan de indeling in sub 1, 2 of 3 van artikel 1a Wed, en involge artikel 2 Wed aan de vraag of het feit opzettelijk is begaan of niet. Voor de strafbaarstellingen die zijn aangehaakt via sub 1 en 2 van artikel la Wed geldt involge artikel 2 dat als sprake is van opzet het een misdrijf betreft en in de overige gevallen sprake is van een overtreding. Het "opzet" is derhalve het enige onderscheidende criterium voor de indeling

48 TK 1998-1999, 25879, nr. 3, p. 25.

49 Zie hoofdstuk 9 paragraaf 2.4.

50 Zie over de strafverzwaring van emstige milieudelicten $T K$ 1992-1993, 23 196, nr. 3, p. 1 en pp. 5-7; zie ook Mulder, A. en Doorenbos, D.R., Schets van het economisch strufrecht, pp. 13, 15-16. 
van deze strafbaarstellingen. Bij het vaststellen welke feiten zodanig ernstig zijn dat zij moeten worden opgenomen in sub 1 is uitgegaan van het criterium ${ }^{51}$

"dat het moet gaan om feiten die een directe aantasting opleveren van het milieu, dan wel daarvoor een emstige en rechtstreekse bedreiging vormen." Hierdoor is "in beginsel de schadelijkheid, respectievelijk het risico van het feit voor het milieu als criteriurn genomen."

De besproken zorgplichtbepalingen in het milieustrafrecht zijn ook ingedeeld in sub 1. Dit is opmerkelijk aangezien zij doorgaans juist niet vereisen dat sprake is van een directe aantasting van het milieu, dan wel daarvoor een ernstige en rechtstreekse bedreiging vormen. ${ }^{52}$ Voor de aanhaking van deze zorgplichtbepalingen aan artikel 1a sub 1 Wed wordt volstaan met deze algemene motivering, en ontbreekt een specifieke motivering.

\subsubsection{De strafbedreiging}

In het kader van de proportionaliteit wordt voorts onderzocht met welke maximum strafbedreiging het schenden van een zorgplichtbepaling wordt bedreigd. Niet alleen bij de gehanteerde indeling van zorgplichtbepalingen lijken er grote verschillen te bestaan tussen de besproken zorgplichtbepalingen. Indien de maximum strafbedreiging van deze zorgplichtbepalingen worden vergeleken, blijken er namelijk eveneens aanzienlijke verschillen aanwezig, die ten dele samenhangen met de gekozen indeling.

Bij de zorgplichtbepalingen in het commuun strafrecht is de maximum strafbedreiging relatief gering. Zo wordt schending van artikel 425 aanhef en sub $2 \mathrm{Sr}$ bedreigd met hechtenis van ten hoogste zes maanden of een geldboete van de derde categorie $(f$. $10.000,-)$. Schending van artikel 426 , eerste lid $\mathrm{Sr}$ wordt bedreigd met hechtenis van ten hoogste zes dagen of een geldboete van de eerste categorie (f. 500,-). Bij artikel 427 aanhef en sub 1 en $5 \mathrm{Sr}$ is de maximum strafbedreiging een geldboete van de eerste categorie $(f .500,-)$. Opvallend is dat schending van deze bepaling niet wordt bedreigd met hechtenis. Ten slotte wordt schending van artikel 429 aanhef en sub $3 \mathrm{Sr}$ bedreigd met hechtenis van ten hoogste veertien dagen of een geldboete van de tweede categorie (f. 5.000,-).

Ook de schending van de zorgplichtbepalingen in het bijzonder strafrecht wordt bedreigd met een relatief lage maximum straf.

Zo wordt het niet naleven van artikel 5 WVW involge artikell 177, eerste lid sub a en d WVW bedreigd met ten hoogste twee maanden hechtenis of een geldboete van de tweede categorie ( $f .5 .000,-)$. Daarnaast bepaalt artikel 179, tweede lid WVW dat bij veroordeling terzake van dit feit de bestuurder van een motorrijtuig een ontzegging van de rijbevoegdheid kan worden opgelegd met een maximum termijn van twee jaren. Deze termijn kan involge artikel 179, vijfde lid WVW worden verruimd naar 
vier jaren indien er sprake is van recidive; hiervan is sprake indien het feit binnen twee jaren na een eerdere ontzegging van de rijbevoegdheid is gepleegd. Deze maximum strafbedreiging is bij de herziening van de WVW in 1994 gedeeltelijk verlaagd ten opzichte van het oude artikel 25 WVW 1935. Alleen de maximaal op te leggen geldboete is bij deze wijziging aanzienlijk verhoogd. Schending van het oude artikel werd bedreigd met hechtenis van ten hoogste drie maanden of geldboete van ten hoogste duizend gulden. Voorts kon de bestuurder van het motorrijtuig bij veroordeling wegens schending van artikel 25 involge artikel 39 WVW 1935 de bevoegdheid tot het besturen van motorrijtuigen voor ten hoogste vijf jaren worden ontzegd. Deze wijzing van de maximum strafbedreiging werd voomamelijk veroorzaakt door de sterke vereenvoudiging van het sanctiestelsel uit de WVW 1994 ten opzichte van de WVW 1935.

Schending van artikel 5 Wet Luchtverkeer 1993 is strafbaar gesteld bij artikel 47 Luchtvaartwet. De maximum strafbedreiging is zes maanden hechtenis of een geldboete van ten hoogste de derde categorie $(f .10 .000,-)$. Bij een veroordeling kan de bevoegdheid een luchtvaartuig te bedienen of luchtverkeersleiding te geven voor ten hoogste drie jaar worden ontzegd.

Het handelen in strijd met alle bepalingen van de Quarantainewet, en derhalve ook met artikel 19, is in artikel 35, eerste lid van deze wet stafbaar gesteld. De maximum strafbedreiging is één jaar hechtenis of een geldboete van ten hoogste de derde categorie (f. 10.000,-).

Schending van het besproken voorbeeld in het economisch strafrecht, artikel 11 Arbowet 1998, wordt in eerste instantie bedreigd met een bestuurlijke boete. Involge artikel 33, eerste lid Arbo-wet 1998 wordt schending van deze zorgplichtbepaling bedreigd met een bestuurlijke boete van ten hoogste de eerste (bestuurlijke boete-) categorie (f. 10.000,-). Het handelen of nalaten in strijd met artikel 33, eerste lid Arbo-wet 1998 kan involge artikel 33, derde lid Arbo-wet 1998 worden aangemerkt als strafbaar feit "indien twee maal binnen 48 maanden voorafgaand aan de handeling of het nalaten ter zake van een zelfde handeling of nalaten een bestuurlijke boete is opgelegd." In dat geval is involge artikel 33, vijfde lid sprake van een overtreding, die involge artikel 46, eerste lid wordt aangehaakt bij artikel 1 sub 3 Wed. Involge artikel 6, eerste lid sub 4 Wed is strafbedreiging hechtenis van ten hoogste zes maanden of een geldboete van ten hoogste de vierde categorie (f. 25.000,-). Daarnaast kunnen ook de bijkomende straffen uit artikel 7 Wed en de matregelen uit artikel 8 Wed worden opgelegd.

Ook hier vallen de zorgplichtbepalingen in het milieustrafrecht (artikel $2 \mathrm{Wms}, 10.3$ Wm en $13 \mathrm{Wbb}$ ) op door hun relatief hoge maximum strafbedreiging. Doordat deze strafbaarstellingen sinds 1994 via artikel la sub 1 Wed zijn aangehaakt aan de Wed, betreft het involge artikel 2, eerste lid Wed misdrijven voor zover zij opzettelijk zijn begaan en in de overige gevallen betreft het overtredingen. De wijziging van de Wed in 1994 was, zoals eerder betoogd, in de eerste plaats gericht op het aanmerkelijk verzwaren van de straffen gesteld op ernstige milieudelicten. De maximum strafmast werd verhoogd, doordat zij gedeeltelijk tot de zwaarste categorie economische delicten 
zijn gaan behoren. Ook de zorgplichtbepalingen werden in deze zwaarste categorie ingedeeld. Bij deze indeling werd uitgegaan van het criterium "dat het moet gaan om feiten die een directe aantasting opleveren van het milieu, dan wel daarvoor een emstige en rechtstreekse bedreiging vormen." ${ }^{33}$ Hierdoor is "in beginsel de schadelijkheid, respectievelijk het risico van het feit voor het milieu als criterium genomen." ${ }^{54}$ Hieruit $^{55}$

"vloeit voort, dat het aantal gevallen waarin aan andere feiten dan de emstige milieudelicten zelf, hogere strafposities worden verbonden, niet groter moet zijn dan praktisch onvermijdelijk is."

Zoals gezegd zijn de zorgplichtbepalingen misdrijven indien opzettelijk begaan, en betreft het in de overige gevallen overtredingen. De overtredingen worden involge artikel 6 Wed bedreigd met ten hoogste één jaar hechtenis of een geldboete van de vierde categorie (f. 25.000,-). Indien het echter een misdrijf betreft, is involge artikel 6 Wed de strafbedreiging gevangenisstraf van ten hoogste zes jaren of een geldboete van de vijfde categorie $(f .100 .000,-)$. Daamaast zijn er involge artikel 7 Wed bijkomende straffen mogelijk, zoals ontzetting van rechten, plaatsing in een rijkswerkinrichting, gehele of gedeeltelijke stillegging van de onderneming, verbeurdverklaring van voorwerpen en openbaarmaking van de rechterlijke uitspraak. Bovendien kent de Wed op grond van artikel 8 Wed een aantal maatregelen zoals onttrekking aan het verkeer, ontneming van wederrechtelijk verkregen voordeel, schadevergoeding, onderbewindstelling van de onderneming van de veroordeelde en het opleggen van de verplichting tot verrichting van bepaalde prestaties. ${ }^{56}$ Ook wordt een enkele keer gebruik gemaakt van de mogelijkheid om een strafzaak voor onbepaalde tijd aan te houden onder voorwaarde dat aan bepaalde voorwaarden wordt voldaan, teneinde een bepaalde gewenste situatie af te dwingen en/ of een bepaalde ongewenste situatie te beëindigen. ${ }^{57}$ Opvallend is dat ook na een einduitspraak voorlopige maatregelen ex artikel 28 en artikel 29 Wed in stand kunnen blijven. Deze behoeven niet op te gaan in een definitieve maatregel op grond van artikel 8 Wed. $^{58}$

$53 \quad T K$ 1992-1993, 23196, nr. 3, p. 5, zie ook pp. 12-13.

$54 \quad T K 1992-1993,23196$, nr. 3, p. 13.

$55 \quad T K 1992-1993,23196$, nr. 3, p. 13.

56 De strafvervolging kan hierdoor meer dan één doel dienen. Naast repressie kan bijvoorbeeld een sanering van een verontreinigd terrein worden afgedwongen, zie $\mathrm{Rb}$. Assen 10 februari 1999, MenR 1999, nr. 99, met noot De Lange (Meer doelen Sr).

57 Dit gebeurde in de zaak Pametex. De rechtbank kan op basis van de Wed bedrijven die zich niet houden aan milieuwetgeving onder toezicht stellen van een bewindvoerder. Deze zou dan zeggenschap krijgen over het hele bedrijf. In de praktijk blijkt dit middel nooit te worden toegepast. Hier werd gekozen voor het benoemen van een milieumanager, waarvan de benoeming moet worden goedgekeurd door het OM en de Provincie. De strafzaak werd voor onbepaalde tijd aangehouden, zodat als het mis gaat, het OM de zaak meteen kan aanbrengen. Zie X., "Pseudo-bewindvoerder moet shredder op het rechte pad brengen", pp. 30-31.

58 Dit gebeurde bijvoorbeeld in Hof Amsterdam 14 maart 1995, MenR 1995, nr. 95, met: noot De Lange (Verwijderen autowrakken), dit is bovendien zeer opvallend aangezien hierdoor een combinatie mogelijk wordt van instrumenten die sterke overeenkomst. vertonen met de combinatie "bestuursdwang" en "dwangsom" een combinatie die het 
De rechter heeft in het algemeen bij het vaststellen van het soort en de omvang van de straf een relatief grote discretionaire bevoegdheid, zodat hij de verdachte weliswaar geen hogere dan de wettelijk toegestane straf, maar wel een (veel) lagere of geen straf kan opleggen, al dan niet in combinatie met bijkomende straffen en maatregelen. Zorgplichtbepalingen kunnen meestal ook worden geschonden zonder dat door de gedraging tastbare schade aan het rechtsgoed behoeft te zijn ontstaan, aangezien deze schade in het algemeen geen voorwaarde voor strafbaarheid is. Gezien het proportionaliteitsbeginsel dient de rechter in een voorliggend geval bij het vaststellen van de straf onder andere rekening te houden met het soort gedraging van de verdachte en of, en zo ja de mate waarin, tastbare schade werd veroorzaakt. Indien sprake is van schade, dient de rechter voorts rekening te houden met de reactie daarop van de verdachte, bijvoorbeeld of hij (pogingen heeft ondernomen) de veroorzaakte schade zoveel mogelijk te beperken of ongedaan te maken.

\subsection{Zorgplichtbepalingen en evenredigheid}

Bij de beoordeling van zorgplichtbepalingen aan het vereiste van evenredigheid is het ten eerste belangrijk dat duidelijk is wat het doel is van de betreffende bepaling. Bij zorgplichtbepalingen is dit meestal eenvoudig te achterhalen aangezien het te beschermen belang in deze bepalingen duidelijk wordt verwoord. Het rechtsgoed lijkt derhalve te worden beschermd door deze bepalingen. ${ }^{59}$

Het is vervolgens van belang na te gaan in hoeverre dit doel wordt behartigd door deze bepaling, waarbij rekening moet worden gehouden met de vraag of de strafbaar gestelde gedraging (potentieel) schadelijk is voor het beschermde rechtsgoed. De door zorgplichtbepalingen verplichte behartiging van een bepaalde graad van zorgvuldigheid vereist meestal niet dat er daadwerkelijk schade ontstaat. Er blijken duidelijk verschillen aanwezig tussen de diverse zorgplichtbepalingen inzake de relatie tussen. de gedraging, de vereiste zorgvuldigheid en mogelijke schade. Zorgplichtbepalingen die zijn vormgegeven als concreet gevaarzettingsdelict vereisen dat moet worden. bewezen dat sprake is van een door de verdachte gevaarzettend gedrag ten aanzien van het beschermde rechtsgoed. De relatie tussen de schade en de zorgplichtbepaling is sterk aanwezig bij bijvoorbeeld artikel 425 , aanhef en sub $2 \mathrm{Sr}$, en ook artikel 426 , eerste lid Sr stelt enkele gedragingen strafbaar die het ontstaan van schade omvatten. Bij veel zorgplichtbepalingen (zie de artikelen $5 \mathrm{WVW}, 5$ Wet Luchtverkeer, $13 \mathrm{Wbb}$, 10.3 Wm, $2 \mathrm{Wms}$ ) is de relatie tussen de gedraging en de schade veel losser nu deze slechts het in gevaar brengen of in gevaar kunnen brengen van het rechtsgoed vereisen. Gezien de gebruikte bestanddelen vereisen zij vaak nauwelijks en soms zelfs geheel niet een gevaarzetting aangezien een potentiële gevaarzetting ook al voldoende is. Daarnaast zijn er zorgplichtbepalingen (zie artikel 19, eerste lid sub a, b, c en derde lid eerste zin Quarantainewet) die in het geheel geen (potentieel) gevolg vereisen

bestuursrecht niet kent.

59 Het kan echter wel een probleem zijn dat het beschermde rechtsgoed zeer ruim is geformuleerd. Tenzij het betekenisbereik door de bestanddelen nauwkeurig wordt gespecificeerd, zal het betekenisbereik van de betreffende bepaling doorgaans groot zijn. 
angezien zij zijn vormgegeven als abstract gevaarzettingsdelict. Het ethischnormatieve oordeel neemt zodoende een belangrijke plaats in bij de beoordeling van de schadelijkheid van de gedraging. Indien de zorgplichtbepalingen vanuit de rechtsgoedbeschermende functie van het strafrecht worden bekeken, zijn voor strafbaarstelling dan ook niet zoveel argumenten aan te voeren.

Voorts is in het kader van de evenredigheid onderzocht in hoeverre voor het nastreven van het doel van de bepaling de regelgeving voldoet aan het subsidiariteitsbeginsel. Zeker bij het formuleren van strafbaarstellingen ten behoeve van de bescherming van rechtsgoederen die geen absolute bescherming genieten, voldoet meestal één alles omvattende bepaling niet. Afhankelijk van de rechtspolitieke keuzes, inzake de afhankelijkheid van het bestuur en de gradatie van bescherming van het rechtsgoed, dient te worden gewerkt met een combinatie van soorten strafbaarstellingen. ${ }^{60}$ Hierbij dient ten eerste te worden gewerkt met concrete gevaarzettingsdelicten, waarnaast vaak abstracte gevaarzettingsdelicten noodzakelijk zijn. Ter complementering van het systeern kan daarnaast gebruik worden gernaakt van zelfstandige delicten. Indien een evenwichtige combinatie van deze strafbaarstellingen wordt bereikt, lijkt het mogelijk een systeem van strafbaarstellingen vorm te geven dat voldoende mogelijkheden biedt het te beschermen rechtsgoed daadwerkelijk te beschermen. Het gebruik van zorgplichtbepalingen met hun specifieke kenmerken zal in een dergelijk systeen niet (meer) nodig zijn, en kan uit oogpunt van het subsidiariteitsbeginsel achterwege blijven.

Indien toch de keuze wordt gemaakt voor het gebruik van zorgplichtbepalingen rijst de vraag naar de proportionaliteit, waarvoor wordt onderzocht of de gehanteerde indeling en de maximum strafbedreiging evenredig zijn met de strafbaar gestelde gedraging. Het strafrecht kan bij zorgplichtbepalingen in een zeer vroeg stadium bescherming bieden aan het beschermde rechtsgoed, aangezien een krenking of daadwerkelijk in gevaar brengen vaak niet wordt geëist. Zorgplichtbepalingen blijken zowel te worden ingedeeld als "beboetbaar feit" (artikel 11 Arbo-wet 1998), als overtreding (de artikelen 425 aanhef en sub 2, artikel 426, eerste lid, artikel 427 aanhef en sub 1 en 5 en artikel 429 aanhef en sub $3 \mathrm{Sr}, 5$ WVW, 5 Wet Luchtverkeer, 19 Quarantainewet) en als overtreding of misdrijf (afhankelijk of sprake is van opzet de artikelen $13 \mathrm{Wbb}$, $10.3 \mathrm{Wm}, 2 \mathrm{Wms})$. Opvallend hierbij is de zwaarte van de indeling van de zorgplichtbepalingen in het milieustrafrecht. Zij zijn immers aangehaakt aan de eerste categorie van artikel 1a Wed, waardoor het ingevolge artikel 2 "voor zover zij opzettelijk zijn begaan" kunnen worden aangemerkt als misdrijf. De keuze voor aanhaking aan artikel la sub I Wed klemt temeer, daar bij de indeling het criterium is gehanteerd dat wil een strafbaarstelling in deze zwaarste categorie worden ingedeeld "het moet gaan om feiten die een directe aantasting opleveren van het milieu, dan wel daarvoor een emstige en rechtstreekse bedreiging vormen". Aangezien hiervan bij zorgplichtbepalingen geen sprake behoeft te zijn, en gezien de daaraan verbonden gevolgen, lijkt de

60 Zie over de opbouw van het systeem van strafbaarstellingen uitgebreid Faure, M. en Visser, M., De strafrechtelijke bescherming van het leefmilieu in België, Duitsland en Nederland. 
keuze voor deze indeling niet te voldoen aan het proportionaliteitsbeginsel. Ook de maximum strafbedreiging lijkt bij een aantal zorgplichtbepalingen niet te voldoen aan het vereiste van proportionaliteit. Wederom betreft dit vooral de zorgplichtbepalingen in het milieustrafrecht. Deze vormen opnieuw een uitzondering ten opzichte van de overige besproken zorgplichtbepalingen. Schending van deze bepalingen wordt, in tegenstelling tot de meeste andere zorgplichtbepalingen, bedreigd met zeer zware sancties.

\section{Rechtszekerheid}

\subsection{Inleiding}

Indien vaststaat dat het incrimineren van bepaalde gedragingen op een bepaald gebied is gewenst, dient de strafbaarstelling zo te worden ingericht dat zoveel mogelijk wordt tegemoet gekomen aan de rechtszekerheid van justitiabelen. Hiervoor is van belang dat de bepaling rechtmatig is, zodat zij voldoet aan de eisen uit internationale verdra. gen, de (grond)wet en algemene rechtsbeginselen. In het kader van de rechtszekerheid wordt voor de bespreking van zorgplichtbepalingen vooral gedacht aan het legaliteitsbeginsel en het daaruit afgeleide lex certa-beginsel.

Ook bij wijziging van regelgeving en ten aanzien van verkregen rechten en opgewekte verwachtingen dient aan het rechiszekerheidsvereiste tegemoet te worden gekomen, bijvoorbeeld door adequaat overgangsrecht. Voor het strafrecht is in dit kader vooral de algemene regel uit artikel 1 , tweede lid $\mathrm{Sr}$ van belang; dat bij verandering van wetgeving na het tijdstip waarop het feit is begaan de voor de verdachte gunstigste bepaling moet worden toegepast. ${ }^{61}$ Hiervoor is nodig dat sprake is van een gewijzigd inzicht van de wetgever omtrent de strafwaardigheid van het feit. Het ziet zowel op verandering inzake de strafwaardigheid van de onderwerpelijke gedraging ${ }^{62}$ als op een verandering in strafbedreiging. Deze regel geldt zowel voor regelgeving in formele als in materiële zin. Opvallend is dat hij niet geldt voor beschikking(voorschriften) ${ }^{63}$, terwijl deze via een gelede normstelling de materiële inhoud van een strafbaarstelling kunnen bevatten.

61 Zie Knigge, G., Verandering van wetgeving.

62 HR 10 december 1991, NJ 1992, 322, met noot Knigge (Wapen tijdelijk bij dochter). De rechter onderzoekt op basis van de bewijsmiddelen of de bestanddelen van de nieuwe bepaling kunnen worden bewezen verklaard. Voor deze uitspraak was de tenlastelegging bepalend voor de beantwoording van de kwalificatievraag. 1919 , pp. 479-650 (Teelt in Beemster). 
3.2. Lex certa

\subsubsection{Inleiding}

De voorwaarden voor strafbaarheid worden in eerste instantie bepaald door de instantie die de strafbaarstelling invoert. Naast de wetgever in formele zin, kunnen dit ook lagere wetgevers zijn. De betreffende wetgever dient de voorwaarden voor strafbaarheid duidelijk, nauwkeurig en inzichtelijk te omschrijven. Artikel 1, eerste lid $\mathrm{Sr}$ stipuleert:

"Geen feit is strafbaar dan uit kracht van een daaraan voorafgegane wettelijke strafbepaling."

De "wettelijke strafbepaling" duidt op de strafbepaling zelf, zodat de tekst van de strafbaarstelling maatgevend is voor de beantwoording van de vraag of de justitiabele hienuit voorafgaande aan zijn handelen kan weten of zijn gedraging al dan niet onder de delictsomschrijving valt. De uitwerking van het lex certa-beginsel is in het Nederlandse strafrecht dan ook strikter (of zou dat tenminste moeten zijn) dan de garantie uit artikel 7 EVRM. Volgens de uitleg die is gegeven aan artikel 7 EVRM dienen strafbaarstellingen immers "clearly defined in law" te zijn. Het begrip "law" heeft dan echter zowel betrekking op het geschreven als het ongeschreven recht. Ondanks dat aan de "law" blijkens de jurisprudentie ook kwaliteitseisen worden gesteld inzake (onder andere) "foreseeability" en "accessibility", is dit minder strikt dan de vereisten die naar Nederlands recht worden gesteld aan de geschreven wettelijke strafbepaling. ${ }^{64}$

Eén van de redenen voor de wetgever om over te gaan tot het opnemen van zorgplichtbepalingen is gelegen in het feit dat de wetgever bij het maken van de regelgeving niet in staat, of bereid was meer specifiek het niet toelaatbare aan te geven ${ }^{65}$ De reden hiervan kan zijn dat de werkelijkheid te veelvormig, te weerbarstig zou zijn $\mathrm{en} /$ of omdat de ontwikkelingen in het betreffende gebied te snel gaan voor adequate en meer specifieke regelgeving. Dit hangt ten dele ook samen met technische ontwikkeling en "vooruitgang". De wetgevei stelt dan iets in algemene termen strafbaar, terwijl hij zelf van tevoren niet altijd weet welke gedragingen hij al dan niet toelaatbaar acht en derhalve welke gedragingen er onder het betekenisbereik van de strafbepaling vallen en/ of dienen te vallen. ${ }^{66}$ Het gevolg hiervan kan zijñ dat het uit de tekst van de strafbaarstelling voor de justitiabele niet duidelijk is of zijn gedraging al dan niet onder het betekenisbereik van de zorgplichtbepaling valt. Hierdoor kan de strafrechtelijke handhaving van zorgplichtbepalingen op gespannen voet staan met het lex certa-beginsel.

Er is sprake van een schending van het lex certa-beginsel, indien het voor justitiabelen wegens de vaagheid van de zorgplichtbepaling voorafgaande aan hun handelen (of

Zie voor de functies van zorgplichtbepalingen hoofdstuk 1 paragraaf 3.6.3.

Indien de wetgever zelf het betekenisbereik van de strafbepaling ex ante niet kent, is het de vraag of dit wel van de normadressaat mag worden verwacht. 
nalaten) niet duidelijk zal zijn of de gedraging(en) tot strafrechtelijke aansprakelijkheid aanleiding kan (kunnen) geven. ${ }^{67}$ De Commissie voor de Toetsing van Wetgevingsprojecten stelde in haar advies over zorgplichtbepalingen dat ${ }^{68}$ :

"Tegen vage strafrechtelijk gesanctioneerde normen bestaan dus bezwaren, omdat de (her)kenbaarheid of de inzichtelijkheid van de norm voor de burger al gauw tekort schiet."

De vraag is of, en zo ja, in welke omstandigheden een zorgplichtbepaling voor de justitiabele zodanig onvoorspelbaar is dat het lex certa-beginsel wordt geschonden. ${ }^{6}$ Dit zal zich met name voordoen indien bij de samenstelling van de zorgplichtbepaling gebruik wordt gemaakt van één of meer vage bestanddelen. Deze kenmerken zich door een grijs gebied tussen wat zeker wel en wat zeker niet onder het betekenisbereik van de bepaling valt. Hoe groter dit gebied, hoe vager de bepaling. ${ }^{70}$ Indien de in de hoofdstukken 6 tot en met 9 besproken zorgplichtbepalingen worden vergeleken valt op dat er duidelijke verschillen aanwezig zijn tussen de diverse bepalingen. Dit wordt in deze paragraaf geîllustreerd door deze zorgplichtbepalingen te analyseren aan de hand van de vragen: voor welke gedraging (hoofdstuk 10 paragraaf 3.2.2.) dat welk gevolg veroorzaakt (hoofdstuk 10 paragraaf 3.2.3.) kan wie als normadressaat (hoofdstuk 10 paragraaf 3.2.4.) strafrechtelijk aansprakelijk worden gesteld.

\subsubsection{De gedraging}

Bij de samensteling van zorgplichtbepalingen, die een algemeen geformuleerde verplichting bevatten tot het in acht nemen van een bepaalde graad van zorgvuldigheid met het oog op een te beschermen belang, is door de wetgever veelvuldig gebruik gemaakt van vage bestanddelen. Bij de meeste zorgplichtbepalingen wordt niet aangegeven welke gedragingen verboden zijn. Als bestanddeel is bijvoorbeeld opgenomen: "hij die geen voldoende zorg draagt voor het onschadelijk houden" (artikel 425 aanhef en sub $2 \mathrm{Sr}$ ), "enige handeling verricht waarbij (...) bijzondere ormzichtigheid of voorzorgen worden vereist" (artikel 426, eerste lid Sr), "de nodige voorzorgsmaatregelen neemt" (artikel 427 aanhef en sub $1 \mathrm{Sr}$ ), "de noodige voorzorgsmaatregelen (...) te hebben genomen" (artikel 427 aanhef en sub $5 \mathrm{Sr}$ ), " gebrek aan de nodige omzichtigheid of voorzorg" (artikel 429 aanhef en sub $3 \mathrm{Sr}$ ), "te gedragen" (artikel 5 WVW), "aan het luchtverkeer deel te nemen" en "luchtverkeersleiding te geven" (artikel 5 Wet Luchtverkeer 1993), "alle maatregelen te nemen die redelijkerwijs van hem kunnen worden gevergd" (artikel $13 \mathrm{Wbb}$ ).

Daarnaast zijn er zorgplichtbepalingen die enigszins aangeven op welke gedragingen de bepaling ziet, maar dit zo uitgebreid doen dat nagenoeg ieder gedraging onder het

67 Zo werd het geformuleerd door Rb. Amsterdam 5 januari 1993, TMA 1993, pp. 77-83, in het bijzonder p. 80, met noot Faure (Cindu-zaak).

68 Advies van de Commissie voor de Toetsing van Wetgevingsprojecten inzake zorgplichtbepalingen, p. 7.

69 Zie over deze vraag uitgebreider: Visser, M.J.C., "Uitholling van het schuldbeginsel bij zorgplichtbepalingen door schending van het lex certa-beginsel", pp. 65-80.

70 Zie hoofdstuk 2 paragraaf 5.4. 
betekenisbereik van de strafbaarstelling wordt gebracht. Het betreft bijvoorbeeld: "een stof of een preparaat vervaardigt, aan een ander ter beschikking stelt, in Nederland invoert of toepast" (artikel $2 \mathrm{Wms}$ ), "handelingen te verrichten als bedoeld in de artikelen 6-11", "de bodem te saneren of de aantasting en de directe gevolgen daarvan te beperken en zoveel mogelijk ongedaan te maken" (artikel $13 \mathrm{Wbb}$ ), "handelingen met betrekking tot die afvalstoffen te verrichten of na te laten" (artikel 10.3, eerste lid Wm), "afvalstoffen in te zamelen of anderszins in ontvangst te nemen, te bewaren, te bewerken, te verwerken, te vernietigen of op of in de bodem te brengen" (artikel 10.3, tweede lid Wm).

Ook de strafbaarstellingen uit artikel 11 sub a tot en met f Arbo-wet 1998 geven (tamelijk duidelijk) aan op welke gedragingen de zorgplichtbepaling betrekking heeft. Het betreft: (sub a) "arbeidsmiddelen en gevaarlijke stoffen op de juiste wijze te gebruiken", (sub b) "de hem ter beschikking gestelde persoonlijke beschermingsmiddelen op de juiste wijze te gebruiken en na gebruik op de daartoe bestemde plaats op te bergen, een en ander voor zover niet krachtens deze wet is bepaald dat werknemers niet verplicht zijn beschermingsmiddelen als vorenbedoeld te gebruiken", (sub c) "de op arbeidsmiddelen of anderszins aangebrachte beveiligingen niet te veranderen of buiten noodzaak weg te halen en deze op de juiste wijze te gebruiken", (sub d) "mede te werken aan het voor hen georganiseerde onderricht bedoeld in artikel 8", (sub e) "de door hem opgemerkte gevaren voor de veiligheid of de gezondheid terstond ter kennis te brengen aan de werkgever of degene die namens deze ter plaatse met de leiding is belast", (sub f) "de werkgever en de werknemers, andere personen en diensten, bedoeld in artikel 14 , indien nodig bij te staan bij de uitvoering van hun verplichtingen en taken op grond van deze wet". Zeker indien voor de strafbaarheid van deze gedragingen het veroorzaken van één van de concrete gevaarzettingen uit de aanhef noodzakelijk is, zijn deze strafbaarstellingen in het algemeen goed voorzienbaar voor de justitiabele voorafgaande aan zijn gedrag.

Opvallend is dat de strafbaarstellingen uit artikel 11 Arbo-wet 1998 worden voorafgegaan door een in de aanhef van dit artikel opgenomen zorgplichtbepaling (die sinds 1 november 1999 is strafbaar gesteld), waarvan het onduidelijk op welke manier deze strafbaarstelling moet worden geïnterpreteerd. ${ }^{71}$ Zo blijft onduidelijk welke gedragingen voorwaarden voor strafbaarstelling vormen. De opvatting dat het betekenisbereik van deze aanhef slechts de gedragingen uit sub a tot en met $f$ omvat, lijkt te beperkt. Onduidelijkheid is ook of de aanhef als zelfstandige strafbaarstelling dient te worden gelezen. Deze zou dan vier verschillende gedragingen omvatten, te weten "de nodige voorzichtigheid in acht te nemen", "de nodige zorgvuldigheid in acht te nemen", "naar vermogen zorg te dragen voor de eigen veiligheid en gezondheid" en "naar vermogen zorg te dragen voor de eigen veiligheid en gezondheid en die van andere personen". Wel wordt door het tussenzinnetje "Met name zijn zij verplicht om:" duidelijk een relatie gelegd tussen de gedragingen uit de aanhef en de specifieker omschreven gedragingen. uit sub a tot en met $\mathrm{f}$. Deze gedragingen lijken door het tussen zinnetje (sinds 1 november 1999) niet (langer) limitatief te zijn opgenomen in 
artikel 11 Arbo-wet 1998, zodat ook andere gedragingen involge deze bepaling strafbaar kunnen zijn. De specifieker omschreven gedragingen uit sub a tot en met $f$ vullen de vage omschrijving uit de aanhef gedeeltelijk in, aangezien de vage omschrijving hierdoor tegen een bepaalde achtergrond wordt geplaatst. De specifiekere gedragingen worden aangevuld door aanhef, waarvan de grenzen ten dele worden bepaaid door de gedragingen uit sub a tot en met $\mathrm{f}$. Zo dienen involge de aanhef strafbaar gestelde gedragingen in redelijke verhouding te staan tot de wel opgesomde gedragingen uit de subs, bijvoorbeeld qua ernst en soort. De context waarin het vage bestanddeel is opgenomen specificeert hierdoor het type gedragingen dat onder de reikwijdte van de strafbaarstelling valt. ${ }^{72}$

Voorts zijn er zorgplichtbepalingen die vrij nauwkeurig aangeven op welke gedragingen de strafbaarstelling betrekking heeft. Dit zijn tevens de zorgplichtbepalingen die kunnen worden aangemerkt als abstract gevaarzettingsdelict aangezien de betreffende gedraging reeds strafbaar is gesteld, onafhankelijk van een (eventueel) gevolg dat hierdoor wordt veroorzaakt. Het betreft bijvoorbeeld de als volgt geformuleerde verplichting voor de normadressaat: "draagt zorg dat hij van zijn wetenschap of vermoeden, zo mogelijk per radio, kennis geeft aan de burgermeester van de gemeente, waarbinnen de haven ligt, welke zijn schip zal aandoen, zodra het binnen de Nederlandse wateren is aangekomen" (artikel 19, eerste lid sub a Quarantainewet), "draagt zorg dat, zodra het schip in het gezicht van de wal komt, een door Onze Minister vast te stellen sein wordt gevoerd, totdat het schip tot het vrije verkeer is toegelaten, of totdat dit het Nederlandse gebied heeft verlaten" (artikel 19, eerste lid sub b Quarantainewet), "draagt zorg dat geen gemeenschap van het schip met de wal of met andere schepen plaatsheeft, alvorens het medische onderzoek is beëindigd en het schip tot het vrije verkeer zal zijn toegelaten" (artikel 19, eerste lid sub c Quarantainewet), "draagt zorg, dat hiervan onverwijld mededeling wordt gedaan aan de burgermeester van de gemeente, waar het vervoermiddel zich bevindt" (artikel 19, derde lid Quarantainewet), "Totdat hij terzake nadere aanwijzingen heeft ontvangen van de burgermeester of de geneeskundige, die deze bijstaat, draagt hij zorg, dat geen gevaar voor besmetting van anderen ontstaat." (artikel 19, derde lid Quarantainewet).

\subsubsection{Het gevolg}

Zoals gezegd zijn niet alle zorgplichtbepalingen vorm gegeven als concreet gevaarzettingsdelict. De artikelen 19, eerste en derde lid Quarantainewet, zijn abstracte gevaarzettingsdelicten die in het geheel geen (mogelijk) gevolg vereisen. Deze strafbaarstellingen geven vrij specifiek aan welke gedragingen strafbaar zijn.

De meeste zorgplichtbepalingen zijn vormgegeven als concreet gevaarzettingsdelict, waarvan de strafbaar gestelde gedraging een bepaald gevolg (potentieel) teweeg moet brengen. Bij de meeste zorgplichtbepalingen wordt echter niet of maar in beperkte mate nauwkeurig aangegeven welke gevolgen de gedraging moet hebben teweeggebracht of potentieel teweeg zou kunnen hebben gebracht. Wederom maakt de 
wetgever veelvuldig gebruik van vage bestanddelen bij het aangeven van dit (potentiële) gevolg.

Zo bevatten de artikelen 426 , eerste lid Sr, 429 aanhef en sub $3 \mathrm{Sr}, 5$ WVW, 5 Wet Luchtverkeer 1993 het bestanddeel "gevaar", en artikel 2 Wms het bestanddeel "gevaren". Gevaar verwijst naar schade. ${ }^{73}$ Van het veroorzaken van gevaar is sprake indien een ongeval met schade voor een persoon of een zaak zich voordoet of hierop een aanzienlijk verhoogde kans bestaat. Het gaat erom dat naar de normale loop der dingen zonder buitengewone omstandigheden de emstige mogelijkheid aanwezig is van een noodlottige afloop. ${ }^{74}$ Ook al was er geen sprake van direct gevaar, dan lag dit eerder aan geluk dan aan wijsheid. ${ }^{75}$ Alhoewel iedereen wel ongeveer aanvoelt wat de betekenis is van gevaar $^{76}$, kunnen geen vaste criteria worden gegeven wanneer een gedraging is aan te merken als gevaarlijk. De beoordeling of sprake was van gevaar vergt een juridisch-normatieve beoordeling, waarbij twee taxaties moeten worden gemaakt. Zo moet worden nagegaan hoe groot de kans is dat het gevaar tot schade zou kunnen leiden (grote kans of kleine kans op intreden gevolg), hetgeen een feitelijke en gedragskundige beoordeling vereist. Tevens moet een taxatie worden gemaakt van de schade (grote schade of kleine schade), hetgeen een normatieve en juridische beoordeling vergt. ${ }^{77}$ Aan de hand van de combinatie van de beoordeling van deze twee vragen $^{78}$ kan de vraag worden beantwoord of sprake was van gevaar dat valt onder het betekenisbereik van de delictsomschrijving. Een antwoord dat niet alleen zal afhangen van geschreven en ongeschreven normen, de feitelijke omstandigheden en de situatie zoals men die normaal gesproken gelet op alle omstandigheden ter plaatse mag verwachten, maar ook tijd-en plaatsgebonden zal zijn. Remmelink stellt ${ }^{79}$ :

"In welke mate een gedraging vanwege de mogelijkheid, dat zij nadeel voor de maatschappij oplevert, gevaarlijk 'is', hangt mede af van de vraag in hoeverre deze laatste dat risico.

73 Zie Mooij, A.W.M., "Gevaar, gevaarlijk, gevaarlijkheid", p. 22.

74 Noyon, T.J., Langemeijer, G.E. en Remmelink, J., bewerkt door Dorst, A.J.A. van, Fokkens, J.W. en Machielse, A.J.M., Het Wetboek van Strafrecht, "Artike! 157", aantekening 2 (juni 1998).

75 Gesteld wordt dat het een "abstract-concrete" vorm van gevaar betreft, zie Noyon, T.J., Langemeijer, G.E. en Remmelink, J., bewerkt door Dorst, A.J.A. van, Fokkens, J.W. en Machielse, A.J.M., Het Wetboek van Strafrecht, "Titel VII, Misdrijven waardoor de algemene veiligheid van personen of goederen wordt in gevaar gebracht", aantekening 2 (juni 1998).

76 Remmelink, J., Mr. D. Hazewinkel-Suringa's Inleiding tot de studie van het Nederlandse strafrecht, p. 98.

77 Zie ook Mooij, A.W.M., "Gevaar, gevaarlijk, gevaarlijkheid", p. 30, die stelt: "En iedere tijd heeft natuurlijk recht op zijn inhoudelijke invulling van het gevaarscriterium en schadebeginsel. Aan het recht is dan een taak het beginsel zelf te bewaken en ervoor te zorgen dat het gevaarscriterium in een ruime toepassing niet buiten zijn oevers treedt. In dat geval zou de grondslag van het moderne recht zelf ondergraven worden."

78 Het betreft de beantwoording van de vraag of sprake is van: kleine kans op kleine schade, kleine kans op grote schade, grote kans op kleine schade, grote kans op grote schade.

79 Remmelink, J., Hoofdwegen door het verkeersrecht, pp. 43-44. 
aanvaardbaar 'acht'. (...) Gevaar is derhalve een ten dele normatief begrip, mede afhankelijk van onze sociaal-ethische opvattingen. Ook zal men (...) de opvatting van de wetgever, zoals deze uit afzonderlijke bepalingen is af te leiden, moeten meewegen."

Zoals gezegd verwijst gevaar naar schade. Enkele zorgplichtbepalingen verbinden uitdrukkelijk het "gevaar" aan een bepaald rechtsgoed, bijvoorbeeld "gevaar voor leven of gezondheid van derden" (artikel 426, eerste lid Sr), "gevaar voor bos-, heide-, helm-, gras- of veenbrand doet ontstaan" (artike! 429 aanhef en sub $3 \mathrm{Sr}$ ), of het veel omvattende "personen of zaken in gevaar worden gebracht" (artikel 5 Wet Luchtverkeer) en "mens en milieu" (artikel 2 Wms). Bij de herziening van de Wegenverkeerswet in 1994 is het beschermde rechtsgoed ("de veiligheid op de weg") niet langer opgenomen in de zorgplichtbepaling (artikel 5 WVW). Desondanks zal het gevaar uit artikel 5 WVW gezien de plaats van de bepaling, het systeem van wetgeving en de wetsgeschiedenis wel betrekking moeten hebben op verkeersrechtelijk. relevante omstandigheden, ook al blijkt dit niet uit de bepaling zelf. ${ }^{80}$ Ondanks de al dan niet expliciete verbinding van gevaar van schade aan een bepaald rechtsgoed wordt, ten gevolge van het grote betekenisbereik van het rechtsgoed, het betekenisbereik van het bestanddeel "gevaar" nauwelijks ingeperkt. Dit geldt nog sterker nu een aantal zorgplichtbepalingen niet alleen strafbaar stellen het in gevaar brengen van het betreffende rechtsgoed, maar ook het in gevaar kumnen brengen, waardoor de relatie tussen de gedraging en de mogelijke schade nog verder wordt afgezwalkt (zie de artikelen 5 WVW, 5 Wet Luchtverkeer en 2 Wms).

In artikel $13 \mathrm{Wbb}$ wordt als gevolg van de handelingen aangeduid dat de bodem "kan worden verontreinigd of aangetast". Er spelen een groot aantal uiteenlopende factoren een rol bij de bepaling of sprake is van een mogelijke verontreiniging of aantasting. Ook hier betreft het een juridisch-normatieve beoordeling, waarbij twee taxaties moeten worden gemaakt. Zo moet worden nagegaan hoe groot de kans is dat de verontreiniging of aantasting zich zal voordoen (grote kans of kleine kans op intreden gevolg), en zal er een taxatie moeten worden gemaakt van de verontreiniging of aantasting (grote verontreiniging/ aantasting of kleine verontreiniging/ aantasting). Aan de hand van de combinatie van de beoordeling van deze twee vragen kan de vraag worden beantwoord of sprake was van een mogelijke verontreiniging of aantasting die valt onder het betekenisbereik van de delictsomschrijving. Wederom zal het antwoord iijd- en plaatsgebonden zijn en afhangen van geschreven en ongeschreven normen, de feitelijke omstandigheden en de situatie zoals men die normaal gesproken, gelet op alle omstandigheden ter plaatse, mag verwachten.

\subsubsection{De nomadressaat}

Uit het voorafgaande blijkt dat bij de samenstelling van zorgplichtbepalingen veelvuldig gebruik wordt gemaakt van vage bestanddelen. Deze vaagheid zit vooral in

Krabbe, H.G.M., "De artikelen 5 en 6 Gevaar veroorzaken, hinderen en schuld aan een verkeersongeval", pp. 95-96, 101-104 en 108-110; Remmelink, J., Hoofdwegen door het verkeersrecht, pp. 43-44. 
de omstandigheid dat de in acht te nemen graad van zorgvuldigheid niet nader is aangegeven. Voorts worden de verboden gedragingen niet of maar in beperkte mate gespecificeerd en (indien aanwezig) wordt het gevolg dat door de gedraging wordt veroorzaakt of kan worden veroorzaakt vaak slechts summier aangegeven. Hierdoor liken de meeste zorgplichtbepalingen op gespannen voet te staan met het lex certabeginsel. $^{81}$ Juist bij instrumentele regelgeving, die toch al minder aansluit bij het rechtsbewustzijn van justitiabelen, kan al snel niet meer worden verwacht dat de normadressaat inzicht heeft wanneer hij wel en wanneer hij niet strafbaar handelt. Indien de strafbaarstelling dan ook nog vage bestanddelen bevat, zal dit het onrechtinzicht niet ten goede komen.

Natuurlijk kan hierop worden gerespondeerd dat de normadressaten van zorgplichtbepalingen doorgaans geen "gemiddelde justitiabelen" zijn, maar justitiabelen die handelen in een bepaalde hoedanigheid of deskundigheid. Zij beschikken veelal over goede informatie ten aanzien van de (on)wenselijkheid van gedragingen. De desbetreffende informatie is zelfs vaak beter beschikbaar bij deze normadressaten dan bijvoorbeeld bij de wetgever, het bestuur, het $\mathrm{OM}$ of de rechtelijke macht. De graad van deskundigheid van de verdachte zal dan ook invloed hebben bij het vaststellen van zijn verwijtbaarheid. ${ }^{82}$

De deskundigheid van de verdachte/ normadressaten kan naast de verwijtbaarheid ook van invloed zijn op de inzichtelijkheid van het betekenisbereik van de strafbaarstelling. ${ }^{83}$ Dit doet zich bijvoorbeeld voor indien binnen een bepaalde beroepsgroep duidelijk(er) is wat de betekenis is van een bepaalde term, terwijl die dat voor anderen niet behoeft te zijn. Het is niet voldoende als de toepassing van de bepaling zich in de praktijk tot deze groep beperkt. Aangezien de tekst van de strafbaarstelling maatgevend is, is het noodzakelijk dat de strafbaarstelling zich beperkt tot deze specifieke groep justitiabelen. Voor hen zal een dergelijk term minder of niet vaag zijn, waardoor de strafbaarstelling op dit punt niet in strijd zal komen met het lex certa-beginsel.

Problemen kunnen echter nog wel ontstaan bij de interpretatie van de term door de rechter. Hij zal de term conform die betekenis dienen te interpreteren en kwalificeren, aangezien door een afwijkende toepassing vaagheid kan ontstaan, waardoor het voor de normadressaat voorafgaande an de gedraging onduidelijk kan zijn wanneer hij wel en wanneer hij niet onder het betekenisbereik valt.

81 Wellicht kunnen dergelijke bepalingen wel een rol spelen in het privaatrecht bij het vaststellen van de (risico)aansprakelijkheid voor bepaalde schade veroorzakende gedragingen, zie Faure, M., "Economic Aspects of Environmental Liability: an Introduction", pp. 85-109.

82 Zie hoofdstuk 3 paragraaf 7.4 .

83 Deze beperking van het betekenisbereik van de zorgplichtbepaling door de feiten te koppelen aan de verdachte is volgens Hendriks, L.E.M. en Wöretshofer J., Milieustrafrecht, pp. 85-88 wel voldoende om strijdigheid van in casus de zorgplichtbepalingen in het milieustrafrecht met het lex certa-beginsel te voorkomen. 
Indien nu wordt gekeken naar de besproken zorgplichtbepalingen valt op dat een aantal zich richt tot ieder, zodat de strafbaarstelling zelf geen onderscheid maakt tussen groepen personen die aangesproken kunnen worden inzake schending, van deze bepaling (artikel 5 WVW en artikel $13 \mathrm{Wbb}$ ). Soms is de normadressaat van de zorgplichtbepaling gekoppeld aan een bepaalde zaak, zo betreft het bijvoorbeeld ieder met een "onder zijn hoede staand gevaarlijk dier" (artikel 425 aanhef en sub $2 \mathrm{Sr}$ ), of "ieder die op de openbare weg een rij-, trek- of lastdier laat staan" (artikel 427, aanhef en sub $5 \mathrm{Sr}$ ). Ook kan de normadressaat gekoppeld zijn aan een bepaalde toestand, zoals ieder die "in staat van dronkenschap verkeert" (artikel 426, eerste lid Sr). Voorts kan de normadressaat worden gekoppeld aan een bepaalde hoedanigheid, zoals "de eigenaar of gebruiker die ten opzichte van toegangen tot of openingen van kluizen, kelders, onderaardsche lokalen en nuimten, waar die op de openbare weg uitkomen", en een beroep zoals de gezagvoerder van het object dat aan het luchtverkeer deel neemt (artikel 5 Wet Luchtverkeer 1993), de "luchtverkeersleiding" (artikel 5 Wet Luchtverkeer 1993), "de gezagvoerder van een schip" (artikel 19, eerste lid Quarantainewet), "hij, die de leiding heeft bij trein- of wegverkeer" (artikel 19, derde lid Quarantainewet), "de werknemer" (artikel 11 Arbo-wet 1998), "ieder die beroepshalve" (artikel 2 Wms), "een ieder bij wie in de uitoefening van zijn beroep of bedrijf" (artikel 10.3, eerste en tweede lid Wm).

Naast de normadressaten đỉe als zodanig worden genoemd in de zorgplichtbepaling, moet worden gerealiseerd dat ook andere vormen van daderschap toepasbaar kunnen zijn. $^{84}$ Naast degene die het feit pleegt of wordt aangemerkt als functioneel leidinggevende, worden involge artikel $47 \mathrm{Sr}$ als daders aangemerkt degene die het feit doen plegen, medeplegen of tuitlokken. Voorts kunnen ex artikel $51 \mathrm{Sr}$ ook rechtspersonen worden aangemerkt als dader. Indien een strafbaar feit wordt begaan door een rechtspersoon kan, indien zij daarvoor in aanmerking komen, ook degene die tot het feit opdracht heeft gegeven, alsmede degene die aan de verboden gedraging feitelijk leiding heeft gegeven worden vervolgd. Voor publiekrechtelijke rechtspersonen zijnde een openbaar lichaam als bedoeld in hoofdstuk $7 \mathrm{Gw}$ wordt alleen een vervolgingsuitsluitingsgrond aangenomen als de desbetreffende gedraging naar haar aard en gelet op het wettelijk systeem rechtens niet anders dan door bestuursfunctionarissen kunnen worden verricht in het kader van de uitvoering van de aan het openbaar lichaam opgedragen bestuurstaak. Alleen de centrale overheid heeft (althans op dit moment nog) totale immuniteit. Vooralsnog met uitzondering van de centrale overheid kunnen al deze categorieën te maken krijgen met een strafrechtelijke vervolging wegens het schenden van zorgplichtbepalingen.

\subsubsection{Aanvullende criteria en het bestuur}

Aangezien bij de samenstelling van zorgplichtbepalingen door de wetgever gebruik wordt gemaakt van vage termen, bestaat de mogelijkheid dat het bestuur, het $\mathrm{OM}$ en of de rechter aanvullende criteria vaststellen die het betekenisbereik van de strafbaarstelling verder specificeren. Hierdoor kan het grijze gebied worden teruggedrongen 
waardoor het bestanddeel en daardoor de bepaling minder vaag worden. Dit zal in het algemeen echter niet voldoende zijn om de spanning met artikel $1 \mathrm{Sr}$ te verminderen, aangezien hiervoor de tekst van de strafbaarstelling zelf bepalend is. Gezien de interpretatie van dit artikel in de rechtspraak, wordt echter (ten onrechte) niet snel strijdigheid van strafbaarstellingen met dit artikel aangenomen. ${ }^{85}$ Aanvullende criteria vastgesteld door het bestuur of de rechter spelen daarom niet alleen een rol bij het tegengaan van de spanning met artikel 7 EVRM, maar worden ook gebruikt teneinde de spanning met het nationale legaliteitsbeginsel te verminderen.

Een mogelijkheid om de in de zorgplichtbepaling gebruikte vage termen verder te specificeren, is het vaststellen van nadere criteria die het betekenisbereik van de vage term, en zo van de strafbaarstelling, aangeven. Interessant is de bedenking van Hart die op het volgende wijst ${ }^{86}$ :

"It may be found best to defer the use of sanctions for violations until the administrative body has by regulations specified what, for a given industry, is to count as a "fair rate" or a "safe system".

Hij suggereert daarmee dat de vage norm weliswaar in wetgeving kan worden gebruikt, maar dat de inhoud van een dergelijke bepaling veeleer door regulering vanuit het bestuur dient te worden ingevuld en dat tot aan een dergelijke invulling met (strafrechtelijke) sanctionering dient te worden gewacht. Het bestuur stelt zo aanvullende criteria vast die de vage term(en) invult en specificeert. Pas indien het betekenisbereik voldoende duidelijk is, zou de bepaling eventueel een rol kunnen spelen in het strafrecht. ${ }^{87}$

Deze visie is ook van belang voor zorgplichtbepalingen. Een enkele zorgplichtbepaling verwijst zelfs expliciet naar uitvoeringsmaatregelen die door het bestuur kunnen worden genomen. Deze kunnen een nadere specificering vormen van de zorgplichtbepaling. Een voorbeeld is artikel $13 \mathrm{Wbb}$, die verwijst naar de artikelen 6 tot en met 11 uit dezelfde wet, op basis waarvan bij amvb regels kunnen worden gesteld. De Hoge Raad biedt echter de mogelijkheid deze zorgplichtbepaling toe te passen zonder dat sprake is van uitvoeringsmaatregelen. ${ }^{88} \mathrm{Nu}$ deze zelfs niet nodig zijn voor de toepassing van de zorgplichtbepaling die duidelijk verwijst naar deze aanvillende criteria, ligt het niet voor de hand dat deze voorwaarde wordt gesteld aan zorgplichtbepalingen die niet zo expliciet hiernaar verwijzen.

Zelfs indien wel uitvoeringsmaatregelen door het bestuur zijn genomen, behoeven deze geen aanvullende criteria op te leveren voor zorgplichtbepalingen. Dit speeit nog

Zie hoofdstuk 3 paragraaf 7.3.

Hart, H.L.A., The Concept of Law, p. 131.

Zie hierover verder bij samenhang hoofdstuk 10 paragraaf 5 en bij rechtszekerheid hoofdstuk 10 paragraaf 3 .

HR 26 oktober 1993, NJ 1994, 99; MenR 1994, nr. 22, met noot Tideman (Kabelbranden). Zie over dit arrest ook: Hendriks, L.E.M., "De Hoge Raad en artikel 14, Wbb", pp. 139-140 en hoofdstuk 10 paragraaf 5. 
sterker indien zij zich niet tot de zorgplichtbepaling verhouden als een lex specialis. Zo is het vaste jurisprudentie dat de bepalingen uit de amvb's die zijn vastgesteld op basis van de artikelen 6 tot en met $11 \mathrm{Wbb}$, zich niet snel tot artikel $13 \mathrm{Wbb}$ zullen verhouden ais een bijzondere strafbaarsteliing tot een algemene in de zin van artikel 55 , tweede lid $\mathrm{Sr}^{89}$ indien een dergelijke verhouding wel zou worden aangenomen, zouden zij deze rol voor het resterende deel van de zorgplichtbepaling uit artikel 13 Wbb kunnen spelen. Deze amvb's kunnen (het resterende deel vani) de zorgplichtbepaling, waarvan het betekenisbereik niet duidelijk is, tegen een bepaalde achtergrond plaatsen. Hierdoor zou bijvoorbeeld de op basis van deze bepaling strafbare gedraging in redelijke verhouding dienen te staan tot de inhoud van de amvb's. Doorgaans zal echter, door de geringe band tussen de zorgplichtbepaling en de inhoud van uitvoeringsbesluiten, de inhoud van deze besluiten niet. snel werken als aanvullende criteria.

\subsubsection{Aanvillende criteria en het Openbaar Ministerie}

De belangrijkste taken ter inperking van de strafrechtelijke aansprakelijkheid liggen bij dit type strafbaarstellingen bij het OM en de rechter. Omdat deze bepalingen in het algemeen vaag zijn geformuleerd en maar in beperkte mate bij de invulling afhankelijk zijn van het bestuur, heeft het OM bij de opsporing en vervolging een duidelijke eigen verantwoordelijkheid, en kan het bij normschending zelfstandig tot actie overgaan. Het zal de eerst geplaatste zijn om te oordelen of in een specifieke casus sprake was van een schending van de zorgplichtbepaling en of dit bijgevolg kan worden ten laste gelegd. Dit geldt natuurlijk niet voor zorgplichtbepalingen die in eerste instantie "beboetbare feiten" opleveren, aangezien daar het bestuur (ook) deze verantwoor. delijkheid heeft.

Het OM dient uit oogpunt van het rechtszekerheidsbeginsel en het lex certa-beginsel geen, althans zo min mogelijk, feiten ten laste te leggen waarvan het onduidelijk is of zij onder het betekenisbereik van de strafbaarstelling vallen. Het OM zal zeer terughoudend moeten zijn bij het ten laste leggen van feiten die vallen in het grijze gebied van de vage termen uit de strafbaarstellingen, angezien de justitiabele anders voorafgaande aan zijn handeling niet kan weten of zijn gedraging al dan niet onder de wettelijke strafbepaling valt.

Bij de vervolging van strafbare feiten op basis van de kern van de vage termen, zal duidelijkheid over het betekenisbereik van de strafbaarstelling worden verkregen. Hierdoor kan het grijze gebied worden teruggedrongen waardooir het bestanddeel en daardoor de bepaling minder vaag worden. Voor de justitiabele kan het zo duidelijker worden wanneer hij al dan niet onder het betekenisbereik van de strafbaarstelling zal vallen. Overigens moet worden opgemerkt dat deze duidelijkheid, gezien artikel $1 \mathrm{Sr}$, voor de justitiabele moet zijn af te leiden uit de strafbaarstelling zelf. 
Alleen indien sprake is van een zeer onwenselijke gedraging die op de grens ligt tussen de kem en het grijze gebied zou het OM, ondanks de spanning die daardoor ontstaat met het lex certa-beginsel, kunnen beslissen toch over te gaan tot vervolging. Deze keuze zal voortvloeien uit de afweging die het OM makt op basis van het opportuniteitsbeginsel. Uit dit beginsel volgt dat bij het bepalen van het vervolgingsbeleid het $\mathrm{OM}$ alle in het geding zijnde belangen moet afwegen, hetgeen aansluit bij het algemeen rechtsbeginsel van eerlijke en billijke belangenafweging. ${ }^{90}$ Door vervolging tot deze gevallen te beperken, wordt tevens het risico beperkt dat tussen de justitiabelen, de controle- en opsporingsambtenaren, het $\mathrm{OM}$ en/ of degene die de zorgplichtbepaling zou hebben geschonden debatten ontstaan over de precieze betekenis van het voorschrift. ${ }^{\text {91 }}$

Het OM dient het strafbare feit zo nauwkeurig mogelijk ten laste te leggen. Hierdoor zou niet mogen worden volstaan met aan te geven dat bijvoorbeeld degene die wordt verdacht van schending van artikel $2 \mathrm{Wms}$ of artikel $13 \mathrm{Wbb}$ "niet alle maatregelen heeft genomen die redelijkerwijs van hem konden worden gevergd.. ${ }^{, 92}$ Het OM zal bijvoorbeeld duidelijk moeten aangeven welke maatregelen, in die specifieke omstandigheden, van de betreffende verdachte konden worden verwacht.

Met het (achteraf) aangeven waarom in een specifiek geval de zorgplichtbepaling is geschonden is echter nog niet gezegd dat de strafbaarstelling zelf voldoende specifiek is. ${ }^{93}$ Het probleem is dat het lex certa-vereiste meebrengt dat vóórdat de gedraging door de justitiabele wordt verricht, helder dient te zijn welk gedrag al dan niet onder de strafbepaling valt. Ex post zal natuurlijk gemakkelijk kunnen worden gezegd welke matregelen de verdachte had moeten treffen om het gevaar dat dreigde te voorkomen. De tenlastelegging kan daarnaar verwijzen om deze voldoende nauwkeurig te laten zijn. Het lex certa-beginsel dat zich richt op de inzichtelijkheid van de delictsomschrijving vóórdat het gedrag plaatsvindt, mag natuurlijk niet worden verward met de eis dat na het delict een feit in voldoende: specifieke bewoordingen dient te worden

90 Het OM maakt de keuze tussen al dan niet vervolgen op basis van het in artikel 167 en 242 Sv vastgelegde opportuniteitsbeginsel, waarbij gezien het tweede lid van deze artikelen het "algemeen belang" een prominente plaats inneemt. Zie hierover Corstens, G.J.M., Het Nederlands strafprocesrecht, pp. 5i1-52 en 483-486.

91 Zie Blomberg, A.B. en Michiels, F.C.M.A., Handhaven met' effect, p. 295. Zij wijzen er terecht op dat ook de rechtszekerheid van derden in het gedrang kan komen bij zorgplichtbepalingen (uit vergunningen) die vage bestanddelen bevatten.

92 Zie ook Hendriks, L.E.M. en Wöretshofer J., Milieustrafrecht, pp. 87-88. Dit voorbeeld komt in de praktijk veel voor, temeer nu in het Tekstenboek tenlasteleggingen van het OM (d.d. I november 1999) bijvoorbeeld bij de standaard uitwerkingen van artikel 13 Wbb niet wordt aangegeven dat dit deel van de tenlastelegging verder moet worden ingevuld/gespecificeerd.

Niet voor niets wordt in het. bestuurstecht gesteld dat concretisering van de zorgplicht vóór de fase van sanctieoplegging moet plaatsvinden. Zie hierover Jong, P., Handhaafbaar milieurecht, 260; Blomberg, A.B., Integrale handhaving van het milieurecht, pp. 327-329. Zie ook Vz ABR 11 september 1997, MenR, 1998, 63, met noot Uylenburg (Lichtstralen van café). 
ten laste gelegd. De stelling dat een specifieke wijze van ten laste leggen de op zichzelf vage zorgplichtbepaling nader gestalte geeft waardoor strijdigheid met het lex certa-beginsel wordt tegengegaan dient dan ook te worden verworpen.

\subsubsection{Aanvullende criteria en de rechter}

Of uiteindelijk sprake is van schending van de zorgplichtbepaling, zal in een voorliggende zaak door de strafrechter worden vastgesteld. Hoe vager de bestanddelen, hoe belangrijker de taak van de strafrechter om de grenzen van het strafrecht en van de strafrechtelijke aansprakelijkheid aan te geven. Het is aan hem om vast te stellen of de strafbaarstelling buiten toepassing moet worden gelaten wegens strijdigheid met het lex certa-beginsel, en als dit niet het geval is de grens vast te stellen tussen strafbare en niet-strafbare gedragingen.

Bij de mogelijkheid van de rechter om aanvullende criteria vast te stellen dient onderscheid te worden gemaakt tussen de soorten regelgeving waarin zorgplichtbepalingen zijn opgenomen. ${ }^{94}$ Dit is ten eerste van belang omdat de Hoge Raad zich niet bevoegd acht tot het uitleggen van beschikkingen, omdat dit kwesties van feitelijke aard zijn en dienen te geschieden naar aanleiding van het onderzoek ter terechtzitting. De Hoge Raad zal zorgplichtbepalingen in beschikkingen niet interpreteren en zodoende hiervoor geen aanvullende criteria vaststellen.

Ten tweede is de soort regelgeving waarin zorgplichtbepalingen zijn opgenomen var belang indien de leer van de formele rechtskracht wordt aanvaard. Bij aanvaarding is de strafrechter niet bevoegd zorgplichtbepalingen die zijn opgenomen in beschikkingen te toetsen op haar rechtmatigheid. Aangezien deze leer niet van toepassing is op besluiten waartegen geen met voldoende waarborgen omklede bestuursrechtelijke rechtsgang open staat, staat deze leer de toetsing van zorgplichtbepalingen uit andere besluiten niet in de weg.

Uit de jurisprudentie blijkt dat de strafrechter niet snel overgat tot het onverbindend verklaren van zorgplichtbepalingen uit algemeen verbindende voorschriften van bestuur en beschikkingen wegens strijd met het lex certa-beginsel. $\mathrm{Bij}$ het interpreteren van deze bepalingen en zorgplichtbepalingen die zijn opgenomen in wetgeving in formele zin, blijkt hij deze ook vaak niet restrictief te interpreteren. Ten eerste zal hierbij het grondwettelijk toetsingsverbod van wetten in formele zin aan de Grondwet een rol kunnen spelen. Hierdoor kunnen zorgplichtbepalingen uit wetten in formele zin niet worden getoetst aan het in artikel $16 \mathrm{Gw}$ vastgelegde legaliteitsbeginsel. ${ }^{95}$ Voor zorgplichtbepalingen in lagere regelgeving is dit geen beletsel. Daarnaast moeten bepalingen in lagere regelgeving ook voldoen aan artikel $1 \mathrm{Sr}$, een artikel dat naast het

94 Zie hoofdstuk 5.

95 De nationale rechter is gezien artikel $120 \mathrm{Gw}$ niet bevoegd wetgeving in formele zin te toetsen aan de Grondwet. Wel mag bij algemeen verbindende voorschriften van bestuur en beschikkingen toetsen aan de Grondwet. Zie over de toetsingsbevoegdheid van de rechter hoofdstuk 5 . 
Wetboek van Strafrecht gezien artikel 91 Sr ook toepasselijk is "op feiten waarop bij andere wetten of verordeningen straf is gesteld, tenzij de wet anders bepaalt." Bij geen van de wetten in formele zin op basis waarvan zorgplichtbepalingen zijn opgenomen wordt door de wet "anders bepaald", zodat zij naast artikel $16 \mathrm{Gw}$ ook moeten voldoen an artikel $1 \mathrm{Sr}$. De rechter is door het grondwettelijk toetsingsverbod niet bevoegd zorgplichtbepalingen uit wetgeving in formele zin te toetsen aan artikel $16 \mathrm{Gw}$. Ook is hij niet bevoegd deze bepalingen uit wetgeving in formele zin buiten toepassing laten wegens strijd met artikel $1 \mathrm{Sr}$, aangezien dit wetgeving van gelijke orde is met dezelfde rechtskracht. Wel dient hij in een voorliggend geval de wettelijke strafbepaling te interpreteren. Zorgplichtbepalingen (ook die in wetten in formele zin) dient hij, conform artikel $1 \mathrm{Sr}$, restrictief te interpreteren. Voorts is hij bevoegd in een voorliggend geval de nationale zorgplichtbepalingen in algemeen verbindende voorschriften en beschikkingen te toetsen aan het (althans theoretisch minder vergaande) verdragsrechtelijke legaliteitsbeginsel uit artikel 7 EVRM.

Zoals aangegeven kunnen zorgplichtbepalingen die zijn opgenomen in algemeen verbindende voorschriften van bestuur en beschikkingen worden getoetst aan het lex certa-beginsel uit artikel I Sī, $16 \mathrm{Gw}$ en/ of 7 EVRM. De strafrechter gaat (soms) toe over. Dat hiervan niet teveel kan worden verwacht blijkt wel, nu een veel voorkomend vergunningvoorschrift als "Het is in de inrichting verboden voor de omgeving hinderlijke werkzaamheden te verrichten", blijkens de Hoge Raad niet in strijd behoeft te zijn met het lex certa-beginsel. Zo overwoog hij ${ }^{96}$ :

"5.4. Het Hof heeft orntrent een ter terechtzitting in hoger beroep gevoerd verweer als volgt overwogen en beslist: "Een redelijke uitleg van dit voorschrift brengt mee hieronder in ieder geval onnodige en/ of uitzonderlijk hinderlijke werkzaamheden te begrijpen, gelijk zich in het onderhavige geval hebben voorgedaan." (...)

5.5. Het Hof heeft. aldus als zijn oordeel tot uitdrukking gebracht dat het voorschrift ertoe strekt om naast specifieke gedragsvoorschriften onnodige - dat wil zeggen gelet op het normale bedrijfsproces redelijkerwijs vermijdbare - hinder opleverende werkzaamheden alsmede werkzaamheden die uitzonderlijk hinderlijk zijn, tegen te gaan. Dat oordeel is niet onbegrijpelijk, terwijl daarin besloten ligt het niet van een verkeerde rechtsopvatting blijk gevende en evenmin onbegrijpelijke oordeel dat het aldus uitgelegde voorschrift voldoende concreet is."

In een aantal vergunningen is een algemene zorgplichtbepaling opgenomen die de vergunininghouder verplichtte alle redelijkerwijs mogelijke maatregelen te treffen teneinde te voorkomen dat door het gebruik van de vergunning schade ontstaat ten opzichte van zowel de bestuurlijke overheid als ten opzichte van derden. Opvallend is dat dergelijke vergunningvoorschriften de toets van de bestuursrechter (waar zij eveneens op voldoende precisie kunnen worden getoetst) niet. altijd hebben doorstaan.

96 HR 27 juni 1995, NJ 1995, 722; MenR 1996, nr. 6, met noot Hendriks (Uitleg vergunningvoorschrift is feitelijk). 
Dergelijke voorschriften werden door de $\mathrm{Kroon}^{97}$ en door de Raad van State vernietigd op grond van hun vaagheid. ${ }^{99}$

Een zeldzaam maar aardig voorbeeld van een zaak waarin een klacht over een te vage norm wel werd gehonoreerd door de strafrechter, is een zaak waarin een arts was ten laste gelegd dat hij een honorarium had aangerekend dat niet overeenkomstig de Wet Tarieven Gezondheidszorg was goedgekeurd of vastgesteld. De goedkeuring of vaststelling van een dergelijk tarief was door de wetgever gedelegeerd aan het Centraal orgaan tarieven gezondheidszorg. De arts diende een bezwaarschrift in tegen de aan hem uitgereikte dagvaarding met als argument dat de norm die hij volgens de tenlastelegging zou hebben geschonden niet in overeenstemming was met het legaliteitsbeginsel. Uit de betreffende richtlijn bleek dat de berekening van dit tarief is gebaseerd op een redelijkheidscriterium, te weten "zoveel X als redelijk is". Het oordeel van de rechtbank luidde ${ }^{100}$ :

"betrokkenen uit deze bepaling niet met voldoende duidelijkheid hun verplichtingen te dezen leren kennen, zodat het besluit van het Centraal orgaan tarieven gezondheidszorg van 20 dec. 1982 in dit opzicht als strafrechtelijke norm onverbindend is, waarmee geen oordeel wordt uitgesproken over de vraag, of de door verdachte in rekening gebrachte tarieven naar civielrechtelijke maatstaven redelijk zijn. Aangezien derhalve de ten laste gelegde feiten niet strafbarr zijn, zal de Rb. de verdachte buiten vervolging stellen."

Veel zorgplichtbepalingen met vage bestanddelen blijken derhalve de toets van de strafrechter aan het lex certa-beginsel te doorstaan. Het is nu aan hem in een voorliggende zaak de grens vast te stellen tussen strafbare en niet-strafbare gedragingen. Omdat een strafrechter slechts met individuele cases wordt geconfronteerd, kan hij slechts een oordeel vellen in het individuele geval en dus ex post. Hart merkt ter zake op $^{101}$ :

"(...) they may leam from a court only ex post facto when they have violated it, what, in terms of specific actions or forbearances, is the standard required of them. Where the decisions of the court on such matters are regarded as precedents, their specification of the variable standard is very like the exercise of deligated rulemaking power by an adninistrative body, though there are also obvious differences."

Het gebruik van vage bestanddelen lijkt een grote discretionaire bevoegdheid om de grenzen van de strafrechtelijke aansprakelijkheid te bepalen te verlenen aan de rechter.

97 KB 29 september 1987, MenR 1988, nr. 36, met noot Addink (Zorgplicht geschrapt).

98 AR 6 januari 1983, $A B$ 1984, 267 (Afval in kleine containers).

99 Dresden, M.J., "De zorgplicht in de milieuwetgeving", p. 57.

$100 \mathrm{Rb}$. Breda I oktober 1985, $N J$ 1986, 114 (Onduidelijke norm). Dit is overigens én van de weinige voorbeelden waar de strafrechter een vage norm strijdig heeft verklaard met het lex certa-beginsel. Zie over dit vonnis ook Mulder, G.E., "Vage normen", pp. 420422; Waling, C., Het materiele milieustrafrecht, p. 64, noot 156 en Hullu, de J., "Rechtszekerheid en vertrouwensbeginsel in het strafrecht", p. 97. Zie ook hoofdstuk 3 paragraaf 7.3.6.

101 Zie daarover Hart, H.L.A., The Concept of Law, p. 132. 
Deze beoordelingsvrijheid is immers groot in situaties waarin het betekenisbereik van de strafbepaling niet op voorhand duidelijk is. Nochtans zal de rechter ook bij die bepaling niet "ins Blaue hinein" interpreteren. Hij kan ter beantwoording van de vraag of een bepaalde gedraging een schending van de zorgplichtbepaling vormde gebruik. maken van de wetsgeschiedenis, eventuele opsomming van gedragingen uit de strafbaarstelling, jurisprudentie, ongeschreven recht en doctrine. Tevens zal hij rekening houden met het systeem en de inhoud van de rest van de betreffende regeling, en de plaats die de bepaling daar inneemt. De regeling in haar geheel kleurt als het ware de (vage termen uit de) zorgplichtbepaling in. ${ }^{102}$ Zo wordt de inhoud van de term nader bepaald door de overige bepalingen en kan het betreffende artikel leemten, die bestaan in de regeling, opvullen. ${ }^{103}$ Het systeem alleen zal echter vaak niet voldoende zijn om de inhoud te specificeren dan wel het bestaansrecht van de vage bepaling te rechtvaardigen.

De rechter kan het bereik van vage termen ook zelf inperken en definiëren door nadere criteria te stellen. ${ }^{105}$ Dergelijke vereisten kunnen het strafbare feit verder concretiseren, zodat eerder wordt voldaan aan de uit het. EVRM voortvloeiende vereisten van "accessibility and forseeability". ${ }^{106}$ Of hiermee ook voldaan is aan de verder gaande vereisten van het nationale recht, te weten of de tekst van de strafbaarstelling voldoende duidelijk en precies is, zodat de verdachte voorafgaande aan zijn handelen kon weten of zijn gedrag al dan niet onder de delictsomschrijving zou vallen, is de vraag. Rechters die in de toekornst worden geconfronteerd met het vaststellen van het betekenisbereik kunnen vervolgens ook de eerdere uitspraken gebruiken als richtsnoer voor de invulling van de bepaling in hun specifieke zaak. Hierdoor bepaalt de rechterlijke macht mede de inhoud van, met name de vage bestanddelen van, de zorgplichtbepalingen. ${ }^{107}$ Het zijn dan de rechters die de aanvullende criteria vaststellen die de

102 Hart, A.C. 't, "Art. 25 WVW en het legaliteitsbeginsel", p. 205; zie ook Simmelink, J.B.H.M., "Het RVV 1990, niet iedere verandering is ook een verbetering", p. 54.

103 Hart, A.C. " $t$, "Art. 25 WVW en het legaliteitsbeginsel", pp. 189-231 bespreekt dit en werkt het uit aan de hand van artikel 25 WVW.

104 Otte, M., Het stelsel van gedragsregels in het wegverkeer, pp. 172-174

105 Zie over vage normen en aanvullende criteria door de rechter hoofdstuk 5. Zie ook: Hullu, J. de, "Rechtszekerheid en vertrouwensbeginsel in het strafrecht", p. 99, die als voorbeeld artikel $140 \mathrm{Sr}$ bespreekt.

106 Deze eis sluit aan bij het later door het Hof gestipuleerde vereiste "that an offence must be clearly defined in law. This condition is satisfied where the individual can know from the wording of the relevant provision and, if need be, with the assistance of the courts' interpretation of it, what acts and omissions will make him criminally liable." EHRM 25 mei 1993, Series A, no. 260-A, nr. 52, p. 22 (Kokkinakis v. Greece).

107 Zie desbetreffend MacCormick die opmerkt dat "The judge must go beyond the law and (without sacrifice of impartiality) consult his own sense of moral and politicall rightness or equity and of social expediency in order to come to what seems the best decision on the problem in hand. At least for the parties to the case he partly makes the "law", which he "applies". And if the rule of recognition sets precedent as a binding source of law, he also makes law for the future by his own decision (...)". MacCormick, N., H.L.A. Hart, p. 126. 
vage bestanddelen verder invullen ter specificering van het betekenisbereik van de strafbepaling.

Het risico is evenwel dat de betreffende bepaling zeer ruim kan worden uitgelegd. Onder invloed van het gevoerde beleid kan de strafrechter onder druk komen te staan om naast de rechtsbeschermende ook de instrumentele aspecten zwaar mee te laten wegen in zijn beoordeling. ${ }^{108} \mathrm{Bij}$ het gebruik van vage termen in de strafbaarstelling zal hij deze echter ondanks het gevoerde beleidl (indien hij niet overgaat tot onverbindend verklaring) restrictief dienen te interpreteren. Door het ruim interpreteren van een toch al vage bepaling wordt het betekenisbereik van deze bepaling nog verder opgerekt. Hierdoor zal het voor de justitiabele nog moeilijker zijn om vast te stellen of zijn gedraging al dan niet onder de delictsomschnjving valt. Deze interpretatie kan daardoor in strijd komen met het lex certa-beginsel.

Uit de jurisprudentie blijkt echter dat de eisen die de rechterlijke macht stelt aan de nauwkeurigheid van wettelijke formulering van de strafbaarstelling in het algemeen gering zijn. ${ }^{109}$ Ook de toepassing van zorgplichtbepalingen in een concrete casus blijkt de strafrechter maar weinig problemen op te leveren, waarbij hij ook nog eens weinig oog heeft voor het specificeren van de betreffende bepaling. ${ }^{110}$ Uiteraard kan het in sommige gevallen duidelijk zijn dat een bepaalde gedraging van de justitiabele de zorgplichtbepaling schendt; daarvan zal doorgaans sprake zijn als het handelen van de betrokkene duidelijk schade aan het beschermde rechtsgoed veroorzaakt. Als dat echter niet het geval is, rijst het probleem van de vaagheid van de zorgplichtbepaling in zijn volle proportie. De strafrechter zal de grenzen van de strafbepaling, zaak voor zaak, dus ex post, dienen af te tasten. Uiteindelijk kan via deze ex post-benadering door de rechter wel duidelijkheid ontstaan over welk gedrag onder de zorgplichtbepaling valt, maar vanuit het (nationale) lex certa-beginsel is dit natuurlijk problematisch. Dit zal zeker het geval zijn als de rechter, die de reikwijdte van de zorgplichtbepaling casusgewijs en dus ex post vaststelt, de vage termen niet restrictief interpreteert waardoor de justitiabele voorafgaande aan zijn handelen niet kon weten dat zijn gedrag onder het betekenisbereik van de delictsomschrijving zou vallen.

\subsection{Zorgplichtbepalingen en rechtszekerheid}

In het kader van de beoordeling in hoeverre zorgplichtbepalingen tegennoet komen aan de rechtszekerheid van justitiabelen, is in deze paragraaf vooral ingegaan op de verhouding van deze bepalingen ten opzichte van het lex certa-beginsel.

108 Zie Kool, R.S.B., "Ontucht(ig): een rechtsonzeker begrip?", p. 268; zie ook Maris, C.W., "Romantisch recht", pp. 896-897.

109 Zie bijvoorbeeld de verwerping van een beroep op de onverbindendheid wegens vaagheid van artikel $140 \mathrm{Sr}$, HR 16 oktober 1990, NJ 1991, 442, met noot Corstens (Mariënburcht); HR 2 april 1985, NJ 1985, 796 (Onbehoorlijk gedrag) en HR ! september 1998, NJ 1999, 61 (Liftportaal).

110 Zie voor een bespreking Visser, M.J.C., "Uitholling van het schuldbeginsel bij zorgplichtbepalingen door schending van het lex certa beginsel", pp. 65-80. 
De grens wanneer een delictsomschrijving wel en wanneer zij niet in overeenstemming is met het lex certa-beginsel blijkt moeilijk te trekken. ${ }^{111}$ Terwijl sommigen stellen dat vage normen hieraan niet voldoen ${ }^{112}$, menen anderen dat een omschrijving van de belangrijkste normen in de wet in formele zin voldoende is. ${ }^{113}$ Het gangbare criterium is of de justitiabele in staat is zijn gedraging af te stemmen op de strafbaarstelling. ${ }^{114}$ De justitiabele moet daarom voorafgaande aan zijn gedraging kunnen weten of zijn gedraging al dan niet onder het betekenisbereik van een strafbaarstelling zal vallen.

Een manier om vage termen in een bepaling te concretiseren is door een opsomming te geven van uitwerkingen van de vage term die wel onder het bereik van de strafbaarstelling vallen. Zo wordt bijvoorbeeld de vage zorgplichtbepaling uit de aanhef van artikel 11 Arbo-wet 1998 door de opgenomen opsomming van verboden gedragingen uit sub a tot en met $f$ tegen een bepaalde achtergrond geplaatst. De concreet omschreven gedragingen worden aangevuld door de vage, waarvan de grenzen ten dele worden bepaald door de specifieke. Het is dan ook wenselijk dat de wetgever indien hij zich genoodzaakt ziet vage bestanddelen te gebruiken de context van deze bestanddelen zoveel mogelijk concretiseert door voorbeelden van gedragingen op te nemen in de delictsomschrijving. Deze kunnen als richtsnoer werken bij de interpretatie door de rechter. Helaas ontbreekt een dergelijke opsomming bij de meeste zorgplichtbepalingen.

Er zijn meer manieren dan het opsommen van gedragingen om een term (verder) te specificeren, bijvoorbeeld door het opnemen van een bestanddeel dat het gevolg aangeeft dat door de gedraging teweeg wordt gebracht. De meeste zorgplichtbepalingen kunnen worden aangemerkt als concreet gevaarzettingsdelict, maar ook de noodzakelijke gevolgen blijken vaak vaag omschreven.

Niet alle zorgplichtbepalingen zijn (even) vaag geformuleerd. Degene die alleen in algemene termen een gevaarlijke of ongewenste gedraging aanduiden, een bepaalde graad van zorgvuldigheid vereisen, het treffen van niet nader aangeduide voorzorgsmaatregelen, voorzorgsmaatregelen of schadebeperkende maatregelen vereisen, lijken. zeer vaag geformuleerd. Zeker als uit de overige bestanddelen geen beperking van het

111 Zie de bespreking van "vaagheid van een regel" in hoofdstuk 2 paragraaf 5.4.

112. Vage normen bevatten één of meer vage termen; hiermee hebben we te maken indien veel gevallen in het grensgebied van het betekenisbereik van de term vallen. Visser, $M$ en Hage, J., "Voorwaarden van regeltoepassing", p. 202. Wanneer sprake is van cen vage term is hierdoor juist bij grensgevallen lastig vast te stellen, waardoor het ook moeilijk is aan de hand daarvan vast te stellen of de regel is strijd is met het lex certabeginsel.

113 Zie Ru, H.J. de, De algemene wet gaat voor de bijzondere wet, p. 44. Pompe stelde zelfs: "de wetgever blijt in de redactie van der strafwet vrij, hij kan deze dus in zoo algemene termen vervatten, en in de keuize der termen zooveel aan het vrije oordeel des rechters overlaten, dat uit den geschreven tekst zelf weinig zekerheid voor den burger of misdadiger overblijf." Pompe, W.P.J., Het nieuwe tijdperk en het recht, p. 50.

114 Zie bijvoorbeeld HR 8 maart 1994, NJ 1994, 412 (Krijgsmacht belemmert). 
betekenisbereik voortvloeit, geen daadwerkelijke schade of gevolg wordt vereist en zij zich richten tot een grote groep van normadressaten (een ieder) kan worden gezegd dat zij in strijd zijn met het lex certa-beginsel.

Artikel 5.WVW spant de kroon. Deze zorgplichtbepaling is dusdanig, vaag dat zeker sprake is van strijd met het lex certa-beginsel. ${ }^{115}$ Zo verbiedt deze bepaling onder andere zonder nadere aanduiding een gedraging die het verkeer op de weg kan hinderen. Niet veel beter is artikel $13 \mathrm{Wbb}$, die ook als "te vaag" en daarom in strijd met het lex certa-beginsel dient te worden aangemerkt. Dit geldt te meer nu deze bepaling niet als een geheel dient te worden gelezen maar gesplitst mag worden in drie verschillende zorgplichtbepalingen. Wel moet worden opgemerkt dat artikel $13 \mathrm{Wbb}$ in tegenstelling tot artikel 5 WVW subjectieve bestanddelen bevat die enige beperking geven aan het betekenisbereik, aangezien moet worden bewezen verklaard dat de verdachte "weet of redelijkerwijs had kunnen vermoeden dat (...)". Ook de artikelen 2 Wms en 10.3, eerste en tweede lid Wm, bevatten subjectieve bestanddelen. Voorts beperken deze bepalingen zich tot degene die beroepsmatig bepaalde gedragingen verricht. Desondanks zijn ook deze twee zorgplichtbepalingen erg vaag nu zij vereisen dat "door zijn handelingen met die stof of dat preparaat gevaren kunnen optreden voor mens en milieu" (artikel $2 \mathrm{Wms}$ ) en "dat daardoor nadelige gevolgen voor het milieu ontstaan of kunnen ontstaan". Het gevaar dat kan ontstaan voor het milieu en de nadelige gevolgen die kunnen ontstaan voor het milieu, zijn door de ook al weinig specifiek omschreven gedragingen zeer ongedefinieerd, zodat ook deze bepalingen "te vaag" lijken. Artikel 5 Wet Luchtverkeer lijkt eveneens "te vaag". Ook van deze beroepsmatig handelende normadressaten wordt zonder verdere specificatie alleen vereist dat door hun gedraging personen of zaken niet in gevaar worden of kunnen worden gebracht.

De zorgplichtbepalingen in het Wetboek van Strafrecht lijken het doorgaans iets beter te doen, aangezien zij meestal meer bestanddelen bevatten die het betekenisbereik van het strafbare feit specificeren. ${ }^{116}$ Dit geldt bij artikel 426 , eerste lid Sr niet onverkort. Duidelijk is dat de normadressaat die in staat van dronkenschap verkeert deze bepaling schendt indien hij het verkeer belemmert. Lastiger is het om vast te stellen wanneer hij "eens anders veiligheid bedreigt", alhoewel dan wel de voorwaarde geldt dat noodzakelijk is dat wordt bewezen dat hij objectief eens anders veiligheid onmiddellijk in gevaar heeft gebracht. Nog moeilijker is het vast te stellen wanneer hij wel of niet "de orde verstoort". De volgende strafbaar gestelde gedraging uit dit artikel is nog vager. Het betreft handelingen van de normadressaat waarbij tot voorkoming van gevaar voor

115. Zie ook Otte, M., Het stelsel van gedragsregels in het wegverkeer, die in zijn studie ingaat op de meerwaarde van artikel 25 WVW, en mede omdat deze bepaling geen gedragsregulerende functie bezit eveneens tot de conclusie komt dat haar geen bestaansrecht toekomt. Overigens komen Simmelink en 't Hart tot de conclusie dat artikel 5 WVW in zijn algemeenheid niet in strijd is met het lex certa-beginsel, zie Simmelink, J.B.H.M., Algemeenheden in het verkeersrecht en Hart, A.C. 't, "Artikel 25 W.V.W. en het legaliteitsbeginsel", pp. 213-224; Hart, A.C. "t, "Art. 25 WVW en het legaliteitsbeginsel", pp. 189-231; Remmelink, J., Hoofdwegen door het verkeersrecht, pp. 33-34.

116. Zie over deze zorgplichtbepalingen uitgebreid hoofdstuk 6 paragraf 6. 
leven of gezondheid van derden bijzondere omzichtigheid of voorzorgen worden vereist. De invulling hiervan is door de wetgever bewust aan de rechter overgelaten, onder andere om "preventief" te kunnen optreden. ${ }^{117}$ Artikel 425 aanhef en sub $2 \mathrm{Sr}$ is al minder vaag, alhoewel ook hier sprake is van het in acht nemen van een bepaalde (niet gespecificeerde) graad van zorgvuldigheid die moet worden betracht. Deze zorg heeft betrekking op "het onschadelijk houden van een onder zijn hoede staand gevaarlijk dier". Het dier moet hiervoor onder zijn feitelijk toezicht staan. Voorts moet voorafgaande aan de gedraging waaruit blijkt dat het dier gevaarlijk is al zijn gebleken dat het als een gevaarlijk dier moest worden beschouwd dat onschadelijk moest worden gehouden. Deze bepaling lijkt enigszins op die van artikel 427 aanhef en sub 5 $\mathrm{Sr}$, angezien daar wordt vereist dat nodige voorzorgsmaatregelen tegen het aanrichten van schade moeten worden genornen, hetgeen weinig specifiek is. Deze verplichting geldt echter alleen voor degene die op de openbare weg een rij-, trek- of lastdier laat staan, hetgeen enige beperking aanbrengt in het betekenisbereik van deze bepaling. Ook artikel 429 aanhef en sub $3 \mathrm{Sr}$ specificeert de strafbaar gestelde gedragingen niet, angezien het een gebrek aan omzichtigheid of voorzorg strafbaar stelt. Dit heeft slechts betrekking op het doen ontstaan van gevaar voor bos-, heide-, helm- of veenbrand, zodat daardoor het potentiële betekenisbereik wordt beperkt.

Specifieker zijn de zorgplichtbepalingen uit artikel 19, eerste en derde lid Quarantainewet. De strafbaar gestelde gedragingen zijn hierin vrij nauwkeurig weergegeven. Bovendien wordt het betekenisbereik beperkt, doordat deze bepalingen zich richten tot bepaalde beroepsmatig handelende normadressaten, te weten "de gezagvoerder van een schip" (artikel 19, eerste lid Quarantainewet) en "hij die de leiding heeft bij trein- of wegvervoer" (artikel 19, derde lid Quarantainewet). Aangezien deze zorgplichtbepalingen zijn vormgegeven als abstract gevaarzettingsdelict, kunnen zij worden overtreden zonder dat de strafbaar gestelde gedraging een bepaald gevolg (potentieel kunnen) veroorzaken. Door het ontbreken van (tastbare) schade als vereiste voor strafbaarheid wordt het betekenisbereik wel weer opgerekt, maar de grens tussen wel en niet strafbare gedragingen blijft voor nagenoeg alle strafbaar gestelde gedragingen niet vaag.

Meer specifiek nog zijn de zorgplichtbepalingen in artikel 11 Arbo-wet 1998. De strafbaar gestelde gedragingen zijn (met uitzondering van de aanhef van artikel 11 Arbo-wet 1998) vrij specifiek weergegeven, waarbij ook de kring van normadressaten is aangepast, omdat dit artikel zich slechts richt tot beroepsmatig handelende personen, namelijk de "werknemer". Deze is "verplicht om in verband met de arbeid de nodige voorzichtigheid en zorgvuldigheid in acht te nemen en naar vermogen zorg te dragen voor de eigen veiligheid en gezondheid en die van andere personen". Vanwege dit doel van de verplichting is de werknemer "in verband met de arbeid" verplicht de in a tot en met f opgesomde gedragingen te verrichten. Doordat dit artikel (afhankelijk van de uiteindelijk gekozen interpretatie waarschijnlijk) is aan te merken als concreet

117 Zie Beraadslagingen Tweede Kamer, Opmerking van Minister Modderman, Smidt, H.J., Geschiedenis van het Wetboek van Strafrecht, Deel III, p. 188 en hoofdstuk 6 paragraaf 6.3 . 
gevaarzettingsdelict, geldt bovendien als voorwaarde voor strafbaarheid dat de gedraging een bepaald (potentieel) gevolg moet hebben teweeg gebracht. Ook hier is niet als voorwaarde gesteld dat daadwerkelijke schade moet optreden, hetgeen het betekenisbereik wel weer enigszins, oprekt. De strafbaarstelling van de aanhef in november 1999 heeft mogelijk tot gevolg dat ook niet opgesomde gedragingen onder het betekenisbereik van deze strafbaarstelling kunnen vallen. Indien dit het geval is zullen de wel opgesomde gedragingen uit at tot en met $f$ hierbij als richtsnoer werken, omdat het de niet opgenomen gedragingen tegen een bepaalde achtergrond plaatst.

De betekenis van het lex certa-beginsel lijkt in de praktijk van de rechtspraak niet groot, aangezien de wetgever veelvuldig gebruik maakt van vage termen bij de samenstelling van zorgplichtbepalingen. Eveneens worden deze termen door het bestuur vaak niet nader ingevuld. Voorts blijkt de strafrechter deze vage strafbaarstellingen niet (althans bijna nooit) onverbindend te verklaren wegens strijd met het lex certabeginsel, terwijl hij ze ook vaak niet restrictief interpreteert en weinig oog lijkt te hebben voor het specificeren van de bepaling door het vaststellen van aanvullende criteria.

De relatief autonome waarde van het legaliteitsbeginsel wordt door het toekennen van een te beperkte rol door de wetgever, het $\mathrm{OM}$ en de strafrechter ten onrechte zeer gering. Het vereiste van een duidelijke en inzichtelijke wettelijke formulering van de verboden gedraging is immers een hoog te noteren belang. ${ }^{118}$ Het zou steeds als toetssteen aan het positieve recht moeten worden voorgehouden, enerzijds om het optreden van controleurs te normeren ${ }^{119}$, maar ook om op een legitieme wijze schadelijke, bedreigende, nadelige gedragingen tegen te gaan. ${ }^{120}$ Voorts is een duidelijke en inzichtelijke wettelijke formulering van groot belang voor de rechtshandhaving. Hieraan hebben politie en justitie immers houvast bij het uitoefenen van hun strafvorderlijke bevoegdheden. ${ }^{121}$ In hoeverre kan immers naleving worden gevraagd en al dan niet met gebruikmaking van strafvorderlijke bevoegdheden worden afgedwongen, indien niet duidelijk is waaraan iemand zich heeft te houden. ${ }^{122}$ Dit is in het kader van de strafvordering onder andere van belang voor de rechtmatige toepassing van dwangmiddelen. ${ }^{123}$ Vage delictsomschrijvingen kunnen immers tot gevolg hebben dat ook dwangmiddelen die inbreuken op grondrechten mogelijk maken, willekeurig of te ruim worden toegepast. ${ }^{124}$

118 Groenhiijsen, M.S., Straf en wet, pp. 49-51.

119 Peters, A.A.G., Het rechtskarakter van het strafrecht, p. 10.

120 Zie Groenhuijsen, M.S., Strafen wet.

121 In de Nota "Zicht op wetgeving" zie hoofdstuk 3 paragraaf 3 wordt gesteld dat "Vage en te complexe delictsomschrijvingen leiden immers niet alleen tot rechtsonzekerheid, mar bieden ook onvoldoende mogelijkheden voor een succesvolle strafvervolging".

122 Zie Blomberg, A.B. en Michiels, F.C.M.A., Handhaven met effect, p. 293.

123 Hullu, J. de, "Rechtszekerheid en vertrouwensbeginsel in het strafrecht", pp. 99-100.

124 Denk aan de vrijheidsbeneming van Eurotop demonstranten op basis. van artikel $140 \mathrm{Sr}$. Zie hierover Prakken, T., "De Eurotop en het individueel daadstrafrecht", pp. 442-446; Hart, A.C. "t, "Strafrecht en beroepsethiek", pp. 1-10. 


\section{Rechtsgelijkheid \\ 4.1. Inleiding}

Gelijke gevallen dienen gelijk te worden behandeld, maai afwijkende gevallen rechtvaardigen ook afwijking, zodat er naast gelijkheid nuimte moet zijn voor individuele rechtsbedeling. De beoordeling van een zaak moet plaatsvinden op zijn merites, waarbij er ruimte is een hardheidsclausule toe te passen indien toepassing van een bepaling in een specifiek geval niet gewenst is. Hierbij is van belang na te gaan tot wie de norm zich richt (zie hierover hoofdstuk 10 paragraaf 3.2.4.), en wie wegens de normschending in een specifiek geval kan worden aangesproken. Hierbij moet in het strafrecht bijvoorbeeld rekening worden gehouden met de mate van verwijtbaarheid van de aangesprokene.

\subsection{Gelijke gevallen gelijk behandelen}

Het gelijkheidsbeginsel ligt aan alle regelgeving ten grondslag, maar speelt geen absolute rol aangezien het steeds dient te worden afgewogen tegen andere beginselen. Regels dienen in onderlinge samenhang zo weinig mogelijk rechtsongelijkheid ten gevolge te hebben. Daarom mag een regeling geen willekeurig of ongemotiveerd onderscheid maken tussen personen of groepen uit de samenleving.

Een vaag geformuleerde regeling die zich tot een ieder of een meer gespecificeerde groep normadressaten richt, behoeft niet noodzakelijk op gespannen voet te staan met het gelijkheidsbeginsel. Toch kan dit wel een gevolg zijn van het gebruik van vage termen. Zo kan, indien het betekenisbereik niet duidelijk is, ongelijkheidl ontstaan bij de vervolgingsbeslissing van het $\mathrm{OM}$ en de beoordeling van de toepasselijkheid door de rechter. Zeker indien de strafbaarstelling een grote werkingssfeer heeft waardoor zij betrekking heeft op een groot aantal gedragingen, met (potentiële) gevolgen en gericht is tot grote groepen justitiabelen zal dit zich kunnen voordoen.

Een probleem in het kader van het gelijkheidsbeginsel is dat indien de strafbaarstelling een grote werkingssfeer heeft, de selectie van zaken waarin wel en waarin niet wordt overgegaan tot vervolging hiermee op gespannen voet kan komen te staan. Om zoveel mogelijk tegemoet te komen aan het gelijkheidsbeginsel is het wenselijk dat het OM geen feiten ten laste legt die in het grijze gebied vallen van een strafbaarstelling. Alleen indien sprake is van een zeer onwenselijke gedraging die op de grens ligt tussen de kern en het grijze gebied zou het OM kunnen beslissen toch over te gaan tot vervolging. ${ }^{125}$ Ook kan het $\mathrm{OM}$ aan het gelijkheidsbeginsel tegemoetkomen door een duidelijk vervolgingsbeleid vast te stellen, bekend te maken en te hanteren bij (in ieder geval) strafbaarstellingen met vage termen, zeker als ook nog sprake is van een grote werkingssfeer.

I25 Hiermee wordt tevens tegemoet gekomen aan het lex certa-beginsel, zie hoofdstuk 10 paragraaf 3.2.6. 
Bij de toetsing van zorgplichtbepalingen aan het lex certa-beginsel (hoofdstuk 10 paragraaf 3.2.) is gebleken dat veel zorgplichtbepalingen vage bestanddelen bevatten, terwijl de meeste zorgplichtbepalingen ook een grote werkingssfeer hebben. Het is echter de vraag of het OM zich terughoudend opstelt bij de beslissing al dan niet over te gaan tot vervolging op basis van deze bepalingen. Voorts heeft het $\mathrm{OM}$ bij geen van deze bepalingen een duidelijk vervolgingsbeleid vastgesteld, waaruit kan worden afgeleid in welke gevallen het wel, en in welke gevallen het niet zal overgaan tot vervolging. Gezien deze punten bestaat het gevaar dat zorgplichtbepalingen niet eenduidig door het $\mathrm{OM}$ worden toegepast, waardoor deze bepalingen op gespannen voet staan met de rechtsgelijkheid.

De rechter zou de vage bestanddelen uit de zorgplichtbepalingen zo veel mogelijk restrictief dienen te interpreteren waarbij hij aanvullende criteria vaststelt. ${ }^{126}$ Hierdoor wordt het betekenisbereik niet opgerekt en wel gespecificeerd. Daardoor zal de rechter bij de (toekomstige) beslissingen en motiveringen beter in staat zijn de gelijkheid in acht te nemen, hetgeen de rechtsgelijkheid ten goede zal komen.

Hielaas is bij de bespreking van het lex certa-beginsel (hoofdstuk 10 paragraaf 3.2.) gebleken, dat eerder sprake lijkt te zijn van een omgekeerd fenomeen. Strafrechters blijken de meeste zorgplichtbepalingen zeker niet restrictief te interpreteren, en ook worden maar zelden duidelijke aanvullende criteria vastgesteld die het betekenisbereik van de zorgplichtbepalingen vaststellen. Aangezien de strafrechter in navolging van het OM geen duidelijke grenzen stelt aan de toepassing van zorgplichtbepalingen, bestaat de mogelijkheid dat bij de vervolging van justitiabelen die verdacht worden van schending van een zorgplichtbepaling, gelijke gevallen niet op gelijke wijze worden behandeld.

\subsection{Verwijtbaarheid}

\subsubsection{Inleiding}

Zoals aangegeven dienen niet alleen gelijke gevallen gelijk te worden behandeld, maar rechtvaardigen afwijkende gevallen ook afwijking. Deze afwijking zal dan ook tegemoet komen aan de rechtsgelijkheid. Indien toepassing van een zorgplichtbepaling in een specifiek geval niet gewenst is, moet daarom kunnen worden afgeweken van het gelijkheidsbeginsel. Aan deze mogelijkheid kan bijvoorbeeld worden tegemoet gekomen door het opnemen van hardheidsclausules, door het toepassen van gelede normstellingen ${ }^{127}$ en door rekening te houden met de mate van verwijtbaarheid van de justitiabele; het schuldbeginsel. ${ }^{128}$

126 Ook hierdoor wordt tevens tegemoet gekomen aan het lex certa-beginsel, zie hoofdstuk 10 paragraaf 3.2.7.

127 Zie over gelede normstellingen hoofdstuk 4.

128 Zie over het schuldbeginsel hoofdstuk 3 paragraaf 7.4. 
Het schuldbeginsel hangt nauw samen met het in hoofdstuk 10 paragraaf 3 besproken lex certa-beginsel. ${ }^{129}$ Hoe duidelijker de gedraging in de delictsomschrijving wordt omschreven, des te legitiemer degene die de handeling verricht hierop kan worden aangesproken. Bij de bespreking van het legaliteitsbeginsel bleek dat de meeste zorgplichtbepalingen vaag tot zeer vaag zijn geformuleerd. De omstandigheden waaronder strafrechtelijke aansprakelijkheid kan ontstaan, zijn dan niet scherp en duidelijk gespecificeerd, waardoor ook onduidelijkheid kan bestaan over de vraag welk gedrag verwijtbaar is en wanneer er dientengevolge sprake is van schuld.

\subsubsection{Zorgplichtbepalingen zonder een subjectief bestanddeel}

De in de hoofdstukken 6 en 7 besproken zorgplichtbepalingen bevatten geen subjectieve bestanddelen. Dit geldt ook voor de in hoofdstuk 8 besproken zorgplichtbepaling uit artikel 11 Arbo-wet 1998. Dit artikel is opgenomen in artikel 1 sub 3 Wed, zodat hiervoor (ex artikel 2, derde lid Wed) niet geldt dat involge de Wed bij opzet sprake is van een misdrijf. Op basis van de Arbo-wet 1998 en de Wed worden deze delicten aangemerkt als een "beboetbaar feit" of een overtreding.

Schuld is bij deze strafbaarstellingen in de vorm van culpa een element, zodat steeds door de strafrechter moet worden onderzocht of de verdachte een verwijt kan worden gemaakt. Hierbij gaat het om de vraag wat van de verdachte kan worden geëist of gevergd. De beantwoording zal niet alleen worden ingekleurd door de persoon van de dader, maar ook door de tijd, de plaats, de situatie waarin de gedraging plaatsvond en de maatschappij waarin de norm zijn gestalte krijgt.

\subsubsection{Zorgplichtbepalingen met een subjectief bestanddeel als overtreding}

Opvallend is dat de in hoofdstuk 9 besproken zorgplichtbepalingen in het milieustrafrecht, in tegenstelling tot alle in de hoofdstukken 6,7 en 8 besproken zorgplichtbepalingen uit andere delen van het strafrecht, wel subjectieve bestanddelen bevatten. De subjectieve bestanddelen van de zorgplichtbepalingen in het milieustrafrecht wijken overigens af van de gebruikelijke redactie; te weten het vereisen van "opzet" of "schuld". 130 Voorts wordt de nieuw gekozen redactie niet consequent gebruikt in de verschillende zorgplichtbepalingen. In de artikelen $13 \mathrm{Wbb}$ en $2 \mathrm{Wms}$ is de schuldvorm geformuleerd als "weet of redelijkerwijs had kunnen vermoeden" en "redelijkerwijs van hem kunnen worden gevergd", terwijl die in artikel 10.3, eerste en tweede lid Wm luidt "weet of redelijkerwijs had moeten weten". Deze subjectieve bestanddelen zijn bij de overtreding-variant niet van toepassing op alle bestanddelen. van de delictsomschrijving, maar zien slechts op enkele bestanddelen. Voor de overige bestanddelen geldt dat culpa daar een element is. De interpretatie van de overtredingvariant van deze zorgplichtbepalingen is uitgewerkt in hoofdstuk $9 .{ }^{131}$

129 Zie uitgebreider Visser, M.J.C., "Uitholling van het schuldbeginsel bij zorgplichtbepalingen door schending van het lex certa-beginsel", pp. 65-80..

130. Zie hoofdstuk 3 paragraaf 7.4 .

I31 Zie hoofdstuk 9 paragrafen 3.2.5., 3.3.8., 3.4.7. en 4. 
Deze subjectieve bestanddelen dienen door het verbindingswoord "of" te worden geïnterpreteerd als alternatieven. Het betreft een culpose en een opzettelijke variant, die beide zijn aan te merken als cvertreding. Bij deze zorgplichtbepalingen speelt culpa als element nog steeds een rol. Dit is het geval voor de bestanddelen die niet worden beheerst door de opgenomen subjectieve bestanddelen. Echter, ook voor de delen van de delictsomschrijving die wel worden beheerst door het culpose subjectieve bestanddeel kan culpa als element een rol spelen. Deze bestanddelen zijn bij de artikelen 13 Wbb en 2 Wms "redelijkerwijs had kunnen vermoeden" en "redelijkerwijs van hem kunnen worden gevergd" en bij artikel 10.3, eerste en tweede lid Wm "redelijkerwijs had moeten weten". Schuld als element heeft namelijk een groter betekenisbereik dan de hier opgenomen bestanddelen. Indien ten aanzien van een verdachte het betreffende culpose bestanddeel kan worden bewezen verklaard, zijn er situaties mogelijk waarin toch geen sprake is van schuld (als element) voor het deel van de delictsomschrijving dat door het specifieke culpose bestanddeel wordt beheerst. De verdachte zal dan (ex artikel 352, tweede lid Sv) moeten worden ontslagen van alle rechtsvervolging.

\subsubsection{Zorgplichtbepalingen met een subjectief bestanddeel als misdrijf}

De in de hoofdstuk 9 besproken zorgplichtbepalingen in het milieustrafrecht zijn via artikel la sub 1 Wed aangehaakt aan de Wed. Involge artikel 2, eerste lid Wed is er bij deze bepalingen sprake van een misdrijf indien de normschending opzettelijk is begaan en is er in de overige gevallen sprake van een overtreding. Aangezien deze strafbaarstellingen zelf ook al subjectieve bestanddelen bevatten, is er bij de misdrijfvariant sprake van een "schuldkwadratuur". ${ }^{132}$ Gezien de in hoofdstuk 3 paragraaf 7.4.6. beschreven oplossingen geldt voor de misdrijf-variant van deze zorgplichtbepalingen dat zij op een aantal manieren kunnen worden geïnterpreteerd.

In hoofdstuk 3 bleek dat de eerste interpretatiemogelijkheid is dat wordt aangesloten bij de opbouw en samenstelling van strafbaarstellingen. De subjectieve bestanddelen uit deze zorgplichtbepalingen zijn als alternatieven geformuleerd, zodat twee strafbare gedragingen onafhankelijk van elkaar strafbaar zijn gesteld. Indien wordt vastgehouden aan de interpretatie uit het commune strafrecht, die inhoudt dat de opzet-eis het overtreden voorschrift in zijn geheel beheerst, behoeft dit niet tot problemen te leiden. Bij de opzettelijke variant van de strafbaarstelling zullen zich geen problemen voordoen. De opzet-eis uit de Wed is ten eerste op meer bestanddelen van toepassing dan het deel dat beheerst wordt door het "weten", zodat voor deze bestanddelen geen probleem ontstaat. De opzet-eis uit de Wed zal voor het "weten" met zijn bestanddelen geen problemen opleveren, aangezien "opzet" geheel valt onder "weten", waarbij aan het "weten" zelfs verdergaande eisen worden gesteld. Bij het culpose bestanddeel leidt deze interpretatie van de reikwijdte van de opzet-eis uit de Wed wel tot onoverkomelijke problemen. Een opzettelijke culpose gedraging is natuurlijk niet mogelijk. 
In de tweede plaats is de interpretatie mogelijk dat de opzet-eis uit de Wed niet van toepassing wordt geacht op de subjectieve bestanddelen en de bestanddelen waar deze betrekking op hebben. Dit heeft tot gevolg dat voor de opzettelijke variant opzet wordt vereist voor alle bestanddelen die niet worden beheerst door het "weten" uit de zorgplichtbepaling. Dat de Wed opzet-eis ten aanzien van het "weten" met zijn bestanddelen niet van toepassing is maakt, gezien de verdergaande eisen die aan "weten" worden gesteld, inhoudelijk niets uit. Tussen de eerste en de tweede interpretatie is zodoende bij de opzet-variant geen inhoudelijk verschil aanwezig. Bij de culpose variant van de strafbaarstelling ligt dit anders. De opzet-eis uit de Wed is bij deze tweede interpretatiemogelijkheid niet van toepassing op het subjectieve bestanddeel en de bestanddelen waarop dit betrekking heeft. Hier doen zich daarom geen onoverkomelijke problemen voor om de culpose bestanddelen als misdrijfvariant strafbaar te stellen.

De praktische consequenties die het volgen van deze interpretatiemogelijkheden tot gevolg hebben, zijn in te vinden in hoofdstuk 9. Hier kan de uitwerking van deze mogelijkheden worden gevonden voor artikel $2 \mathrm{Wms}$, artikel $13 \mathrm{Wbb}$ en artikel 10.3, eerste en tweede lid Wm. ${ }^{133}$ Indien deze uitwerkingen worden bestudeerd valt op dat het verschil tussen de overtreding- en misdrijf-varianten van deze zorgplichtbepalingen niet erg groot lijkt te zijn. Bij deze strafbaarstellingen worden vooral de bestanddelen die de strafbare gedraging aangeven niet beheerst door subjectieve bestanddelen uit de strafbaarstelling van de milieuwet. Hiervoor geldt dat zij involge artikel 2 Wed bij de misdrijf-variant wel worden beheerst door het bestanddeel "opzet".

Bij de misdrijf-variant dient te worden gekozen voor de eerste interpretatiemogelijkheid. De opzet-eis uit artikel 2 Wed is hierdoor van toepassing op de strafbare gedragingen uit de zorgplichtbepalingen. Deze eis zal praktisch echter niet veel consequenties hebben, aangezien zij die deze gedragingen beroepshalve verrichten, nagenoeg altijd deze gedragingen (voorwaardelijk) opzettelijk verrichten. Deze gedragingen zijn, tenzij wederrechtelijk verricht, op zichzelf ook niet strafbaar, en zullen zeifs vaak tot de kern van de bedrijfsmatige activiteiten behoren. Wat deze gedragingen strafbaar maakt, is de concrete gevaarzetting die uitgaat van deze gedragingen. Deze zijn door de wetgever dan ook opgenomen in de strafbaarstelling. Deze bestanddelen worden beheerst door de subjectieve bestanddelen. Hierdoor maakt niet enkel het mogelijk intreden van het gevolg de gedraging strafbaar, maar is dit pas het geval indien de verdachte ten aanzien van dit mogelijke gevolg over een bepaalde subjectieve gesteldheid beschikte. Deze gelden (als alternatieven) ook voor de overtreding-variant. Indien hier bij de misdrijf-variant voor de tweede interpretatie wordt gekozen, wordt voor deze bestanddelen geen onderscheid gemaakt in de interpretatiemogelijkheden tussen de misdrijf- en de overtreding-variant. Indien wordt gekozen voor de eerste variant geldt dat deze interpretatie ook mogelijk is bij overtredingen, maar geldt dit alleen voor het alternatief waarbij de bestanddelen worden beheerst door "weten" en niet het alternatief waarbij zij worden beheerst door

Zie hoofdstuk 9 paragrafen 3.2.6., 3.3.9., 3.4.8. en 4 . 
"redelijkerwijs had kunnen vermoeden". Aangezien misdrijven in het algemeen als ernstiger en meer afkeurenswaardig worden beschouwd dan overtredingen ${ }^{34}$ ligt deze interpretatie voor de hand. Voorts wordt met deze keuze ook tegemoet gekomen aan het uitgangspunt in dubio pro reo. De keuze voor deze interpretatie wordt ook ingegeven doordat het $\mathrm{OM}$, gezien de samenstelling van de zorgplichtbepaling bij het ten laste leggen van de overtreding-variant, kan kiezen tussen "weet of redelijkerwijs had kunnen vermoeden". Hierbij zal het waarschijnlijk de voorkeur geven aan het eenvoudiger te bewijzen "redelijkerwijs had kunnen vermoeden". Door het maken van de keuze voor de eerste interpretatiemogelijkheid wordt tevens bereikt dat er in de praktijk althans, tenminste enig verschil ontstaat tussen de overtreding- en misdrijfvariant op het gebied van de ernst en de afkeurenswaardigheid van deze strafbare feiten.

Duidelijk is wel dat de extra opzet-eis uit artikel 2 Wed niet veel toegevoegde waarde zal hebben. Aangezien misdrijven in het algemeen als emstiger en meer afkeurenswaardig worden beschouwd dan overtredingen ${ }^{135}$ is het opvallend dat dit onderscheid slechts in geringe mate tot uiting komt bij de zorgplichtbepalingen in het milieustrafrecht. Dit geldt nog sterker nu dit onderscheid vergaande processuele en materiële consequenties tot gevolg kan hebben. ${ }^{136}$

\subsubsection{Zorgplichtbepalingen en verwijtbaarheid}

De mate van verwijtbaarheid van de verdachte dient een rol te spelen bij de beoordeling in het kader van artikel $350 \mathrm{~Sv}$ of het feit kan worden bewezen (indien de verwijtbaarheid is opgenomen in een bestanddeel) en/ of bij de vraag of de dader strafbaar is (bij de beoordeling van schuld als element). Indien de verwijtbaarheid ontbreekt dient de verdachte op basis van artikel $352 \mathrm{~Sv}$ te worden vrijgesproken of te worden ontslagen van alle rechtsvervolging. Hierdoor wordt tegemoet gekomen aan de rechtsgelijkheid, aangezien op deze manier ruimte bestaat voor individuele rechtsbedeling. In deze paragraaf worden enkele opmerking gemaakt ten aanzien van het algemene leerstuk inzake schulduitsluitingsgronden. Deze worden hier gemaakt ter illustratie van het feit dat in de praktijk de rol van schulduitshitingsgronden bij zorgplichtbepalingen maar beperkt is.

Zorgplichtbepalingen in het bijzonder, economisch of milieustrafrecht kunnen, zeker als zij zijn opgenomen in gelede normstellingen, moeilijk toegankelijk zijn. Ook kan de verhouding van deze bepalingen ten opzichte van andere bepalingen onduidelijk en onoverzichtelijk zijn. Het gebruikte jargon en het technische karakter van de regelingen maken het er vaak niet beter op. Dit betekent overigens niet dat een beroep op error iuris snel zal worden geaccepteerd: zeker aan ondernemers wordt doorgaans de

134. Zie hoofdstuk 6 paragraaf 3.

135 Zie hoofdstuk 6 paragraaf 3.

136 Denk hierbij bijvoorbeeld aan de mogelijkheid tot gebruik van dwangmiddelen, de verjaringstermijn, de registratie en de maximum strafbedreiging. Zie over het verschil tussen misdrijven en overtredingen hoofdstuk 6 paragraaf 3 . 
eis gesteld dat zij zich terdege van toepasselijke regels op de hoogte stellen. De redenering lijkt te zijn dat ingewikkelde regelgeving erbij hoort, indien beroepsmatig gedragingen worden verricht die soms ook nog eens zeer gecompliceerde technische procédés omvatten. Dat dit geen vrijbrief oplevert voor de wetgever om zich te bezondigen aan slordigheden, gebrek aan inzichtelijkheid en onduidelijkheden, lijkt daarbij soms te worden vergeten. ${ }^{137}$

\subsection{Zorgplichtbepalingen en rechtsgelijkheid}

Bij de beoordeling van zorgplichtbepalingen aan het vereiste van rechtsgelijkheid is in deze paragraaf vooral ingegaan op het vereiste om gelijke gevallen gelijk te behandelen, en op de mogelijkheid afwijkende gevallen afwijkend te behandelen. Deze laatste mogelijkheid is besproken aan de hand van het schuldbeginsel.

Ook bij deze beoordeling speelt de vaagheid van de meeste zorgplichtbepalingen een belangrijke rol. De vage bestanddelen behoeven niet per definitie tot rechtsongelijkheid te leiden, maar indien het betekenisbereik minder duidelijk is én dit betekenisbereik vrij groot is, ligt dit gevaar wel op de loer. Ongelijkheid zal dan vooral ontstaan door de ongelijkheid bij de controle door toezichthouders, de opsporing door opsporingsambtenaren, de vervolgingsbeslissing van het $\mathrm{OM}$ en bij de beoordeling van een casus door de rechter. Ondanks dat hier geen uitgebreid onderzoek naar is gedaan, valt op dat de zorgplichtbepalingen die veel lijken te worden gebruikt (zoals de artikelen 13 Wbb en 5 WVW) ook (misschien zelfs vooral) worden ingezet bij relatief "lichte" zaken. ${ }^{138}$ Dit soort gedragingen zal zich relatief vaak voordoen. Meestal zal dit echter niet tot gevolg hebben dat justitiabelen hierop worden aangesproken, laat staan dat zij hiervoor worden vervolgd en/ of veroordeeld. ${ }^{139}$

In het kader van de rechtsgelijkheid is het niet enkel van belang dat gelijke gevallen gelijk worden beoordeeld, maar ook dat afwijkende gevallen afwijking rechtvaardigen. Van belang is in dit kader vooral de beoordeling van de verwijtbaarheid van de verdachte. De meeste zorgplichtbepalingen blijken geen subjectief element te bevatten. De strafrechter zal dan involge artikel $350 \mathrm{~Sv}$ de vraag moet beantwoorden of de verdachte strafbaar is. Indien sprake is van een schulduitsluitingsgrond zal hij de verdachte moeten ontslaan van alle rechtsvervolging, tenzij culpa door het $\mathrm{OM}$ is ten laste gelegd. Indien dan sprake is van een schulduitsluitingsgrond zal dit niet kunnen worden bewezen, en zal de verdachte moeten worden vrijgesproken.

De zorgplichtbepalingen in het milieustrafrecht bevatten wel subjectieve bestanddelen. Zij verankeren het schuldbeginsel bij deze bepalingen, en geven enige beperking aan

Zie ook hoofdstuk 6 paragraaf 5.2 .
Zie bijvoorbeeld bij artikel 13 Wbb HR 22 november 1994, MenR, 1995, nr. 50, met noot Hendriks (Motorblok); HR 15 november 1994, MenR, nr. 10-K (Bodemkunstenaar).

139 Overigens hebben zij vaak ook geen idee dat zij strafbare feiten plegen, zodat dit ook op gespannen voet zal staan met de bovengenoemde rechtszekerheid, nu niet voldaan lijkt te zijn aan het lex certa-beginsel. 
het betekenisbereik nu deze bestanddelen ook zullen moeten worden bewezen verklaard wil de rechter tot een eventuele veroordeling kunnen komen. Indien de verdachte wordt vervolgd vanwege het schenden van een dergelijke bepaling levert de overtreding-variant geen bijzondere problemen op. Dit kan niet worden gezegd van de misdrijf-variant. De milieustrafbepalingen zijn immers aangehaakt aan de Wed, zodat involge artikel 2 Wed sprake is van een misdrijf indien het delict opzettelijk is begaan. Hierbij zijn verschillende interpretaties van de reikwijdte van deze opzet-eis mogelijk. Eenduidige interpretatie is in het kader van de rechtsgelijkheid vereist. Aangezien het wenselijk is een duidelijk verschil aan te brengen tussen de overtreding- en de opzetvariant én het strafrechtelijk uitgangspunt in dubio pro reo, is gekozen voor de eerste interpretatiemogelijkheid. Hierbij heeft de opzet-eis op zo veel mogelijk bestanddelen betrekking.

\section{Samenhang \\ 5.1. Inleiding}

$\mathrm{Na}$ de toetsing van zorgplichtbepalingen aan de in hoofdstuk 3 geformuleerde evenredigheid, rechtszekerheid en rechtsgelijkheic (hoofdstuk 10 paragrafen 2, 3 en 4), worden zij in deze paragraaf getoetst aan het vereiste van "samenhang". Dit vereiste heeft in zijn algemeenheid betrekking op de samenhang tussen bepalingen in één rechtsgebied en de samenhang tussen één of meer bepalingen uit één rechisgebied met bepalingen buiten dat rechtsgebied. Het is van belang voor de rechtseenheid, en in die zin ook voor de rechtszekerheid en rechtsgelijkheid dat regels voldoende op elkaar worden afgestemd. Dit wil overigens niet zeggen dat regels, en overeenkomstige termen uit regels, in verschillende rechtsgebieden nooit een andere betekenis kunnen hebben. In deze paragraaf zal vooral worden ingegaan op de samenhang van zorgplichtbepalingen met overige strafbaarstellingen in het systeem van wetgeving, en de al dan niet eenduidige interpretatie van zorgplichtbepalingen.

\subsection{Samenhang binnen het systeem van wetgeving}

Indien gekeken wordt naar de plaats van zorgplichtbepalingen binnen het systeem van wetgeving in formele zin, valt op dat zij vrij willekeurig lijken te zijn ingevoerd. Zo zijn een aanta! zorgplichtbepalingen ingevoerd na een daartoe strekkend amendement. Dit was bij de besproken zorgplichtbepalingen het geval bij artikel 5 Wet Luchtverkeer 1993 en artikel $13 \mathrm{Wbb}$. Ook werd het betekenisbereik van enkele bepalingen zonder uitvoerige discussie vergaand verruimd bij wetsherzieningen. Gewezen kan worden op artikel $5 \mathrm{WVW}$ (dat bij iedere wijziging een ruimer toepassingsgebied kreeg), artikel 19 Quarantainewet (dat aanvankelijk alleen voor schepen gold) en artikel 11 Arbo-wet 1998 (waarvan sinds november 1999 ook het bepaalde in de aanhef is strafbaar gesteld).

Voorts blijkt er nauwelijks sprake van systematiek in het opnemen, of juist niet opnemen van zorgplichtbepalingen. Naast historische redenen is het soms moeilijk 
verklaarbaar waarom in het Wetboek van Strafrecht bepaalde zorgplichtbepalingen wel en andere niet zijn opgenomen. ${ }^{140}$ Zo rijst bijvooibeeld de vraag waarom daarin wel zorgplichtbepalingen staan voor (kort gezegd): het onschadelijk houden van gevaarlijke dieren (artikel 425 aanhef en sub $2 \mathrm{Si}$ ), maar niet voor niet als gevaarlijk bekend staande (huis)dieren; en wel voor degene die in staat van dronkenschap verkeert (artikel 426, eerste lid Sr) maar niet voor degene die onder invloed zijn van andere middelen die het bewustzijn beïnvloeden, zoals opiaten en medicijnen; en wel voor rij-, trek- of lastdieren (artikel 427 aanhef en sub $5 \mathrm{Sr}$ ), maar niet voor andere dieren die zonder toezicht worden achtergelaten op de openbare weg, zoals al dan niet vastgebonden honden; en wel voor bos-, heide-, helm-, gras- of veenbrand (artikel 429 aanhef en sub $3 \mathrm{Sr}$ ) maar niet voor andere branden, bijvoorbeeld van gebouwen of voertuigen.

Dit geidt overigens niet alleen voor de zorgplichtbepalingen in het Wetboek van Strafrecht, ook de vormgeving van bijvoorbeeld artikel 19 Quarantainewet lijkt eerder historisch dan wetstechnisch te zijn bepaald. Dit blijkt niet alleen uit de verschillen in vormgeving van het eerste en derde lid. Het is ook opvallend dat deze bepaling zich wel richt tot de gezagvoerder van een schip en degene die de leiding heeft bij trein- en wegvervoer, maar ontbreekt voor de gezagvoerder van een luchtvaartuig. Ook in het milieurecht blijkt het gebrek aan systematiek duidelijk. Zo is in de algemene zorgplicht uit de overkoepelende milieuwet, artikel 1.1a Wm, niet strafrechtelijk te handhaven. ${ }^{141}$ In de sectorale milieuwetgeving bevat artikel $13 \mathrm{Wbb}$ wel een zorgplichtbepaling, maar ontbreekt deze (zonder overwegingen dienaangaande) in de Wvo en (wordt uitdrukkelijk afgewezen) in de Wet inzake de luchtverontreiniging. Binnen de soortgerichte milieuwetgeving is een dergelijke bepaling wel te vinden in artikel 13, vierde lid (voorheen derde lid) Bestrijdingsmiddelenwet, artikel $2 \mathrm{Wms}$ en artikel $10.3 \mathrm{Wm}$, hoofdstuk Afvalstoffen, maar ontbreekt zij in de meeste andere soortgerichte wetgeving.

Het voorgaande geldt overigens niet alleen voor de wetgeving in formele zin; ook het bestuur onderkent (soms) het voordeel van deze bepalingen en laat ze dan deel uitmaken van besluiten. Of in een besluit zoals een beschikking een dergelijke bepa= ling wordt opgenomen lijkt, wederom, eerder afhankelijk van toeva! dan van beleid.

Well is duidelijk dat de opgenomen zorgplichtbepalingen vaak niet op zichzelf staan, maar deel uitmaken van een systeem van wetgeving. Soms verwijst de bepaling zelf naar uitvoeringsmaatregelen die kunnen worden genomen. Deze uitvoeringsmaatregelen kunnen een nadere specificering vormen van de zorgplichtbepaling. Een voorbeeld van een zorgplichtbepaling die wetstechnisch on deze manier is samengesteld is artikel $13 \mathrm{Wbb}$. Deze bepaling verwijst naar de artikelen 6 tot en met 11 uit dezelfde wet, op basis waarvan bij amvb regels kunnen worden gesteld. In de volgende

Zie hierover hoofdstuk 6.

1.41 Vanwege dit gebrek aan systematiek wordt wel gepleit er hierin een op te nemen, zie bijvoorbeeld Bastmeijer, C.J., "De algemene zorgplicht in de Wet milieubeheer", pp. 466-475. 
paragraaf zal echter blijken dat de Hoge Raad het mogelijk maakt dat artikel 13 Wbb wordt toegepast zonder dat deze amvb's zijn vastgesteld. Nu deze zelfs niet nodig zijn voor de toepassing van de enige van de in de vorige hoofdstukken besproken zorgplichtbepaling die zo duidelijk verwijst naar deze aanvullende criteria, ligt het niet voor de hand dat deze eis wordt gesteld aan zorgplichtbepalingen die hier niet zo expliciet naar verwijzen. Hierdoor wordt de samenhang binnen het systeem van wetgeving gedeeltelijk losgelaten.

\subsection{Samenhang in interpretatie van zorgplichtbepalingen door de rechter}

De strafrechter, bestuursrechter en civiele rechter proberen in het algemeen zo veel mogelijk dezelfde termen of bepalingen op dezelfde manier te interpreteren. ${ }^{142}$ Dit zal naast de vereiste samenhang ook ten goede komen aan andere algemene vereisten van behoorlijke regelgeving, zoals de rechtszekerheid (vooral het door het lex certabeginsel vereiste kenbaarheid) en de rechtsgelijkheid. ${ }^{143}$ Zeker indien onduidelijkheid bestaat over de manier van interpreteren en er zodoende verschillende mogelijkheden openstaan, is dit belangrijk. Het gevolg zou anders zijn dat een zelfde bepaling door verschillen in interpretatie een ander betekenisbereik heeft of krijgt in verschillende casus in één rechtsgebied of tussen één of meer casus in verschillende rechtsgebieden. Bij zorgplichtbepalingen is vooral de (afstemming van de) interpretatie van de strafrechter en de bestuursrechter relevant. Hoewel zij ook civielrechtelijk handhaafbaar zijn, spelen zij in het civielrecht maar een kleine rol. Zorgplichtbepalingen introduceren civielrechtelijk namelijk weinig nieuws, gezien de algernene zorgvuldigheidsnorm uit artikel 6:162 $\mathrm{BW} .^{14}$

De afstemming van de interpretatie door de strafrechter en de bestuursrechter kan worden geillustreerd aan de hand van artikel $13 \mathrm{Wbb}$. Bij dit artikel was het bijvoorbeeld onduidelijk op welke manier de bestanddelen handelingen als bedoeld in de artikelen 6 tot en met 11 , moesten worden geïnterpreteerd. De vraag rees of het nodig is voor het constateren van een schending van artikel $13 \mathrm{Wbb}$ dat op grond van die artikelen uitvoeringsmaatregelen bestaan in de vorm van amvb's die betrekking hebben op de op grond van artikel 13 Wbb ongewenste handelingen waartegen een handhavingsactie wordt ingesteld.

142 Zie hoofdstuk 5 paragrafen 5, 6 en 7 en Faure, M. en Visser, M., De strafrechtelijke bescherming van het leefmilieu in België, Duitsland en Nederland, pp. 85-112; Roos, Th.A. de en Visser M.J.C., "Milieustrafrecht", 70.2.

143 Zie over de toetsing van zorgplichtbepalingen aan rechtszekerheid en rechtsgelijkheid hoofdstuk 10 paragrafen 3 en 4.

144 Zie bijvoorbeeld Bauw, E. "De privaatrechtelijke betekenis van zorgplichten in de milieuwetgeving", pp. 96.102; Acht, R.J.J. van en Bauw, E., Milieuprivaatrecht, pp. 35 68; Bauw, E., Buiten-contrachuele aansprakelijkheid voor bodemverontreiniging, pp. 103-180; Drupsteen, Th.G., "Aansprakelijkheid voor milieuschade", p. 278; Betlem, G. en Messer, E.A., "Aansprakelijkheid voor milieuschade: een reactie", pp. 522-523 die aangeven die erop wijzen dat nu de onrechtmatigheidsgrond niet meer schending van de zorgvuldigheidsnom is maar schending van een wettelijke plicht. 
"dat zolang en voor zover geen uitvoering is gegeven aan de art. 8 tot en met 13 van deze wet de in art. 14 van deze wet neergelegde zorgplicht niet is geconcretiseerd en derhalve niet vast staat ten aanzien van welke handelingen de daarin neergelegde zorgplicht geldt. Dientengevolge heeft deze rechter geoordeeld dat nadere uitvoering van de art. 8 tot en met 13 bepalend is voor de werking van art. 14 van de wet.

Wij stellen vast dat die nadere uitvoering voor het aanbrengen van slib op de grond niet is geschied. (...) Gelet hierop zijn wij van oordeel dat art. 14 van de Wet bodembescherming in dit geval geen betekenis heeft en derhalve niet kan dienen als grondslag voor de in geding zijnde aanschrijving."

De Hoge Raad volgde het betoog van het Hof in de Kabelbrandenzaak niet en besliste dat op basis van artikel 13 de wetgever de mogelijkheid heeft geschapen om reeds in afwachting van amvb's strafrechtelijk te kunnen optreden tegen (kort gezegd) bodembedreigende handelingen ${ }^{150}$, zodat strafrechtelijke sanctionering mogelijk is als er nog geen (bestuurlijke) invulling van de zorgplicht heeft plaatsgevonden. Nu de Hoge Raad op deze manier het mogelijk heeft gemaakt artikel $13 \mathrm{Wbb}$ toe te passen zonder dat sprake is van amvb's, zal het geen verbazing wekken dat controle- en opsporingsinstanties niet staan te springen om nadere regeis op basis van de artikelen 6 tot en met $11 \mathrm{Wbb}$, te meer daar de eisen die worden gesteld aan het bewijs dat sprake is van een schending van artikel $13 \mathrm{Wbb}$ relatief laag zijn. ${ }^{15 !}$

De Afdeling bestuursrechtspraak van de Raad van State volgde deze interpretatie van de Hoge Raad, waarbij zij uitdrukkelijk verwees naar dit arrest en de wetsgeschiedenis van artikel 14 (oud thans 13 ) Wbb. Zij overwoog dat ${ }^{152}$ :

"moet worden aangenomen dat de wetgever met art. 14 van deze wet voor het bevoegd gezag de mogelijkheid heeft geschapen om reeds, in afwachting van de totstandkoming van op de art. 8 $t / m 13$ berustende algemene maatregel van bestuur, met gebruikmaking van hern toekomende administratiefrechtelijke handhavingsinaatregelen te kunnen optreden tegen bodemverontreinigende handelingen."

Zo kwamen de diverse rechterlijke instanties op één lijn. Sinds deze uitspraken is het binnen het strafrecht en het bestuursrecht vaste jurisprudentie dat ook zonder dat er uitvoeringsmaatregelen bestaan op grond van de artikelen 6 tot en met 1! Wbb, op basis van artikel $13 \mathrm{Wbb}$ strafrechtelijk en bestuursrechtelijk ${ }^{153}$ handhavend kan worden opgetreden tegen mogelijke aantastingen of verontreinigingen van de bodem.

schending $13 \mathrm{Wbb}$ ).

HR 26 oktober 1993, NJ 1994, 99; MenR 1994, nr. 22, met noot Tideman (Kabelbranden); zie over dit arrest ook Hendriks, L.E.M, "De Hoge Raad en artikel 14 Wbb", pp. 139-140

151 Zie hierover uitgebreider Faure, M. en Visser, M., De strafrechtelijke bescherming van het leefmilieu in Belgie, Duitsland en Nederland, pp. 358-364.

152. ABR 5 juli 1994, $A B$ 1994, 636, met noot Michiels (Geen amvb, wel schending 13 Wbb). In deze zaak betrof het de rechtmatigheid van de oplegging van dwangsommen.

153 Zie bijvoorbeeld ABR 24 oktober 1995, AB 1996, 357, met noot Backes (Bestuursdwangaanschrijving na niet notariële overdracht). 
Ook de afstemming van de interpretatie binnen het strafrecht kan naast bovenstaand voorbeeld worden geilllustreerd aan de hand van artikel $13 \mathrm{Wbb}$. In bovengenoemde Kabelbrandenzaak werd door de Hoge Raad aangegeven dat "in afwachting van de totstandkoming van op de art. $8 \mathrm{t} / \mathrm{m} 13$ berustende algemene maatregel van bestuur" strafrechtelijk zou kunnen worden opgetreden tegen bodemverontreinigende handelingen. ${ }^{154}$ De vraag deed zich voor hoe wel bestaande amvb's, genomen op grond van de artikelen 6 tot en met $11 \mathrm{Wbb}$, zich verhouden tot artikel $13 \mathrm{Wbb}$. Ook dit leidde tot interpretatieproblemen. Uit de Kabelbranden-uitspraak leek te kunnen worden afgeleid dat de situatie anders zou kunnen liggen indien deze amvb's wel tot stand zouden zijn gekomen. $^{155}$ Lange tijd werd (in lagere jurisprudentie) aangenomen dat een strafbaarstelling op grond van een dergelijke amvb een bijzondere strafbaarstelling is ten opzicht van de algernene zorgplichtbepaling uit artikel $13 \mathrm{Wbb}$. $^{156}$ Hierdoor zou involge artikel 55, tweede lid $\mathrm{Sr}$ alleen de bijzondere strafbaarstelling uit het nitvoeringsbesluit in aanmerking komen. Zo oordeelde het hof Amhem ${ }^{157}$ :

"Ten laste gelegd is primair overtreding van art. $14 \mathrm{Wbb}$. Blijkens de toelichting op dit artikel van de minister (Hand. II, 26 maart 1985, p. 4285) heeft deze te kennen gegeven dat art. 14 slechts een vangnetfunctie heeft en van toepassing is voor zover niet reeds een andere bepaling in strafbaarstelling van de in dit artikel bedoelde verontreiniging of aantasting van de bodem voorziet.

(...) Op dit perceel bouwland waren derhalve de bepalingen van het Besluit gebruik dierlijke meststoffen van toepassing.

Dit besluit verhoudt zich ten opzichte van art. $14 \mathrm{Wbb}$ als een bijzondere tot een algemene strafbepaling in de zin van het tweede lid van art. $55 \mathrm{Sr}$, zodat, nu overtreding van art. $14 \mathrm{Wbb}$ is telastegelegd, verdachte ten aanzien van het primair telastegelegde dient te worden ontslagen van alle rechtsvervolging."

De strafbepalingen uit de amvb's die zijn vastgesteld op grond van de artikelen 6 tot en met $11 \mathrm{Wbb}$ zouden zich, door de verwijzing naar de handelingen uit deze artikelen in artikel $13 \mathrm{Wbb}$, tot artikel $13 \mathrm{Wbb}$ verhouden als een bijzondere tot een algemene strafbepaling in de zin van artikel 55, tweede lid Sr. Het gevolg hiervan was dat indien de amvb's door het bestuur waren vastgesteld, de hierin uitgewerkte gedragingen niet langer via artikel $13 \mathrm{Wbb}$ strafrechtelijk konden worden gehandhaafd. Handhaving van de artikelen 6 tot en met 11 Wbb zou dan de aangewezen weg zijn. Deze interpretatie van de verhouding tussen de uitvoeringsmaatregelen en artike! 13 (voorheen 14) Wbb werd door de Hoge Raad niet gevolgd. De Hoge Raad overwoog ${ }^{158}$ :

\footnotetext{
154 HR. 26 oktober 1993, NJ 1994, 99; MenR 1994, nr. 22, met noot Tideman (Kabelbranden).

155 Zie bijvoorbeeld Hof Amsterdam 7 juni 1994, MenR 1995, nr. 16 (Paardenmest lex specialis $13 \mathrm{Wbb}$ ), waar het hof de beslissing dat artike! ! 4 (nu 13) Wbb op overtreding waarvan de tenlastelegging is gericht buiten toepassing moet blijven, zodat de verweten gedraging geen strafbaar feit oplevert, onder andere motiveert met een verwijzing naar de Kabelbrandenzaak.

156 Zie bijvoorbeeld ook Hof Amsterdam 25 februari 1994, NJ 1994, 382; MenR 1994, nr. 58K (Olielozing op Eikenweg).

157 Hof Amhem 22 april 1991, MenR 1992, nr. 106, met noot Addink (Mest in Epe).

158 HR 17 januari 1995, MenR 1995, nr. 80 (Olielozing op straat).
} 
"5.1. Art. 14 van de Wet bodembescherming, zoals dit luidde tot 15 mei 1994, bepaalde (...).

5.2. Dit artikel is in het wetsontwerp dat heeft geleid tot de Wet op de bodembescherming (...) opgenomen naar aanleiding van een amendement van het Tweede-Kamerlid Lansink. De toelichting daarop (die tevens betrekking had op een in dit verband niet relevant amendement) luidde (...): 'Deze amendementen beogen een algemene zorgplicht in de wet vast te leggen'. Bij de mondelinge behandeling van het wetsontwerp in de Tweede Kamer heeft genoemd Kamerlid nog aangevoerd (...): 'Een vierde punt van kritiek betreft het ontbreken van een algemene zorgplicht Het lijkt mij verstandig nu al een zorgplicht vast te leggen, in aansluiting op de artikelen $8 \mathrm{t} / \mathrm{m} 13$. Ook daartoe heb ik een amendement ingediend.'

5.3. Art. 25 van het krachtens art. 8 Wet bodembescherming gegeven Lozingenbesluit bodembescherming luidt: 'Het is verboden een lozing van overige vloeistoffen in de bodem uit te voeren.'

5.4. De hiervoor onder 5.3. weergegeven strafbepaling omvat derhalve niet dezelfde bestanddelen als de hiervoor onder 5.1. weergegeven strafbepaling, vermeerderd met een of meer andere. Mede in aanmerking genomen hetgeen hiervoor onder 5.2. is overwogen gaat het in art. 14 Wet bodembescherming om het niet voldoen aan de zorgplichtbodemverontreiniging te voorkomen dan wel te beperken dan wel ongedaan te maken, terwijl art. 25 Lozingenbesluit bodembescherming de lozing van bepaalde vloeistoffen in de bodem zelf strafbaar stelt. Er is mitsdien onvoldoende grond om aan te nemen dat de wetgever desondanks tussen die strafbepalingen een verhouding als bedoeld in art. 55 tweede lid Sr heeft gewild."

In deze lin kan ook worden gewezen op het afwijzen van het cassatieberoep van een verdachte dat het Hof het bewezenverklaarde feit ten onrechte had gekwalificeerd als overtreding van artikel $13 \mathrm{Wbb}$, terwijl het feitelijke gebeuren dat daaraan ten grondslag ligt tevens valt onder een bijzondere strafbepaling, namelijk artikel 2 , eerste lid Besluit gebruik dierlijke meststoffen. De Hoge Raad overwoog ${ }^{159}$ :

"Uit het voorgaande blijkt dat artikel 2 eerste lid, Besluit gebruik dierlijke meststoffen niet dezelfde bestanddelen bevat als artikel 14 Wet Bodembescherming, vermeerderd met één of meer andere. Mede in aanmerking genomen (...) gaat artikel 14 Wet Bodembescherming om niet voldoen aan de zorgplicht bodemverontreiniging te voorkomen dan wel te beperken dan wel ongedaan te maken, terwijl artikel 2 eerste lid Besluit gebruik dierlijke meststoffen het gebruik van dierlijke meststoffen in bepaalde hoeveelheden op bepaalde soorten land zelf strafbaar steli. $\mathrm{Er}$ is mitsdien onvoldoende grond om aan te nemen dat de wetgever desondanks tussen die strafbepalingen een verhouding als bedoeld in artikel 55 tweede lid $\mathrm{Sr}$ heeft gewild."

De interpretatie dat de strafbaarstellingen uit de amvb's die zijn vastgesteld op grond van de artikelen 6 tot en met 11 Wbb zich niet snel zullen verhouden als een bijzondere strafbaarstelling tot een algemene in de zin van artikel 55 , tweede lid $\mathrm{Sr}$, is sinds deze uitspraak vaste jurisprudentie. ${ }^{160}$ Derhalve staat het het $\mathrm{OM}$ vrij om bij een schending van een strafbaarstelling uit deze amvb's te kiezen op basis waarvan het de justitiabele wil vervolgen. Het OM kan het schenden van het gestelde bij of krachtens de amvb en/ of het schenden van de zorgplichtbepaling in artikel 13 Wbb ten laste leggen. 
Zoals aangegeven werden in deze paragraaf enkele afsternmingen bij de interpretatie van zorgplichtbepalingen besproken aan de hand van artikel $13 \mathrm{Wbb}$. Artikel $13 \mathrm{Wbb}$ staat in de gemaakte keuzes niet op zichzelf. Wel is dit de enige van de besproken zorgplichtbepalingen die zo duidelijk verwijst naar door het bestuur vast te stellen uitvoeringsbesluiten. Uit het voorgaande bleek dat de werking van artikel $13 \mathrm{Wbb}$ niet afhankelijk is gesteld van het al dan niet bestaan van deze besluiten en zich niet snel zal verhouden tot het strafbaar gestelde schenden van deze besluiten als lex specialis in de zin van artikel 55 , tweede lid Sr.

Ten aanzien van de zorgplichtbepalingen uit de voorgaande hoofdstukken wordt bij de interpretaties niet altijd dezelfde keuze inzake van artikel 55, tweede lid $\mathrm{Sr}$ gemaakt. Het ligt voor de hand om hier een vergelijking te maken met artikel 5 WVW. Niet alleen wordt herhaaldelijk naar dit artikel verwezen bij de totstandkoming van artikel $13 \mathrm{Wbb}$; maar ook maakt artikel $5 \mathrm{WVW}$ deel uit van een systeem van wetgeving waarin veel gedragsvoorschriften worden uitgewerkt in een besluit, te weten het RVV. De toepassingsmogelijkheid van artikel 5 WVW wordt evenals artikel $13 \mathrm{Wbb}$ niet afhankelijk gesteld van het al dan niet in het betreffende besluit opgenomen zijn van een strafbaarstelling. Opvallend is dat ten aanzien van een aantal strafbaarstellingen in het oude RVV werd aangenomen dat deze zich tot artikel 25 WVW (de voorloper van artikel 5 WVW) verhielden als lex specialis in de zin van artikel 55, tweede lid Sr. Dit was het geval indien een bepaling van het RVV voor de strafbaarheid van het feit het bestanddeel gevaar of mogelijk gevaar vereiste. Ten aanzien van strafbaarstellingen in het oude RVV die niet als voorwaarden voor strafbaarheid gevaar of mogelijk gevaar vereisten, prevaleerde involge artikel 55, eerste lid $\mathrm{Sr}$ artikel $25 \mathrm{WVW}$ met zijn hogere strafbedreiging. Dit was ook het geval indien de strafbaarstelling in het RVV niet het (mogelijk) gevaar als voorwaarde voor strafbaarheid vereiste, maar het OM dit gevaar wel ten laste legde en het ter zitting werd bewezen. Ten aanzien van strafbaarstellingen in het nieuwe RVV doet deze vraag zich niet meer voor aangezien bij de herziening van het RVV geen strafbaarstellingen in het RVV meer zijn opgenomen die (mogelijke) gevaar als voorwaarde voor strafbaarheid vereisen. Aangezien er nog wel verschil in maximum strafbedreiging bestaat tussen het schenden van de strafbaarstellingen in het RVV en artikel 5 WVW, zal indien het (mogelijk) gevaar is ten laste gelegd involge artikel 55, eerste lid Sr de zorgplichtbepaling uit artike! 5 WVW van toepassing zijn. Schending van artikel $5 \mathrm{WVW}$ wordt immers met een hogere straf bedreigd dan de schending van de bepaling in het RVV. ${ }^{16 !}$ Dit verschil in strafbedreiging doet zich overigens niet voor bij de Wet bodembescherming nu zowel het schenden van de artikelen 6 tot en met 11 Wbb als 13 Wbb met een zelfde straf worden bedreigd, daar deze artikelen allemaal zijn opgenomen in artike! la sub 1 Wed. Wederom een verschil, nu ook in de systematiek, tussen zorgplichtbepalingen uit verschillende gebieden van, het strafrecht.

161 Zie hierover Remmelink, J., Hoofdwegen door het verkeersrecht, pp. 41-42; Otte, M., Het stelsel van gedragsregels in het wegverkeer, pp. 137-165. 


\subsection{Zorgplichtbepalingen en samenhang}

Indien in het kader van de vereiste samenhang wordt onderzocht of bij zorgplichtbepalingen sprake is van samenhang binnen het systeem van wetgeving, blijkt dat zij niet alleen vrij willekeurig lijken te zijn ingevoerd, maar ook dat er weinig sprake is van systematiek in het al dan niet opnemen van deze bepalingen. Onduidelijk is waarom zij wel gelden voor een bepaald gebied (bijvoorbeeld de bodern) maar niet voor andere gebieden (zoals bijvoorbeeld lucht en water). Ook bij lagere regelgeving lijkt eerder sprake van toeval dan van beleid of zij daarvan deel uitmaken.

Indien wordt onderzocht of sprake is van samenhang in de interpretatie van zorgplichtbepalingen door rechters, blijkt dat de strafrechter en de bestuursrechter zoveel mogelijk proberen dezelfde termen of bepalingen op dezelfde manier te interpieteren. Zeker bij zorgplichtbepalingen is dit van belang. Door het gebruik van vage bestanddelen is het vaak onduidelijk wat het betekenisbereik van deze bepalingen is. Het vaststellen hiervan wordt veelal aan de rechterlijke macht overgelaten. Aanvankelijk ontstaan hierdoor vaak interpretatie verschillen, maar na een uitspraak van een gezaghebbend rechtscollege, blijkt dat deze interpretatie door andere colleges wordt overgenomen waardoor vaste rechtspraak ontstaat. Bij zorgplichtbepalingen uit wetgeving in formele zin is voor het strafrecht vooral de interpretatie van de strafkamer van de Hoge Raad, en in mindere mate die van de Raad van State, van groot belang.

6.

Effectiviteit

\subsection{Inleiding}

Behalve dat regels evenredig moeten zijn, voldoende tegemoet moeten komen aan het vereiste van rechtszekerheid en het vereiste van rechtsgelijkheid en voldoende samenhang moeten vertonen, dienen zij ook uitvoerbaar en handhaafbaar te zijn, aangezien zij anders niet effectief zijn. Hierbij is van belang dat ex ante wordt onderzocht in hoeverre door een bepaling het gestelde doel kan worden verwezenlijkt, en $e x$ post wordt getoetst of dit doel werd bereik.t. Het meten van de effectiviteit van regelgeving blijkt zeer moeilijk te zijn, en vraagt uitgebreid sociaal-wetenschappelijk onderzoek, waarbij rekening moet worden gehouden met de vele factoren die een rol spelen bij het al dan niet bereiken van het beoogde doel. Daarom zal deze paragraaf zich beperken tot de bespreking van enkele factoren die een rol spelen bij de beantwoording van de effectiviteit van zorgplichtbepalingen.

Het gaat hier om de vraag of zorgplichtbepalingen tot het vooropgestelde doel kunnen leiden. Het doel van deze bepalingen kan in zijn algemeenheid ruim worden omschreven $^{162}$; zorgplichtbepalingen zouden een extra algemene normerende werking bewerkstelligen door het vastleggen van de verplichting tot het in acht nemen van de 
maatschappelijke zorgvuldigheid in de specifieke casus. ${ }^{163}$ Hierdoor zouden zij als vangnet kunnen functioneren op het moment dat andere bepalingen niet toepasselijk blijken te zijn. Dit zou een signaalwerking naar de wetgever kunnen hebben om, indien mogelijk, specifiekere normstellingen te maken. Tevens zou van de zorgplichtbepalingen een preventieve werking kunnen uitgaan. Door het opleggen van een zorgplicht ten opzichte van een bepaald beschermd rechtsgoed, lijken zij dit ook daadwerkelijk te kunnen beschermen.

\subsection{Bestuursrechtelijke factoren}

Het invoeren en gebruik van zorgplichtbepalingen lijkt samen te hangen met het disfunctioneren of het ontbreken van de andere strafbaarstellingen die de betreffende rechtsgoederen (indirect) beschermen. ${ }^{164}$ Door de invoering wordt een relatief eenvoudig toepasbaar middel gegeven aan de opsporende en vervolgende instantie ${ }^{165}$, waardoor het erop lijkt dat zorgplichtbepalingen vooral zijn geïncorporeerd om de handhavers te hulp te komen om (bepaalde vormen van) onwenselijk gedrag tegen te gaan, zelfs indien ook specifiekere strafbepalingen hadden kunnen worden gebruikt.

Indien er wel specifieke strafbepalingen aanwezig zijn, blijken deze aan het gebruik van zorgplichtbepalingen vaak niet in de weg te staan. Zo worden zorgplichtbepalingen niet "leeggegeten" door deze bepalingen. Zij blijven daardoor behalve op gedragingen die niet onder het betekenisbereik van deze specifieke bepalingen vallen, ook van toepassing op gedragingen waarop de specifieke bepalingen wel zien. Voorts blijken deze specifieke bepalingen dan meestal niet te worden aangemerkt als lex specialis. ${ }^{166}$ Hierdoor komt het voor dat specifiekere bepalingen, die wellicht hogere eisen stellen aan de legislatieve kennis en de deskundigheid van de betreffende handhaver en aan het noodzakelijke bewijsmateriaal, (ten onrechte) niet worden gebruikt. Om onvolkomenheden in het aanlooptraject en problemen bij de rechter te voorkomen, kan zowel door de wetgever als door het OM de keuze voor zorgplichtbepalingen snel worden gemaakt. ${ }^{167}$ De nadere invulling van de vage bestanddelen uit deze bepalingen wordt door de wetgever voor een groot deel aan de praktijk overgelaten.

163 Zie ook over zorgplichtbepalingen in het milieurecht Lambers, C., De ontbrekende schakel in het milieurecht, pp. 25-27.

164 Zo spelen de artikelen $173 \mathrm{a}$ en $173 \mathrm{~b}$ Sr nauwelijks een rol bij grote milieustrafzaken, zie Berg, E.A.I.M. van den en Eshuis, R.J.J., Grote strafrechtelijke milieuonderzoeken, pp. 87-95.

165 Zie hierover uitgebreider Faure, M. en Visser, M., De strafrechtelijke bescherming van het leefmilieu in Belgiē, Duits!and en Nederland; Faure, M., "Het Nederlandse milieustrafrecht: dringend aan herziening toe!", pp. 3-12 en Faure, M. en Visser, M., "Het tekort van het Nederlandse milieustrafrecht", pp. 123-144.

166 Zie artikel 55, tweede lid Sr.

167 Het OM lijkt dan ook enthousiast over een aantal zorgplichtbepalingen, zie bijvoorbeeld Biezeveld, G.A. en Fransen, A.M., "Zorgplichtbepalingen spelen nuttige rol in milieustrafrecht", p. 64. 
Nochtans moet worden opgemerkt dat de verleende bescherming van het rechtsgoed ook bij het gebruik van zorgplichtbepalingen niet onbeperkt geldt. Andere belangen kunnen hun werking doorkruisen. Dit blijkt bijvoorbeeld uit de relatie tussen de strafrechtelijk afdwingbare zorgplichtbepaling en de besluiten van het bestuur. Zo zal bij handelen conform een vergunning of amvb, dit besluit van het bestuur doorgaans bevrijdend werken ten aanzien van een ten laste gelegde schending van een zorgplichtbepaling. Artikel 10.3, eerste en tweede lid Wm stellen dit als enige van de in de vorige hoofdstukken besproken zorgplichtbepalingen zelfs uitdrukkelijk. Maar ook indien in de zorgplichtbepaling een dergelijke formulering niet is opgenomen, zal het rechtszekerheidsbeginsel dicteren dat degene die schadelijk handelt binnen de grenzen van een besluit, bij vervolging op grond van de zorgplichtbepaling, zich kan beroepen op een strafuitsluitingsgrond. ${ }^{68}$ Daaruit volgt dat het door het bestuur vastgestelde besluit doorgaans een rechtvaardigende werking behoudt.

\subsection{Maatschappelijke factoren}

Er zijn echter ook nadelen verbonden aan het gebruik van (vooral de vaag geformuleerde) zorgplichtbepalingen die van invloed kunnen zijn op de effectiviteit ervan. Op een zeker ogenblik kan de vaagheid zo groot worden dat voor de normadressaat voorafgaande aan zijn gedraging moeilijk vait uit te maken of deze gedraging a! dan niet onder het betekenisbereik van de strafbepaling zaí vallen. Deze onvoorspelbaarheid veroorzaakt niet alleen spanning met het lex certa-vereiste, maar ook de effectiviteit kan hierdoor minder groot zijn dan beoogd. De justitiabele zal zijn gedrag immers moeilijker kunnen afstemmen op vage regelgeving. Voorts wordt de effectiviteit verminderd doordat zij ook van toepassing zijn als er nog geen sprake is van een betrekkelijk uitgekristalliseerd verwachtingspatroon ten aanzien van de inhoud van deze bepalingen. De normerende en preventieve werking die uitgaat van deze bepalingen zal daardoor minder groot zijn dan beoogd. De ontwikkeling van een verwachtingspatroon wordt ook belemmerd doordat er geen sprake is van een eenduidige formulering en doordat de wettelijke formulering van een aantal van deze bepalingen regelmatig aan wijzigingen onderhevig zijn, zoals dat bijvoorbeeld gebeurde bij de artikelen $5 \mathrm{WVW}, 13 \mathrm{Wbb}, 10.3 \mathrm{Wm}$.

Daarnaast kan het gebruik van zorgplichtbepalingen aanleiding geven tot discussies over de precieze betekenis van het voorschrift tussen de controlerende instantie en de potentiële verdachte, tussen de controlerende instantie en het $\mathrm{OM}$, tussen het $\mathrm{OM}$ en de verdachte, tussen het $\mathrm{OM}$, de verdachte en de strafrechter. ${ }^{169}$ Ook dit wordt versterkt door de inconsistente wijze van formuleren en het (herhaaldelijk) wijzigen van de formulering.

Discussies over de vraag of de verdachte in een specifieke zaak de zorgplichtbepaling al dan niet heeft geschonden, zullen behalve in het voortraject ook ter terechtzitting

168 Zie Roos, Th.A. de en Visser, M.J.C., "Milieustrafrecht", 70.2. en hoofdstuk 4 paragraf 6.

169 Zie ook Blomberg, A.B. en Michiels, F.C.M.A., Handhaven met effect, p. 295. 
spelen. Er werd voorspeld dat deze discussies en twijfels tot vrijspraken kunnen leiden, hetgeen de beoogde bescherming van het betreffende rechtsgoed niet ten goede zal komen. ${ }^{170}$ Door de extensieve interpretatie lijkt veeleer het tegenovergestelde het geval, zodat niet vrijspraken, maar juist veroordelingen volgen op dergelijke discussies. Hiermee is niet gezegd dat daarmee ook een daadwerkelijke bescherming van het rechtsgoed wordt bereikt, aangezien door het ontbreken van een duidelijke afgrenzing die maatschappelijk wordt gedragen, het bewustwordingsproces welke gedragingen ongewenst worden geacht minder goed op gang zal komen.

\section{4.}

\section{Bewijsrechtelijke factoren}

Dè schending van de zorgplichtbepaling kan met behulp van alle wettige bewijsmiddelen worden aangetoond. Het is voor het $\mathrm{OM}$, mede omdat het bewijs van schade niet noodzakelijk is, vrij eenvoudig aan te tonen dat een zorgplichtbepaling is geschonden. In het algemeen behoeft het OM slechts aan te tonen dat sprake was van mogelijk gevaar, mogelijke hinder of een mogelijke aantasting. Het OM is voor dit bewijs niet gebonden aan gedetailleerde procedures die bijvoorbeeld beschrijven op welke wijze een schending van een dergelijke bepaling dient te worden bewezen, of an welke eisen bij het vergaren en analyseren van technische bewijsmiddelen zoals monsters moet worden voldaan.

Zo kan het OM ten behoeve van het bewijs van de potentiële gevaarzetting van het beschermde rechtsgoed bijvoorbeeld gebruik maken van (deskundigen)verklaringen. De verklaringen van de verdachte en de agenten speelden bijvoorbeeld een grote rol in de Bodemkunstenaar-zaak ${ }^{171}$, terwijl in de Kabelbrandenzaak de verklaring van een deskundige van groot belang was voor de rechter om tot de overtuiging te komen dat sprake was van schending van de zorgplichtbepaling uit de Wet bodembescherming. ${ }^{172}$ Nu ook bij de bewijsvoering van een tenlastelegging gebaseerd op een zorgplichtbepaling deskundigen een belangrijke rol kunnen spelen, kan worden verwacht dat ook

170 Zie ook Gerritzen-Rode, P.W.A., "Kroniek van het milieurecht", p. I231. Zie echter de reactie van Biezeveld, G.A. en Fransen, A.M., "Zorgplichtbepalingen spelen nuttige rol in milieustrafrecht", p. 64.

171 De politierechter leidde uit de omstandigheden dat de verdachte de stof gebruikte om een metalen voorwerp een oud uiterlijk te geven, dat de stof stonk en de keel van de verbaliserende agent irriteerde en dat de verdachte zelf omstanders had gewaarschuwd niet in een plas met die stof te trappen, omdat die "bijtend" zou zijn af dat de stof verontreinigend was én dat verdachte zich daarvan bewust is geweest. Om welke stof het in deze zaak ging en of er inderdaad schade is toegebracht aan de bodem is niet onderzocht. Hoge Raad 15 november 1994, MenR 1995, nr. 10-K (Bodemkunstenaar), zie over deze zaak hoofdstuk 9 paragraaf 3.3.7.

172 Hij verklaarde ter zitting dat het verbranden van elektriciteitskabels steeds bijzonder schadelijk is voor de bodem vanwege de plastic vezels, maar ook de zware metalen die door dit verbrandingsproces vrijkomen en in het milieu worden verspreid. In deze zaak leidde die verklaring er mede toe dat schending van de zorgplichtbepaling uit de Wbb werd bewezen verklaard. Rb. Amsterdam, 29 maart 1990, NJ 1990, 521; MenR 1990, nr. 58, met noot Fransen (Kabelbranden), zie hierover hoofdstuk 9 paragraaf 3.3.7. 
de verdediging in toenemende mate gebruik zal gaan maken van deskundigen om aan te tonen dat de gedraging van de verdachte niet strafbaar is. Hierdoor kan het voor de rechter, mede vanwege het gebrek aan specifieke wettelijke criteria waaruit hij kan afleiden wanneer sprake is van een schending, lastiger worden vast te stellen of de gedraging strafbaar is. Mede vanwege de extensieve uitleg die wordt gegeven aan de zorgplichtbepalingen levert dit echter tot op heden voor de rechter weinig problemen op.

Zo wordt van artikel $13 \mathrm{Wbb}$, in weerwil van de diverse sceptische opmerkingen bij de totstandkoming, veelvuldig gebruik gemaakt. ${ }^{173}$ De voorspelde bewijsproblemen hebben zich ook hier niet voor gedaan. Het tegenovergestelde lijkt het geval. Door het splitsen van de zorgplichtbepaling in drie afzonderlijke zorgplichten en het niet vereisen van uitvoeringsmaatregelen op basis van artikel 6 tot en met $11 \mathrm{Wbb}$ zijn de meeste bewijsproblemen opgelost. Natuurlijk dienen nog steeds de bestanddelen te worden bewezen, maar door de interpretatie van het artikel is dit nu dusdanig onproblematisch dat het bewijs vaak relatief eenvoudig kan worden geleverd. Het door de minister voorspelde beperkte gebruik van deze bepaling tot "zeer ernstige gevallen" heeft zich in de praktijk dan ook niet gemanifesteerd. Het artikel lijkt in de rechtspraktijk een grote populariteit genieten. Juist door de vage formulering zijn zij in de handen van het OM een dankbaar gebruikt instrument.

\subsection{Zorgplichtbepalingen en effectiviteit}

Zorgplichtbepalingen blijken in het algemeen veelvuldig te worden gebruikt door het OM. Zij lijken zeer goed toepasbaar bij het streven naar de bescherming van het door hen beoogde beschermide rechtsgoed. Mede door hun formulering en de extensieve interpretatie daarvan door de rechterlijke macht, doen zich weinig bewijsrechtelijke problemen voor. Daardoor zijn zij door het OM relatief eenvoudig en effectief in te zetten bij het tegengaan van bepaalde ongewenste gedragingen.

Toch zal de effectiviteit van deze bepalingen minder groot zijn dan op het eerste gezicht het geval lijkt te zijn. Dit wordt ten eerste veroorzaakt door de maatschappelijke factoren die ook van invloed zijn op de effectiviteit. De meeste zorgplichtbepalingen zijn vaag geformuleerd. ${ }^{174}$ De vaagheid van deze strafbaarstellingen heeft tot gevolg dat het voor een justitiabele voorafgaande aan zijn gedraging moeilijk valt uit te maken of hij al dan niet een strafbaar feit pleegt. De onvoorspelbaarheid van het betekenisbereik leidt ertoe dat de effectiviteit minder groot zal zijn dan beoogd. Dit zal nog worden versterkt indien de redactie van de zorgplichtbepaling regelmatig wordt gewijzigd.

De effectiviteit zal nog sterker onder druk komen te staan indien de zorgplichtbepaling niet alleen vage bestanddelen bevat, maar ook een grote reikwijdte heeft. Deze

173 Zie bijvoorbeeld Tonnaer, F.P.C.L., Handboek van het Nederlandse milieurecht, p. 1240.

174 Zie hoofdstuk 10 paragraaf 3.2 . 
combinatie zal tot gevolg hebben dat het OM in de praktijk gelijke gevallen (bijna) niet gelijk kàn behandelen. ${ }^{175}$ Ook dit komt de normbevestigende werking, en daarmee de effectiviteit, niet ten goede. Hierdoor keert uiteindelijk de eenvoudige toepasbaarheid door het $O M$ en de rechter zich tegen de effectiviteit.

Indien sprake is van de combinatie van vaagheid en grote reikwijdte, kunnen bij vermeende schending van deze bepalingen, buiten en binnen de rechiszaal, discussies ontstaan. Er kan bijvoorbeeld onenigheid bestaan over de inhoud van deze bepalingen, de bevoegdheid tot het toepassen van dwangmiddelen en het maatschappelijk belang van de vervolging. ${ }^{176}$ Dit zal wederom de effectiviteit, zeker op de lange ternijn, niet ten goede komen.

\section{Zorgplichtbepalingen en algemene vereisten van behoorlijke regelgeving}

\subsection{Inleiding}

Voorbeelden van zorgplichtbepalingen kunnen zowel in wetgeving in formele als in materiële zin worden gevonden. Daarnaast worden zij door het bestuur gebruikt bij de formulering van besluiten, zoals beschikkingen en amvb's. Bij de toetsing van zorgplichtbepalingen aan de algemene vereisten van behoorlijke regelgeving valt op dat de meeste van deze bepalingen enigszins, en een aantal sterk, op gespannen voet staan met de vereisten die invulling geven aan de waarborgfunctie van regelgeving. Hiermee is niet gezegd dat zij wel tegemoet komen aan de andere functie van regelgeving; te weten regelgeving als instrument. Ook daar blijken problemen aanwezig, die grotendeels dezelfde oorzaak lijken te hebben. In deze paragraaf worden de eerdere bevindingen uit dit hoofdstuk achtereenvolgens besproken. Afgesloten wordt met een korte weergave van de belangrijkste knelpunten. Deze keren terug bij de bespreking van aanbevelingen in hoofdstuk 11.

\subsection{Evenredigheid}

Voor de toetsing aan de evenredigheid is belangrijk dat duidelijk is wat het doel is van de betreffende bepaling. Bij zorgplichtbepalingen is dit meestal cenvoudig te achterhalen aangezien het te beschermen belang in deze bepalingen duidelijk wordt verwoord. Het rechtsgoed lijkt derhalve te worden beschermi door deze bepalingen.

Het is vervolgens van belang na te gaan in hoeverre dit doel wordt behartigd door deze bepaling, waarbij rekening moet worden gehouden met de vraag of de strafbaar gestelde gedraging (potentieel) schadelijk is voor het beschermde rechtsgoed. Er blijken duidelijk verschillen te bestaan tussen de diverse zorgplichtbepalingen met het

175 Zie hoofdstuk 10 paragrafen 4 en 5.

176 Zie ook de bespreking van zorgplichtbepalingen aan de hand van het lex certa-beginsel hoofdstuk 10 paragraaf 3.2 . 
oog op de relatie tussen de gedraging, de vereiste zorgvuldigheid en mogelijke schade. Zorgplichtbepalingen die zijn vormgegeven als concreet gevaarzettingsdelict vereisen dat moet worden bewezen dat sprake is van een door de verdachte verrichte gevaarzettende gedraging ten aanzien van het beschermde rechtsgoed. De relatie tussen de schade en de zorgplichtbepaling is sterk, indien alleen gedragingen zijn strafbaar gesteld die het ontstaan van schade omvatten. ${ }^{177}$ Bij veel zorgplichtbepalingen is de relatie tussen de gedraging en de schade veel losser. Zij vereisen slechts het in gevaar brengen of in gevaar kunnen brengen van een bepaald rechtsgoed. Gezien de gebruikte bestanddelen vereisen zij vaak nauwelijks en soms zelfs geheel niet een gevaarzetting. Meestal is een potentiële gevaarzetting al voldoende. ${ }^{178}$ Daarnaast zijn er zorgplichtbepalingen die in het geheel geen (potentieel) gevolg vereisen, aangezien zij zijn vormgegeven als abstract gevaazzettingsdelict. ${ }^{179}$ Indien de zorgplichtbepalingen vanuit de rechtsgoedbeschermende functie van het strafrecht worden bekeken, zijn voor dit type strafbaarstelling in het algemeen dan ook niet zoveel argumenten aan te voeren.

Voorts is in het kader van de evenredigheid onderzocht in hoeverre voor het nastreven van het doel van de bepaling de regelgeving voldoet aan het subsidiariteitsbeginsel. Zeker bij het formuleren van strafbaarstellingen ten behoeve van de bescherming van rechtsgoederen die geen absolute bescherming genieten, voldoet meestal één alles omvatiende bepating niet. Athankelijk van de rechtspolitieke keuzes inzake de afhankelijkheid van het bestuur en de gradatie van bescherming van het rechtsgoed, dient er te worden gewerkt met een combinatie van soorten strafbaarstellingen. Naast concrete gevaarzettingsdelicten, zijn vaak abstracte gevaarzettingsdelicten noodzakelijk, terwijl ter complementering van het systeem gebruik kan worden gemaakt van zelfstandige delicten. Indien een evenwichtige combinatie van deze strafbaarstellingen wordt bereikt, lijkt het mogelijk een systeem van strafbaarstellingen te ontwikkelen dat voldoende mogelijkheden biedt het te beschermen rechtsgoed daadwerkelijk te beschermen. Het gebruik van zorgplichtbepalingen (met hun specifieke kenmerken) zal in een dergelijk systeem niet (meer) nodig zijn, en kan uit oogpunt van het subsidiariteitsbeginsel achterwege blijven.

Zorgplichtbepalingen kunnen gezien hun specifieke kenmerken worden beschouwd als een apart model, maar zij blijken tevens (afhankelijk van de redactie) tot één van de andere drie modellen te kunnen worden gerekend. Bij bestudering van de vraag op welke manier zij zijn in te passen in deze modellen valt op dat zorgplichtbepalingen een a-typische plaats innemen in het totale systeem van strafbaarstellingen.

De zorgplichtbepalingen die zijn vormgegeven als abstract gevaarzettingsdelict waarbij de strafbare gedragingen in deze bepalingen zèlf zijn te vinden, lijken het best

177 Zie bijvoorbeeld artikel 425 aanhef en sub 2 Sr en 426 , eerste lid Sr.

178 Zie bijvoorbeeld de artikelen 5 WVW, 5 Wet Luchtverkeer, 13 Wbb, 10.3 Wm en 2 Wms.

179 Zie bijvoorbeeld artikel 19, eerste lid sub a, b, c en tweede lid eerste zin Quarantainewet en 11 sub a tot en met f Arbo-wet 1998. 
in het totale systeem van strafbaarstellingen in te passen. Zij stellen een bepaalde gedraging ongeacht het gevolg strafbaar. Deze bepalingen uit wetgeving in formele zin geven (tamelijk duidelijk) aan welke gedragingen worden geîncrimineerd.

Daarnaast zijn er abstracte gevaarzettingsdelicten die gedragingen in strijd met door het bestuur vastgestelde normstellingen strafbaar stellen. De materiële normstelling is dan niet in de bepaling zelf te vinden. In deze gelede normstellingen zijn soms ook (tamelijk vage) zorgplichtbepalingen opgenomen. Het is de vraag of het bestuur als het van de wetgever in formele zin de bevoegdheid heeft gekregen een (uitgebreid) stelsel te ontwikkelen van nadere normstellingen, daarbij gebruik moet maken van zorgplichtbepalingen. Dit klemt te meer indien deze bepalingen vage bestanddelen bevatten.

Bij bestudering van het systeem van strafbaarstellingen blijkt voorts dat zorgplichtbepalingen (bijna) nooit zijn vormgegeven als concrete gevaarzettingsdelicten. Dit type strafbaarstelling vereist niet alleen dat sprake is van een bepaalde wederrechtelijke gedraging, maar tevens dat door deze wederrechtelijke gedraging een bepaald gevolg wordt of kan worden teweeggebracht. Indien de gedraging plaatsvindt conform de bestuurlijke regelgeving, wordt dit type strafbaarstelling niet geschonden vanwege het bestanddeel "wederrechtelijk" of een equivalent daarvan. Het is zeer opvallend dat de zorgplichtbepalingen die een bepaald rechtsgoed beschermen, dat in het totale stelsel juist geen absolute bescherming wordt geboden, niet op deze manier zijn vormgegeven. Zo ontbreekt het bestanddeel "wederrechtelijk" (of een equivalent) in de zorgplichtbepalingen in het milieustrafrecht ${ }^{180}$, terwijl deze bepalingen zien op de bescherming van componenten van het leefmilieu. Deze rechtsgoederen worden doorgaans slechts beschermd indien de schending verder gaat dan de door het bestuur toegestane inbreuk. Dit is bijvoorbeeld de reden geweest om in de "commune milieubepalingen" 173a en 173b Sr het bestanddeel "wederrechtelijk" op te nemen, terwijl die strafbaarstellingen de menselijke gezondheid en het menselijk leven beschermen. ${ }^{181}$ Rechtsgoederen die in het algemeen juist een meer absolute bescherming genieten.

Voorts kan in het totale systeem van strafbaarstellingen gebruik worden gemaakt van zelfstandige delicten. Dit type strafbaarstelling incrimineert zeer ernstige inbreuken op het beschermde rechtsgoed, zelfs als deze plaatsvinden conform de bestuurlijke regelgeving. Het belangrijkste verschil met het tweede soort strafbaarstelling is dat het bestanddeel "wederrechtelijk" ontbreekt. Ten behoeve van de bescherming van het rechtsgoed wordt de "administratieve afhankelijkheid" in beginsel ${ }^{182}$ doorbroken. Hierdoor wordt een meer zelfstandige strafrechtelijke bescherming verleend. Bij dit

180 Afhankelijk van de interpretatie kan artike! 10.3, eerste en tweede lid Wm zijn aan te merken als een concreet gevaarzettingsdelict. Zie hoofdstuk 4 paragraaf 6.

181 Zie over wederrechtelijkheid en 173a en 173b. Sr onder andere TK 1984-1985, 19 020, nr. 3, p. 13; Faure, M. en. Visser., De strafrechtelijke bescherming van het leefmilieu in Belgiê, Duitsland en Nederland, pp. 236-237; Koopmans, I.M., De strafbaarstelling van miliewverontreiniging, pp. 37-38; Waling, C., Het materiële milieustrafrecht, pp. 53-57.

182 In beginsel, omdat de bestuurlijke voorbeslissing natuurlijk wel een rol blijft spelen bij de beslissing of al dan niet sprake is van een strafuitsluitingsgrond. 
type strafbaarstellingen wordt meestal gekozen om als beschermd rechtsgoed de menselijke gezondheid of het menselijk leven aan te merken.

Opvallend is dat de meeste zorgplichtbepalingen als zelfstandig delict zijn vormgegeven. Dit valt op omdat er geen ernstige inbreuken op de verschillende rechtsgoederen noodzakelijk zijn, wil er sprake zijn van schending van de zorgplichtbepaling. Voorts betreft het doorgaans gedragingen die veelvuldig voorkomen, en wel op gebieden waarop door het bestuur wordt bepaald wat voor soort inbreuken op de beschermde rechtsgoederen zijn toegestaan en in welke mate. In het strafrecht is het dan, met oog op het specificeren en beperken van het betekenisbereik van de strafbaarstelling, gebruikelijk de strafrechtelijke aansprakelijkheid te beperken tot die gevallen waarin sprake is van een wederrechtelijke schending van het beschermde rechtsgoed, tenzij dit rechtsgoed zo beschermenswaardig wordt geacht dat de wetgever ervoor kiest dat daarop in beginsel geen inbreuken mogen worden gemaakt. Naast het menselijk leven en de menselijke gezondheid (die zelfs niet altijd deze graad van bescherming krijgen), kan ook aan andere rechtsgoederen dit vergaande beschermingsniveau worden geboden. Of dit gebeurt is veeleer een rechtspolitieke keuze. Bij zorgplichtbepalingen lijkt echter geenszins sprake van een dergelijke principiële keuze om deze bescherming te verlenen aan andere rechtsgoederen dan het menselijk leven of de menselijke gezondheid. Dit is des te opvallender indien door deze zorgplichtbepalingen rechtsgoederen worden beschermd waarop bepaalde inbreuken door het bestuur worden toegestaan.

Indien toch de keuze wordt gemaakt voor het gebruik van zorgplichtbepalingen rijst de vraag naar de proportionaliteit, waarvoor wordt onderzocht of de gehanteerde indeling en de maximum strafbedreiging evenredig zijn met de strafbaar gestelde gedraging. Het strafrecht kan bij zorgplichtbepalingen in een zeer vroeg stadium bescherming bieden aan het beschermde rechtsgoed aangezien een krenking of daadwerkelijk in gevaar brengen vaak niet wordt geëist. Zorgplichtbepalingen blijken zowel te worden ingedeeld als "beboetbaar feit" ${ }^{\text {"183 }}$, als overtreding ${ }^{184}$ en als overtreding of misdrijf. ${ }^{185}$ Opvallend hierbij is dat de zorgplichtbepalingen in het milieustrafrecht zijn aangehaakt aan de Wed via artikel la sub I Wed. Voor het opnemen in deze categorie is het criterium gehanteerd "dat het moet gaan om feiten die een directe aantasting opleveren van het milieu, dan wel daarvoor een ernstige en rechtstreekse bedreiging vormen" ${ }^{186}$ Hiervan behoeft bij zorgplichtbepalingen geen sprake te zijn. Ten gevolge van deze indeling kunnen zij "voor zover zij opzettelijk zijn begaan" involge artike! 2 Wed worden angemerkt als misdrijf. De keuze voor deze indeling lijkt hierdoor niet te voldoen aan het proportionaliteitsbeginsel. Dit geldt eveneens voor de beoordeling van

is3 Zie bijvoorbeeld artikel 11 Arbo-wet 1998.

184. Zie bijvoorbeeld artikel 425 aanhef en sub 2, artikel 426, eerste lid, artikel 427 aanhef en sub. I en 5 en artikel 429 aanhef en sub $3 \mathrm{Sr}$, artikel 5 WVW, artikel 5 Wet Luchtverkeer en artikel 19 Quarantainewet.

185 Zie bijvoorbeeld de artikelen $13 \mathrm{Wbb}, 10.3 \mathrm{Wm}$ en $2 \mathrm{Wms}$, waarbij het onderscheid tussen overtreding en misdrijf afhankelijk is gesteld van de vraag of sprake is van opzet in de zin van artikel 2 Wed.

186 Zie TK 1992-1993, 23 196, nr. 3, pp. 5 en 13. 
de maximum strafbedreiging. Ook hier vormen de zorgplichtbepalingen in het milieustrafrecht een uitzondering. Schending van deze bepalingen wordt, in tegenstelling tot de schending van de meeste andere zorgplichtbepalingen, bedreigd met zeer zware sancties.

\subsection{Rechtszekerheid}

Voor de toetsing aan de rechtszekerheid is het in het kader van de beoordeling van zorgplichtbepalingen vooral van belang na te gaan in hoeverre zij voldoen aan het lex certa-beginsel. Involge artikel $1 \mathrm{Sr}$ is de tekst van de strafbaarstelling zelf maatgevend voor de beantwoording van de vraag of de justitiabele hieruit voorafgaande aan zijn handelen kan weten of zijn gedraging al dan niet onder de delictsomschrijving valt.

Hoewel de grens moeilijk blijkt te trekken tussen bepalingen die hier wel en die hier niet aan voldoen, is duidelijk dat het bij enkele zorgplichtbepalingen zeer moeilijk is vast te stellen welke gedragingen hier wel en welke hier niet onder vallen. Zeker die zorgplichtbepalingen die alleen in algemene termen een gevaarlijke of ongewenste gedraging aanduiden, een bepaalde graad van zorgvuldigheid vereisen, het treffen van niet nader aangeduide voorzorgsmaatregelen of schadebeperkende maatregelen vereisen, zijn zeer vaag geformuleerd. Indien uit de overige bestanddelen ook geen beperking van het betekenisbereik voortvloeit, geen daadwerkelijke schade of gevolg wordt vereist en zij zich richten tot een grote groep van normadressaten (een ieder) kan worden gezegd dat zij in strijd zijn met het lex certa-beginsel.

Dit geldt nog sterker nu ook de rechter deze bepalingen niet restrictief interpreteert en maar zeer beperkt aanvullende criteria formuleert. Hierbij spant artikel 5 WVW de kroon, maar niet veel beter zijn de artikelen 5 Wet Luchtverkeer, 13 Wbb, 2 Wms en $10.3 \mathrm{Wm}$. De zorgplichtbepalingen in het Wetboek van Strafrecht bevatten meer bestanddelen die het betekenisbereik van het strafbare feit specificeren, en staan daarom minder op gespannen voet met het lex certa-beginsel dan de hiervoor genoemde bepalingen.

Artikel 19, eerste en derde lid Quarantainewet zijn vormgegeven als abstracte gevaarzettingsdelicten. Zij bevatten als voorwaarde geen beperking in het betekenisbereik door het stellen van een bepaald gevolg dat (potentieel) moet worden veroorzaakt door de strafbaar gestelde gedraging. Deze zorgplichtbepalingen komen niet snel in strijd met het lex certa-beginsel, omdat de strafbare gedragingen hierin vrij specifiek zijn weergegeven, èn zij zich richten tot een specifieke groep normadressaten.

Meer specifiek zijn de zorgplichtbepalinger uit artikel 11 Arbo-wet 1998. Niet alleen zijn hier de strafbaar gestelde gedragingen (met uitzondering van de aanhef) vrij specifiek weergegeven, maar ook de kring van normadressaten is aangepast, omdat dit artikel zich slechts richt tot de "werknemer" die verplicht is "in verband met de arbeid". Doordat dit artikel (afhankelijk van de viteindelijk gekozen interpretatie waarschijnlijk) is aan te merken als concreet gevaarzettingsdelict, geldt bovendien als voorwaarde voor strafbaarheid dat de gedraging een bepaald (potentieel) gevolg moet 
hebben teweeggebracht. De strafbaarstelling van de aanhef in november 1999 heeft mogelijk tot gevolg dat ook niet opgesomde gedragingen onder het betekenisbereik van deze strafbaarstelling kunnen vallen. De wel opgesomde gedragingen uit a tot en met $f$ zullen hierbij als richtsnoer werken, omdat het de niet opgenomen gedragingen tegen een bepaalde achtergrond plaatst. Indien de rechter hiermee rekening houdt, zal deze bepaling niet snel in strijd zijn met het lex certa-beginsel.

\section{4 .}

\section{Rechtsgelijkheid}

In het kader van de toetsing van zorgplichtbepalingen aan de rechtsgelijkheid valt op dat de meeste veel vage bestanddelen bevatten. Dit behoeft niet per definitie tot rechtsongelijkheid te leiden, maar indien het betekenisbereik minder duidelijk is én dit betekenisbereik vrij groot is ligt dit gevaar wel op de loer. Ongelijkheid zal dan vooral ontstaan door de ongelijkheid bij de vervolgingsbeslissing van het $\mathrm{OM}$ en bij de beoordeling ervan dooi de rechter. Ondanks dat hier geen uitgebreid onderzoek naar is gedaan, valt op dat de zorgplichtbepalingen die veel lijken te worden gebruikt ook worden ingezet bij relatief "lichte" zaken. ${ }^{187}$ Soortgelijke gedragingen worden vaak verricht, zonder dat deze personen hierop worden aangesproken, laat staan vervolgd $\mathrm{en} /$ of veroordeeld zullen worden. ${ }^{188}$

In het kader van de rechtsgelijkheid is het niet enkel van belang dat gelijke gevallen, gelijk worden beoordeeld, maar ook dat afwijkende gevallen afwijking rechtvaardigen. Van belang is in dit kader vooral de beoordeling van de verwijtbaarheid van de verdachte. De meeste zorgplichtbepalingen blijken geen subjectief element te bevatten. Aangezien het $\mathrm{OM}$ daarom meestal zal afzien van het ten laste leggen van een subjectieve gesteldheid van de verdachte, behoeft dit ook niet te worden bewezen verklaard. De rechter zal de verwijtbaarheid onderzoeken in het kader van de derde (en niet de eerste) vraag uit artikel $350 \mathrm{~Sv}$.

De zorgplichtbepalingen in het milieustrafrecht bevatten, in tegenstelling tot de besproken zorgplichtbepalingen uit de andere gebieden van het strafrecht, wel subjectieve bestanddelen. Zij verankeren het schuldbeginsel bij deze bepalingen, en geven enige beperking aan het betekenisbereik nu deze bestanddelen ook zullen moeten worden bewezen verklaard wil de rechter tot een eventuele veroordeling kunnen komen. Indien de verdachte wordt vervolgd vanwege het schenden van een dergelijke bepaling levert de overtreding-variant geen bijzondere problemen op. Dit kan niet worden gezegd van de misdrijf-variant. De milieustrafbepalingen zijn immers aangehaakt aan de Wed, zodat involge artikel 2 Wed sprake is van een misdrijf indien het delict opzettelijk is begaan. Hierbij zijn verschillende interpretaties van de reikwijdte

187 Denk aan artikel 5 WVW en artikel 13 Wbb. Zie bijvoorbeeld bij HR 22 november 1994, MenR, 1995, nr. 50, met noot Hendriks (Motorblok); HR 15 november 1994, MenR, nr. 10-K (Bodemkunstenaar).

is8 Overigens hebben zij vaak ook geen idee dat zij strafbare feiten plegen, zodat dit ook op gespannen voet zal staan met de bovengenoemde rechtszekerheid, nu niet voldaan lijkt te zijn aan het lex certa-beginsel. 
van deze opzet-eis mogelijk. Eenduidige interpretatie is in het kader van de rechtsgelijkheid vereist. Aangezien het wenselijk is duidelijk verschil aan te brengen tussen de overtreding- en de opzet-variant en om tegemoet te komen aan het strafrechtelijk uitgangspunt in dubio pro reo, is gekozen voor de (eerste) interpretatie waarbij de opzet-eis op zo veel mogelijk bestanddelen betrekking heeft.

\section{5 .}

\section{Samenhang}

Indien in het kader van de vereiste samenhang wordt onderzocht of bij zorgplichtbepalingen sprake is van samenhang binnen het systeem van wetgeving, blijkt dat zij niet alleen vrij willekeurig lijken te zijn ingevoerd, maar ook dat er weinig sprake is van systematiek in het al dan niet opnemen van deze bepalingen. Onduidelijk is waarom zij wel gelden voor een bepaald gebied (bijvoorbeeld de bodem) maar niet voor andere gebieden (zoals bijvoorbeeld lucht en water). Ook bij lagere regelgeving lijkt eerder sprake van toeval dan van beleid of zij deel uitmaken van een bepaald besluit.

Indien wordt onderzocht of sprake is van samenhang in de interpretatie van zorgplichtbepalingen door rechters, blijkt dat de strafrechter en de bestuursrechter zoveel mogelijk proberen dezelfde termen of bepalingen op dezelfde manier te interpreteren. Zeker bij zorgplichtbepalingen is dit van belang. Door het gebruik van vage bestanddelen is het vaak onduidelijk wat het betekenisbereik van deze bepalingen is. Het vaststellen hiervan wordt veelal aan de rechterlijke macht overgelaten. Aanvankelijk ontstaan hierdoor vaak interpretatieverschillen, maar na een uitspraak van een gezaghebbend rechtscollege, blijkt dat deze interpretatie door andere colleges wordt overgenomen waardoor vaste rechtspraak ontstaat. $\mathrm{Bij}$ zorgplichtbepalingen uit wetgeving in formele zin is voor het strafrecht vooral de interpretatie van de strafkamer van de Hoge Raad, en in mindere mate die van de Raad van State, van groot belang.

Hoewel gelijkluidende interpretatie binnen de diverse rechtsgebieden van groot belang is, wil dit niet zeggen dat hierop geen uitzonderingen zouden zijn toegestaan. Zeker indien blijkt dat zorgplichtbepalingen onrechtmatig zijn, dient de strafrechter zijn eigen weg te gaan. Dit is ook het geval indien hij daardoor in afwijking van het bestuur of de bestuursrechter oordeelt. Het vasthouden aan eenheid mag er immers nooit toe leiden dat een justitiabele wordt veroordeeld op basis van onrechtmatige regelgeving.

7.6.

\section{Effectiviteit}

Indien wordt gekeken naar enkele belangrijke factoren die van invloed zijn op de effectiviteit valt op, dat deze bepalingen zeer goed toepasbaar blijken bij het streven naar de bescherming van het desbetreffende rechtsgoed. Mede door hun formulering en de extensieve interpretatie daarvan door de rechterlijke macht, doen zich weinig bewijsrechtelijke problemen voor. Meestal ontbreken gedetailleerde procedures die beschrijven op welke wijze een (potentiële) schending van het betreffende rechtsgoed dient te worden bewezen. Opmerkelijk is dat dit vaak niet het geval is voor andere 
strafbaarstellingen uit de betreffende wettelijke regeling. Hierdoor heeft de zorgplichtbepaling niet alleen ten aanzien van de gedraging maar ook bewijstechnisch ten aanzien van het gevolg van die gedraging een "vangnetfunctie". Zij zijn daarom relatief eenvoudig en effectief inzetbaar voor het tegengaan van bepaalde ongewenste gedragingen

Het is dan ook niet verwonderlijk dat zorgplichtbepalingen in het algemeen veelvuldig worden gebruikt door het $\mathrm{OM}$. Toch zal de effectiviteit van deze bepalingen minder zijn dan op het eerste gezicht het geval lijkt te zijn. Dit wordt ten eerste veroorzaakt door de maatschappelijke factoren die ook van invloed zijn op de effectiviteit. De meeste zorgplichtbepalingen zijn vaag geformuleerd. De vaagheid van deze strafbaarstellingen heeft tot gevolg dat het voor een justitiabele voorafgaande aan zijn gedraging moeilijk valt uit te maken of hij al dan niet een strafbaar feit pleegt. De onvoorspelbaarheid van het betekenisbereik leidt ertoe dat de effectiviteit minder groot zal zijn dan beoogd. Dit zal nog worden versterkt indien de redactie van de zorgplichtbepaling regelmatig wordt gewijzigd.

De effectiviteit zal nog sterker onder druk komen te staan indien de zorgplichtbepaling niet alleen vage bestanddelen bevat, maar ook een grote reikwijdte heeft. Deze combinatie zal tot gevolg hebben dat het $\mathrm{OM}$ gelijke gevallen niet gelijk kàn behandelen. Ook dit komt de normbevestigende werking, en daarmee de effectiviteit, niet ten goede. Hierdoor keert uiteindelijk de eenvoudige toepasbaarheid door het $\mathrm{OM}$ en de rechter zich tegen de effectiviteit.

Indien sprake is van de combinatie vaagheid en grote reikwijdte, zullen bij vermeende schending van deze bepalingen, buiten en binnen de rechtszaal, discussies (kunnen) ontstaan. Er kan bijvoorbeeld onenigheid bestaan over de inhoud van deze bepalingen, de bevoegdheid tot het toepassen van dwangmiddelen en het maatschappelijk belang van de vervolging. Dit zal wederom de effectiviteit, zeker op de lange termijn, niet ten goede komen.

\subsection{Zorgplichbepalingen en algemene vereisten van behoorlijke regelgeving}

Bij de beoordeling van zorgplichtbepalingen aan de algemene vereisten van behoorlijke regelgeving valt op dat de meeste van deze bepalingen enigszins, en een aantal sterk, op gespannen voet staan met de vereisten die invulling geven aan de waarborgfunctie van regelgeving. Bij de beoordeling blijkt dat $z i j$ in het algemeen niet tegemoetkomen aan zowel het vereiste van evenredigheid, rechtszekerheid, rechtsgelijkheid als samenhang.

Deze spanning is overigens niet voor alle zorgplichtbepalingen even groot. De meeste problemen doen zich voor met zorgplichtbepalingen die vage bestanddelen bevatten, zoals artikel 5 WVW, artike! 5 Wet Luchtverkeer en de zorgplichtbepalingen in het milieustrafrecht. Deze laatste worden ook nog eens gekenmerkt door hoge maximum strafbedreigingen, waardoor zij ook met andere vereisten op gespannen voet staan. 
De zorgplichtbepalingen waarbij de spanning met de vereisten die invulling geven aan de waarborgfunctie van regelgeving het grootst is, blijken ook het meest op gespannen voet te staan met de vereisten die invulling geven aan de andere functie van regelgeving; te weten regelgeving als instrument.

Doordat zij maar in geringe mate tegemoetkomen aan de waarborgfunctie, lijken zij op het eerste gezicht juist een gemakkelijk te hanteren instrument. Hoewel dit zeker bij de bestrijding van bepaalde ongewenste gedragingen het geval zal zijn, wil dit niet zeggen dat zij uiteindelijk daadwerkelijk effectief zijn. Dit wordt grotendeels veroorzaakt door dezelfde kenmerken die maken dat zij niet voldoende tegemoet komen aan de waarborgfunctie. De zorgplichtbepalingen die vage bestanddelen bevatten en een grote reikwijdte hebben, lijken minder goed te passen in het totale systeem van strafbaarstellingen en missen voldoende normbevestigende werking, hetgeen de effectiviteit niet ten goede komt. 



\section{Zorgplichtbepalingen in het strafrecht}

\section{Inleiding}

In dit boek is verslag gedaan van een onderzoek naar zorgplichtbepalingen in het Nederlandse strafrecht. Het betreft die zargplichtbepalingen die een vrij algemeen geformuleerde (zorg)verplichting bevatten, die een bepaalde verantwoordelijkheid van de normadressaat markeren en die strafrechtelijk kunnen worden gehandhaafd. Deze bepalingen bevatten een algemene verplichting tot het in acht nemen van een bepaalde graad van zorgvuldigheid met het oog op het door de desbetreffende wet te beschermen belang. Het onderzoek had betrekking op de vraag wie het betekenisbereik van zorgplichtbepalingen en dus de grenzen van de strafrechtelijke aansprakelijkheid vaststelt, op welke manier dat gebeurt, welke knelpunten hierdoor (kunnen) ontstaan en hoe deze (ten dele) kunnen worden opgelost. Dit laatste onderdeel van het onderzoek wordt in dit hoofdstuk gepresenteerd.

\section{Historische verschuiving}

Hoewel het gebruik van zorgplichtbepalingen in de literatuur tot veel discussie heeft geleid, is er duidelijk sprake van het opnemen van steeds meer zorgplichtbepalingen. Dit. blijkt vooral het geval te zijn in het (relatief jonge) milieustrafrecht. Ook de reeds bestaande zorgplichtbepalingen in het bijzonder, economisch en milieustrafrecht blijken geen rustig bestaan beschoren. De redactie, de indeling en/ of de maximum strafbedreiging van de meeste van deze bepalingen zijn recentelijk gewijzigd. Steeds vaker lijken de wetgever, het bestuur en het $\mathrm{OM}$ de mogelijkheid te creëren of bereid te zijn om met behulp van dergelijke bepalingen vermeende misstanden strafrechtelijk aan te pakken.

Het in het strafrecht inzetten van steeds grovere middelen ter bescherming van een bepaald rechtsgoed ten koste van de rechtsbescherming van justitiabelen, is bepaaid niet alleen te zien op het gebied van de invoering en het gebruik van zorgplichtbepalingen. Ook door andere tendensen lijkt er sprake van een verschuiving van wetgeving als waarborgfunctie naar wetgeving als instrument. Het is echter de vraag of men door minder tegemoet te komen aan de waarborgfunctie, uiteindelijk de instrumentele functie wel dient.

Toch lijkt het streven van zowel de wetgever als het bestuur naar het ontwikkelen en inzetten van steeds makkelijker, vaker en effectiever toepasbare en steeds meer verschillende juridische instrumenten onmiskenbaar. Dit geldt zowel voor het 
materiêle (straf)recht, als voor het formele (strafproces)recht. ${ }^{1}$ Dit uit zich niet alleen door de introductie van nieuwe en de uitbreiding van het betekenisbereik van reeds bestaande zorgplichtbepalingen, maar ook door de verruiming van toezicht- en opsporingsmogelijkheden.

Deze tendens is overigens niet alleen aanwezig in het strafrecht, maar juist ook in het bestuursrecht, dat van oudsher mede ten gevolge van het sterke ordeningskarakter van dit rechtsgebied toch al wordt gekenmerkt door een veel instrumenteler benadering dan het strafrecht. Deze ontwikkeling blijkt duidelijk uit de overheveling die in gang is gezet van punitieve handhavingsmogelijkheden van het strafrecht naar het bestuursrecht. Ook voor een aantal zorgplichtbepalingen heeft deze verschuiving al plaatsgevonden.

Voor deze overheveling zijn diverse oorzaken en redenen aan te geven. $\mathrm{Zij}$ gaan verder dan het al dan niet terechte oordeel dat sprake zou zijn van een handhavingstekort binnen het strafrecht èn de steeds verdergaande ordening en daarmee gepaard. gaande juridisering van de samenleving. ${ }^{2}$ Dit uit zich natuurlijk niet alleen op nationaal niveau. Juist niet, de toenemende uitbreiding en invloed van Europese en internationale regelgeving werkt niet alleen deze overheveling, maar ook de toenemende juridisering en instrumentalisering, in de hand. Dit uit zich bijvoorbeeld in de instelling van steeds meer gespecialiseerde toezichthoudende en inspecterende instanties, zoals de NMA (Nederlandse Mededingings Autoriteit), de STE (Stichting Toezicht Effectenverkeer) en de OPTA (Onafhankelijke Post en Telecommunicatie Autoriteit). Daarnaast is er sprake van een takkverschuiving binnen de bestaande instanties van informerend en controlerend naar handhavend en sanctionerend. Dit speelt niet alleen bij de al langer bestaande diensten zoals de Arbeidsinspectie en de Scheepvaartinspectie, maar ook bij bovenstaande relatief jonge instellingen.

Hierdoor beschikt het bestuursrecht over steeds meer en op steeds grotere schaal inzetbare "opsporings"- en "sanctionerende" bevoegdheden voor de handhaving van de al maar uitdijende wet- en regelgeving op vele specifieke gebieden. Denk. bijvoorbeeld aan de (dwang)bevoegdheden van toezichthouders op basis van hoofdstuk $5 \mathrm{Awb}$, zoals het betreden van plaatsen, het vorderen van inlichtingen, het inzagerecht in zakelijke gegevens en het onderzoeksrecht van zaken en vervoers. middelen waaraan een ieder verplicht is mee te werken. Ook de invoering van de bestuurlijke ophouding is een voorbeeld van deze ontwikkeling. Dat tevens het aantal

1 Zie over deze ontwikkeling onder andere Brouwer, D.A.V., Dwangmiddelen in bijzondere wetten; Facetten van strafrechtspleging. Brouwer, D.A.V., "Het verkennend onderzoek in strafzaken en de wetgevingsspiraal", pp. 637-640.

2 Zie over de ontwikkelingen van wetgeving en wetgevingsbeleid hoofdstuk, 3 paragraf 2 , en over de toenemende juridisering bijvoorbeeld Werkgroep terugdringing van de juridisering van het openbaar bestuur (onder voorzitterschap van J.A. van Kemenade), Bestuar in geding.

3 Dit werd mogelijk door de "Wet van 25 april 2000 tot wijziging van de Gemeentewet ter. verbetering van de mogelijkheden tot bestrijding van grootschalige verstoringen van de openbare orde van de artikelen Gemeentewet", Stb. 2000, 174. Zie hierover Brouwer, 
reactiemogelijkheden van het bestuur op door hem als ongewenst beoordeelde situaties toeneemt, blijkt ook uit de (verder gaande) invoering en/ of opgerekte uitvoering van bestuursdwang, de dwangsom ${ }^{4}$, de bestuurlijke boete en de bestuurlijke transactie.

Opgemerkt moet worden dat de meeste nieuwe bestuursrechtelijke instrumenten en handhavingsmogelijkheden naast de reeds bestaande strafrechtelijke komen. Daarnaast zijn er die ervoor in de plaats komen. Deze ontwikkeling is ten dele onafwendbaar en een teken van deze tijd. Er dient echter voor te worden gewaakt dat de nieuwe instrumenten en bevoegdheden voldoende tegemoet komen an de specifieke kenmerken van de verschillende rechtsgebieden en handhavingsdiensten, en de algemene vereisten van behoorlijke regelgeving, zodat de waarborgfunctie en de instrumentele functie in evenwicht blijven.

\section{Knelpunten en aanbevelingen}

\subsection{Inleiding}

Ongeacht of zorgplichtbepalingen zijn opgenomen in wetgeving in formele dan wel in materiële zin, zij dienen altijd voldoende tegemoet te komen aan de, in hoofdstuk 3 gedefinieerde en uitgewerkte, algemene vereisten van behoorlijke regelgeving. Een belangrijke taak is in dit opzicht weggelegd voor de instantie die de zorgplichtbepaling vaststelt, maar ook het bestuur en de rechter dienen bij de invulling van deze bepalingen zoveel mogelijk tegemoet te komen aan deze vereisten. Immers, zowel de wetgever, het bestuur en de rechter kunnen invloed hebben op de vaststelling van de grenzen van het betekenisbereik van de bepaling, aangezien zij een rol (kumnen) spelen bij het vaststellen van de grenzen van de strafrechtelijke aansprakelijkheid.

De vereisten waaraan zoveel mogelijk moet zijn voldaan wil regelgeving behoorlijk zijn, zijn de vereisten van evenredigheid, rechtszekerheid, rechtsgelijkheid, samenhang en effectiviteit. Bij de toetsing van de in de hoofdstukken 6, 7, 8 en 9 geanalyseerde zorgplichtbepalingen aan deze vereisten valt op dat de meeste van deze bepalingen hiermee enigszins en een aantal hiermee sterk op gespannen voet staan. Dit geldt niet alleen voor de vereisten die invulling geven aan de waarborgfunctie van regelgeving, maar ook voor de vereisten die invulling geven aan de functie van regelgeving als instrument. In deze paragraaf $\mathrm{zal}$, in aansluiting bij hoofdstuk 10 , kort worden

J.G. en Schilder, A.E., "Het wetsvoorstel bestuurlijke ophouding; Een verkenning van de rechtsstatelijke grenzen", pp. 1640-1648.

4 Bestuursdwang en de dwangsom zijn wettelijk geregeld als reacties op overtredingen bij of krachtens de wet gestelde voorschriften. Bestuursdwang kan in de praktijk ook worden aangezegd indien er klaarblijkelijk gevaar is van overtreding, zie AR 1 februari 1985, AB 1985, 587, met noot Van Buuren (Natuurgebied Swalmen) en ook de preventieve dwangsom lijkt onder stringente voorwaarden (zoals dreigende emstige schade) tot de mogelijkheden te behoren, zie AB 4 september 1997, $A B$ 1997, 396, met noot Michiels (Verwijderen reclameborden Geleen). Zie hierover Buuren, P.J.J. van, Jurgens, G.T.J.M. en Michiels, F.C.M.A., Bestuursdwang en dwangsom, met name pp. 14-17. 
aangegeven wat de belangrijkste knelpunten zijn, waarna aanbevelingen worden geformuleerd om deze knelpunten zoveel mogelijk weg te nemen. Hierbij wordt ook ingegaan op de in de hoofdstukken 4 en 5 gesignaleerde problemen. Ten behoeve van de inzichtelijkheid wordt in deze paragraaf bij de bespreking van knelpunten de volgorde aangehouden die is gehanteerd bij de bespreking van de vereisten in hoofdstuk 3 en de toetsing van zorgplichtbepalingen aan deze vereisten in hoofdstuk 10.

\subsection{Evenredigheid: bescherming van het rechtsgoed}

Voor de toetsing aan de evenredigheid blijken er duidelijk verschillen aanwezig tussen de diverse zorgplichtbepalingen inzake de relatie tussen de gedraging, de vereiste zorgvuldigheid en het optreden van (potentiële) schade aan het beschermde rechtsgoed.

De meeste zorgplichtbepalingen zijn gericht op de bescherming van het door de betreffende wet of regelgeving beschermde rechtsgoed. Meestal vereisen zij echter niet dat aan het rechtsgoed daadwerkelijk schade moet zijn berokkend. Hoewel er een aantal is die alleen gedragingen strafbaar stellen die het ontstaan van schade omvatten, blijkt de relatie tussen de gevaarzettende gedraging en het ontstaan van schade meestal minder duidelijk aanwezig. Vereist wordt dan het in gevaar brengen, of kunnen brengen van het rechtsgoed. Een potentieel gevaarlijke gedraging is dan al voldoende voor het schenden van de betreffende bepaling. Daamaast zijn er ook zorgplichtbepalingen geformuleerd als abstract gevaarzettingsdelict. Zij stellen een bepaalde gedraging strafbaar, ongeacht of er sprake is van het (potentieel) in gevaar brengen van het rechtsgoed. Vanuit de rechisgoed beschermende functie van het strafrecht zijn voor de meeste zorgplichtbepalingen dan ook niet veel argumenten aan te voeren.

Aanbevelingen

1. Zorgplichtbepalingen dienen zoveel mogelijk tegemoet te komen aan de evenredigheid, en meer specifiek aan de rechtsgoedbeschermende functie van het strafrecht. De relatie tussen de strafbaar gestelde gedraging, de vereiste zorgvuldigheid en het optreden van (potentiële) schade aan het beschermde rechtsgoed dient zoveel mogelijk aanwezig te zijn. Om hieraan tegemoet te komen dient deze relatie duidelijk terug te komen in de delictsomschrijving van zorgplichtbepalingen.

2. Juist bij zorgplichtbepalingen, die immers een algemene verplichting bevatten tot het in acht nemen van een bepaalde graad van zorgvuldigheid met het oog op het door de desbetreffende wet te beschermen belang, is het aan te bevelen deze relatie duidelijk te verwoorden in de strafbaarstelling.

3. Formuleringen waarbij de relatie tussen de in acht nemen van een bepaalde graad van zorgvuldigheid en het door de desbetreffende wet of bepaling te beschermen belang niet of maar zeer zwak aanwezig is, dienen te worden vermeden. $Z_{0}$ is. 
bijvoorbeeld het via een zorgplichtbepaling strafbaar stellen van het "in gevaar kunnen brengen" van een bepaald rechtsgoed onwenselijk.

4. De rechtspolitieke keuze of naast het strafbaar stellen van een bepaalde gedraging die daadwerkelijk schadelijk is voor het beschermde rechtsgoed, ook het strafbaar stellen van potentiële schadelijke gedragingen is beoogd, dient expliciet te worden gemaakt. Dit kan worden verduidelijkt door deze twee varianten niet in één delictsomschrijving op te nemen. De bepaling moet worden gesplitst, zodat het $\mathrm{OM}$ en de rechter een keuze moeten maken voor welke gedraging de verdachte eventueel wordt vervolgd en veroordeeld. Hierdoor is het tevens mogelijk de strafbedreiging aan te passen aan de ernst van het feit, waardoor ook kan worden tegemoet gekomen aan de vereiste evenredigheid inzake strafbedreiging (zie aanbeveling 8.).

\subsection{Evenredigheid: systeem van strafbaarstellingen}

Vanuit het oogpunt van subsidiariteit lijken zorgplichtbepalingen niet noodzakelijk. Meestal blijkt één alles omvattende bepaling onvoldoende om een bepaald rechtsgoed te beschermen. ${ }^{5}$ Afhankelijk van de rechtspolitieke keuzes inzake de afhankelijkheid van het bestuur en de gradatie van bescherming van het rechtsgoed, kan een strafrechtelijk systeem worden vormgegeven dat een goede bescherming biedt aan het rechtsgoed, zonder dat zich de vele rechtsstatelijke bezwaren manifesteren die zorgplichtbepalingen oproepen. Er dient te worden gewerkt met een combinatie van soorten strafbaarstellingen: naast concrete gevaarzettingsdelicten zijn vaak abstracte gevaarzettingsdelicten noodzakelijk, terwiji ter complementering van het systeem gebruik kan worden gemaakt van zelfstandige delicten. Indien een evenwichtige combinatie van deze strafbaarstellingen wordt bereikt lijkt het mogelijk een systeem van strafbaarstellingen te ontwikkelen dat voldoende mogelijkheden biedt het te beschermen rechtsgoed daadwerkelijk te beschermen. Het gebruik van zorgplichtbepalingen (met hun specifieke kenmerken) zal in een dergelijk systeem niet (meer) nodig zijn, en kan achterwege blijven.

Zorgplichtbepalingen kunnen gezien hun specifieke kenmerken worden beschouwd als een aparte groep delicten, maar zij blijken tevens afhankelijk van de redactie ook tot één van de andere delictstypen te kunnen worden gerekend. Zo zijn er enkele vormgegeven als abstract gevaarzettingsdelict. Indien de materiële normstelling is opgenomen in de delictsomschrijving zèlf, wordt hierin (tamelijk duidelijk) aangegeven welke gedraging worden geỉncrimineerd. Afhankelijk van de redactie kunnen zij goed inpasbaar zijn in het totale systeem van strafbaarstellingen.

Er zijn echter ook abstracte gevaarzettingsdelicten waarvan de materiële normstelling niet is te vinden in de delictsomschrijving in de wet in formele zin. Zij stellen via een

Zie Faure, M. en Visser., De strafrechtelijke bescherming van het leefmilieu in België, Duitsland en Nederland, waarin dit systeem in uitgewerkt voor het beschermde rechtsgoed "leefmilieu". 
gelede normstelling gedragingen strafbaar in strijd met door het bestuur vastgestelde normen. In deze materiële normen zijn soms ook zorgplichtbepalingen opgenomen. Het is de vraag of het bestuur, als het van de wetgever in formele zin de bevoegdheid heeft gekregen een (uitgebreid) stelsel te ontwikkelen van nadere normstellingen, daarbij gebruik moet maken van zorgplichtbepalingen. Dit klemt te meer indien deze bepalingen vage bestanddelen bevatten.

Bij bestudering van het systeem van strafbaarstellingen blijkt voorts dat zorgplichtbepalingen (bijna) nooit zijn vorm gegeven als concrete gevaarzettingsdelicten. Dit type strafbaarstelling vereist niet alleen dat sprake is van een bepaalde wederrechtelijke gedraging, maar tevens dat door deze wederrechtelijke gedraging een bepaald gevolg wordt of kan worden teweeggebracht. ${ }^{6}$ Indien de gedraging plaatsvindt conform de bestuurlijke regelgeving, is het feit op basis van een dergelijke bepaling doorgaans niet strafbaar vanwege het bestanddeel "wederrechtelijk" of een equivalent daarvan. Het is zeer opvallend dat de zorgplichtbepalingen die een bepaald rechtsgoed beschermen waaraan geen absolute bescherming wordt geboden, niet op deze manier zijn vorm gegeven. Zo ontbreekt het bestanddeel "wederrechtelijk" (of een equivalent) in de zorgplichtbepalingen in het milieustrafrecht. ${ }^{7}$ Dit is vreemd daar deze bepalingen zien op de bescherming van componenten van het leefimilieu; rechtsgoederen die geen absolute bescherming genieten. $\mathrm{Zij}$ worden slechts beschermd indien de schending verder gaat dan de door het bestuur toegestane inbreuk. De samenhang tussen de bestuurlijke vaststelling van de toegestane mate en soort inbreuk op het rechtsgoed en de bescherming door het strafrecht van dit rechtsgoed ontbreekt door het weglaten van het bestanddeel "wederrechtelijk" in deze strafbaarstellingen.

Binnen een systeem van strafbaarstelling kan voorts gebruik worden gemaakt van zelfstandige delicten. Dit type strafbaarstelling incrimineert zeer emstige inbreuken op het beschermde rechtsgoed, zelfs als deze plaatsvinden conform de bestuurlijke regelgeving. Het belangrijkste verschil met het tweede soort strafbaarstelling is dat het bestanddeel "wederrechtelijk" ontbreekt. Ten behoeve van de bescherming van het rechtsgoed wordt de "administratieve afhankelijkheid" in beginsel ${ }^{8}$ doorbroken. Hierdoor wordt een meer zelfstandige strafrechtelijke bescherming verleend. Dit type strafbaarstellingen is doorgaans gericht op de bescherming van de menselijke gezondheid of het menselijk leven.

Opvallend is dat de meeste zorgplichtbepalingen als zelfstandig delict zijn vormgegeven. Dit is ten eerste opmerkelijk aangezien er geen ernstige inbreuken op de verschillende rechtsgoederen noodzakelijk zijn, wil er sprake zijn van schending van de zorgplichtbepaling. Voorts betreft het in het algemeen gedragingen die veelvuldig

6 Deze wederrechtelijk-eis wordt hier aan concrete gevaarzettingsdelicten gesteld ter onderscheiding van de zelfstandige delicten.

7 Afhankelijk van de interpretatie kan artikel 10.3, eerste en tweede lid Wm worden aangemerkt als een concreet gevaarzettingsdelict. Zie hoofdstuk 4 paragraaf 6.

8 In beginsel, omdat de bestuurlijke voorbeslissing natuurlijk wel een rol blijft spelen bij de vraag of al dan niet sprake is van een strafuitsluitingsgrond. 
voorkomen, en wel op gebieden waar door het bestuur wordt bepaald wat voor soorten inbreuken er op het beschermde rechtsgoed zijn toegestaan en in welke mate. In het strafrecht is het dan, met het oog op het specificeren en beperken van het betekenisbereik van de strafbaarstelling, gebruikelijk de strafrechtelijke aansprakelijkheid te beperken tot die gevallen waarin sprake is van een wederrechtelijke schending van het beschermde rechtsgoed, tenzij dit rechtsgoed zo beschermenswaardig wordt geacht dat de wetgever ervoor kiest dat daarop in beginsel geen inbreuken mogen worden gemaakt. Behalve aan het menselijk leven en de menselijke gezondheid (die zelfs niet altijd deze graad van bescherming krijgen), kan ook aan andere rechtsgoederen dit vergaande beschermingsniveau worden geboden. Of dit gebeurt is een rechtspolitieke keuze. Bij zorgplichtbepalingen lijkt echter geenszins sprake van een dergelijke principiële keuze. Dit is des te opvallender indien door deze zorgplichtbepalingen rechtsgoederen worden beschermd waarop bepaalde inbreuken door het bestuur worden toegestaan.

Aanbevelingen

5. Het opnemen van zorgplichtbepalingen door het bestuur in gelede normstellingen dient zoveel mogelijk te worden vermeden.

6. Het is wenselijk een optimaal sluitend systeem van strafbaarstellingen vorm te geven om rechtsgoederen te beschermen. Zorgplichtbepalingen die zijn geredigeerd als zelfstandig delict, maar waarvan het beschermde rechtsgoed geen absolute bescherrning geniet en de toegestane inbreuken worden gereguleerd door het bestuur, dienen te worden omgevormd tot concrete gevaarzettingsdelicten. Dit kan door het opnemen van het bestanddeel "wederrechtelijk" in de delictsomschrijving.

7. In een evenwichtig en goed functionerend systeem van strafbaarstellingen, zijn vanuit het subsidiariteitsoogpunt beschouwd deze als zelfstandig delict geredigeerde zorgplichtbepalingen niet meer noodzakelijk. Een dergelijk systeern zal ook de effectiviteit van de bescherming van rechtsgoederen ten goede komen. Door een dergelijke herziening van zorgplichtbepalingen wordt tevens enigszins tegemoet gekomen aan het lex certa-beginsel, aangezien het betekenisbereik duidelijker wordt gespecificeerd.

\subsection{Evenredigheid: indeling en strafbedreiging}

Indien toch de keuze wordt gemaakt voor het gebruik van zorgplichtbepalingen rijst de vraag naar de proportionaliteit. Met het oog daarop is onderzocht of de gehanteerde indeling en de maximum strafbedreiging evenredig zijn met de strafbaar gestelde gedraging. Het strafrecht kan bij zorgplichtbepalingen in een zeer vroeg stadium bescherming bieden aan het beschermde rechtsgoed aangezien een krenking of daadwerkelijk in gevaar brengen vaak niet wordt geêist. Zorgplichtbepalingen blijken 
te worden ingedeeld als "beboetbaar feit" misdrijf ${ }^{\prime \prime}$. Opvallend hierbij is dat de zorgplichtbepalingen in het milieustrafrecht zijn aangehaakt aan de Wed via artikel la sub I Wed, temeer daar voor het opnemen in deze categorie het criterium is gehanteerd "dat het moet gaan om feiten die een directe aantasting opleveren van het milieu, dan wel daarvoor een emstige en rechtstreekse bedreiging vormen". ${ }^{12}$ Hiervan behoeft bij zorgplichtbepalingen echter geen sprake te zijn. Ten gevolge van deze indeling kunnen zij "voor zover zij opzettelijk zijn begaan" involge artikel 2 Wed worden aangemerkt als misdrijf. De keuze voor deze indeling lijkt hierdoor niet te voldoen aan het proportionaliteitsbeginsel. Dit geldt eveneens voor de beoordeling van de maximum strafbedreiging. Ook hier vormen de zorgplichtbepalingen in het milieustrafrecht een uitzondering. Schending van deze bepalingen wordt, in tegenstelling tot de meeste andere zorgplichtbepalingen, bedreigd met zeer zware sancties.

\section{Aanbevelingen}

8. Indien in één bepaling zowel het veroorzaken van schade aan het beschermde rechtsgoed, als het in gevaar brengen van dit rechtsgoed wordt strafbaar gesteld, dient deze bepaling te worden gesplitst in twee (of meer) afzonderlijke strafbaarstellingen. Niet alleen wordt hierdoor de door de wetgever als ongewenst beschouwde gedraging inzichtelijker, maar tevens kan zo beter worden tegemoet gekomen aan de vereiste evenredigheid aangezien hierdoor een differentiatie kan worden gemaakt in de maximum strafbedreiging.

9. De culpose zorgplichtbepalingen in het milieustrafrecht dienen niet langer te worden aangehaakt aan de Wed via artikel la sub 1 Wed. Zij dienen (na splitsing van de bepaling in een culpose en opzet-variant) te worden overgebracht naar artikel 1a sub 3 Wed. Hierdoor wordt tegemoetgekomen aan de vereiste proportionaliteit als uitwerking van de evenredigheid. Zij zijn dan niet langer ook als misdrijf strafbaar gesteld, maar alleen als overtreding. De maximum strafbedreiging is dan minder disproportioneel.

10. Indien de zorgplichtbepalingen in het milieustrafrecht worden gesplitst op basis van de mate van schade aan het beschermde rechtsgoed, lijkt een nadere differentiatie in het kader van de proportionaliteit voor de hand te liggen. Afhankelijk van de redactionele aanpassing en de rechtspolitieke keuze inzake strafwaardigheid van de gedraging, lijkt een aantal oplossingen mogelijk. Zo kan

9 Zie bijvoorbeeld artikel 11 Arbo-wet 1998.

10 Zie bijvoorbeeld artikel 425 aanhef en sub 2, artikel 426, eerste lid, artikel 427 aanhef en sub I en 5, artikel 429 aanhef en sub $3 \mathrm{Sr}$, artikel 5 WVW, artikel 5 Wet Luchtverkeer en artikel 19 Quarantainewet.

11 Zie bijvoorbeeld de artikelen $13 \mathrm{Wbb}, 10.3 \mathrm{Wm}$ en $2 \mathrm{Wms}$, waarbij het onderscheid tussen overtreding en misdrijf afhankelijk is gesteld van de vraag of sprake is van opzet in de zin van artikel 2 Wed.

12 Zie de toelichting bij de invoering van deze indeling in de Wed, TK 1992-1993, 23 196, nr. 3, pp. 5 en 13 . 
worden afgezien van het strafbaar stellen van bepaalde gedragingen. Indien wordt gekozen voor strafbaarstelling, moet een weloverwogen keuze worden gemaakt via welke categorie het delict moet worden aangehaakt aan artikel 1 of la van de Wed. De mogelijkheid van sub $1 \mathrm{kan}$ worden gebruikt voor delicten waarin gedragingen worden strafbaar gesteld die (wederrechtelijk; zie aanbeveling 6) daadwerkelijk schade veroorzaken an het beschermde rechtsgoed.

\section{5 .}

\section{Rechtszekerheid: het lex certa-beginsel}

Voor de toetsing aan de rechtszekerheid is het in het kader van de beoordeling van zorgplichtbepalingen vooral van belang na te gaan in hoeverre zij voldoen aan het lex certa-beginsel. Involge artikel $1 \mathrm{Sr}$ is de tekst van de strafbaarstelling zelf maatgevend voor de beantwoording van de vraag of de justitiabele hieruit voorafgaande aan zijn. handelen kan weten of zijn gedraging al dan niet onder de delictsomschrijving valt.

Hoewel de grens moeilijk blijkt te trekken tussen bepalingen die hier wel en bepalingen die hier niet aan voldoen, is duidelijk dat het bij enkele zorgplichtbepalingen zeer moeilijk is vast te stellen welke gedragingen onder de delictsomschrijving vallen. Zeker die bepalingen die alleen in algemene termen een gevaarlijke of ongewenste gedraging aanduiden, een bepaalde graad van zorgvuldigheid vereisen, of het treffen van niet nader aangeduide voorzorgsmaatregelen of schadebeperkende maatregelen vereisen zijn zeer vaag geformuleerd. Indien uit de overige bestanddelen ook geen beperking van het betekenisbereik voortvloeit, geen daadwerkelijke schade of gevolg wordt vereist en zij zich richten tot een grote groep van normadressaten (een ieder) kan worden gezegd dat zij in strijd zijn met het lex certa-beginsel.

Artikel 5 WVW spant in dit opzicht de kroon, maar niet veel beter zijn de artikelen 5 Wet Luchtverkeer, $13 \mathrm{Wbb}, 2 \mathrm{Wms}$ en $10.3 \mathrm{Wm}$. De zorgplichtbepalingen in het Wetboek van Strafrecht bevatten meer bestanddelen die het betekenisbereik van het strafbare feit specificeren, en staan daarom minder op gespannen voet met het lex certa-beginsel dan de hiervoor genoemde bepalingen.

De als abstracte gevaarzettingsdelicten geformuleerde artikelen 19, eerste lid en 19, derde lid Quarantainewet bevatten geen beperking van het betekenisbereik door het vereisen vain een bepaald gevolg dat (potentieel) moet worden veroorzaakt door de strafbaar gestelde gedraging. Toch komen deze strafbaarstellingen door hun formulering niet snel in strijd met het lex certa-beginsel. Dit worde veroorzaakt door het feit dat zij vrij nauwkeurig bepaalde gedragingen strafbaar stellen, én zich richten tot een specifieke groep normadressaten.

Meer specifiek zijn de zorgplichtbepalingen uit artikel 11 Arbo-wet 1998. De strafbaar gestelde gedragingen zijn (met uitzondering van de aanhef van artikel 11 Arbo-wet 1998) vrij specifiek weergegeven, waarbij zij zich richten tot een beperkte groep normadressaten. Doordat dit artikel (afhankelijk van de uiteindelijk gekozen interpretatie waarschijnlijk) is aan te merken als concreet gevaarzettingsdelict, geldt bovendien 
als voorwaarde voor strafbaarheid dat de gedraging een bepaald (potentieel) gevolg moet hebben teweeggebracht. De strafbaarstelling van de aanhef heeft mogelijk tot gevolg dat ook niet opgesomde gedragingen onder het betekenisbereik van deze strafbaarstelling kunnen vallen. De wel opgesomde gedragingen uit at tot en met f zullen hierbij als richtsnoer werken, omdat zij de niet opgenomen gedragingen tegen een bepaalde achtergrond plaatsen. De spanning tussen het lex certa-beginsel en artikel 11 Arbo-wet 1998 zal dan waarschijnlijk gering zijn.

De spanning met het lex certa-beginsel, die wordt veroorzaakt door vage bestanddelen, wordt vooral duidelijk indien het OM zich niet erg terughoudend opstelt bij het ten laste leggen van gedragingen die in het grijze gebied van de strafbaarstelling vallen. Deze spanning wordt nog versterkt indien het $\mathrm{OM}$ de verweten gedraging en, indien vereist, de subjectieve bestanddelen, weinig specifiek ten laste legt. Dit komt de kenbaarheid door de justitiabele van wat hem wordt verweten niet ten goede, evenmin als de nombevestigende werking die uitgaat van de strafbaarstelling. Ook wordt zo door het OM niet bijgedragen aan het ontwikkelen van aanvullende criteria van de betreffende zorgplichtbepaling.

Indien de strafrechter de vage bestanddelen in de zorgplichtbepalingen niet restrictief interpreteert, worden deze problemen nog duidelijker. Dit wordt nog sterker indien hij daarbij zijn uitspraak spaarzaam motiveert. Wederom komt dit de kenbaarheid voor de justitiabele van wat hem in casu is verweten niet te goede. Hierdoor zal tevens de normbevestigende werking van de strafbaarstelling minder groot zijn. Daarbij komit dat juist door een goede motivering de strafrechter de mogelijkheid heeft aanvullende criteria te formuleren die het betekenisbereik markeren.

\section{Aanbevelingen}

11. Vage bestanddelen dienen zo weinig mogelijk te worden gebruikt. Indien het niet mogelijk is de strafbaar gestelde gedraging en/ of ongewenste gevolgen specificker te omschrijven, verdient het aanbeveling een aantal voorbeelden van deze gedragingen on/ of gevolgen op te nemen in de delictsomschrijving.

12. Zorgplichthepalingen die in één (lid van een) artikel meer dan éến zorgplicht bevatten, dienen ten behoeve van de inzichtelijkheid zoveel mogelijk te worden gesplitst.

13. Indien én zorgplichtbepaling, die uit verschillende zorgplichten bestaat wordt gesplitst, is het wenselijk deze afzonderlijke zorgplichtbepalingen op te nemen in één artikel of de artikelen onder elkaar te plaatsen. Hierdoor blijft de samenhang behouden.

14. Indien wordt gekozen yoor de aanhaking van zorgplichtbepalingen die subjectieve bestanddelen bevatten, aan artikel 1 sub 1 en 2 en artikel la sub 1 of 2 Wed dient de wetgever duidelijk te maken op welke bestanddelen het opzetvereiste uit artikel 2 Wed betrekking heeft. 
15. Het oplossen van de "schuldkwadratuur" door het schrappen van de subjectieve bestanddelen uit deze bepalingen verdient géén aanbeveling, aangezien deze bestanddelen het betekenisbereik specificeren, waardoor beter wordt tegemoet gekomen aan het lex certa-beginsel.

16. Indien door de wetgever vage bestanddelen zijn gebruikt, dient het $O M$ gedragingen die vallen in het grijze gebied van de strafbaarstelling niet, of slechts bij zeer ongewenste gedragingen, ten laste te leggen.

17. Het $\mathrm{OM}$ dient, zeker indien vage bestanddelen worden ten laste gelegd, deze zo specifiek mogelijk uit te werken in de tenlastelegging.

18. De rechter dient vage bestanddelen restrictief te interpreteren.

19. Indien een zorgplichtbepaling uit een algemeen verbindend voorschrift van bestuur of beschikking (dermate vaag is geformuleerd, en/ of het betekenisbereik dermate groot is dat de bepaling een) ernstige schending oplevert van het lex cetra-beginsel, dient de strafrechter de bepaling onverbindend te verklaren.

20. Het toetsingsverbod van wetgeving in formele zin aan de Grondwet dient te worden opgeheven. De strafrechter dient de bevoegdheid te krijgen, zorgplichtbepalingen uit een wet in formele zin die (doordat zij dermate vaag zijn geformuleerd, en/ of het betekenisbereik dermate groot is dat zij) ernstig in strijd zijn met het lex certa-beginsel, onverbindend te verklaren wegens strijd met artikel $16 \mathrm{Gw}$.

21. De rechter dient zijn uitspraak duidelijk te motiveren. Het is wenselijk indien hij hierbij aanvullende criteria formuleert die het betekenisbereik van vage termen markeren.

Voorts is het van belang tegemoet te komen aan de aanbevelingen 16 tot en met 21 om de spanning met het vereiste van rechtsgelijkheid te verminderen.

\subsection{Rechtsgelijkheid: gelijke gevallen, gelijk behandelen}

In het kader van de toetsing van zorgplichtbepalingen aan de rechtsgelijkheid valt op dat de meeste zorgplichtbepalingen veel vage bestanddelen bevatten. Dit behoeft niet per definitie tot rechtsongelijkheid te leiden, maar indien het betekenisbereik minder duidelijk is én dit betekenisbereik vrij groot is, ligt dit gevaar wel op de loer. Ongelijkheid zal dan vooral ontstaan door de ongelijkheid bij de vervolgingsbeslissing van het OM en bij de beoordeling ervan door de rechter. De indruk bestaat dat de zorgplichtbepalingen die veel lijken te worden gebruikt ook worden ingezet bij relatief "lichte" zaken. ${ }^{13}$ Soortgelijke gedragingen worden nochtans ook vaak verricht, zonder dat 1994, MenR, 1995, nr. 50, met noot Hendriks (Motorblok); HR 15 november 1994, 
justitiabelen hierop worden aangesproken, laat staan dat zij hiervoor vervolgd en/ of veroordeeld zullen worden. ${ }^{14}$ Door vage bestanddelen en een grote werkingssfeer wordt zodoende het risico van rechtsongelijkheid in de hand gewerkt.

\section{Aanbeveling}

22. Het is wenselijk dat het OM een duidelijk vervolgingsbeleid vaststelt, bekend maakt en hanteert bij zorgplichtbepalingen met vage termen en een grote werkingssfeer.

Voorts dient te worden opgemerkt dat teneinde de spanning met het vereiste van rechtsgelijkheid te verminderen het van belang is tegemoet te komen aan de aanbevelingen 16 tot en met 21. Deze zijn geformuleerd om de knelpunten te verminderen die zijn gesignaleerd in het kader van de rechtszekerheid: het lex certa-beginsel.

\subsection{Rechtsgelijkheid: afwijkende gevallen rechtvaardigen afwijking}

In het kader van de rechtsgelijkheid is het niet enkel van belang dat gelijke gevallen gelijk worden beoordeeld, maar ook dat afwijkende gevallen afwijking rechtvaardigen. Van belang is in dit kader vooral de beoordeling van de verwijtbaarheid van de verdachte. De meeste zorgplichtbepalingen blijken geen subjectief element te bevatten. Indien het OM de verwijtbaarheid niet opneemt in de tenlastelegging, zal de rechter de vraag naar de strafbaarheid van de verdachte beantwoorden in het kader van de derde, en niet de eerste, vraag van artikel $350 \mathrm{~Sv}$.

De zorgplichtbepalingen in het milieustrafrecht bevatten wel subjectieve bestanddelen. $Z_{i j}$ verankeren het schuldbeginsel bij deze bepalingen, en geven enige beperking aan het betekenisbereik nu deze bestanddelen ook zullen moeten worden bewezen verklaard wil de rechter tot een eventuele veroordeling kunnen komen. ${ }^{15}$ Indien de verdachte wordt vervolgd vanwege het schenden van een dergelijke bepaling levert de overtreding-variant geen bijzondere problemen op. Dit kan niet worden gezegd van de misdrijf-variant. De milieustrafbepalingen zijn immers aangehaakt aan de Wed via artikel la sub 1 Wed, zodat involge artikel 2 Wed sprake is van een misdrijf indien het delict opzettelijk is begaan.

\section{Aanbevelingen}

23. Door de "schuldkwadratuur" zijn verschillende interpretaties van de reikwijdte van de opzet-eis mogelijk. De wetgever dient aan te geven welke interpretatie

\section{MenR, nr. 10-K (Bodemkunstenaar).}

14 Overigens hebben zij vaak ook geen idee dat zij strafbare feiten plegen, zodat dit ook op gespannen voet zal staan met de bovengenoemde rechtszekerheid, nu niet voldaan lijkt te zijn aan het lex certa-beginsel.

15 Door het gebruik van subjectieve bestanddelen wordt ook tegemoetgekomen aan het lex certa-beginsel; zie Visser, M.J.C., "Uitholling van het schuldbeginsel bij zorgplichtbepalingen door schending van het lex certa-beginsel", pp. 65-80. 
moet worden gehanteerd. Eenduidige interpretatie is niet alleen in het kader van de rechtsgelijkheid vereist, maar ook vanuit de vereisten van rechtszekerheid en evenredigheid. Overigens verdient het geen aanbeveling de subjectieve bestanddelen te schrappen (zie aanbeveling 15).

24. Zorgplichtbepalingen dienen (in navolging van onder andere artikel 5 WVW) onder omstandigheden ook strafiuitsluitend te kunnen werken.

25. Aangezien het wenselijk is een duidelijk verschil aan te brengen tussen de overtreding- en de opzet-variant, verdient het aanbeveling te kiezen voor de interpretatie waarbij de opzet-eis op zo veel mogelijk bestanddelen betrekking heeft. (Deze aanbeveling is vooral van belang indien de zorgplichtbepalingen met "schuldkwadratuur" niet overeenkomstig aanbeveling 9 worden gesplitst.)

26. In zorgplichtbepalingen met vage bestanddelen en een grote werkingssfeer dienen subjectieve bestanddelen te worden opgenomen die betrekking hebben op de gedraging en het daardoor veroorzaakte gevolg.

3.8. Samenhang: het systeem van strafbaarstellingen

Indien in het kader van de vereiste samenhang wordt onderzocht of bij zorgplichtbepalingen sprake is van samenhang binnen het systeem van wetgeving, blijkt dat zij niet alleen vrij willekeurig lijken te zijn ingevoerd, maar ook dat er weinig sprake is van systematiek in het al dan niet opnemen van deze bepalingen. Onduidelijk is waarom zij wel gelden voor een bepaald gebied (bijvoorbeeld de bodem) maar niet voor andere gebieden (zoals bijvoorbeeld lucht en water). Ook bij lagere regelgeving lijkt eerder sprake van toeval dan van beleid of dat zij deel uitmaken van een bepaald besluit.

Aanbevelingen

27. Het verdient aanbeveling voor diverse "soortgelijke" rechtsgoederen een overeenkomstig en sluitend systeem van strafbaarstellingen te ontwerpen, dat zoveel mogelijk tegemoet komt aan de bijzondere eigenschappen van het specifieke rechtsgoed. Bij het vereiste van de evenredigheid is besproken op welke manier een dergelijk systeem kan worden vormgegeven. Dit systeem dient niet uitsluitend te worden ingevoerd ter bescherming van de rechtsgoederen waar zorgplichtbepalingen nu deei van uitmaken.

28. De wetgever dient bij de formulering van zorgplichtbepalingen de criteria die het betekenisbereik beperken, zoveel mogelijk in de delictsomschrijving op te nemen als bestanddeel, en niet als bijzondere rechtvaardigingsgrond. De clausulering dient daarom in dezelfde zin te staan als die waarin het verbod of de strafbaarstelling is opgenomen. 
29. De interpretatie van clausuleringen die in dezelfde zin staan als de zorgplichtbepaling, dient zoveel mogelijk volgens het formele criterium te geschieden.

30. Indien de clausulering niet in dezelfde zin is opgenomen als de zorgplichtbepaling en er twijfel bestaat of deze als bestanddeel of als rechtvaardigingsgrond moet worden aangemerkt, dient zij gezien het uitgangspunt in dubio pro reo te worden aangemerkt als bestanddeel.

\subsection{Samenhang: interpretatie}

Indien wordt onderzocht of sprake is van samenhang in de interpretatie van zorgplichtbepalingen door rechters, blijkt dat de strafrechter en de bestuursrechter zoveel mogelijk proberen dezelfde termen of bepalingen op dezelfde manier te interpreteren. Zeker bij zorgplichtbepalingen is dit van groot belang. Door het gebruik van vage bestanddelen is het vaak onduidelijk wat het betekenisbereik van deze bepalingen is. Het vaststellen hiervan wordt veelal aan de rechterlijke macht overgelaten. Hierdoor kunnen verschillen in interpretatie ontstaan. Zeker vanuit het oogpunt van de toenemende geïntegreerde handhaving van strafbaarstellingen in het bijzonder, economisch en milieustrafrecht is dit onwenselijk.

Hoewel gelijkluidende interpretatie binnen de diverse rechtsgebieden van groot belang is, wil dit niet zeggen dat hierop geen uitzonderingen zouden zijn toegestaan. Zeker indien blijkt dat zorgplichtbepalingen onrechtmatig zijn, dient de strafrechter zijn eigen weg te gaan. Dit is ook het geval indien hij daardoor in afwijking van het bestuur of de bestuursrechter oordeelt. Het vasthouden aan eenheid mag er immers nooit toe leiden dat een justitiabele wordt veroordeeld op basis van onrechtmatige regelgeving.

Aanbevelingen

31. Gelijkluidende begrippen dienen zoveel mogelijk op dezelfde manier te worden geïnterpreteerd door rechters uit verschillende rechtsgebieden.

32. Indien de materiële normstelling van abstracte gevaarzettingsdelicten in beschikkingen zijn te vinden, is de Hoge Raad bevoegd termen uit deze beschikkingen uit te leggen. Er is geen sprake van een feitelijke vraag, aangezien het niet gaat om een eenmalige, unieke en onherhaalbare vraag over geïsoleerde (waarderings)oordelen ter zake van het bijzondere of onherhaalbare. Aangezien deze termen deel uitmaken van de materiële normstelling van de strafbaarstellingen uit wetgeving in formele zin, én in verschillende beschikkingen gebruik wordt gemaakt van dezelfde termen betreft het rechtsvragen. Het betreft namelijk oordelen en/ of redeneringen waarvan de algemeenheid in geding is. Hiermee wordt ook de rechtsgelijkheid gediend.

33. Het streven naar gelijkluidende interpretatie mag er nooit toe leiden dat justitiabelen kunnen worden veroordeeld op basis van onrechtmatige 
regelgeving. Indien in beginsel wordt vastgehouden aan de leer van de formele rechtskracht, dient deze leer hier niet te worden gevolgd.

\subsection{Effectiviteit}

Het is op zichzelf niet verwonderlijk dat zorgplichtbepalingen in het algemeen veelvuldig worden gebruikt door het $\mathrm{OM}$. Toch zal de effectiviteit van deze bepalingen minder groot zijn dan op het eerste gezicht het geval lijkt te zijn. Dit wordt ten eerste veroorzaakt door de maatschappelijke factoren die ook van invloed zijn op de effectiviteit. De meeste zorgplichtbepalingen zijn vaag geformuleerd. De vaagheid van deze strafbaarstellingen heeft tot gevolg dat het voor een justitiabele voorafgaande aan zijn gedraging moeilijk valt uit te maken of hij al dan niet een strafbaar feit pleegt. De onvoorspelbaarheid van het betekenisbereik leidt ertoe dat de effectiviteit minder groot zal zijn dan beoogd. Dit zal nog worden versterkt indien de redactie van de zorgplichtbepaling regelmatig wordt gewijzigd.

De effectiviteit zal nog sterker onder druk komen te staan indien de zorgplichtbepaling niet alleen vage bestanddelen bevat, maar ook een grote reikwijdte heeft. Deze combinatie zal tot gevolg hebben dat het $\mathrm{OM}$ gelijke gevallen niet gelijk kàn behandelen. Ook dit komt de normbevestigende werking, en daarmee de effectiviteit, niet ten goede. Hierdoor keert uiteindelijk de eenvoudige toepasbaarheid door het $\mathrm{OM}$ en de rechter zich tegen de effectiviteit.

Indien sprake is van de combinatie van vaagheid en grote reikwijdte, zullen bij vermeende schending van deze bepalingen, buiten en binnen de rechtszaal, discussies (kunnen) ontstaan. Er kan bijvoorbeeld onenigheid bestaan over de inhoud van deze bepalingen, de bevoegdheid tot het toepassen van dwangmiddelen en het maatschappelijk belang van de vervolging. Dit zal wederom de effectiviteit, zeker op de lange termijn, niet ten goede komen.

\section{Aanbeveling}

34. De onduidelijkheden inzake de toepassing en de toepasselijkheid van zorgplichtbepalingen dienen te worden verminderd. De realisering van de eerder genoemde aanbevelingen zal daaraan bijdragen.

\subsection{Knelpunten en aanbevelingen; algemeen}

Bij de beoordeling van zorgplichtbepalingen aan de algemene vereisten van behoorlijke regelgeving valt op dat de meeste van deze bepalingen enigszins en sommige sterk op gespannen voet staan met de vereisten die invulling geven aan de waarborgfunctie van regelgeving én met de vereisten die invulling geven aan de functie van regelgeving als instrument.

De problemen met zowel de waarborgfunctie als de functie van regelgeving als instrument worden ten dele door dezelfde kenmerken veroorzaakt. Deze kunnen 
worden voor een belangrijk deel worden verminderd door het tegengaan van vage bestanddelen en het inperken van het betekenisbereik van deze zorgplichtbepalingen.

Door de onderlinge verschillen tussen de verschillende zorgplichtbepalingen, is de spanning met de algemene vereisten van behoorlijke regelgeving niet voor alle bepalingen even groot. De meeste problemen doen zich voor met zorgplichtbepalingen die vage bestanddelen bevatten, zoals de artikelen 5 WVW, artikel 5 Wet Luchtverkeer en de zorgplichtbepalingen in het milieustrafrecht. Deze laatste worden ook nog eens gekenmerkt door hoge maximum strafbedreigingen, waardoor zich nog meer knelpunten voordoen.

Ondanks het veelvuldig gebruik van een aantal van deze bepalingen, is het nodig de redactie van de bestaande zorgplichtbepalingen te herzien. Bij de invoering van nieuwe zorgplichtbepalingen is het van groot belang de redactie daarvan zoveel mogelijk in overeenstemming te brengen met de algemene vereisten van behoorlijke regelgeving. Er dient gezocht te worden naar goede alternatieven, ook indien het zorgplichtbepalingen betreft die een primaire rol spelen in de handhavingspraktijk. Door de realisering van de aanbevelingen kunnen knelpunten worden verminderd én is het mogelijk een evenwichtiger systeem van strafbaarstellingen te realiseren. Dit zal, zeker op de langere termijn, de waarborgfunctie én de instrumentele functie ten goede komen. 


\section{Samenvatting}

Dit boek is een verslag van het onderzoek dat is verricht naar zorgplichtbepalingen in het Nederlandse strafrecht. Het onderzoek heeft betrekking op de vraag wie het betekenisbereik van zorgplichtbepalingen, en daarmee de grenzen van de strafrechtelijke aansprakelijkheid, vaststelt; op welke manier dat gebeurt; en welke knelpunten hierdoor (kunnen) ontstaan. Op basis van de bevindingen uit dit onderzoek worden aanbevelingen geformuleerd die kunnen bijdragen aan het (ten dele) oplossen van deze knelpunten.

In hoofdstuk I wordt het onderwerp van dit onderzoek toegelicht en wordt een plan van aanpak gepresenteerd. Onder zorgplichten worden verstaan: Een vrij algemeen geformuleerde (zorg)verplichting die een bepaalde verantwoordelijkheid van de normadressaat markeert en die strafrechtelijk kan worden gehandhaafd. Een zorgplichtbepaling bevat een algemene verplichting tot het in acht nemen van een bepaalde graad van zorgvuldigheid met het oog op het door de desbetreffende wet te beschermen belang, en kan zowel betrekking hebben op een handelen als een nalaten van de normadressaat. De wetstechnische vormgeving van een zorgplichtbepaling kan verschillen; het kan gaan om een gebod (een positief geformuleerde verplichting), of om een verbod.

In hoofdstuk 2 wordt een theoretisch onderscheid gemaakt inzake de voorwaarden voor de toepassing van strafbaarstellingen. Aangegeven wordt wat wordt verstaan onder toepassing en toepasselijkheid van een rechtsregel. Hierbij spelen interpretatie en kwalificatie een belangrijke rol. Bij het onderzoek naar het betekenisbereik van zorgplichtbepalingen worden beide methoden gehanteerd. Bij zorgplichtbepalingen kunnen zich problemen voordoen bij het vaststellen van de voorwaarden waaronder zij van toepassing zijn. Aangesloten wordt bij de Stereotypentheorie. Met behulp van de Stereotypentheorie is het mogelijk een analyse te geven van de semantische problematiek met betrekking tot de toepassing van rechtsregels. Aangegeven wordt wat wordt verstaan onder vaagheid en "open texture"; abstracte, concrete en graduele termen; en evaluatieve en normatieve termen.

Indien de factoren die maken dat het vaststellen van de voorwaarden waaronder zorgplichtbepalingen van toepassing zijn zijn onderscheiden en de daarbij gehanteerde termen zijn uitgewerkt, doet zich de vraag voor welke instantie het toepassingsbereik van zorgplichtbepalingen vaststelt. Het onderzoek naar de vraag wie de inhoud van een strafbaarstelling en dus de grenzen van de strafrechtelijke aansprakelijkheid vaststelt, vergt onderzoek naar de vraag welke actor de reikwijdte van de aansprakelijkheid kan bepalen, uitbreiden of inperken. De verschillende instituties die hier een rol spelen zijn de wetgever, het bestuur en de rechterlijke macht. Zij kunnen de 
(aanvullende) criteria bepalen waaraan moet worden voldaan voordat de voorwaarden van de strafbaarstelling zijn vervuld.

In hoofdstuk 3 zijn algemene vereisten van behoorlijke regelgeving geformuleerd, waarmee de instantie die de zorgplichtbepaling invoert rekening moet houden. Het betreft de vereisten van evenredigheid, rechtszekerheid, rechtsgelijkheid, samenhang en effectiviteit. Deze vereisten vormen een uitwerking van de waarborgfunctie en de instrumentele functie van wetgeving. Deze functies dienen zoveel mogelijk in evenwicht te zijn. Het gaat niet om een of - of keuze, maar juist om het zoveel mogelijk tegemoet komen aan beide functies: waar inbreuken groter kunnen zijn, moeten de waarborgen sterker zijn.

Toetsing van regelgeving aan deze vereisten dient plaats te vinden voordat de regelgeving wordt ingevoerd. Ook bij de evaluatie en herziening van regelgeving kunnen zij worden gebruikt. Door deze toetsing wordt duidelijk waar en waardoor knelpunten (kunnen) ontstaan bij de toepassing en toepasselijkheid van regelgeving. Hierdoor is het mogelijk een bewustere rechtspolitieke keuze te maken ten aanzien van de inhoud en betekenis van de betreffende regelgeving.

In hoofdstuk 4 is de rol van het bestuur beschreven bij het vaststellen van de voorwaarden voor strafbaarheid. Het bestuur speelt in het bijzonder strafrecht door het gebruik van gelede normstellingen een grote rol bij het vaststellen van de materiële norm van strafbaarstellingen, maar het is op zijn beurt nooit geheel vrij de inhoud van de materiële norm te bepalen.

Aangezien onder een strafbaarstelling niet minder maar ook niet meer gedragingen moeten vallen dan wordt beoogd, bevatten veel strafbaarstellingen specifiekere bestanddelen. Dit kunnen bestanddelen zijn die verwijzen naar de bestuurlijke norm, zoals "wederrechtelijk". Een andere veel gehanteerde methode is om aan een algemeen verbod één of meer uitzonderingen te voegen, die verwijzen naar bestuurlijke normstellingen. Niet altijd is duidelijk of het anvullende criterium is aan te merken als bestandideel of als bijzondere strafuitsluitingsgrond. Dit onderscheid heeft procesrechtelijke implicaties. Gewerkt wordt met een "formeel criterium". Indien de uitzondering is opgenomen in de zin waarin het verbod is vervat, wordt het aangemerkt als bestandideel. Als de wetgever van oordee! is dat de uitzondering een bestanddeel behoort te zijn, is het wenselijk dat hij de strafbaarstelling op deze manier vorm geeft. De rechter zal door het uitgangspunt in dubio pro reo alleen in zeer uitzonderlijke omstandigheden af mogen wijken van de hoofdregel dat het aanvullende criterium dat in dezelfde zin is opgenomen als de strafbaarstelling, een bestanddeel is. Indien het aanvullend criterium elders staat, maar er bestaat reesle twijfel op welke wijze het moet worden aangemerkt, dient de rechter dit criterium eveneens aan te merken als bestanddeel.

In hoofdstuk 5 wordt de rol van de rechter bij de voorwaarden voor strafbaarstelling besproken. Ingegaan wordt op de formele rechtskracht, de exceptie van onverbindend- 
heid, de samenloop van bestuursrechtelijke en strafrechtelijke procedure en haar consequenties, en de cumulatie van bestuursrechtelijke en strafrechtelijke reactie.

In hoofdstuk 6 staat het commune strafrecht centraal. Aan de orde komen de verschillen tussen misdrijven en overtredingen, de overheveling van strafrechtelijke naar bestuursrechtelijke handhaving en daderschap. Vervolgens wordt een aantal zorgplichtbepalingen uit het Wetboek van strafrecht besproken. Deze maken al lang deel uit van het Nederlandse strafrecht, aangezien zij al in 1886 zijn opgenomen in het Wetboek, met uitzondering van artikel 429 aanhef en sub $3 \mathrm{Sr}$ dat in 1918 werd ingevoerd.

De vijf besproken voorbeelden van zorgplichtbepalingen uit het Wetboek van Strafrecht zijn alle opgenomen in Boek III (overtredingen). De maximum strafbedreiging loopt uiteen van een geldboete van de eerste categorie (artikel 427 aanhef en sub 1 en $5 \mathrm{Sr}$ ) en/ of hechtenis van zes dagen (artikel 426 aanhef, eerste lid $\mathrm{Sr}$ ), hechtenis van veertien dagen en/ of een geldboete van de tweede categorie (artikel 429 aanhef en sub $3 \mathrm{Sr}$ ), tot hechtenis van zes maanden en/ of een geldboete van de derde categorie (artikel 425 aanhef en sub $2 \mathrm{Sr}$ ).

Hoofdstuk 7 betreft het bijzonder strafrecht. De ontwikkeling van het bijzonder strafrecht heeft zich na de totstandkoming van het Wetboek van Strafrecht in hoog tempo voltrokken. In dit deel van het strafrecht kunnen ook zorgplichtbepalingen worden aangetroffen. Besproken worden artikel 5 Wegenverkeerswet, artikel 5 Wet Luchtverkeer 1993 en artikel 19 Quarantainewet. Het dikwijls toegepaste artikel 5 WVW heeft model gestaan voor een aantal zorgplichtbepalingen in het bijzonder strafrecht. De reikwijdte van dit artikel is in de loop der tijd steeds groter geworden, waardoor mede de regulering is verschoven van de specifieke bepalingen uit de RVV naar deze bepaling.

Opvallend is dat deze bepaling twee kanten op werkt: aan de ene kant kunnen gedragingen op basis van dit artikel strafbaar zijn zelfs als ze conform de overige regels plaatsvinden; aan de andere kant kunnen gedragingen die in strijd zijn met een andere regel door dit artikel worden gerechtvaardigd. Zij werkt dus zowel strafbaarstellend als disculperend. Criterium voor de beoordeling van de gedraging wordt hierbij gevormd door het door artikel 5 WVW beschermde belang: de verkeersveiligheid.

De besproken voorbeelden zijn allen als overtreding strafbaar gesteld. Schending van deze zorgplichtbepalingen wordt bedreigd met maximaal twee maanden hechtenis en/ of een geldboete van de tweede categorie (artike! 5 WVW), zes maanden hechtenis en/ of een geldboete van de derde categorie (artikel 5 Wet Luchtverkeer), één jaar hechtenis en/ of een geldboete van de derde categorie (artikel 19 Quarantainewet).

Hoofdstuk 8 gaat over het economisch strafrecht. Dit maakt reeds lang deel uit van het strafrecht. Met de invoering in 1951 van de Wet op de economische delicten is het economisch strafrecht een apart deel geworden van het bijzonder strafrecht. Strafbaar- 
stellingen uit andere wetten die zijn aangehaakt bij de Wed worden aangemerkt als economisch delict. In de Arbo-wet 1998 is in artikel 11 een zorgplichtbepaling opgenomen die is aangehaakt bij de Wed.

Het is opmerkelijk dat deze bepaling in eerste instantie wordt aangemerkt als (een via het bestuursrecht) beboetbaar feit. Het kan worden aangemerkt als strafbaar feit "indien twee maal binnen 48 maanden voorafgaand aan de handeling of het nalaten ter zake van eenzelfde handeling of nalaten een bestuurlijke boete is opgelegd." In dat geval is sprake van een overtreding, die wordt bedreigd met een hechtenis van ten hoogste zes maanden of een geldboete van ten hoogste de vierde categorie. Opmerkelijk is dat door deze constructie niet langer het feit maar de frequentie en het al dan niet beboeten van het feit bepalend zijn of sprake is van een strafbaar feit.

In hoofdstuk 9 wordt het milieustrafrecht besproken. In de bijzondere milieuwetten zijn enkele zorgplichtbepalingen opgenomen. Er lijkt echter nauwelijks sprake van systematiek zowel in het opnemen als in het afwijzen van dergelijke bepalingen, terwijl ook de vormgeving verschillen vertoont. Besproken wordt een drietal zorgplichtbepalingen in het milieustrafrecht, te weten de artikelen $2 \mathrm{Wms}, 13 \mathrm{Wbb}$ en 10.3 Wm.

Opvallend is dat deze bepalingen zijn aangehaakt bij de zwaarste categorie strafbaarstellingen van de Wed. Zij kunnen daardoor zijn aan te merken als misdrijf. Ook kennen zij een relatief zware maximale strafbedreiging. Voorts is het opmerkelijk dat de zorgplichtbepalingen uit het milieustrafrecht, in tegenstelling tot alle andere besproken zorgplichtbepalingen, subjectieve bestanddelen bevatten. De redactie van deze subjectieve bestanddelen wijkt overigens af van de gebruikelijke redactie; te weten "opzet" of "schuld". De afwijkende redactie wordt niet consequent gebruikt in de verschillende zorgplichtbepalingen.

Door de subjectieve bestanddelen ontstaat onduidelijkheid inzake de te volgen interpretatie. De subjectieve bestanddelen zijn bij de overtreding-variant niet van toepassing op alle bestanddelen van de delictsomschrijving, maar zien slechts op enkele bestanddelen. Voor de overige bestanddelen geldt dat culpa daar een element is. Deze subjectieve bestanddelen dienen door het verbindingswoord "of" te worden geïnterpreteerd als alternatieven. Hierdoor kennen de overtreding-varianten van deze zorgplichtbepalingen zowel een culpose als een opzettelijke variant. Schending van de besproken zorgplichtbepalingen vormt een misdrijf indien de normschending opzettelijk is begaan; in de overige gevallen is sprake van een overtreding. Hierdoor is bij de misdrijf-variant sprake van een "schuldkwadratuur". Diverse interpretatiemogelijkheden en de praktische consequenties daarvan worden besproken. Op basis hiervan wordt aangegeven welke interpretatiemethode moet worden gevolgd.

In hoofdstuk 10 worden de zorgplichtbepalingen die zijn geanalyseerd in de hoofdstukken $6,7,8$ en 9 getoetst aan de in hoofdstuk 3 ontwikkelde algemene vereisten van behoorlijke regelgeving. Hierbij wordt gebruik gemaakt van het in hoofdstuk 2 ontwikkelde terminologisch kader en van de in de hoofdstukken 4 en 5 onderzochte 
verhouding tussen het bestuur en de rechter en de voorwaarden voor strafbaarstelling. Door deze toetsing wordt duidelijk waar en waardoor knelpunten (kunnen) ontstaan bij de toepassing en toepasselijkheid van zorgplichtbepalingen.

In hoofdstuk $I I$ wordt aangegeven wat de belangrijkste knelpunten zijn. Teneinde deze zoveel mogelijk weg te nemen worden 34 concrete aanbevelingen geformuleerd. Hierbij is ook ingegaan op de in de hoofdstukken 4 en 5 gesignaleerde problemen.

De meeste zorgplichtbepalingen blijken enigszins (en sommige sterk) op gespannen voet te staan met de vereisten die invulling geven aan de waarborgfunctie van rege!geving én met de vereisten die invulling geven aan de functie van regelgeving als instrument. Deze spanning is overigens niet voor alle zorgplichtbepalingen even groot. De meeste problemen doen zich voor met zorgplichtbepalingen die vage bestanddelen bevatten, zoals de artikelen 5 WVW, artikel 5 Wet Luchtverkeer en de zorgplichtbepalingen in het milieustrafrecht.

De problemen met zowel de waarborgfunctie als met de functie van regelgeving als instrument worden ten dele door dezelfde kenmerken veroorzaakt. Deze kunnen voor een belangrijk deel worden opgelost door het vermijden van vage bestanddelen en door het inperken van het betekenisbereik van deze zorgplichtbepalingen.

Het is nodig de redactie van de bestaande zorgplichtbepalingen te herzien. Bij de invoering van nieuwe zorgplichtbepalingen is het van groot belang de redactie daarvan zoveel mogelijk in overeenstemming te brengen met de algemene vereisten van behoorlijke regelgeving. Er dient te worden gezocht naar goede alternatieven, ook indien het zorgplichtbepalingen betreft die een primaire rol spelen in de handhavingspraktijk. Door de realisering van de aanbevelingen kunnen knelpunten (ten dele) worden opgelost én is het mogelijk een evenwichtiger systeem van strafbaarstellingen te realiseren. Dit zal, zeker op de langere termijn, de waarborgfunctie én de instrumentele functie ten goede komen. 


\section{Summary}

This book deals with research that focuses on the role of duty of care provisions in Dutch criminal law. The central focus is on criminal provisions which punish the violation of a duty of care with criminal sanctions. The research deals with the question who determines the scope of the duty of care, and thereby sets the boundaries of criminal liability. It also investigates the way in which the boundaries are set and the (possible) problems associated with it. On the basis of the outcome of this research recommendations are given that can contribute to a (partial) solution of the identified problems.

In chapter $I$ the subject of the research is explained. This chapter also includes a description of the methodology. A duty of care provision is described as: A relatively generally formulated duty (of care) that represents a certain responsibility of the person to whom the norm refers and which can be enforced through criminal law. A law that uses a duty of care provision contains a general obligation to act with a certain degree of care regarding the interest of the matter that is protected by that law. The duty of care can deal with the actions as well as omissions by the persons concerned. The statutory implementation of a duty of care provision can take the form of a command (a positively formulated obligation), or the form of a prohibition.

In chapter 2 a theoretical distinction is made regarding the conditions for applying criminal law. It is indicated what is meant by the application and applicability of a legal rule. Interpretation and classification play an important role in this respect. Both methods are applied in the research on the scope of the duty of care provisions. The determination of the conditions under which duties of care are applicable can lead to difficulties. This work uses the so-called "Stereotype theory". By using this theory it is possible to give an analysis of the semantic problems involved in the application of legal rules. A description is given of the nature of vagueness and "open texture"; abstract, concrete and gradual terms; and evaluative and normative terms.

When the factors that determine the conditions under which duties of care can be applied are properly distinguished and the terms involved have been defined properly, the question is raised which body determines the scope of the duty of care provision. Research dealing with the question who determines the content of penalisation and therefore also the criminal liability, leads to the question which "actor" can determine, widen or restrict the extent of the liability. The various bodies that play a role in this connection are the legislator, the administrative authority and the judiciary. They can determine the additional criteria that must be fulfilled before the requirements for criminal liability are met. 
In chapter 3 the general requirements of proper legislation are formulated that should be taken into account by the body that introduces the duty of care provision. This concerns requirements of proportionality, legal certainty, equality before the law, coherence and effectiveness. These demands elaborate both the protective and instrumental function of legislation. These functions should be properly balanced. This is not a choice of one above the other, but it is a matter of trying to harmonise both functions. When infringements by the legislator are more significant, the guarantees should also be more secure.

Review of legal rules by means of the (aforernentioned) requirements should take place before the legislation comes into effect. The requirements can also be used for evaluation and revision of legislation. Through this process of review it will become clear where and why (possible) problems associated with the application and. applicability of legislation will occur. In this way it is possible to make a more conscious policy choice regarding the content and the meaning of the law under consideration.

In chapter 4 the role of the administrative authorities in determining the conditions for criminal provisions is described. In criminal legislation that falls outside the scope of the Penal Code, the administrative authorities play an important role in determining the material norm for the criminal provisions by using segmented norms. However, the administrative authority is never entirely free to determine the material norm.

Since criminal provisions intended to cover a certain type of conduct should cover neither more nor less than what is intended, many criminal provisions contain more specific elements. These can be elements that refer to the administrative norm, such as "unlawful". Another common approach is to add one or more exceptions to a general prohibition that referred to an administrative norm. It is not always clear whether the added criterion can be interpreted as a component or as a special ground for justification. This distinction has implication for criminal procedure. A "formal criterion" is used. If the exception is included in the sentence that contains the prohibition it is interpreted as a component. If the legislator finds that the exception should be a component, then it is desirable that he specify this accordingly. Due to the presumption in dubio pro reo, the judge may only deviate from the primary rule that the added criterion is a component when included in the sarne sentence as the criminal provisions. If the added criterion is laid down in a different place but there is reasonable doubt as to the correct interpretation, then the judge should likewise interpret the criterion as a component.

Chapter 5 discusses the role of the judge concerning the conditions for criminal provisions. It focuses on the legal powers, "exception through non-binding provisions", the convergence of procedures in administrative and criminal law and its consequences and the cumulation of the reactions in administrative and criminal law.

In chapter 6 the main focus is on the duties of care provisions contained in the Penal Code. This chapter addresses the difference between criminal offences and mis- 
demeanours as well as the transfer of law enforcement from criminal to administrative law. Subsequently five provisions in the Penal Code ( $\mathrm{Sr}$ ) regarding duties of care are discussed. These examples of duties of care provisions were laid down in the Dutch Penal Code in 1886, with the exception of article 429 at, paragraph $3 \mathrm{Sr}$, which was introduced in 1918.

The examples given for the duties of care in the Penal Code are all part of Book III (misdemeanours). The maximum penalty varies from a fine of the first category (article 427 at, paragraph 1 and $5 \mathrm{Sr}$ ) and or custody for a period of six days (article 426 at, first paragraph Sr), custody for fourteen days and/ or a fine of the second category (article 429 at, paragraph $3 \mathrm{Sr}$ ) to custody for a period of 6 months and a fine of the third category (article 425 at, paragraph $2 \mathrm{Sr}$ ).

Chapter 7 deals with criminal legislation that falls outside the scope of the Penal Code, which has developed rapidly since the establishment of the Penal Code. This area of criminal law also covers duties of care provisions. Moreover this chapter discusses article 5 of the Traffic Act (WVW), article 5 of the Air-traffic Act 1993 and article 19 of the Quarantine Act. Article 5 WVW, which is frequently applied, has served as a model for a number of duty of care provisions in this area of criminal law. In time the scope of this article has become wider and as a result the provisions have shifted from the specific provisions in the Regulation for Traffic Rules and Traffic Signs (RVV) to this provision.

It is striking that this provision has a twofold effect: on the one hand actions can be liable to punishment based on this article even when they are in accordance with other provisions; on the other hand actions that are in violation of another provision can be justified by this article. Therefore this article determines both the liability and the justifying circumstances. A criterion for the assessment of the actions in this case is determined by the interest to be protected by article $5 \mathrm{WVW}$ : traffic safety.

The examples discussed are all misdemeanours liable to punishment. When these duties of care provisions are violated this can lead to a maximum of two months custody and/ or a fine of the second category (article 5 WVW), six months custody and/ or a fine of the third category (article 5 Air-traffic Act), one year custody and/ or a fine of the third category (article Quarantine Act).

Chapter 8 deals with economical criminal law. This has been part of criminal law for quite a long time. With the introduction in 1951 of the Economic Crimes Act (Wed), economical criminal law became a separate part of criminal law. Provisions from other acts that have been linked with the Wed are qualified as economical crimes. The Occupational Health Act (Arbo-wet) of 1998 contains a duty of care provision in article 11 that has been linked with the Wed. It is noteworthy that this provision is initially qualified as an offence that can be punished with a fine (through administrative law). It can be considered a criminal offence if "twice within $\mathbf{4 8}$ months preceding the action or the omission of this action or negligence an administrative fine has been imposed". In such a case it is a (criminal) offence, that is liable to a 
maximum punishment of six months custody and/ or a fine of the fourth category. It is striking that through this construction it is no longer an (criminal) offence by itself but it is the frequency and consideration whether the offence has been fined that determine whether the act is a criminal offence.

In chapter 9 environmental law is discussed. Duties of care provisions have been included in some environmental laws. However, the way in which these provisions have been included or rejected does not appear very systematic. Furthermore when they are included this has not been done in a very uniform way. Three examples of duty of care provisions are discussed, viz: 2 Environmentally Dangerous Substances Act (Wms), 13 Protection of the Soil Act (Wbb) and 10.3 Environmental Management Act $(\mathrm{Wm})$.

It is notable that these provisions are linked with the most severe category of penalisation in the Wed. Consequently they can be qualified as a criminal offence. Furthermore they are also liable to relatively severe sanctions. In addition it is noteworthy that duty of care provisions in environmental law, contrary to all other duty of care provisions that have been discussed, contain a subjective component. The terminology used for these subjective components differs from the usual terminology; namely "opzet" ("intent") or "schuld" ("culpability"). This different terminology is not used consistently for the various duty of care provisions.

The subjective components create uncertainty concerning the intended interpretation. In case of the misdemeanour-variant the subjective components are not applicable to all components of the offence description, but are only applicable to some of them. As for the other components, Culpa is a condition for penalisation. These subjective components must be interpreted as alternatives giving the presence of the word "or". Consequently the misdemeanour version of these duty of care provisions contain two variants: one of culpability and one of intent. The duty of care provisions discussed are a criminal offence if the norm was intentionally violated; otherwise it concerns a misdemeanour. Therefore the criminal offence-variant can be qualified as a case of "guilt multiplication". Various interpretations and their practical consequences are discussed, on the basis of which an indication is given of the appropriate method of interpretation.

In chapter 10 the duty of care provisions that has been analysed in chapters $6,7,8$ and 9 is tested against the general requirements for proper legislation as developed in chapter 3. For this purpose use is made of the terminology developed in chapter 2 and of the relationship between administrative authority and judge, and the conditions for penalisation as investigated in chapters 4 and 5 . Through this test it becomes clear where and how problems (can) occur with the application and applicability of duty of care provisions.

In chapter $\| /$ the most problematic issues are discussed. A total of 34 concrete recommendations are formulated, aimed at resolving these problems as much as possible. The problems identified in chapters 4 and 5 are also taken into account here. 
Most duty of care provisions are found to be somewhat (and in some cases very much) at odds with the requirements that determine the safeguarding function of legislation and with the requirements for the function of legislation as an instrument. This problem is not equally significant for all duty of care provisions. Most problems occur with the duty of care provisions that contain vague terms; such as article $5 \mathrm{WVW}$, article 5 Air-traffic Act and the duty of care provisions in environmental law.

The problems with the safeguarding function and the function of legislation as instrument are in part caused by the same vague terminology. For the most part these problems can be solved by avoiding vague terminology and by reducing the scope of these duty of care provisions.

It is necessary to revise the terminology of existing duty of care provisions. With the introduction of new duty of care provisions it is important that the terminology used is in agreement with the general requirements for proper legislation. Good alternatives should be looked for, also in case it concerns the duty of care provisions that play a primary role in the law enforcement. The most important problems identified can be (partly) solved and it is possible to achieve a more balanced system of penalisation by implementing the proposed recommendations. This will, certainly in the more distant future, improve the safeguarding function as well as the instrumental function. 



\section{Literatuur}

* Aalders, M.V.C., "De politiefunctie van de bijzondere opsporingsambtenaar: Met beleid een overtreder naar de wettelijk gewenste situatie toe praten", Tijdschrift voor Criminologie, 1980, pp. 287-298.

* Aalders, M.V.C., Industrie, milieu en wetgeving; De Hinderwet tussen symboliek en effectiviteit, Amsterdam, Kobra, 1984.

* Aalders, M., "Handhaving en zelfregulering: Milieurecht in bedrijven", JV, 1994, nr. 9, pp. 47-69.

* Aalders, M. en Niemeijer, B., "Zelfregulering en reflexief handhaven in vier sectoren", in Coolsma, C. en Wiering, M., Handhaving in stukken; Bescouwingen over theorie en praktijk van de handhaving van recht, Amsterdam, Siswo, 1999, pp. 75-113.

* Acht, R.J.J. van en Bauw, E., Milieuprivaatrecht, Zwolle, Tjeenk Willink, 1996, pp. 35-68.

* Addink, G.H., "Het normerend karakter van de nieuwe afvalstoffenregelgeving", MenR, 1993, p. 687.

* Albinski, M., "Inbreng van sociaal-wetenschappelijk onderzoek in de beleidsvoering", in Nelissen, N., Geurts, J. en Wit, H. de (red.), Het verkennen van beleidsproblemen, Zeist, Kerckebosch, 1986, pp. 495-520.

* Alexy, R., Theorie der juristischen Argumentation; Die Theorie des Rationalen Diskarsus als Theorie der juristischen Begründung, Frankfurt am Main, Suhrkamp, 1978.

* Alkema, E.A., Studies over Europese grondrechten; De invloed van de Europese Conventie op het Nederlandse recht, Deventer, Kluwer, 1978.

* Alkema, E.A., Noot bij EHRM 20 november 1989, $N J$ 1991, 738 (Markt inern Verlag G.m.b.H. en Klaus Beermann v. Germany).

* Andel, L. van, De Indeeling der strafbare feiten in Misdrijven en Overtredingen, Leiden, D. Donner, 1894.

* André de la Porte, E., "Commentaar bij artikel 261", in Melai, A.L., voortgezet onder redactie van Groenhuijsen, M.S., Roos, Th.A. de en Swart, A.H.J. (red.), Het Wetboek van Strafvordering, Arnhem, Gouda Quint (losbladig).

" Angeren, J.A.M. van, "Beginselen van behoorlijke wetgeving", in Angeren, J.A.M. van, Fasseur, C, Hirsch Ballin, E.M.H. en Wiarda, J.J. (red.), Kracht van wet; Opstellen over publiekrechtelijke wetgeving, aangeboden aan Mr. W.J. van Eijkern bij zijn afscheid als hoofd van de Stafafdeling Wetgeving Publiekrecht van het Ministerie van Justitie, Zwolle, Tjeenk Willink, 1984, pp. 63-74. 
* Backes, Ch.W., Juridische bescherming van ecologisch waardevolle gebieden; Een rechtsvergelijkende studie overhet instrumentarium ter bescherming en ontwikkeling van ecologisch waardevolle gebieden en habitats in Nederland en Duitsland, Zwolle, Tjeenk Willink, 1993.

* Backes, Ch., "Legaliteit van een flexibele vergunning", in Wiggers-Rust, L.F. (red.), De flexibele milieuvergunning en bedriffsinterne milieuzorg, Lelystad, Vermande, 1997, pp. 23-38.

* Bakels, H.L., Schets van het Nederlands arbeidsrecht, Deventer, Kluwer, 1998.

* Bakker, S., Faure, M., Landen, D. van der, Niessen, R. en Roos, Th. de, "Algemene conclusies en vuistregels", in Faure, M. en Roos, Th. de (red.), De berekening van het wederrechtelijk verkregen voordeel uit milieudelicten, Den Haag, Sdu, 1998, pp. 249-275.

* Barendrecht, J.M., Recht als model van rechtvaardigheid; Beschouwingen over vage en scherpe normen, over binding aan het recht en over rechtsvorming, Deventer, Kluwer, 1992.

* Barendrecht, J.M., "Het constitutionele toetsingsrecht van de rechter", in Handelingen Nederlandse Juristen-Vereniging, 1992, Deel 1, Zwolle, Tjeenk Willink, pp. 85-172.

* Bart, M.P., "Enkele kanttekeningen bij het RVV 1990", VR, 1991, pp. 253-261.

* Bastmeijer, C.J., "De algemene zorgplicht in de Wet milieubeheer", MenR, 1993, pp. $466-475$.

* Bauw, E., Buiten-contractuele aansprakelijkheid voor bodemverontreiniging, Deventer, Kluwer, 1994.

* Bauw, E., "De privaatrechtelijke betekenis van zorgplichten in de milieuwetgeving", $A \& V, 1996$, pp. 96-102.

* Beccaria, C., Over misdaden en straffen, Zwolle, Tjeenk Willink, 1971.

* Beck, U., Risicogesellschaft; Auf dem Weg in eine andere Moderne, Frankfurt am Main, Suhrkamp, 1986.

* Beck, U., De wereld als risicomaatschappij; Essays over de ecologische crisis en de politiek van de vooruitgang, Amsterdam, De balie, 1997.

" Becker, G., "Crime and Punishment: an Economic Approach", Joumal of Political Economy, 1968, pp. 169-217.

* Beckers, W.J.G.M., "Artikel 25 Wegenverkeerswet, een blijk van legislatieve onmacht", $V R, 1975$, pp. 121-124.

* Beekhuis, J.H., Rechterlijke matiging bij de actie tot schadevergoeding uit onrechtmatige daad: rede uitgesproken bij de aanvaarding van het hoogleeraarsambt in de faculteit der rechtsgeleerdheid aan de Rijksuniversiteit te Groningen op Zaterdag 21 Januari 1939, Groningen, Wolters, 1939.

* Bekkers, V.J.J.M., Hurk, H.T.P.M. van den en Leenknegt, G. (red.), Subsidiariteit en Europese integratie; Een oude wijsheid in een nieuwe context, Zwolle, Tjeenk Willink, 1995.

* Belinfante, A.D., Kort begrip van het administratief recht, Alphen a/d Rijn, Samsom, 1968.

* Bemmelen, J.M. van, "Aansprakelijkheid voor Economische Delicten", NJB, 1954, pp. 689-695. 
* Bemmelen, J.M. van, Op de grenzen van het strafrecht, Haarlem, Tjeenk Willink, 1955.

* Bermmelen, J.M. van, "Positieve criteria voor strafbaarstelling", in Glastra van Loon, J.F., Haersolte, R.A.V. van en Polak, J.M. (red.), Speculum Langemeijer; 31 rechtsgeleerde opstellen, Zwolle, Tjeenk Willink, 1973, pp. 1-14.

* Bermmelen, J.M. van en Veen, Th.W. van, bewerkt door Jong, D.H. de en Knigge, G., Het materiële strafrecht; Algemeen deel, Deventer, Gouda Quint, 1998.

* Berg, E.A.I.M. van den, Openbaar Ministerie en milieu; terugblik op 1992: tweede meting 'planning \& control milieuwethandhaving', Den Haag, Ministerie van Justitie, WODC, 1994.

* Berg, E.A.I.M. van den en Eshuis, R.J.J., Grote strafrechtelijke milieuonderzoeken, WODC, Amhem, Gouda Quint, 1996.

* Berg, W., "Vom Wettlauf zwischen Recht und Technik", Juristen Zeitung, 1985, pp. 401-407.

* Berge, J.B.J.M. ter en Zijlstra, S.E., "De publiekrechtelijke rechtspersoon in ontwikkeling", in Handelingen Nederlandse Juristen-Vereniging, De ontwikkeling van de rechtspersoon in het publiekrecht en het privaatrecht, Deventer, Tjeenk Willink, 2000, pp. 1-101.

* Bergh, G.C.J.J. van den, Themis en de muzen; de functie van de gebonden vormen in het recht, Haarlem, Tjeenk Willink, 1964.

* Bergh, G.C.J.J. van den, Recht en Taal; Preadvies, Publikatie van de Koninklijke Notariële Broederschap, Deventer, Kluwer, 1979.

* Bergh, G.C.J.J., van den, "Inleiding" in J.I. de Haan, De taal zegt meer dan zij verantwoorden kan; een keuze uit de verspreide rechtskundig-signifische geschriften van Mr. Jacob Israel de Haan, Verzameld en ingeleid door Prof. Mr. G.C.J.J. van den Bergh, Ars Aequi Libri, Nijmegen, 1994, pp. IX.LIII.

* Besier, B.J., "Het kapstokartikel 22 sub a der Motor- en Rijwielwet", NJB, 1934, pp. 282-284.

* Besier, L.Ch, "Rechtvaardigingsgrond of bestanddeel van het strafbaar feit?", Rechtsgeleerd Magazijn, 1897, pp. 183-207.

* Betlem, G. en Messer, E.A., "Aansprakelijkheid voor milieuschade: een reactie", $A A, 1990$, pp. 519-523.

* Biegman-Hartogh, Conclusie bij HR 3 oktober1986, NII 1987, 911, met noot Scheltema; $A B$ 1987, 90, met noot van der Burg (Heffing op auto's Antillen).

* Biezeveld, G.A. en Fransen, A.M., "Zorgplichtbepalingen spelen nuttige rol in milieustrafrecht", NJB, 1994, p. 64.

" Biezeveld, G.A., "Naar een Europees milieustrafrecht", in Biezeveld, G.A., e.a. (red.), Strafrechtelijke aanpak van grensoverschrijdende milieucriminaliteit, Capita Selecta: rapport, Zwolle, Tjeenk Willink, 1996, pp. 117-130.

* Biezeveld, G.A., "Handhaving op basis van de flexibele vergunning vanuit strafrechtelijk perspectief", in Wiggers-Rust, L.F. (red.), De flexibele milieuverginning en bedrijfsinterne milieuzorg, Lelystad, Vermande, 1997, pp. 57-65.

* Biggelaar, G.J.M. van den, De buitengerechtelijke afdoening van strafbare feiten door het openbaar ministerie, Arnhem, Gouda Quint, 1994. 
* Bijloos, A.W.M., Administratieve boeten en art. 6 EVRM in Nederland. Preadvies Vereniging voor de Vergelijkende Studie van het Recht van Belgiẻ en Nederland, Zwolle, Tjeenk Willink, 1989.

* Binding, G., Die Normen und ihre Ubertretung, Erster Band Normen und Strafgesetze, Leipzig, Verlag von Wilhelm Engelmann, 1890.

- Bins, A.J., "Cassatie in strafzaken", in Davelaar-van Tongeren, V.H., Keijzer, N. en Pol, U. van de (red.), Strafrecht in Perspectief. Een bundel bijdragen op strafrechtelijk gebied ter gelegenheid van het 100-jarig bestaan der Vrije Universiteit te Amsterdam, Amhem, Gouda Quint, 1980, pp. 263-288.

* Binsbergen, W.C. van, "Analogische uitbreiding van strafbepalingen in het licht der rechtsgeschiedenis", in Opstellen over recht, wet en samenleving op 1 October 1948 door vrienden en leerlingen aangeboden aan Prof. Mr. W.P.J. Pompe, Nijmegen-Utrecht, Dekker \& Van de Vegt, 1948, pp. 36-54.

- Binsbergen, W.C. van, Algemeen karakter van het Crimineel Wetboek voor het Koninkrijk Holland, Utrecht, De Vioede, 1949.

* Bloembergen, A.R., "Rechtsvorming door de rechter", Bouwrecht, 1989, pp. 494. 496.

* Bloembergen, E., "Met welke straffen en maatregelen, door welke rechterlijke en bestuursorganen, naar welke regelen van proces behooren overtredingen van overheidsregelingen van het economisch leven te worden beteugeld?", in Handelingen der Nederlandsche juristen-vereeniging, (eerste stuk), Zwolle, Tjeenk Willink, 1947, pp. 96-129.

* Blornberg, A.B. en Michiels, F.C.M.A., Handhaven met effect. Een empirischjuridische studie naar de mogelijkheden voor een effectieve handhaving van het milieurecht, 's-Gravenhage, Vuga, 1997.

* Blomberg, A.B., Integrale handhaving van het milieurecht, Den Haag, Boom, 2000.

* Boek, J.L.M. in Cleiren, C.P.M. en Nijboer, J.F. (red.), Strafrecht. Tekst en Commentaar, Deventer, Kluwer, 1997.

* Boes, M. en Deketelaere, K., "Administratieve sancties", in Bocken, H. en Verbeek, P. (red.), Voorontwerp van kaderdecreet milieuhygiëne, Verslag van de werkzaamheden van de Interuniversitaire Commissie tot Herziening van het Milieurecht, Gent, Seminarie voor Milieurecht, 1991, pp. 165-195.

* Boon, P.J., Brouwer, J.G. en Schilder, A.E., Regelgeving in Nederland, Deventer, Tjeenk Willink, 1999.

* Borman, T.C., Wet op de economische delicten, Zwolle, Tjeenk Willink, 1994.

* Bos, A.M., Het begrip strafbaar feit in de rechtsvorming, Deventer, Kluwer, 1971 .

* Bos, J.T., "Het schuldoordeel als machtswoord", Recht en Kritiek, 1982, pp. 5-42.

* Bos, P.A.H., "Osmose tussen het economische en commune strafrecht", SEW, 1976, pp. 381-387.

* Bosch, A.G., Het ontstaan van het Wetboek van Strafrecht; Aantekeningen over de werkzaamheden van de staatscommissie in 1870 belast met de samenstelling. van een ontwerp van een nieuw Wetboek van Strafrecht, Zwolle, Tjeenk Willink, 1965. 
* Bovens, M.A.P. en Witteveen, W.J. (red.), Het schip van staat; Beschouwingen over recht, staat en sturing, Zwolle, Tjeenk Willink, 1985.

* Bovens, M.A.P., Derksen, W. en Witteveen, W.J. (red.), Sturing van de samenleving; Conferentie over 'Het schip van staat', Zwolle, 'Tjeenk Willink, 1986.

* Bovens, M.A.P., Derksen, W. en Witteveen, W.J., (red.), Rechtsstaat en sturing, Zwolle, Tjeenk Willink, 1987.

* Bracke, N.E., Voorwaarden voor goede EG-wetgeving; Een onderzoek naar de kwaliteit van Europese wetgeving, Den Haag, Sdu, 1996.

* Brandhof, J.C.E. van den, "Reactie; Pretenties van wetgeving", Openbaar bestuur, 1992, nr. 8, pp. 6-7.

* Brants C.H. en Lange, R. de, Strafvervolging van overheden, Deventer, Gouda Quint, 1996.

* Brants, C., "The King can do no wrong. Daderschap, feitelijk leidinggeven en de Staat", $D D, 1996$, pp. 509-532.

* Brants, C., "The King can do no wrong", naschrift, DD, 1996, pp. 655-659.

* Brenninkmeijer, A.F.M., "Constitutioneel toetsingsrecht als vraagstuk van constitutioneel recht", NJB, 1992, pp. 721-725.

* Brenninkmeijer, A.F.M., "Democratische rechtspraak en ondemocratische wetgeving", NJB, 1993, pp. 1387-1395.

* Broek, J.H.G. van den, "Europa op weg naar een integrale milieuvergunning. IPPC in werking getreden", MenR, 1997, pp. 7-15.

* Bronswijk, F. van, "Afval als aalmoes", Ons Amsterdam, 1998, pp. 64-68.

* Brouns, P.J.H.M., Opzet in het wetboek van strafrecht, Arnhem, Gouda Quint, 1988.

* Brouwer, D.A.V., Dwangmiddelen in bijzondere wetten; Facetten van strafrechtspleging, Deventer, Gouda Quint, 1999.

* Brouwer, D.A.V., "Het verkennend onderzoek in strafzaken en de wetgevingsspiraal", $N J B, 2000$, pp. 637-640.

* Brouwer, J.G. en Schilder, A.E., "Het wetsvoorstel bestuurlijke ophouding; Een verkenning van de rechtsstatelijke grenzen", NJB, 1999, pp. 1640-1648.

* Brucken Fock, E.P. von, bewerkt door Dorst, A.J.A. van, Cassatie in strafzaken, Deventer, Tjeenk Wilink, 1998.

* Buiting, Th.J.B. en Huygen, A.E.H., "Milieustrafrecht: een ondoordachte chaos", in Buuren, P.J.J. van, Betlem, G. en Ylstra, T. (red.), Milieurechi in stelling, Utrechtse opstellen over actuele thema's in het milieurecht, Zwolle, 1990, pp. 72 95.

* Buiting, Th.J.B., Strafrecht en milieu, Amhem, Gouda Quint, 1993.

* Bunt, H. van de en Roos, Th. de, "Zwarte toga's kontra witte boorden?", Recht en Kritiek, 1983, pp. 6-50.

* Bunt, H.G. van de, "Bestuurlijke verwachtingen en ervaringen omtrent de strafrechtelijke handhaving van milieurecht", in Bunt, H.G. van der, Veen, O.C.W. van der en Verfaille, P. (red.), Strafrechtelijke handhaving van het milieurecht; Verslag van de zestiende ledenvergadering van de Vereniging voor Milieurecht op 17 september 1987, Zwolle, Tjeenk Willink, 1989, (tweede deel) pp. 1-28. 
* Buruma, Y., De strafrechtelijke handhaving van bestuurswetten, Arnhem, Gouda Quint, 1993.

* Buruma, Y. en Daalder, E.J., "Formele rechtskracht in het strafrecht", RM Themis, 1994, pp. 320-334.

- Buruma, Y., "Het schuldig subject", in Borgers, M.J., Koopmans, I.M. en Kristen, F.G.H. (red.), Verwijtbare uitholling van schuld?, Nijmegen, Ars Aequi Libri, 1998, pp. 1-9.

* Buuren, P.J.J. van, "De bestuurlijke boete in het bestuursrecht", MenR, 1998, pp. 60-62.

* Buuren, P.J.J. van, Jurgens, G.T.J.M. en Michiels, F.C.M.A., Bestuursdwang en dwangsom, Deventer, Tjeenk Willink, 1999.

* Carnap, R. Meaning and Necessity; A study in semantics and modal logic, Chicago, The University of Chicago Press, 1956.

- Cleiren, C.P.M., Beginselen van een goede procesorde; Een analyse van rechtspraak in strafzaken, Amhem, Gouda Quint, 1989.

- Cleiren, C.P.M. en Nijboer, J.F. (red.), Strafrecht. Tekst en Commentaar, Deventer, Kluwer, 1997.

* Cluysenaer, J.L.H., "De toetsing van administratieve beschikkingen door de strafrechter", NJB, 1970, pp. 1000-1007.

* Cnopius, A.A., "Het derde boek van het Wetboek van strafrecht in de praktijk", TvS, 1898, pp. 51-73.

* Commissie bestuursrechtelijke en privaatrechtelijke handhaving (Commissie Michiels), Handhaven op niveau, Deventer, Tjeenk Willink, 1998.

* Commissie Kleine Criminaliteit (onder voorzitterschap van H.J. Roethof), Interimrapport, 's-Gravenhage, Staatsuitgeverij, 1984.

* Commissie Kleine Criminaliteit (onder voorzitterschap van H.J. Roethof), Eindrapport, 's-Gravenhage, Staatsuitgeverij, 1986.

* Commissie Vermindering en vereenvoudiging van overheidsregelingen (Commissie Geelhoed), "Eindrapport", TK 1983-1984, nr. 17 931, nr. 9.

* Commissie Marktwerking, Deregulering en Wetgevingskwaliteit een MDWwerkgroep ingesteld die de opdracht heeft gekregen bouwstenen aan te dragen voor een adviesaanvraag aan de SER over de heroriëntatie op de Arbo-wet 1980.

* Commissie voor de Toetsing van Wetgevingsprojecten, "Jaarverslag van de Commissie voor de Toetsing van Wetgevingsprojecten over het jaar 1987-1988", TK 1988-1989, 20 800, hoofdstuk VI, nr. 13.

* Commissie voor de Toetsing van Wetgevingsprojecten, Advies van de Commissie voor de Toetsing van Wetgevingsprojecten inzake zorgplichtbepalingen, CTW 90/6, 20 augustus 1990 .

* Commissie voor de Toetsing van Wetgevingsprojecten, "Jaarverslag van de Commissie voor de Toetsing van Wetgevingsprojecten over het jaar 1989-1990", TK 1990-1991, 21800 VI, nr. 24.

* Conmissie voor de Toetsing van Wetgevingsvraagstukken, Implementatie van EG-regelgeving in de nationale rechtsorde, CTW 90/22, 21 december 1990.

- Commissie voor de Toetsing van Wetgevingsprojecten, Handhaving door bestuurlijke boeten, CTW 94/1, 12 januari 1994. 
* Commissie voor de Toetsing van Wetgevingsprojecten, Van Keurslijf naar Keurmerk; Wetgevingsbeleid voor veilig en gezond werk, CTW 1994/12, 30 juni 1994.

* Commissie Wetgeving algemene regels van bestuursrecht (Commissie Scheltema), Voorontwerp Algemene wet bestuursrecht; Vierde tranche, Den Haag, 1999.

* Cormmissie Wetgevingsvraagstukken, Orde in de regelgeving; Eindrapport van de Commissie Wetgevingsvraagstukken, 's-Gravenhage, Staatsuitgeverij, 1985.

* Coopmans, J.P.A., "Nullum delictum, nulla poena sine praevia lege poenali", in Spruit, J.E. en Vrugt, M. van de (red.), Brocardica in honorem G.C.J.J. van den Bergh; 22 studies over oude rechtsspreuken, Deventer, Kluwer, 1987, pp. 21-26.

* Corstens, G.J.M., Een stille revolutie in het strafrecht, Amhem, Gouda Quint, 1995.

* Corstens, G.J.M., Het Nederlands strafprocesrecht, Deventer, Gouda Quint, 1999.

* Corstens, G.J.M., "Civielrechtelijke, administratiefrechtelijke of strafrechtelijke rechtshandhaving?", Handelingen 1984 der Nederlandse Juristen-Vereniging, Deel I, eerste stuk, Zwolle, Tjeenk Willink, pp. 1-126.

* Crombag, H.F.M., Wijkerslooth, J.L. de en Cohen, M.J., Een theorie over rechterlijke beslissingen, Groningen, Tjeenk Willink, 1977.

* Daudt, H., "Legitimiteit en legitimatie", Beleid en maatschappij, 1975, pp. 5-16.

* Deinse, A.J. van, Het Wetboek van Strafregt (Code Pénal); Met wijzigingen, daarin aangebragt sedert 1810 en laatstelijk bij de wetten van 29 junij 1854, Staatsblad 102 en 103, benevens de opgave van eenige speciale straf-verordeningen, Middelburg, Altorffer, 1854.

* Deinse, A.J. van, Strafwetten; Opgave van Speciale wetten en koninklijke besluiten als algemene maatregelen van inwendig bestuur, welke onderwerpen behelzen, waarop strafbepalingen zijn vastgesteld of betrekking hebben, en welke met en benevens het Wetboek van Strafregt regtsgeldende zijn; met aantekeningen, verzameld door Mr. A.J. van Deinse, Middelburg, Altorffer, 1857.

* Deketelaere, K., "Administratiefrechtelijke handhaving van de milieuhygiënewetgeving in het Vlaanse gewest", Jura Falconis, 1990-1991, pp. 207-26i.

* Demeersseman, H.A., De autonomie van het materiële strafrecht, Armhem, Gouda Quint, 1985.

* Denuyck, F., De rechtspersoon in het strafrechi, Gent, Mys \& Breesch, 1996.

* Deruyck, F., "Naar een strafrechtelijke aansprakelijkheid van de rechtspersoon in Belgiê?", in Faure, M. en Schwarz, K. (red.), De strafrechtelijke en civielrechtelijke aansprakelijkheid van de rechtspersoon en zijn bestuurders, Groningen-Antwerpen, Intersentia, 1998, pp. 35-47.

* Diepenhorst, P.A., De Nederlandsche arbeidswetgeving, Utrecht, G.J.A. Ruys, 1921.

* Diez, J. en Gneiting, J., "Koordinationsprobleme zwischen Verwaltungs- und Strafrechtsimplemention im Umweltbereich", Monatschrift für Kriminologie und Strafrechtreform, 1989, pp. 190-211.

* Dijke, P. van, Goede, B. de, Kocken, E.H.A., Polak, J.M. en Reijen, L.G. van (red.), De 14 wetsfamilies; Verslag van de op 18 februari 1977 gehouden 
studiedag aangeboden aan dr. S.O. van Poelje in verband met zijn afscheid van het Institunt voor bestuurswetenschappen, 's-Gravenhage, Uitgeverij van de Vereniging van Nederlandse Gemeenten, 1977.

" Doelder, H. de, "De verhouding van artikel 25 WVW en het nieuwe RVV", $V R$, 1989, pp. 291-294.

* Dölle, A.H.M., "De prijs voor afschaffing van het toetsingsverbod is nog te hoog", Namens, 1989, afl. 5, pp. 13-15.

* Dölle, A.H.M. en Engels, J.W.M., Constitutionele rechtspraak, Groningen, Wolters-Noordhoff, 1989.

* Dölle, H., Vom Stil der Rechtssprache, Tübingen, Verlag J.C.B. Mohr (Paul Siebeck), 1949.

- Dommering, E.J., "Wetgevingsonrecht en wetsprekende rechters", Regelmaat, 1989, pp. 1-9.

* Donk, W.A. van der, "Rondom de regel 'Nulla poena sine lege, nulla poena sine crime, nullum crimen sine poena legali"', TvS, 1935, pp. 337-399.

- Doorenbos, D.R., "Schuldkwadratuur. Iets over de betekenis van art. 2 lid 1 WED"', DD, 1990, pp. 810-819.

- Doorenbos, D.R., Financieel strafrecht; een studie inzake strafrechtelijk gesanctioneerde voorschriften uit de bank- en effectenwetgeving, Deventer, Kluwer, 1992.

* Doorenbos, D.R., "De WED als bron van strafprocesrecht", in Balkema, J.P., Barels, M., Lensing, J.A.W., Machielse, A.J.M. en Sackers, H.J.B., Dynamisch strafrecht. Opstellen ter gelegenheid van het afscheid van Prof. mr. G.J.M. Corstens van de Katholieke Universiteit Nijmegen, Arnhem, Gouda Quint, 1995, pp. 69-83.

* Dorst, A.J.A. van, "Enkele aspecten van art 1 Wetboek van Strafrecht", in Geppaart, Ch.P.A., Schoordijk, H.C.F. en Dorst, A.J.A. van (red.), Macht en onmacht van de wetgever. Opstellen uitgegeven ter gelegenheid van het 50-jarig bestaan van de katholieke hogeschool en het i5-jarig bestaan van de faculteit der rechtsgeleerdheid in Tilburg, Deventer, Kluwer, 1978, pp. 169-187.

* Dorst, A.J.A. van, Conclusie bij HR 27 juni 1995, NJ 1995, 722; MenR 1996, nr. 6 , met noot Hendriks (Uitleg, vergunningvoorschritt is feitelijk).

* Dreher, E. en Tröndle, H. (Hrsg.), Beck'sche Kurzkommentar, Strafgesetzbuch und Nebengesetze, München, C.H. Beck'sche Verlagbuchhandlung, 1993.

* Dresden, M.J., "De zorgplicht in de milieuwetgeving", MenR, 1989, pp. 50-67.

* Driessche, H. van, "Evolutie naar de strafrechtelijke (milieu) aansprakelijkheid van alle publiekrechtelijke rechtspersonen?", $R W, 1999-2000$, pp. 833-843.

* Diongelen, J. van, De ontwikkeling van de arbeidsinspectie in een veranderende wetgeving, Scheveningen, Ellkerbout, 1991.

* Drupsteen, Th.G., "Aansprakelijkheid voor milieuschade", $A A, 1990$, pp. 275285.

* Drupsteen, Th.G. en Kleijs-Wijnnobel, C.J., "Handhaving van milieurecht door middel van civiel-, administratief- en strafrecht", in Faure, M., Oudijk, J.C. en Schaffmeister, D. (red.), Zorgen van heden. Opstellen over het Milieustrafrecht in theorie en praktijk, Amhem, Gouda Quint, 1991, pp. 31-47.

* Drupsteen, Th.G., "De overheid straffeloos?", MenR, 1996, 155. 
* Drupsteen, Th.G., "Kroniek van het milieurecht", NJB, 1999, pp. 1531-1539.

* Dullemen, A.A.L.F. van, "Met welke straffen en maatregelen, door welke rechterlijke en bestuursorganen en naar welke regels van proces behooren overtredingen van overheidsregelingen van het economisch leven te worden beteugeld?", in Handelingen der Nederlandsche juristen-vereeniging, (eerste stuk), Zwolle, Tjeenk Willink, 1947.

* Duk, W., "Beoordelingsvrijheid en beleidsvrijheid", RM Themis, 1988, pp. 156169.

* Dupont, L., Beginselen van behoorlijke strafrechtsbedeling: bijdrage tot het grondslagenonderzoek van het strafrecht, Amhem, Gouda Quint, 1979.

* Eck, D. van, "Enkele beschouwingen omtrent het nulla-poena-beginsel", in Recht en ethiek; Geschriften van prof. $m r$. D. van Eck, (samengesteld door van Agt A.A.M. en Pijls H.M.), Deventer, Kluwer, 1971, pp. 107-127.

* Eck, D. van, Luchtverkeersleiding en aansprakelijkheid, Ridderkerk, Ridderprint, 1997.

* Eggens, J., Transpositie en conversie, Den Haag, Drukkerij Belinfante, 1946.

* Eggens, J., Verzamelde privaatrechtelijke opstellen van mr. J. Eggers, Deel 2, Alphen aan den Rijn, Samsom, 1959.

* Eijkern, W.J. van, "De macht van de zwoegers in het vooronder. Rechtsvorming door juristen via het werk van de afdeling wetgeving", in Leyten, J., Maarseveen, H. van, d'Oliveira, U., Polak, J.M., Verburgh, I. (red.), De jurist-ambtenaar, Bundel opstellen opgedragen aan Mr. J.M. Kan, Zwolle, Tjeenk Willink, 1977, pp. 39-48.

* Eijlander, $\mathrm{Ph}$. , "Wetgeving in de jaren negentig; van deregulering naar algerneen wetgevingsbeleid", Regelmaat, 1990, pp. 26-32.

* Eijlander, Ph., De wet stellen. Beschouwingen over onderwerpen van wetgeving, Zwolle, Tjeenk Willink, 1993.

* Eijlander, Ph. en Voermans, W., "Nieuwe aanwijzingen voor de regelgeving", NJB, 1993, pp. 169-174.

- Eijlander, P. en Voermans, W.I.M., Wetgevingsleer, Deventer, Tjeenk Willink, 1999.

* Eikema Hommes, H.J. van, De elementaire grondbegrippen der rechtswetenschap, Deventer, Kluwer, 1972.

* Engels, J.W.M., "Toetsing van de wet: rechter naast wetgever", Namens, 1989, pp. 5-12.

* Enschedé, Ch.J., "Strafrecht", in Vooruitzichten der Rechtswetenschap, Deventer, Kluwer, 1964, pp. 31-65.

* Enschedé, Ch.J., "Strafrecht" in Vooruitzichten der Rechtswetenschap, Deventer, Kluwer, 1983, pp. 15-36.

" Enschedé, Ch.J., "Het wetboek als boek", in Balkema, J.P., Corstens, G.J.M., Fijnaut, C., Keijzer, N., Melai, A.L., Rüter, C.F. en Strijards, G.A.M. (red), Gedenkboek. Honderd jaar Wetboek van Strafrecht, Amhem, Gouda Quint, 1986, pp. 7-13. 
* Enschedé, Ch.J. en Corstens, G.J.M., "Strafrecht en strafvordering", in Komen, A. en Rutten-Roos, A. (red.), Nederlands recht in kort bestek, Deventer, Kluwer, 1988, pp. 229-230.

* Eser, A., Heine, G. en Huber, B. (red.), Criminal Responsibility of Legal and Collective Entities, Freiburg, Max-Planck-Institut, 1999.

* Faure, M. en Heine, G., "The Insurance of Fines: the Case of Oil Pollution", The Geneva Papers on Risk and Insurance, 1991, pp. 39-58.

- Faure, M.G., "De gevolgen van de 'administratieve afhankelijkheid' van het milieurecht: een inventarisatie van knelpunten", in Faure, M.G., Oudijk, J.C., Schaffmeister D. (red.), Zorgen van heden. Opstellen over milieustrafrecht in theorie en praktijk, Arnhem, Gouda Quint, 1991, pp. 91-150.

- Faure, M., "Bedenkingen over de rol van het strafrecht bij de bestrijding van milieuverontreiniging", in Om deze redenen. Liber Amicorum Armand Vandeplas, Gent, Mys en Breesch uitgevers, 1994, pp. 229-263.

* Faure, M., "De handhaving van het Bodemsaneringsdecreet via toezicht, dwangmaatregelen en strafsancties", in Deketelaere, K. (red.), Het decreet betreffende de bodemsanering, Brugge, De Keure, 1995, pp. 215-252.

" Faure, M., "Waarom milieustrafrecht?", Recht en Kritiek, 1995, pp. 446-479.

- Faure, M., "Bedenkingen over de rol van het recht bij grensoverschrijdende milieuverontreiniging", in Biezeveld, G.A., e.a. (red.), Strafrechtelijke aanpak van grensoverschrijdende milieucriminaliteit. Capita Selecta, Zwolle, Tjeenk Willink, 1996, pp. 231-242.

* Faure, M., "Economic Aspects of Environmental Liability: an Introduction", European Review of Private Law, 1996, pp. 85-110.

* Faure, M., "Strafrechtelijke aansprakelijkheid, toezicht en sancties in het Decreet Bedrijfsinterne Milieuzorg", in Deketelaere, K. (red.), Algemene bepalingen Vlaams milieubeleid en bedrijfsinterne milieuzorg, Brugge, Die Keure, 1996, pp. 217-269.

* Faure, M. en Lefevere, J.G.J., "The Draft Directive on Integrated Pollution Prevention and Control: an Economic Perspective", European Environmental Law Review, 1996, pp. 112-122.

* Faure, M. en Visser, M., "Het tekort van het Nederlandse milieustrafrecht", in Kraaij, M. van en Veen, A. van (red.), Onderneming en strafrecht, Nijmegen, Ars Aequi Libri, 1997, pp. 123-144.

* Faure, M. en Roos, Th. de (red.), De berekening van het wederrechtelijk verkregen voordeel uit milieudelicten, Den Haag, Sdu, 1998.

* Faure, M. en Visser, M., De strafrechtelijke bescherming van het leefmilieu in België, Duitsland en Nederland. Modellen van strafbaarstelling en hun bewijsrechtelijke implicaties, Antwerpen, Intersentia, 1999.

* Faure, M., "Opinie; Afscheid van het milieustrafrecht?", MenR, 2000, p. 143.

* Feltz, A.A. van der, "Element of Fait justificatif", W., nr. 6343, 12 juni 1893.

* Feuerbach P.J.A. Revision der Grundszäte und Grundbegriffe des positiven peinlichen Rechts, Chemniß, Georg Freiedrid Faßche, 1800.

* Feuerbach P.J.A., Lehrbuch des gemeinen in Deutschland geltenden peinlichen Rechts, Gießen, Georg Friedrich Heyer, 1801. 
* Fockema Andreae, J.P., "Welke methode behoort te worden gevolgd bij de herziening van ons Burgerlijk Recht (inrichting en indeeling van het Wetboek; herziening in een of bij gedeelten; wijze van voorbereiding en behandeling)" in Handelingen der Nederlandsche Juristen-Vereeniging, Tweede stuk, 'sGravenhage, F.B. Belinfante, 1912, pp. 161-233.

* Fokkens, Conclusie bij HR 6 november 1990, $N J$ 1991, 257, met noot van Veen (Daalse Tunnel).

* Fokkens, Conclusie bij HR 25 januari 1994, $N J$ 1994, 598, met noot Corstens (Vliegbasis Volkel).

* Fokkens, Conclusie bij HR 23 april 1996, NJ 1996, 512 (Waterschap Westfriesland).

* Foqué, R. en Hart, A.C. 't, Instrumentaliteit en Rechtsbescherming, Arnhem, Gouda Quint, 1990.

* Fortanier, G.F. en Veraart, J.J.M., herzien door Rang, J.F., Arbeidsrecht, 'sGravenhage, Vuga, 1983.

* Foyer, H.A., "Economisch Recht; Een nieuw onderdeel der rechtswetenschap", RM Themis, 1945/1946, pp. 410-452.

* Franken, A.A., Hoofdstuk 23 "Alternatieve afdoeningsmogelijkheden" (augustus 1998), in Corstens, G.J.M., Doorenbos, D.R., Keijzer, N. en Sutorius, E.W.H.R. (red.), Vademecum strafzaken, Amhem, Gouda Quint (losbladig).

* Franken, H., e.a., InLeiden tot de rechtswetenschap, Deventer, Gouda Quint, 1995.

* Fransen, T., "Arrest Hoge Raad stelt overheid boven wet", Handhaving, 1996, nr. 3, p. 3.

* Frege, "Über Sinn und Bedeutung", Zeitschrift für Philosophie und philosophische Kritik, 1892, Teil 100, pp. 25-50.

* Frenkel, B.S. en Jacobs, A.T.J.M., Sociaal bestuursrecht, Alphen aan den Rijn, Samsom/H.D. Tjeenk Willink, 1986.

* Geers, A.J.C.M. en Gevers, J.K.M., Arbeidsomstandighedenrecht, Deventer, Kluwer, 1979.

* Geers, A., Veilig en wel; de Arbeidsomstandighedenwet: een nieuwe taak voor de OR, Alphen aan den Rijn, Samsom, 1981.

* Geers, A.J.C.M., "Arbeidsbeschermingsrecht", in Fase, W.P.J.M. (red.), Inleiding sociaal recht, Groningen, Wolters-Noordhoff, 1987, pp. 200-220.

* Geers, A.J.C.M., Recht en humanisering van arbeid, Deventer, Kluwer, 1988.

" Geers, A., "Inleiding", in Geers, A. (red.), Schets Arbeidsomstandighedenrecht, Deventer, Kluwer, 1991, pp. 13-24.

* Geers, A.J.C.M. en Popma, J.R., "Voorstel arbeidsomstandighedenwet 1998", SMA, 1998, pp. 247-256.

* Geers, A.J.C.M. en Popma, J.R., "Arbowet 1998 niet millenniumproof", SMA, 1999, pp. 234-245.

* Geest, H.J.A.M. van, Leede, L.J.M. de en Ringeling, A.B., "De weerbarstige norm" in Geest, H.J.A.M. van, Leede, L.J.M. de en Ringeling, A.B. (red.), Regel en Praktijk; Opstellen aangeboden aan prof. mr. S. F. L. baron van Wijnbergen, ter gelegenheid van zijn 25-jarig ambtsjubileum als hoogleraar staats- en 
bestuursrecht aan de Katholieke Universiteit te Nijmegen, Zwolle, Tjeenk Wilink, 1979, pp. 1-12.

* Geest, H.J.A.M. van, "Marktwerking, deregulering en wetgevingskwaliteit: forenzen tussen macht en markt", MenR, 1996, pp. 118-122.

* Gerritzen-Rode, P.W.A., "Kroniek van het milieurecht", NJB, 1993, p. 1229 1238.

* Gestel, R.A.J. van, "Zelfregulering door bedrijfsinterne milieuzorg gaat niet vanzelf", MenR, 1994, pp. 166-175.

* Gestel, R.A.J. van en Verschuuren, J.M., "Marktwerking, deregulering en wetgevingskwaliteit ... en de kwaliteit van het milieu?", in Gestel, R.A.J. van en Eijlander, Ph., e.a. (red.), Markt en wet, Deventer, Tjeenk Willink, 1996, pp. 157. 164.

" Gestel, R.A.J. van, "Milieuzorg op maat", in Bedrijfsinterne milieuzorg en vergunningverlening. "Is het gras groener bij de buren?", Zwolle, Tjeenk Willink, 1998, pp. 26-68.

* Gestel, R.A.J. van en Verschuuren, J.M., Juridische handleiding bedrijfsinterne milieuzorg en vergunning op hoofdzaken, Deventer, Gouda Quint, 1999.

* Giele, J., Een kwaad leven: de arbeidsenquête van 1887, Nijmegen, Link, 1981.

* Gijsen, H.A.J., "Is het wenselijk, dat verband wordt gelegd tusschen de verschillende maatregelen naar aanleiding van een zelfde feit, te nemen door den strafrechter en andere bij of krachtens de wet ingestelde organen? Zoo ja, op welke wijze ware dit verband te regelen?", in Handelingen der Nederlandsche juristen-vereeniging, (eerste stuk), 's-Gravenhage, Belinfante, 1936, pp. 1-52.

* Gilhuis, P., "Experiences and Perspectives with Regard to the Codification of Environmental Law in the Netherlands", in Bocken, H. en Ryckbost, D. (eds.), Codification of Environmental Law, Proceedings of the International Conference, The Hague, Kluwer, 1996, pp. 101-114.

* Gille, B., "Milieu-audit in het Decreet Bedrijfsinterne Milieuzorg", in Deketelaere, K. (red.), Algemene bepalingen Vlaams milieubeleid en bedrijfsinterne milieuzorg, Brugge, Die Keure, 1996, pp. 167-191.

* Goeman Borgesius, H., De Nederlandsche Arbeids- en Fabriekswetten benevens de beshiten ter witvoering, met inleiding en aanteekeningen, Sneek, J.F. van Druten, 1897.

* Goorden, C.P.J., "Verzelfstandiging: naar een doorzichtig en geregeld bestuur", in Vereniging voor administratief recht, $Z B O$ 's, verzelfstandiging en privatisering; Preadviezen, Alphen aan den Rijn, Samsom H.D. Tjeenk Willink, 1997, pp. 7123.

* Griffiths, J., "Recht en ontwikkeling", Recht en Kritiek, 1983, pp. 175-191.

* Groenendaal, J., Inleiding tot de wetgevingstechniek, Alphen aan den Rijn, Samsom, 1956.

* Groenhuijsen, M.S., "Legaliteit als probleem", NJB, 1982, pp. 277-287.

* Groenhuijsen, M.S. en Kaimthout, A.M. van, "Transactie en voorwaardelijk sepot: lood OM oud ijzer", $D D, 1983$, pp. 474-487.

* Groenhuijsen, M.S., Straf en wet, Amhem, Gouda Quint, 1987.

* Groenhuijsen, M.S. en Wiemans, F.P.E., Van electriciteit naar computercriminaliteit, Amhem, Gouda Quint, 1989. 
* Groenhuijsen, M.S., "Schuld en boete; Een beschouwing over strafrechtelijke verantwoordelijkheid", in Bovens, M.A.P., Schuyt, C.J.M. en Witteveen, W.J. (red.), Verantwoordelijkheid: retoriek en realiteit, Zwolle, Tjeenk Willink, 1989, pp. 43-62.

* Giroenhuijsen, M.S. en Peters, J.A.F., "Over het stuk en de spelers", in Groenhuijsen, M.S. en Peters, J.A.F. (red.), Rechtsontwikkeling door wetgeving, Zwolle, Tjeenk Willink, 1990, pp. 1-10.

* Groenhuijsen, M.S. en Hullu, J. de, Het stelsel van rechtsmiddelen in strafzaken, Nijmegen, Ars Aequi, 1994.

* Groenhuis, P., "Bollenteelt", Opportuun, nummer 9, mei 1999, pp. 23-24.

* Gunster, J.W., "Certificatie van milieuzorg", MenR, 1996, pp. 204-209.

* Gunsteren, H.R. van, The quest for control; A critique of the rational-central-rule approach in public affairs, London, John, Wiley, 1976.

* Haan, P. de, Drupsteen, Th.G. en Fernhout, R., Bestuursrecht in de sociale rechtsstaat, Deel I Ontwikkeling, organisatie, instrumentarium, Deventer, Kluwer, 1996.

* Haentjens, R.C.P, "De bedreiging der samenleving door aantasting van het natuurlijk milieu en het strafrecht als middel tot afweer", in Balkema, J.P., Corstens, G.J.M., Fijnaut, C., Keijzer, N., Melai, A.L., Rüter, C.F. en Strijards, G.A.M. (red), Gedenkboek. Honderd jaar Wetboek van Strafrecht, Amhem, Gouda Quint, 1986, pp. 471-487.

* Haft, F., "Recht und Sprache", in Kaufmann, A. en Hassemer, W. (red.), Einfihrung in Rechtsphilosophie und Rechtstheorie der Gegenwart, Heidelberg, C.F. Müller Juristischer Verlag, 1994, pp. 269-291.

* Hajer, M en Schwarz, M., "Inleiding", in Beck, U., De wereld als risicomaatschappij; Essays over de ecologische crisis en de politiek van de vooruitgang, Amsterdam, De balie, 1997, pp. 7-37.

* Hamel, G.A. van, "Is vereenvoudiging van het strafgeding voor den Kantonregter wenselijk? Zoo ja, in welken zin?", in Handelingen der Nederlandsche JuristenVereeniging, Eerste stuk, 's-Gravenhage, Gebr. Belinfante, 1884, pp. 262-334.

* Hamel, G.A. van, bijgewerkt door Dijck, J.V. van, Inleiding tot de studie van het Nederlandse strafrecht, Haarlem, De erven F. Bohn, 's-Gravenhage, Gebr. Belinfante, 1927.

* Harryvan, R., Overtredingen van de Arbeidsomstandighedenwet, Groningen, Onderzoekscentrum voor Criminologie en Jeugdcriminologie, 1990.

* Hart, H.L.A., The Concept of Law, Oxford, Clarendon Press, 1961, herdruk 1994.

* Hart, A.C. 't, Om het OM, openbare les Tilburg, Zwolle, Tjeenk Willink, 1976.

* Hart, A.C. "t, "Artikel 25 W.V.W. en het legaliteitsbeginsel", in Geppaart, Ch.P.A., Schoordijk, H.C.F. en Dorst, A.J.A. van (red.), Macht en onmacht van de wetgever. Opstellen uitgegeven ter gelegenheid van het 50-jarig bestaan van de katholieke hogeschool en het 15-jarig bestaan van de faculteit der rechtsgeleerdheid te Tilburg, Deventer, Kluwer, 1978, pp. 213-224.

* Hart, A.C. 't, "Het nulla-poenabeginsel", in Koekkoek, A.K., Konijnenbelt, W. en Crijns, F.C.L.M. (red.), Grondrechten; Commentaar op Hoofdstuk I van de herziene grondwet, Nijmegen, Ars Aequi Libri, 1982, pp. 332-345. 
* Hart, A.C. "t, "Strafrecht: de macht van een verhaalsstructuur", in Doelder, H. de en Sien Hien Ong (red.), Strafrecht en Beleid. Essays, Zwolle, Tjeenk Willink, 1983, pp. 413-470.

* Hart, A.C. "t, "Art. 25 WVW en het legaliteitsbeginsel", in Doelder, H. de en Sien Hien Ong (red.), Strafrecht en Beleid. Essays, Zwolle, Tjeenk Willink, 1983, pp. 189-231.

* Hart, A.C. 't, Het schild van Perseus. Voordrachten over strafrechtstheorie, Amhem, Gouda Quint, 1991.

* Hart, A.C. "t, "Strafrecht en beroepsethiek", DD, 1998, pp. 1-10.

- Harteveld, A.E. en Krabbe, H.G.M. (red.), De Wegenverkeerswet 1994; een strafrechtelijk commentaar, Arnhem, Gouda Quint, 1994.

* Hartmann, A.R. en Russen Groen, P.M. van, Contouren van het bestuursstrafrecht, Amhem, Gouda Quint, 1998.

* Hartog, R.J. den, Hofland, J. en Meynen, P.F., Handleiding Milieuwetgeving, "8 Bodem", (januari 1996), Alphen aan den Rijn, Samsom (losbladig).

* Haveman, R, Voorwaarden voor strafbaarstelling van vrouwenhandel, Deventer, Gouda Quint, 1998.

* Hazewindus, W.G.A., Wilthagen, A.J.J.M. en Grimminck, E., "Handhaving van de Arbeidsomstandighedenwet", in Commissie bestuursrechtelijke en privaatrechtelijke handhaving, Handhaven op niveau, Deventer, Tjeenk Willink, 1998, pp. $401-428$.

* Heijder, A., "Rechtsdwaling-arrest; noot bij HR 18 november 1975", $A A, 1977$, pp. 66-76.

* Heijder, A., "Nullum crimen sine lege?", in Non sine causa; Opstellen aangeboden aan Prof.Mr. G.J. Scholten ter gelegenheid van zijn afscheid als hoogleraar aan de Universiteit van Amsterdam, Zwolle, Tjeenk Willink, 1979, pp. 137-153.

* Heine, G., "Umweltstrafrecht in der Bundesrepublik Deutschland: Entwicklung und gegenwärtiger Stand, Grundprobleme und Alternativen", in Eser, A. en Kaiser, G. (Hrsg.), Drittes deutsch-sowjetisches Kolloquium über Strafrecht und Kriminologie, Baden-Baden, NOMOS, 1987, pp. 67-129.

* Heine, G. en Meinberg, V., Empfehlen sich Änderungen im strafrechtlichen Umweltschutz, insbesondere in Verbindung mit dem Verwaltungsrecht? Gutachten für den 57. deutschen Juristentag, München, Beck, 1988.

" Heine, G., "Zur Rolle des strafrechtlichen Umweltschutzes", ZSiW, 1989, pp. 722-755.

* Heine, G., "Verwaltungsakzessorietät des Umweltstrafrechts", NJW, 1990, pp. 2425-2434.

* Heine, G., "Die Verwaltungsakzessorietät im deutschen Umweltstrafrecht unter Berücksichtigung des österreichischen Rechts. Aktuelle Probleme und Reformüberregungen", Österreichische Juristenzeitung, 1991, pp. 370-378.

* Heine, G., "Verwaltungsakzessorietät des Unaweltstrafrechts - rechtsvergleichende Funktionsanalysen - unbestimmte Rechtsbegriffe - Reichweite von Genehmigungen", in Schulz, L. (Hrsg.), Ökologie und Recht, 1991, Köln, Berlin, Bonn, München, Carl Heymanns Verlag, 1991, pp. 55-80. 
* Hendriks, L.E.M., "De strafrechtelijke boete en de transactie in het milieurecht.", in Acht, R.J.J. van en Uylenburg, R. (red.), Financiële instrumenten in het milieurecht, Zwolle, Tjeenk Willink, 1993, pp. 129-144.

* Hendriks, L.E.M., "De Hoge Raad en artikel 14 Wbb", Men/R, 1994, pp. 138-146.

* Hendriks, L.E.M., Noot bij Hoge Raad 11 januari 1994, MenR 1994, nr. 85 (Mobil Oil).

* Hendriks, L.E.M. en Wöretshofer, J., Milieustrafrecht, Zwolle, Tjeenk Willink, 1995.

* Hendriks, L.E.M., "Het systeem van vergunningen en algemene regels (hoofdstuk $8 \mathrm{Wm}$ ) in strafrechtelijk perspectief", TMA, 1997, pp. 85-90.

Hendriks, L.E.M. en Lange, A. de, "Strafvervolging van overheden na het tweede Pikmeer-arrest", MenR, 1998, pp. 41-47.

Heringa, A.W. en Zwart, T., Grondwet 1983, Zwolle, Tjeenk Willink, 1983.

* Heringa, A.W., Sociale grondrechten; hun plaats in de gereedschapskist van de rechter, T.M.C. Asser Instituut, "s-Gravenhage, 1989.

* Heuvel, J.H. van den "Ontwikkelingen in het milieubeleid voor bedrijven", in Wiggers-Rust, L.F. (red.), De flexibele milieuvergunning en bedriffsinterne milieuzorg, Lelystad, Vermande, 1997, pp. 11-21.

* Hirsch Ballin, E.M.H., "Rechtsbeginselen en algemene beginselen van behoorlijk bestuur", $R \& R, 1982$, pp. 105-111.

* Hirsch Ballin, E.M.H. en Houten, M.L.P. van, "Toetsing van wetgeving: sluitstuk van de democratische rechtsstaat", Namens, 1989, Afl. 5, pp. 19-26.

* Hoeven, H. van der, De vraag: mag het Wetboek van Strafrecht ongewijzigd ingevoerd worden?, Leiden, 1884.

* Hoeven, H. van der, "De invoering van het Strafivetboek", $W ., 1884$, nr. 5005.

* Hoeven, H. van der, "Misdrijven en overtredingen", TvS, 1886-1887, pp. 453-485.

* Hollander, F., "Het kapstokartikel 22 sub a der Motor- en Rijwielwet", NJB, 1934, pp. 285-286.

* Hollander, F., Wet op de economische delicten; Commentaar op de wet van 22 jumi 1950 Staatsblad K 258; Amhem, Gouda Quint, 1952.

* Hout, P.J. van den, Knooppunt van valsheid en bedrog, Arnhem, Gouda Quint, 1993.

* Houten, M.C. van, Wet Luchtverkeer, Zwolle, Tjeenk Willink, 19195.

* Houweling, P., "Zorgplichtbepalingen in de nieuwe art. $8.40 \mathrm{Wm}$-besluiten", MenR, 1997, pp. 142-148.

* Huiberts, W., Verschuuren, J. en Berg, K. van den, Onderzoek naar vangnetregels, 's-Hertogenbosch, Samenwerkende Partners in Milieuzorg, 1996.

* Huidekoper, P.A., Hantering van het economisch strafrecht in Nederland, Deventer, Kluwer, 1975.

* Huisman, W. en Bunt, H.G. van de, "Sancties, organisatiecriminaliteit en milieudelicten", $A A, 1997$, pp. 684-697.

* Hullu, J. de, Over rechtsmiddelen in sirafzaken, Amhem, Gouda Quint, 1989.

* Hullu, J. de, Zijn er grenzen aan de strafrechtelijke aansprakelijkheid, Amhem, Gouda Quint, 1993.

* Hullu, J. de, "De Staat zelf in de verdachtenbank?", AA, 1995, pp. 50-56. 
* Hullu, J, de, "Het legaliteitsbeginsel in de Straatsburgse spiegel", in Brants, C.H., Kelk, C. en Moerings, M., Er is meer; Opstellen over mensenrechten in internationaal en nationaal perspectief, Deventer, Gouda Quint, 1996, pp. 181-190.

* Hullu, J. de, "Het legaliteitsbeginsel in de Straatsburgs perspectief", $A A, 1996$, pp. 508-514.

* Hullu, J. de, "Rechtszekerheid en vertrouwensbeginsel in het strafrecht", in Vereniging voor de vergelijkende studie van het recht van Belgiê en Nederland, Preadviezen; Vertrouwensbeginel en rechtszekerheid in Nederland, Deventer, Tjeenk Willink, 1997, pp. 91-134.

* Hullu, J. de in Cleiren, C.P.M. en Nijboer, J.F. (red.), Strafvordering. Tekst en Commentaar, 1999.

* Hullu, J. de, Koopmans, I.M. en Roos, Th.A. de, Het wettelijk strafmaximum, Deventer, Gouda Quint, 1999.

* Hulsman, L.H.C., Handhaving van recht, Deventer, Kluwer, 1965.

* Hulsman, L.H.C., "Dient het Wetboek van Strafrecht bepalingen te bevatten betreffende het daderschap en de strafrechtelijke aansprakelijkheid van andere dan natuurlijke personen?", in Handelingen der Nederlandse juristen-vereniging, (tweede stuk), Zwolle, Tjeenk Willink, 1966, pp. 73-157.

* Hulsman, L.H.C., "Kriteria voor strafbaarstelling", in Strafrecht terecht? Over dekriminalisering en depenalisering, Baarn, In den Toren, 1972, pp. 80-92.

* Hulsman, L.H.C., Afscheid van het strafrecht: een pleidooi voor zelfregulering, Houten, Het Wereldvenster, 1986.

* Huppes-Cluysenaer, L., "Onderzoek naar de effectiviteit van strafrechtelijk optreden", in Davelaar-van Tongeren, V.H., Keijzer, N. en Pol, U. van de (red.), Strafrecht in Perspectief. Een bundel bijdragen op strafrechtelijk gebied ter gelegenheid van het 100-jarig bestaan der Vrije Universiteit te Amsterdam, Amhem, Gouda Quint, 1980, pp. 133-158.

* Immink, P.W.A., At the roots of medieval sociery I, The Western empire, Oslo, Aschehoug, 1958.

* Ingelse H.C., De rol van het Comité in de ontwikkeling van het VN-Verdrag tegen Foltering, Amsterdam, Thelat Thesis, 1999.

* Jacobs, A.T.J.M., Frenkel, B.S., Heerma van Voss, G.J.J. en Pieters, D.C.H.M., Elementair sociaal recht, Alphen aan den Rijn, Sarnsom, 1992.

* Jakobs, G., Strafrecht Allgemeiner Teil. Die Grundlagen und die Zurechnungslehre, Berlin, Walter de Gruyter, 1993.

* Jans, J.H., Sevenster, H.G. en Vedder H.H.B. (red.), Europees milieurecht in Nederland, Den Haag, Boom, 2000.

* Jansen, O.J.D.M.L., Het handhavingsonderzoek; Behoren het handhavingstoezicht, het boeteonderzoek en de opsporing verschillend te worden genormeerd?, Nijmegen, Ars Aequi Libri, 1999.

* Jebbink, P.J., "Tot wie richt zich de norm van art. 25 W.V.W.", VR, 1971, pp. 169-171.

* Jescheck, H-H en Weigend, T., Lehrbuch des Strafrechts: Allgemeiner Teil, Berlin, Duncker \& Humblot, 1996. 
* Jong, D.H. de, De macht van de telastelegging in het strafproces, Amhem, Gouda Quint, 1981.

* Jong, P., Handhaafbaar milieurecht: Bestuursrechtelijke handhaafbaarheid van milieurecht als normstellingsprobleem, Deventer, Tjeenk Willink, 1997.

* Jonkers, J.E., "Raakpunten tussen straf- en burgerlijk recht", TvS, 1957, pp. 143155.

* Jonkers, W.H.A., "Het strafrechtelijk schuldverwijt", in Balkema, J.P., Corstens, G.J.M., Fijnaut, C., Keijzer, N., Melai, A.L., Rüter, C.F. en Strijards, G.A.M. (red), Gedenkboek. Honderd jaar Wetboek van Strafrecht, Amhem, Gouda Quint, 1986, pp 227-241.

* Jörg, N., Recht voor militairen, Alphen aan den Rijn, Samsom, 1979.

* Jörg, N, Hoofdstuk 64, "Economische delicten" (mei 1997), in Corstens, G.J.M., Doorenbos, D.R., Keijzer, N. en Sutorius, E.W.Ph.R. (red.), Vademecum strafzaken, Amhem, Gouda Quint (losbladig).

* Jurgens, G.T.J.M. en Michiels, F.C.M.A., Bestuurlijke boeten in het milieurecht, Publicatiereeks milieubeheer, VROM, 1997, nr. 5.

* Keizer, V.G., Milieuwetgeving; Wet inzake de luchtverontreiniging, Zwolle, Tjeenk Willink, 1998.

* Kemper, J.M., Crimineel Wetboek voor het Koninkrijk Holland met eene Inleiding en aanmerkingen, I, Amsterdam, Allart, 1809.

* Keulen, B.F., Economisch strafrecht, Arnhem, Gouda Quint, 1995.

* Kist, F.C., "Dient het Wetboek van Strafrecht bepalingen te bevatten betreffende het daderschap en de strafrechtelijke aansprakelijkheid van andere dan natuurlijke personen?", in Handelingen der Nederlandse juristen-vereniging, (tweede stuk), Zwolle, Tjeenk Willink, 1966, pp. 1-70.

* Kistenkas, F.H., Problemen van regelgeving, Lelystad, Vermande, 1994.

* Kistenkas, F.H., "Contra legem: een leerstuk op drift?", Iust, 1998, pp. 81-98.

* Klap, A.P., Vage normen in het bestuursrecht, Zwolle, Tjeenk Willink, 1994.

* Klink, B. van, De wet als symbool; Over wettelijke communicatie en de Wet gelijke behandeling van mannen en vrouwen bij de arbeid, Deventer, Tjeenk Willink, 1998.

* Klip, A.H., "Uniestrafrecht is op hol geslagen", $N J B, 1997$, pp. 663-670.

* Kloepfer, M., Zur Rechtsumbildung durch Umweltschutz, Heidelberg, C.F. Müller juristischer Verlag, 1990.

* Kloepfer, M. en Vierhaus, H.P., Umweltstrafrecht, München, Beck, 1995.

* Knigge, G., Verandering van wetgeving, Arnhem, Gouda Quint, 1984.

* Krigge, G., Noot bij EHRM 27 september 1995, Series A, no. 325-B, $N J$ 1996, 49 (G. v. France).

* Knigge, G., Noot bij EHRM 22 november 1995, Series A, no. 335-C, NJ 1997, 1 (C.R. v. United Kingdom).

* Knigge, G., "De bestuurlijke boete als teken aan de wand", MenR, 1998, pp. 6368.

* Knoops, G.G.J., "Politie vervolgd; Doorbreking van strafrechtelijke immuniteit", Advocatenblad, 1999, pp. 541-543. 
* Koeman, N.S.J., "25 Jaar milieurecht: van geitenharen sokken naar een groen poldermodel", in Zilver voor een gouden formule, Ontwikkelingen in het recht 1973-1998, Rotterdam, 1998, pp. 203-214.

* Kok, E.H.J., "Bedrijfsinterne milieuzorg", in Milieu-Almanak. Handleiding voor ondernemers, particulieren, adviseurs en ambtenaren, Diemen, De Bussy Uitgeverij, 1994, pp. 183-185.

* Konijnenbelt, W., "Het specialiteitsbeginsel in het Nederlandse en het Franse administratieve recht", NTB, 1994, pp. 305-313.

* Kool, R.S.B., "Ontucht(ig): een rechtsonzeker begrip?", $D D, 1992$, pp. 251-269.

* Koopmans, I.M., De strafbaarstelling van milieuverontreiniging, Arnhem, Gouda Quint, 1996.

* Koopmans, I.M., "Ontwikkelingen in het milieustrafrecht", MenR, 1996, pp. 140141.

- Koopmans, I.M., "Zeven jaar milieustrafrecht in Nederland: een evaluatie", $D D$, 1996, pp. 350-363.

* Koopmans, I.M., "Strafrechtelijke aansprakelijkheid in het milieustrafrecht: afscheid van schuld?", $D D, 1997$, pp. 545-562.

* Koopmans, T., "De rol van de wetgever", in Honderd jaar rechtsleven, Zwolle, Tjeenk Willink, 1970, pp. 221-235.

* Koopmans, T., "Beginselen van wetgeving", in Claessen, P.D.A., Ham-Wagner, W. van en Jongh, C.F.J. de (red.), Beeld van een Goede vriendschap, 's-Gravenhage, VUGA, 1980, pp. 123-133.

* Koopmans, T., "Constitutionele toetsing" in Handelingen Nederlandse JuristenVereniging, 1992, Deel 1, Zwolle, Tjeenk Willink, pp. 35-84.

* Kortenhorst, B.M., De motiveringsplicht in strafzaken; Een analyse van de artikelen 358 en 359 van het Wetboek van Strafvordering, Amhem, Gouda Quint, 1990.

* Kortmann, C.A.J.M., "Behoorlijke wetgeving", in Geest, H.J.A.M. van, Leede, L.J.M. de en Ringeling, A.B. (red.), Regel en Praktijk, Zwolle, Tjeenk Willink, 1979, pp. 63-75.

*. Kortmann, C.A.J.M., "Ontregeling", NJB, 1993, pp. 1375-1380.

* Kortmann, C.A.J.M., Constitutioneel recht, Deventer, Kluwer, 1997.

* Kortmann, C.A.J.M., "Hoofdstuk 7", in Kortmann, C.A.J.M., Bovend'reert, P.P.T., Ackermans-Wijn, J.C.E., Fleuren, J.W.A. en Nat, M.N.H. van der, Grondwet voor het Koninkrijk der Nederlanden; Tekst en Commentaar, Deventer, Kluwer, 1998, pp. 127-137.

* Krabbe, H.G.M., "De artikelen 5 en 6 Gevaar veroorzaken, hinderen en schuld aan een verkeersongeval", in Harteveld, A.E. en Krabbe, H.G.M. (red.), De Wegenverkeerswet 1994; een strafrechtelijk commentaar, Amhem, Gouda Quint, 1994, pp. 87-143.

* Kroeze, F.J.J., Wegenverkeerswetgeving, Zwolle, Tjeenk Willink, 1994.

* Kühl, K., "Probleme der Verwaltungsakzessorietät des Strafrechts, insbesondere im Umweltstrafrecht", in Kuper, W., Puppe, I. en Tenckhoff, J. (Hrsg.), Festschrift für Karl Lackner zum 70. Geburtstag am 18. Februar 1987, Berlin, Walter de Gruyter, 1987, pp. 815-861. 
* Lambers, C., De ontbrekende schakel in het milieurecht; het tekort aan normen in de Wet milieubeheer, Deventer, Kluwer, 1994.

* Lambers, C., "Een algemene zorgplicht voor het milieu", NJB, 1994, pp. 10061007.

* Lange, A. de, "Herijking van het milieustrafrecht", in Aalders, M.V.C. en Grieken, D. van (red.), Bestuursrechtelijke en strafrechtelijke handhaving van het milieurecht, Zwolle, Tjeenk Willink, 1996, pp. 71-83.

* Lange, A. de, "De bestuurlijke boete in het juiste spoor", MenR, 1998, pp. 74-78.

* Lange, A. de, Noot bij Hof 's-Hertogenbosch, 20 april 1999, MenR 1999 nr. 98 (Terugwerkende vergunning).

* Langemeijer, G.E., "Beweringslast en bewijsrisico in het strafproces", $T v S, 1931$, pp. 73-102.

* Langemeijer, G.E., Inleiding tot de studie van de wijsbegeerte des rechts, Zwolle, Tjeenk Willink, 1973.

* Langemeijer, G.E., "De toekomst van onze rechtspleging", NJB, 1973, pp. 61-67.

* Lash, S., Szerszynski, B. en Wynne, B. (red.), Risk, Environment \& Modernity; Towards a New Ecology, London, Sage, 1996.

* Laufhütte, H. en Möhrenschlager, M., "Umweltstrafrecht in neuer Gestalf", ZStW, 1980, pp. 912-935.

* Leede, L.J.M. de en Ringeling, A.B. (red.), Regel en Praktijk, Zwolle, Tjeenk Willink, 1979, pp. 1-12.

* Lefevere, J., "Soevereiniteit: gevaarlijke stof? De rol van soevereiniteitsargumenten bij het totstandkomen van milieuwetgeving in de Europese gemeenschap", in Faure, M. en Deketelaere, K. (red.), lus Commune en milieurecht, Antwerpen, Intersentia, 1997, pp. 53-74.

* Leijten, Conclusie bij HR 13 september 1994, NJ 1994, 746 (Olielozing door Financial Enterprise).

* Leliard, J.D.M., Het kleed van themis; Beschouwingen over de Rechtstaal in het Nederlandse taalgebied, Antwerpen/ Amsterdam, Maarten Kluwer's internationale uitgeversonderneming, 1979.

* Levenbach, M.G., Arbeid: Sociale verzekering, Alphen aan de Rijn (uitgeverij onbekend), 1964.

* Linden, E.C.H.J. van der, Formele en materiële rechtskracht. De kleren van de keizer, Den Haag, Sdu, 1998.

* Loeff, J.J., "Enkele opmerkingen aangaande de verhouding van taal en recht", in Glastra van Loon, J.F., Haersolte, R.A.V. van en Polak, J.M. (red.), Speculum Langemeijer; 31 rechtsgeleerde opstellen, Zwolle, Tjeenk Willink, 1973, pp. 303314.

* Lokin, J.H.A. en Zwalve, W.J., Hoofdstukken uit de Europese Codificatiegeschiedenis, Wolters-Noordhoff/Egbert Forsten, 1992.

* Loth, M.A., Recht en Taal. Een kleine methodologie, Amhem, Gouda Quint, 1991.

* Luigies, H.H., "Bodemsanering in Nederland", in Bodemsanering, Deventer, Tjeenk Willink, 1997, pp. 49-67. 
* MacCormick, N., Legal Reasoning and Legal Theory, Oxford, Clarendon Press, 1978.

* MacCormick, N., H.L.A. Hart, London, Edward Amold Publishers, 1981.

* Machielse, A.J., "Enige opmerkingen over het rechtsgoed", DD, 1979, pp. 24-43.

* Male, R.M. van, "Geen wetgeving zonder motivering", in Backx H.A.M. e.a. (red.), Recht doen door wetgeving, Zwolle, Tjeenk Willink, 1990, pp. 279-291.

* Maris, C.W., "Romantisch recht", NJB, 1991, pp. 887-898.

- Meijenfeldt, H.G. von en Wildeboer, L.J. (red.), Wet bodembescherming, Band 1, "Toelichting (B-1)", 11-'95, (losbladig).

- Meijer, E.M., Algemene Leer van het Burgerlijk Recht; Deel I De Algemene Begrippen van het Burgerlijk Recht, Leiden, Universitaire pers Leiden, 1948.

* Meinberg, V., "Empirische Erkentnisse zum Vollzug des Umweltstrafrechts", ZStW, 1988, pp. 112-157.

* Melai, A.L., Het gezag van norm en feit in strafzaken, Amhem, Gouda Quint, 1968.

* Melai, A.L., Noot bij HR 8 juni 1971, NJ 1972, 218 (Houden varkers).

- Mevis, P.A.M., Hoofdlijnen van het strafrechtelijk sanctiestelstel, Deventer, Tjeenk Willink, 1997.

- Michiels, F.C.M.A., De boete in opmars, Zwolle, Tjeenk Willink, 1994.

* Michiels, F.C.M.A., "De bestuurlijke boete in het milieurecht", MenR, 1998, pp. 69-73.

* Michiels, F.C.M.A., De Wet milieubeheer, Deventer, Tjeenk Willink, 1998.

* Ministerie van Justitie, Aanwijzingen voor de regelgeving, Den Haag, Sdu, 1996.

* Ministerie van Justitie, Aanwijzingen voor de regelgeving; Aanwijzingen voor convenanten, Den Haag, Sdu, 1998.

* Ministerie van Sociale Zaken en Werkgelegenheid, De Arbeidsomstandighedenwet 1990, 's-Gravenhage, Sdu, 1990.

* Ministerie van Sociale Zaken en Werkgelegenheid, Heroriëntatie Arbobeleid en Arbowet; Adviesaanvraag aan SER, maart 1996, met "Bijlage 1 Voorstellen wijziging Arbowet".

* Ministerie van VROM, Circulaire Vergunning op Hoofdzaken/Vergunning op Maat, Den Haag, 3 juni 1999.

* Möhrenschlager, M., "Kausalitätsprobleme im Umweltstrafrecht des Strafgesetzbuches", $W u V, 1984$, pp. 47-67.

* Mok, M.R., Op prijs gesteld; Overheid en prijzen in een tijd van inflatie, Zwolle, Tjeenk Willink, 1971.

* Mok, M.R., "Economisch recht", in Gaay Fortman, W.F. de (red.), Problemen van wetgeving, Deventer, Kluwer, 1982, pp. 145-164.

* Mok, Conclusie bij HR 16 mei 1986, NJ 1987, 251, met noot Scheltema (Landbouwvliegers).

* Mok M.R. en Tjittes, R.P.J.L., "Formele rechtskracht en overheidsaansprakelijkheid", RM Themis, 1995, pp. 383-404.

* Molenaar, A.N., Arbeidsrecht, Eerste deel, Algemeen gedeelte, Zwolle, Tjeenk Willink, 1953. 
* Monté ver loren, J.Ph. de, bewerkt door Spruit, J.E., Hoofdlijnen uit de ontwikkeling der rechterlijke organisatie in de Noordelijke Nederlanden tot de Bataafse omwenteling, Deventer, Kluwer, 1982.

* Mooij, A.W.M., "Gevaar, gevaarlijk, gevaarlijkheid", DD, 2000, pp. 21-30.

* Morrens, P., "Het leefmilieu als handhavingsmiddel", Panopticon, 1990, pp. 342 347.

* Mulder, A., De handhaving der sociaal economische wetgeving: Naast strafrechtspraak bedrijfsrechtspraak?, 's-Gravenhage, Daamen's Uitgeversmaatschappij, 1950.

* Mulder, A., "De ontwikkeling van de Sociaal-economische Wetgeving", in Polak, J.M. (red.), Vooruitzichten van de Rechtswetenschap, Deventer, Kluwer, 1964, pp. 103-138.

* $\quad$ Mulder, A., "Economisch strafrecht en bestuur", SEW, 1976, pp. 372-380.

* Mulder, A., "Departementale voorbereiding van wetgeving. Een exemplarische benadering", in Gaay Fortman, W.F. de (red.), Problemen van wetgeving, Deventer, Kluwer, 1982, pp. 71-88.

* Mulder, A. en Doorenbos, D.R., Schets van het economisch strafrecht, Zwolle, Tjeenk Willink, 1995.

* Mulder, G.E., "P.J.A. Feuerbach en het crimineel wetboek voor het Koninkrijk Holland", in Faber, S., Gaay Fortman, W.F. de, Schrage, E.J.H. (red), Uit het recht. Rechtsgeleerde opstellen aangeboden aan $m r$. P.J. Verdam, Deventer, Kluwer, 1971, pp. 175-185.

* Mulder, G.E., "Vage normen", in Naar eer en geweten: Liber Amicorum J. Remmelink, Arnhem, Gouda Quint, 1987, pp. 409-427.

* Nauw, A. de, Les métamorphoses administratives du droit pénal de l'entreprise, Gent, Meys \& Breesch, 1994.

* Neerhof, A.R., Het geschil voorbij; een studie naar de bruikbaarheid van bestuursrechtelijke jurisprudentie als kenbron van recht, Deventer, Kluwer, 1995.

* Nelissen, N.J.M., "Effectiviteit van milieuwetgeving", in Eijlander, Ph., Gilhuis, P.C., Peeters, M.G.W.M., Peters, J.A.F. en Voermans, W.J.M. (red.), Milieu als wetgevingsvraagstuk, Zwolle, Tjeenk Willink, 1991, pp. 123-143.

* Nentjes, A. en Hommes, J., "Handhaving van het milieurecht", TMA, 1990, pp. 1-7.

* Net, B.J. van der, "Naar invulling van algemene beginselen van behoorlijke wetgeving?", Tijdschrift voor Openbaar bestuur, 1979, pp. 195-200.

* Nicolaï, P., Beginselen van behoorlijk bestuur, Deventer, Kluwer, 1990.

* Nicolaï, P., Olivier, B.K., Vlies, I.C. van der, Damen, L.J.A. en Schueler, B.J., Bestuursrecht, Amsterdam, Factotum, 1997.

* Nieboer, W., "Causaliteit en aansprakelijkheid", in Balkema, J.P., Corstens, G.J.M., Fijnaut, C., Keijzer, N., Melai, A.L., Rüter, C.F. en Strijards, G.A.M. (red), Gedenkboek. Honderd jaar Wetboek van Strafrecht, Amhem, Gouda Quint, 1986, pp. 215-225.

* Nieboer, W., "Verzuim", in Naar eer en geweten, Liber Amicorum J. Remmelink, Amhem, Gouda Quint, 1987, pp. 455-464. 
* Niessen, R. "Fiscaaljuridische en Bedrijfseconomische analyse", in Faure, M. en Roos, Th. de (red.), De berekening van het wederrechtelijk verkregen voordeel uit milieudelicten, Den Haag, Sdu, 1998, pp. 235-248.

- Nieuwenhuis, J.H., "Legitimatie en heuristiek van het rechterlijk oordeel", RM Themis 1976, pp. 494-515.

* Nijboer, J.F. en Koning, A.M. de, "De vervolging en berechting van overheden, Een beknopte analyse van de 'Pikmeer'-rechtspraak", NJB, 1998, pp. 732-737.

- Nijenhuis, C.T. en Aalders, M.V.C., Naar een flexibele vergunning: koppeling van het milieuzorgsysteem aan de milieuvergunning, Amsterdam, Centrum voor Milieurecht, 1995.

* Nijenhuis, C.T., in Drupsteen, Th.G. en Koeman, N.S.J., Wet milieubeheer; Tekst en Commentaar, Deventer, Kluwer, 1996.

* Noll, P., Gesetzgebungslehre, Hamburg, Rowohlt, 1973.

- Nolte, H.J.A., Het strafrecht in de afzonderlijke wetten, Utrecht-Nijmegen, Dekker \& Van de Vegt, 1949.

* Noyon, T.J., Langemeijer, G.E. en Remmelink, J., bewerkt door Dorst, A.J.A. van, Fokkens, J.W. en Machielse, A.J.M., Het Wetboek van Strafrecht, Deventer, Gouda Quint (losbladig).

- Nuchelmans, G., Overzicht van de analytische wijsbegeerte, Utrecht, Het Spectrum, 1969.

* Ommeren, F.J. van, De verplichting verankerd. De reikwijdte van het legaliteitsbeginsel en het materiële wetsbegrip, Zwolle, Tjeenk Willink, 1996.

* Oostenbrink, J.J., Algemene beginselen van behoorlijke wetgeving?, Deventer, Kluwer, 1973.

* Osinga, P., Transactie in strafzaken, Arnhem, Gouda Quint, 1992.

* Otte, M., "Beginselen in het verkeers(straf)recht", $V R$, 1992, pp. 289-296.

* Otte, M., Het stelsel van gedragsregels in het wegverkeer, Amhem, Gouda Quint, 1993.

* Otte, M., Verkeersregels in revisie; Pleidooi voor een uitputtende RVV, Amhem, Gouda Quint, 1994.

* Otte, M., "In memoriam art. 25 WVW 1935. Een kleine geschiedenis", $V R, 1994$, pp. 349-358.

* Oudijk, J.C., "Een strafrechtelijke schikking? Enige opmerkingen naar aanleiding van een opmerkelijk transactie", in Coppelmans A.J.H.W., Valkenburg, W.E.C.A., Vriesendorp, R.D. en Witteveen, W.J., (red), Het actuele recht 2 : Tilburgse commentaren, Lelystad, Vermande, 1995, pp. 171-174.

* Packer, H.L., The Limits of the Criminal Sanction, Stanford, Stanford University Press, 1969.

* Peeters, M.G.W.M., "Effectiviteit van milieuwetgeving: toepassing van wettelijke instrumenten", in Eijlander, Ph., Gillhuis, P.C., Peeters, M.G.W.M., Peters, J.A.F. en Voermans, W.J.M. (red.), Milieu als wetgevingsvraagstuk, Zwolle, Tjeenk Willink, 1991, pp. 145-160.

* Pelser, C.M., "Reactie op D.R. Doorenbos 'Schuldkwadratuur: iets over de betekenis van art. 2 lid 1 WED"', DD, 1991, pp. 387-389. 
* Pennock, J.R. en Chapman, J.W., The limits of law, New York, Lieber-Atherton, 1974.

* Peters, A.A.G., Opzet en schuld in het strafrecht, Deventer, Kluwer, 1966.

* Peters, A.A.G., Het rechtskarakter van het strafrecht, Deventer, Kluwer, 1972.

* Peters, J.A.F., "Informatie en effectiviteit", in Eijlander, Ph., Gilhuis, P.C., Peeters, M.G.W.M., Peters, J.A.F. en Voermans, W.J.M. (red.), Milieu als wetgevingsvraagstuk, Zwolle, Tjeenk Willink, 1991, pp. 161-169.

* Peters, J.A.F., "Gedachten over 'pretenties van wetgeving"', Openbaar bestuur, 1992, pp. 25-29.

* Peters, J.A.F., Publiekrechtelijke rechtspersonen, Deventer, Kluwer, 1997.

* Peters, J.A.F., "Wordt vervolgd?; Over de criteria bij het beleid inzake vervolging van overheden", NTB, 1997, pp. 379-389.

* Podlech, A., "Die juristische Fachsprache und die Umgangssprache", in Koch, HJ. (red.), Juristische Methodelehre und analytische Philosophie, Kronberg, Athenäum Verlag, 1976, pp. 31-52.

* Poelje, S.O. van, "Coördinatie van het milieubeleid", in Mastrigt, F. van (red.), Overheid en milieu; de groei van de beperkingen, Baarn, Het Wereldvenster, 1974, pp. 63-71.

* Poest Clemert, P.E. van der en Boere, A.H.M., Handboek ARBO wet; Rechten en verplichtingen toegelicht voor werkgever en werknemer, Den Haag, Sdu, 1994.

* Polak, C.H.F., "Interventie", in Geschriften van de Vereniging voor administratief recht, Algemene beginselen van behoorlijk bestuur; Verslag van de Algemene vergadering gehouden te Utrecht op 30 mei 1952, ter behandeling van de preadviezen van Prof. dr I. Samkaden en Prof. mr G.J. Wiarda, XXV, Haarlem, Tjeenk Willink, 1952, p. 30.

* Polak, C.H.F., "Hulp voor de wetgever", NJB, 1976, pp. 909-913.

* Polak, J.M., "De wetgeving van het Departement van Justitie", $N J B, 1975$, pp. 17.

* Polak, J.M., "Codificerende wetgeving", in Geest, H.J.A.M. van, Leede, L.J.M. de en Ringeling, A.B. (red.), Regel en Praktijk, Zwolle, Tjeenk Willink, 1979, pp. 15-22.

* Polak, J.M., "De wetgeving van het Departement van Justitie", NJB, 1989, pp. 16.

* Polak, J.M., "Aanwijzingen voor de regelgeving", $N J B, 1993$, pp. 1396-1399.

* Polak, R.J., Wegenverkeersrecht, Zwolle, Tjeenk Willink, 1996.

* Pompe, W.P.J., "Verruiming van de toepasselijkheid van wettelijke strafbepalingen", TvS, 1943, pp. 105-116.

* Pompe, W.P.J., Het nieuwe tijdperk en het recht, Amsterdam, Vrij Nederland, 1945.

* Pompe, W.P.J., Geschiedenis der Nederlandsche rechtswetenschap, deel II, Afl. III, Amsterdarn, Noord-Hollandsche uitgevers mij., 1956.

* Pompe, W.P.J., Handboek van het Nederlandse strafrecht, Zwolle, Tjeenk Willink, 1959.

* Pompe, Noot bij HR 3 november 1959, NI 1960, 209 (Gevaarlijke cirkelzagen).

* Pols, M.S., "De invoering van het Wetboek van strafrecht", W., 1884, 5010. 
* Pols, M.S., "De verdeeling der strafbare handelingen in misdrijven en overtredingen", $T v S, 1886-1887$, pp. 223-248.

- Prakke, L., "Bedenkingen tegen het toetsingsrecht", in Handelingen Nederlandse Juristen-Vereniging, 1992, Deel 1, Zwolle, Tjeenk Willink, pp. 1-33.

- Prakke, L., Reede, J.L. de en Wissen, G.J.M. van, Handboek van het Nederlands staatsrecht, Zwolle, Tjeenk Willink, 1995.

* Prakken, T., "De Eurotop en het individueel daadstrafrecht", NJB, 1998, pp. 442 446.

* Putnam, H., "The Meaning of Meaning", in Putman, H, Mind, Language and Reality, Cambridge, Cambridge University Press, 1975.

* R. en H., "De Algemene pensioenwet politieke ambtsdragers in de Eerste Kamer gestrand; Prof. Troostwijk, de exorbitante pensioenen en de politieke zeden", Weekblad voor de Nederlandse Bond van Gemeente-ambtenaren, 1967, pp. 242243.

* Raad van advies voor de ruimtelijke ordening, "Advies van 25-06-1981", 'sGravehage, Staatsuitgeverij, 1981.

* Raad van State, Jaarverslag 1998, 's-Gravenhage, 1999.

* Raad van State, Jaarverslag 1999, 's-Gravenhage, 2000.

* Reijntjes, J.M., "Voorwaardelijk sepot", in Liber Amicorum Th.W. van Veen, Amhem, Gouda Quint, 1985, pp. 295-316.

* Reijntijes, J.M., “Artikel 167; beslissing omtrent vervolging" (november 1997), in Melai, A.L., voortgezet door Groenhuijsen, M.S., Roos, Th.A. de en Swart, A.H.J. (red.), Het wetboek van strafvordering, Amhem, Gouda Quint (losbladig).

* Remmelink, J., "Omvang en functie van art. 25 W.V.W.", VR, 1954, pp. 85-90.

* Remmelink, J., "Disharmonieën tussen civiel- en strafrecht", RM Themis, 1959, 243-288.

* Remmelink, J., "'Prinzipiënreiterei' door het verkeersrecht”, VR, 1965, pp. 193197.

* Remmelink, J., Conclusie bij HR 14 mei 1974, NJ 1974, 325 (Zelftank Kreekhuizen).

* Remmelink, J., Conclusie bij HR 24 november 1981, NJ 1982, 209 (Gekwalificeerde luchtvervoerders).

* Remmelink, J., "Visies op telastelegging", in André de la Porte, E., Bremmer, W.M.A., Haersolte, R.A.V. van, Remmelink, J. en Stolwijk, S.A.M., Bij deze stand van zaken; Bundel opstellen aungeboden aan A.L. Melai, Amhem, Gouda Quint, 1983, pp. 405-439.

* Remmelink, J., Hoofdwegen door het verkeersrecht, Zwolle, Tjeenk Willink, 1992.

* Remmelink, J., "Tijd en plaats in het verkeersrecht", VR 1993, pp. 205-209.

* Remmelink, J., Mr. D. Hazewinkel-Suringa's Inleiding tor de studie van het Nederlandse strafrecht, Deventer, Gouda Quint, 1996.

* Riet Paap, K.W. van, Arbeidsomstandighedenwet, Zwolle, Tjeenk Willink, 1996.

* Rikmenspoel, E., "Het kapstokartikel 22 sub a der Motor- en Rijwielwet", NJB, 1934, pp. 286-287.

- Robroek, F. in Boetelijst; Arbo \& Milieu, Alphen aan den Rijn, Samsom, 1998. 
* Roef, D., "Kan de Staat in haar eigen staart bijten?", DD, 1995, pp. 332-348.

* Roef, D., "Strafrecht versus leefmilieu: van geschiktheid naar ondergeschiktheid?", TMR, 1995, pp. 466-476.

* Roef, D., "Zoektocht naar een meer-zinnige betekenis van het strafrecht voor het leefmilieu", Recht en Kritiek, 1995, pp. 480-510.

* Roef, D., "De strafrechtelijke aansprakelijkheid van overheden voor milieuverontreiniging in rechtsvergelijkend perspectief", in Faure, M. en Deketelaere, K. (red.), Ius Commune en Milieurecht; Actualia in het Milieurecht in België en Nederland', Groningen-Antwerpen, Intersentia, 1997, pp. 243-290.

* Roef D. en Roos, Th.A. de, "De strafrechtelijke aansprakelijkheid van de rechtspersoon in Nederland: rechtstheoretische beschouwingen bij enkele praktische knelpunten", in Faure, M. en Schwartz, K. (red), De strafrechtelijke en civielrechtelijke aansprakelijkheid van de rechtspersoon en zijn bestuurders, Antwerpen-Groningen, Intersentia, 1998, pp. 49-121.

* Rogier, L.J.J., Strafsancties, administratieve sancties en het una via beginsel, Arrhem, Gouda Quint, 1992.

* Röling, B.V.A., "Is het wenselijk, dat verband wordt gelegd tusschen de verschillende maatregelen naar aanleiding van een zelfde feit, te nemen door den strafrechter en andere bij of krachtens de wet ingestelde organen? Zoo ja, op welke wijze ware dit verband te regelen?", Handelingen der Nederlandsche juristen-vereeniging, (eerste stuk), 's-Gravenhage, Belinfante, 1936, pp. 1-113.

* Röling, B.V.A.R, Noot bij HR 24 november 1953, NJ 1954, 73 (Vastgelegde hond).

* Röling, B.V.A.R, Noot bij HR 14 december 1954, NJ 1955, 118 (Herbebossing)

* Rood, M.G., Introductie in het sociaal recht, Deventer, Gouda Quint, 1998.

* Roos, Th.A. de, Strafbaarstelling van econonische delicten. Een crimineelpolitieke studie, Annhem, Gouda Quint, 1987.

* Roos, Th. de, "Het Pikmeerarrest en zijn gevolgen", $A A$, 1997, pp. 226-233.

* Roos, Th.A. de en Visser M.J.C., Hoofdstuk 70 "Milieustrafrecht", (juni 1998), in Corstens, G.J.M., Doorenbos, D.R., Keijzer, N. en Sutorius, E.W.H.R. (red.), Vademecum strafzaken, Amhem, Gouda Quint (losbladig).

* Roos, Th.A. de en Visser, M.J.C., "Strafrechtelijke milieurisico's van ondernemer en onderneming; Nederlands recht gekenmerkt door pragmatische aanpak", Tijdschrift voor BedrijfsAdministratie, 1999, pp. 279-284.

* Roos, Th.A. de, "Geen strafrechtelijke aansprakelijkheid voor de Staat? Minister Korthals als Oblomov", $A A, 2000$, p. 92-96.

* Rosch, E., "Principles of Categorization", in Rosch, E. en Lloyd, B.B. (red.), Cognition and Categorization, Hillsdale, Erlbaum Associates, New York-London, 1978.

* Rosendahl Hubber, A.E., "Het kapstokartikel 22 sub a der Motor- en Rijwielwet $\Gamma^{\prime \prime}, N J B, 1934$, pp. 221-227.

* Rosendahl Hubber, A.E., "Het kapstokartikel 22 sub a der Motor- en Rijwielwet II", NJB, 1934, pp. 237-243.

* $\mathrm{Ru}, \mathrm{H} . J$. de, De algemene wet gaat voor de bijzondere, notities over wetgevingsbeleid, deel 1 , reeks achtergrondstudies algemeen wetgevingsbeleid, Den Haag, Ministerie van Justitie, 1992. 
* Ruiter, D.W.P., "Kloven in het bestuursrecht", in Bestuurswetenschappen, 1978, pp. 352-370.

* Salomon, F. (red.), "RVV 1990 Alg.", Wegenverkeerswetgeving, Amhem, Gouda Quint (losbladig).

* Salomon, F., "Flankerend beleid", in Bleichrodt, C.J.G. en Scheffer, J.P. (red.), Het RVV 1990 en het BABW, Lochem, Van den Brink, 1991, pp. 93-105.

* Sartor, G., "The Structure of Norm Conditions and Nonmonotonic Reasoning in Law", Proc. of the Third International Conference on Artificial Intelligence and Law, ACM Press, 1991, pp. 155-164.

* Sassen, P.E.M.S., "De arbeidsenquête van 1887", in Schetsen voor Bakels, Deventer, Kluwer, 1987, pp. 239-249.

- Schaafsma, R.W., Quarantainewet, Zwolle, Tjeenk Willink, 1995.

* Schaffmeister, D. en Heijder A., "Concretisering van de wederrechtelijkheid in het strafrecht", in André de la Porte, E., Bremmer, W.M.A., Haersolte, R.A.V. van, Remmelink, J. en Stolwijk, S.A.M. (red.), Bij deze stand van zaken. Opstellen aangeboden aan A.L. Melai, Amhem, Gouda Quint, 1983, pp. 441-474.

* Schaffmeister, D., "Politiële en justitiële delikten", Handelingen 1984 der Nederlandse Juristen-Vereniging, Deel $I_{n}$ eerste stuk, Zwolle, Tjeenk Willink, pp. 127-291.

* Schaffmeister, D., "Delictsclassificaties - misdrijven en overtredingen", in Balkema, J.P., Corstens, G.J.M., Fijnaut, C., Keijzer, N., Melai, A.L., Rüter, C.F. en Strijards, G.A.M. (red), Gedenkboek. Honderd jaar Wetboek van Strafrecht, Arnhem, Gouda Quint, 1986, pp. 189-214.

* Schaffineister, D., "De strafrechtelijke bescherming van ecologische rechtsgoederen", in Faure, M.G., Oudijk, J.C. en Schaffmeister, D. (red.), Zorgen van heden. Opstellen over het milieustrafrecht in theorie en praktijk, Amhem, Gouda Quint, 1991, pp. 153-204.

" Schaffmeister, D., "Handhaving van bestuursrecht door boete of straf?", in Hazewindus, W.G.A. en Janssen, O.J.D.M.L. (red.), Van boete-atelier tot boetefabriek, Deventer, Kluwer, 1995, pp. 59-80.

* Schall, H., "Umweltschutz durch Strafrecht: Anspruch und Wirklichkeit", NJW, 1990, pp. 1263-1273.

* Scheltema, M., "Preadvies; Dient wijziging te worden gebracht in het proces van wetgeving?", Handelingen 1979 der Nederladse Juristen-Vereniging, Deel I, tweede stuk, pp. 63-134.

* Scheltema, M., De partijdige wetgever; Inleiding ter gelegenheid van een symposium, (met korte reacties), Deventer, Kluwer, 1984, pp. 4-18 en 39-42.

* Scheltema, M., Noot bij HR 16 mei 1986, $N J$ 1987, 251 (Landbouwvliegers).

* Scheltema, M., Noot bij HR 3 oktober 1986, NJ 1987, 911 (Heffing op auto's Antillen).

* Scheltema, M., "De verwachtingen voor de toekomst", in Baardman, Bloembergen, Bouten, Hartkamp, Meijers, Van Nispen tot Sevenaer en Verburgh (red.), De Hoge Raad der Nederlanden; De plaats van de Hoge Raad in het huidige staatsbestel, Zwolle, Gouda Quint, 1988, pp. 335-349. 
* Scheltema, M., Noot bij HR 6 juni 1995, NJ 1995, 696 (Vergissing met dwangbevel).

* Scherer, W., Poetik, Berlin, Weidmann, 1888.

* Schilfgaarde, P. van, "Vage normen", WPNR, 1993, pp. 61-62.

* Schimmel-Bonder, W.G., "Onderscheid naar geslacht in de wetgeving", in Angeren, J.A.M. van, Fasseur, C, Hirsch Ballin, E.M.H. en Wiarda, J.J. (red.), Kracht van wet; Opstellen over publiekrechtelijke wetgeving, aangeboden aan Mr. W.J. van Eijkern bij zijn afscheid als hoofd van de Stafafdeling Wetgeving Publiekrecht van het Ministerie van Justitie, Zwolle, Tjeenk Willink, 1984, pp. 179-195.

* Schlössels, R., "Het specialiteitsbeginsel en derdebelangen: een frisse benadering of rechtsstatelijk drijfzand?", NTB, 1996, pp. 81-96.

* Schlössels, R.J.N., Het specialiteitsbeginsel; Over de structuur van bestuursbevoegdheden, wetmatigheid van bestuur en beleidsvrijheid, Den Haag, Sdu, 1998.

* Schmitz, R., Verwaltungshandeln und Strafrecht: zur Verwaltungsakzessorietät des Umweltstrafrecht, Heidelberg, C.F. Müller juristischer Verlag, 1992.

* Schneider, R., "Recht und Sprache", ZRP, 1993, pp. 482-484.

* Scholten, P., De structuur der rechtswetenschap, Mededeelingen der Koninklijke Nederlandsche Akademie van Wetenschappen, Afd. Letterkunde, Nieuwe reeks, Deel 8, no. 1, Amsterdam, N.V. Noord-Hollandsche uitgevers maatschappij, 1945.

* Scholten, P., samengesteld door Scholten, G.J., Scholten, Y. en Bregstein, M.H., Verzamelde Geschriften van Mr. Paul Scholten, deel I, Zwolle, Tjeenk Willink, 1949 heruitgave in 1980.

* Scholten, P., bewerkt door Scholten, G.J., Mr. C. Asser's Handleiding tot de beoefening van het Nederlands Burgerlijk Recht, Algemeen deel, Zwolle, Tjeenk Willink, 1974.

* Schoordijk, H.C.F., Oordelen en vooroordelen, Deventer, Kluwer, 1972.

* Schreiber, H.L., Gesetz und Richter, Frankfurt am Main, Metzner, 1976.

* Schreuder-Vlasblom, M., "Boekbespreking", NJB, 1985, pp. 324-326.

* Schreuder-Vlasblom, M., "De harde wet en haar zachte kant; enige opmerkingen over hardheidsclausules", Bestuurswetenschappen, 1987, pp. 100-117.

* Schreuder-Vlasblom, M., "De noordwand van het gelijkheidsbeginsel. Opmerkingen over ongelijkheden en hardheidsclausules", Bestuurswetenschappen, 1989, pp. 5-20.

* Schünemann, B., Nulla poena sine lege? Rechtstheoretische und Verfassungsrechtliche Implikationen der Rechtsgewinnung im Strafrecht, Berlin/New York, De Gruyter, 1978.

* Schwartz, S.P. (red.), Naming, Necessity and Natural Kinds, Ithaca, Cornell University Press, 1977.

* Seerden, R. en Heldeweg, M., "Public Environmental Law in the Netherlands", in Seerden R. en Heldeweg, M. (eds.), Comparative Environmental Law in Europe, an Introduction to Public Environmental Law in the EU Member States, Antwerp, Maklu, 1996, pp. 269-311.

* Shavell, S., "Criminal Law and the Optimal Use of Non-Monetary Sanctions as a Deterrent", Columbia Law Review, 1985, pp. 1232-1262. 
* Siemerink, J.B.M., De vuilnisverwerking in Amsterdam 1673-1804 - de rol van het Aalmoezeniersweeshuis bij de organisatie van de afvalverwerking en de betekenis van de afvalstoffen voor de agrarische sector, Amsterdam, 1979, in Gemeentearchief Amsterdam.

* Simmelink, J.B.H.M. en Otte, M., "De herziening van het RVV: Een 'Salomonsoordeel'?", $R V, 1989$, pp. 294-301.

* Simmelink, J.B.H.M., "Het RVV 1990, niet iedere verandering is ook een verbetering", in Bleichrodt, C.J.G. en Scheffer, J.P. (red.), Het RVV 1990 en het $B A B W$, Lochem, Van den Brink, 1991, pp. 21-61.

* Simmelink, J.B.H.M., "Nieuwe orde in de wegenverkeerswetgeving (Deel 1)", VR, 1993, pp. 1-9.

* Simmelink, J.B.H.M., "Nieuwe orde in de wegenverkeerswetgeving (Deel 2)", $V R, 1993$, pp. 33-42.

* Simmelink, J.B.H.M., "Algemene opmerkingen over de WVW '94", in Harteveld, A.E. en Krabbe, H.G.M. (red.), De Wegenverkeerswet 1994; een strafrechtelijk commentaar, Amhem, Gouda Quint, 1994, pp. 17-85.

* Simmelink, J.B.H.M., Algemeenheden in het wegenverkeersrecht, Arnhem, Gouda Quint, 1995.

* Simons, D. bijgewerkt door Pompe, W.P.J., Leerboek van het Nederlandsche strafrecht; Eerste deel Algemene leerstukken, Groningen-Batavia, Noordhoff, 1937.

* Simons, D. bijgewerkt door Pompe, W.P.J., Leerboek van het Nederlandsche strafrecht; Tweede deel Bijzondere strafbare feiten, Groningen-Batavia, Noordhoff, 1941.

* Slotemaker, L.H., Luchtvaartwet, Zwolle, Tjeenk Willink, 1940.

* Smidt, H.J., Geschiedenis van het Wetboek van Strafrecht. Volledige verzameling van regeeringsontwerpen, gewisselde stukken, gevoerde beraadslagingen, enz., Deel I, II en III, Haarlem, Tjeenk Willink, 1891.

* Smits, J.M., "Stelen van cornputergegevens voortaan strafbaar; Het spook in de kraag gevat?", Computerrecht, 1984, pp. 33-38.

* Snellen, I.Th.M., Boeiend en geboeid; Ambivalenties en ambities in de bestuurskunde, Alphen aan de Rijn, Samsom H.D. Tjeenk Willink, 1987.

* Sociaal Economische Raad, Advies: Heroriëntatie arbobeleid en Arbowet, aan de Staatssecretaris van Sociale Zaken en Werkgelegenheid, SER 97/03, 21 februari 1997.

* Sorgdrager, W., Op de grens tussen Europa en de nationale wetgeving. Speech van de Minister van Justitie bij de opening van de European law school te Maastricht op 4 maart 1996 om 16.00 uur, de tekst werd door de Directie voorlichting van het Ministerie van Justitie verspreid.

* Stolwijk, S.A.M., "Artikel 1, eerste lid en het legaliteitsbeginsel", in Balkema, J.P., Corstens, G.J.M., Fijnaut, C., Keijzer, N., Melai, A.L., Rüter, C.F. en Strijards, G.A.M. (red), Gedenkboek. Honderd jaar Wetboek van Strafrecht, Amhen, Gouda Quint, 1986, pp. 159-170.

* Stoter, W.S.R., De belangenafweging door de wetgever, Den Haag, Boom, 2000.

* Strien, A.L.J. van, "Het daderschap van de rechtspersoon bij milieudelicten", in Faure, M.G., Oudijk, J.C., Schaffmeister, D. (red.), Zorgen van heden. Opstellen 
over het milieustrafrecht in theorie en praktijk, Amhem, Gouda Quint, 1991, pp. 257-301.

* Strien, A.L.J. van, De rechtspersoon in het strafproces, Den Haag, Sdu, 1996.

* Strijards, G.A.M., Aansprakelijkheidsgronden, Zwolle, Tjeenk Willink, 1988.

* Stroink, F.A.M., De plaats van de rechter in het staatsbestel, Zwolle, Tjeenk Willink, 1990.

* Swinderen, P.J. van, "Is vereenvoudiging van het strafgeding voor den Kantonregter wenselijk? Zoo ja, in welken zin?", in Handelingen der Nederlandsche Juristen-Vereeniging, Eerste stuk, 's-Gravenhage, Gebr. Belinfante, 1884, pp. 336-369.

* Taat, J.F., Beschouwingen over tuchtrecht, Boskoop, Taat \& van der Neut, 1948.

* Tak, A.Q.C. en Teunissen J.M.H.F., "Wie zorgt er voor de rechtsstaat? Een voortgezet debat", Recht en Kritiek, 1994, pp. 340-354.

* Taverne, Noot bij HR 24 april 1939, NJ 1939, 1017 ("Tenzij" dan bestanddeel).

* Taverne, Noot bij HR 20 oktober 1941, NJ 1942, 60 (Boven de gemeentegrond).

* Teubner, G., "Substantive and reflexive elements in modern law", Law and Society Review, 1983, pp. 239-285.

* Teunissen, J.M.H.F. en Tak, A.Q.C., "Recht ist was der Umwelt nutzt?", NJB, 1994, pp. 605-616.

* Tiedemann, K., Tatbestandsfunktionen im Nebenstrafrecht, Tubingen, J.C.B. Mohr Verlag, 1969.

* Tiedemann, K., Wirtschaftsstrafrecht und Wirtschaftskriminalität, I Allgemeiner Teil, II Besonderer Teil, Reinbek bei Hamburg, Rowohlt, 1976.

* Tiedemann, K, Die Neuordnung des Umweltstrafrechts. Gutachtliche Stellungnahme zu dem Entwurf eines Sechzehnten Strafrechtsänderubgsgesetzes (Gesetz. zur Bekämpfung der Umweltkriminalität), Berlin, De Gruyter, 1980.

* Tiedemann, K. en Kindhäuser, H., "Umweltstrafrechtiche Bewährung oder Reform?", NStZ, 1988, pp. 337-339.

* Tieman, J.R.C., "Het ruime begrip afvalstof", MenR, 2000, pp. 229-236.

* Tonino, L.J.M., "Titel IV. Beslissingen omtrent verdere vervolging; Artikelen 242-257", (april 1987), in Melai, A.L., voortgezet door Groenhuijsen, M.S., Roos, Th.A. de en Swart, A.H.J. (red.), Het wetboek van strafvordering, Arnhem, Gouda Quint (losbladig).

* Tonnaer, F.P.C.L., Handboek van het Nederlandse milieurecht, Utrecht, Lemma BV, 1994.

* Toorenburg, M.M. van, Medeplegen, Deventer, Tjeenk Willink, 1998.

* Torringa, R.A., Strafbaarheid van rechispersonen, Amhem, Gouda Quint, 1984.

* Torringa, R.A., De rechtspersoon als dader; Strafbaar leidinggeven aan rechtspersonen, Amhem, Gouda Quint, 1988.

* Traest, P., "Recht(on)zekerheid in materieel en formeel strafrecht en strafrechtelijk legaliteitsbeginsel", $R W, 1994$, pp. 1190-1207.

* Triemstra, R.O. (red.), Arbeidsomstandighedenwet 1998, PS-special Arbowet 1998, Deventer, Kluwer, 1999.

* Triepel, H., Vom Stil des Rechts; Beiträge zu einer Ärihetik des Rechts, Heidelberg, Verlag Lambert Schneider, 1947. 
* Tuin, L.J.M. van der, Catechese en diaconie; Een empirisch theologisch onderzoek naar de effecten van milieucatechese op milieubewust handelen, Tilburg, Tilburg University Press, 1999.

* Valk, M.H. van der, De regel nullum crimen sine lege en het Chinese recht, Leiden, Brill, 1951.

* Valkhoff, J., Inleiding tot het sociaal-economisch recht in Nederland, Groningen, N.V. erven P. Noordhoff, 1964.

* Valkhoff, J., Recht en economie, Zwolle, Tjeenk. Willink, 1967.

* Valkhoff, J., "Nieuwe termen en begrippen in de rechtswetenschap", in Faber, S., Gaay Fortman, W.F. de, Schrage, E.J.H. (red), Uit het recht. Rechtsgeleerde opstellen aangeboden aan mr. P.J. Verdam, Deventer, Kluwer, 1971, pp. 61-73.

* Veegers, D.J., "Samenloop van strafbaar feit en tuchtrechtelijke overtreding bij de toepassing der Landbouw-Crisiswet", W. 1934, 12810.

* Veegers, D.J., bewerkt door Korthals Altes, E. en Groen, H.A., Cassatie in burgerlijke zaken, Zwolle, Tjeenk Willink, 1989.

* Veen, G. van der, "Recht ist was der Umwelt nützt?", NJB, 1994, pp. 1008-1010.

* Veen, Th.W. van, "Strafrecht en verkeersveiligheid (I)", VR, 1974, pp. 121-125.

" Veld, R.J. in 't, "Planning: ge(s)laagde ontregeling?", in Geest, H.J.A.M. van, Leede, L.J.M. de en Ringeling, A.B. (red.), Regel en Praktijk, Zwolle, Tjeenk Willink, 1979, pp. 215-230.

* Vellinga, W.H., Gevaar en schuld op de weg, Alphen aan de Rijn, Tjeenk Willink, 1979.

* Vellinga, W.H., Schuld in spiegelbeeld. Afwezigheid van alle schuld, Amhem, Gouda Quint, 1982.

* Vellinga, W.H., "Strafwetgeving als techniek van regel en uitzondering", in Liber Amicoram Th. W. van Veen, Arhnem, Gouda Quint, 1985, pp. 359-368.

* Vellinga, W.H., "De strafbepalingen in de nieuwe Wegenverkeerswet", $V R, 1995$, pp. 195-196.

* Ven, J.J.M. van der, "Recht spreken. Aantekeningen over recht en taal", in Glastra van Loon, J.F., Haersolte, R.A.V. van en Polak, J.M. (red.), Speculum Langemeijer; 31 rechisgeleerde opstellen, Zwolle, Tjeenk Willink, 1973, pp. 501516.

* Verheij, N., "Bekendmaking van gemeentelijke regelgeving", Regelmaat, 1990, pp. 7-11.

* VerLoren van Themaat, P., "Het ontwerp vestigingswet detailhandel, de cyclische ontwikkeling van de sociaal-economische wetgeving en de EEG", SEW, 1971, pp. 75-93.

* Verschuuren, J.M., "Het belang van algemene normen in het milieurecht", NJB, 1994, pp. 1007-1008.

* Viering, M.L.W.M. en Widdershoven, R.J.G.M., "De strafrechtelijke positie van de overheid na Pikmeer II", in Publikaties van de Staatsrechtkring, Strafbaarheid van overheden, Deventer, Gouda Quint, 1998, pp.67-85.

- Visser, M., "Strafrechtelijke zorgplichtbepalingen over de grens? De strafrechtelijke afdwingbaarheid van zorgplichtbepalingen in Belgiê en Nederland", in Faure, M. en Deketelaere K., lus Commune en Milieurecht; 
Actualia in het milieurecht in België en Nederland, Antwerpen, Intersentia, 1997, pp. 203-242.

* Visser, M. en Hage, J., "Voorwaarden van regeltoepassing", Nederlands Tijdschrift voor Rechtsfilosofie en Rechtstheorie, 1997, pp. 196-212.

* Visser, M.J.C., "Uitholling van het schuldbeginsel bij zorgplichtbepalingen door schending van het lex certa-beginsel", in Borgers, M.J., Koopmans, I.M. en Kristen, F.G.H. (red.), Verwijtbare uitholling van schuld?, Nijmegen, Ars Aequi Libri, 1998, pp. 65-80.

* Vlemminx, F., Het profiel van sociale grondrechten, Zwolle, Tjeenk Willink, 1994.

* Vlies, I.C. van der, Het wetsbegrip, en beginselen van behoorlijke regelgeving. De verandering van het legaliteitsbeginsel in de twintigste eeuw, 's-Gravenhage, Vuga, 1984.

* Vlies, I.C. van der, Handboek wetgeving, Zwolle, Tjeenk Willink, 1991.

* Vlies, I.C. van der, "Het tweede Pikmeer-arrest", $A A$, 1998, pp. 306-313.

* Voermans, W.J.M. (red.), Milieu als wetgevingsvraagstuk, Zwolle, Tjeenk Willink, 1991, pp. 123-143.

* Vranken, J.B.M., Asser serie; Algemeen deel, Zwolle, Tjeenk Willink, 1995.

* Vries, F.J. de, "Actualiteiten milieuaansprakelijkheid; Een emstig geval van stroperigheid; Hoe zevenenzeventig weken al meer dan vijf jaren duren", TMA, 1998, pp. 173-174.

* Vrugt, M. van de, Aengaende Criminele Saken; Drie hoofdstukken uit de geschiedenis van het strafrecht, Deventer, Kluwer, 1982.

* Waaldijk, K., Motiveringsplichten van de wetgever, Lelystad, Koninklijke Vermande, 1994.

* Waismann, F., "Verifiability", Proceedings of the Aristotelian Society, 1949, suppl. vol. 20.

* Waling, C., Het materiële milieustrafrecht, Arnhem, Gouda Quint, 1990.

* Waling, C., "Het milieustrafrecht, een uitdaging voor de advocatuur", Advocatenblad, 1991, pp. 460-466.

* Waling, C., Koopmans, I., Rutgers, M., Sjöcrona, J., Strien, N. van en Tak, P, "Pays-Bas: Crimes Against the Environment", International Review of Penal Law, 1994, pp. 1065-1099.

* Waling, C., "Bedrijfsinterne milieuzorg; De keerzijde van transparantie", $J V$, 1999, nummer 3, pp. $94-99$.

* Weersma, W.J.M. en Polak, N.J., De Wegenverkeerswet, Groningen, Wolters, 1950.

* Wemes, L.T., "Commune delicten betreffende de milieuvervuiling in de sleutel van de schuld", in Faure, M.G., Oudijk, J.C. en Schaffmeister, D. (red.), Zorgen van heden. Opstellen over het milieustrafrecht in theorie en praktijk, Arnhem, Gouda Quint, 1991, pp. 205-256.

* Wemes, L.T., in Cleiren, C.P.M. en Nijboer, J.F. (red.), Strafrecht. Tekst en commentaar, Deventer, Kluwer, 1997. 
* Werkgroep Inrichtingen- en vergunningenbesluit milieubeheer, Eindrapport van de Werkgroep Inrichtingen- en vergunningenbesluit milieubeheer, Bijlage bij TK 1994-1995, 24 036, nr. 6.

* Werkgroep Kwaliteit van EG-regelgeving, ingesteld door de Commissie toetsing van wetgevingsprojecten, De kwaliteit van EG-regelgeving; Aandachtspunten en voorstellen, Den Haag, 1995.

* Werkgroep terugdringing van de juridisering van het openbaar bestuur (onder voorzitterschap van J.A. van Kemenade), Bestuur in geding, Haarlem, Provinciehuis Noord- Holland, 1997.

* Wesselius, E.T., "De alternatieve Wet op de economische delicten", Algemeen Politieblad, 1999, nr. 13, p. 22.

* Wetenschappelijke Raad voor het Regeringsbeleid, Rechtshandhaving, 's-Gravenhage, Staatsuitgeverij, 1988.

* Wiarda, G.J., Drie typen van rechtsvinding, Zwolle, Tjeenk Willink, 1988.

* Wiemans, F.P.E., "De Rotterdamse computerfraude", Nieuwsbrief Bedriffsjuridische berichten 1991, pp. 115-119.

* Wiggers-Rust, L.F. en Wasch, E.P.J. (red.), Handboek milieu en onderneming, Zwolle, Tjeenk Willink, 1996.

* Wiggers-Rust, L.F. (red.), De flexibele milieuvergunning en bedrijfsinterne milieuzorg, Lelystad, Vermande, 1997.

* Wijk, H.D. van, De norm is per definitie abstract, Deventer, Kluwer, 1971.

* Wijk, H.D. van, bewerkt door Konijnenbelt, W. en Male, R.M. van, Hoofdstukken van bestuursrecht, Den Haag, Elsevier bedrijfsinformatie, 1999.

* Wijnbergen, A. van, "Element van strafbaar feit, of fait d'excuse, in eene verbodsbepaling met 'tenzij"', $T$ vS, 1900, pp. 128-137.

* Wijnveldt, J., Openingsrede voor de Vereniging voor strafrechtspraak. 1935 opgenomen in de rubriek "Berichten en mededeelingen", W., 1935, 12909.

* Wilt, C.J. van der, "Functiegericht saneren is nog steeds in strijd met de wet", MenR, 1999, pp. 220-221.

* Wilt, C.J. van der, Sanering en hergebruik van reinigbare grond; Spanning tussen wet en beleid, Amsterdam, Centrum voor Milieurecht UvA, 1999.

* Wilt, C.J. van der, Het saneringsbevel in de Wet bodembescherming, Alphen aan den Rijn, Samsom, 2000.

* Winkelbatier, W., Zur Verwaltungsakzessorietät des Umweltstrafrechts, Berlin, Duncker \& Humblot, 1985.

* Winter, H.B., Scheltema, M. en Herweijer, M., Evaluatie van wetgeving; Terugblik en perspectief, Deventer, Kluwer, 1990.

* Winter, H.B., Evaluatie in het wetgevingsforum; een onderzoek naar de relatie tussen evaluatie en kwaliteit van wetgeving, Deventer, Kluwer, 1996.

* Winter, R.E. de, "Toetsing van gemeentelijke verordeningen door de strafkamer van de Hoge Raad", in Geschriften van de Vereniging voor Administratief Recht, XCVI, Alphen aan den Rijn, Samsom/ Tjeenk Willink, 1987, pp. 181-266.

* Wittgenstein, L., Philosophical Investigations, Oxford, Blackwell, 1967.

* Wittgenstein, L., Philosophische Grammatik, Oxford, Blackwell, 1969. 
* Wladimiroff, M., Niets Bijzonders; Een beschouwing over de dominantie van het bijzonder strafrecht bij de handhaving van sociaal-economische normen, Deventer, Kluwer, 1989.

* Woensel, A.M. van, In de daderstand verheven; Beschouwingen over functioneel daderschap in het Nederlandse strafrecht, Arnhem, Gouda Quint, 1993.

* Woensel, A.M. van, in Cleiren, C.P.M. en Nijboer, J.F. (red.), Strafrecht. Tekst en commentaar, Deventer, Kluwer, 1997.

* Wüterich, Ch., "Die Bedeutung von Verwaltungsakten für die Strafbarkeit wegen Urnweltvergehen ( $\$ 324$ ff. StGB)", NStZ, 1987, pp. 108-109.

* X., "Milieuregels voor bedrijven worden vereenvoudigd", Handhaving, 1995, nr. 5, pp. 30-31.

* X., "Pseudo-bewindvoerder moet shredder op het rechte pad brengen", Handhaving, 2000, nr. 2, pp. 30-31

* Zippelius, R., Einführung in die juristische Methodenlehre, München, Beck, 1974.

* Zwam, H.J. van, Veranderingen in het arbeidsomstandighedenrecht; Tien Arbovragen, Deventer, Kluwer, 1983.

* Zwam, H.J. van, De handhaving van de Arbowet, Deventer, Kluwer, 1994.

* Zwart, H.M., Privaatrechtelijke instellingen in de landbouw-crisiswetgeving, Alphen aan den Rijn, Samsom, 1937. 


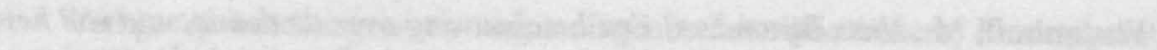

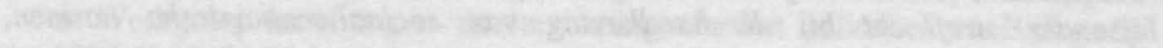
-

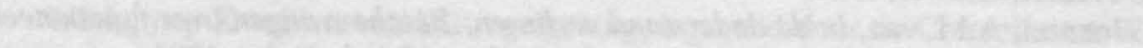

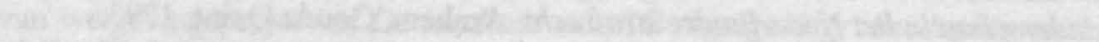

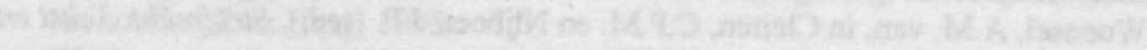

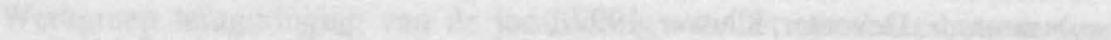

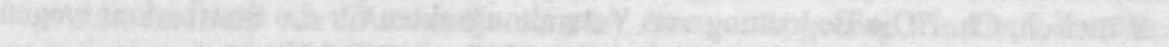

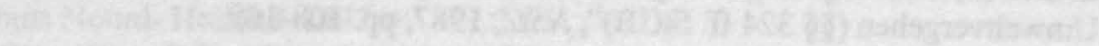

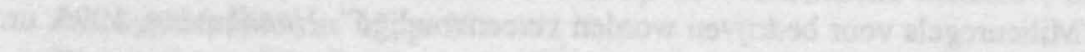
-

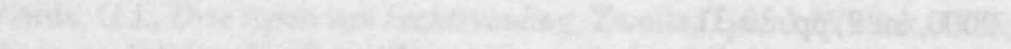

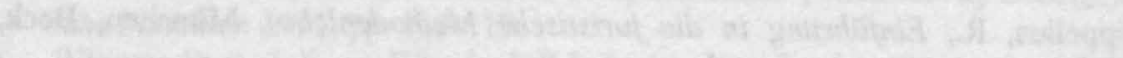

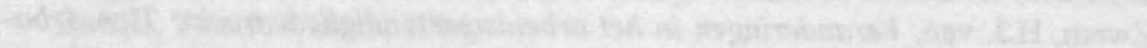

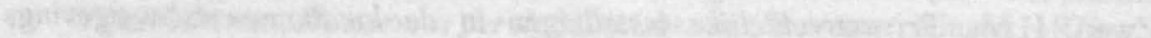

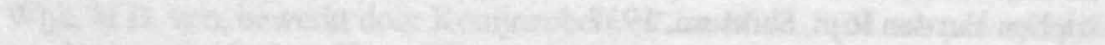

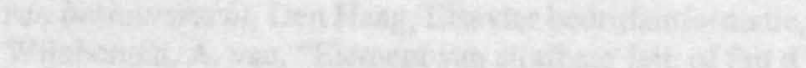

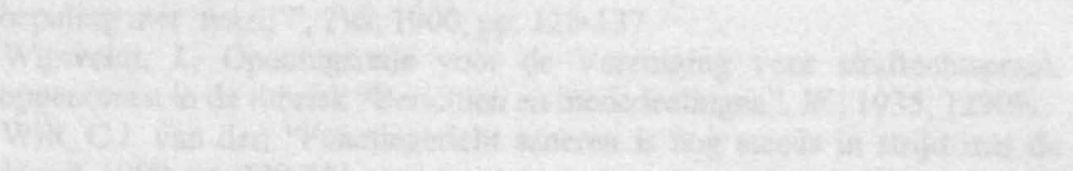




\section{Jurisprudentieregister}

\section{EHRM}

EHRM 8 juni 1976, $N J$ 1978, 223 (Engel).

EHRM 26 april 1979, $N J$ 1980, 146, met noot Alkema (Sunday Times). EHRM 23 juni 1981, $N J$ 1982, 602 (Le Compte, Van Leuven en De Meyere).

EHRM 10 februari 1983, $N J$ 1987, 315 (Albert en Le Compte).

EHRM 21 februari 1984, $N J 1988,937 ; A A$ 1985, pp. 145-154, met noot Swart (Oztürk).

EHRM 2 augustus 1984, $N J$ 1988, 534, met noot van Dijk (Malone).

EHRM 25 augustus 1987, $N J$ 1988, 938, met noot Alkema (Lutz).

EHRM 7 oktober 1988, $N J$ 1991, 351, met noot Alkema (Salabiaku).

EHRM 29 november 1988, $N J$ 1989, 815, met noot Alkema (Brogan).

EHRM 20 november 1989, $N J$ 1990, 245, met noot Alkema (Kostovski).

EHRM 20 november 1989, NJ 1991, 738, met noot Alkema (Markt inern Verlag en Klaus Beermann).

EHRM 25 februari 1992, Series A, no. 226-A (Margareta and Roger Andersson).

EHRM 25 september 1992, $N J$ 1995, 593, met noot Alkema (Pham Hoang).

EHRM 16 december 1992, $N J$ 1993, 400, met noot Dommering (Niemietz).

EHRM 25 mei 1993, Series A, no. 260-A (Kokkinakis v. Greece).

EHRM 22 september 1993, $N J$ 1994, 733, met noot Knigge (Lala).

EHRM 24 februari 1994, $N J$ 1994, 496, met noot Alkema (Bendenoun).

EHRM 13 juli 1995, $N J$ 1996, 544, met noot Dommering (Tolstoy Miloslavsky).

EHRM 26 september 1995, $N J$ 1996, 545, met noot Dommering (Vogt).

EHRM 27 september 1995, NJ 1996, 49, met noot Knigge (G. v. France).

EHRM 22 november 1995, NJ 1997, 1, met noot Knigge (C.R. v. United Kingdom).

\section{Hof van Justitie}

Hof van Justitie EG 21 juni 1979, zaak 240/78, Jur. 2137 (Atalanta).

Hof van Justitie EG 14 juli 1994, zaak C-379/92 (Strafzaak tegen M. Peralta).

Hof van Justitie EG 30 april 1996, $N J$ 1997, 214 (Securitel)

Hof van Justitie EG 16 juni 1998, zaak C-226/97, NJB 1998, nr. 23 (Bewijs ondanks Securitel).

\section{Hoge Raad}

HR 19 december 1860, W. 2244 (Rieten dak te Gastel). 
HR 30 juni 1890, W. 1890, 5905 (Opening naast openbare weg). HR 28 april 1902, W. 1902, 7765 (Ordeverstoring in bierhuis). HR 18 mei 1903, $W .1903,7927$ (Dronken op eigen erf). HR 14 maart 1904, W. 1904, 8049 (Hond bijt rijksveldwachter). HR 13 juni 1905, W. 1905, 8244 (Vrouwen ook "Hij").

HR 14 januari 1907, W. 1907, 8488 (Gevaarlijk dier en schade). HR 5 oktober 1908, W. 1908, 8753 (IJzer op weg).

HR 14 februari 1916, $N J$ 1916, pp. 681-684 (Melk en water-arrest). HR 1 maart 1918, $N J$ 1918, pp. 440-443 (Overgedragen straten). HR 10 juni. 1919, $N J$ 1919, pp. 647-650 (Teelt in Beemster). HR 10 juni 1919, $N J 1919$, pp. 650-651 (Verbod aflevering rogge). HR 23 mei 1921, NJ 1921, pp. 564-574 (Elektriciteitsarrest). HR 16 januari 1922, $N J$ 1922, 343-345 (Afgerichte hond). HR 6 juni 1922, NJ 1922, pp. 922-925 (Geen bevoegde rechter). HR 16 januari 1928, $N J 1928$, pp. 250-251 (Hoede over koe). HR 28 april 1930, $N J$ 1930, pp. 842-843 (Paard en voorzorgsmaatregelen). HR 23 juni 1930, $N J 1$ 1930, pp. 1662-1664, met noot Taverne (Verblindende lantaarn). HR 29 september 1930, NJ 1931, pp. 28-29 (Vervoer mollen). HR 11 januari 1932, NJ 1932, pp. 464-465 (Motorrijtuig in Overschie) . HR 26 februari 1934, NJ 1934,p. 1136-1139 (Gedwongen toetteding)!

HR 29 juni 1936, Slotemaker, L.H., Luchtvaartwet, Zwolle, Tjeenk Willink, 1940, pp. 34-35 (Buiten paticuliere sfeer).

HR 7 juni 1937, $N J$ 1937, 1145, met noot Taverne (Vogelnetten in Angerlo).

HR 24 april 1939, $N J$ 1939, 1017, met noot Taverne ("Tenzij" dan bestanddeel).

HR 25 november 1940, NJ 1941, 209 (Neergeworpen vuilnis).

HR 20 oktober 1941, $N J$ 1942, 60, met noot Taverne (Boven de gemeentegrond).

HR 31 januari 1950, $N J$ 1950, 668, met noot Pompe (Broodjeswinkel-arrest).

HR 9 mei 1950, $N J$ 1951, 357 (Parkeren van auto op trottoir).

HR 18 maart 1952, $N J 1952,314$ en 315, met noot Röling (Kleurloos opzet).

HR 10 maart 1953, $N J$ 1965, 304; VR 1955, 56 (Afsluit-boom).

HR 24 november 1953, $N J$ 1954, 73, met noot Röling (Vastgelegde hond).

HR 23 februari 1954, NJ 1954, 378, met noot Röling (IJzerdraad).

HR 14 december 1954, NJ 1955, 118, met noot Röling (Herbebossing)

HR 5 maart 1957, $N J$ 1957, 396, met noot Pompe (Groen voor tram).

HR 3 november 1959, $N J$ 1960, 209, met noot Pompe (Gevaarlijke cirkelzagen).

HR 25 april 1961, VR 1961, 58 (Schuin overstekende truck).

HR 26 juni 1962, $N J$ 1963, 32, met noot Röling (Bijzondere voorwaarde $70 \mathrm{~km} / \mathrm{u}$ ).

HR 14 juni 1963, NJ 1965, 82, met noot Beekhuis (Hinder bokken dor overspanning Lek).

HR 26 juni 1964, $N J$ 1965, 83 (Overspanning Lek).

HR 23 februari 1965, $N J$ 1965, 303, met noot Pompe; VR 1965, 65 (Rangeerder is weggebruiker).

HR I8 april 1967, $N J$ 1967, 442; AA 1968, pp. 229-235, met noot Jeukens (Zuivering waterkering in Polder).

HR 15 oktober 1968, $N J$ 1969, 141. (Algemeen verbod $50 \mathrm{~km} / \mathrm{u}$ in bebouwde kom). HR 8 juni 1971, $N J$ 1972, 218, met noot Melai (Houden varkers). 
HR 1 februari 1972, $N J 1974,450$, met noot Van Veen (Meer en Vaart).

HR 26 juni 1973, $N J 1973,376$ (Rood voor auto in militaire colonne).

HR 14 mei 1974, NJ 1974, 325 (Zelftank Kreekhuizen).

HR 4 november 1975, $N J$ 1976, 173, met noot Prins (Regel na verschijning Stb.).

HR 18 november 1975, $A A, 1977$, pp. 66-76, met noot Heijder (Rechtsdwaling-arrest).

HR 13 januari 1976, $N J$ 1976, 339 (Hyacinthenteelverordening).

HR 13 april 1976, $N J 1976,425$ (Vluchtige bijen).

HR 3 mei 1977, $N J$ 1977, 536, met noot Van Veen (Avondzaak Rosmalen).

HR 28 april 1981, $N J 1981,461$ (Rook boven weg).

HR 27 oktober 1981, $N J$ 1982, 474 (Tilburgse verkeersdrempels).

HR 24 november 1981, NJ 1982, 209 (Gekwalificeerde luchtvervoerders).

HR 26 april 1983, NJ 1983, 689 (Gevaar voor vallende voorwerpen).

HR 2 oktober 1984, MenR 1986, nr. 6 (Afsluiter op slang).

HR 13 november 1984, $N J$ 1985, 294; $A B$ 1985, 361, met noot Van der Burg (Kam* peerverordening Domburg).

HR 19 februari 1985, DD 85.286 (Stof en kaf).

HR 2 april 1985, $N J$ 1985, 796 (Onbehoorlijk gedrag).

HR 16 mei 1986, $N J$ 1987, 251, met noot Scheltema; $A B$ 1986, 574, met noot Van der Burg (Landbouwvliegers).

HR 3 oktober 1986, $N J$ 1987, 911, met noot Scheltema; $A B$ 1987, 90, met noot Van der Burg (Heffing op auto's Antillen).

HR 16 december 1986, $N J$ 1987, 321, met noot 't Hart (Slavenburg II).

HR 23 december 1986, $N J$ 1987, 640 (Gevelde houtopstand)

HR 10 februari 1987, $N J$ 1987, 662, met noot 't Hart (Onterechte vergunning).

HR 10 februari 1987, $N J$ 1987, 848, met noot Corstens (Herziening, ex tunc-redenering).

HR 17 maart 1987, NJ 1987, 771, met noot Mulder (Pobelmann Pinschers, één kat en dode konijnen).

HR 10 november 1987, $N J 1988,303$, met noot Van Veen (RU Groningen vervolgd).

HR 10 november 1987, $N J$ 1988, 426 (Flacons met antibioticum).

HR 16 februari 1988, $N J 1988,821$ (Openlijk geweld op parkeerplaats).

HR 6 december 1988, MenR 1989, nr. 38 (Aangifte ondanks brief B\&W).

HR 14 februari 1989, $N J 1989,671$ (Kind in draagzak in auto).

HR 14 april 1989; $N J$ 1989, 469, met noot Scheltema; $A B$ 1989, 207, met noot Van der Burg (Harmonisatiewetarrest).

HR 9 juni 1989, $N J$ 1989, 718; $A B$ 1989, 412, met noot Van der Burg (Kortverbanders).

HR 30 januari 1990, $N J 1990,610$ (Rechtsdwaling rechter geen herzieningsgrond).

HR 16 oktober 1990, NJ 1991, 442, met noot Corstens (Mariënburcht).

HR 6 november 1990, $N J$ 1991, 257, met noot Van Veen (Daalse Tunnel).

HR 15 januari 1991, $N J$ 1991, 668, met noot Corstens (Rotterdamse computerfraude).

HR 10 december 1991, $N J$ 1992, 322, met noot Knigge (Wapen tijdelijk bij dochter).

HR 10 maart 1992, NJ 1992, 571 (Pitbullterriër).

HR 9 juni 1992, NJ 1992, 794; MenR 1993, nr. 37 (Streekgewest Oostelijk ZuidLimburg).

HR 7 oktober 1992, $N J$ 1994, 44 (Legesverordening Beerta). 
HR 13 oktober 1992, $N J 1993,141$ (Straf afleveren pistool).

HR 17 november 1992, $N J$ 1993,267, met noot Van Veen (Aannemelijke overmacht).

HR 8 december 1992, NJ 1993, 618, met noot Corstens (Sluitingsbevel).

HR 23 februari 1993, NJ 1993, 605, met noot 't Hart (Monsters bij Orphahell).

HR 26 oktober 1993, NJ 1994, 99, MenR 1994, nr. 22, met noot Tideman (Kabelbranden).

HR 22 december 1993, NJ 1994, 313 (Naheffingen voor bestuur BV).

HR 24 december 1993, NIJ 1994, 303 (Geen onderzoek volmacht).

HR 11 januari 1994, MenR 1994, nr. 85, met noot Hendriks (Mobil Oil).

HR 25 januari 1994, NJ 1994, 598, met noot Corstens (Vliegbasis Volkel).

HR 8 maart 1994, NJ 1994, 412 (Krijgsmacht belemmert).

HR 8 juli 1994, NJI 1994, 758 (Verkoop Kooivogels)

HR 13 september 1994, NJ 1994, 746 (Olielozing door Financial Enterprise).

HR 15 november 1994, MenR 1995, nr. 10-K (Bodemkunstenaar).

HR 22 november 1994, MenR, 1995, nr. 50, met noot Hendriks (Motorblok).

HR 29 november 1994, MenR 1995, nr. 73, met noot De Lange (Afgeleverde afvalstoffen).

HR 17 januari 1995, MenR 1995, nr. 80 (Olie op straat).

HR 14 februari 1995, MenR 1995, nr. 81, met noot Hendriks (Mest op bodem).

HR 14 februari 1995, NJ 1995, 407 ((On)bevoegd rijden).

HR 7 april 1995, $N J$ 1997, 166, met noot Scheltema (Terugbetaling bezoldiging).

HR 21 april 1995, $N J$ 1995, 437 (Professioneel automobielbedrijf).

HR 23 mei 1995, NJ 1995, 695, met noot Scheltema; MenR 1996, nr. 5, met noot Hendriks (Uitleg vergunning van feitelijke aard).

HR 6 juni 1995, $N J$ 1995, 696, met noot Scheltema (Vergissing met dwangbevel).

HR 20 juni 1995, MenR 1995, nr. 61-K (Niet vrijgestelde mest).

HR 27 juni 1995, $N J$ 1995, 722; MenR 1996, nr. 6, met noot Hendriks (Uitleg vergunningvoorschrift is feitelijk).

HR 17 juli 1995, NJ 1995, 697, met noot Schelterna (Motorhuis M.).

HR 30 januari 1996, MenR 1996, nr. 47, met noot De Lange (Dwangsom en strafvervolging).

HR 20 februari 1996, MenR 1997, nr. 62 (Asbestplaten in bodern).

HR 23 april 1996, $N J$ 1996, 512; TMA 1997, pp. 11-12 en 16-18, met noot Fransen (Waterschap Westfriesland).

HR 23 april 1996, $N J$ 1996, 513, met noot 't Hart; TMA 1997, pp. 13-14 en 16-18, met noot Fransen (Pikmeer I).

HR 11 juni 1996, $N J$ 1996, 700 (Cassatie overtreding Opiumwet).

HR 1 juli 1996, DD 96.364 (Mestbassin).

HR 11 oktober 1996, $N J 1997,165$, met noot Scheltema (Ventvergunning en APV).

HR 24 juni 1997, $N J$ 1998, 70, met noot 't Hart (Rusttijd AETR is geen Wettelijke strafbepaling).

HR 2 december 1997, NJB 1998, 137 (Vernietiging computerbestanden).

HR 6 januari 1998, NJ 1998, 367, met noot De Hullu; MenR 1998, nr. 19, met noot

Hendriks en de Lange (Pikmeer II).

HR 1 september 1998, NJ 1999, 61 (Liftportaal).

HR 12 januari 1999, $N J$ 1999, 289 (Samenloop sancties 5 WVW). 
HR 19 januari 1999, $N J$ 1999, 291 (Vaten op bodem).

HR 18 mei 1999, $N J 1999,578$ (Opgeduwde spoorwegwagons).

HR 28 mei 1999, $N J$ 1999, 508, met noot Bloembergen (Tariefcommissie en invoerrechten Transol).

HR 6 juli 1999, $N J$ 1999, 800, met noot De Hullu (EHRM is geen herzieningsgrond).

\section{Raad van State}

AR 6 januari 1983, $A B$ 1984, 267 (Afval in kleine containers).

AR 1 februari 1985, $A B$ 1985, 587, met noot Van Buuren (Natuurgebied Swalmen).

VzAR 6 november 1987, $A B$ 1989, 96 (Woonwagens zonder vergunning).

VzAR 30 november 1989, $A B$ 1990, 279 (Grenzen vrije beroepskeuze).

VzAR 19 januari 1993, MenR 1994, nr. 21, met noot Verschuuren (Geen amvb, geen schending $13 \mathrm{Wbb}$ ).

ABR 5 juli 1994, $A B$ 1994, 636, met noot Michiels (Geen amvb, wel schending 13 Wbb).

ABR State 24 oktober 1995, $A B$ 1996, 357, met noot Backes (Bestuursdwangaanschrijving na niet notariele overdracht).

$\mathrm{Vz}$ ABR 18 juni 1997, 03.97 .0316 (niet gepubliceerd) (Bevoegd gezag $13 \mathrm{Wbb}$ is minister).

ABR 4 september 1997, $A B$ 1997, 396, met noot Michiels (Verwijderen reclameborden Geleen).

Vz ABR 11 september 1997, MenR, 1998, 63, met noot Uylenburg (Lichtstralen van café).

ABR 21 juli 1998, $A B$ 1998, 142, met noot Backes (Bevoegd gezag 13 Wbb is B\&W).

\section{KB}

KB 29 september 1987, MenR 1988, nr. 36, met noot Addink (Zorgplicht geschrapt).

\section{Hof}

Hof Amhem 27 oktober 1983, $N J$ 1984, 80 (Computergegevens)

Hof Amhem 22 april 1991, MenR 1992, nr. 106, met noot Addink (Mest in Epe).

Hof Amsterdam 30 december 1992, MenR 1993, nr. 85 (Mobil Oil bij Hof).

Hof Amsterdam 25 februari 1994, NJ 1994, 382; MenR 1994, nr. 58K (Olielozing op Eikenweg).

Hof Amsterdam 7 juni 1994, MenR 1995, nr. 16 (Paardenmest lex specialis 13 Wbb).

Hof Amsterdam 14 maart 1995, MenR 1995, nr. 95, met noot De Lange (Verwijderen autowrakken).

Hof Amsterdam 23 mei 1995, MenR 1995, nr. 56K (Accu's op bodem).

Hof Amsterdam 31 januari 1996, MenR 1996, nr. 38-K (Open laadbak).

Hof 's-Gravenhage 15 mei 1996, MenR 1996, nr. 56K (Afval aanwezig). 
Hof 's-Hertogenbosch 15 oktober 1998, MenR 1999, nr. 27, met noot De Lange (Rutte II).

Hof 's-Hertogenbosch (Beschikking) 2 april 1999, niet gepubliceerd (Politie vervolgd).

Hof 's-Hertogenbosch 20 april 1999, MenR 1999, nr. 98, met noot De Lange (Terugwerkende vergunning).

Hof Amsterdam 17 mei 2000, MenR 2000, nr. 66, met noot Hendriks (Gedoogbeschikking als vergunning).

\section{Rechtbank}

Rb. Middelburg 24 september 1901, W. 1902, 7696 (Hond in wei).

Rb. Haarlem, 19 maart 1936, Slotemaker, L.H., Luchtvaartwet, Zwolle, Tjeenk Willink, 1940, p. 34 (Natuurlijke orde in de maatschappij).

Rb. Assen, 8 december 1972, $N J$ 1973, 446 (Knellende pers).

Rb. Breda 1 oktober 1985, $N J$ 1986, 114 (Onduidelijke norm).

Rb. 's-Hertogenbosch 2 januari 1990, MenR 1990, nr. 66 (Fout advies provinciaal ambtenaar).

Rb. Amsterdam 9 maart 1990, MenR 1990, nr. 58, met noot Fransen (Kabelbranden in Edam).

Rb. Amsterdam 29 maart 1990, $N J$ 1990, 521; MenR 1990, nr. 58, met noot Fransen (Kabelbranden).

Rb. Amsterdam 18 december 1990, MenR 1992, nr. 14 (Opslag oil slobs).

Rb. Amsterdam 26 april 1991, MenR 1991, nr. 121 (Geen carte blanche).

Rb. Amsterdam 5 januari 1993, TMA 1993, pp. 77-83, met noot Faure (Cindu-zaak).

Rb. 's-Hertogenbosch 1 februari 1993, MenR 1993, nr. 45, met noot Hendriks (Vliegbasis Volkel-Rb.)

Rb. Middelburg, 9 maart 1995, MenR, 1995, 48-K (Compliance officier).

Rb. Assen 10 februari 1999, MenR 1999, nr. 99, met noot De Lange (Meer doelen Sr).

\section{Kantongerecht}

Kantonrechter Gorinchem 6 november 1951, NJ 1952, 655 (Laadbrug raakt bus).

\section{Arbitragehof}

Arbitragehof 14 juli 1997, nr. 40/97, $R W, 1997-98$, pp. 1047-1049. 


\section{Curriculum Vitae}

Marjolein Visser werd op 2 december 1965 geboren te Rosmalen. Zij studeerde van september 1984 tot juli 1988 ergotherapie aan de Hogeschool Heerlen. Van september 1988 tot januari 1994 was zij werkzaam als ergotherapeut bij het Revalidatiecentrum Hoensbroeck en het Ziekenhuis de Wever te Heerlen. In deze tijd verzorgde zij als gastdocent enkele vakken aan de Hogeschool Heerlen en verrichtte zij anderhalf jaar onderzoek naar de inhoud en uitvoering van de arbeidsomstandighedenwetgeving in Europees perspectief. Zij studeerde van september 1990 tot augustus 1993 Nederlands recht aan de Universiteit Maastricht. Van juli 1992 tot januari 1994 was zij tevens werkzaam als student- en onderzoeksassistent bij de vakgroep Strafrecht en Criminologie. Na haar studie werkte zij korte tijd als docent bij het Willem Pompe Instituut voor Strafrechtswetenschappen van de Universiteit Utrecht. In mei 1994 ging zij als assistent in opleiding werken bij het Maastrichts Europees Instituut voor Transnationaal Rechtswetenschappelijk Onderzoek (METRO) van de Universiteit Maastricht. Sinds december 1995 maakt zij deel uit van de (met ingang van mei 1998 erkende) onderzoeksschool Ius Commune. In januari 1998 ging zij werken als universitair docent straf(proces)recht bij het Seminarium van Hamel van de Universiteit van Amsterdam. Een jaar later werd zij universitair onderzoeker bij het Centrum voor Milieurecht van de Universiteit van Amsterdam. Vanaf februari 2001 is Marjolein Visser tevens werkzaam als advocaat te Amsterdam. 
